\title{
LITHOSPHERIC XENOLITHS FROM THE MARIE BYRD LAND VOLCANIC PROVINCE, WEST ANTARCTICA.
}

\section{Richard J. Wysoczanski}

Submitted in fulfilment for the degree of Doctor of Philosophy, September, 1993.

Geology Department, Research School of Earth Sciences, Victoria University of Wellington, P.O. Box 600, Wellington, New Zealand. 


\section{ABSTRACT}

Studies of the Earths lithosphere, and particularly the lower crust, have in the past relied on geophysical methods, and on geochemical studies of granulite terrains exposed at the surface. Geophysical studies can not evaluate the compositions to any large extent. Granulite terrains typically represent ancient rather than present day sections, have invariably suffered retrograde metamorphism, and have been affected by fluids during uplift. More recently, studies of lithospheric xenoliths (fragments of the lithosphere brought to the surface by entraining (typically alkaline) melts) have been used to study the composition of, and processes influencing, the lithosphere. Xenoliths have the advantage of representing relatively unaltered and young fragments of the lithosphere, and together with other studies have added much to our understanding of the Earths composition and processes.

The study of the lithosphere in Marie Byrd Land (MBL), West Antarctica, is complicated by the difficult access and harsh climate of the region. Geophysical studies are limited, and deep crustal exposures are entirely absent. In an attempt to study the composition and structure of the MBL lithosphere, xenoliths were collected from various volcanic edifices in MBL, including the volcanoes of the Executive Committee Range (ECR), and the USAS Escarpment in central MBL, and Mount Murphy on the Walgreen coast. The xenolith suite consists of peridotites, pyroxenites and granulites, spanning a vertical section from upper mantle to lower crust, that are in pristine condition, due to the arid Antarctic conditions.

The peridotite suite from MBL consists of spinel lherzolites from Mounts Hampton and Cumming in the ECR, the USAS Escarpment, and Mount Murphy. Cr-diopside rich peridotites also occur at Mounts Hampton and Murphy, indicating a more chemically diverse upper mantle in these regions (e.g. Mg\# 75-92 in Cr-diopside rich peridotites compared to Mg\# 87-92 in spinel lherzolites). REE contents of the peridotites vary from LREE-depleted (up to $0.293(\mathrm{La} / \mathrm{Yb})_{n}$ in USAS Escarpment peridotites) to LREE-enriched (up to $10.015(\mathrm{La} / \mathrm{Yb})_{n}$ in Mount Hampton peridotites), further indicating the extreme heterogeneity of the MBL upper mantle.

Lower crustal xenoliths from Mounts Sidley and Hampton in the ECR, and from Mount Murphy have meta-igneous textures ranging from pyroxenite to gabbro. They consist of varying amounts of olivine, clinopyroxene, orthopyroxene, plagioclase and spinels; garnet is entirely absent. 
Orthopyroxene is absent in Mount Sidley xenoliths, whereas olivine is rare in Mount Hampton xenoliths. Mineral P-T equilibria indicate crystallisation of Mounts Sidley and Murphy pyroxenites at lower levels (7-11 $\mathrm{kb}$ and 6.5-12 $\mathrm{kb}$ respectively) than the granulites (3-5.5 $\mathrm{kb}$ and 3-9 $\mathrm{kb})$, with Mount Hampton pyroxenites (6-7.5 kb) and granulites (5.5-8.5 kb) crystallising at similar crustal levels. High temperatures of equilibration $\left(>1000^{\circ} \mathrm{C}\right.$ ) are consistent with a rift-like geotherm in the MBL lithosphere.

Whole rock composition of the lower crustal xenoliths is controlled by the mineral assemblage, reflecting their origin as mafic cumulate rocks. Elements that partition readily into the xenolith mineral assemblage are present in higher abundances (e.g. up to $1700 \mathrm{ppm} \mathrm{Sr}$ in plagioclase rich xenoliths, and $3745 \mathrm{ppm} \mathrm{Cr}$ in clinopyroxene rich pyroxenites) than elements that do not (e.g. $\mathrm{Rb}$ $<6 \mathrm{ppm}$ in all lower crustal xenoliths). ${ }^{87} \mathrm{Sr} /{ }^{86} \mathrm{Sr}(0.702861 \pm 7$ to $0.704576 \pm 15)$ and ${ }^{143} \mathrm{Nd} /{ }^{144} \mathrm{Nd}$ $(0.512771 \pm 6$ to $0.512870 \pm 5)$ ratios indicate that the melts were primitive magmas, that did not assimilate any isotopically evolved crustal material prior to or during crystallisation. The singlepyroxene mineral assemblage of Mount Sidley (and possibly Mount Murphy) xenoliths crystallised from an alkaline melt, whereas the two-pyroxene assemblage of Mount Hampton xenoliths crystallised from a sub-alkaline melt.

Xenoliths from Mount Sidley reveal petrographic and geochemical evidence for melt-fluid interaction at lower crustal depths. This interaction is inferred to be associated with late Cenozoic plume-related volcanism. It is manifested by high-temperature oxidation of olivine, replacement of clinopyroxene by kaersutite, traces of alkaline mafic glass, and the growth of apatite, Fe-Ti oxides and plagioclase. The xenolith suite has been enriched in elements that readily partition into these mineral phases (e.g. Ti, K, P, Sr, Ba), as well as in mobile elements (e.g. LILEs and LREEs). Pb isotopic ratios (e.g. ${ }^{206} \mathrm{~Pb} /{ }^{204} \mathrm{~Pb}$ from 18.005 - 19.589) and REEs define mixing lines between unradiogenic lower crust $\left({ }^{206} \mathrm{~Pb} /{ }^{204} \mathrm{~Pb}=18.005\right)$ and small volume melts $\left({ }^{206} \mathrm{~Pb} /{ }^{204} \mathrm{~Pb}>19.53\right)$ approaching HIMU composition, sourced from the inferred mantle plume. The composition of the infiltrating melts has also evolved, by percolative fractional crystallisation in the lower crust.

The chemical heterogeneity detected in the MBL lower crust indicates a lower crustal discontinuity in the ECR, between Mount Sidley and Mount Hampton, here termed the ECR lower crustal discontinuity. Granulites from Mount Sidley are similar in composition to granulites from the Transantarctic Mountains (TM) in the McMurdo Sound region, Mount Ruapehu and Fiordland (New Zealand). Granulites from Mount Hampton are similar in composition to granulites from Mount Murphy, and the Ross Embayment (RE). These groups have been termed the TM Group and the RE Group respectively. The compositional similarity of granulites in each group may indicate the derivation of the lower crust in these regions from similar melts, and possibly indicate their juxtaposition as parts of the Gondwana supercontinent.

The mafic cumulate character of the xenolith suite is inferred to represent original oceanic crust, and a model for the growth of the crust since its formation in latest pre-Cambrian - early Cambrian is presented here. 


\section{ACKNOWLEDGEMENTS AND DEDICATION}

As with all theses, this work could not have been completed with the help of a great number of people, both academic and otherwise. I would like to take this opportunity to thank them all.

This study was conceived and initiated by my supervisor, and sometimes caretaker and even nemesis, John Gamble, who I would like to thank most of all. His continued support, correcting of manuscripts (particularly conference abstracts!), and friendship were invaluable, especially when faced with a rebellious doctorate student.

The collection of xenoliths in Marie Byrd Land was undertaken by the WAVE programme (Nelia Dunbar, John Gamble, Phil Kyle, Bill McIntosh, Kurt Panter, and John Smellie) and I would like to thank all of them for the fieldwork, and good times at conferences, on the ice, and elsewhere. Thanks also to John Berg (Northern Illinois) for unpublished data on McMurdo Sound xenoliths.

The technical staff of Victoria, also deserve my thanks for their help, most notably Ken Palmer, for numerous XRF analyses, and many hours spent repairing the microprobe (the black box from hell), and to Christina Smits for countless thin sections. Brett Robertson was especially invaluable in preparing many photographs in record breaking time over the years. Other technical and academic staff alike have provided assistance over the years, especially Peter Barrett and Alex Pyne (Antarctic Research Centre), John Carter (chief technician), and Sally Rowe (graphic design) who had to cope with both myself and Gary Wilson no less, during the final stages of this thesis.

The staff of other universities must also be thanked for their help, including Matthew Thirlwall, Gerry Ingram, and Martin Menzies of Royal Holloway and Bedford New College, University of London, and Phil Kyle of New Mexico Institute of Mining and Technology. Matthew Thirlwall and Gerry Ingram were particularly helpful in supervising me in the radiogenic isotope lab, notably in an 
initially difficult situation, and Phil Kyle and family are also especially thanked for taking me into their home in Socorro, New Mexico, and for providing rare earth element analyses.

Financial and logistic support, with which this thesis would not have been possible, was provided by a number of people and organisations. The University Grants Committee are primarily thanked for providing me with a university scholarship. Thanks also to the New Zealand Antarctic Programme staff, for all matters Antarctic. Sources of funding for research costs came from the Internal Research Grants Committee for fieldwork and isotopic analyses, the ICOG 7 organising committee for conference costs in Canberra, Dr Tori of the Japan Polar Research Association, and the Antarctic Society for conference costs in Japan, and The Royal Society of New Zealand, for a Prince and Princess of Wales Award.

Last, but in no ways least, I extend my thanks to my family and friends for their continued support, and for providing welcome relief to my studies. My family were never short of help and encouragement, particularly during difficult times for us all, and I owe them my grateful thanks. Many students at Victoria and overseas provided me with much needed diversions, especially Joel Baker for many helpful discussions and magic times both in Wellington and in Egham. The list of other people is endless, and includes flatmates and friends of 39 E.T., other students such as Malcolm Arnot, Monica Handler, Ngaire Hill, Richard Levy, Randall McDonnell, Geoff Rait, Gary Wilson, and Ken Woolfe of Victoria, Colin MacPherson of RHBNC, Kurt Panter of NM Tech, Des Patterson of ANU, and the greatest soccer team in the world, for the best of times both on and of the field. This list would not be complete without thanking Monica Handler, whose constant help and companionship was especially appreciated.

Finally, this thesis is dedicated to my father, Wladyslaw Wysoczanski, who was never short of support, and who died during the writing of this thesis. 


\section{TABLE OF CONTENTS}

$\begin{array}{ll}\text { Abstract } & i \\ \text { Acknowledgements and Dedication } & i i i \\ \text { Table of Contents } & v \\ \text { List of Figures } & x i i i \\ \text { List of Plates } & x i x \\ \text { List of Tables } & x x i\end{array}$

\section{PART ONE: InTRODUCTION}

Chapter one: WeSt ANTARCTIC XENOLITH STUDIES

1.1 Introduction 2

1.1.1 Objectives of this study 2

1.1.2 Thesis organisation 2

1.2 Marie Byrd Land, West Antarctica 4

1.2.1 Location and description of the Antarctic continent 4

1.2.2 Tectonic history of West Antarctica 5

1.2.3 Geologic history of Marie Byrd Land 8

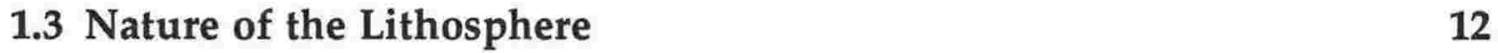

1.3.1 Structure of the lithosphere 12

1.3.2 Lithospheric studies 14

1.3.3 Lithospheric studies in Marie Byrd Land $\quad 15$

$\begin{array}{ll}1.4 \text { Overview of Xenolith Studies } & 16\end{array}$

1.4.1 The study of lithospheric xenoliths 16

1.4.2 Lower crustal conditions and the recognition of lower $\begin{array}{ll}\text { crustal xenoliths } & 21\end{array}$ 
Chapter two: NOMENCLATURE 23

2.1 Introduction $\quad 24$

2.2 Rock Nomenclature $\quad 24$

2.2.1 Volcanic rock classification $\quad 25$

2.2.2 Plutonic rock classification 26

2.2.3 Metamorphic rock classification $\quad 26$

$\begin{array}{ll}2.2 .4 \text { Rock textures } & 30\end{array}$

2.3 Mineral Nomenclature 33

2.3.1 Pyroxenes 34

2.3.2 Amphiboles 36

Chapter three: FIELD EXCURSIONS

3.1 The WAVE Programme 42

3.2 The Collection of the Xenolith Suite 42

3.2.1 The 1989/1990 field season 42

3.2.2 The 1990/1991 field season 43

3.2.3 The 1992/1993 field season 43

3.3 Xenolith Localities $\quad 44$

3.3.1 The Executive Committee Range 44

3.3.2 Mount Murphy 47

3.3.3 The USAS Escarpment 47

3.3.4 The Ross Embayment and the Transantarctic Mountains 48

\section{Part Two: The XenOlith SuIte}

Chapter four: THE MOUNT SIDLEY XENOLITH SUITE 49

4.1 Mount Sidley $\quad 50$

4.2 The Xenolith Suite $\quad 51$

4.3 Petrography 52

4.3.1 The granulite suite 53

4.3.2 The pyroxenite suite $\quad 58$

4.3.3 Composite and intermediate xenoliths 61

4.3.4 Secondary mineral reactions 63

4.3.5 Summary of textures and bearing on petrogenesis 64

$\begin{array}{ll}\text { 4.4 Mineral Chemistry } & 67\end{array}$

$\begin{array}{ll}\text { 4.4.1 Olivine } & 67\end{array}$ 
$\begin{array}{ll}\text { 4.4.2 Clinopyroxene } & 70\end{array}$

$\begin{array}{ll}\text { 4.4.3 Plagioclase } & 76\end{array}$

$\begin{array}{ll}\text { 4.4.4 Non-silicates } & 78\end{array}$

$\begin{array}{ll}4.4 .5 \text { Accessory minerals } & 80\end{array}$

4.4.6 Summary of mineral chemistry $\quad 80$

4.5 Secondary Mineral Reactions $\quad 82$

4.5.1 Host rock - xenolith interactions 83

4.5.2 Kaersutitisation $\quad 89$

$\begin{array}{ll}\text { 4.5.3 Oxidation reactions } & 98\end{array}$

4.5.4 Geochemistry and origin of glasses 111

4.5.5 Summary and discussion of secondary mineral reactions 116

$\begin{array}{ll}\text { 4.6 Whole Rock Geochemistry } & 119\end{array}$

$\begin{array}{ll}\text { 4.6.1 Major element geochemistry } & 119\end{array}$

4.6.2 Trace element geochemistry 123

$\begin{array}{ll}4.6 .3 \text { Isotopic geochemistry } & 130\end{array}$

4.6.4 Summary and discussion of whole rock geochemistry $\quad 134$

$\begin{array}{ll}\text { 4.7 Summary and Conclusion } & \mathbf{1 3 5}\end{array}$

4.7.1 Summary of the xenolith suite 135

4.7.2 Nature of the crystallising melt and cumulate derivatives 137

4.7.3 Stratigraphy of the lower crust and secondary processes 139

$\begin{array}{ll}\text { 4.7.4 Conclusion } & 140\end{array}$

Chapter five: THE MOUNT HAMPTON XENOLITH SUITE 141

5.1 Mount Hampton $\quad 142$

5.2 The Xenolith Suite 143

5.3 Petrography 143

5.3.1 The granulite suite 144

$\begin{array}{ll}\text { 5.3.2 The pyroxenite suite } & 147\end{array}$

5.3.3 Summary of textures and bearing on petrogenesis $\quad 149$

5.4 Mineral Chemistry 151

5.4.1 Clinopyroxene 153

5.4.2 Orthopyroxene 156

$\begin{array}{ll}5.4 .3 \text { Plagioclase } & 160\end{array}$

5.4.4 Non-silicates 163

5.4.5 Geothermobarometry 163

5.4.6 Summary of mineral chemistry 165

$\begin{array}{ll}5.5 \text { Secondary Mineral Reactions } & 167\end{array}$

$\begin{array}{ll}\text { 5.5.1 Oxidation of the xenolith suite } & 167\end{array}$ 
5.5.2 Secondary mineral chemistry 174

$\begin{array}{ll}\text { 5.5.3 Geochemistry and origin of glasses } & 178\end{array}$

5.5.4 Summary and discussion of symplectite growth 182

5.6 Whole Rock Geochemistry 183

$\begin{array}{ll}\text { 5.6.1 Major element geochemistry } & 183\end{array}$

$\begin{array}{ll}\text { 5.6.2 Trace element geochemistry } & 188\end{array}$

$\begin{array}{ll}\text { 5.6.3 Isotope geochemistry } & 193\end{array}$

5.6.4 Summary and discussion of whole rock geochemistry 195

$\begin{array}{ll}\text { 5.7 Summary and Conclusion } & \mathbf{1 9 6}\end{array}$

5.7.1 Summary of the xenolith suite 196

5.7.2 Nature of the crystallising melt and cumulate derivatives 199

5.7.3 Stratigraphy of the lower crust and secondary processes $\quad 200$

$\begin{array}{ll}5.7 .4 \text { Conclusion } & 201\end{array}$

Chapter six: THE MOUNT MURPHY XENOLITH SUITE 203

6.1 Mount Murphy $\quad 204$

6.2 The Xenolith Suite $\quad 205$

$\begin{array}{ll}6.3 \text { Petrography } & 206\end{array}$

$\begin{array}{ll}\text { 6.3.1 The granulite suite } & 207\end{array}$

$\begin{array}{ll}\text { 6.3.2 The pyroxenite suite } & 209\end{array}$

6.3.3 Summary of textures and bearing on petrogenesis 212

$\begin{array}{ll}\text { 6.4 Mineral Chemistry } & \mathbf{2 1 5}\end{array}$

$\begin{array}{ll}\text { 6.4.1 Olivine } & 215\end{array}$

$\begin{array}{ll}\text { 6.4.2 Clinopyroxene } & 217\end{array}$

$\begin{array}{ll}6.4 .3 \text { Plagioclase } & 224\end{array}$

$\begin{array}{ll}\text { 6.4.4 Non-silicates } & 226\end{array}$

6.4.5 Summary and discussion of mineral chemistry 230

6.5 Secondary Mineral Reactions 233

6.5.1 Host melt - xenolith interactions 233

$\begin{array}{ll}6.5 .2 \text { Oxidation of olivine } & 239\end{array}$

6.5.3 Secondary mineral chemistry 244

6.5.4 Geochemistry and origin of glasses 250

6.5.5 Summary and discussion of secondary mineral reactions 254

6.6 Whole Rock Geochemistry 256

6.6.1 Major element geochemistry 256

6.6.2 Trace element geochemistry 260

6.6.3 Isotope geochemistry 265

6.6.4 Summary and discussion of whole rock geochemistry 267 
6.7 Summary and Conclusions

6.7.1 Summary of the xenolith suite 268

6.7.2 Nature of the crystallising melt and cumulate derivatives 269

6.7.3 Stratigraphy of the lower crust and secondary processes $\quad 272$

6.7.4 Conclusion

\section{PART Three: The MARIE ByRd LAND Lithosphere}

Chapter seven: SYNTHESIS OF THE MARIE BYRD LAND LITHOSPHERE 273

7.1 Introduction 274

7.2 The Marie Byrd Land Upper Mantle 274

7.2.1 Introduction 274

7.2.2 Major element geochemistry of upper mantle peridotites $\quad 275$

7.2.3 Trace element geochemistry of upper mantle peridotites $\quad 277$

7.2.4 Cr-diopside veins in MBL peridotites 279

7.2.5 Summary of the MBL upper mantle 281

7.3 The Marie Byrd Land Lower Crust 282

7.3.1 Introduction 282

7.3.2 Textural and mineral characteristics 282

7.3.3 Major element comparison of the xenolith suite 284

7.3.4 Trace element comparison of the xenolith suite 286

7.3.5 Summary of the MBL lower crust 291

7.4 Comparison with Other Gondwana Lower Crustal Xenolith Suites 291

7.4.1 Introduction 291

7.4.2 McMurdo Sound xenoliths 292

7.4.3 New Zealand xenoliths 292

7.4.4 Eastern Australia xenoliths 293

7.4.5 A geochemical comparison 293

7.4.6 Summary and discussion $\quad 300$

7.5 Comparison with Lower Crustal Xenolith Suites World-Wide 301

7.5.1 Introduction 301

7.5.2 A geochemical comparison 301

7.5.3 A lower crustal average composition 304

$\begin{array}{ll}7.6 \text { Conclusion } & 309\end{array}$ 
8.1 Introduction

8.2 Structure of the Lower Crust

8.2.1 Heterogeneity in the MBL lithosphere 312

8.2.2 The origin of the lower crustal xenoliths 312

8.2.3 A stratified lower crustal model 314

8.3 Modification Processes in the Lower Crust 320

8.3.1 Entrainment of the xenoliths and ascent to the surface $\quad 320$

8.3.2 Metamorphism and deformation in the lower crust 321

8.3.3 Metasomatism and PFC processes in the lower crust 322

8.3.4 Plume-lithosphere interaction 327

8.4 Evolution of the Marie Byrd Land Crust 327

8.4.1 Stratigraphy of the MBL crust 328

8.4.2 Crustal growth 329

8.4.3 Tectonic reconstructions of MBL 331

$\begin{array}{ll}8.5 \text { Conclusion } & 338\end{array}$

Chapter nine: SUMMARY AND CONCLUSIONS 341

9.1 The Xenolith Suite 341

9.2 Composition of the Marie Byrd Land Lithosphere 341

9.3 Metasomatic Processes in the Marie Byrd Land Lithosphere 343

9.4 Lithospheric Structure and Evolution $\quad 344$

PART Four: ApPENDiCes, GLOSSARY AND REFERENCES

\section{APPENDICES}

A1 Sample Lists $\quad 345$

A1.1 Mount Sidley xenoliths 347

A1.2 Mount Hampton xenoliths 349

A1.3 Mount Murphy xenoliths $\quad 350$

A1.4 Mount Cumming xenoliths 351

A1.5 Mount Waesche xenoliths 352

A1.6 USAS Escarpment xenoliths 352

A2 Representative Petrographic Descriptions and Modal Counts 353

A2.1 Mount Sidley xenolith modes 355

A2.2 Mount Hampton xenolith modes $\quad 356$ 
A2.3 Mount Murphy xenolith modes

A3 Microprobe analyses

A3.1 Mount Sidley xenolith mineral analyses

A3.2 Mount Hampton xenolith mineral analyses

A3.3 Mount Murphy xenolith mineral analyses

A4 Whole Rock Geochemistry

A4.1 Mount Sidley xenolith analyses

A4.2 Mount Hampton xenolith analyses

A4.3 Mount Murphy xenolith analyses

A4.4 Mount Cumming xenolith analyses

A4.5 Mount Waesche xenolith analyses

A4.6 USAS Escarpment xenolith analyses

A5.1 MBL xenolith trace and rare earth element analyses 439

A6 Isotopic Analyses

A6.1 MBL xenolith isotopic analyses 


\section{LIST OF FIGURES}

\section{Chapter one: INTRODUCTION}

Figure 1.1 Map of Antarctica, showing the tectono-stratigraphic boundary between East and West Antarctica.

Figure 1.2 Tectonic map of West Antarctica, showing the crustal blocks of West Antarctica.

Figure 1.3 Position of the crustal blocks of Gondwana at magnetic anomaly 10 (118 ma), and magnetic anomaly A30 (70 Ma). Map of Marie Byrd Land showing the positions of volcanic centres and

Figure 1.4 Mountain Ranges.

Figure 1.5

Figure 1.6

Figure 1.7

Chronostratigraphic column of Marie Byrd Land.

Structure of the Earths outer layers.

The division of the Earths outer layers into a mechanical boundary layer, a thermal boundary layer, and an adiabatic interior. Stylised section of the crust-mantle boundary (the Moho).

Figure 1.8

Figure 1.9 Calculated geotherms of Foster Crater (in the Transantarctic Mountains), southeastern Australia, and western Australia.

\section{Chapter two: NOMENCLATURE}

Figure $\mathbf{2 . 1}$

Figure 2.2

Figure 2.3

Figure 2.4

Figure 2.5

Figure 2.6

Figure 2.7

Figure 2.8

Figure 2.9

Figure 2.10

Figure 2.11

Figure 2.12

Figure 2.13

Figure 2.14

Figure 2.15

Figure 2.16
Total alkali - silica (TAS) diagram for the classification of volcanic rocks.

QAPF diagram for the classification of plutonic rocks with $<90 \%$ mafic minerals.

Classification diagram for ultramafic rocks. 28

P-T conditions for metamorphic facies. 29

Development of orthocumulate, mesocumulate and adcumulate textures. $\quad 30$

Recrystallisation of igneous textures into a metamorphic fabric. 31

Development of layered igneous textures from shear and compaction experiments, and as seen in layered gabbroic rocks.

Classification diagram for Ca-Na pyroxenes. 34

Classification diagram for Ca-Mg-Fe pyroxenes.

Classification diagram of Deer et al. (1966) for all pyroxenes. 35

$\begin{array}{ll}\text { Classification diagram for alkali amphiboles. } & 37\end{array}$

Classification diagram for sodic-calcic amphiboles. 38

Classification diagram for calcic amphiboles. $\quad 39$

$\begin{array}{ll}\text { Classification diagram for Fe-Mg-Mn amphiboles. } & 40\end{array}$ 


\section{Chapter three: FIELD EXCURSIONS}

Figure 3.1

Figure 3.2

Figure 3.3

Figure 3.4
Location map of the Executive Committee Range, Marie Byrd Land.

Location map of Mount Murphy, Marie Byrd Land.

Location map of USAS Escarpment, Marie Byrd Land.

Location map of the McMurdo Sound region.

\section{Chapter four: THE MOUNT SIDLEY XENOLITH SUITE}

Figure 4.1

Figure 4.2

Figure 4.3

Figure 4.4

Figure 4.5

Figure 4.6

Figure 4.7

Figure 4.8

Figure 4.9

Figure 4.10

Figure 4.11

Figure 4.12

Figure 4.13

Figure 4.14

Figure 4.15

Figure 4.16

Figure 4.17

Figure 4.18

Figure 4.19

Figure 4.20

Figure 4.21

Figure 4.22

Figure 4.23

Figure 4.24

Figure 4.25

Figure 4.26

Figure 4.27

Figure 4.28

Figure 4.29
Types of composite and intermediate xenoliths in the xenolith suite.

Cumulus and intercumulus phases in the xenolith suite.

Models for the stratigraphy of the lower crust beneath Mount Sidley.

Composition of Mount Sidley xenolith olivines in the system Ca-Mg-Fe.

Plot of $\mathrm{MgO} v \mathrm{CaO}$ and $\mathrm{MnO}$ for Mount Sidley xenolith olivines.

Composition of Mount Sidley xenolith clinopyroxenes in the system Ca-Mg-Fe.

Wo v Fs plot of Mount Sidley xenolith clinopyroxenes.

$\mathrm{Ti}$ v $\mathrm{Al}^{\mathrm{IV}}$ and $\mathrm{Al}^{\mathrm{VI}}$ in Mount Sidley xenolith clinopyroxenes.

Partitioning of $\mathrm{Al}$ into $\mathrm{Al}^{\mathrm{IV}}$ and $\mathrm{Al}^{\mathrm{VI}}$ in Mount Sidley xenolith

clinopyroxenes.

Composition of Mount Sidley xenolith plagioclase's in the system

Or-Ab-An.

Composition of all primary Mount Sidley xenolith oxides in the system $\mathrm{TiO}_{2}-\mathrm{FeO}-\mathrm{Fe}_{2} \mathrm{O}_{3}$.

$100 \mathrm{Fe} / \mathrm{Ca}+\mathrm{Mg}+\mathrm{Fe}$ v $100 \mathrm{Ca} / \mathrm{Ca}+\mathrm{Mg}+\mathrm{Fe}$ plot of secondary Mount Sidley xenolith kaersutites.

Al v Ti plot of secondary Mount Sidley xenolith kaersutites, compared to crustal and mantle kaersutites.

$100 \mathrm{Fe} / \mathrm{Ca}+\mathrm{Mg}+\mathrm{Fe}$ v $100 \mathrm{Ca} / \mathrm{Ca}+\mathrm{Mg}+\mathrm{Fe}$ plot of secondary Mount Sidley xenolith rhönites.

$\mathrm{Ca}+\mathrm{Al}$ v Na+Si plot of secondary Mount Sidley xenolith rhönites.

Composition of all secondary Mount Sidley xenolith oxides in the system $\mathrm{TiO}_{2}-\mathrm{FeO}-\mathrm{Fe}_{2} \mathrm{O}_{3}$, by xenolith type.

Composition of secondary Mount Sidley xenolith oxide pairs in the system

$\mathrm{TiO}_{2}-\mathrm{FeO}-\mathrm{Fe}_{2} \mathrm{O}_{3}$, and redox conditions of the xenolith suite.

62

64

66

67

69

72

73

74

74

76

80

95

95

97

97

108

Schematic cross-sections of redox conditions in the lithosphere and

asthenosphere of ocean ridge, ocean island, subduction and continental rift settings.

xenoliths.

Total alkali-silica diagram (Le Bas et al., 1986) of glasses occurring in the Mount Sidley xenolith suite.

Silica v major element plots of glasses occurring in the Mount Sidley xenolith suite.

CIPW normative compositions of Mount Sidley xenoliths.

Silica v major element plots of Mount Sidley xenoliths.

$\mathrm{Al}_{2} \mathrm{O}_{3}$ and $\mathrm{Fe}_{2} \mathrm{O}_{3} \mathrm{v}$ silica for Mount Sidley xenoliths, showing the control of the mineral assemblage on whole rock compositions.

Silica v trace element plots of Mount Sidley xenoliths.

Multi-element variation diagrams of Mount Sidley xenoliths normalised to MORB (Pearce, 1983).

patterns for Mount Sidley xenoliths and clinopyroxene separates. 
Figure 4.30

Figure 4.31

Figure 4.32

Figure 4.33

Figure 4.34
${ }^{87} \mathrm{Sr} /{ }^{86} \mathrm{Sr}$ v Mg-number plot for Mount Sidley xenoliths and volcanics.

${ }^{87} \mathrm{Sr} /{ }^{86} \mathrm{Sr} \mathrm{v}{ }^{143} \mathrm{Nd} /{ }^{144} \mathrm{Nd}$ plot for Mount Sidley xenoliths and host basanites.

${ }^{206} \mathrm{~Pb} /{ }^{204} \mathrm{~Pb} \mathrm{v}{ }^{207} \mathrm{~Pb} /{ }^{204} \mathrm{~Pb}$ plot for Mount Sidley xenoliths and host basanites.

Crystallisation sequence of the Mount Sidley xenolith suite from a primitive mantle melt.

Stratigraphic sequence of the Mount Sidley xenolith suite, and secondary processes affecting the lower crust.

\section{Chapter five: THE MOUNT HAMPTON XENOLITH SUITE}

Figure 5.1

Figure 5.2

Figure 5.3

Figure 5.4

Figure 5.5

Figure 5.6

Figure 5.7

Figure 5.8

Figure 5.9

Figure 5.10

Figure 5.11

Figure 5.12

Figure 5.13

Figure 5.14

Figure 5.15

Figure 5.16

Figure 5.17

Figure 5.18

Figure 5.19

Figure 5.20

Figure 5.21

Figure 5.22

Figure 5.23

Figure 5.24

Figure 5.25

Figure 5.26

Figure 5.27
Cumulus and intercumulus phases in the xenolith suite.

Models for the stratigraphy of the lower crust beneath Mount Hampton.

Composition of Mount Hampton xenolith clinopyroxenes in the system $\mathrm{Ca}-\mathrm{Mg}-\mathrm{Fe}$.

Wo v Fs plot of Mount Hampton xenolith clinopyroxenes.

$\mathrm{Ti}$ v $\mathrm{Al}^{\mathrm{IV}}$ and $\mathrm{Al}^{\mathrm{VI}}$ in Mount Hampton xenolith clinopyroxenes.

Partitioning of $\mathrm{Al}$ into $\mathrm{Al}^{\mathrm{IV}}$ and $\mathrm{Al}^{\mathrm{VI}}$ in Mount Hampton xenolith

clinopyroxenes.

Composition of Mount Hampton xenolith orthopyroxenes in the system

$\mathrm{Ca}-\mathrm{Mg}-\mathrm{Fe}$.

Wo v Fs plot of Mount Hampton xenolith orthopyroxenes.

Compositional plot of Battacharyya (1971) to distinguish

metamorphic and igneous orthopyroxenes.

$\mathrm{Ti} \mathrm{v} \mathrm{Al}^{\mathrm{IV}}$ and $\mathrm{Al}^{\mathrm{VI}}$ in Mount Hampton xenolith clinopyroxenes.

Composition of Mount Hampton xenolith plagioclase's in the system

Or-Ab-An.

Composition of all primary Mount Hampton xenolith oxides in the system $\mathrm{TiO}_{2}-\mathrm{FeO}-\mathrm{Fe}_{2} \mathrm{O}_{3}$.

Composition of Mount Hampton xenolith olivines on orthopyroxene symplectite rims, in the system Ca-Mg-Fe.

Composition of all secondary Mount Hampton xenolith oxides in the system $\mathrm{TiO}_{2}-\mathrm{FeO}-\mathrm{Fe}_{2} \mathrm{O}_{3}$, by xenolith type.

CIPW normative compositions of glasses occurring in Mount Hampton xenoliths.

Total alkali-silica diagram (Le Bas et al., 1986) of glasses occurring in the Mount Hampton xenolith suite.

Silica v major element plots of glasses occurring in the Mount Hampton xenolith suite.

CIPW normative compositions of Mount Hampton xenoliths.

Histograms of silica and Mg-number contents in Mount Hampton xenoliths. Silica $v$ major element plots of Mount Hampton xenoliths. $\mathrm{Al}_{2} \mathrm{O}_{3}$ and $\mathrm{MgO}$ v silica for Mount Hampton xenoliths, showing the control of the mineral assemblage on whole rock compositions.

Silica $\mathrm{v}$ trace element plots of Mount Hampton xenoliths.

Multi-element variation diagrams of Mount Hampton xenoliths normalised to MORB (Pearce, 1983).

Rare Earth Element normalised to chondrite (Wheatley and Rock, 1988)

patterns for Mount Hampton xenoliths and clinopyroxene separates.

${ }^{87} \mathrm{Sr} /{ }^{86} \mathrm{Sr} v \mathrm{Mg}$-number plot for Mount Hampton xenoliths and volcanics.

${ }^{87} \mathrm{Sr} /{ }^{86} \mathrm{Sr} \mathrm{v}{ }^{143} \mathrm{Nd} /{ }^{144} \mathrm{Nd}$ plot for Mount Hampton xenoliths and host basanites.

${ }^{206} \mathrm{~Pb} /{ }^{204} \mathrm{~Pb}$ v ${ }^{207} \mathrm{~Pb} /{ }^{204} \mathrm{~Pb}$ plot for Mount Hampton xenoliths and host basanites. 
Figure 5.28

Figure 5.29
Crystallisation sequence of the Mount Hampton xenolith suite from a primitive mantle melt.

Stratigraphic sequence of the Mount Hampton xenolith suite, and

secondary processes affecting the lower crust.

\section{Chapter six: THE MOUNT MURPHY XENOLITH SUITE}

Figure 6.1

Figure 6.2

Figure 6.3

Figure 6.4

Figure 6.5

Figure 6.6

Figure 6.7

Figure 6.8

Figure 6.9

Figure 6.10

Figure 6.11

Figure 6.12

Figure 6.13

Figure 6.14

Figure 6.15

Figure 6.16

Figure 6.17

Figure 6.18

Figure 6.19

Figure 6.20

Figure 6.21

Figure 6.22

Figure 6.23

Figure 6.24

Figure 6.25

Figure 6.26

Figure 6.27

Figure 6.28

Figure 6.29
Cumulus and intercumulus phases in the xenolith suite.

Models for the stratigraphy of the lower crust beneath Mount Murphy.

Composition of Mount Murphy xenolith olivines in the system Ca-Mg-Fe.

Plot of $\mathrm{MgO} v \mathrm{CaO}$ and $\mathrm{MnO}$ for Mount Murphy xenolith olivines.

Composition of Mount Murphy xenolith clinopyroxenes in the system $\mathrm{Ca}-\mathrm{Mg}-\mathrm{Fe}$.

Wo v Fs plot of Mount Murphy xenolith clinopyroxenes.

$\mathrm{Ti}$ v $\mathrm{Al}^{\mathrm{IV}}$ and $\mathrm{Al}^{\mathrm{VI}}$ in Mount Murphy xenolith clinopyroxenes.

Partitioning of $\mathrm{Al}$ into $\mathrm{Al}^{\mathrm{IV}}$ and $\mathrm{Al}^{\mathrm{VI}}$ in Mount Murphy xenolith clinopyroxenes.

Composition of coexisting clinopyroxene and orthopyroxene from a site 90044 pyroxenite, in the system Ca-Mg-Fe.

Or-Ab-An.

$\mathrm{TiO}_{2}-\mathrm{FeO}-\mathrm{Fe}_{2} \mathrm{O}_{3}$.

Oxide pair thermometry and oxygen fugacity calculations for primary Mount Murphy xenolith oxides.

Composition of secondary Mount Murphy xenolith olivines in the system $\mathrm{Ca}-\mathrm{Mg}$-Fe.

Composition of secondary Mount Murphy xenolith pyroxenes in the system $\mathrm{Ca}-\mathrm{Mg}-\mathrm{Fe}$, including exsolution pairs and pyroxenes associated with the oxidation of olivine.

An content $v \mathrm{FeO}$ content of secondary Mount Murphy xenolith plagioclase's formed by alteration of primary plagioclase, and from crystallisation by infiltrating host melts.

Al v Ti plot of secondary Mount Murphy xenolith kaersutites, compared to crustal and mantle kaersutites.

$\mathrm{Ca}+\mathrm{Al} v \mathrm{Na}+\mathrm{Si}$ plot of secondary Mount Murphy xenolith rhönites.

Composition of all secondary Mount Murphy xenolith oxides in the system $\mathrm{TiO}_{2}-\mathrm{FeO}-\mathrm{Fe}_{2} \mathrm{O}_{3}$, by xenolith type.

CIPW normative compositions of glasses occurring in Mount Murphy xenoliths. the Mount Murphy xenolith suite.

Silica v major element plots of glasses occurring in the Mount Murphy xenolith suite.

CIPW normative compositions of Mount Murphy xenoliths. 255

Histograms of silica and Mg-number contents in Mount Murphy xenoliths. 256

Silica v major element plots of Mount Murphy xenoliths.

$\mathrm{Al}_{2} \mathrm{O}_{3}$ and $\mathrm{MgO} v$ silica for Mount Murphy xenoliths, showing the control of the mineral assemblage on whole rock compositions.

Silica v trace element plots of Mount Murphy xenoliths.

Multi-element variation diagrams of Mount Murphy xenoliths normalised to MORB (Pearce, 1983).

Rare Earth Element normalised to chondrite (Wheatley and Rock, 1988)

patterns for Mount Murphy xenoliths and clinopyroxene separates.

${ }^{87} \mathrm{Sr} /{ }^{86} \mathrm{Sr} v \mathrm{Mg}$-number plot for Mount Murphy xenoliths and volcanics. 
Figure 6.30 Crystallisation sequence of the Mount Murphy xenolith suite from a primitive mantle melt.

Figure 6.31 Stratigraphic sequence of the Mount Murphy xenolith suite, and secondary processes affecting the lower crust.

\section{Chapter seven: SYNTHESIS OF THE MARIE BYRD LAND LITHOSPHERE}

Figure 7.1

Figure 7.2

Figure 7.3

Figure 7.4

Figure 7.5

Figure 7.6

Figure 7.7

Figure 7.8

Figure 7.9

Figure 7.10

Figure 7.11

Figure 7.12

Figure 7.13

Figure 7.14

Figure 7.15

Figure 7.16

Figure 7.17

Figure 7.18

Figure 7.19

Figure 7.20
Silica v selected major element plots for Marie Byrd Land peridotites. $\mathrm{Cr} v \mathrm{Ni}$ and $\mathrm{SiO}_{2}$ for Marie Byrd Land peridotites.

Rare Earth Element normalised to chondrite (Wheatley and Rock, 1988) patterns for Marie Byrd Land peridotites and clinopyroxene separates. Rare Earth Element normalised to chondrite (Wheatley and Rock, 1988) patterns for Marie Byrd Land peridotites, $\mathrm{Cr}$-diopside veins and clinopyroxene separates.

Silica v selected major element plots for Marie Byrd Land granulites and pyroxenites.

Trace element plots (Ba v Ni, La v Ce and $\mathrm{Zr} v \mathrm{Nb}$ ) for Marie Byrd Land granulites and pyroxenites.

Multi-element variation diagrams of Mount Murphy granulites and pyroxenites normalised to MORB (Pearce, 1983).

Rare Earth Element normalised to chondrite (Wheatley and Rock, 1988) patterns for Marie Byrd Land granulites, pyroxenites, and clinopyroxene separates.

${ }^{87} \mathrm{Sr} /{ }^{86} \mathrm{Sr}$ v Mg-number plot for Marie Byrd Land granulites, pyroxenites, and volcanics.

Silica v selected major element plots for granulites from Marie Byrd Land, the Ross Embayment, the Transantarctic Mountains, Fiordland and

Mount Ruapehu, New Zealand, and southeastern Australia.

Silica v selected major element plots for pyroxenites from Marie Byrd Land, Mount Ruapehu, New Zealand, and eastern Australia.

Trace element plots ( $\mathrm{Ba} v \mathrm{Ni}, \mathrm{Mg \#}$ v Cr, $\mathrm{Zr}$ v Nb, and) for granulites and pyroxenites from Marie Byrd Land, the Ross Embayment, the Transantarctic Mountains, New Zealand, and eastern Australia. Multi-element variation diagrams normalised to MORB (Pearce, 1983) of granulites from Marie Byrd Land, the Ross Embayment, the Transantarctic Mountains, Fiordland and Mount Ruapehu, New Zealand, and southeastern Australia, including average compositions. Multi-element variation diagrams normalised to MORB (Pearce, 1983) of pyroxenites from Marie Byrd Land, the Transantarctic Mountains, and eastern Australia, including average compositions.

Rare Earth Element normalised to chondrite (Wheatley and Rock, 1988) patterns for granulites and pyroxenites from Marie Byrd Land, the Ross Embayment, the Transantarctic Mountains, New Zealand, and eastern Australia.

${ }^{87} \mathrm{Sr} /{ }^{86} \mathrm{Sr} \mathrm{v}{ }^{143} \mathrm{Nd} /{ }^{144} \mathrm{Nd}$ plot for granulites and pyroxenites from Marie Byrd Land, the Ross Embayment, the Transantarctic Mountains, New Zealand, and eastern Australia.

${ }^{87} \mathrm{Sr} /{ }^{86} \mathrm{Sr} v \mathrm{Mg}$-number for Marie Byrd granulites compared to granulites world-wide.

Multi-element variation diagram of Marie Byrd Land granulites normalised to an average lower crustal composition (Rudnick, 1992).

Rare Earth Element diagram of Marie Byrd Land granulites normalised to an average lower crustal composition (Rudnick, 1992).

${ }^{87} \mathrm{Sr} /{ }^{86} \mathrm{Sr} \mathrm{v}{ }^{143} \mathrm{Nd} /{ }^{144} \mathrm{Nd}$ plot for Marie Byrd Land granulites compared to granulites world-wide. 
Figure 7.21 ${ }^{206} \mathrm{~Pb} /{ }^{204} \mathrm{~Pb} \mathrm{v}{ }^{207} \mathrm{~Pb} /{ }^{204} \mathrm{~Pb}$ plot for Marie Byrd Land granulites compared to granulites world-wide.

\section{Chapter eight: LOWER CRUSTAL ARCHITECTURE AND PROCESSES}

Figure 8.1

Figure 8.2

Figure 8.3

Figure 8.4

Figure 8.5

Figure 8.6

Figure 8.7

Figure 8.8
A model geotherm for Marie Byrd Land calculated using P-T estimates of the xenolith suite mineral assemblage.

Cross section of the Marie Byrd Land lithosphere from Mount Murphy to the Executive Committee Range, based on the study of xenoliths.

Styles of metasomatic processes in the Marie Byrd Land lithosphere, including infiltration of silicate melts by the 'blotting paper' and 'plumbing system' styles.

Idealised section through the Marie Byrd Land lithosphere, based on outcrops at the surface and xenoliths entrained in basanitic magmas.

The classification of types of continental crust according to tectonic environment.

Chronostratigraphy of the Transantarctic Mountains, Ellesworth

Mountains, and Marie Byrd Land in Paleozoic times.

Early-mid-Paleozoic tectono-stratigraphic provinces of Antarctica, consisting of the Transantarctic Mountain and Ross Sea provinces.

Tectonic reconstruction model of Marie Byrd Land during the Phanerozoic. 


\section{List of Plates}

\section{Chapter four: THE MOUNT SIDLEY XENOLITH SUITE}

Plate 4.1

Plate 4.2

Plate 4.3

Plate 4.4

Plate 4.5

Plate 4.6

Plate 4.7

Plate 4.8

Plate 4.9

Plate 4.10

Plate 4.11

Plate 4.12

Plate 4.13

Plate 4.14

Plate 4.15

Plate 4.16

Plate 4.17

Plate 4.18

View of Mount Sidley.

Thin section of a Type L granulite from Mount Sidley (sample 90031A). $\quad 54$

Thin section of a Type L granulite from Mount Sidley (sample 90029H1). $\quad 55$

Thin section of a Type M granulite from Mount Sidley (sample 90029Q). 56

Thin section of a Type M granulite from Mount Sidley (sample 90029H). 57

Thin section of a Type C pyroxenite from Mount Sidley (sample 90033H1). 58

Thin section of a Type C pyroxenite from Mount Sidley (sample 90039M1). $\quad 59$

Thin section of a Type P pyroxenite from Mount Sidley (sample 90033C). 60

Thin section of a Type P pyroxenite from Mount Sidley (sample 90033R1). 61

Back-scattered electron image of host melt - xenolith interaction in a Type P pyroxenite (sample 90033Q1).

Back-scattered electron image of host melt - xenolith interaction in a Type L granulite (sample 90039E).

Back-scattered electron image of host melt - xenolith interaction in a Type L granulite (sample 90033X).

Back-scattered electron images of kaersutite replacement of clinopyroxene in a Type P pyroxenite (sample 90033C).

Back-scattered electron image of kaersutite replacement of clinopyroxene in a Type C pyroxenite (sample 90033J).

Back-scattered electron image of oxidation reactions in a Type L granulite (sample 900330).

Back-scattered electron image of oxidation reactions in a Type $M$ granulite (sample 90039V).

Back-scattered electron image of oxidation reactions in a Type L granulite (sample 90033U).

Back-scattered electron image of oxidation reactions in a Type $\mathrm{P}$

pyroxenite (sample 90033F).

\section{Chapter five: THE MOUNT HAMPTON XENOLITH SUITE}

Plate 5.1

Plate 5.2

Plate 5.3

Plate 5.4

Plate $\mathbf{5 . 5}$

Plate 5.6
View of Mount Hampton.

Thin section of a granulite from Mount Hampton (sample PK4A).

Thin section of a granulite from Mount Hampton (sample PK4C1).

Thin section of a pyroxenite from Mount Hampton (sample PK4D1).

Thin section of a pyroxenite from Mount Hampton (sample PK4D).

Back-scattered electron images of oxidation reactions in a granulite

(sample PK4Y). 
Plate 5.7 Back-scattered electron image of oxidation reactions in a granulite (sample PK4A).

Plate 5.8 Back-scattered electron image of oxidation reactions in a pyroxenite (sample PK4S).

\section{Chapter six: THE MOUNT MURPHY XENOLITH SUITE}

Plate 6.1

Plate 6.2

Plate 6.3

Plate 6.4

Plate 6.5

Plate 6.6

Plate 6.7

Plate 6.8

Plate 6.9

Plate 6.10

Plate 6.11
View of Mount Murphy.

Thin section of a granulite from Mount Murphy (sample 90048C).

Thin section of a granulite from Mount Murphy (sample 90041C).

Thin section of a pyroxenite from Mount Murphy (sample 90048D).

Thin section of a pyroxenite from Mount Murphy (sample 90054C).

Back-scattered electron image of host melt - xenolith interaction in a granulite (sample 90041A).

Back-scattered electron image of host melt - xenolith interaction in a granulite (sample 90048E).

Back-scattered electron image of host melt - xenolith interaction in a pyroxenite (sample 90048D).

Back-scattered electron image of an oxidised olivine in a granulite (sample 90041A).

Back-scattered electron image of oxidised olivines in a granulite (sample 90041I).

Back-scattered electron image of an oxidised olivine in a pyroxenite (sample 90054A). 


\section{LIST OF TABLES}

\section{Chapter two: NOMENCLATURE}

Table 2.1

Adjective modifiers for the classification of pyroxenes.

\section{Chapter four: THE MOUNT SIDLEY XENOLITH SUITE}

Table 4.1

Table 4.2

Table 4.3

Table 4.4

Table 4.5

Table 4.6

Table 4.7

Table 4.8

Table 4.9

Table 4.10

Table 4.11

Table 4.12

Table 4.13

Table 4.14

Table 4.15

Table 4.16
Range of modal assemblages in Mount Sidley xenoliths by xenolith type. Representative electron microprobe analyses of Mount Sidley xenolith olivines.

Representative electron microprobe analyses of Mount Sidley xenolith clinopyroxenes.

Estimations of P-T equilibration conditions of the Mount Sidley xenolith suite.

Representative electron microprobe analyses of Mount Sidley xenolith plagioclase's.

Representative electron microprobe analyses of primary Mount Sidley xenolith oxides.

Summary of the petrography and mineral chemistry of the Mount Sidley xenolith suite by xenolith type.

Electron microprobe analyses of host melt - xenolith reactions in a Type $\mathrm{P}$ pyroxenite (sample $90033 \mathrm{Q} 1$ ).

Electron microprobe analyses of host melt - xenolith reactions in a Type L granulite (sample 90039E).

Electron microprobe analyses of host melt - xenolith reactions in a Type L granulite (sample 90033X).

Electron microprobe analyses of kaersutitisation reactions in a Type $P$ pyroxenite (sample 90033C).

Electron microprobe analyses of kaersutitisation reactions in a Type C pyroxenite (sample 90033J).

Representative electron microprobe analyses of secondary Mount Sidley xenolith kaersutites.

Representative electron microprobe analyses of secondary Mount Sidley xenolith rhönites.

Electron microprobe analyses of oxidation reactions in a Type $\mathrm{L}$ granulite (sample 900330).

Electron microprobe analyses of oxidation reactions in a Type $\mathrm{M}$ granulite (sample 90039V). 
Table 4.18

Table 4.19

Table 4.20

Table 4.21

Table 4.22

Table 4.23

Table 4.24

Table 4.25
Electron microprobe analyses of oxidation reactions in a Type $P$ pyroxenite (sample 90033F).

Representative electron microprobe analyses of secondary Mount Sidley xenolith oxides and redox conditions.

Representative electron microprobe analyses of glasses occurring in the Mount Sidley xenolith suite.

Summary of secondary mineral reactions in the Mount Sidley xenolith suite. 117 Representative Mount Sidley xenolith compositions, determined by XRF, and normative mineralogies.

Trace element (including rare earth element) analyses of Mount Sidley xenoliths, determined by INAA.

$\mathrm{Sr}, \mathrm{Nd}, \mathrm{Pb}$ and $\mathrm{O}$ isotopic ratios for Mount Sidley xenoliths and basanites. 129 Summary of the salient characteristics of the Mount Sidley xenolith suite. 135

\section{Chapter five: THE MOUNT HAMPTON XENOLITH SUITE}

Table 5.1

Table 5.2

Table 5.3

Table 5.4

Table 5.5

Table 5.6

Table 5.7

Table 5.8

Table 5.9

Table 5.10

Table 5.11

Table 5.12

Table 5.13

Table 5.14

Table 5.15

Table 5.16

Table 5.17

Table 5.18

Table 5.19

Range of modal assemblages in Mount Hampton xenoliths by xenolith type. Representative electron microprobe analyses of Mount Hampton xenolith clinopyroxenes.

Representative electron microprobe analyses of Mount Hampton xenolith orthopyroxenes.

Representative electron microprobe analyses of Mount Hampton xenolith plagioclase's.

Representative electron microprobe analyses of primary Mount Hampton xenolith oxides and redox conditions.

Two-pyroxene P-T estimates for the Mount Hampton xenolith suite. Summary of the petrography and mineral chemistry of the Mount Hampton xenolith suite by xenolith type.

Sequences of crystallisation of the Mount Hampton xenolith suite.

Electron microprobe analyses of oxidation reactions in a granulite (sample PK4Y).

Electron microprobe analyses of oxidation reactions in a granulite (sample PK4Y).

Electron microprobe analyses of oxidation reactions in a granulite (sample PK4A).

Electron microprobe analyses of oxidation reactions in a pyroxenite (sample PK5S).

Representative electron microprobe analyses of secondary Mount Hampton xenolith olivines in symplectite rims on orthopyroxenes.

Representative electron microprobe analyses of secondary Mount Hampton xenolith oxides in symplectite rims on orthopyroxenes, and in glass veins. Representative electron microprobe analyses of glasses occurring in the Mount Hampton xenolith suite.

Representative Mount Hampton xenolith compositions, determined by XRF, and normative mineralogies.

Trace element (including rare earth element) analyses of Mount Hampton xenoliths, determined by INAA.

$\mathrm{Sr}, \mathrm{Nd}$, and $\mathrm{Pb}$ isotopic ratios for Mount Hampton xenoliths and basanites. Summary of the salient characteristics of the Mount Hampton xenolith suite. 


\section{Chapter six: THE MOUNT MURPHY XENOLITH SUITE}

Table 6.1

Table 6.2

Table 6.3

Table 6.4

Table 6.5

Table 6.6

Table 6.7

Table 6.8

Table 6.9

Table 6.10

Table 6.11

Table 6.12

Table 6.13

Table 6.14

Table 6.15

Table 6.16

Table 6.17

Table 6.18

Table 6.19

Table 6.20

Table 6.21
Range of modal assemblages in Mount Murphy xenoliths by xenolith type. Representative electron microprobe analyses of Mount Murphy xenolith olivines.

Representative electron microprobe analyses of Mount Murphy xenolith clinopyroxenes.

Estimations of P-T equilibration conditions of the site 90044 pyroxenite from Mount Murphy.

Estimations of P-T equilibration conditions of the Mount Murphy xenolith suite.

Representative electron microprobe analyses of Mount Murphy xenolith plagioclase's.

Representative electron microprobe analyses of primary Mount Murphy xenolith oxides.

Representative electron microprobe analyses of primary Mount Murphy xenolith oxide pairs and redox conditions.

Summary of the petrography and mineral chemistry of the Mount Murphy xenolith suite by xenolith type.

Electron microprobe analyses of host melt - xenolith reactions in a granulite (sample 90041A).

Electron microprobe analyses of host melt - xenolith reactions in a granulite (sample 90048E).

Electron microprobe analyses of host melt - xenolith reactions in a pyroxenite (sample 90048D).

Electron microprobe analyses of oxidation reactions in a granulite (sample 90041A).

Electron microprobe analyses of oxidation reactions in a granulite (sample 90041I).

Electron microprobe analyses of oxidation reactions in a pyroxenite (sample 90054A).

Representative electron microprobe analyses of secondary Mount Murphy xenolith oxides.

Representative electron microprobe analyses of glasses occurring in the Mount Murphy xenolith suite.

Representative Mount Murphy xenolith compositions, determined by XRF, and normative mineralogies.

Trace element (including rare earth element) analyses of Mount Murphy xenoliths, determined by INAA.

${ }^{87} \mathrm{Sr} /{ }^{86} \mathrm{Sr}$ ratios and $\mathrm{Rb}$ and $\mathrm{Sr}$ contents of Mount Murphy xenoliths and basalts.

Summary of the salient characteristics of the Mount Murphy xenolith suite. 268

\section{Chapter seven: COMPARISONS OF THE MARIE BYRD LAND LITHOSPHERE}

Table 7.1

Table 7.2

Table 7.3

Table 7.4

Table 7.5
Representative compositions of Marie Byrd Land peridotites, determined by XRF, and normative mineralogies.

Trace element (including rare earth element) analyses of Marie Byrd Land peridotites, determined by INAA.

Summary of the main characteristics of the Marie Byrd land lower crust, based on xenoliths from Mounts Sidley, Hampton and Murphy.

Average compositions of lower crustal xenoliths by locality world-wide, excluding Marie Byrd Land.

Average compositions of granulite xenoliths from Mounts Sidley, Hampton 
Table 7.6

and Murphy, Marie Byrd Land, the Ross Embayment, the

Transantarctic Mountains, and Mount Ruapehu, New Zealand.

Estimates of average lower crustal compositions as deduced from granulite

terrains, and from granulite xenoliths, including this study.

\section{Chapter eight: LOWER CRUSTAL ARCHITECTURE AND PROCESSES}

Table 8.1

Pressure and temperature estimates for Marie Byrd Land lower crustal and upper mantle xenoliths, used to construct a model geothermal gradient for Marie Byrd Land. 


\section{Part One}

\section{INTRODUCTION}

An introduction to the main objectives of this study, to the geology of Marie Byrd Land, West Antarctica, to the study of xenoliths, to the fieldwork undertaken, and to the nomenclature used in this study. 


\section{Chapter one \\ WEST ANTARCTIC XENOLITH STUDIES}

\section{Synopsis}

Marie Byrd Land is one of four major crustal blocks that make up West Antarctica. Prior to rifting at c. $100 \mathrm{Ma}$, Marie Byrd Land, together with the Ross Sea region of Antarctica, Australia, the Campbell Plateau and New Zealand, was a part of the paleo-Pacific margin of the Gondwana supercontinent. Since Oligocene times, Marie Byrd Land has experienced a period of plume related alkaline volcanism.

Studies of the lithosphere of Marie Byrd Land have been hampered by its extensive ice sheet, which covers much of the land mass, and makes accessibility difficult. Basement exposures are rare, with the Fosdick Metamorphic Complex in the Ford Ranges representing the only exposed section of deep crust in Marie Byrd Land, where P-T estimates indicate middle crustal conditions of equilibration. A limited number of geophysical studies have been undertaken in Marie Byrd Land, indicating crustal thicknesses of between 25-35 km, possibly increasing to $40 \mathrm{~km}$ at the coast. The thickness of the lithosphere has been estimated at approximately $100 \mathrm{~km}$.

Suites of lithospheric xenoliths, brought to the surface by alkaline magmas, were collected from Marie Byrd Land, over the summers of 1989-90 and 1990-91. The xenoliths include meta-igneous mafic granulites and pyroxenites, taken here to represent the lower crust, and ultramafic peridotites, considered to represent the lithospheric upper mantle of Marie Byrd Land; the lower crustal-upper mantle boundary lies between these suites (the petrologic Moho). The xenolith suite, which is the subject of this study, presents an opportunity to examine the composition of, and processes occurring within, the lithosphere. 


\subsection{Introduction}

This study is concerned with the description of the Marie Byrd Land (MBL) lithosphere, West Antarctica, based on a suite of lower crustal and upper mantle xenoliths. A limited amount of geophysical studies, restricted by the remoteness of MBL and its extensive ice sheet, have added to our knowledge of the nature of the lithosphere. As xenoliths (fragments of rock brought to the surface by ascending magmas) represent actual samples of the lithosphere at the time of their entrainment, they provide the best means of determining its composition. These results will be integrated with those from other petrological studies, and from geophysical studies, to obtain a better understanding of the MBL lithosphere.

\subsubsection{Objectives of this study}

The primary aim of this study is to determine the composition of the lower crust of MBL, and to compare it to other examples of the lower crust world-wide. In particular, a comparison to other regions that were once joined as the Gondwana supercontinent, including Antarctica, Australia and New Zealand, will be undertaken to achieve this objective. The upper mantle and upper crust, from this work and from other works, will also be documented to establish a model for the structure and composition of the MBL lithosphere as a whole.

Specific problems to be addressed by this study include: the overall composition of the MBL lower crust in particular, and lithosphere in general; petrographic and chemical variations within the lithosphere; the thickness of the crust and P-T conditions derived from mineral equilibria; structural regimes (whether brittle or ductile) and layering in the crust; the origin of the crust; tectonic reconstructions for MBL; and an examination of processes that have modified the crust.

\subsubsection{Thesis organisation}

To achieve the objectives mentioned above, this study is divided into three parts.

\section{Part One: Overview and Background}

Part One consists of the first three chapters, and is an introduction to this work, including the location (Marie Byrd Land, West Antarctica), the nomenclature used, and the background of this study.

Chapter one introduces the study, and outlines its objectives. An overview of MBL, including its tectonic and geologic histories, is followed by a brief 
examination of lithospheric studies, especially those based on xenoliths. Of particular interest are previous lithospheric studies in MBL, the problems and assumptions inherent in xenolith studies, and the recognition of lower crustal xenoliths.

Chapter two presents the various classification schemes adopted in this study, including the classification and textures of igneous and metamorphic rocks, and of minerals (especially of pyroxenes and amphiboles).

Chapter three discusses the background of this study as a part of a larger research programme, and documents the fieldwork undertaken to collect the xenolith suite. The location of the xenolith suites in particular is addressed.

\section{Part Two: The Xenolith Suite}

Part Two, which includes Chapters Four to Six, is a full description of the xenoliths themselves, from three major localities. Each chapter is designed to stand on its own, with no comparison to other xenolith suites. Issues addressed in each chapter include the petrographic and geochemical descriptions of the xenoliths, their mineral assemblages and compositions, $\mathrm{P}-\mathrm{T}$ and redox conditions, secondary reactions that have affected them, the nature of the parental melt, and the structure of the lower crust in that region.

Chapter four documents the lower crustal xenolith suite from Mount Sidley, at the southern end of the Executive Committee Range.

Chapter five documents the lower crustal xenolith suite from Mount Hampton, at the northern end of the Executive Committee Range, some $80 \mathrm{~km}$ to the north of Mount Sidley.

Chapter six documents the lower crustal xenolith suite from Mount Murphy, on the coast of MBL, $450 \mathrm{~km}$ east of the Executive Committee Range.

\section{Part Three: The Antarctic lithosphere}

Part Three, consisting of Chapters Seven to Nine, includes: a comparison of the MBL lower crustal with lower crustal xenolith localities world-wide; a synthesis of the MBL lithosphere, including its composition, structure, and processes responsible for its growth and modification; and a summary of the main conclusions of this work.

Chapter Seven documents the petrologic composition of the upper mantle in MBL, and compares the lower crust to other Gondwana lower crustal regions, including the McMurdo Sound region of Antarctica (the Transantarctic Mountains and the Ross Embayment), Australia (from southeast and east Australia), and New Zealand (from Fiordland, South Island, and Mount 
Ruapehu, North Island). The lower crustal composition from these areas is compared to other lower crustal segments as inferred by xenoliths world-wide. Lower crustal xenoliths from MBL, Antarctica and New Zealand are added to the existing database of lower crustal xenoliths world-wide (Rudnick, 1992) to establish a new average lower crustal composition.

Chapter Eight is a synthesis of the MBL lithosphere, including upper mantle and lower crustal compositions and processes documented in this study, middle and upper crustal compositions from other studies, and from geophysical studies in MBL. This synthesis is used to establish a crustal stratigraphy for MBL, and to construct models for its growth and tectonic reconstruction through time.

Chapter Nine is a brief summary of the salient points of this study, concentrating on the composition of the MBL lower crust (and lithosphere), the structure of the lithosphere and its evolution, and metasomatic processes occurring in the lithosphere.

\subsection{Marie Byrd Land, West Antarctica}

All samples collected and analysed as a part of this study are from Marie Byrd Land, West Antarctica. In order to understand fully the significance of the xenolith suite to their environment (MBL in particular, and Gondwana in general), it is necessary to outline the setting of this region, including its location, tectonic history and geologic history.

\subsubsection{Location and description of the Antarctic continent}

Antarctica (Figure 1.1) underwent a period of cooling at c. $40 \mathrm{Ma}$, and has been covered by continental ice sheets for most of the last c. 14 Ma (Kennett, 1982), with the present ice sheet being stable for the past 2.4-3.0 Ma (Barrett et al., 1992; Harwood et al., 1992; Wilson, 1993). The continent is divided into two tectonostratigraphic regions, West and East Antarctica (Dalziel and Elliot, 1982), separated by the most conspicuous feature on the continent, the Transantarctic Mountains, which rise to over $4000 \mathrm{~m}$ above sea level. The boundary extends from the Transantarctic Mountains to the Pensacola Mountains, and to the eastern Filchner Ice Shelf, all of which are a part of East Antarctica (Laird, 1991a and 1991b; Tingey, 1991). While the continent is covered by ice, much of West Antarctica remains below sea level, forming islands bridged by the ice sheet (Bentley et al., 1960). In contrast, East Antarctica is mostly above sea level. 
Despite the relatively recent discovery of Antarctica, the continent has attracted a relatively large amount of scientific interest, so despite its recent discovery and poor accessibility, a surprising amount is known about the continent.

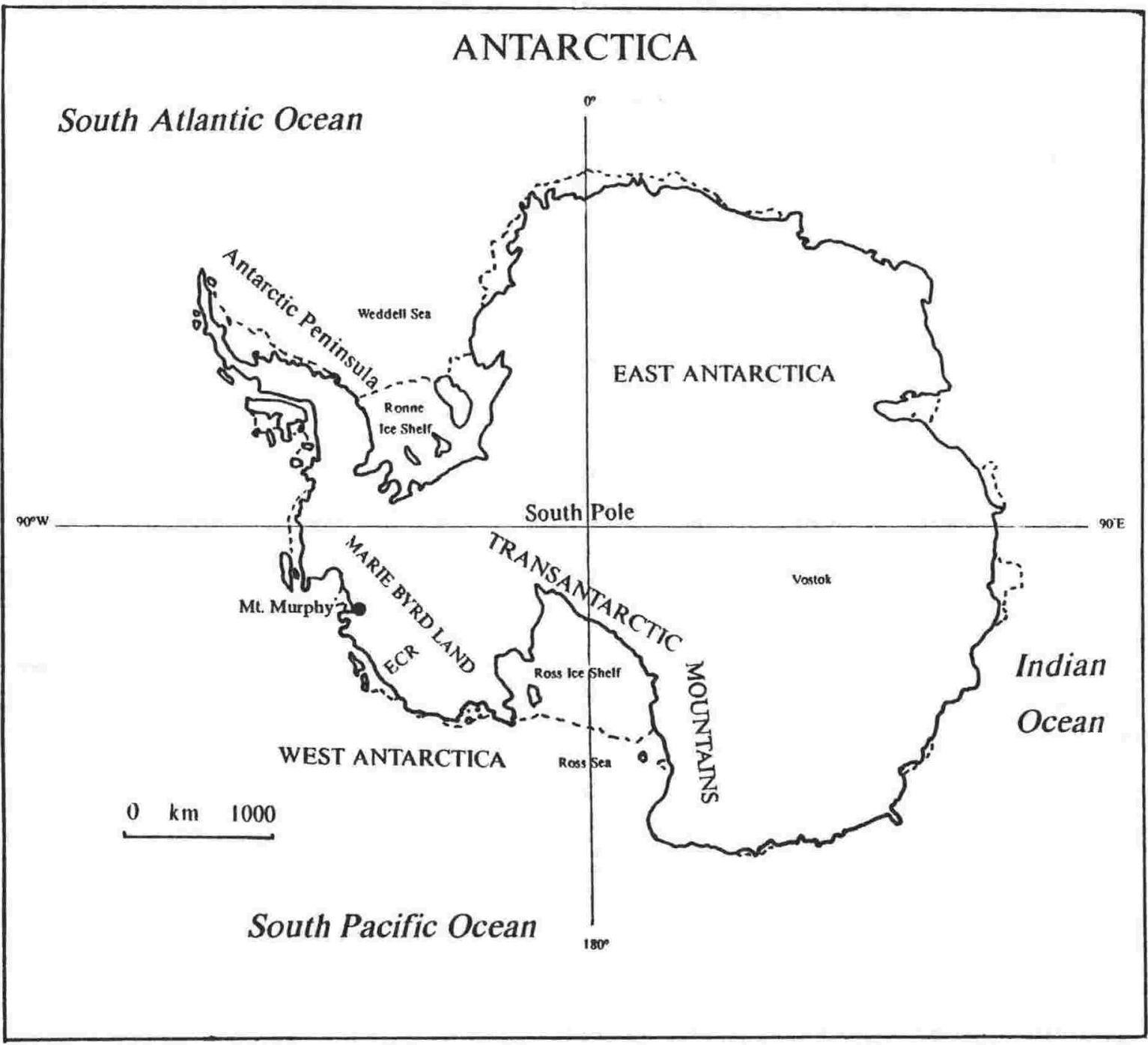

FIGURE 1.1: Map of Antarctica showing the two tectono-stratigraphic regions of West and East Antarctica. The boundary between the two regions runs from the Transantarctic Mountains and the Pensacola Mountains, to the eastern Filchner Ice Sheet, all of which are a part of East Antarctica. The locations of the Executive Committee Range (ECR) and Mount Murphy in Marie Byrd Land, the subject of this thesis, are also shown.

\subsubsection{Tectonic history of West Antarctica}

East Antarctica is a stable craton (a pre-Cambrian shield separated by Proterozoic and younger belts), while West Antarctica appears to be much younger, having been a part of the continental assemblage since Paleozoic times.

West Antarctica is comprised of a number of allochthonous blocks sutured on to East Antarctica to form the Antarctic continent (Cooper et al., 1982; Bradshaw et al., 1983; Borg et al., 1987; Findlay, 1987; Vetter and Tessenshon, 1987). 


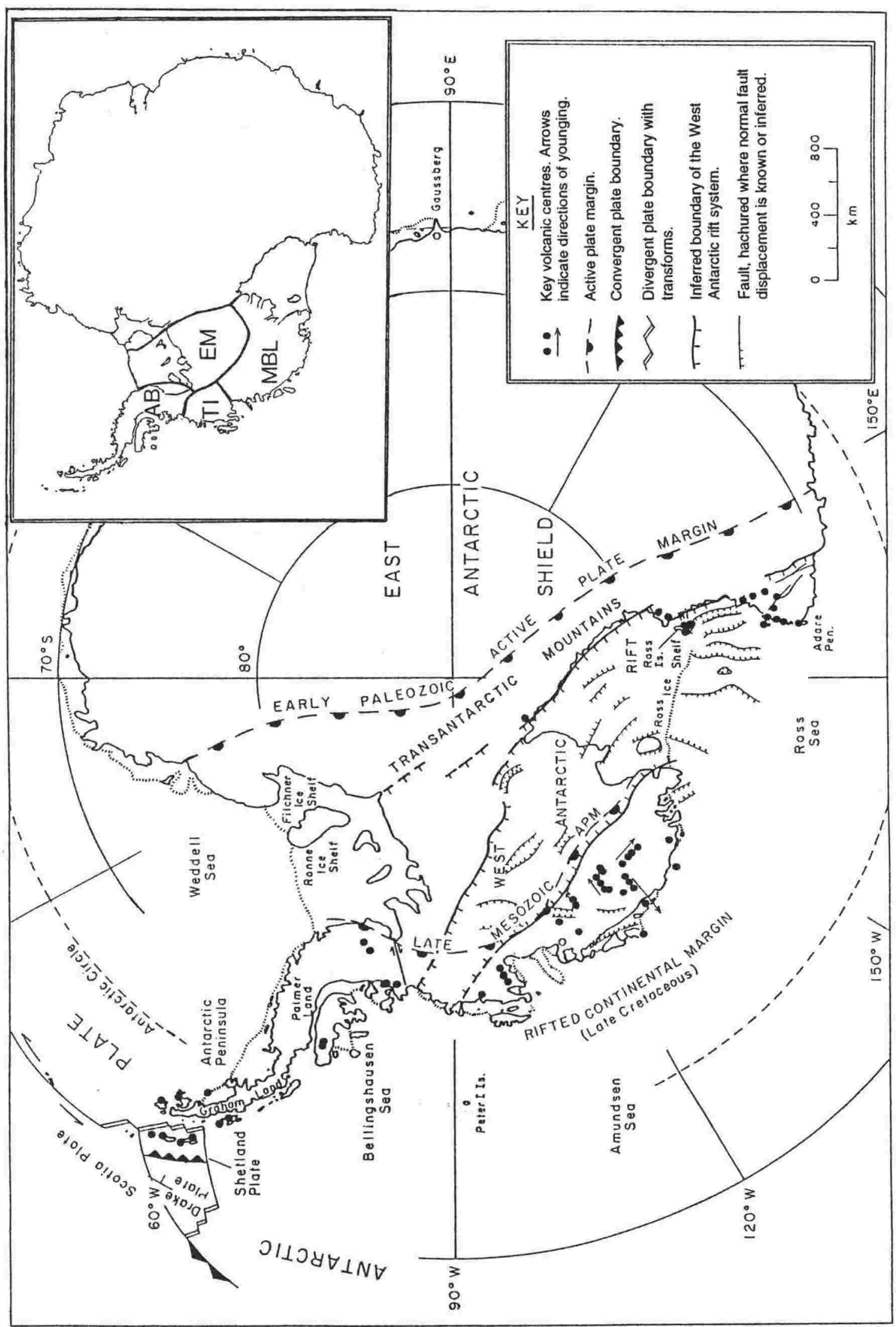


FIGURE 1.2 (opposite): Tectonic Map of West Antarctica (modified from Le Masurier, 1990), showing the approximate positions of the major tectonic features since the Paleozoic, including: the Early Paleozoic Active Plate Margin; the Jurassic Rift (position similar to the West Antarctic Rift); the Late Mesozoic Active Plate Margin; and the West Antarctic Rift. The crustal blocks that make up West Antarctica, consisting of Marie Byrd Land (MBL), Thurston Island (TI), the Ellsworth Mountains (EM) and the Antarctic Peninsula (AP), are shown in the inset.

These are the blocks of Marie Byrd Land (MBL), Thurston Island (TI), the Ellsworth Mountains (EM) and the Antarctic Peninsula (AP) (see inset, Figure 1.2). The present configuration and position of West Antarctica dates from the Jurassic, and reconstructions prior to this time are somewhat ambiguous (Borg et al., 1990; Dalziel, 1991; Hoffman, 1991; Moores, 1991). Tectonic reconstructions for this region are discussed more fully in Chapter 8.3. Since the Jurassic, the West Antarctic lithosphere has experienced events of convergence and divergence, associated with the Late Mesozoic Active Plate Margin, the Jurassic Rift, and the present day West Antarctic Rift and Antarctic Peninsula Convergent Plate Margin (Figure 1.2).
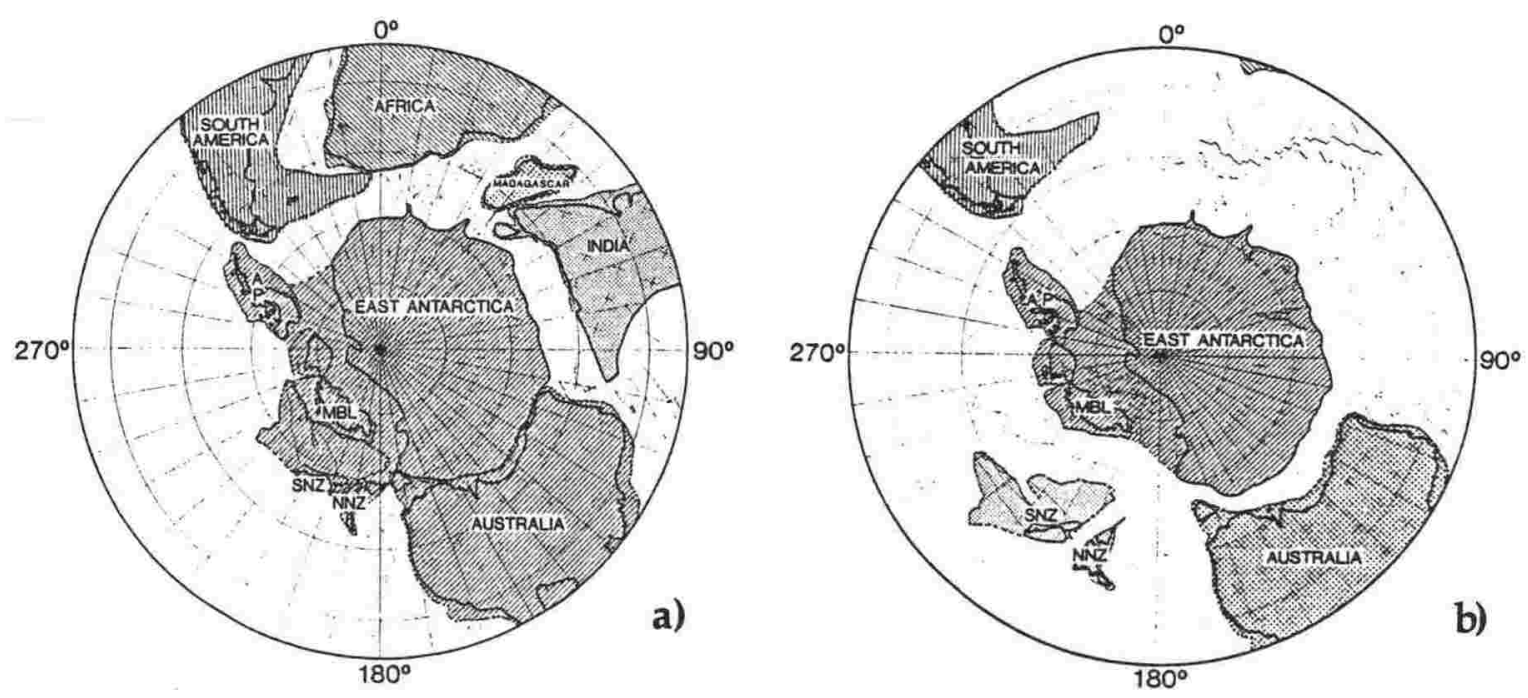

FIGURE 1.3: Position of the crustal blocks of the Gondwana supercontinent (after Lawver et al., 1991) at: a) magnetic anomaly M10 (118 Ma); b) and magnetic anomaly A30 (70 Ma). At $118 \mathrm{Ma}$, West Antarctica, with the exception of Marie Byrd Land, had assumed its present day location with respect to East Antarctica. Rifting between India and Antarctica had also began. By $70 \mathrm{Ma}$, rifting had begun between Antarctica and Australia and between Antarctica and New Zealand. Cenozoic extension between Marie Byrd Land and East Antarctica has resulted in the present day configuration of Antarctica.

Antarctica, Australia and New Zealand were all a part of the Gondwana Supercontinent prior to c. $100 \mathrm{Ma}$ (Grindley and Davey, 1982; Lawver et al., 1991) (Figure 1.3). The break-up of Gondwana occurred in a number of events, which include: 
- the cessation of subduction along the Gondwana margin beneath northeastern Australia and New Zealand by c. 100 Ma (Bradshaw, 1987), and the initiation of stretching between the crustal blocks of this region (Lawver et al., 1991) (Figure 1.3a);

- mid Cretaceous break-up of Australia and Antarctica (Wilkes Land) from c. $95 \mathrm{Ma}$ (Cande and Mutter, 1982; Veevers, 1986) to c. $45 \mathrm{Ma}$ (anomaly 20) at 4.5 $\mathrm{mm} / \mathrm{y}$, and from c. $45 \mathrm{Ma}$ until the present at 22-38 mm/y (Cande and Mutter, 1982) (Figure 1.3b);

- the initiation of sea floor spreading in the Tasman Sea between New Zealand and Australia prior to c. $76 \mathrm{Ma}$ (anomaly 33) (Stock and Molnar, 1982), and possibly as early as c. $100 \mathrm{Ma}$ (Bradshaw, 1987) (Figure 1.3b);

- stretching in the Ross Sea region some time during Late Cretaceous-early Cenozoic time (late Mesozoic, Cooper et al., 1991; Paleocene, Bradshaw 1987), with MBL reaching its present position with respect to Antarctica (Figure 1.3b);

- rifting in Marie Byrd Land from Late Oligocene time to the present (Le Masurier and Rex, 1989; Le Masurier, 1990), which may be plume related (Hole and Le Masurier, 1990; Behrendt et al., 1991; Kyle et al., 1991; Storey and Alabaster, 1991; Behrendt et al., 1992);

- recent active extension in the Ross Sea region (Cooper et al., 1991).

A number of authors have argued that the Antarctic plate itself has remained stationary for the last c. $80 \mathrm{Ma}$ (Herron and Tucholke, 1975: Weissel et al., 1977; Grindley and Oliver, 1983; Stock and Molnar, 1987; Le Masurier and Rex, 1989).

\subsubsection{Geologic history of Marie Byrd Land}

Major centres of late Cenozoic volcanism, which dominate the exposed surface geology of MBL, are shown in Figure 1.4 (including the Executive Committee Range, Mount Murphy and the USAS Escarpment).

The stratigraphic record of MBL is incomplete, with many gaps due to the lack of surface exposures, and periods of non-deposition and erosion. The chronostratigraphy of MBL (Figure 1.5) can be summarised as follows.

The oldest exposed basement in MBL is the Swanson Formation which crops out in the Ford Ranges of the Fosdick Mountains (Figure 1.4). The Swanson Formation is a unit of interbedded sandstone and mudstone, interpreted as gravity flows deposits formed in a submarine fan setting, and suggested to be a potential correlative of the Robertson Bay Group in Northern Victoria Land, Antarctica, and the Greenland Group in Westland, New Zealand. (Bradshaw et al., 1983; Adams, 1986; Laird, 1991a and 1991b). A Rb-Sr radiometric age of c. $450 \mathrm{Ma}$ 
has been obtained on deformed Swanson Formation sediments, and a maximum age of c. $593 \mathrm{Ma}$ is estimated for unmetamorphosed sediments (Adams, 1986). It is unclear whether this maximum age is an age of deposition or a relict age from the source rock of the sediments. A depositional age is supported by the presence of the fossil Palaeodictyon, which is thought to be restricted to Ordovician and younger rocks (Hantzschell, 1975).

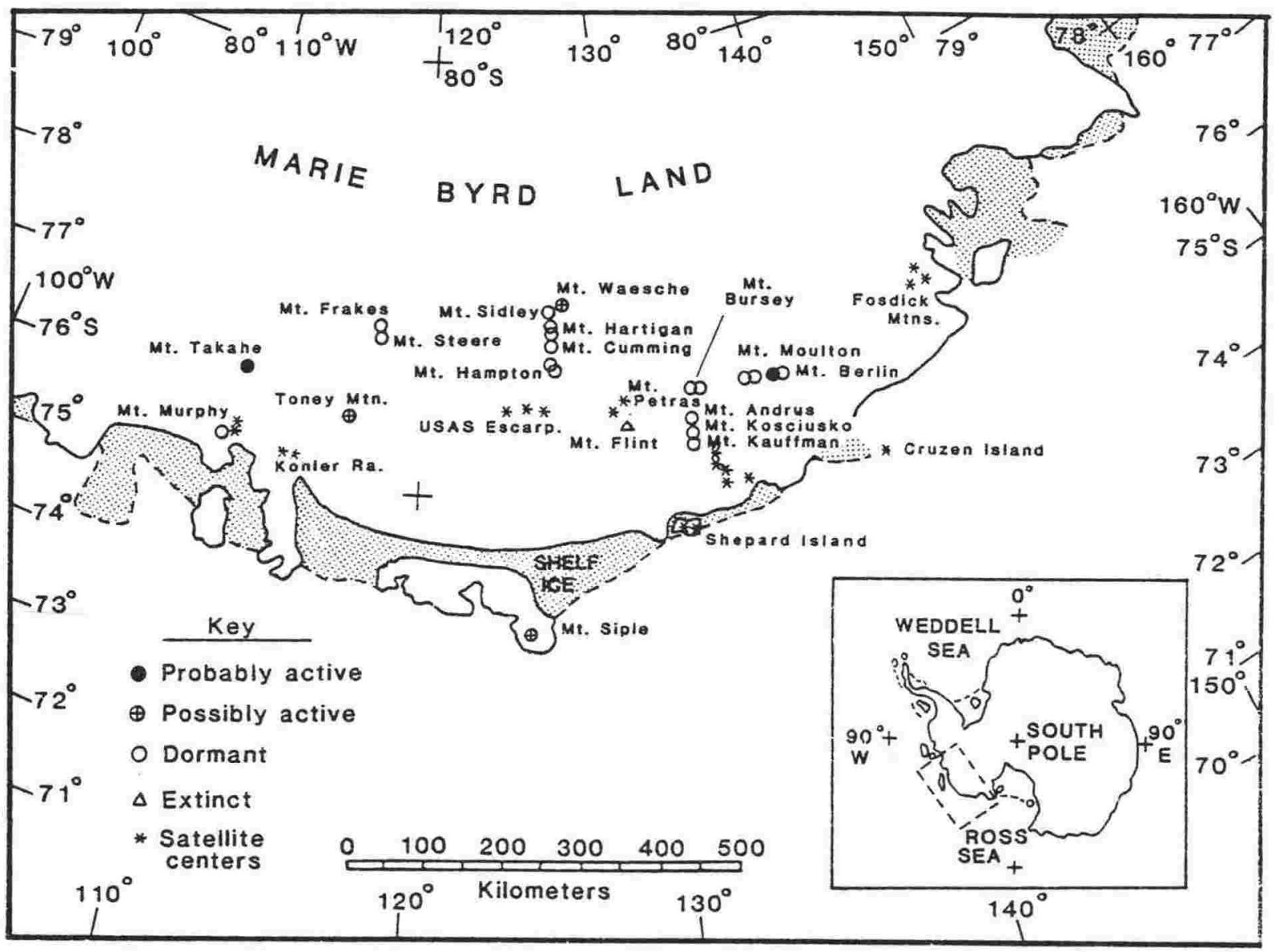

FIGURE 1.4: Map of Marie Byrd Land (from Le Masurier, 1990) showing late Cenozoic volcanic centres and Mountain Ranges. Sites of interest to this study include: Mounts Waesche, Sidley, Hartigan, Cumming and Hampton, of the Executive Committee range (centre); the USAS Escarpment, north of the Executive Committee Range (centre); and Mount Murphy on the eastern coast (left).

The Ross Orogeny (Gunn and Warren, 1962), recognised in many localities in the Transantarctic Mountains, was a widespread deformational event (c. 500 Ma) along the paleo-Pacific margin of Antarctica (Stump, 1982; Borg, 1983; Schmidt, 1983; Weaver et al., 1984; Borg et al., 1987). This event however has not been recognised in MBL, and the deformational age of c. $450 \mathrm{Ma}$, recorded in Swanson Formation sediments, is the oldest recorded tectonic event in MBL (Laird, 1991a and 1991b).

After deposition of the Swanson Formation, there is a break in the stratigraphic record until Late Devonian-Early Carboniferous times, when the 


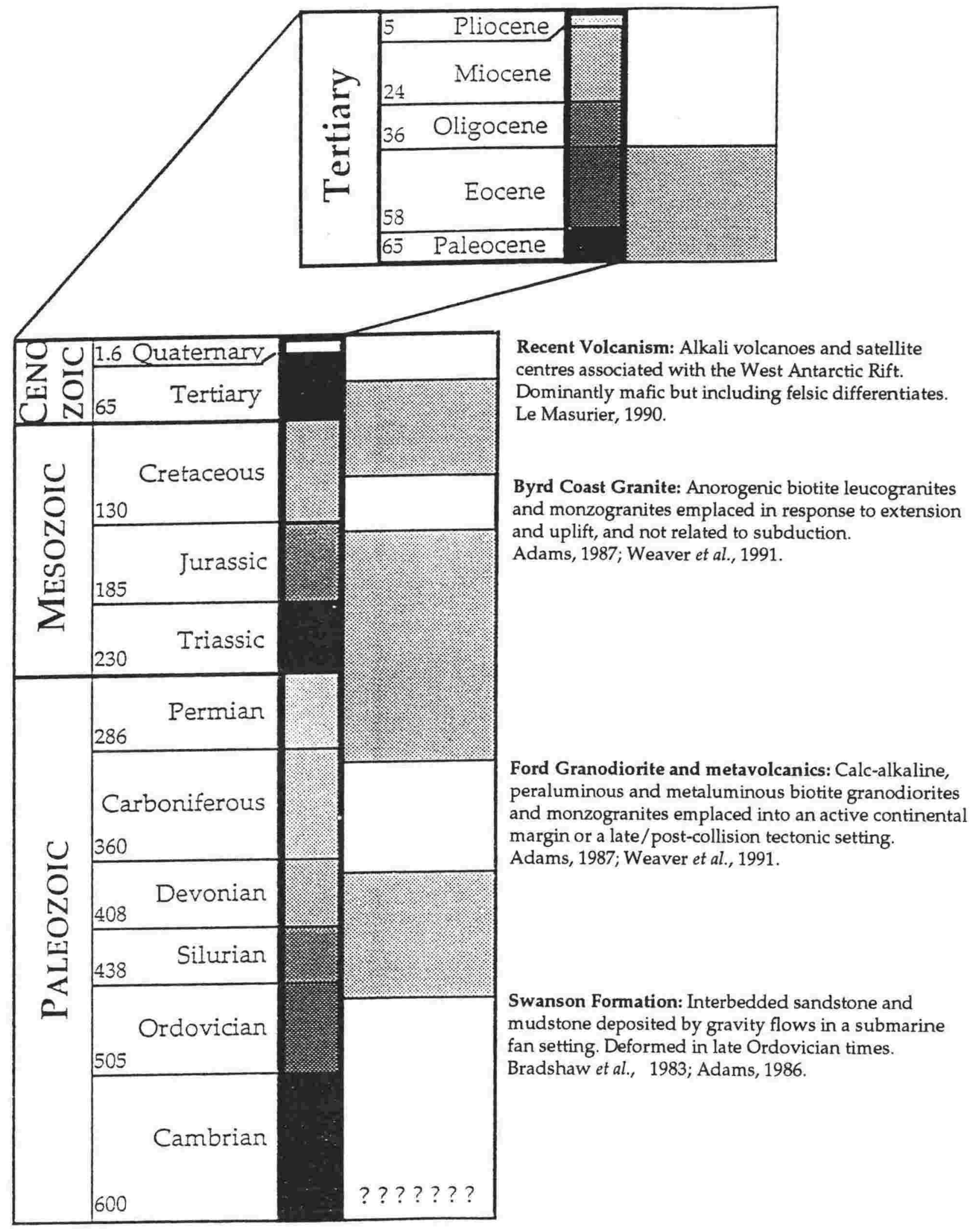

FIGURE 1.5: Chronostratigraphic column highlighting the major geological events in Marie Byrd Land. Shaded areas represent periods of non-deposition, erosion, or lack of exposed lithologies. The lower age of the Swanson Formation is uncertain. Timescale is that of Harland et al. (1982). 
Ford Granodiorite (a calc-alkaline granodiorite-monzogranite suite) was intruded. These have been $\mathrm{Rb}-\mathrm{Sr}$ dated at 380-345 Ma (Adams, 1987). Calc-alkaline metavolcanics (mainly but not entirely andesite) on the Ruppert Coast of MBL also date from this period. Probable correlative metavolcanics from eastern MBL give K-Ar ages of 361-288 Ma (Lopatin et al.,, 1974).

The Fosdick Metamorphic Complex has been interpreted as a metamorphic core complex with a Swanson Formation and granitoid protolith (Bradshaw et al., 1983; Weaver et al., 1991; Luyendyk, et al., 1992). U-Pb zircon dates define a lower intercept age of $353 \mathrm{Ma}$, interpreted as the age of crystallisation of the magma. The upper intercept age is c. $1300 \mathrm{Ma}$ - the oldest date obtained from MBL. This is not a depositional age but is interpreted to reflect the presence of pre-Cambrian continental crust in the source region (Kimborough and Richard, 1991; Richard, 1992).

$\mathrm{U}-\mathrm{Pb}$ zircon dating indicates that migmatization in the Fosdick Metamorphic Complex occurred during the Mesozoic and was coeval with the intrusion of the Byrd Coast Granites which have been U-Pb zircon dated at c. 130 Ma and c. 103 Ma (Richard, 1992; Smith, 1992). The Byrd Coast Granite (Wade et al., 1977a, and 1978; Weaver et al., 1991) is a fractionated suite of anorogenic biotite leucogranites, Rb-Sr dated at $103 \pm 3 \mathrm{Ma}$ (Halpern, 1968), which agrees well with the c. $103 \mathrm{Ma} \mathrm{U}-\mathrm{Pb}$ age.

${ }^{39} \mathrm{Ar}-{ }^{40} \mathrm{Ar}$ dating indicates rapid cooling of the Fosdick Metamorphic Complex between $100 \mathrm{Ma}$ and $94 \mathrm{Ma}$. A mechanism of rapid tectonic uplift is postulated, with the initiation of continental extension preceding the break-up of southern Gondwana (Kimborough and Richard, 1991; Richard, 1992).

The Cenozoic geology of MBL consists of alkaline volcanism argued to be associated with the West Antarctic Rift (Le Masurier, 1990). The exact nature and dimensions of the rift are difficult to assess largely because of the ice cover, although it is estimated to be $750 \mathrm{~km}$ across and $3000 \mathrm{~km}$ long, consisting of a series of block faulted horsts and grabens, likened to the Basin and Range province of western United States (Le Masurier, 1990 and Le Masurier and Rex, 1991). Volcanism is evident as 18 large central volcanoes with more than 30 satellitic volcanic centres extending from late Oligocene time to the present. Some of these volcanoes define linear trends that have been interpreted to represent fracture propagation in a stationary plate environment (Le Masurier and Rex, 1983 and 1989), although a mantle plume initiating rifting has also been postulated for the area (Hole and Le Masurier, 1990; Behrendt et al., 1991; Kyle et al., 1991; Storey and Alabaster, 1991; Behrendt et al., 1992). 


\subsection{Nature of the Lithosphere}

A brief summary of the structure of the lithosphere is presented here as an introduction to the study of lithospheric xenoliths. An in-depth review of the Earths crust and lithosphere, including terminology, is given by White (1988).

\subsubsection{Structure of the lithosphere}

The lithosphere can simplistically be defined as the rigid outer carapace of the Earth, floating on asthenospheric mantle which contains traces of melt. The crust is the outer shell of the lithosphere, with underlying lithospheric mantle comprising the bulk of the lithosphere. Lithospheric mantle and asthenospheric mantle are both a part of the upper mantle (Figure 1.6).

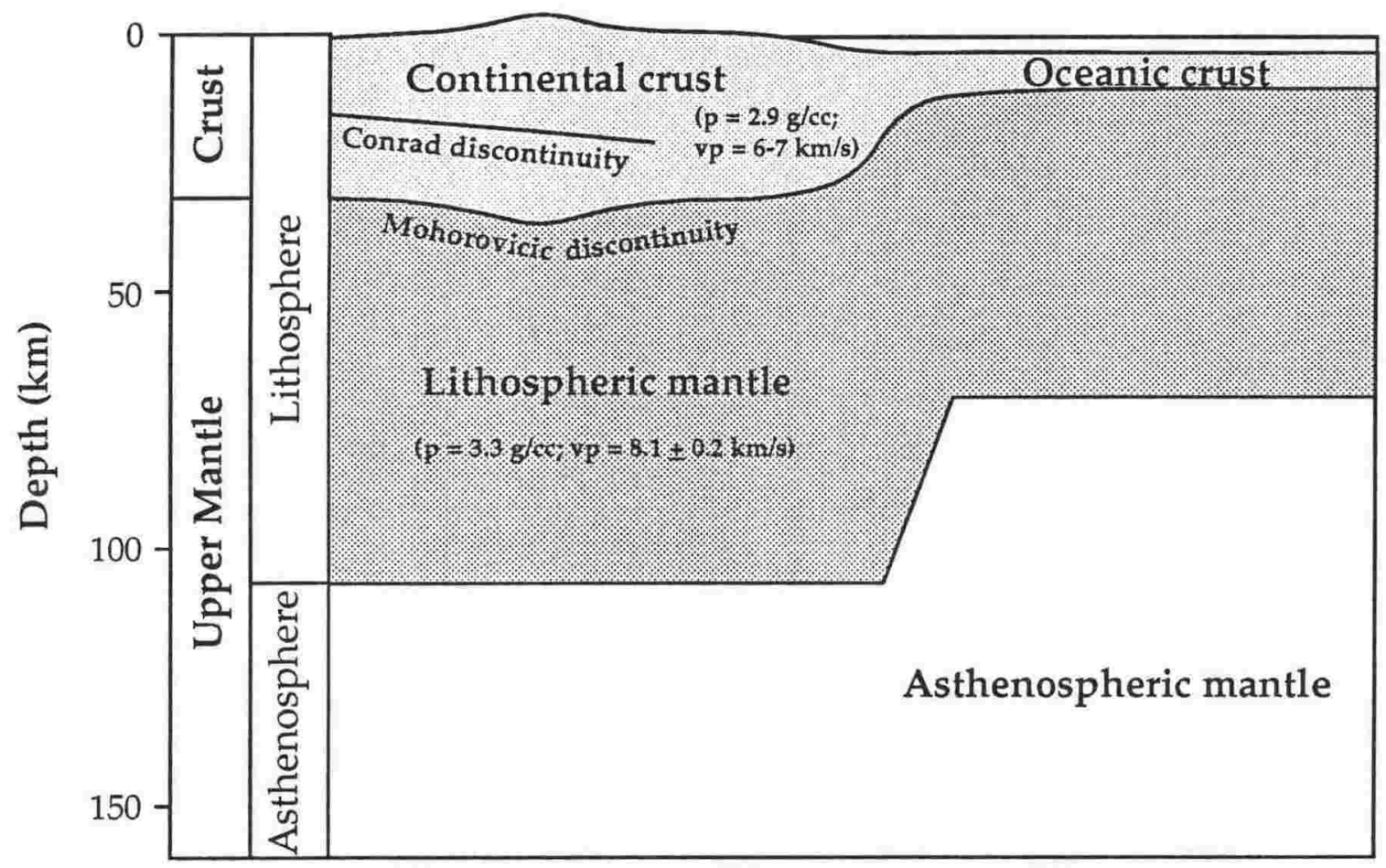

FIGURE 1.6: The Earths outer structure consists of crust (oceanic and continental crust) and upper mantle (lithospheric and asthenospheric mantle), bounded by the Mohorovicic discontinuity (the Moho). The Conrad discontinuity, at $16-18 \mathrm{~km}$, is a seismic transition from lower to higher P-wave velocities, that has been detected in many regions of the continental crust. The lithosphere is a relatively rigid layer consisting of crust and lithospheric mantle, floating on the more fluid asthenospheric mantle. Average densities ( $p$ ) and P-wave velocities (v) are shown for the crust and lithospheric mantle.

The crust can be divided into continental and oceanic segments. Oceanic crust consists dominantly of basaltic rocks (basalts and gabbros) formed at mid ocean ridges, whereas continental crust is more felsic, and variable in composition and age. The thickness of the crust also differs, from thin oceanic crust $(<10 \mathrm{~km}$; average of approximately $7 \mathrm{~km}$ ), to thick continental crust of variable thickness. 
The average density of the crust is $2.9 \mathrm{~g} / \mathrm{cc}$, and seismic velocities (of compressional (P) waves) are typically $6.0-7.0 \mathrm{~km} / \mathrm{s}$ (White, 1988). In many continental crustal localities there is a seismic discontinuity at approximately 16$18 \mathrm{~km}$ (the Conrad Discontinuity), where the seismic velocity of a P-waves rises from 6.0 to $6.7 \mathrm{~km} / \mathrm{s}$ (Dohr and Fuchs, 1967). The boundary between the crust and the lithospheric mantle is a seismically reflective layer termed the 'Mohorovicic discontinuity' (the 'Moho').

Lithospheric mantle consists of ultramafic peridotites, with an average density of approximately $3.3 \mathrm{~g} / \mathrm{cc}$, and a P-wave velocity of $8.1 \mathrm{~km} / \mathrm{s}$. It is rigid compared to the underlying asthenosphere, which consists of similar material that can convert to lithospheric mantle simply by cooling, with no compositional change (White, 1988).

Lithospheric material moves in variable fashion, depending on temperature and depth. This concept is especially important in the study of melt production, and of the maintenance of geochemical (especially isotopic) anomalies in any region of the lithosphere.

The outer layers of the Earth can be divided in three temperature-depth regions; the adiabatic interior, the thermal boundary layer, and the mechanical boundary layer (Parsons and McKenzie, 1978). A model of these regions, based on older oceanic lithosphere, is shown in Figure 1.7.

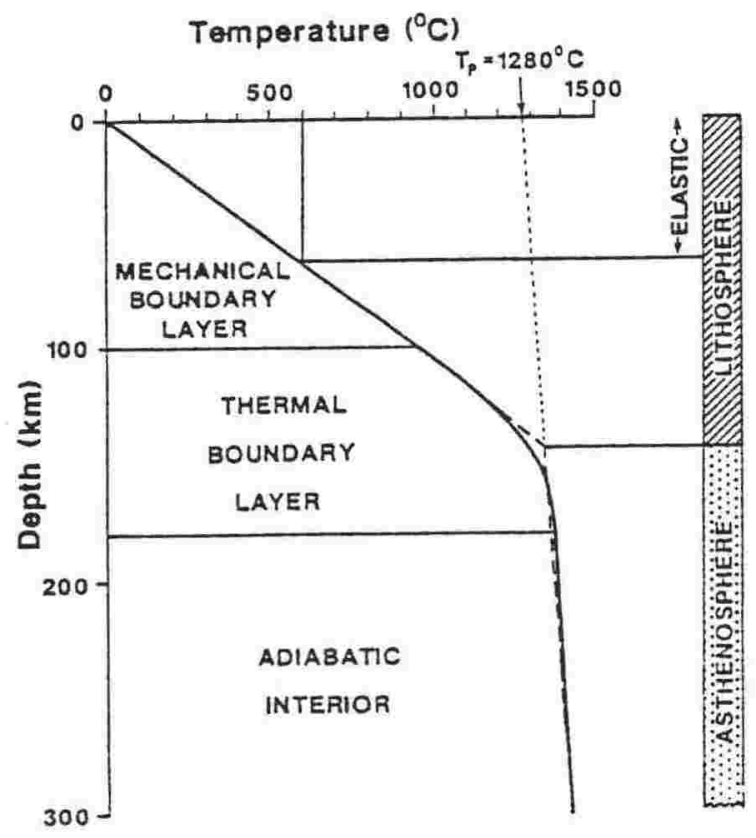

FIGURE 1.7: The outer layers of the Earth can be divided into three boundary layers (Parsons and McKenzie, 1978), beneath the solidus temperature curve, consisting of: a lower adiabatic interior; the thermal boundary layer; and the mechanical boundary layer (from White, 1988). Geochemical anomalies are not preserved in the adiabatic interior, due to vigorous convective mixing, but can be preserved indefinitely in the rigid mechanical boundary layer. There is small scale convection in the thermal boundary, allowing geochemical anomalies to accumulate over short terms. The dotted line is the adiabatic upwelling curve, in the absence of melting, which is $1,280 \pm 20^{\circ} \mathrm{C}$ world-wide.

The adiabatic interior has a Rayleigh number far above critical. Convection results in vigorous mixing of the region, so geochemical anomalies will not be preserved. It has a consistent potential temperature (the temperature it would 
have if brought to the surface adiabatically without melting) world-wide of $1,280 \pm$ $20{ }^{\circ} \mathrm{C}$, although this rises in the vicinity of hot mantle plumes (Courtney and White, 1986).

Above the adiabatic interior is the thermal boundary layer, which has a Rayleigh number close to critical. It is neither vigorously convecting, nor rigid, but intermediate in nature with small scale convection. The temperature gradient changes from curved to linear at the top of the layer. As this layer still moves with respect to the overlying mechanical boundary layer, geochemical anomalies will only accumulate over a short term. The thermal boundary layer marks a transition zone between the adiabatic interior, and the brittle carapace.

The mechanical boundary layer, with a Rayleigh number well below critical, and a linear temperature gradient, moves rigidly with respect to the crust. In this region, geochemical anomalies may be preserved indefinitely.

\subsubsection{Lithospheric studies}

Geophysical methods provide much of the regional information on lithospheric studies. From reflection and refraction data seismic cross-sections of the crust can be constructed, defining such features as the thickness of the crust, structural characteristics and layering observed in the lithosphere. Magnetic, gravity and electrical resistivity studies further add to the data set.

Evaluating the composition of the lithosphere, and the lower crust in particular, has concentrated on metamorphic terrains exposed at the Earths surface. While these exposures provide near-continuous lateral and vertical sections, the rocks have invariably suffered retrograde metamorphism during uplift and have been affected by fluids throughout their metamorphic history. Consequently there is no guarantee that they preserve truly representative sections through the whole of the lower crust, unless upper and lower contacts can be seen. As lower crustal metamorphic terrains are dominantly pre-Cambrian (Weaver and Tarney, 1980a and 1980b; Griffin and O'Reilly, 1987a), they seldom represent the composition of the lithosphere at the present time.

Another means of evaluating the composition of the lower crust is provided by felsic melts sourced from this region and emplaced as granitoids. They do not represent samples of the crust itself, only of melts generated from crustal anatexis which may have been contaminated by upper crustal rocks, or undergone other processes that have obscured their original geochemical features. Furthermore they can only provide information on the nature of their source regions (the lower crust) at the time of their emplacement, and not at the present. 
Isotopic data have been used on granitoids in Antarctica to place important constraints on the lower crust, delineating regions of similar model ages. These studies are important in identifying crustal provinces in Antarctica (Borg et al, 1987; Borg et al., 1990; Borg and DePaolo, 1991).

Lithospheric compositions and processes can also be documented by the study of xenoliths sourced from this region. Xenoliths have the advantage of providing whole rock specimens that have been transported rapidly to the surface from the lithosphere. A full discussion of their advantages and inherent problems follows this section.

\subsubsection{Lithospheric studies in Marie Byrd Land}

The methods outlined above have all been used to some degree in an attempt to understand the lithosphere in MBL. Several independent geophysical studies have ascertained a mean difference in crustal thickness of $5 \mathrm{~km}$ between East and West Antarctic (Evison et al., 1960; Kovach and Press, 1961; Bentley and Ostenso, 1962). Interpretations of gravity anomaly data have placed the thickness of the crust at $30-35 \mathrm{~km}$ in MBL, rising to $40 \mathrm{~km}$ at the coast (Groushinsky and Sazhina, 1982). This contrasts with seismic and other gravity estimations, which show thicknesses of between 25-30 km (Davey and Cooper, 1987; Bentley, 1991).

The thickness of the West Antarctic lithosphere has been estimated at 100 $\mathrm{km}$ (Segawa et al., 1986). Gravity surveys have indicated a low positive gravity anomaly across MBL, with regional highs in the mountains (Bentley, 1991).

As lower crustal sections are not exposed in MBL, the study of metamorphic facies terrains is not applicable to MBL. The only exposure of metamorphic basement is the Fosdick Metamorphic Complex in the Ford Ranges. These sediments have been regionally metamorphosed to amphibolite, and locally to granulite facies at crustal depths of 15-17 km (Smith, 1992). This metamorphic core complex represents (in part at least) the middle section of the crust in MBL.

Devonian-Carboniferous and Cretaceous granitoids (the Ford Granodiorites and the Byrd Coast Granites respectively) are exposed on the coast and in the ranges of $\mathrm{MBL}$, and can be studied to provide clues on the nature of the lower crust at their times of emplacement. Such studies are limited as their occurrence is not widespread. Nevertheless they can provide important information on crustal composition and processes.

Given the limited exposure and logistic problems present in MBL, the study of xenoliths entrained in Cenozoic alkaline volcanoes may contribute most in the attempt to characterise the lithosphere in this region, as they can be found in 
scoria cones throughout $\mathrm{MBL}$, and provide relatively unaltered whole rock samples of the lithosphere at the time of their entrainment.

\subsection{Overview of Xenolith Studies}

The use of xenoliths is relatively recent in the study of the lithosphere compared with other disciplines (Griffin and O'Reilly, 1986; Rudnick, 1992). This section seeks to document lithospheric studies as applied to the MBL lithosphere, to introduce the concept of using xenoliths to study the lithosphere, and to define inherent problems and conflicts with other studies.

\subsubsection{The study of lithospheric xenoliths}

Lithospheric xenoliths have been reported in alkali basalts and kimberlites from every continent including other Antarctic localities (e.g. Berg and Herz, 1986; Kalamarides et al., 1987; Gamble and Kyle, 1987; Gamble et al., 1988; Wörner et al., 1989; Berg, 1991; Kalamarides and Berg, 1991; Berg and Wu, 1992). While they have been reported from localities in MBL (Futa and Le Masurier, 1983; Le Masurier, 1990), this is the first detailed study of lower crustal and upper mantle xenoliths from this region. The xenolith suite documented here consists of peridotites, pyroxenites, granulites and sintered granitoids, which show considerable textural variability and in some instances cross-cutting relations.

The study of xenoliths is not without its assumptions and difficulties. Xenolith studies have disagreed with other studies in several important areas, including the conflict in the definition of the Moho by petrologic and geophysical methods, and the variance between granulite facies rocks exposed at the Earths surface by tectonic processes, uplift and erosion, and those sampled as xenoliths. There are other complications in the study of xenoliths; the problems associated with entrainment in melts at elevated magmatic temperatures; the relationship of xenoliths to each other; possible selective sampling by humans and volcanoes, and the preservation of the xenoliths at the Earths surface.

\section{The seismic Moho $\mathrm{v}$ the petrologic Moho}

The division between the lower crust and upper mantle based on seismic data (the seismic Moho; Figure 1.8) is taken as a change in velocity corresponding to the base of seismic layering of the crust (e.g. Hall, 1986; Matthews, 1986; White, 1988). The Conrad discontinuity has been suggested to correspond with the top of the layering, and to represent the top of the lower crust (Dohr \& Fuchs, 1967; Hall, 
1986). This layering, on a scale of tens to hundreds of metres (Blundell and Raynaud, 1985), may be due to an interlayering between lower crustal rocks and underplated melts (Meissner, 1973; Griffin and O'Reilly, 1986; White, 1988). Other possible causes for the layering include flowage effects (Phinney and Jurdy, 1979; Ramsay, 1982; Hurich et al., 1985), fluids (Matthews, 1986; Matthews and Cheadle, 1986) and sills (McKenzie, 1984; Cheadle et al., 1987). Some xenolith studies also define the lower crust based on seismic data. Rudnick (1992) defines the lower crust as that part of the crust bounded at its base by the Moho, recognised by seismic definition, with its upper boundary as the midpoint of the continental crust.

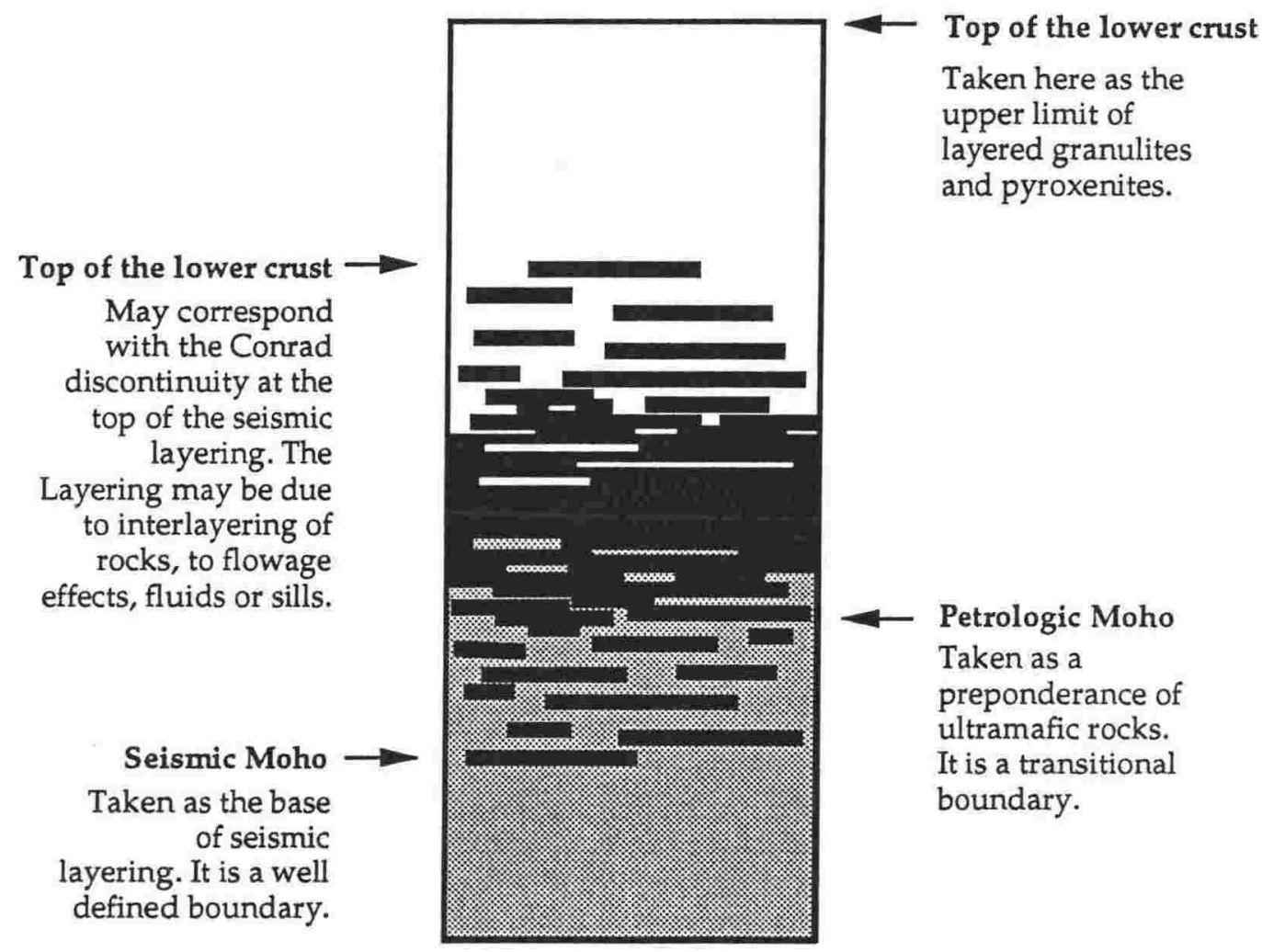

\section{Layered Granulites}

Mafic pyroxenites

Mantle peridotites

FIGURE 1.8: Stylised section through the lithosphere showing the crust-mantle boundary, (the Moho), as defined by seismic (Hall, 1986; Matthews, 1986) and by petrologic (Griffin and O'Reilly, 1986) means. The seismic Moho is typically lower than the petrologic Moho, as layering is also present in the petrologic upper mantle. The difference between the two may be due to re-equilibrium of the seismic Moho to a level independent of lithologic boundaries (Rosendahl et al., 1992). The top of the seismic lower crust is taken to be the top of the layering, which coincides with the Conrad Discontinuity (Dohr and Fuchs, 1967; Hall, 1986). The top of the petrologic lower crust defined in this study is the upper limit of the granulite xenolith suite estimated from P-T calculations. 
The Moho has also been defined by geochemical methods (the petrologic Moho (Figure 1.8); Malpas, 1978). Composite xenoliths indicate an interlayering of spinel lherzolites with pyroxenites and granulites. Clearly granulites and pyroxenites can occur in both the upper mantle and lower crust, showing the boundary between the two to be complex. Petrologically, the Moho is a transitional boundary, defined by a preponderance of ultramafic rocks (Griffin and O'Reilly, 1986; Griffin and O'Reilly, 1987a and 1987b).

The petrologic Moho does not generally correspond with the seismic Moho (Figure 1.8). A partial resolution to this problem is provided by Rosendahl et al. (1992). They consider the Moho to be a temporal or isostatic level that defines the top (and sometimes the base) of a low velocity zone, caused by partial melts or zones of softer and more ductile material. A reflection Moho would then have little relevance to lithology (in terms of a gabbro-peridotite interface), and so crustal thicknesses based on a seismic moho may be incorrect. The original Moho may be erased or obscured as the Moho restores itself to new equilibrium positions.

The definition used in this study follows the petrologic Moho definition of Griffin and O'Reilly (1986) for two main reasons. Firstly, there are no deep seismic data from MBL, so the Moho cannot be identified by these means. Secondly, the xenolith suite consists of ultramafic peridotites, representative of the upper mantle, and a granulite suite taken to represent lower crustal rocks. The pyroxenite suite is typical of Type II upper mantle rocks (Frey and Prinz, 1978) described elsewhere. They are genetically related to, are sometimes interlayered with, and show gradational textures with the granulite suite, rather than the Type I upper mantle (Frey and Prinz, 1978) peridotite suite. They are therefore here considered to be a part of the lower crust. The upper boundary is taken to be the portion of the crust where the granulites and pyroxenites cease to occur, based on P-T estimates (Chapter Eight).

\section{Composition of the lower crust}

The average composition of the crust as determined from many approaches is andesitic (e.g. Poldervaart, 1955; Smithson et al., 1981; Taylor \& McLennan, 1981), with an overall range from 58-63 wt. \% $\mathrm{SiO}_{2}$ (Kay and Kay, 1986). In all these approaches, the composition of the lower crust is the greatest unknown variable, and therefore the major source of potential error.

The composition of the lower crust as defined from xenolith studies shows marked differences from granulite facies rocks exposed at the surface. Mafic compositions are dominant in xenoliths, while granulite metamorphic terrains 
are predominantly felsic. Furthermore, xenoliths tend to be sourced from rocks younger than granulite terrains, many of which are Archean (Weaver and Tarney, 1980a and 1980b; Griffin and O'Reilly, 1986; Bohlen, 1987; Griffin and O'Reilly, 1987; Rudnick and Taylor, 1987; Bohlen and Mezger, 1989; Rudnick, 1992). Possible models for these discrepancies include:

- the lower crust is primarily mafic, but these rocks are not often exposed, perhaps due to higher densities inhibiting uplift. In addition, granulite terrains often contain meta-sedimentary rocks formed at the Earths surface, primarily through continent-continent collision. Granulite terrains are therefore not representative of the lower crust in other tectonic settings;

- mafic xenoliths may represent younger magmatic additions to the crust. As they occur in areas of volcanism, they are selectively and preferentially entrained by the host melts. Xenoliths are therefore not representative of the lower crust in non-magmatic areas;

- granulite xenoliths and terrains may represent different levels of the crust, with typically higher equilibrium pressures for xenoliths than terrains;

- the difference in age may reflect a change in composition with time, reflecting crustal growth processes. The age discrepancy may however simply represent the difficulties of small xenoliths surviving at the Earths surface for any period of time, whereas large terrains are not so easily destroyed. Xenoliths studied tend to come from relatively young volcanoes and typically represent young crust, whereas terrains take a longer time to reach the surface and represent older crust.

Any one of these models, or a combination of them, may be responsible for the granulite xenolith-terrain paradox.

\section{Entrainment of xenoliths}

The host rock of the xenoliths is a magma at an elevated temperature, and ascent is rapid (up to 50 hours at most; Kushiro et al., 1976; Spera, 1980), passing through progressively lower P-T regimes. The modification of the xenoliths due to melt-solid reactions and decompression is likely (Selverstone, 1982: Jones et al., 1983; Emery et al., 1985; Rudnick, 1992; Lee et al., 1993).

Changes in the composition of the xenolith can occur in a number of ways as a result of entrainment in the host magma. The heat inherent in the ascending magma may affect the xenolith, causing melting or at least sintering. Infiltration of the melt itself (or from fluids associated with the melt, including hydrothermal fluids) into the xenolith may cause chemical reactions and change the composition of the xenolith. Decompression reactions, including melting along 
grain boundaries, development of rims on minerals adjusting to a lower P-T regime, and the opening of cracks, can occur during ascent to the surface.

Care must be taken in recognising features due to entrainment from those occurring at source depths. An examination of the xenoliths in this study (Part Two) shows them to be rounded by entrainment, and host rock interaction is noted beyond the millimetre-scale in some suites.

\section{Xenolith relationships and sampling bias}

Another problem due to the mode of ascent of the xenoliths - their entrainment in magmas - is that there is no absolute constraint on the source region of the xenoliths. Analytical methods must be employed to ascertain whether or not the xenolith suite is even related. Furthermore, the xenolith suite can only represent a vertical section through the lithosphere beneath the volcano, and a mixed assemblage at that. The small size of xenoliths means that only a small proportion of the lithosphere is actually sampled, and the probability that large sections have not been sampled is high. Entire sequences may be missing without recognition.

The selective sampling of melts is well known, both from this study and elsewhere (Jackson, 1969; Griffin and O'Reilly, 1986; Griffin and O'Reilly, 1987a; O'Reilly et al., 1989). Sites close together often display very different xenolith assemblages. Furthermore, xenoliths occur in areas of basaltic volcanism and are rare from cratonic areas, providing a definite sampling bias in xenolith studies.

Of particular concern is the relationship of the xenoliths to the host melts. They may be cogenetic, and simply represent cumulates from the host melt in the conduit rather than lithospheric xenoliths. However, they may represent cumulates or melts from the magma, or from earlier episodes of related volcanism, that have underplated, or solidified within, the lithosphere. This distinction is a very important one and is the difference between lithospheric xenoliths per se and host magma conduit cumulates.

A number of factors can help in recognising xenoliths that are not cogenetic with the host magma (Rudnick, 1992):

- metamorphic textures of the xenolith suite precludes derivation from the host melt, however crystallisation from an earlier episode of related volcanism cannot be ruled out;

- chemical analyses of many suites negate derivation from the host magma;

- isotopic signatures of the xenolith often differ from those of the host melt, however isotopic homogenisation of the xenolith suite with the host magma may occur. 
Having identified the many problems inherent in the study of xenoliths, care must also be taken in identifying the suite as being sourced from the lower crust or upper mantle. The similarity of many xenoliths to upper crustal gabbros and cumulates, combined with the inherent problems of xenolith studies previously mentioned, makes the recognition of lower crustal xenoliths in particular more difficult than is immediately apparent.

\subsubsection{Lower crustal conditions and the recognition of lower crustal xenoliths}

The lower crust is believed to be a regime of eclogite and granulite facies conditions. However, these conditions may also extend into the upper mantle and upper crust. An integrated approach of P-T geothermometry, seismic data and a study of peridotites from the same lithospheric column is needed where possible to establish if granulite rocks are from the lower crust, or the upper mantle (Griffin and O'Reilly, 1987; O'Reilly et al., 1989).

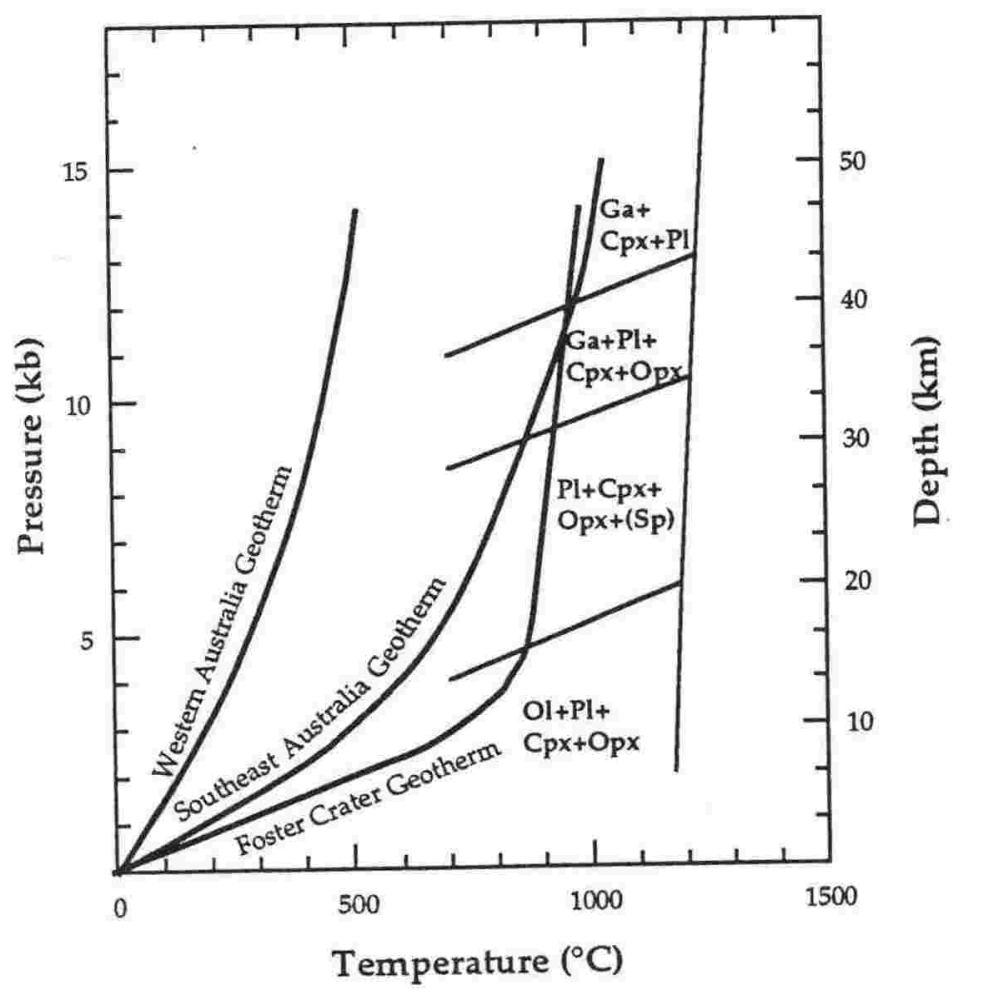

FIGURE 1.9: Geotherms for Foster Crater (Berg and Herz, 1986), Antarctica, and for southeastern (O'Reilly and Griffin, 1985) and western (Sass and Lachenbruch, 1979) Australia, with stable mineral assemblages and estimates of transition zones from granulite to eclogite and spinel peridotite and garnet peridotite (Irving, 1974; Griffin et al., 1984; Griffin and O'Reilly, 1987a). The Foster Crater and southeastern Australia geotherms are high and rift-like, whereas the western Australia geotherm is typical of a stable cratonic shield. $\mathrm{Cpx}=$ Clinopyroxene; $\mathrm{Ga}=$ Garnet; Opx = Orthopyroxene; $\mathrm{Pl}=$ Plagioclase; $\mathrm{Sp}=$ Spinel.

Figure 1.9 depicts the calculated geotherms for Foster Crater (Berg and Herz, 1986) in the Transantarctic Mountains, and of southeastern (O'Reilly and Griffin, 1985) and western (Sass and Lachenbruch, 1979) Australia, together with the P-T conditions and stability fields of mineral assemblages (Irving, 1974). MBL xenoliths include spinel lherzolites and granulites that are garnet-free, indicating that they come from relatively shallow ( $<30-35 \mathrm{~km}$; Irving, 1974) lithospheric depths. 
The identification of lower crustal xenoliths is constrained by several criteria (Griffin and O'Reilly, 1986 and 1987a). Primarily, the xenoliths should not resemble rocks exposed at the surface as they could well have come from these, at upper crustal depths. Secondly, geothermometry estimates should be consistent with inferred lower crustal depths and conditions for the region (Figure 1.9). This is often complicated by freezing in of temperatures and pressures before equilibrium is attained.

Unfortunately in MBL, exposures of basement at xenolith sites are not generally present due to the ice cover. Nevertheless, xenoliths documented in this study are recognised as being from the lower crust on several grounds (see Griffin and O'Reilly, 1986; Rudnick, 1992):

- the similarity of the granulite suite to other xenolith granulites world-wide, where P-T regimes are well constrained, suggests that these xenoliths are derived from similar (lower crustal) depths;

- mineral assemblages and textures are consistent with rocks equilibrated to granulite facies. P-T estimates of granulites and pyroxenites are in agreement with their derivation from the lower crust (Chapter 8.2.3);

- development of decompression features suggests rapid ascent of the xenoliths from deep crustal levels;

- their restricted occurrence in mantle-derived primitive alkaline host lavas suggests that they originated from deep levels in the crust;

- upper mantle peridotites and upper crustal granitoids are easily identifiable in the xenolith suite, and the occurrence of the granulite suite in association with upper mantle and upper crustal xenoliths indicates that they are from lower crustal (and possibly middle crustal) depths. 


\section{Chapter two \\ NOMENCLATURE}

\section{Synopsis}

There is presently an abundance of rock, texture and mineral nomenclature in the literature, resulting in an ambiguity of definitions and terminology. This chapter seeks to clarify the terminology used in this study, by summarising the classification schemes adopted herein. All the rock classification schemes are based on modal mineralogy, normalised to 100 per cent.

The total alkali-silica (TAS) diagram of Le Bas et al. (1986), which is based on the schemes of Le Maitre (1984) and Zanettin (1984), is used here for the classification of associated volcanic rocks and glasses. Plutonic rocks are classified according to their modal mineral assemblage, particularly the proportion of mafic to felsic mineral phases (Streckeisen, 1976). These include the meta-igneous xenoliths documented in this work, including granulites, pyroxenites and peridotites. Many of the xenoliths are cumulates (or had cumulate protoliths), and their textures are described according to the definitions of Wager and Brown (1968) and Irvine (1982).

Polygonal fabrics of equant grains with well developed $120^{\circ}$ triple junctions have overprinted primary igneous textures in many xenoliths that have been metamorphosed under granulite facies conditions. Igneous layering evident in many plagioclase-bearing cumulates is preserved (and mostly enhanced) by metamorphism. Granulites are defined here as plagioclase-bearing rocks that have equilibrated to granulite facies conditions (O'Reilly et al., 1989).

Mineral nomenclature generally follows the schemes of Deer et al. (1966), with the exceptions of pyroxenes, classified according to Morimoto et al. (1988), and amphiboles, defined according to the scheme of Leake (1978). 


\subsection{Introduction}

Identical terms often have different meanings according to different classification schemes. The purpose of this section is to define the terminology and nomenclature used in this study, in order to avoid any confusion of terms. The schemes favoured in this study are adopted primarily because they are in widespread use, particularly in the field of xenolith studies. Adopting these schemes allows easy comparison of this study with past works, especially in the use of diagrams which cannot be compared unless they are based on the same criteria, and use the same nomenclature.

\subsection{Rock Nomenclature}

Rock classifications schemes are discussed here according to rock type; volcanic, plutonic and metamorphic. In all cases classifications are based on modal mineralogy where possible, and are recalculated to 100 per cent. This is followed by an examination of cumulate and metamorphic textures.

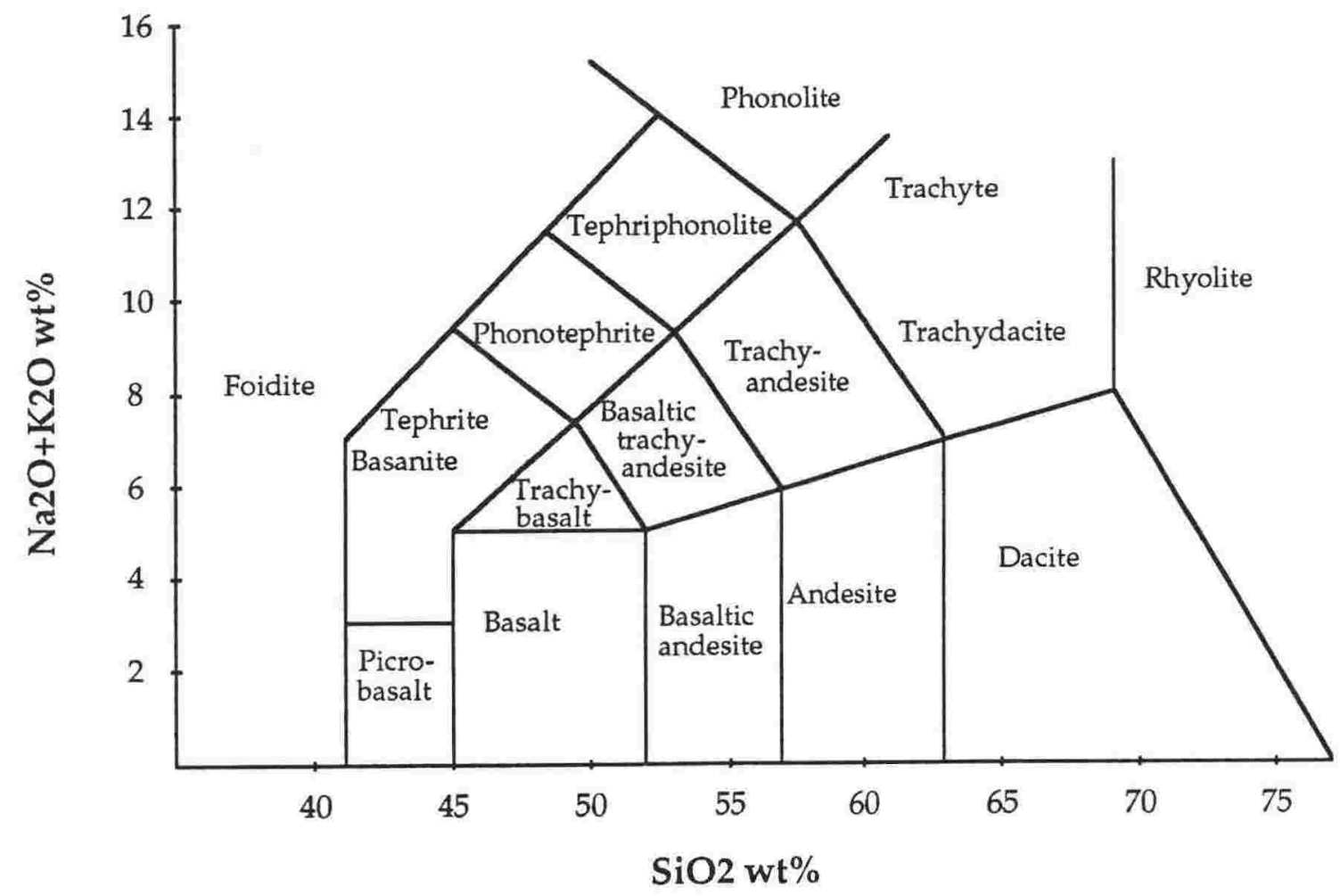

FIGURE 2.1: Total alkali $\left(\mathrm{Na}_{2} \mathrm{O}+\mathrm{K}_{2} \mathrm{O}\right)$ - silica (TAS) diagram for the classification of volcanic rocks (from Le Bas et al., 1986). Ultrabasic rocks have < $45 \mathrm{wt}$ \% $\mathrm{SiO}_{2}$, basic rocks between $45-52 \mathrm{wt} \%$ $\mathrm{SiO}_{2}$, intermediate rocks between $52-63 \mathrm{wt}$. $\% \mathrm{SiO}_{2}$, and acidic rocks have $>63$ wt. $\% \mathrm{SiO}_{2}$. 


\subsubsection{Volcanic rock classification}

The classification of volcanic rocks adopted in this study follows the scheme of Le Bas et al. (1986), which is based on those of Le Maitre (1984) and Zanettin (1984), and is in widespread use in the classification of volcanic rocks (see Wilson, 1989).

Volcanic rocks are classified according to their total alkali $\left(\mathrm{Na}_{2} \mathrm{O}+\mathrm{K}_{2} \mathrm{O}\right)$ and silica contents, plotted on the biaxial Total Alkali-Silica (TAS) diagram (Figure 2.1). For a full list of criteria used in its development and restraints of use, see Le Bas et al. (1986).

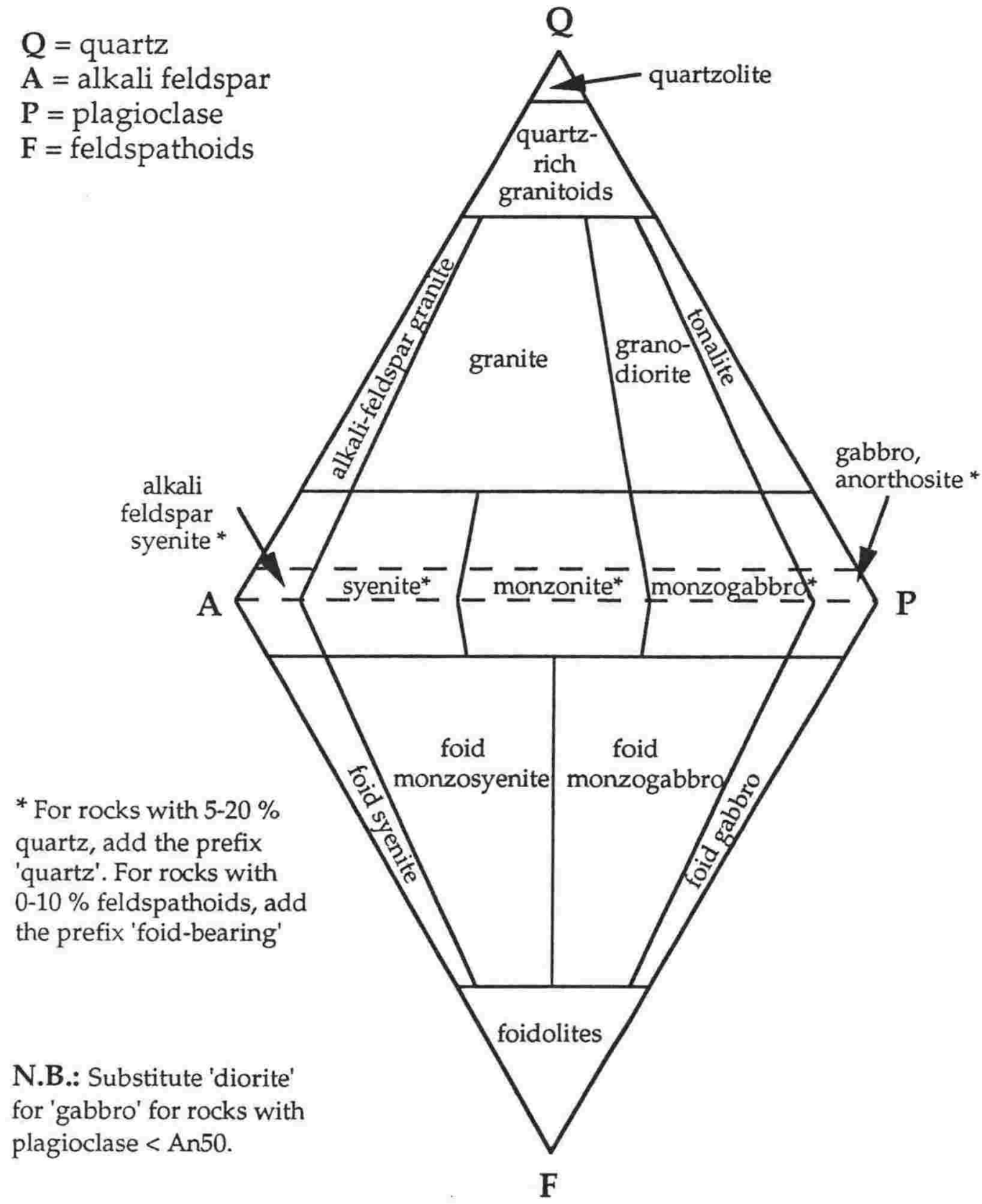

FIGURE 2.2: QAPF diagram of Streckeisen (1976) for the classification of plutonic rocks with less than $90 \%$ mafic minerals by volume. 


\subsubsection{Plutonic rock classification}

The xenoliths in this study (including those with metamorphic textures) are classified as plutonic rocks according to the scheme of Streckeisen (1976) and Frey and Prinz (1978). Genetic terms are not used in this scheme; cumulate rocks are not distinguished from plutonic rocks derived from melts or from restites. As grain size in the xenolith suite is large, classification is based solely on the modal mineral assemblage, and not on normative compositions.

Streckeisen's classification scheme is based primarily on the proportion (by volume) of mafic minerals relative to felsic minerals in the rock, normalised to $100 \%$. Mafic minerals include olivine, pyroxene, amphibole, mica, opaque minerals, apatite and other accessory minerals. The proportion of these minerals is the ' $M$ ' content.

Where $\mathrm{M}$ is less than $90 \%$, classification is based on the proportion of felsic minerals (Figure 2.2). Rocks are plotted and named according to their $Q$ (quartz), A (alkali feldspar; albite, anorthoclase, perthite, microcline and orthoclase), P (plagioclase feldspar ( $\left.\mathrm{An}_{5-100}\right)$ and antiperthite) and $\mathrm{F}$ (feldspathoid) component. Gabbroic rocks are further classified by Figure 2.3a which takes the mafic mineral content into account. A subdivision of gabbroic rocks into gabbro, gabbronorite and norite is made based on the proportion of orthopyroxene, clinopyroxene and plagioclase (Figure 2.3b). Plagioclase-rich gabbros are denoted by the prefix 'leuco-', and plagioclase-poor gabbros are prefixed 'mela-'. Hornblende (> 5\%) bearing gabbros are classified according to Figure 2.3c. A distinction can also be made between gabbro (and norite) and diorite, according to the average plagioclase composition in the rock; if the average plagioclase composition of a gabbro is < $\mathrm{An}_{50}$, then it is termed a diorite.

Plutonic rocks with $>90 \% \mathrm{M}$ are ultramafic in composition, and classified according to Figure 2.4a. If the modal proportion of hornblende is $>5 \%$, Figure $2.4 \mathrm{~b}$ is referred to instead. For rocks with more than $5 \%$ additional minerals present (e.g. biotite or oxides) a prefix is added to the name (e.g. chromite dunite). If contents are in excess of $50 \%$ the nomenclature is reversed (e.g. olivine chromitite). Garnet contents of $\leq 5 \%$ are indicated by the modifier 'garnetbearing', and garnet contents $>5 \%$ are indicated by the modifier 'garnet' (e.g. garnet-bearing lherzolite, and garnet lherzolite).

\subsubsection{Metamorphic rock classification}

Metamorphic xenoliths are classified individually in this study by the plutonic scheme previously outlined, although as a group they are termed by their metamorphic facies; e.g. granulite facies. The various P-T conditions of 


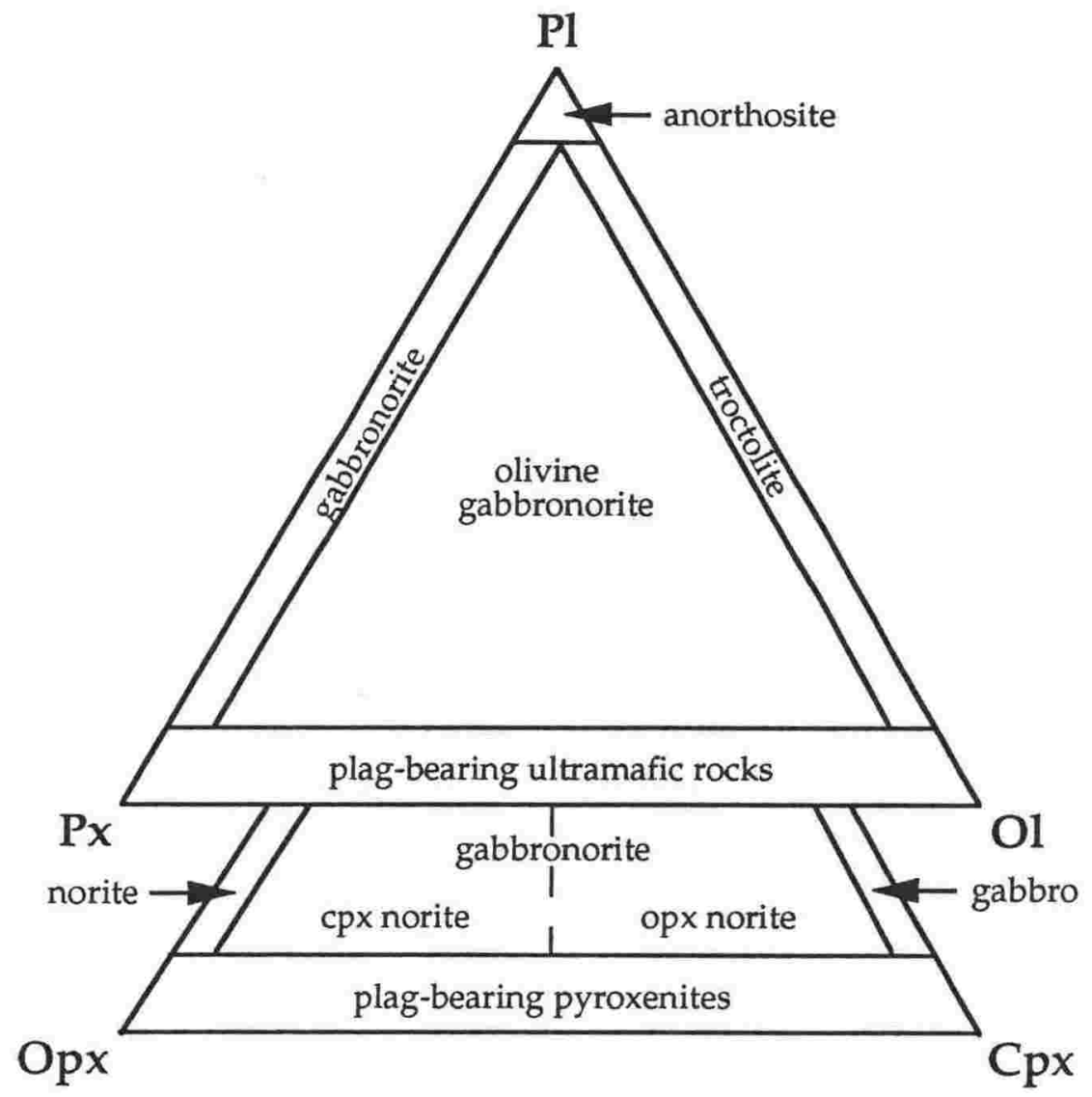

a)

b)

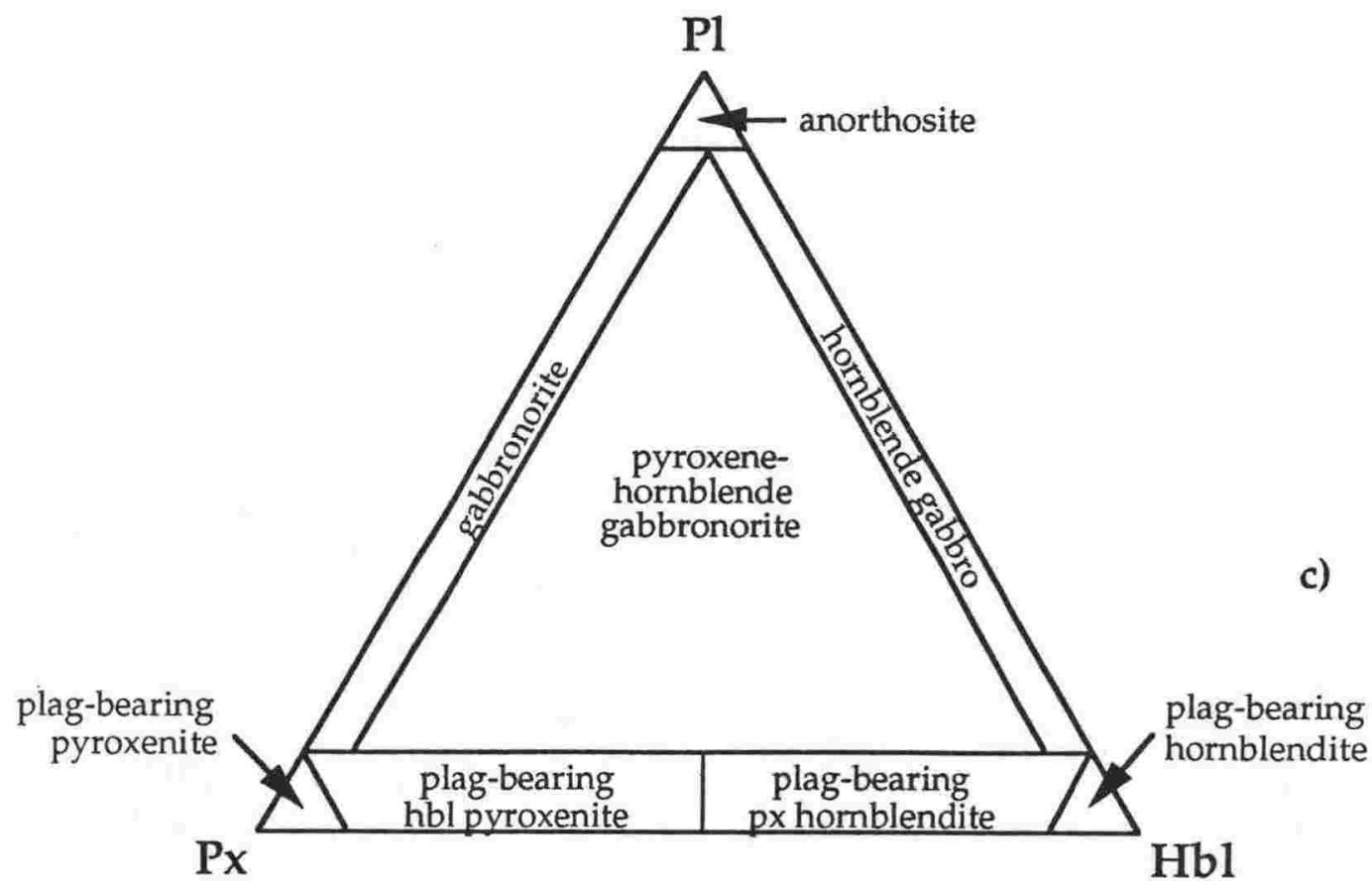

FIGURE 2.3: Classification diagram (after Streckeisen, 1976) for: (a) gabbroic rocks; (b) with a subdivision into gabbro, gabbronorite and norite; (c) and for hornblende-bearing (>5\%) gabbroic rocks. $\mathrm{Cpx}=$ Clinopyroxene; $\mathrm{Hbl}=$ Hornblende; $\mathrm{Ol}=$ Olivine; $\mathrm{Opx}=$ Orthopyroxene; $\mathrm{Pl}=\mathrm{Plagioclase} ;$ $\mathrm{Px}=$ Pyroxene. 

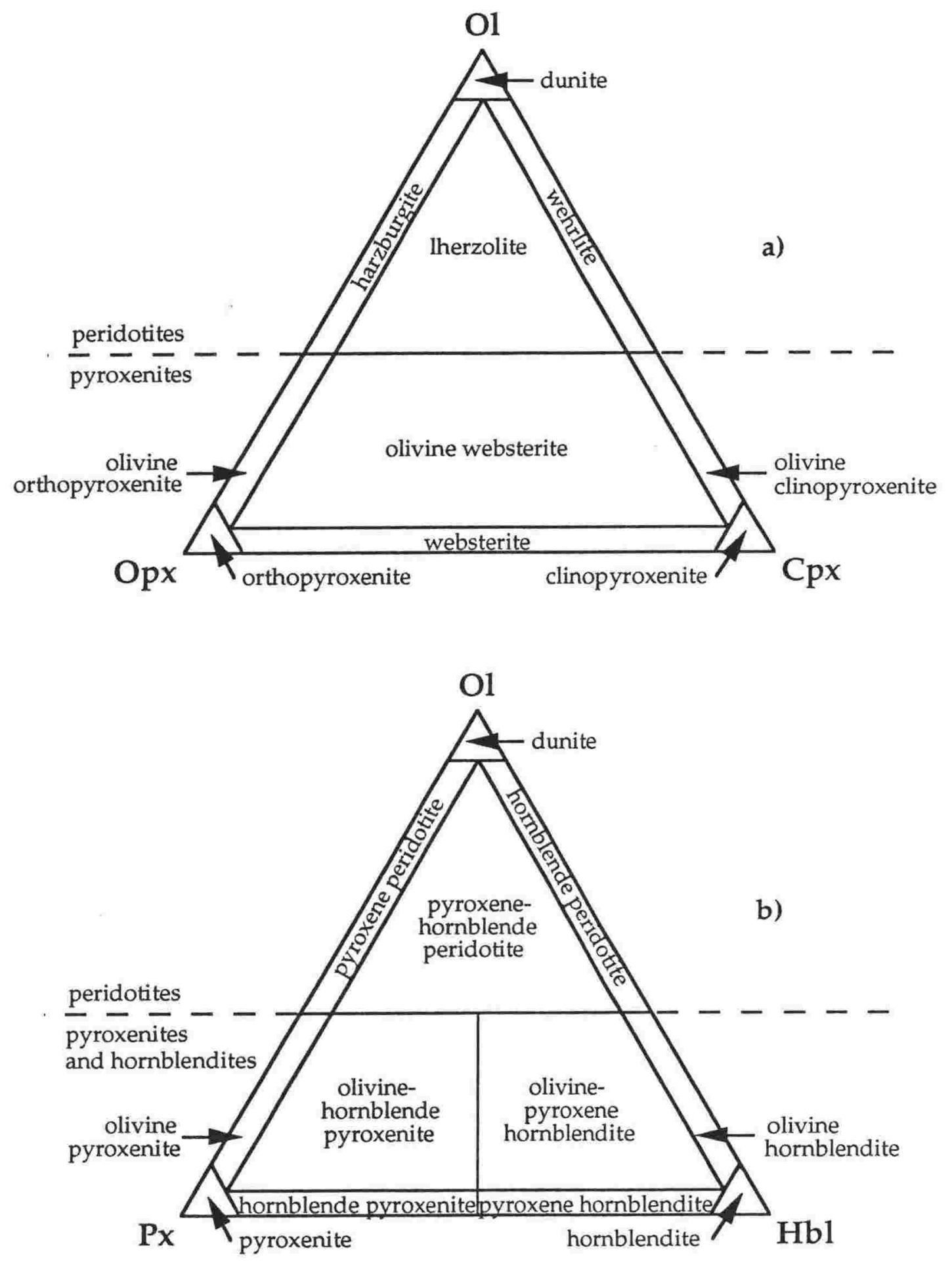

FIGURE 2.4: Classification diagram (after Streckeisen, 1976) for ultramafic rocks composed of: a) olivine and pyroxene; b) and olivine, pyroxene and ( $>5 \%)$ hornblende. Abbreviations are as for Figure 2.3.

metamorphic facies are summarised as Figure 2.5. Boundaries between these facies are not clear cut. 


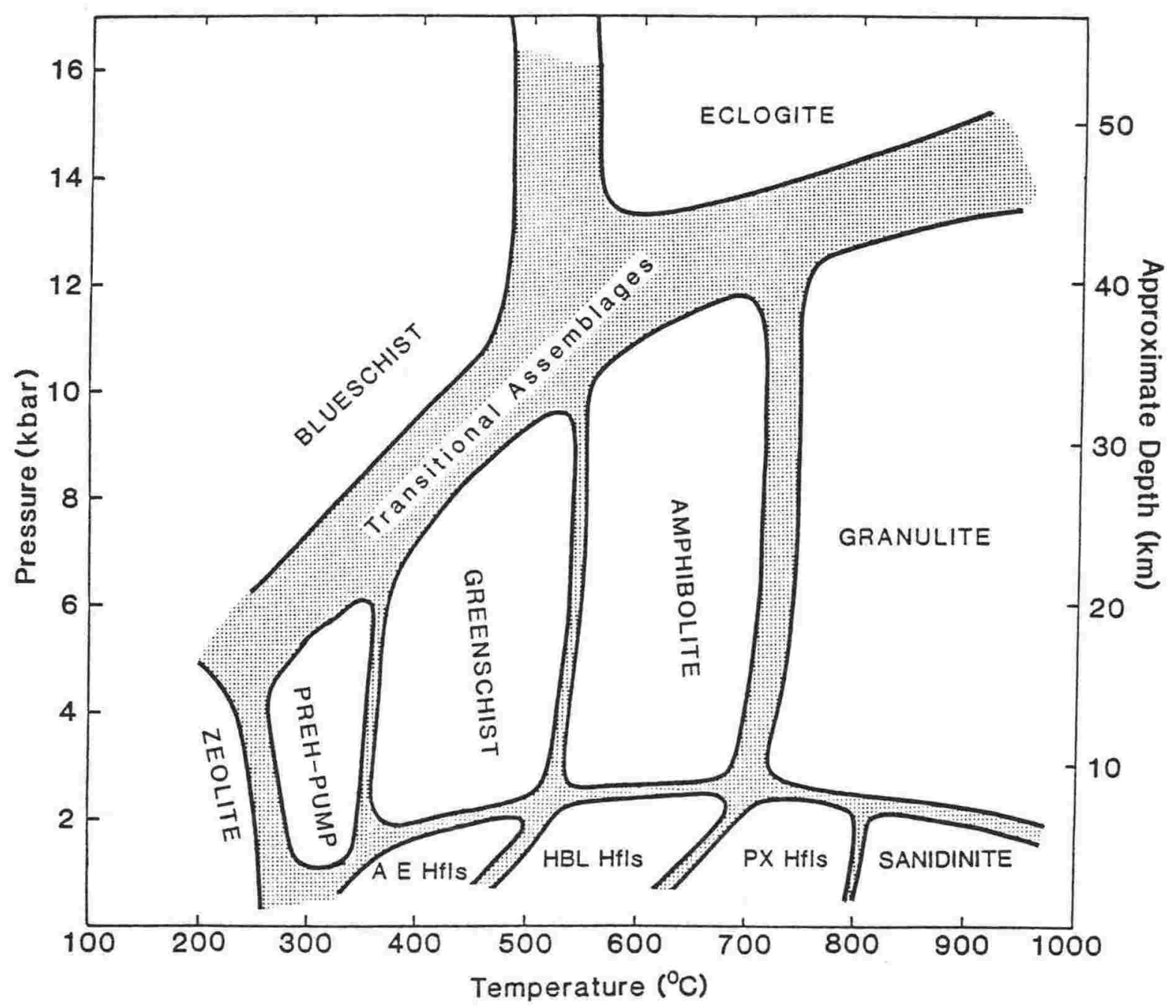

FIGURE 2.5: P-T conditions over which various metamorphic facies form (from Yardley, 1989). Boundaries are not rigid but transitional, and are represented as stippled bands. $\mathrm{AE}=$ albite-epidote; $\mathrm{HBL}=$ hornblende; Hfls = hornfels; $\mathrm{PREH}-\mathrm{PUMP}=$ prehnite-pumpellyite; $\mathrm{PX}=$ pyroxene. Note the high- $\mathrm{T}$ and variable-P conditions of the granulite facies.

The identification and classification of lower crustal xenoliths is based on the identification of granulite facies characteristics as discussed in Chapter One. The definitions of granulite and eclogite facies (facies generally considered to be consistent with lower crustal conditions) used in this study are based on those of O'Reilly et al. (1989).

Granulites are plagioclase-bearing rocks that may also contain pyroxene(s) or garnet. Eclogites contain Na- and Al-rich clinopyroxene with or without other pyroxenes, garnet, quartz or kyanite. These should be equilibrated to their respective facies conditions (Chapter 1.3.3). Both facies may be derived from protoliths ranging from primitive mafic melts to sedimentary rocks. 


\subsubsection{Rock textures}

Textures in the xenolith suite are particularly important in understanding their origin and subsequent development, as well as their geochemical characteristics. Of particular importance is the development of metamorphic textures over cumulate protoliths, which is common in the MBL xenolith suite.

\section{Cumulate rocks}

The interpretation and classification of cumulate textures is discussed by Wager and Brown (1968) and Irving (1982), and only a brief summary is presented here (Figure 2.6).

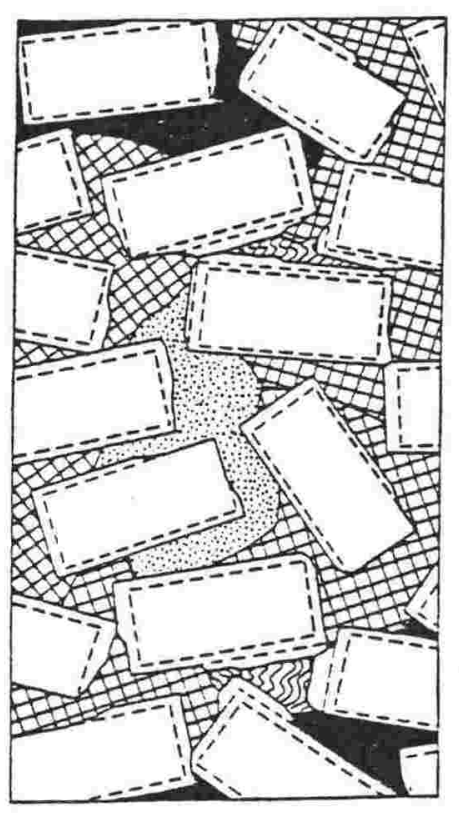

A

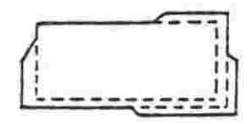

PLAGIOCLASE: Boundary of the cumulus crystals (labradorite) diagrammatically shown by the innermost rectangle. The limits of medium and low temperature zones, where developed, shown outside the cumulus crystal boundaries.
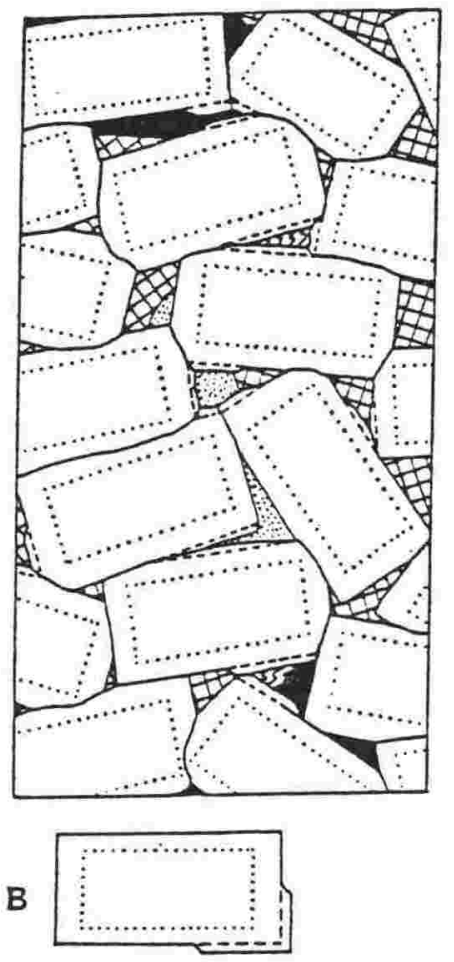

PLAGIOCLASE: Boundary of the cumulus crystals (labradorite) shown by the dotted line. Outside is adcumulate growth of plagioclase of similar composition. In places beyond the broken lines, lower temperature zones are shown.

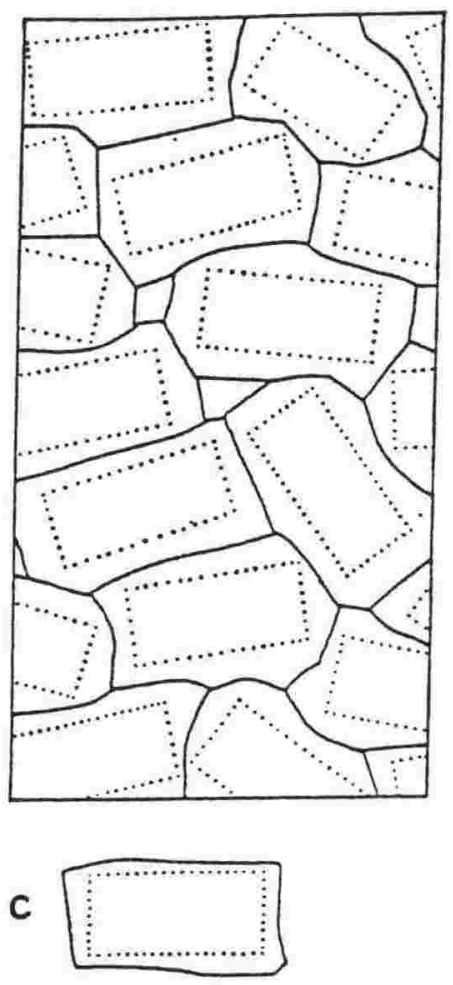

Plagioclase: The cumulus part of the crystal is shown within the dotted line. This has been enlarged by growth of more plagioclase of the same composition, which fills the crystal interstices.
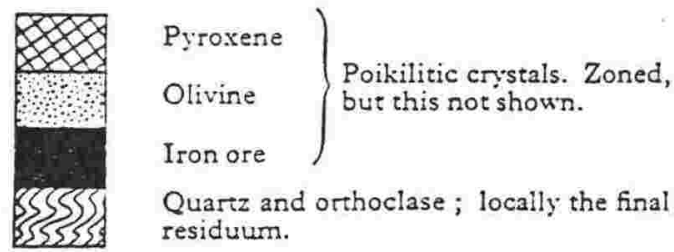

Quartz and orthoclase; locally the final residuum.

FIGURE 2.6: Development of cumulate textures from a basic magma (from Wager and Brown, 1968) showing: a) plagioclase orthocumulate; b) plagioclase mesocumulate; c) and plagioclase adcumulate. See text for further discussion. 
The term cumulate refers to rocks formed by the crystallisation of cumulus crystals that settled out from a fractionating melt. The liquid that cumulus crystals are enclosed in is the intercumulus liquid. This liquid may react with the cumulus minerals by diffusion, or by forming overgrowths on the crystals, or it may crystallise as intercumulus crystals.

Adcumulates form when the intercumulus liquid is squeezed out, leaving unzoned cumulus crystals. If the intercumulus liquid solidifies within the cumulate, the rock develops an orthocumulate texture. Mesocumulates have textures intermediate to these extremes.

(a)

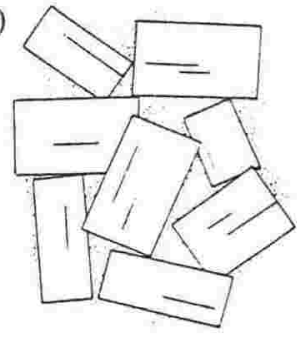

(c)

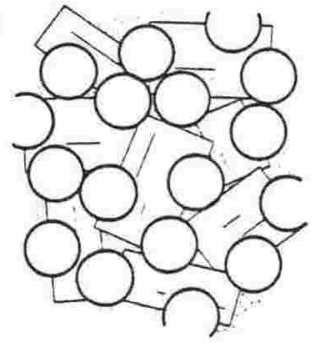

(e)

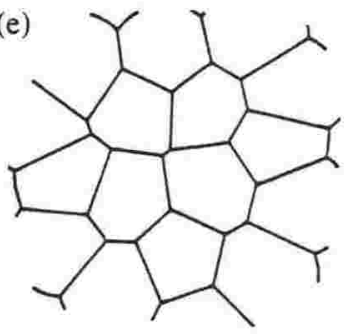

(b)

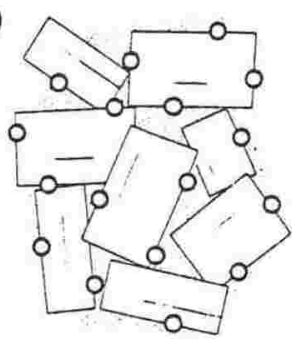

(d)

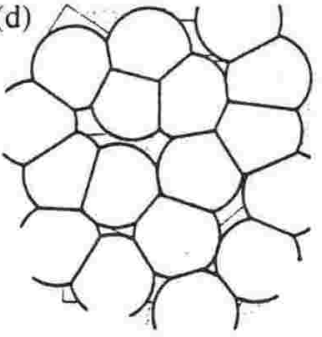

(f)

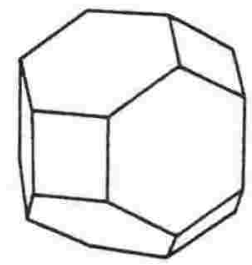

FIGURE 2.7: Schematic model depicting the recrystallisation of an igneous fabric by solid state crystal growth, into a metamorphic crystalloblastic fabric with polygonal grains (after Best, 1982). a) Initial rock with an igneous fabric. b) Development of nucleation and initial growth of stable minerals (small circles). ce) Continued growth of grains until recrystallisation is complete with a crystalloblastic fabric, showing well developed $120^{\circ}$ angles between equant grains. f) Representation of a single polygonal grain, with a truncated octahedron shape.

\section{Metamorphic rocks}

Recrystallisation of the protolith takes the form of solid-state crystal growth of stable mineral phases by nucleation. This results in crystalloblastic fabrics, consisting of polygonal grains, typically of similar grain size, that grow together to form $120^{\circ}$ angle triple-junctions. A schematic representation of this process from an igneous protolith is presented as Figure 2.7. 


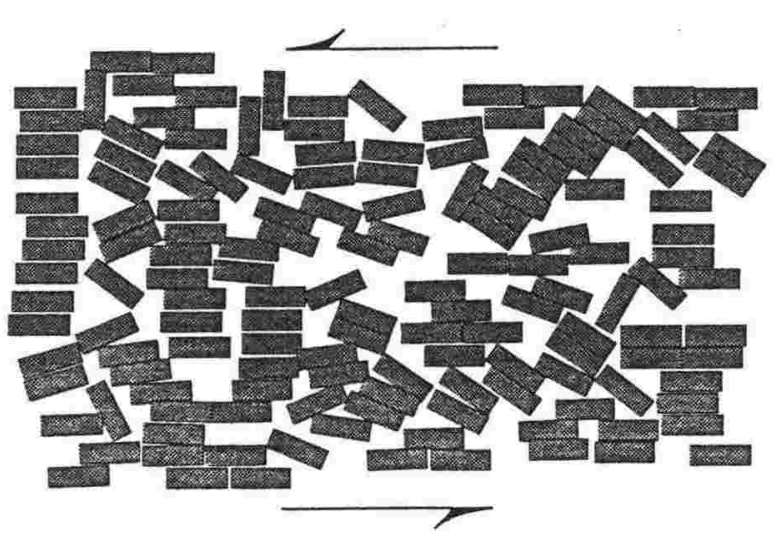

a)

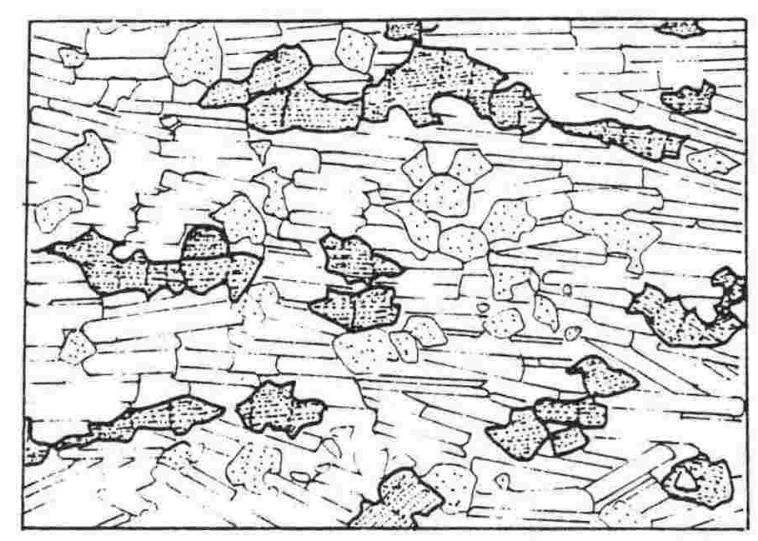

b)

FIGURE 2.8: Layered fabrics (a) developed by paraffin rods (representing plagioclase laths) in shear and compaction experiments, with a melt fraction below $35 \%$ (Freydier, 1991), is similar to the fabric of a layered gabbro (b) from Oman ophiolite (Nicholas et al., 1993; drawing of thin section). The layered fabric has resulted from the preferred orientation of plagioclase laths due to magmatic foliation. Igneous layered fabrics are evident in the Marie Byrd Land xenolith suite (e.g. Plate 4.2). Patterns for (b) are: unpatterned area = plagioclase; heavy outlines with dotted lines = olivine; dot pattern $=$ pyroxene.

An understanding of the development of metamorphic facies from a cumulate protolith is especially important in the study of the MBL xenolith suite. This process is similar to that outlined in Figure 2.7, resulting in the recrystallisation of cumulate textures to crystalloblastic fabrics. An important aspect in the development of overprinted metamorphic fabrics on cumulate protoliths is the occurrence of layered textures in some cumulates.

Layered textures in igneous rocks result from the preferential layering of minerals (especially rectangular plagioclase laths) in the magma chamber, by settling or due to magmatic foliation. Figure 2.8a indicates how layered fabrics developed in shear and compaction experiments, where the melt fraction is below $35 \%$ (Freydier, 1991). Figure 2.8b is an example of this texture in layered gabbros from the Oman ophiolite (Nicholas et al., 1993).

Identical textures to those of Figure 2.8 can be seen in the MBL xenolith suite (e.g. Plate 4.2), where metamorphic recrystallisation of layered cumulates has resulted in polygonal fabrics that maintain layering (and in some cases enhance layering), producing layered granulites. Polygonal plagioclase typically nucleate from igneous plagioclase laths within the original plagioclase boundary. In unlayered igneous xenoliths, polygonal fabrics develop by nucleation as shown in Figure 2.7. 


\subsection{Mineral Nomenclature}

Mineral nomenclature is generally more straightforward than rock nomenclature, although the possibilities are many and varied. Minerals are named according to groups as outlined in Deer et al. (1966) on the basis of general formulae and chemical characteristics. The nomenclature of most minerals (e.g. olivine, plagioclase, oxides and rhönite) follow this scheme; the exception being pyroxene and amphibole.

All mineral analyses were determined by electron microscopy, as outlined in Appendix Three. Iron is measured as $\mathrm{FeO}$, with $\mathrm{Fe}^{2+}$ and $\mathrm{Fe}^{3+}$ being recalculated assuming stoichiometry.

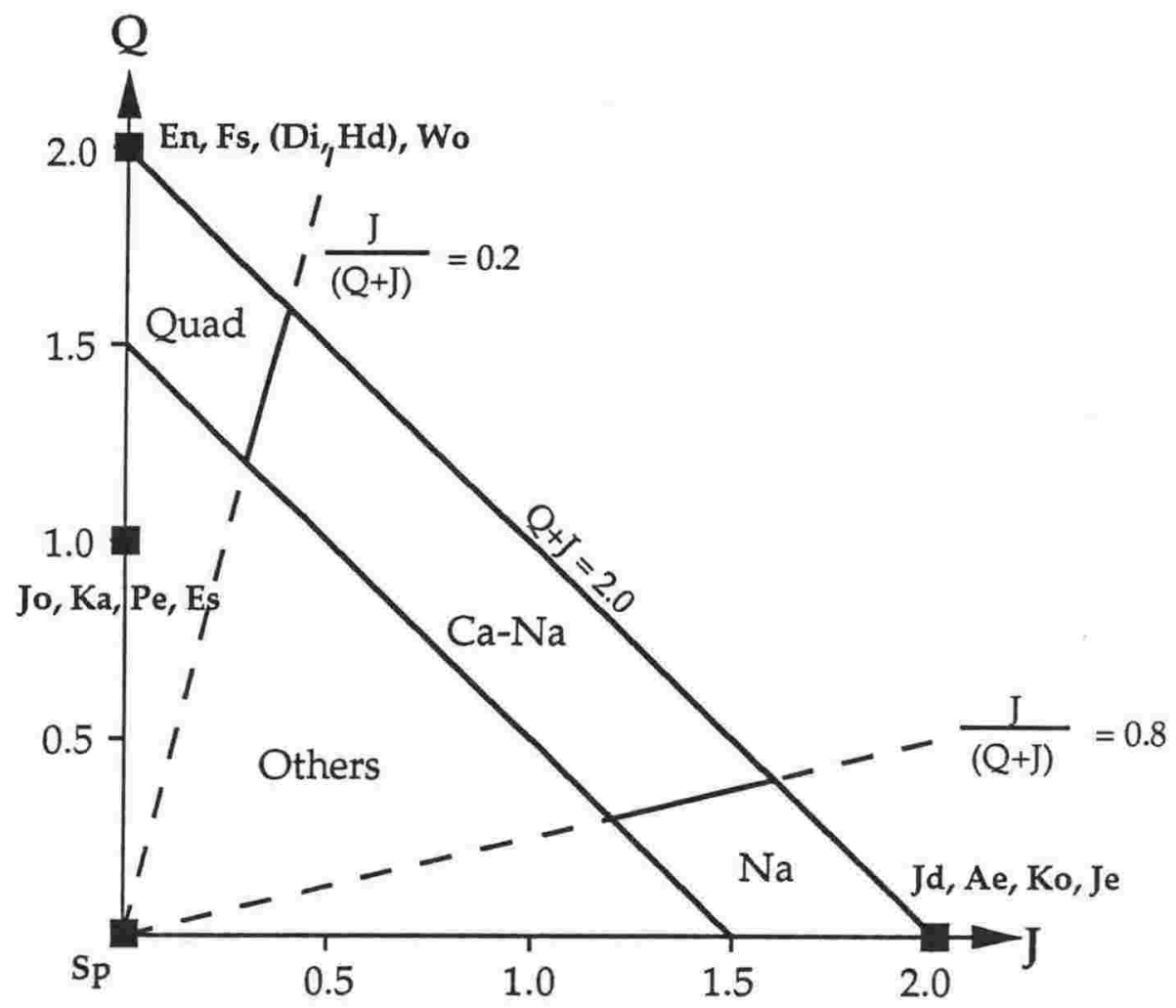

FIGURE 2.9: Q-J diagram (from Morimoto et al., 1988) for the classification of pyroxenes. $\mathrm{Q}=\mathrm{Ca}+\mathrm{Mg}+\mathrm{Fe}^{2+}$, and $\mathrm{J}=2 \mathrm{Na}$. $\mathrm{Ae}=$ Aegirine; $\mathrm{Di}=$ diopside; $\mathrm{En}=$ Enstatite; $\mathrm{Es}=$ Esseneite; $\mathrm{Fs}=$ Ferrosilite; $\mathrm{Hd}=$ Hedenbergite; $\mathrm{Jd}=$ Jadeite; Je = Jervisite; $\mathrm{Jo}=$ Johannsenite; $\mathrm{Ka}=$ Kanoite; $\mathrm{Ko}=$ Kosmochlor; $\mathrm{Pe}=$ Petedunnite; $\mathrm{Sp}=$ Spodumene; $\mathrm{Wo}=$ Wollastonite.

\subsubsection{Pyroxenes}

Nomenclature for pyroxenes is based on the pyroxene quadrilateral. Recently the Commission on New Minerals and Mineral names of the International Mineralogical Association (Subcommittee on Pyroxenes) established a scheme for the nomenclature of pyroxenes (Morimoto et al., 1988). This scheme 
is adopted here, although it is not at present widely used in the field of xenolith studies.

Pyroxenes are divided into four groups on the basis of $\mathrm{Na}, \mathrm{Ca}$ and 'other' contents. This is a division based on a binary diagram (Figure 2.9) with a 'Q' axis $\left(\mathrm{Q}=\mathrm{Ca}+\mathrm{Mg}+\mathrm{Fe}^{2+}\right)$ and a ' $\mathrm{J}$ ' axis $(\mathrm{J}=2 \mathrm{Na})$. Pyroxenes are then named according to the group they fall in (see Figure 2.9 for abbreviations):

- Na and Ca-Na pyroxenes are classified by their Quad, Jd and Ae contents (Figure 2.10). To calculate the $\mathrm{Q}$ (Wo+En+Fs), Jd and Ae components, the sum of $\mathrm{Ca}+\mathrm{Mg}+\mathrm{Fe}^{2+}+2 \mathrm{Na}$ is normalised to $100 \%$. The normalised percentage of $2 \mathrm{Na}$ is divided by the ratio $\mathrm{Al} / \mathrm{Fe}^{3+}$ to give the $\mathrm{Jd} / \mathrm{Ae}$ ratio. $\mathrm{Q}+\mathrm{Jd}+\mathrm{Ae}$ must always $=100 \%$;

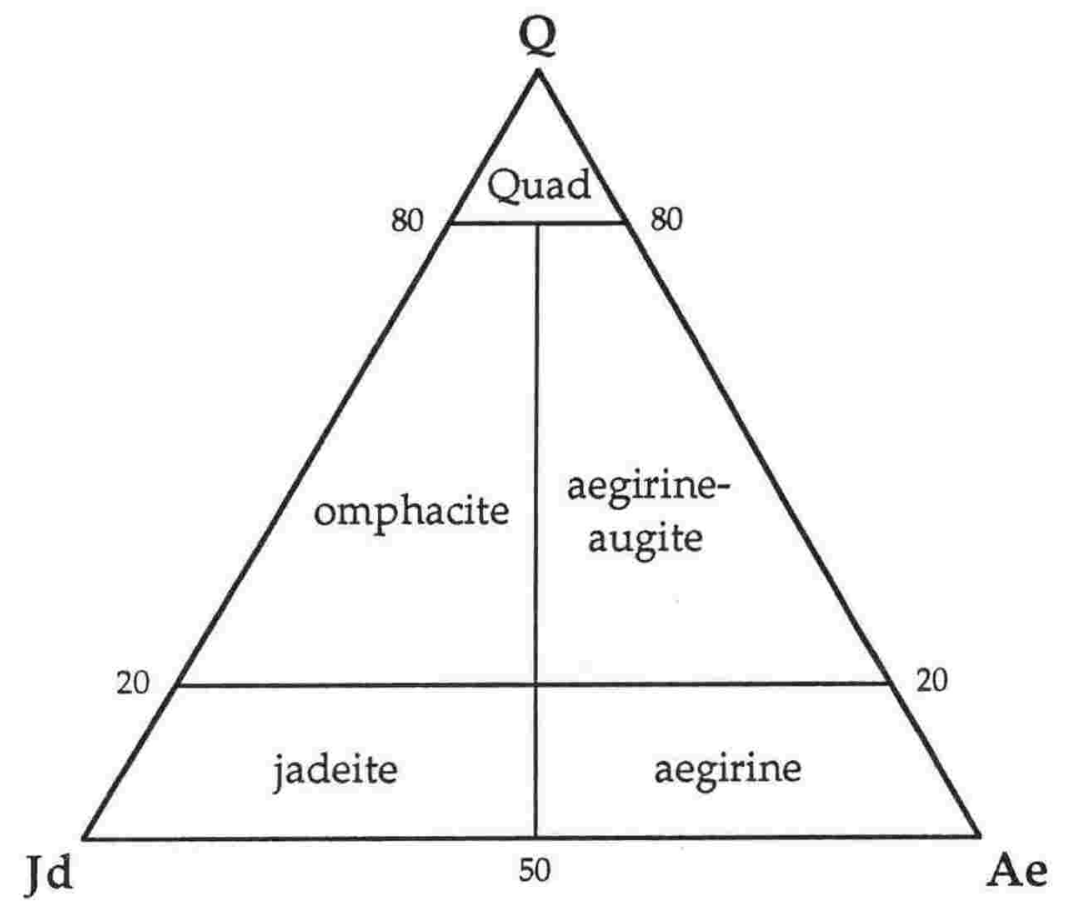

FIGURE 2.10: Classification of the Ca-Na pyroxenes from Figure 2.9 (from Morimoto et al., 1988). Abbreviations as for Figure 2.9.

- Ca-Mg-Fe (Quad(rilateral)) pyroxenes are subdivided by normalising $\mathrm{Ca}+\mathrm{Mg}+\sum \mathrm{Fe}\left(\sum \mathrm{Fe}=\mathrm{Fe}^{2+}+\mathrm{Fe}^{3+}+\mathrm{Mn}\right)$ to $100 \%$ and the pyroxenes named according to their Wo $\left(\mathrm{Ca}_{2} \mathrm{Si}_{2} \mathrm{O}_{6}\right)$, En $\left(\mathrm{Mg}_{2} \mathrm{Si}_{2} \mathrm{O}_{6}\right)$ and $\mathrm{Fs}\left(\mathrm{Fe}^{2+}{ }_{2} \mathrm{Si}_{2} \mathrm{O}_{6}\right)$ content (Figure 2.11). Using this system, it is possible for pyroxenes to plot above $50 \%$ Wo. $\mathrm{Mn}$ substitutes with $\mathrm{Fe}$, and should be included when naming pyroxenes. However, $\mathrm{Mn}$ is not included in plots in this study to allow direct comparisons with other works, which have not taken this substitution into consideration;

- most pyroxene compositions falling in the 'other' field of the Q-J diagram are johannsenite $\left(\mathrm{CaMnSi}_{2} \mathrm{O}_{6}\right)$, petedunnite $\left(\mathrm{CaZnSi}_{2} \mathrm{O}_{6}\right)$ and spodumene $\left(\mathrm{LiAlSi}_{2} \mathrm{O}_{6}\right)$. 


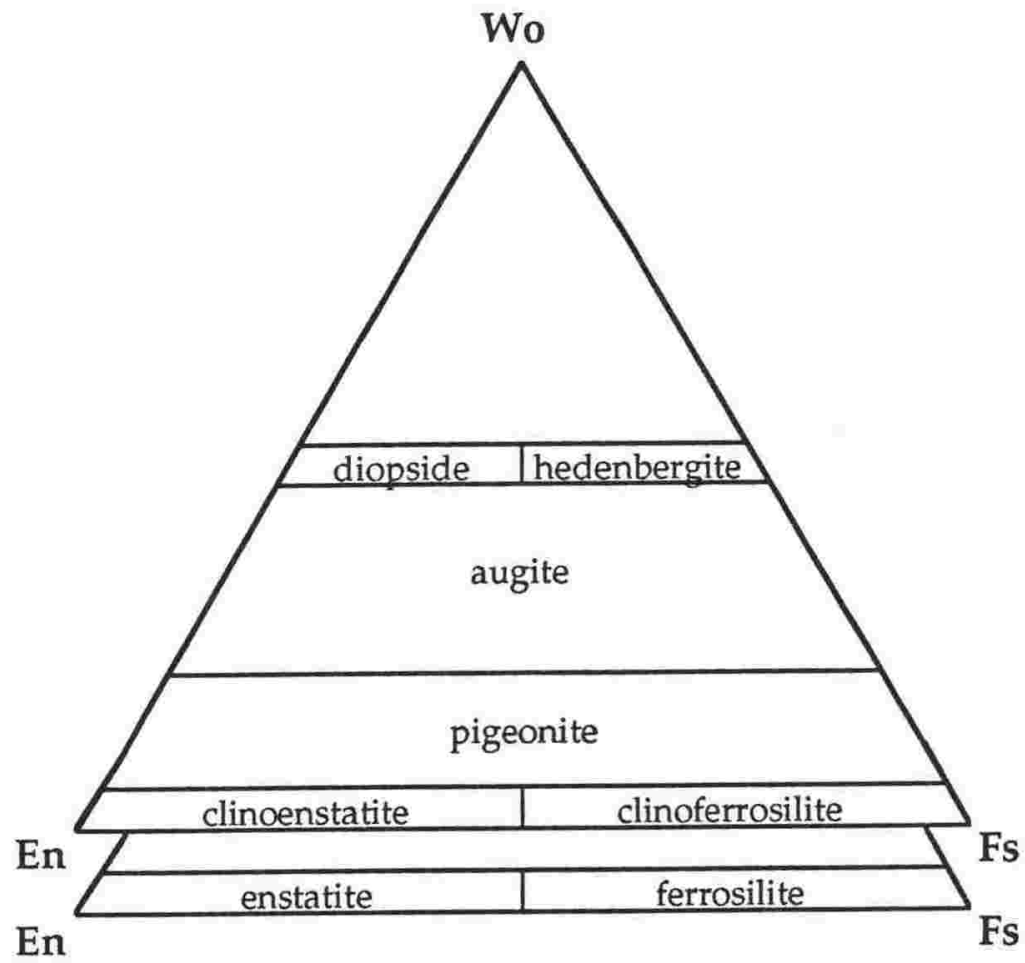

a)

b)

FIGURE 2.11: Classification of the Ca-Mg-Fe pyroxenes from Figure 2.9, including: a) clinopyroxenes; b) and orthopyroxenes (from Morimoto et al., 1988). Abbreviations as for Figure 2.9.

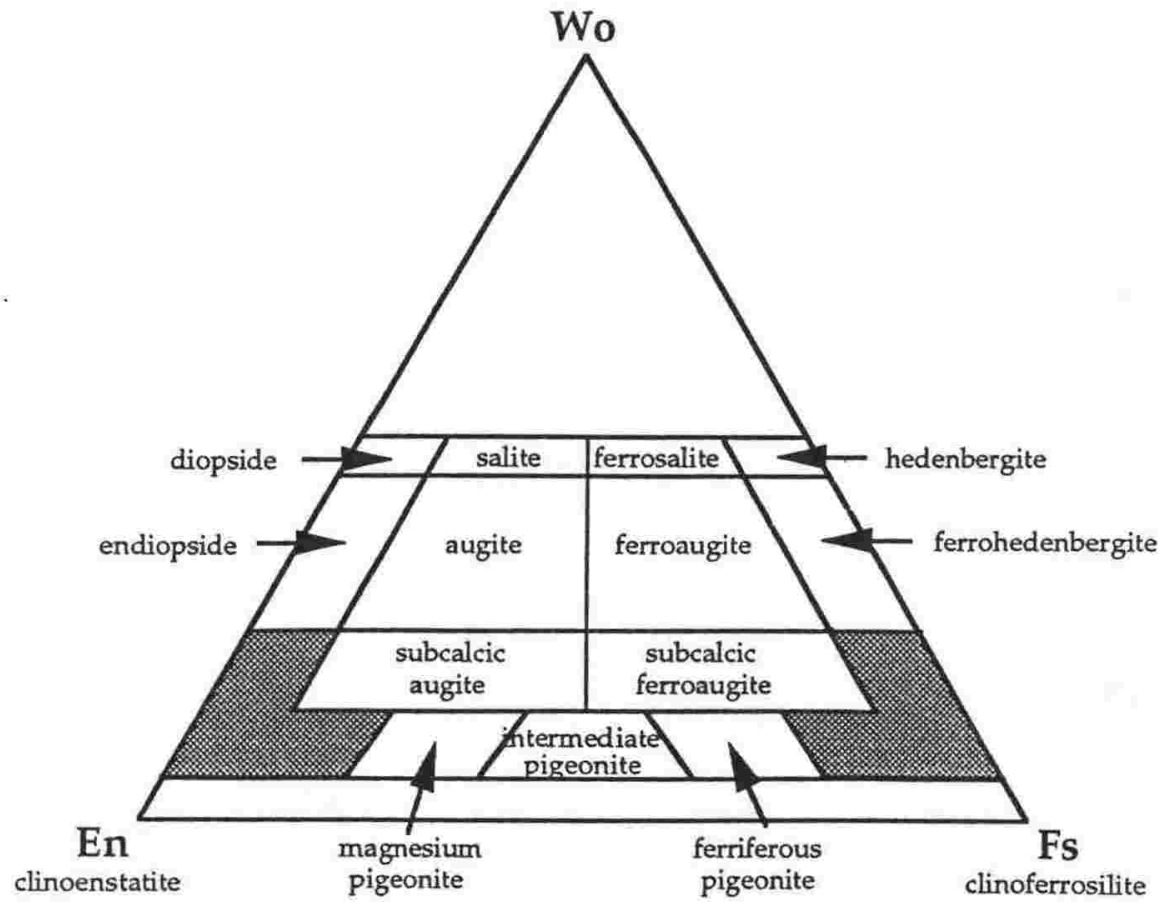

FIGURE 2.12: Classification scheme for all pyroxenes, from Deer et al. (1966). 
Pyroxenes with unusual compositions are modified by an adjective according to Table 2.2. This only applies if the cation content (on the basis of 6 oxygens) is unusual to that group of pyroxene.

\begin{tabular}{lll}
\hline \hline Cation & Content* & Name \\
\hline $\mathrm{Al}^{3+}$ & $>0.10$ & aluminian \\
$\mathrm{Ca}^{2+}$ & $>0.10$ & calcian \\
$\mathrm{Cr}^{3+}$ & $>0.01$ & chromian \\
$\mathrm{Fe}^{2+}$ & $>0.10$ & ferroan \\
$\mathrm{Fe}^{3+}$ & $>0.10$ & ferrian \\
$\mathrm{Li}^{+}$ & $>0.01$ & lithian \\
$\mathrm{Mg}^{2+}$ & $>0.10$ & magnesian \\
$\mathrm{Mn}^{2+}$ & $>0.10$ & manganoan \\
$\mathrm{Mn}^{3+}$ & $>0.01$ & manganian \\
$\mathrm{Na}^{+}$ & $>0.10$ & sodian \\
$\mathrm{Ni}^{2+}$ & $>0.01$ & nickeloan \\
$\mathrm{Si}^{++}$ & $<1.75$ & subsilicic \\
$\mathrm{Ti}^{3+}$ & $>0.01$ & titanoan \\
$\mathrm{Ti}^{4+}$ & $>0.10$ & titanian \\
$\mathrm{Zn}^{2+}$ & $>0.01$ & zincian \\
\hline
\end{tabular}

Note: The limit of the content is based on the values listed in Table 4.

* Number of cations per formula unit $M 2 M 1 T_{2} \mathrm{O}_{5}$. If the mineral name itself implies the presence of certain cations, adjectival modifiers for these cations should not be used ("subsilicic" is an exception).

TABLE 2.1: Adjective modifiers used for pyroxene classification, if cation contents (based on 6 oxygens) are unusual for that group of pyroxene (from Morimoto et al., 1988).

This classification scheme replaces the long established scheme of Deer et al. (1966), which is presented as Figure 2.12 for comparison with the scheme of Morimoto et al. (1988). The major change to the classification of the quadrilateral pyroxenes is its simplification and rigid use of adjective modifiers. A complete list of obsolete pyroxene names using the nomenclature of Deer et al. (1966) can be found in Morimoto et al. (1988).

\subsubsection{Amphiboles}

The classification scheme of Leake (1978) is favoured for the classification of amphiboles. The standard amphibole formula, based on 23 oxygens, is:

$$
\mathrm{A}_{0-1} \mathrm{~B}_{2} \mathrm{C}_{5} \mathrm{~T}_{8} \mathrm{O}_{22}(\mathrm{OH}, \mathrm{F}, \mathrm{Cl})_{2}
$$

Cations are assigned to sites using the following guide, where: 


$$
\begin{aligned}
& \mathrm{T}=\mathrm{Si} \text {, then } \mathrm{Al}, \mathrm{Cr}^{3+}, \mathrm{Fe}^{3+} \text { and } \mathrm{Ti}^{4+} ; \\
& \mathrm{C}=\text { excess } \mathrm{Al}, \mathrm{Cr}, \mathrm{Ti}, \mathrm{Fe}^{3+}, \mathrm{Mg}^{2} \mathrm{Fe}^{2+} \text { and } \mathrm{Mn} ; \\
& \mathrm{B}=\text { excess } \mathrm{Fe}^{2+}, \mathrm{Mn}, \mathrm{Mg}, \mathrm{Ca} \text { and } \mathrm{Na} ; \\
& \mathrm{A}=\text { excess } \mathrm{Na} \text { and all } \mathrm{K} .
\end{aligned}
$$

Classification is then based on the $\mathrm{Ca}$ and $\mathrm{Na}$ content of the ' $\mathrm{B}$ ' site, with amphiboles being divided into four groups:

- the alkali amphiboles, where $(\mathrm{Na})_{\mathrm{B}} \geq 1.34$ (Figure 2.13).
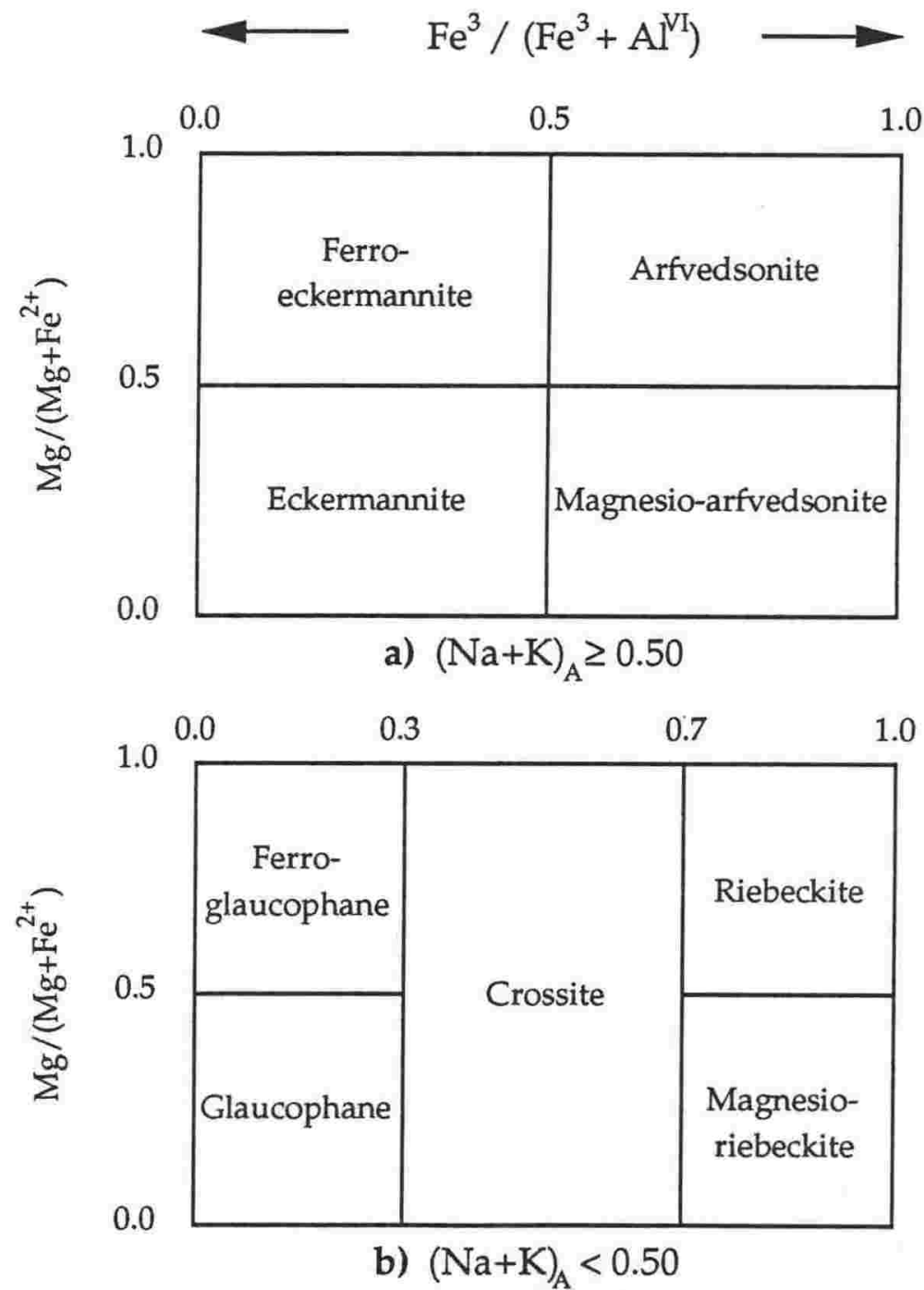

FIGURE 2.13: Classification of alkali amphiboles, based on 23 oxygens (from Leake, 1978).

- the sodic-calcic amphiboles, where $(\mathrm{Ca}+\mathrm{Na})_{B} \geq 1.34$ and $0.67 \geq(\mathrm{Na})_{B} \leq 1.34$ (Figure 2.14);

- the calcic amphiboles, where $(\mathrm{Ca}+\mathrm{Na})_{B} \geq 1.34$ and $(\mathrm{Na})_{B}<0.67$ (Figure 2.15); 
- the Fe-Mg-Mn amphiboles, where $(\mathrm{Ca}+\mathrm{Na})_{\mathrm{B}}<1.34$ (Figure 2.16). Includes orthorhombic and monoclinic;

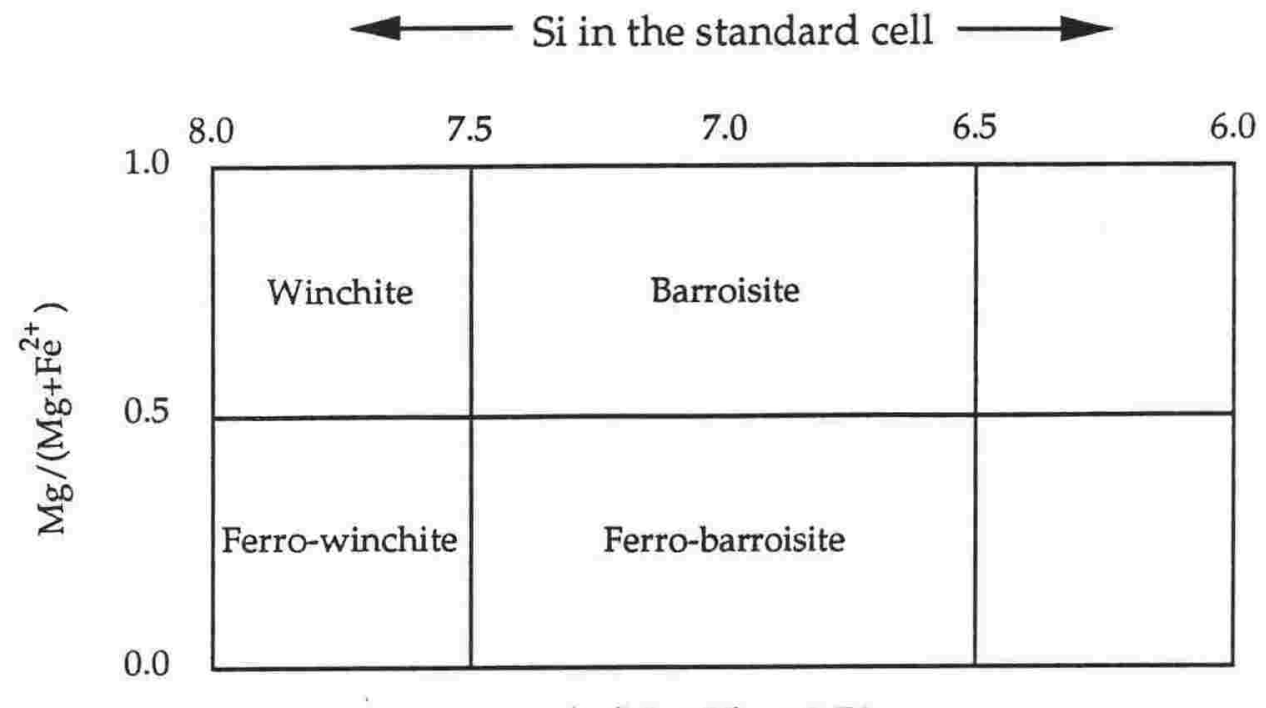

a) $(\mathrm{Na}+\mathrm{K})_{\mathrm{A}}<0.50$

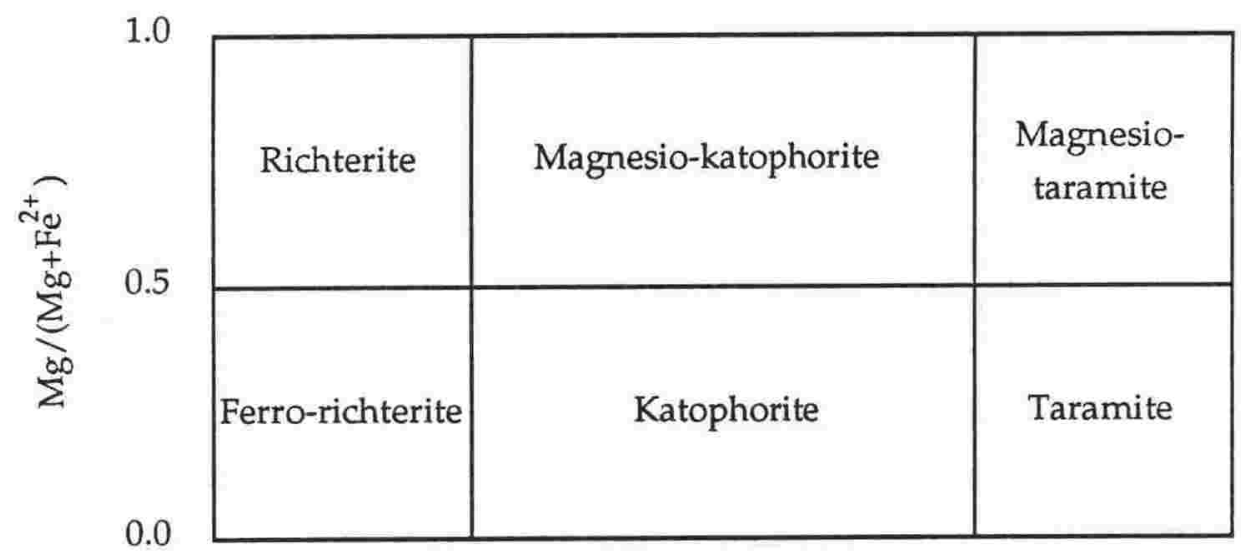

a) $(\mathrm{Na}+\mathrm{K})_{\mathrm{A}} \geq 0.50$

FIGURE 2.14: Classification of sodic-calcic amphiboles, based on 23 oxygens (from Leake, 1978).

A substantial list of adjective modifiers is further used to indicate substitution by end members. This list can be found in Leake (1978).

This scheme is not simple or easy to use, and has the disadvantage of classifying very similar amphiboles with only slight chemical variations into totally different groups. The division is based on a cut-off principle with no petrologic basis. For instance, the common amphibole in xenoliths reported in this study is kaersutite. However, these amphiboles are split into kaersutite and pargasite because of their $\mathrm{Ti}$ content being close to 0.5 - the cut-off line (Figure 2.14). It is important to realise than these amphiboles are identical except for 
slightly differing cation totals, and should not be treated as two differing amphiboles. In this work they are treated as one group in terms of their geochemistry, and in mineral composition plots.

Si cations on the basis of 23 oxygens

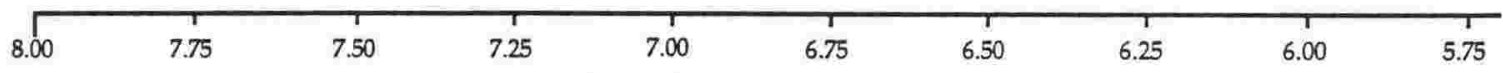

a) $(\mathrm{Na}+\mathrm{K})<0.5: \mathrm{Ti}<0.5$

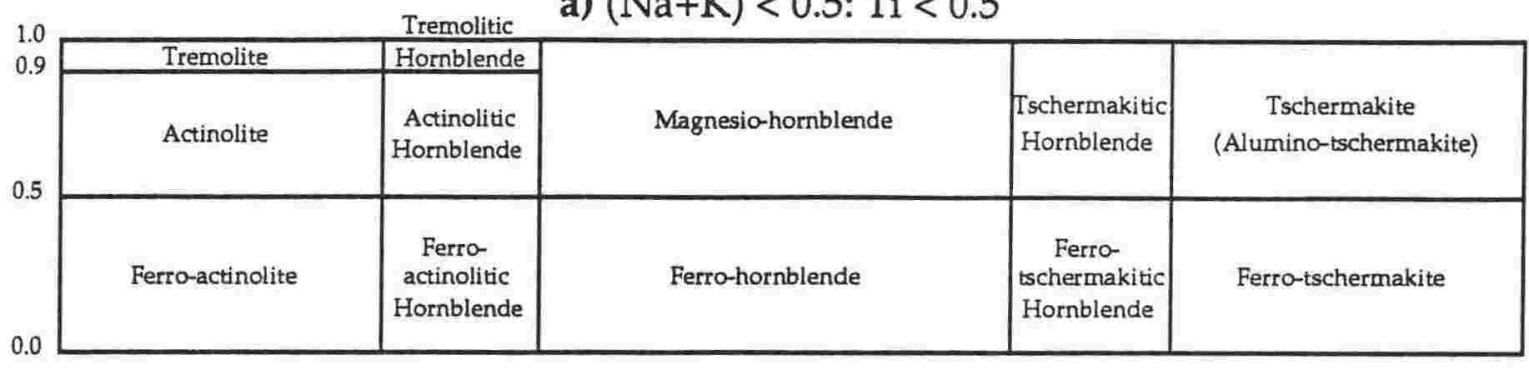

b) $(\mathrm{Na}+\mathrm{K}) \geq 0.5: \mathrm{Ti}<0.5: \mathrm{Fe}^{3+} \leq \mathrm{Al}$ VI

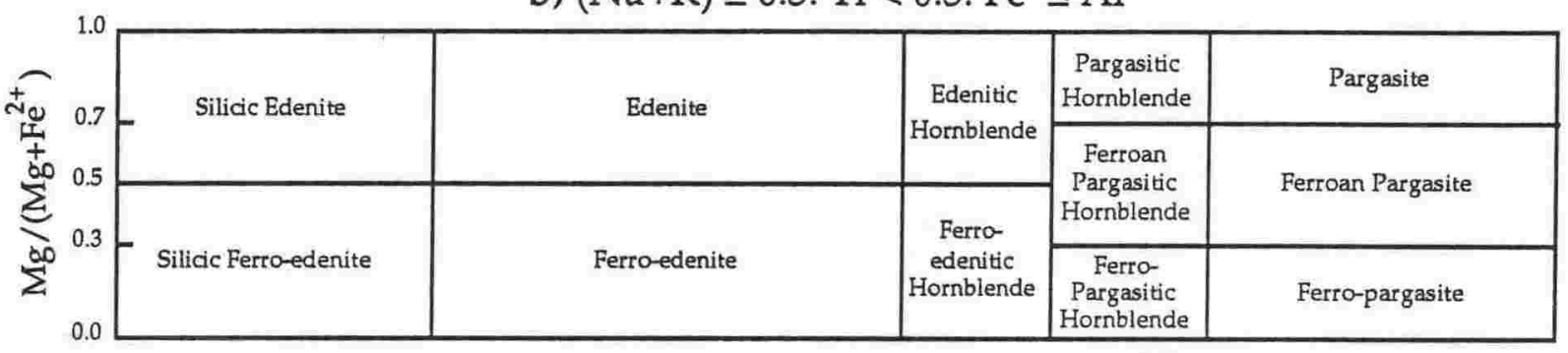

c) $(\mathrm{Na}+\mathrm{K}) \geq 0.5: \mathrm{Ti}<0.5: \mathrm{Fe}^{3+}>\mathrm{Al}^{\mathrm{VI}}$

\begin{tabular}{|c|c|c|c|c|}
\hline \multirow[t]{2}{*}{ Silicic Edenite } & \multirow[t]{2}{*}{ Edenite } & \multirow{2}{*}{$\begin{array}{l}\text { Edenitic } \\
\text { Hornblende }\end{array}$} & \begin{tabular}{|c|} 
Magnesio- \\
hastingsitic \\
Hornblende \\
\end{tabular} & Magnesio-hastingsite \\
\hline & & & \multirow{2}{*}{$\begin{array}{l}\text { Magnesian } \\
\text { Hastingsitic } \\
\text { Hornblende }\end{array}$} & \multirow{2}{*}{ Magnesian Hastingsite } \\
\hline \multirow[b]{2}{*}{ Silicic Ferro-edenite } & \multirow[b]{2}{*}{ Ferro-edenite } & \multirow{2}{*}{$\begin{array}{c}\text { Ferro- } \\
\text { Edenitic } \\
\text { Hornblende }\end{array}$} & & \\
\hline & & & $\begin{array}{l}\text { Hastingsitic } \\
\text { Hornblende }\end{array}$ & Hastingsite \\
\hline
\end{tabular}

d) $\mathrm{Ti} \geq 0.5$

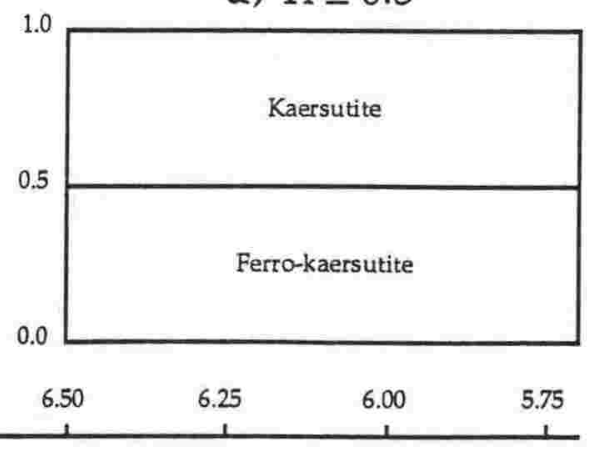

Si cations on the basis of 23 oxygens

FIGURE 2.15: Classification of calcic amphiboles, based on 23 oxygens (from Leake, 1978). 
a) Orthorhombic

$\mathrm{Si}$ in the standard cell

8.0

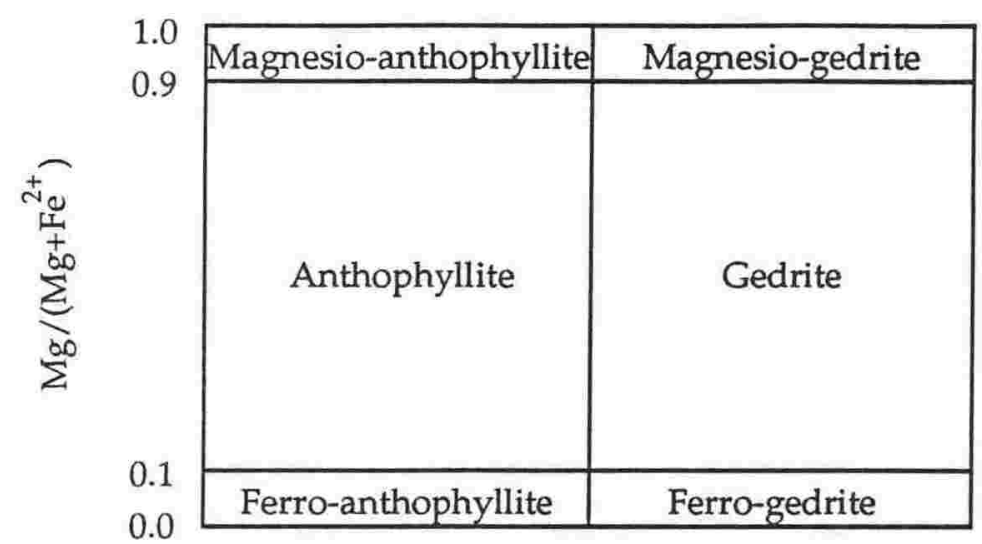

b) Monoclinic

$\mathrm{Si}$ in the standard cell 6.0

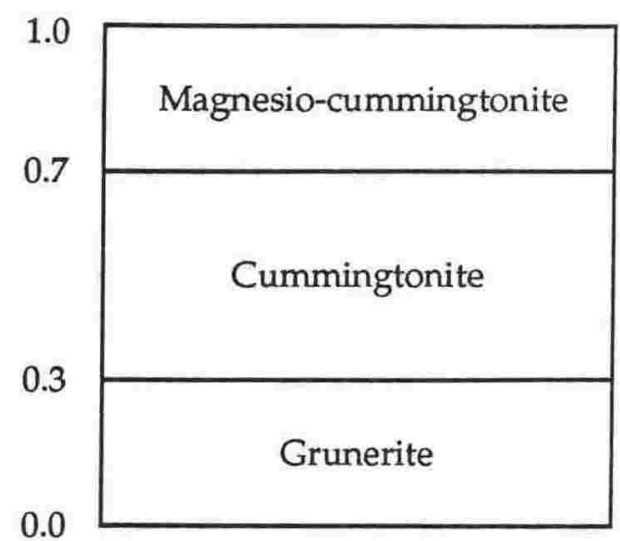

FIGURE 2.16: Classification of Fe-Mg-Mn amphiboles, based on 23 oxygens (from Leake, 1978) for: a) orthorhombic amphiboles; b) and monoclinic amphiboles. 


\section{Chapter three \\ FIELD EXCURSIONS}

\section{Synopsis}

Lithospheric xenoliths were collected as part of a programme to study the volcanoes and lithosphere of West Antarctica (the West Antarctic Volcano Exploration Programme). Xenoliths were collected from scoria cones in Marie Byrd Land during two field seasons (1989-90 and 1990-91), and from the McMurdo Sound region in a third field season (1992-93).

The Marie Byrd Land xenolith suite consists of samples from the Executive Committee Range (Mounts Waesche, Sidley, Cumming and Hampton), from Mount Murphy on the Walgreen coast, and from Mount Aldaz in the USAS Escarpment. Granulites were collected from Mount Waesche, granulites and pyroxenites from Mount Sidley, granulites and peridotites from Mount Cumming, granulites, pyroxenites and peridotites from Mounts Hampton and Murphy, and peridotites from Mount Aldaz.

Lithospheric samples from the McMurdo Sound region were collected from localities on both sides of a major crustal boundary between the Ross Embayment and the Transantarctic Mountains, previously identified by xenolith studies (Kalamarides et al., 1987). Sample sites included: Sulphur Cones and Turtle Rock on Hut Point Peninsula, Ross Island; Mount Aurora, Black Island; and from Foster Crater in the Transantarctic Mountains. In addition, peridotites were collected from Half Moon Crater and Twin Craters on Hut Point Peninsula, and from Cape Byrd in the north of Ross Island. The xenolith suite from the McMurdo Sound region has not been documented as a part of this study. 


\subsection{The WAVE Programme}

The West Antarctic Volcano Exploration (WAVE) programme was a joint New Zealand, United States and United Kingdom project, initiated to study various aspects of the volcanology, petrology, and geochemistry of the late Cenozoic intraplate volcanism and lithosphere of West Antarctica. A longer term aim was to compare and contrast the Marie Byrd Land lithosphere to other lithospheric sections from elsewhere in Gondwana, including the Ross Sea Embayment and Transantarctic Mountains in the McMurdo Sound region, New Zealand and eastern Australia.

The WAVE program was completed in three field seasons; during 1989-90, 1990-91, and 1992-93. The first two seasons involved the collection of xenoliths from MBL, although some lower crustal samples were also obtained in the third season. The third season concentrated on the Ross Embayment and Transantarctic Mountains of the McMurdo Sound region as a follow-up season to document the 
the ECR (Figure 1.4). Unfortunately, inclement weather combined with delays in logistic support limited the field season to the southern end of the ECR, with only a reconnaissance visit to Mount Cumming.

Geologic mapping was completed on Mount Waesche and Mount Sidley, and samples were collected for geochemical studies. Sections were measured through the volcanic pile on the exposed caldera wall of Mount Sidley (Panter et al., in prep).

Crustal and mantle xenoliths were collected from sites on Mount Waesche, Mount Sidley and Mount Cumming. Xenoliths from Mount Waesche were limited to crustal xenoliths, while those from Mount Cumming were dominantly spinel lherzolites, although a small amount of lower crustal xenoliths were located and collected. The Mount Sidley xenolith suite spanned from upper mantle through to upper crustal xenoliths, however the peridotite suite was comprised of only very small xenoliths that were extremely oxidised, and therefore not analysed.

\subsubsection{The 1990/1991 field season}

The second field season aimed to complete work abandoned from the first field season (to visit the rest of the ECR and the USAS Escarpment) and to visit a number of new sites; Mount Murphy on the Walgreen coast, Toney Mountain, and the Crary Mountains (Figure 1.4). Once again bad weather, as well as damage to aircraft, limited the field season, and only visits to Mount Murphy, Mount Waesche and Mount Hampton, with a brief visit to the USAS Escarpment (Mount Aldaz) were possible.

Field work during this season meant that detailed geological mapping and sampling had now been undertaken on Mount Waesche, Mount Sidley, and Mount Murphy, and further samples for geochemical study were collected from Mount Cumming, Mount Hampton and Mount Aldaz (Smellie et al., 1993). A suite of xenoliths ranging from the upper mantle to the upper crust were collected from Mount Hampton and from Mount Murphy during this field season, while a suite of spinel lherzolites was collected from Mount Aldaz.

\subsubsection{The 1992/1993 field season}

The field season in November-December 1992 consisted of collecting samples from localities in the McMurdo Sound region rather than in MBL. The Antarctic Ross Sea Lithosphere Study (ARSLS) collected upper mantle and lower crustal xenolith suites from the Ross Embayment and the foothills of the Transantarctic Mountains. The WAVE programme (WAVE II) was also completed with visits to 
further MBL sites, and lower crustal xenoliths were collected from the Crary Mountains. The samples collected during this field season are not a subject of this study.

Ross Embayment localities included several sites from Ross Island, and from Mount Aurora, Black Island. The Ross Island localities consisted of Turtle Rock, Sulphur Cones and Half Moon Crater, all of which are on Hut Point Peninsula, and Cape Byrd in the north of Ross Island.

Only one site was visited in the Transantarctic Mountains, that of Foster Crater previously described by Gamble and Kyle (1987), Kyle et al. (1987), Gamble et al. (1988), Berg (1991), McGibbon (1991), and Berg and Wu (1992). Another site, the Pipecleaner Glacier in the Roaring Valley, was scheduled to be visited but this was not accomplished due to bad weather.

\subsection{Xenolith Localities}

Xenoliths were collected primarily from satellitic scoria cones on the flanks of the major stratovolcanoes. All xenolith localities are indicated on the following figures.

Sample sites are numbered in two series according to their original field sample numbers. The first series is numbered by year $(89,90,91)$ followed by a sample number from 001 to 054 , corresponding to the sample site in chronological order of collection (only these numbers are shown on the following locality maps). Multiple samples from one site are further identified alphabetically ( $a, b$, $c . . . z, a 1, b 1, c 1 . . . z 1, a 2, b 2$ etc.). The second series contains samples with the prefix 'PK' or 'MB'. The 'PK' samples are from Mount Hampton with the first numeral representing the sample site, and following alpha-numerics indicating the sample number. All the 'MB' samples (followed by a numeric sample number) come from Mount Aldaz, in the USAS Escarpment.

\subsubsection{The Executive Committee Range}

Samples were collected from four of the five volcanoes comprising the ECR (Figure 3.1), with Mount Hartigan being the exception, over the first two field seasons.

Samples from Mount Waesche consist of crustal xenoliths only. Of these, only site 001 (from Rhyolite Moraine) yielded any lower crustal xenoliths (two granulites). 


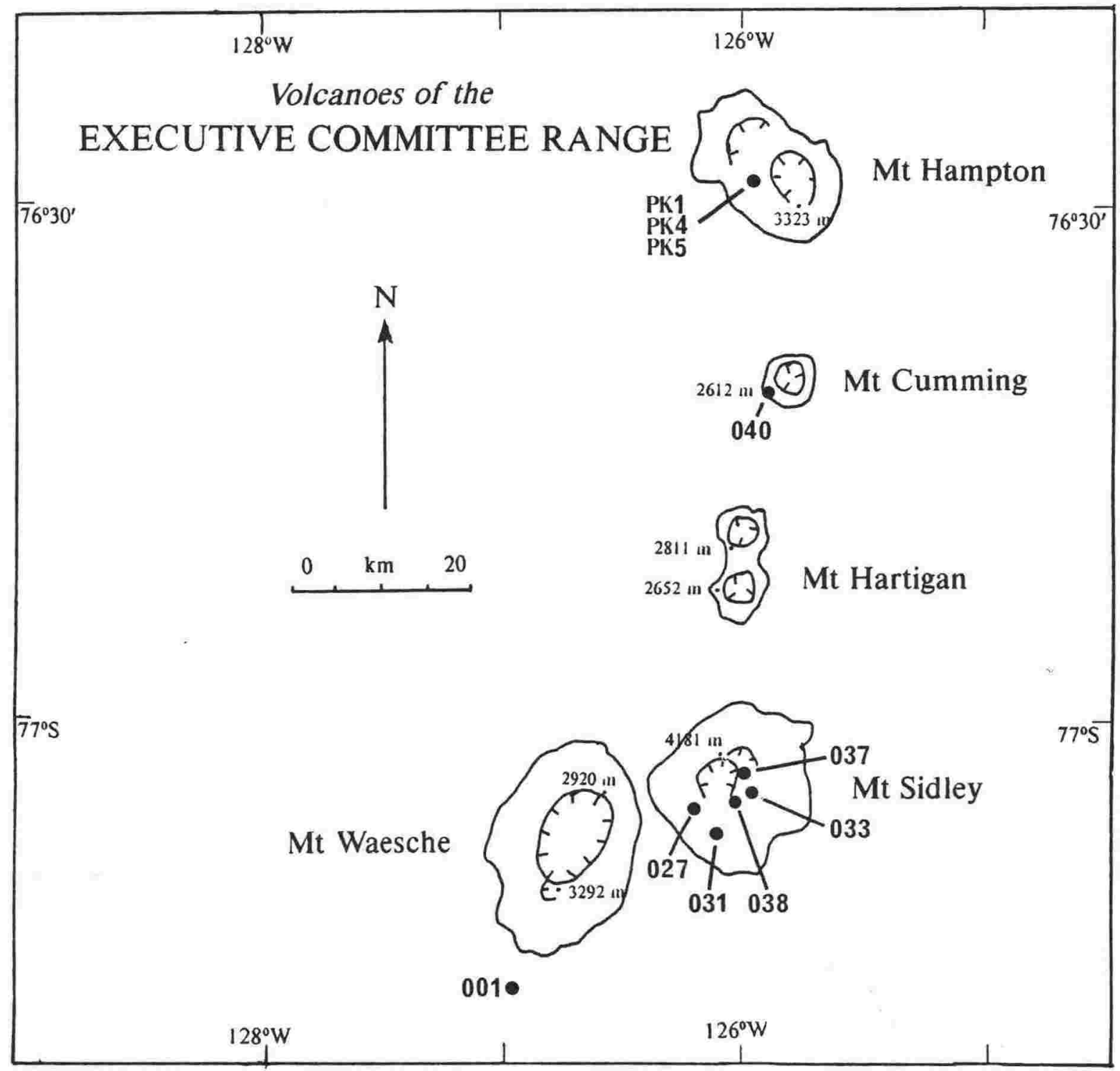

FIGURE 3.1: Location map of the Executive Committee Range, Marie Byrd Land (after Le Masurier, 1990). Lower crustal and upper mantle xenoliths were collected from all the volcanoes, with the exception of Mount Hartigan. Sample sites are labelled.

Mount Sidley samples spanned the range from upper mantle to upper crustal xenoliths. Mount Sidley granulite and pyroxenite xenoliths are fully documented as Chapter Four. Granulites were recovered from sites 029 (Xenolith Cone), 031 (East Doumani Cone), 033 (scoria cone east of caldera rim), 038 (east rim of caldera) and 039 (Kurt's Cone). Pyroxenites were located from sites 033 and 039 although single pyroxenites were also found at sites 029 and 031 . Spinel lherzolites were located only at site 039 , although these were not analysed due to their small size and oxidised state. This xenolith suite is documented in Chapter Four. 
Mount Cumming yielded a large suite of fresh spinel lherzolites, as well as granulitic xenoliths from a single locality; site 040 at the southwest foot of Annexstad Peak. Pyroxenites were not located from this site.

Xenoliths from Mount Hampton were found at three sites. A single spinel lherzolite was collected from site PK1. PK4 consists of granulite, pyroxenite and lherzolite xenoliths, while site PK5 includes pyroxenites and peridotites. The peridotite suite consists of spinel lherzolites as in other localities, as well as a suite of $\mathrm{Cr}$-diopside rich samples, which were common as large (dm) specimens and as veins cross-cutting spinel lherzolites.

Only one site (PK) is represented for Mount Hampton on Figure 3.1; all three sites were from this vicinity, and formed a triangle with the apex (PK1) upslope. This xenolith suite, rich in granulites, pyroxenites and peridotites, is documented as Chapter Five.

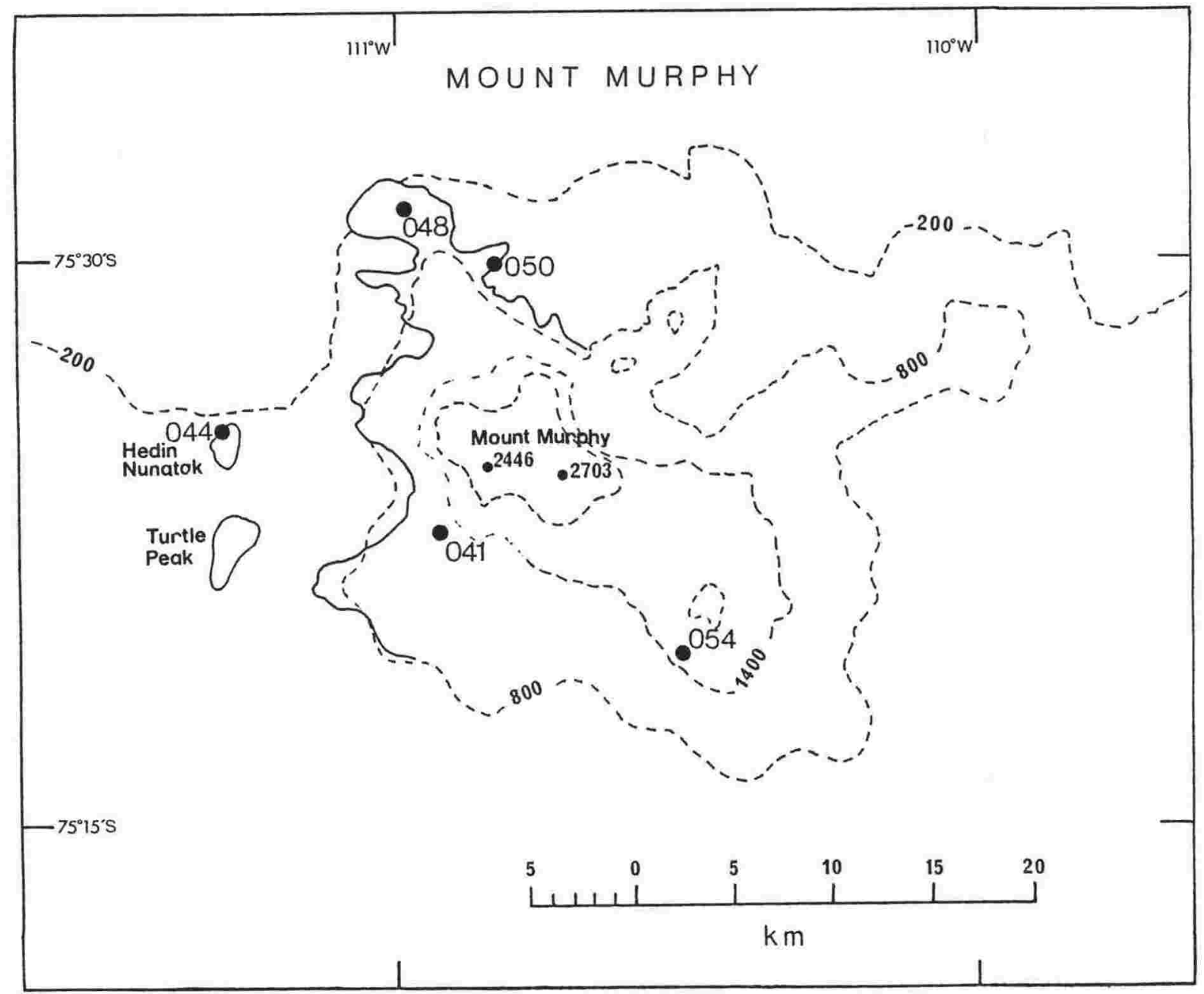

FIGURE 3.2: Location map of Mount Murphy, on the Walgreen coast, Marie Byrd Land (after Le Masurier, 1990). Xenolith localities are shown. 


\subsubsection{Mount Murphy}

Xenoliths from Mount Murphy (Figure 3.2) were collected during the second field season (1990/91). A suite of granulites was collected from sites 041 (east uphill from Sechrist Peak) and 048. Site 41 was discovered during a reconnaissance, and only a few samples were collected, with the intention to return to collect more samples at a later date. Unfortunately, on the next visit a snow cover up to one metre thick had covered the locality, and no more samples could be collected. The largest pyroxenite locality was site 054 (scoria cone southwest of Hawkins Peak), which was also rich in peridotites. A small number of pyroxenites were also collected from other sites: one from site 044 (scoria cone NW side of Hedin Nunatak); three from site 048 (scoria cone northwest of Kay Peak); and one highly altered pyroxenite from site 050 (bluffs east of Kay Peak).

No single site spanned the range from peridotite to upper crustal samples. The Mount Murphy locality was the third major lower crustal and upper mantle xenolith locality visited, and the xenolith suite is discussed in Chapter Six.

\subsubsection{The USAS Escarpment}

Nine spinel lherzolites, were collected from the west side of Mount Aldaz (Figure 3.3) in the USAS Escarpment, during the second WAVE field season. No pyroxenite or granulite xenoliths were found at this locality.

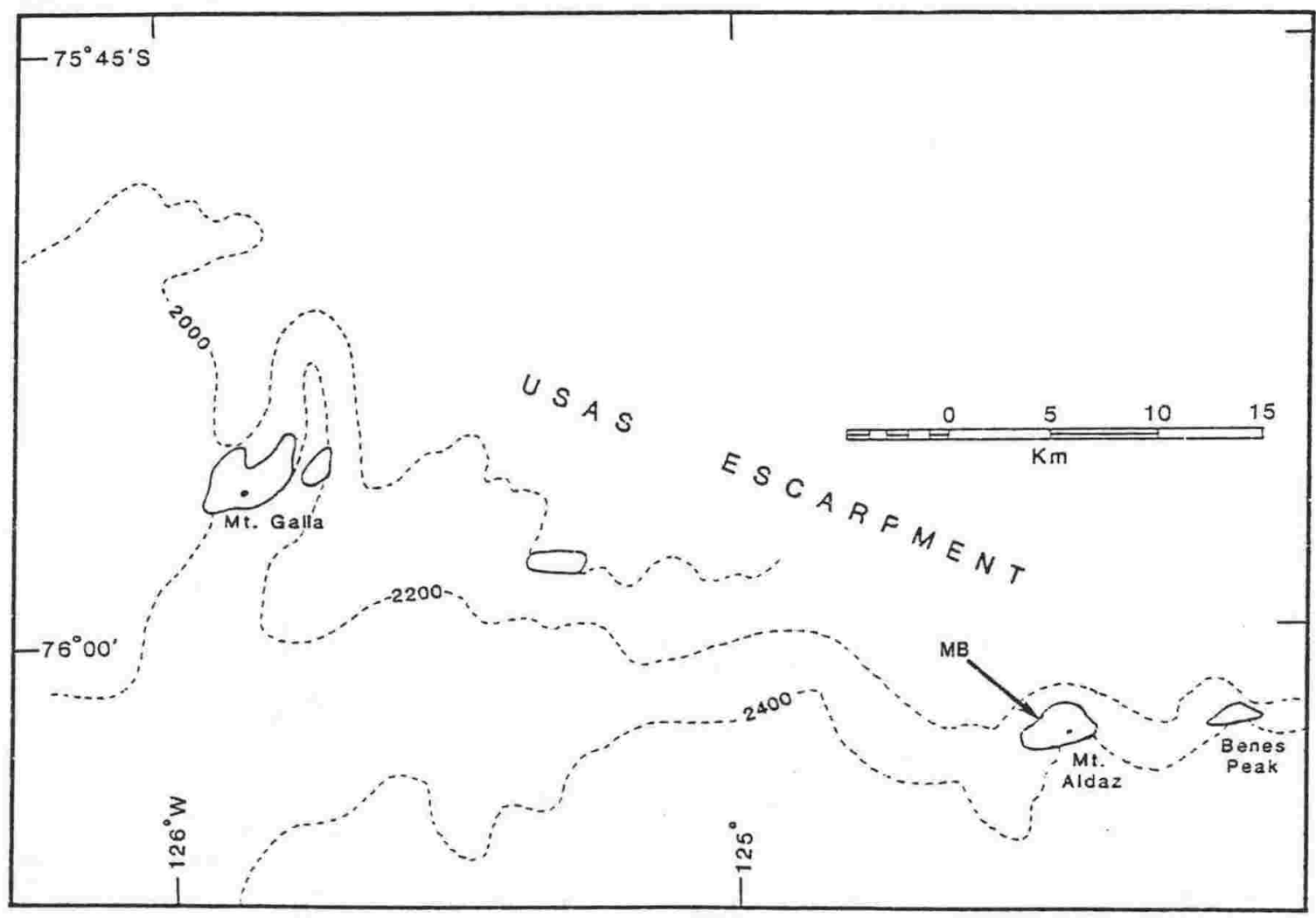

FIGURE 3.3: Location map of the USAS Escarpment, Marie Byrd Land (after Le Masurier, 1990). Upper mantle peridotites (site MB) were collected from Mount Aldaz. 


\subsubsection{The Ross Embayment and the Transantarctic Mountains}

Lower crustal and upper mantle xenoliths were collected from the McMurdo Sound region as a follow up season to the first two field seasons, to document this section of the Antarctic lithosphere and to compare it with other lithospheric sections, including MBL. The xenolith suite collected included an exceptionally rich diversity of granulites, pyroxenites and peridotites from both sides of the Ross Embayment-Transantarctic Mountains crustal boundary, identified by previous xenolith studies (Kalamarides et al., 1987). Xenolith localities visited in this field season included: Sulphur Cones and Turtle Rock on Hut Point Peninsula, Ross Island; Mount Aurora, Black Island; and Foster Crater in the foothills of the Transantarctic Mountains, on the Koettlitz Glacier (Figure 3.4). Peridotite xenoliths were also collected from Twin Crater (McMurdo Base) and Half Moon Crater, both on Hut Point Peninsula, and from Cape Byrd in the north of Ross Island.

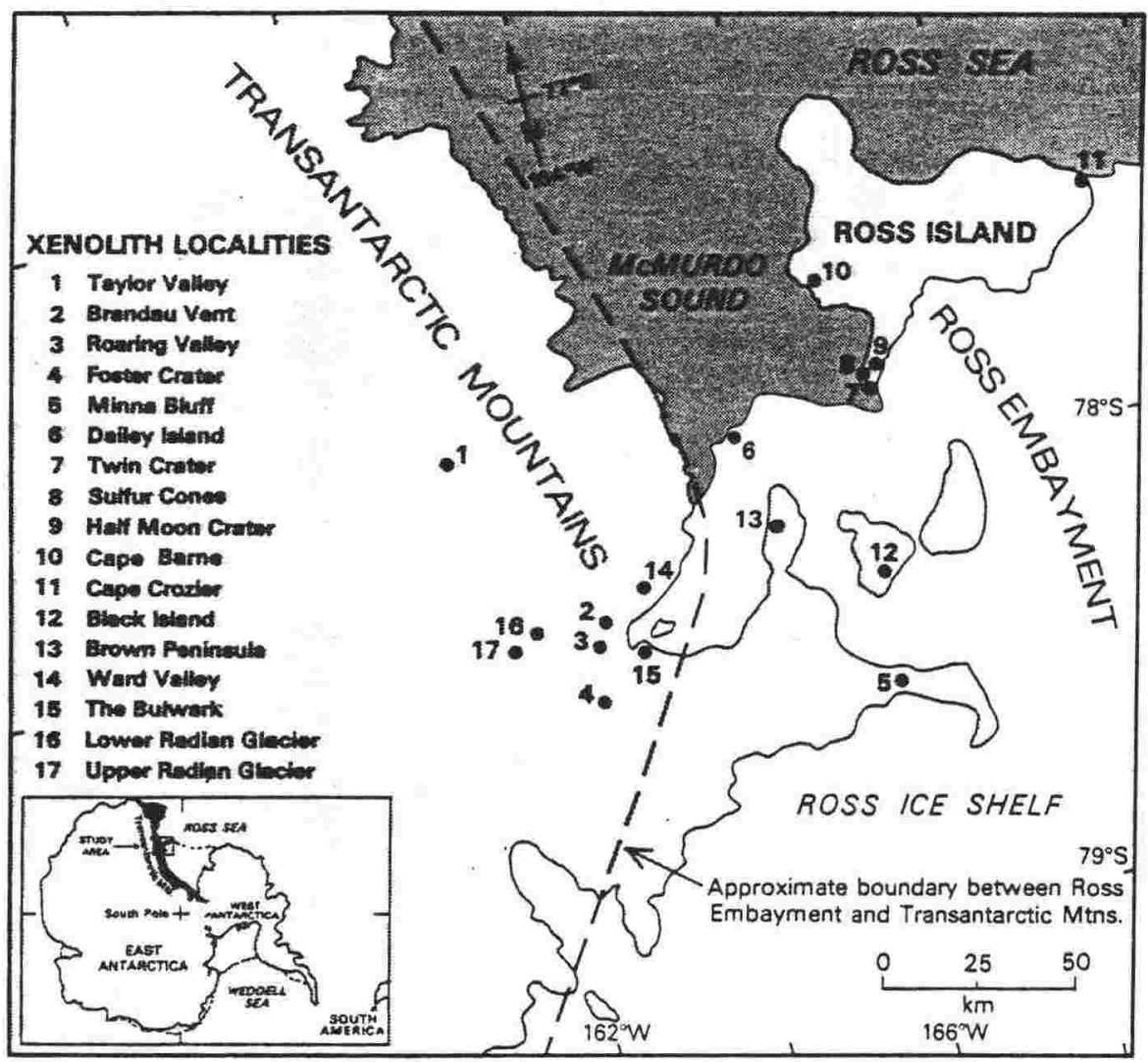

FIGURE 3.4: Location map of the McMurdo Sound region, including the Ross Embayment, and the Transantarctic Mountains (after Berg, 1991). The dashed line shows the Ross EmbaymentTransantarctic Mountains boundary, identified by previous xenolith studies (Kalamarides et al., 1987). During the 1992-93 field season, granulite, pyroxenite and peridotite xenoliths were collected from: Sulphur Cones (8), and Turtle Rock (near 8), on Hut Point Peninsula, Ross Island; Mount Aurora (12), Black Island; and Foster Crater (4), Koettlitz Glacier, Transantarctic Mountains. Peridotite xenoliths were also collected from Half Moon Crater (9) and Twin Crater (7) on Hut Point Peninsula, and from Cape Byrd, in the north of Ross Island. 


\section{Chapter four \\ THE MOUNT SIDLEY XENOLITH SUITE}

\section{Synopsis}

Lower crustal xenoliths have been collected from several localities on Mount Sidley, a stratovolcano at the southern end of the Executive Committee Range, Marie Byrd Land. The suite can be divided petrographically and geochemically into four groups. Type $P$ (pyroxenites) and Type $C$ (plagioclase-bearing cumulates) xenoliths comprise the pyroxenite suite, which have cumulate textures, and Type $M$ (mafic granulites) and Type $L$ (layered granulites) xenoliths comprise the metaigneous granulite suite. The mineral assemblage consists of a single pyroxene (clinopyroxene), olivine, spinels, and plagioclase, which is a minor phase in the pyroxenite suite, and the dominant phase in the granulite suite.

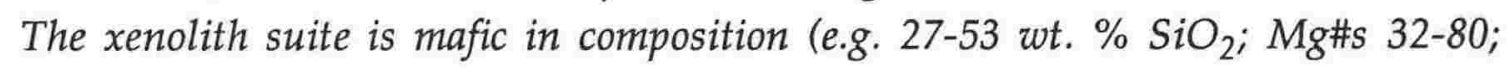
${ }^{87} \mathrm{Sr} /{ }^{86} \mathrm{Sr}$ 0.702861-0.703758), consistent with crystallisation from primitive (possibly alkaline) melt(s). Their geochemistry is controlled by the abundance and composition of the mineral assemblage; i.e. elements that partition into mineral phases are present in higher concentrations than other elements. Mineral compositions range from primitive Type $P$ minerals (e.g. olivine Fo 68-82; plagioclase An 60-77), to the more evolved Type L minerals (e.g. olivine Fo 39-68; plagioclase An 43-59). P-T estimates indicate that fractionation of the melt occurred at progressively higher crustal levels, from Type $P$ xenoliths (8-12 kb, 1160-1240 $\left.{ }^{\circ} \mathrm{C}\right)$, to Type $C$, Type $M$ and Type L xenoliths $\left(4-6.5 \mathrm{~kb}, 980-1160{ }^{\circ} \mathrm{C}\right)$ at higher levels, resulting in a stratified lower crust.

Since original crystallisation of the xenolith suite, the lower crust has experienced periods of metamorphism, deformation and secondary reactions, including oxidation and the replacement of clinopyroxene by kaersutite. The extent of metamorphism and deformation decreases with depth, with Type $L$ granulites displaying extensive recrystallisation and brittle deformation, and Type $P$ pyroxenites retaining undeformed cumulate textures. 


\subsection{Mount Sidley}

Mount Sidley is a phonolitic and trachytic stratovolcano at the southern end of the Executive Committee Range ( $\left.77^{\circ} 03^{\prime} \mathrm{S}, 126^{\circ} 07^{\prime} \mathrm{W}\right)$. At $4181 \mathrm{~m}$ above sea level, and $2200 \mathrm{~m}$ above ice level, it is the highest volcano in Antarctica.

Discovery of Mount Sidley occurred during an airplane flight on November 18, 1934 by Rear Admiral Richard E. Byrd. He named the volcano after Mabelle E. Sidley, daughter of William Horlick, a contributor to the second Byrd Antarctic Expedition, 1933-35. The first geological reports of the edifice (Doumani and Ehlers, 1962; Doumani, 1964) were based on the 1959 'Executive Committee Range Traverse' expedition by tracked vehicles and a reconnaissance flight. Another team visited Mount Sidley in 1967 for one day of helicopter-supported reconnaissance fieldwork (Le Masurier, 1972; Le Masurier, 1990; Le Masurier and Rex, 1991). Most recently, the WAVE programme visited Mount Sidley between 31.12.89-20.1.90 in the most extensive study of the edifice to date (Smellie and Panter, 1991; Smellie et al., 1993; Panter et. al., in prep).

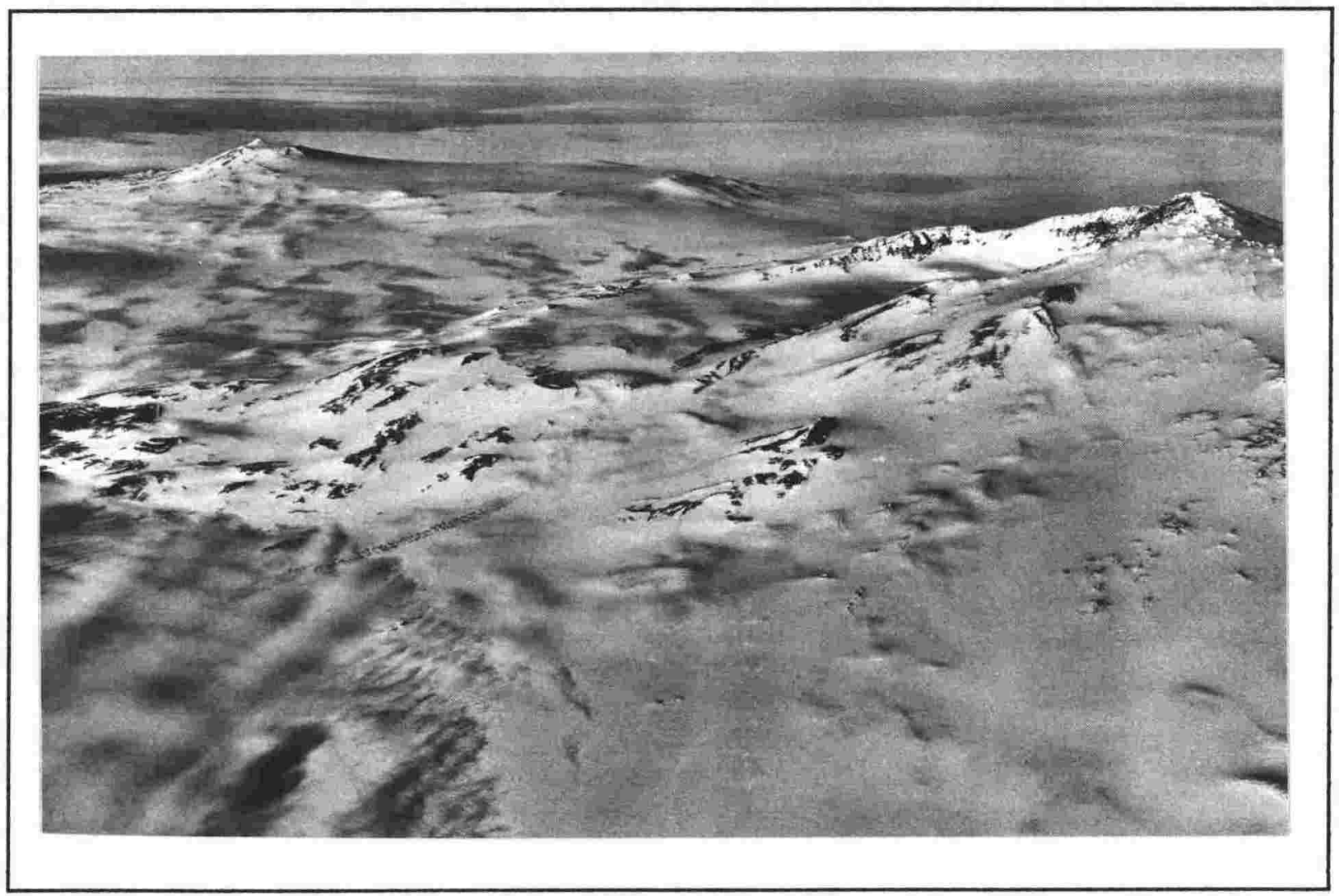

PLATE 4.1: View looking west to Mount Sidley (right) and Mount Waesche (left) (from Le Masurier, 1990; U.S. Navy photo TMA 571 F31 009). The Mount Sidley caldera, $5 \mathrm{~km}$ across and $1.2 \mathrm{~km}$ high, was produced by sector collapse associated with phonolitic ignimbrite deposits dated at $4.3 \pm 0.5 \mathrm{Ma}$ (Panter et al., in prep). Satellitic late-stage scoria cones on the edifice contain lithospheric xenoliths brought to the surface by basanitic magmas. 
The most conspicuous feature on Mount Sidley is its large caldera, that exceeds five $\mathrm{km}$ in diameter (Plate 4.1). The south side of the caldera has been breached by an explosive event leaving a $1200 \mathrm{~m}$ high scarp as its northern wall, that provides the best exposed section through the volcanic edifice.

Construction of the volcano occurred during several episodes of activity over a period of approximately 1.5 Ma (Panter et al., 1991; Panter et al., in prep). Volcanic activity commenced c. 5.7 Ma producing a succession of anorthoclase phonolitic lavas. A later series of phonolitic and trachytic lavas (4.7-5.3 Ma) together with hyaloclastic and epiclastic sediments were then emplaced. Further volcanism at c. $4.5 \mathrm{Ma}$ produced trachytic lavas and flow domes with breccia deposits. The caldera was probably produced by an explosive sector collapse associated with emplacement of phonolitic ignimbrite dated at $4.3 \pm 0.5 \mathrm{Ma}$ from pyroclastic fall deposits. A final phase of mafic volcanism formed parasitic basanitic scoria cones, and brought to the surface numerous and lithologically diverse crustal and mantle xenoliths. Field evidence indicates that some of these cones post-dated caldera formation.

\subsection{The Xenolith Suite}

Xenoliths entrained in late-stage basanitic lavas, and collected from Mount Sidley (Figure 3.1), include lower crustal granulites and pyroxenites. Upper mantle peridotites are rare, and were not analysed due to their small size $(1-2 \mathrm{~cm})$ and highly oxidised condition. Sintered upper crustal granitoids were also collected, but are not discussed here. The Mount Sidley xenolith suite is defined in this study as the granulite and pyroxenite xenolith suites, which are inferred to be lower crustal in origin (Chapter 1.4).

Granulites and pyroxenites range in size from $1-2 \mathrm{~cm}$, up to $20 \times 17 \times 11 \mathrm{~cm}$, with the majority of hand size. All the samples are fresh, unweathered and in very good condition due to the cold arid desert conditions of the Antarctic continent. The outer surfaces of many xenoliths however, are oxidised. This is only a surface feature obtained through host melt - xenolith reaction, and does not extend more than a few millimetres into the cores of the xenoliths. These rims have not been analysed geochemically. Some xenoliths are more extensively oxidised (Plates 4.2, 4.3, 4.4, 4.5 and 4.9), and this feature will be further discussed (Chapter 4.5).

The xenoliths are typically angular-subangular with rounded edges as a consequence of milling during transport in the ascending lavas. The angular 
nature of the samples may also be due to entrainment, or they may be a feature of the source area. Some samples display cracked oxidised rims exposing fresh rock unaffected to slightly affected by the entraining lava, suggesting that the cracks opened in response to decompression during entrainment and transport. The rarity of such cracks in comparison to the widespread occurrence of angular faces further implies that the angularity of the xenoliths is a source characteristic. This is similar to rocks transported by sedimentary processes, with rounding of the clasts and occasional cracking or breaking. Whether the source region is an extensively fractured area under brittle conditions, or whether the fracturing is a function of the conduit zone alone cannot be determined.

Mineral and whole rock descriptions and analyses, and the methods used in their preparation can be found in Wysoczanski (1993) and in the appropriate appendices of this thesis.

\subsection{Petrography}

The xenolith suite from Mount Sidley has been subdivided into four groups on the basis of petrography: layered granulites, rich in plagioclase (Type ' $\mathrm{L}$ ' granulites); mafic granulites, rich in mafic minerals and not as well layered (Type ' $\mathrm{M}$ ' granulites); plagioclase-bearing cumulate pyroxenites (Type ' $\mathrm{C}$ ' pyroxenites); and cumulate pyroxenites comprised wholly of mafic minerals (Type ' $\mathrm{P}$ ' pyroxenites). While these groups are quite distinct, they do form a continuous series grading from one type to another. A summary of the range of modal assemblages for each xenolith type is presented as Table 4.1.

TABLE 4.1: Range of modal assemblages present in granulites and pyroxenites from Mount Sidley. Primary oxides are not distinguished from secondary oxides (both are classed as 'opaques') because of the difficulty in identifying primary oxides due to the large extent of secondary oxidation. Note the absence of orthopyroxene as a primary mineral phase. Accessory minerals are apatite and rhönite.

\begin{tabular}{lcccc}
\hline Xenolith Type & Type L & Type M & Type C & Type P \\
\hline Olivine & $2.0-27.8$ & $2.6-22.2$ & $0.0-7.6$ & $7.8-70.8$ \\
Clinopyroxene & $0.2-20.6$ & $3.0-47.8$ & $34.4-51.2$ & $8.8-79.8$ \\
Orthopyroxene & Trace & - & - & - \\
Plagioclase & $62.6-83.0$ & $24.0-52.0$ & $26.4-36.4$ & $0.2-16.2$ \\
Kaersutite & $0.2-10.0$ & Trace & $6.6-23.2$ & $0.4-22.6$ \\
Opaques * & $1.2-35.4$ & $20.8-50.8$ & $5.6-8.2$ & $2.0-20.6$ \\
Accessories + & $0.4-8.8$ & $0.2-2.2$ & $0.0-0.4$ & $0.0-1.2$ \\
& & & & \\
\hline
\end{tabular}


Many granulites have been extensively oxidised along mafic mineral layers, resulting in olivine being replaced by oxides (titanomagnetite and ilmenite). These have been classed as opaques in modal tables (Table 4.1), along with primary oxides, which are difficult to distinguish due to the large extent of oxidation. For the purpose of rock classification (see Chapter 2.2.2), opaques are treated as olivine - the original mineral phase prior to oxidation. It must be emphasised that many of the samples showing complete oxidation of olivine are now titanomagnetite-ilmenite bearing granulites and their classification here is that of the protolith before oxidation. The oxidation of the xenolith suite along with other secondary processes will be discussed separately from the primary characteristics of the xenolith protoliths (Chapter 4.5).

\subsubsection{The granulite suite}

The granulite suite consists of layered granulites rich in plagioclase (Type $\mathrm{L})$, and mafic granulites rich in mafic minerals (Type M).

\section{Layered Granulites (Type 'L')}

The most abundant xenolith type, these are meta-igneous holocrystalline plagioclase-rich granulites, with a definitive layering of felsic and mafic minerals on a sub-cm scale (Plates 4.2 and 4.3). Olivine leucogabbros are the most abundant rock type, and olivine gabbros, leucogabbros, leucotroctolites, troctolites and anorthosites are also present, as well as kaersutite-bearing olivine gabbros and leucogabbros. The major mineral assemblage consists of plagioclase (always the most abundant) \pm clinopyroxene \pm olivine $\pm \mathrm{Fe}-\mathrm{Ti}$ oxides. A strong orientation of mineral phases has imparted a layering on the granulites, which is interpreted to represent a primary igneous cumulate layering (Parsons, 1987). An overprinted metamorphic fabric is developed in all samples to varying degrees, with the recrystallisation of igneous mineral phases producing an equant polygonal texture with $120^{\circ}$ triple junctions (Plate 4.2 ). Samples which have not been recrystallised are not as well layered, indicating that metamorphism enhances any original igneous layering.

Two generations of plagioclase are present (Plate 4.2). Large hypidiomorphic tabular crystals up to $5 \mathrm{~mm}$ long have a preferred orientation, imparting a layered texture on the xenoliths. Twinning ranges from well developed multiple twins to absent. Relict oscillatory zoning is present in some plagioclase, and many are strongly deformed with cracks and irregular extinction. These large deformed plagioclase crystals are interpreted as being cumulus in origin. 


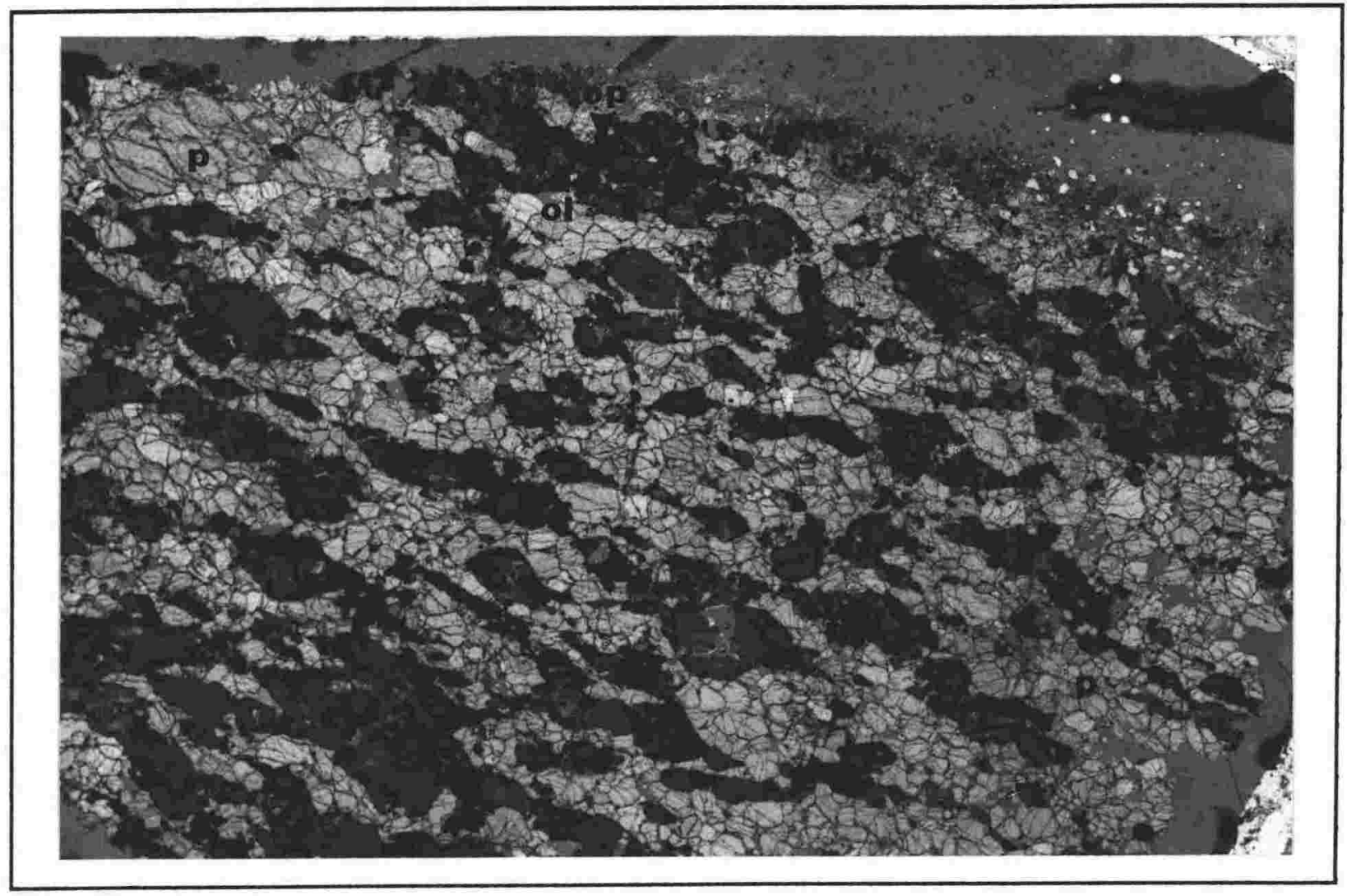

PLATE 4.2: Type L granulite (sample 90031A) with a well developed layering. Two generations of plagioclase (p) are present: large cumulus grains (e.g. extreme top left plagioclase) and small grains with $120^{\circ}$ triple junctions that have recrystallised from larger igneous grains (e.g. small plagioclase at bottom right). Note the large proportion of oxidised olivines (ol) that are becoming opaque (op). Clinopyroxene (c) is also present. Width of plate is $18 \mathrm{~mm}$.

A second form of plagioclase consists of equant polygonal grains up to 2 $\mathrm{mm}$ in size (but generally $<1 \mathrm{~mm}$ ). Twinning is generally absent, with only a minority of grains exhibiting simple twinning. These plagioclase are interpreted as being entirely metamorphic in origin and many can be seen to be forming from large tabular plagioclase crystals (Plates 4.2). They take their form from the older crystals, and in contact with each other the grains show well-developed triplejunctions. Most crystals are undeformed, although some crystals do display deformational features similar to those of tabular plagioclase crystals, indicating that deformation was probably pre- to syn-metamorphic.

Clinopyroxene occurs as a cumulus and an intercumulus phase (Plate 4.3), in two textural forms similar in character to the plagioclase generations. Large (up to $3 \mathrm{~mm}$ ) tabular clinopyroxenes are preferentially orientated along layering and have crystallised together with tabular plagioclase. Smaller $(<1 \mathrm{~mm}$ ) equant polygonal crystals are identical to equant plagioclase in form and origin.

Olivine is common in many samples with sizes varying from $100-\mu \mathrm{m}$ to mm scale. Forms displayed by olivine crystals include: cumulus rounded primary 
crystals, often as inclusions in tabular plagioclase and clinopyroxene; smaller crystals developed interstitially to cumulus plagioclase and clinopyroxene; and small recrystallised equant grains. Cumulus and intercumulus olivines are typically highly oxidised, ranging from rust-brown in colour to opaque (Plate 4.3). Small (10-100 $\mu \mathrm{m}$ scale) hypidiomorphic orthopyroxene crystals occur rarely on the edges of altered olivines. The relative freshness of the recrystallised olivines compared to other olivines is apparent and suggests they are either much younger or have grown in equilibrium with present $\mathrm{fO}_{2}$ conditions.

Kaersutite occurs in many samples as a secondary mineral replacing clinopyroxene. The extent of replacement varies from minimal to extensive, with kaersutite becoming a major mineral phase at the expense of clinopyroxene. When fully developed, kaersutite grains display strong pleochroism (alpha = brownish-yellow, beta = reddish-brown, gamma = deep chestnut-brown), with high-order interference colours.

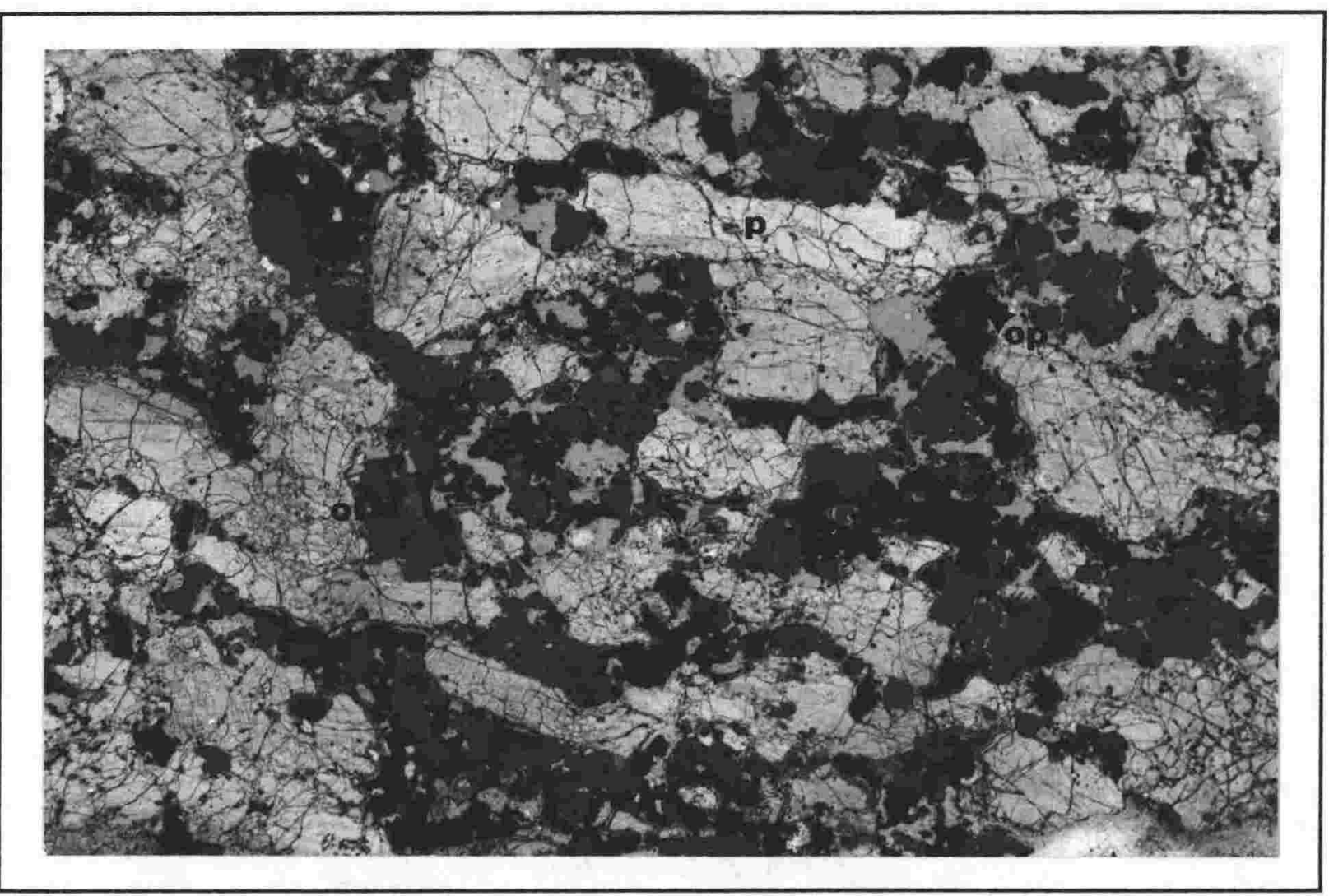

PLATE 4.3: Type L granulite (sample 90029H1) with moderate igneous layering. Tabular igneous plagioclase (p) is easily recognisable (e.g. top of centre). Clinopyroxene (c) is both a cumulus and an intercumulus phase. Note the large proportion of oxidised olivine (ol) that is becoming opaque (op) as a result of oxidation. Width of plate is $18 \mathrm{~mm}$.

Apatite is a common accessory phase, occurring as small idiomorphic inclusions in plagioclase. Another abundant generation of apatite occurs as 
idiomorphic-hypidiomorphic grains ranging in size from $<100 \mu \mathrm{m}$ to $2 \mathrm{~mm}$. These form along grain boundaries and in triple junctions of recrystallised equant minerals. They are slightly oxidised and secondary to other mineral phases, and are interpreted as secondary in origin.

Titanomagnetite and ilmenite have formed interstitially to all other phases, both igneous and metamorphic. They occur as primary intercumulus grains, and as secondary grains associated with the oxidation of olivine. Glass is also present in Type $\mathrm{L}$ xenoliths along mafic layers that have been oxidised.

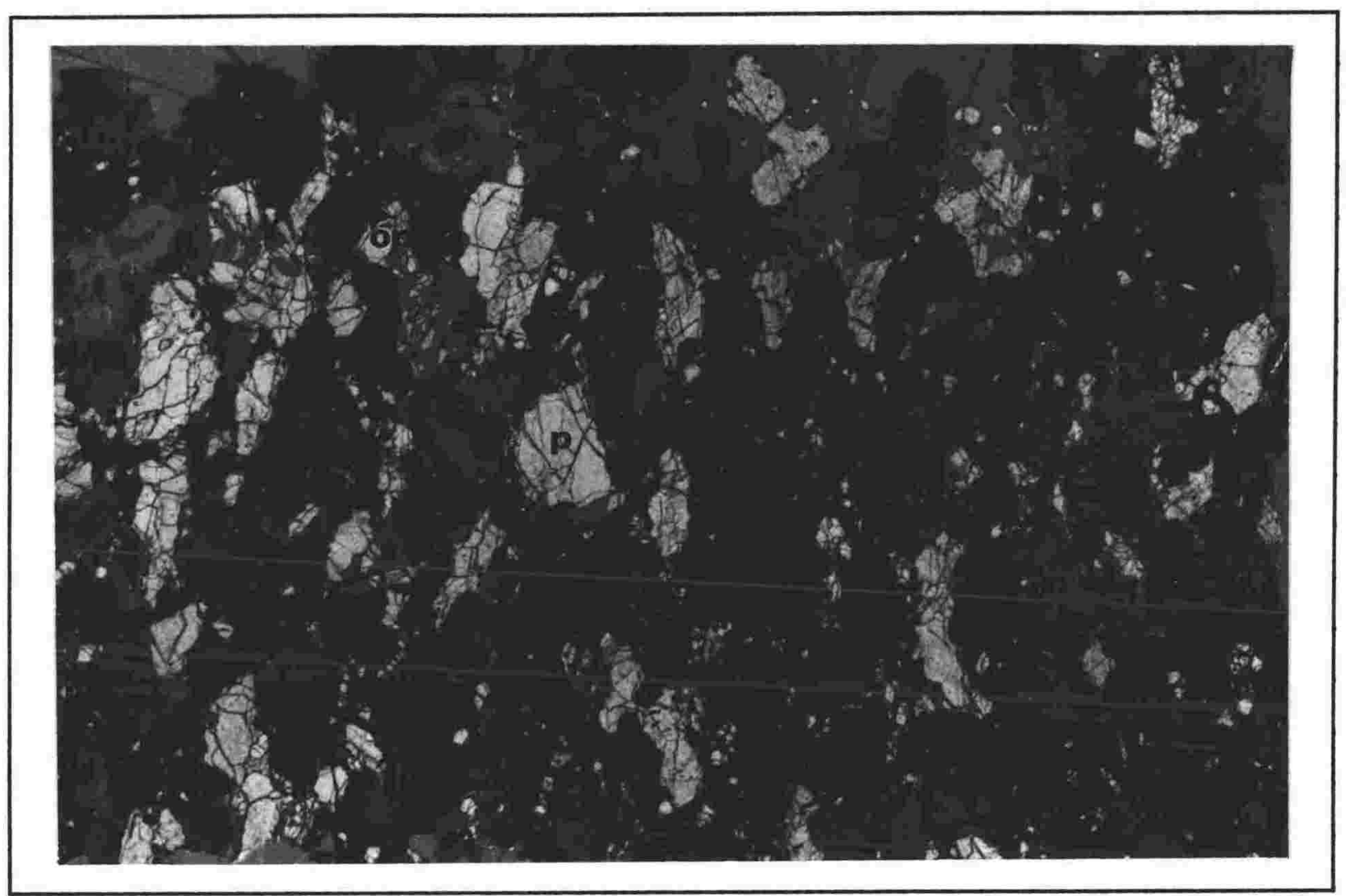

PLATE 4.4: Type M granulite (sample 90029Q) with a layering of mafic phases (clinopyroxene (c) and olivine) and plagioclase (p). Olivine has been wholly oxidised and is opaque (op). Width of plate is $19 \mathrm{~mm}$.

\section{Mafic Granulites (Type ' $M$ ')}

This suite consists of holocrystalline olivine-melagabbros, gabbros and troctolites, with a layering of mafic and felsic phases. Mafic phases are generally more abundant than plagioclase (Plate 4.4; Table 4.1). Mineral phases include plagioclase + olivine + clinopyroxene + oxides. Recrystallisation of mineral phases has occurred in some samples, but relict polycrystalline heteradcumulate textures are well preserved in other samples. The layering and recrystallisation is pronounced but not as well developed as in Type L xenoliths (Plate 4.4). 


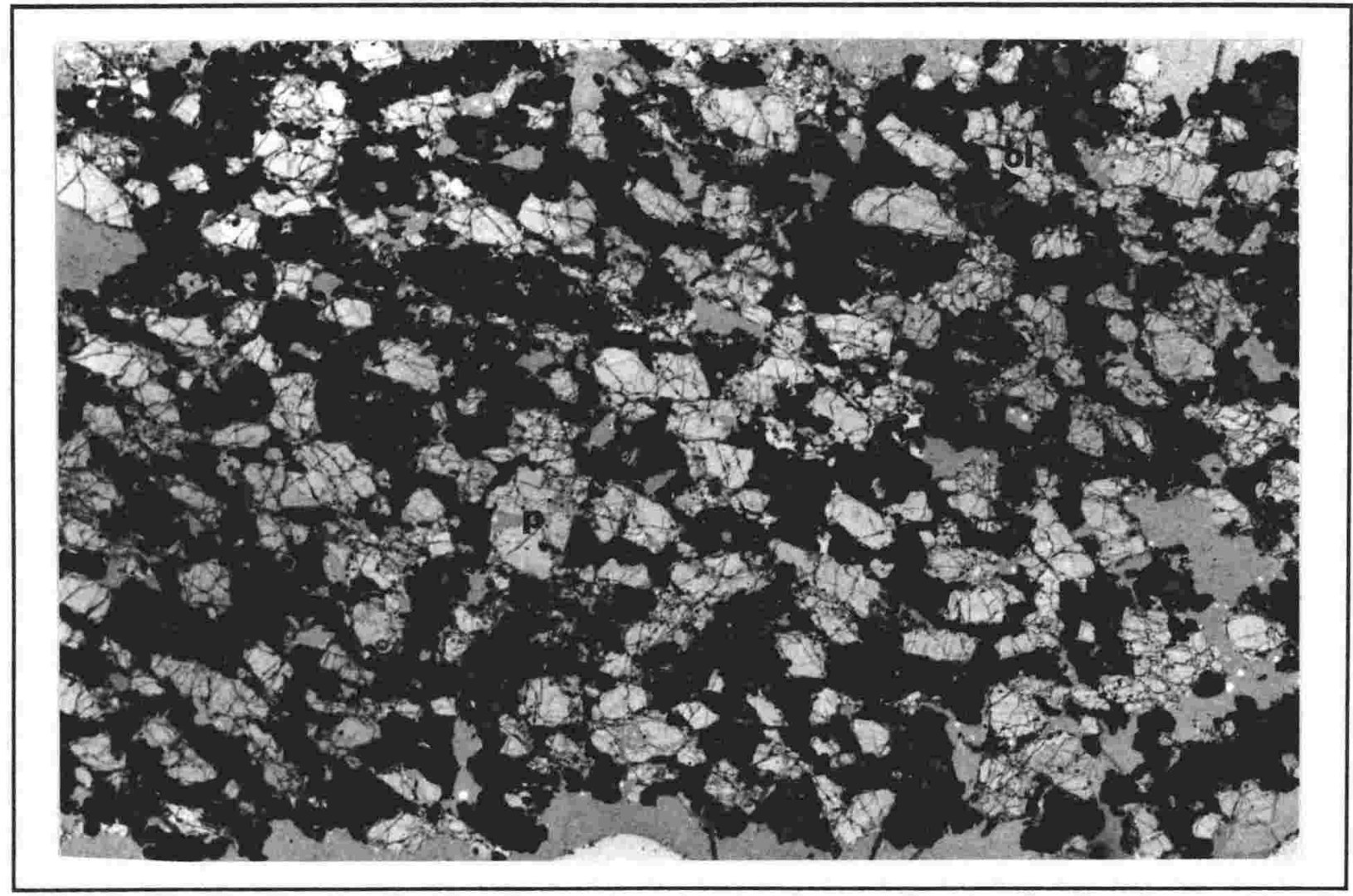

PLATE 4.5: Type M granulite (sample $90029 \mathrm{H}$ ) rich in plagioclase (p), with many plagioclase having mafic inclusions. Clinopyroxene (c) is cumulus and subordinate to olivine (ol), which is both a cumulus and an intercumulus phase. Width of plate is $18 \mathrm{~mm}$.

Large rounded olivines $(100 \mu \mathrm{m}-2.5 \mathrm{~mm})$ are cumulus and intercumulus in origin. They are moderately oxidised to a rust-brown colour (Plate 4.5). Slightly green to black spinels are common inclusions in olivines. Rounded clinopyroxenes (up to $2 \mathrm{~mm}$ ) are cumulus, displaying identical form and habit to cumulus olivine, which crystallised synchronously with clinopyroxene. Smaller olivines $(<100 \mu \mathrm{m})$ have formed around cumulus olivine and clinopyroxene grains and in interstices, representing late stage crystallisation from a melt. In some samples, clinopyroxene also occurs as an intercumulus phase.

Plagioclase is present as large (up to $3 \mathrm{~mm}$ across), tabular allotriomorphic crystals displaying multiple twinning, with some signs of deformation (cracks, irregular extinction), and relict oscillatory zoning. Inclusions of olivine and clinopyroxene are common. Tabular plagioclase represent first formed interstitial plagioclase followed by allotriomorphic plagioclase which are poikilitic, enclosing olivine and clinopyroxene. Tabular crystals have a poorly defined orientation in some samples, but are random in others.

Smaller $(<100 \mu \mathrm{m})$ polygonal equant grains are metamorphic in origin, growing from other plagioclase phases. They are commonly not twinned, have 
good triple-junctions, and are generally undeformed, although a minority are deformed.

Titanomagnetite and ilmentite fill interstices and occur around grain boundaries, through cracks and replacing olivine. Traces of kaersutite are present as a secondary phase replacing clinopyroxene.

\subsubsection{The pyroxenite suite}

The pyroxenite suite consists of Type C pyroxenites, which contain cumulate plagioclase, and Type $\mathrm{P}$ pyroxenites, which contain only trace amounts of interstitial plagioclase.

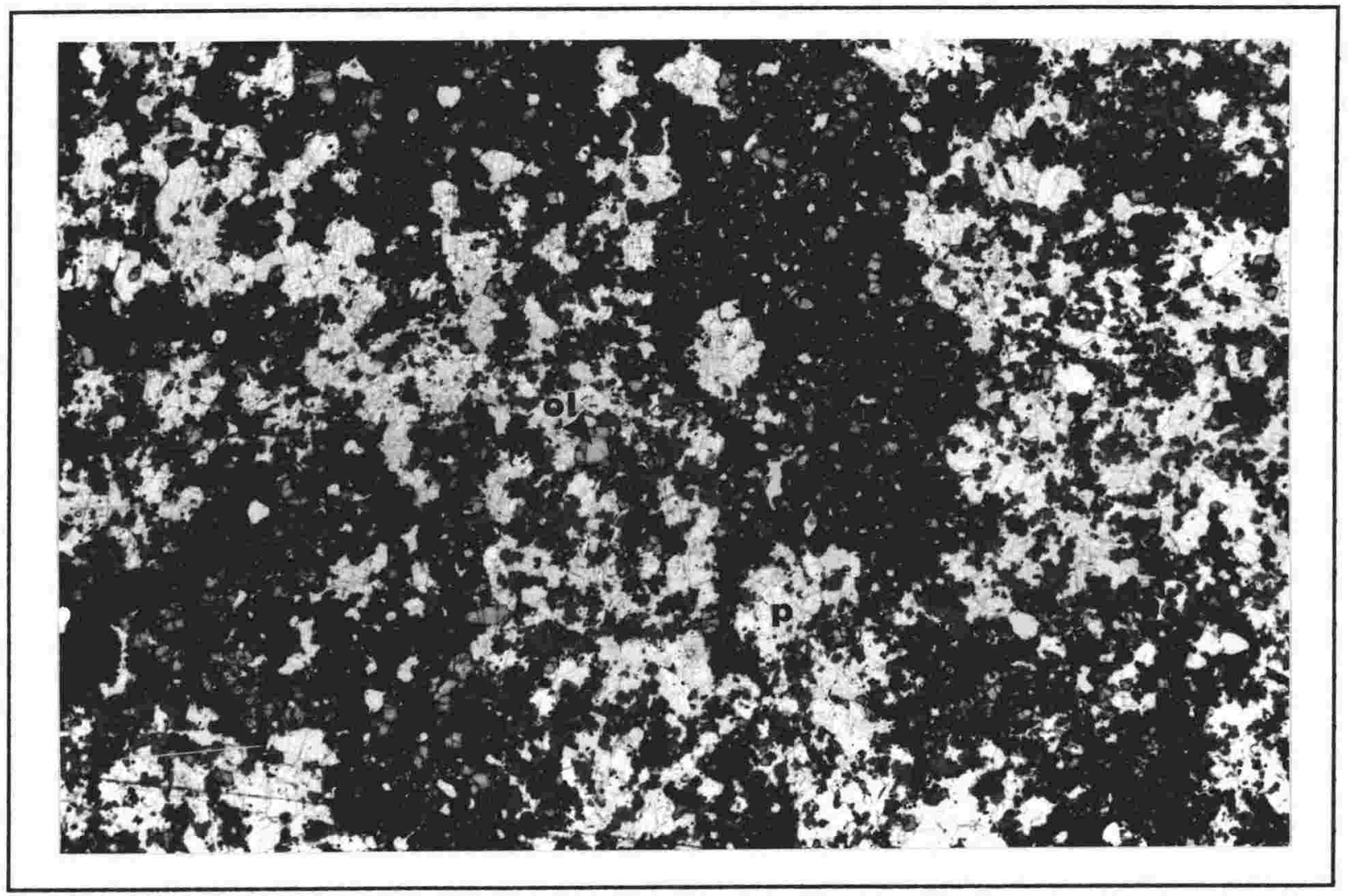

PlATE 4.6: Type C pyroxenite (sample 90033H1) with intercumulus clinopyroxene (c) and a large proportion of intercumulus plagioclase (p). Cumulus olivine $(o l)$ is enclosed in intercumulus phases. Width of plate is $18 \mathrm{~mm}$.

\section{Cumulate Plagioclase Pyroxenites (Type ' $C$ ')}

Type $\mathrm{C}$ xenoliths are holocrystalline igneous rocks with definitive cumulate textures, and plagioclase as an intercumulus phase (Plates 4.6 and 4.7). Heteradcumulate and mesocumulate textures are strongly preserved, although metamorphism has resulted in an overprinted polygonal texture in some samples. The suite consists of olivine gabbro and olivine melagabbro and includes kaersutite-olivine gabbros and melagabbros. 
The mineral assemblage is dominated by clinopyroxene + plagioclase \pm olivine \pm spinels (including $\mathrm{Cr}$-bearing spinel). Kaersutite is a common secondary phase. No layering of minerals is evident in Type $C$ xenoliths.

Olivine is present as rounded and subidiomorphic cumulus crystals up to 2 $\mathrm{mm}$ in size, but generally $100 \mu \mathrm{m}-1 \mathrm{~mm}$ (Plate 4.6). Many grains are highly oxidised, as in the other xenolith types. Black to green ( $\mathrm{Cr}$-bearing) spinels are common as rounded inclusions in olivine and occupying interstices. Clinopyroxene also occurs as both a cumulus phase, with similar forms and sizes to olivine, and as an intercumulus phase. Cumulus olivine and clinopyroxene are rarely recrystallised in situ, having developed equant habits with $120^{\circ}$ triplejunctions.

Plagioclase occurs as an intercumulus phase, forming large (up to $5 \mathrm{~mm}$ ) tabular crystals and smaller $(100 \mu \mathrm{m}-2 \mathrm{~mm})$ xenomorphic crystals surrounding and enclosing cumulus phases. Deformational features are sometimes developed, but to a less degree than in Type $\mathrm{L}$ and Type $\mathrm{M}$ xenoliths. Recrystallisation of plagioclase has occurred, resulting in small (up to $1 \mathrm{~mm}$ ) equant plagioclase with triple junctions between grains.

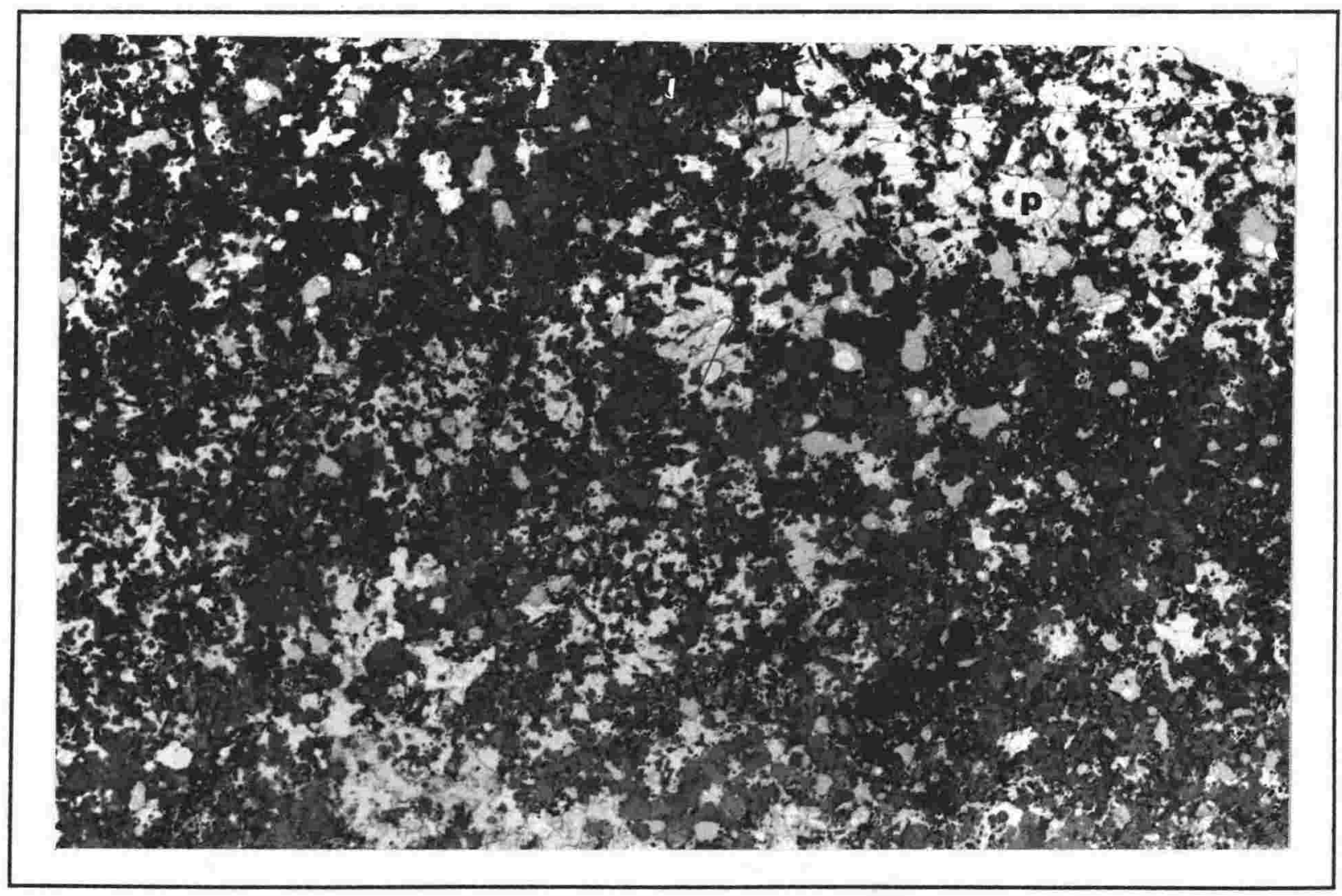

PLATE 4.7: Type C pyroxenite (sample 900M1) with a large proportion of cumulus (round) and intercumulus (irregular) clinopyroxene (c) and cumulus plagioclase ( $\mathrm{p}$; top right). Width of plate is $17 \mathrm{~mm}$. 
Kaersutite is present in some samples replacing clinopyroxene, and ranges from well developed brown pleochroic grains to xenomorphic partially formed crystals where replacement is incomplete. Titanomagnetite and ilmenite are also common as secondary minerals having crystallised interstitially and along grain boundaries.

\section{Cumulate Pyroxenites (Type 'P')}

Type $\mathrm{P}$ xenoliths include olivine clinopyroxenites and wehrlites, with subordinate gabbro, including spinel-, kaersutite- and plagioclase-bearing cumulates (Plates 4.8 and 4.9). Heteradcumulate textures are well developed with no apparent recrystallisation; the complete absence of metamorphic textures differs from all other xenolith types.

Olivine is present as hypidiomorphic to rounded cumulus crystals (up to 4 $\mathrm{mm}$ in size, but generally 1-2 $\mathrm{mm}$ ). Green Cr-spinels (up to $4 \mathrm{~mm}$ in size but generally much less) occur as inclusions in olivine and as cumulus grains. Some spinels are altered, with small $(10-100 \mu \mathrm{m})$ plagioclase grains growing as coronas around the spinels.

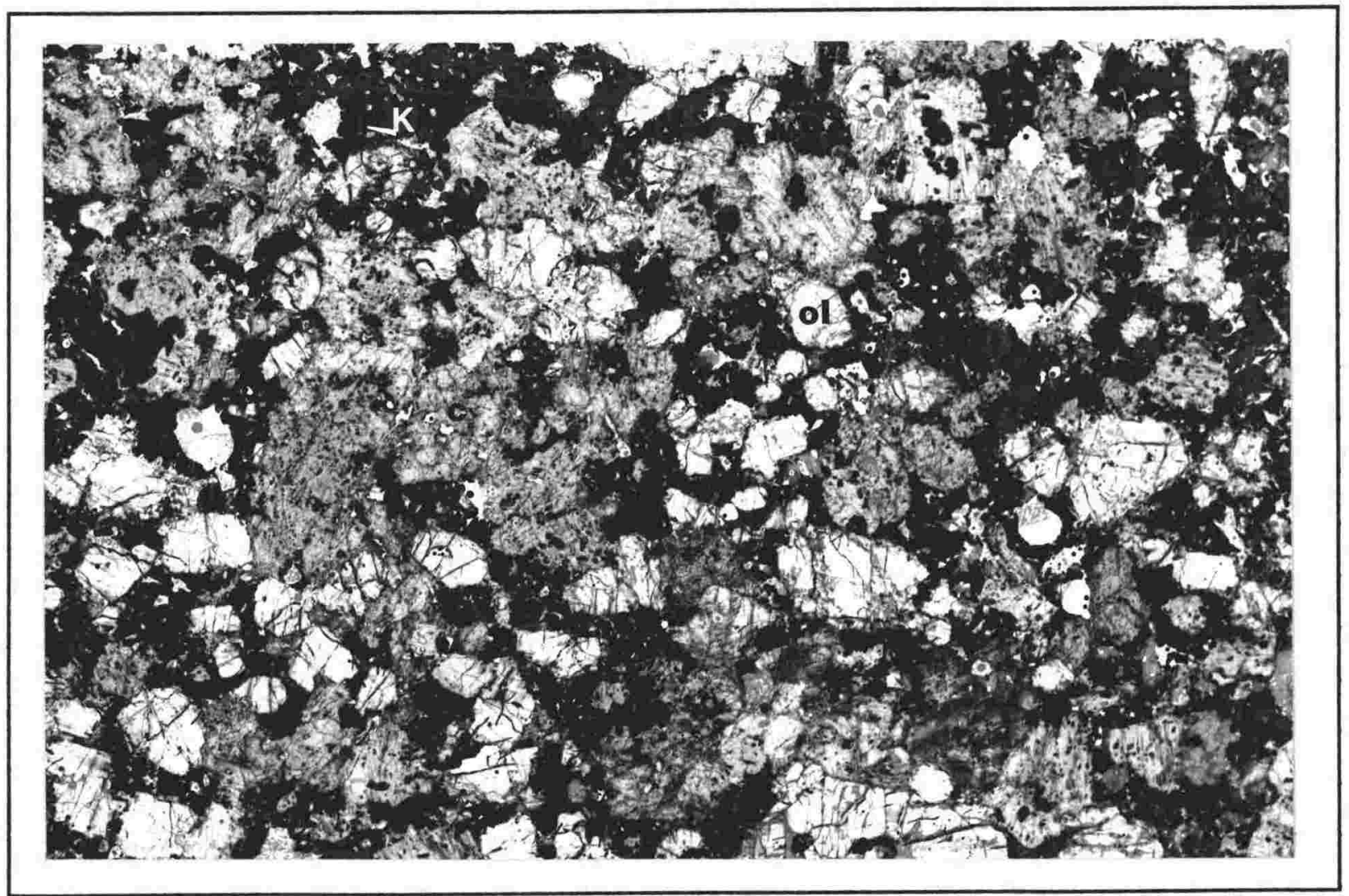

PLATE 4.8: Type P pyroxenite (sample 90033C) comprised of round cumulus olivine (ol) and intercumulus clinopyroxene (c). Kaersutite (k) can be seen replacing clinopyroxene. Width of plate is $15 \mathrm{~mm}$. 


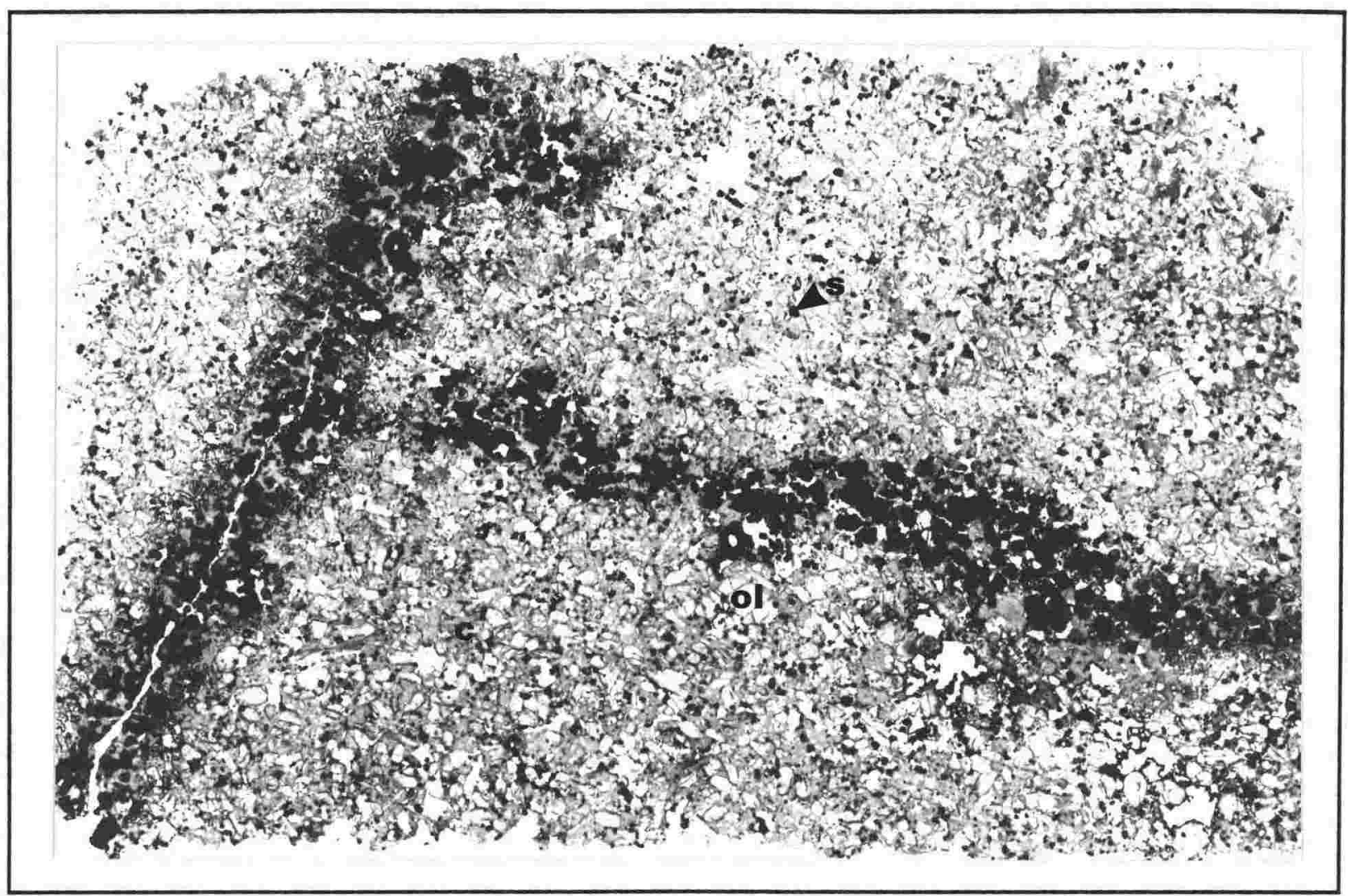

PLATE 4.9: Type $P$ pyroxenite (sample 90033R1) comprised of round cumulus olivine (ol) and spinels (sp) with enclosing clinopyroxene (c). Oxidising veins, that can be traced to xenolith rims, have infiltrated the xenolith oxidising olivine but not clinopyroxene. Width of plate is $17 \mathrm{~mm}$.

Clinopyroxene is an intercumulus phase, occurring as poikilitic grains (up to $5 \mathrm{~mm}$ ) enclosing cumulus phases, typically olivine. Exsolved orthopyroxene ( $\mu \mathrm{m}$-scale) occurs in some clinopyroxenes. Kaersutite is present in some samples where it replaces intercumulus clinopyroxene (Plate 4.8). Small rhönite grains also occur in many samples, in association with melts or kaersutite replacement of clinopyroxene. Small plagioclase laths $(<100 \mu \mathrm{m})$ are common in interstices, but they are not modally abundant. A few samples contain very large poikilitic (up to $1 \mathrm{~cm}+$ ) and tabular plagioclase. Plagioclase-bearing samples are similar in texture to Type $C$ pyroxenites. Twinning is present in some plagioclase.

Type $\mathrm{P}$ pyroxenites are generally unaltered, although disequilibrium reactions have occurred, including the breakdown of spinels to plagioclase, and exsolution in clinopyroxene. These reactions are probably a result of decompression. Oxidation of olivine has also affected the suite, occurring as mmscale veins along cracks (Plate 4.9).

\subsubsection{Composite and intermediate xenoliths}

Xenoliths also occur that are composites of the above xenolith types, grading from one type to another, or including one within another ('xenoliths 
within xenoliths'). Other xenoliths are petrographically intermediate in texture to two xenolith types. Figure 4.1 is a representation of the types of composite and intermediate xenoliths occurring in the suite.

a)

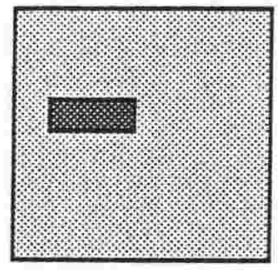

b)

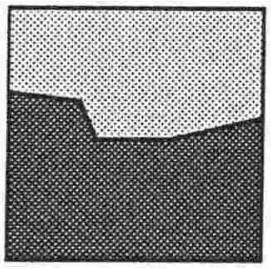

or

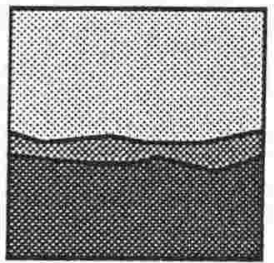

c)

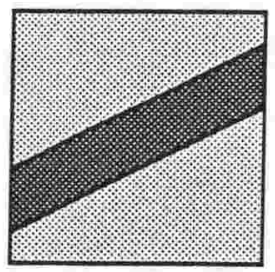

d)

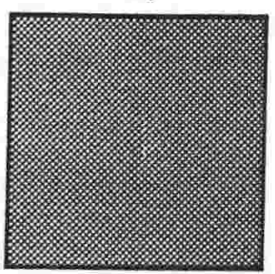

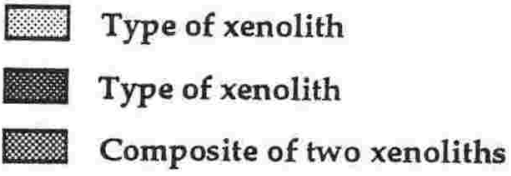

FIGURE 4.1: Diagram showing the types of composite and intermediate xenoliths present in the xenolith suite: a) xenolith entrained within another xenolith (a xenolith in a xenolith); b) the contact between xenoliths may be sharp (top), or indistinct with an intermediate nature at the contact (bottom); c) one xenolith may occur as a vein within another; d) and a xenolith may be intermediate in nature to two xenolith types.

Composite xenoliths include a Type $\mathrm{C}$ xenolith with Type $\mathrm{M}$ inclusions (90039O), and a Type P xenolith with Type $\mathrm{M}$ inclusions (90033G); these are 'xenoliths within xenoliths' (Figure 4.1a). Another composite xenolith type includes two Type L granulites grading to Type C xenoliths (90033B1 and 33K1). The gradation between the two is sharp in one (90033B1), but gradational on a cmscale in the other $(90033 \mathrm{~K} 1)$, with the intermediate region consisting of a mix of the two (Figure 4.1b). A Type $\mathrm{P}$ xenolith with plagioclase-rich Type $\mathrm{C}$ veins (90039S) represents another type of composite xenolith, with veins of one xenolith type occurring in another (Figure 4.1c).

Intermediate xenoliths (Figure 4.1d) include a xenolith resembling a plagioclase-poor Type L xenolith (90033C1), a xenolith resembling a plagioclaserich Type $\mathrm{M}$ xenolith (90039J), and a xenolith that is petrographically similar to a combination of Type L, M and C xenoliths (90039T).

The presence of composite and intermediate xenoliths is important, as they represent a group of xenoliths outside of the major types and are a reminder that the xenolith suite is not simple in texture, but is interlayered and gradational, with some xenoliths representing a mixing of two types. 


\subsubsection{Secondary mineral reactions}

Several secondary mineral reactions (reactions involving the formation of (secondary) mineral phases after initial (primary) crystallisation of the xenolith suite) are widespread and diverse in the xenolith suite (see Plates 4.2 to 4.9 ). The illustration and chemistry of these reactions, and their bearing on $\mathrm{P}-\mathrm{T}-\mathrm{fO}_{2}$ conditions, will be further discussed in Chapter 4.5.

A notable reaction is that between the host melts and the xenolith suite. Pockets of host melt can be seen in some xenoliths, where it has infiltrated into the xenolith via cracks. Mineral reactions are not extensive, and the infiltrating melt can be clearly seen complete with crystallising phases and groundmass phases. These areas were avoided in whole-rock and mineral geochemical analyses.

Oxidation reactions are widespread throughout all sample types. In the granulite suite oxidation reactions result in the replacement of olivine by $\mathrm{Fe}-\mathrm{Ti}$ oxide minerals, the growth of euhedral apatite, and disequilibrium textures (sieved rims) and overgrowths on plagioclase in contact with the oxidised zones (Plates 4.2 and 4.3). Glass, is present in conjunction with disequilibrium textures and secondary mineral growth, indicating that oxidation may be due to an infiltrating hydrous silicate melt. In the pyroxenite suite, rare oxidised veins occur, resulting in the extensive oxidation of olivine (Plate 4.9); clinopyroxene in these veins is generally unaffected.

The oxidation of olivine is $\mathrm{T}-\mathrm{f} \mathrm{O}_{2}$ dependant, a relationship that will be further discussed in Chapter 4.5. The presence of olivine with plagioclase in the granulite suite indicates that the xenolith assemblage is characteristic of a low pressure - high temperature granulite suite (Griffin and O'Reilly, 1987a; see Chapter 1.4.2 and Figure 1.9).

Some Al-spinels in the pyroxenite suite have plagioclase-coronas signifying a breakdown to a lower pressure assemblage. This is likely to be a decompression reaction, although whether it occurs in situ in response to uplift, or due to ascent of the xenolith in the host magma is difficult to distinguish.

Another reaction present in many xenoliths, most notably the pyroxenite suite, is the replacement of clinopyroxene by kaersutite (kaersutitisation). This reaction is complete in some cases, with well developed kaersutite crystals, and incomplete in others, with discontinuous anhedral kaersutite growth (Chapter 4.5.2). Kaersutitisation signifies an addition of $\mathrm{H}_{2} \mathrm{O}$ that cannot be accounted for by the xenolith mineral assemblage, which is anhydrous. Glass is rarely associated with this reaction, suggesting that the agent responsible for this process is a hydrous silicate melt or a hydrous fluid associated with a silicate melt. 


\subsubsection{Summary of textures and bearing on petrogenesis}

All xenolith types were formed as cumulates with varying textures, including orthocumulate, mesocumulate, adcumulate and heteradcumulate. The appearance of cumulus and intercumulus phases differs between xenolith types, with a gradational change from Type $\mathrm{P}$ to $\mathrm{C}, \mathrm{M}$ and $\mathrm{L}$ xenoliths. Olivine changes from a cumulus phase to an intercumulus phase from Type $\mathrm{P}$ to Type $\mathrm{L}$ xenoliths, and clinopyroxene and plagioclase change from intercumulus to cumulus phases (Figure 4.2). Plagioclase is rare in Type $\mathrm{P}$ xenoliths, but is abundant as a mineral phase in Type L xenoliths. The converse is true for Al-spinel.

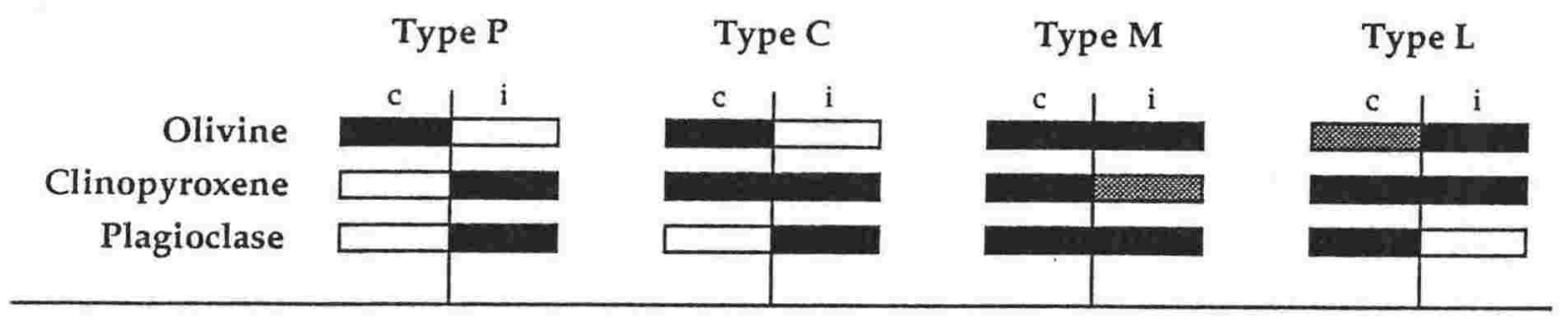

FIGURE 4.2: The appearance of cumulus and intercumulus mineral phases in the Mount Sidley xenolith suite changes from Type P to Type L xenoliths. Black areas represent a presence, and white areas an absence of phases, with shaded areas reflecting the rare occurrence of the mineral as a cumulus/intercumulus phase. Note the transition of olivine from a cumulus to an intercumulus phase, and the converse for plagioclase and clinopyroxene from Type $\mathrm{P}$ to Type $\mathrm{L}$ xenoliths.

Cumulate textures are well preserved in Type $\mathrm{P}$ and $\mathrm{C}$ xenoliths, but are strongly overprinted by a metamorphic fabric in Types $\mathrm{M}$ and especially Type $\mathrm{L}$ xenoliths. Primary cumulus clinopyroxene and plagioclase can be seen to be recrystallising to smaller polygonal equant grains with $120^{\circ}$ angles between grains. The magnitude of recrystallisation is greatest in Type $\mathrm{L}$ xenoliths, moderate in Type $\mathrm{M}$ xenoliths, rare in Type $\mathrm{C}$ xenoliths and absent in Type $\mathrm{P}$ xenoliths. Consequently, the textures of Type $\mathrm{P}$ and $\mathrm{C}$ xenoliths are cumulate, whereas textures of Type $\mathrm{L}$ and $\mathrm{M}$ xenoliths are metamorphic, with relict igneous textures (meta-igneous).

Deformation features (irregular extinction, twinning and fracturing) are common in all xenolith types, with the exception of Type $\mathrm{P}$ xenoliths. As deformation is only well developed in plagioclase in the other xenolith types, the absence of deformational features in Type $\mathrm{P}$ xenoliths does not necessitate a deformation-free locality, but may be due to the absence of plagioclase. The extent of deformation is greatest in Type $\mathrm{L}$ xenoliths, least in Type $\mathrm{P}$ xenoliths, and intermediate in Types $\mathrm{M}$ and $\mathrm{C}$ xenoliths. 
If deformation was due solely to conduit processes and ascent of the xenoliths in the host melt, then deformational features would be similar in all xenolith types, however this is not the case. The difference in the extent of deformation between xenolith types suggests varying deformational regimes at the source areas of the xenoliths, with Types $\mathrm{P}$ and $\mathrm{C}$ xenoliths originating from relatively deformation-free localities, whereas Types $\mathrm{L}$ and $\mathrm{M}$ xenoliths originated from areas of strong brittle deformation. The xenolith suite may therefore represent a region of the lithosphere that is at the transition from the brittle mechanical boundary layer, to the ductile thermal boundary layer (Parsons and McKenzie, 1978).

The timing of deformation can also be constrained. The limited occurrence of deformation features in metamorphic plagioclase crystals suggests that deformation in the granulites preceded metamorphism, and may have also been syn-metamorphic.

Oxidation by silicate melts is a major secondary process that has affected the xenolith suite. As with metamorphism and deformation, the extent of oxidation varies between xenolith types, from most extensive in Type $\mathrm{L}$ to least in Type $\mathrm{P}$. The timing of oxidation is uncertain. One indicator is that some equant plagioclase crystals display disequilibrium reactions with the oxidation products while others do not. All tabular igneous grains show disequilibrium reactions with oxidation. Oxidation may therefore have occurred after crystallisation and during metamorphism. Its association with silicate glass indicates that the oxidation process is related to silicate melts; most probably the host melt.

From the above discussion, a generalised sequence of events can be established:

- initial crystallisation of the xenolith suite from a mafic melt at lower crustal or upper mantle depths as cumulate rocks;

- metamorphism of the suite resulting in the recrystallisation of mineral phases to smaller polygonal grains with $120^{\circ}$ triple junctions between grains;

- deformation resulting in the development of dislocation twinning and irregular extinction in mineral phases, and fracturing of the xenolith suite resulting in the opening of cracks;

- oxidation of the suite by silicate melts, or hydrous fluids possibly associated with silicate melts, resulting in Fe-Ti oxide, plagioclase, apatite and kaersutite growth, and disequilibrium reactions in xenolith mineral phases;

- the entrainment of the xenolith suite in basanitic magmas and their ascent to the surface. 
The textural features and processes discussed above allow a simplified stratigraphy of the xenolith suite to be established. A common trend of all the processes documented is a gradation in the extent of each process from Type $\mathrm{P}$, to Types $\mathrm{C}, \mathrm{M}$ and $\mathrm{L}$ xenoliths. This gradation may be stratigraphic, temporal, or both. For example, there may be a simple stratigraphy of Type L to Type P xenoliths with depth (Figure 4.3a). Such a stratigraphy suggests that olivine crystallised as a cumulus phase at lower depths and became intercumulus at higher depths, with plagioclase and clinopyroxene becoming cumulus phases. The processes of metamorphism, deformation and oxidation are greater in their affects at higher crustal levels, with progressively less influence at lower depths.

a)

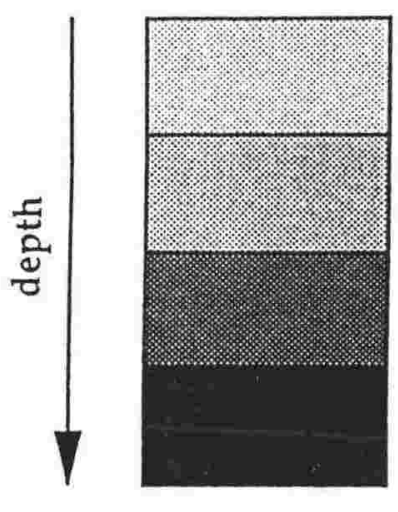

b)

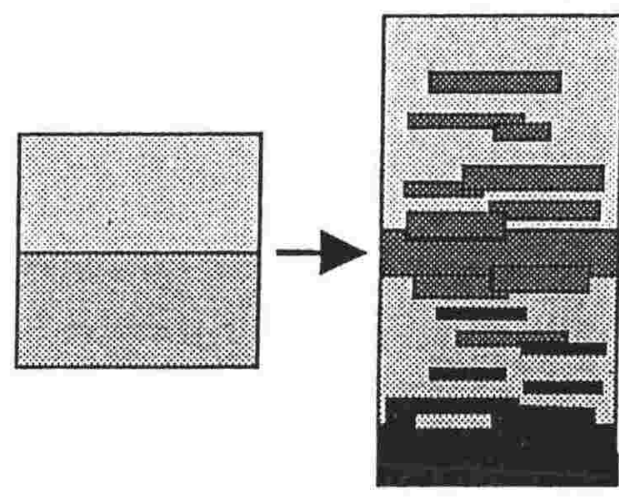

c)

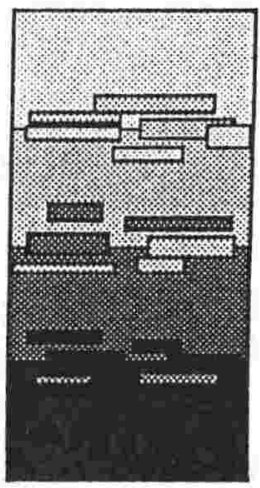

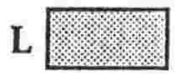

$\mathrm{M}$

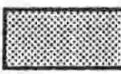

C

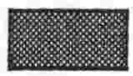

$\mathbf{P}$

FIGURE 4.3: Possible models of the stratigraphy of the lower crust beneath Mount Sidley as represented by the xenolith suite. a) A simple layering of xenolith types with a decrease in secondary process affects with depth. b) Growth of the lower crust followed by secondary processes and further growth unaffected by these processes. c) A combination of a) and b), with interlayered growth in stages.

Alternatively, the variation in processes may be temporal (Figure 4.3b). Initial crystallisation of the granulites (Types $\mathrm{L}$ and $\mathrm{M}$ xenoliths) was followed by metamorphism, deformation and oxidation. The subsequent crystallisation of Types $\mathrm{P}$ and $\mathrm{C}$ xenoliths preserved their cumulate textures as the affects of metamorphism, deformation and oxidation were not as great.

The actual stratigraphy may well be a combination of these extremes (Figure 4.3c), with perhaps the simple stratigraphy of Figure $4.3 \mathrm{a}$ and an interlayering of xenolith types as in Figure 4.3b. The gradational nature of the xenolith suite and the presence of composite xenoliths of all types suggests that this is the most likely possibility. 


\subsection{Mineral Chemistry}

This section seeks to document the chemistry of the mineral assemblages in the Mount Sidley xenolith suite, particularly to ascertain any relationship between the suites, and to establish the stratigraphy of the lower crust beneath Mount Sidley. In order to fully understand the diversity of the xenolith suite mineralogy and to appreciate the effects of alteration reactions on mineral (and therefore rock) geochemistry, only unaltered cores of minerals are documented. Variations in mineralogy due to alteration reactions will be discussed in more detail separately (Chapter 4.5).

While many diagrams show good correlations and trends, care must be taken in ascertaining whether these trends indicate that the suites are related. For the most part, samples between each type are probably related, but the relationship between xenolith types is uncertain.

\subsubsection{Olivine}

Olivine is the mineral phase most affected by oxidation, and while only the least oxidised crystals are discussed in this section, many have suffered some degree of oxidation. Representative olivine analyses are presented as Table 4.2.

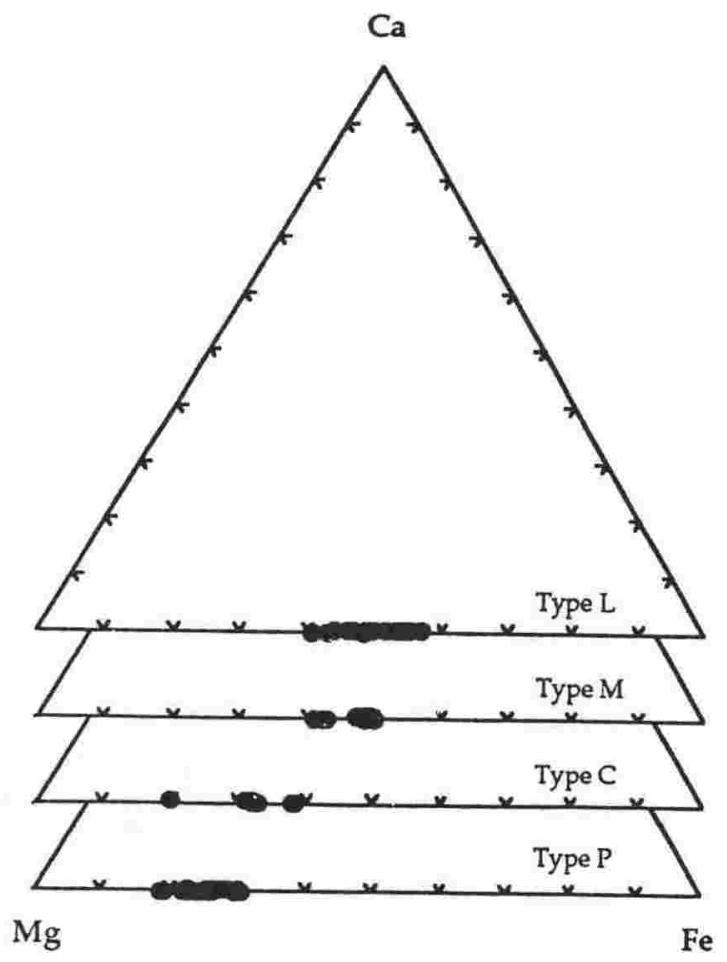

FIGURE 4.4: Composition of Mount Sidley xenolith olivines in the system $\mathrm{Ca}-\mathrm{Mg}-\mathrm{Fe}$. Note the increasing $\mathrm{Mg}: \mathrm{Mg}+\mathrm{Fe}$ content in olivines from Type L to Type P xenoliths.

Fo contents $\left(\mathrm{Mg} / \mathrm{Mg}+\sum \mathrm{Fe} ; \sum \mathrm{Fe}=\right.$ all $\mathrm{Fe}$ measured as $\left.\mathrm{Fe}^{2+}\right)$ of olivine show little variation within samples, but differ greatly between xenolith types. Compositional ranges vary between Type L (Fo 43-59), Type M (Fo 50-59), Type C 
(Fo 61-70) and Type $\mathrm{P}$ xenoliths (Fo 68-82), with a general increase in $\mathrm{Mg}$ from one type to another (Figure 4.4).

TABLE 4.2: Representative electron microprobe analyses of Mount Sidley xenolith olivines.

\begin{tabular}{|c|c|c|c|c|c|c|c|c|c|c|}
\hline Sample & 90029B1 & $90033 \mathrm{~V}$ & $90033 \mathrm{G} 1$ & $90039 \mathrm{~B}$ & $90039 \mathrm{~V}$ & $90033 \mathrm{~J}$ & 900390 & $90033 \mathrm{H}$ & 90033 Q1 & $90033 \mathrm{~S} 1$ \\
\hline Type & L & $\mathrm{L}$ & $\mathrm{L}$ & $\mathbf{M}$ & $\mathbf{M}$ & C & C & $\mathrm{P}$ & $\mathbf{P}$ & $\mathbf{P}$ \\
\hline $\mathrm{SiO} 2$ & 36.36 & 34.09 & 34.52 & 36.48 & 35.06 & 38.20 & 37.16 & 38.82 & 38.47 & 38.10 \\
\hline $\mathrm{A} 12 \mathrm{O} 3$ & 0.19 & 0.02 & 0.00 & 0.00 & 0.00 & 0.04 & 0.04 & 0.03 & 0.01 & 0.00 \\
\hline $\mathrm{TiO} 2$ & 0.12 & 0.03 & 0.01 & 0.00 & 0.11 & 0.01 & 0.01 & 0.01 & 0.04 & 0.02 \\
\hline $\mathrm{FeO}$ & 36.24 & 43.62 & 42.25 & 34.86 & 40.19 & 27.01 & 32.39 & 18.06 & 21.71 & 23.75 \\
\hline $\mathrm{MnO}$ & 0.84 & 0.75 & 0.91 & 0.57 & 0.69 & 0.44 & 0.70 & 0.21 & 0.21 & 0.30 \\
\hline $\mathrm{MgO}$ & 25.96 & 21.06 & 22.27 & 28.00 & 24.22 & 34.46 & 30.01 & 43.20 & 39.58 & 38.34 \\
\hline $\mathrm{CaO}$ & 0.16 & 0.20 & 0.21 & 0.10 & 0.18 & 0.23 & 0.13 & 0.07 & 0.11 & 0.09 \\
\hline $\mathrm{Na} 2 \mathrm{O}$ & 0.00 & 0.00 & 0.00 & 0.00 & 0.08 & 0.00 & 0.00 & 0.00 & 0.01 & 0.00 \\
\hline $\mathrm{K} 2 \mathrm{O}$ & 0.00 & 0.03 & 0.00 & 0.00 & 0.06 & 0.00 & 0.03 & 0.00 & 0.00 & 0.01 \\
\hline
\end{tabular}

$\begin{array}{lllllllllll}\text { TOTAL } & 99.87 & 99.79 & 100.17 & 100.01 & 100.59 & 100.39 & 100.47 & 100.41 & 100.14 & 100.60\end{array}$

cations on the basis of 4 oxygens

\begin{tabular}{lllllllllll}
$\mathrm{Si}$ & 1.020 & 0.995 & 0.996 & 1.010 & 0.991 & 1.010 & 1.010 & 0.986 & 0.995 & 0.991 \\
$\mathrm{Al}$ & 0.010 & 0.002 & 0.000 & 0.000 & 0.000 & 0.000 & 0.000 & 0.001 & 0.000 & 0.000 \\
$\mathrm{Ti}$ & 0.000 & 0.001 & 0.001 & 0.000 & 0.002 & 0.000 & 0.000 & 0.000 & 0.001 & 0.000 \\
$\mathrm{Fe}$ & 0.850 & 1.065 & 1.020 & 0.807 & 0.950 & 0.600 & 0.740 & 0.384 & 0.470 & 0.517 \\
$\mathrm{Mn}$ & 0.020 & 0.019 & 0.022 & 0.010 & 0.016 & 0.010 & 0.020 & 0.005 & 0.005 & 0.007 \\
$\mathrm{Mg}$ & 1.080 & 0.917 & 0.958 & 1.155 & 1.020 & 1.360 & 1.220 & 1.636 & 1.526 & 1.487 \\
$\mathrm{Ca}$ & 0.010 & 0.006 & 0.006 & 0.000 & 0.006 & 0.010 & 0.000 & 0.002 & 0.003 & 0.002 \\
$\mathrm{Na}$ & 0.000 & 0.000 & 0.000 & 0.000 & 0.004 & 0.000 & 0.000 & 0.000 & 0.000 & 0.000 \\
$\mathrm{~K}$ & 0.000 & 0.003 & 0.000 & 0.000 & 0.002 & 0.000 & 0.000 & 0.000 & 0.000 & 0.000 \\
& & & & & & & & & & \\
\hline TOTAL & 2.990 & 3.008 & 3.003 & 2.982 & 2.991 & 2.990 & 2.990 & 3.014 & 3.000 & 3.004 \\
\hline & & & & & & & & & & \\
Mg\# & 55.96 & 46.27 & 48.43 & 58.87 & 51.78 & 69.39 & 62.24 & 80.99 & 76.45 & 74.20 \\
\end{tabular}

Olivine calcium contents are similar in all xenolith types, ranging from 0.08-0.42 wt. \% CaO and 0.06-0.41 wt. \% CaO in Type L and P olivines respectively, with slightly lower contents in Type $\mathrm{M}$ and $\mathrm{C}$ olivines (Figure 4.5). Calcium contents in olivine are not temperature dependant, but do show correlations with pressure (Simkin and Smith, 1970; Stormer, 1973). Finnerty and Boyd (1978) supported this experimentally showing the solubility of $\mathrm{Ca}$ in forsterite coexisting with orthopyroxene and clinopyroxene to decrease with increasing pressure due 
to its large cation size $(r=1.0 \AA)$, and therefore increasing incompatibility in octahedral sites. Mount Sidley olivine $\mathrm{Ca}$ contents conform to low pressure phases, however the absence of orthopyroxene as a mineral phase may also result in the high $\mathrm{Ca}$ contents in olivine. Furthermore, high $\mathrm{Ca}$ contents in olivines may simply reflect high $\mathrm{Ca}$ contents in the crystallising magma.

A correlation between $\mathrm{Mn}$ and $\mathrm{Mg}$ in olivines is strongly related to fractionation, with a rise in $\mathrm{MnO}$ and a decrease in $\mathrm{MgO}$ contents (Simkin and Smith, 1970; Dodd, 1973). Type L olivines have the highest $\mathrm{MnO}$ contents (0.7-1.6 wt. \%), followed by Type M (0.6-1.1 wt. \%), Type C (0.44-0.7 wt. \%), and Type P olivines (0.2-0.6 wt. \%), which have the lowest $\mathrm{MnO}$ contents (Figure 4.5). Trends of $\mathrm{MnO}$ with $\mathrm{MgO}$ are not generally evident by xenolith type, but considered as a whole there is a strong negative trend of decreasing $\mathrm{MnO}$ content with increasing $\mathrm{MgO}$ content. The range of $\mathrm{MnO}$ contents is higher than values reported by Simkin and Smith (1970), possibly reflecting high MnO contents in the crystallising melt. Given the correlation discussed above, this trend may signify fractionation occurring in the suite from Type $\mathrm{P}$ to Type $\mathrm{L}$ xenoliths, with Type $\mathrm{L}$ xenoliths as the last formed cumulates, representing the final stage of fractionation of the crystallising melt.

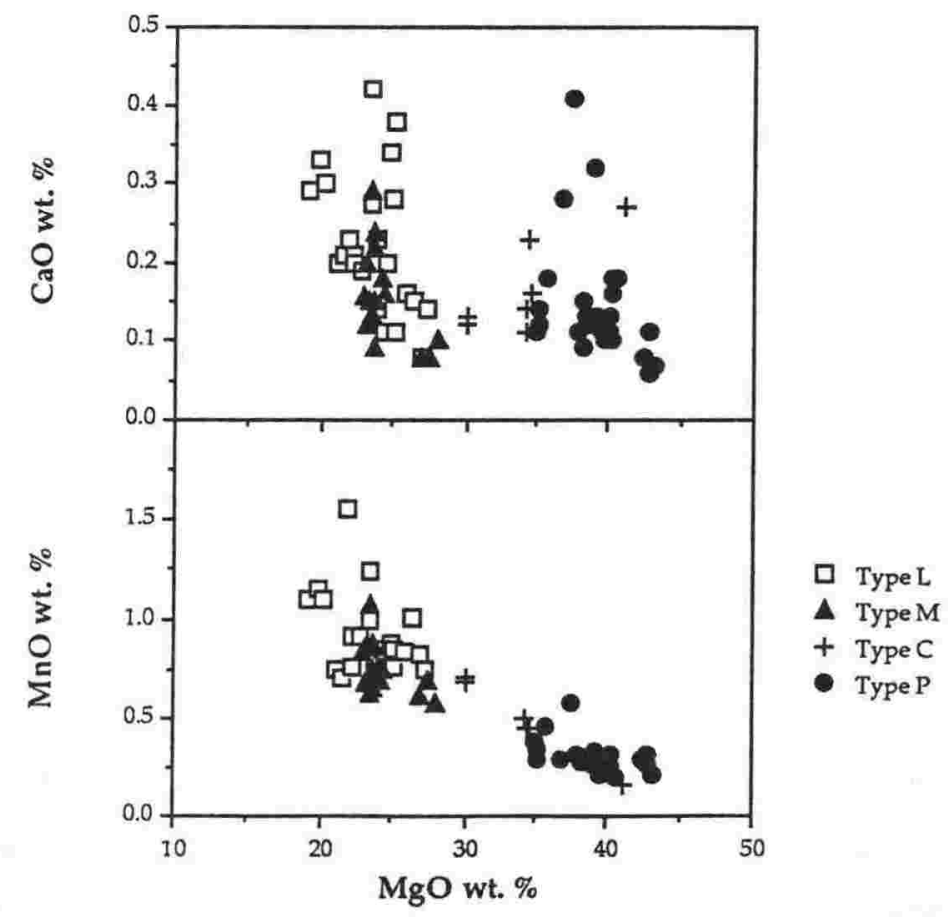

FIGURE 4.5: Plot of $\mathrm{MgO} v \mathrm{CaO}$ and $\mathrm{MnO}$ for olivine by xenolith type. Type $\mathrm{L}$ and $\mathrm{M}$ olivine is $\mathrm{MgO}$-poor compared with Type $\mathrm{C}$ and $\mathrm{P}$ olivine. $\mathrm{CaO}$ contents are similar in olivine from all xenolith types. $\mathrm{MnO}$ contents are high compared with contents reported by Simkin and Smith (1970) but still show a strong linear trend with $\mathrm{MgO}$ from Type $L$ to Type $P$ xenoliths, as a result of the fractionation process.

Nickel contents in olivines are generally below 0.5 wt. \% $\mathrm{NiO}$ (Appendix 3.1) and correlate with $\mathrm{Mg}$, which it readily substitutes for due to its similar size. $\mathrm{Ni}$ contents are probably a function of the Ni content in the crystallising melt, with high $\mathrm{Ni}$ melts crystallising high-Ni olivine. $\mathrm{NiO}$ is below detection limit in 
Type L olivines but is present above the detection limit in all other xenolith types. This is not surprising given the low MgO contents of Type $\mathrm{L}$ xenoliths and the relationship between $\mathrm{Ni}$ and $\mathrm{Mg}$ mentioned above.

Titanium has been detected in concentrations up to $0.19 \mathrm{wt} \% \mathrm{TiO}_{2}$ in one Type $\mathrm{M}$ olivine, but is usually present from below detection limit up to $0.8 \mathrm{wt}$. \% $\mathrm{TiO}_{2}$. Aluminium, $\mathrm{Cr}$ and $\mathrm{Na}$ are all below the detection limit in olivines of all xenolith types. Potassium has however been detected in small amounts (up to 0.12 wt. $\% \mathrm{~K}_{2} \mathrm{O}$ ). While this may be due to analytical error, the consistent values of $\mathrm{K}_{2} \mathrm{O}$ above detection limit suggests that there is a minor amount of $\mathrm{K}_{2} \mathrm{O}$ in some olivines.

The presence of $\mathrm{K}^{+}$cations in olivine is problematical. Their large size (1.33 $\AA)$ prohibits them from entering tetrahedral and octahedral sites which can accommodate cations in the range 0.11-0.55 $\AA$ and 0.53-1.02 $\AA$ respectively (Muller and Roy, 1974). Only the oxygen site can accommodate such large ions ( $\mathrm{O}=1.4 \AA$ ), however the positive charge of the $\mathrm{K}$ ion makes this extremely unlikely. The only possibility is an octahedral site occupancy. The flexibility of $M(1)$ and $M(2)$ sites due to factors including cation size effects is well established (Brown, 1970). At P-T conditions different to those of Muller and Roy's experiments, an octahedral site could possibly accommodate such a large ion if small ions entered the other octahedral sites. Low Fe and Mg totals, and excess silica accompanies $\mathrm{K}$ excess; the small size of $\mathrm{Si}$ ions $(0.42 \AA)$ in an octahedral site could offset large $\mathrm{K}^{+}$cations in other octahedral sites. The low charge of the $\mathrm{K}^{+}$cation could further be balanced by the large $\mathrm{Si}^{4+}$ cation charge. The occurrence of $\mathrm{K}^{+}$is unlikely to result from crystallisation, as $\mathrm{K}^{+}$does readily not enter the olivine structure. Its presence is probably a result of the oxidation reactions that have affected all olivine crystals to various degrees. If $\mathrm{K}^{+}$substitution occurs due to oxidation, the charge balance could easily be restored by oxidation of $\mathrm{Fe}^{2+}$ to $\mathrm{Fe}^{3+}$ (see Chapter 4.6.).

\subsubsection{Clinopyroxene}

Clinopyroxene compositions have the ability to reveal a great deal about the melt from which they crystallised, as they can accommodate a large number of cations of various sizes and valencies in their structure. This section concentrates on their major and minor element compositions; rare earth element (REE) contents will be discussed with whole rock REEs (Chapter 4.5.2). Representative clinopyroxene analyses are presented as Table 4.3; all are aluminian augites.

Mount Sidley clinopyroxenes are $\mathrm{Ca}-\mathrm{Mg}-\mathrm{Fe}$ quadrilateral clinopyroxenes (Figure 4.6) with only a small 'J' component (Chapter 2.3.1). The majority are diopsides and augites, although many plot above the quadrilateral $\mathrm{CaMg}-\mathrm{CaFe}$ 
TABLE 4.3: Representative electron microprobe analyses of Mount Sidley xenolith clinopyroxenes.

\begin{tabular}{|c|c|c|c|c|c|c|c|c|c|c|}
\hline Sample & $90029 X$ & $90033 \mathrm{~S}$ & 90039M & $90039 \mathrm{~F}$ & $90039 \mathrm{~V}$ & 90033R & 90033P1 & $90033 \mathrm{~A}$ & $90033 C$ & $90033 I$ \\
\hline Type & L & L & L & $\mathbf{M}$ & $\mathbf{M}$ & C & C & $\mathrm{P}$ & $\mathbf{P}$ & $\mathbf{P}$ \\
\hline $\mathrm{SiO} 2$ & 48.93 & 48.40 & 49.75 & 50.02 & 47.06 & 47.98 & 48.05 & 48.42 & 47.60 & 48.96 \\
\hline $\mathrm{Al} 2 \mathrm{O} 3$ & 5.35 & 5.73 & 4.23 & 3.69 & 6.03 & 9.46 & 7.73 & 7.84 & 8.52 & 8.55 \\
\hline $\mathrm{TiO} 2$ & 2.02 & 1.76 & 1.55 & 1.19 & 2.84 & 2.16 & 1.85 & 1.68 & 2.23 & 1.43 \\
\hline $\mathrm{FeO}$ & 9.14 & 8.73 & 9.50 & 10.24 & 9.78 & 8.09 & 8.05 & 8.25 & 7.56 & 5.70 \\
\hline $\mathrm{MnO}$ & 0.28 & 0.22 & 0.23 & 0.24 & 0.18 & 0.19 & 0.21 & 0.12 & 0.14 & 0.29 \\
\hline $\mathrm{MgO}$ & 14.01 & 12.62 & 12.66 & 12.75 & 11.62 & 12.20 & 12.23 & 12.64 & 12.04 & 13.53 \\
\hline $\mathrm{CaO}$ & 19.95 & 21.82 & 21.39 & 21.38 & 22.07 & 19.87 & 21.06 & 20.12 & 20.62 & 20.65 \\
\hline $\mathrm{Na} 2 \mathrm{O}$ & 0.31 & 0.70 & 0.59 & 0.50 & 0.41 & 0.00 & 0.81 & 0.93 & 1.22 & 0.88 \\
\hline $\mathrm{K} 2 \mathrm{O}$ & 0.00 & 0.02 & 0.03 & 0.00 & 0.06 & 0.05 & 0.01 & 0.00 & 0.00 & 0.02 \\
\hline $\mathrm{Fe} 2 \mathrm{O} 3$ * & 1.24 & 3.62 & 1.85 & 2.28 & 2.74 & 0.00 & 1.92 & 1.78 & 2.59 & 0.98 \\
\hline $\mathrm{FeO} *$ & 8.02 & 5.47 & 7.83 & 8.19 & 7.50 & 8.09 & 6.32 & 6.65 & 5.23 & 4.81 \\
\hline TOTAL & 99.99 & 99.98 & 99.90 & 100.01 & 99.99 & 99.95 & 99.99 & 100.00 & 99.93 & 100.01 \\
\hline
\end{tabular}

cations on the basis of 6 oxygens

\begin{tabular}{lllllllllll} 
Si & 1.830 & 1.800 & 1.859 & 1.881 & 1.766 & 1.770 & 1.782 & 1.791 & 1.760 & 1.795 \\
AlIV & 0.170 & 0.200 & 0.141 & 0.119 & 0.230 & 0.230 & 0.218 & 0.209 & 0.240 & 0.205 \\
AlVI & 0.065 & 0.051 & 0.045 & 0.045 & 0.040 & 0.180 & 0.120 & 0.130 & 0.130 & 0.160 \\
Ti & 0.057 & 0.049 & 0.044 & 0.034 & 0.080 & 0.060 & 0.052 & 0.047 & 0.062 & 0.039 \\
FeIII & 0.040 & 0.101 & 0.052 & 0.064 & 0.072 & 0.000 & 0.054 & 0.049 & 0.072 & 0.027 \\
FeII & 0.250 & 0.170 & 0.245 & 0.256 & 0.236 & 0.250 & 0.196 & 0.206 & 0.162 & 0.148 \\
Mn & 0.010 & 0.007 & 0.007 & 0.008 & 0.001 & 0.010 & 0.007 & 0.004 & 0.004 & 0.009 \\
Mg & 0.780 & 0.700 & 0.705 & 0.715 & 0.650 & 0.670 & 0.676 & 0.697 & 0.664 & 0.740 \\
Ca & 0.800 & 0.870 & 0.857 & 0.862 & 0.888 & 0.790 & 0.837 & 0.798 & 0.817 & 0.811 \\
Na & 0.023 & 0.050 & 0.043 & 0.036 & 0.030 & 0.000 & 0.058 & 0.067 & 0.087 & 0.063 \\
K & 0.000 & 0.002 & 0.002 & 0.000 & 0.003 & 0.020 & 0.000 & 0.000 & 0.001 & 0.001 \\
& & & & & & & & & & \\
\hline TOTAL & 4.025 & 4.000 & 4.000 & 4.020 & 3.996 & 3.980 & 4.000 & 4.001 & 4.000 & 4.002 \\
\hline & & & & & & & & & & \\
Wo & 42.78 & 47.26 & 46.10 & 45.44 & 48.10 & 46.20 & 47.48 & 45.60 & 47.64 & 46.99 \\
En & 41.71 & 38.02 & 37.92 & 37.69 & 35.21 & 39.18 & 38.34 & 39.83 & 38.72 & 42.87 \\
Fs & 15.51 & 14.72 & 15.98 & 16.87 & 16.68 & 14.62 & 14.18 & 14.57 & 13.64 & 10.14 \\
& & & & & & & & & & \\
Q & 1.83 & 1.74 & 1.81 & 1.83 & 1.77 & 1.71 & 1.71 & 1.70 & 1.64 & 1.70 \\
J & 0.05 & 0.10 & 0.09 & 0.07 & 0.06 & 0.00 & 0.12 & 0.13 & 0.17 & 0.13
\end{tabular}

* Recalculated assuming stoichiometry based on 4.0 cations 
join (Figure 4.6). Varieties include aluminian and aluminian titanian diopsides and augites, as well as rare subsilicic $(\mathrm{Si}<1.75)$ clinopyroxenes. There is no major element difference between igneous and metamorphic clinopyroxenes, identified petrographically (Chapter 4.3).

Type $\mathrm{L}$ and $\mathrm{P}$ clinopyroxenes plot in overlapping fields on standard quadrilateral diagrams (Figure 4.6). Wo content plotted against Fs content (Figure 4.7) shows well defined fields for Type $\mathrm{L}$ and $\mathrm{P}$ clinopyroxenes, and emphasises the gradational nature between them, previously identified by Wysoczanski and Gamble (1992). Type $M$ and C clinopyroxenes are intermediate to the Type L and Type $\mathrm{P}$ compositions, straddling both fields. Wo values of $>50$ can be attributed to lower $\mathrm{Fe}$ and $\mathrm{Mg}$ values, rather than high $\mathrm{Ca}$ contents, as a result of widespread substitution of minor elements for $\mathrm{Mg}$ and $\mathrm{Fe}$ in preference to $\mathrm{Ca}$.

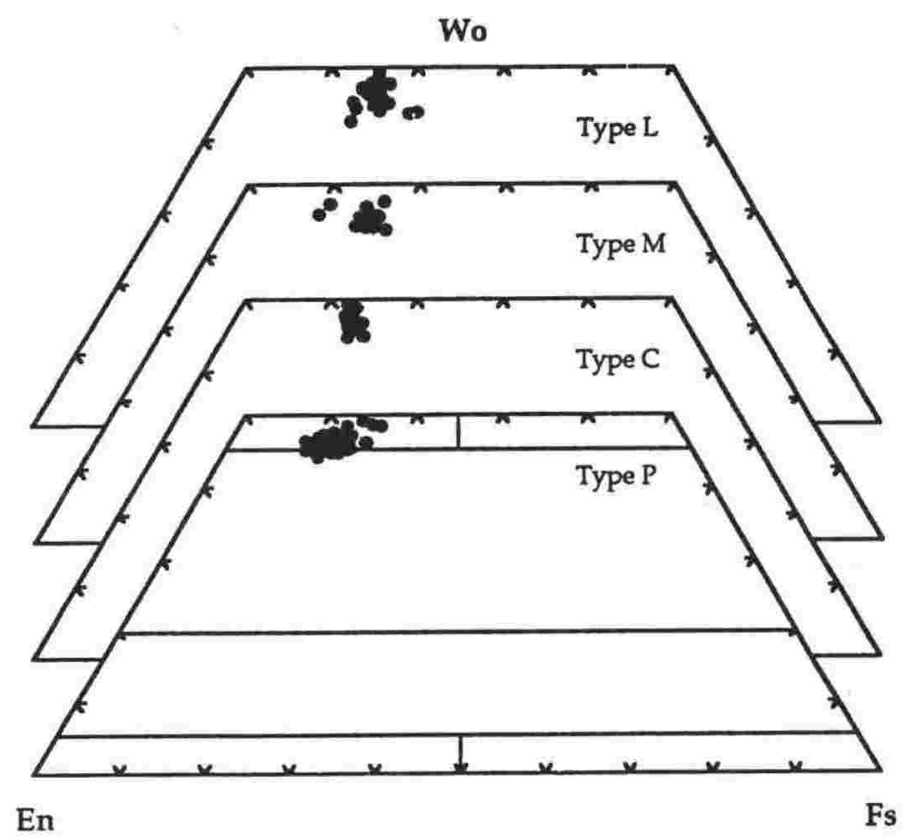

FIGURE 4.6: Composition of clinopyroxenes from the Mount Sidley xenolith suite, in the system WoEn-Fs (fields from Morimoto et al., 1988). Compositions become more Mg rich from Type L to Type P.

The composition of clinopyroxenes is mainly due to the variety of cations able to enter the structure, and substitutions that occur at various sites. The general formula of pyroxenes can be expressed by:

$$
\mathrm{M}(2) \mathrm{M}(1) \mathrm{T}_{2} \mathrm{O}_{6}
$$

where:

$$
\begin{aligned}
\mathrm{M}(2) & =\mathrm{Mg}, \mathrm{Fe}^{2+}, \mathrm{Mn}, \mathrm{Li}, \mathrm{Ca}, \mathrm{Na} \\
\mathrm{M}(1) & =\mathrm{Al}, \mathrm{Fe}^{3+}, \mathrm{Ti}, \mathrm{Cr}, \mathrm{V}, \mathrm{Ti}, \mathrm{Zr}, \mathrm{Sc}, \mathrm{Zn}, \mathrm{Mg} \mathrm{Fe}^{2+}, \mathrm{Mn} \\
\mathrm{T} & =\mathrm{Si}, \mathrm{Al}, \mathrm{Fe}^{3+}
\end{aligned}
$$


in order of filling of sites (Cameron and Papike, 1980; Morimoto et al., 1988).

Calcium is the main occupant of $\mathrm{M}(2)$ sites, but is not present in sufficient quantities to fill the site, and minor amounts of $\mathrm{Na}$ may enter the site (up to 0.92 wt. $\% \mathrm{Na}_{2} \mathrm{O}, 0.91$ wt. $\% \mathrm{Na}_{2} \mathrm{O}, 1.17$ wt. $\% \mathrm{Na}_{2} \mathrm{O}$ and 1.35 wt. $\% \mathrm{Na}_{2} \mathrm{O}$ in Types $\mathrm{L}, \mathrm{M}$, $\mathrm{C}$ and $\mathrm{P}$ clinopyroxenes respectively). Remaining $\mathrm{M}(2)$ sites are occupied by minor amounts of $\mathrm{Mg}$.

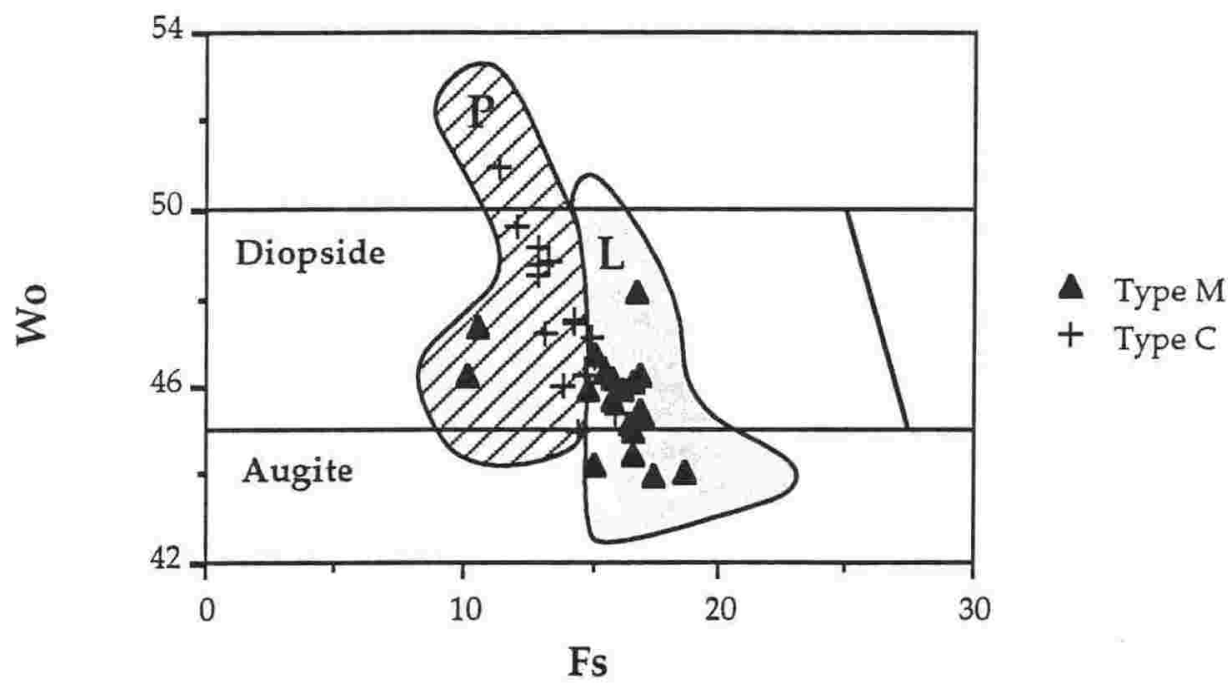

FIGURE 4.7: Wo v Fs binary diagram of clinopyroxene compositions based on the quadrilateral diagram of Morimoto et al. (1988). Fields are those of Type L and Type P clinopyroxenes, with plots of Type $\mathrm{M}$ and Type $\mathrm{C}$ clinopyroxenes.

In Mount Sidley clinopyroxenes, all $\mathrm{Fe}$ and the remaining $\mathrm{Mg}$ (which is most of the total $\mathrm{Mg}$ ) is confined to the $\mathrm{M}(1)$ site. Remaining $\mathrm{M}(1)$ sites contain $\mathrm{Al}, \mathrm{Ti}$, and small amounts of $\mathrm{Fe}^{3+}$ and $\mathrm{Mn}$.

Silica is not present in quantities sufficient to entirely fill the tetrahedral site. This deficiency is made up by $\mathrm{Al}$ occupying the remaining sites, with excess $\mathrm{Al}$ entering the $\mathrm{M}(1)$ site. This substitution of $\mathrm{Al}^{3+}$ for $\mathrm{Si}^{4+}$ results in a charge imbalance, which is balanced by one $\mathrm{Ti}^{4+}$ cation entering the $\mathrm{M}(1)$ site for every two $\mathrm{Al}^{3+}$ cations in the tetrahedral site. The coupled substitution;

$$
\mathrm{M}(2) \mathrm{M}(2) \mathrm{Si}^{4+}{ }_{2} \mathrm{O}_{6} \rightarrow \mathrm{M}(2) \mathrm{Ti}^{4+} \mathrm{Al}^{3+}{ }_{2} \mathrm{O}_{6}
$$

is complete, with no other substitution necessary, and very little Ti otherwise enters the clinopyroxene structure.

This relationship between $\mathrm{Ti}$ and $\mathrm{Al}$ entering the tetrahedral site $\left(\mathrm{Al}{ }^{\mathrm{IV}}\right)$ can be seen in Figure 4.8, which shows a strong positive trend between these cations. In contrast, there is no systematic relationship between $\mathrm{Ti}$ and octahedral $\mathrm{Al}$ $\left(\mathrm{Al}{ }^{\mathrm{VI}}\right.$ ). $\mathrm{Al}_{2} \mathrm{O}_{3}$ contents (and $\mathrm{TiO}_{2}$ contents due to the substitution discussed above) 


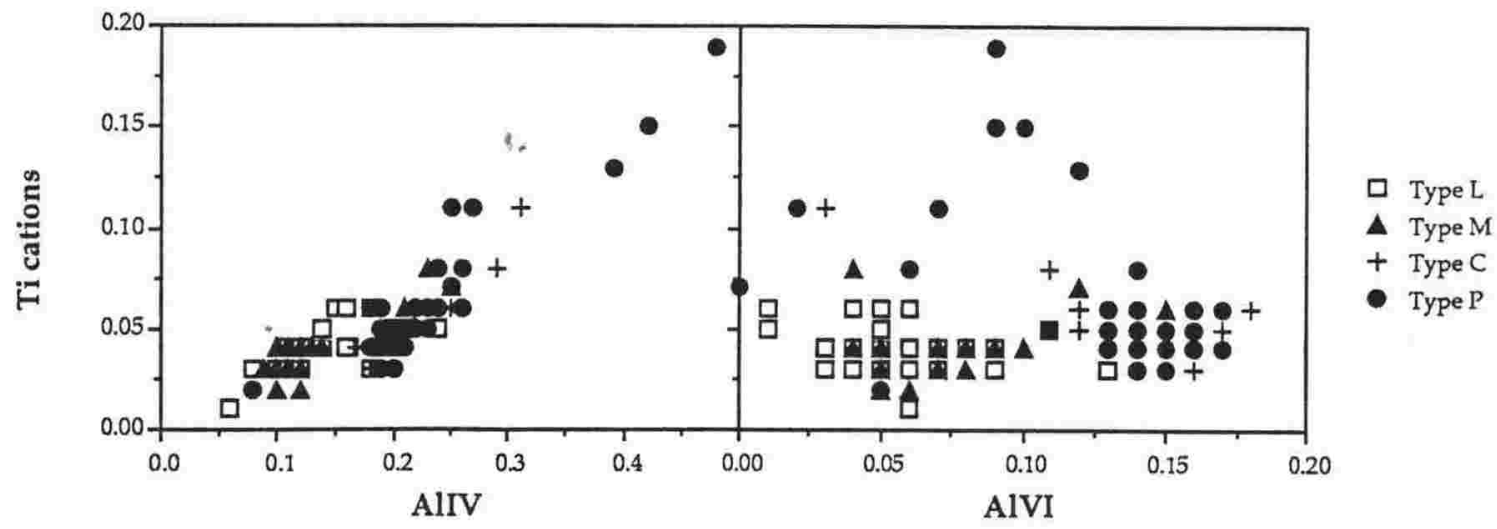

FIGURE 4.8: $\mathrm{Ti}$ v Al contents of clinopyroxenes from the Mount Sidley xenolith suite. a) $\mathrm{Ti}_{\mathrm{v} \mathrm{Al}} \mathrm{Al}^{\mathrm{IV}}$ (tetrahedral site $\mathrm{Al}$ ) shows a strong positive trend reflecting the coupled substitution of $\mathrm{Al}$ for $\mathrm{Si}$ in the tetrahedral site, and the substitution of $\mathrm{Ti}$ in the $\mathrm{M}(1)$ octahedral site to negate the resulting charge imbalance. b) In contrast, $\mathrm{Ti}$ and $\mathrm{Al}^{\mathrm{VI}}$ (octahedral site $\mathrm{Al}$ ) show no relationship.

are higher in pyroxenite (Type $\mathrm{P}$ and $\mathrm{C}$ ) clinopyroxenes compared to granulite (Type $\mathrm{L}$ and $\mathrm{M}$ ) clinopyroxenes; e.g. 2.80-7.80 wt. \% $\mathrm{Al}_{2} \mathrm{O}_{3}$ in Type $\mathrm{L}$, compared to 6.80-12.91 wt. $\% \mathrm{Al}_{2} \mathrm{O}_{3}$ in Type $\mathrm{P}$ clinopyroxenes. This may be due to crystallisation at different pressures (Wass, 1979), or to crystallisation by melts with different $\mathrm{Al}_{2} \mathrm{O}_{3}$ contents. The crystallisation of plagioclase as a cumulus phase prior to clinopyroxene in the granulite suite would result in a depletion of $\mathrm{Al}_{2} \mathrm{O}_{3}$ in the melt. Clinopyroxenes crystallising from such a melt would have lower $\mathrm{Al}_{2} \mathrm{O}_{3}$ contents than those that crystallised prior to plagioclase, as is the case for pyroxenite clinopyroxenes. If plagioclase fractionation is controlled by pressure (i.e. at lower pressures), then $\mathrm{Al}_{2} \mathrm{O}_{3}$ content of clinopyroxenes is also indirectly pressure controlled, due to its dependence on plagioclase crystallisation.

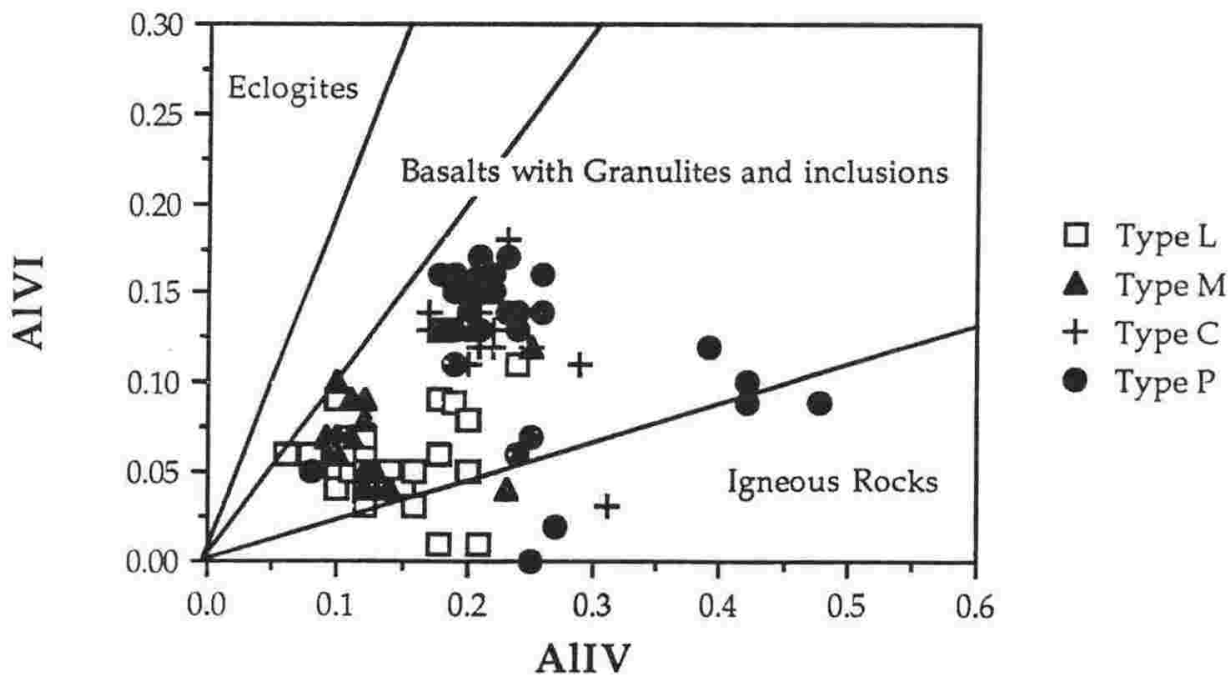

FIGURE 4.9: Tetrahedral $\left(\mathrm{Al}^{\mathrm{IV}}\right)$ and octahedral $\left(\mathrm{Al}^{\mathrm{VI}}\right)$ partitioning of aluminium in clinopyroxene. Mount Sidley clinopyroxenes fall into Aoki and Shiba's (1973) field of 'Basalts with Granulites and inclusions' with some plotting in the igneous field due to their low Si contents. 
The partitioning of $\mathrm{Al}$ into tetrahedral $\left(\mathrm{Al}^{\mathrm{IV}}\right)$ and octahedral $\left(\mathrm{Al}^{\mathrm{VI}}\right)$ sites has been used by Aoki and Shiba (1973) and Wass (1979) to characterise clinopyroxenes of differing origins. Most Mount Sidley clinopyroxenes vary in $\mathrm{Al}^{\mathrm{IV}}: \mathrm{Al}^{\mathrm{VI}}$ ratios of from 1:1 to much higher ratios (Figure 4.9). With few exceptions, Mount Sidley xenolith clinopyroxenes of all types fall within Aoki and Shiba's (1973) field of "granulites and inclusions in basalts", consistent with their formation at lower crustal/upper mantle depths.

Two-pyroxene compositions are useful for the purposes of geothermometry, and many schemes have made use of the partitioning of elements between two-pyroxene phases to determine their temperatures of equilibration (e.g. Wood and Banno, 1973; Wells, 1977; Kretz, 1982; Lindsley, 1983; and Gasparik, 1984). Xenoliths from the Mount Sidley xenolith suite contain a single monoclinic pyroxene, and orthopyroxene-clinopyroxene geothermometers are therefore inappropriate. The Gasparik method makes use of the Al-content of clinopyroxene (the Ca-Tschermak component), the Al-content of orthopyroxene (the Mg-Tschermak component), and the En content of the clinopyroxene (1-Ca), to determine the temperature and pressure of equilibration. However, in anorthite-bearing assemblages of the graphic geothermobarometer, clinopyroxene compositions alone are capable of producing accurate temperatures and pressures, without the need of orthopyroxene compositions.

TABLE 4.4: Estimations of P-T equilibration conditions of the Mount Sidley xenolith suite using the geothermobarometer of Gasparik (1984), which is based on the Ca-Tschermak (Al/2) and the En (1Ca) contents of clinopyroxenes. Calibration of this method using only clinopyroxene compositions, determined from two-pyroxene xenoliths from MBL (Chapter 6.4.2), indicate that results may be high by $100-200^{\circ} \mathrm{C}$ and $1 \mathrm{~kb}$.

\begin{tabular}{lcccc}
\hline Xenolith type & Type L & Type $\mathbf{M}$ & Type C & Type P \\
\hline & & & & \\
& 980 & Temperature $\left({ }^{\circ} \mathrm{C}\right)$ & & \\
Estimate & to & 1060 & 1080 & 1160 \\
& 1160 & to & to & to \\
& & 1150 & 1140 & 1240 \\
& 4.0 & Pressure $(\mathrm{kb})$ & & \\
Estimate & to & 4.5 & 9.0 & 8.0 \\
& 6.5 & to & to & to \\
& & 6.5 & 11.5 & 12.0 \\
\hline
\end{tabular}

The accuracy of P-T estimates using an assemblage where orthopyroxene is not present is uncertain, however internally consistent P-T estimates using this method, within and between xenolith types, and with Fe-Ti oxide thermometry 
(Chapter 4.4.4), indicates that the geothermobarometer is suitable to use on the Mount Sidley xenolith assemblages. Calibrations with two-pyroxene assemblages from MBL (Chapter 6.4.2) indicate that single pyroxene calculations may be high by approximately $100-200{ }^{\circ} \mathrm{C}$, and $1 \mathrm{~kb}$. Original results of this method are discussed here, and P-T estimates calibrated with other MBL xenolith suites are presented in Chapter 8.2.3.

The results of the Gasparik geothermobarometer applied to the Mount Sidley xenolith suite are listed in Table 4.4. The P-T conditions of the xenolith suite indicate a general trend of decreasing temperature and pressure from Type $P$ to Type L xenoliths, consistent with the inferred stratigraphy of Type P to Type L xenoliths from lower to higher crustal levels (Chapter 4.3.5). Temperatures of all xenolith types fall over a range of approximately $100^{\circ} \mathrm{C}\left(180^{\circ} \mathrm{C}\right.$ for Type $\left.\mathrm{L}\right)$, with magmatic temperatures indicating equilibration at lower crustal levels at high temperatures (i.e. a high geothermal gradient).

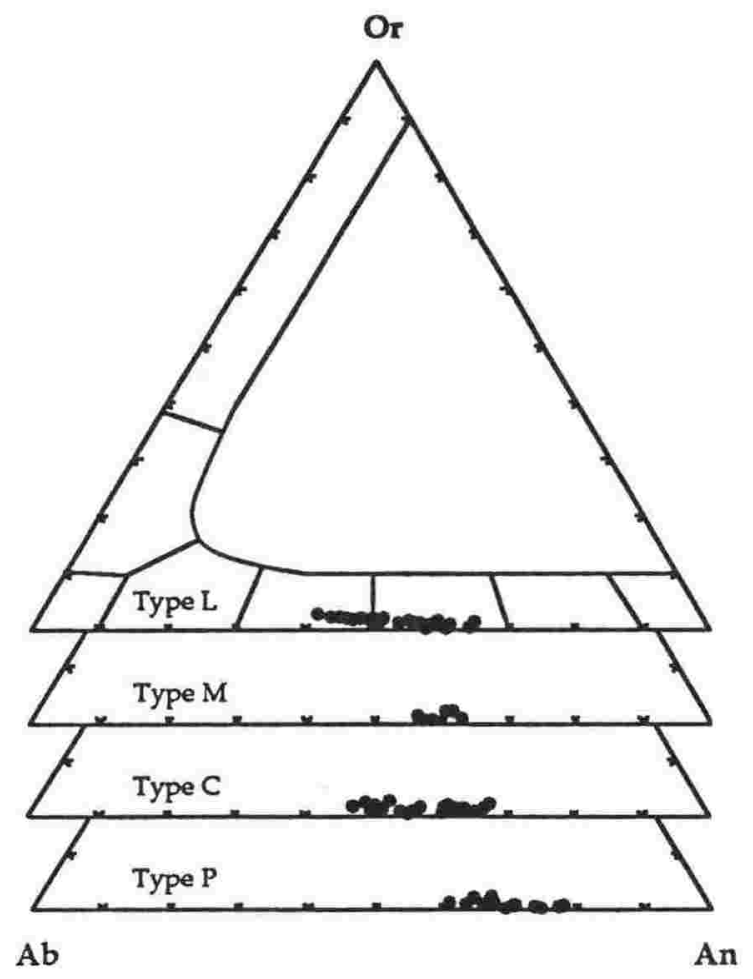

FIGURE 4.10: Composition of plagioclase from Mount Sidley xenoliths in the system Or-An-Ab with fields from Deer et al. (1966). Note the progressively higher An contents of plagioclase from Type L to Type $P$ xenoliths.

\subsubsection{Plagioclase}

Plagioclase is the only feldspar phase present in all Mount Sidley xenoliths. Alkali feldspars are absent as primary phases, but occur due to secondary mineral reactions (Chapter 4.5.2). Representative analyses are given in Table 4.5, and compositions are plotted as Figure 4.10. 
TABLE 4.5: Representative electron microprobe analyses of plagioclase from Mount Sidley xenoliths.

\begin{tabular}{|c|c|c|c|c|c|c|c|c|c|c|}
\hline SAMPLE & $90029 X$ & $90033 \mathrm{~S}$ & 90039D & $90039 \mathrm{~V}$ & $90039 \mathrm{~V}$ & $90033 R$ & 90033P1 & $90033 \mathrm{~B}$ & $90033 C$ & $90033 \mathrm{Q1}$ \\
\hline TYPE & L & L & L & $\mathbf{M}$ & M & C & C & $\mathbf{P}$ & $\mathbf{P}$ & $\mathbf{P}$ \\
\hline $\mathrm{SiO} 2$ & 53.76 & 53.45 & 52.35 & 53.37 & 53.59 & 55.86 & 54.09 & 50.62 & 47.76 & 52.01 \\
\hline $\mathrm{Al} 2 \mathrm{O} 3$ & 29.10 & 28.79 & 30.35 & 29.50 & 29.45 & 27.62 & 28.90 & 31.03 & 33.05 & 30.14 \\
\hline TiO2 & 0.05 & 0.15 & 0.06 & 0.13 & 0.09 & 0.05 & 0.09 & 0.17 & 0.16 & 0.16 \\
\hline $\mathrm{FeO}$ & 0.11 & 0.45 & 0.20 & 0.24 & 0.25 & 0.17 & 0.20 & 0.54 & 0.56 & 0.50 \\
\hline $\mathrm{MnO}$ & 0.12 & 0.09 & 0.01 & 0.11 & 0.02 & 0.05 & 0.00 & 0.00 & 0.00 & 0.00 \\
\hline $\mathrm{MgO}$ & 0.00 & 0.08 & 0.04 & 0.10 & 0.06 & 0.03 & 0.03 & 0.12 & 0.00 & 0.09 \\
\hline $\mathrm{CaO}$ & 11.83 & 12.38 & 13.05 & 11.76 & 11.83 & 9.65 & 11.79 & 14.41 & 15.70 & 12.94 \\
\hline $\mathrm{Na} 2 \mathrm{O}$ & 4.66 & 4.13 & 3.93 & 4.65 & 4.91 & 5.72 & 4.96 & 3.38 & 2.48 & 3.97 \\
\hline $\mathrm{K} 2 \mathrm{O}$ & 0.22 & 0.38 & 0.23 & 0.12 & 0.13 & 0.47 & 0.27 & 0.16 & 0.11 & 0.28 \\
\hline TOTAL & 99.85 & 99.89 & 100.21 & 99.98 & 100.33 & 99.62 & 100.33 & 100.43 & 99.81 & 100.10 \\
\hline
\end{tabular}

cations on the basis of 8 oxygens

\begin{tabular}{lcccccccccc}
$\mathrm{Si}$ & 2.435 & 2.428 & 2.369 & 2.409 & 2.414 & 2.524 & 2.440 & 2.301 & 2.195 & 2.363 \\
$\mathrm{Al}$ & 1.554 & 1.541 & 1.619 & 1.570 & 1.563 & 1.471 & 1.537 & 1.662 & 1.790 & 1.614 \\
$\mathrm{Ti}$ & 0.002 & 0.005 & 0.002 & 0.004 & 0.003 & 0.002 & 0.003 & 0.006 & 0.006 & 0.006 \\
$\mathrm{Fe}$ & 0.004 & 0.017 & 0.007 & 0.009 & 0.009 & 0.006 & 0.007 & 0.020 & 0.021 & 0.019 \\
$\mathrm{Mn}$ & 0.005 & 0.003 & 0.000 & 0.004 & 0.000 & 0.002 & 0.000 & 0.000 & 0.000 & 0.000 \\
$\mathrm{Mg}$ & 0.000 & 0.005 & 0.003 & 0.006 & 0.000 & 0.002 & 0.000 & 0.008 & 0.000 & 0.006 \\
$\mathrm{Ca}$ & 0.574 & 0.603 & 0.633 & 0.568 & 0.571 & 0.467 & 0.570 & 0.702 & 0.773 & 0.630 \\
$\mathrm{Na}$ & 0.409 & 0.364 & 0.345 & 0.407 & 0.428 & 0.501 & 0.433 & 0.298 & 0.221 & 0.350 \\
$\mathrm{~K}$ & 0.013 & 0.022 & 0.013 & 0.007 & 0.008 & 0.027 & 0.016 & 0.009 & 0.007 & 0.016 \\
& & & & & & & & & & \\
\hline TOTAL & 4.996 & 4.988 & 4.991 & 4.984 & 4.996 & 5.002 & 5.006 & 5.006 & 5.013 & 5.004 \\
\hline & & & & & & & & & & \\
$\mathrm{An}$ & 57.63 & 60.97 & 63.87 & 57.84 & 56.70 & 46.93 & 55.94 & 69.57 & 77.22 & 63.25 \\
$\mathrm{Ab}$ & 41.06 & 36.80 & 34.81 & 41.45 & 42.50 & 50.35 & 42.49 & 29.53 & 22.08 & 35.14 \\
$\mathrm{Or}$ & 1.31 & 2.22 & 1.31 & 0.71 & 0.79 & 2.71 & 1.57 & 0.89 & 0.70 & 1.61 \\
& & & & & & & & & & \\
\hline
\end{tabular}

Compositions of unaltered plagioclase crystals are homogeneous in all rock types. Where two generations of plagioclase exist (a larger relict igneous plagioclase and a smaller metamorphic phase), these phases are in equilibrium, with no significant variation in their compositions. There is also little variation in composition in single plagioclase crystals, oscillatory zoning is rare, indicating that solid state diffusion has homogenised most plagioclase compositions.

Plagioclase compositions increase in average An content from Type $\mathrm{L}$ to Types M, C, and P xenoliths (Figure 4.10). Type L plagioclase show a large range in composition, from An 40-68, whereas Type M plagioclase have a relatively restricted range from An 56-62. Type $C$ and Type $P$ plagioclase, which are 
intercumulus phases, also have relatively large compositional ranges, from An 46-66, and An 60-77 respectively.

Other than $\mathrm{Ca}, \mathrm{Na}$ and $\mathrm{K}$, elemental compositions vary little in plagioclase. Silica is generally depleted in Type $P$ plagioclase relative to other types, probably as a result of increased $\mathrm{Al}$ substitution for $\mathrm{Si}$. Iron is also present in small concentrations (< $0.6 \mathrm{wt}$. \% $\mathrm{FeO}$ ), probably occurring as $\mathrm{Fe}^{3+}$ replacing $\mathrm{Al}$ in the lattice (Smith, 1975).

\subsubsection{Non-silicates}

Extensive oxidation of the xenolith suite has resulted in the growth of Fe$\mathrm{Ti}$ oxides to such an extent that the recognition of primary oxide minerals is frequently difficult. Oxides that may be primary in origin include inclusions in large oikocrysts (in olivine, clinopyroxene and plagioclase), small disseminated crystals, and large cumulus Al-spinels common in Type P xenoliths. It is not clear whether or not primary oxide compositions have been affected by oxidation (i.e. $\mathrm{Fe}^{2+}$ oxidised to $\mathrm{Fe}^{3+}$ ). A lack of disequilibrium reactions suggests that they may not have exsolved into two species. Representative microprobe analyses of primary oxides are given in Table 4.6. Low totals indicate other elements that were not analysed; Ni has been found in small quantities in some oxides, and V and $\mathrm{Zn}$ may also be present.

\section{Spinel series}

Spinels sensu stricto occur in Type C and P pyroxenites as a cumulus phase, varying in colour from green to almost black. They form a solid solution between spinel $\left(\mathrm{MgAl}_{2} \mathrm{O}_{4}\right)$ and hercynite $\left(\mathrm{Fe}^{2+} \mathrm{Al}_{2} \mathrm{O}_{4}\right)$ compositions, with small amounts of $\mathrm{Cr}_{2} \mathrm{O}_{3}\left(\leq 4.38\right.$ wt. \%) substituting for $\mathrm{Al}_{2} \mathrm{O}_{3}$ ), and $\mathrm{TiO}_{2}$ ( $\leq 1.45$ wt. \%).

In Type $\mathrm{M}$ xenoliths, the spinels are $\mathrm{Cr}$-spinels, with lower $\mathrm{Al}_{2} \mathrm{O}_{3}$ contents and higher $\mathrm{Cr}_{2} \mathrm{O}_{3}$ contents $\left(\leq 9.84 \mathrm{wt}\right.$. \%.). Some $\mathrm{Cr}$-spinels have very low $\mathrm{Al}_{2} \mathrm{O}_{3}$ and $\mathrm{FeO}$ contents, and high $\mathrm{Fe}_{2} \mathrm{O}_{3}$ contents.

Rare spinels also occur in Type L xenoliths. These spinels are very low in $\mathrm{FeO}$ ( $\leq 9.62$ wt. \%), high in $\mathrm{MgO}(\geq 20.95$ wt. \%), and have insignificant contents of other elements in their structure.

\section{Magnetite Series}

Fe-Ti oxides form a solid solution series between ilmenite $\left(\mathrm{FeTiO}_{3}\right)$ and hematite $\left(\mathrm{Fe}_{2} \mathrm{O}_{3}\right)$, and between ulvöspinel $\left(\mathrm{Fe}_{2} \mathrm{TiO}_{4}\right)$ and magnetite $\left(\mathrm{Fe}_{3} \mathrm{O}_{4}\right)$. Fe-Ti oxides are common in Type L xenoliths, with highly variable compositions intermediate to these solid solutions (Figure 4.11), that include 27.2-51.56 wt. \% 
FeO, 8.14-29.08 wt. \% $\mathrm{TiO}_{2}$, and 10.04-50.93 wt. $\% \mathrm{Fe}_{2} \mathrm{O}_{3}$. Unoxidised primary Fe-Ti oxides have not been detected from Type M, C or P xenoliths.

TABLE 4.6: Representative electron microprobe analyses of primary oxides from Mount Sidley xenoliths.

\begin{tabular}{|c|c|c|c|c|c|c|c|c|c|c|}
\hline SAMPLE & $90029 \mathrm{~B}$ & $90029 B 1$ & $90033 \mathrm{~S}$ & $90033 X$ & $90033 \mathrm{~K}$ & $90033 R$ & $90033 \mathrm{~A}$ & $90033 C$ & $90033 Q$ & $90033 \mathrm{~S} 1$ \\
\hline TYPE & L & L & $\mathrm{L}$ & L & M & C & $\mathbf{P}$ & $\mathbf{P}$ & $\mathbf{P}$ & $P$ \\
\hline & II & $\operatorname{Tm}$ & Sp & & $\mathrm{Cr}-\mathrm{Sp}$ & Sp & $S_{p}$ & $\mathrm{Sp}_{\mathrm{p}}$ & $\mathrm{Sp}$ & $\mathrm{Hm}$ \\
\hline $\mathrm{SiO} 2$ & 0.06 & 0.06 & 0.24 & 0.13 & 0.00 & 0.04 & 0.17 & 0.05 & 0.07 & 0.87 \\
\hline $\mathrm{Al} 2 \mathrm{O} 3$ & 0.77 & 3.24 & 64.29 & 4.76 & 53.14 & 56.84 & 58.99 & 54.24 & 59.89 & 0.13 \\
\hline $\mathrm{TiO} 2$ & 47.76 & 13.22 & 0.13 & 27.34 & 1.09 & 0.69 & 0.59 & 0.97 & 0.45 & 0.02 \\
\hline $\mathrm{Fe} 2 \mathrm{O} 3$ & 10.24 & 40.22 & 3.65 & 10.04 & 4.10 & 6.25 & 4.76 & 5.76 & 3.60 & 96.86 \\
\hline $\mathrm{FeO}$ & 32.41 & 41.19 & 9.62 & 51.56 & 17.10 & 22.37 & 20.57 & 21.28 & 16.85 & 0.47 \\
\hline $\mathrm{MnO}$ & 0.35 & 0.17 & 0.88 & 0.53 & 0.15 & 0.09 & 0.18 & 0.19 & 0.06 & 0.00 \\
\hline $\mathrm{MgO}$ & 5.72 & 1.61 & 20.95 & 2.92 & 15.93 & 12.39 & 13.83 & 13.05 & 16.21 & 0.26 \\
\hline $\mathrm{CaO}$ & 0.05 & 0.02 & 0.00 & 0.04 & 0.00 & 0.00 & 0.01 & 0.02 & 0.02 & 0.10 \\
\hline $\mathrm{Cr} 2 \mathrm{O} 3$ & 0.00 & 0.00 & 0.17 & 0.00 & 9.27 & 0.69 & 0.48 & 4.38 & 2.14 & 0.00 \\
\hline TOTAL & 97.35 & 99.72 & 99.92 & 97.30 & 100.78 & 99.37 & 99.57 & 99.93 & 99.28 & 98.71 \\
\hline
\end{tabular}

cations on the basis of 2 (rhombohedral) or 3 (spinel) sites

\begin{tabular}{lllllllllll}
$\mathrm{Si}$ & 0.001 & 0.002 & 0.006 & 0.005 & 0.000 & 0.001 & 0.005 & 0.000 & 0.002 & 0.023 \\
$\mathrm{Al}$ & 0.023 & 0.148 & 1.910 & 0.206 & 1.677 & 1.826 & 1.861 & 1.750 & 1.862 & 0.004 \\
$\mathrm{Ti}$ & 0.892 & 0.366 & 0.002 & 0.754 & 0.022 & 0.014 & 0.012 & 0.020 & 0.009 & 0.000 \\
$\mathrm{FeIII}$ & 0.191 & 1.115 & 0.069 & 0.277 & 0.083 & 0.128 & 0.096 & 0.120 & 0.072 & 1.949 \\
$\mathrm{FeII}$ & 0.673 & 1.269 & 0.203 & 1.581 & 0.383 & 0.510 & 0.460 & 0.490 & 0.372 & 0.010 \\
$\mathrm{Mn}$ & 0.007 & 0.006 & 0.019 & 0.016 & 0.003 & 0.002 & 0.004 & 0.000 & 0.001 & 0.000 \\
$\mathrm{Mg}$ & 0.212 & 0.093 & 0.787 & 0.160 & 0.636 & 0.503 & 0.552 & 0.530 & 0.637 & 0.010 \\
$\mathrm{Ca}$ & 0.001 & 0.001 & 0.000 & 0.002 & 0.000 & 0.000 & 0.000 & 0.000 & 0.001 & 0.003 \\
$\mathrm{Cr}$ & 0.000 & 0.000 & 0.003 & 0.000 & 0.196 & 0.015 & 0.010 & 0.090 & 0.045 & 0.000 \\
& & & & & & & & & & \\
\hline TOTAL & 2.000 & 3.000 & 2.999 & 3.001 & 3.000 & 2.999 & 3.000 & 3.000 & 3.001 & 1.999 \\
\hline & & & & & & & & & & \\
X (Usp) & & 0.408 & 0.290 & 0.895 & 0.825 & 0.630 & 0.697 & 0.726 & 0.718 & \\
X (II) & 0.890 & & & & & & & & & 0.002
\end{tabular}

$\mathrm{Hm}=$ Hematite, $\mathrm{Il}=$ Ilmenite, $\mathrm{Sp}=$ Al-Spinel, $\mathrm{Tm}=$ Titanomagnetite

Primary ilmenite (Figure 4.11) has only been detected in one sample (90029B1). An estimate of temperature and oxygen fugacity (on co-existing ilmenite and titanomagnetite) was determined on this sample using the method of Stormer (1983), that yielded a temperature of $874{ }^{\circ} \mathrm{C}$ and oxygen fugacity of -12 $\left(\log _{10} \mathrm{fO}_{2}\right)$. Such conditions are high in temperature for granulite facies rocks and 
it is possible that these grains have been affected by oxidation reactions. The estimated temperature however is consistent with pyroxene geothermometry which indicates magmatic temperatures of equilibration (Chapter 4.4.2).

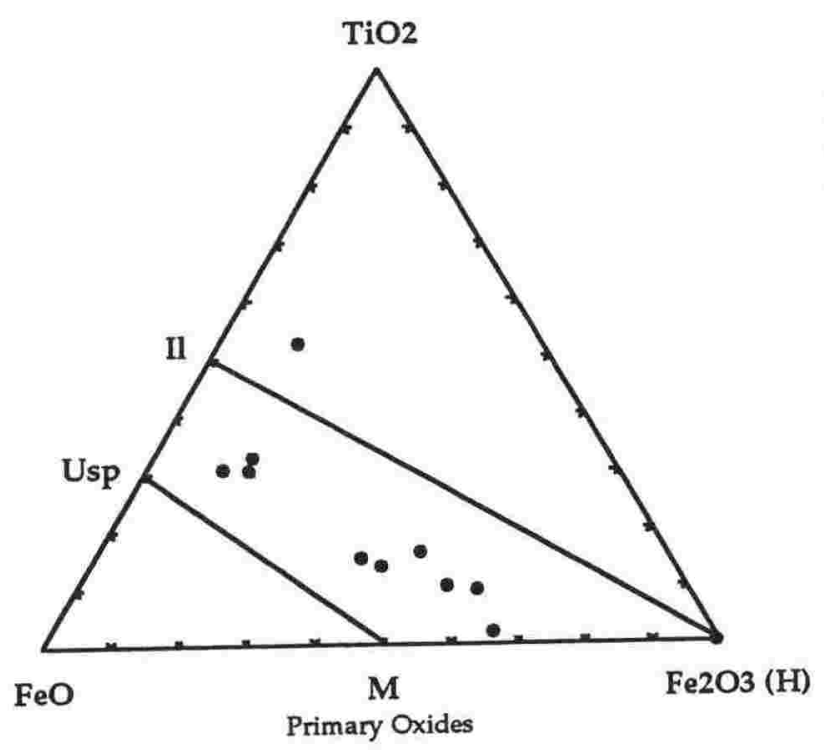

FIGURE 4.11: Compositions of primary oxides from Type L Mount Sidley xenoliths in the system $\mathrm{TiO}_{2}-\mathrm{FeO}-\mathrm{Fe}_{2} \mathrm{O}_{3}$. Most oxides are from the ulvöspinel-magnetite series, with only one sample detected from the ilmenite-hematite series. Primary unoxidised $\mathrm{Fe}-\mathrm{Ti}$ oxides have not been detected from Type $\mathrm{M}, \mathrm{C}$ and $\mathrm{P}$ xenoliths. $\mathrm{H}=$ hematite; Il = ilmenite; $\mathrm{M}=$ magnetite; Usp = ulvöspinel.

\subsubsection{Accessory minerals}

Apatite is an ubiquitous accessory mineral in Type $\mathrm{L}$ xenoliths. Whether apatite is primary or secondary in origin is uncertain, but petrographic evidence (Chapters 4.3 and 4.5.3) suggests that very small apatite crystals enclosed in large crystals are primary in origin, whereas large euhedral apatites are secondary, having crystallised from infiltrating silicate melts.

\subsubsection{Summary of mineral chemistry}

The petrographic and mineralogical characteristics of the Mount Sidley xenolith suite are summarised in Table 4.7. The granulite xenoliths (Type L and M) are similar, with the major difference being the higher proportion of plagioclase in Type L granulites. The pyroxenite xenoliths (Types $C$ and $P$ ) are also similar, with Type $\mathrm{C}$ containing plagioclase, and Type $\mathrm{P}$ being plagioclase-free. The granulite and pyroxenite suites differ in texture, mineral chemistry, and in the types of secondary reactions present.

An examination of the mineral chemistry of the xenolith suite has indicated a number of characteristics:

- the textural similarity between Types L and M granulites, and between Types $\mathrm{C}$ and $\mathrm{P}$ pyroxenites, is also apparent in mineral chemistry. In the granulite suite, olivines have low Fo contents, clinopyroxenes have low $\mathrm{Mg}$ contents, and plagioclase have low An contents, compared to minerals of the pyroxenite suite. There is a gradation in composition between xenolith types; 
- there is no difference in major element chemistry between igneous and metamorphic generations of minerals - metamorphism was closed-system with regard to major elements;

TABLE 4.7: Summary of the petrography and mineral chemistry of the Mount Sidley xenolith suite, by xenolith type.

\begin{tabular}{|c|c|c|c|c|}
\hline TYPE & Type L & Type M & Type C & Type $\mathbf{P}$ \\
\hline ROCK TYPES & $\begin{array}{c}\text { Leuco-/Gabbros } \\
\text { Leuco-/Troctolites } \\
\text { Anorthosites }\end{array}$ & $\begin{array}{l}\text { Mela-/Gabbros } \\
\text { Troctolites }\end{array}$ & Mela-/Gabbros & $\begin{array}{c}\text { Clinopyroxenites } \\
\text { Wehrlites }\end{array}$ \\
\hline TEXTURE & $\begin{array}{l}\text { Meta-Igneous } \\
\text { Granulites }\end{array}$ & $\begin{array}{l}\text { Meta-Igneous } \\
\text { Granulites }\end{array}$ & $\begin{array}{l}\text { Cumulate } \\
\text { Pyroxenites }\end{array}$ & $\begin{array}{l}\text { Cumulate } \\
\text { Pyroxenites }\end{array}$ \\
\hline $\begin{array}{l}\text { MINERALOGY } \\
\text { Olivine }\end{array}$ & Fo $43-59$ & Fo $50-59$ & Fo $61-70$ & Fo $68-82$ \\
\hline Clinopyroxene & $\begin{array}{l}\text { Wo } 43-51 \\
\text { En } 33-42 \\
\text { Fs } 15-23\end{array}$ & $\begin{array}{l}\text { Wo } 44-48 \\
\text { En } 35-44 \\
\text { Fs } 10-19\end{array}$ & $\begin{array}{l}\text { Wo } 45-51 \\
\text { En } 38-41 \\
\text { Fs } 11-16\end{array}$ & $\begin{array}{l}\text { Wo } 44-53 \\
\text { En } 34-45 \\
\text { Fs } 9-16\end{array}$ \\
\hline Plagioclase & An 39-68 & An 55-62 & An $46-66$ & An $60-77$ \\
\hline Oxides & $\begin{array}{c}\text { Fe-Ti oxides } \\
\text { Al-spinels (rare) }\end{array}$ & Al-spinels & Al-spinels & Al-spinels \\
\hline $\begin{array}{l}\text { Temperature }\left({ }^{\circ} \mathrm{C}\right) \\
\text { Pressure }(\mathrm{kb})\end{array}$ & $\begin{array}{c}980-1160 \\
4.0-6.5\end{array}$ & $\begin{array}{c}1060-1150 \\
4.5-6.5\end{array}$ & $\begin{array}{c}1080-1140 \\
9.0-11.5\end{array}$ & $\begin{array}{c}1160-1240 \\
8.0-12.0\end{array}$ \\
\hline $\begin{array}{l}\text { SECONDARY } \\
\text { REACTIONS }\end{array}$ & $\begin{array}{c}\text { Oxidation } \\
\text { Kaersutitisation }\end{array}$ & Oxidation & $\begin{array}{l}\text { Kaersutitisation } \\
\text { Oxidation }\end{array}$ & $\begin{array}{c}\text { Kaersutitisation } \\
\text { Oxidation }\end{array}$ \\
\hline
\end{tabular}

- Al substitution for $\mathrm{Si}$ in the tetrahedral site of clinopyroxenes results in a charge imbalance, and is accompanied by $\mathrm{Ti}$ substitution for $\mathrm{Mg}$ and $\mathrm{Fe}$ in an octahedral site to restore the imbalance. The partitioning of $\mathrm{Al}$ into tetrahedral $\left(\mathrm{Al}^{\mathrm{IV}}\right)$ and octahedral sites $\left(\mathrm{Al}{ }^{\mathrm{VI}}\right)$ is typical of clinopyroxenes equilibrated to granulite conditions;

- granulite clinopyroxenes have lower $\mathrm{Al}_{2} \mathrm{O}_{3}$ contents than pyroxenite clinopyroxenes as a result of prior plagioclase crystallisation depleting the crystallising melt in $\mathrm{Al}_{2} \mathrm{O}_{3}$;

- clinopyroxene geothermobarometry indicates high (magmatic) temperatures of equilibration reflecting a high geothermal gradient. The 
pyroxenites are a higher $\mathrm{P}-\mathrm{T}$ assemblage than the granulites, with a trend to lower pressures and temperatures from Type $\mathrm{P}$ to Type $\mathrm{L}$ xenoliths. Plagioclase crystallisation may correspond with crystallisation of the xenoliths at lower temperatures;

- primary oxides are rare, with many having been affected by secondary oxidation reactions. Limited temperature-oxygen fugacity determinations indicate temperatures of approximately $874^{\circ} \mathrm{C}$, further indicating high temperatures of equilibration.

Mineral chemistry supports the trend of increasing metamorphic texture, deformation and oxidation of the xenolith suite from Type P to Type L xenoliths, which may equate to a temporal and/or stratigraphic trend (Chapter 4.3 .5 and Figure 4.3). The decrease in $\mathrm{Mg}: \mathrm{Fe}$ ratios in olivine and clinopyroxene, and $\mathrm{Ca}: \mathrm{Na}$ ratios in plagioclase, together with the change from $\mathrm{Al}$-spinel and olivine, to clinopyroxene and plagioclase as cumulus phases indicates that the trend is due to crystallisation and fractionation from an evolving melt.

P-T estimates decrease along this trend, indicating crystallisation of the xenolith types at progressively higher levels. The xenolith suite therefore represents a sequence of cumulate rocks formed from the fractionation of an evolving melt, with initial crystallisation of the Type $\mathrm{P}$ xenolith suite, and final crystallisation of the Type L xenolith suite. Such a sequence is common in layered intrusions exposed at the surface (e.g. Wager and Brown, 1968; Grapes, 1975; Parsons, 1987; Nicol, 1977; Baker, 1990) and suggests that the xenolith suite is a layered sequence that has crystallised at lower crustal/upper mantle depths.

\subsection{Secondary Mineral Reactions}

Having documented the primary mineral assemblage it is necessary to examine the various secondary mineral reactions that have changed the mineral assemblage and the composition of the xenoliths as a whole. These reactions involve interaction with host melt, replacement of clinopyroxene by kaersutite, and oxidation of silicate and oxide minerals. These reactions may be discrete, or a combination of styles. In order to best understand these reactions a number of case studies (various back scattered electron photomicrographs with tables of analyses) are presented to document each of the reaction types (host melt-xenolith interaction, kaersutitisation, and oxidation), with a following discussion of each process. In secondary mineral reaction tables, minerals are identified by their association: 'core' = primary mineral core; 'inc' = inclusion in primary mineral; 
'kaerst.' = associated with kaersutitisation; 'melt' = associated with the infiltrating melt; 'oxid.' = associated with oxidation; 'rim' = primary mineral rim; 'vein' = vein minerals.

\subsubsection{Host rock - xenolith interactions}

The effects of host melts on xenolith compositions can be readily seen where the host melts have come in contact with the xenoliths through cracks, and on the xenolith rims. The affects of host melt xenolith interactions include the crystallisation of microphenocryst phases, and the development of disequilibrium textures on the rims of the xenolith minerals.

TABLE 4.8: Electron microprobe analyses of host melt - xenolith reactions in a Type P pyroxenite (sample 90033Q1). See Plate 4.10 for analyses sites.

\begin{tabular}{|c|c|c|c|c|c|c|c|c|c|c|}
\hline $\begin{array}{l}\text { PHASE } \\
\text { SITE }\end{array}$ & $\begin{array}{c}\text { Olivine } \\
\text { core } \\
\mathbf{1}\end{array}$ & $\begin{array}{c}\text { Cpx } \\
\text { core } \\
2\end{array}$ & $\begin{array}{c}\text { Cpx } \\
\text { core } \\
3\end{array}$ & $\begin{array}{c}\text { Rhönite } \\
\text { melt } \\
4\end{array}$ & $\begin{array}{c}\text { Rhönite } \\
\text { melt } \\
5\end{array}$ & $\begin{array}{c}\text { Plag } \\
\text { melt } \\
6\end{array}$ & $\begin{array}{c}\text { Plag } \\
\text { melt } \\
7\end{array}$ & $\begin{array}{c}\text { Plag } \\
\text { melt } \\
8\end{array}$ & $\begin{array}{c}\text { Cpx } \\
\text { melt } \\
9\end{array}$ & $\begin{array}{c}\text { Glass } \\
\text { melt } \\
10\end{array}$ \\
\hline $\mathrm{SiO} 2$ & 37.85 & 48.73 & 47.09 & 24.41 & 24.02 & 52.77 & 52.69 & 53.39 & 45.59 & 46.83 \\
\hline $\mathrm{Al} 2 \mathrm{O} 3$ & 0.00 & 8.20 & 7.22 & 18.22 & 18.73 & 29.68 & 29.72 & 20.90 & 9.16 & 17.68 \\
\hline $\mathrm{TiO} 2$ & 0.00 & 1.32 & 3.79 & 12.41 & 12.13 & 0.27 & 0.19 & 2.20 & 5.27 & 3.65 \\
\hline $\mathrm{Fe} 2 \mathrm{O} 3$ & & 2.32 & 0.00 & & & & & & 1.83 & \\
\hline $\mathrm{FeO}$ & 22.37 & 4.09 & 6.10 & 17.62 & 17.84 & 0.35 & 0.39 & 4.82 & 7.20 & 9.70 \\
\hline $\mathrm{MnO}$ & 0.26 & 0.17 & 0.11 & 0.08 & 0.07 & 0.00 & 0.02 & 0.06 & 0.21 & 0.18 \\
\hline $\mathrm{MgO}$ & 39.69 & 13.57 & 13.41 & 13.68 & 13.51 & 0.07 & 0.07 & 2.21 & 9.88 & 4.73 \\
\hline $\mathrm{CaO}$ & 0.10 & 20.35 & 21.90 & 12.04 & 11.97 & 12.71 & 12.76 & 9.34 & 18.59 & 10.67 \\
\hline $\mathrm{Na} 2 \mathrm{O}$ & 0.00 & 1.06 & 0.20 & 1.05 & 0.99 & 4.28 & 4.44 & 5.76 & 1.86 & 3.94 \\
\hline $\mathrm{K} 2 \mathrm{O}$ & 0.01 & 0.00 & 0.01 & 0.00 & 0.01 & 0.36 & 0.23 & 1.19 & 0.58 & 0.90 \\
\hline TOTAL & 100.28 & 99.79 & 99.83 & 99.51 & 99.27 & 100.49 & 100.51 & 99.87 & 100.17 & 98.28 \\
\hline $\mathrm{Si}$ & 0.980 & 1.800 & 1.750 & 3.270 & 3.231 & 2.180 & 2.380 & 2.410 & 1.712 & \\
\hline $\mathrm{Al}$ & 0.000 & 0.357 & 0.320 & 2.880 & 2.971 & 1.690 & 1.590 & 1.160 & 0.406 & \\
\hline $\mathrm{Ti}$ & 0.000 & 0.037 & 0.110 & 1.250 & 1.221 & 0.010 & 0.010 & 0.080 & 0.149 & \\
\hline FeIII & & 0.064 & 0.000 & & & & & & 0.052 & \\
\hline FeII & 0.490 & 0.126 & 0.200 & 1.970 & 2.007 & 0.010 & 0.020 & 0.180 & 0.225 & \\
\hline $\mathrm{Mn}$ & 0.010 & 0.005 & 0.000 & 0.010 & 0.008 & 0.000 & 0.000 & 0.000 & 0.007 & \\
\hline Mg & 1.540 & 0.747 & 0.740 & 2.730 & 2.709 & 0.010 & 0.000 & 0.160 & 0.553 & \\
\hline $\mathrm{Ca}$ & 0.000 & 0.805 & 0.870 & 1.730 & 1.726 & 0.660 & 0.620 & 0.450 & 0.748 & \\
\hline $\mathrm{Na}$ & 0.000 & 0.076 & 0.010 & 0.270 & 0.258 & 0.410 & 0.390 & 0.490 & 0.135 & \\
\hline K & 0.000 & 0.000 & 0.000 & 0.000 & 0.002 & 0.020 & 0.010 & 0.070 & 0.028 & \\
\hline TOTAL & 3.020 & 4.017 & 4.000 & 14.110 & 14.133 & 4.990 & 5.020 & 5.000 & 4.015 & \\
\hline
\end{tabular}




\section{Sample 90033Q1: Type P xenolith (Plate 4.10; Table 4.8)}

Host lava has infiltrated the pyroxenite along cracks, reacting with the primary mineral assemblage, which is typical of Type $\mathrm{P}$ xenoliths, consisting mainly of olivine (1) and clinopyroxene $(2,3)$. Xenolith mineral phases are affected on their rims in contact with the infiltrating melt (as with sample 90039E in the next case study).

Various mineral phases have crystallised from the melt, including euhedral rhönite $(4,5)$ and euhedral plagioclase $(6,7)$. Plagioclase crystals are labradorite (An 61), and differ little from xenolith plagioclase except for elevated $\mathrm{TiO}_{2}$ contents.

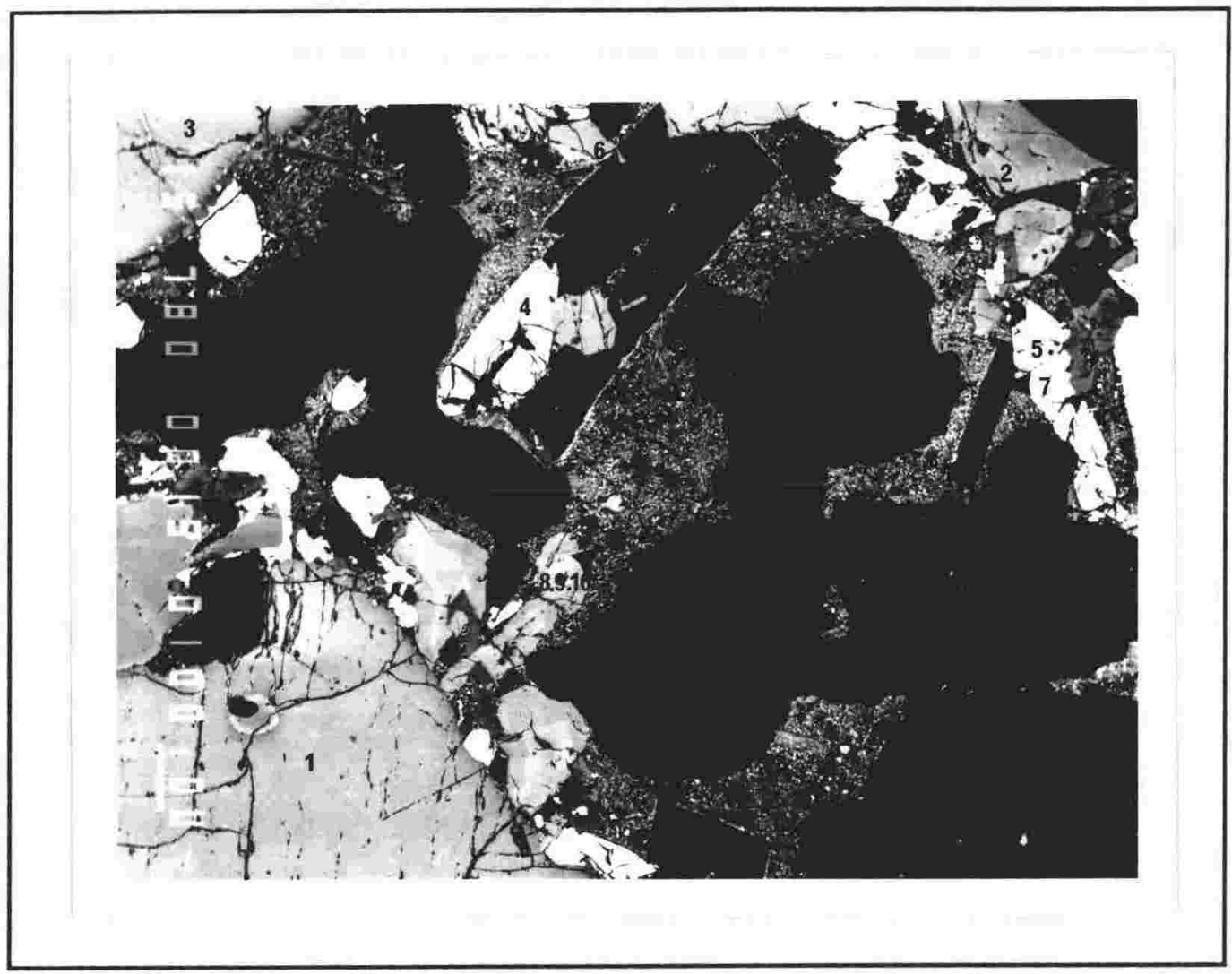

PLATE 4.10: Host melt has infiltrated a Type P pyroxenite (sample 90033Q1), reacting with xenolith mineral phases and crystallising microphenocrysts within the xenolith. Analyses of sites 1-10 are presented as Table 4.8. See text for further explanation. Scale bar is $100 \mu \mathrm{m}$.

Groundmass phases in the melt are markedly different to pyroxenite and melt phenocryst phases. Plagioclase (8) is sodic (An 44) with high $\mathrm{TiO}_{2}, \mathrm{FeO} \mathrm{Na}_{2} \mathrm{O}$ and $\mathrm{K}_{2} \mathrm{O}$ contents, and clinopyroxene (9) is Fe-rich (Fs 18 compared to Fs 11), and has higher $\mathrm{TiO}_{2}, \mathrm{Na}_{2} \mathrm{O}$ and $\mathrm{K}_{2} \mathrm{O}$ contents than pyroxenite clinopyroxenes. Glass (10) associated with the groundmass is a high-alkali basalt similar in composition to other host lavas. The presence of groundmass phases indicates that the glass represents an evolved composition. The addition of the groundmass assemblage 
to the glass composition increases the alkali content markedly, indicating an initially more alkaline composition.

\section{Sample 90039E: Type L xenolith (Plate 4.11; Table 4.9)}

This troctolite has been infiltrated by the host melt at its rim for several $\mathrm{mm}$ to a $\mathrm{cm}$. The xenolith phases, olivine (1; not seen on Plate 4.11 ) and plagioclase (2), have both been affected by this melt.

TABLE 4.9: Electron microprobe analyses of host melt - xenolith reactions in a Type L granulite (sample 90039E). See Plate 4.11 for analyses sites.

\begin{tabular}{|c|c|c|c|c|c|c|c|c|c|c|}
\hline $\begin{array}{l}\text { PHASE } \\
\text { SITE }\end{array}$ & $\begin{array}{c}\text { Olivine } \\
\text { core } \\
1 \\
\end{array}$ & $\begin{array}{c}\text { Plag } \\
\text { core- } \\
2 \\
\end{array}$ & $\begin{array}{c}\text { Plag } \\
\text { rim } \\
3 \\
\end{array}$ & $\begin{array}{c}\text { Olivine } \\
\text { melt } \\
4\end{array}$ & $\begin{array}{c}\text { Plag } \\
\text { melt } \\
5 \\
\end{array}$ & $\begin{array}{c}\text { Ilmenite } \\
\text { melt } \\
6\end{array}$ & $\begin{array}{c}\text { Ti-mag } \\
\text { melt } \\
7 \\
\end{array}$ & $\begin{array}{c}\text { Apatite } \\
\text { melt } \\
8\end{array}$ & $\begin{array}{c}\text { Glass } \\
\text { melt } \\
9 \\
\end{array}$ & $\begin{array}{c}\text { Glass } \\
\text { melt } \\
10 \\
\end{array}$ \\
\hline $\mathrm{SiO} 2$ & 34.93 & 55.98 & 52.42 & 37.10 & 50.50 & 0.00 & 0.25 & 1.29 & 46.13 & 45.32 \\
\hline $\mathrm{Al} 2 \mathrm{O} 3$ & 0.00 & 27.46 & 28.75 & 0.05 & 31.27 & 0.49 & 12.81 & 0.04 & 16.31 & 14.97 \\
\hline $\mathrm{TiO} 2$ & 0.00 & 0.14 & 0.21 & 0.05 & 0.18 & 42.48 & 13.82 & 0.08 & 4.07 & 4.35 \\
\hline $\mathrm{Fe} 2 \mathrm{O} 3$ & & & & & & 22.10 & 29.62 & & & \\
\hline $\mathrm{FeO}$ & 39.91 & 0.12 & 0.70 & 26.46 & 0.51 & 27.61 & 32.50 & 0.66 & 11.12 & 14.54 \\
\hline $\mathrm{MnO}$ & 0.69 & 0.00 & 0.07 & 0.39 & 0.01 & 0.57 & 0.48 & 0.00 & 0.32 & 0.30 \\
\hline $\mathrm{MgO}$ & 24.78 & 0.01 & 0.08 & 35.38 & 0.06 & 5.61 & 8.63 & 0.32 & 3.09 & 3.38 \\
\hline $\mathrm{CaO}$ & 0.07 & 10.73 & 14.02 & 0.33 & 14.21 & 0.01 & 0.01 & 49.05 & 11.22 & 7.43 \\
\hline $\mathrm{Na} 2 \mathrm{O}$ & 0.00 & 5.44 & 3.61 & 0.01 & 3.47 & 0.25 & 0.00 & 0.00 & 3.99 & 4.39 \\
\hline $\mathrm{K} 2 \mathrm{O}$ & 0.00 & 0.24 & 0.76 & 0.00 & 0.18 & 0.06 & 0.08 & 0.03 & 0.70 & 2.24 \\
\hline $\mathrm{Cr} 2 \mathrm{O} 3$ & 0.00 & 0.14 & 0.06 & 0.03 & 0.00 & 0.05 & 0.21 & 0.04 & 0.03 & 0.03 \\
\hline $\mathrm{P} 2 \mathrm{O} 5$ & & 0.02 & 0.11 & & & 0.16 & 0.00 & 45.68 & 2.98 & 3.22 \\
\hline TOTAL & 100.38 & 100.28 & 100.78 & 99.80 & 100.38 & 99.38 & 98.41 & 97.17 & 99.95 & 100.17 \\
\hline $\mathrm{Si}$ & 0.992 & 2.470 & 2.388 & 0.989 & 2.298 & 0.000 & 0.008 & 0.260 & & \\
\hline Al & 0.000 & 1.430 & 1.543 & 0.001 & 1.677 & 0.014 & 0.513 & 0.002 & & \\
\hline $\mathrm{Ti}$ & 0.000 & 0.005 & 0.007 & 0.001 & 0.006 & 0.787 & 0.353 & 0.002 & & \\
\hline FeIII & & & & & & 0.410 & 0.758 & & & \\
\hline FeII & 0.948 & 0.000 & 0.025 & 0.590 & 0.020 & 0.569 & 0.924 & 0.130 & & \\
\hline $\mathrm{Mn}$ & 0.017 & 0.000 & 0.003 & 0.009 & 0.001 & 0.012 & 0.000 & 0.000 & & \\
\hline $\mathrm{Mg}$ & 1.049 & 0.001 & 0.005 & 1.407 & 0.004 & 0.206 & 0.437 & 0.130 & & \\
\hline $\mathrm{Ca}$ & 0.002 & 0.510 & 0.684 & 0.009 & 0.693 & 0.000 & 0.001 & 13.500 & & \\
\hline $\mathrm{Na}$ & 0.000 & 0.460 & 0.318 & 0.000 & 0.306 & 0.000 & 0.000 & 0.000 & & \\
\hline K & 0.000 & 0.130 & 0.015 & 0.000 & 0.010 & 0.000 & 0.000 & 0.000 & & \\
\hline $\mathrm{Cr}$ & 0.000 & 0.005 & 0.002 & 0.000 & 0.000 & 0.001 & 0.006 & 0.000 & & \\
\hline$P$ & & 0.000 & 0.004 & & & 0.000 & 0.000 & 9.880 & & \\
\hline TOTAL & 3.008 & 5.011 & 4.994 & 3.006 & 5.015 & 1.999 & 3.000 & 23.904 & & \\
\hline
\end{tabular}




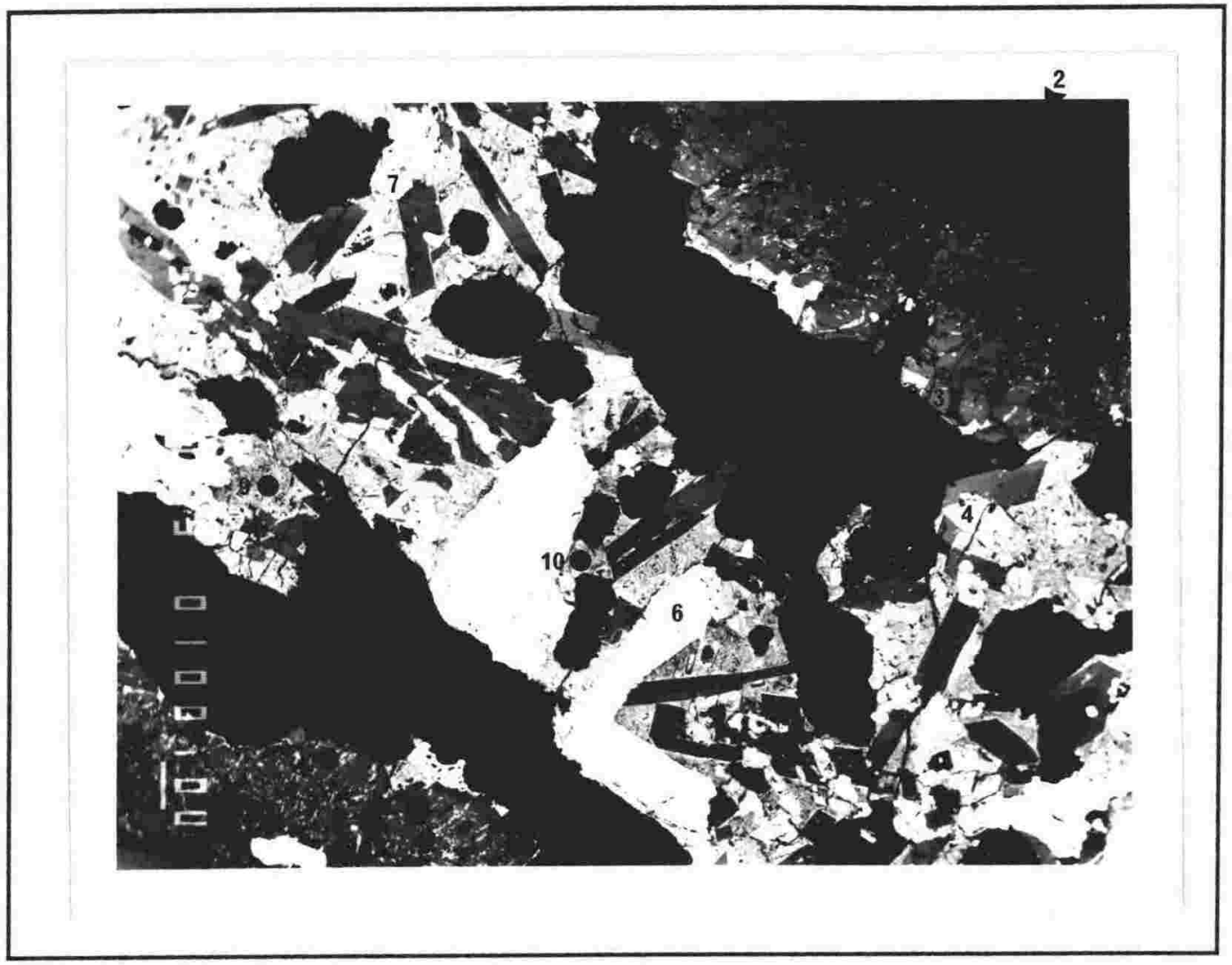

PLATE 4.11: Host melt - xenolith reactions in a Type L granulite (sample 90039E). Xenolith mineral phases show reaction rims in contact with the melt, which has crystallised euhedral microphenocrysts. Analyses of sites 1-10 are presented as Table 4.9. See text for further explanation. Scale bar is $100 \mu \mathrm{m}$.

The rims (3) of affected plagioclase crystals are markedly more Ca-rich than the primary cores (An 67 compared to An 46), and have higher $\mathrm{K}_{2} \mathrm{O}$ and $\mathrm{FeO}$ totals. The increase in Fe accompanies the growth of oxides in plagioclase rims.

Microphenocrysts that have crystallised directly from the melt are quite different in composition to xenolith phases. Olivine (4) is forsteritic (Fo 70) compared to xenolith olivine (Fo 53), and has a higher $\mathrm{CaO}$ content. Plagioclase (5) microphenocrysts are labradorite (An 69) and similar in composition to reaction rims on xenolith plagioclase. Fe-Ti oxides have also crystallised from the melt and consist of both ilmenite (6) and titanomagnetite (7). Co-existing oxide geothermometry (Stormer, 1983) on these phases yields high temperatures $(1,100$ $\left.{ }^{\circ} \mathrm{C}\right)$ and high $\mathrm{fO} 2\left(-7.7 \log _{10}\right)$ conditions consistent with crystallisation from a melt at magmatic temperatures and redox conditions similar to the FMQ buffer curve, which is typical of basalts (Haggerty, 1990). Apatite is another microphenocryst phase, and its subhedral nature contrasts with the euhedral plagioclase, olivine and oxides that crystallised at an earlier stage.

The glass $(9,10)$ is alkaline in composition, reflecting the nature of the host lavas. Compositions vary from relatively primitive (Mg\# 49) to very evolved 
(Mg\# 17) compositions within the same thin section, indicating an evolution of the melt within the xenolith (see Chapter 4.5.4).

\section{Sample 90033X: Type L xenolith (Plate 4.12; Table 4.10)}

Melt trapped in this xenolith is present between plagioclase and mafic mineral layers rather than in veins. Xenolith minerals display reaction rims, indicating disequilibrium reactions with the melt.

TABLE 4.10: Electron microprobe analyses of host melt - xenolith reactions in a Type L granulite (sample 90033X). See Plate 4.12 for analyses sites.

\begin{tabular}{|c|c|c|c|c|c|c|c|c|c|c|}
\hline $\begin{array}{l}\text { PHASE } \\
\text { SITE }\end{array}$ & $\begin{array}{c}\text { Olivine } \\
\text { core- } \\
1\end{array}$ & $\begin{array}{l}\text { Olivine } \\
\text { rim } \\
2\end{array}$ & $\begin{array}{c}\text { Cpx } \\
\text { core- } \\
3\end{array}$ & $\begin{array}{c}C_{p x} \\
\text { rim } \\
4\end{array}$ & $\begin{array}{l}\text { Plag } \\
\text { core } \\
5\end{array}$ & $\begin{array}{c}\text { Plag } \\
\text { rim } \\
6\end{array}$ & $\begin{array}{c}\text { Ti-mag } \\
\text { melt } \\
8\end{array}$ & $\begin{array}{c}\text { Glass } \\
\text { melt } \\
7\end{array}$ & $\begin{array}{c}\text { Glass } \\
\text { melt } \\
9\end{array}$ & $\begin{array}{c}\text { Olivine } \\
\text { melt } \\
10\end{array}$ \\
\hline $\mathrm{SiO} 2$ & 33.56 & 35.35 & 49.53 & 50.18 & 57.93 & 55.46 & 0.14 & 43.58 & 45.13 & 34.68 \\
\hline $\mathrm{Al} 2 \mathrm{O} 3$ & 0.01 & 0.04 & 4.16 & 2.60 & 26.48 & 27.95 & 4.44 & 10.52 & 10.49 & 0.01 \\
\hline $\mathrm{TiO} 2$ & 0.06 & 0.17 & 1.18 & 1.43 & 0.03 & 0.17 & 25.61 & 4.63 & 2.68 & 0.07 \\
\hline $\mathrm{Fe} 2 \mathrm{O} 3$ & & & 3.29 & 2.98 & & & 17.69 & & & \\
\hline $\mathrm{FeO}$ & 45.16 & 38.65 & 10.21 & 8.89 & 0.29 & 0.46 & 48.76 & 23.08 & 21.39 & 39.67 \\
\hline $\mathrm{MnO}$ & 1.15 & 0.85 & 0.47 & 0.30 & 0.00 & 0.03 & 0.65 & 0.60 & 0.65 & 0.99 \\
\hline $\mathrm{MgO}$ & 19.62 & 25.10 & 10.97 & 13.02 & 0.05 & 0.07 & 3.48 & 3.43 & 9.59 & 23.46 \\
\hline $\mathrm{CaO}$ & 0.33 & 0.38 & 20.10 & 20.94 & 8.27 & 10.17 & 0.02 & 10.01 & 7.75 & 0.42 \\
\hline $\mathrm{Na} 2 \mathrm{O}$ & 0.00 & 0.00 & 0.91 & 0.43 & 6.44 & 5.33 & 0.00 & 2.72 & 0.36 & 0.00 \\
\hline $\mathrm{K} 2 \mathrm{O}$ & 0.01 & 0.02 & 0.00 & 0.00 & 0.53 & 0.37 & 0.02 & 0.76 & 1.17 & 0.00 \\
\hline $\mathrm{Cr} 2 \mathrm{O} 3$ & 0.08 & 0.00 & 0.00 & 0.05 & 0.00 & 0.01 & 0.00 & 0.04 & 0.00 & 0.00 \\
\hline TOTAL & 99.97 & 100.54 & 100.81 & 100.81 & 100.02 & 100.03 & 100.81 & 99.37 & 99.21 & 99.29 \\
\hline $\mathrm{Si}$ & 0.988 & 0.990 & 1.876 & 1.889 & 2.597 & 2.501 & 0.010 & & & 1.000 \\
\hline $\mathrm{Al}$ & 0.001 & 0.002 & 0.186 & 0.115 & 1.399 & 1.486 & 0.180 & & & 0.000 \\
\hline $\mathrm{Ti}$ & 0.003 & 0.005 & 0.034 & 0.041 & 0.001 & 0.006 & 0.670 & & & 0.004 \\
\hline FeIII & & & 0.090 & 0.080 & & & 0.480 & & & \\
\hline FeII & 1.110 & 0.910 & 0.320 & 0.280 & 0.011 & 0.017 & 1.470 & & & 0.960 \\
\hline $\mathrm{Mn}$ & 0.030 & 0.020 & 0.015 & 0.010 & 0.000 & 0.001 & 0.020 & & & 0.020 \\
\hline $\mathrm{Mg}$ & 0.870 & 1.050 & 0.619 & 0.730 & 0.004 & 0.005 & 0.180 & & & 0.010 \\
\hline $\mathrm{Ca}$ & 0.010 & 0.010 & 0.816 & 0.844 & 0.397 & 0.491 & 0.000 & & & 0.010 \\
\hline $\mathrm{Na}$ & 0.000 & 0.000 & 0.067 & 0.031 & 0.560 & 0.466 & 0.000 & & & 0.000 \\
\hline K & 0.001 & 0.001 & 0.000 & 0.000 & 0.029 & 0.021 & 0.000 & & & 0.000 \\
\hline $\mathrm{Cr}$ & 0.004 & 0.000 & 0.000 & 0.001 & 0.000 & 0.000 & 0.000 & & & 0.000 \\
\hline TOTAL & 3.017 & 2.988 & 4.023 & 4.021 & 4.998 & 4.994 & 3.010 & & & 2.004 \\
\hline
\end{tabular}

Olivine $(1,2)$ reaction rims are more forsteritic than unaffected cores (Fo 54 compared to Fo 44). Clinopyroxene $(3,4)$ rims are also more magnesian than 
cores, with higher $\mathrm{CaO}$ and $\mathrm{TiO}_{2}$ contents, and lower $\mathrm{FeO}$ and $\mathrm{Al}_{2} \mathrm{O}_{3}$. Plagioclase (5, 6) cores are andesine (e.g. An 40) and reaction rims are more Ca-rich (e.g. An 50). $\mathrm{FeO}$ contents are also higher in plagioclase rims, and small Fe-Ti oxides have crystallised between plagioclase cores and rim overgrowths. Fe-Ti oxides (7) have also crystallised as phenocrysts from the melt.

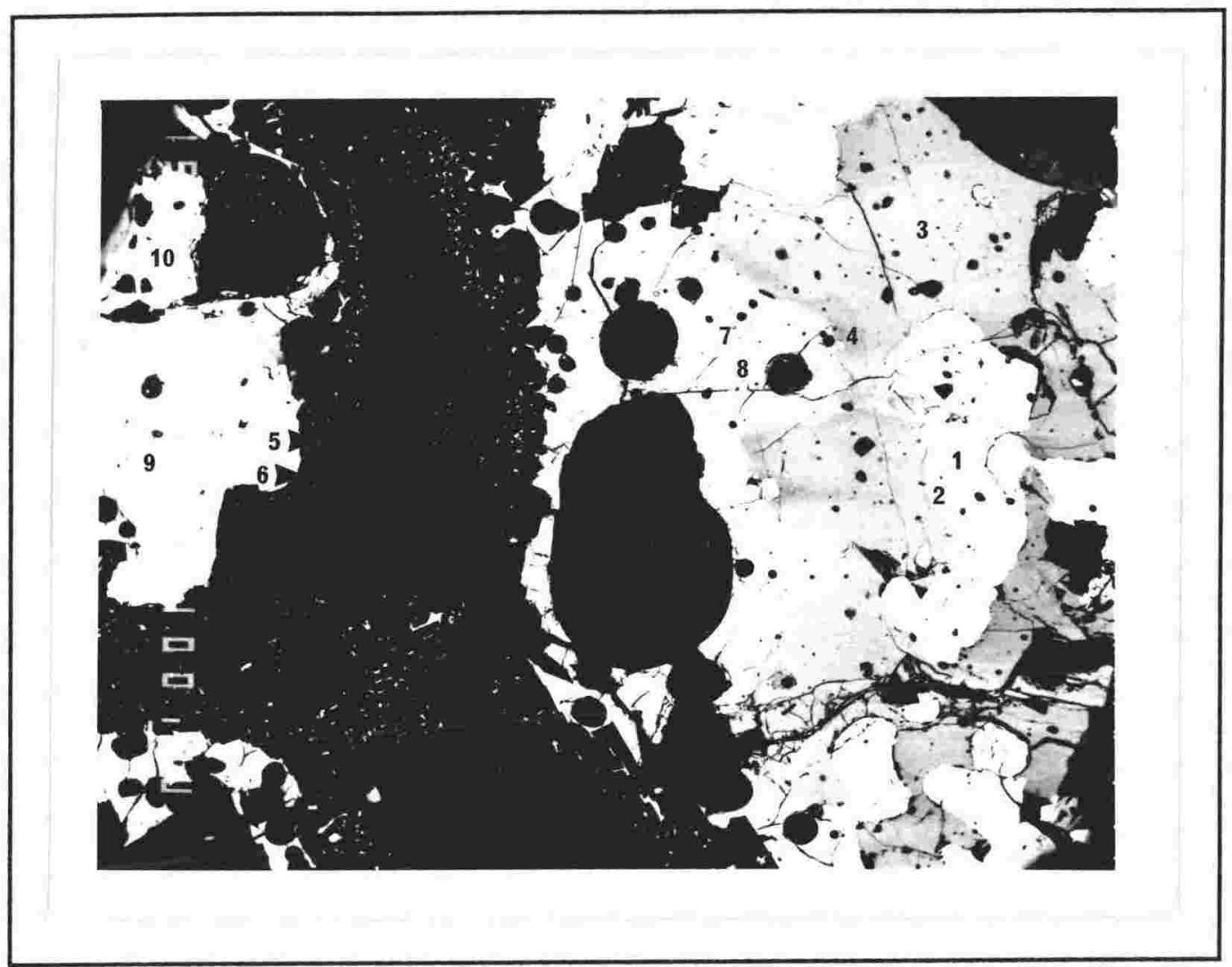

PLATE 4.12: Host melt - xenolith reactions in a Type L granulite (sample 90033X). A large amount of basanitic melt has caused severe reaction rims on xenolith olivine and plagioclase. Analyses of sites 1-10 are presented as Table 4.10. See text for further explanation. Scale bar is $100 \mu \mathrm{m}$.

The infiltrating melt is basanitic (8), with a high FeO content and low Mgnumber, reflecting its evolved nature. Its relatively high $\mathrm{Ca}: \mathrm{Na}$ ratio has led to the observed reaction rims on plagioclase, but the $\mathrm{Mg}$-rich rims on olivine and clinopyroxene are difficult to explain with crystallisation from this melt, unless the melt was more Mg-rich at the time and has subsequently inherited its low Mgnumber from further crystal fractionation; e.g. crystallisation of olivine from the melt will lower its Mg\#. Glasses with higher Mg-numbers (9) are present elsewhere in the sample, and these melts are capable of crystallising the observed rims (Mg-number of 44 and olivines of Fo 54). For example, olivine that has crystallised from this glass (10) is similar in composition (Fo 51) to olivine reaction rims on xenolith olivines elsewhere. 


\section{Discussion of host melt - xenolith reactions}

The infiltration of host lava is easy to identify petrographically (as seen in Plates 4.10 to 4.11 ) and to avoid when analysing bulk samples. Host magma crystallisation consists of variations of plagioclase \pm olivine \pm clinopyroxene \pm rhönite $\pm \mathrm{Fe}-\mathrm{Ti}$ oxides \pm apatite. The compositions of these phases are quite similar to pyroxenite phases, but differ markedly to granulite phases.

The main affects of melt interaction on the xenolith suite is the growth of $\mathrm{Mg}$ - and Ca-rich rims on xenolith crystals, and the crystallisation of Fe-Ti oxides, all of which alter the composition of the entrained xenolith. These overgrowths are similar in composition to microphenocrysts crystallising directly from the infiltrating melt.

\subsubsection{Kaersutitisation}

Kaersutite replacement of clinopyroxene is common in all xenolith types from Mount Sidley, with the exception of Type $M$ xenoliths where it is rare (Table 4.1). As a result of this reaction, kaersutite is a major secondary mineral phase in many xenoliths, especially in the pyroxenite suite.

Kaersutite is the only hydrous phase present in the xenolith suite. It is easily distinguishable in thin section by its high order interference colours and strong pleochroism (alpha = brownish-yellow, beta = reddish-brown, gamma = deep chestnut-brown). It forms by replacing clinopyroxene, and varies in texture from crystalline to anhedral depending on the nature of replacement.

\section{Sample 90033C: Type P xenolith (Plate 4.13; Table 4.11)}

The mineral assemblage of this sample includes clinopyroxene (1), olivine (2) and spinel (3). Kaersutite $(4,5,6)$ has replaced clinopyroxene (1), with the formation of a reaction rim on the kaersutite-clinopyroxene boundary consisting of the intermediate phases rhönite (7), olivine (8) and K-feldspar (9).

Rhönite is similar in composition to those occurring as inclusions in clinopyroxene (10). Olivine associated with this reaction is $\mathrm{Mg}$-rich with a forsterite content of Fo 81 compared to Fo 73 in primary olivine (2). K-feldspar does not occur elsewhere in the xenolith suite.

The reaction has well defined boundaries (the intermediate mineral assemblage), and kaersutite growth is fully crystalline, displaying well developed cleavage. The observed reaction has resulted in a decrease in $\mathrm{Si}, \mathrm{Mn}$ and $\mathrm{Ca}$, and an increase in all other analysed elements in the system, notably $\mathrm{Fe}, \mathrm{Ti}, \mathrm{Na}, \mathrm{K}$ and $\mathrm{H}_{2} \mathrm{O}$. 


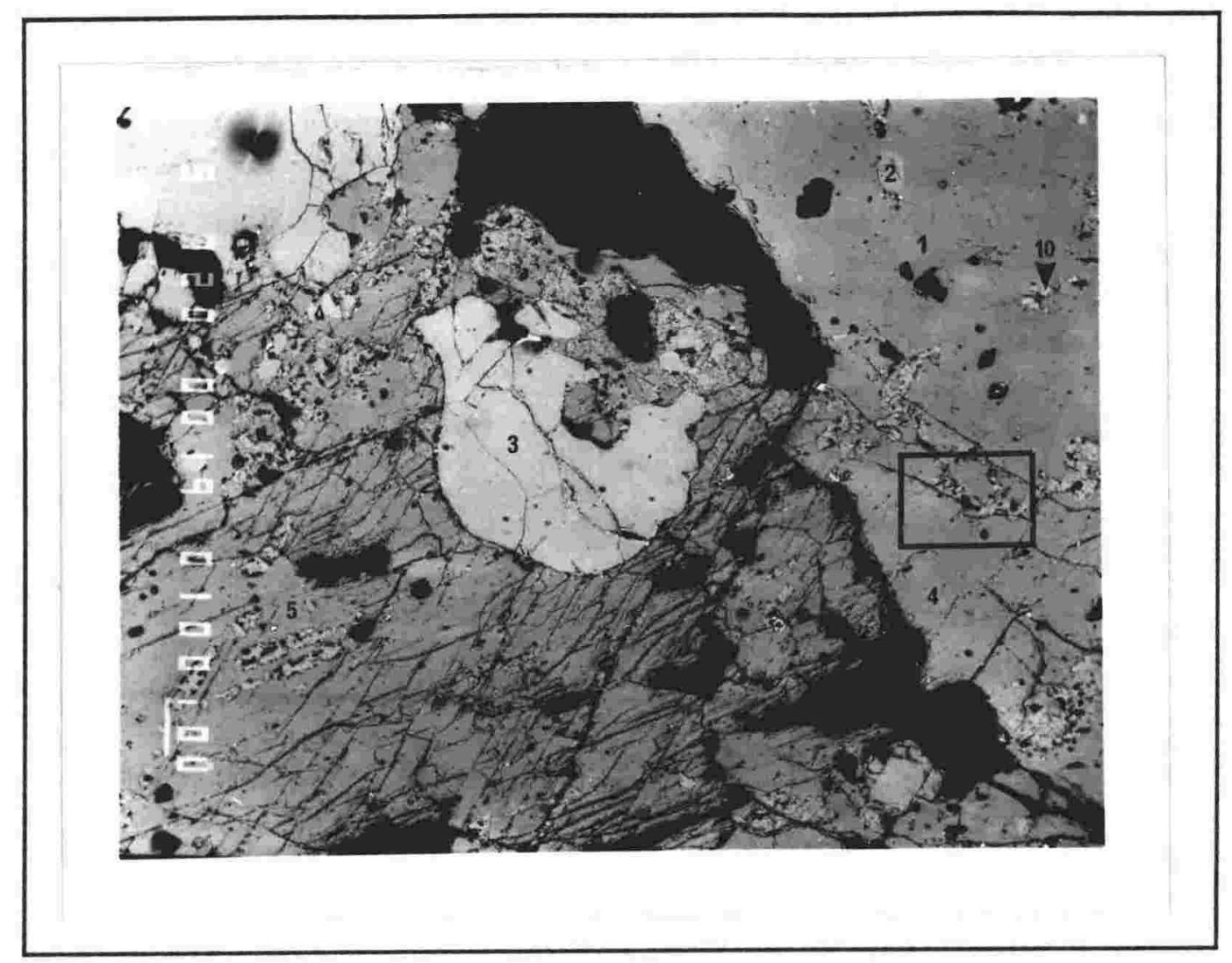

a)

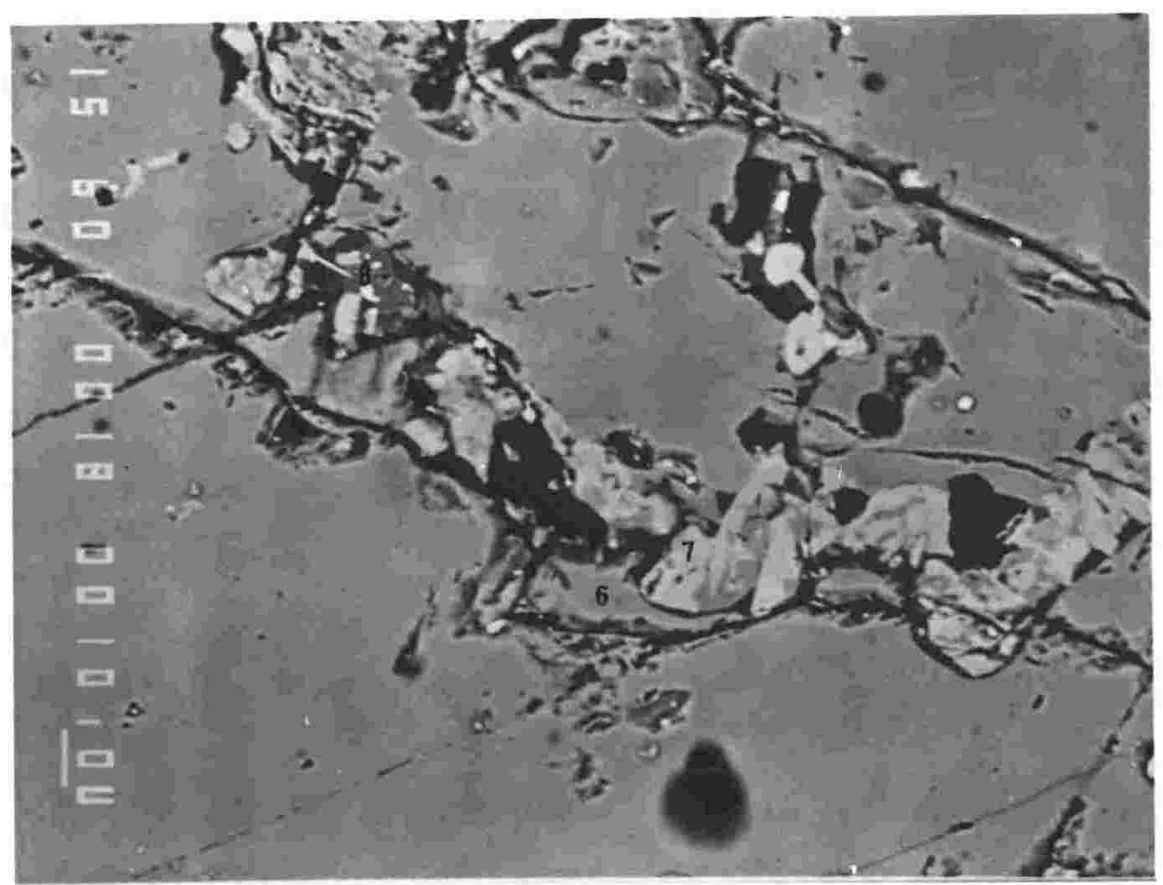

b) 
TABLE 4.11: Electron microprobe analyses of kaersutitisation reactions in a Type $\mathrm{P}$ pyroxenite (sample 90033 C). See Plate 4.13 for analyses sites.

\begin{tabular}{|c|c|c|c|c|c|c|c|c|c|c|}
\hline $\begin{array}{l}\text { PHASE } \\
\text { SITE }\end{array}$ & $\begin{array}{c}\text { Cpx } \\
\text { core } \\
1 \\
\end{array}$ & $\begin{array}{c}\text { Olivine } \\
\text { core } \\
2 \\
\end{array}$ & $\begin{array}{c}\text { Spinel } \\
\text { core } \\
3 \\
\end{array}$ & $\begin{array}{c}\text { Kaer } \\
\text { kaerst. } \\
4 \\
\end{array}$ & $\begin{array}{c}\text { Kaer } \\
\text { kaerst. } \\
5 \\
\end{array}$ & $\begin{array}{c}\text { Kaer } \\
\text { kaerst. } \\
6\end{array}$ & $\begin{array}{c}\text { Rhönite } \\
\text { kaerst. } \\
7\end{array}$ & $\begin{array}{c}\text { Olivine } \\
\text { kaerst. } \\
8 \\
\end{array}$ & $\begin{array}{c}\text { Kspar } \\
\text { kaerst. } \\
9\end{array}$ & $\begin{array}{c}\text { Rhönite } \\
\text { inc } \\
10 \\
\end{array}$ \\
\hline $\mathrm{SiO} 2$ & 49.17 & 37.55 & 0.05 & 39.04 & 39.31 & 38.30 & 28.89 & 37.51 & 62.67 & 28.49 \\
\hline $\mathrm{A} 12 \mathrm{O} 3$ & 7.15 & 0.03 & 54.24 & 15.04 & 14.74 & 14.78 & 15.93 & 0.70 & 25.48 & 14.86 \\
\hline $\mathrm{TiO} 2$ & 1.44 & 0.03 & 0.97 & 6.42 & 7.08 & 6.10 & 9.80 & 3.08 & 1.01 & 9.88 \\
\hline $\mathrm{Fe} 2 \mathrm{O} 3$ & 2.03 & & 5.76 & & & & & & & \\
\hline $\mathrm{FeO}$ & 4.99 & 24.10 & 21.28 & 10.29 & 8.94 & 10.95 & 16.89 & 17.06 & 1.12 & 17.18 \\
\hline $\mathrm{MnO}$ & 0.17 & 0.29 & 0.19 & 0.10 & 0.08 & 0.07 & 0.11 & 0.37 & 0.04 & 0.22 \\
\hline $\mathrm{MgO}$ & 12.89 & 36.79 & 13.05 & 12.24 & 12.51 & 12.25 & 15.29 & 40.09 & 1.63 & 16.17 \\
\hline $\mathrm{CaO}$ & 20.69 & 0.28 & 0.02 & 11.30 & 11.54 & 11.10 & 10.81 & 0.23 & 0.54 & 10.03 \\
\hline $\mathrm{Na} 2 \mathrm{O}$ & 1.17 & 0.00 & 0.00 & 3.16 & 2.90 & 2.83 & 2.23 & 0.01 & 1.99 & 2.53 \\
\hline $\mathrm{K} 2 \mathrm{O}$ & 0.00 & 0.00 & 0.00 & 1.14 & 1.06 & 1.08 & 0.02 & 0.13 & 5.48 & 0.01 \\
\hline $\mathrm{Cr} 2 \mathrm{O} 3$ & & & 4.38 & 0.24 & 0.24 & 0.20 & 0.34 & & & 0.58 \\
\hline TOTAL & 99.70 & 99.07 & 99.94 & 98.97 & 98.40 & 97.65 & 100.30 & 99.18 & 99.96 & 99.95 \\
\hline $\mathrm{Si}$ & 1.820 & 1.000 & 0.000 & 5.700 & 5.720 & 5.682 & 3.800 & 0.960 & 2.890 & 3.781 \\
\hline $\mathrm{Al}$ & 0.310 & 0.000 & 1.740 & 2.590 & 2.530 & 2.584 & 2.470 & 0.020 & 1.390 & 2.325 \\
\hline $\mathrm{Ti}$ & 0.040 & 0.000 & 0.030 & 0.710 & 0.780 & 0.680 & 0.980 & 0.060 & 0.030 & 0.986 \\
\hline FeIII & 0.060 & & 0.120 & & & & & & & \\
\hline FeII & 0.150 & 0.540 & 0.480 & 1.260 & 1.090 & 1.359 & 1.870 & 0.370 & 0.040 & 1.906 \\
\hline $\mathrm{Mn}$ & 0.010 & 0.010 & 0.000 & 0.010 & 0.010 & 0.009 & 0.004 & 0.010 & 0.000 & 0.025 \\
\hline $\mathrm{Mg}$ & 0.710 & 1.460 & 0.540 & 2.670 & 2.720 & 2.709 & 3.000 & 1.540 & 0.120 & 3.198 \\
\hline $\mathrm{Ca}$ & 0.820 & 0.010 & 0.000 & 1.770 & 1.800 & 1.765 & 1.530 & 0.060 & 0.030 & 1.426 \\
\hline $\mathrm{Na}$ & 0.080 & 0.000 & 0.000 & 0.890 & 0.820 & 0.815 & 0.570 & 0.000 & 0.180 & 0.662 \\
\hline K & 0.000 & 0.000 & 0.000 & 0.210 & 0.200 & 0.203 & 0.001 & 0.040 & 0.320 & 0.002 \\
\hline $\mathrm{Cr}$ & & & 0.090 & 0.030 & 0.030 & 0.023 & 0.011 & & & 0.062 \\
\hline TOTAL & 4.000 & 3.020 & 3.000 & 15.840 & 15.700 & 15.829 & 14.236 & 3.060 & 5.000 & 14.373 \\
\hline
\end{tabular}

PLATE 4.13 (opposite): Kaersutite replacement of clinopyroxene in a Type P xenolith (sample $90033 \mathrm{C})$. a) The boundary between kaersutite and clinopyroxene (boxed area) is comprised of intermediate minerals that are replaced by kaersutite, as it advances. The intermediate phases are generally consumed by this replacement, although some may survive as inclusions in the kaersutite. b) Magnification of boxed area, showing the intermediate minerals rhönite, olivine and K-feldspar, at the boundary between clinopyroxene and kaersutite. Analyses of sites 1-10 are presented as Table 4.11. See text for further explanation. Scale bar is $100 \mu \mathrm{m}$. 


\section{Sample 90033J: Type C xenolith (Plate 4.14; Table 4.12)}

This sample is dominated by olivine (1), and clinopyroxene (2) that is being replaced by kaersutite (3). Rhönite (4) and andesine (5) are the only intermediate mineral phases involved in this reaction. Unlike the previous example (90033C), replacement is an incomplete reaction, with kaersutite growth not yet crystalline. Furthermore, the intermediate phases do not appear on the boundary of the reaction but mixed in with both the host clinopyroxene and replacing kaersutite.

TABLE 4.12: Electron microprobe analyses of kaersutitisation reactions in a Type $C$ pyroxenite (sample 90033J). See Plate 4.14 for analyses sites.

\begin{tabular}{|c|c|c|c|c|c|c|c|c|c|c|}
\hline $\begin{array}{l}\text { PHASE } \\
\text { SITE }\end{array}$ & $\begin{array}{c}\text { Olivine } \\
\text { core } \\
\mathbf{1}\end{array}$ & $\begin{array}{c}\text { Cpx } \\
\text { core } \\
2 \\
\end{array}$ & $\begin{array}{c}\text { Kaer } \\
\text { kaerst. } \\
3 \\
\end{array}$ & $\begin{array}{c}\text { Rhönite } \\
\text { kaerst. } \\
4\end{array}$ & $\begin{array}{c}\text { Plag } \\
\text { kaerst. } \\
5 \\
\end{array}$ & $\begin{array}{c}\text { Olivine } \\
\text { core } \\
6 \\
\end{array}$ & $\begin{array}{c}\text { Cpx } \\
\text { core } \\
7 \\
\end{array}$ & $\begin{array}{c}\text { Kaer } \\
\text { kaerst. } \\
8 \\
\end{array}$ & $\begin{array}{c}\text { Rhönite } \\
\text { kaerst. } \\
9\end{array}$ & $\begin{array}{c}\text { Plag } \\
\text { kaerst. } \\
10 \\
\end{array}$ \\
\hline $\mathrm{SiO} 2$ & 38.20 & 48.76 & 37.13 & 25.87 & 57.62 & 38.80 & 45.30 & 38.94 & 24.84 & 54.49 \\
\hline $\mathrm{A} 12 \mathrm{O} 3$ & 0.04 & 8.14 & 14.40 & 15.99 & 26.08 & 0.00 & 7.79 & 14.70 & 15.97 & 26.57 \\
\hline $\mathrm{TiO} 2$ & 0.01 & 1.70 & 5.98 & 10.13 & 0.28 & 0.04 & 3.87 & 5.66 & 9.83 & 0.76 \\
\hline $\mathrm{Fe} 2 \mathrm{O} 3$ & & 0.09 & & & & & 2.77 & & & \\
\hline $\mathrm{FeO}$ & 27.01 & 6.55 & 13.54 & 21.06 & 0.77 & 18.21 & 4.64 & 12.18 & 22.97 & 1.07 \\
\hline $\mathrm{MnO}$ & 0.44 & 0.14 & 0.15 & 0.19 & 0.00 & 0.44 & 0.12 & 0.15 & 0.07 & 0.00 \\
\hline $\mathrm{MgO}$ & 34.46 & 12.17 & 12.44 & 13.80 & 0.01 & 41.64 & 12.41 & 12.52 & 13.33 & 0.84 \\
\hline $\mathrm{CaO}$ & 0.23 & 21.89 & 11.15 & 10.91 & 7.90 & 0.24 & 22.29 & 11.23 & 10.54 & 10.17 \\
\hline $\mathrm{Na} 2 \mathrm{O}$ & 0.00 & 0.73 & 3.04 & 1.73 & 5.76 & 0.03 & 0.87 & 3.04 & 1.68 & 5.53 \\
\hline $\mathrm{K} 2 \mathrm{O}$ & 0.00 & 0.00 & 0.73 & 0.01 & 1.37 & 0.00 & 0.01 & 0.75 & 0.02 & 0.57 \\
\hline TOTAL & 100.39 & 100.17 & 98.56 & 99.68 & 99.78 & 99.40 & 100.07 & 99.17 & 99.25 & 100.00 \\
\hline $\mathrm{Si}$ & 1.010 & 1.790 & 5.400 & 3.500 & 2.599 & 1.000 & 1.690 & 5.580 & 3.417 & 2.480 \\
\hline $\mathrm{Al}$ & 0.000 & 0.350 & 2.470 & 2.550 & 1.386 & 0.000 & 0.340 & 2.480 & 2.590 & 1.420 \\
\hline $\mathrm{Ti}$ & 0.000 & 0.050 & 0.650 & 1.050 & 0.009 & 0.000 & 0.110 & 0.610 & 1.017 & 0.030 \\
\hline FeIII & & 0.030 & & & & & 0.130 & & & \\
\hline FeII & 0.600 & 0.200 & 1.480 & 2.400 & 0.029 & 0.390 & 0.090 & 1.310 & 2.642 & 0.040 \\
\hline $\mathrm{Mn}$ & 0.010 & 0.000 & 0.020 & 0.004 & 0.000 & 0.010 & 0.000 & 0.020 & 0.008 & 0.000 \\
\hline $\mathrm{Mg}$ & 1.360 & 0.670 & 2.700 & 2.800 & 0.000 & 1.600 & 0.690 & 2.670 & 2.733 & 0.060 \\
\hline $\mathrm{Ca}$ & 0.010 & 0.860 & 1.740 & 1.600 & 0.382 & 0.010 & 0.890 & 1.720 & 1.554 & 0.500 \\
\hline $\mathrm{Na}$ & 0.000 & 0.050 & 0.860 & 0.450 & 0.503 & 0.000 & 0.060 & 0.850 & 0.448 & 0.490 \\
\hline K & 0.000 & 0.000 & 0.140 & 0.000 & 0.079 & 0.000 & 0.000 & 0.140 & 0.004 & 0.030 \\
\hline$\overline{\mathrm{TOT}}$ & 2.990 & 4.000 & 15.460 & 14.354 & 4.987 & 3.010 & 4.000 & 15.380 & 14.413 & 5.050 \\
\hline
\end{tabular}

The same reaction is observed throughout the sample (analyses $1 \mathrm{~b}-5 \mathrm{~b}$; no photo) and in other samples. While the reaction style and intermediate phases of incomplete replacement are different from reactions with crystalline replacement 
(Plate 4.13), the compositional change of the xenolith is the same, with increases in $\mathrm{Fe}, \mathrm{Ti}, \mathrm{Na}, \mathrm{K}$ and $\mathrm{H}_{2} \mathrm{O}$.

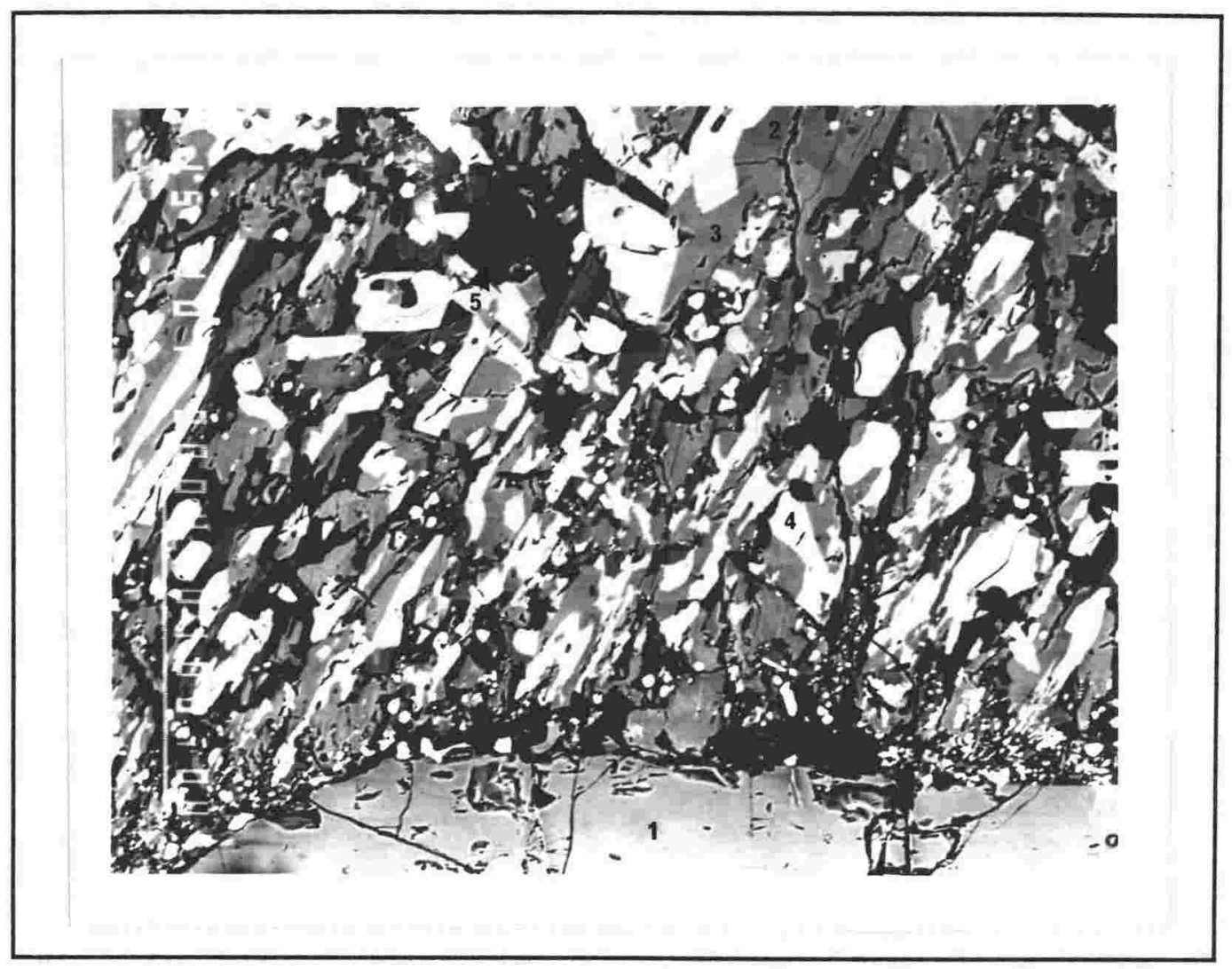

PLATE 4.14: Kaersutite replacement of clinopyroxene in a Type C pyroxenite (sample 90033J) where replacement is incomplete with the formation of intermediate minerals with kaersutite and clinopyroxene in the reaction area. Analyses of sites 1-10 are presented as Table 4.12. See text for further explanation. Scale bar is $100 \mu \mathrm{m}$.

\section{Discussion of kaersutitisation reactions}

In view of these reactions, and the association of the single chain silicate rhönite with kaersutitisation, it is appropriate to now consider the mineral chemistry of these secondary minerals and to investigate the agent of this process. Representative kaersutite analyses are presented as Table 4.13.

Kaersutite compositions (in the system $\mathrm{Ca}-\mathrm{Mg}-\mathrm{Fe}$ ) generally take their forms from the replaced clinopyroxene; kaersutites from Type L xenoliths are $\mathrm{Fe}-$ rich, while those from Type $\mathrm{P}$ xenoliths are Fe-poor (Figure 4.12). In other elements, such as $\mathrm{Al}$ and $\mathrm{Ti}$ (Figure 4.13), there is little difference between kaersutites from different xenolith types. Xenolith kaersutites differ in composition from those of crustal and mantle origin (as defined by Vinx and Jung, 1977), but show a striking resemblance to Foster Crater Group II xenolith kaersutites (Gamble et al., 1988). A plot of Al v Ti (Figure 4.13) emphasises this similarity, and the difference between these and crustal and mantle kaersutites. 
This field may represent a lower crustal kaersutite field with Foster Crater High Calcium Pyroxenite Suite (FC HCPS) pargasites being a lower Ti extension of this lower crustal field.

TABLE 4.13: Representative electron microprobe analyses of kaersutite from Mount Sidley xenoliths.

\begin{tabular}{lcccccccc}
\hline SAMPLE & $90033 \mathrm{~S}$ & $90033 \mathrm{~S}$ & $90033 \mathrm{P}$ & $90033 \mathrm{P}$ & \multicolumn{5}{c}{$90033 \mathrm{C}$} & \multicolumn{5}{c}{$90033 \mathrm{H}$} & 90033 Q1 & $90033 \mathrm{~S} 1$ \\
$\mathrm{TYPE}$ & $\mathrm{L}$ & $\mathrm{L}$ & $\mathrm{C}$ & $\mathrm{C}$ & $\mathbf{P}$ & $\mathbf{P}$ & $\mathbf{P}$ & $\mathbf{P}$ \\
\hline & & & & & & & & \\
$\mathrm{SiO} 2$ & 37.39 & 38.36 & 41.00 & 39.94 & 39.31 & 38.71 & 38.29 & 39.76 \\
$\mathrm{~A} 12 \mathrm{O} 3$ & 14.90 & 14.58 & 13.53 & 13.35 & 14.74 & 14.39 & 13.83 & 14.71 \\
$\mathrm{TiO} 2$ & 6.49 & 6.46 & 4.35 & 4.39 & 7.08 & 7.08 & 8.09 & 6.10 \\
$\mathrm{FeO}$ & 12.71 & 9.96 & 14.54 & 13.94 & 8.94 & 9.12 & 10.09 & 9.78 \\
$\mathrm{MnO}$ & 0.07 & 0.09 & 0.18 & 0.24 & 0.08 & 0.12 & 0.08 & 0.13 \\
$\mathrm{MgO}$ & 12.03 & 12.32 & 10.84 & 11.09 & 12.51 & 13.20 & 12.57 & 13.44 \\
$\mathrm{CaO}$ & 12.41 & 12.67 & 10.64 & 11.30 & 11.54 & 12.02 & 12.20 & 10.77 \\
$\mathrm{Na} 2 \mathrm{O}$ & 2.64 & 2.80 & 3.07 & 2.88 & 2.90 & 2.95 & 2.84 & 2.87 \\
$\mathrm{~K} 2 \mathrm{O}$ & 0.62 & 0.69 & 0.81 & 0.81 & 1.06 & 0.60 & 0.83 & 0.81 \\
$\mathrm{Cr} 2 \mathrm{O} 3$ & 0.01 & 0.07 & 0.00 & 0.01 & 0.24 & 0.62 & 0.05 & 0.19 \\
& & & & & & & & \\
\hline TOTAL & 99.27 & 98.00 & 98.94 & 97.94 & 98.41 & 98.81 & 98.86 & 98.55 \\
\hline
\end{tabular}

cations on the basis of 23 oxygens

\begin{tabular}{lllllllll}
$\mathrm{Si}$ & 5.393 & 5.662 & 6.052 & 5.969 & 5.723 & 5.638 & 5.616 & 5.784 \\
$\mathrm{Al}$ & 2.532 & 2.537 & 2.354 & 2.351 & 2.534 & 2.469 & 2.392 & 2.522 \\
$\mathrm{Ti}$ & 0.704 & 0.717 & 0.482 & 0.494 & 0.776 & 0.776 & 0.892 & 0.667 \\
$\mathrm{Fe}$ & 1.379 & 1.230 & 1.795 & 1.742 & 1.090 & 1.111 & 1.238 & 1.189 \\
$\mathrm{Mn}$ & 0.008 & 0.011 & 0.022 & 0.030 & 0.009 & 0.015 & 0.010 & 0.016 \\
$\mathrm{Mg}$ & 2.586 & 2.712 & 2.385 & 2.471 & 2.719 & 2.866 & 2.748 & 2.914 \\
$\mathrm{Ca}$ & 1.917 & 2.004 & 1.683 & 1.810 & 1.803 & 1.876 & 1.918 & 1.679 \\
$\mathrm{Na}$ & 0.739 & 0.800 & 0.880 & 0.835 & 0.821 & 0.832 & 0.808 & 0.811 \\
$\mathrm{~K}$ & 0.115 & 0.131 & 0.152 & 0.154 & 0.198 & 0.111 & 0.155 & 0.150 \\
$\mathrm{Cr}$ & 0.001 & 0.008 & 0.000 & 0.001 & 0.028 & 0.071 & 0.003 & 0.022 \\
& & & & & & & & \\
\hline TOTAL & 15.374 & 15.812 & 15.805 & $\mathbf{1 5 . 8 5 7}$ & $\mathbf{1 5 . 7 0 1}$ & $\mathbf{1 5 . 7 6 5}$ & $\mathbf{1 5 . 7 8 0}$ & $\mathbf{1 5 . 7 5 4}$ \\
\hline & & & & & & & & \\
$\mathrm{Mg \#}$ & 65.22 & 68.80 & 57.06 & 58.65 & 71.38 & 72.06 & 68.94 & 71.02 \\
& & & & & & & & \\
\hline
\end{tabular}

Rhönite microphenocrysts ( $<100 \mu \mathrm{m}$ in length) occur in association with kaersutite replacement (Plates $4.13,4.14$ ), as well as crystallising directly from 
infiltrating host lavas (Plate 4.10). They are also present as inclusions in clinopyroxene crystals, that are sometimes associated with infiltrating melts.

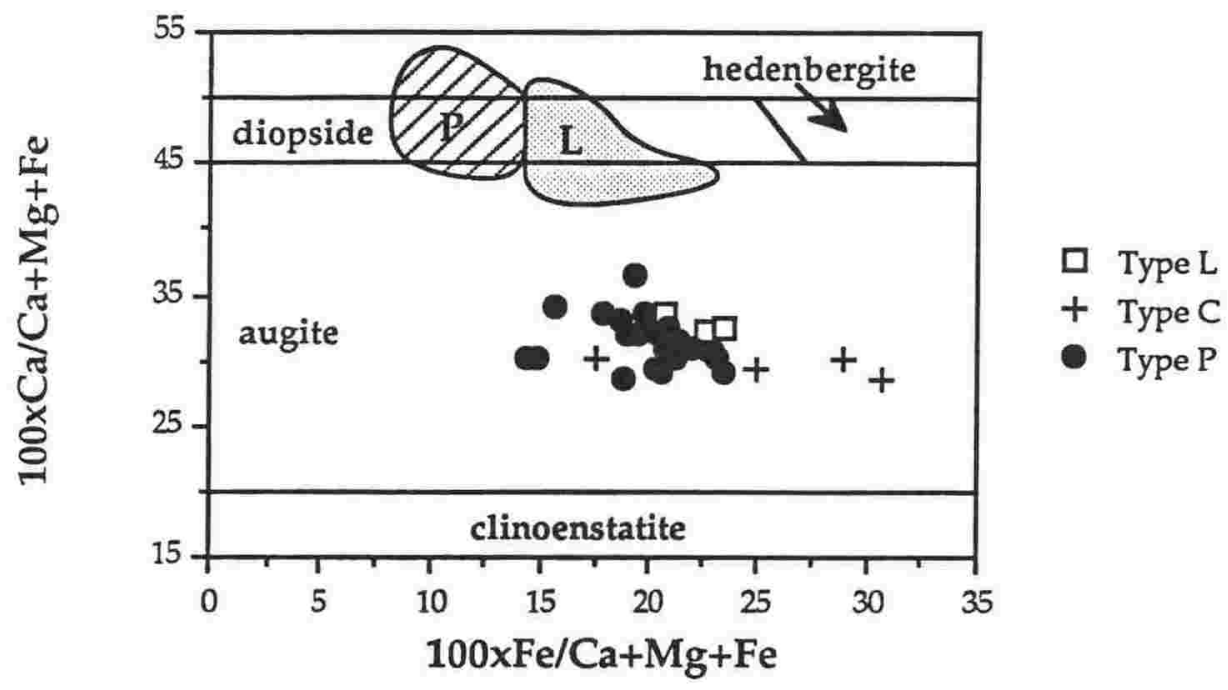

FIGURE 4.12: Composition of kaersutites from Mount Sidley xenoliths in the system $\mathrm{Ca}-\mathrm{Mg}$-Fe, with Type $\mathrm{L}$ and $\mathrm{P}$ xenolith clinopyroxene fields for comparison. Kaersutite inherits its composition from the original clinopyroxene e.g. Type L kaersutites and clinopyroxenes are high in Fe compared with those from Type P xenoliths. Clinopyroxene classification fields are from Morimoto et al. (1988).

Representative analyses of rhönite occurring in the Mount Sidley xenolith suite are presented as Table 4.14. Analyses fall within the ranges of previously published rhönite analyses (Deer et al., 1972; Gamble et al., 1988).

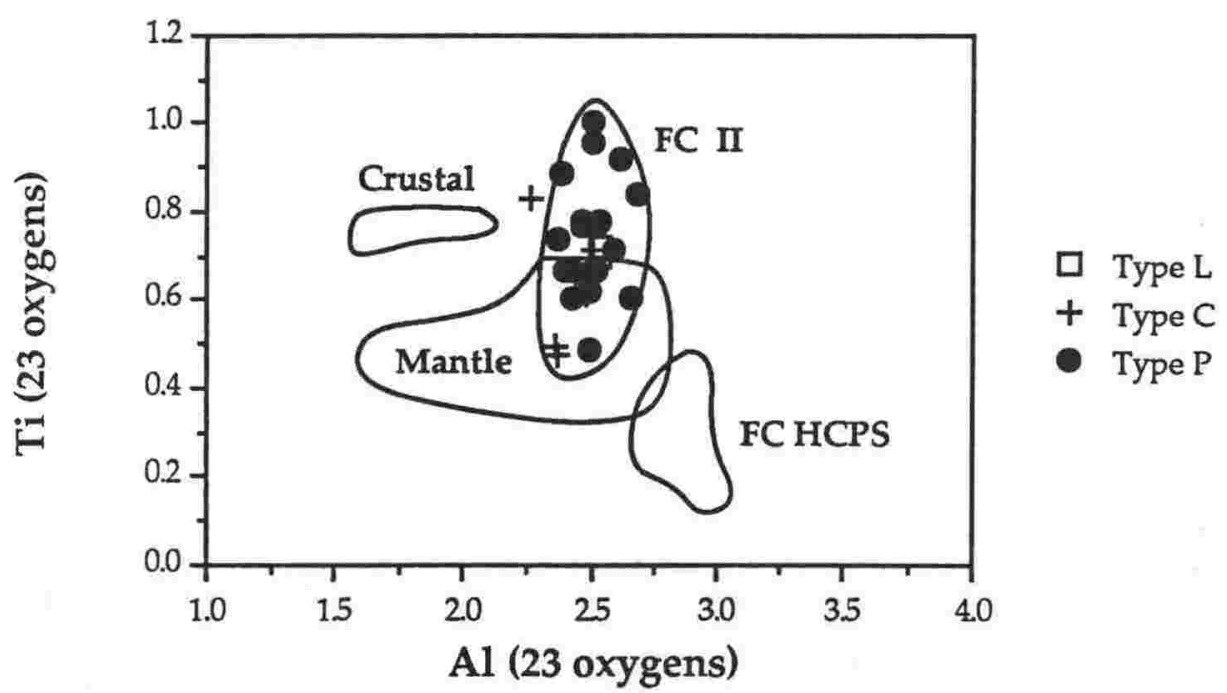

FIGURE 4.13: $\mathrm{Al} v \mathrm{Ti}$ composition (based on 23 oxygens) of kaersutites from Mount Sidley xenoliths, compared with those from Foster Crater (Gamble et al. (1988), and crustal and mantle fields (Vinx and Jung, 1977). Mount Sidley kaersutites fall within the field of Foster Crater Group II (FC II) xenolith kaersutites. This field may represent a lower crustal kaersutite field with Foster Crater High Calcium Pyroxene Suite (FC HCPS) pargasites being an extension of the field. 
TABLE 4.14: Representative electron microprobe analyses of rhönites from Mount Sidley xenoliths.

\begin{tabular}{lccccccccccc}
\hline SAMPLE & $90033 \mathrm{~A}$ & $90033 \mathrm{Q} 190033 \mathrm{Q} 1$ & $90033 \mathrm{R}$ & $90033 \mathrm{~A}$ & $90033 \mathrm{G}$ & $90033 \mathrm{~S} 1$ & $90033 \mathrm{~J}$ & \multicolumn{2}{c}{$90033 \mathrm{C}$} & $90033 \mathrm{C}$ \\
& melt & melt & melt & melt & inc & inc & kaerst. & kaerst. & kaerst. & kaerst. \\
\hline & & & & & & & & & & \\
$\mathrm{SiO} 2$ & 23.73 & 24.02 & 24.41 & 23.62 & 26.34 & 23.96 & 25.46 & 24.84 & 28.89 & 28.49 \\
$\mathrm{A12O} 3$ & 17.62 & 18.73 & 18.22 & 18.76 & 16.93 & 17.87 & 16.70 & 15.97 & 15.93 & 14.86 \\
$\mathrm{TiO} 2$ & 11.26 & 12.13 & 12.41 & 12.90 & 11.14 & 11.08 & 12.56 & 9.83 & 9.80 & 9.88 \\
$\mathrm{FeO}$ & 20.08 & 17.84 & 17.62 & 18.26 & 18.10 & 21.69 & 17.01 & 22.97 & 16.89 & 17.18 \\
$\mathrm{MnO}$ & 0.14 & 0.07 & 0.08 & 0.03 & 0.11 & 0.00 & 0.10 & 0.07 & 0.11 & 0.22 \\
$\mathrm{MgO}$ & 13.00 & 13.51 & 13.68 & 13.45 & 14.33 & 12.17 & 14.24 & 13.33 & 15.29 & 16.17 \\
$\mathrm{CaO}$ & 12.00 & 11.97 & 12.04 & 11.73 & 12.37 & 11.64 & 11.32 & 10.54 & 10.81 & 10.03 \\
$\mathrm{Na2O}$ & 0.89 & 0.99 & 1.05 & 1.02 & 0.76 & 0.93 & 1.43 & 1.68 & 2.23 & 2.53 \\
$\mathrm{~K} 2 \mathrm{O}$ & 0.01 & 0.01 & 0.00 & 0.00 & 0.00 & 0.00 & 0.01 & 0.02 & 0.02 & 0.01 \\
$\mathrm{Cr} 2 \mathrm{O} 3$ & 0.27 & 0.32 & 0.29 & 0.01 & 0.07 & 0.11 & 0.16 & 0.53 & 0.34 & 0.58 \\
& & & & & & & & & & \\
\hline TOTAL & 99.00 & 99.59 & 99.80 & 99.78 & $\mathbf{1 0 0 . 1 5}$ & 99.45 & 98.99 & 99.78 & 100.30 & 99.95 \\
\hline
\end{tabular}

cations on the basis of 20 oxygens

\begin{tabular}{lllllllllll} 
& & & & & & \\
$\mathrm{Si}$ & 3.253 & 3.231 & 3.270 & 3.170 & 3.511 & 3.283 & 3.420 & 3.417 & 3.803 & 3.781 \\
$\mathrm{Al}$ & 2.848 & 2.971 & 2.880 & 2.970 & 2.661 & 2.888 & 2.650 & 2.590 & 2.470 & 2.325 \\
$\mathrm{Ti}$ & 1.161 & 1.221 & 1.250 & 1.300 & 1.117 & 1.140 & 1.270 & 1.017 & 0.970 & 0.986 \\
$\mathrm{Fe}$ & 2.302 & 2.007 & 1.970 & 2.050 & 2.018 & 2.486 & 1.910 & 2.642 & 1.860 & 1.906 \\
$\mathrm{Mn}$ & 0.016 & 0.008 & 0.010 & 0.000 & 0.012 & 0.000 & 0.010 & 0.008 & 0.013 & 0.025 \\
$\mathrm{Mg}$ & 2.657 & 2.709 & 2.730 & 2.690 & 2.847 & 2.486 & 2.860 & 2.733 & 3.000 & 3.198 \\
$\mathrm{Ca}$ & 1.764 & 1.726 & 1.730 & 1.690 & 1.768 & 1.710 & 1.630 & 1.554 & 1.523 & 1.426 \\
$\mathrm{Na}$ & 0.237 & 0.258 & 0.270 & 0.270 & 0.196 & 0.247 & 0.370 & 0.448 & 0.580 & 0.662 \\
$\mathrm{~K}$ & 0.002 & 0.002 & 0.000 & 0.000 & 0.000 & 0.000 & 0.000 & 0.004 & 0.003 & 0.002 \\
$\mathrm{Cr}$ & 0.029 & 0.034 & 0.030 & 0.020 & 0.007 & 0.012 & 0.020 & 0.058 & 0.036 & 0.062 \\
& & & & & & & & & & \\
\hline TOTAL & $\mathbf{1 4 . 2 6 9}$ & $\mathbf{1 4 . 1 6 7}$ & $\mathbf{1 4 . 1 4 0}$ & $\mathbf{1 4 . 1 6 0}$ & $\mathbf{1 4 . 1 3 7}$ & $\mathbf{1 4 . 2 5 2}$ & $\mathbf{1 4 . 1 4 0}$ & $\mathbf{1 4 . 4 7 1}$ & $\mathbf{1 4 . 2 5 8}$ & $\mathbf{1 4 . 3 7 3}$ \\
\hline & & & & & & & & & & \\
Mg\# & 53.58 & 57.44 & 58.09 & 56.75 & 58.52 & 50.00 & 59.96 & 50.85 & 61.73 & 62.66
\end{tabular}

Compositions of rhönites (Figures 4.14, 4.15) formed by crystallisation directly from the host lavas differ to those formed in association with kaersutite replacement of clinopyroxene. Melt derived rhönite is high in $\mathrm{Ca}+\mathrm{Al}$, and low in $\mathrm{Na}+\mathrm{Si}$, whereas the converse is true for kaersutite-associated rhönites (Figure 4.15). This difference highlights the coupled substitution $\mathrm{Ca}^{2+} \mathrm{Al}^{3+} \longleftrightarrow-\mathrm{Na}^{+} \mathrm{Si}^{4+}$ towards an aenigmatite composition. Rhönite inclusions in clinopyroxene that can be linked to an infiltrating melt fall within the melt-associated rhönite range, 


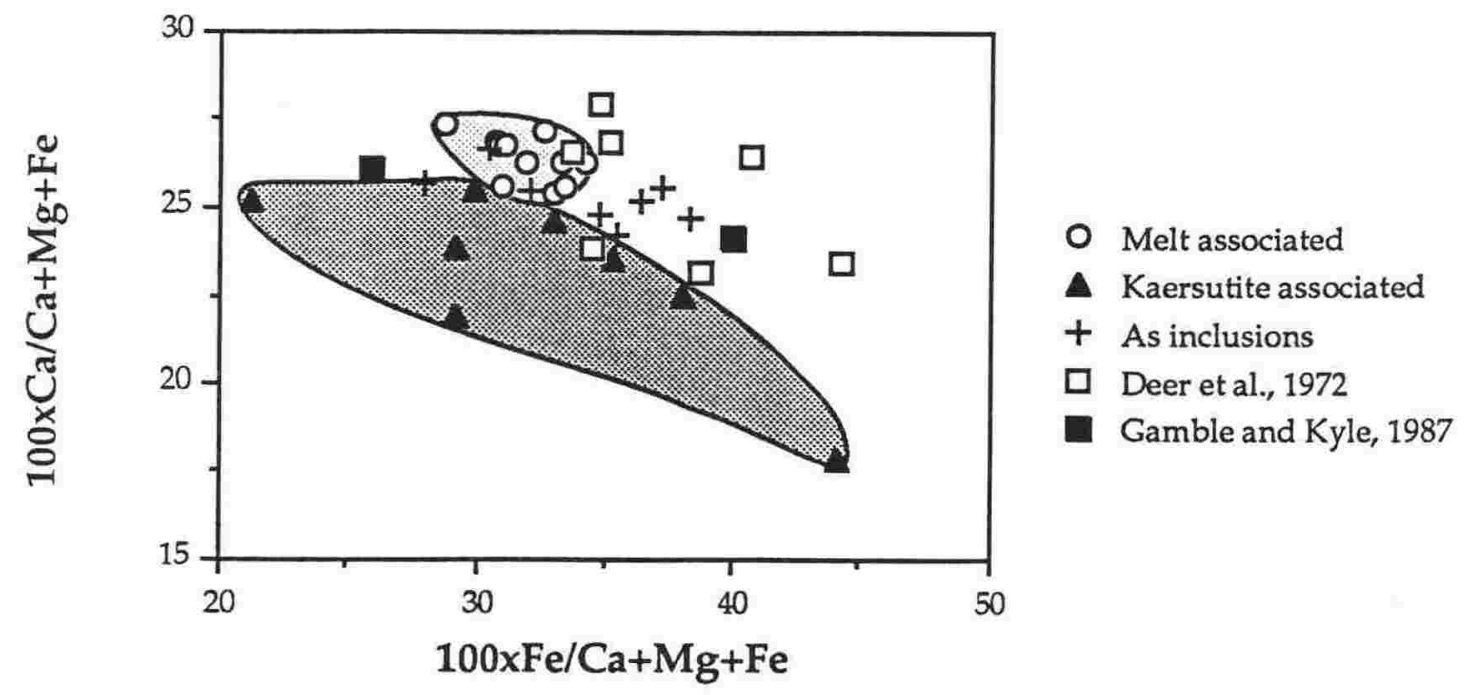

FIGURE 4.14: Composition of rhönites from Mount Sidley xenoliths in the system Ca-Mg-Fe. Rhönite crystallised from host melts differ from those associated with kaersutite replacement of clinopyroxene. Rhönite occurring as inclusions in crystals are intermediate in composition. Previously documented rhönite compositions (Deer et al., 1972; Gamble and Kyle, 1987 (from Foster Crater)) are shown for comparison.

indicating that these rhönite inclusions formed directly from the melt. Other rhönite inclusions are either intermediate to melt- and kaersutite-associated compositions, or fall within the kaersutite-associated field.

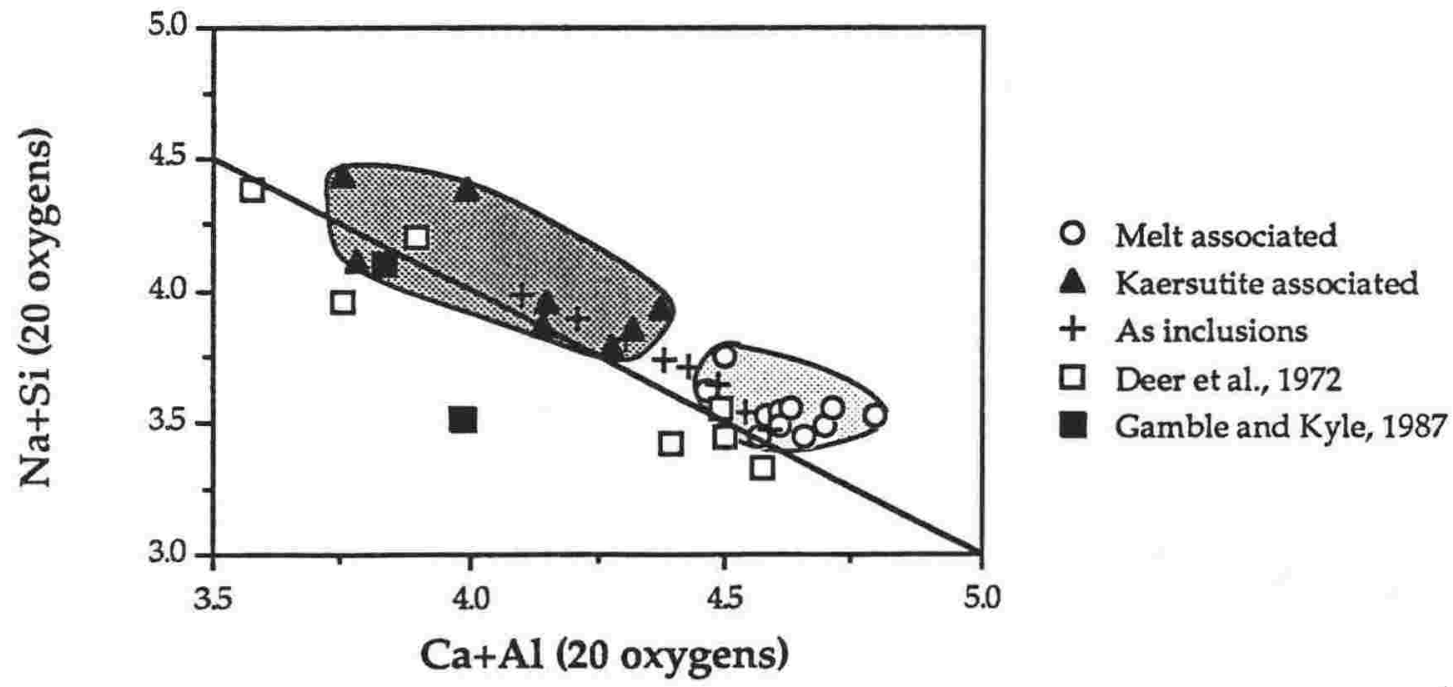

FIGURE 4.15: $\mathrm{Ca}+\mathrm{Al}$ v $\mathrm{Na}+\mathrm{Si}$ composition of rhönites, reflecting the coupled substitution of these elements towards the aenigmatite end-member composition. Melt-associated and kaersutiteassociated rhönites form two end-members, with rhönites occurring as inclusions being variable in composition. Rhönites previously documented (Deer et al., 1972; Gamble and Kyle, 1987 (from Foster Crater)) are shown for comparison. 
A change in rhönite composition with temperature, oxygen fugacity and silica activity has been discounted by Kyle and Price (1975), based on analyses of rhönites from McMurdo Volcanic Group lavas, Antarctica, and Dunedin volcano lavas, New Zealand. While the depth of formation of melt rhönites cannot be established, the depth of formation of kaersutite (and therefore kaersutiteassociated rhönite) is estimated to be lower crustal (Figure 4.13). In view of this, and the probability that melt rhönites formed at near-surface depths, the difference in chemistry between the rhönite groups may be pressure related.

An association between rhönite and aenigmatite seems to be confined to limited solid solution (Cameron et al., 1970; Grünhagen and Seck, 1972). Limited solid solution is evidenced in the Mount Sidley rhönite population, from a rhönite composition to a sodic composition, approaching aenigmatite (Table 4.14).

The reaction resulting in kaersutite replacement of clinopyroxene is not a simple two-mineral reaction, but involves intermediate phases which may include rhönite, olivine, plagioclase and $\mathrm{K}$-feldspar. The source of the elements introduced into the system as a result of this reaction $\left(\mathrm{Fe}, \mathrm{Ti}, \mathrm{Na}, \mathrm{K}, \mathrm{H}_{2} \mathrm{O}\right.$ ) cannot be explained by melting (by decompression or otherwise) of the xenolith assemblage. The small and temporary intermediate assemblage cannot compensate for the chemical change, nor is the primary mineral assemblage capable of producing this change. An agent capable of introducing new components into the system (especially $\mathrm{H}_{2} \mathrm{O}$ into the anhydrous xenoliths) is necessary with the most obvious possibility being the glasses found in association with these reactions. However, glass is rare in association with any of these reactions indicating that the agent responsible may primarily be a solid-solid reaction or a vapour-solid reaction rather than a liquid. Furthermore, the incomplete reaction in many samples indicates that the process was occurring at the time of entrainment.

\subsubsection{Oxidation reactions}

The most extensive and dramatic secondary reaction in the xenolith suite is that involving the oxidation of olivine and associated phases throughout the granulite suite (Plates 4.15 to 4.17 ). In pyroxenite xenoliths, oxidation reactions are rare, and are manifested as veins (Plate 4.18).

A number of mineral reactions characterise this process: the oxidation of olivine into two phases with accompanying oxide growth; the growth of Fe-Ti oxides and apatite typically with euhedral faces; and sieved plagioclase rims with small ( $\mu$ m-scale) oxides, and more Ca-rich plagioclase overgrowths. 
TABLE 4.15: Electron microprobe analyses of oxidation reactions in a Type L granulite (sample 90033O). See Plate 4.15 for analyses sites.

\begin{tabular}{|c|c|c|c|c|c|c|c|c|c|c|}
\hline $\begin{array}{l}\text { PHASE } \\
\text { SITE }\end{array}$ & $\begin{array}{c}\text { Olivine } \\
\text { core } \\
1\end{array}$ & $\begin{array}{c}\text { Olivine } \\
\text { oxid. } \\
2\end{array}$ & $\begin{array}{c}\text { Olivine } \\
\text { oxid. } \\
3\end{array}$ & $\begin{array}{c}\text { Ti-mag } \\
\text { oxid. } \\
4\end{array}$ & $\begin{array}{c}\text { Ilmenite } \\
\text { oxid. } \\
5\end{array}$ & $\begin{array}{c}\text { Plag } \\
\text { core- } \\
6\end{array}$ & $\begin{array}{c}\text { Plag } \\
\text { rim } \\
7\end{array}$ & $\begin{array}{c}\text { Apatite } \\
\text { oxid. } \\
8\end{array}$ & $\begin{array}{c}\text { Glass } \\
\text { oxid. } \\
9\end{array}$ & $\begin{array}{c}\text { Glass } \\
\text { oxid. } \\
10\end{array}$ \\
\hline $\mathrm{SiO} 2$ & 38.67 & 39.20 & 41.69 & 0.11 & 0.10 & 58.87 & 54.62 & 2.69 & 50.63 & 50.18 \\
\hline $\mathrm{Al} 2 \mathrm{O} 3$ & 0.37 & 0.10 & 0.09 & 2.73 & 3.05 & 25.39 & 26.51 & 0.97 & 18.08 & 18.38 \\
\hline $\mathrm{TiO} 2$ & 0.03 & 0.01 & 0.12 & 7.54 & 45.50 & 0.06 & 0.18 & 1.45 & 1.96 & 2.57 \\
\hline $\mathrm{Fe} 2 \mathrm{O} 3$ & & & & 49.45 & 12.95 & & & & & \\
\hline $\mathrm{FeO}$ & 36.32 & 55.55 & 1.89 & 34.46 & 34.21 & 0.25 & 2.46 & 9.13 & 10.39 & 11.05 \\
\hline $\mathrm{MnO}$ & 1.24 & 0.86 & 0.74 & 1.05 & 0.62 & 0.02 & 0.00 & 0.22 & 0.14 & 6.12 \\
\hline $\mathrm{MgO}$ & 23.44 & 3.95 & 55.18 & 1.35 & 3.44 & 0.23 & 0.30 & 3.88 & 3.61 & 0.87 \\
\hline $\mathrm{CaO}$ & 0.28 & 0.06 & 0.17 & 0.08 & 0.05 & 7.65 & 9.71 & 40.85 & 6.88 & 6.23 \\
\hline $\mathrm{Na} 2 \mathrm{O}$ & 0.05 & 0.12 & 0.08 & 0.09 & 0.15 & 6.90 & 5.80 & 2.04 & 3.60 & 4.66 \\
\hline $\mathrm{K} 2 \mathrm{O}$ & 0.18 & 0.10 & 0.02 & 0.03 & 0.02 & 0.48 & 0.34 & 0.25 & 1.28 & 2.76 \\
\hline $\mathrm{Cr}_{2} \mathrm{O}_{3}$ & $0.0 \Omega$ & & & هחم & 03 & & مחمـ & م20. & 0.53 & 7ممـ \\
\hline
\end{tabular}




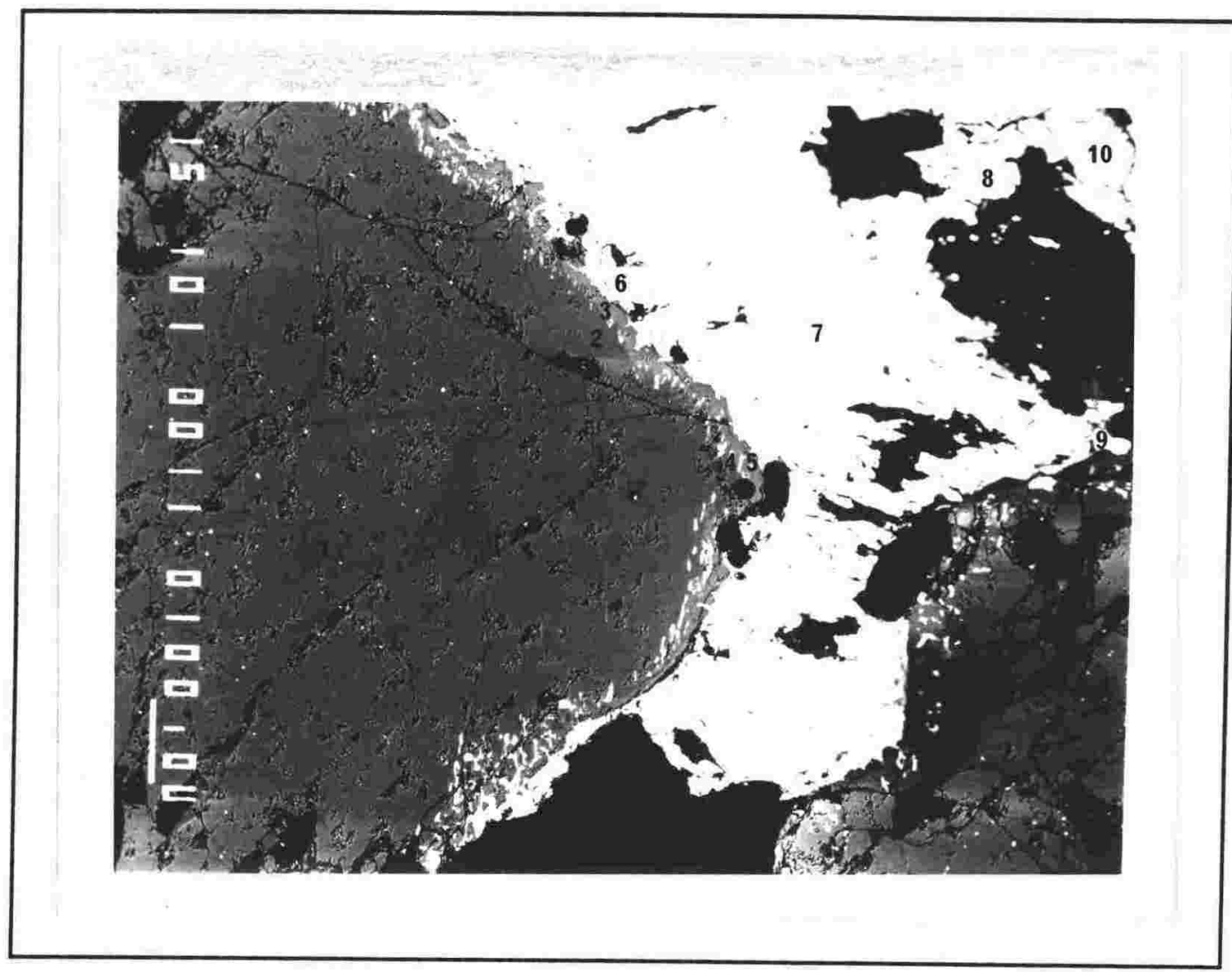

PLATE 4.16: Oxidation reactions in a Type M granulite (sample 90039V) involving the growth of secondary oxides (bright) and severe disequilibrium of plagioclase (dark) rims with small oxide growth. The melt (grey) responsible for these reactions is present between the plagioclase and oxides. Analyses of sites 1-10 are presented as Table 4.16. See text for further explanation. Scale bar is $100 \mu \mathrm{m}$.

Fe-Ti oxides occur in sieved rims, as well as small clinopyroxene crystals (4) and glass $(5,6)$. The glass has crystallised the Fe-Ti oxides (ilmenite (7) and titanomagnetite (8)), and clinopyroxene $(4,9)$ that is Fe-rich compared to primary clinopyroxene (10).

\section{Sample 90033U: Type L xenolith (Plate 4.17; Table 4.17)}

Another form of oxidation reaction occurs as blebs in clinopyroxene (1). In the main form of oxidation previously discussed, clinopyroxene is largely unaffected. Here it is absorbed by a bleb consisting of small clinopyroxene (2), two compositions of olivine $(3,4)$ and orthopyroxene $(5)$. The two phases of olivine are Fe-rich (3; Fo 47) and Fe-poor (4; Fo 91), as in other oxidation reactions. Bleb clinopyroxene is $\mathrm{Fe}$ - and $\mathrm{Ca}$-rich compared to primary clinopyroxene.

The presence of orthopyroxene in this reaction is the only occurrence of orthopyroxene in the xenolith suite. Two-pyroxene geothermometry (Wood and Banno, 1973; Wells, 1977; and Kretz, 1982) on the orthopyroxene and secondary clinopyroxene yields temperatures of $750-800{ }^{\circ} \mathrm{C}$, which are lower than previous 
near-magmatic temperature estimates at lower crustal depths. This reaction may have resulted during ascent to the surface, at lower P-T conditions.

TABLE 4.17: Electron microprobe analyses of oxidation reactions in a Type $M$ granulite (sample 90033U). See Plate 4.17 for analyses sites.

\begin{tabular}{|c|c|c|c|c|c|c|c|c|c|c|}
\hline $\begin{array}{l}\text { PHASE } \\
\text { SITE }\end{array}$ & $\begin{array}{c}\text { Cpx } \\
\text { ccie } \\
1 \\
\end{array}$ & $\begin{array}{c}\text { Cpx } \\
\text { oxid. } \\
2 \\
\end{array}$ & $\begin{array}{c}\text { Olivine } \\
\text { oxid. } \\
3 \\
\end{array}$ & $\begin{array}{c}\text { Olivine } \\
\text { oxid. } \\
4\end{array}$ & $\begin{array}{l}\text { Opx } \\
\text { oxid. } \\
5 \\
\end{array}$ & $\begin{array}{c}\text { Ti-mag } \\
\text { oxid. } \\
6 \\
\end{array}$ & $\begin{array}{c}\text { Ti-mag } \\
\text { oxid. } \\
7 \\
\end{array}$ & $\begin{array}{c}\text { Ilmenite } \\
\text { oxid. } \\
8 \\
\end{array}$ & $\begin{array}{c}\text { Ti-mag } \\
\text { oxid. } \\
9 \\
\end{array}$ & $\begin{array}{c}\text { Plag } \\
\text { core } \\
10 \\
\end{array}$ \\
\hline $\mathrm{SiO} 2$ & 49.95 & 49.22 & 39.17 & 40.74 & 54.55 & 0.57 & 0.14 & 0.07 & 0.13 & 54.21 \\
\hline $\mathrm{A} 12 \mathrm{O} 3$ & 4.43 & 4.78 & 0.28 & 0.02 & 0.36 & 1.31 & 1.33 & 1.26 & 0.68 & 28.54 \\
\hline $\mathrm{TiO} 2$ & 1.22 & 1.32 & 0.06 & 0.09 & 0.12 & 4.32 & 0.31 & 31.29 & 0.24 & 0.00 \\
\hline $\mathrm{Fe} 2 \mathrm{O} 3$ & 2.27 & 3.30 & & & 2.09 & 54.64 & 66.14 & 41.45 & 61.09 & \\
\hline $\mathrm{FeO}$ & 7.68 & 8.02 & 39.59 & 9.15 & 13.42 & 31.29 & 22.89 & 22.27 & 28.58 & 0.19 \\
\hline $\mathrm{MnO}$ & 0.48 & 0.17 & 0.81 & 0.88 & 0.67 & 0.16 & 0.53 & 0.44 & 0.00 & 0.00 \\
\hline $\mathrm{MgO}$ & 11.68 & 11.28 & 19.57 & 48.90 & 28.11 & 1.15 & 4.40 & 3.06 & 0.05 & 0.00 \\
\hline $\mathrm{CaO}$ & 21.64 & 21.87 & 0.44 & 0.19 & 0.88 & 0.89 & 0.25 & 0.04 & 0.03 & 11.69 \\
\hline $\mathrm{Na} 2 \mathrm{O}$ & 0.89 & 0.80 & 0.01 & 0.00 & 0.00 & 0.00 & 0.00 & 0.00 & 0.00 & 5.09 \\
\hline $\mathrm{K} 2 \mathrm{O}$ & 0.00 & 0.00 & 0.06 & 0.01 & 0.00 & 0.00 & 0.01 & 0.03 & 0.00 & 0.29 \\
\hline TOTAL & 100.24 & 100.76 & 99.99 & 99.97 & 100.20 & 94.33 & 96.00 & 99.91 & 90.80 & 100.01 \\
\hline $\mathrm{Si}$ & 1.880 & 1.840 & 1.100 & 1.000 & 1.960 & 0.173 & 0.085 & 0.000 & 0.000 & 2.450 \\
\hline $\mathrm{Al}$ & 0.190 & 0.210 & 0.010 & 0.002 & 0.020 & 0.460 & 0.060 & 0.040 & 0.030 & 1.520 \\
\hline $\mathrm{Ti}$ & 0.030 & 0.040 & 0.000 & 0.004 & 0.000 & 0.097 & 0.009 & 0.580 & 0.000 & 0.000 \\
\hline FeIII & 0.060 & 0.090 & & & 0.060 & 1.230 & 1.911 & 0.780 & 1.950 & \\
\hline FeII & 0.240 & 0.250 & 0.930 & 0.190 & 0.400 & 0.780 & 0.735 & 0.460 & 1.020 & 0.010 \\
\hline $\mathrm{Mn}$ & 0.020 & 0.010 & 0.020 & 0.020 & 0.020 & 0.000 & 0.017 & 0.020 & 0.000 & 0.000 \\
\hline $\mathrm{Mg}$ & 0.650 & 0.630 & 0.820 & 1.780 & 1.510 & 0.051 & 0.252 & 0.120 & 0.000 & 0.000 \\
\hline $\mathrm{Ca}$ & 0.870 & 0.880 & 0.010 & 0.013 & 0.030 & 0.029 & 0.010 & 0.000 & 0.000 & 0.570 \\
\hline $\mathrm{Na}$ & 0.070 & 0.060 & 0.000 & 0.000 & 0.000 & 0.000 & 0.000 & 0.000 & 0.000 & 0.450 \\
\hline K & 0.000 & 0.000 & 0.010 & 0.001 & 0.000 & 0.000 & 0.000 & 0.000 & 0.000 & 0.020 \\
\hline TOTAL & 4.010 & 4.010 & 2.900 & 3.010 & 4.000 & 2.820 & 3.079 & 2.000 & 3.000 & 5.020 \\
\hline
\end{tabular}

Small Fe-Ti oxides $(6,7)$ occur on the rim of the bleb, and to a less extent within. Melt has not been detected in association with this reaction. Elsewhere in the sample (Plate 4.17, top right), the main form of oxidation previously documented occurs, with titanomagnetite (8) and ilmenite (9) growth and disequilibrium of primary plagioclase (10). 


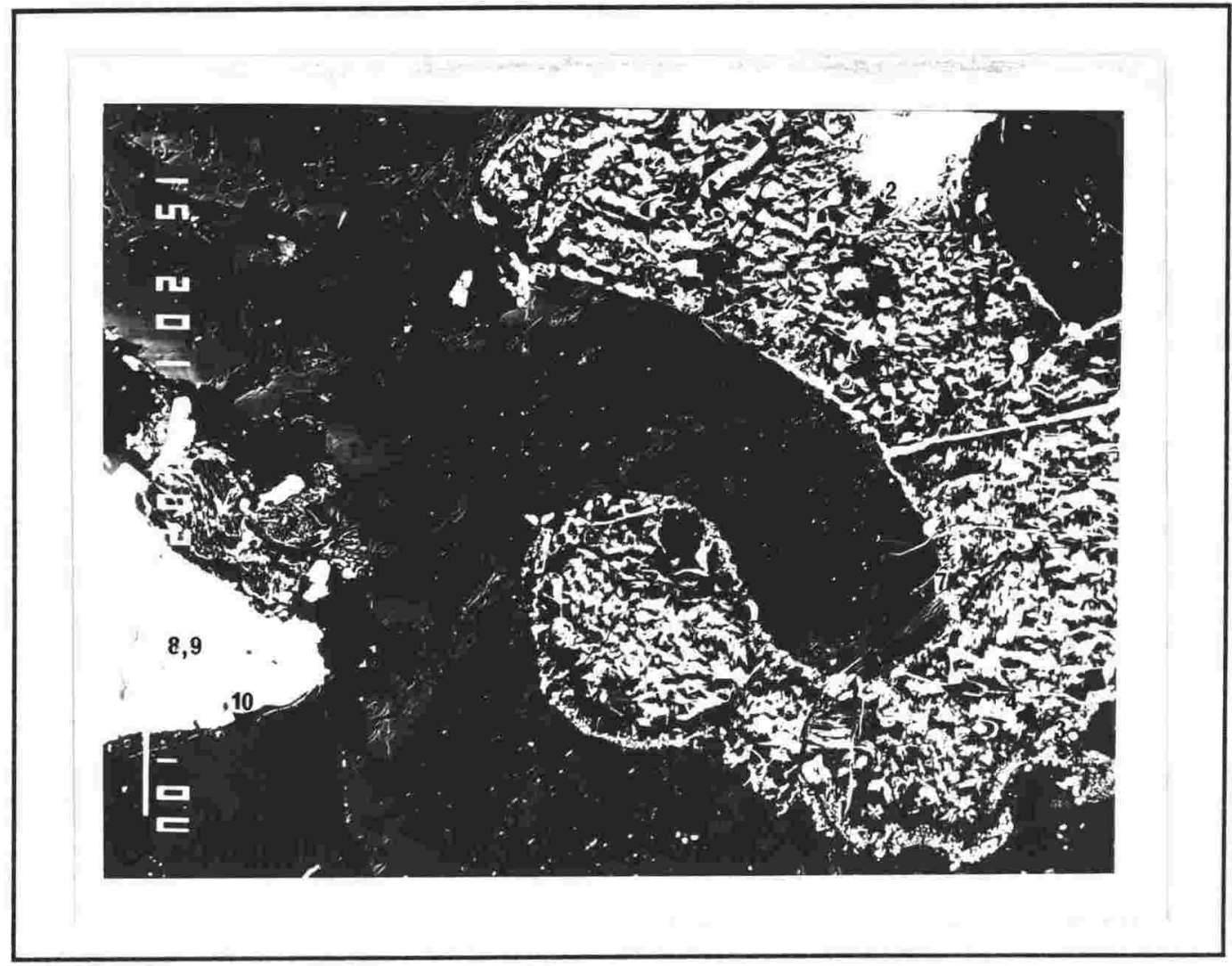

PLATE 4.17: See caption opposite.

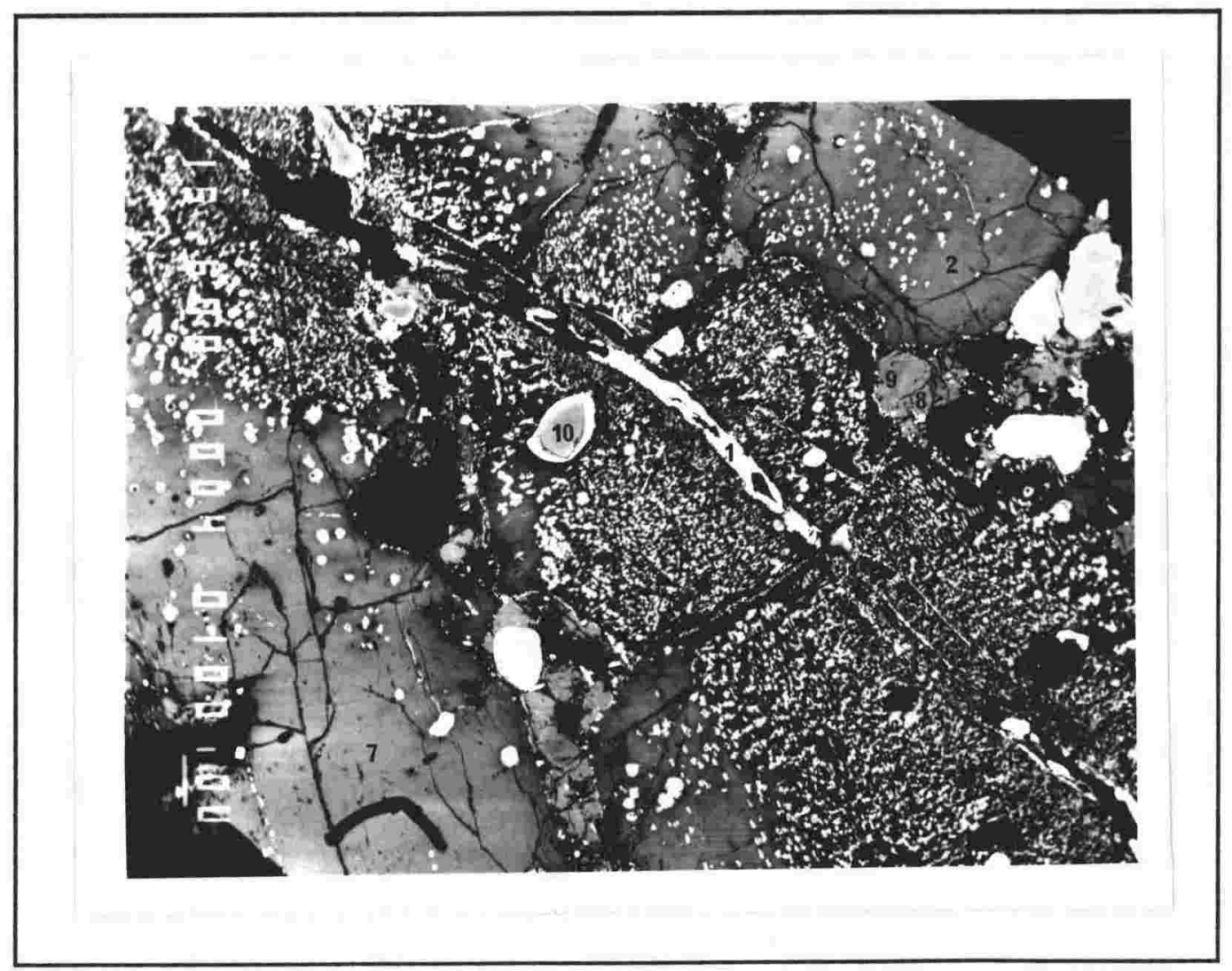

PLATE 4.18: See caption opposite. 
TABLE 4.18: Electron microprobe analyses of oxidation reactions in a Type P pyroxenite (sample 90033F). See Plate 4.18 for analyses sites.

\begin{tabular}{|c|c|c|c|c|c|c|c|c|c|c|}
\hline $\begin{array}{l}\text { PHASE } \\
\text { SITE }\end{array}$ & $\begin{array}{c}\text { Oxide } \\
\text { vein } \\
1 \\
\end{array}$ & $\begin{array}{c}\text { Olivine } \\
\text { core } \\
2 \\
\end{array}$ & $\begin{array}{c}\text { Olivine } \\
\text { oxid. } \\
3\end{array}$ & $\begin{array}{c}\text { Olivine } \\
\text { oxid. } \\
4\end{array}$ & $\begin{array}{c}\text { Olivine } \\
\text { oxid. } \\
5 \\
\end{array}$ & $\begin{array}{c}\text { Olivine } \\
\text { oxid. } \\
6 \\
\end{array}$ & $\begin{array}{c}\text { Cpx } \\
\text { core } \\
7 \\
\end{array}$ & $\begin{array}{c}\text { Cpx } \\
\text { core- } \\
8 \\
\end{array}$ & $\begin{array}{c}\text { Kaer } \\
\text { rim } \\
9 \\
\end{array}$ & $\begin{array}{c}\text { Spinel } \\
\text { core } \\
10 \\
\end{array}$ \\
\hline $\mathrm{SiO} 2$ & 0.12 & 40.72 & 38.77 & 39.18 & 42.26 & 40.63 & 49.97 & 50.75 & 39.84 & 0.09 \\
\hline $\mathrm{Al} 2 \mathrm{O} 3$ & 2.67 & 0.07 & 0.21 & 1.93 & 0.11 & 0.10 & 7.87 & 6.82 & 14.97 & 50.45 \\
\hline TiO2 & 0.70 & 0.01 & 0.16 & 1.47 & 0.07 & 0.09 & 2.11 & 1.64 & 8.81 & 0.44 \\
\hline $\mathrm{Fe} 2 \mathrm{O} 3$ & 74.17 & & & & & & 0.00 & 0.00 & & \\
\hline $\mathrm{FeO}$ & 3.04 & 20.47 & 35.37 & 6.68 & 9.45 & 13.84 & 6.44 & 5.63 & 8.30 & 13.14 \\
\hline $\mathrm{MnO}$ & 0.47 & 0.27 & 0.34 & 0.16 & 0.20 & 0.21 & 0.10 & 0.17 & 0.17 & 0.28 \\
\hline $\mathrm{MgO}$ & 18.64 & 38.33 & 24.86 & 48.85 & 48.16 & 45.57 & 12.90 & 14.23 & 13.36 & 21.69 \\
\hline $\mathrm{CaO}$ & 0.05 & 0.15 & 0.30 & 0.39 & 0.06 & 0.13 & 20.32 & 20.79 & 13.37 & 0.07 \\
\hline $\mathrm{Na} 2 \mathrm{O}$ & 0.00 & 0.00 & 0.00 & 0.00 & 0.00 & 0.00 & 0.93 & 0.00 & 0.00 & 0.00 \\
\hline $\mathrm{K} 2 \mathrm{O}$ & 0.00 & 0.02 & 0.03 & 0.10 & 0.00 & 0.02 & 0.02 & 0.01 & 0.80 & 0.02 \\
\hline $\mathrm{Cr} 2 \mathrm{O} 3$ & 0.03 & & 0.02 & 0.03 & 0.06 & 0.08 & & 0.56 & 0.36 & 10.44 \\
\hline $\mathrm{P} 2 \mathrm{O} 5$ & 0.09 & & 0.14 & 0.92 & 0.00 & 0.04 & & 0.09 & 0.15 & \\
\hline
\end{tabular}

\begin{tabular}{lllllllllll}
\hline TOTAL & 99.98 & 100.03 & 100.18 & 99.69 & 100.37 & 100.69 & 100.66 & 100.69 & 100.12 & 96.63 \\
\hline & & & & & & & & & & \\
$\mathrm{Si}$ & 0.004 & 1.043 & 1.063 & 0.949 & 1.025 & 1.005 & 1.824 & 1.843 & 1.476 & 0.004 \\
$\mathrm{Al}$ & 0.104 & 0.002 & 0.007 & 0.055 & 0.003 & 0.003 & 0.339 & 0.292 & 0.654 & 1.600 \\
$\mathrm{Ti}$ & 0.017 & 0.000 & 0.003 & 0.027 & 0.001 & 0.002 & 0.058 & 0.045 & 0.245 & 0.010 \\
$\mathrm{FeIII}$ & 1.853 & & & & & & 0.000 & 0.000 & & 0.160 \\
$\mathrm{FeII}$ & 0.084 & 0.438 & 0.811 & 0.135 & 0.191 & 0.286 & 0.197 & 0.171 & 0.257 & 0.140 \\
$\mathrm{Mn}$ & 0.013 & 0.006 & 0.008 & 0.003 & 0.004 & 0.000 & 0.003 & 0.005 & 0.005 & 0.000 \\
$\mathrm{Mg}$ & 0.922 & 1.462 & 1.016 & 1.763 & 1.740 & 1.680 & 0.701 & 0.770 & 0.737 & 0.870 \\
$\mathrm{Ca}$ & 0.002 & 0.004 & 0.009 & 0.010 & 0.002 & 0.003 & 0.794 & 0.809 & 0.530 & 0.003 \\
$\mathrm{Na}$ & 0.000 & 0.000 & 0.000 & 0.000 & 0.000 & 0.000 & 0.065 & 0.000 & 0.000 & 0.000 \\
$\mathrm{~K}$ & 0.000 & 0.000 & 0.001 & 0.003 & 0.000 & 0.006 & 0.001 & 0.000 & 0.038 & 0.001 \\
$\mathrm{Cr}$ & 0.000 & & 0.000 & 0.001 & 0.001 & 0.001 & & 0.016 & 0.011 & 0.220 \\
$\mathrm{P}$ & 0.000 & & 0.003 & 0.019 & 0.000 & 0.001 & & 0.003 & 0.005 &
\end{tabular}

\begin{tabular}{lllllllllll}
\hline TOTAL & 2.999 & 2.955 & 2.921 & 2.965 & 2.967 & 2.987 & 3.982 & 3.954 & 3.958 & 3.008 \\
\hline
\end{tabular}

PLATE 4.17 (opposite): Oxidation reactions in a Type L granulite (sample 90033U) occurring as blebs of oxides, two phases of olivine, and pyroxene in host clinopyroxene. Analyses of sites 1-10 are presented as Table 4.17. See text for further explanation. Scale bar is $100 \mu \mathrm{m}$.

PLATE 4.18 (opposite): Oxidising vein in a Type P pyroxenite (sample 90033F) resulting in the breakdown of olivine (mottled appearance) into two phases - Fe-rich (light); and Fe-poor (dark) and the development of Fe-rich rims on spinels. The extent of oxidation diminishes away from the vein (bright line). Oxidised veins are the only style of oxidation to occur in the pyroxenite suite. Clinopyroxene (unmottled) is unaffected by oxidation. Analyses of sites 1-10 are presented as Table 4.18. See text for further explanation. Scale bar is $100 \mu \mathrm{m}$. 


\section{Sample 90033F: Type P xenolith (Plate 4.18; Table 4.18)}

In Type $\mathrm{P}$ xenoliths, oxidation reactions are not pervasive, but occur as veins (Plates 4.9 and 4.18) within the xenolith that can be traced to its edge. As pyroxenite rims are oxidised, the extensive internal oxidation of the granulites is seen as a function of their susceptibility to oxidation, rather than any difference in the process at varying source regions.

Fe-Mg rich veins (1) oxidise adjacent olivine (2) breaking it into two phases; Fe-rich (3) and Fe-poor (4). The products of breakdown become nearer in composition to the original olivine with distance from the vein, where the affects of oxidation are less e.g. the Fe-poor phase becomes more Fe-rich $(5,6)$ and closer to the original olivine in composition (Fo 93, Fo 90, Fo 85).

Clinopyroxene is largely unaffected (7), although on some clinopyroxene crystals (8) kaersutite rims (9) may develop, that are Fe- and $\mathrm{Na-poor}$ and $\mathrm{Mg}$ - and Ca-rich compared to other kaersutite phases present in the xenolith suite. Kaersutite is a common secondary phase elsewhere in the sample.

Spinel (10) is also severely affected by the oxidising agent, developing Ferich rims (e.g. spinels in the oxidised zone in Plate 4.18 have oxide rims and spinels outside the oxidised zone are unaffected).

\section{Discussion of oxidation reactions}

While the style of oxidation reactions varies between and within xenolith suites, the results are much the same. Oxide growth from the oxidation of the xenolith suite is the same in all cases; a mix of titanomagnetite and ilmenite grains and intergrowths with no compositional change in the oxides between different xenolith types (Figure 4.16). Representative secondary oxide analyses are presented as Table 4.19 .

Coexisting spinel phases (ulvöspinel-magnetite) and rhombohedral phases (ilmenite-hematite) can be used to calculate temperatures and oxygen fugacities. These estimates are only meaningful if the minerals are equilibrated and have not suffered subsequent alteration such as subsolidis exsolution, regrowths or retrograde metamorphism. Smooth grain boundaries and a lack of compositional zoning in individual oxide grains from analysed oxides is taken as petrographic evidence for their equilibration and unaltered state. Individual titanomagnetite and ilmenite grains are similar in composition to titanomagnetite-ilmenite intergrowths.

Various methods have been used to model temperatures and oxygen fugacities (e.g. Anderson, 1968; Carmichael, 1967; Lindsley and Spencer, 1982; Stormer, 1983), and the results of this modelling for five oxide pairs are presented 
TABLE 4.19: Representative electron microprobe analyses of all secondary oxides from Mount Sidley xenoliths, with temperature and oxygen fugacity calculations using various methods.

\begin{tabular}{lcccccccccc}
\hline SAMPLE & $90029 X$ & $90029 X$ & $90033 \mathrm{~A}$ & $90033 \mathrm{~A}$ & $90033 \mathrm{G} 190033 \mathrm{G} 1$ & $90033 \mathrm{P} 1$ & $90033 \mathrm{P} 1$ & $90039 \mathrm{~V}$ & $90039 \mathrm{~V}$ \\
$\mathrm{TYPE}$ & $\mathrm{L}$ & $\mathbf{L}$ & $\mathbf{P}$ & $\mathbf{P}$ & $\mathbf{L}$ & $\mathrm{L}$ & $\mathbf{C}$ & $\mathbf{C}$ & $\mathbf{M}$ & $\mathbf{M}$ \\
\hline & & & & & & & & & & \\
$\mathrm{SiO} 2$ & 0.00 & 0.00 & 0.29 & 0.11 & 0.65 & 1.72 & 0.04 & 0.06 & 0.18 & 0.01 \\
$\mathrm{Al2O} 3$ & 3.02 & 1.75 & 1.52 & 0.19 & 2.13 & 8.11 & 0.70 & 1.61 & 5.60 & 0.46 \\
$\mathrm{TiO} 2$ & 8.96 & 50.67 & 12.79 & 46.93 & 14.62 & 40.17 & 18.97 & 48.63 & 18.58 & 51.97 \\
$\mathrm{Fe} 2 \mathrm{O} 3$ & 49.95 & 5.24 & 42.98 & 13.86 & 36.24 & 18.54 & 34.08 & 10.08 & 27.60 & 5.66 \\
$\mathrm{FeO}$ & 33.73 & 36.14 & 38.53 & 34.00 & 39.65 & 20.24 & 40.40 & 33.68 & 45.23 & 37.12 \\
$\mathrm{MnO}$ & 0.52 & 0.35 & 0.26 & 0.41 & 0.49 & 0.41 & 0.40 & 0.18 & 0.58 & 0.66 \\
$\mathrm{MgO}$ & 3.51 & 5.06 & 2.49 & 4.15 & 3.10 & 8.60 & 4.90 & 5.28 & 2.47 & 4.99 \\
$\mathrm{CaO}$ & 0.00 & 0.04 & 0.23 & 0.08 & 0.00 & 1.03 & 0.03 & 0.01 & 0.06 & 0.05 \\
& & & & & & & & & & \\
\hline TOTAL & 99.69 & 99.25 & 99.09 & 99.74 & 96.88 & 98.82 & 99.53 & 99.52 & 100.30 & 100.92 \\
\hline
\end{tabular}

cations on the basis of 3 (spinel) or 2 (rhombehedral) sites

$\begin{array}{lllllllllll}\mathrm{Si} & 0.000 & 0.000 & 0.013 & 0.003 & 0.024 & 0.041 & 0.002 & 0.002 & 0.006 & 0.000 \\ \mathrm{Al} & 0.136 & 0.050 & 0.078 & 0.006 & 0.095 & 0.229 & 0.032 & 0.048 & 0.228 & 0.013 \\ \mathrm{Ti} & 0.246 & 0.926 & 0.354 & 0.866 & 0.414 & 0.685 & 0.517 & 0.882 & 0.504 & 0.942 \\ \mathrm{FeIII} & 1.372 & 0.096 & 1.189 & 0.256 & 1.027 & 0.317 & 0.928 & 0.183 & 0.749 & 0.103 \\ \mathrm{FeII} & 1.030 & 0.734 & 1.184 & 0.698 & 1.249 & 0.384 & 1.223 & 0.679 & 1.364 & 0.748 \\ \mathrm{Mn} & 0.017 & 0.007 & 0.010 & 0.009 & 0.016 & 0.008 & 0.013 & 0.004 & 0.017 & 0.013 \\ \mathrm{Mg} & 0.199 & 0.183 & 0.161 & 0.160 & 0.174 & 0.307 & 0.281 & 0.200 & 0.127 & 0.179 \\ \mathrm{Ca} & 0.000 & 0.000 & 0.011 & 0.002 & 0.000 & 0.026 & 0.001 & 0.000 & 0.002 & 0.001\end{array}$

\begin{tabular}{lllllllllll}
\hline TOTAL & 3.000 & 1.996 & 3.000 & 2.000 & 2.999 & 1.997 & 2.997 & 1.998 & 2.997 & 1.999 \\
\hline X (Usp) & 0.250 & & 0.350 & & 0.430 & & 0.480 & & 0.610 & \\
X(Ilm) & & 0.950 & & 0.860 & & 0.760 & & 0.890 & & 0.940
\end{tabular}

$\begin{array}{crrrrrr}\text { T (C) } & 1 & 665.09 & 896.24 & 1088.49 & 914.24 & 841.37 \\ & 2 & 666.15 & 896.65 & 1135.37 & 920.15 & 835.89 \\ & 3 & 710.85 & 886.66 & 1140.25 & 965.58 & 775.25 \\ & 4 & 746.31 & 886.73 & 1001.71 & 906.43 & 957.13 \\ & & & & & \\ \text { fO2 } & 1 & -18.06 & -11.53 & -8.45 & -11.95 & -14.47 \\ & 2 & -17.64 & -11.32 & -7.67 & -11.62 & -14.30 \\ & 3 & -16.14 & -11.82 & -7.72 & -11.08 & -15.65 \\ & 4 & -14.89 & -11.85 & -9.95 & -12.37 & -11.54\end{array}$

1 = Stormer (1983) model; 2 = Anderson (1968) model;

3 = Carmichael (1967) model; 4 = Lindsley and Spencer (1982) model. 
with mineral analyses as Table 4.19. The method of Stormer (1983) has the advantage of considering the effects of minor element compositions. The results of these calculations are plotted in terms of oxide composition, with tie-lines between coexisting mineral pairs (Figure 4.17a), and on a temperature- $f \mathrm{O}_{2}$ plot (Figure 4.17b; open squares), together with the results of geothermometry and oxygen fugacity calculations from other oxide pairs (closed circles).
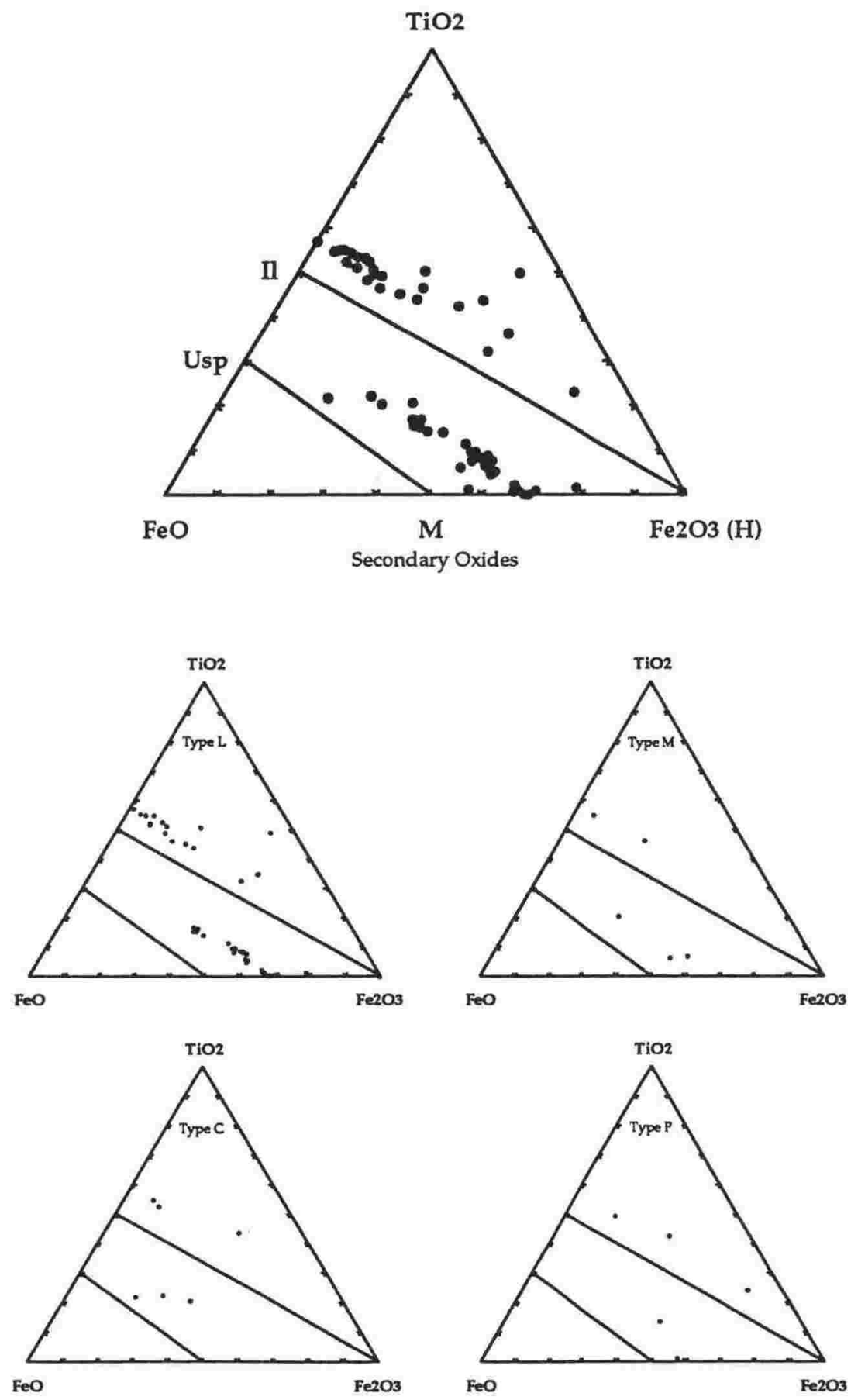

FIGURE 4.16: Oxide compositions of secondary oxides formed by oxidation processes in the Mount Sidley xenolith suite (top diagram). Spinel and rhombohedral oxides are similar in composition in all xenolith types (bottom diagrams). $\mathrm{H}$ = hematite; $\mathrm{Il}=$ ilmenite; $\mathrm{M}=$ magnetite; Usp = ulvöspinel. 

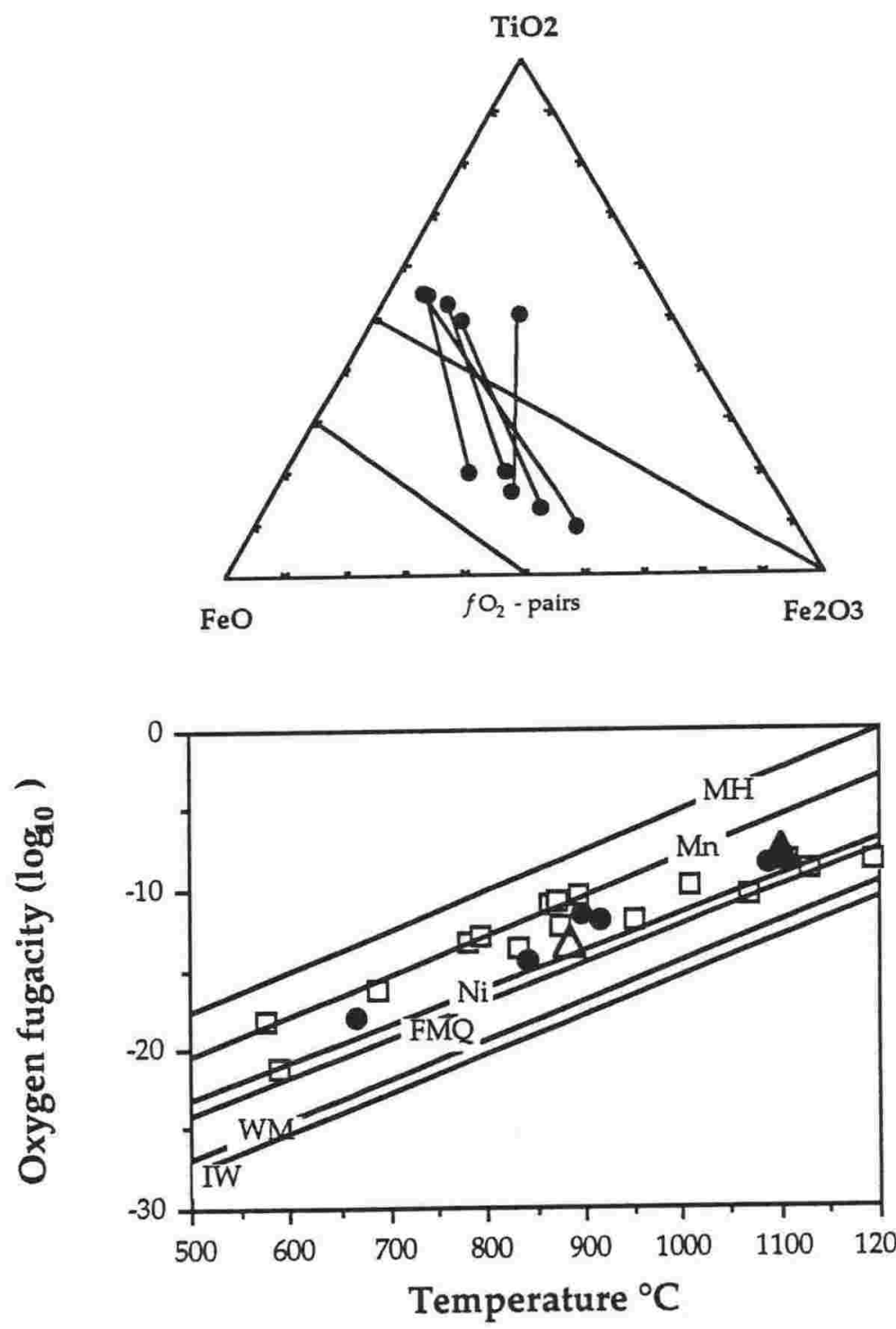

$\square$ Secondary oxides

- Secondary oxides in Table 4.18

Melt and primary oxides

FIGURE 4.17: Redox conditions of the Mount Sidley xenolith suite determined using the oxide-pair thermometry and oxygen fugacity calculations of Stormer (1983). a) Tie lines showing the compositions of oxide pairs from Table 4.19. b) Redox conditions of secondary oxide pairs from Mount Sidley xenoliths (including pairs from Table 4.19 and Figure 4.17a (open squares) and other oxide pairs (closed circles)), from a primary xenolith oxide pair (large open triangle), and from a host melt oxide pair (large closed triangle). Redox buffer fields are from Buddington and Lindsley (1964), and Haggerty (1990).

The oxide pair calculations fall within the FMQ-FMQ+4 (Buddington and Lindsley, 1964) buffer (Figure $4.17 \mathrm{~b}$ ), indicating low oxygen fugacities ( -9 to -20 $\log _{10} \mathrm{fO}_{2}$ ), with temperatures ranging from $600-1200^{\circ} \mathrm{C}$. The high temperatures are magmatic, and lower temperatures indicate that the xenoliths have equilibrated to lower temperature conditions.

Oxidation reactions involving a change in the state of iron (with $\mathrm{Fe}^{2+}$ oxidising to $\mathrm{Fe}^{3+}$ ), are buffered by a change in oxide mineralogy. The change at the FMQ buffer can be described in terms of the simple equation: 
$3 \mathrm{Fe}^{2+}($ silicate $)+1 / 2 \mathrm{O}_{2} \longrightarrow \mathrm{Fe}_{3} \mathrm{O}_{4}+\mathrm{Fe}$-poor silicate \pm fluid

Oxidation reactions in the Mount Sidley xenolith suite are dominated by the breakdown of olivine into a Fe-rich olivine, and a $\mathrm{Mg}$-rich olivine and its replacement by Fe-Ti oxides:

$3 \mathrm{FeMgSiO}_{4}+2 \mathrm{O}_{2} \rightarrow \mathrm{Fe}_{3} \mathrm{O}_{4}+3 \mathrm{MgSiO}_{4} \pm$ fluid

$\mathrm{Fe}-\mathrm{Mg}$ olivine $\rightarrow$ magnetite $+\mathrm{Mg}$-olivine

Thermochemical experiments by Eggler and Baker (1982) indicate that the upper mantle redox state is between the FMQ and WM fields, a view supported by other studies (e.g. Eggler, 1983; O'Neill and Wall, 1987). Electrochemical intrinsic oxygen fugacity models developed by Sato (1970 and 1972) indicate that Type II (Al-augite bearing) upper mantle rocks fall within the FMQ-NNO field, whereas Type I (Cr-diopside bearing) upper mantle rocks are highly reduced at approximately the IW buffer (Arculus and Delano, 1980 and 1981). There is therefore an uncertainty as to the redox state of the mantle, between a homogenous redox-state (FMQ-WM), and a heterogeneous redox state (FMQNNO and IW).

Oxygen fugacities increase with increasing temperature and total pressure, and upper crustal rocks are typically oxidised at $\mathrm{MH}$ buffer conditions. Oceanic basalts typically have redox states clustering around the FMQ buffer, and continental basalts are between the FMQ and WM buffers (Haggerty, 1990).

From petrographic textures and the association of basanitic melts with oxidation reactions, the agent responsible for the oxidation of the Mount Sidley xenolith suite to a FMQ-FMQ+4 redox state was the host silicate melts. Temperature and $\mathrm{fO}_{2}$ conditions determined on host melt crystallisation (Figure $4.17 \mathrm{~b}$, closed triangle at right) fall at the high- $\mathrm{T}$ end of the xenolith range consistent with the host melt as the oxidising agent. Lower temperatures are clearly not magmatic, and indicate that the xenoliths have equilibrated to lower temperatures, probably at the surface.

A single primary oxide pair (open triangle of Figure $4.17 \mathrm{~b}$ ) also plots within this field, indicating that either redox conditions of the lower crust and of the host melts is similar, or that primary oxides have also been affected by oxidation. Primary oxides from Mount Murphy have similar redox conditions, suggesting that lower crustal conditions in MBL are similar to the FMQ buffer, as expected for Type II rocks (Arculus and Delano, 1980 and 1981). 
Tectonic redox stratigraphy

(a) Ocean ridge

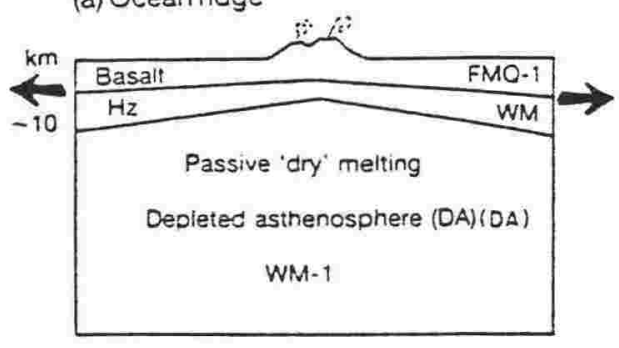

(b) Ocean isiand

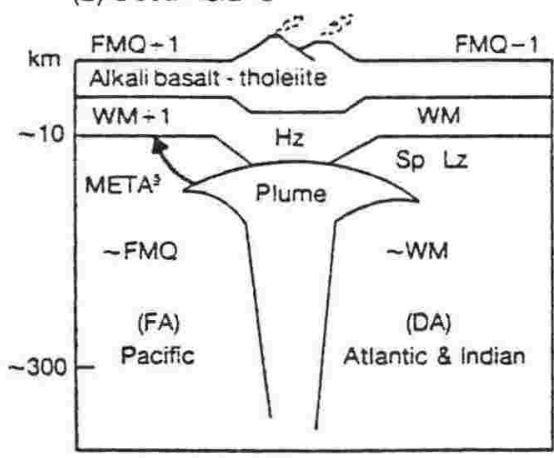

(c) Subduction

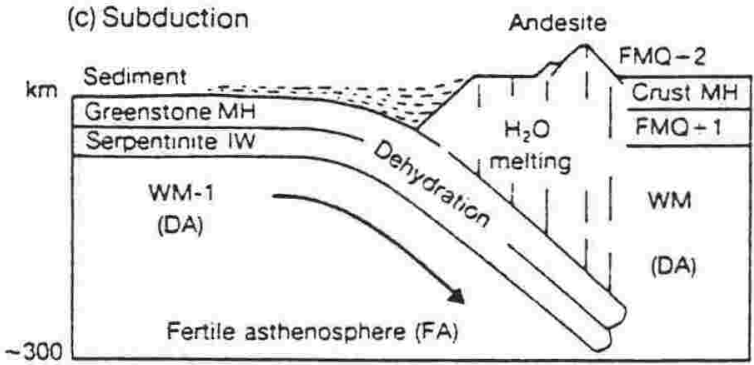

(d) Continental-rift \& craton

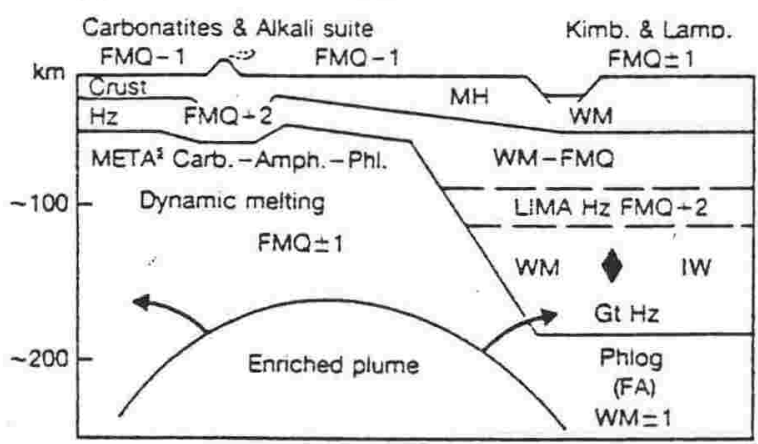

FIGURE 4.18: Schematic cross-sections and $\mathrm{fO}_{2}$ estimates for the lithosphere and asthenosphere in ocean ridge, ocean island, subduction zone and continental rift settings (from Haggerty, 1990). Contrasting redox states are invoked for asthenospheres that have undergone previous depletion (Atlantic type) relative to moderately fertile asthenospheres (Indian and Pacific types). a) Passive rifting and 'dry' melting produces an oceanic lithosphere of WM. b) Plume enrichment in oceanic islands results in $W M+1$. c) Subducted oceanic lithosphere with underlying depleted slab results in a complex but highly oxidised marginal continental lithosphere. d) Plume activity, enrichment and dynamic melting affect the evolution of $\mathrm{fO}_{2}$ in deep continental keels and subadjacent rift zones.

If lower crustal redox conditions are approximately at the FMQ buffer, an indication of the tectonic setting of the lower crust can be obtained by examining the redox stratigraphy of the Mount Sidley lithosphere. Figure 4.18 shows the redox states of the lithosphere from different tectonic settings. Oxygen fugacities are too high in the lower crust beneath Mount Sidley to be from an ocean ridge or ocean island setting. Crustal conditions of subduction zone settings (MH-FMQ+1) and continental rift settings (MH-FMQ+2) are consistent with Mount Sidley xenolith redox states. The present setting of Marie Byrd Land is clearly not a subduction zone (nor for that matter an ocean ridge or ocean island) but one of a thin crust undergoing rifting (Chapter 1.2). The redox state of the xenolith suite is consistent with that of lower crust in a continental rift setting (Figure 4.18).

\subsubsection{Geochemistry and origin of glasses}

Many glasses occurring in the Mount Sidley xenolith suite are host basanitic lavas that have infiltrated the xenoliths (Chapter 4.5.1). The origins of glasses found in association with kaersutitisation (Chapter 4.5.2) and oxidation 
TABLE 4.20: Representative electron microprobe analyses of glasses occurring in the Mount Sidley xenolith suite. Normative compositions were calculated at an $\mathrm{Fe}_{2} \mathrm{O}_{3}: \mathrm{FeO}$ ratio of 0.15 .

\begin{tabular}{|c|c|c|c|c|c|c|c|c|c|c|}
\hline SAMPLE & $\begin{array}{c}900330 \\
\text { oxid. }\end{array}$ & $\begin{array}{l}90033 P \\
\text { kaerst. }\end{array}$ & $\begin{array}{l}\text { 90033P } \\
\text { kaerst. }\end{array}$ & $\begin{array}{l}90033 P \\
\text { kaerst. }\end{array}$ & $\begin{array}{c}90033 X \\
\text { melt }\end{array}$ & $\begin{array}{c}\text { 90039G } \\
\text { oxid. }\end{array}$ & $\begin{array}{c}90039 \mathrm{~V} \\
\text { oxid. }\end{array}$ & $\begin{array}{r}90039 \mathrm{E} \\
\text { melt }\end{array}$ & $\begin{array}{c}90039 \mathrm{E} \\
\text { melt }\end{array}$ & $\begin{array}{c}90039 \mathrm{E} \\
\text { melt }\end{array}$ \\
\hline $\mathrm{SiO} 2$ & 50.63 & 48.00 & 54.63 & 44.70 & 42.94 & 48.99 & 38.46 & 47.69 & 45.73 & 51.93 \\
\hline $\mathrm{Al} 2 \mathrm{O} 3$ & 18.08 & 18.72 & 16.62 & 15.97 & 10.34 & 18.99 & 5.61 & 16.11 & 14.79 & 17.05 \\
\hline $\mathrm{TiO} 2$ & 1.96 & 3.99 & 2.62 & 4.69 & 3.21 & 4.69 & 8.36 & 3.44 & 4.09 & 2.93 \\
\hline $\mathrm{FeO}$ & 10.39 & 12.23 & 9.59 & 14.01 & 22.42 & 9.84 & 22.6 & 9.78 & 14.47 & 7.97 \\
\hline $\mathrm{MnO}$ & 0.14 & 0.01 & 0.22 & 0.15 & 0.61 & 0.18 & 0.5 & 0.33 & 0.30 & 0.27 \\
\hline $\mathrm{MgO}$ & 3.61 & 3.43 & 4.40 & 2.98 & 6.60 & 2.74 & 8.04 & 5.33 & 4.76 & 3.15 \\
\hline $\mathrm{CaO}$ & 6.88 & 3.20 & 4.35 & 10.49 & 8.25 & 7.96 & 13.72 & 9.64 & 8.61 & 7.39 \\
\hline $\mathrm{Na} 2 \mathrm{O}$ & 3.69 & 3.80 & 2.96 & 4.00 & 2.52 & 4.81 & 1.32 & 3.91 & 4.23 & 1.79 \\
\hline $\mathrm{K} 2 \mathrm{O}$ & 1.28 & 6.16 & 4.18 & 1.11 & 0.67 & 1.43 & 0.44 & 1.67 & 1.32 & 4.70 \\
\hline $\mathrm{Cr} 2 \mathrm{O} 3$ & 0.53 & 0.02 & 0.00 & 0.06 & & 0.11 & 0.03 & 0.00 & 0.03 & 0.04 \\
\hline $\mathrm{Cl}$ & & 0.23 & 0.28 & 0.16 & 0.03 & 0.02 & & & & \\
\hline $\mathrm{P} 2 \mathrm{O} 5$ & 3.03 & & & 0.77 & 2.12 & & & 2.66 & 3.24 & 3.06 \\
\hline TOTAL & 100.22 & 99.80 & 99.85 & 99.08 & 99.72 & 99.76 & 99.08 & 100.56 & 101.56 & 100.28 \\
\hline Mg\# & 38.24 & 33.32 & 44.96 & 27.50 & 34.41 & 33.16 & 38.80 & 49.27 & 36.96 & 41.32 \\
\hline $\mathrm{Q}$ & 3.80 & 0.00 & 1.13 & 0.00 & 0.00 & 0.00 & 0.00 & 0.00 & 0.00 & 4.75 \\
\hline Or & 7.56 & 36.40 & 24.70 & 6.56 & 3.96 & 8.45 & 2.60 & 9.87 & 7.80 & 27.78 \\
\hline $\mathrm{Ab}$ & 33.22 & 10.78 & 25.05 & 21.20 & 21.32 & 32.41 & 1.02 & 33.09 & 35.79 & 15.15 \\
\hline An & 15.36 & 15.83 & 19.72 & 22.34 & 14.92 & 26.00 & 8.08 & 21.48 & 17.47 & 16.69 \\
\hline $\mathrm{Ne}$ & 0.00 & 11.58 & 0.00 & 6.85 & 0.00 & 4.49 & 5.50 & 0.00 & 0.00 & 0.00 \\
\hline $\mathrm{Di}$ & 12.02 & 0.04 & 1.54 & 20.84 & 10.27 & 11.19 & 49.73 & 7.36 & 3.42 & 13.77 \\
\hline $\mathrm{Hy}$ & 16.67 & 0.00 & 20.75 & 0.00 & 14.43 & 0.00 & 0.00 & 0.69 & 0.84 & 8.23 \\
\hline $\mathrm{Ol}$ & 0.00 & 15.15 & 0.00 & 7.89 & 19.77 & 6.42 & 12.22 & 13.64 & 18.07 & 0.00 \\
\hline Mt & 0.00 & 0.00 & 0.00 & 0.00 & 0.00 & 0.00 & 0.00 & 0.00 & 0.00 & 0.00 \\
\hline Il & 3.72 & 7.58 & 4.98 & 8.91 & 6.10 & 8.91 & 15.88 & 6.53 & 7.77 & 5.56 \\
\hline Ap & 7.17 & 0.00 & 0.00 & 1.82 & 5.02 & 0.00 & 0.00 & 6.30 & 7.67 & 7.24 \\
\hline TOTAL & 99.52 & 97.36 & 97.87 & 96.41 & 95.79 & 97.87 & 95.03 & 98.96 & 98.83 & 99.17 \\
\hline
\end{tabular}

(Chapter 4.5.3) reactions are less obvious, although petrographic textures suggest that these glasses also originated from the host lavas. Compositions of individual glasses from all three associations are presented as Table 4.20. Glass compositions were determined by electron microscopy, which can yield large errors, especially in volatile elements (e.g. $\mathrm{Na}, \mathrm{K}, \mathrm{P}$ have estimated errors of $>5-10 \%$ ). The scatter in 
many trends in the following diagrams may be due to this error (Appendix Three).

The CIPW normative compositions of the glasses vary considerably, from highly nepheline-normative to highly hypersthene-normative, including quartznormative compositions (Figure 4.19). These variations occur between glasses within the same sample as well as from different samples.

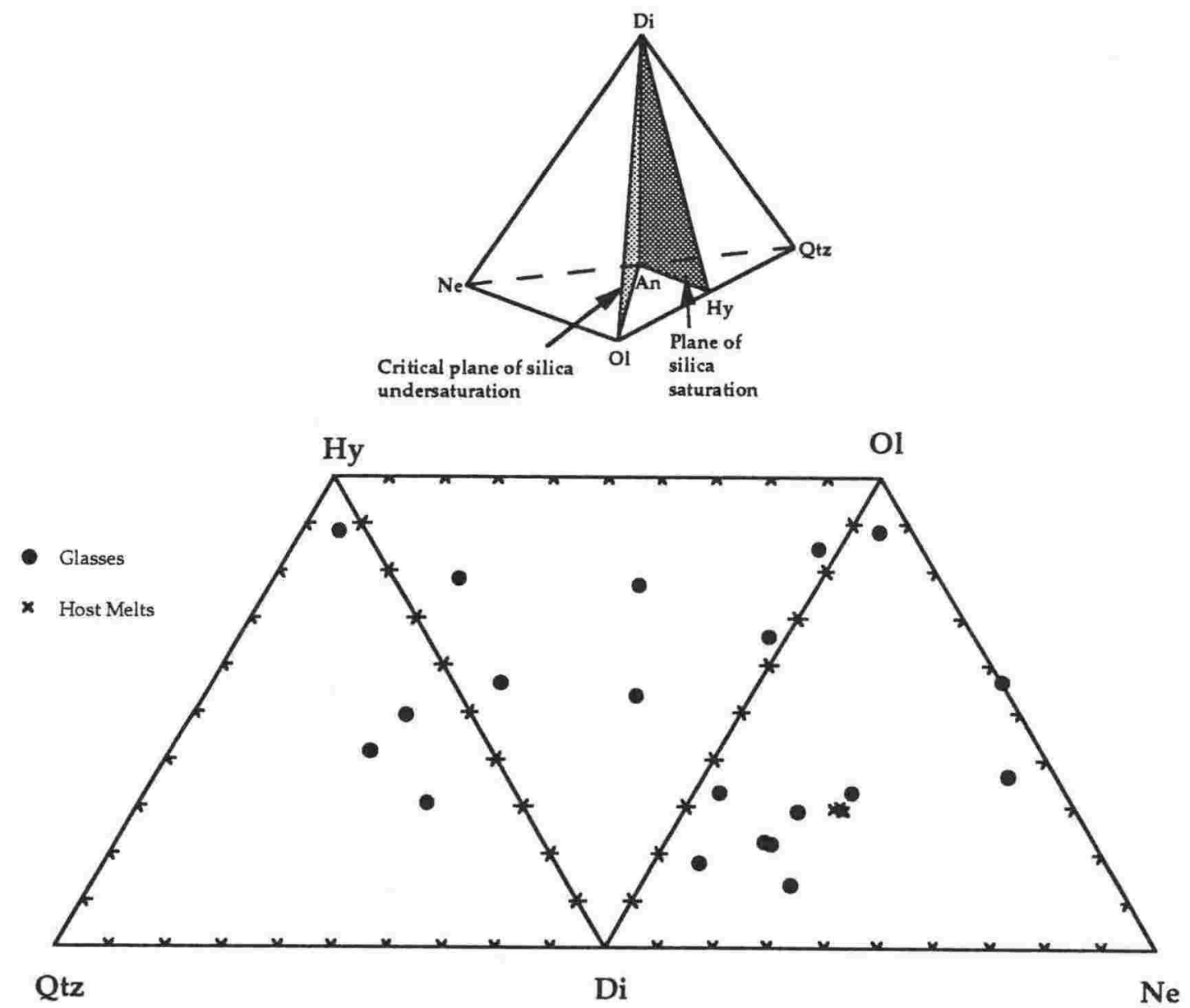

FIGURE 4.19: CIPW normative compositions of individual glass in the Mount Sidley xenolith suite. Compositions vary from nepheline- to hypersthene- and quartz-normative.

Glass compositions range from $38-55$ wt. $\% \mathrm{SiO}_{2}$. On a total alkali-silica (TAS) diagram (Le Bas et al., 1986) they exhibit a large scatter, although a general linear trend can be identified, similar to the volcanics, with compositions above and below the main trend from basanite/picrobasalt to mugearite (Figure 4.20). A split trend has been identified in the Mount Sidley volcanic rocks (Figure 4.20), which trend from basanite to benmoreite, and then split towards phonolite and trachyte (Panter et al., in prep). 


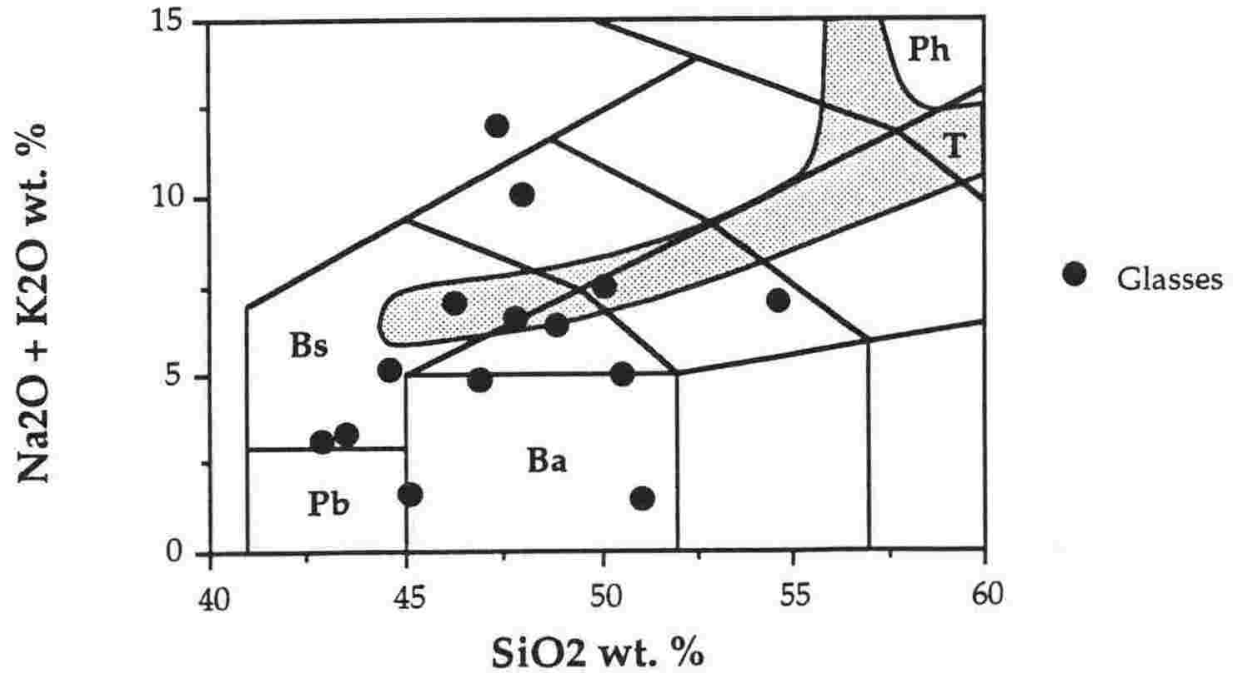

FIGURE 4.20: Total alkali-silica (TAS) plot of Le Bas et al. (1986) showing compositions of glasses from the Mount Sidley xenolith suite, and of Mount Sidley volcanic rock compositions (field; from Panter et al., in prep). Analytical error may be responsible for some of the scatter. $\mathrm{Ba}=$ basalt, $\mathrm{Bs}=$ basanite; $\mathrm{Pb}=$ picrobasalt; $\mathrm{Ph}=$ phonolite; and $\mathrm{T}=$ trachyte. See Figure 2.1 for other fields.

The large variations in normative compositions and silica $v$ total alkali compositions indicates that the compositions are evolved, and that simple fractionation of mineral phases from melts cannot account for the variability seen in the glass compositions. Linear trends of many silica $\mathrm{v}$ major element diagrams (Figure 4.21) do show the affects of simple mineral fractionation, however the wide scatters in many cases are large, and not accountable by analytical error, indicating that other processes have also influenced the glass chemistry.

Microphenocrysts have crystallised directly from the glasses, including plagioclase (the dominant phase) \pm olivine \pm clinopyroxene \pm rhönite $\pm \mathrm{Fe}-\mathrm{Ti}$ oxides \pm apatite. The trends of major elements and silica are largely reconcilable with fractionation of the glasses by the observed assemblage; in particular the decrease in $\mathrm{TiO}_{2}, \mathrm{Fe}_{2} \mathrm{O}_{3}$ (total), $\mathrm{MgO}$ and $\mathrm{CaO}$, and the increase in $\mathrm{Al}_{2} \mathrm{O}_{3}, \mathrm{Na}_{2} \mathrm{O}$ and $\mathrm{K}_{2} \mathrm{O}$ with increasing silica.

A possible origin of some glasses is as a result of decompression melting of xenolith phases due to entrainment in the host lava, and the subsequent rapid increase in temperature and then decrease in pressure as they are brought to the surface. This however is discarded for a number of reasons.

At Foster Crater, similar glasses have been reported from lower crustal/upper mantle spinel wehrlite xenoliths (Gamble and Kyle, 1987). As pointed out by Gamble and Kyle (1987), the observed reactions do not equate with decompression reactions expected from experimental studies. With increasing temperature, decompression assemblages at $10 \mathrm{~kb}$ consist of kaersutite $\rightarrow$ kaersutite + clinopyroxene $\rightarrow$ clinopyroxene + olivine + magnetite $\rightarrow$ clinopyroxene + olivine + magnetite + melt (Yagi et al., 1975). At $1025^{\circ} \mathrm{C}$ and $10-$ 

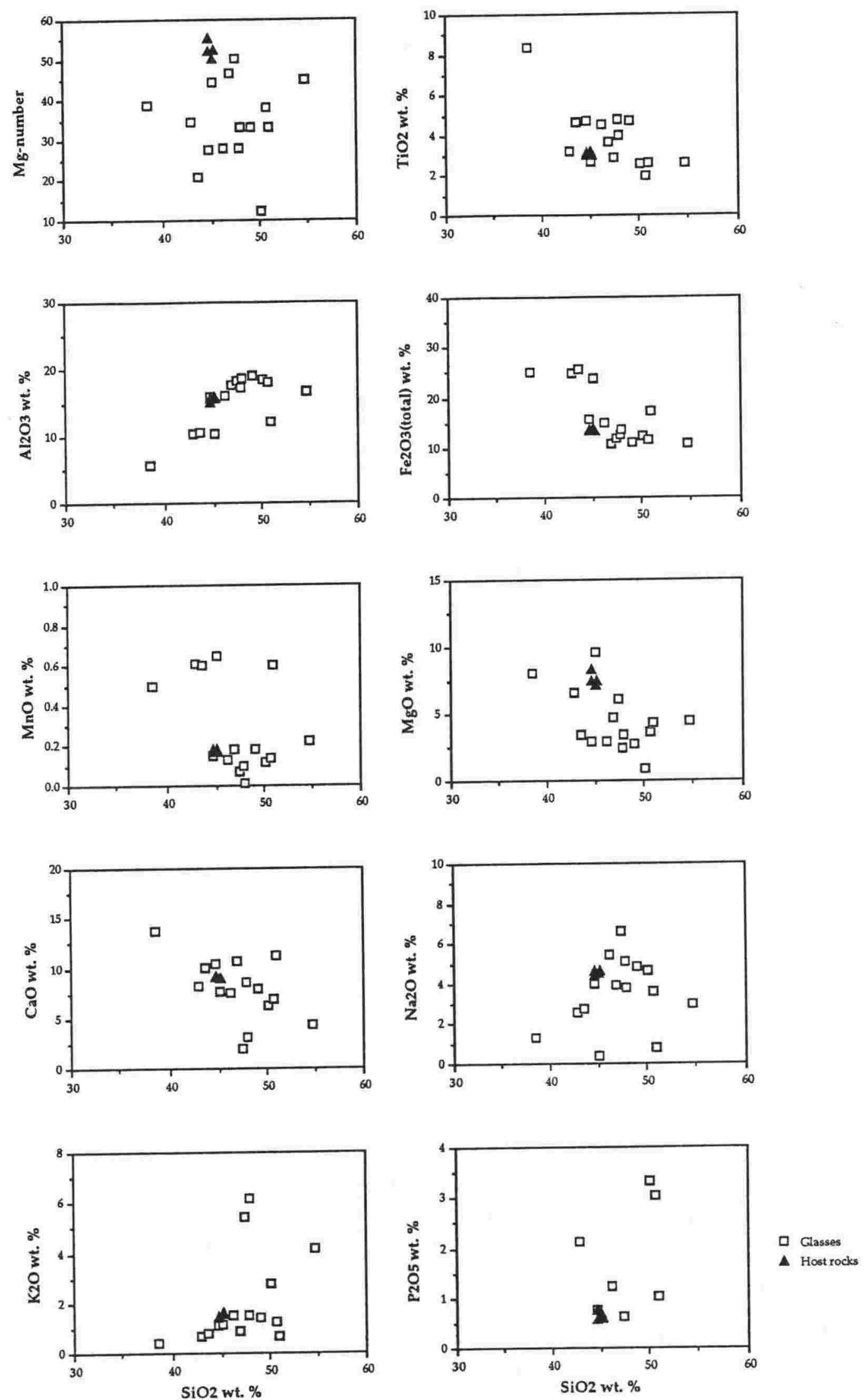

FIGURE 4.21: Silica v major element plots of glasses occurring in the Mount Sidley xenolith suite compared to host basanites (basanite data from Panter (pers. comm.)). Analyses were determined by electron microscopy, and errors for volatile elements $(\mathrm{Na}, \mathrm{K}$ and $\mathrm{P})$ may be substantial $(>5-10 \%)$. 
$22 \mathrm{~kb}$, the observed assemblage is kaersutite + pargasite + rutile + spinel. These phases are not present at Foster Crater, or at Mount Sidley.

While many major element compositions of the glasses can be produced by melting of the primary xenolith mineral assemblage, the high content of some elements (e.g. $\mathrm{Na}, \mathrm{K}$ and $\mathrm{P}$ ) cannot be explained by such melting. In addition to this, and most importantly in discounting decompression melting as a sourcefor these glasses, is the textural and chemical relationships between the glasses and minerals. The characteristics of the melt have been imparted on the mineral assemblage (not the opposite as is the case in decompression melting), which have developed rims rich in components present in the glass, and poor in components that are not present in the glass.

The similarity of host basanites with xenolith glasses (Figures 4.20, 4.21) indicates that the glasses found in the Mount Sidley xenolith suite are derived from the host magmas that have brought the xenoliths to the surface. This includes not only glasses associated with host melt-xenolith reactions, but also glasses in association with kaersutitisation and oxidation reactions. The highest Mg\#s of the glasses correspond with those of the host basanites, and at the same silica composition (44-45 wt. \% $\mathrm{SiO}_{2}$ ). Furthermore, the composition of olivine (Fo 70-80) that has crystallised from the glasses requires a melt composition of Mg\# 50-60, which is consistent with their crystallisation from host basanite compositions. Interaction between xenolith phases and infiltrating melts, in addition to crystal fractionation, may therefore be responsible for the observed glass compositions. This process is a combination of assimilation and fractionation processes (AFC).

\subsubsection{Summary and discussion of secondary mineral reactions}

The affects of secondary mineral reactions are summarised as Table 4.21. The similarity between host melt-xenolith interactions, oxidation and to a less extent kaersutitisation, are evident in their effects on xenolith compositions, introducing some components into the xenolith ('system enrichment' in Table 4.21) and depleting others ('system depletion' in Table 4.21). They differ primarily in the crystallisation of different mineral phases, and in the affects of their interaction with the xenoliths.

In all cases glass originating from the host lavas are associated with these processes. In the case of kaersutitisation, glass is rare and non-liquid derivatives (gas or solid interactions) may be primarily responsible for the replacement of clinopyroxene by kaersutite. The similarities of all three processes, and in 
particular of their glass chemistry, provides a direct link to late Cenozoic alkaline volcanism as the agent responsible for these secondary processes.

Kaersutitisation processes are widespread in Type $P$ xenoliths, less common in Types $\mathrm{C}$ and $\mathrm{M}$ xenoliths, and absent in Type $\mathrm{L}$ xenoliths. The mineral chemistry of kaersutites indicates that they formed at lower crustal depths rather than upper mantle or upper crustal depths.

TABLE 4.21: Summary of secondary mineral reactions on the xenolith suite.

\begin{tabular}{|c|c|c|c|}
\hline REACTION & Melt-Xenolith & Oxidation & Kaersutitisation \\
\hline $\begin{array}{l}\text { Mineral } \\
\text { Crystallisation }\end{array}$ & $\begin{array}{l}\text { Ca-rich plagioclase } \\
\text { Mg-rich ol/cpx } \\
\text { Rhönite } \\
\text { Fe-Ti oxides } \\
\text { Apatite }\end{array}$ & $\begin{array}{c}\text { Ca-rich plagioclase } \\
\text { Fe-Ti oxides } \\
\text { Apatite }\end{array}$ & $\begin{array}{c}\text { Kaersutite } \\
\text { Minor rhönite, } \\
\text { plagioclase } \\
\text { K-feldspar, olivine }\end{array}$ \\
\hline $\begin{array}{l}\text { Xenolith } \\
\text { Interaction }\end{array}$ & $\begin{array}{l}\text { Disequilibrium } \\
\text { reactions }\end{array}$ & $\begin{array}{l}\text { Disequilibrium } \\
\text { reactions }\end{array}$ & $\begin{array}{l}\text { Replacement of } \\
\text { clinopyroxene }\end{array}$ \\
\hline Glass & $M g \# 21-49$ & Mg\# 21-49 & $\mathrm{Mg \#} \mathrm{27-50}$ \\
\hline $\begin{array}{l}\text { System } \\
\text { Enrichment }\end{array}$ & $\mathrm{Ti}, \mathrm{Fe}, \mathrm{Ca}, \mathrm{P}$ & $\mathrm{Ti}, \mathrm{Fe}, \mathrm{Ca}, \mathrm{K}, \mathrm{P}$ & $\mathrm{Ti}, \mathrm{Fe}, \mathrm{Na}, \mathrm{K}, \mathrm{H} 2 \mathrm{O}$ \\
\hline $\begin{array}{l}\text { System } \\
\text { Depletion }\end{array}$ & $\mathrm{Ca}: \mathrm{Na}$ ratio, $\mathrm{Mg \#}$ & Ca:Na ratio, $\mathrm{Mg \#}$ & $\mathrm{Si}, \mathrm{Mn}, \mathrm{Mg}, \mathrm{Ca}, \mathrm{Mg} \#$ \\
\hline Redox State & FMQ & FMQ-FMQ+4 & Uncertain \\
\hline Agent & Host melts & Host melts & $\begin{array}{c}\text { Host melts } \\
\text { or non-liquid derivatives }\end{array}$ \\
\hline
\end{tabular}

Oxidation of the xenolith suite by host melts has occurred from magmatic temperatures to lower temperatures, with redox conditions similar to those from the FMQ buffer to FMQ+4. Lower crustal redox conditions may also be in this range. The pervasive oxidation of Type $\mathrm{L}$ xenoliths, with a decreased effect on Type $\mathrm{P}$ xenoliths, where it is evident only as isolated veins of oxidising fluids, is an indication of the selective oxidation of the xenolith suite. However, as pyroxenite rims are oxidised, the extensive oxidation of granulite xenoliths is seen as a function of their susceptibility to internal oxidation reactions, rather than the occurrence of oxidation reactions only at higher crustal levels. In contrast, the pyroxenite suite appears to be more susceptible to kaersutitisation. The process of secondary reactions is discussed more fully in Chapter 8.3.3. 
Assimilation and fractionation (AFC) of glasses within the xenolith suite indicates that the host magmas themselves may have undergone AFC processes at lower crustal depths. The scale of such a process depends on two main factors. Firstly, the ability of the melts to escape from the lower crust will determine if affected melts are seen at the surface. If the glasses present in the xenolith suite represent melts trapped at lower crustal depths, they will not be present at the surface. Secondly, the scale of interaction between the host melts and the xenoliths will determine if the host melts are affected by AFC processes in the lower crust. A large volume of melt must interact with lower crustal rocks, not just melt in contact with conduit rocks. If infiltration of the host melts into the lower crust is pervasive, and the melts then ascend to the surface, AFC processes of the melt at lower crust levels will have a major bearing on the final composition of the volcanic suite.
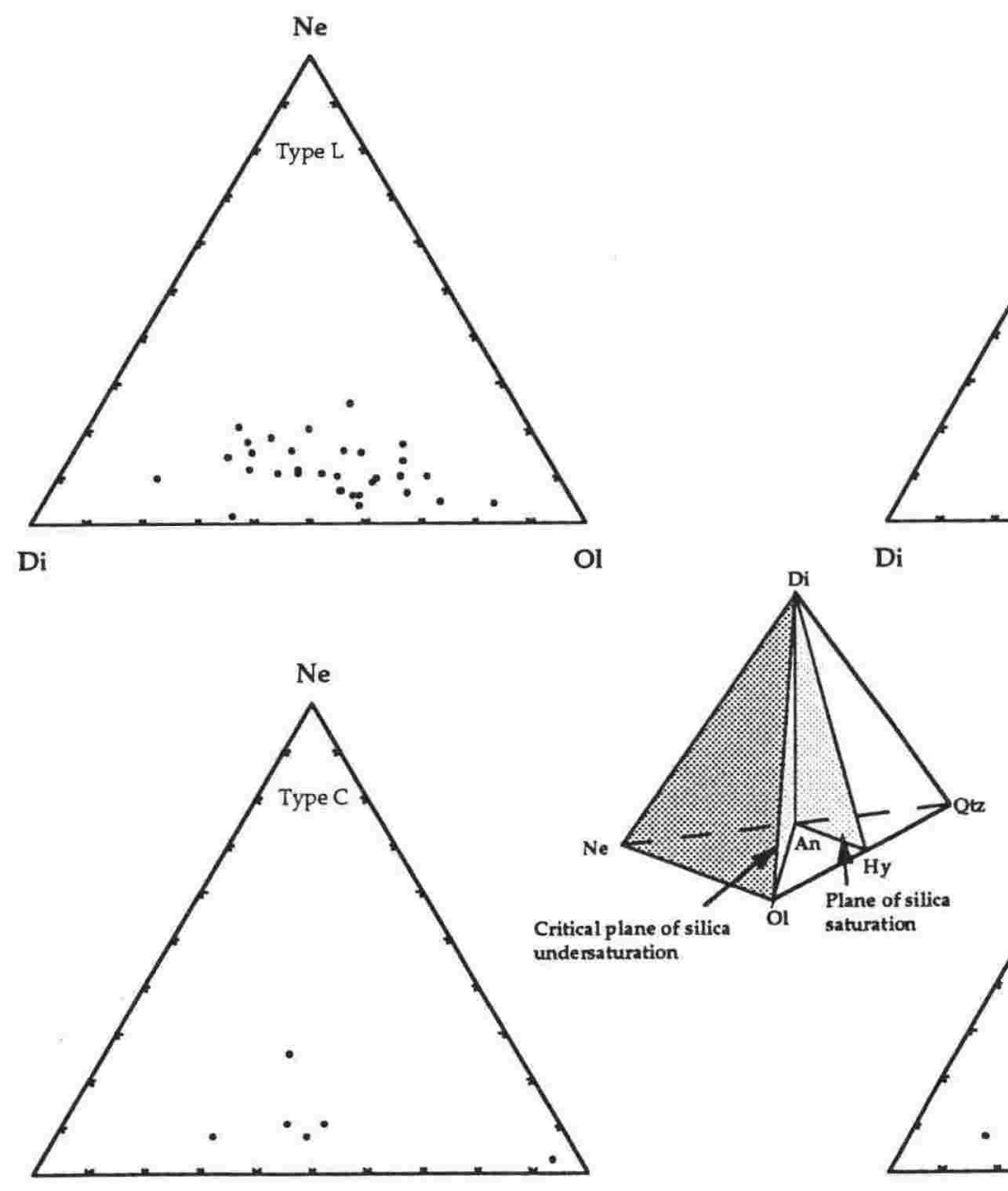

Di

$$
\text { Ol }
$$

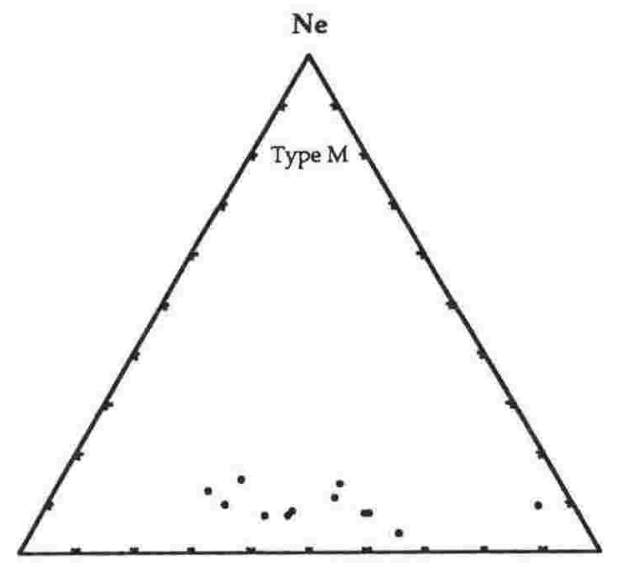

Di

Ol

FIGURE 4.22: CIPW normative compositions of the Mount Sidley xenolith suite on the nephelineolivine-diopside face of the basalt tetrahedron (dark shaded face). All xenolith types are nepheline normative. 


\subsection{Whole Rock Geochemistry}

Whole-rock geochemical analyses were undertaken on representative samples of all four xenolith types. Representative analyses are presented as Table 4.22, and a complete list of analyses can be found in Appendix 4.1. Magnesium numbers (Mg\#) are calculated as $100 \mathrm{Mg} / \mathrm{Mg}+\Sigma \mathrm{Fe}$, with $\Sigma \mathrm{Fe}$ taken as FeO. CIPW normative compositions are calculated with an $\mathrm{Fe}_{2} \mathrm{O}_{3}: \mathrm{FeO}$ ratio of 0.15 . The small number of Type $\mathrm{C}$ xenoliths has resulted in only a small number of analyses, with restricted ranges that may not be indicative of the suite as a whole.

\subsubsection{Major element geochemistry}

The Mount Sidley xenolith suite is wholly nepheline-normative (Table 4.22), although nepheline does not occur as a modal phase in the xenolith suite. A projection onto the nepheline-olivine-diopside face of the basalt tetrahedron shows the similarities between the suites (Figure 4.22). Normative mineral assemblages however do differ between xenolith types. Type $\mathrm{L}$ xenoliths are rich in plagioclase, and low in mafic phases, whereas Type $\mathrm{P}$ xenoliths are plagioclasepoor and rich in mafic phases (olivine and clinopyroxene). Types $\mathrm{M}$ and $\mathrm{C}$ fall between these extremes. This range in normative mineralogy is a reflection of the modal mineral assemblages of the xenolith types.

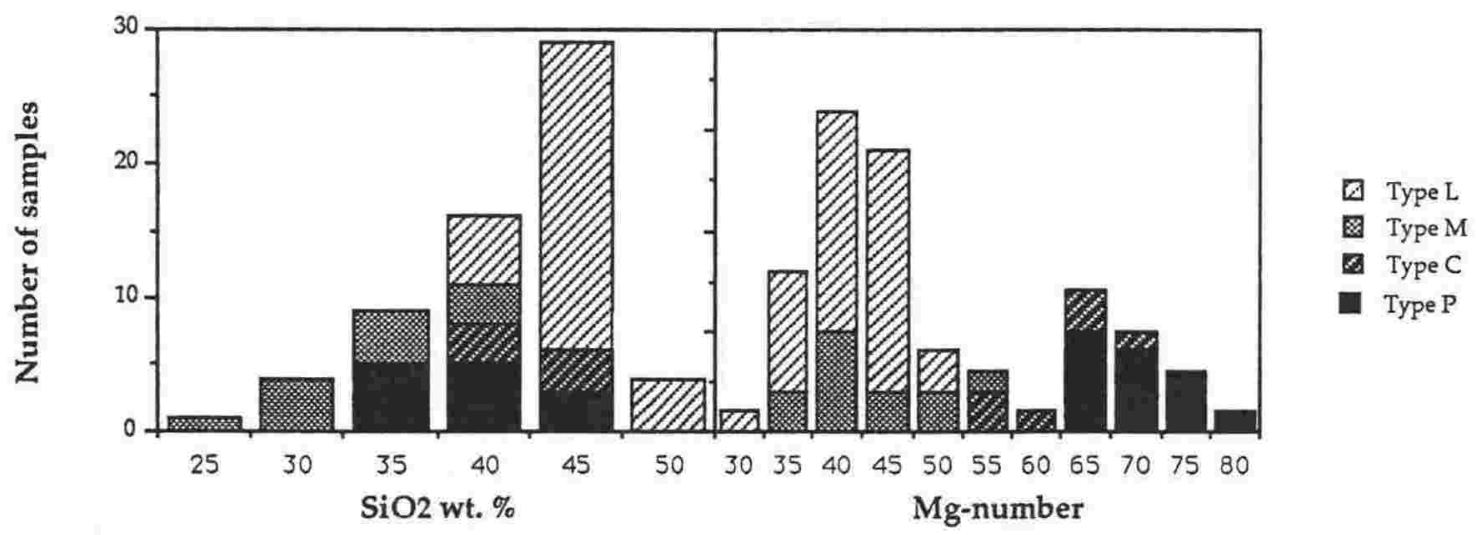

FIGURE 4.23: Histograms of silica and Mg-number contents in the Mount Sidley xenolith suite. Silica contents are highest in Type L granulites, and lowest in Type $\mathrm{M}$ xenoliths. Mg\#s are higher in pyroxenites than in granulites reflecting higher $\mathrm{Mg}: \mathrm{Mg}+\mathrm{Fe}$ ratios of pyroxenite mafic minerals. $\mathrm{SiO}_{2}$ and Mg\# abscissas are by 5 wt. \% gradations (e.g. $30=30.0-34.9$ ).

Xenolith compositions are mafic (32-53 wt. \% $\mathrm{SiO}_{2}$ ), with Type $\mathrm{L}$ granulites having the highest silica contents and Type $\mathrm{M}$ granulites having the lowest silica contents. These variations reflect the high plagioclase content of Type L granulites, and the high oxide content of Type $\mathrm{M}$ granulites. Types $\mathrm{C}$ and $\mathrm{P}$ pyroxenites have silica contents intermediate to the granulites (Figure 4.23). 
TABLE 4.22: Representative Mount Sidley xenolith whole rock compositions.

\begin{tabular}{|c|c|c|c|c|c|c|c|c|c|c|}
\hline $\begin{array}{l}\text { SAMPLE } \\
\text { TYPE }\end{array}$ & $\begin{array}{c}90029 K \\
\text { L }\end{array}$ & $\begin{array}{c}90031 \mathrm{P} \\
\mathrm{L}\end{array}$ & $\begin{array}{c}90039 \mathrm{M} \\
\text { L }\end{array}$ & $\begin{array}{c}90029 \mathrm{~V} \\
\mathrm{M}\end{array}$ & $\begin{array}{c}90039 \mathrm{~B} \\
\mathrm{M}\end{array}$ & $\begin{array}{c}90029 \mathrm{~B} \\
\mathrm{C}\end{array}$ & $\begin{array}{c}90033 \mathrm{P} 1 \\
\mathrm{C}\end{array}$ & $\begin{array}{c}90031 Q \\
\text { P }\end{array}$ & $\begin{array}{c}90033 B \\
\text { P }\end{array}$ & $\begin{array}{c}90039 \mathrm{U} \\
\mathbf{P}\end{array}$ \\
\hline $\mathrm{SiO} 2$ & 52.15 & 46.16 & 40.48 & 33.65 & 40.89 & 44.65 & 45.72 & 43.43 & 40.80 & 45.16 \\
\hline $\mathrm{TiO} 2$ & 1.32 & 3.44 & 5.19 & 6.74 & 3.21 & 0.67 & 1.86 & 1.34 & 1.49 & 0.94 \\
\hline $\mathrm{Al} 2 \mathrm{O} 3$ & 23.50 & 20.02 & 15.54 & 8.91 & 8.87 & 18.54 & 14.10 & 9.29 & 15.77 & 7.25 \\
\hline $\mathrm{Fe} 2 \mathrm{O} 3$ & 5.01 & 10.60 & 16.80 & 25.10 & 21.35 & 14.30 & 10.21 & 14.81 & 12.27 & 11.12 \\
\hline $\mathrm{MnO}$ & 0.06 & 0.12 & 0.21 & 0.32 & 0.31 & 0.22 & 0.14 & 0.20 & 0.16 & 0.18 \\
\hline $\mathrm{MgO}$ & 1.72 & 4.63 & 5.32 & 9.63 & 12.86 & 10.08 & 10.38 & 18.09 & 13.22 & 20.00 \\
\hline $\mathrm{CaO}$ & 9.87 & 11.00 & 11.56 & 11.13 & 11.87 & 8.19 & 14.32 & 11.38 & 15.18 & 15.07 \\
\hline $\mathrm{Na} 2 \mathrm{O}$ & 5.24 & 3.47 & 3.22 & 2.14 & 1.51 & 2.77 & 2.13 & 1.45 & 1.28 & 0.84 \\
\hline $\mathrm{K} 2 \mathrm{O}$ & 0.31 & 0.34 & 0.28 & 0.22 & 0.12 & 0.20 & 0.19 & 0.21 & 0.09 & 0.08 \\
\hline $\mathrm{P} 2 \mathrm{O} 5$ & 0.72 & 0.06 & 1.48 & 2.34 & 0.02 & 0.15 & 0.07 & 0.07 & 0.04 & 0.00 \\
\hline LOI & 0.37 & 0.22 & -0.65 & 0.12 & -0.74 & -0.23 & 0.19 & -0.26 & -0.18 & -0.33 \\
\hline TOTAL & 100.27 & 100.06 & 99.43 & 100.30 & 100.27 & 99.54 & 99.31 & 100.01 & 100.12 & 100.31 \\
\hline Sc & 10 & 17 & 23 & 20 & 36 & 3 & 39 & 33 & 43 & 54 \\
\hline V & 47 & 215 & 288 & 291 & 347 & 45 & 279 & 246 & 444 & 280 \\
\hline $\mathrm{Cr}$ & $<1$ & 3 & 9 & 10 & 106 & 66 & 376 & 1224 & 205 & 3004 \\
\hline $\mathrm{Ni}$ & 1 & 5 & 8 & 9 & 41 & 136 & 133 & 399 & 166 & 428 \\
\hline $\mathrm{Cu}$ & 8 & 26 & 16 & 38 & 62 & 15 & 53 & 29 & 32 & 33 \\
\hline $\mathrm{Zn}$ & 21 & 41 & 72 & 119 & 92 & 70 & 52 & 109 & 122 & 63 \\
\hline $\mathrm{Ga}$ & 23 & 23 & 21 & 18 & 15 & 18 & 17 & 12 & 27 & 12 \\
\hline $\mathrm{Rb}$ & 1 & 3 & 4 & 2 & 2 & 2 & 3 & 4 & 3 & 1 \\
\hline $\mathrm{Sr}$ & 1325 & 993 & 775 & 461 & 386 & 754 & 557 & 282 & 114 & 84 \\
\hline Y & 5 & 7 & 19 & 25 & 11 & $<1$ & 14 & 12 & 15 & 10 \\
\hline $\mathrm{Zr}$ & 29 & 61 & 54 & 47 & 43 & 21 & 67 & 45 & 45 & 28 \\
\hline $\mathrm{Nb}$ & 5 & 12 & 16 & 20 & 5 & 3 & 7 & 8 & 4 & 1 \\
\hline $\mathrm{Ba}$ & 446 & 147 & 213 & 20 & 55 & 143 & 78 & 65 & 37 & 14 \\
\hline $\mathrm{La}$ & 10 & 7 & 22 & 14 & 5 & 8 & 4 & 6 & 4 & 3 \\
\hline $\mathrm{Ce}$ & 21 & 19 & 66 & 109 & 23 & 19 & 16 & 19 & 23 & 8 \\
\hline $\mathrm{Pb}$ & 3 & 4 & 7 & 7 & 6 & 5 & 4 & 6 & 5 & 3 \\
\hline Th & $<1$ & $<1$ & 2 & 1 & 1 & 2 & 1 & 2 & 1 & 1 \\
\hline $\mathrm{U}$ & $<1$ & $<1$ & 1 & $<1$ & $<1$ & $<1$ & $<1$ & 1 & $<1$ & $<1$ \\
\hline Q & 0.00 & 0.00 & 0.00 & 0.00 & 0.00 & 0.00 & 0.00 & 0.00 & 0.00 & 0.00 \\
\hline Or & 1.83 & 2.01 & 1.65 & 1.30 & 0.71 & 1.18 & 1.12 & 1.24 & 0.00 & 0.00 \\
\hline $\mathrm{Ab}$ & 43.24 & 23.97 & 16.33 & 3.62 & 3.30 & 21.45 & 10.20 & 4.50 & 0.00 & 0.00 \\
\hline An & 39.69 & 38.05 & 27.12 & 14.06 & 17.07 & 37.57 & 28.35 & 18.22 & 37.02 & 15.78 \\
\hline $\mathrm{Ne}$ & 0.60 & 2.92 & 5.91 & 7.85 & 5.13 & 1.08 & 4.24 & 4.21 & 5.87 & 3.85 \\
\hline $\mathrm{Di}$ & 3.80 & 13.24 & 17.08 & 21.41 & 34.18 & 1.71 & 34.05 & 30.42 & 28.69 & 47.08 \\
\hline $\mathrm{Hy}$ & 0.00 & 0.00 & 0.00 & 0.00 & 0.00 & 0.00 & 0.00 & 0.00 & 0.00 & 0.00 \\
\hline Ol & 5.26 & 10.22 & 14.33 & 27.20 & 28.91 & 31.45 & 14.81 & 35.12 & 23.57 & 29.54 \\
\hline Mt & 0.86 & 0.00 & 2.90 & 4.33 & 3.68 & 2.47 & 1.76 & 0.00 & 2.12 & 1.92 \\
\hline Il & 2.51 & 6.53 & 9.86 & 12.80 & 6.10 & 1.27 & 3.53 & 2.54 & 2.83 & 1.79 \\
\hline Ap & 1.70 & 0.14 & 3.50 & 5.54 & 0.05 & 0.36 & 0.17 & 0.17 & 0.09 & 0.00 \\
\hline TOTAL & 99.49 & 97.08 & 98.68 & 98.11 & 99.13 & 98.54 & 98.23 & 96.42 & 100.19 & 99.96 \\
\hline
\end{tabular}


Whole rock magnesium numbers $\left(\mathrm{Mg} \#=100 \times \mathrm{Mg} /\left(\mathrm{Mg}+\sum \mathrm{Fe}\right.\right.$ as $\left.\left.\mathrm{FeO}\right)\right)$ are lower in granulite suite xenoliths (Mg\# 32-59), and higher in pyroxenite suite xenoliths (Mg\# 55-80), with only a slight overlap in composition (Figure 4.23). This distinction reflects the composition of mineral phases present in each xenolith type; i.e. high $\mathrm{Mg}: \mathrm{Mg}+\mathrm{Fe}$ ratios of pyroxenite mafic minerals, and low $\mathrm{Mg}: \mathrm{Mg}+\mathrm{Fe}$ ratios in granulite mafic minerals, correspond with high $\mathrm{Mg \# s}$ in the pyroxenites, and lower Mg\#s in the granulite suite.

Cumulate rocks are not liquids and do not form liquid lines of descent. Their compositions therefore represent the cumulate assemblage, and the amount of intercumulus melt trapped in the assemblage, which can vary from none in the case of adcumulates, to substantial in the case of orthocumulates. The well defined trends of major elements plotted against silica in granulite compositions, and scattered trends in pyroxenite compositions, is a direct reflection of their mineral assemblages, and the proportion of each mineral phase (Figure 4.24).

The affect of relative abundances of mineral phases on whole rock compositions is evident in Figure 4.25, which depicts the trends of $\mathrm{Fe}_{2} \mathrm{O}_{3}$ (total) v $\mathrm{SiO}_{2}$ and $\mathrm{Al}_{2} \mathrm{O}_{3} \vee \mathrm{SiO}_{2}$ in the granulite and pyroxenite suites, together with the compositions of mineral phases. The whole rock trends are easily explainable as mixing trends between the dominant mineral phases, with deviations due to minor mineral phases.

$\mathrm{Al}_{2} \mathrm{O}_{3}$ contents in the granulite suite form a well defined trend controlled by plagioclase abundance, relative to olivine and clinopyroxene. There is also a significant trend to low- $\mathrm{SiO}_{2}$ due to olivine and oxide content. In the pyroxenite suite, the low abundance of plagioclase has resulted in lower $\mathrm{Al}_{2} \mathrm{O}_{3}$ content being controlled by the relative proportions of olivine and clinopyroxene, with minor influences due to Al-spinel, kaersutite, and plagioclase (in Type $\mathrm{C}$ xenoliths).

Granulite $\mathrm{Fe}_{2} \mathrm{O}_{3}$ (total) contents also form a well defined trend, controlled by olivine abundances, with lower contents due to $\mathrm{Fe}_{2} \mathrm{O}_{3}$ (total)-poor plagioclase (and clinopyroxene). Some granulites have high $\mathrm{Fe}_{2} \mathrm{O}_{3}$ (total) contents, indicating the major influence of secondary oxides on $\mathrm{Fe}_{2} \mathrm{O}_{3}$ (total) contents. This is also reflected in high $\mathrm{V}$ contents in Type $\mathrm{M}$ xenoliths (Figure 4.26). In the pyroxenite suite, $\mathrm{Fe}_{2} \mathrm{O}_{3}$ (total) contents are a reflection of olivine and clinopyroxene abundances, with a minor influence from kaersutite.

Secondary reactions have acted to modify the composition of the protoliths. Secondary oxide growth, especially evident in Type $\mathrm{M}$ xenoliths, has resulted in increased $\mathrm{Fe}_{2} \mathrm{O}_{3}$ (total), $\mathrm{TiO}_{2}$ and $\mathrm{MnO}$ contents, and a lowering of $\mathrm{SiO}_{2}$ contents, and $\mathrm{Mg \# s}$. Secondary apatite growth has resulted in high $\mathrm{P}_{2} \mathrm{O}_{5}$ contents, notably in 

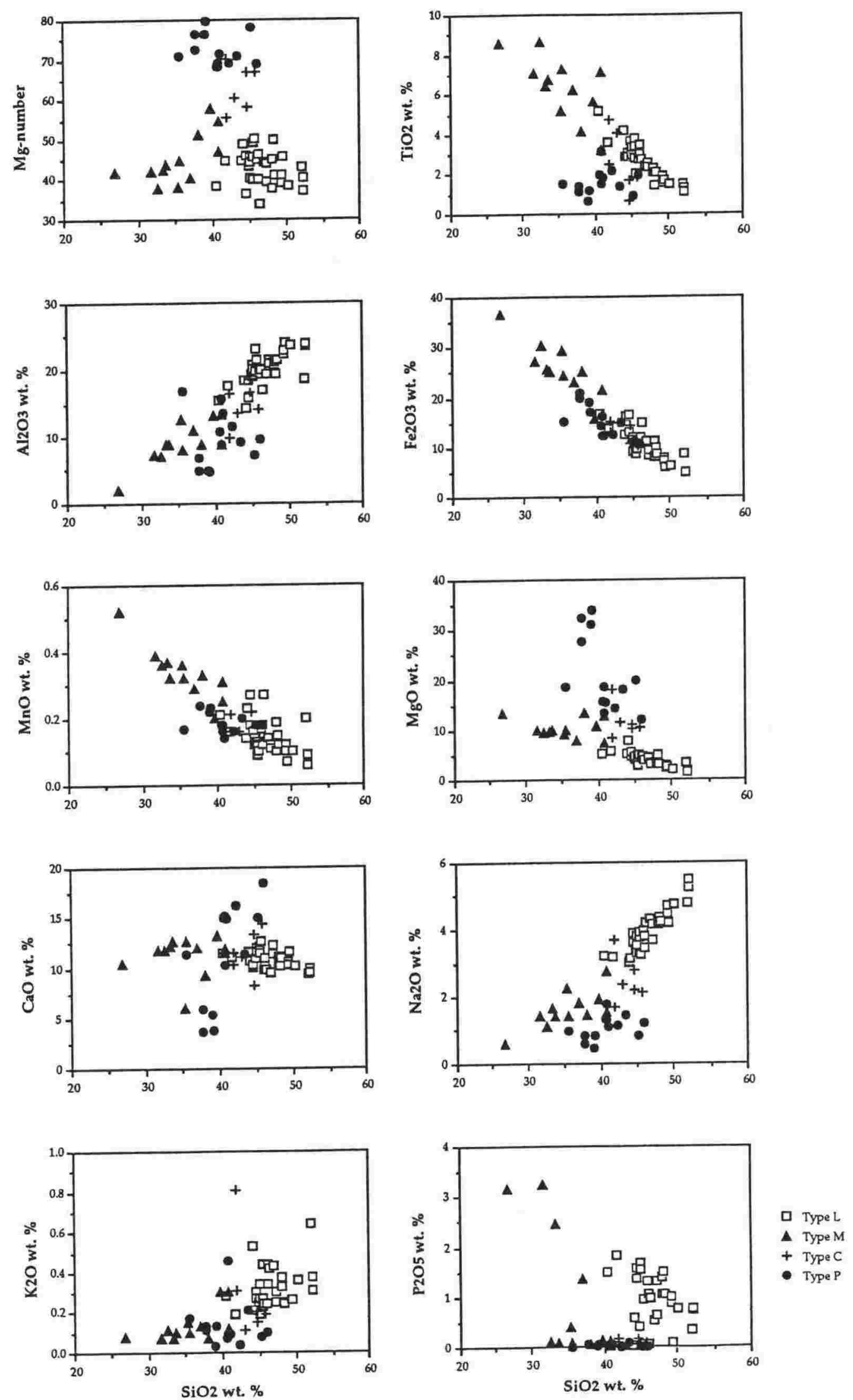

FIGURE 4.24: Silica v major element plots of Mount Sidley xenoliths. Major element concentrations reflect the mineral assemblage, and the proportion of each mineral phase, in the xenolith suite. 


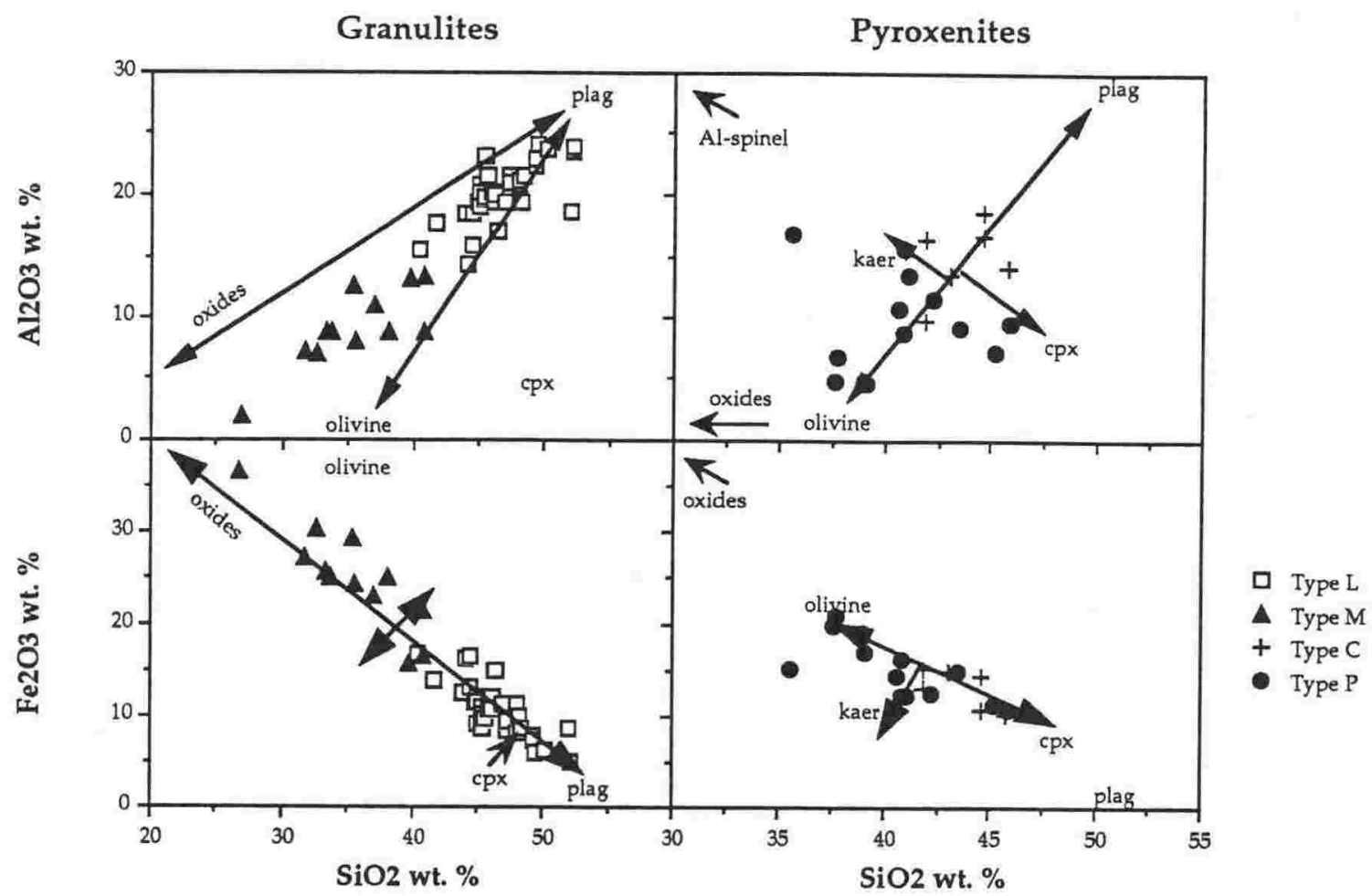

FIGURE 4.25: $\mathrm{Al}_{2} \mathrm{O}_{3}$ and $\mathrm{Fe}_{2} \mathrm{O}_{3} \mathrm{v}$ silica plots showing the influence of the modal mineral assemblage of the xenoliths on major element compositions. Mineral compositions are plotted, with large arrows depicting the mixing vectors between the major mineral phases, and small arrows showing the minor affects of other mineral phases. Major element composition of the granulite suite is controlled by the proportions of plagioclase and olivine, and pyroxenite compositions are controlled by the proportions of olivine and clinopyroxene.

Type $\mathrm{L}$ xenoliths. In the pyroxenite suite, the replacement of clinopyroxene by kaersutite has resulted in higher $\mathrm{Na}_{2} \mathrm{O}$ and $\mathrm{K}_{2} \mathrm{O}$ contents, as well as having an affect on $\mathrm{Fe}_{2} \mathrm{O}_{3}$ (total) contents (Figure 4.25).

\subsubsection{Trace element geochemistry}

Trace element abundances also reflect the proportions of the mineral phases present in the xenoliths. Figure 4.26 depicts the influence of mineral phases on element abundances. Elements which are compatible in mineral phases abundant in the xenoliths have higher concentrations than those which are incompatible in the mineral phases present in the xenoliths.

$\mathrm{Ba}$ and $\mathrm{Sr}$ are strongly partitioned into plagioclase, and are excluded from the other mineral phases present in the xenolith suite. Their high abundance in Type $\mathrm{L}$, and to a less extent Types $\mathrm{M}$ and $\mathrm{C}$, xenoliths reflects the high modal plagioclase contents of these xenoliths, with plagioclase-free xenoliths (Type P) being depleted in $\mathrm{Ba}$ and $\mathrm{Sr} . \mathrm{Ni}$ and $\mathrm{Cr}$ are incorporated into olivine and clinopyroxene respectively (and to a less extent in clinopyroxene and olivine 

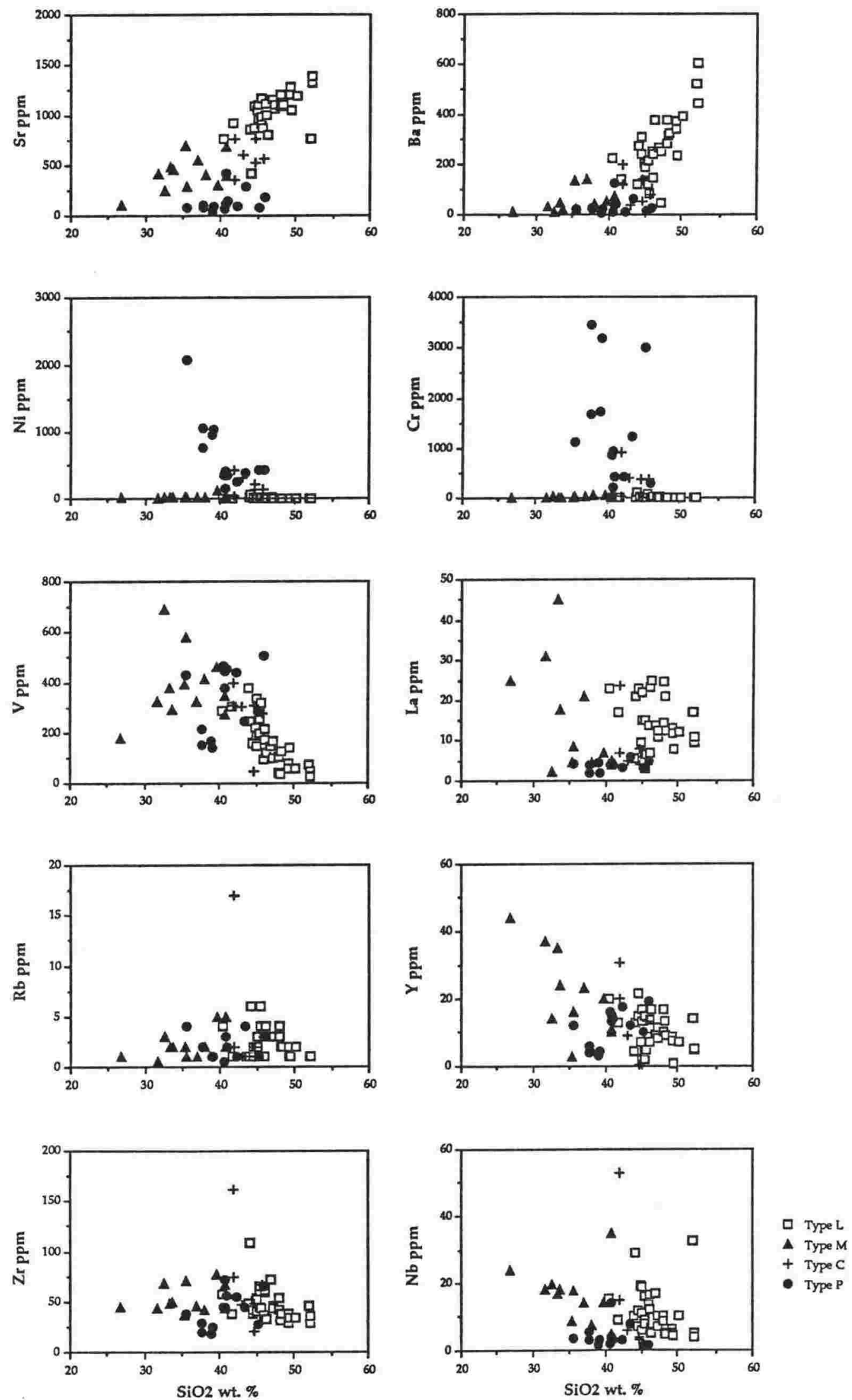

FIGURE 4.26: Silica v trace element plots of Mount Sidley xenoliths. As with major elements, the distribution of trace element concentrations are a result of the assemblage and composition of minerals in the xenolith suite. 
respectively), and therefore show high abundances in xenoliths rich in suites dominated by these phases (Types $\mathrm{P}$ and $\mathrm{C}$ ). They show low abundances in xenoliths poor in these phases (Types $\mathrm{L}$ and $\mathrm{M}$ ). $\mathrm{V}$ is also present in high concentrations, especially in Type $M$ xenoliths, reflecting its high abundance in oxide phases.

Elements which have low tendencies to partition into the mineral phases present in the xenolith suite include $\mathrm{La}, \mathrm{Rb}, \mathrm{Y}, \mathrm{Zr}$ and $\mathrm{Nb}$. These elements are present in low concentrations in the suite. La and $\mathrm{Nb}$, while having low abundances, are enriched in the granulites relative to the pyroxenites.

The low and variable concentration of elements that do not readily partition into xenolith mineral phases testifies to the lack of trapped melt in these cumulate rocks. Where cumulate textures are well preserved (Types $\mathrm{P}$ and $\mathrm{C}$ ), there is no petrographic evidence of trapped melt in the xenoliths (Chapter 4.3). As these elements have similar (and low) abundances in both igneous (Type $\mathrm{P}$ and $\mathrm{C}$ ) and metamorphosed (most Type L and $\mathrm{M}$ ) xenoliths, it is likely that recrystallisation had little effect on the xenoliths. Metamorphism of the xenolith suite was essentially a closed-system process.

Host melt interactions are likely to have affected the trace element concentration of the xenolith suite. Elements that are present in low abundances in the xenolith suite, especially mobile elements (e.g. $\mathrm{Rb}, \mathrm{Nb}$ and $\mathrm{Zr}$ ), will be enriched by only minor reaction with silicate melts that are rich in these elements. The xenolith suite may also be enriched in elements that readily partition into mineral phases (e.g. Sr and $\mathrm{Ba}$ ), as one of the major affects of oxidation reactions is the growth of oxides, plagioclase, apatite and kaersutite in the xenolith suite. The affect of secondary reactions on major element chemistry (e.g. increased $\mathrm{Fe}_{2} \mathrm{O}_{3}$ (total), $\mathrm{TiO}_{2}$ and $\mathrm{P}_{2} \mathrm{O}_{5}$ contents) has previously been discussed (Chapter 4.6.1). Host melt reactions, including oxidation and kaersutitisation, have occurred as open-system reactions.

Multi-element variation diagrams normalised to MORB (Pearce, 1983) highlight the trace element abundances and their dependence on the modal mineral assemblage (Figure 4.27). Large ion lithophile elements (LILEs), that do not partition readily in any mineral phase present in the suite (e.g. $\mathrm{K}, \mathrm{Rb}, \mathrm{Nb}$ and $\mathrm{Ce})$ systematically increase in abundance from Type $\mathrm{P}$ to Type $\mathrm{L}$ xenoliths. High field strength elements (HFSEs) that readily partition into mineral phases and are more enriched in Type P xenoliths becoming more depleted in Type L xenoliths.

The overall pattern of the xenoliths becoming relatively LILE-enriched and HFSE-depleted from Type $\mathrm{P}$ to Type $\mathrm{L}$ xenoliths may be due to a combination of the mineral assemblage and composition, and of secondary enrichment. The 


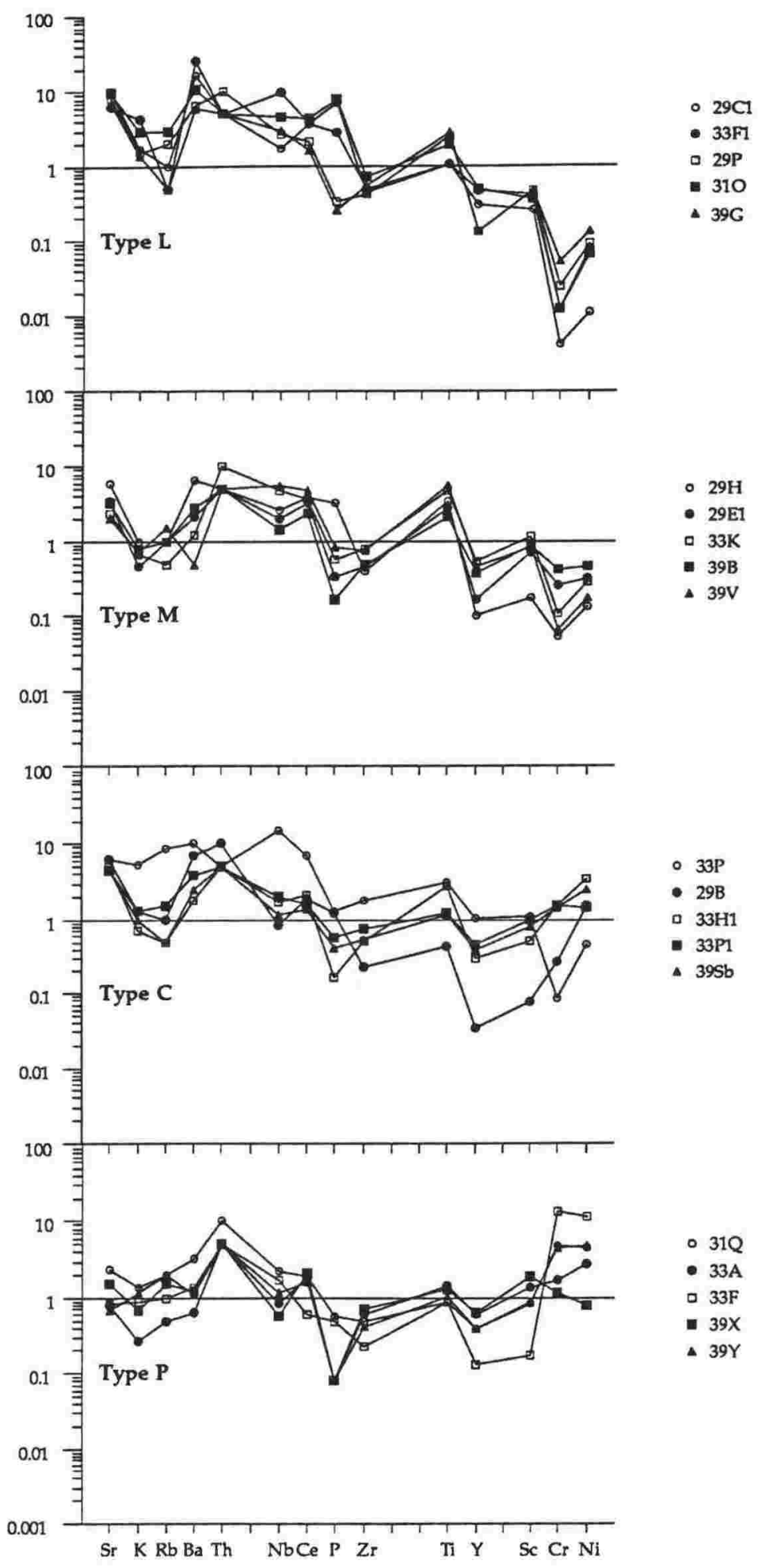

FIGURE 4.27: Multi element variation diagrams of trace elements in Mount Sidley xenoliths normalised to MORB (Pearce, 1983). Trace element abundances are low, reflecting the cumulate nature of the xenolith suite. Elements that readily partition into xenolith mineral phases are present in higher concentrations than other elements: e.g. $\mathrm{Ni}$ and $\mathrm{Cr}$ are high in the olivine and clinopyroxene-rich pyroxenite suite, and $\mathrm{Sr}$ and $\mathrm{Ba}$ are high in the plagioclase-rich granulite suite. The overall pattern of the xenolith suite ranges from MORB-like patterns in Type $P$ xenoliths, to relatively enriched LILE patterns in Type L xenoliths, reflecting their differing mineral assemblages and compositions, the secondary enrichment of the granulite suite, or both.

clinopyroxene-rich assemblage of the pyroxenite suite results in higher HFSE concentrations (particularly $\mathrm{Zr}, \mathrm{Ni}$ and $\mathrm{Cr}$ ) in the pyroxenite suite relative to the granulite suite. In contrast, the plagioclase-rich granulite assemblage would result in higher LILE contents (notably in Ba and Sr). The more evolved composition of 
granulite mineral phases (Chapter 4.4.6) may also have resulted in higher LILE contents than in the more primitive pyroxenite mineral assemblage. Furthermore, the enrichment of the granulite suite by alkaline silicate has also result in a relative enrichment of LILEs to HFSEs.

TABLE 4.23: Trace element (including rare earth element) analyses of Mount Sidley xenoliths, determined by INAA.

\begin{tabular}{|c|c|c|c|c|c|c|c|c|}
\hline $\begin{array}{l}\text { SAMPLE } \\
\text { Analysis } \\
\end{array}$ & $\begin{array}{c}\text { 90029G1 } \\
\text { rock }\end{array}$ & $\begin{array}{c}90029 \mathrm{H} 1 \\
\text { rock }\end{array}$ & $\begin{array}{c}90029 \mathrm{H} 1 \\
\mathrm{cpx}\end{array}$ & $\begin{array}{c}90029 \mathrm{H} 1 \\
\text { cpx re }\end{array}$ & $\begin{array}{c}\text { 90031D } \\
\text { rock }\end{array}$ & $\begin{array}{c}90033 \mathrm{C} \\
\text { rock }\end{array}$ & $\begin{array}{c}\text { 90033C } \\
\text { rock* }^{*}\end{array}$ & $\begin{array}{c}90033 C \\
\text { rock* }\end{array}$ \\
\hline Sc & 5.75 & 24.86 & 87.8 & 24.79 & 20.32 & 34.6 & 34.7 & 34.4 \\
\hline $\mathrm{Cr}$ & 2.3 & 10 & 16 & 11.6 & 3.8 & 872 & 875 & 872 \\
\hline $\mathrm{Ni}$ & 0 & 49 & 0 & 0 & 58 & 482 & 472 & 450 \\
\hline $\mathrm{Zn}$ & 32 & 48 & 108 & 50 & 61 & 88 & 85 & 70 \\
\hline $\mathrm{Rb}$ & 7 & 0 & 0 & 0 & 0 & 0 & 0 & 0 \\
\hline $\mathrm{Sr}$ & 1110 & 848 & 0 & 850 & 1111 & 530 & 417 & 400 \\
\hline $\mathrm{Ba}$ & 417 & 149 & 0 & 99 & 192 & 142 & 170 & 43 \\
\hline $\mathrm{La}$ & 14.94 & 4.07 & 3.24 & 4.18 & 17.83 & 6.52 & 6.61 & 6.49 \\
\hline $\mathrm{Ce}$ & 31.5 & 8.7 & 11.7 & 8.1 & 40.4 & 17.1 & 20.3 & 18.7 \\
\hline $\mathrm{Nd}$ & 17 & 5 & 8.3 & 3.9 & 21.1 & 10.7 & 12.8 & 11 \\
\hline $\mathrm{Sm}$ & 3.49 & 1.3 & 3.3 & 1.31 & 5.61 & 3.85 & 3.93 & 3.87 \\
\hline $\mathrm{Eu}$ & 3.26 & 1.05 & 1.11 & 1.064 & 2.7 & 1.38 & 1.36 & 1.373 \\
\hline $\mathrm{Tb}$ & 0.414 & 0.171 & 0.56 & 0.219 & 0.686 & 0.57 & 0.57 & 0.566 \\
\hline $\mathrm{Yb}$ & 0.56 & 0.39 & 0.97 & 0.4 & 1.14 & 0.93 & 0.99 & 0.93 \\
\hline Lu & 0.063 & 0.047 & 0.187 & 0.077 & 0.128 & 0.122 & 0.138 & 0.131 \\
\hline Hf & 0.37 & 0.94 & 2.95 & 0.93 & 1.02 & 2.26 & 2.29 & 2.11 \\
\hline $\mathrm{Ta}$ & 1.2 & 1 & 3.73 & 0.97 & 1.03 & 1.23 & 1.21 & 1.19 \\
\hline Th & 0.29 & 0.18 & 0 & 0.11 & 0.34 & 0.37 & 0.43 & 0.39 \\
\hline $\begin{array}{l}\text { SAMPLE } \\
\text { Analysis } \\
\end{array}$ & $\begin{array}{c}90033 X \\
\text { rock }\end{array}$ & $\begin{array}{c}\text { 90039G } \\
\text { rock }\end{array}$ & $\begin{array}{c}90039 \mathrm{G} \\
\mathrm{cpx}\end{array}$ & $\begin{array}{c}\text { 90039Sa } \\
\text { rock }\end{array}$ & $\begin{array}{c}\text { 90039Sa } \\
\mathrm{cpx}\end{array}$ & $\begin{array}{c}\text { 90039Sb } \\
\text { rock }\end{array}$ & $\begin{array}{c}90039 Y \\
\text { rock }\end{array}$ & \\
\hline $\mathrm{Sc}$ & 23.99 & 29.08 & 87.7 & 51 & 33.6 & 4.11 & 38.8 & \\
\hline $\mathrm{Cr}$ & 24.3 & 10.4 & 17.9 & 795 & 314 & 14.9 & 947 & \\
\hline $\mathrm{Ni}$ & 0 & 0 & 252 & 449 & 188 & 173 & 556 & \\
\hline $\mathrm{Zn}$ & 101 & 80 & 83 & 119 & 75 & 60 & 185 & \\
\hline $\mathbf{R b}$ & 0 & 0 & 0 & 0 & 0 & 11 & 10 & \\
\hline $\mathrm{Sr}$ & 780 & 816 & 0 & 0 & 528 & 1720 & 141 & \\
\hline $\mathrm{Ba}$ & 268 & 124 & 0 & 45 & 49 & 222 & 0 & \\
\hline La & 23.78 & 4.35 & 4.29 & 2.65 & 3.83 & 8.33 & 3.44 & \\
\hline $\mathrm{Ce}$ & 54.9 & 9.3 & 12.9 & 10 & 10.3 & 16.4 & 10.1 & \\
\hline $\mathrm{Nd}$ & 31.5 & 5 & 10 & 10.9 & 0 & 6.2 & 0 & \\
\hline $\mathrm{Sm}$ & 7.45 & 1.53 & 4.01 & 3.68 & 2.88 & 1.21 & 2.54 & \\
\hline Eu & 3.47 & 1.184 & 1.48 & 1.26 & 1.13 & 1.144 & 0.89 & \\
\hline $\mathrm{Tb}$ & 0.837 & 0.248 & 0.62 & 0.68 & 0.507 & 0.133 & 0.396 & \\
\hline $\mathrm{Yb}$ & 1.05 & 0.47 & 1.24 & 1.35 & 0.97 & 0.27 & 0.9 & \\
\hline Lu & 0.151 & 0.053 & 0.236 & 0.179 & 0.124 & 0.042 & 0.139 & \\
\hline Hf & 0.67 & 1.17 & 2.83 & 2.28 & 1.55 & 0.73 & 1.56 & \\
\hline $\mathrm{Ta}$ & 0.94 & 1.17 & 1.48 & 0.46 & 0.53 & 1.5 & 0.47 & \\
\hline Th & 0.42 & 0.18 & 0 & 0 & 0 & 0.39 & 0.18 & \\
\hline
\end{tabular}

cpx = clinopyroxene; rock $=$ whole rock sample; ${ }^{*}=$ repeat analysis 

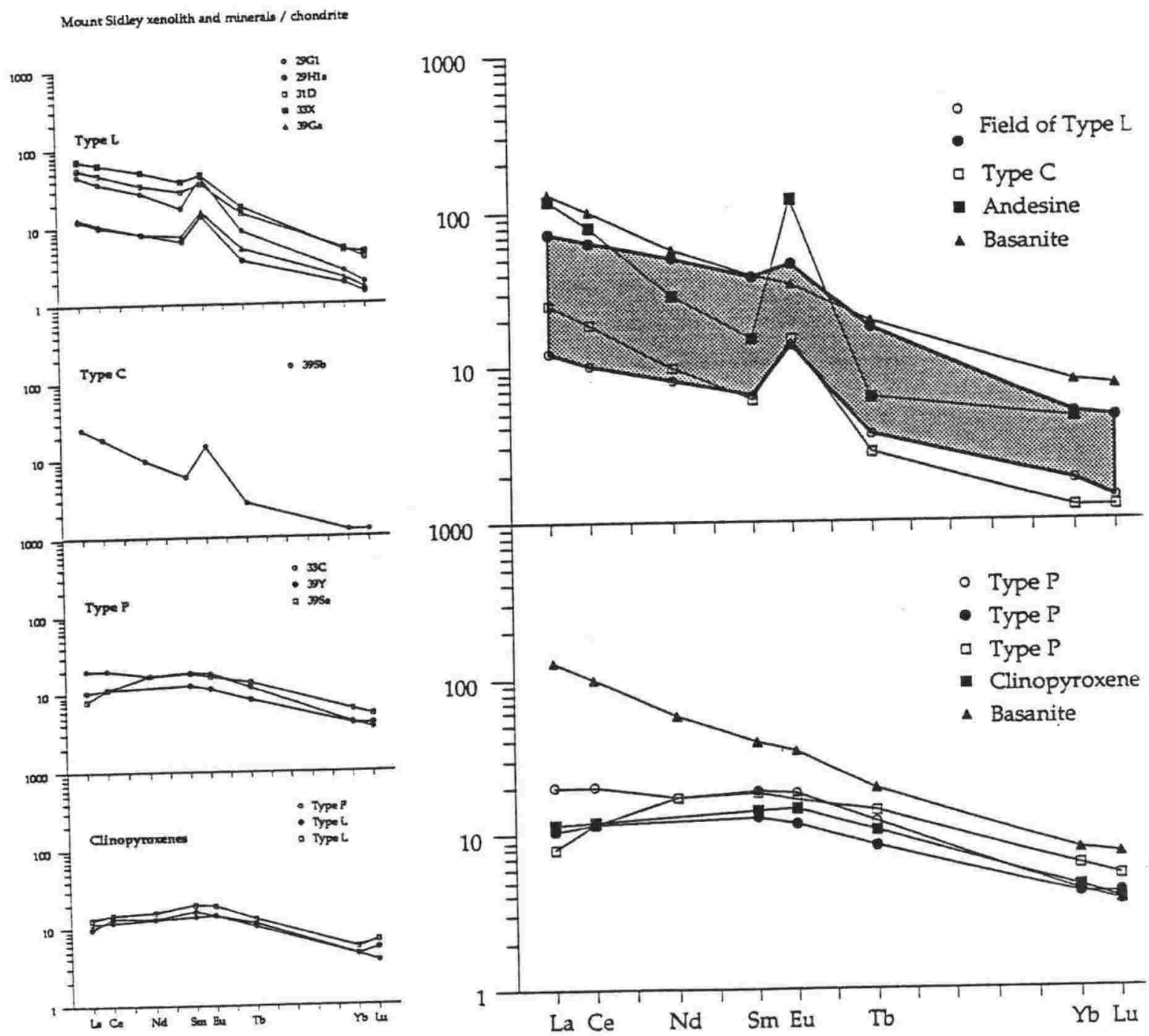

FIGURE 4.28: Rare Earth Elements normalised to chondrite (Wheatley and Rock, 1988) patterns for Mount Sidley xenoliths and minerals. All REE patterns are presented on the left side plots, including Type L, C and P xenoliths, and clinopyroxenes from Type $\mathrm{P}$ and $\mathrm{L}$ xenoliths (bottom left). The large plot at top right shows the field of REE patterns of Type $\mathrm{L}$ xenoliths compared to a Type $C$ xenolith, a host basanite from Mount Sidley (K. Panter pers. comm.), and an andesine from an alkaline magma in the McMurdo Volcanic Province, Antarctica (Kyle and Rankin, 1976). Type L patterns reflect the influence of plagioclase and host basanites, with an enrichment in REEs and a flattening of the positive Eu anomaly with basanite enrichment. Bottom left plot shows Type P xenoliths compared to clinopyroxene compositions and a host basanite. Type P patterns reflect their clinopyroxene compositions.

REE patterns of xenoliths normalised to chondrite (Wheatley and Rock, 1988) are presented as Figure 4.28, with all xenolith and mineral patterns from the Mount Sidley xenolith suite shown in the diagrams on the left, and composite diagrams on the right. REE and trace element contents analysed by INAA are presented as Table 4.23. 
Type $\mathrm{P}$ xenolith patterns show heavy rare earth element (HREE) depleted patterns, with a slight enrichment in light rare earth elements (LREEs). This is similar to clinopyroxene compositions, reflecting the dominance of clinopyroxene as a REE repository in the Type $\mathrm{P}$ pyroxenite suite. Plagioclase-bearing xenoliths (Type L and C in Figure 4.28) have higher LREE abundances and positive Eu anomalies, reflecting the presence of plagioclase.

Type L REEs exhibit a large range in concentrations from compositions similar to Type $C$ xenoliths, to more enriched patterns. This enrichment can not be due to increased plagioclase content, as there is no correlation of plagioclase abundance with enrichment. Furthermore an increased plagioclase content should preserve or increase the Eu anomaly with enrichment. The Eu anomaly however decreases, indicating that REE enrichment is due to another process.

The most enriched granulites have REE abundances approaching basanite in composition, notably with a decreasing positive Eu anomaly (Figure 4.28). Host melt enrichment of the xenolith suite discussed previously appears to have also enriched the granulite suite in REE abundance. The lack of host melt infiltration in the pyroxenite suite has left these xenoliths essentially free from enrichment.

TABLE 4.24: $\mathrm{Sr}, \mathrm{Nd}, \mathrm{Pb}$ and $\mathrm{O}$ Isotopic ratios for xenoliths from the Mount Sidley xenolith suite, and basanites from Mount Sidley (courtesy K. Panter). Rb and Sr errors are approximately $\pm 1 \mathrm{ppm}$. For analytical details see Appendix Six.

\begin{tabular}{|c|c|c|c|c|c|c|c|c|c|c|c|c|c|}
\hline SAMPLE & $\begin{array}{l}\text { Rock } \\
\text { Type }\end{array}$ & Mg\# & $\mathbf{R} \mathbf{b}$ & Sr & $\begin{array}{l}875 \mathrm{r} \\
86 \mathrm{Sr}_{\mathrm{r}}\end{array}$ & $\mathrm{Sm}$ & Nd & $\begin{array}{l}143 \mathrm{Nd} \\
144 \mathrm{Nd}\end{array}$ & eps $\mathrm{No}$ & $\begin{array}{r}\frac{206 \mathrm{~Pb}}{204 \mathrm{~Pb}} \\
\end{array}$ & $\begin{array}{l}202 \mathrm{~Pb} \\
204 \mathrm{~Pb}\end{array}$ & $\frac{208 \mathrm{~Pb}}{204 \mathrm{~Pb}}$ & $\Delta 180 \%$ \\
\hline \multicolumn{14}{|c|}{ Mount Sidley Granulites } \\
\hline $90029 \mathrm{G} 1$ & Type L & 38.44 & 2 & 1190 & $0.703466+-26$ & 3 & 17 & $0.512864+-5$ & 4.41 & 19.364 & 15.650 & 39.008 & \\
\hline $90029 \mathrm{H} 1$ & Type L & 49.21 & 1 & 903 & $0.703250+-10$ & 1 & 5 & & & & & & 4.62 \\
\hline 90031D & Type L & & 4 & 1122 & $0.703490+9$ & 6 & 21 & $0.512870+-5$ & 4.53 & 19.589 & 15.660 & 39.182 & 5.33 \\
\hline $90033 x$ & Type L & 36.64 & 1 & 869 & $0.703758+-11$ & 7 & 32 & & & 18.005 & 15.577 & 37.876 & 4.04 \\
\hline 90039G & Type L & 44.69 & 1 & 849 & $0.703250+-9$ & 2 & 5 & & & & & & \\
\hline \multicolumn{14}{|c|}{ Mount Sidley Pyroxenites } \\
\hline $90033 \mathrm{C}$ & Type P & 69.18 & 3 & 420 & $0.703066+-12$ & 4 & 11 & & & & & & \\
\hline 90039Sa & Type P & 68.16 & 1 & 67 & $0.702861+7$ & 1 & 6 & $0.502819+-5$ & 3.53 & 17.653 & 15.539 & 37.378 & 4.13 \\
\hline $90039 \mathrm{Sb}$ & Type C & 67.00 & 1 & 529 & $0.702886+-17$ & 1 & 6 & & & 18.252 & 15.607 & 38.087 & 3.78 \\
\hline $90039 Y$ & Type P & 70.72 & 4 & 80 & $0.702931+-11$ & 3 & 1 & & & & & & \\
\hline \multicolumn{14}{|c|}{ Mount Sidley Volcanics } \\
\hline MB27.5 & Basanite & 52.00 & 32 & 877 & 0.702999 & 8 & 36 & 0.512907 & 5.31 & 19.524 & 15.650 & 39.099 & 5.17 \\
\hline MB29.4 & Mugearite & & & & 0.703118 & & & 0.512814 & 3.50 & 19.534 & 15.669 & 39.174 & 1.78 \\
\hline K168 & Basanite & 50.10 & 37 & 877 & 0.703025 & 8 & 36 & 0.512902 & 5.21 & & & & 5.68 \\
\hline
\end{tabular}




\subsubsection{Isotope geochemistry}

Measured isotopic compositions of Mount Sidley xenoliths, and Mount Sidley lavas (courtesy K. Panter), are presented as Table 4.24. Samples were selected to span the range of compositions within and between the xenolith types as much as possible, and only fresh cores were analysed. The limited number of analyses restricts the use of the isotopes, as the full isotopic compositional range of the xenolith suite cannot be determined. Details of isotopic analyses are presented in Appendix Six.

\section{Stable (oxygen) isotopes}

Mount Sidley xenoliths are depleted in $\Delta^{18} \mathrm{O}$ relative to magmatic values, and are similar to the Mount Sidley volcanic suite (Figure 4.29). Mount Sidley volcanics and xenoliths have low $\Delta^{18} \mathrm{O}$ values, interpreted to be the result of depletion by Antarctic meteoric waters ( $\Delta^{18} \mathrm{O}-40 \%$ ) (Panter pers. comm.). Only a small amount of exchange with the highly depleted meteoric waters will result in low $\Delta^{18} \mathrm{O}$ values, masking original $\Delta^{18} \mathrm{O}$ values.

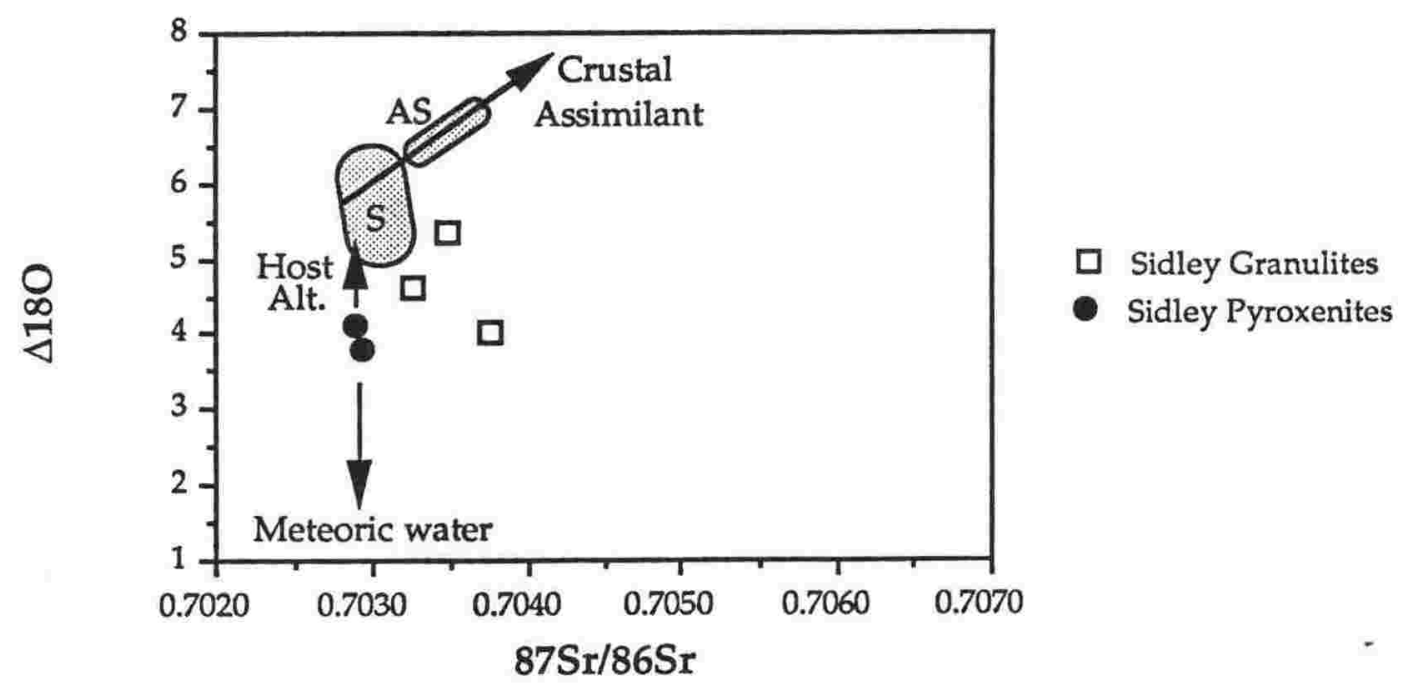

FIGURE 4.29: ${ }^{87} \mathrm{Sr} /{ }^{86} \mathrm{Sr}$ v $\Delta^{18} \mathrm{O}$ plot of Mount Sidley xenoliths and volcanics. The volcanics trend towards low $\Delta^{18} \mathrm{O}$ values as a result of interaction with depleted Antarctic meteoric waters $\left(\Delta^{18} \mathrm{O}\right.$ $-40 \%$ ). The low $\Delta^{18} \mathrm{O}$ values of the xenolith suite may also be due to exchange with Antarctic meteoric waters. Some volcanics are enriched, possibly as a result of crustal contamination. AS = altered Sidley volcanics, $\mathrm{S}=$ Sidley volcanics.

Some volcanics however have higher $\Delta^{18} \mathrm{O}$ values, and corresponding higher ${ }^{87} \mathrm{Sr} /{ }^{86} \mathrm{Sr}$ ratios, possibly due to a crustal assimilant (AS (altered Sidley) volcanics of Figure 4.29). Crustal contamination of the xenolith suite cannot be discounted, particularly in the granulite suite, which has higher $\Delta^{18} \mathrm{O}$ values, and higher ${ }^{87} \mathrm{Sr} /{ }^{86} \mathrm{Sr}$ ratios than the pyroxenite suite. 


\section{Radiogenic ( $\mathrm{Sr}, \mathrm{Nd}, \mathrm{Pb})$ isotopes}

Measured ${ }^{87} \mathrm{Sr} /{ }^{86} \mathrm{Sr}$ ratios of the xenolith suite are low (Figure 4.30 ), with pyroxenites (0.702861-0.703066) having lower ratios than granulites (0.7032500.703758 ). These ratios do not correspond with $\mathrm{Rb} / \mathrm{Sr}$ ratios, as a result of: the errors involved in determining the very low $\mathrm{Rb}$ (typically 1-2 ppm) contents of the xenolith suite (errors by $\mathrm{XRF}$ are approximately $\pm 1 \mathrm{ppm}$ at low $\mathrm{Rb}$ concentrations (Roser, 1983)); depletion of $\mathrm{Rb}$ contents in the suite by metamorphic processes; enrichment of the suite by secondary processes, altering the $\mathrm{Rb} / \mathrm{Sr}$ ratio; or a combination of these factors. The lack of a correlation between ${ }^{87} \mathrm{Sr} /{ }^{86} \mathrm{Sr}$ and $\mathrm{Rb} / \mathrm{Sr}$ ratios prohibits any calculation of a meaningful model age for the xenolith suite.

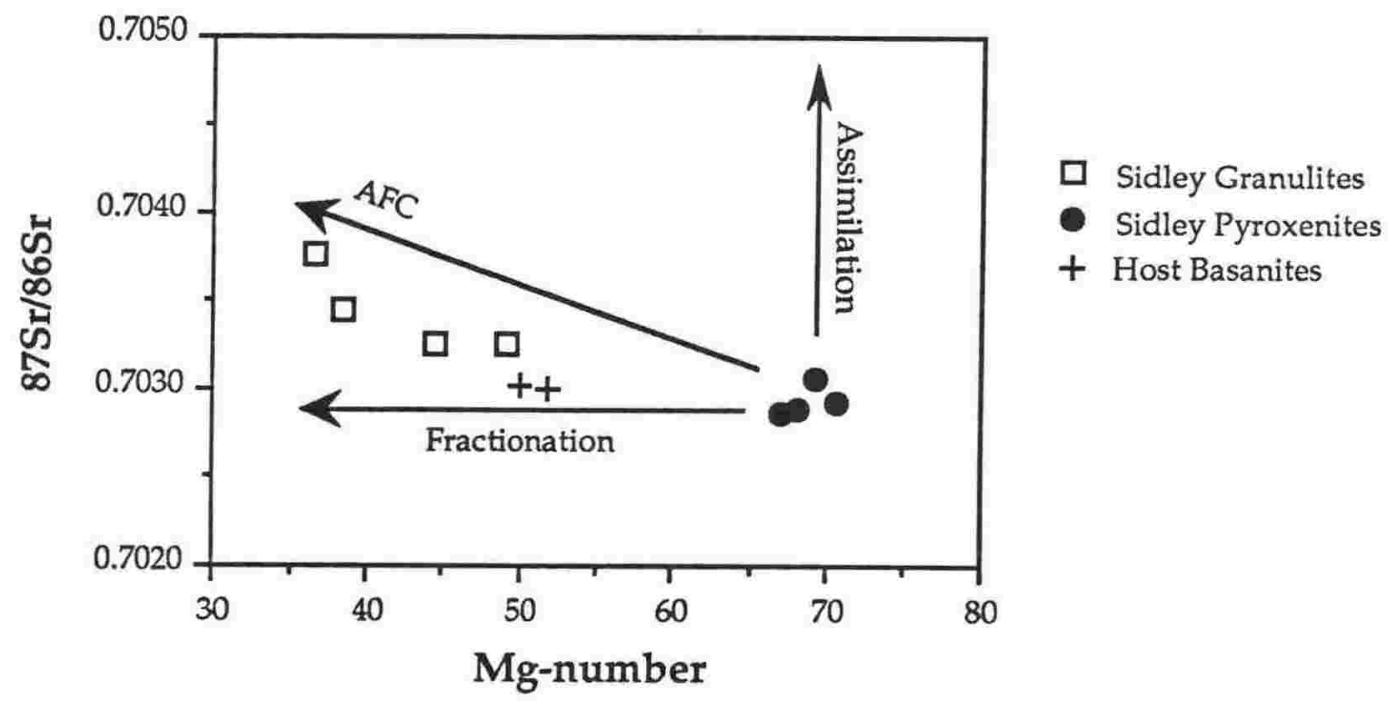

FIGURE 4.30: ${ }^{87} \mathrm{Sr} /{ }^{86} \mathrm{Sr}$ v Mg\# plot of Mount Sidley xenoliths shows a negative trend, with decreasing Mg\# accompanying increasing ${ }^{87} \mathrm{Sr} /{ }^{86} \mathrm{Sr}$ ratios. Host basanites have ${ }^{87} \mathrm{Sr} /{ }^{86} \mathrm{Sr}$ ratios too low for their enrichment by silicate melts to be responsible for the observed trend. This correlation may be due to AFC processes in the lower crust, resulting from crystal fractionation of the melt, providing the latent heat required for the assimilation of country rock (Rudnick et al., 1986). The result is an evolved series of cumulates with lower $\mathrm{Mg \# s}$ (due to fractionation), and higher ${ }^{87} \mathrm{Sr} /{ }^{86} \mathrm{Sr}$ ratios (due to assimilation). The effects of pure crystal fractionation and AFC processes are shown.

${ }^{87} \mathrm{Sr} /{ }^{86} \mathrm{Sr}$ ratios correlate with $\mathrm{Mg} \# \mathrm{~s}$, forming a curved trend from the relatively high $\mathrm{Mg \#} \mathrm{-} \mathrm{low}{ }^{87} \mathrm{Sr} /{ }^{86} \mathrm{Sr}$ pyroxenites, to the relatively low $\mathrm{Mg \#} \mathrm{-} \mathrm{high}$ ${ }^{87} \mathrm{Sr} /{ }^{86} \mathrm{Sr}$ granulites (Figure 4.30 ). The host lavas have ${ }^{87} \mathrm{Sr} /{ }^{86} \mathrm{Sr}$ ratios too low to produce this trend. Furthermore, interaction with more evolved volcanics passing through the lower crust cannot have increased the ${ }^{87} \mathrm{Sr} /{ }^{86} \mathrm{Sr}$ ratios of the xenolith suite, as the high $\mathrm{Rb} / \mathrm{Sr}$ ratios of the evolved volcanics should also have increased the $\mathrm{Rb} / \mathrm{Sr}$ ratio of the xenoliths.

Such correlations have been inferred to represent combined fractionation and assimilation (AFC) processes in the lower crust (Rudnick et al., 1986). Mg\#s 
decrease due to the continuing crystal fractionation of the coexisting melt, producing an evolving suite of cumulate rocks (represented here by the xenolith suite). As fractionation provides the latent heat necessary to assimilate crustal rock (Taylor, 1980), ${ }^{87} \mathrm{Sr} /{ }^{86} \mathrm{Sr}$ ratios increase with continued fractionation due to the accompanying larger amounts of assimilant. If such a process has occurred during crystallisation of the xenolith suite, the low ${ }^{87} \mathrm{Sr} /{ }^{86} \mathrm{Sr}$ ratios require only a small amount of high ${ }^{87} \mathrm{Sr} /{ }^{86} \mathrm{Sr}$ assimilant (i.e. felsic rocks), or a low ${ }^{87} \mathrm{Sr} /{ }^{86} \mathrm{Sr}$ assimilant (i.e. relatively mafic rocks).

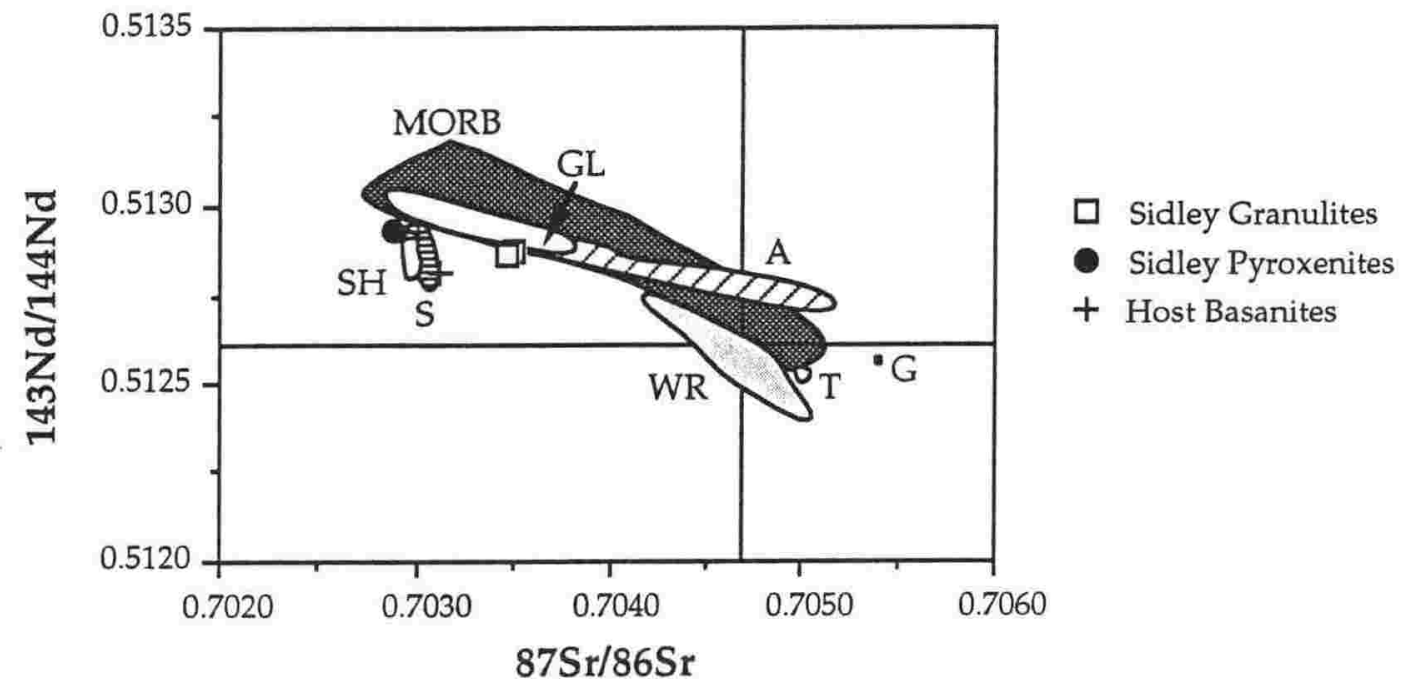

FIGURE 4.31: ${ }^{87} \mathrm{Sr} /{ }^{86} \mathrm{Sr} \mathrm{v}{ }^{143} \mathrm{Nd} /{ }^{144} \mathrm{Nd}$ plot of Mount Sidley xenoliths, reflecting their mantle-like isotopic signature, with little or no contamination by evolved crustal material. Host basanites fall within the Mount Sidley volcanic field, and differ from the granulites, indicating no genetic relation between them. Fields of basalts shown for comparison are from Wilson (1989): $A=$ Azores; $G$ = Gough; $\mathrm{Gl}=$ Galapagos; MORB = Mid Ocean Ridge Basalts; $\mathrm{S}=$ Sidley; $\mathrm{SH}=$ St Helena; $\mathrm{T}=$ Tristan da Cunha; WR = Walvis Ridge.

A limited number of ${ }^{143} \mathrm{Nd} /{ }^{144} \mathrm{Nd}$ ratios indicates a high ${ }^{143} \mathrm{Nd} /{ }^{144} \mathrm{Nd}$ - low ${ }^{87} \mathrm{Sr} /{ }^{86} \mathrm{Sr}$ isotopic signature for the xenolith suite (Figure 4.31 ). These ratios are well above bulk earth values, indicating crystallisation from mantle melts, with little or no contamination by felsic crust. Host rock ratios fall within the Mount Sidley volcanic field (Panter pers. comm.), which is similar to St Helena (HIMU) ratios. The host volcanics are similar to the single pyroxenite ratio, but differ from the granulites, which have higher ${ }^{87} \mathrm{Sr} /{ }^{86} \mathrm{Sr}$ ratios. This indicates that the host melts have not affected the $\mathrm{Sr}-\mathrm{Nd}$ isotopic ratios of the xenolith suite, and that the xenolith and volcanic rocks are not genetically related (Lee et al., 1993).

The xenolith suite has highly variable $\mathrm{Pb}$-isotopic ratios (Figure 4.32), ranging from unradiogenic pyroxenites to radiogenic granulites, which form a trend parallel to the Northern Hemisphere Reference Line (NHRL). Host 
basanites have high $\mathrm{Pb}$-isotope ratios, approaching those of St Helena volcanics. The range in $\mathrm{Pb}$-isotopic ratios of the xenolith suite is extremely large compared to other lower crustal suites (Chapter 7.5.2).

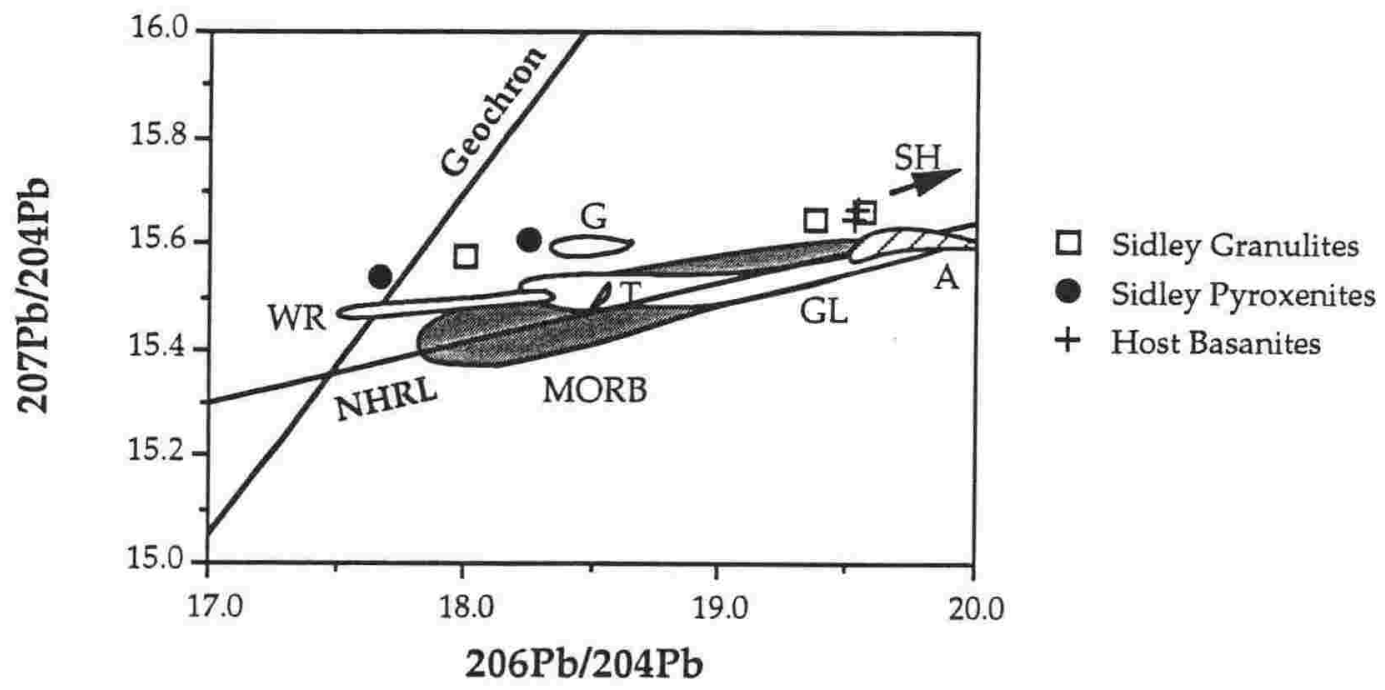

FIGURE 4.32: ${ }^{206} \mathrm{~Pb} /{ }^{204} \mathrm{~Pb} \mathrm{v}{ }^{207} \mathrm{~Pb} /{ }^{204} \mathrm{~Pb}$ plot of Mount Sidley xenoliths and volcanics, indicating a mixing trend from unradiogenic pyroxenites to radiogenic granulites with St Helena-like ratios. Host basanites also fall along this trend. The trend is near parallel to the Northern Hemisphere Reference Line (NHRL), and to the right of the $4.57 \mathrm{Ga}$ Geochron. Fields shown for comparison are as in Figure 4.31.

The extensive enrichment in the granulite suite, and the well preserved nature of the pyroxenite suite (i.e. no metamorphic recrystallisation, no indication of secondary enrichment) indicates that the trend is a result of mixing between original ratios represented by the pyroxenite suite, and the radiogenic host melts. This is unlike the $\mathrm{Sr}$ and $\mathrm{Nd}$ isotopic ratios of the xenolith suite, which have not been altered by contamination of the host melts.

$\mathrm{Nd}$ and $\mathrm{Sr}$ isotopic ratios are insensitive to mixing with a St Helena-like component, as their ratios are not vastly different (Wilson, 1989). The extreme variation in $\mathrm{Pb}$ isotopic ratios between the xenoliths and the volcanics means that only a small amount of mixing is necessary to have a large affect on $\mathrm{Pb}$ isotopic compositions. In contrast, the similarity of $\mathrm{Sr}$ and $\mathrm{Nd}$ isotopic ratios between the two requires a large amount of mixing to have any affect on $\mathrm{Sr}$ and $\mathrm{Nd}$ isotopic ratios.

As the trend exhibited by the xenolith suite is the result of mixing, it has no age significance. The unradiogenic $\mathrm{Pb}$-ratios of the xenoliths are very different to the radiogenic volcanic suite, further indicating no genetic relationship between the suites. 


\subsubsection{Summary and discussion of whole rock geochemistry}

The lower crustal xenolith suite from Mount Sidley consists of cumulate rocks with little or no intercumulus melt. The cumulate mineral assemblage, consisting of olivine, clinopyroxene, plagioclase, and Fe-Ti oxides, controls the whole rock geochemistry of the xenolith suite. Variations in geochemistry are the result of differing mineral phases, and differing mineral compositions, in the xenoliths. Elements that readily partition into the mineral phases are present in high concentrations in the xenolith suite, and elements that are excluded from the mineral phases are present in only low concentrations. Secondary enrichment by the host alkaline silicate melts has also affected the xenolith suite, most notably the extensively oxidised granulite suite.

The salient geochemical features of the xenolith suite include:

- the xenolith suite is nepheline-normative and mafic in composition. The abundance of elements in the suite, as discussed above, is controlled by the mineral assemblage. Trace element abundances are low, except for elements that are preferentially incorporated into mineral phases (e.g. $\mathrm{Sr}$ and $\mathrm{Ba}$ in plagioclase, $\mathrm{Cr}$ in clinopyroxene, and $\mathrm{Ni}$ in olivine). REE contents are controlled by plagioclase in the granulite suite (high LREE contents with a positive Eu anomaly), and by clinopyroxene in the pyroxenite suite (LREE-depleted relative to HREE). These minerals are responsible for the main differences in composition between the granulite and pyroxenite suites;

- the more evolved mineral assemblage of xenoliths from Type $\mathrm{P}$ to Type $\mathrm{L}$ xenoliths (e.g. lower Fo content of olivine, and lower An content of plagioclase), is manifested as lower Mg\#s, and generally higher mobile trace element contents (e.g. LILEs, LREEs) in Type P to Type L xenoliths;

- the xenolith suite has low ${ }^{87} \mathrm{Sr} /{ }^{86} \mathrm{Sr}$ ratios and high ${ }^{143} \mathrm{Nd} /{ }^{144} \mathrm{Nd}$ ratios, indicating crystallisation from a mantle melt, with little or no contamination by an evolved crustal component. A trend of decreasing $\mathrm{Mg \#}$ with increasing ${ }^{87} \mathrm{Sr} /{ }^{86} \mathrm{Sr}$ indicates that $\mathrm{AFC}$ processes may have occurred at the time of crystallisation of the xenolith suite;

- $\mathrm{Pb}$ isotopic ratios exhibit an extremely large range from unradiogenic to radiogenic ratios, as a result of mixing between the unradiogenic xenoliths and the radiogenic St Helena-like host melts. This is in contrast to the $\mathrm{Sr}$ and $\mathrm{Nd}$ isotopic ratios of the xenoliths, which have not been affected by the host melts. The difference in isotopic ratios $(\mathrm{Sr}, \mathrm{Nd}$ and $\mathrm{Pb}$ ) between the xenoliths and the host melts indicates that they are not genetically related;

- secondary enrichment by the host alkaline melts has resulted in higher LILE, LREE and $\mathrm{Pb}$ isotopic ratios in affected xenoliths. Furthermore, the 
crystallisation of microphenocrysts (e.g. kaersutite, plagioclase, Fe-Ti oxides, apatite) by the host melt within the xenoliths has resulted in the enrichment of elements compatible in these mineral phases (e.g. $\mathrm{TiO}_{2}, \mathrm{~K}_{2} \mathrm{O}, \mathrm{P}_{2} \mathrm{O}_{5}, \mathrm{H}_{2} \mathrm{O}, \mathrm{Rb}, \mathrm{Sr}, \mathrm{V}$ in the xenolith suite.

\subsection{Summary and Conclusion}

\subsubsection{Summary of the xenolith suite}

The Mount Sidley xenolith suite is a series of genetically related cumulates that crystallised from a single melt or series of melts. The suite can be petrographically and geochemically divided into four types; Type P, Type C, Type M and Type L . A summary of their characteristics is presented as Table 4.25.

Type P (pyroxenites) xenoliths are olivine + clinopyroxene cumulates. They have with primitive characteristics (e.g. Mg\# of 67-80), and represent the products of early fractionation of the crystallising melt. Type $\mathrm{C}$ (plagioclase-bearing pyroxenites) have more evolved compositions than Type $\mathrm{P}$ xenoliths, and represent a later stage of crystallisation where plagioclase has started crystallising as an intercumulus phase. Type $\mathrm{M}$ (mafic granulites) are olivine + clinopyroxene granulites with modal plagioclase occurring both as a cumulus and an intercumulus phase. Type $\mathrm{M}$ compositions are more evolved than the pyroxenite suite, with a small overlap in composition with Type C xenoliths. Type L (layered granulites) xenoliths have the most evolved compositions (Mg\# of 33-50) and represent the last identified fractionation episode of the melt/s.

The granulite suite (Type $\mathrm{L}$ and $\mathrm{M}$ xenoliths) has relict igneous textures with a strong metamorphic overprint of recrystallised equant grains with $120^{\circ}$ triple junctions. Deformation features are also apparent in these xenoliths. Type C pyroxenites show minimal signs of metamorphism and deformation, and Type $P$ pyroxenites have no metamorphic texture and are deformation-free.

Mineral compositions vary between xenolith types. Pyroxenite minerals have more primitive characteristics (e.g. higher Fo contents of olivine, and higher An contents in plagioclase) than granulite minerals. Variations in mineral chemistry indicate that the xenolith suite is genetically related, and a gradation in mineral chemistry from primitive Type $\mathrm{P}$ compositions to evolved Type $\mathrm{L}$ compositions suggests that the suite represents the products of fractional crystallisation from an evolving melt, as identified in many layered cumulates exposed at the surface (e.g. Wager and Brown, 1968; Grapes, 1975; Nicol, 1977; Parsons, 1987; Baker, 1990). 
TABLE 4.25: Summary of the main characteristics of the Mount Sidley xenolith suite. Chemical characteristics are those of the xenoliths at present (i.e. after modification by secondary processes). There is no REE data for Type $M$ and Type $C$ xenoliths, and no isotopic data for Type $M$ xenoliths.

\begin{tabular}{|c|c|c|c|c|}
\hline TYPE & Type L & Type M & Type C & Type $P$ \\
\hline TEXTURE & $\begin{array}{c}\text { Meta-Igneous } \\
\text { Layered } \\
\text { Granulites }\end{array}$ & $\begin{array}{c}\text { Meta-Igneous } \\
\text { Layered } \\
\text { Granulites }\end{array}$ & $\begin{array}{c}\text { Igneous } \\
\text { Cumulate } \\
\text { Pyroxenites }\end{array}$ & $\begin{array}{c}\text { Igneous } \\
\text { Cumulate } \\
\text { Pyroxenites }\end{array}$ \\
\hline MINERALOGY & $\mathrm{Pl}+\mathrm{Ol}+\mathrm{Cpx}$ & $\mathrm{Plag}+\mathrm{Cpx}+\mathrm{Ol}$ & $\mathrm{Cpx}+\mathrm{Ol}+\mathrm{Plag}+\mathrm{Sp}$ & $\mathrm{Cpx}+\mathrm{Ol}+\mathrm{Sp}$ \\
\hline TEMP. $\left({ }^{\circ} \mathrm{C}\right)$ & $980-1160$ & $1060-1150$ & $1080-1140$ & $1160-1240$ \\
\hline PRESSURE (kb) & $4.0-6.5$ & $4.5-6.5$ & $9.0-11.5$ & $8.0-12.0$ \\
\hline $\begin{array}{l}\text { SECONDARY } \\
\text { MINERALS }\end{array}$ & $\begin{array}{c}\text { Fe-Ti oxides } \\
\text { Apatite } \\
\text { Kaersutite }\end{array}$ & $\begin{array}{l}\text { Fe-Ti oxides } \\
\text { Apatite }\end{array}$ & $\begin{array}{l}\text { Kaersutite } \\
\text { Rhönite }\end{array}$ & $\begin{array}{l}\text { Kaersutite } \\
\text { Rhönite }\end{array}$ \\
\hline $\begin{array}{l}\text { MAJOR } \\
\text { ELEMENTS }\end{array}$ & $\begin{array}{l}\text { High } \mathrm{Si} \text {, alkalis } \\
\text { Low Mg\# }\end{array}$ & $\begin{array}{l}\text { High Ti, Fe, P } \\
\text { Low Si, Mg\# }\end{array}$ & High Mg\# & High $\mathrm{MgO}, \mathrm{Mg \#}$ \\
\hline $\begin{array}{l}\text { TRACE } \\
\text { ELEMENTS }\end{array}$ & $\begin{array}{l}\text { High } \mathrm{Sr}, \mathrm{Ba} \\
\text { Low } \mathrm{Ni}, \mathrm{Cr}\end{array}$ & Low $\mathrm{Ni}, \mathrm{Cr}$ & High $\mathrm{Ni}, \mathrm{Cr}$ & High $\mathrm{Ni}, \mathrm{Cr}$ \\
\hline REE & LREE-enriched & & LREE-enriched & LREE-depleted \\
\hline ISOTOPES & $\begin{array}{l}\text { Low } 87 \mathrm{Sr} / 86 \mathrm{Sr} \\
\text { Radiogenic } \mathrm{Pb}\end{array}$ & & $\begin{array}{l}\text { Low } 87 \mathrm{Sr} / 86 \mathrm{Sr} \\
\text { Unradiogenic } \mathrm{Pb}\end{array}$ & $\begin{array}{l}\text { Low } 87 \mathrm{Sr} / 86 \mathrm{Sr} \\
\text { Unradiogenic } \mathrm{Pb}\end{array}$ \\
\hline
\end{tabular}

The melt-free cumulate nature of the xenolith suite dominates their geochemical characteristics. Elements abundant in the cumulate phases are present in large concentrations, and elements that do not partition into xenolith mineral phases are low in abundance. As such, geochemical variation between xenolith types is a result of varying mineral assemblages, abundances (notably the presence or absence of plagioclase), and compositions.

Secondary reactions are evident in the xenolith suite, resulting from the migration of the host silicate melts at source depths. Kaersutite has replaced clinopyroxene in many pyroxenites, but this process is rare in the granulites. Melts are rarely associated with kaersutitisation, suggesting that it is a solid-solid or gas-solid reaction, and may represent alteration by derivatives of the silicate melt rather than the liquid itself. The granulite suite has been extensively oxidised, with olivine breaking down into two phases, and plagioclase showing 
disequilibrium textures in contact with the oxidising agent. Secondary oxide, apatite and plagioclase growth has accompanied oxidation. Oxidation is not an extensive process in the pyroxenite suite.

These reactions have resulted in the chemical enrichment of the xenolith suite, particularly of the extensively oxidised granulite suite. Modal mineral growth has enriched the xenoliths in elements compatible in these mineral phases (e.g. $\mathrm{K}, \mathrm{H}_{2} \mathrm{O}, \mathrm{Na}$ in kaersutite; $\mathrm{Fe}$, $\mathrm{Ti}$ in oxides; $\mathrm{P}$ in apatite). Interaction with host silicate melts has resulted in the enrichment of mobile elements, such as LILEs, LREEs, and isotopic compositions. This mineral and chemical enrichment of the xenolith suite in their source regions represents the modal metasomatism (Dawson, 1982; Harte, 1987; Menzies et al., 1987) of the lower crust beneath Mount Sidley by melts related to present-day Cenozoic volcanism. In addition to the metasomatism of the xenolith suite, the crystallisation of microphenocrysts from the infiltrating melt and interaction with the lower crust has resulted in assimilation and fractional crystallisation of the infiltrating melt at lower crustal depths (Chapter 4.5.4). These processes, and their affects, as further discussed in Chapter 8.3.

\subsubsection{Nature of the crystallising melt and cumulate derivatives}

The characteristics of the melt that crystallised the xenolith suite cannot be determined from elemental abundances of the xenolith suite, as they are cumulates and not liquids. However, several characteristics of the melt can be ascertained from the composition of the xenolith suite, in particular from the pyroxenite suite, which has not undergone metamorphic recrystallisation, and in which the affect of secondary processes have been minimal, thus retaining the characteristics of the protolith:

- the mineral assemblage of olivine + clinopyroxene \pm plagioclase requires the melt to have had a mafic composition;

- the appearance of new cumulus phases (notably plagioclase), and of more evolved compositions (lower $\mathrm{Mg}: \mathrm{Mg}+\mathrm{Fe}$ ratios of mafic minerals, and lower An content of plagioclase) from Type $\mathrm{P}$ to Type $\mathrm{L}$ xenoliths, indicates that the melt was evolving by fractional crystallisation;

- Fo contents of olivine from the first formed cumulates (Type $P$ pyroxenites) of Fo 67-80 require an initial $\mathrm{Mg} \#$ of $>60$, indicating a mantle melt;

- isotopic ratios of unaltered pyroxenites indicate crystallisation from a melt with low ${ }^{87} \mathrm{Sr} /{ }^{86} \mathrm{Sr}$, high ${ }^{143} \mathrm{Nd} /{ }^{144} \mathrm{Nd}$ and unradiogenic $\mathrm{Pb}$ ratios. The primitive $\mathrm{Sr}-\mathrm{Nd}$ ratios of the xenolith suite indicate that isotopically evolved crustal material was not assimilated into the crust; 
- the absence of orthopyroxene as a mineral phase, the Ti-rich and Ca-rich clinopyroxene compositions, the Cr-poor spinel compositions suggests that the crystallising melt may have been alkaline.

From these features, it is clear that the melt that crystallised the xenolith suite was a primitive mafic melt derived from a mantle source, possibly an enriched source. The xenolith suite represents the cumulate products of fractional crystallisation of this melt (Figure 4.33).

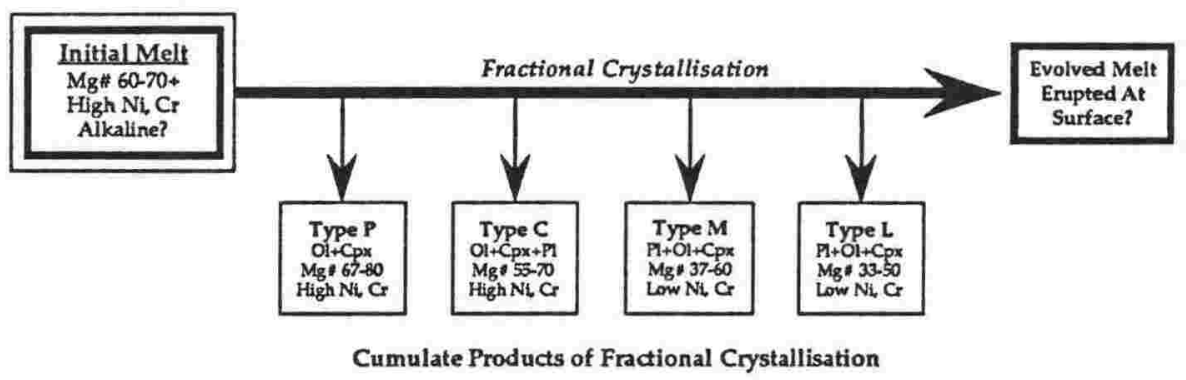

FIGURE 4.33: Crystallisation sequence of the Mount Sidley xenolith suite from a primitive melt sourced from a depleted mantle. Xenolith types crystallised in the sequence; Type P, Type C, Type M, and Type L

The late Cenozoic volcanics that brought the suite to the surface cannot have been the crystallising melt for a number of reasons:

- metamorphic textures in the xenolith suite indicates crystallisation prior to entrainment in the host melts and ascent to the surface;

- the volcanics and the xenolith suite have differing isotopic compositions;

- secondary mineral reactions have occurred wherever the host melts have come into contact with the xenolith suite. In particular, severe disequilibration reactions exhibited by olivine and plagioclase indicate that they are in disequilibrium with the melt and cannot have crystallised from it;

- crystallisation of plagioclase from the melt requires a negative Eu anomaly in the crystallising melt, which is not present.

Melts fitting the criteria of the crystallising melt have not been detected from Marie Byrd Land to date. Late Cenozoic alkaline volcanics can be discounted as discussed above, and the xenolith suite does not have any arc-related characteristics to link them with the Carboniferous volcanics on the MBL coast (Laird, 1991b). They cannot represent melts that have not reached the surface, as they would then have melt-like compositions, rather than cumulate compositions. The xenolith suite may have been derived from a melt that failed to reach the surface, or represent an old, possibly original lower crust. 


\subsubsection{Stratigraphy of the lower crust and secondary processes.}

Textural and chemical relationships indicate a gradation of xenolith types from Type $\mathrm{P}$ to Types C, M and L. The presence of composite xenoliths (xenoliths intermediate to two types, or xenoliths of one type containing another xenolith type) further indicates that interlayering of xenolith types occurs (Figure 4.3).

Geothermometry and geobarometry calculations indicate a high geothermal gradient in the lithosphere beneath Mount Sidley, with higher temperatures and pressures of equilibration in the pyroxenite suite compared to the granulite suite. This suggests that the gradation from Type $\mathrm{P}$ to Type $\mathrm{L}$ xenolith types is stratigraphic, with pyroxenites occurring at lower levels and granulites at higher levels in the lithosphere (Figure 4.34).

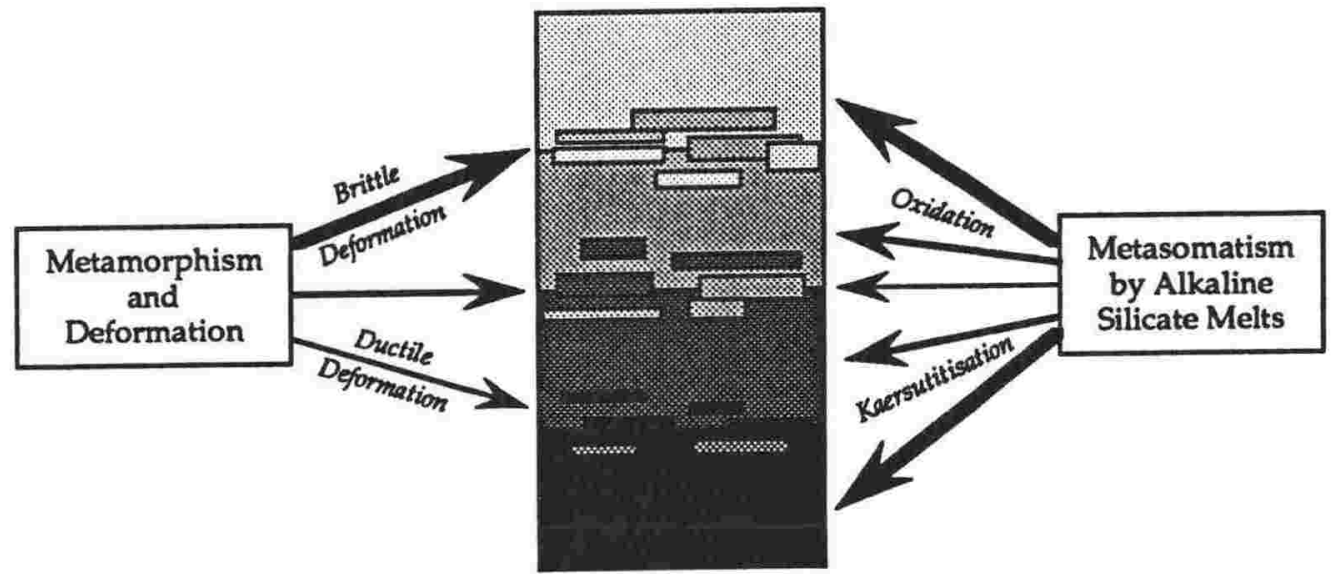

\section{METAMORPHISM}

Recrystallisation of mineral phases to equant grains, with no apparant chemical change.

\section{CRYSTALLISATION}

Crystallisation of cumulates from a primitive melt, sourced from depleted mantle.

\section{METASOMATISM}

Enrichment of LILES, LREES, isotopic ratios, and elements compatible in crystallising phases.

FIGURE 4.34: Stratigraphic sequence of the xenolith suite from Type $P$ pyroxenites (darkest shade) at lower depths to Type L granulites (lightest shade) at upper levels. Metamorphic processes have recrystallised the upper levels, and metasomatism by alkaline melts has enriched the lower crust, especially in the upper levels. The extent/secondary processes at different levels is represented by the thickness of the arrows.

The extent of metamorphism, deformation and secondary processes is greatest in Type $\mathrm{L}$ xenoliths and least in Type $\mathrm{P}$ xenoliths, indicating that these processes become more extensive at higher crustal levels. The style of deformation changes with depth, from brittle at higher levels to ductile at lower levels, possible reflecting a change in conditions from a mechanical boundary layer, to a thermal boundary layer (Parsons and McKenzie, 1978; Chapter 1.3.1).

The occurrence of kaersutitisation at lower levels (in the pyroxenite suite) and oxidation at higher levels (in the granulite suite) indicates that the affect of 
silicate melt interaction changes with decreasing depth. At greater depths, nonliquid derivatives of the melt react with the lithosphere in solid-solid or gas-solid reactions. At higher levels, the affect of the liquid silicate melt itself dominates, interacting with the lithosphere in liquid-solid reactions.

The differing manifestation of these enrichment processes at different crustal levels, may be a result of the change in lithology of the lower crust. The kaersutitisation process is capable of infiltrating the pyroxenite suite, possibly because it occurs by gas-solid or solid-solid reactions. The oxidation process however is a liquid-solid reaction, and may not be able to infiltrate the impermeable pyroxenite suite, limiting its affects to the rims of the pyroxenites, and through open cracks. In the granulite suite, oxidation occurs along boundaries of mafic (clinopyroxene and olivine) and felsic (plagioclase) layers. This layering may be conducive to melt infiltration by providing a permeable (mafic) layer. The differing styles of the kaersutitisation and oxidation processes are further discussed in Chapter 8.3.3.

\subsubsection{Conclusion}

Lower crustal xenoliths from Mount Sidley initially crystallised as a layered series of cumulates from a fractionating melt, or series of related melts, with primitive mantle characteristics (e.g. high $\mathrm{Mg \# ,} \mathrm{low}{ }^{87} \mathrm{Sr} /{ }^{86} \mathrm{Sr}$ ratios and high ${ }^{143} \mathrm{Nd} /{ }^{144} \mathrm{Nd}$ ratios). The absence of orthopyroxene, the high-Ti and $\mathrm{Ca}$ content of clinopyroxene, and the low $\mathrm{Cr}$-content of spinels suggest that the crystallising melt may have been alkaline in composition. Volcanic rocks exposed at the surface do not have the characteristics of this crystallising melt.

The xenolith suite underwent metamorphism and deformation, resulting in an overprinted metamorphic fabric in the granulite suite. The pyroxenite suite remained undeformed, indicating a decrease in the extent of metamorphism with depth. The affect of metamorphism on the composition of the xenoliths is difficult to establish, due to the originally low content of mobile elements in the cumulate suite. The style of deformation changed from brittle to ductile with depth, indicating a change from the brittle conditions of the mechanical boundary layer to the more ductile conditions of the thermal boundary layer at lower crustal depths (Parsons and McKenzie, 1978).

Cenozoic alkaline melts infiltrated the xenolith suite at lower crustal depths, resulting in the modal and geochemical enrichment of the xenolith suite. Secondary reactions associated with melt migration through the xenolith suite include oxidation, dominant in the granulite suite, and kaersutitisation (kaersutite replacement of clinopyroxene), dominant in the pyroxenite suite. 


\section{Chapter five \\ THE MOUNT HAMPTON XENOLITH SUITE}

\section{Synopsis}

A suite of lower crustal and upper mantle xenoliths has been collected from Mount Hampton, a phonolitic stratovolcano at the northern end of the Executive Committee Range, Marie Byrd Land. The mineral assemblage consists of plagioclase, clinopyroxene, orthopyroxene and spinels, reflecting crystallisation from a mafic sub-alkaline melt. Olivine also occurs in a minority of xenoliths. Relict igneous textures, and chemical compositions, suggest that the xenolith suite initially crystallised as cumulates, prior to their metamorphism and recrystallisation. P-T estimates indicate equilibration to lower crustal depths, under a high geothermal gradient (6.5-9.5 kb, 875-1125 $\left.{ }^{\circ} \mathrm{C}\right)$.

The granulite and pyroxenite suites are similar in texture, with the dominance of plagioclase and pyroxenes in the granulite and pyroxenite suites respectively accounting for most of the geochemical differences between the suites. The whole rock geochemistry is dominated by the mineral assemblage. Only elements that partition readily into mineral phases (e.g. Sr in plagioclase, and $\mathrm{Cr}$ in clinopyroxene) are present in high abundances (e.g. up to $1746 \mathrm{ppm} \mathrm{Cr}$ and up to $1065 \mathrm{ppm}$ Sr, and clinopyroxene-like REE abundances).

The primitive characteristics of the mineral phases (e.g. clinopyroxene $\mathrm{Mg}: \mathrm{Mg}+\mathrm{Fe}$ ratios of 82-88, and plagioclase An contents of 49-71) has resulted in a mafic xenolith suite (43-52 wt. \% $\mathrm{SiO}_{2}$; original $\mathrm{Mg \# s}$ of 67-72), and reflects their crystallisation from a primitive mantle melt. Low ${ }^{87} \mathrm{Sr} /{ }^{86} \mathrm{Sr}$ ratios 0.704198 $0.704576)$ and high ${ }^{143} \mathrm{Nd} /{ }^{44} \mathrm{Nd}$ ratios $(0.512818-0.512771)$ are depleted mantle-like, and indicate that the suite assimilated little or no evolved crustal material. The mineral assemblage and geochemical characteristics of the xenolith suite indicate that the crystallising melt was not related to the present late Cenozoic volcanism occurring in Marie Byrd Land. 


\subsection{Mount Hampton}

The northernmost volcano of the ECR, Mount Hampton is also one of the oldest volcanoes in MBL. It was first discovered during a U.S. Antarctic Service Expedition reconnaissance flight on December 15, 1940 and named after Ruth Hampton, a member of the executive committee for the expedition. Prior to the second WAVE field season in 1990/91 (Chapter 3.3), Mount Hampton had only been visited once; for two days in December, 1967 (Doumani, 1964).

The massif consists of two calderas. Mount Hampton (11-12 Ma; Smellie et al., 1993), rising to an altitude of $3323 \mathrm{~m}$ asl, is comprised of phonolite lavas, however as only the upper $700 \mathrm{~m}$ of the edifice is exposed, other lithologies may be present beneath the ice cover. In contrast, Whitney Peak (13.2 Ma; Smellie et al., 1993), on the northwest flank of Mount Hampton, rises to a height of $3003 \mathrm{~m}$ asl, and consists of quartz-normative trachytes. Basanites, benmoreites and hawaiites also occur on the massif as late-stage scoria cones, that contain abundant lithospheric xenoliths. These include plagioclase peridotites, websterites and hypersthene granulites (Le Masurier, 1990; Smellie et al., 1993).

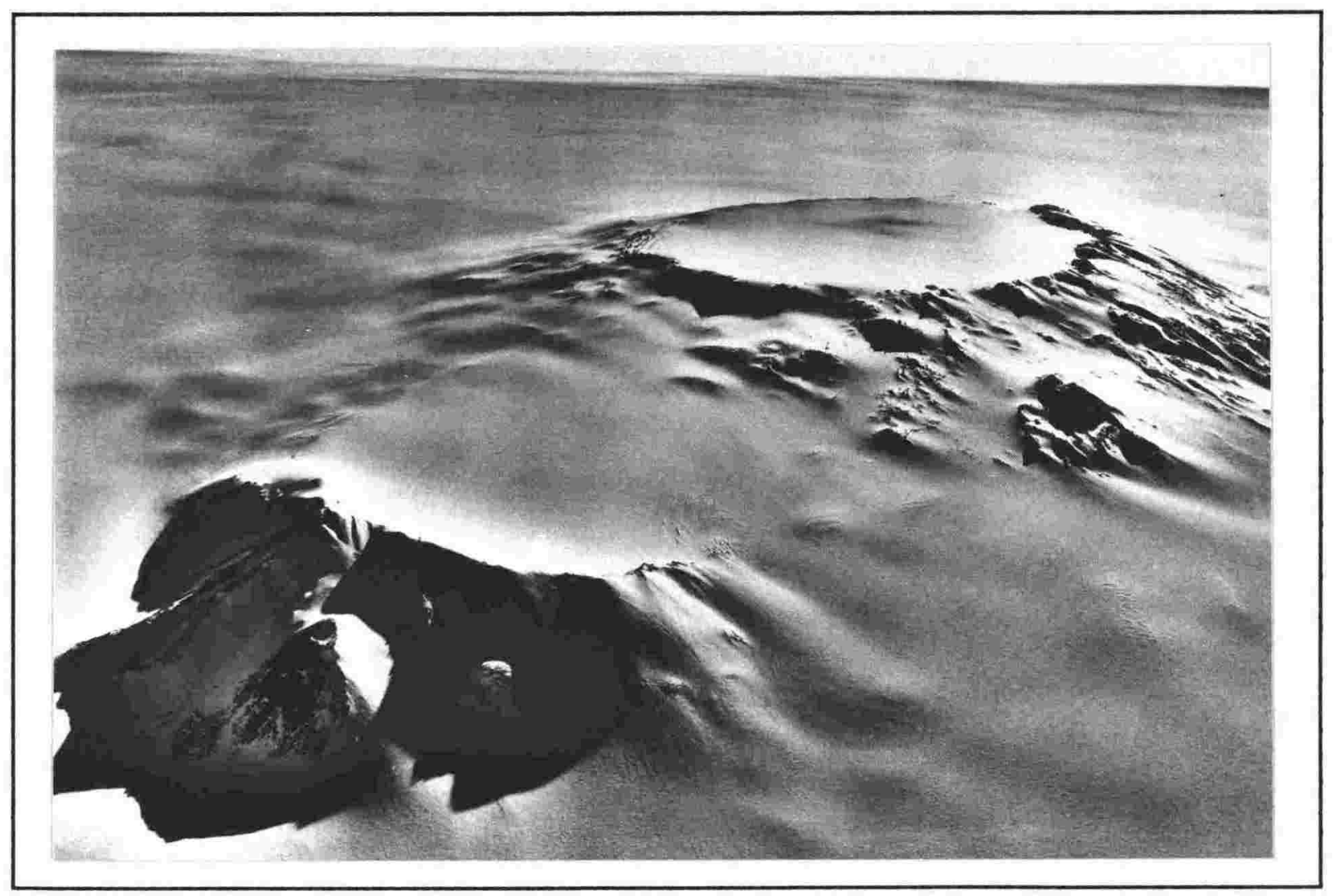

PLATE 5.1: Mount Hampton, viewed looking southeast (from Le Masurier, 1990; U.S. Navy photograph TMA 573 F31 201). Whitney Peak caldera is in the foreground, with the larger and higher caldera of Mount Hampton (caldera is $5 \mathrm{~km}$ in diameter) in the background. The Crary Mountains, $230 \mathrm{~km}$ southeast of Mount Hampton, can be seen on the horizon. 


\subsection{The Xenolith Suite}

The Mount Hampton xenolith suite is dominated by peridotites, including both plagioclase-bearing and plagioclase-free spinel lherzolites. $\mathrm{Cr}$-diopside rich peridotites are also abundant, as veins in spinel lherzolites and as nodules up to $10 \mathrm{~cm}$ in size. The upper mantle peridotite suite is described in Chapter 7.2, and whole rock geochemical analyses are presented in Appendix 4.2.

Lower crustal xenoliths consist of a suite of pyroxenites, typical of Type II upper mantle rocks (Frey and Prinz, 1978), and a suite of layered granulites. These samples are interpreted to represent the lower crust beneath Mount Hampton (Chapter 1.4). Both suites were entrained in late-stage basanitic host rocks which have oxidised the rims of the xenoliths. Some samples however have been pervasively oxidised. During analyses, care was taken to avoid these oxidised rims. The xenoliths are otherwise unweathered and remarkably free of xenolith host melt interaction.

The xenoliths are typically hand size or smaller. The pyroxenites are angular with slightly rounded faces due to milling during transport in the entraining melts. The granulite suite is more rounded. This may be a result of the susceptibility of plagioclase-bearing xenoliths to rounding on transport, or a function of source depths.

Mineral and whole rock descriptions and analyses, and the methods used in their preparation can be found in Wysoczanski (1993) and in the appropriate appendices of this thesis.

\subsection{Petrography}

In the Mount Hampton xenolith suite, two varieties of lower crustal xenoliths are immediately clear in hand specimen; a layered plagioclase-rich granulite suite, and a mafic pyroxenite suite typical of Type II upper mantle xenoliths (Frey and Prinz, 1978). These types appear to be gradational in texture. A range of modal assemblages for the xenolith types is presented as Table 5.1, and modal assemblages of individual samples can be found in Appendix 2.2.

Both suites have been oxidised to varying degrees, with orthopyroxene displaying oxidised rims (e.g. Plates 5.2 and 5.4). The oxide products of orthopyroxene are opaque under transmitted light (Table 5.1), but are nevertheless classified as orthopyroxenes for the purposes of rock classification, reflecting the protolith before oxidation. However, as it is often difficult to 
distinguish between primary oxides, and secondary oxides formed by oxidation of the xenolith suite, both oxide generations are included together in modal mineral tables as 'opaques' (Table 5.1, Appendix 2.2).

\begin{tabular}{lcc}
\hline Xenolith Type & Granulites & Pyroxenites \\
\hline Olivine & $0.0-5.6$ & $0.0-2.8$ \\
Clinopyroxene & $15.4-40$ & $30.2-84.4$ \\
Orthopyroxene & $0.0-14.2$ & $9.6-54.6$ \\
Plagioclase & $27.6-70.0$ & $0.0-2.4$ \\
Opaques & $8.2-17.2$ & $2.0-14.2$ \\
& & \\
\hline
\end{tabular}

TABLE 5.1: Range of modal assemblages present in granulites and pyroxenites from Mount Hampton. Primary oxides are often difficult to distinguish from secondary oxides which form on the rims of orthopyroxene; both oxide generations are included together as 'opaques'. Note the presence of olivine in only small abundances; it is completely absent from the majority of xenoliths.

\subsubsection{The granulite suite}

The granulite suite consists of well layered norites and gabbros, including leuco- and mela-norites and gabbros (Plates 5.2 and 5.3). The mineral assemblage consists of plagioclase + orthopyroxene + clinopyroxene + spinels. In one sample, olivine occurs in clusters in a mineral assemblage otherwise typical of the granulite suite.

Granulite textures are metamorphic (granoblastic with equant polygonal crystals), with relict cumulate textures identifiable in some samples. Relict igneous textures include: tabular cumulus grains that have either not been recrystallised, or have recrystallised with the formation of equant grains within the original tabular igneous mineral boundaries (Plate 5.2); oscillatory zoning in plagioclase; and inclusions of minerals in other mineral phases. Where recrystallisation is complete, relict textures are not preserved. Granulites with relict igneous textures (Plates 5.2 and 5.3) indicate that the layering in the granulite suite is igneous in origin, reflecting a layered cumulate protolith (Parsons, 1987). Well developed layering in fully recrystallised samples indicates that metamorphism has further enhanced the layering (Chapter 2.2.4).

Intercumulus textures are preserved as smaller grains surrounding tabular cumulus phases (Plate 5.2), or as anhedral interstitial grains (Plate 5.3). Plagioclase is primarily a cumulus phase and clinopyroxene is both cumulus and intercumulus (Plate 5.2), although in some samples clinopyroxene is cumulus and plagioclase is intercumulus (Plate 5.3). Orthopyroxene is both a cumulus and an intercumulus phase. 


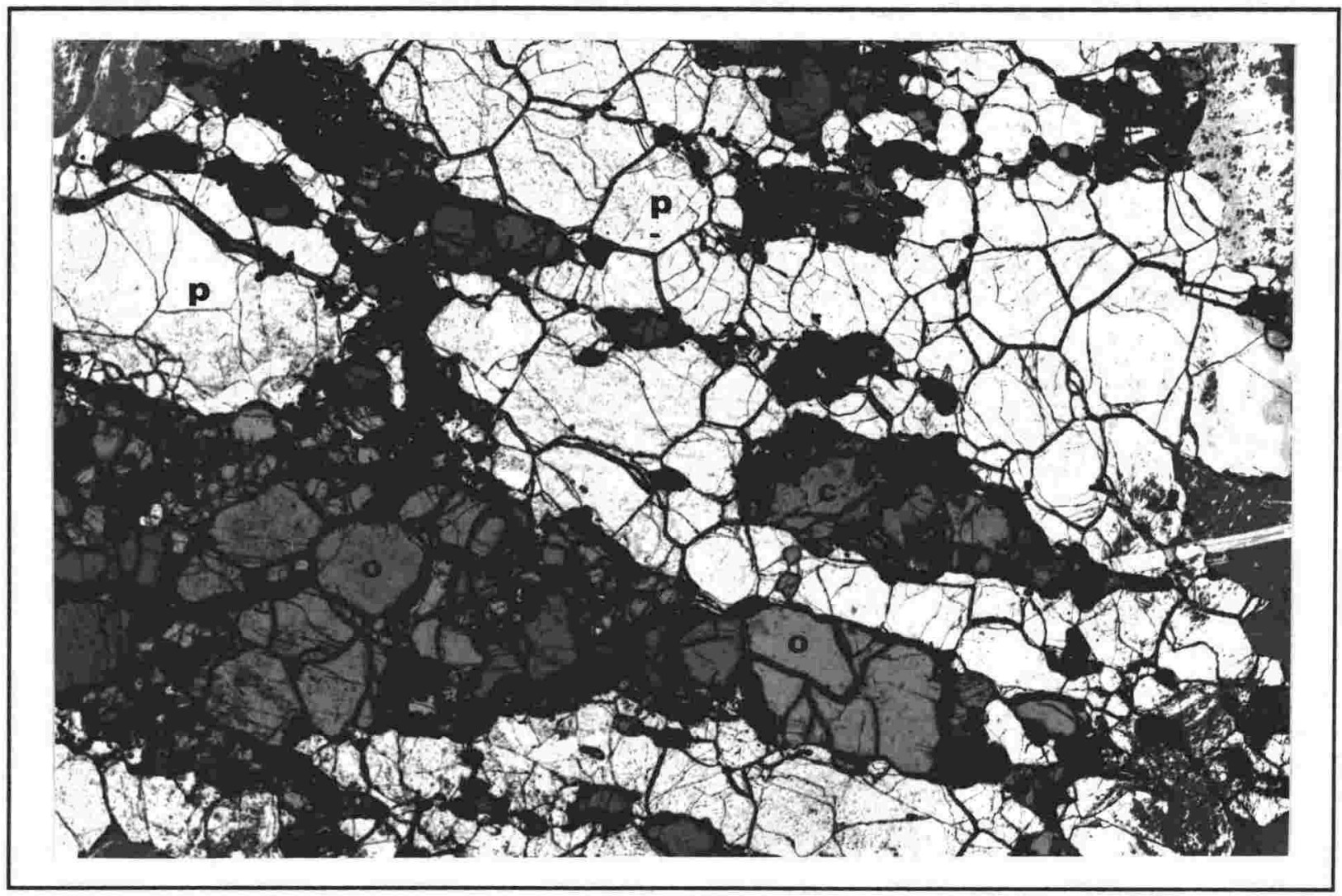

PLATE 5.2: Granulite xenolith from Mount Hampton (sample PK4A) with relict tabular cumulus plagioclase ( $\mathrm{p}$; top centre left) and clinopyroxene ( $\mathrm{c}$; lower right of centre), and crystals that have recrystallised to small equant grains with well developed $120^{\circ}$ triple junctions within tabular igneous crystal boundaries (e.g. top of centre plagioclase). Orthopyroxenes (o) have opaque symplectite (s) rims (e.g. large cluster of grains bottom left of centre) and small veins of oxides can be seen in pyroxene and plagioclase crystals causing disequilibrium textures in plagioclase. Width of plate is $17 \mathrm{~mm}$.

Plagioclase crystals are generally subidiomorphic and of $\mathrm{mm}$ scale $(<10$ $\mathrm{mm}$ ). Large plagioclase crystals display multiple twinning, and rare oscillatory zoning. Many are broken, indicating brittle conditions in the lower crust. They have not been recrystallised and are interpreted to represent relict cumulus plagioclase (Plate 5.2, plagioclase left of centre). Smaller plagioclase crystals, that have recrystallised from larger plagioclase crystals, occur as equant crystals with well developed $120^{\circ}$ triple junctions. They are undeformed and not twinned. In some samples, plagioclase recrystallisation is complete with the formation of small crystals within a rectangular-shaped boundary, up to $10 \mathrm{~mm}$ in size, reflecting the tabular form of the protolith plagioclase crystal (Plate 5.2, plagioclase right of centre).

Clinopyroxene crystals range from sub-mm to $5 \mathrm{~mm}$ in size, often with well developed idiomorphic forms. Large crystals are tabular and broken, and are interpreted to represent older igneous phases (Plates 5.2 and 5.3). Smaller 
recrystallised equant grains are metamorphic in origin, having recrystallised from igneous phases (Plate 5.2). Clinopyroxenes are unaffected by secondary processes, however fine orthopyroxene exsolutions are discernible in some clinopyroxenes. Their origin is uncertain, but may be due to a decrease in pressure during ascent of the xenoliths to the surface in host lavas.

Orthopyroxene is the major Ca-poor mafic phase in the xenolith suite, occurring as subidiomorphic crystals, generally 1-2 $\mathrm{mm}$ in size (but ranging from $<1 \mathrm{~mm}$ to $5 \mathrm{~mm}$ in length), and as small ( $\mu \mathrm{m}$ scale) exsolutions in clinopyroxene. Their moderately strong pleochroism (alpha = pink, beta = pale greenish-brown, gamma = pale green) is a distinguishing characteristic. Their forms range from large tabular early-formed crystals (Plate 5.2), to recrystallised crystals displaying well developed $120^{\circ}$ triple junctions with other minerals (Plate 5.3). Clusters of recrystallised orthopyroxenes within well formed boundaries indicate recrystallisation from a large (up to $15 \mathrm{~mm}$ ) parent orthopyroxene (Plate 5.3).

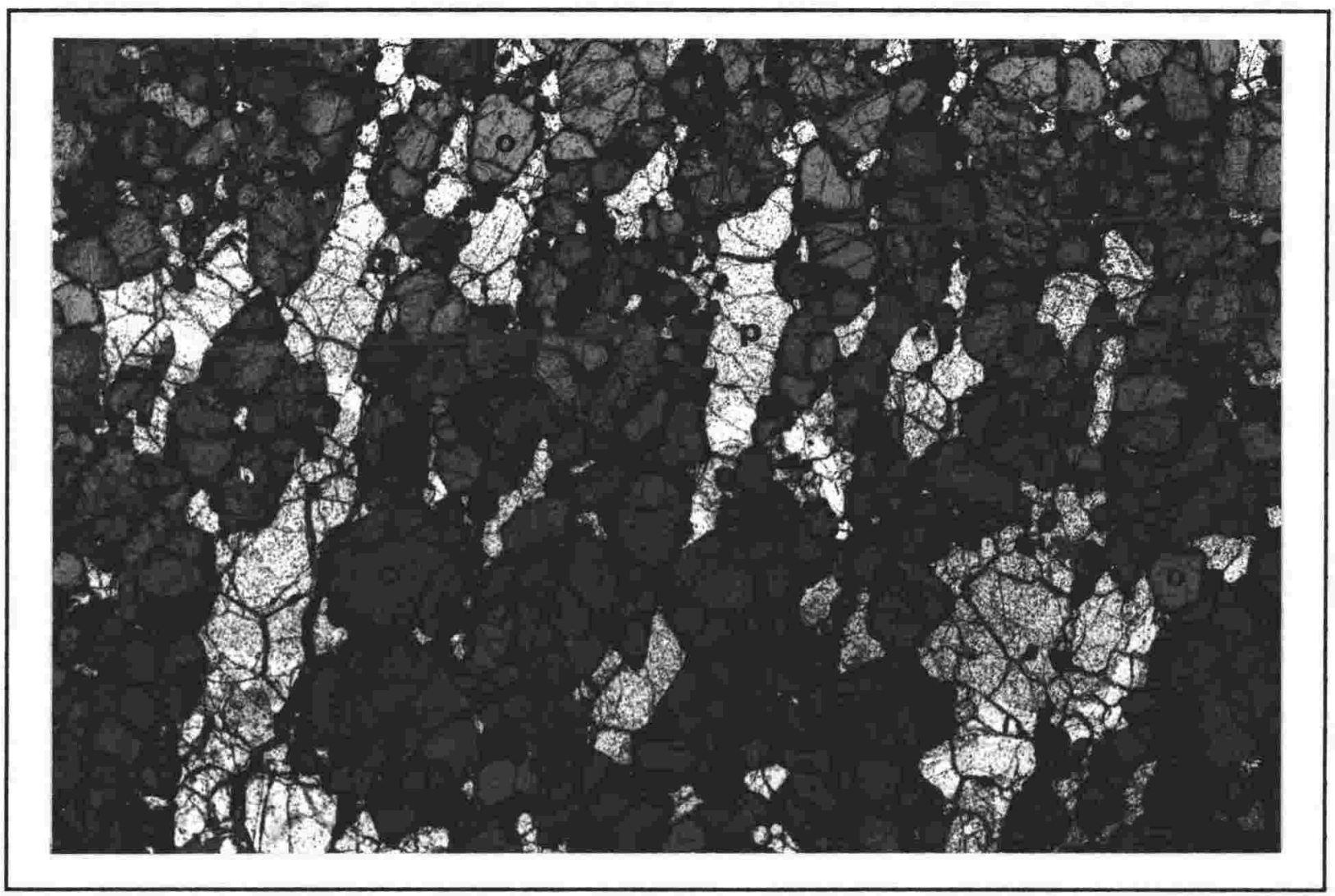

PLATE 5.3: Granulite xenolith from Mount Hampton (sample PK4C1) with a layered cumulate texture. Clinopyroxene (c) is a cumulus phase and orthopyroxene (o) is intercumulus. Orthopyroxene can be identified by its moderate pleochroism and by its oxidised symplectite rims. Plagioclase (p) is intercumulus, occurring as anhedral grains between pyroxene layers. Recrystallisation of plagioclase to equant grains with $120^{\circ}$ triple junctions has occurred (bottom left). Width of plate is $17 \mathrm{~mm}$. 
Most orthopyroxenes have been affected by a secondary process resulting in symplectite growth of olivine and Fe-Ti oxides on their rims and along cracks, giving them a rusty appearance (Plates 5.2 and 5.3). In advanced cases, symplectite growth has almost totally replaced the host orthopyroxene, resulting in symplectites that are opaque under transmitted light. Symplectites occur on both igneous and metamorphic orthopyroxenes, indicating symplectite formation after metamorphism. The origin of the symplectites may be due to decompression associated with uplift, or ascent to the surface, or it may be due to oxidation by the host melts. This reaction is more fully discussed in Chapter 5.5.

Secondary oxide growth also occurs in cracks and along plagioclase rims (Plate 5.2). Plagioclase in contact with these veins show disequilibrium textures. The pervasive nature of secondary oxide growth makes the identification of primary $\mathrm{Fe} \mathrm{Ti}$ oxides difficult, although small oxide inclusions in tabular crystals are identifiable as primary in origin.

\subsubsection{The pyroxenite suite}

The pyroxenite suite is comprised of websterites (including plagioclasebearing websterites) and clinopyroxenites, with equant polygonal metamorphic fabrics, displaying $120^{\circ}$ triple junctions (Plates 5.4 and 5.5). The mineral assemblage consists of orthopyroxene + clinopyroxene + spinels \pm plagioclase \pm olivine.

Clinopyroxene occurs as early formed subidiomorphic crystals, as well as late formed xenomorphic crystals, taking their form from other crystals (Plates 5.4 and 5.5). Most are 1-2 mm in size, however large broken clinopyroxenes up to 20 $\mathrm{mm}$ in size, with pronounced orthopyroxene exsolutions (on a 10- $\mu \mathrm{m}$ scale), also occur (Plate 5.4). Some exsolutions are curved, indicating ductile deformation (Plate 5.4).

Orthopyroxene crystals are generally subidiomorphic, and 1-2 $\mathrm{mm}$ in size, although crystals up to $5 \mathrm{~mm}$ in size occur. Orthopyroxenes in many samples have developed narrow (10 $\mu \mathrm{m}$ scale) olivine and $\mathrm{Fe}-\mathrm{Ti}$ oxide symplectites on their rims, and along cracks (Plates 5.4), similar to the granulite suite, but not nearly as well developed. Symplectite growth on exsolved orthopyroxenes, and the ductile deformation of exsolution lamellae, indicates that exsolution preceded metamorphism and symplectite formation, and can not have been related to ascent in the magma. The pleochroism (alpha = pink, beta = pale greenish-brown, gamma = pale green) and weak interference colours of orthopyroxenes, together with their symplectite rims, distinguishing them from clinopyroxenes. 


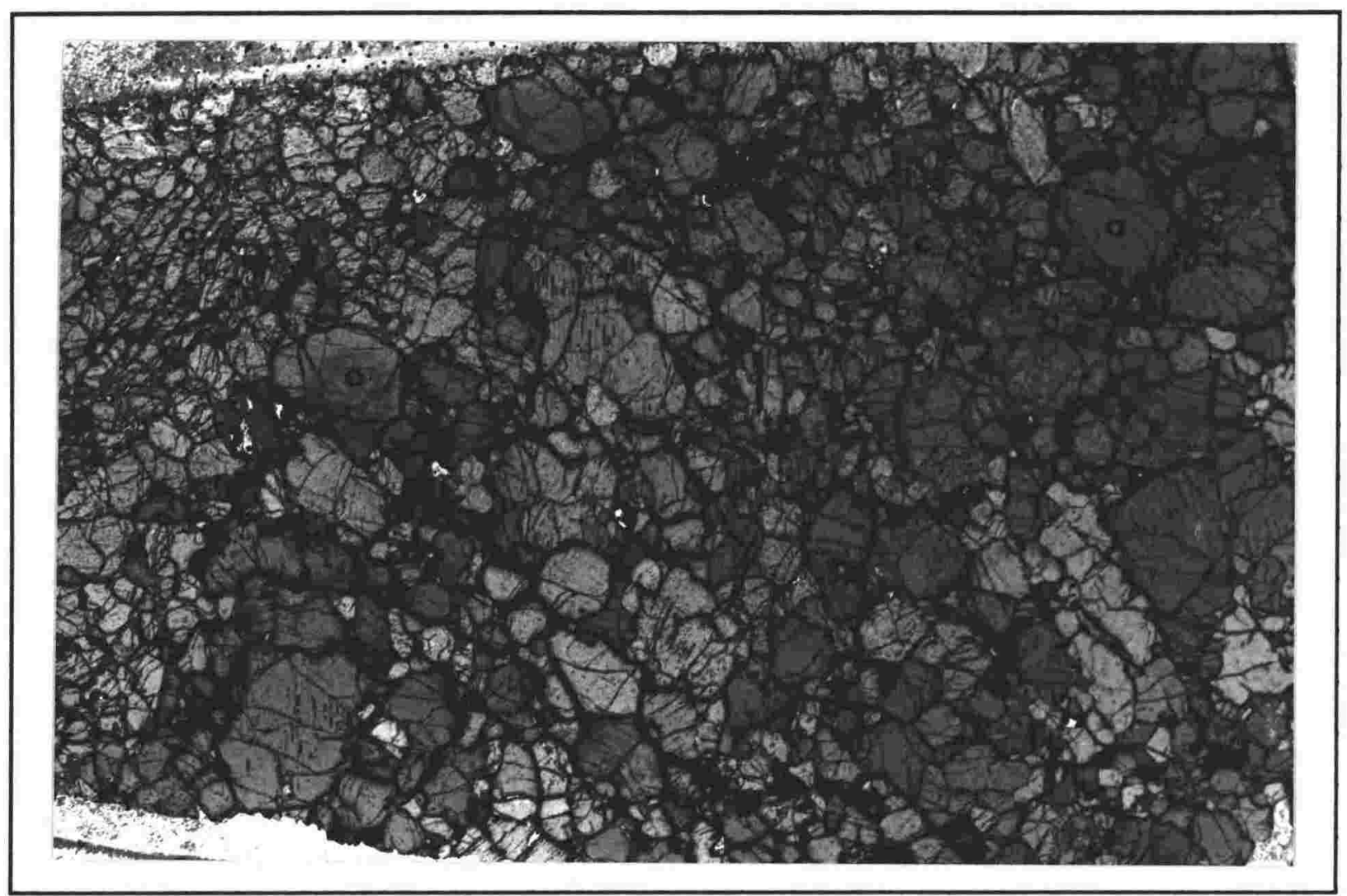

PLATE 5.4: See caption opposite.

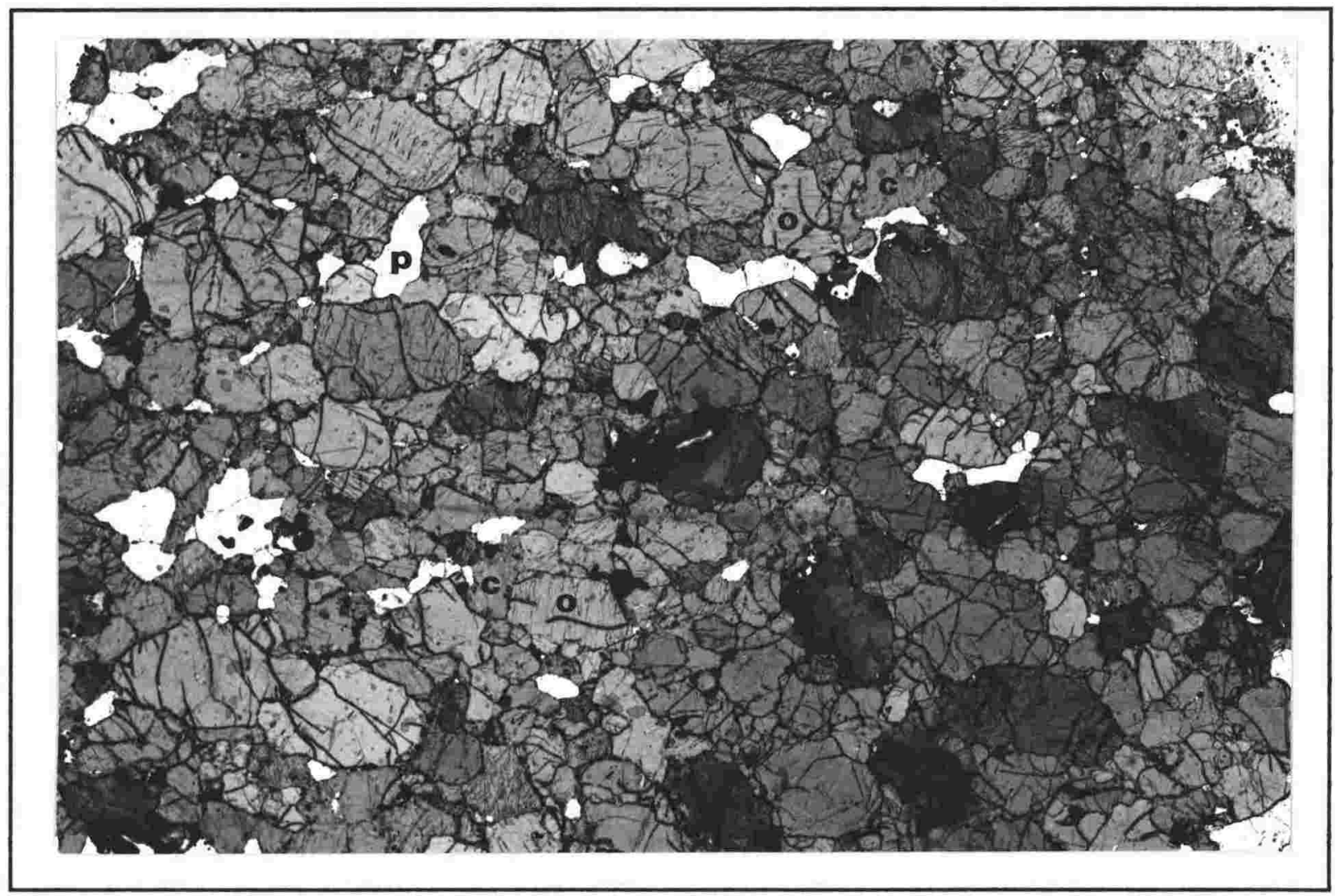

PLATE 5.5: See caption opposite. 
PLATE 5.4 (opposite): Pyroxenite from Mount Hampton (sample PK4D1) comprised of orthopyroxene (o) and clinopyroxene (c). Large clinopyroxenes have exsolved orthopyroxene that are curved, probably as a result of ductile deformation after exsolution (e.g. top left). Orthopyroxene occurs as rounded cumulus grains, typically with symplectite (s) rims. Width of plate is $17 \mathrm{~mm}$.

PLATE 5.5 (opposite): Pyroxenite from Mount Hampton (sample PK4D) with a meta-igneous texture, comprised of orthopyroxene (o), clinopyroxene (c) and interstitial plagioclase (p). Narrow symplectite (s) rims have developed on some orthopyroxene crystals and through cracks, although in general the sample is unaffected by secondary processes. Width of plate is $17 \mathrm{~mm}$.

Plagioclase is rare, and occurs as interstitial crystals associated with recrystallised mafic phases. Olivine is present in two pyroxenites in conjunction with orthopyroxene and clinopyroxene. Oxides occurring as inclusions in large tabular host crystals are primary in origin, but other oxides have originated in response to secondary processes.

Metamorphic textures are well developed in the pyroxenite suite, although the presence of large broken exsolved clinopyroxenes may indicate an igneous cumulate protolith. The tabular form of many clinopyroxene and orthopyroxene crystals suggests crystallisation as cumulus minerals, although others may have been intercumulus. The interstitial form of plagioclase crystals indicates crystallisation as an intercumulus phase.

The resemblance of the pyroxenite suite (in particular of plagioclase-bearing pyroxenites) to melagabbros and norites of the granulite suite suggests that the two suites may grade into one another and be genetically related.

\subsubsection{Summary of textures and bearing on petrogenesis}

The granulite suite consists of gabbros and norites with a strong layering of mafic and felsic phases, inherited from igneous layering in a cumulate protolith. Websterites comprise the bulk of the pyroxenite suite, which is plagioclase-poor. Both pyroxenites and granulites consist of orthopyroxene + clinopyroxene + spinels \pm plagioclase, signifying a sub-alkaline affinity. Olivine is also present in a small number of xenoliths from both suites.

The xenolith suite is meta-igneous in texture. Large tabular plagioclase and pyroxene crystals represent relict cumulus crystals that have been metamorphosed, and recrystallised to equant polygonal grains displaying $120^{\circ}$ triple junctions between crystals. Plagioclase, clinopyroxene and orthopyroxene all occur as both cumulus and intercumulus phases in the granulite suite. In the pyroxenite suite, clinopyroxene and orthopyroxene are both cumulus and intercumulus phases, and plagioclase occurs only as an intercumulus phase. The only appreciable difference between the granulite and pyroxenite suites is the 
abundance and cumulus form of plagioclase in the granulite suite compared to the pyroxenite suite (Figure 5.1).

The similarity in petrographic textures and associations of the xenolith suites (in particular granulite melagabbros and norites and plagioclase-bearing pyroxenites) indicate that the granulite and pyroxenite suites are genetically related. However, composite xenoliths have not been found to indicate whether there is an interlayering of, or a gradation between granulites and pyroxenites. This may be a reflection of the small sample size of the xenolith suite, and a gradation or an interlayering of granulites and pyroxenites cannot be discounted.

Pyroxenites

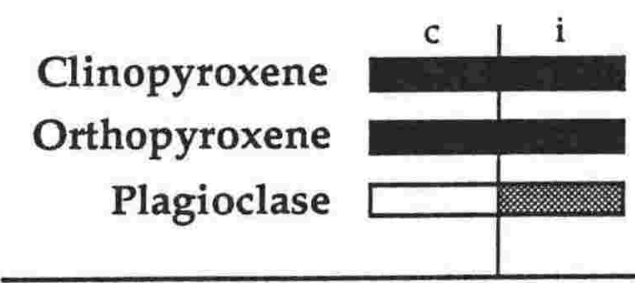

Granulites

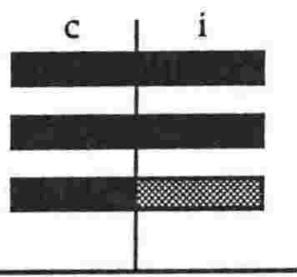

FIGURE 5.1: Cumulus (c) and intercumulus (i) phases in the Mount Hampton xenolith suite differ between the pyroxenite and granulite suites. However, the only appreciable difference is the high abundance of cumulus plagioclase in the granulite suite, and its low abundance and intercumulus form in the pyroxenite suite. Clear $=$ absence of a phase; light stipple = only rare occurrence of a phase; black $=$ presence of a phase.

Orthopyroxene of all forms (primary igneous crystals, recrystallised metamorphic crystals, and exsolution lamellae in clinopyroxene) has been oxidised, resulting in the formation of symplectites. Symplectite rims on recrystallised and exsolved orthopyroxene indicates that oxidation occurred after exsolution and metamorphism, and exsolution did not occur as a result of decompression due to ascent of the xenoliths to the surface.

Deformational features in plagioclase crystals (e.g. fractured grains) of the granulite suite indicate brittle conditions in the lower crust. However, curved orthopyroxene exsolution lamellae in clinopyroxene reflects ductile deformation. The lower crust beneath Mount Hampton may be in the transition region between the brittle conditions of the mechanical boundary layer, and the more plastic conditions of the thermal boundary layer in the lithosphere (Parsons and McKenzie, 1978; Chapter 1.3.1).

From the textural relationships evident in the xenolith suite, a sequence of events in the xenolith suite can be inferred:

- crystallisation of the suite as a series of cumulates (including layered plagioclase-rich cumulates) that crystallised from a fractionating sub-alkaline melt. Pyroxenite crystallisation may have preceded granulite crystallisation, or 
they may have crystallised together. Possible stratigraphic relationships of the xenolith suite are represented as Figure 5.2;

- exsolution of clinopyroxenes in the xenolith suite in response to changing equilibration conditions, possibly associated with cooling due to uplift;

- metamorphism of the suite resulting in the recrystallisation of igneous crystals to smaller equant polygonal grains;

a)

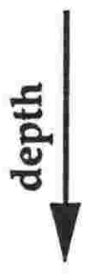

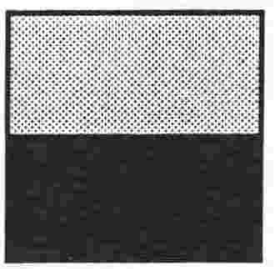

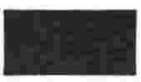

Pyroxenites b)
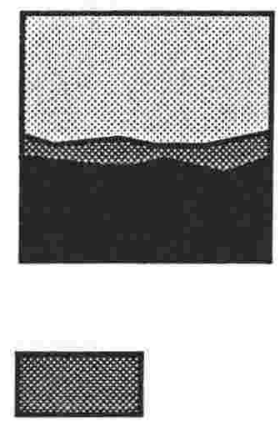

Intermediate c)
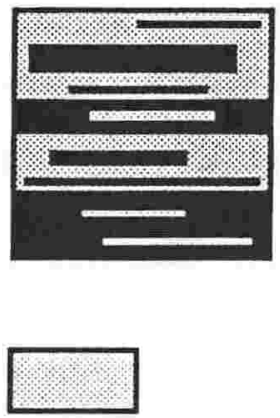

Granulites

FIGURE 5.2: Schematic diagram showing some possible stratigraphic relationships between the granulite and pyroxenite suites. a) The suite may represent fractionation from an evolving melt with crystallisation of the pyroxenites and then granulites. b) The pyroxenite suite may represent cumulates of a mafic melt intruded into, or underplating, pre-existing granulitic crust. c) The suite may represent an interlayering of genetically related cumulates with no stratigraphic control. Textural similarities between the suites indicates that they are related, and crystallised from the same melt. Furthermore, the appearance of plagioclase as a cumulate phase signifies a change in conditions, resulting in the crystallisation of the granulite suite instead of the pyroxenite suite. For these reasons, a) or c) are most likely.

- ductile deformation of the pyroxenite suite (and possibly brittle deformation of the granulite suite), both synchronous with and after metamorphism;

- oxidation of the suite resulting in the formation of secondary oxides, and symplectite growth on orthopyroxenes;

- entrainment of the suite in basanitic lavas and their ascent to the surface.

\subsection{Mineral Chemistry}

Metamorphism of the xenolith suite has obscured most of the original igneous textures, and in some cases has resulted in an alteration to the mineral chemistry. Mineral compositions are useful in determining the extent of alteration and of identifying relic characteristics, thereby giving an insight into the 
TABLE 5.2: Representative electron microprobe analyses of Mount Hampton xenolith clinopyroxenes.

\begin{tabular}{lcccccccccc}
\hline SAMPLE & PK4A & PK4A & PK4R & PK4Y & PK4C1 & PK4B & PK4D & PK4S & PK4B1 & PK5G \\
TYPE & Gran & Gran & Gran & Gran & Gran & Pyxite & Pyxite & Pyxite & Pyxite & Pyxite \\
\hline & & & & & & & & & & \\
$\mathrm{SiO2}$ & 48.97 & 49.66 & 51.52 & 50.09 & 47.64 & 48.23 & 48.59 & 48.19 & 47.22 & 50.92 \\
$\mathrm{Al2O} 3$ & 8.67 & 6.03 & 3.98 & 8.31 & 8.44 & 8.31 & 7.86 & 7.25 & 9.14 & 6.87 \\
$\mathrm{TiO} 2$ & 0.77 & 0.92 & 1.05 & 0.91 & 1.28 & 1.43 & 1.54 & 1.33 & 1.54 & 1.11 \\
$\mathrm{FeO}$ & 7.90 & 8.47 & 9.66 & 8.38 & 8.33 & 7.95 & 8.32 & 8.45 & 8.61 & 6.76 \\
$\mathrm{MnO}$ & 0.19 & 0.17 & 0.28 & 0.21 & 0.21 & 0.22 & 0.17 & 0.20 & 0.24 & 0.13 \\
$\mathrm{MgO}$ & 12.47 & 15.16 & 14.77 & 13.19 & 13.41 & 12.72 & 12.70 & 12.88 & 12.69 & 13.88 \\
$\mathrm{CaO}$ & 21.04 & 19.29 & 18.50 & 17.55 & 19.94 & 19.51 & 19.81 & 20.56 & 19.27 & 19.89 \\
$\mathrm{Na2O}$ & 1.07 & 0.34 & 0.70 & 1.40 & 0.99 & 1.04 & 1.05 & 0.91 & 1.30 & 0.93 \\
$\mathrm{~K} 2 \mathrm{O}$ & 0.01 & 0.00 & 0.06 & 0.03 & 0.02 & 0.07 & 0.05 & 0.04 & 0.03 & 0.00 \\
& & & & & & & & & & \\
\hline Fe2O3* & 3.37 & 1.93 & 0.99 & 0.33 & 4.70 & 2.12 & 2.30 & 3.89 & 4.83 & 0.00 \\
$\mathrm{FeO}^{*}$ & 4.86 & 6.74 & 8.77 & 8.08 & 4.09 & 6.04 & 6.26 & 4.95 & 4.27 & 6.76 \\
\hline
\end{tabular}

\begin{tabular}{lllllllllll}
\hline TOTAL & 101.09 & 100.04 & 100.47 & 100.07 & 100.23 & 99.48 & 100.09 & 99.78 & 100.01 & 100.48 \\
\hline
\end{tabular}

cations on the basis of 6 oxygens

\begin{tabular}{lllllllllll} 
Si & 1.799 & 1.840 & 1.902 & 1.842 & 1.770 & 1.791 & 1.801 & 1.799 & 1.754 & 1.855 \\
AlIV & 0.200 & 0.160 & 0.100 & 0.160 & 0.230 & 0.210 & 0.200 & 0.200 & 0.250 & 0.140 \\
AlVI & 0.180 & 0.100 & 0.070 & 0.200 & 0.140 & 0.150 & 0.140 & 0.120 & 0.150 & 0.150 \\
Ti & 0.020 & 0.025 & 0.029 & 0.025 & 0.035 & 0.040 & 0.040 & 0.037 & 0.043 & 0.030 \\
FeIII & 0.093 & 0.010 & 0.027 & 0.009 & 0.130 & 0.059 & 0.064 & 0.108 & 0.134 & 0.000 \\
FeII & 0.148 & 0.053 & 0.270 & 0.248 & 0.126 & 0.187 & 0.193 & 0.153 & 0.131 & 0.205 \\
Mn & 0.006 & 0.007 & 0.008 & 0.007 & 0.006 & 0.010 & 0.010 & 0.006 & 0.007 & 0.000 \\
Mg & 0.682 & 0.836 & 0.812 & 0.722 & 0.742 & 0.703 & 0.701 & 0.716 & 0.702 & 0.753 \\
Ca & 0.828 & 0.765 & 0.731 & 0.691 & 0.794 & 0.776 & 0.786 & 0.822 & 0.767 & 0.776 \\
Na & 0.076 & 0.024 & 0.050 & 0.098 & 0.070 & 0.074 & 0.075 & 0.065 & 0.093 & 0.065 \\
K & 0.000 & 0.000 & 0.003 & 0.001 & 0.001 & 0.000 & 0.002 & 0.001 & 0.001 & 0.000 \\
& & & & & & & & & & \\
\hline TOTAL & 4.032 & 3.820 & 4.002 & 4.003 & 4.044 & 4.000 & 4.012 & 4.027 & 4.032 & 3.974 \\
\hline & & & & & & & & & & \\
Wo & 47.29 & 45.97 & 39.73 & 41.38 & 44.31 & 44.99 & 45.07 & 45.69 & 44.23 & 44.75 \\
En & 38.95 & 50.24 & 44.13 & 43.23 & 41.41 & 40.75 & 40.19 & 39.80 & 40.48 & 43.43 \\
Fs & 13.76 & 3.79 & 16.14 & 15.39 & 14.29 & 14.26 & 14.74 & 14.51 & 15.28 & 11.82 \\
& & & & & & & & & & \\
Q & 1.66 & 1.65 & 1.81 & 1.66 & 1.66 & 1.67 & 1.68 & 1.69 & 1.60 & 1.73 \\
J & 0.15 & 0.05 & 0.10 & 0.20 & 0.14 & 0.15 & 0.15 & 0.13 & 0.19 & 0.13 \\
& & & & & & & & & & \\
\hline
\end{tabular}

* Recalculated assuming stoichiometry based on 4.0 cations 
nature of the protolith prior to metamorphism. Mineral compositions may also clarify the genetic relationship between the granulite and pyroxenite suites, and ascertain their sequence of crystallisation in the lower crust.

\subsubsection{Clinopyroxene}

Clinopyroxene shows the widest compositional range of the major rock forming minerals in the Mount Hampton xenolith suite. Representative analyses are presented as Table 5.2, and major element compositions are discussed below. Rare earth element contents of clinopyroxene separates are discussed with whole rock geochemistry (Chapter 5.6.2).

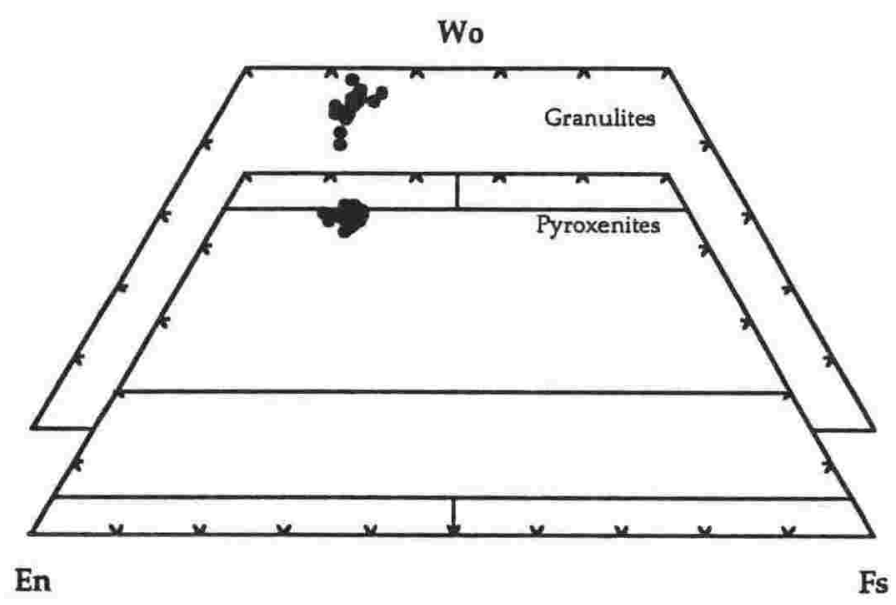

FIGURE 5.3: Composition of clinopyroxenes from the Mount Hampton xenolith suite in the system Wo-En-Fs (fields from Morimoto et al., 1988). Compositions of granulite and pyroxenite clinopyroxenes are similar, except for a larger range in the granulite suite, possibly due to unmixing (with exsolution).

Mount Hampton xenolith clinopyroxenes are $\mathrm{Ca}-\mathrm{Mg}-\mathrm{Fe}$ quadrilateral clinopyroxenes with minor ' $\mathrm{J}$ ' $(\mathrm{J}=2 \mathrm{Na}$ ) components (Chapter 2.3.1). Without exception, both granulite and pyroxenite clinopyroxenes are aluminian augites or aluminian diopsides (Morimoto et. al, 1988). Granulite and pyroxenite clinopyroxene compositions overlap on pyroxene quadrilateral diagrams, although a larger range is represented in the granulite suite with relatively calcium-rich and calcium-poor clinopyroxenes compared to the pyroxenite suite (Figure 5.3). This compositional range may be a result of unmixing due to exsolution. A plot of Wo v Fs (Figure 5.4) better illustrates this compositional range and highlights the strong trend between Wo and En, with Wo-rich clinopyroxenes having lower En contents. Pyroxenite clinopyroxenes fall within the granulite clinopyroxene field.

The M2 octahedral site in xenolith clinopyroxenes consists mainly of $\mathrm{Ca}(\leq$ 0.86 and $\leq 0.82$ cations in granulites and pyroxenites respectively), with remaining 
sites filled by $\mathrm{Na}$ (up to 0.1 cations in both granulites and pyroxenites) and $\mathrm{Mg}$. The M1 octahedral sites are occupied mainly by $\mathrm{Fe}, \mathrm{Mg}$, and $\mathrm{Al}(\leq 0.21$ and $\leq 0.20$ cations in granulites and pyroxenites respectively) with smaller amounts of $\mathrm{Ti}(\leq$ 0.7 and $\leq 0.5$ cations) and Mn (generally $\leq 0.01$ cations).

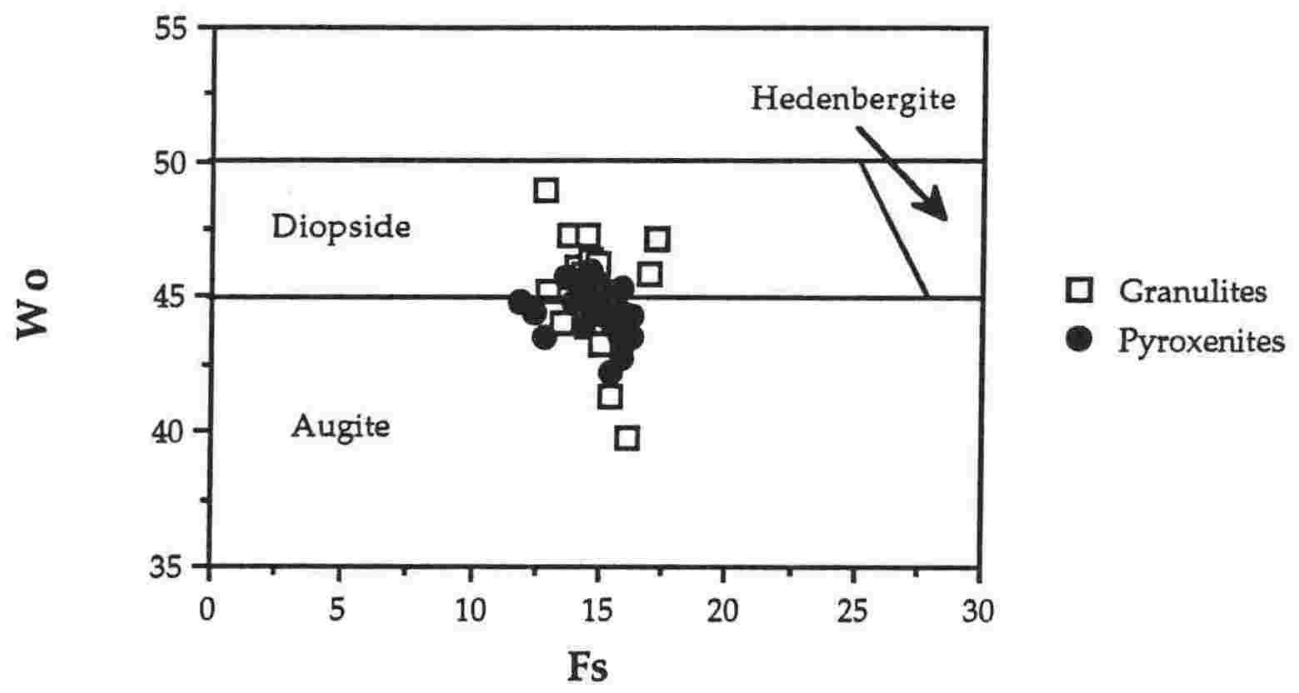

FIGURE 5.4: Binary diagram of clinopyroxene Wo $v$ Fs compositions. Fields are those of the Morimoto et al. (1988) pyroxene quadrilateral. Granulite and pyroxenite clinopyroxene compositions are similar except for the extended $\mathrm{Ca}$ content range in the former.

The tetrahedral site is comprised mainly of $\mathrm{Si}$ (1.75-1.90 and 0.75-1.86 cations), with a variable amount of $\mathrm{Al}$ substituting for $\mathrm{Si}$ (up to 0.25 cations). The substitution of $\mathrm{Si}^{4+}$ by $\mathrm{Al}^{3+}$;

$$
\mathrm{M}(2)^{2+} \mathrm{M}(1)^{2+} \mathrm{Si}^{4+}{ }_{2} \mathrm{O}_{6} \rightarrow \mathrm{M}(2)^{2+} \mathrm{Ti}^{4+} \mathrm{Al}^{3+}{ }_{2} \mathrm{O}_{6}
$$

results in a charge imbalance which is restored by the substitution of one $\mathrm{Ti}^{4+}$ cation entering the $\mathrm{M} 1$ site for every two $\mathrm{Al}^{3+}$ cations entering the tetrahedral site. $\mathrm{Al}$ is therefore partitioned into two structural sites; the tetrahedral site $\left(\mathrm{Al}^{\mathrm{IV}}\right)$ and an octahedral (M1) site $\left(\mathrm{Al}{ }^{\mathrm{VI}}\right)$. The coupled substitution of $\mathrm{Al}^{3+}$ for $\mathrm{Si}^{4+}$, and $\mathrm{Ti}^{4+}$ for $\mathrm{Mg}^{2+}$ or $\mathrm{Fe}^{2+}$ is not very evident in $\mathrm{Tiv} \mathrm{Al}{ }^{\mathrm{IV}}$ contents, possibly due to the small totals. There is however a general positive trend between $\mathrm{Ti}$ and $\mathrm{Al}{ }^{\mathrm{IV}}$ contents, whereas no such correlation is evident between $\mathrm{Ti}$ and $\mathrm{Al}^{\mathrm{VI}}$ contents (Figure 5.5).

The partitioning of $\mathrm{Al}$ into two sites has been used as an indicator for the origin of clinopyroxenes (Aoki and Shiba, 1973; Wass, 1979). All Mount Hampton xenolith clinopyroxenes fall in the field of 'granulites and inclusions in basalts', reflecting their crystallisation at lower crustal conditions (Figure 5.6). 


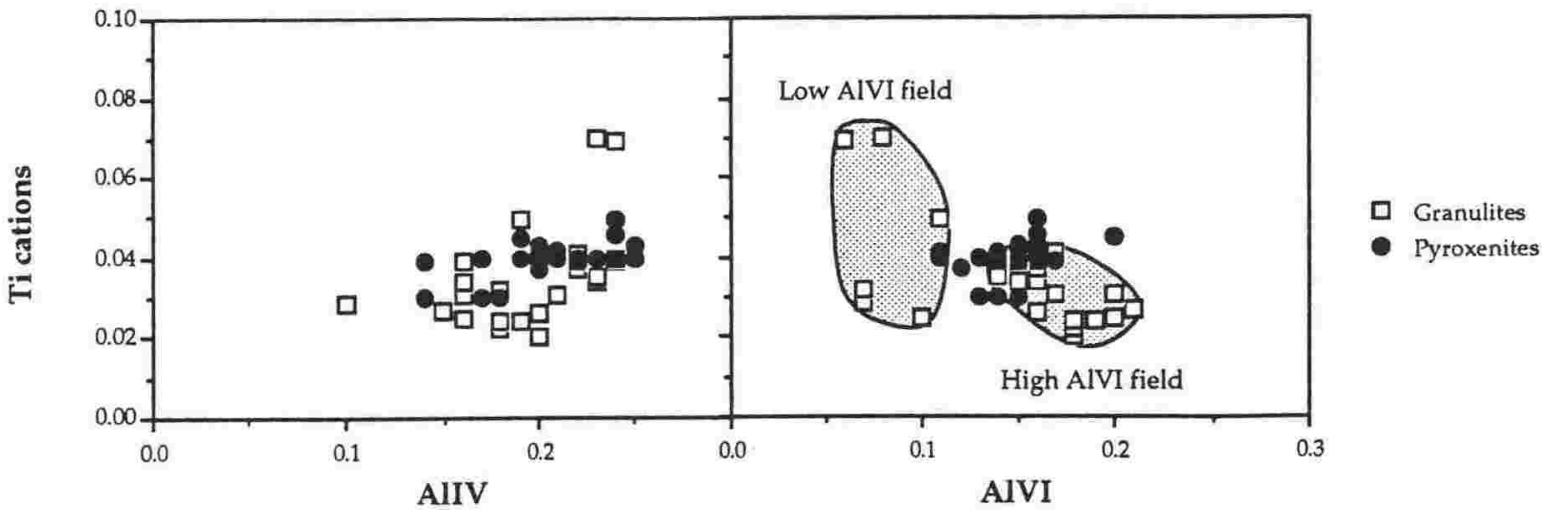

FIGURE 5.5: Ti contents of clinopyroxenes form: a) a generally positive trend with $\mathrm{Al}^{\mathrm{IV}}$ reflects the coupled substitution of $\mathrm{Al}$ for $\mathrm{Si}$ in the tetrahedral site, and $\mathrm{Ti}$ for $\mathrm{Mg}$ and $\mathrm{Fe}$ in the octahedral site: b) and a scattered trend with $\mathrm{Al}^{\mathrm{VI}}$ shows no relationship between $\mathrm{Ti}$ and $\mathrm{Al}^{\mathrm{VI}}$ partitioning in clinopyroxene. Stippled fields distinguish high- $\mathrm{Al}^{\mathrm{VI}}$ from low- $\mathrm{Al}^{\mathrm{VI}}$ clinopyroxenes, resulting from their crystallisation prior to and after plagioclase respectively.

Granulite clinopyroxene compositions are bimodal, with a high- $\mathrm{Al} \mathrm{VI}^{\mathrm{VI}}$ group similar to all pyroxenite clinopyroxenes, and a low-Al ${ }^{\mathrm{VI}}$ group with a compositional gap of 0.11-0.14 $\mathrm{Al}^{\mathrm{VI}}$ at constant $\mathrm{Al}^{\mathrm{IV}}$ (shown as fields in Figures 5.5 and 5.6). As $\mathrm{Al}^{\mathrm{VI}}$ contents are unaffected by the substitution of $\mathrm{Al}$ for $\mathrm{Si}$, the bimodal distribution is most likely a reflection of different $\mathrm{Al}$ contents in the crystallising melt. The most obvious method of depleting a melt in $\mathrm{Al}$ is through plagioclase fractionation.

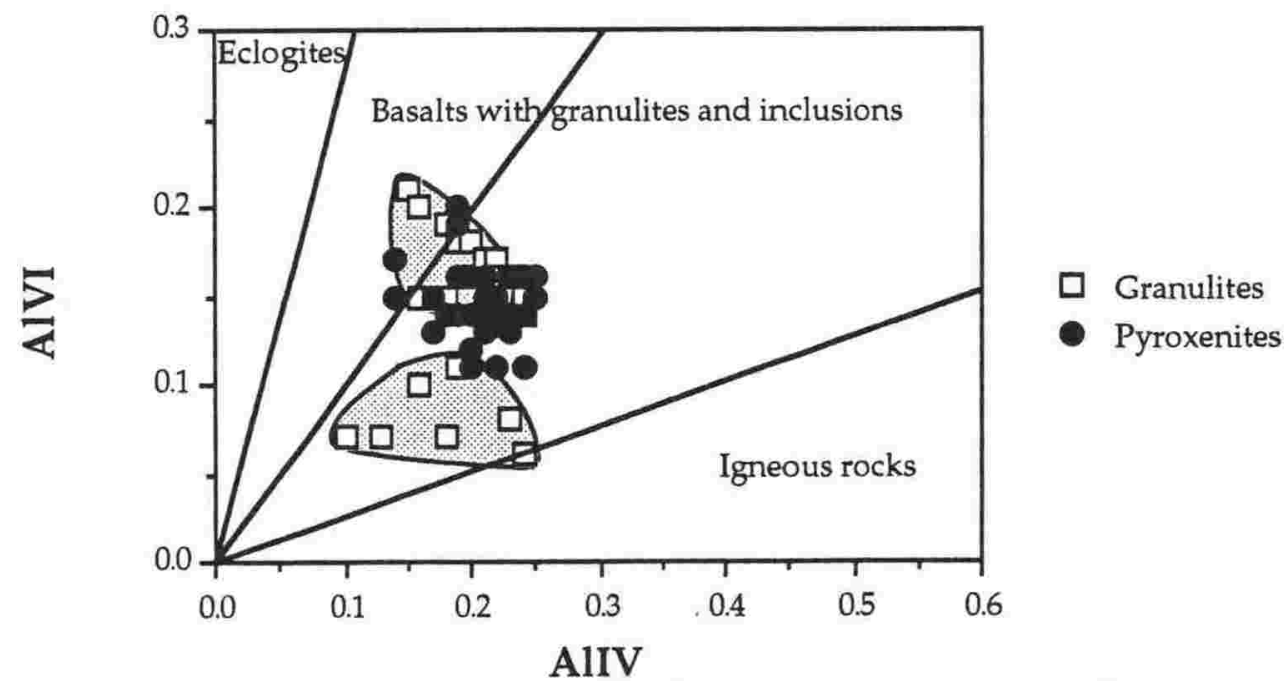

FIGURE 5.6: Tetrahedral $\left(\mathrm{Al}^{\mathrm{IV}}\right)$ and octahedral $\left(\mathrm{Al}^{\mathrm{VI}}\right)$ partitioning of aluminium in clinopyroxene. Mount Hampton granulite clinopyroxenes fall into two groups (light shade) with a compositional gap at 0.11-0.14 $\mathrm{Al}^{\mathrm{VI}}$. The high $\mathrm{Al}^{\mathrm{VI}}$ group crystallised prior to plagioclase, and the low $\mathrm{Al}^{\mathrm{VI}}$ group crystallised after plagioclase, which depleted the melt in Al. Pyroxenite clinopyroxene compositions are intermediate to the granulite groups. The diagram is divided into the fields of Aoki and Shiba (1973), with all Mount Hampton xenolith clinopyroxenes falling within the 'basalts with granulites and inclusions' field. 
If plagioclase crystallised prior to clinopyroxene, the melt would be depleted in $\mathrm{Al}$, resulting in lower $\mathrm{Al}$ contents in clinopyroxenes. If plagioclase did not crystallise prior to clinopyroxene, $\mathrm{Al}$ contents of the clinopyroxene would remain high, and similar to pyroxenite clinopyroxenes, which crystallised from a melt previously unaffected by plagioclase fractionation. This process has also been documented in the Mount Sidley xenolith suite, where granulite (and some plagioclase-bearing pyroxenite) clinopyroxene $\mathrm{Al}$ contents are low compared to most pyroxenite clinopyroxenes (Chapter 4.4.2).

This behaviour makes it possible to identify clinopyroxenes that have crystallised from a melt prior to plagioclase crystallisation, from those that crystallised after plagioclase crystallisation. The former have high $\mathrm{Al}_{2} \mathrm{O}_{3}$ contents (8.0-9.0 wt. $\% \mathrm{Al}_{2} \mathrm{O}_{3}$ ) and the latter have low $\mathrm{Al}_{2} \mathrm{O}_{3}$ contents (3.5-7.7 wt. $\% \mathrm{Al}_{2} \mathrm{O}_{3}$ ). Reviewing clinopyroxene data from the granulite suite (Table 5.2 and Appendix 3.2), it is evident that plagioclase crystallised first in some granulites (e.g. PK4R), while in others clinopyroxene crystallised first (e.g. PK4Y, PK4C1). Granulites with both types of clinopyroxene probably crystallised both phases simultaneously (e.g. PK4A), although some clinopyroxene crystallisation preceded plagioclase crystallisation. Textural evidence supports these orders of crystallisation; e.g. sample PK4A (Plate 5.2) contains cumulus plagioclase with both cumulus and intercumulus clinopyroxene, whereas in sample PK4C1 (Plate 5.3) clinopyroxene is also a cumulus and an intercumulus phase, but plagioclase is only an intercumulus phase.

\subsubsection{Orthopyroxene}

The other major mafic phase together with clinopyroxene, and the dominant Ca-poor mineral phase, is orthopyroxene. Orthopyroxene analyses are from unoxidised cores only, and do not include exsolved orthopyroxenes. Secondary orthopyroxene compositions are documented in Chapter 5.5.2.

Compositions of orthopyroxene from both the granulite and pyroxenite suites are aluminian clinoenstatites (Morimoto et. al, 1988). Granulite orthopyroxenes range from En 67-73, whereas pyroxenite orthopyroxene compositions are bimodal in distribution, with one group similar to granulite orthopyroxenes and another Mg-rich group, ranging from En 75-77 (Figure 5.7). A plot of Wo v Fs highlights this Mg-rich subset (Figure 5.8).

Orthopyroxene textures indicate that igneous orthopyroxenes have been metamorphosed and recrystallised. This is highlighted by the plot of $\mathrm{MgO}+\mathrm{FeO}+$ $\mathrm{Fe}_{2} \mathrm{O}_{3} \vee \mathrm{Al}_{2} \mathrm{O}_{3}$ contents (Figure 5.9), which distinguishes metamorphic from 
TABLE 5.3: Representative electron microprobe analyses of Mount Hampton xenolith orthopyroxenes.

\begin{tabular}{lcccccccccc}
\hline SAMPLE & $\begin{array}{c}\text { PK4A } \\
\text { TYPE }\end{array}$ & $\begin{array}{c}\text { PKan } \\
\text { Gran }\end{array}$ & $\begin{array}{c}\text { PK4Y } \\
\text { Gran }\end{array}$ & $\begin{array}{c}\text { PK4C1 } \\
\text { Gran }\end{array}$ & $\begin{array}{c}\text { PK4C1 } \\
\text { Gran }\end{array}$ & $\begin{array}{c}\text { PK4D } \\
\text { Pyxite }\end{array}$ & $\begin{array}{c}\text { PK4L } \\
\text { Pyxite }\end{array}$ & $\begin{array}{c}\text { PK4S } \\
\text { Pyxite }\end{array}$ & $\begin{array}{c}\text { PK4B1 } \\
\text { Pyxite }\end{array}$ & $\begin{array}{c}\text { PK5G } \\
\text { Pyxite }\end{array}$ \\
\hline $\mathrm{SiO2}$ & 50.82 & 52.53 & 51.44 & 50.88 & 51.05 & 51.57 & 50.17 & 52.00 & 49.68 & 52.75 \\
$\mathrm{Al2O} 3$ & 6.69 & 4.17 & 5.99 & 5.88 & 6.17 & 5.40 & 6.53 & 5.31 & 6.64 & 4.72 \\
$\mathrm{TiO2}$ & 0.15 & 0.23 & 0.16 & 0.26 & 0.26 & 0.38 & 0.40 & 0.39 & 0.41 & 0.31 \\
$\mathrm{FeO}$ & 16.86 & 18.53 & 16.23 & 17.38 & 17.06 & 15.74 & 16.85 & 16.93 & 17.35 & 13.41 \\
$\mathrm{MnO}$ & 0.34 & 0.45 & 0.37 & 0.35 & 0.43 & 0.38 & 0.33 & 0.45 & 0.25 & 0.33 \\
$\mathrm{MgO}$ & 24.30 & 23.39 & 25.09 & 24.18 & 24.10 & 25.29 & 24.33 & 24.39 & 24.11 & 27.28 \\
$\mathrm{CaO}$ & 0.73 & 0.74 & 0.83 & 0.87 & 0.95 & 0.97 & 1.03 & 1.00 & 1.22 & 0.98 \\
$\mathrm{Na2O}$ & 0.12 & 0.06 & 0.09 & 0.01 & 0.14 & 0.15 & 0.11 & 0.12 & 0.15 & 0.24 \\
$\mathrm{~K} 2 \mathrm{O}$ & 0.01 & 0.03 & 0.01 & 0.00 & 0.01 & 0.03 & 0.03 & 0.05 & 0.04 & 0.02 \\
& & & & & & & & & & \\
\hline Fe2O3* & 1.21 & 0.00 & 1.29 & 2.11 & 0.42 & 1.35 & 0.00 & 0.31 & 3.54 & 1.53 \\
FeO* & 15.77 & 18.53 & 15.07 & 15.49 & 16.68 & 14.53 & 16.85 & 16.64 & 14.16 & 12.03 \\
\hline & & & & & & & & & & \\
\hline TOTAL & 100.02 & 100.09 & 100.21 & 99.82 & 100.15 & 99.90 & 99.75 & 100.56 & 99.81 & 100.01 \\
\hline
\end{tabular}

cations on the basis of 6 oxygens

\begin{tabular}{lcccccccccc} 
Si & 1.846 & 1.918 & 1.860 & 1.858 & 1.852 & 1.866 & 1.830 & 1.877 & 1.815 & 1.878 \\
AlIV & 0.150 & 0.080 & 0.140 & 0.140 & 0.150 & 0.130 & 0.170 & 0.120 & 0.180 & 0.120 \\
AlVI & 0.140 & 0.100 & 0.120 & 0.110 & 0.110 & 0.100 & 0.110 & 0.110 & 0.110 & 0.080 \\
Ti & 0.004 & 0.006 & 0.004 & 0.007 & 0.007 & 0.010 & 0.011 & 0.010 & 0.010 & 0.010 \\
FeIII & 0.033 & 0.000 & 0.035 & 0.058 & 0.012 & 0.037 & 0.000 & 0.009 & 0.097 & 0.041 \\
FeII & 0.478 & 0.565 & 0.454 & 0.470 & 0.507 & 0.444 & 0.513 & 0.503 & 0.430 & 0.359 \\
Mn & 0.010 & 0.013 & 0.011 & 0.010 & 0.013 & 0.010 & 0.010 & 0.013 & 0.008 & 0.010 \\
Mg & 1.315 & 1.272 & 1.351 & 1.315 & 1.303 & 1.363 & 1.321 & 1.311 & 1.312 & 1.446 \\
Ca & 0.028 & 0.028 & 0.032 & 0.034 & 0.037 & 0.037 & 0.040 & 0.038 & 0.048 & 0.037 \\
Na & 0.008 & 0.004 & 0.007 & 0.001 & 0.010 & 0.010 & 0.008 & 0.008 & 0.010 & 0.016 \\
K & 0.001 & 0.001 & 0.000 & 0.000 & 0.000 & 0.000 & 0.000 & 0.002 & 0.002 & 0.000 \\
& & & & & & & & & & \\
\hline TOTAL & 4.013 & 3.987 & 4.014 & 4.003 & 4.001 & 4.007 & 4.013 & 4.001 & 4.022 & 3.997 \\
\hline & & & & & & & & & & \\
Wo & 1.51 & 1.50 & 1.71 & 1.81 & 1.99 & 1.97 & 2.13 & 2.04 & 2.54 & 1.96 \\
En & 70.93 & 68.20 & 72.17 & 70.06 & 70.09 & 72.46 & 70.49 & 70.45 & 69.53 & 76.79 \\
Fs & 27.56 & 30.29 & 26.12 & 28.13 & 27.92 & 25.57 & 27.37 & 27.51 & 27.93 & 21.24 \\
& & & & & & & & & & \\
Q & 1.82 & 1.87 & 1.84 & 1.82 & 1.85 & 1.84 & 1.87 & 1.85 & 1.79 & 1.84 \\
J & 0.02 & 0.01 & 0.01 & 0.00 & 0.02 & 0.02 & 0.02 & 0.02 & 0.02 & 0.03
\end{tabular}

* Recalculated assuming stoichiometry based on 4.0 cations 


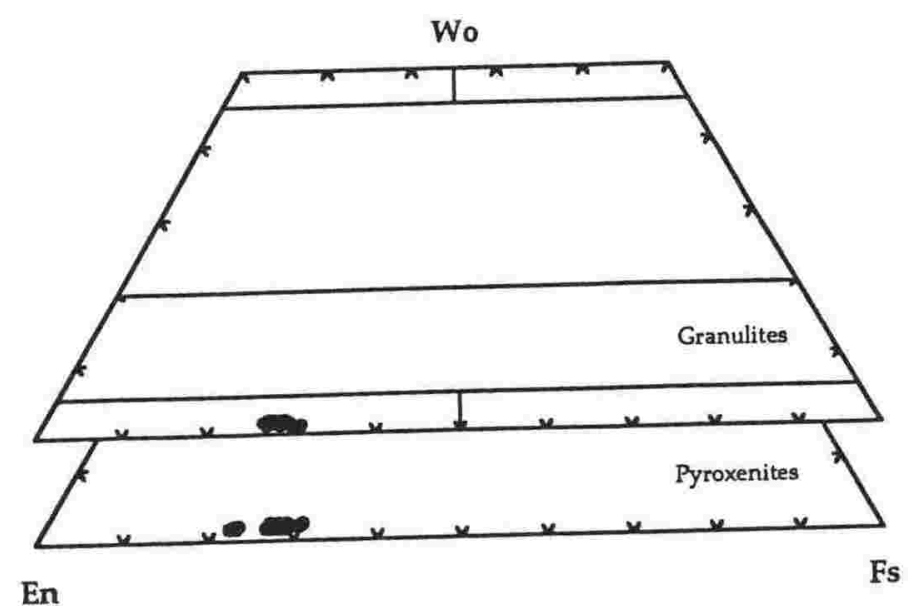

FIGURE 5.7: Composition of orthopyroxenes from the Mount Hampton xenolith suite in the system Wo-En-Fs (fields from Morimoto et al., 1988). Compositions of granulite and pyroxenite orthopyroxenes are similar.

igneous orthopyroxenes (Bhattacharyya, 1971). Nearly all orthopyroxenes plot in the field of metamorphic minerals.

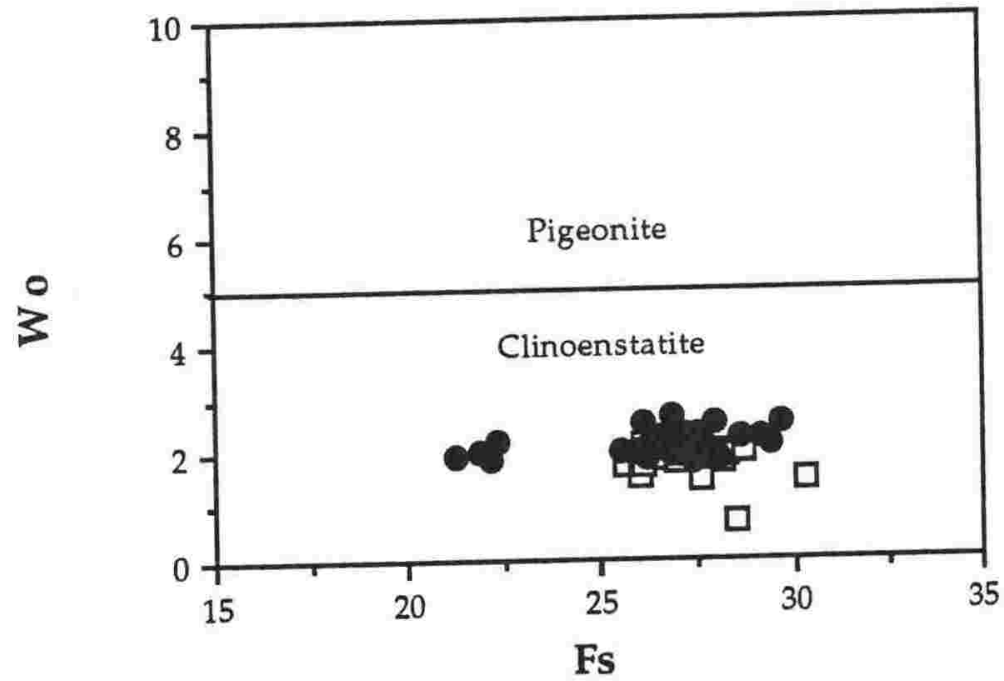

$\square$ Granulites

- Pyroxenites

FIGURE 5.8: Binary diagram of orthopyroxene Wo $v$ Fs compositions. Fields are those of the Morimoto et al. (1988) pyroxene quadrilateral. Granulite and pyroxenite clinopyroxene compositions are similar, except for a small $\mathrm{Mg}$-rich group of pyroxenite clinopyroxenes.

While this method does allow a comparison of orthopyroxenes of metamorphic and igneous origins, there are important limitations:

- original compositions of the orthopyroxene may impart metamorphic contents on non-metamorphic orthopyroxenes; 
- any departures from ion-exchange equilibrium during regional metamorphism of orthopyroxene-bearing igneous rocks may result in igneous characteristics of metamorphosed orthopyroxene;

- in thermally metamorphosed rocks, orthopyroxenes may retain igneous characteristics.

Metamorphic textural characteristics in the xenolith suite invalidates the latter two limitations, and supports the metamorphic chemical signature of the orthopyroxenes indicated by Figure 5.9.

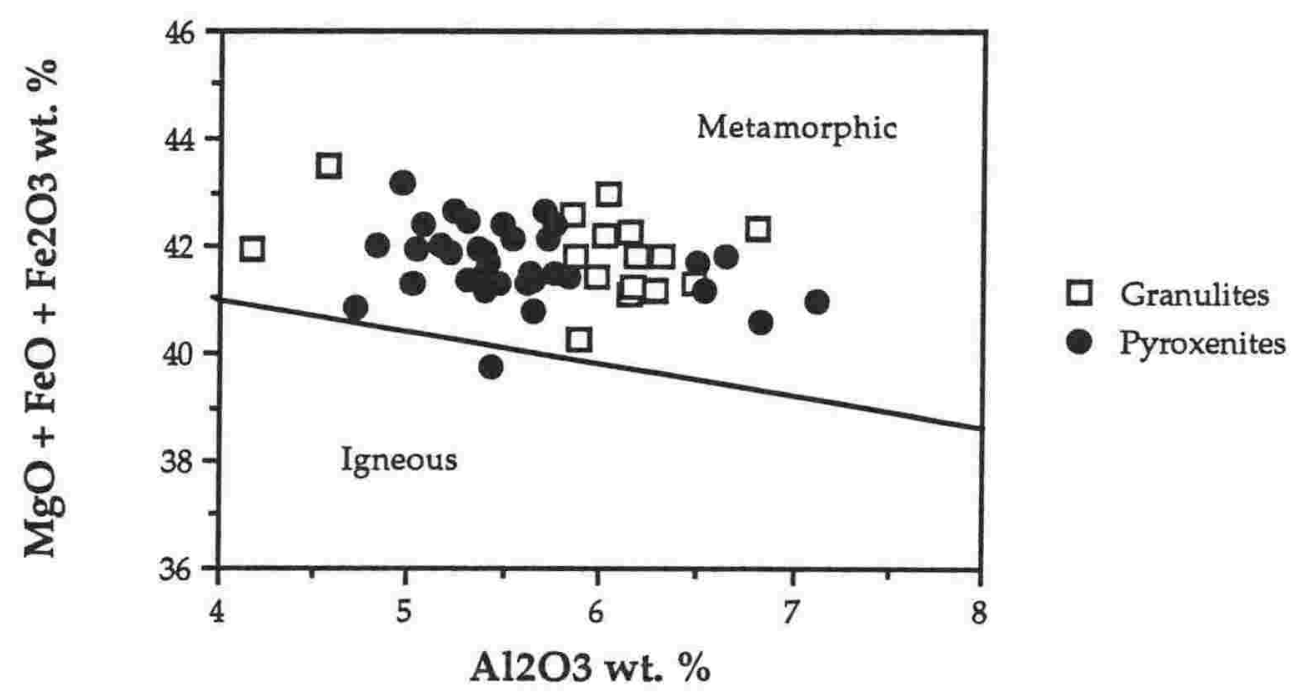

FIGURE 5.9: Compositional plot of Bhattacharyya (1971), distinguishing between metamorphic and igneous orthopyroxenes. This method is dependant on original compositions, on ion-exchange equilibria, and on possible retentions of igneous characteristics in metamorphic orthopyroxenes.

Compositions of granulite and pyroxenite orthopyroxenes are similar. The M1 and M2 octahedral sites are filled by $\mathrm{Mg}$ and $\mathrm{Fe}$, with only minor amounts of $\mathrm{Ca}(\leq 0.05$ cations), $\mathrm{Na}(\leq 0.04$, but generally $\leq 0.01$ cations) and $\mathrm{Mn}(\leq 0.2$ cations). Ti also occurs in minor amounts (generally 0.01 cation per 6 oxygens).

Silica dominates the tetrahedral site, but large amounts of $\mathrm{Al}$ substitute for $\mathrm{Si}\left(\leq 0.25 \mathrm{Al}^{\mathrm{IV}}\right.$ cations). The charge imbalance of $\mathrm{Al}^{3+}$ substituting for $\mathrm{Si}^{4+}$ cannot be balanced by the coupled substitution of $\mathrm{Ti}^{4+}$ for $\mathrm{Mg}^{2+}$ or $\mathrm{Fe}^{2+}$ in octahedral sites as the quantity of Ti present is insufficient. This is evident in that lack of a correlation between $\mathrm{Al}^{\mathrm{IV}}$ and $\mathrm{Ti}$ in the xenolith suite (Figure 5.10), indicating that $\mathrm{Ti}^{4+}$ does not restore the charge imbalance due to $\mathrm{Al}^{3+}$ substitution of $\mathrm{Si}^{4+}$. The lack of any trends between $\mathrm{Ti}$ and $\mathrm{Al}^{\mathrm{IV}}$ or $\mathrm{Al}^{\mathrm{VI}}$ (Figure 5.10) may reflect the low abundance of $\mathrm{Ti}$ in orthopyroxenes, resulting in relatively high analytical errors. The presence of appropriate $\mathrm{Fe}^{3+}$ may however restore the charge imbalance. 


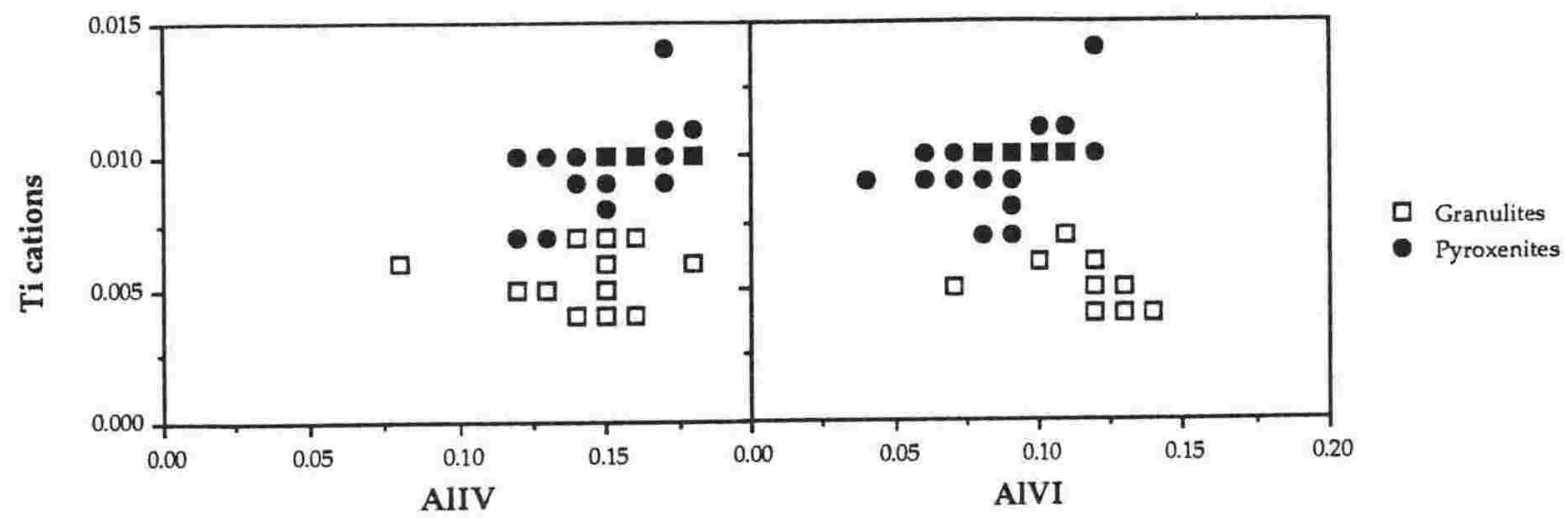

FIGURE 5.10: $\mathrm{Ti}$ shows no correlation with either a) $\mathrm{Al}^{\mathrm{IV}}$ content, or b) $\mathrm{Al}^{\mathrm{VI}}$ content, indicating that the substitution of $\mathrm{Ti}$ for $\mathrm{Mg}$ or Fe may not restore the charge imbalance from the substitution of $\mathrm{Al}$ for $\mathrm{Si}$ in the tetrahedral site. Closed squares represent analyses of both granulite and pyroxenite orthopyroxenes.

Unlike the bimodal compositions of granulite clinopyroxenes, granulite orthopyroxene compositions are not bimodal as a result of prior plagioclase crystallisation in low $-\mathrm{Al}_{2} \mathrm{O}_{3}$ clinopyroxenes (Chapter 5.4.1). The lack of such a trend in orthopyroxenes, and the cumulus textures of granulite plagioclase and intercumulus texture of granulite orthopyroxenes, indicates that plagioclase crystallisation preceded orthopyroxene crystallisation.

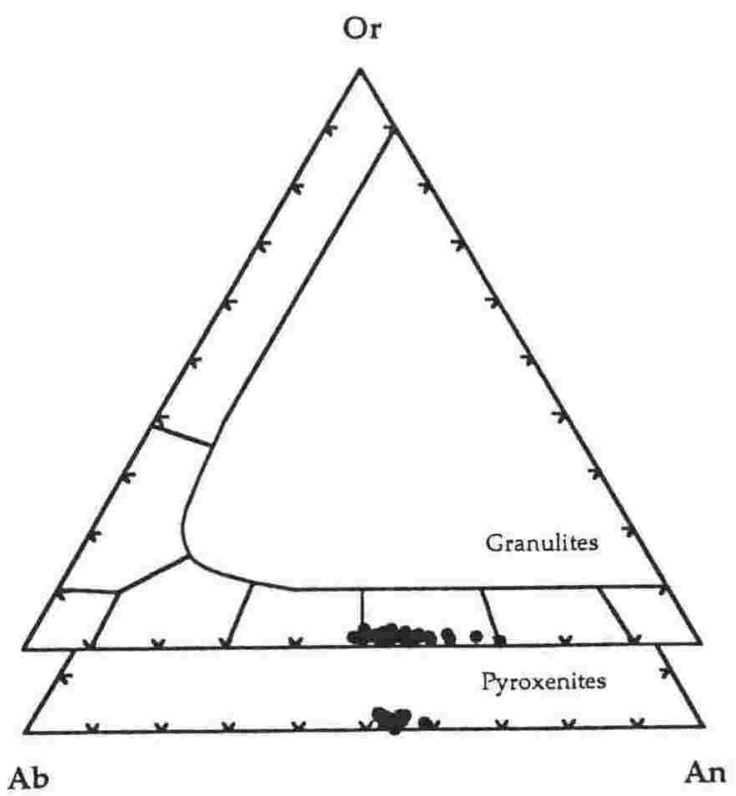

FIGURE 5.11: Composition of plagioclase from Mount Hampton xenoliths in the system Or-An-Ab. Fields are those of Deer et al. (1966). The range of plagioclase An composition is greater in the granulite suite than in the pyroxenite suite.

\subsubsection{Plagioclase}

Plagioclase is a major constituent of the granulite suite xenoliths, but only a minor component of the pyroxenite suite. All feldspars in the xenolith suite are plagioclase feldspars; alkali feldspars are totally absent. Table 5.4 presents representative analyses of plagioclase cores from both suites. 
Granulite plagioclase is mainly labradorite in composition, with minor andesine, forming a continuum from An 49-70 (Figure 5.11). Ranges in An content of $>10$ in some samples signifies crystallisation from an evolving melt or varying pressure, temperature or water conditions. In other samples, compositional ranges are small, indicating crystallisation under stable conditions.

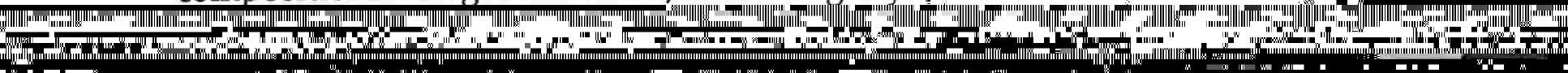

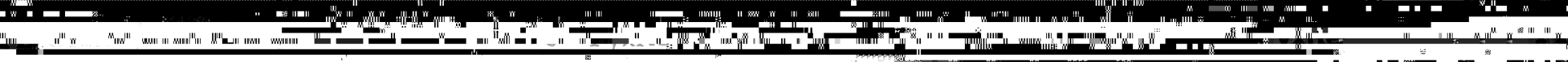

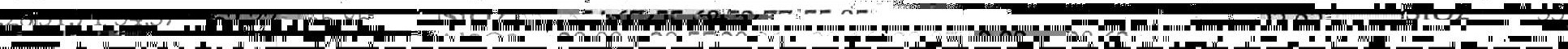
M 1. - int

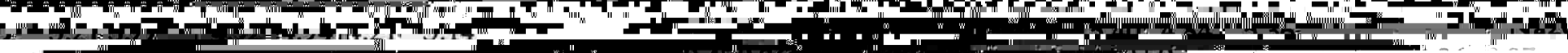
"

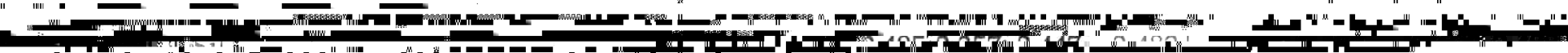
7na

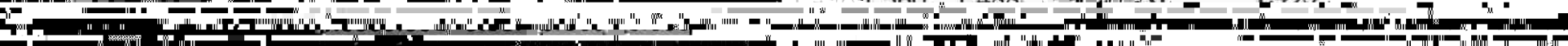

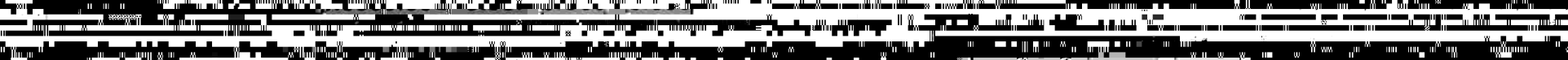

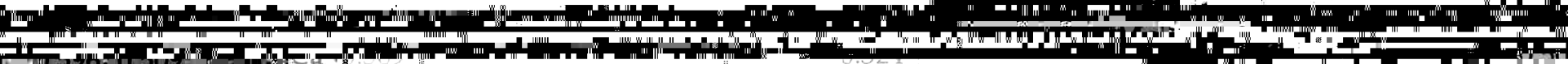
Prin

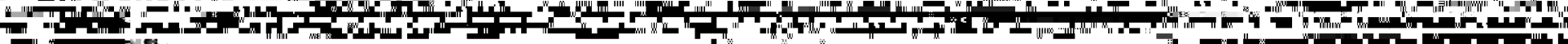
ל

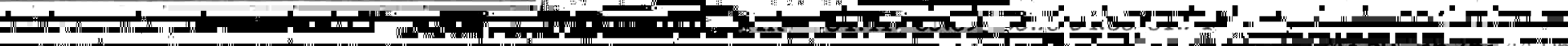

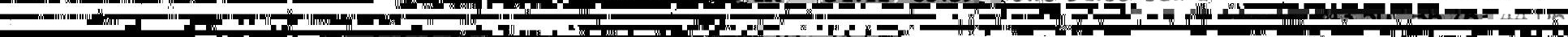
C-1 - -1. Nifum (III) 
crystallisation under stable conditions, and from more Ca-poor melts than granulite plagioclase that crystallised as a cumulus phase earlier in the crystallisation sequence.

Plagioclase from both suites contain minor amounts of $\mathrm{FeO}(\leq 0.55$ wt. \%), and trace amounts of $\mathrm{Mg}$ and $\mathrm{Mn}$. Other than the extended range of granulite plagioclase composition, there is no difference in plagioclase from the granulite and pyroxenite suites.

TABLE 5.5: Representative electron microprobe analyses of Mount Hampton primary xenolith oxides.

\begin{tabular}{|c|c|c|c|c|c|c|c|c|c|}
\hline $\begin{array}{l}\text { SAMPLE } \\
\text { TYPE }\end{array}$ & $\begin{array}{c}\text { PK4V } \\
\text { Gran } \\
\text { Il }\end{array}$ & $\begin{array}{c}\text { PK4V } \\
\text { Gran } \\
\text { Il }\end{array}$ & $\begin{array}{c}\text { PK4C1 } \\
\text { Gran } \\
\text { Al-Sp }\end{array}$ & $\begin{array}{c}\text { PK4B } \\
\text { Pyxite } \\
\text { Il }\end{array}$ & $\begin{array}{c}\text { PK4D } \\
\text { Pyxite } \\
\text { Il }\end{array}$ & $\begin{array}{l}\text { PK4L } \\
\text { Pyxite } \\
\text { Al-Sp }\end{array}$ & $\begin{array}{c}\text { PK4T } \\
\text { Pyxite } \\
\text { Il }\end{array}$ & $\begin{array}{c}\text { PK4T } \\
\text { Pyxite } \\
\text { Il }\end{array}$ & $\begin{array}{c}\text { PK4D1 } \\
\text { Pyxite } \\
\text { Il }\end{array}$ \\
\hline $\mathrm{SiO}_{2}$ & 0.03 & 0.82 & 0.13 & 0.12 & 0.11 & 0.06 & 0.11 & 0.17 & 0.08 \\
\hline $\mathrm{Al} 2 \mathrm{O} 3$ & 2.27 & 0.75 & 61.42 & 1.40 & 0.11 & 58.13 & 0.23 & 0.41 & 0.50 \\
\hline $\mathrm{TiO} 2$ & 53.44 & 50.59 & 0.23 & 51.09 & 51.28 & 0.40 & 46.89 & 48.89 & 48.37 \\
\hline $\mathrm{Fe} 2 \mathrm{O} 3$ & 0.96 & 3.42 & 4.10 & 1.19 & 5.58 & 5.67 & 13.56 & 9.25 & 10.81 \\
\hline $\mathrm{FeO}$ & 36.87 & 40.28 & 20.21 & 39.14 & 32.26 & 19.24 & 31.72 & 33.37 & 31.31 \\
\hline $\mathrm{MnO}$ & 0.14 & 0.24 & 0.25 & 0.19 & 0.37 & 0.16 & 0.38 & 0.41 & 0.22 \\
\hline $\mathrm{MgO}$ & 6.03 & 2.72 & 14.24 & 3.67 & 7.47 & 13.99 & 5.83 & 5.75 & 6.75 \\
\hline $\mathrm{CaO}$ & 0.02 & 0.15 & 0.01 & 0.04 & 0.09 & 0.04 & 0.14 & 0.32 & 0.02 \\
\hline $\mathrm{Cr} 2 \mathrm{O} 3$ & 0.00 & 0.01 & 0.00 & 0.16 & 0.31 & 0.00 & 0.03 & 0.24 & 0.17 \\
\hline $\mathrm{NiO}$ & 0.01 & 0.03 & 0.00 & 0.16 & 0.19 & 0.00 & 0.11 & 0.12 & 0.03 \\
\hline TOTAL & 99.75 & 99.01 & 100.59 & 97.16 & 97.77 & 97.68 & 99.00 & 98.93 & 98.25 \\
\hline
\end{tabular}

cations on the basis of 3 (spinel) or 2 (rhombehedral) sites

\begin{tabular}{|c|c|c|c|c|c|c|c|c|c|}
\hline $\mathrm{Si}$ & 0.001 & 0.024 & 0.005 & 0.003 & 0.003 & 0.002 & 0.003 & 0.004 & 0.002 \\
\hline $\mathrm{Al}$ & 0.066 & 0.026 & 1.903 & 0.041 & 0.003 & 1.864 & 0.007 & 0.011 & 0.014 \\
\hline $\mathrm{Ti}$ & 0.958 & 0.931 & 0.005 & 0.967 & 0.946 & 0.008 & 0.869 & 0.900 & 0.889 \\
\hline FeIII & 0.017 & 0.063 & 0.081 & 0.019 & 0.099 & 0.116 & 0.251 & 0.171 & 0.204 \\
\hline FeII & 0.734 & 0.824 & 0.440 & 0.827 & 0.666 & 0.438 & 0.653 & 0.687 & 0.635 \\
\hline $\mathbf{M n}$ & 0.003 & 0.006 & 0.006 & 0.004 & 0.008 & 0.004 & 0.008 & 0.008 & 0.004 \\
\hline $\mathrm{Mg}$ & 0.221 & 0.120 & 0.558 & 0.138 & 0.273 & 0.567 & 0.207 & 0.205 & 0.246 \\
\hline $\mathrm{Ca}$ & 0.000 & 0.005 & 0.000 & 0.001 & 0.003 & 0.001 & 0.003 & 0.008 & 0.006 \\
\hline $\mathrm{Cr}$ & 0.000 & 0.000 & 0.000 & 0.003 & 0.000 & 0.000 & 0.000 & 0.003 & 0.003 \\
\hline $\mathrm{Ni}$ & 0.000 & 0.000 & 0.000 & 0.003 & 0.000 & 0.000 & 0.010 & 0.003 & 0.001 \\
\hline TOTAL & 2.000 & 1.999 & 2.998 & 2.006 & 2.001 & 3.000 & 2.011 & 2.000 & 2.004 \\
\hline$X(U s p)$ & & & 0.55 & & & 0.51 & & & \\
\hline $\mathrm{X}(\mathrm{II})$ & 0.99 & 0.97 & & 0.99 & 0.94 & & 0.86 & 0.90 & 0.88 \\
\hline
\end{tabular}




\subsubsection{Non-silicates}

Primary oxides (Table 5.5) occur mainly as inclusions in host plagioclase and pyroxene. Ilmenite is the dominant primary Fe-Ti oxide in the xenolith suite, and titanomagnetite has not been detected. The absence of ilmenite as a secondary oxide (Chapter 5.5.2) signifies that they have not been reset by recent secondary reactions, but have been protected and preserved by their host minerals. Al-spinel also occurs in both suites (Figure 5.12).

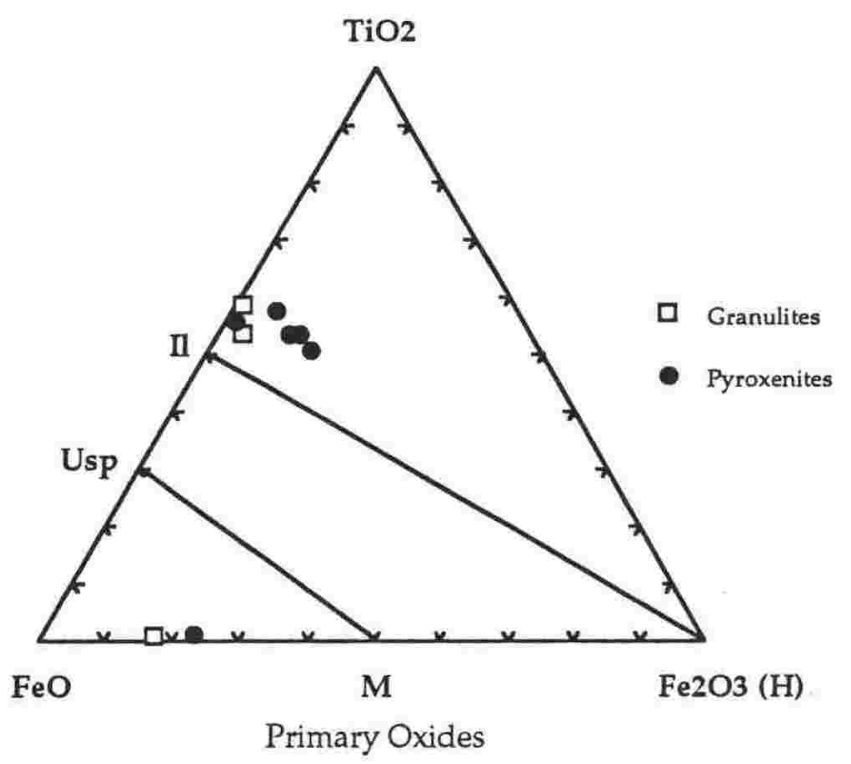

FIGURE 5.12: Composition of primary oxides from Mount Hampton xenoliths in the system $\mathrm{TiO}_{2}-\mathrm{FeO}-\mathrm{Fe}_{2} \mathrm{O}_{3}$. Ilmenite is the dominant Fe-Ti oxide phase present. Small amounts of Al-spinels also occur (plotting on the $\mathrm{FeO}-\mathrm{Fe}_{2} \mathrm{O}_{3}$ line). $\mathrm{H}=$ hematite; $\mathrm{I}=$ ilmenite; $\mathrm{M}=$ magnetite; Usp = ulvöspinel.

There is little difference in composition between oxides of the granulite and the pyroxenite suites. The oxide mineral assemblage is not appropriate for determining temperature and oxygen fugacity conditions. The presence of ilmenite however does constrain the source region to low $\mathrm{fO}_{2}$ conditions, which is consistent with their formation at lower crustal or upper mantle conditions (Haggerty, 1990).

\subsubsection{Geothermobarometry}

The two-pyroxene assemblage of the xenolith suite allows the determination of equilibration temperatures. Several methods are available based on the partitioning of elements between two pyroxene assemblages (e.g. Wood and Banno (1973), Wells (1977), Powell (1978), Kretz (1982), Lindsley (1983), Gasparik (1984), Bertrand and Mercier (1985) and Nickel et al. (1985)). Not all methods are appropriate for the xenolith suite, and those used show some variation in their results. Table 5.6 is a summary of the results using various methods on adjacent (and unaltered) clinopyroxene and orthopyroxene cores.

Some geothermometers are unsuitable to use on the xenolith suite. The geothermometer of Powell (1978) requires garnet to be present, and Lindsley (1983) 
considers his graphic geothermometer to be unsuitable for microprobe analyses, because of the uncertainty in $\mathrm{Fe}^{3+}$ determinations. This is supported by results on the Mount Hampton xenolith suite which returned very low temperature estimates of $500-600^{\circ} \mathrm{C}$.

TABLE 5.6: Two-pyroxene temperature and pressure estimations of the Mount Hampton xenolith suite using the methods of Wood and Banno (1973), Wells (1977), Kretz (1982), Gasparik (1984), Bertrand and Mercier (1985), and Nickel et al. (1985). 'Estimation' refers to the estimated limitations of the methods. See text for further explanation.

\begin{tabular}{|c|c|c|c|c|c|c|c|}
\hline Method & $\begin{array}{l}\text { W\&B } \\
\text { Temp }\end{array}$ & $\begin{array}{l}\text { Wells } \\
\text { Temp }\end{array}$ & $\begin{array}{l}\text { Kretz } \\
\text { Temp }\end{array}$ & $\begin{array}{l}\text { B\&M } \\
\text { Temp } \\
\end{array}$ & $\begin{array}{c}\text { Nickel } \\
\text { Temp }\end{array}$ & $\begin{array}{c}\text { Gasparik } \\
\text { Temp } \\
\end{array}$ & $\begin{array}{l}\text { Gasparik } \\
\text { Pressure }\end{array}$ \\
\hline Estimation & - & - & Low & $900-1500^{\circ} \mathrm{C}$ & High & High & - \\
\hline \multicolumn{8}{|l|}{ Granulites } \\
\hline Low & 906 & 863 & 642 & 762 & 1100 & 1150 & 6.5 \\
\hline High & 1007 & 1047 & 1160 & 1029 & 1254 & 1215 & 9.5 \\
\hline \multicolumn{8}{|l|}{ Pyroxenites } \\
\hline Low & 906 & 871 & 770 & 778 & 1118 & 1150 & 7 \\
\hline High & 1032 & 1033 & 995 & 896 & 1235 & 1225 & 8.5 \\
\hline
\end{tabular}

Of the geothermometers used here, many provide variable results due to problems in their estimations. For example, the methods of Wood and Banno (1973) and Wells (1977) are erratic, and produce high temperatures for temperatures $<900{ }^{\circ} \mathrm{C}$. The method of Kretz (1982) produces low estimates for granulite assemblages, and the method of Nickel et al. (1985) produces high estimates for granulite assemblages. Bertrand and Mercier (1985) provide a geothermometer suitable for mantle rocks between 950 and $1500{ }^{\circ} \mathrm{C}$. Results were unobtainable for many pyroxene pairs using this method, and only a few pairs yielded temperatures within the optimum range. This geothermometer proved unreliable for the Mount Hampton assemblage.

The geothermometer of Gasparik (1984) is based on the partitioning of Al between co-existing clinopyroxene and orthopyroxene, and the En content of the clinopyroxene. The partitioning of $\mathrm{Al}$ is pressure dependant, allowing the pressure of equilibration to be determined. Temperature estimates are higher than estimates determined by other methods, reflecting the affect of temperature on En (1-Ca) content. High Ca contents in clinopyroxene will therefore yield high temperature estimates. 
Based on the limitations discussed above, the most reliable estimates lie between the Kretz (1982) method, which produce low temperatures for granulites, and the Nickel et al. (1985) method, which produce high temperatures for granulites. The results of the Wood and Banno (1973) and Wells (1977) methods fall within this range. An average estimate of temperatures for the Mount Hampton xenolith suite using these methods ranges from temperatures of 875$1125^{\circ} \mathrm{C}$ for the granulite suite, to $915-1075^{\circ} \mathrm{C}$ for the pyroxenite suite.

Despite the uncertainty in temperature estimations using different methods, all geothermometers yield similar (magmatic) temperatures for the granulites and the pyroxenites. The recrystallised fabric of many pyroxenes indicate that the temperatures are not temperatures of crystallisation, but have equilibrated to local P-T conditions. The determination of high pressures (6.5-9.5 kb; Gasparik, 1984) and high temperatures (Table 5.6), implies a high geothermal gradient in the Mount Hampton lithosphere. This is further discussed in Chapter 8.2.3.

\subsubsection{Summary of mineral chemistry}

A summary of granulite and pyroxenite textures and minerals is presented as Table 5.7. There is little difference in mineral chemistry between the granulite and pyroxenite suite, or between metamorphic and igneous mineral phases.

Mineral textures and compositions indicate a number of factors about the xenolith suite and the crystallisation of the cumulate protoliths:

- clinopyroxene and orthopyroxene are both cumulus and intercumulus phases in the granulite and pyroxenite suites. Only plagioclase differs between the suites, from intercumulus in pyroxenites to cumulus in granulites. Orders of crystallisation represented by the xenolith suite are presented as Table 5.8;

- original cumulate textures are preserved in some xenoliths, but have been overprinted by strong metamorphic fabrics in most xenoliths, resulting in metaigneous textures. Mineral phases have been recrystallised to small equant grains, with well developed $120^{\circ}$ triple junctions between grains;

- in the granulite suite, clinopyroxene compositions are either Al-rich or Al-poor due to clinopyroxene crystallisation before or after plagioclase respectively. Pyroxenite clinopyroxene compositions are unimodal, reflecting the absence of plagioclase crystallisation;

- orthopyroxene $\mathrm{Al}$ compositions are unimodal in the granulite suite, reflecting their crystallisation after plagioclase; 
- two-pyroxene geothermometry indicates magmatic to sub-magmatic temperatures $\left(875-1125^{\circ} \mathrm{C}\right)$, and high pressures $(6.5-9.5 \mathrm{~kb})$, which indicate their equilibration to a high geothermal gradient;

TABLE 5.7: Summary of the petrography and mineral chemistry of the granulite and pyroxenite xenolith suites from Mount Hampton.

\begin{tabular}{lcc}
\hline TYPE & Granulites & Pyroxenites \\
\hline ROCK TYPES & $\begin{array}{c}\text { Norites } \\
\text { Gabbros }\end{array}$ & $\begin{array}{c}\text { Websterites } \\
\text { Clinopyroxenites }\end{array}$ \\
TEXTURE & $\begin{array}{c}\text { Meta-Igneous } \\
\text { Granulites }\end{array}$ & $\begin{array}{c}\text { Meta-Igneous } \\
\text { Granulites }\end{array}$ \\
MINERALOGY & Wo 40-49 & Wo 42-46 \\
Clinopyroxene & En 36-44 & En 39-44 \\
& Fs 13-17 & Fs 12-16 \\
Orthopyroxene & Wo 1-2 & Wo 2-3 \\
& En 67-73 & En 68-77 \\
& Fs 26-31 & Fs 21-30 \\
Plagioclase & An 47-70 & An 50-57 \\
Oxides & Ilmenite & Ilmenite \\
& Al-spinels & Al-spinels \\
Temperature $\left({ }^{\circ} \mathrm{C}\right)$ & 1150-1215 & 1150 - 1225 \\
Pressure (kb) & $6.5-9.5$ & $7.0-8.5$ \\
SECONDARY & Oxidation & Oxidation \\
REACTIONS & (extensive) & (less intense) \\
& & \\
\hline
\end{tabular}

- oxide phases in both suites are similar, consisting predominantly of ilmenite and Al-spinel. The presence of ilmenite as a primary oxide phase indicates low oxygen fugacities of IW redox conditions in the lower crust beneath Mount Hampton (Buddington and Lindsley, 1964);

- metamorphic and igneous mineral phases are identical, indicating that metamorphism was closed-system with regard to major elements, maintaining bulk chemical compositions and characteristics.

The similarity of the granulite and pyroxenite mineral compositions suggests that the Mount Hampton xenolith suite is genetically related, having 
TABLE 5.8: Sequences of crystallisation present in the Mount Hampton xenolith suite. The transition from crystallisation of pyroxenites to granulites occurs due to the change in plagioclase crystallisation from intercumulus (i) and rare, to cumulus (c) and abundant.

\section{Pyroxenites Clinopyroxene $(\mathrm{c}, \mathrm{i})+$ Orthopyroxene $(\mathrm{c}, \mathrm{i})$}

Clinopyroxene $(c, i)+$ Orthopyroxene $(c, i)+$ Plagioclase $(i)$

Granulites Clinopyroxene $(c, i)+$ Orthopyroxene $(c, i)+$ Plagioclase $(c, i)$

Plagioclase $(\mathrm{c}, \mathrm{i})+$ Clinopyroxene $(\mathrm{c}, \mathrm{i})+$ Orthopyroxene $(\mathrm{i})$

Plagioclase (c) + Clinopyroxene (i) + Orthopyroxene (i)

crystallised from the same parent melt. Granulites represent the appearance of plagioclase as a cumulus phase, with a possible sequence of crystallisation represented in order of Table 5.8 .

\subsection{Secondary Mineral Reactions}

The pervasive oxidation of orthopyroxene constitutes the main secondary process affecting the xenolith suite. The association of oxidation with the host melt is evidenced by reactions extending from the oxidised rims of the xenoliths into the xenoliths forming reaction rims on orthopyroxenes, as well as the previously documented close association of oxidation and host melt interactions in the Mount Sidley xenolith suite (Chapter 4.5). The host melt is the agent responsible for the process of oxidation.

\subsubsection{Oxidation of the xenolith suite}

Orthopyroxene is the phase most affected by oxidation, with symplectite rims of two phases of olivine and Fe-Ti oxides in a glass matrix. Oxidised areas are opaque under transmitted light, however individual phases are easily distinguishable by back-scattered electron images. The only notable difference between oxidation in the granulite and pyroxenite suites is its severity, with more pervasive and complete oxidation in the granulite suite, and only a mild degree of oxidation in the pyroxenite suite. The style of oxidation is best evidenced in the following case studies, with plates showing oxidised areas and sites of analyses presented in accompanying tables. In secondary mineral reaction tables, minerals are identified by their association: 'core' = primary mineral core; 'oxid.' = associated with oxidation; 'rim' = primary mineral rim; 'vein' = vein minerals. 
TABLE 5.9: Electron microprobe analyses of oxidation reactions in a granulite (sample PK4Y). See Plate $5.6 \mathrm{a}$ for analyses sites.

\begin{tabular}{|c|c|c|c|c|c|c|c|c|c|c|}
\hline $\begin{array}{l}\text { PHASE } \\
\text { SITE }\end{array}$ & $\begin{array}{c}\text { Opx } \\
\text { core } \\
1\end{array}$ & $\begin{array}{c}\text { Olivine } \\
\text { oxid. } \\
2\end{array}$ & $\begin{array}{c}\text { Olivine } \\
\text { oxid. } \\
3\end{array}$ & $\begin{array}{l}\text { Oxide } \\
\text { oxid. } \\
4\end{array}$ & $\begin{array}{c}\text { Glass } \\
\text { oxid. } \\
5\end{array}$ & $\begin{array}{c}\text { Glass } \\
\text { oxid. } \\
6\end{array}$ & $\begin{array}{c}\text { Opx } \\
\text { oxid. } \\
7\end{array}$ & $\begin{array}{c}\text { Cpx } \\
\text { core } \\
8\end{array}$ & $\begin{array}{c}\text { Plag } \\
\text { core- } \\
9\end{array}$ & $\begin{array}{c}\text { Plag } \\
\text { rim } \\
10\end{array}$ \\
\hline $\mathrm{SiO} 2$ & 50.54 & 40.80 & 42.91 & 0.11 & 56.34 & 56.41 & 54.33 & 49.76 & 55.55 & 50.79 \\
\hline $\mathrm{Al} 2 \mathrm{O} 3$ & 6.14 & 0.13 & 0.00 & 1.28 & 14.98 & 15.37 & 1.20 & 8.57 & 28.25 & 30.60 \\
\hline $\mathrm{TiO} 2$ & 0.23 & 0.13 & 0.02 & 2.78 & 3.08 & 2.73 & 0.31 & 0.88 & 0.00 & 0.11 \\
\hline $\mathrm{Fe} 2 \mathrm{O} 3$ & & & & 64.46 & & & 1.77 & 2.21 & & \\
\hline $\mathrm{FeO}$ & 16.50 & 27.16 & 1.85 & 23.20 & 9.60 & 7.58 & 11.97 & 6.25 & 0.20 & 0.66 \\
\hline $\mathrm{MnO}$ & 0.31 & 0.52 & 0.37 & 0.58 & 0.10 & 0.21 & 0.42 & 0.30 & 0.09 & 0.03 \\
\hline $\mathrm{MgO}$ & 24.39 & 30.47 & 54.67 & 6.30 & 3.77 & 3.41 & 27.62 & 12.44 & 0.01 & 0.05 \\
\hline $\mathrm{CaO}$ & 0.88 & 0.47 & 0.07 & 0.12 & 4.57 & 5.50 & 1.92 & 19.91 & 10.43 & 14.33 \\
\hline $\mathrm{Na} 2 \mathrm{O}$ & 0.25 & 0.06 & 0.09 & 0.11 & 6.48 & 5.53 & 0.21 & 1.27 & 5.86 & 3.72 \\
\hline $\mathrm{K} 2 \mathrm{O}$ & 0.07 & 0.13 & 0.04 & 0.01 & 2.16 & 1.97 & 0.08 & 0.04 & 0.37 & 0.17 \\
\hline TOTAL & 99.30 & 99.88 & 100.01 & 98.95 & 101.07 & 98.70 & 99.82 & 101.63 & 100.76 & 100.44 \\
\hline $\mathrm{Si}$ & 1.850 & 1.079 & 1.013 & 0.000 & & & 1.959 & 1.818 & 2.482 & 2.314 \\
\hline Al & 0.264 & 0.003 & 0.000 & 0.060 & & & 0.050 & 0.368 & 1.502 & 1.643 \\
\hline $\mathrm{Ti}$ & 0.010 & 0.002 & 0.004 & 0.080 & & & 0.000 & 0.024 & 0.000 & 0.000 \\
\hline FeIII & & & & 1.782 & & & 0.050 & 0.060 & & \\
\hline FeII & 0.504 & 0.600 & 0.037 & 0.713 & & & 0.360 & 0.190 & 0.010 & 0.020 \\
\hline Mn & 0.010 & 0.011 & 0.007 & 0.018 & & & 0.012 & 0.010 & 0.000 & 0.000 \\
\hline $\mathrm{Mg}$ & 1.330 & 1.200 & 1.925 & 0.352 & & & 1.483 & 0.676 & 0.000 & 0.000 \\
\hline $\mathrm{Ca}$ & 0.034 & 0.013 & 0.002 & 0.010 & & & 0.073 & 0.778 & 0.504 & 0.699 \\
\hline $\mathrm{Na}$ & 0.017 & 0.003 & 0.004 & 0.000 & & & 0.014 & 0.090 & 0.512 & 0.328 \\
\hline K & 0.000 & 0.004 & 0.007 & 0.000 & & & 0.000 & 0.000 & 0.021 & 0.010 \\
\hline TOTAL & 4.019 & 2.915 & 2.999 & 3.015 & & & 4.001 & 4.014 & 5.031 & 5.014 \\
\hline
\end{tabular}

\section{Sample PK4Y: Granulite xenolith (Plate 5.6; Tables 5.9, 5.10)}

Extensive oxidation in this sample (Plate 5.6a) has resulted in the almost complete oxidation of orthopyroxene (1) into symplectites of Fe-rich olivine (2) and Fe-poor olivine (3), as well as and Fe-Ti oxides (4), surrounded by a matrix of glass $(5,6)$. The $\mathrm{Mg}: \mathrm{Mg}+\mathrm{Fe}$ ratio of the orthopyroxene host falls between those of the two olivine phases, which may also derive their other chemical characteristics from the host orthopyroxene. Oxidised orthopyroxene (7) is rich in $\mathrm{Si}, \mathrm{Mg}$ and $\mathrm{Ca}$, and poor in $\mathrm{Al}$ compared to unoxidised orthopyroxene (1).

In marked contrast to orthopyroxene, clinopyroxene (8) is unaffected, however plagioclase (9) shows disequilibrium textures with sieved rims in contact with melt. Plagioclase disequilibrium however is not widespread, occurring in 


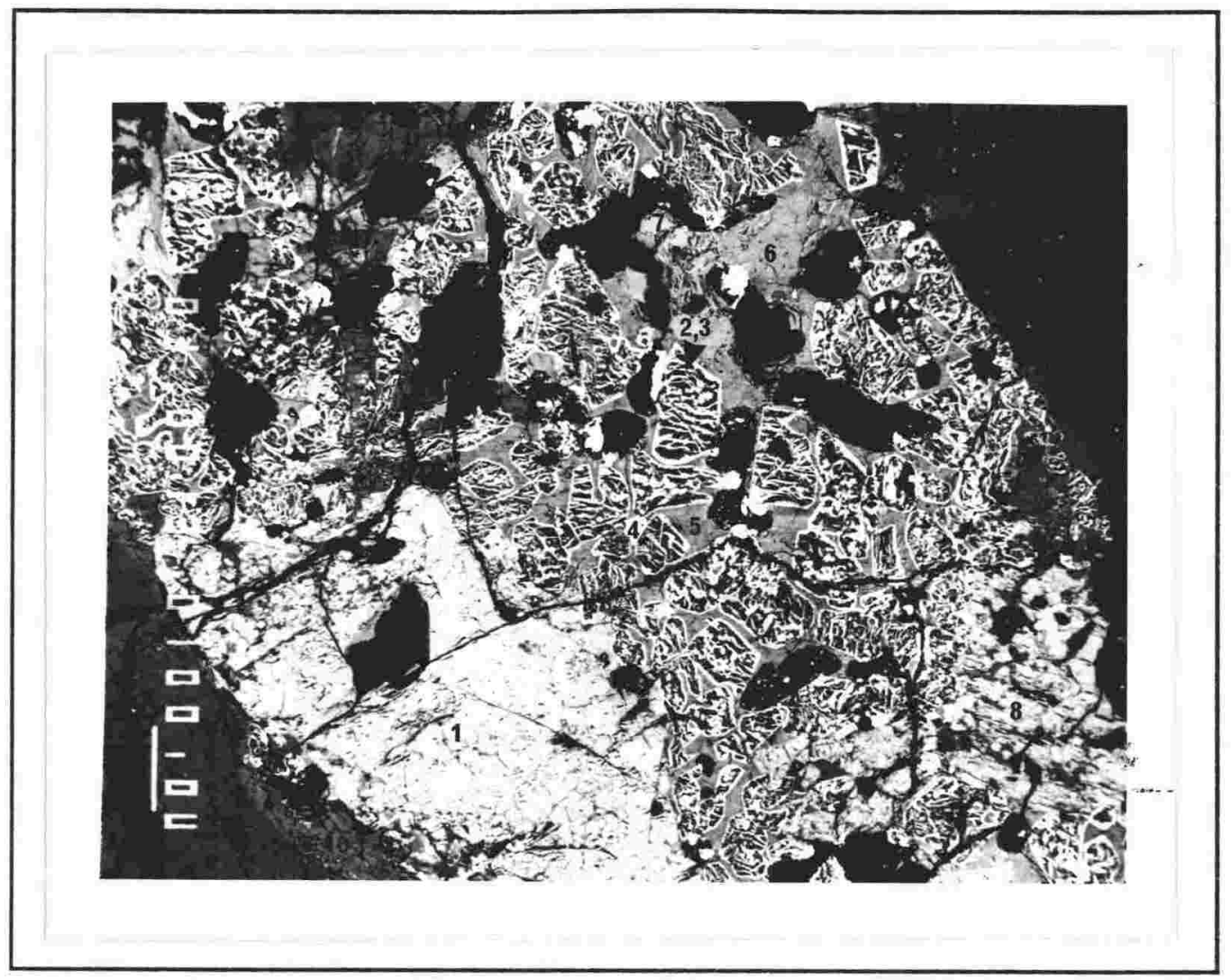

Plate 5.6a: See caption overleaf.

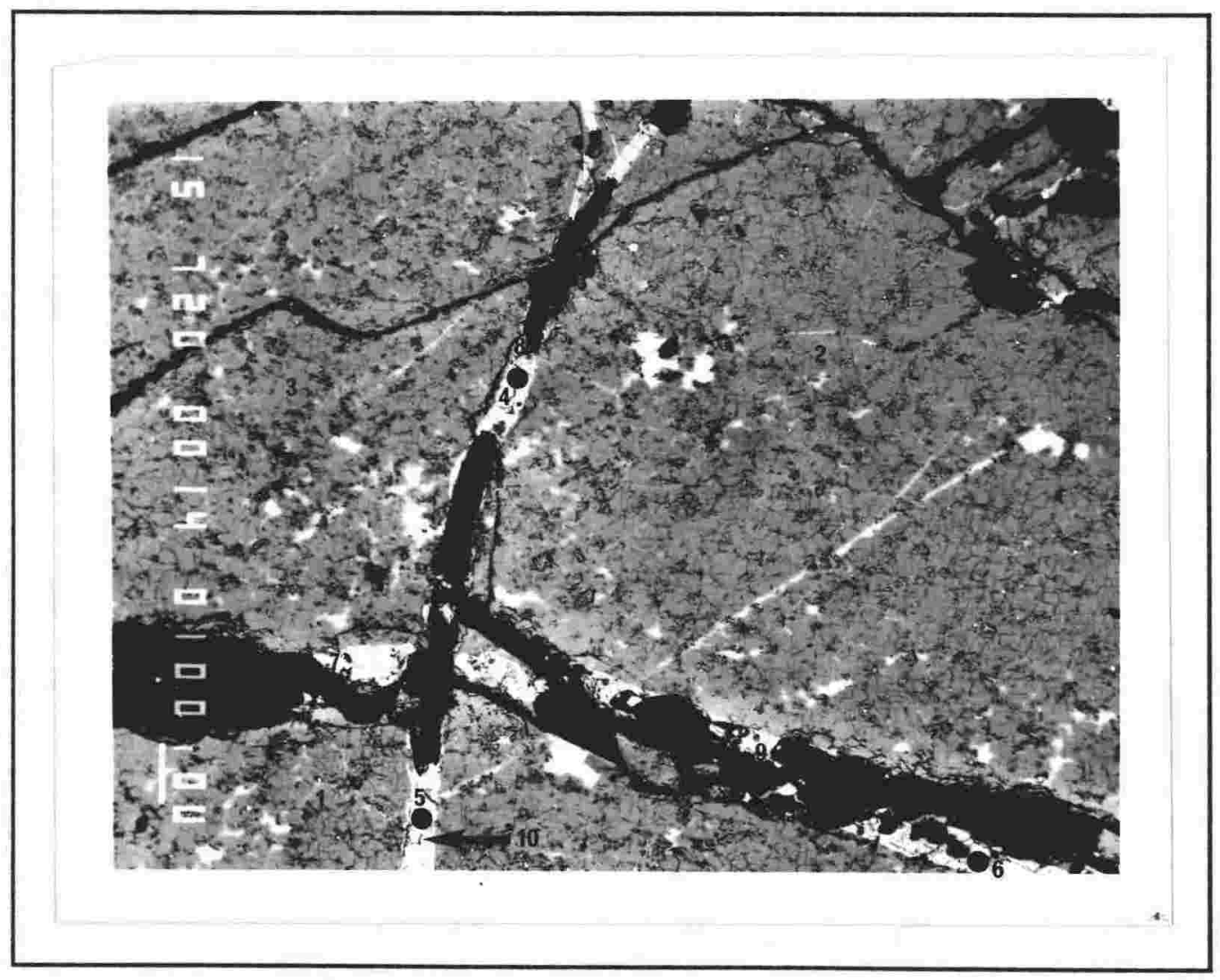

Plate 5.6b: See caption overleaf. 
PLATE 5.6 (overleaf): Oxidation reactions in a granulite (sample PK4Y). (a) Symplectite rims of olivine (Fe-rich are light, Fe-poor are dark), oxides and glass have formed around an orthopyroxene host. The extent of oxidation is greater than $50 \%$ in this example. Analyses of sites 1-10 are presented as Table 5.9. (b) Elsewhere, cracks in plagioclase host glass veins which have crystallised microphenocrysts of plagioclase and Fe-Ti oxides. Analyses of sites 1-10 are presented as Table 5.10. See text for further explanation. Scale bars are $100 \mu \mathrm{m}$.

isolated areas. Sieved plagioclase rims have overgrowths of Ca-rich plagioclase (10) that is in equilibrium with oxidation conditions.

TABLE 5.10: Electron microprobe analyses of oxidation reactions in a granulite (sample PK4Y). See Plate $5.6 \mathrm{~b}$ for analyses sites.

\begin{tabular}{|c|c|c|c|c|c|c|c|c|c|c|}
\hline $\begin{array}{l}\text { PHASE } \\
\text { SITE }\end{array}$ & $\begin{array}{c}\text { Plag } \\
\text { core } \\
1 \\
\end{array}$ & $\begin{array}{c}\text { Plag } \\
\text { core } \\
2 \\
\end{array}$ & $\begin{array}{c}\text { Plag } \\
\text { core } \\
3 \\
\end{array}$ & $\begin{array}{c}\text { Glass } \\
\text { vein } \\
4 \\
\end{array}$ & $\begin{array}{c}\text { Glass } \\
\text { vein } \\
5 \\
\end{array}$ & $\begin{array}{c}\text { Glass } \\
\text { vein } \\
6 \\
\end{array}$ & $\begin{array}{c}\text { Oxide } \\
\text { vein } \\
7 \\
\end{array}$ & $\begin{array}{c}\text { Oxide } \\
\text { vein } \\
8 \\
\end{array}$ & $\begin{array}{c}\text { Plag } \\
\text { vein } \\
9 \\
\end{array}$ & $\begin{array}{c}\text { Plag } \\
\text { vein } \\
10 \\
\end{array}$ \\
\hline $\mathrm{SiO} 2$ & 54.89 & 55.80 & 54.50 & 52.59 & 56.01 & 56.25 & 0.23 & 0.42 & 54.12 & 53.80 \\
\hline $\mathrm{Al} 2 \mathrm{O} 3$ & 28.16 & 27.95 & 28.36 & 16.57 & 15.05 & 13.54 & 4.55 & 2.07 & 28.07 & 28.60 \\
\hline TiO2 & 0.05 & 0.00 & 0.23 & 2.82 & 4.42 & 3.41 & 0.74 & 14.22 & 0.38 & 0.29 \\
\hline $\mathrm{Fe} 2 \mathrm{O} 3$ & & & & & & & 59.96 & 30.77 & & \\
\hline $\mathrm{FeO}$ & 0.17 & 0.43 & 0.76 & 9.09 & 11.51 & 9.78 & 22.84 & 33.59 & 1.15 & 0.85 \\
\hline $\mathrm{MnO}$ & 0.02 & 0.00 & 0.00 & 0.16 & 0.23 & 0.15 & 0.44 & 0.54 & 0.00 & 0.06 \\
\hline $\mathrm{MgO}$ & 0.01 & 0.00 & 0.00 & 2.41 & 3.14 & 3.52 & 4.82 & 4.21 & 0.18 & 0.10 \\
\hline $\mathrm{CaO}$ & 11.21 & 10.90 & 12.11 & 6.31 & 5.25 & 4.11 & 0.15 & 0.19 & 11.68 & 11.68 \\
\hline $\mathrm{Na} 2 \mathrm{O}$ & 4.94 & 5.64 & 5.02 & 7.49 & 4.33 & 5.14 & 0.09 & 0.09 & 5.26 & 4.74 \\
\hline $\mathrm{K} 2 \mathrm{O}$ & 0.33 & 0.45 & 0.44 & 3.32 & 1.28 & 3.52 & 0.09 & 0.09 & 0.35 & 0.33 \\
\hline TOTAL & 99.77 & 101.17 & 101.41 & 100.76 & 101.23 & 99.44 & 93.91 & 86.17 & 101.19 & 100.44 \\
\hline $\mathrm{Si}$ & 2.483 & 2.496 & 2.446 & 1.009 & 1.067 & 1.070 & 0.010 & 0.018 & 2.439 & 2.434 \\
\hline Al & 1.501 & 1.473 & 1.500 & 0.000 & 0.007 & 0.019 & 0.213 & 0.104 & 1.490 & 1.525 \\
\hline $\mathrm{Ti}$ & 0.000 & 0.000 & 0.010 & 0.000 & 0.005 & 0.000 & 0.018 & 0.452 & 0.012 & 0.010 \\
\hline FeIII & & & & & & & 1.732 & 0.967 & & \\
\hline FeII & 0.010 & 0.016 & 0.028 & 0.097 & 0.816 & 0.650 & 0.731 & 1.182 & 0.043 & 0.032 \\
\hline Mn & 0.000 & 0.000 & 0.000 & 0.006 & 0.007 & 0.010 & 0.009 & 0.016 & 0.000 & 0.000 \\
\hline $\mathrm{Mg}$ & 0.000 & 0.000 & 0.000 & 1.868 & 0.996 & 1.155 & 0.280 & 0.262 & 0.010 & 0.010 \\
\hline $\mathrm{Ca}$ & 0.543 & 0.522 & 0.582 & 0.003 & 0.022 & 0.010 & 0.010 & 0.011 & 0.563 & 0.566 \\
\hline $\mathrm{Na}$ & 0.432 & 0.488 & 0.436 & 0.002 & 0.000 & 0.010 & 0.000 & 0.000 & 0.459 & 0.415 \\
\hline K & 0.018 & 0.025 & 0.025 & 0.000 & 0.000 & 0.000 & 0.000 & 0.000 & 0.020 & 0.018 \\
\hline TOTAL & 4.987 & 5.020 & 5.027 & 2.985 & 2.920 & 2.924 & 3.003 & 3.012 & 5.036 & 5.010 \\
\hline
\end{tabular}

Elsewhere in the sample (Plate 5.6b), cracks in plagioclase $(1,2,3)$ are host to glass $(4,5,6)$ occurring as veins throughout the xenolith suite. Disequilibrium of 


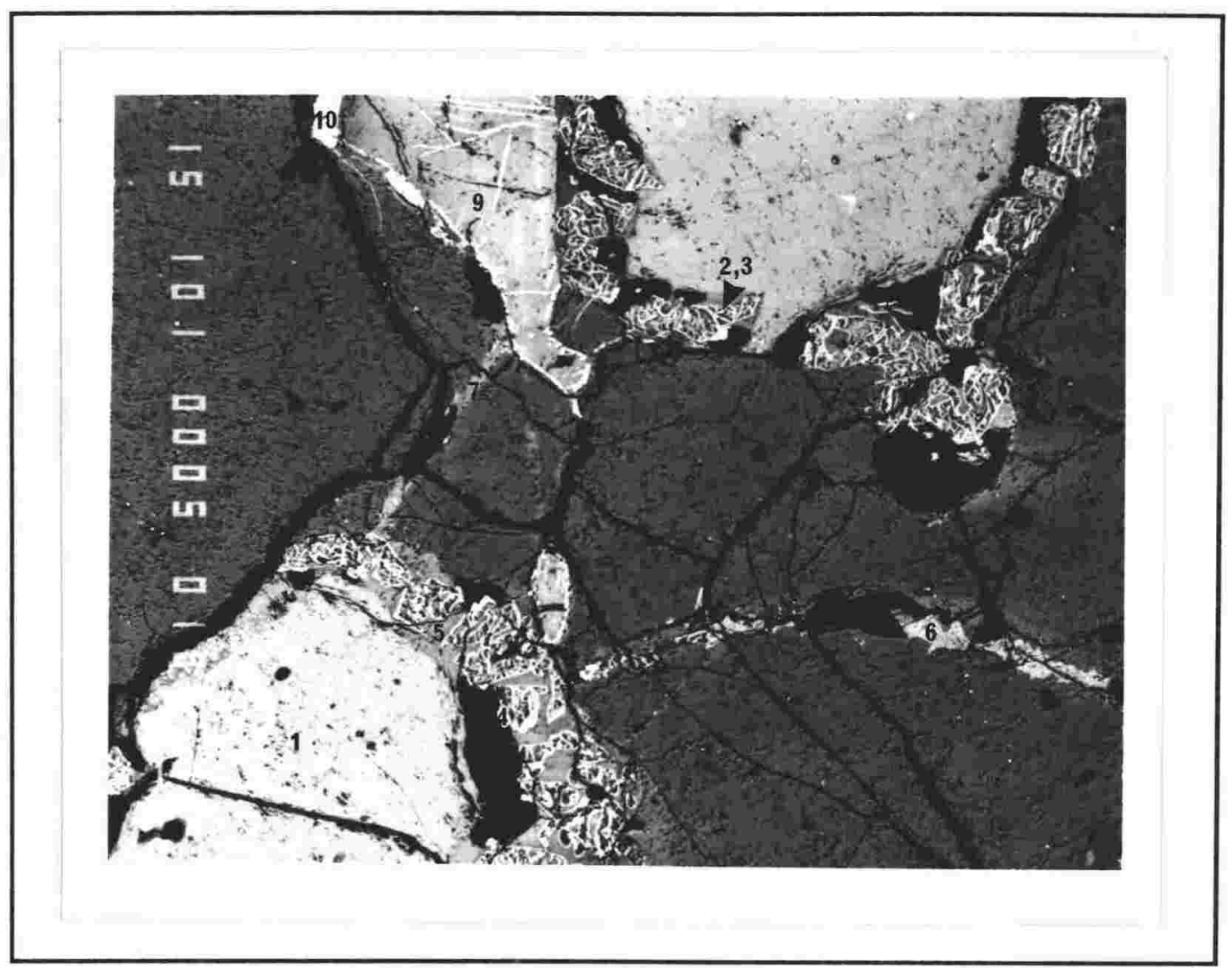

PLATE 5.7: Oxidation reactions in a granulite (sample PK4A) showing symplectite rims on host orthopyroxene, consisting of glass, Fe-poor (dark) and Fe-rich (light) olivine, and oxides (bright). Veins of glass occur in cracks in plagioclase that are cross-cut by glass-free veins, which may have opened in response to decompression Analyses of sites 1-10 are presented as Table 5.11. See text for further explanation. Scale bars are $100 \mu \mathrm{m}$.

plagioclase in contact with the oxidising agents is rare (see Plate 4.6a). Microphenocrysts of Fe-Ti oxides $(7,8)$ and euhedral plagioclase $(9,10)$ have crystallised directly from the melt in the veins. Plagioclase microphenocrysts that have crystallised from the melts are similar in composition to xenolith plagioclase, (except for higher $\mathrm{Fe}$ contents), accounting for the lack of disequilibrium reactions in xenolith plagioclase.

\section{Sample PK4A: Granulite xenolith (Plate 5.7; Table 5.11)}

Oxidation in this sample also occurs on orthopyroxene rims and along cracks through plagioclase. The extent of oxidation is quite typical of the granulite suite, with rims approximately $100 \mu \mathrm{m}$ thick around orthopyroxene crystals.

Host orthopyroxene (1) has been oxidised to form symplectites of two phases of olivine (Fe-rich (bright; 2) and Fe-poor (dark; 3)), and small Fe-Ti oxides (4) in a matrix of glass (5). Glass-free cracks cross cut glass-filled veins $(6,7)$, indicating that they opened after the appearance of glass veining, possibly as a 
result of decompression during ascent to the surface. The migration of melts through these cracks preceded the opening of glass-free cracks, making it unlikely that this process occurred during ascent to the surface.

TABLE 5.11: Electron microprobe analyses of oxidation reactions in a granulite (sample PK4A). See Plate 5.7 for analyses sites.

\begin{tabular}{|c|c|c|c|c|c|c|c|c|c|c|}
\hline $\begin{array}{l}\text { PHASE } \\
\text { SITE }\end{array}$ & $\begin{array}{c}\text { Opx } \\
\text { core } \\
1 \\
\end{array}$ & $\begin{array}{c}\text { Olivine } \\
\text { oxid. } \\
2 \\
\end{array}$ & $\begin{array}{c}\text { Olivine } \\
\text { oxid. } \\
3\end{array}$ & $\begin{array}{c}\text { Oxide } \\
\text { oxid. } \\
4 \\
\end{array}$ & $\begin{array}{c}\text { Glass } \\
\text { oxid. } \\
5 \\
\end{array}$ & $\begin{array}{c}\text { Glass } \\
\text { vein } \\
6 \\
\end{array}$ & $\begin{array}{c}\text { Glass } \\
\text { vein } \\
7 \\
\end{array}$ & $\begin{array}{c}\text { Plag } \\
\text { core } \\
8 \\
\end{array}$ & $\begin{array}{c}\text { Cpx } \\
\text { core } \\
9 \\
\end{array}$ & $\begin{array}{c}\text { Oxide } \\
\text { vein } \\
10 \\
\end{array}$ \\
\hline $\mathrm{SiO} 2$ & 50.82 & 35.85 & 43.47 & 0.24 & 58.27 & 58.93 & 60.77 & 55.28 & 48.97 & 6.22 \\
\hline $\mathrm{Al} 2 \mathrm{O} 3$ & 6.69 & 0.15 & 0.02 & 1.42 & 17.23 & 15.25 & 15.10 & 28.08 & 8.67 & 3.89 \\
\hline TiO2 & 0.15 & 0.09 & 0.08 & 0.08 & 1.61 & 2.97 & 2.32 & 0.03 & 0.77 & 1.91 \\
\hline $\mathrm{Fe} 2 \mathrm{O} 3$ & 1.21 & & & 76.54 & & & & & 3.37 & \\
\hline $\mathrm{FeO}$ & 15.77 & 37.10 & 1.63 & 0.33 & 5.09 & 8.87 & 9.13 & 0.35 & 4.86 & 79.69 \\
\hline $\mathrm{MnO}$ & 0.34 & 0.23 & 0.33 & 0.55 & 0.14 & 0.19 & 0.03 & 0.08 & 0.19 & 0.30 \\
\hline $\mathrm{MgO}$ & 24.30 & 24.52 & 55.73 & 19.73 & 2.41 & 2.36 & 2.99 & 0.03 & 12.47 & 6.15 \\
\hline $\mathrm{CaO}$ & 0.73 & 0.51 & 0.14 & 0.08 & 8.03 & 2.87 & 4.31 & 10.52 & 21.04 & 0.18 \\
\hline $\mathrm{Na} 2 \mathrm{O}$ & 0.12 & 0.00 & 0.03 & 0.00 & 5.69 & 4.60 & 4.77 & 5.21 & 1.07 & 0.13 \\
\hline $\mathrm{K} 2 \mathrm{O}$ & 0.01 & 0.08 & 0.00 & 0.04 & 1.69 & 4.50 & 0.76 & 0.45 & 0.01 & 0.03 \\
\hline TOTAL & 100.14 & 98.54 & 101.42 & 99.00 & 100.16 & 100.54 & 100.17 & 100.03 & 101.42 & 98.48 \\
\hline $\mathrm{Si}$ & 1.846 & 1.532 & 1.517 & 0.005 & & & & 2.495 & 1.798 & \\
\hline $\mathrm{Al}$ & 0.290 & 0.008 & 0.001 & 0.009 & & & & 1.493 & 0.375 & \\
\hline $\mathrm{Ti}$ & 0.000 & 0.003 & 0.000 & 0.000 & & & & 0.001 & 0.021 & \\
\hline FeIII & 0.030 & & & 1.923 & & & & & 0.090 & \\
\hline FeII & 0.480 & 1.104 & 0.048 & 0.008 & & & & 0.013 & 0.150 & \\
\hline Mn & 0.010 & 0.008 & 0.010 & 0.020 & & & & 0.003 & 0.005 & \\
\hline $\mathrm{Mg}$ & 1.320 & 1.320 & 2.418 & 0.981 & & & & 0.002 & 0.682 & \\
\hline $\mathrm{Ca}$ & 0.030 & 0.024 & 0.005 & 0.001 & & & & 0.509 & 0.827 & \\
\hline $\mathrm{Na}$ & 0.010 & 0.000 & 0.002 & 0.000 & & & & 0.455 & 0.076 & \\
\hline K & 0.000 & 0.004 & 0.000 & 0.000 & & & & 0.026 & 0.000 & \\
\hline TOTAL & 4.016 & 4.003 & 4.001 & 2.947 & & & & 4.997 & 4.024 & \\
\hline
\end{tabular}

Plagioclase (8) shows only rare disequilibrium textures in contact with glass (light patches in plagioclase of Plate 5.7). Clinopyroxene (9) is also largely unaffected by oxidation, although Fe-Ti oxides (10) have developed around clinopyroxene rims and small oxide exsolutions may have also occurred as an affect of oxidation. 


\section{Sample PK4S: Pyroxenite xenolith (Plate 5.8; Table 5.12)}

Oxidation is generally not as pervasive or extreme in the pyroxenite suite. Symplectite rims only a few microns thick develop around orthopyroxene rims, although under transmitted light these rims appear to be thicker. In isolated areas larger symplectites have developed (Plate 5.8).

TABLE 5.12: Electron microprobe analyses of oxidation reactions in a pyroxenite (sample PK4S). See Plate 5.8 for analyses sites.

\begin{tabular}{|c|c|c|c|c|c|c|c|c|c|c|}
\hline $\begin{array}{l}\text { PHASE } \\
\text { SITE }\end{array}$ & $\begin{array}{c}\text { Opx } \\
\text { core } \\
1 \\
\end{array}$ & $\begin{array}{l}\text { Olivine } \\
\text { oxid. } \\
2 \\
\end{array}$ & $\begin{array}{c}\text { Olivine } \\
\text { oxid. } \\
3 \\
\end{array}$ & $\begin{array}{c}\text { Oxide } \\
\text { oxid. } \\
4 \\
\end{array}$ & $\begin{array}{c}\text { Oxide } \\
\text { oxid. } \\
5 \\
\end{array}$ & $\begin{array}{c}\text { Glass } \\
\text { oxid. } \\
6 \\
\end{array}$ & $\begin{array}{c}\text { Plag } \\
\text { oxid. } \\
7 \\
\end{array}$ & $\begin{array}{l}\text { Olivine } \\
\text { vein } \\
8 \\
\end{array}$ & $\begin{array}{c}\text { Opx } \\
\text { rim } \\
9 \\
\end{array}$ & $\begin{array}{c}\text { Cpx } \\
\text { core } \\
10 \\
\end{array}$ \\
\hline $\mathrm{SiO} 2$ & 51.07 & 39.18 & 42.96 & 0.70 & 0.17 & 47.70 & 53.22 & 31.90 & 51.28 & 48.76 \\
\hline $\mathrm{Al} 2 \mathrm{O} 3$ & 5.16 & 0.12 & 0.05 & 0.97 & 3.84 & 17.02 & 26.87 & 3.90 & 4.90 & 7.29 \\
\hline $\mathrm{TiO} 2$ & 0.36 & 0.11 & 0.11 & 6.92 & 0.02 & 3.47 & 1.27 & 0.27 & 0.33 & 1.24 \\
\hline $\mathrm{Fe} 2 \mathrm{O} 3$ & 2.58 & & & 49.97 & 64.49 & & & & 6.10 & 3.54 \\
\hline $\mathrm{FeO}$ & 14.73 & 30.99 & 1.04 & 29.39 & 7.26 & 10.78 & 2.45 & 39.45 & 6.88 & 5.73 \\
\hline $\mathrm{MnO}$ & 0.36 & 0.44 & 0.26 & 0.33 & 1.15 & 0.23 & 0.06 & 0.37 & 0.46 & 0.18 \\
\hline $\mathrm{MgO}$ & 24.69 & 27.63 & 56.39 & 4.12 & 13.28 & 9.38 & 0.34 & 22.89 & 29.14 & 13.16 \\
\hline $\mathrm{CaO}$ & 1.14 & 0.35 & 0.10 & 0.17 & 0.06 & 8.36 & 10.66 & 0.76 & 1.36 & 19.87 \\
\hline $\mathrm{Na} 2 \mathrm{O}$ & 0.16 & 0.00 & 0.00 & 0.89 & 0.01 & 3.72 & 5.05 & 0.42 & 0.09 & 0.97 \\
\hline $\mathrm{K} 2 \mathrm{O}$ & 0.03 & 0.02 & 0.02 & 0.01 & 0.05 & 0.09 & 0.09 & 0.04 & 0.06 & 0.01 \\
\hline TOTAL & 100.27 & 98.85 & 100.92 & 93.47 & 90.32 & 100.76 & 100.01 & 99.99 & 100.60 & 100.75 \\
\hline $\mathrm{Si}$ & 1.862 & 1.069 & 1.003 & 0.030 & 0.009 & & 2.433 & 0.912 & 1.834 & 1.806 \\
\hline Al & 0.221 & 0.003 & 0.002 & 0.051 & 0.017 & & 1.447 & 0.136 & 0.206 & 0.318 \\
\hline $\mathrm{Ti}$ & 0.009 & 0.002 & 0.001 & 0.211 & 0.000 & & 0.043 & 0.005 & 0.010 & 0.034 \\
\hline FeIII & 0.070 & & & 1.487 & 1.919 & & & & 0.160 & 0.100 \\
\hline FeII & 0.450 & 0.706 & 0.020 & 0.968 & 0.235 & & 0.090 & 0.941 & 0.200 & 0.180 \\
\hline $\mathrm{Mn}$ & 0.010 & 0.010 & 0.005 & 0.010 & 0.040 & & 0.000 & 0.008 & 0.013 & 0.010 \\
\hline $\mathrm{Mg}$ & 1.341 & 1.123 & 1.962 & 0.241 & 0.742 & & 0.023 & 0.965 & 1.553 & 0.726 \\
\hline $\mathrm{Ca}$ & 0.044 & 0.010 & 0.002 & 0.008 & 0.000 & & 0.521 & 0.022 & 0.051 & 0.788 \\
\hline $\mathrm{Na}$ & 0.011 & 0.000 & 0.000 & 0.000 & 0.000 & & 0.446 & 0.022 & 0.006 & 0.069 \\
\hline $\mathrm{K}$ & 0.001 & 0.000 & 0.000 & 0.000 & 0.000 & & 0.010 & 0.001 & 0.000 & 0.000 \\
\hline TOTAL & 4.019 & 2.923 & 2.995 & 3.006 & 2.962 & & 5.013 & 3.012 & 4.033 & 4.031 \\
\hline
\end{tabular}

Symplectite rims on orthopyroxene (1) consists of Fe-rich (2) and Fe-poor (3) olivine, Fe-Ti oxides (4,5), glass (6) and plagioclase (7). The occurrence of plagioclase in symplectites and the smaller size of symplectite rims are the only differences between symplectites in the pyroxenite suite compared to symplectites in the granulite suite. 


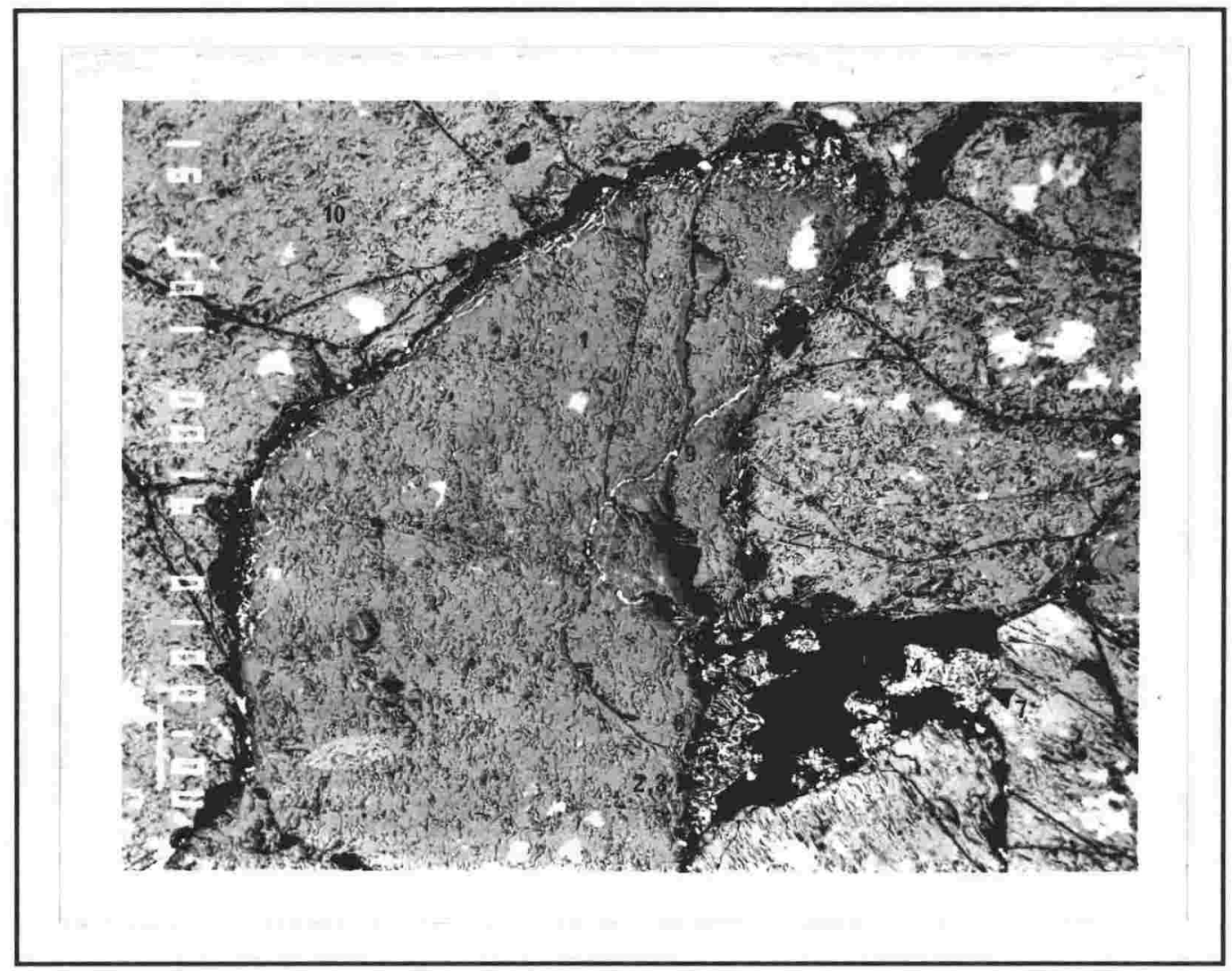

PLATE 5.8: Oxidation reactions in a pyroxenite (sample PK4S) showing only thin symplectite rims, and an olivine vein in host orthopyroxene (centre). Analyses of sites 1-10 are presented as Table 5.12. See text for further explanation. Scale bars are $100 \mu \mathrm{m}$.

A vein of olivine (8) extends through the host orthopyroxene (1), resulting in a depletion of $\mathrm{Fe}$ and enrichment in $\mathrm{Mg}$ in the host (9) adjacent to the vein. Clinopyroxene (10) crystals in contact with symplectite formation are unaffected.

\subsubsection{Secondary mineral chemistry}

Mineral phases involved in secondary mineral reactions differ in composition from primary xenolith mineral phases (Chapter 5.4). This section discusses these differences in an attempt to determine their origin. Analyses of secondary olivine and oxides are presented here, and analyses of other secondary minerals occurring in the xenolith suite can be found in Chapter 5.5.1 (Tables 5.9 to 5.12), and in the appropriate appendices (Appendix 3.2).

Calcium contents of both olivine phases are relatively high $(\leq 1.05 \mathrm{wt}$. \% $\mathrm{CaO}$ ). High $\mathrm{Ca}$ contents may be due to their shallow levels of crystallisation (Simkin and Smith, 1970; Stormer, 1973), or be directly inherited from the orthopyroxene hosts, which have similar Ca contents (Chapter 5.4.2; Table 5.3). 
TABLE 5.13: Representative electron microprobe analyses of Mount Hampton xenolith olivines in symplectite rims on orthopyroxene.

\begin{tabular}{lcccccccccc}
\hline SAMPLE & $\begin{array}{c}\text { PK4A } \\
\text { TYPE }\end{array}$ & $\begin{array}{c}\text { PK4an } \\
\text { Gran }\end{array}$ & $\begin{array}{c}\text { PK4Y } \\
\text { Gran }\end{array}$ & $\begin{array}{c}\text { PK4Y } \\
\text { Gran }\end{array}$ & $\begin{array}{c}\text { PK4C1 } \\
\text { Gran }\end{array}$ & $\begin{array}{c}\text { PK4C1 } \\
\text { Gran }\end{array}$ & $\begin{array}{c}\text { PK4L } \\
\text { Pyxite }\end{array}$ & $\begin{array}{c}\text { PK4L } \\
\text { Pyxite }\end{array}$ & $\begin{array}{c}\text { PK4S } \\
\text { Pyxite }\end{array}$ & $\begin{array}{c}\text { PK4S } \\
\text { Pyxite }\end{array}$ \\
\hline & & & & & & & & & & \\
$\mathrm{SiO} 2$ & 43.47 & 35.85 & 42.91 & 37.00 & 37.63 & 42.34 & 42.07 & 38.60 & 42.96 & 39.18 \\
$\mathrm{Al2O} 3$ & 0.02 & 0.15 & 0.00 & 0.16 & 0.26 & 0.00 & 0.07 & 0.23 & 0.05 & 0.12 \\
$\mathrm{TiO} 2$ & 0.08 & 0.09 & 0.02 & 0.20 & 0.18 & 0.11 & 0.04 & 0.25 & 0.11 & 0.11 \\
$\mathrm{FeO}$ & 1.63 & 37.10 & 1.85 & 36.53 & 33.05 & 0.90 & 4.86 & 35.34 & 1.04 & 30.99 \\
$\mathrm{MnO}$ & 0.33 & 0.23 & 0.37 & 0.40 & 0.46 & 0.37 & 0.31 & 0.30 & 0.26 & 0.44 \\
$\mathrm{MgO}$ & 55.73 & 24.52 & 54.67 & 24.15 & 26.05 & 56.93 & 52.28 & 24.18 & 56.39 & 27.63 \\
$\mathrm{CaO}$ & 0.14 & 0.51 & 0.07 & 0.38 & 0.43 & 0.08 & 0.14 & 0.76 & 0.10 & 0.35 \\
$\mathrm{Na2O}$ & 0.03 & 0.00 & 0.09 & 0.35 & 0.19 & 0.00 & 0.06 & 0.00 & 0.00 & 0.00 \\
$\mathrm{~K} 2 \mathrm{O}$ & 0.00 & 0.08 & 0.04 & 0.10 & 0.05 & 0.03 & 0.02 & 0.04 & 0.02 & 0.02 \\
& & & & & & & & & & \\
\hline TOTAL & 101.42 & 98.54 & $\mathbf{1 0 0 . 0 1}$ & 99.26 & $\mathbf{9 8 . 3 0}$ & $\mathbf{1 0 0 . 7 6}$ & 99.83 & 99.70 & $\mathbf{1 0 0 . 9 2}$ & 98.85 \\
\hline
\end{tabular}

cations on the basis of 4 oxygens

\begin{tabular}{lllllllllll}
$\mathrm{Si}$ & 1.010 & 1.020 & 1.013 & 1.040 & 1.049 & 0.991 & 1.009 & 1.067 & 1.003 & 1.069 \\
$\mathrm{Al}$ & 0.001 & 0.008 & 0.000 & 0.005 & 0.008 & 0.000 & 0.000 & 0.007 & 0.002 & 0.003 \\
$\mathrm{Ti}$ & 0.000 & 0.003 & 0.004 & 0.004 & 0.004 & 0.002 & 0.000 & 0.005 & 0.001 & 0.002 \\
$\mathrm{Fe}$ & 0.032 & 0.883 & 0.037 & 0.858 & 0.770 & 0.018 & 0.097 & 0.816 & 0.020 & 0.706 \\
$\mathrm{Mn}$ & 0.010 & 0.008 & 0.007 & 0.009 & 0.010 & 0.007 & 0.006 & 0.007 & 0.005 & 0.010 \\
$\mathrm{Mg}$ & 1.932 & 1.040 & 1.925 & 1.011 & 1.082 & 1.986 & 1.868 & 0.996 & 1.962 & 1.123 \\
$\mathrm{Ca}$ & 0.000 & 0.024 & 0.002 & 0.011 & 0.012 & 0.002 & 0.003 & 0.022 & 0.002 & 0.010 \\
$\mathrm{Na}$ & 0.002 & 0.000 & 0.004 & 0.018 & 0.010 & 0.000 & 0.002 & 0.000 & 0.000 & 0.000 \\
$\mathrm{~K}$ & 0.000 & 0.004 & 0.007 & 0.003 & 0.002 & 0.001 & 0.000 & 0.000 & 0.000 & 0.000 \\
& & & & & & & & & & \\
\hline TOTAL & 2.987 & 2.990 & 2.999 & 2.959 & 2.947 & 3.007 & 2.985 & 2.920 & 2.995 & 2.923 \\
\hline & & & & & & & & & & \\
Mg\# & 98.37 & 54.08 & 98.11 & 54.09 & 58.42 & 99.10 & 95.06 & 54.97 & 98.99 & 61.40 \\
& & & & & & & & & & \\
\hline
\end{tabular}

Olivine symplectites on orthopyroxene cores consist of two phases of olivine (Table 5.13). Fo contents $\left(\mathrm{Mg} / \mathrm{Mg}+\sum \mathrm{Fe}\right.$, with $\sum \mathrm{Fe}$ calculated as $\mathrm{Fe}^{2+}$ ) of $\mathrm{Mg}$ rich olivine is near pure forsterite, ranging from Fo 97-99 in the granulite suite, and Fo 95-99 in the pyroxenite suite (Figure 5.13). The other olivine phase is more Fe-rich, ranging from Fo 51-58 in the granulites and Fo 40-65 in the pyroxenites. Host orthopyroxene $\mathrm{Mg}: \mathrm{Mg}+\mathrm{Fe}$ compositions fall between these extremes (although closer to Fe-rich olivine Fo contents), indicating derivation of olivines from the orthopyroxene.

Cation totals of analysed olivine are typically well below 3.0, an indication that elements other than those analysed are present. $\mathrm{NiO}$ is a minor constituent 
in symplectite olivines, and $\mathrm{Cr}_{2} \mathrm{O}_{3}$ may also be present in significant amounts. Fe is measured as $\mathrm{FeO}$, and the presence of large amounts of $\mathrm{Fe}^{3+}$ in addition to $\mathrm{Fe}^{2+}$ is possible resulting from the oxidation of $\mathrm{Fe}^{2+}$. The presence of $\mathrm{Fe}^{3+}$ would markedly increase cation totals.

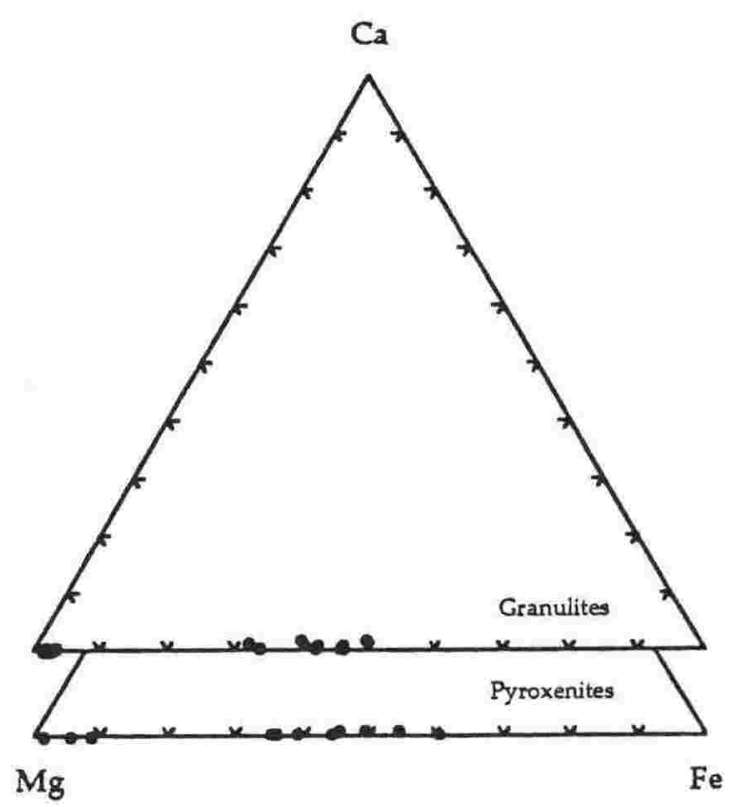

FIGURE 5.13: Composition of olivines in the system Wo-En-Fs, from symplectite rims on xenolith orthopyroxenes formed by the oxidation of the host orthopyroxene.

Minor amounts of pyroxene (both orthopyroxene and clinopyroxene) are also present in symplectites. Compared to xenolith pyroxenes they are low in $\mathrm{Al}_{2} \mathrm{O}_{3}, \mathrm{TiO}_{2}$ and $\mathrm{CaO}$, and high in $\mathrm{MgO}$ and $\mathrm{SiO}_{2}$. Silica contents are higher in the tetrahedral site, which has only minor $\mathrm{Al}^{\mathrm{VI}}$ contents. These marked differences distinguish them from primary xenolith pyroxenes, and indicate a different source, probably as igneous pyroxenes that have crystallised from the melt associated with symplectite rims. Some pyroxenes in symplectites are identical to xenolith pyroxenes, and probably represent relic pyroxenes amongst the symplectite growth.

Plagioclase is associated with olivine symplectites, and as overgrowths of sieved rims of plagioclase in disequilibrium with glasses; both are very similar and are discussed together. They are labradorite-bytownite in composition ranging from An 52-72; compared to xenolith plagioclase, they are An-rich. In addition, $\mathrm{FeO}$ contents are far higher, ranging from $0.66-2.45 \mathrm{wt}$. \% $\mathrm{FeO}$, as are $\mathrm{MgO}$ contents of up to $1.08 \mathrm{wt}$. \%. Such exceptionally high totals are difficult to reconcile with the plagioclase lattice, and their elevated abundances probably represent a Fe and $\mathrm{Mg}$ rich source (i.e. derivation from orthopyroxene), or the presence of small amounts of Fe-Mg oxides (Smith, 1975). 
TABLE 5.14: Representative electron microprobe analyses of Mount Hampton xenolith oxides formed on symplectite rims of orthopyroxene (symp), and in glass filled veins (vein).

\begin{tabular}{|c|c|c|c|c|c|c|c|c|c|c|}
\hline $\begin{array}{l}\text { SAMPLE } \\
\text { TYPE }\end{array}$ & $\begin{array}{c}\text { PK4A } \\
\text { Gran } \\
\text { symp }\end{array}$ & $\begin{array}{l}\text { PK4Y } \\
\text { Gran } \\
\text { symp } \\
\end{array}$ & $\begin{array}{l}\text { PK4Y } \\
\text { Gran } \\
\text { symp } \\
\end{array}$ & $\begin{array}{c}\text { PK4C1 } \\
\text { Gran } \\
\text { symp } \\
\end{array}$ & $\begin{array}{l}\text { PK4A } \\
\text { Gran } \\
\text { vein } \\
\end{array}$ & $\begin{array}{l}\text { PK4Y } \\
\text { Gran } \\
\text { vein } \\
\end{array}$ & $\begin{array}{l}\text { PK4L } \\
\text { Pyxite } \\
\text { symp }\end{array}$ & $\begin{array}{l}\text { PK4L } \\
\text { Pyxite } \\
\text { symp }\end{array}$ & $\begin{array}{l}\text { PK4S } \\
\text { Pyxite } \\
\text { symp }\end{array}$ & $\begin{array}{l}\text { PK4S } \\
\text { Pyxite } \\
\text { symp }\end{array}$ \\
\hline $\mathrm{SiO} 2$ & 0.24 & 0.70 & 0.36 & 1.34 & 6.22 & 0.42 & 0.12 & 0.05 & 0.63 & 0.17 \\
\hline $\mathrm{Al} 2 \mathrm{O} 3$ & 1.42 & 3.37 & 2.78 & 0.45 & 3.89 & 2.07 & 0.54 & 0.15 & 0.38 & 3.84 \\
\hline $\mathrm{TiO} 2$ & 0.08 & 0.17 & 0.14 & 0.57 & 1.91 & 16.53 & 0.02 & 0.07 & 6.77 & 0.02 \\
\hline $\mathrm{Fe} 2 \mathrm{O} 3$ & 76.66 & 73.16 & 73.94 & 65.07 & 50.04 & 35.78 & 66.52 & 69.34 & 55.97 & 71.06 \\
\hline $\mathrm{FeO}$ & 0.22 & 2.15 & 1.59 & 28.69 & 30.86 & 39.05 & 30.20 & 26.88 & 31.83 & 5.53 \\
\hline $\mathrm{MnO}$ & 0.55 & 1.16 & 1.16 & 0.37 & 0.30 & 0.54 & 0.09 & 0.04 & 0.35 & 1.15 \\
\hline $\mathrm{MgO}$ & 19.73 & 18.85 & 19.56 & 2.59 & 6.15 & 4.21 & 0.15 & 2.54 & 3.61 & 13.28 \\
\hline $\mathrm{CaO}$ & 0.08 & 0.14 & 0.10 & 0.12 & 0.18 & 0.19 & 0.06 & 0.08 & 0.18 & 0.06 \\
\hline $\mathrm{Cr} 2 \mathrm{O}_{3}$ & 0.13 & 0.37 & 0.35 & & 0.12 & & & & & 0.29 \\
\hline $\mathrm{NiO}$ & 0.18 & & & & 0.11 & & & & & 3.19 \\
\hline TOTAL & 99.28 & 100.06 & 99.98 & 99.20 & 99.76 & 98.78 & 97.69 & 99.17 & 99.73 & 98.58 \\
\hline
\end{tabular}

cations on the basis of 3 sites

$\begin{array}{lllllllllll}\mathrm{Si} & 0.008 & 0.022 & 0.011 & 0.051 & 0.211 & 0.017 & 0.005 & 0.002 & 0.024 & 0.006 \\ \mathrm{Al} & 0.056 & 0.124 & 0.105 & 0.020 & 0.155 & 0.102 & 0.025 & 0.007 & 0.018 & 0.164 \\ \mathrm{Ti} & 0.002 & 0.004 & 0.004 & 0.016 & 0.049 & 0.447 & 0.000 & 0.002 & 0.188 & 0.000 \\ \mathrm{FeIII} & 1.924 & 1.825 & 1.864 & 1.846 & 0.934 & 0.969 & 1.965 & 1.985 & 1.557 & 1.823 \\ \mathrm{FeII} & 0.009 & 0.060 & 0.045 & 0.905 & 1.326 & 1.175 & 0.991 & 0.855 & 0.984 & 0.158 \\ \mathrm{Mn} & 0.016 & 0.030 & 0.032 & 0.012 & 0.009 & 0.019 & 0.003 & 0.001 & 0.012 & 0.035 \\ \mathrm{Mg} & 0.982 & 0.931 & 0.935 & 0.145 & 0.311 & 0.262 & 0.009 & 0.144 & 0.210 & 0.718 \\ \mathrm{Ca} & 0.003 & 0.005 & 0.003 & 0.005 & 0.006 & 0.009 & 0.002 & 0.003 & 0.007 & 0.000 \\ \mathrm{Cr} & 0.003 & 0.002 & 0.004 & & 0.000 & & & & & 0.000 \\ \mathrm{Ni} & 0.000 & & & & 0.000 & & & & & 0.092\end{array}$

\begin{tabular}{lllllllllll}
\hline TOTAL & 3.003 & 3.003 & 3.003 & 3.000 & 3.001 & 3.000 & 3.000 & 2.999 & 3.000 & 2.996 \\
\hline
\end{tabular}

Secondary oxides occur in the symplectites rims of orthopyroxene and in glass-filled veins of granulites and pyroxenites (Table 5.14). Oxides of both forms are identical in composition, a further indication that symplectite rims and glass veins are related. Secondary oxides (titanomagnetite and hematite) are rich in $\mathrm{Fe}_{2} \mathrm{O}_{3}+\mathrm{FeO}$, and poor in $\mathrm{TiO}_{2}$ (up to 14.2 wt. $\% \mathrm{TiO}_{2}$ but generally $\leq 6.9$ wt. $\% \mathrm{TiO}_{2}$ ) (Figure 5.14) compared to primary oxides (Figure 5.12). The state of iron in secondary oxides is mainly $\mathrm{Fe}^{3+}$, compared to $\mathrm{Fe}^{2+}$ in primary oxides, reflecting their formation from oxidising processes, with $\mathrm{FeO}$ being oxidised to $\mathrm{Fe}_{2} \mathrm{O}_{3}$.

The oxide assemblage is unsuitable for temperature and $\mathrm{fO}_{2}$ determinations, although the presence of hematite and magnetite (Figure 5.14) 
does denote high $\mathrm{fO}_{2}$ conditions quite different from those of the primary oxides, and suggestive of higher-level oxidation than at source depths, where oxide phases consist of ilmenite and Al-spinels.

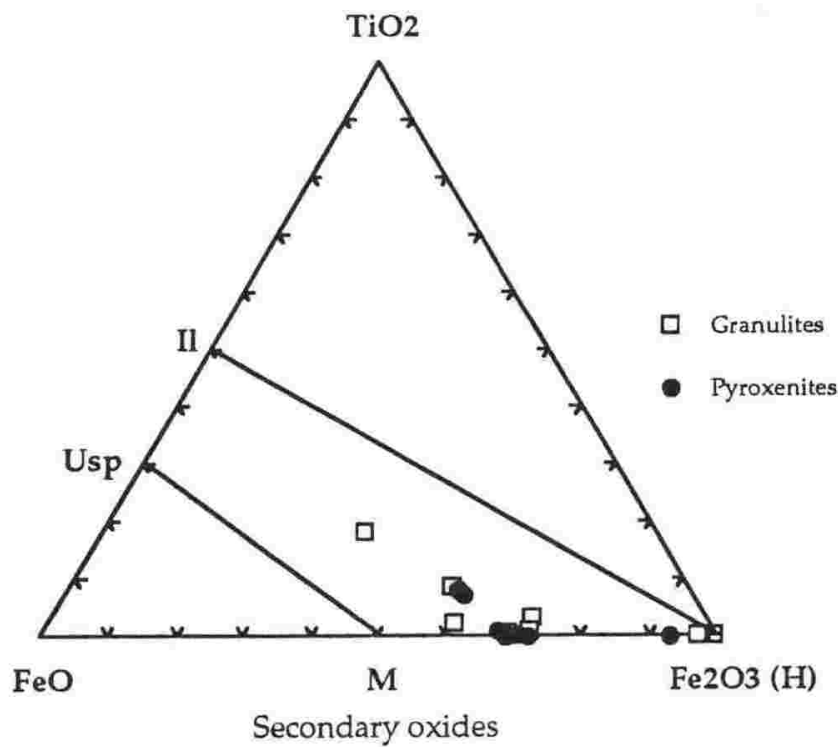

FIGURE 5.14: Compositions of secondary oxides from Mount Hampton xenoliths in the system $\mathrm{TiO}_{2}-\mathrm{FeO}-\mathrm{Fe}_{2} \mathrm{O}_{3}$. Titanomagnetite and hematite are the secondary oxide phases present in both symplectite rims and glass veins. $\mathrm{H}=$ hematite; $\mathrm{I}=$ ilmenite; $\mathrm{M}=$ magnetite; Usp = ulvöspinel.

Glass is also present in the symplectite rims surrounding microphenocryst (especially olivine) growth, and in veins. The chemistry and source of these glasses are discussed below.

\subsubsection{Geochemistry and origin of glasses}

There is little difference in the composition of symplectite and vein glass, and they are treated here as one group. Representative analyses of single determinations are presented as Table 5.15. Details for the procedure of glass analyses, and the approximate errors involved, are included in Appendix Three.

CIPW normative mineralogy's reflect the diversity of glass compositions, which include nepheline-normative, hypersthene-normative and quartznormative compositions. A general trend can be identified from nephelinenormative to quartz-normative compositions (Figure 5.15).

A total alkali-silica (TAS) plot of the glasses (Le Bas et al., 1986) indicates a range in composition from mafic to intermediate, with a general trend of increasing alkalis with silica, and a large scatter (Figure 5.16). Figure 5.17 is a plot of major elements against silica, with host basanites for comparison (basanite compositions are from Le Masurier, 1990). Strong trends of major elements with silica are evident, many with wide scatters due in part to the errors associated with electron microprobe analyses of glass (especially volatile elements such as $\mathrm{Na}$ and $\mathrm{K}$ ). 

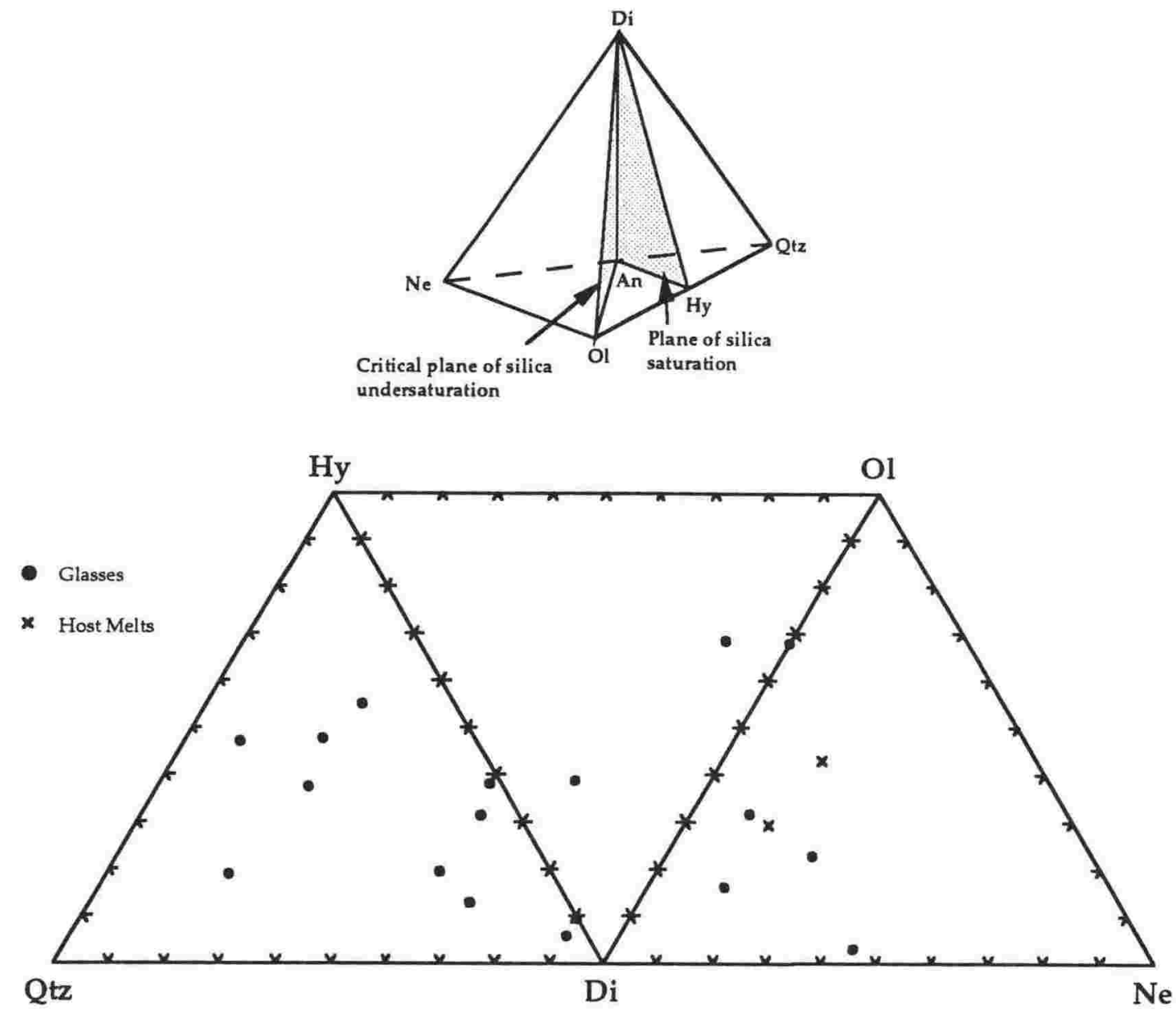

FIGURE 5.15: Normative mineral contents of glasses in the Mount Hampton xenolith suite. Compositions show a high-diopside trend from nepheline to quartz normative compositions.

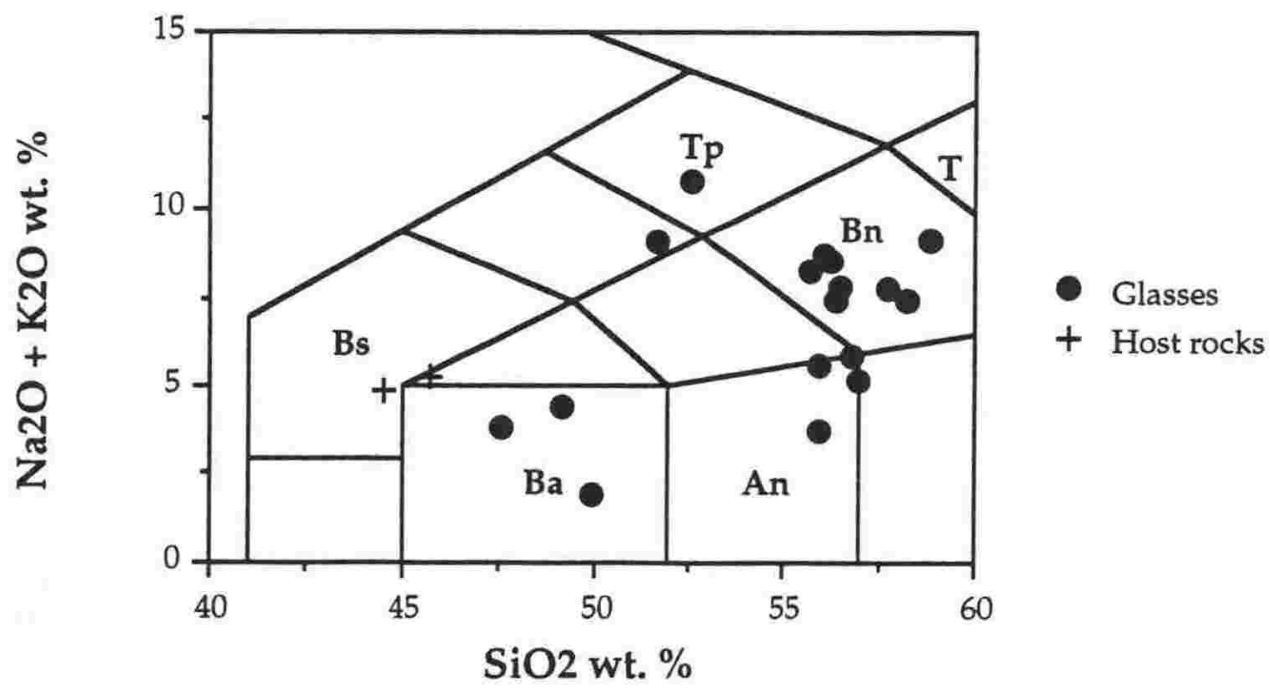

FIGURE 5.16: Total alkali-silica plot (Le Bas et al., 1986) of glasses occurring in the Mount Hampton xenolith suite, showing a general trend (with much scatter) of increasing alkali content with silica. Host lavas (from Le Masurier, 1990) are basanites. $\mathrm{An}=$ andesite; $\mathrm{Ba}=$ basalt; $\mathrm{Bn}=$ benmoreite; $\mathrm{Bs}=$ basanite; $\mathrm{T}=$ trachyte; $\mathrm{Tp}=$ tephriphonolite. See Figure 2.1 for other fields. 
TABLE 5.15: Representative electron microprobe analyses of individual glasses in Mount Hampton xenoliths. CIPW normative abundances were calculated assuming a $\mathrm{Fe}_{2} \mathrm{O}_{3}: \mathrm{FeO}$ ratio of 0.15 .

\begin{tabular}{lcccccccccc}
\hline SAMPLE & PK4A & PK4A & PK4A & PK4L & PK4S & PK4Y & PK4Y & PK4Y & PK4C1 & PK4C1 \\
TYPE & Gran & Gran & Gran & Pyxite & Pyxite & Gran & Gran & Gran & Gran & Gran \\
\hline SiO2 & 58.27 & 58.93 & 60.77 & 49.95 & 47.70 & 55.67 & 56.01 & 56.84 & 56.96 & 49.25 \\
Al2O3 & 17.23 & 15.25 & 15.10 & 17.80 & 17.02 & 14.80 & 15.05 & 15.76 & 17.09 & 10.58 \\
TiO2 & 1.61 & 2.97 & 2.32 & 0.97 & 3.47 & 2.83 & 4.42 & 3.19 & 3.65 & 3.08 \\
FeO & 5.09 & 8.87 & 9.13 & 4.38 & 10.78 & 8.97 & 11.51 & 6.04 & 7.32 & 11.43 \\
MnO & 0.14 & 0.19 & 0.03 & 0.12 & 0.23 & 0.11 & 0.23 & 0.19 & 0.17 & 0.14 \\
MgO & 2.41 & 2.36 & 2.99 & 7.50 & 9.38 & 3.72 & 3.14 & 3.80 & 3.54 & 15.19 \\
CaO & 8.03 & 2.87 & 4.31 & 17.54 & 8.36 & 6.58 & 5.25 & 8.65 & 6.88 & 5.86 \\
Na2O & 5.69 & 4.60 & 4.77 & 1.84 & 3.72 & 5.97 & 4.33 & 4.49 & 3.74 & 3.16 \\
K2O & 1.69 & 4.50 & 0.76 & 0.02 & 0.09 & 2.27 & 1.28 & 1.34 & 1.50 & 1.30 \\
& & & & & & & & & & \\
\hline TOTAL & 100.16 & 100.54 & 100.17 & 100.12 & 100.76 & 100.92 & 101.23 & 100.29 & 100.85 & 99.99 \\
\hline & & & & & & & & & & \\
Mg\# & 45.74 & 32.12 & 36.88 & 75.32 & 60.78 & 42.52 & 32.73 & 52.85 & 46.32 & 70.31 \\
& & & & & & & & & & \\
\hline & & & & & & & & & & \\
Q & 0.88 & 3.31 & 13.32 & 0.00 & 0.00 & 0.00 & 7.77 & 5.08 & 9.39 & 0.00 \\
Or & 9.99 & 26.59 & 4.49 & 0.12 & 0.53 & 13.42 & 7.56 & 7.92 & 8.86 & 7.68 \\
Ab & 48.15 & 38.93 & 40.36 & 15.57 & 31.43 & 42.67 & 36.64 & 37.99 & 31.65 & 26.74 \\
An & 16.48 & 7.67 & 17.55 & 40.25 & 29.48 & 6.88 & 17.85 & 18.89 & 25.42 & 10.85 \\
Ne & 0.00 & 0.00 & 0.00 & 0.00 & 0.02 & 4.25 & 0.00 & 0.00 & 0.00 & 0.00 \\
Di & 19.15 & 5.48 & 3.19 & 37.24 & 9.66 & 21.19 & 6.81 & 19.27 & 7.05 & 14.55 \\
Hy & 1.14 & 10.59 & 14.49 & 3.97 & 0.00 & 0.00 & 13.19 & 3.53 & 9.65 & 5.44 \\
Ol & 0.00 & 0.00 & 0.00 & 0.00 & 20.23 & 4.81 & 0.00 & 0.00 & 0.00 & 25.91 \\
Mt & 0.00 & 0.00 & 0.00 & 0.00 & 0.00 & 0.00 & 0.00 & 0.00 & 0.00 & 0.00 \\
Il & 3.06 & 5.64 & 4.41 & 1.84 & 6.59 & 5.37 & 8.39 & 6.06 & 6.93 & 5.85 \\
Ap & 0.00 & 0.00 & 0.00 & 0.00 & 0.00 & 0.00 & 0.00 & 0.00 & 0.00 & 0.00 \\
& & & & & & & & & & \\
\hline TOTAL & 98.85 & 98.21 & 97.81 & 98.99 & 97.94 & 98.59 & 98.21 & 98.74 & 98.95 & 97.02 \\
\hline & & & & & & & & & &
\end{tabular}

An origin of these glasses by decompression melting of orthopyroxene can be discounted by the high $\mathrm{TiO}_{2}, \mathrm{Al}_{2} \mathrm{O}_{3} \mathrm{CaO}, \mathrm{Na}_{2} \mathrm{O}$ and $\mathrm{K}_{2} \mathrm{O}$ contents of the glasses, which are not compatible with orthopyroxene compositions deficient in these elements. Furthermore, the presence of glasses in veins originating from the host melts negates decompression melting as an origin for these glasses. Their similarity to symplectite glasses also indicates that the latter were sourced from the host melts.

Strong negative trends of decreasing $\mathrm{Fe}_{2} \mathrm{O}_{3}, \mathrm{MnO}, \mathrm{MgO}$ and $\mathrm{CaO}$ with increasing silica are apparent and suggest an evolving glass composition due to 

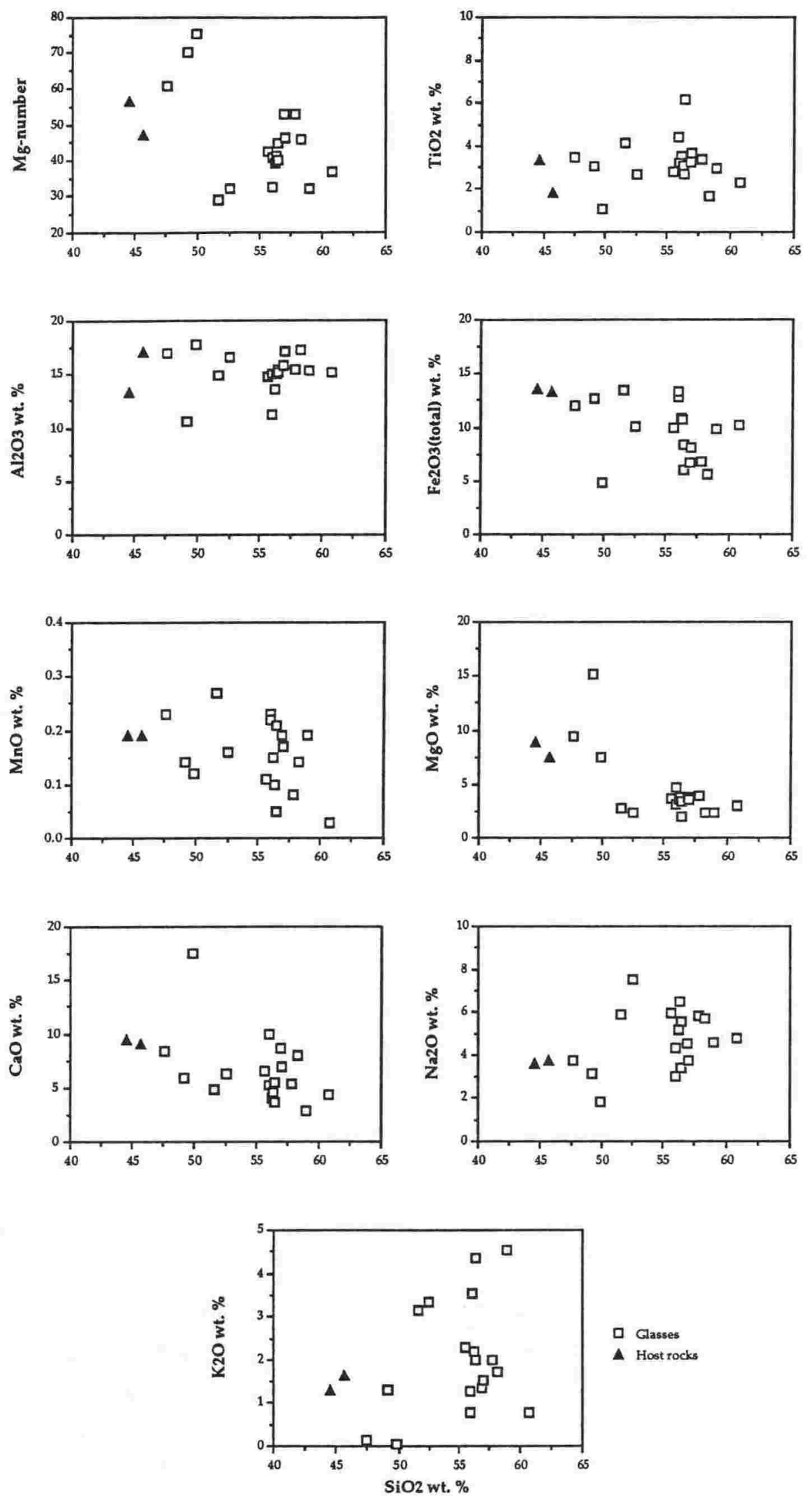

FIGURE 5.17: Major elements v silica variation diagrams of glasses in Mount Hampton xenoliths compared to host basanite compositions (basanites from Le Masurier, 1990). Host basanites fall at one end of these trends, suggesting that the glasses may be evolved host lavas. 
the fractionation of mineral phases. The occurrence of host melt compositions at the silica-poor end of these plots further indicates that the melt evolved from an initial basanitic composition similar to host melt composition. The crystallisation of clinopyroxene, plagioclase and Fe-Ti oxides (ilmenite and titanomagnetite), from glasses in veins and in orthopyroxene symplectites, is the most likely explanation for the observed trends. Olivine has not been detected in veins, and may be derived directly from the host orthopyroxene.

The wide scatters observed in major element plots are too large to be due solely to analytical error, and suggest the presence of another process other than simple crystal fractionation. Crystallisation of mineral phases from the glass in conjunction with melting of the orthopyroxene host would affect both the host orthopyroxene and glass composition. As the host melt provides the impetus for the breakdown of orthopyroxene into olivine, assimilation of orthopyroxene into the melt is likely. The result is the evolution of the glass from basanitic composition (of the host melts) to more evolved compositions by AFC processes.

\subsubsection{Summary and discussion of symplectite growth}

Symplectites of two phases of olivine and glass with minor amounts of FeTi oxides, plagioclase and pyroxenes have developed on the rim and through cracks of orthopyroxene crystals in both the granulite and pyroxenite suites.

Glass chemistry, and their association with host melts negates an origin of the glasses from orthopyroxene melting due to decompression. Rather, the glasses represent host melts that have infiltrated the xenoliths along cracks and around grain boundaries, causing the breakdown of orthopyroxene into olivine symplectites in response to changing P-T conditions. The melts have subsequently evolved by crystallisation of clinopyroxene, plagioclase and Fe oxides, together with the mixing of xenolith orthopyroxene compositions, equating to AFC processes.

The presence of hematite and magnetite as secondary oxide phases suggest high oxygen fugacities during symplectite growth, corresponding to higher crustal levels than primary oxides which formed at lower oxygen fugacity conditions. This indicates that oxidation probably occurred during entrainment to the surface. The presence of glass filled cracks cross-cut by younger glass-free cracks suggests that melt infiltration in some instances occurred prior to decompression due to ascent to the surface. This indicates that melt infiltration and oxidation occurred from source depths to emplacement at the surface. 


\subsection{Whole Rock Geochemistry}

Representative major and trace element whole rock analyses for Mount Hampton granulites and pyroxenites are presented as Table 5.16, and a complete list of analyses can be found in Appendix 4.2. Mg\#s are calculated as $100 \mathrm{Mg} / \mathrm{Mg}+\sum \mathrm{Fe}$, with total $\Sigma \mathrm{Fe}$ taken as $\mathrm{FeO}$. CIPW normative compositions are calculated at an $\mathrm{Fe}_{2} \mathrm{O}_{3}: \mathrm{FeO}$ ratio of 0.15 .

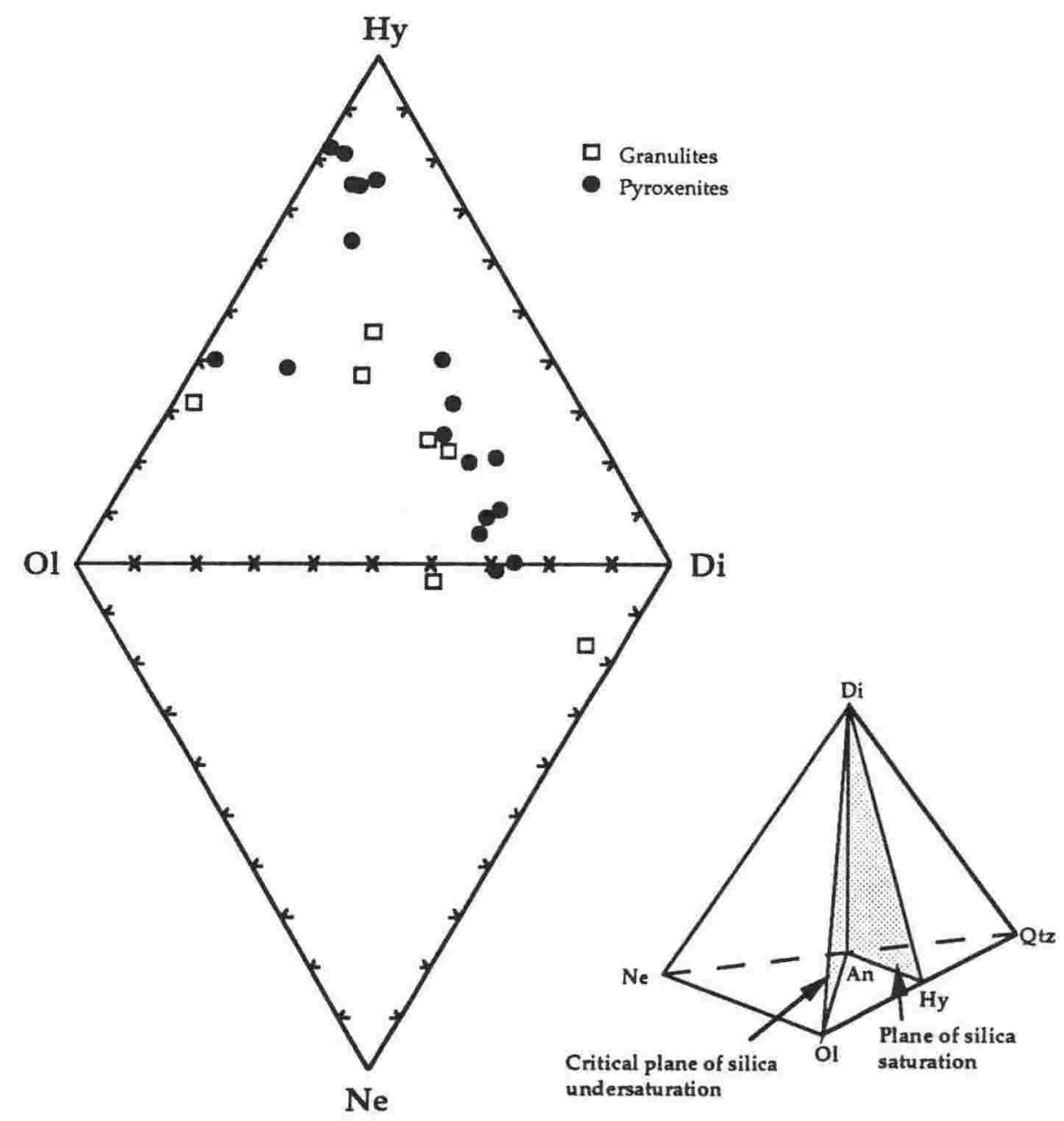

FIGURE 5.18: Normative mineral compositions of the Mount Hampton xenolith suite plotted on the diopside-hypersthene-olivine-nepheline faces of the basalt tetrahedron. The xenolith suite forms a well defined linear trend, with olivine-bearing xenoliths plotting away from the trend towards normative olivine.

\subsubsection{Major element geochemistry}

The majority of granulites and pyroxenites are hypersthene-normative, forming a linear trend from hypersthene-rich to hypersthene-poor compositions (Figure 5.18). A few samples of both suites are mildly nepheline-normative, due to their Si-poor mineral assemblage. These samples lie on the trend depicted by hypersthene-normative samples and represent an extension of this trend into the 
TABLE 5.16: Representative analyses of granulite and pyroxenite xenoliths from Mount Hampton.

\begin{tabular}{lcccccccccc}
\hline $\begin{array}{l}\text { Sample } \\
\text { Type }\end{array}$ & $\begin{array}{c}\text { PK4A } \\
\text { Gran }\end{array}$ & $\begin{array}{c}\text { PK4R } \\
\text { Gran }\end{array}$ & $\begin{array}{c}\text { PK4V } \\
\text { Gran }\end{array}$ & $\begin{array}{c}\text { PK4Y } \\
\text { Gran }\end{array}$ & $\begin{array}{c}\text { PK4C1 } \\
\text { Gran }\end{array}$ & $\begin{array}{c}\text { PK4C } \\
\text { Pyxite }\end{array}$ & $\begin{array}{c}\text { PK4J } \\
\text { Pyxite }\end{array}$ & $\begin{array}{c}\text { PK4N } \\
\text { Pyxite }\end{array}$ & $\begin{array}{c}\text { PK5E } \\
\text { Pyxite }\end{array}$ & $\begin{array}{c}\text { PK5G } \\
\text { Pyxite }\end{array}$ \\
\hline $\mathrm{SiO} 2$ & 50.62 & 46.13 & 49.08 & 51.93 & 49.68 & 45.85 & 48.06 & 43.40 & 49.96 & 49.65 \\
$\mathrm{TiO} 2$ & 0.22 & 1.31 & 1.58 & 0.44 & 0.81 & 0.42 & 1.28 & 0.40 & 0.58 & 0.86 \\
$\mathrm{~A} 2 \mathrm{O} 3$ & 21.78 & 7.58 & 22.65 & 19.62 & 12.64 & 3.67 & 7.12 & 4.28 & 5.95 & 6.35 \\
$\mathrm{Fe} 2 \mathrm{O} 3$ tot & 6.74 & 14.12 & 5.43 & 6.15 & 10.43 & 21.65 & 12.27 & 24.26 & 17.19 & 10.13 \\
$\mathrm{MnO}$ & 0.08 & 0.23 & 0.06 & 0.10 & 0.17 & 0.29 & 0.23 & 0.28 & 0.23 & 0.19 \\
$\mathrm{MgO}$ & 8.19 & 16.14 & 3.77 & 8.44 & 13.10 & 26.70 & 15.42 & 25.54 & 24.09 & 17.76 \\
$\mathrm{CaO}$ & 8.88 & 13.36 & 13.30 & 9.59 & 11.15 & 1.39 & 14.87 & 2.51 & 2.05 & 14.07 \\
$\mathrm{Na} 2 \mathrm{O}$ & 3.50 & 1.63 & 3.86 & 3.37 & 2.11 & 1.10 & 0.95 & 0.51 & 0.35 & 0.87 \\
$\mathrm{~K} 2 \mathrm{O}$ & 0.31 & 0.08 & 0.23 & 0.26 & 0.13 & 0.08 & 0.01 & 0.03 & 0.02 & 0.03 \\
$\mathrm{P} 2 \mathrm{O} 5$ & 0.02 & 0.01 & 0.02 & 0.01 & 0.00 & 0.06 & 0.00 & 0.04 & 0.02 & 0.00 \\
LOI & 0.04 & -0.55 & 0.15 & -0.08 & -0.13 & -0.90 & 0.00 & -1.10 & -0.55 & 0.10 \\
& & & & & & & & & & \\
\hline TOTAL & 100.38 & 100.04 & $\mathbf{1 0 0 . 1 3}$ & $\mathbf{9 9 . 8 3}$ & $\mathbf{1 0 0 . 0 9}$ & $\mathbf{1 0 0 . 3 1}$ & $\mathbf{1 0 0 . 2 1}$ & $\mathbf{1 0 0 . 1 5}$ & $\mathbf{9 9 . 8 9}$ & $\mathbf{1 0 0 . 0 1}$ \\
\hline
\end{tabular}

\begin{tabular}{llllllllllll}
\hline $\mathrm{Mg \#}$ & 70.64 & 69.36 & 57.89 & 73.10 & 71.33 & 70.95 & 71.34 & 67.58 & 73.51 & 77.64
\end{tabular}

\begin{tabular}{|c|c|c|c|c|c|c|c|c|c|c|}
\hline $\mathrm{Sc}$ & 7 & 40 & 19 & 18 & 33 & 19 & 58 & 14 & 26 & 51 \\
\hline V & 45 & 259 & 155 & 115 & 251 & 177 & 421 & 120 & 227 & 313 \\
\hline $\mathrm{Cr}$ & 45 & 1940 & 28 & 233 & 448 & 236 & 926 & 144 & 1636 & 1746 \\
\hline $\mathrm{Ni}$ & 130 & 414 & 32 & 122 & 222 & 499 & 248 & 421 & 555 & 484 \\
\hline $\mathrm{Cu}$ & 5 & 66 & 38 & 15 & 36 & 28 & 44 & 7 & 49 & 68 \\
\hline $\mathrm{Zn}$ & 38 & 73 & 22 & 36 & 57 & 153 & 64 & 127 & 98 & 58 \\
\hline $\mathrm{Ga}$ & 15 & 10 & 20 & 15 & 15 & 8 & 13 & 6 & 9 & 10 \\
\hline $\mathrm{Rb}$ & 2 & $<1$ & 2 & 1 & 2 & 1 & 1 & $<1$ & 1 & 1 \\
\hline $\mathrm{Sr}$ & 719 & 164 & 1065 & 635 & 302 & 3 & 33 & 22 & 6 & 35 \\
\hline Y & $<1$ & 17 & 3 & 1 & 9 & 1 & 16 & $<1$ & $<1$ & 11 \\
\hline $\mathrm{Zr}$ & 19 & 59 & 38 & 20 & 22 & 3 & 29 & 10 & $<1$ & 20 \\
\hline $\mathrm{Nb}$ & $<1$ & 2 & 1 & $<1$ & $<1$ & 1 & $<1$ & $<1$ & $<1$ & $<1$ \\
\hline $\mathrm{Ba}$ & 158 & 23 & 129 & 136 & 65 & 5 & 2 & 5 & 4 & 7 \\
\hline $\mathrm{La}$ & 2 & 6 & 3 & 1 & 3 & 7 & 3 & 4 & 4 & 1 \\
\hline $\mathrm{Ce}$ & 8 & 18 & 9 & 6 & 11 & 17 & 9 & 15 & 8 & 8 \\
\hline $\mathrm{Pb}$ & 3 & 3. & 5 & 5 & 2 & 4 & 5 & 5 & 3 & 4 \\
\hline Th & 1 & $<1$ & $<1$ & $<1$ & $<1$ & 1 & $<1$ & 1 & $<1$ & $<1$ \\
\hline U & $<1$ & 1 & $<1$ & 1 & 2 & $<1$ & $<1$ & 1 & $<1$ & $<1$ \\
\hline Q & 0.00 & 0.00 & 0.00 & 0.00 & 0.00 & 0.00 & 0.00 & 0.00 & 0.00 & 0.00 \\
\hline Or & 1.83 & 0.47 & 1.36 & 1.54 & 0.77 & 0.47 & 0.06 & 0.18 & 0.12 & 0.18 \\
\hline $\mathrm{Ab}$ & 29.62 & 8.28 & 23.63 & 28.52 & 17.85 & 9.31 & 8.04 & 4.32 & 2.96 & 7.36 \\
\hline An & 42.80 & 13.13 & 43.80 & 37.64 & 24.64 & 4.84 & 15.13 & 9.30 & 10.04 & 13.33 \\
\hline $\mathrm{Ne}$ & 0.00 & 2.99 & 4.89 & 0.00 & 0.00 & 0.00 & 0.00 & 0.00 & 0.00 & 0.00 \\
\hline Lc & 0.00 & 0.00 & 0.00 & 0.00 & 0.00 & 0.00 & 0.00 & 0.00 & 1.67 & 0.00 \\
\hline $\mathrm{Di}$ & 0.90 & 42.82 & 17.83 & 7.93 & 24.69 & 1.22 & 47.17 & 2.35 & 8.07 & 45.10 \\
\hline Hy & 7.49 & 0.00 & 0.00 & 13.59 & 12.81 & 35.88 & 7.37 & 32.22 & 61.20 & 15.15 \\
\hline $\mathrm{Ol}$ & 15.48 & 26.72 & 3.78 & 8.23 & 15.19 & 42.79 & 16.83 & 45.71 & 12.77 & 14.52 \\
\hline Mt & 1.16 & 2.43 & 1.18 & 1.06 & 1.80 & 3.73 & 2.12 & 4.18 & 2.96 & 1.75 \\
\hline Il & 0.42 & 2.49 & 3.00 & 0.84 & 1.54 & 0.80 & 2.43 & 0.76 & 1.10 & 1.63 \\
\hline Ap & 0.05 & 0.02 & 0.05 & 0.02 & 0.00 & 0.14 & 0.00 & 0.09 & 0.05 & 0.00 \\
\hline TOTAL & 99.75 & 99.35 & 99.52 & 99.37 & 99.29 & 99.18 & 99.15 & 99.11 & 100.94 & 99.02 \\
\hline
\end{tabular}


silica undersaturated plane of the basalt tetrahedron. Silica undersaturated phases, such as nepheline, do not occur as modal mineral phases in the xenolith suite. A departure from the main trend is exhibited by olivine-bearing xenoliths of both suites towards an olivine-rich normative composition.

Mount Hampton granulites and pyroxenites are mafic (43-52 wt. \% $\mathrm{SiO}_{2}$ ) with little variation between the suites, although the granulites are on average slightly more silica-rich (Figure 5.19). High magnesium numbers, with an average Mg\# of approximately 70, highlight the primitive nature of the xenolith suite (Figure 5.19). Exceptions to this are one granulite (PK4V) with a low Mg\# of 57.9, and one high-Mg\# pyroxenite (PK5G) with an Mg\# of 77.6 (Table 5.16, Figure 5.19). The low-Mg\# granulite may reflect either an evolved composition, derivation from another source, or the result of secondary alteration. The high-Mg\# pyroxenite is from a different basanitic cone to the bulk of other samples and may therefore represent a local sampling heterogeneity. The only other sample from this cone (PK5E) also has a high Mg\# of 73.5 (Table 5.16).

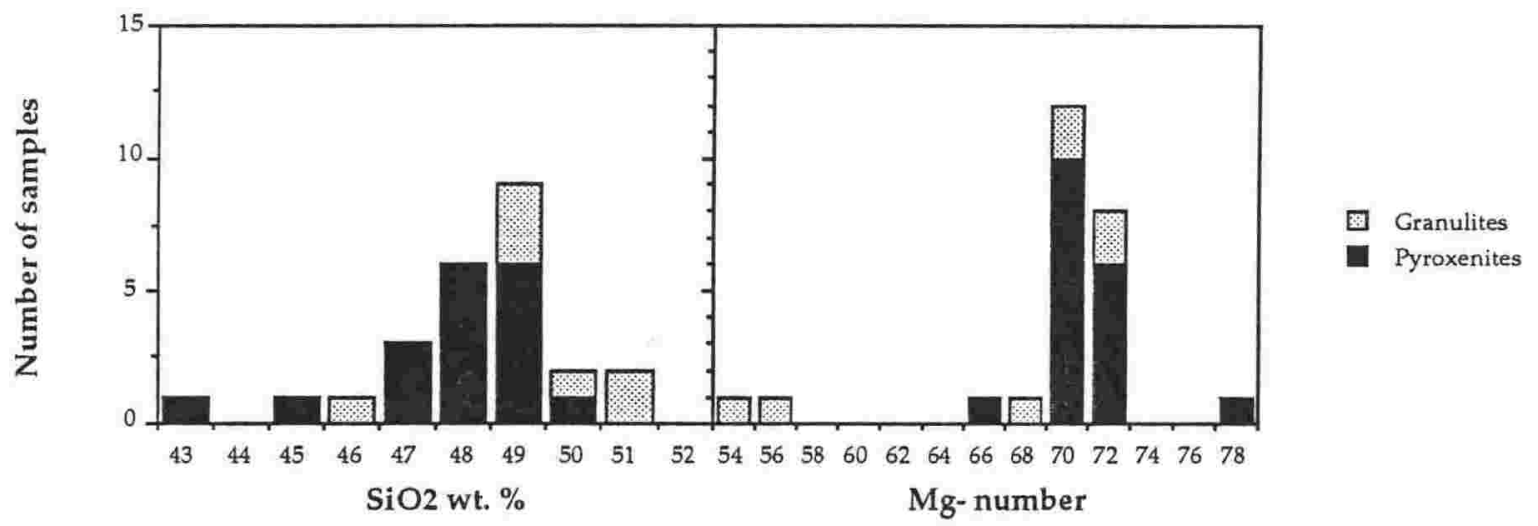

FIGURE 5.19: Silica and Mg\# histograms of Mount Hampton granulites and pyroxenites demonstrate the similarity of the two suites, and their primitive mafic compositions. One granulites has a low $\mathrm{Mg \#} \mathrm{(57.9),} \mathrm{and} \mathrm{a} \mathrm{single} \mathrm{pyroxenite} \mathrm{with} \mathrm{a} \mathrm{high} \mathrm{Mg \#} \mathrm{(77.6)} \mathrm{originates} \mathrm{from} \mathrm{a} \mathrm{different} \mathrm{locality} \mathrm{to} \mathrm{all}$ but one of the other pyroxenites, which also has a high $\mathrm{Mg \#} \mathrm{(73.5).} \mathrm{SiO}_{2}$ abscissa is by 1 wt. \% gradations (e.g. $43=43.0-43.9$ ), and $\mathrm{Mg \#}$ is by $2 \mathrm{Mg} \#$ gradations (e.g. $54=54.0-55.9$ ).

The positive correlation of $\mathrm{SiO}_{2}$ with $\mathrm{Mg} \#$ (Figure 5.20) is unusual, as trends between the two are normally negative, with increasing silica and decreasing Mg\#, due to the evolution of the suite by crystal fractionation. The xenolith suite however does not represent a melt, but the products of crystal fractionation. Their geochemistry is therefore controlled by the mineral assemblage.

Strong trends of many elements with silica (Figure 5.20) can be attributed to mixing between varying modal abundances of clinopyroxene + orthopyroxene \pm 

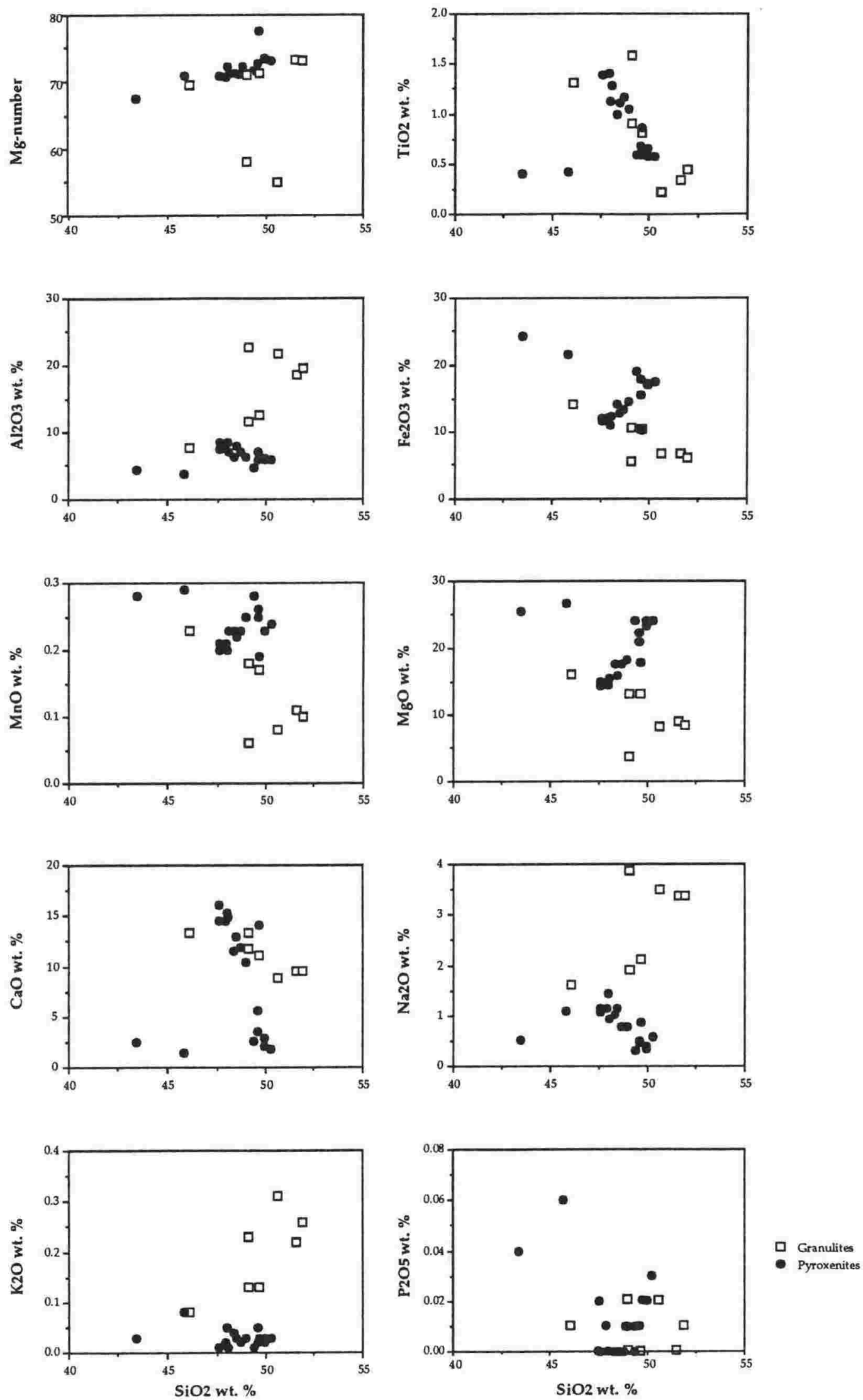

FIGURE 5.20: Silica v major element plots of Mount Hampton xenoliths. Major element concentrations reflect the mineral assemblage, and the proportion of each mineral phase, in the xenolith suite. 
plagioclase. This is emphasised by plots of $\mathrm{Al}_{2} \mathrm{O}_{3}$ and $\mathrm{MgO}$ against $\mathrm{SiO}_{2}$ for both suites (Figure 5.21).

The major element trends (large double-headed arrows) are controlled by plagioclase and clinopyroxene in the granulite suite, and by orthopyroxene and clinopyroxene in the pyroxenite suite, reflecting the high modal proportions of these phases (Table 5.1). Minor vectors (small single-headed arrows) result from higher olivine, Al-spinel and orthopyroxene in some granulites, and from olivine in some pyroxenites. The dominant role of orthopyroxene in the pyroxenite suite contrasts with its minor role in the granulite suite, reflecting its low abundance in the granulite suite (Table 5.1).

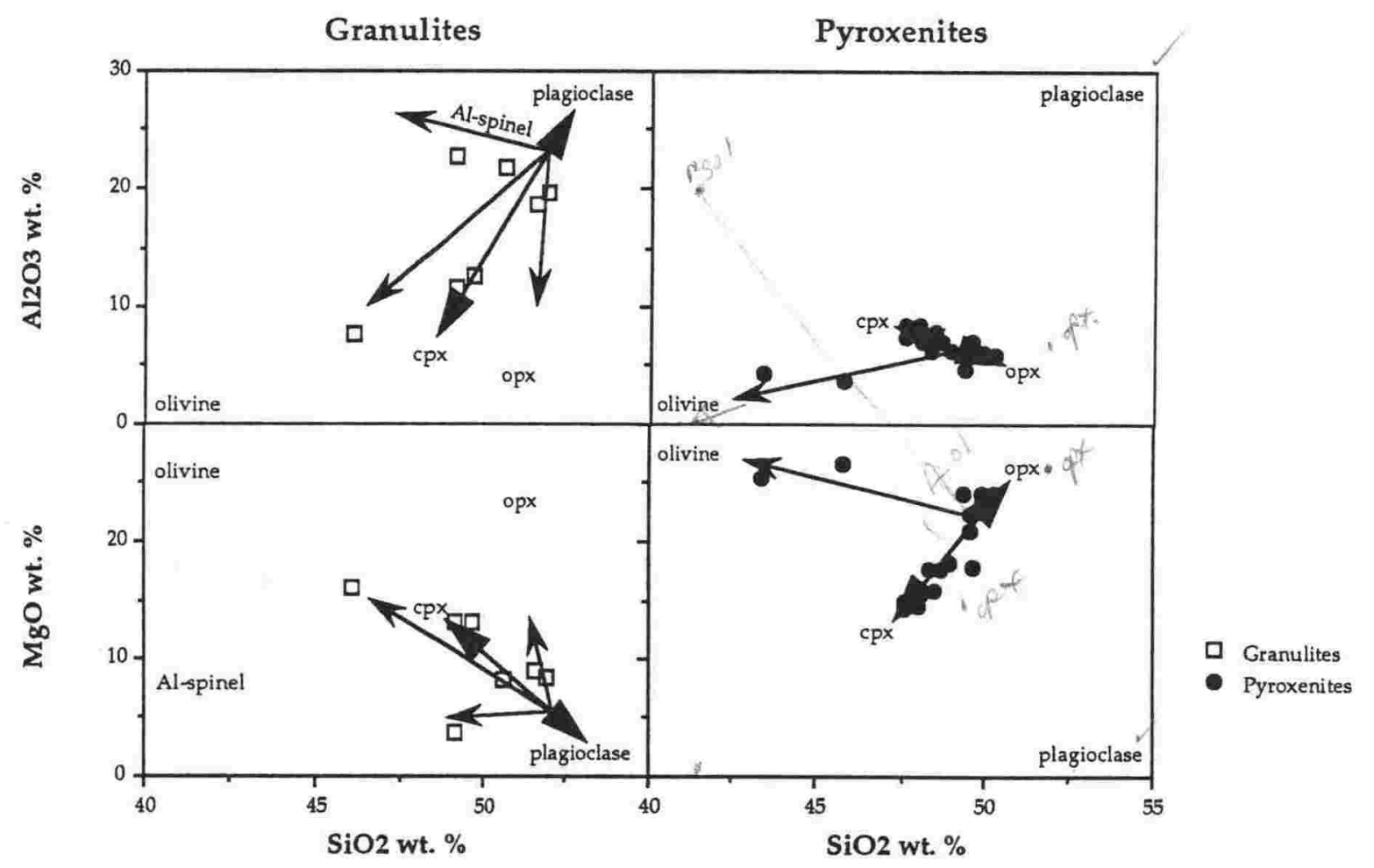

FIGURE 5.21: a) $\mathrm{Al}_{2} \mathrm{O}_{3}$ and b) $\mathrm{MgO}_{\mathrm{v} \mathrm{SiO}}$ plots of granulites and pyroxenites from Mount Hampton showing the influence of their modal mineral assemblage on element abundance. Large double headed arrows reflect the dominant trends of plagioclase and clinopyroxene in the granulite suite, and orthopyroxene and clinopyroxene in the pyroxenite suite. Small single headed arrows reflect the minor influences of other modal mineral phases, including olivine, orthopyroxene and Al-spinel in the granulite suite, and olivine in the pyroxenite suite. Note the dominant role of orthopyroxene in the pyroxenite suite, compared to its minor role in the granulite suite, reflecting its high proportion in the former, and low proportion in the latter.

Other element abundances are also influenced by the modal mineral assemblage (Figure 5.20 ). $\mathrm{Na}_{2} \mathrm{O}$ and $\mathrm{K}_{2} \mathrm{O}$ totals in granulites are controlled by the abundance of plagioclase in the granulite suite. The dominance of pyroxene in the pyroxenite suite is also reflected in their high $\mathrm{Fe}_{2} \mathrm{O}_{3}$ (total) and $\mathrm{MnO}$ abundances. 
The dominance of clinopyroxene or orthopyroxene as the major mafic phase in the pyroxenites is evident in their $\mathrm{CaO}$ contents. Clinopyroxene-rich pyroxenites have high $\mathrm{CaO}$ totals, and orthopyroxene-rich pyroxenites have low $\mathrm{CaO}$ totals. The relatively stable and moderately high $\mathrm{CaO}$ totals $(8.9-13.3$ wt. \% $\mathrm{CaO}$ ) in the granulites is attributable to high modal plagioclase contents.

The presence of olivine in some samples is evidenced by lower $\mathrm{SiO}_{2}, \mathrm{Al}_{2} \mathrm{O}_{3}$, $\mathrm{Na}_{2} \mathrm{O}$ and $\mathrm{CaO}$ totals, and higher $\mathrm{Fe}_{2} \mathrm{O}_{3}$ (total), $\mathrm{MgO}$ and $\mathrm{MnO}$ totals reflecting the relative abundance of these elements in the olivine structure.

The control of the mineral assemblage on whole rock compositions allows a comparison of the low- $\mathrm{Mg} \#$ granulite, and the high $\mathrm{Mg \#}$ pyroxenite with other granulites and pyroxenites.

The low-Mg\# granulite (PK4V) has a low $\mathrm{MgO}$ content, and a $\mathrm{Fe}_{2} \mathrm{O}_{3}$ (total) content similar to other granulites. The composition of pyroxenes from this sample is typical of pyroxenes from the granulite suite, indicating that low $\mathrm{MgO}$ contents of the mineral phases are not responsible for the low $\mathrm{Mg \#}$. The sample does however have a low abundance of pyroxene compared to plagioclase, and a relatively high abundance of Fe-Ti oxides (Appendix 2.2), which has resulted in its low Mg\#. The low pyroxene content is also apparent in the granulites low $\mathrm{Cr}$ (and $\mathrm{Ni}$ ) contents, and the high proportion of plagioclase is also reflected in its high $\mathrm{Na}_{2} \mathrm{O}$ and $\mathrm{Sr}$ content. The high oxide content is also evident in its high $\mathrm{TiO}_{2}$ and $\mathrm{V}$ contents relative to other granulites (Table 5.16, Figures 5.20 and 5.22).

The high-Mg\# pyroxenite (PK5G) has a low $\mathrm{Fe}_{2} \mathrm{O}_{3}$ (total) content, but is otherwise typical of other pyroxenites, plotting along the main trend exhibited by the pyroxenite suite (Table 5.16, Figures 5.20 and 5.22). Mineral phases from this sample are similar in composition to other pyroxenites, although its does have a very low $\mathrm{Fe}-\mathrm{Ti}$ oxide content. This indicates that its high-Mg\# is a reflection of its low Fe-Ti oxide content (Appendix 2.2).

\subsubsection{Trace element geochemistry}

Trace element abundances in the xenolith suite are also controlled by their mineral assemblage (Figure 5.22). Elements that partition readily into mineral phases of the xenolith suite are present in high concentrations. For example, plagioclase-rich xenoliths have high $\mathrm{Sr}$ and $\mathrm{Ba}$ totals, and clinopyroxene-rich xenoliths have high $\mathrm{Cr}$ (and $\mathrm{Ni}$ ) contents. Elements that do not readily enter any mineral phase are present in low concentrations (e.g. $\mathrm{Rb}$ and $\mathrm{Nb}$ ).

Trace element abundances in the granulite suite generally correlate with silica (e.g. Sr, Ba, Ni, V, La, $\mathrm{Y}$ and $\mathrm{Zr}$ ), indicating their crystallisation as cumulate rocks. The strong trends further indicate that post-crystallisation enrichment or 

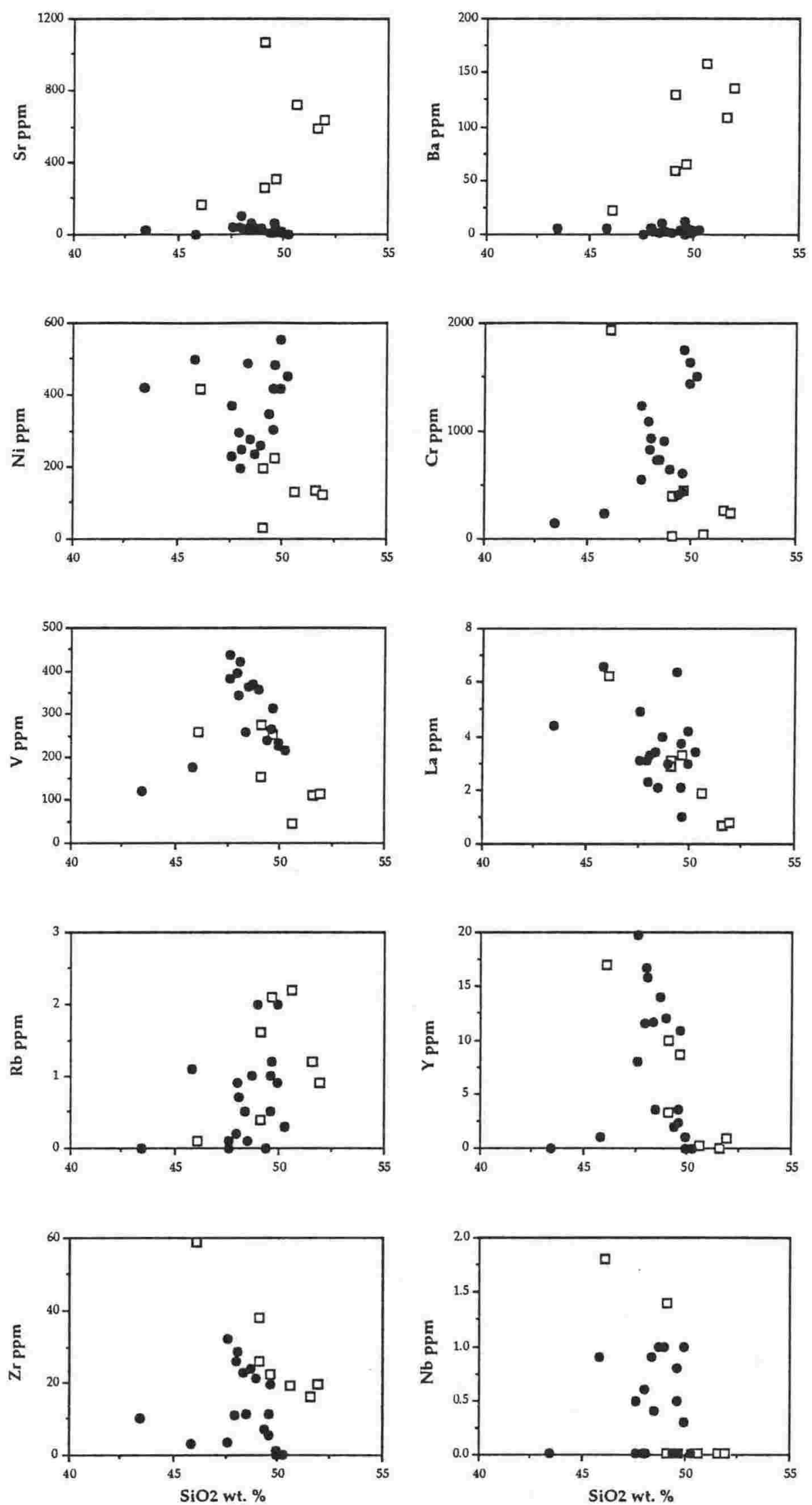

Granulites

- Pyroxenites

FIGURE 5.22: Silica v trace element plots of Mount Sidley xenoliths. As with the major elements, trace element concentrations reflect the xenolith mineral assemblage. 
depletion of these elements has not occurred to any large extent. The pyroxenite suite however does not generally show strong trends, reflecting the similarity of orthopyroxene and clinopyroxene $\mathrm{SiO}_{2}$ contents.

The presence of olivine in some samples is also evident from trace element contents. The olivine-bearing granulite (PK4R) has a higher Ni content (in addition to low $\mathrm{SiO}_{2}$ content) than other granulites due to the preferential partitioning of $\mathrm{Ni}$ in olivine. Olivine-bearing pyroxenites (PK4C and PK4N) have high $\mathrm{Ni}$, and low $\mathrm{SiO}_{2}$ and $\mathrm{Cr}$ contents, reflecting the presence of olivine at the expense of clinopyroxene. The only other influence of olivine on trace element abundances is a general depletion in most other trace elements, as they are not compatible in the olivine structure.

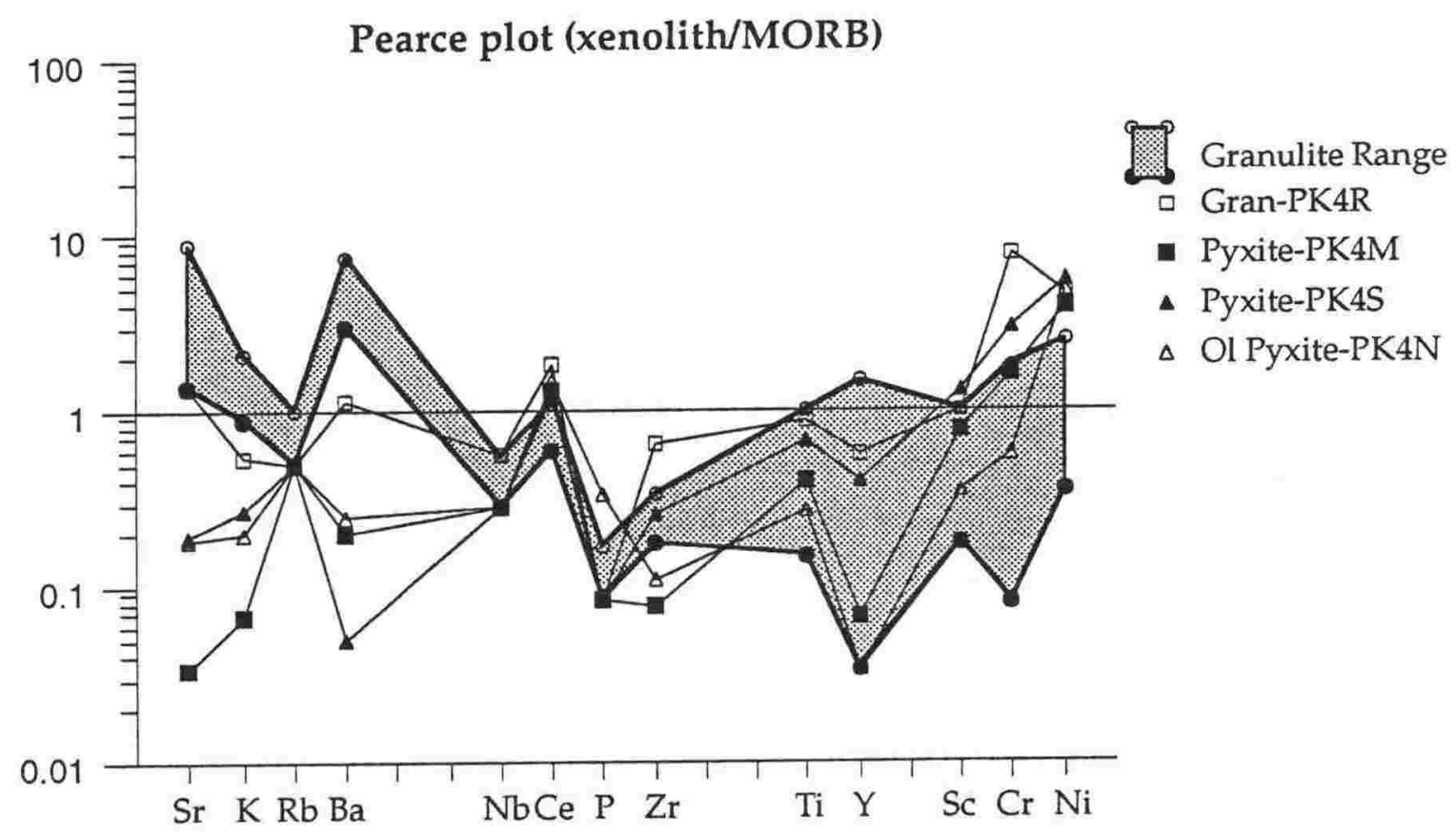

FIGURE 5.23: Multi-element variation diagram of trace elements normalised to MORB (Pearce, 1983) for Mount Hampton granulites (shaded area), two representative pyroxenites, and one olivinebearing pyroxenite. Xenolith types differ only in elements that are preferentially incorporated into the mineral assemblage of the xenoliths, as granulites are dominated by plagioclase, and pyroxenites are dominated by pyroxene. In all other aspects, the two xenolith suites are identical.

Trace element abundances are also shown in multi-element variation diagrams normalised to MORB (Pearce, 1983). Figure 5.23 depicts the full range of granulite compositions (shaded area), two pyroxenite compositions, and an olivine-bearing pyroxenite. Source characteristics cannot be determined for these plots as the samples represent mineral assemblages and not liquids, however a comparison between xenolith types can be made.

The relatively high $\mathrm{Sr}, \mathrm{K}$, and Ba contents of the granulite suite, due to an abundance of plagioclase, and relatively high $\mathrm{Cr}$ and $\mathrm{Ni}$ contents in the pyroxenite 
suite due to an abundance of clinopyroxene, are apparent (Figure 5.23). The overall abundance of trace elements in the xenolith suite is low.

The low abundances of trace elements emphasises three salient points. Firstly, apart from elements compatible in plagioclase or pyroxene, the two suites are very similar and cannot be distinguished in trace element abundances. Secondly, there is no evidence for the enrichment of elements since metamorphism, by the host melt or any other agent. Finally, the low abundances of elements that do not partition into xenolith mineral phases suggests a cumulate protolith with very little associated melt. This is also evident in xenolith textures.

Another possibility is that the samples represent restites that have been depleted in these elements during partial melting and/or metamorphism (Rudnick et al, 1986). The affects of metamorphism on the xenolith suite are difficult to assess, as elements likely to be affected (mobile elements such as the LILEs) were most likely initially present in low concentrations due to their mineral assemblage. The well defined trends of many trace elements (e.g. Sr, Ba, $\mathrm{Ni}, \mathrm{V}, \mathrm{La}, \mathrm{Y}$ and $\mathrm{Zr}$ ) with silica (Figure 5.22) in the granulite suite however does indicate that these elements have not been depleted or enriched.

TABLE 5.17: Trace element (including rare earth element) analyses of Mount Hampton xenoliths and clinopyroxene. $\mathrm{Cpx}=$ clinopyroxene; rock $=$ whole rock; 0 = below detection; ' - ' $=$ not analysed.

\begin{tabular}{|c|c|c|c|c|}
\hline $\begin{array}{l}\text { Sample } \\
\text { Type }\end{array}$ & $\begin{array}{c}\text { PK4L } \\
\text { Pyxite } \\
\text { rock }\end{array}$ & $\begin{array}{c}\text { PK4C1 } \\
\text { Gran } \\
\text { rock }\end{array}$ & $\begin{array}{c}\text { PK4C1 } \\
\text { Gran } \\
\text { cpx }\end{array}$ & $\begin{array}{c}\text { PK4L1 } \\
\text { Gran } \\
\text { rock } \\
\end{array}$ \\
\hline $\mathrm{Sc}$ & 50.3 & 39.8 & 71.9 & 42.7 \\
\hline $\mathrm{Cr}$ & 1216 & 421 & 685 & 365 \\
\hline $\mathrm{Ni}$ & 223 & 255 & 193 & 259 \\
\hline $\mathrm{Zn}_{\mathbf{n}}$ & 62 & 63 & 60 & 65 \\
\hline As & - & 0 & 0 & 0 \\
\hline $\mathbf{R b}$ & - & - & - & - \\
\hline $\mathrm{Sr}$ & 0 & 262 & 0 & 314 \\
\hline $\mathrm{Ba}$ & - & 86 & 0 & 0 \\
\hline $\mathrm{La}$ & 0.58 & 0.95 & 1.24 & 1 \\
\hline $\mathrm{Ce}$ & 2.5 & 3.2 & 6.8 & 3.8 \\
\hline $\mathrm{Nd}$ & 0 & - & - & - \\
\hline $\mathrm{Sm}$ & 2.08 & 1.46 & 3 & 1.69 \\
\hline Eu & 0.92 & 0.782 & 1.26 & 0.844 \\
\hline $\mathrm{Tb}$ & 0.38 & 0.326 & 0.71 & 0.407 \\
\hline $\mathrm{Yb}$ & 0.61 & 0.95 & 1.83 & 1.19 \\
\hline Lu & 0.102 & 0.119 & 0.209 & 0.159 \\
\hline $\mathrm{Hf}$ & 0.38 & 0.79 & 1.32 & 1.2 \\
\hline $\mathrm{Ta}$ & 0 & 0.19 & 0.05 & 0.15 \\
\hline Th & 0.09 & 0 & 0 & 0.17 \\
\hline
\end{tabular}


REE contents are presented as Table 5.17, and shown as plots normalised to chondrite (Wheatley and Rock, 1988) in Figure 5.24. The convex-up patterns of both the granulites and the pyroxenites are very similar, further indicating the close genetic relationship between the suites.

The influence of mineral phases and the lack of melt is also evident in rare earth element abundances (Table 5.17). Low abundances of LREEs compared to HREEs has resulted in a convex up shape for the REE pattern of the xenolith suites, which mimics that of clinopyroxenes formed from a mafic melt (Irving, 1978). This is the case for both the pyroxenite suite and the granulite suite, although the influence of plagioclase is apparent in the positive Eu anomaly in the granulite suite.

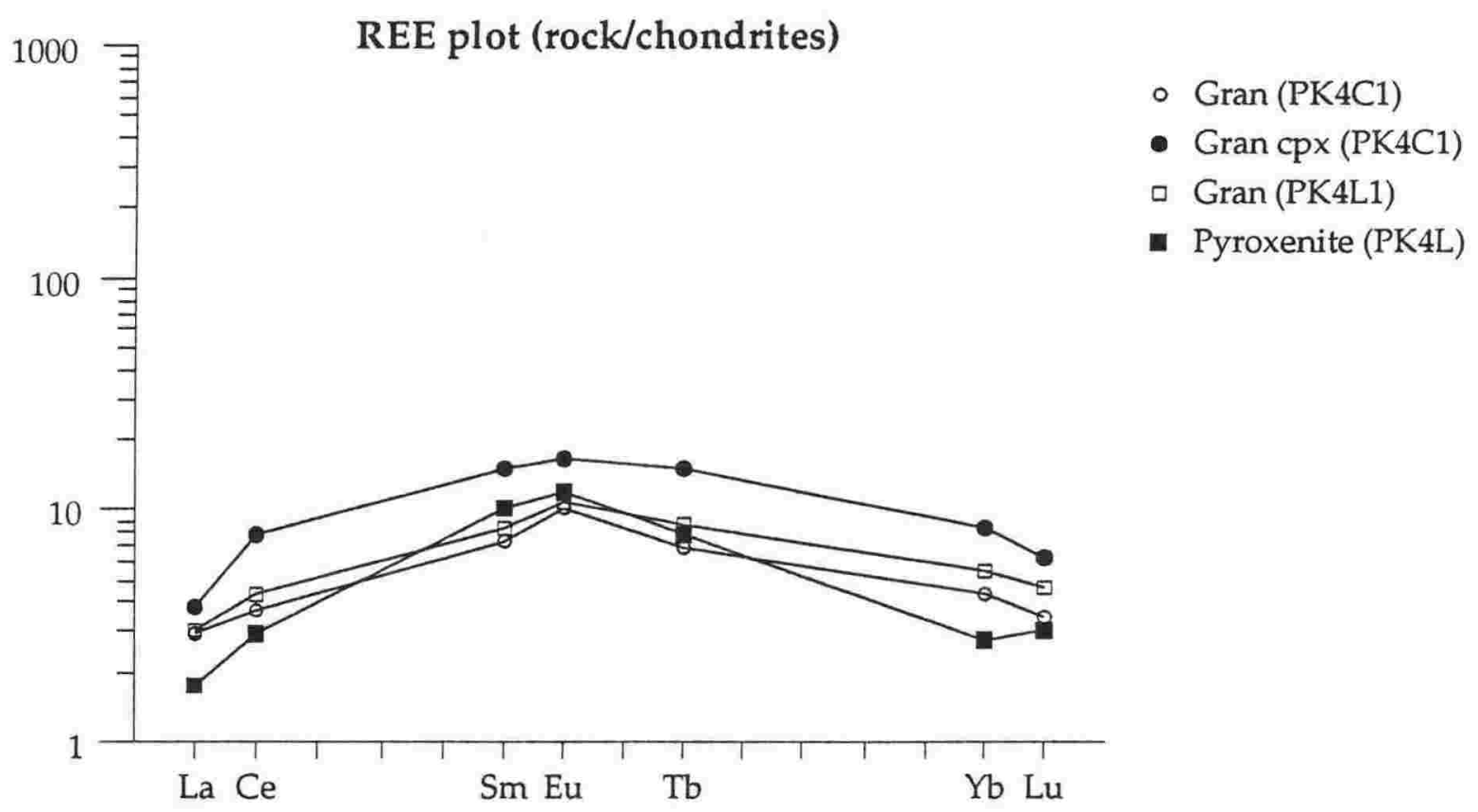

FIGURE 5.24: Rare earth element patterns normalised to chondrite (Wheatley and Rock, 1988) for Mount Hampton xenoliths and clinopyroxenes. All patterns are similar, reflecting the dominance of clinopyroxene on the pattern. Granulite patterns have small positive Eu-anomalies, reflecting the presence of plagioclase in these xenoliths.

No evidence of enrichment by the host melt or any other agent is apparent in the pyroxenite patterns which follow those of clinopyroxene. A minor amount of interaction with the LREE-enriched host melts would increase the LREE abundances of the xenolith suite; this has not occurred.

The low abundances of LREEs in the granulite suite is striking, as plagioclase contents should result in higher LREE contents (Irving, 1978; Rudnick et al., 1986; Chapter 4.5.2; Figure 4.24). A depletion in LREEs often signifies a melting episode or depletion due to metamorphism. The xenolith suite does not appear to have undergone a melting episode (unless no liquid remained after 
melting), however metamorphism resulting in their recrystallised fabric may have depleted the xenolith suite in LREEs. Alternatively, plagioclase in the granulite suite may have low REE abundances as a result of crystallisation from an LREE-depleted melt. The restricted data set makes it difficult to ascertain which possibility (if either) is correct.

\subsubsection{Isotope geochemistry}

Isotope analyses of Mount Hampton xenoliths are presented as Table 5.18, and full details of isotopic analyses are presented in Appendix Six. Due to the small number of analyses, the range of isotopic ratios exhibited by the entire xenolith suite cannot be ascertained, severely limiting their usefulness. Samples were collected that represent the xenolith suite, with only fresh cores of xenoliths being analysed. A further discussion of these results is presented in Chapter Seven, where they are compared with lower crustal xenoliths world-wide, including others from MBL.

TABLE 5.18: $\mathrm{Sr}, \mathrm{Nd}$ and $\mathrm{Pb}$ Isotopic ratios for xenoliths and host lavas (from Le Masurier, 1990) from Mount Hampton. $\mathrm{Rb}$ and $\mathrm{Sr}$ determinations have an error of approximately $\pm 1 \mathrm{ppm} ; \mathrm{Rb} / \mathrm{Sr}$ ratios at such low Rb concentrations are therefore meaningless. Nd has not been analysed, and Sm data is only available for two samples (PK4L1 $=1.69$, and PK4L $=2.08$ ). For analytical details see Appendix Six.

\begin{tabular}{|c|c|c|c|c|c|c|c|}
\hline SAMPLE & $\begin{array}{l}\text { Rock } \\
\text { Type }\end{array}$ & Mg\# & $\mathbf{R b}$ & $\mathrm{Sr}$ & $\frac{87 \mathrm{Sr}}{86 \mathrm{Sr}}$ & $\underline{143 \mathrm{Nd}}$ & $206 \mathrm{~Pb} 207 \mathrm{~Pb} 208 \mathrm{~Pb}$ \\
\hline
\end{tabular}

Mount Hampton Granulites

\begin{tabular}{|c|c|c|c|c|c|c|c|}
\hline $\mathrm{K} 4 \mathrm{C} 1$ & Rock & 71.33 & 2 & 302 & $0.704242+-10$ & & $19.179 \quad 15.647 \quad 38.883$ \\
\hline C4L1 & Rock & 70.94 & 1 & 259 & $.704198+-46$ & $0.512818+-5$ & $\begin{array}{lll}19.048 & 15.650 & 38.830\end{array}$ \\
\hline K4L1 & Cpx & & & & & $0.512818+-5$ & \\
\hline
\end{tabular}

Mount Hampton Pyroxenite

$\begin{array}{lllllll}\text { PK4L } & \text { Rock } & 71.21 & 1 & 37 & 0.704576+-15 & 0.512771+-6\end{array}$

Mount Hampton Volcanics

$\begin{array}{llllll}\text { 22D } & \text { Basanite } & 52.80 & 41 & 765 & 0.7028\end{array}$

$\begin{array}{lllll}\text { MB29.4 Phonolite } & 2.00 & 176 & 12 & 0.7047\end{array}$

Present-day ${ }^{87} \mathrm{Sr} /{ }^{86} \mathrm{Sr}$ ratios of three Mount Sidley xenoliths range from 0.704198-0.704576. $\mathrm{Rb} / \mathrm{Sr}$ ratios do not correlate with do not correlate with ${ }^{87} \mathrm{Sr} /{ }^{86} \mathrm{Sr}$ ratios, due to the error involved in $\mathrm{Rb}$ determinations approximately \pm 1 ppm at low Rb abundances; Appendix Four), the small sample size, a resetting of the $\mathrm{Rb} / \mathrm{Sr}$ ratio by secondary processes, or a combination of these factors. Model $\mathrm{Rb}-\mathrm{Sr}$ age calculations for the xenolith suite are therefore meaningless. 


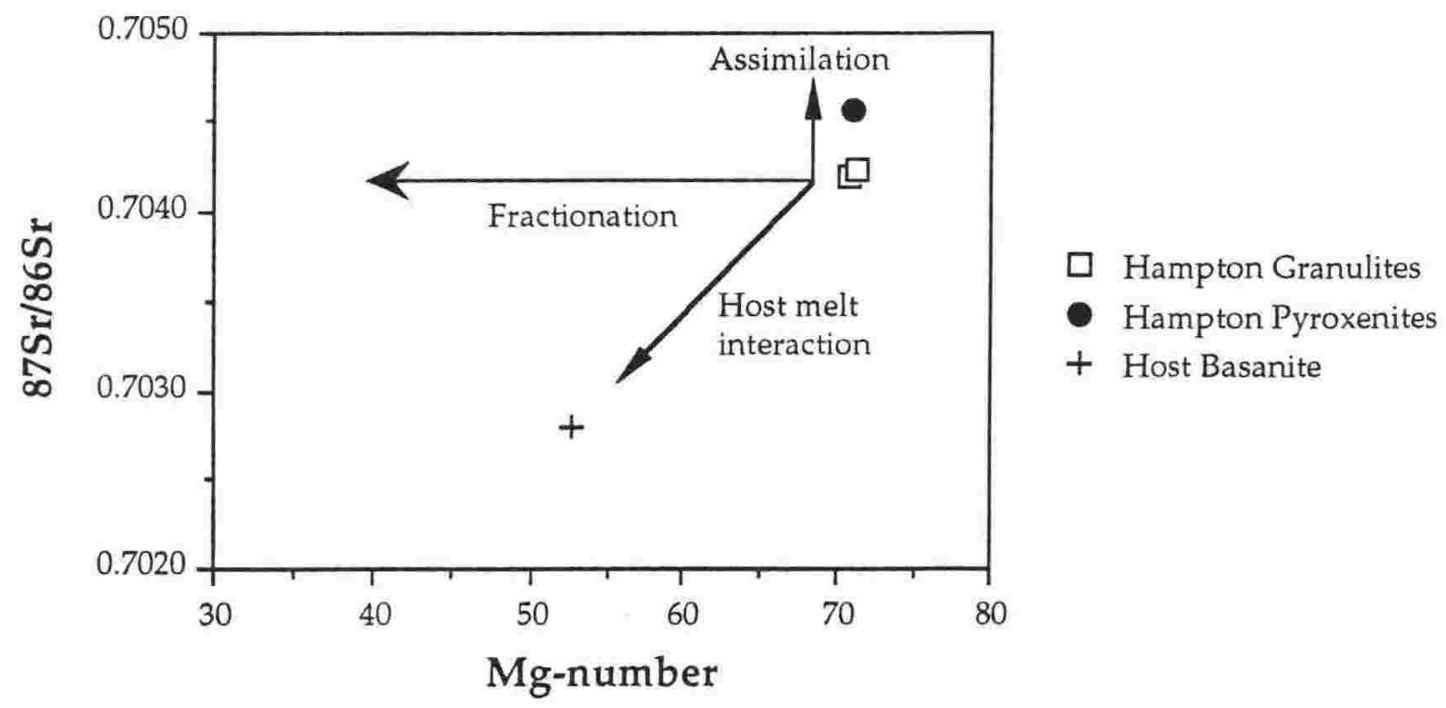

FIGURE 5.25: Mg-number $\mathrm{v}^{87} \mathrm{Sr} /{ }^{86} \mathrm{Sr}$ ratios for two granulites and one pyroxenite. The trend of increasing ${ }^{87} \mathrm{Sr} /{ }^{86} \mathrm{Sr}$ ratios at constant $\mathrm{Mg \#}$ indicates that fractional crystallisation did not result in a substantially more evolved melt, with lower Mg\#s. The increase in ${ }^{87} \mathrm{Sr} /{ }^{86} \mathrm{Sr}$ ratio may be due to assimilation of evolved crustal material, the result of evolution of the ${ }^{87} \mathrm{Sr} /{ }^{86} \mathrm{Sr}$ ratio with time, or source heterogeneity. Host rock ${ }^{87} \mathrm{Sr} /{ }^{86} \mathrm{Sr}$ ratios (from Le Masurier, 1990) are lower than the xenolith suite, and have not influenced the isotopic signature of the xenoliths.

$\mathrm{Mg \# s}$ are constant with increasing ${ }^{87} \mathrm{Sr} /{ }^{86} \mathrm{Sr}$ ratios (Figure 5.25), indicating that the higher ${ }^{87} \mathrm{Sr} /{ }^{86} \mathrm{Sr}$ ratios may be due to assimilation of an isotopically more evolved contaminant, such as felsic crust. However, there is no indication of prolonged fractional crystallisation having occurred, resulting in a lowering of $\mathrm{Mg \# ;}$ the crystallisation of the xenolith suite therefore did not result in a substantially evolved melt.

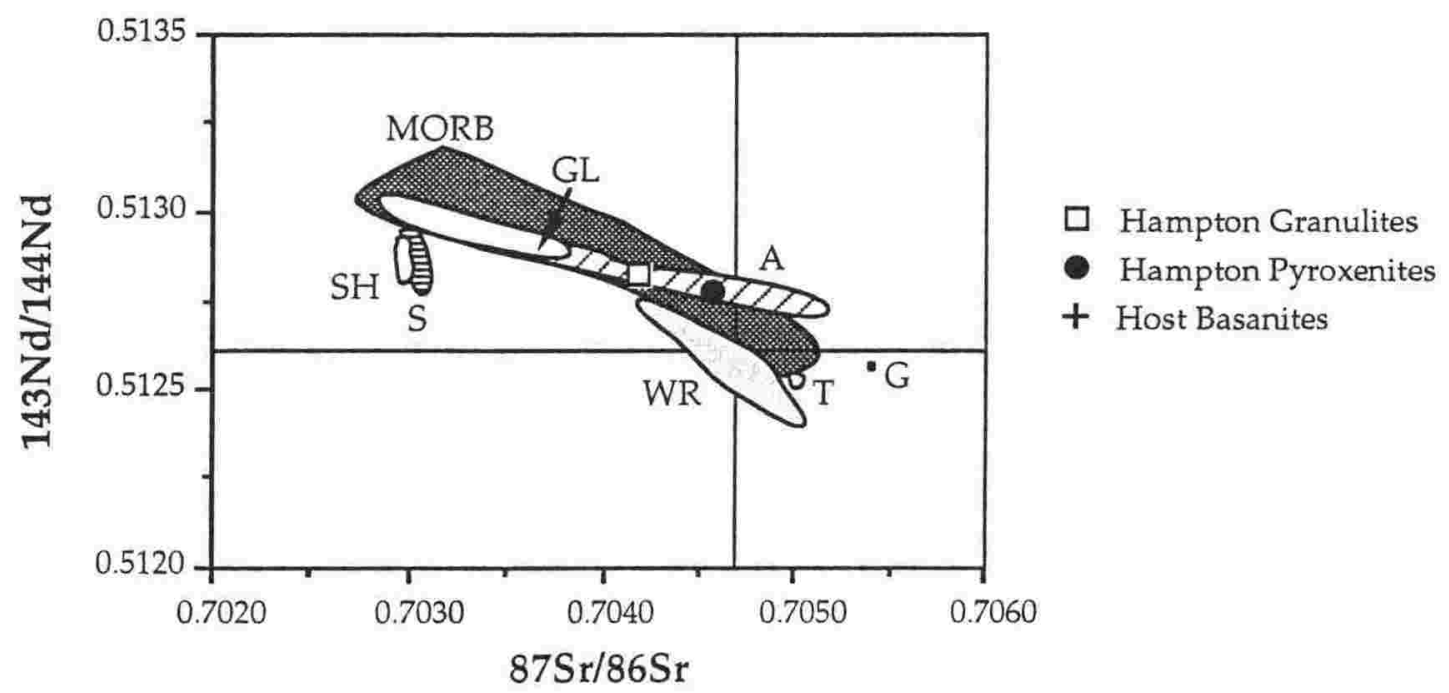

FIGURE 5.26: ${ }^{87} \mathrm{Sr} /{ }^{86} \mathrm{Sr} \mathrm{v}{ }^{143} \mathrm{Nd} /{ }^{144} \mathrm{Nd}$ isotopic diagram showing the depleted ratios of the xenolith suite, consistent with their crystallisation from a primitive sub-alkaline (depleted) mantle melt. If the host rocks are similar to Mount Sidley ('S' Field) host rocks (HIMU-like), then the volcanic and xenolith suites can not be related, and entrainment in the host rocks has not affected the Sr-Nd isotopic signature of the xenolith suite. Fields shown (from Wilson, 1989) are: $A=$ Azores; $G=$ Gough; $\mathrm{Gl}=$ Galapagos; $\mathrm{MORB}=$ Mid Ocean Ridge Basalts; $\mathrm{SH}=$ St Helena; $\mathrm{T}=$ Tristan da Cunha; $\mathrm{WR}=$ Walvis Ridge. 
This also indicates that AFC processes have not occurred, with fractional crystallisation providing the latent heat necessary to assimilate evolved crustal material, resulting in a decrease of $\mathrm{Mg} \#$ and an increase in ${ }^{87} \mathrm{Sr} /{ }^{86} \mathrm{Sr}$ ratios (Rudnick et al., 1986). The trend of increasing ${ }^{87} \mathrm{Sr} /{ }^{86} \mathrm{Sr}$ ratios at constant $\mathrm{Mg} \#$ is more likely to have either evolved with time, or represent a heterogeneity in the source region.

The relatively low ${ }^{87} \mathrm{Sr} /{ }^{86} \mathrm{Sr}$ ratios, and high ${ }^{143} \mathrm{Nd} /{ }^{144} \mathrm{Nd}$ ratios (Figure 5.26) are typical of many mafic basaltic rocks, and further indicate little or no assimilation of evolved crustal material. Their Sr-Nd isotopic signature falls above the bulk-earth ratio, and within the MORB field, consistent with their crystallisation from a primitive sub-alkaline (depleted) mantle melt.

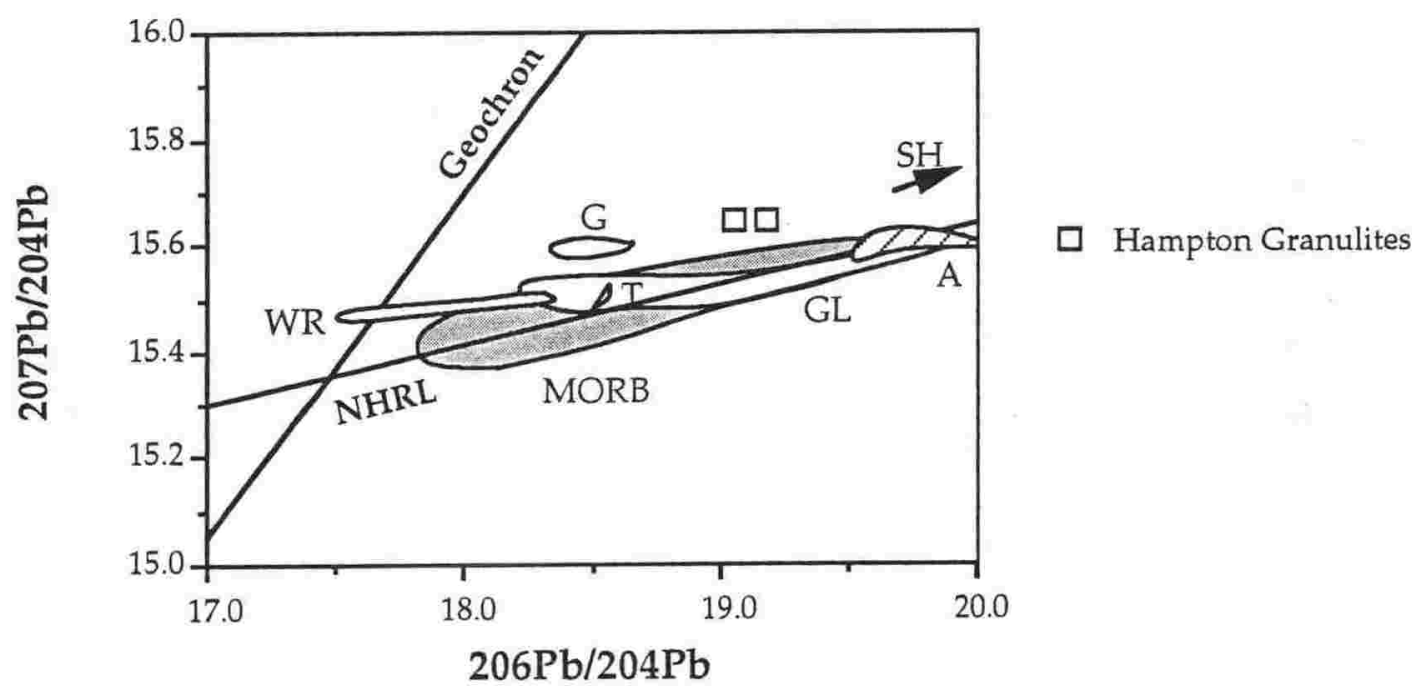

FIGURE 5.27: ${ }^{206} \mathrm{~Pb} /{ }^{204} \mathrm{~Pb} \mathrm{v}{ }^{207} \mathrm{~Pb} /{ }^{204} \mathrm{~Pb}$ isotopic diagram showing the radiogenic values of two Mount Hampton granulites. $\mathrm{Pb}$ isotopic ratios plot parallel to the Northern Hemisphere Reference Line (NHRL), and are similar to radiogenic basalts; as with the Mount Sidley xenolith suite, $\mathrm{Pb}$ isotopic ratios have been altered by the host rocks, which have St Helena-like ratios. Fields are as for Figure 5.26.

$\mathrm{Pb}$ isotopic ratios of the granulite suite are similar to radiogenic basaltic rocks, plotting parallel to the NHRL (Figure 5.27). Pb isotopic ratios of the Mount Sidley xenolith suite have been affected by the entraining host melts, which have not affected the xenolith $\mathrm{Sr}-\mathrm{Nd}$ isotopic ratios (Chapter 4.6.3). The host rocks are also likely to have affected the Mount Hampton xenolith $\mathrm{Pb}$ isotopic ratios.

\subsubsection{Summary and discussion of whole rock geochemistry}

The mineral assemblage of the xenolith suite controls the whole rock geochemical characteristics of the xenolith suite. As there is little or no trapped melt in the xenoliths, only elements that are readily partitioned into mineral phases are present in high abundances. Other elements are present in low 
concentrations. The main geochemical characteristics of the xenolith suite include;

- as discussed above, concentrations of elements in the xenolith suite are controlled by the mineral assemblage. The xenolith suite is mafic and hypersthene-normative in composition. Trace elements are present in generally low concentrations (relative to MORB), and REE concentrations are similar to REE concentrations of the clinopyroxenes, which are LREE depleted. Granulite xenoliths have a positive Eu anomaly as a result of high plagioclase abundances;

- apart from differences due to differing mineral assemblages, the pyroxenite and granulites suites are very similar, reflecting a genetic relationship;

- low ${ }^{87} \mathrm{Sr} /{ }^{86} \mathrm{Sr}$ ratios and high ${ }^{143} \mathrm{Nd} /{ }^{144} \mathrm{Nd}$ ratios indicate crystallisation from a primitive mantle melt with little or no assimilation of evolved crustal material. A trend of increasing ${ }^{87} \mathrm{Sr} /{ }^{86} \mathrm{Sr}$ ratios at constant $\mathrm{Mg \#}$ suggests that fractionation of the cumulates did not produce a substantially evolved melt, and that AFC processes were not occurring during crystallisation;

- there is no evidence for geochemical enrichment of the xenolith suite by the alkaline host melts: e.g. no enrichment of LILEs or LREEs, and ${ }^{87} \mathrm{Sr} /{ }^{86} \mathrm{Sr}$ ratios that differ from the host melts. However, oxide growth in symplectites are related to host melt infiltration has resulted in lower $\mathrm{Mg \# s}$ of some xenoliths, and the radiogenic $\mathrm{Pb}$ isotopic ratios of two granulites (the only $\mathrm{Pb}$ isotopic ratios analysed) may also be a result of host melt - xenolith interaction;

- any depletion of the xenolith suite due to metamorphism is difficult to determine due to their low abundance of mobile elements (the elements most likely to be affected by metamorphism). However, well defined trends of many trace elements with silica suggest that metamorphism has not affected the geochemical characteristics of the xenolith suite;

- the geochemical attributes of the xenolith suite differ to those of the host melts (e.g. isotopic ratios) indicating no genetic relationship between them.

\subsection{Summary and Conclusion}

\subsubsection{Summary of the xenolith suite}

The lower crustal xenolith suite from Mount Hampton consists of metaigneous granulites (dominantly gabbros and norites) and pyroxenites (dominantly websterites). A summary of the features of these suites is presented as Table 5.19.

The xenoliths have simple anhydrous mineral assemblages of clinopyroxene + orthopyroxene + spinel, with plagioclase occurring as the 
dominant mineral phase in the granulite suite. Olivine is also present as a modal phase in some xenoliths of both suites. An interlayering of plagioclase and mafic minerals is evident in the granulites, imparting a layered texture on the granulite suite, originally derived from igneous cumulate layering, and enhanced by metamorphism.

TABLE 5.19: Summary of the main characteristics of the granulite and pyroxenite xenolith suites from Mount Hampton.

\begin{tabular}{|c|c|c|}
\hline TYPE & Granulites & Pyroxenites \\
\hline Texture & $\begin{array}{c}\text { Meta-Igneous } \\
\text { Layered } \\
\text { Granulites }\end{array}$ & $\begin{array}{l}\text { Meta-Igneous } \\
\text { Pyroxenites }\end{array}$ \\
\hline Mineralogy & $\begin{array}{c}\mathrm{Pl}+\mathrm{Cpx}+\mathrm{Opx} \\
(+\mathrm{Ol})\end{array}$ & $\begin{array}{c}C p x+O p x \\
(+O l)\end{array}$ \\
\hline Temperature $\left({ }^{\circ} \mathrm{C}\right)$ & $1150-1215$ & $1150-1225$ \\
\hline Pressure (kbars) & $6.5-9.5$ & $7-8.5$ \\
\hline $\begin{array}{l}\text { Secondary } \\
\text { Reactions }\end{array}$ & $\begin{array}{c}\text { Oxidation } \\
\text { (pervasive) }\end{array}$ & Oxidation \\
\hline $\begin{array}{l}\text { Major } \\
\text { Elements }\end{array}$ & $\begin{array}{c}\text { High } \mathrm{Mg \#} \\
\text { High } \mathrm{Al}, \mathrm{Na}, \mathrm{K}\end{array}$ & $\begin{array}{c}\text { High } \mathrm{Mg \#} \\
\text { High } \mathrm{Fe}, \mathrm{Mg}, \mathrm{Mn}\end{array}$ \\
\hline $\begin{array}{l}\text { Trace } \\
\text { Elements }\end{array}$ & $\begin{array}{c}\text { High Sr, } \mathrm{Ba} \\
\text { High } \mathrm{Zr} / \mathrm{Nb}, \mathrm{Y} / \mathrm{Nb}\end{array}$ & $\begin{array}{c}\text { High } \mathrm{Ni}, \mathrm{Cr} \\
\text { High } \mathrm{Zr} / \mathrm{Nb}, \mathrm{Y} / \mathrm{Nb}\end{array}$ \\
\hline REEs & LREE-depleted & LREE-depleted \\
\hline Isotopes & $\begin{array}{c}\text { Low } \mathrm{Sr} \\
\text { Radiogenic } \mathrm{Pb}\end{array}$ & Low $\mathrm{Sr}$ \\
\hline
\end{tabular}

Textural, mineral and geochemical attributes indicate that the granulite and pyroxenite suites are genetically related, with the presence and absence of plagioclase respectively constituting the only major difference between the two suites. Thermobarometric estimations indicate similar P-T conditions for both suites, suggesting that they are sourced from similar crustal levels.

Differences in mineral compositions are attributable to their crystallisation as cumulus or intercumulus phases; e.g. clinopyroxene that crystallised prior to plagioclase is rich in $\mathrm{Al}_{2} \mathrm{O}_{3}$ compared to clinopyroxene that crystallised subsequent to plagioclase. Differences in whole rock geochemistry results from differences in 
the modal mineral assemblage, i.e. elements that partition readily into xenolith mineral phases are present in higher abundances than elements that do not. The low abundance of these elements indicates that there is little or no melt in the xenolith suite.

Metamorphic fabrics, consisting of recrystallised equant grains, dominate the xenolith suite, although relict igneous textures are evident as larger crystals that have not been recrystallised, and as small grains enclosed by larger grains. The effects of metamorphism on the composition of the xenolith suite is difficult to ascertain, however there is no evidence for either depletion or enrichment of the xenolith suite after crystallisation.

Brittle deformation features are evident as broken plagioclase in the granulite suite, and ductile deformation is apparent as curved exsolution lamellae in the pyroxenite suite, indicating that deformation occurred subsequent to exsolution. The difference in deformation styles may reflect differing conditions in the source areas of the suites, with the granulite source area experiencing brittle deformation, typical of mechanical boundary conditions, and the pyroxenite source area experiencing ductile deformation, typical of thermal boundary conditions in the lithosphere (Parsons and McKenzie, 1978). The transition between the two boundaries may therefore occur in the lower crust beneath Mount Hampton.

The xenoliths have been oxidised by the host silicate melts resulting in olivine symplectite rims on xenolith orthopyroxenes. Oxidation reactions are pervasive in the granulite suite (occurring as thick $(\geq 10 \mu \mathrm{m})$ symplectite rims on orthopyroxene), but are rare in the pyroxenite suite (occurring only as thin symplectite ( $\mu \mathrm{m}$-scale) rims around orthopyroxene). The edges of pyroxenite xenoliths however are as oxidised as granulite rims, indicating that oxidation reactions have also affected them, but that the host melt was unable to penetrate into the pyroxenites as extensively as it was able to infiltrate the granulite suite.

Primary, exsolved (in clinopyroxene), and recrystallised orthopyroxene have all been affected by oxidation, indicating the late stage of this reaction. Oxide geothermometry and oxygen fugacity estimations indicate that oxidation of the xenolith suite occurred from source depths and during ascent to the surface. Oxidation of orthopyroxene exsolution lamellae, together with their ductile deformation, indicate that exsolution occurred at lower crustal depths, and not due to ascent to the surface. As exsolution occurs in response to a change in P-T conditions, the lower crust may have experienced uplift at some stage in its history. 


\subsubsection{Nature of the crystallising melt and cumulate derivatives}

The composition of the melt that originally crystallised the xenolith suite cannot be determined, as remnants of the co-existing melt are not present. The melt either totally escaped the cumulates after their crystallisation (as suggested by the low abundances of elements incompatible in the mineral assemblage), or was recrystallised during metamorphism. Several characteristics of the crystallising melt can however be ascertained from the xenolith suite:

- the simple and anhydrous mineral assemblage present in the xenolith suite consists of clinopyroxene + orthopyroxene + spinel \pm plagioclase \pm olivine, indicating that the crystallising melt was mafic in composition. The occurrence of plagioclase in the granulite suite is the only difference between the granulite and pyroxenite suites, which probably crystallised at a similar period in the fractionation sequence. The presence of orthopyroxene as a major phase further suggests that the melt was sub-alkaline;

- mineral contents (e.g. high $\mathrm{Mg}: \mathrm{Mg}+\mathrm{Fe}$ ratios in pyroxenes) and isotopic compositions (e.g. ${ }^{87} \mathrm{Sr} /{ }^{86} \mathrm{Sr}$ of $0.74198-0.70576$ ) indicate that the co-existing melt was a mantle melt with a primitive composition;

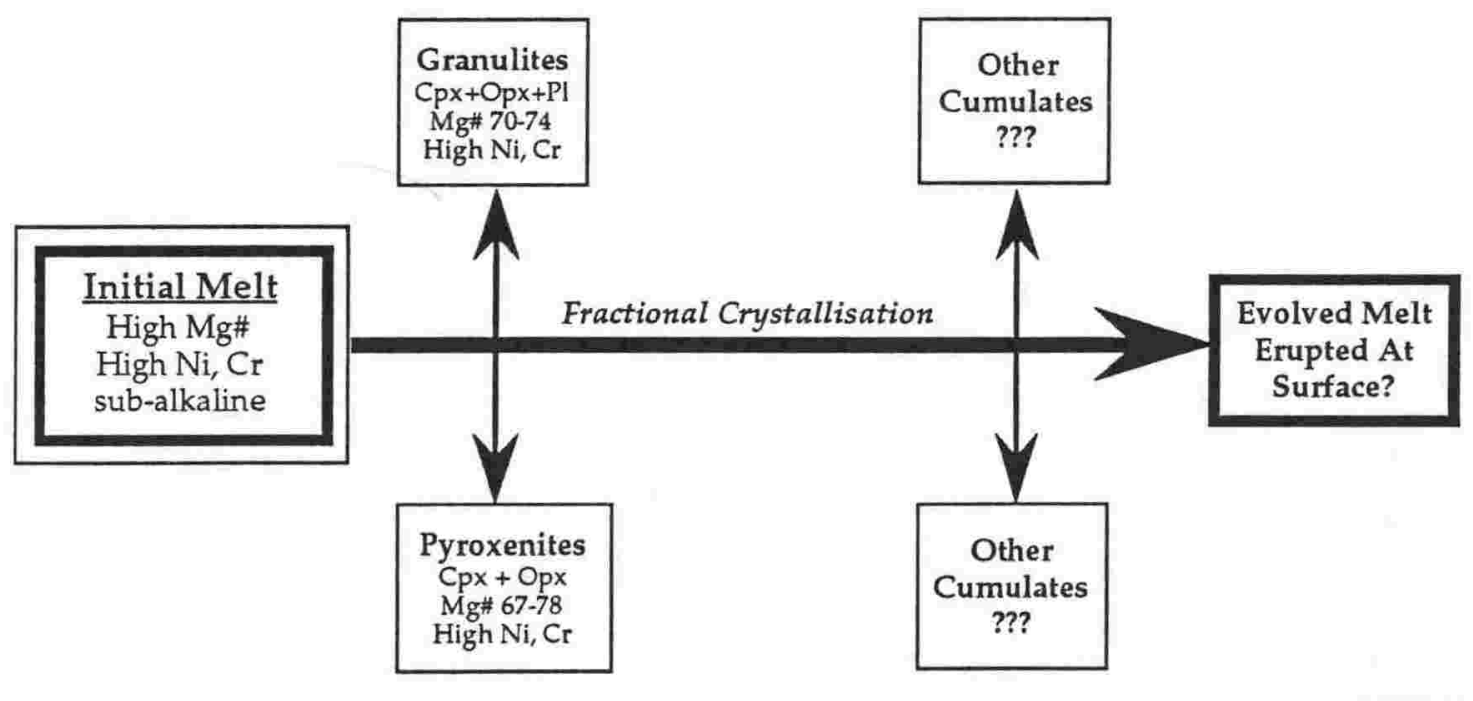

Cumulate Products of Fractional Crystallisation

FIGURE 5.28: Summary diagram showing the formation of the granulite and pyroxenite suites as cumulates formed by fractionation of a crystallising melt. The co-existing melt was a primitive mafic melt with sub-alkaline characteristics.

- the variation of cumulus and intercumulus phases, and positive correlation of silica with $\mathrm{Mg \# ,} \mathrm{indicates} \mathrm{that} \mathrm{the} \mathrm{melt} \mathrm{was} \mathrm{evolving} \mathrm{by} \mathrm{crystal}$ fractionation;

- the high Mg\#s of the xenolith suite, and their small range in Mg\#s (67-78), suggests that they formed as cumulates from an early stage of fractionation by the 
melt, and not from later more evolved compositions (if the melt continued to evolve by fractionation).

These features indicate that the xenolith suite crystallised as early cumulates from a fractionating sub-alkaline melt with primitive mantle characteristics (Figure 5.28). Both the granulite and pyroxenite suites crystallised early in the sequence, and the crystallising melt may or may not have undergone further fractionation.

The characteristics of the co-existing melt are quite different from the host melt characteristics, indicating that they are not simple cumulates from recent volcanism. The host melts for example are alkaline, with a different isotopic signature. Melts with the characteristics outlined above have not at present been found in MBL, although a possible candidate is the arc-metavolcanics related to the Carboniferous Ford Granodiorite. However, the xenolith suite is quite primitive, unlike continental arc volcanics, and have no obvious arc-signatures. A more likely possibility is that the xenolith suite represents an older (perhaps > $600 \mathrm{Ma}$, as this is the age of the oldest exposed rocks in MBL), possibly original, lower crust.

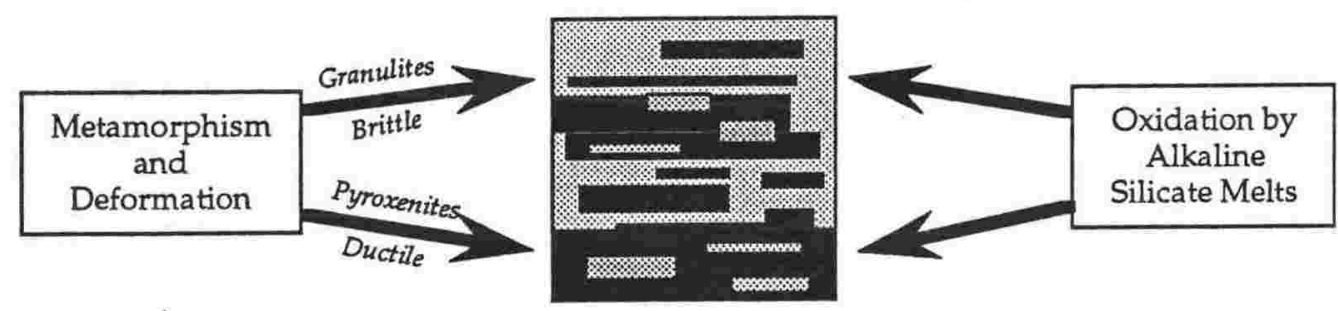

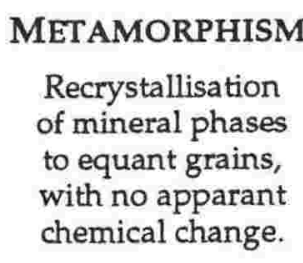

$$
\begin{aligned}
& \text { CRYSTALLISATION } \\
& \text { Synchronous } \\
& \text { crystallisation of } \\
& \text { cumulates from a } \\
& \text { primitive melt, sourced } \\
& \text { from depleted mantle. }
\end{aligned}
$$

\section{OXIDATION}

Olivine symplectite growth on orthopyroxene rims. Resetting of isotopic ratios?

FIGURE 5.29: Stylised stratigraphy of the lower crust beneath Mount Hampton, showing the similar sources of the granulite (shaded) and pyroxenite (black) suites (indicating an interlayered lower crust), their initial formation as cumulates derived from a fractionating melt, and the processes of metamorphism, deformation, and host melt oxidation that have affected the lower crust since initial crystallisation.

\subsubsection{Stratigraphy of the lower crust and secondary processes}

Textural and geochemical characteristics of the granulites and pyroxenites indicates that they crystallised as cumulates at approximately the same time from a primitive parental melt. Thermobarometric estimations indicate similar P-T conditions for both suites, indicating similar source depths. This indicates a mafic 
lower crust beneath Mount Hampton, consisting of both granulite and pyroxenite cumulates (Figure 5.29).

Metamorphic recrystallisation and deformational processes have affected both the granulites and the pyroxenites. Deformation may have been both brittle and ductile, corresponding to a change from mechanical boundary conditions to thermal boundary conditions in the lower crust (Parsons and McKenzie, 1978).

Oxidation by migrating host silicate melts has occurred in the xenolith suite from lower crustal depths, and during ascent to the surface.

\subsubsection{Conclusion}

A suite of lower crustal xenoliths from beneath Mount Hampton consists of genetically related granulites and pyroxenites that initially formed as cumulates from a fractionating melt. The melt was a primitive mantle melt (e.g. high Mg\#s and MORB-like $\mathrm{Sr}$ and Nd isotopic ratios), and the presence of orthopyroxene as a major mineral phase indicates that the melt was sub-alkaline. Lavas with these characteristics do not occur at the surface, suggesting that the xenoliths may represent an old, possible initial, lower crust.

Metamorphism and deformation have affected the xenolith suite, resulting in meta-igneous textures. The cumulate geochemistry of the xenoliths which have low abundances of elements incompatible in xenolith mineral phases, makes it difficult to ascertain whether metamorphism has resulted in a depletion of mobile elements from the xenolith suite. However, well defined trends of trace elements with silica suggests if depletion has occurred, it has not been significant.

The suite has undergone limited secondary alteration by the host alkaline melts, which is more pervasive in the granulite suite than in the pyroxenite suite, and has resulted in the oxidation of orthopyroxene rims to olivine symplectites. Oxidation has not resulted in any substantial geochemical change in the xenoliths, although the growth of Fe-Ti oxides has resulted in lower Mg\#s in some xenoliths, and radiogenic $\mathrm{Pb}$ isotopic ratios may have been inherited from the host alkaline melts. 


\section{Chapter six \\ THE MOUNT MURPHY XENOLITH SUITE}

\section{Synopsis}

Lower crustal and upper mantle xenoliths, including meta-igneous granulites, cumulate pyroxenites and peridotites, have been found at four localities on Mount Murphy, on the Walgreen coast of Marie Byrd Land. This chapter seeks to document the granulite and pyroxenite suites, which represent the lower crust beneath the volcanic edifice.

The mineral assemblage consists of clinopyroxene, olivine, plagioclase (abundant in the granulites, but only a minor phase in the pyroxenites) and spinels. One pyroxenite contains abundant orthopyroxene, and no olivine. The xenoliths crystallised as cumulates from a mafic melt, and have subsequently been metamorphosed and recrystallised to varying degrees. Oxidation processes related to the host melts have also affected the xenolith suite, particularly the granulites.

Textural, mineral and geochemical features of the suite indicate that the xenoliths are genetically related. The crystallisation of xenoliths from varying melts has produced an evolved series of mineral phases (e.g. olivine from Fo 5584, plagioclase from An 42-88). The whole rock composition of the xenoliths is controlled by their cumulate assemblages, which has resulted in a mafic series of cumulates (e.g. 41-51 wt. \% $\mathrm{SiO}_{2}$; original $\mathrm{Mg} \# \mathrm{~S} 71-86 ;{ }^{87} \mathrm{Sr} /{ }^{86} \mathrm{Sr}$ 0.702688-0.704416). Trace element concentrations are low, except for elements that are present in mineral phases (e.g. up to $1683 \mathrm{ppm} \mathrm{Sr}$ in plagioclase rich granulites, and up to $3745 \mathrm{ppm} \mathrm{Cr}$ in clinopyroxene and $\mathrm{Cr}$-spinel rich pyroxenites). Xenoliths that crystallised from more evolved melts have generally higher trace element abundances. These characteristics indicate that the crystallising melt was a primitive mantle melt, and probably sub-alkaline in composition. Possible parental melts have not been detected at the surface. 


\subsection{Mount Murphy}

Mount Murphy (Figure 3.2; Plate 6.1), on the Walgreen coast of MBL $\left(75^{\circ}\right.$ $22^{\prime} \mathrm{S}, 110^{\circ} 40^{\prime} \mathrm{W}$ ), is a basalt-trachyte stratovolcano, that rises to a height of $2703 \mathrm{~m}$ asl. The main volcanic succession has been dated at c. 8-9 $\mathrm{Ma}$, however more recent volcanic episodes have also been recorded from Hedin Nunatak, dated at 6 Ma, and Sechrist Peak, dated at c. 0.5 Ma (Smellie et al., 1993).

The edifice is named after Robert Cushman Murphy, who studied the wildlife of South Georgia in the summer of 1912-13. The first description of the volcano was from aerial photographs taken in 1947, and the first visit was a helicopter-supported reconnaissance on January 6, 1968. A second visit of 4 days occurred in January, 1985 (Le Masurier 1990). The WAVE programme visited the edifice to collect volcanic and xenolith samples (detailed in this chapter) in late 1990, and the latest expedition to the region to date occurred in late 1992, by the South Pacific Rim International Tectonic Expedition (SPRITE), to collect samples of the basement previously identified by the WAVE expedition.

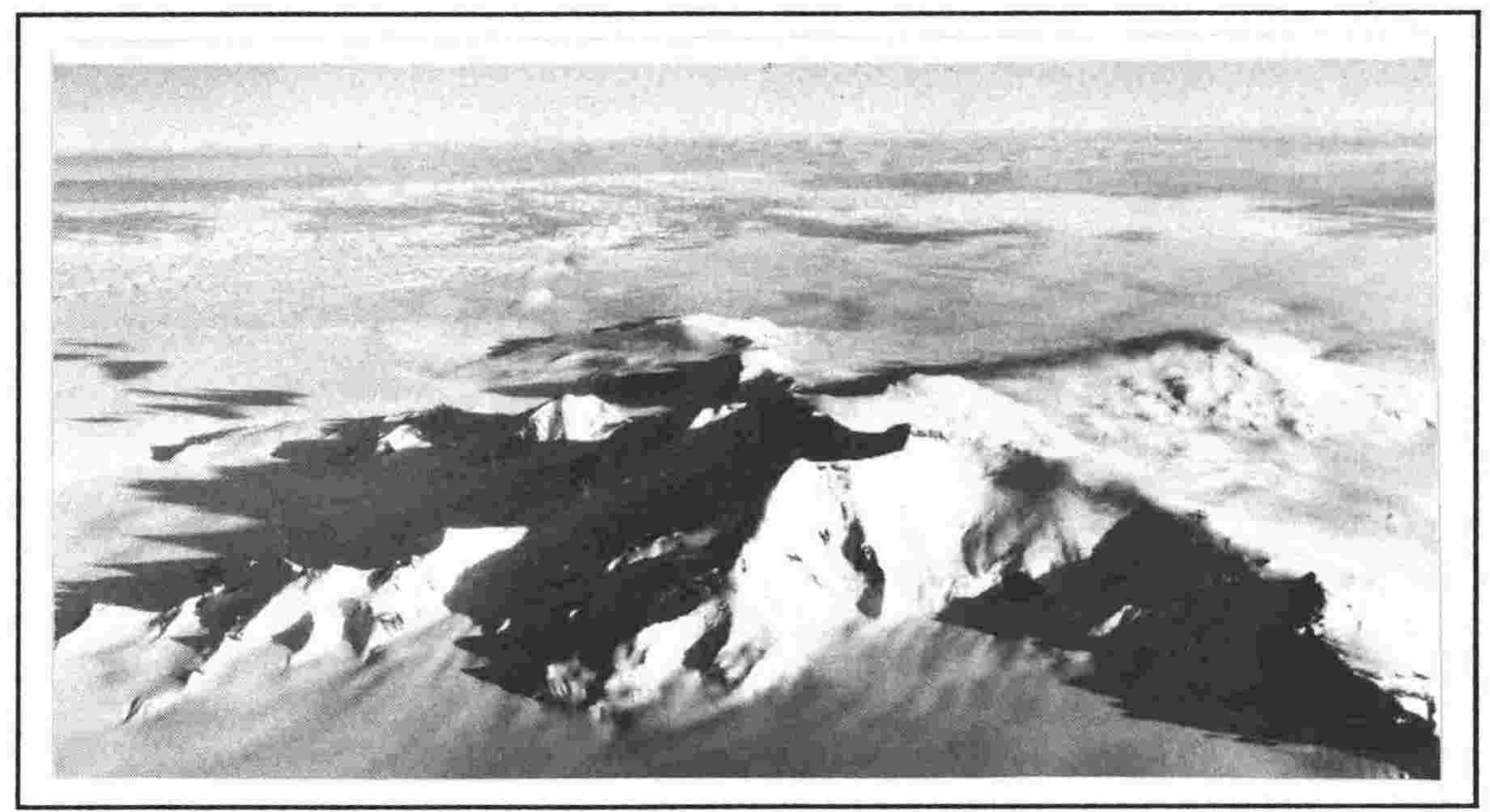

PLATE 6.1: View of Mount Murphy looking east-northeast, from a distance of $20 \mathrm{~km}$ (from Le Masurier, 1990; U.S. Navy photograph TMA 1719 F31 133).The diameter of Mount Murphy at its base is approximately $30 \mathrm{~km}$, and its vertical relief if over $2 \mathrm{~km}$. Hedin Nunatak is in the left foreground, and Turtle Peak is in the right foreground.

Glaciation has deeply dissected the edifice, forming glacial valleys that have exposed large sections of the internal morphology of the volcano. A basal succession consisting of hypersthene-normative basalts and hawaiites can be seen overlain by trachytes and benmoreites (including one nepheline-normative 
trachyte), which comprise the upper levels of the structure above $1500 \mathrm{~m}$. This is interpreted to represent a small felsic cone built on top of a basaltic shield volcano (Le Masurier, 1990). Volcanic lithofacies associations indicate a complex interaction between volcanism and either ice sheets or sea level (Smellie et al., 1993).

Parasitic basaltic cinder cones are common on the southwest ridge of Mount Murphy. These are nepheline-normative, and differ from basal basalts, having higher $\mathrm{Mg}$-numbers and $\mathrm{Ni}$ contents. Basement contacts are also observable at the northwest of the structure. Prior to this study, ultramafic xenoliths had not been noted from the Mount Murphy region.

\subsection{The Xenolith Suite}

Xenoliths from Mount Murphy consist of plagioclase-rich granulites (the 'granulite suite'), Al-diopside pyroxenites (the 'pyroxenite suite', which are typical of Type II upper mantle xenoliths (Frey and Prinz, 1978)), and Cr-diopside peridotites (the 'peridotite suite', which are typical of Type I upper mantle xenoliths (Frey and Prinz, 1978)). The granulite and pyroxenite xenoliths are described in this chapter, and peridotite xenoliths are discussed in Chapter 7.2. Mineral and whole rock descriptions and analyses of the xenoliths, and the methods used in their preparation can be found in Wysoczanski (1993) and in the appropriate appendices of this thesis.

Only a small number of samples were collected, as part of a reconnaissance sampling programme. Unfortunately, adverse weather conditions prohibited the collection of more samples at a later date. Samples were collected from four sites (Chapter 3.3.2), consist of site 90041 (granulites), site 90044 (one pyroxenite), site 90048 (granulites and pyroxenites), and site 90054 (pyroxenites and peridotites).

The xenoliths are typically rounded to subrounded, and vary in size (up to $20 \mathrm{~cm}$ ), with the majority being hand-size. The rounded nature of the clasts is produced by milling of the xenoliths during ascent to the surface in the host melts. Cracks are visible in some samples that have developed during ascent, oxidising the freshly exposed faces to various degrees (the extent of oxidation presumably depending on the time of cracking since entrainment). Angular edges that have been rounded are also apparent. These are unlike cracked surfaces (being more rounded) and may represent brittle conditions in the source area. Whether this is due to lower crustal conditions or simply conduit conditions cannot be ascertained. 
Most xenoliths have rims of the entraining host basalt, and in many cases oxidised rims 1-2 mm thick have developed on the xenoliths. The granulite suite has been infiltrated by the host melt through cracks and along grain boundaries, however the pyroxenite suite has only rarely been infiltrated by the host magma. This process will be discussed in detail in Chapter 6.5.1.

Apart from oxidation due to the host magmas, the xenolith is suite is in pristine condition, with the cold dry Antarctic climate prohibiting any surface weathering. Only unoxidised samples were analysed for mineral and whole rock compositions, with oxidised rims being avoided.

\subsection{Petrography}

Xenoliths from Mount Murphy differ between xenolith types (granulites and pyroxenites) and between sites (granulites from sites 90041 and 90048 differ, and pyroxenites from sites 90044,90048 and 90054 differ). Modal abundances of mineral phases in the granulite and pyroxenite suites are presented in Table 6.1, and individual sample modes can be found in Appendix 2.3.

\begin{tabular}{lccc}
\hline Xenolith Type & Granulites & 44 Pyrox. Pyroxenites \\
\hline & & & \\
Olivine & $0.0-29.4$ & - & 11.226 .2 \\
Clinopyroxene & $3.6-30.6$ & 66.2 & $54.4-87.6$ \\
Orthopyroxene & - & 31.6 & - \\
Plagioclase & $54.6-83.4$ & - & $0.0-10.8$ \\
Kaersutite & $0.0-4.4$ & - & - \\
Opaques & $3.2-6.4$ & 2.2 & $1.2-8.8$ \\
Accessories & $0.8-1.4$ & - & $0.0-0.6$ \\
& & & \\
\hline
\end{tabular}

TABLE 6.1: Range of modal assemblages present in granulites and pyroxenites from Mount Murphy. Primary oxides are often difficult to distinguish from secondary oxides, and both generations are included together as 'opaques'. Note the presence of orthopyroxene as a major phase in only one pyroxenite (the only xenolith from site 90044).

The xenoliths generally consist of a single pyroxene (clinopyroxene), although minor amounts of orthopyroxene are also present, and one pyroxenite (sample 90044A; the only xenolith from this site) contains abundant orthopyroxene. The modal assemblage of the orthopyroxene-rich pyroxenite is also presented in Table 6.1. The extent of oxidation in some xenolith makes the identification of primary and secondary oxides difficult, and both are classified as 'opaques' in modal tables. Olivine that has been oxidised to secondary oxides are 
classified as olivine rather than oxides for the purposes of classification, to reflect the protolith prior to oxidation.

\subsubsection{The granulite suite}

Granulite xenoliths from Mount Murphy (Plates 6.2 and 6.3) are plagioclase rich, with subordinate amounts of clinopyroxene and olivine (generally 60-90\% plagioclase with the exception of one sample (90048C) which consists of only $30 \%$ plagioclase). Orthopyroxene is also present in some samples, occurring as small (100 $\mu \mathrm{m}$ scale) crystals on the rims of olivine, possibly as secondary reaction products. The majority of granulites are leucogabbros and olivine leucogabbros with some olivine gabbros, troctolites and one olivine melagabbro.

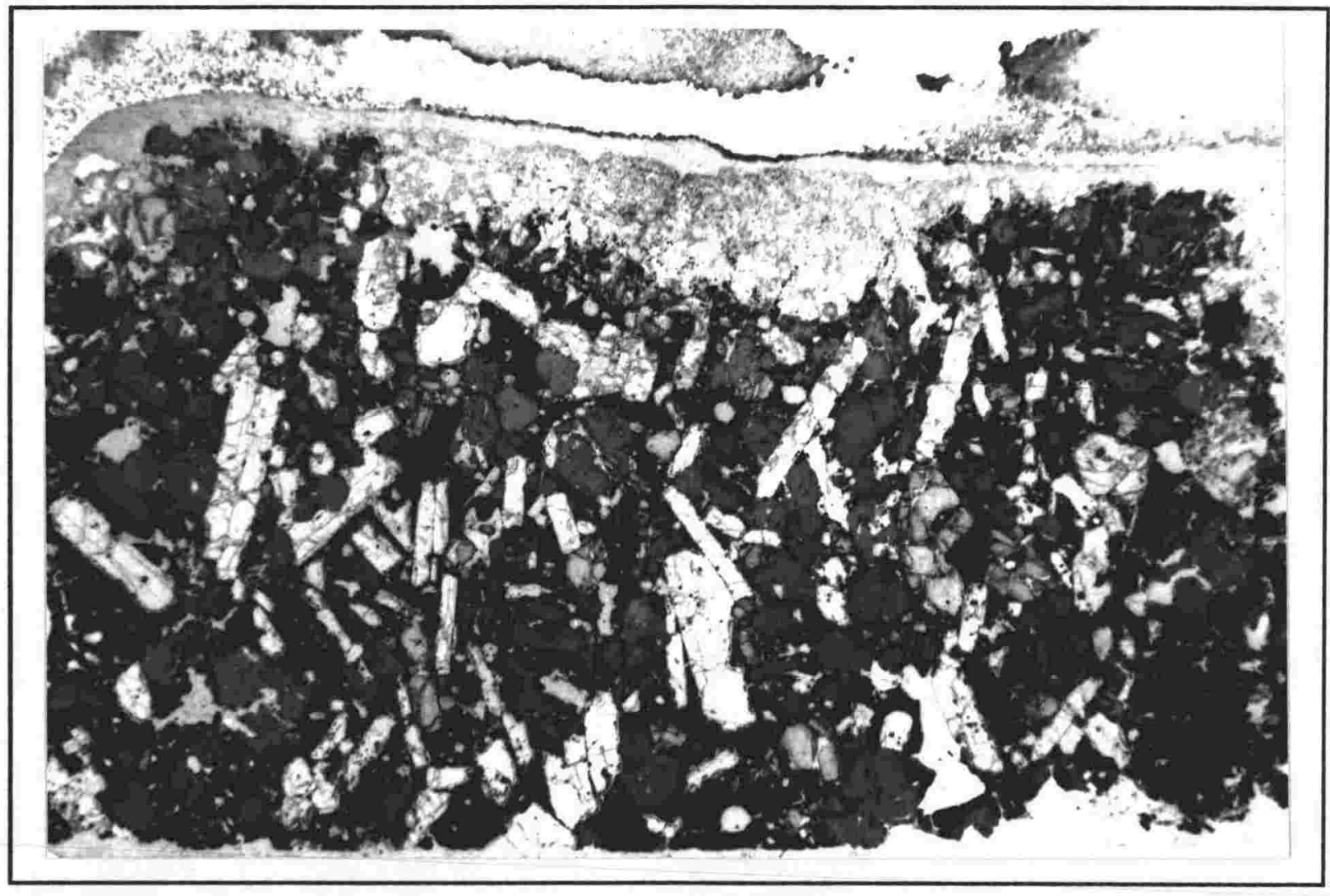

PLATE 6.2: Gabbroic granulite from site 90048 (sample 90048C), consisting of large crystals (many > 2 $\mathrm{mm}$ ) of euhedral plagioclase (p), olivine (ol), clinopyroxene (c) and Fe-Ti oxides (ox). A rim of host melt (b; bottom right) can be seen to extend only 1-2 mm into the xenolith. Width of plate is $17 \mathrm{~mm}$.

Textures of the granulite suite vary from igneous (gabbros, including cumulate gabbros) to metamorphic. Many igneous granulites (Plate 6.2) show metamorphic overprints (meta-igneous textures), and metamorphic granulites (Plate 6.3) show relict igneous textures (e.g. inclusions, euhedral outlines of crystal phases, and remnant oscillatory zoning in plagioclase), indicating a gradation 
from protolith igneous textures to recrystallised metamorphic textures. Granulites from site 90048 (Plate 6.2) have retained their igneous textures, with only one sample showing signs of recrystallisation.

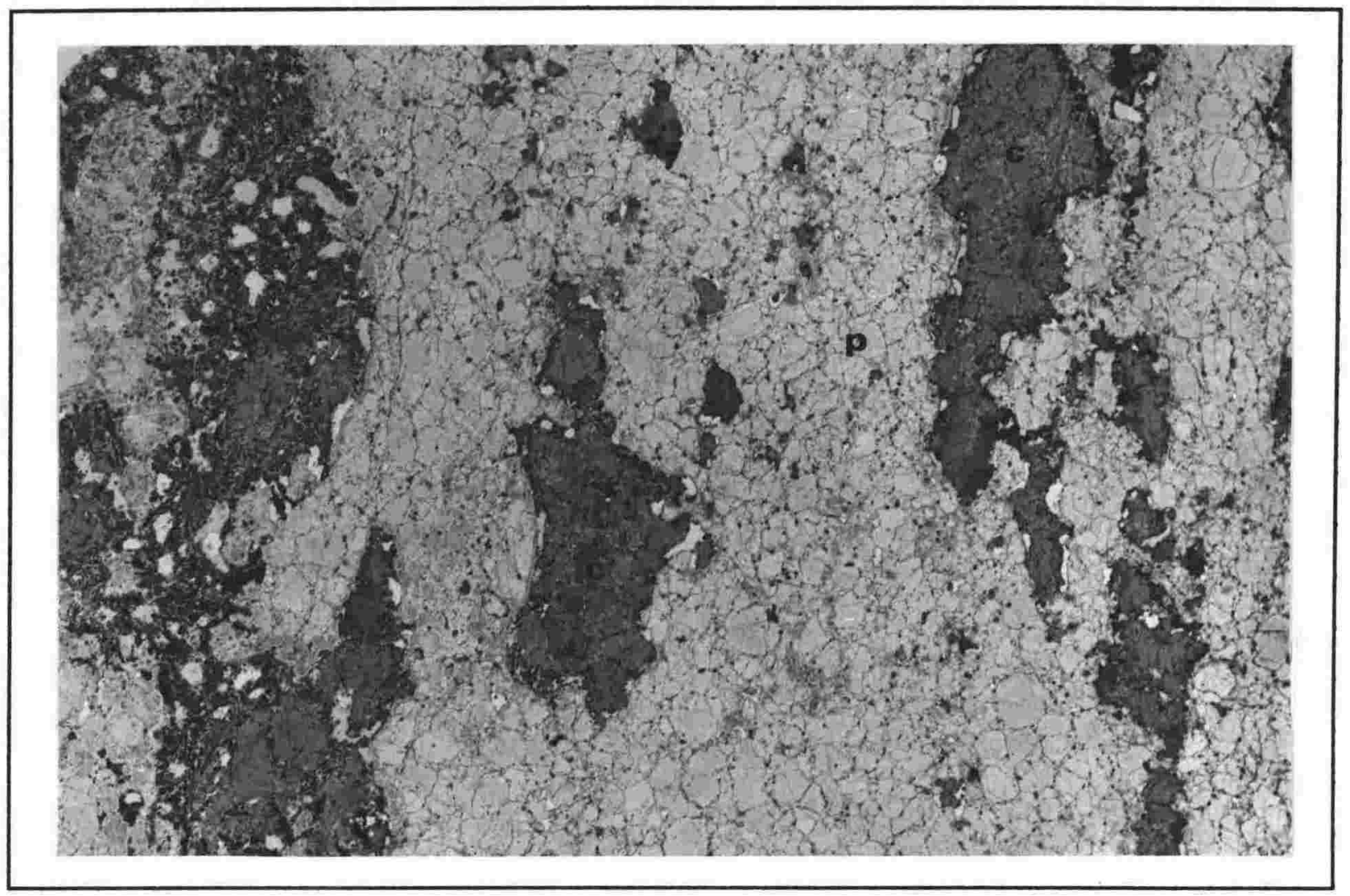

PLATE 6.3: Granulite from site 90041 (sample 90041C) with a recrystallised metamorphic texture of 1-2 mm size equant grains with $120^{\circ}$ triple junctions between many grains. Clusters of clinopyroxene (c) form flasers between plagioclase (p) layers resulting in a layered texture. Host melt has infiltrated the xenolith (left flaser), reacting with xenolith minerals. Width of plate is $17 \mathrm{~mm}$.

Plagioclase crystals are generally 1-2 $\mathrm{mm}$ in size, with some igneous crystals being up to $5 \mathrm{~mm}$ in size. Igneous plagioclase (Plate 6.2) is typically euhedral, displaying multiple twinning, with many showing oscillatory zoning, indicating growth from a melt under changing conditions. Many grains are broken, possibly indicating brittle deformation. Metamorphic plagioclase (Plate 6.3) consist of recrystallised granular grains generally $1-2 \mathrm{~mm}$ in size, typically displaying well developed $120^{\circ}$ triple-junctions with other recrystallised minerals. They are undeformed, suggesting recrystallisation after deformation of igneous plagioclase.

Olivine occurs as igneous crystals up to $5 \mathrm{~mm}$ in size (Plate 6.2), and as recrystallised grains with equant textures, approximately $1 \mathrm{~mm}$ in diameter. Igneous olivine occurs as euhedral grains to rounded anhedral grains around euhedral plagioclase and in interstices between plagioclase, indicating crystallisation from the melt after plagioclase. The rounded form of igneous 
olivine makes them difficult to distinguish from recrystallised granular olivine. Olivine in some samples has reacted to form orthopyroxene on their rims. This reaction may be due to a change in pressure, with the stability of orthopyroxene increasing, and olivine decreasing at 5-15 kb (O'Hara, 1968; Cox et al., 1979).

Clinopyroxene is the only other major mineral phase occurring as igneous grains up to $4 \mathrm{~mm}$ in size (Plate 6.2), and recrystallised equant grains $1-2 \mathrm{~mm}$ in size (Plate 6.3). Clinopyroxene occurs with olivine in interstices between euhedral plagioclase indicating crystallisation after plagioclase, and together with olivine. In some samples however, euhedral clinopyroxene occurs which preceded other mineral phases in crystallisation. In fully recrystallised granulites, clinopyroxene occurs with olivine as flasers amongst plagioclase layers, imparting a layered fabric on the granulites (Plate 6.3), which is in part inherited from igneous layering (Chapter 2.2.4).

Rare green Al-spinels (spinel series sensu stricto) also occur as primary phases, and coexisting Fe-Ti oxides of primary origin are present. Primary oxides are difficult to distinguish from secondary oxides which have formed as a result of oxidation of olivine, however small oxides occurring within other primary phases are undoubtedly primary in origin (Plate 6.2).

The host melt has infiltrated the granulite suite along grain boundaries and through cracks (Plate 6.3) causing disequilibrium reactions with granulite mineral phases. Widespread oxidation of olivine crystals has occurred, giving a rusted appearance to olivine crystals, highlighting their cleavage planes. The oxidation of olivine has in some samples resulted in the formation of olivine and $\mathrm{Fe}-\mathrm{Ti}$ oxide symplectites, ranging from small rims on olivine to the complete replacement of olivine by Fe-Ti oxides (Plate 6.2). Plagioclase grains in contact with the melt (and secondary oxide products) show disequilibrium relationships in the form of sieved rims, overgrown by narrow (10 $\mu \mathrm{m}$ scale) rims that crystallised from the melt. Clinopyroxene and orthopyroxene are not oxidised, maintaining a fresh appearance. In most samples the amount of infiltrated melt is small, with the exception of some samples from site 90048, which contain higher amounts of infiltrated host melt ( $\leq 5 \%)$.

\subsubsection{The pyroxenite suite}

Clinopyroxenites and olivine clinopyroxenites dominate the pyroxenite suite with lesser amounts of plagioclase-bearing clinopyroxenites, reflecting the simple mineral assemblage of clinopyroxene + olivine \pm plagioclase (Plates 6.4 and 6.5). Cumulate textures are often well preserved, although recrystallised 
equigranular metamorphic textures have overprinted cumulate textures of some samples.

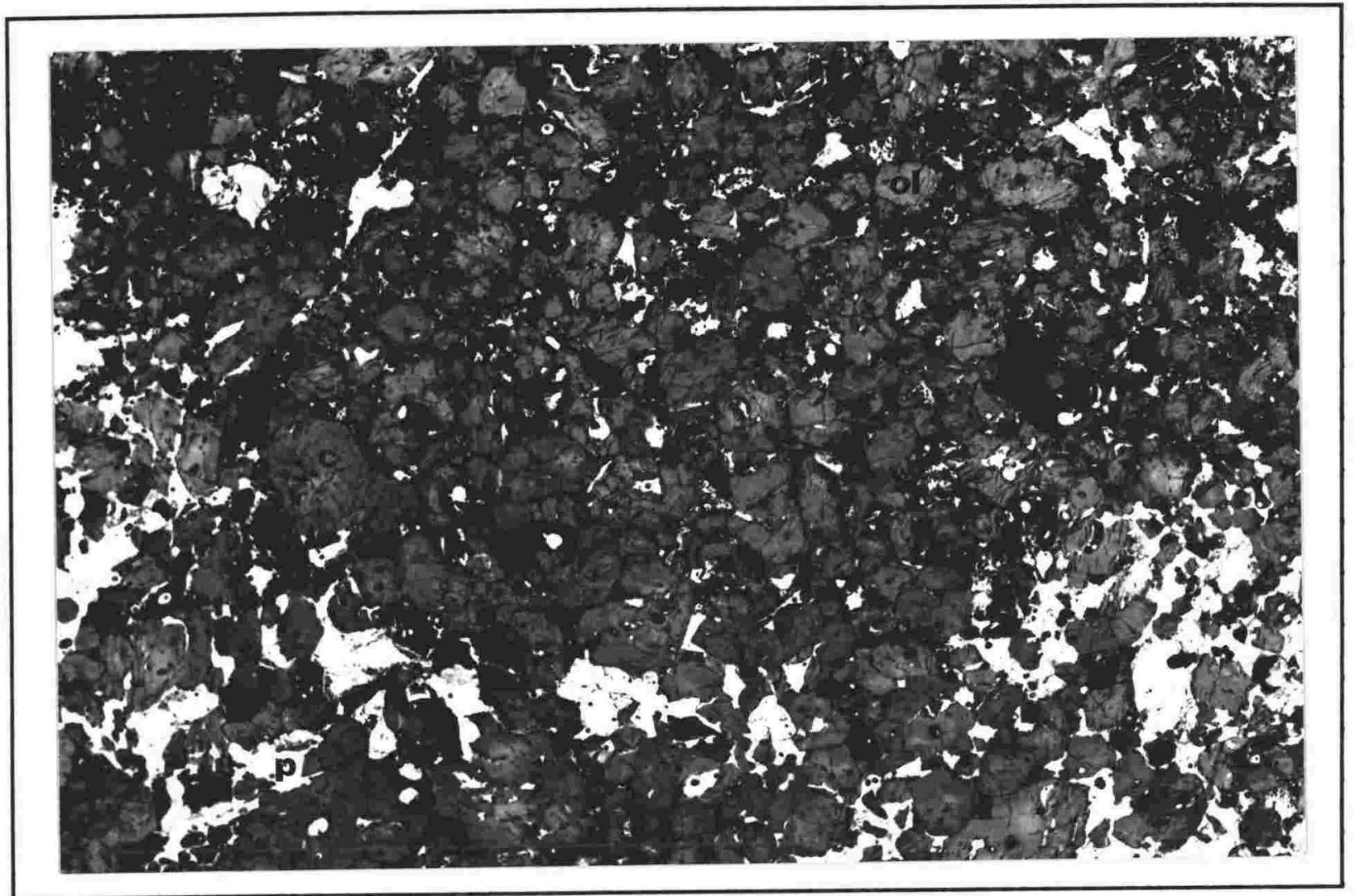

PLATE 6.4: Cumulus pyroxenite from site 90048 (sample 90048D), consisting of: subrounded olivine (ol), occurring as a cumulus phase; clinopyroxene (c), occurring as both a cumulus and an intercumulus phase; and plagioclase (p), occurring as an intercumulus phase, often as oikocrysts surrounding olivine and clinopyroxene. All phases are generally $1-2 \mathrm{~mm}$ in size, although plagioclase oikocrysts may be larger. Width of plate is $17 \mathrm{~mm}$.

Pyroxenites from different sites vary in texture and mineral assemblage. Pyroxenites from site 90048 (Plate 6.4) contain more plagioclase than those from site 90054 (Plate 6.5), and are generally less recrystallised. A single pyroxenite from site 90044 contains no olivine, but abundant orthopyroxene. This is the only xenolith from Mount Murphy that contains orthopyroxene as an abundant primary mineral phase.

Clinopyroxene occurs as large cumulus and intercumulus crystals up to 2 $\mathrm{cm}$ in size (Plate 6.5), with most between $2-5 \mathrm{~mm}$ in diameter (Plate 6.4). In some cases, recrystallisation has occurred with smaller grains crystallising from larger cumulus crystals, developing polygonal equant textures with $120^{\circ}$ triple junctions. A few clinopyroxene grains display simple twinning, and narrow orthopyroxene exsolution lamellae are evident in some clinopyroxenes (Plate 6.5), indicating 
equilibration to lower temperatures, possibly associated with uplift, or ascent to the surface.

Olivine is a minor phase relative to clinopyroxene (Table 6.1), occurring as rounded igneous grains up to $4 \mathrm{~mm}$ in size (Plates 6.4 and 6.5). Some have been recrystallised to small equant grains generally $1 \mathrm{~mm}$ in size. All are slightly to moderately oxidised with a rusty appearance, especially on their rims. The rounded euhedral appearance of olivine indicates that it crystallised before other phases, although some olivine may be intercumulus in origin.

Plagioclase occurs in some samples as oikocrysts from 1-5 mm in size enclosing clinopyroxene and olivine grains (Plate 6.4). Twinning is evident in some crystals. Unlike granulite plagioclase however, they do not show any signs of deformation.

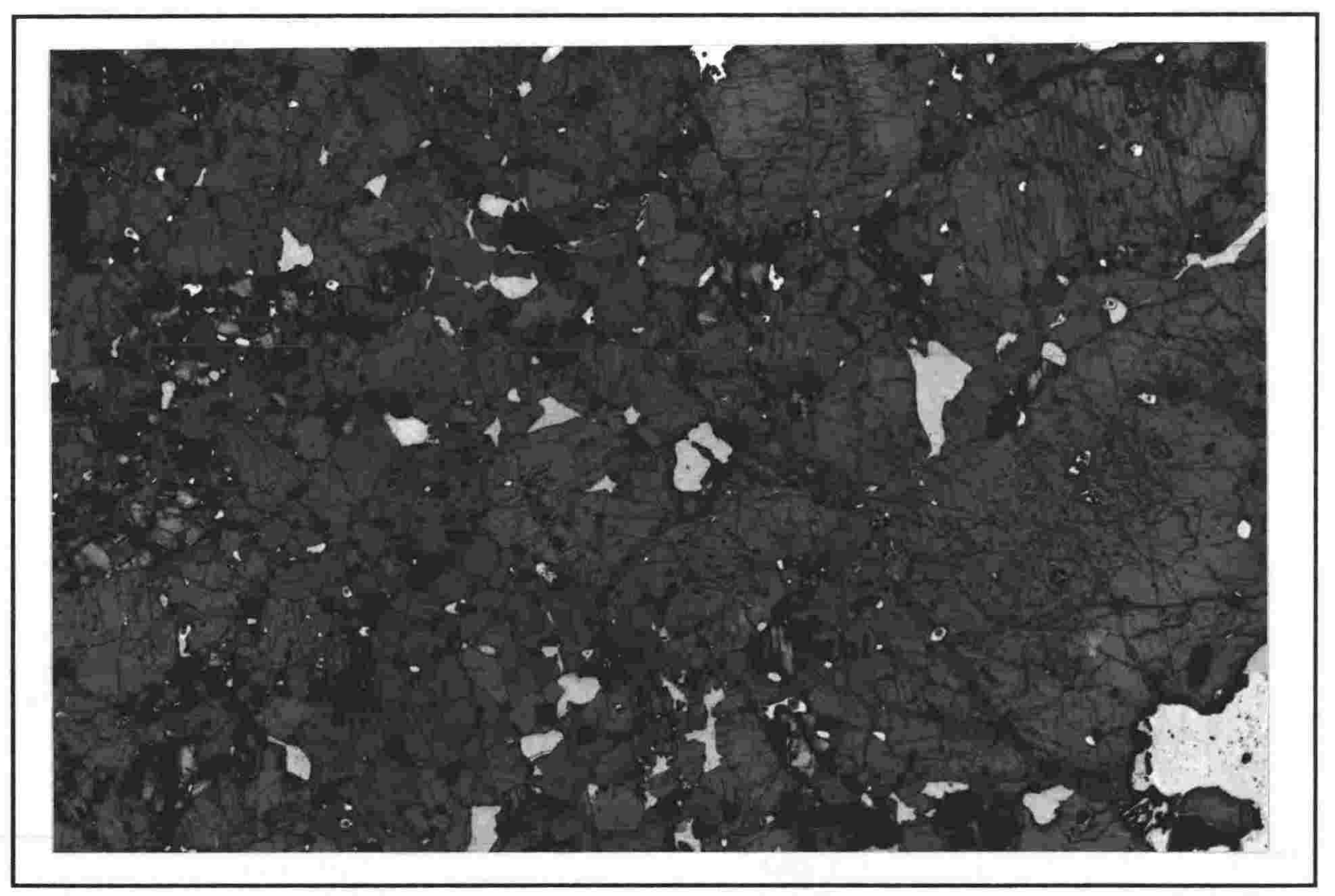

PLATE 6.5: Pyroxenite from site 90054 (sample 90054C) with a cumulate texture. Olivine occurs as subrounded grains (ol), surrounded by clinopyroxene (c), which occurs as rounded grains $1-2 \mathrm{~mm}$ in size, and as large oikocrysts up to $2 \mathrm{~cm}$ in size (right). Many clinopyroxenes, particularly large crystals, show fine orthopyroxene exsolutions. Plagioclase is rare in these xenoliths. Width of plate is $19 \mathrm{~mm}$.

Green to black Al-bearing spinels are abundant in pyroxenite xenoliths (Table 6.1), occurring as inclusions in other phases, and in interstices between other phases (Plate 6.5). Intercumulus Fe-Ti oxides range in size from sub-mm to 4 $\mathrm{mm}$ in diameter. The euhedral form of some Fe-Ti oxides, and widespread 
reaction rims in contact with clinopyroxene and plagioclase, suggests that these are secondary in nature and may be related to an infiltrating melt.

\subsubsection{Summary of textures and bearing on petrogenesis}

The lower crustal and upper mantle xenolith suite from Mount Murphy discussed in this chapter consists of granulites and pyroxenites, comprised of clinopyroxene \pm olivine \pm plagioclase. These samples have been collected from four sites, only one of which (site 90048) contains both granulites and pyroxenites, with the other sites containing only granulites (site 90041) or pyroxenites and peridotites (site 90054). A single pyroxenite collected from site 90044 consists of orthopyroxene + clinopyroxene.

Granulites vary in texture from igneous to metamorphic, with many granulites showing meta-igneous textures (igneous gabbros, that have been partially recrystallised). The range in textures indicate original igneous protoliths (gabbros and cumulate gabbros) that have undergone metamorphism to varying degrees. Granulites from site 90048 tend to be less recrystallised than those from site 90041 .

In contrast, the pyroxenites have preserved igneous cumulate textures, with only minor recrystallisation in the form of equant grains with $120^{\circ}$ triplejunction boundaries between grains. The majority of pyroxenites have not been metamorphosed to any degree.

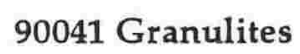

90048 Granulites

90048 Pyroxenites 90054 Pyroxenites
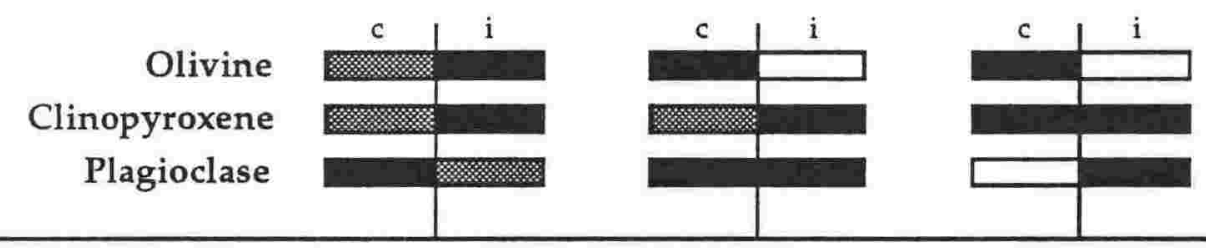

FIGURE 6.1: The presence of cumulus and intercumulus phases in the xenolith suite corresponds with their order of crystallisation. Black areas represent the presence of a phase, and white areas an absence of the phase, with shaded areas reflecting only minor occurrences of that mineral as a cumulus or intercumulus phase. A comparison of granulites and pyroxenites from different sites suggests that the occurrence of plagioclase as an early-formed mineral phase in the granulites is the major difference between the two suites. Note also the rarity of plagioclase in site 90054 pyroxenites, and the occurrence of olivine only as a cumulus phase in site 90048 granulites, and as dominantly an intercumulus phase in site 90041 granulites.

The identification of cumulus and intercumulus grains in the xenolith suites allows the order of crystallisation of mineral phases to be established (Figure 6.1). A comparison of granulites and pyroxenites from the three major sites indicates that olivine was the first formed mineral phase in the pyroxenite 
suite, followed by clinopyroxene. Plagioclase is rare (and is more abundant in site 90048 pyroxenites than in site 90054 pyroxenites), and only occurs as the last formed mineral phase. The order of crystallisation in the granulite suite is essentially reversed, with plagioclase forming first, followed by olivine and clinopyroxene. This suggests that the major difference between the granulite and pyroxenite suites is the occurrence of large abundances of plagioclase in the former due to its early crystallisation.

The occurrence of plagioclase as an initial crystallising phase indicates the differing conditions of crystallisation during granulite and pyroxenite crystallisation. This may be due to differences in composition of the fractionating melts that crystallised these cumulates, or in differences in P-T conditions, inferring different levels of formation in the lower crust.

a)

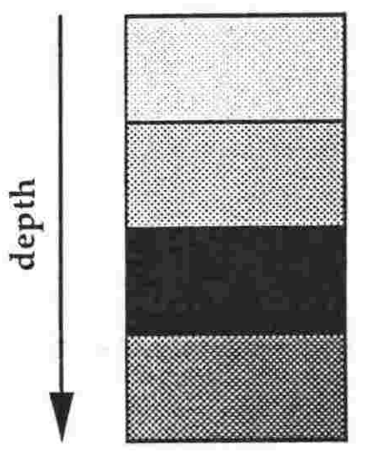

b)

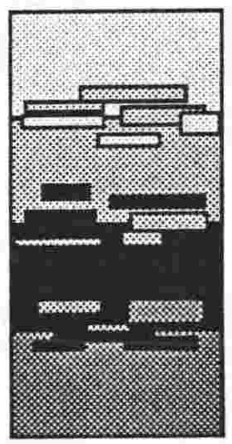

c)

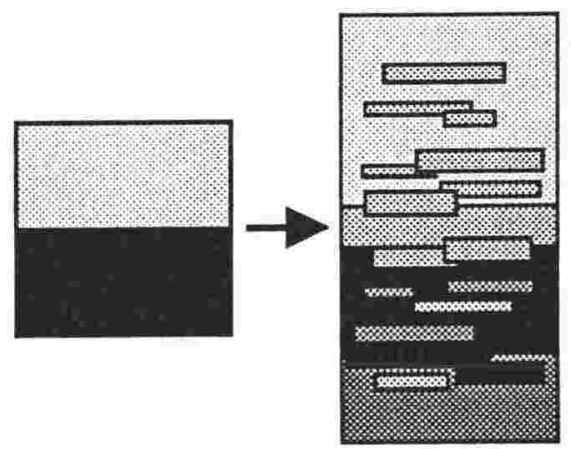

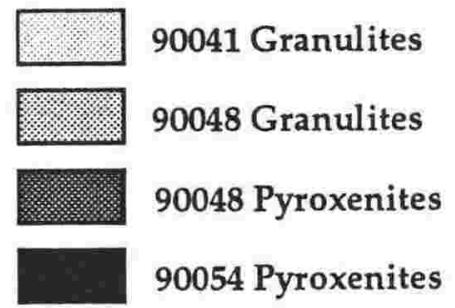

FIGURE 6.2: Simplified models of the lower crust can be established given the textural differences in the xenolith suite, and their occurrence at different sites. In particular, the occurrence of site 90048 granulites and pyroxenites together suggests they came from similar levels in the lower crust, and the occurrence of upper mantle peridotites with pyroxenites from site 90054 indicates that they came from lower levels in the crust near the Moho. Possible models include: a) a simple stratigraphy from site 90054 pyroxenites near the Moho to site 90041 granulites at higher levels; b) a variation of a), with some interlayering between xenolith types; c) the formation of the lower crust by multiple episodes with the initial crust being intruded by fractionating melts, resulting multiple periods of crustal growth. This last model is complex, and any variation on c) is possible.

The crystallisation of different xenolith types at different crustal levels is supported by the variation in recrystallisation and deformation that the xenolith 
types exhibit. Both processes are common in the granulite suite (especially those from site 90041), but are rare in the pyroxenite suite, indicating more pervasive recrystallisation and deformation at granulite source regions. Furthermore, xenolith types differ between sample sites only a few kilometres apart (Figure 3.2), suggesting that the host magmas sampled different levels of the lower crust and upper mantle. It is notable that only site 90048 contains both granulites and pyroxenites, whereas only site 90054 selected only peridotites (that are assumed to constitute the upper mantle). The presence of peridotites from this site suggests that the pyroxenites come from lower levels of the crust, near the Moho. The absence of pyroxenites at site 90041 suggests that a higher crustal level, containing only granulites, was sampled. Site 90048 xenoliths, consisting of both granulites and pyroxenites, may have been sourced from intermediate lower crustal levels.

From these inferences, a simplified model of the lower crust can be established, with site 90054 pyroxenites at the base, overlain by site 90048 pyroxenites and granulites, and site 90041 granulites at higher levels of the lower crust (Figure 6.2). Such a sequence could explain the variance of recrystallisation and deformation in the xenolith suite, which ranges from widespread in site 90041 granulites, to absent in site 90054 pyroxenites. Plagioclase abundance also decreases from the granulite suite to site 90054 pyroxenites. This corresponds with the change of olivine as an intercumulus phase in site 90041 (but not site 90048) granulites, to a cumulus phase in pyroxenites. Differing P-T conditions in different levels of the lower crust could be responsible for these changes.

The exact stratigraphy of the lower crust can not be ascertained by textures and occurrences alone, and several models are presented in Figure 6.2. The stratigraphy may be simple as mentioned above (Figure 6.2a), or slightly more complex, with an interlayering of xenolith types (Figure $6.2 \mathrm{~b}$ ), as is inferred to occur in many lower crustal localities (Griffin and O'Reilly, 1987a). Alternatively, the model may be complex, with the lower crust experiencing two or more periods of growth by melt fractionation. For example, site 90048 xenoliths may have formed from a different episode than the rest of the xenolith suite. Injection of the melts into a pre-existing lower crust comprised of site 90041 granulites underlain by site 90054 pyroxenites, could lead to the formation of site 90048 granulites and pyroxenites within the lower crust (Figure 6.2c). Any variation on this theme is possible, and an examination of mineral and whole rock geochemistry may help to determine the stratigraphy of the lower crust beneath Mount Murphy. 


\subsection{Mineral Chemistry}

Unaltered cores of xenolith mineral phases have been analysed by electron microscopy (Appendix 3.3) and are discussed here in order to characterise the chemistry of the mineral assemblage, and to establish if the granulite and pyroxenite types are genetically related. Minerals altered by secondary reactions (e.g. oxidation of olivine) or that have crystallised from the host melt are discussed in Chapter 6.5 (secondary mineral reactions).

\subsubsection{Olivine}

With the exception of one olivine-free pyroxenite (the only sample from site 90044), olivine is the major Ca-poor mafic mineral phase in the Mount Murphy xenolith suite. Olivine occurs as a late-stage mineral phase in the granulite suite (after plagioclase), and as an early-formed phase in the pyroxenite suite (Chapter 6.3). Representative compositions of olivine from the xenolith suite are presented as Table 6.2.

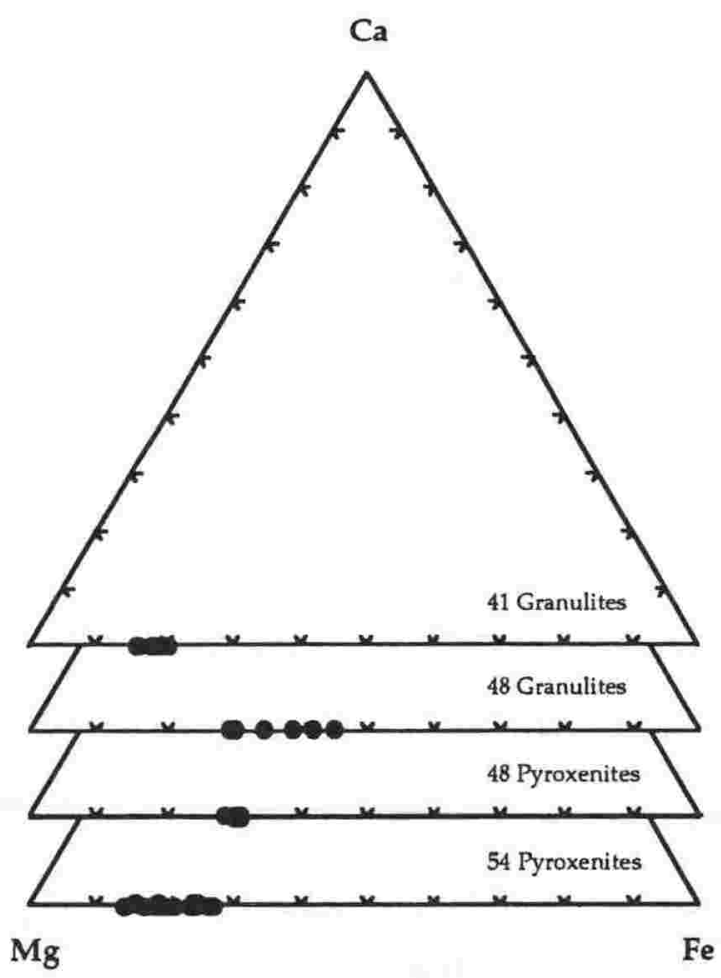

FIGURE 6.3: Composition of olivines in Mount Murphy xenoliths plotted in the system Ca-Mg-Fe. Site 90041 granulite olivines have the highest Fo $(\mathrm{Mg} / \mathrm{Mg}+\mathrm{Fe})$ contents, followed by site 90054 pyroxenites and site 90048 pyroxenites and granulites, indicating crystallisation from melts with lower Mg\#s.

Fo contents $\left(\mathrm{Fo}=\mathrm{Mg} / \mathrm{Mg}+\sum \mathrm{Fe} ; \sum \mathrm{Fe}=\right.$ all $\mathrm{Fe}$ measured as $\mathrm{Fe}^{2+}$ ) are similar between site 90041 granulite and site 90054 pyroxenite olivines (Figure 6.3), with a wider range of values in the latter (Fo 73-87 in the pyroxenite olivines compared to Fo 80-84 in the granulite olivines). The spread to lower Fo contents in pyroxenite olivines may reflect crystallisation from an evolving melt, whereas the 
small range in granulite olivines reflects crystallisation from a melt of stable composition during olivine crystallisation.

TABLE 6.2: Representative electron microprobe analyses of Mount Murphy xenolith olivines.

\begin{tabular}{lcccccccccc}
\hline SAMPLE & $90041 \mathrm{~B}$ & $90041 \mathrm{G}$ & $90041 \mathrm{I}$ & $90048 \mathrm{E}$ & $90048 \mathrm{~F}$ & $90048 \mathrm{~B}$ & $90048 \mathrm{D}$ & $90054 \mathrm{C}$ & $90054 \mathrm{I}$ & $90054 \mathrm{~K}$ \\
TYPE & Gran & Gran & Gran & Gran & Gran & Pyxite & Pyxite & Pyxite & Pyxite & Pyxite \\
\hline & & & & & & & & & & \\
$\mathrm{SiO} 2$ & 39.52 & 39.34 & 39.73 & 36.25 & 37.05 & 37.12 & 36.98 & 38.60 & 39.23 & 38.44 \\
$\mathrm{A12O3}$ & 0.01 & 0.02 & 0.08 & 0.01 & 0.07 & 0.06 & 0.06 & 0.15 & 0.05 & 0.06 \\
$\mathrm{TiO2}$ & 0.03 & 0.08 & 0.00 & 0.01 & 0.02 & 0.01 & 0.08 & 0.07 & 0.01 & 0.05 \\
$\mathrm{FeO}$ & 17.47 & 17.87 & 14.94 & 32.95 & 26.22 & 27.45 & 27.12 & 21.19 & 18.07 & 21.78 \\
$\mathrm{MnO}$ & 0.36 & 0.31 & 0.27 & 0.57 & 0.54 & 0.42 & 0.38 & 0.38 & 0.22 & 0.38 \\
$\mathrm{MgO}$ & 42.91 & 41.96 & 44.79 & 29.80 & 35.71 & 35.25 & 35.67 & 39.33 & 42.38 & 39.08 \\
$\mathrm{CaO}$ & 0.05 & 0.09 & 0.04 & 0.18 & 0.17 & 0.15 & 0.22 & 0.11 & 0.11 & 0.17 \\
$\mathrm{Na2O}$ & 0.08 & 0.12 & 0.04 & 0.00 & 0.00 & 0.04 & 0.04 & 0.00 & 0.00 & 0.01 \\
$\mathrm{~K} 2 \mathrm{O}$ & 0.01 & 0.02 & 0.03 & 0.00 & 0.00 & 0.04 & 0.01 & 0.04 & 0.01 & 0.00 \\
$\mathrm{Cr} 2 \mathrm{O} 3$ & & 0.07 & 0.11 & & 0.05 & 0.21 & 0.04 & 0.15 & 0.05 & 0.00 \\
& & & & & & & & & & \\
\hline TOTAL & $\mathbf{1 0 0 . 4 5}$ & 99.87 & $\mathbf{1 0 0 . 0 1}$ & 99.77 & 99.83 & $\mathbf{1 0 0 . 7 5}$ & 100.60 & $\mathbf{1 0 0 . 0 2}$ & $\mathbf{1 0 0 . 1 3}$ & 99.97 \\
\hline
\end{tabular}

cations on the basis of 4 oxygens

\begin{tabular}{lllllllllll}
$\mathrm{Si}$ & 0.998 & 1.002 & 0.997 & 0.998 & 0.987 & 0.989 & 0.982 & 0.998 & 0.998 & 0.997 \\
$\mathrm{Al}$ & 0.000 & 0.000 & 0.002 & 0.000 & 0.002 & 0.001 & 0.002 & 0.004 & 0.001 & 0.002 \\
$\mathrm{Ti}$ & 0.000 & 0.001 & 0.000 & 0.000 & 0.000 & 0.000 & 0.002 & 0.001 & 0.000 & 0.001 \\
$\mathrm{Fe}$ & 0.369 & 0.380 & 0.313 & 0.759 & 0.584 & 0.611 & 0.602 & 0.458 & 0.384 & 0.472 \\
$\mathrm{Mn}$ & 0.007 & 0.006 & 0.005 & 0.013 & 0.012 & 0.009 & 0.008 & 0.008 & 0.004 & 0.008 \\
$\mathrm{Mg}$ & 1.615 & 1.593 & 1.676 & 1.223 & 1.418 & 1.378 & 1.411 & 1.515 & 1.607 & 1.510 \\
$\mathrm{Ca}$ & 0.001 & 0.002 & 0.000 & 0.005 & 0.005 & 0.004 & 0.006 & 0.003 & 0.002 & 0.004 \\
$\mathrm{Na}$ & 0.003 & 0.005 & 0.001 & 0.000 & 0.000 & 0.002 & 0.002 & 0.000 & 0.000 & 0.000 \\
$\mathrm{~K}$ & 0.000 & 0.000 & 0.000 & 0.000 & 0.000 & 0.001 & 0.000 & 0.001 & 0.000 & 0.000 \\
$\mathrm{Cr}$ & & 0.001 & 0.002 & & 0.001 & 0.004 & 0.001 & 0.003 & 0.001 & 0.000 \\
& & & & & & & & & & \\
\hline TOTAL & 2.993 & 2.990 & 2.996 & 2.998 & 3.009 & 2.999 & 3.016 & 2.991 & 2.997 & 2.994 \\
\hline & & & & & & & & & & \\
Mg\# & 81.40 & 80.74 & 84.26 & 61.71 & 70.83 & 69.28 & 70.09 & 76.79 & 80.71 & 76.19 \\
& & & & & & & & & & \\
\hline
\end{tabular}

Granulite and pyroxenite olivines from site 90048 have lower Fo contents than other granulites and pyroxenites, reflecting crystallisation from a more evolved (lower Mg:Fe ratio) melt. In particular, granulite olivines from site 90048 have very low Fo contents (Fo 55-71), an indication that the composition of the melt that crystallised them was different from the melt that crystallised olivines from site 90041 granulites.

Calcium contents of olivine (Figure 6.4) are lower in granulite olivines (< 0.1 wt. \% $\mathrm{CaO})$ than in pyroxenite olivines $(0.06-0.24$ wt. \% $\mathrm{CaO})$, and olivines 
from site 90048 xenoliths have the highest $\mathrm{CaO}$ contents $(0.15-0.44$ wt. \% $\mathrm{CaO})$. The affects of melt composition on olivine $\mathrm{CaO}$ content is poorly understood, with higher $\mathrm{CaO}$ contents in olivine possibly reflecting higher $\mathrm{CaO}$ contents in the crystallising melt. $\mathrm{CaO}$ contents of olivine have been shown to correlate with pressures of crystallisation (Simkin and Smith, 1970; Stormer, 1973; Finnerty and Boyd, 1978), indicating that olivines from different xenoliths formed at different depths, with site 90041 granulite olivines having formed at the highest pressures. However, lower pressures have been recorded by site 90041 granulites compared to other xenoliths (Chapter 6.4.2), indicating that low $\mathrm{CaO}$ contents of site 90041 olivine has not resulted from their crystallisation at higher pressures. The composition of the crystallising melt was more likely to have been responsible for the $\mathrm{CaO}$ contents of olivine in the xenolith suite.

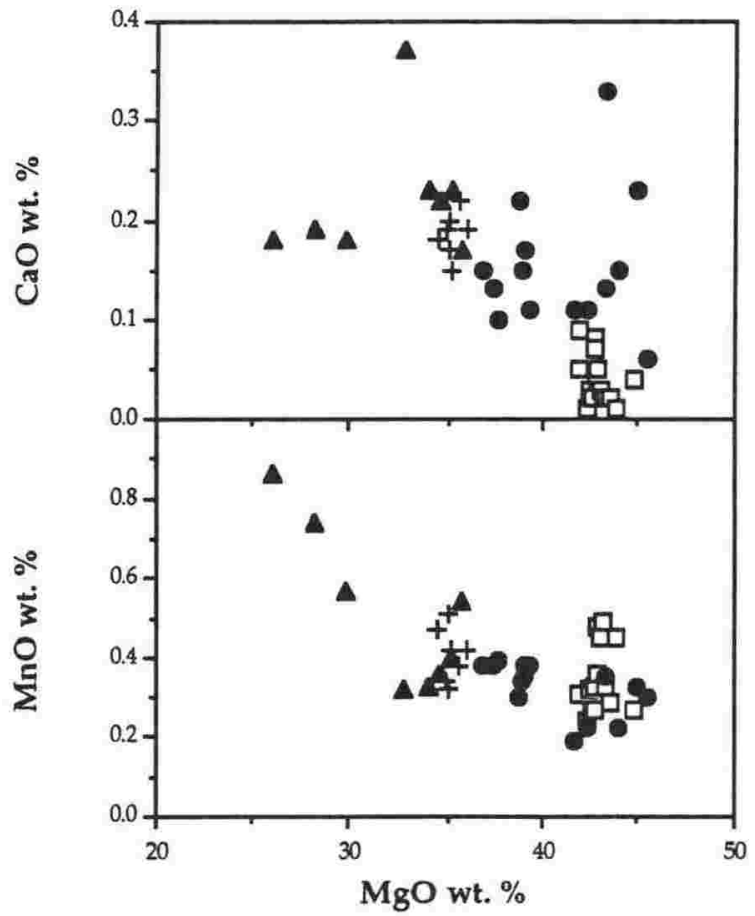

FIGURE 6.4: Plots of $\mathrm{CaO}$ and $\mathrm{MnO}$ against $\mathrm{MgO}$ for olivines from the Mount Murphy xenolith suite, by xenolith type and site. $\mathrm{CaO}$ contents of olivine are lowest in site 90041 granulites, and highest in site 90048 xenoliths. $\mathrm{MnO}$ contents are similar in the xenolith suite, and define an increasing trend with decreasing $\mathrm{MgO}$ content, which represent a fractionation trend (Simkin and Smith, 1970). Compositions of site 90048 granulite and pyroxenite olivines are similar.

D 41 Granulites

48 Granulites

+48 Pyroxenites

- 54 Pyroxenites

Manganese content in olivine (Figure 6.4) is dependant on fractionation (Simkin and Smith, 1970; Dodd, 1973), with increasing MnO content and decreasing $\mathrm{MgO}$ content. High $\mathrm{MnO}$ and low $\mathrm{MgO}$ contents of site 90048 olivines is a further indication that these olivines crystallised from a more fractionated melt than other olivines. Other elements, such as $\mathrm{Al}, \mathrm{Ti}, \mathrm{Na}, \mathrm{K}, \mathrm{Cr}$ and $\mathrm{Ni}$, have only been detected in olivine in minor amounts ( $<0.03$ cations per 4 oxygens).

\subsubsection{Clinopyroxene}

The majority of clinopyroxenes from the Mount Murphy xenolith suite are aluminian diopsides. Rare diopsides and sub-silicic aluminian diopsides also 
TABLE 6.3: Representative electron microprobe analyses of Mount Murphy xenolith clinopyroxenes.

\begin{tabular}{lcccccccccc}
\hline SAMPLE & $90041 G$ & 90041I & 90044A & 90044A & 90048E & 90048G & 90048B & 90048D & 90054C & 90054K \\
TYPE & Gran & Gran & Pyxite & Pyxite & Gran & Gran & Pyxite & Pyxite & Pyxite & Pyxite \\
\hline & & & & & & & & & & \\
$\mathrm{SiO2}$ & 51.75 & 48.49 & 51.17 & 53.16 & 48.67 & 49.99 & 49.22 & 47.44 & 49.19 & 47.46 \\
$\mathrm{Al2O}$ & 3.98 & 7.01 & 6.68 & 5.25 & 7.04 & 2.49 & 7.25 & 7.91 & 6.85 & 8.36 \\
$\mathrm{TiO2}$ & 0.94 & 1.63 & 0.81 & 0.19 & 1.84 & 0.50 & 1.59 & 2.36 & 0.86 & 2.05 \\
$\mathrm{FeO}$ & 4.70 & 3.89 & 4.55 & 9.65 & 8.91 & 10.54 & 7.69 & 7.97 & 6.50 & 7.51 \\
$\mathrm{MnO}$ & 0.11 & 0.10 & 0.27 & 0.29 & 0.21 & 0.59 & 0.25 & 0.24 & 0.17 & 0.22 \\
$\mathrm{MgO}$ & 14.83 & 15.14 & 14.67 & 29.49 & 11.93 & 13.24 & 12.48 & 12.02 & 14.83 & 12.43 \\
$\mathrm{CaO}$ & 22.55 & 22.39 & 20.53 & 0.92 & 20.57 & 21.59 & 20.57 & 21.08 & 21.23 & 20.54 \\
$\mathrm{Na2O}$ & 0.69 & 0.59 & 1.06 & 0.12 & 0.83 & 0.69 & 1.10 & 0.98 & 0.43 & 0.99 \\
$\mathrm{K2O}$ & 0.01 & 0.04 & 0.01 & 0.03 & 0.02 & 0.01 & 0.02 & 0.08 & 0.02 & 0.00 \\
$\mathrm{Cr2O3}$ & 0.49 & 0.79 & 0.59 & 0.28 & 0.05 & 0.30 & 0.72 & 0.13 & 0.30 & 0.17 \\
& & & & & & & & & & \\
\hline Fe2O3* & 0.74 & 3.36 & 0.37 & 0.65 & 0.09 & 6.07 & 1.63 & 2.63 & 3.06 & 2.63 \\
FeO* & 4.04 & 0.87 & 4.21 & 9.06 & 8.10 & 5.08 & 6.22 & 5.14 & 3.75 & 5.14 \\
\hline & & & & & & & & & & \\
\hline TOTAL & $\mathbf{1 0 0 . 0 4}$ & $\mathbf{1 0 0 . 0 7}$ & $\mathbf{1 0 0 . 3 3}$ & $\mathbf{9 9 . 3 6}$ & $\mathbf{1 0 0 . 0 6}$ & $\mathbf{9 9 . 9 4}$ & $\mathbf{1 0 0 . 8 9}$ & $\mathbf{1 0 0 . 2 1}$ & $\mathbf{1 0 0 . 3 8}$ & $\mathbf{9 9 . 7 4}$ \\
\hline
\end{tabular}

cations on the basis of 6 oxygens

\begin{tabular}{lllllllllll} 
Si & 1.901 & 1.783 & 1.860 & 1.880 & 1.815 & 1.894 & 1.813 & 1.768 & 1.812 & 1.768 \\
AlIV & 0.100 & 0.220 & 0.140 & 0.120 & 0.180 & 0.110 & 0.190 & 0.230 & 0.190 & 0.230 \\
AlVI & 0.069 & 0.080 & 0.150 & 0.100 & 0.130 & 0.000 & 0.124 & 0.117 & 0.104 & 0.137 \\
Ti & 0.025 & 0.044 & 0.021 & 0.005 & 0.050 & 0.014 & 0.044 & 0.066 & 0.024 & 0.057 \\
FeIII & 0.020 & 0.096 & 0.010 & 0.017 & 0.025 & 0.171 & 0.045 & 0.071 & 0.064 & 0.073 \\
FeII & 0.124 & 0.026 & 0.128 & 0.268 & 0.252 & 0.159 & 0.191 & 0.177 & 0.115 & 0.159 \\
Mn & 0.003 & 0.002 & 0.008 & 0.008 & 0.007 & 0.019 & 0.007 & 0.008 & 0.005 & 0.006 \\
Mg & 0.811 & 0.829 & 0.794 & 1.554 & 0.663 & 0.747 & 0.685 & 0.668 & 0.813 & 0.690 \\
Ca & 0.887 & 0.881 & 0.799 & 0.034 & 0.822 & 0.876 & 0.811 & 0.842 & 0.837 & 0.819 \\
Na & 0.047 & 0.040 & 0.074 & 0.008 & 0.061 & 0.050 & 0.078 & 0.069 & 0.030 & 0.071 \\
K & 0.000 & 0.001 & 0.000 & 0.001 & 0.001 & 0.001 & 0.001 & 0.003 & 0.001 & 0.000 \\
Cr & 0.013 & 0.022 & 0.016 & 0.007 & 0.001 & 0.009 & 0.020 & 0.004 & 0.009 & 0.005 \\
& & & & & & & & & & \\
\hline TOTAL & 4.000 & 4.024 & 4.000 & 4.002 & 4.007 & 4.050 & 4.009 & 4.023 & 4.004 & 4.015 \\
\hline & & & & & & & & & & \\
Wo & 48.15 & 48.09 & 46.16 & 1.82 & 46.65 & 44.85 & 46.82 & 47.90 & 45.76 & 47.04 \\
En & 44.03 & 45.25 & 45.87 & 82.97 & 37.63 & 38.25 & 39.55 & 38.00 & 44.45 & 39.63 \\
Fs & 7.82 & 6.66 & 7.97 & 15.22 & 15.72 & 16.90 & 13.63 & 14.11 & 9.79 & 13.33 \\
& & & & & & & & & & \\
Q & 1.82 & 1.74 & 1.72 & 1.86 & 1.74 & 1.78 & 1.69 & 1.69 & 1.77 & 1.67 \\
J & 0.09 & 0.08 & 0.15 & 0.02 & 0.12 & 0.10 & 0.16 & 0.14 & 0.06 & 0.14 \\
& & & & & & & & & & \\
\hline
\end{tabular}

* Recalculated assuming stoichiometry based on 4.0 cations 
occur in the granulite suite, and many clinopyroxenes from site 90048 xenoliths are sub-silicic aluminian diopsides. Representative clinopyroxene compositions from the Mount Murphy xenolith suite are presented as Table 6.3.

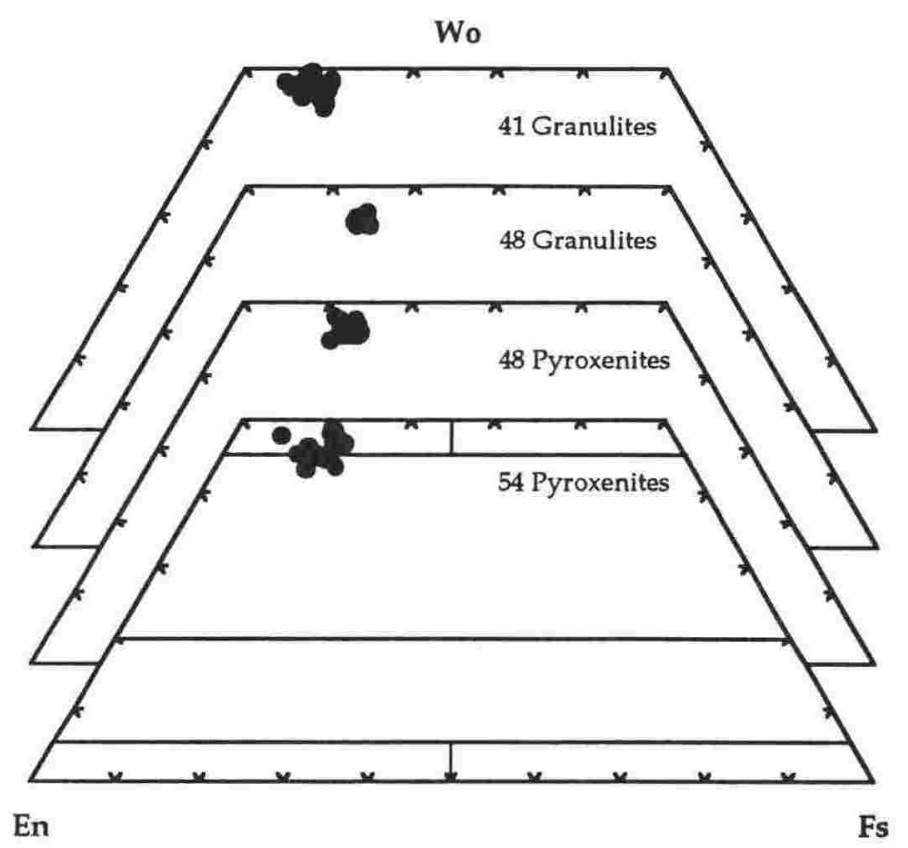

FIGURE 6.5: Composition of clinopyroxenes from the Mount Murphy xenolith suite in the system WoEn-Fs (fields are those of Morimoto et al., 1988). Granulites from site 90041, and pyroxenites from site 90054 are more En-rich than those from site 90048.

Clinopyroxenes from site 90048 are less calcic and more Fe-rich than other clinopyroxenes (Figure 6.5). A plot of Wo v Fs (Figure 6.6) highlights the differences between clinopyroxenes from different xenolith types, especially the composition of site 90048 clinopyroxenes compared to other clinopyroxenes.

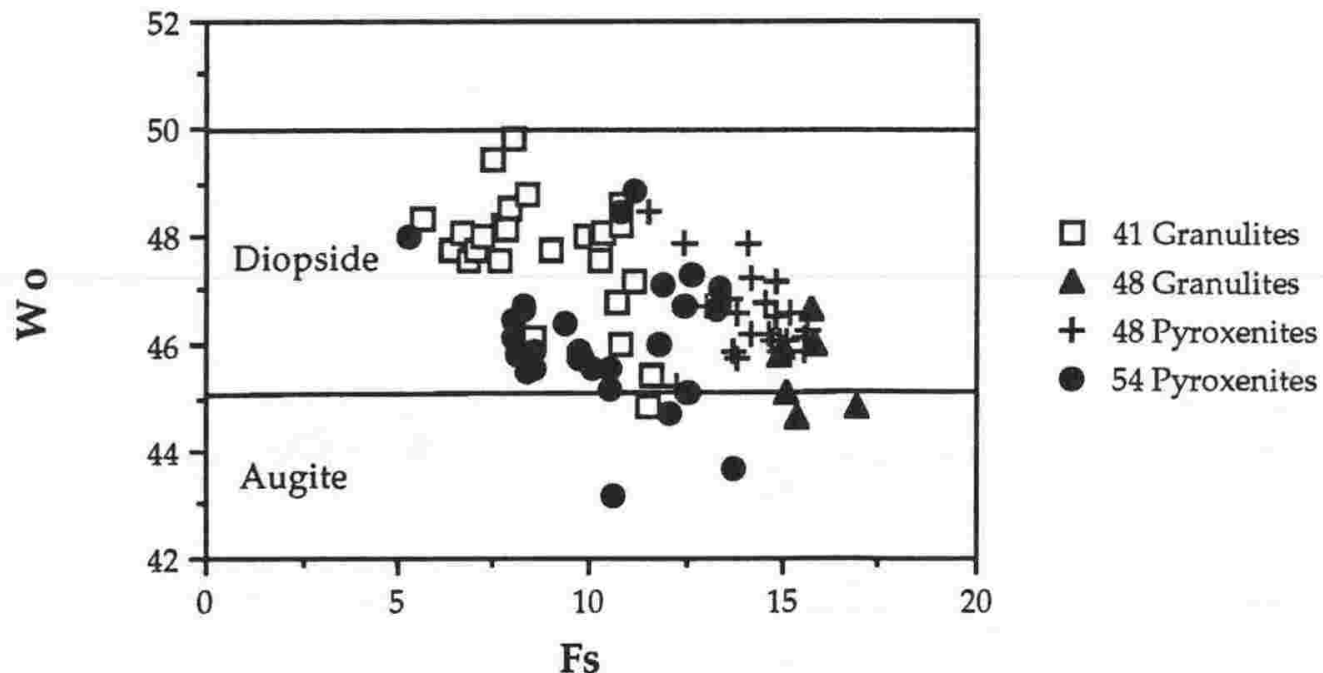

FIGURE 6.6: Fs v Wo binary diagram of clinopyroxenes, based on the quadrilateral diagram of Morimoto et al., 1988. The similar compositions of clinopyroxenes from site 90041 granulites and site 90054 pyroxenites is emphasised, as is the more Fe-rich and Ca-poor composition of site 90048 xenoliths, especially in the granulites. 
'J' components (Chapter 2.3.1) of clinopyroxenes from the xenolith suite range from 0.04 to 0.20 . Site 90048 granulites have a higher 'J' component than other granulites ( 0.12 to 0.17 compared with 0.06 to 0.12 ) and site 90048 pyroxenites have a more restricted range of 'J' component than other pyroxenites $(0.14$ to 0.17 compared with 0.06 to 0.20 ). These contents reflect the presence of $\mathrm{Na}$ in the $\mathrm{M}(2)$ octahedral site (as 'J' $=2 \mathrm{Na}$ ), which ranges from 0.41 to $1.33 \mathrm{wt}$. $\% \mathrm{Na}_{2} \mathrm{O}$.

$\mathrm{Si}^{4+}$ is not present in sufficient quantities to entirely fill the tetrahedral site, and remaining sites are filled by $\mathrm{Al}^{3+}\left(\mathrm{Al}^{\mathrm{IV}}\right)$. Remaining $\mathrm{Al}$ occupies the $\mathrm{M}(1)$ octahedral sites $\left(\mathrm{Al}^{\mathrm{VI}}\right)$. The partitioning of $\mathrm{Al}^{3+}$ into two sites creates a charge imbalance which is negated by the presence of $\mathrm{Ti}^{3+}$ in the $\mathrm{M}(1)$ octahedral site. The effect of the coupled substitution;

$$
\mathrm{M}(2)^{2+} \mathrm{M}(1)^{2+} \mathrm{Si}^{4+}{ }_{2} \mathrm{O}_{6} \rightarrow \mathrm{M}(2)^{2+} \mathrm{Ti}^{4+} \mathrm{Al}^{3+}{ }_{2} \mathrm{O}_{6}
$$

can be seen in the positive linear trend of the plot $\mathrm{Al}^{\mathrm{IV}} \mathrm{v} \mathrm{Ti}$, indicating the codependence of the two, compared to $\mathrm{Al}^{\mathrm{VI}} \mathrm{v} \mathrm{Ti}$, which shows no relationship (Figure 6.7). the partitioning of $\mathrm{Al}$ into two sites can be used to distinguish between clinopyroxenes of differing origins, and Mount Murphy clinopyroxenes fall largely within the field of 'basalts with granulites and inclusions' (Figure 6.8), indicating their equilibration to lower crustal conditions (Aoki and Shiba, 1973; Wass, 1979).

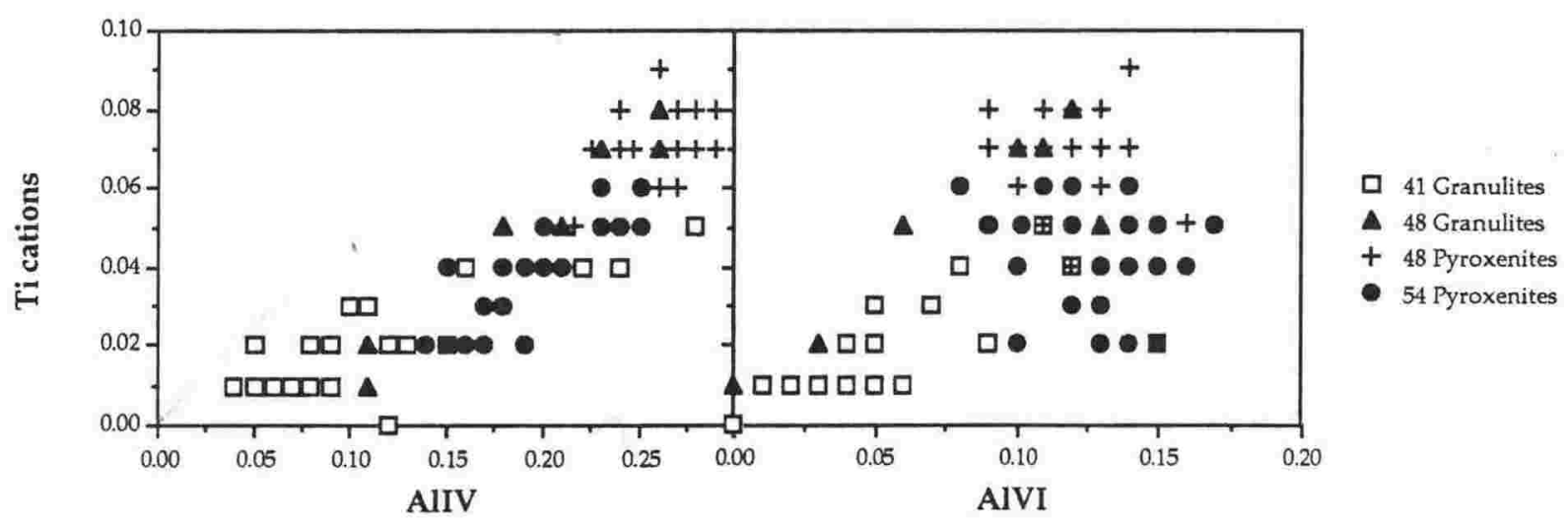

FIGURE 6.7: a) $\mathrm{Ti} v$ tetrahedral $\mathrm{Al}\left(\mathrm{Al}^{\mathrm{IV}}\right)$ defines a positive linear trend, reflecting the coupled substitution of $\mathrm{Al}$ for $\mathrm{Si}$ in the tetrahedral site, and the corresponding substitution of $\mathrm{Ti}$ into the $\mathrm{M}(1)$ octahedral site to restore the resulting charge imbalance. b) There is no trend between $\mathrm{Ti}$ and octahedral $\mathrm{Al}\left(\mathrm{Al}^{\mathrm{VI}}\right)$, as abundances of the two are not linked.

The lower $\mathrm{Al}_{2} \mathrm{O}_{3}$ contents of some granulite clinopyroxenes compared to pyroxenite clinopyroxenes can be ascribed to their crystallisation from a melt previously depleted in $\mathrm{Al}_{2} \mathrm{O}_{3}$ by plagioclase fractionation. Where clinopyroxenes crystallised prior to plagioclase (i.e. all pyroxenite, and most site 90048 granulite 
clinopyroxenes), the higher $\mathrm{Al}_{2} \mathrm{O}_{3}$ content of the undepleted melt is reflected in higher $\mathrm{Al}_{2} \mathrm{O}_{3}$ contents of the clinopyroxenes. This is similar to pyroxenes from Mounts Sidley and Hampton, which also reflect crystallisation from the melt either prior to or after plagioclase by their respective high or low $\mathrm{Al}_{2} \mathrm{O}_{3}$ contents (Chapters 4.4.2 and 5.4.1).

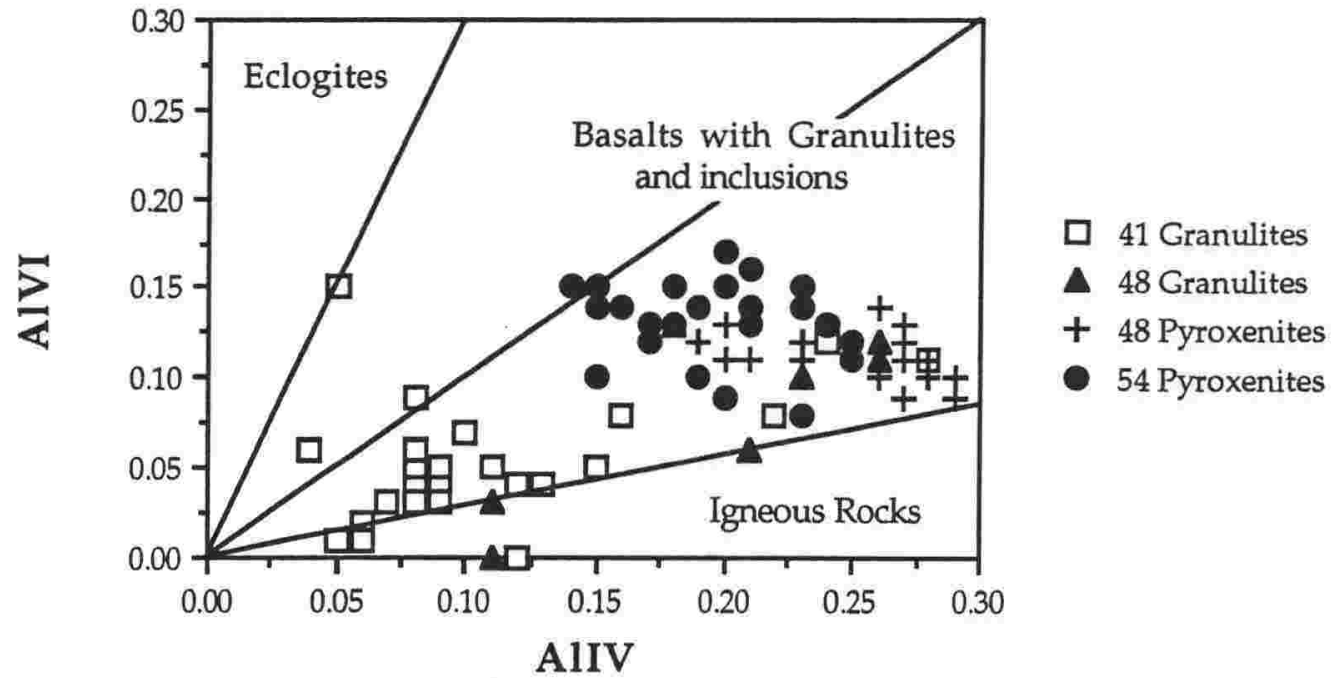

FIGURE 6.8: Tetrahedral $\left(\mathrm{Al}^{\mathrm{IV}}\right)$ and octahedral $\left(\mathrm{Al}^{\mathrm{VI}}\right)$ partitioning of aluminium in clinopyroxene has been used to characterise clinopyroxenes of different origins (Aoki and Shiba, 1973; Wass, 1979). Mount Murphy clinopyroxenes fall in Aoki and Shiba's field of 'basalts with granulites and inclusions'. Note the similar $\mathrm{Al}^{\mathrm{IV}} / \mathrm{Al}^{\mathrm{VI}}$ ratios of all the clinopyroxenes, but the higher total $\mathrm{Al}$ content of the pyroxenite clinopyroxenes compared to those in granulites.

Other minor elements in xenolith clinopyroxenes include $\mathrm{Mn}$ (up to 0.59 wt. \% $\mathrm{MnO}$ ) and $\mathrm{Cr}$ (up to 0.81 wt. $\% \mathrm{Cr}_{2} \mathrm{O}_{3}$ ) in the $\mathrm{M}(1)$ octahedral site, and $\mathrm{K}_{2} \mathrm{O}$ (up to 0.08 wt. $\% \mathrm{~K}_{2} \mathrm{O}$, with one clinopyroxene having up to $0.31 \mathrm{wt}$. $\% \mathrm{~K}_{2} \mathrm{O}$ ) in the $\mathrm{M}(2)$ octahedral site.

Clinopyroxenes from the orthopyroxene-bearing pyroxenite from site 90044 are plotted in Figure 6.9, together with coexisting orthopyroxene compositions. All clinopyroxenes from this pyroxenite are aluminium diopsides similar in composition to clinopyroxenes from site 90054 pyroxenites, except for their higher $\mathrm{Cr}_{2} \mathrm{O}_{3}$ contents $\left(0.39-0.68\right.$ and $0.03-0.20$ wt. $\% \mathrm{Cr}_{2} \mathrm{O}_{3} ; 5.17-6.97$ and 5.69-8.47 wt. \% $\mathrm{Al}_{2} \mathrm{O}_{3} ; 0.16-0.95$ and $1.3-2.05$ wt. $\% \mathrm{TiO}_{2}$ in site 90044 and site 90054 clinopyroxenes respectively). $\mathrm{Al}_{2} \mathrm{O}_{3}$ and $\mathrm{TiO}_{2}$ contents of site 90044 clinopyroxenes are also well below those of clinopyroxenes from site 90048 pyroxenites, further stressing the heterogeneity of xenolith compositions between sites.

Site 90044 pyroxenite orthopyroxenes are aluminian enstatites, with high En contents (En 82.1-82.97). They have very low 'J' components, reflecting the low 
abundance of $\mathrm{Na}_{2} \mathrm{O}\left(0.1\right.$ to 0.17 wt. \% $\left.\mathrm{Na}_{2} \mathrm{O}\right)$. Other minor elements, such as $\mathrm{Cr}_{2} \mathrm{O}_{3}$, $\mathrm{Al}_{2} \mathrm{O}_{3}$ and $\mathrm{TiO}_{2}$, are present in smaller quantities than in clinopyroxenes.

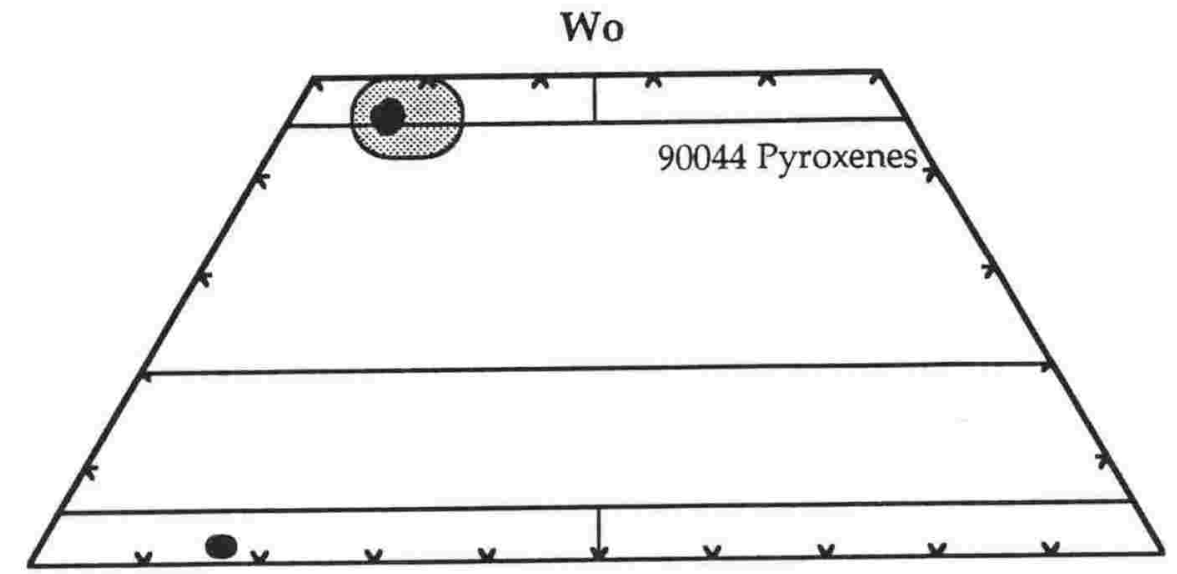

En

Fs

FIGURE 6.9: Compositions of coexisting clinopyroxene and orthopyroxene from a two-pyroxene pyroxenite from site 90044 , in the system Wo-En-Fs. Clinopyroxene compositions are similar to those from site 90054 nurovanitoc Classification fields are those of Morimoto et al. (1988). 
Temperature estimates vary between geothermometers and the accuracy of each thermometer is shown in Table 6.4. The Kretz (1985) geothermometer gives low temperatures, and the Nickel et al. (1985) thermometer gives high temperatures for lower crustal rocks. Estimates using the thermometer of Gasparik (1984), which indicate temperatures of $1140-1210^{\circ} \mathrm{C}$, are similar to these methods, indicating that this thermometer also yields results that are too high, by approximately $100^{\circ} \mathrm{C}$ to $200^{\circ} \mathrm{C}$. The best temperature estimates are given by the Wood and Banno (1973), the Wells (1977), and the Bertrand and Mercier (1985) thermometers, which give good estimates for temperatures above $900^{\circ} \mathrm{C}$.

Pressure estimates using the two-pyroxene thermobarometer of Gasparik (1984) indicate pressures of 7-8 kbs. This method can also be used on orthopyroxene-free assemblages at lower crustal depths and pressures (Gasparik, 1984). Using only clinopyroxene compositions, temperature estimates are the same as if using clinopyroxene and orthopyroxene compositions, but the pressure estimates of $8-9 \mathrm{~kb}$ are higher by $1 \mathrm{~kb}$. When applying this geothermobarometer to orthopyroxene-free xenoliths, P-T estimates are likely to be $1 \mathrm{~kb}$, and $100^{\circ} \mathrm{C}$ to $200^{\circ} \mathrm{C}$ too high (Chapter 8.2.3).

TABLE 6.5: Temperature and pressure estimates of Mount Murphy xenoliths using the graphic thermobarometer of Gasparik (1984). The accuracy of this method when using only clinopyroxene compositions is estimated to be $100-200{ }^{\circ} \mathrm{C}$ and $1 \mathrm{~kb}$ too high. Results indicate the highest P-T conditions of equilibration for site 90048 pyroxenites, and lowest P-T conditions for site 90041 granulites.

\begin{tabular}{lcccc}
\hline Xenolith type & 90041 Granulites & 90048 Granulites & 90048 Pyroxenites & 90054 Pyroxenites \\
\hline & \multicolumn{5}{c}{ Temperature $\left({ }^{\circ} \mathrm{C}\right)$} \\
Estimate & 840 & 1120 & 1110 & 1190 \\
& to & to & to & to \\
& 1070 & 1210 & 1230 & 1320 \\
& & & & \\
Estimate & 4.0 & Pressure $(\mathrm{kb})$ & 8.0 & 7.5 \\
& to & 7.0 & to & to \\
& 7.5 & 10.0 & 13.0 & 11.0 \\
\hline
\end{tabular}

The results of the Gasparik geothermobarometer applied to orthopyroxenefree xenoliths from Mount Murphy (granulites from site 90041, granulites and pyroxenites from site 90048, and pyroxenites from site 90054) are presented as Table 6.5. As discussed above, pressures and temperatures using this method are likely to be high. Revised P-T estimates taking this into account are presented in Chapter 8.2.3, and only unrevised results are presented here. 
Granulites from site 90041 range in P-T conditions from $840-1070{ }^{\circ} \mathrm{C}$ and 4.0 $7.5 \mathrm{kbs}$. P-T estimates vary according to texture, with metamorphic granulites yielding the lowest pressures and temperatures, followed by meta-igneous and igneous granulites. This range in P-T conditions suggests that metamorphism decreases with depth, with granulites at higher crustal levels being the most metamorphosed.

Granulites from site 90048 vary in P-T estimations from $1120-1210^{\circ} \mathrm{C}$ and 7.0-10 kbs, indicating equilibration at greater depths than site 90041 granulites. A meta-igneous granulite from site 90048 yielded P-T estimates of $980-1000{ }^{\circ} \mathrm{C}$ and $4.5 \mathrm{kbs}$, indicating that these granulites also occur at, and are metamorphosed at, higher crustal levels.

Pyroxenites from site 90048 indicate P-T conditions of $1110-1230{ }^{\circ} \mathrm{C}$ and $8-13$ kbs. These estimates overlap with estimates from site 90048 granulites, indicating that the suites occur at similar crustal levels. The pyroxenites may also occur at lower depths, however the small population size of these suites makes this difficult to ascertain.

Site 90054 pyroxenites yield P-T estimates of $1190-1320{ }^{\circ} \mathrm{C}$ and $7.5-11 \mathrm{kbs}$. Such temperatures are much higher than in site 90048 pyroxenites. The presence of plagioclase in the latter may therefore be due to lower temperatures of crystallisation, and indicate that site 90054 pyroxenites represent a hightemperature suite of pyroxenites.

While these estimates do place constraints on the occurrence of xenolith types at source depths, it must be noted that the small population of samples may have resulted in large portions of the lower crust not being represented. The temperature and pressure estimates for the xenolith suite can only be taken as an approximation, and not as a total range of $\mathrm{P}-\mathrm{T}$ conditions.

\subsubsection{Plagioclase}

Although there are only a small number of analyses of plagioclase from pyroxenites, it is evident that compositions vary between xenolith types and sites. Plagioclase that has been recrystallised has similar compositions to igneous plagioclase, indicating that recrystallisation has not affected plagioclase composition. Representative compositions of plagioclase from the Mount Murphy xenolith suite are presented as Table 6.6.

Granulite plagioclase from site 90041 have the highest An contents, ranging from An 67-88 (Figure 6.10). Granulites from site 90048 have lower contents of An 42-61, reflecting their crystallisation from a more evolved melt. This large range 
in composition is consistent with their crystallisation from a continuously fractionating melt (Chapter 6.3).

Pyroxenites from site 90048 and 90054 are interstitial, having formed as a final phase from the crystallising melt (Chapter 6.3). They vary in composition from An 51-55 and An 53-58 respectively (Figure 6.10). This small range in composition may reflect their late-stage of crystallisation, or simply the limited number of analyses of plagioclase from the pyroxenite suites.

TABLE 6.6: Representative electron microprobe analyses of Mount Murphy xenolith plagioclase's.

\begin{tabular}{|c|c|c|c|c|c|c|c|c|c|c|}
\hline $\begin{array}{l}\text { SAMPLE } \\
\text { TYPE }\end{array}$ & $\begin{array}{c}\text { 90041B } \\
\text { Gran }\end{array}$ & $\begin{array}{c}90041 C \\
\text { Gran }\end{array}$ & $\begin{array}{c}\text { 90041G } \\
\text { Gran }\end{array}$ & $\begin{array}{c}90048 \mathrm{E} \\
\text { Gran }\end{array}$ & $\begin{array}{c}90048 \mathrm{~F} \\
\text { Gran }\end{array}$ & $\begin{array}{c}90048 \mathrm{G} \\
\text { Gran }\end{array}$ & $\begin{array}{c}90048 \mathrm{~B} \\
\text { Pyxite }\end{array}$ & $\begin{array}{c}90048 \mathrm{D} \\
\text { Pyxite }\end{array}$ & $\begin{array}{l}\text { 90054I } \\
\text { Pyxite }\end{array}$ & $\begin{array}{l}90054 \mathrm{I} \\
\text { Pyxite }\end{array}$ \\
\hline $\mathrm{SiO}_{2}$ & 45.91 & 48.53 & 45.64 & 52.59 & 53.32 & 54.02 & 52.63 & 52.94 & 51.73 & 52.53 \\
\hline $\mathrm{Al} 2 \mathrm{O} 3$ & 34.50 & 33.33 & 34.84 & 29.78 & 28.85 & 28.74 & 29.08 & 29.01 & 30.12 & 28.91 \\
\hline $\mathrm{TiO} 2$ & 0.00 & 0.04 & 0.04 & 0.06 & 0.11 & 0.03 & 0.07 & 0.19 & 0.17 & 0.10 \\
\hline $\mathrm{FeO}$ & 0.12 & 0.12 & 0.17 & 0.20 & 0.39 & 0.20 & 0.58 & 0.56 & 0.70 & 0.71 \\
\hline $\mathrm{MnO}$ & 0.10 & 0.04 & 0.10 & 0.09 & 0.05 & 0.03 & 0.01 & 0.17 & 0.00 & 0.06 \\
\hline $\mathrm{MgO}$ & 0.02 & 0.03 & 0.00 & 0.02 & 0.07 & 0.11 & 0.08 & 0.08 & 0.14 & 0.11 \\
\hline $\mathrm{CaO}$ & 17.87 & 15.47 & 17.38 & 12.65 & 11.45 & 10.60 & 11.18 & 11.66 & 12.70 & 11.72 \\
\hline $\mathrm{Na} 2 \mathrm{O}$ & 1.58 & 2.67 & 1.83 & 4.14 & 4.53 & 6.80 & 5.88 & 4.99 & 4.95 & 5.59 \\
\hline $\mathrm{K} 2 \mathrm{O}$ & 0.07 & 0.09 & 0.04 & 0.24 & 0.29 & 0.30 & 0.30 & 0.30 & 0.15 & 0.19 \\
\hline TOTAL & 100.17 & 100.32 & 100.04 & 99.77 & 99.05 & 100.83 & 99.81 & 99.90 & 100.66 & 99.92 \\
\hline
\end{tabular}

cations on the basis of 8 oxygens

\begin{tabular}{lcccccccccc}
$\mathrm{Si}$ & 2.112 & 2.213 & 2.101 & 2.392 & 2.436 & 2.435 & 2.399 & 2.407 & 2.338 & 2.398 \\
$\mathrm{Al}$ & 1.870 & 1.791 & 1.889 & 1.596 & 1.553 & 1.527 & 1.562 & 1.554 & 1.620 & 1.555 \\
$\mathrm{Ti}$ & 0.000 & 0.001 & 0.001 & 0.002 & 0.004 & 0.001 & 0.002 & 0.007 & 0.005 & 0.003 \\
$\mathrm{Fe}$ & 0.004 & 0.004 & 0.006 & 0.008 & 0.015 & 0.007 & 0.022 & 0.021 & 0.026 & 0.026 \\
$\mathrm{Mn}$ & 0.004 & 0.000 & 0.004 & 0.004 & 0.002 & 0.001 & 0.000 & 0.007 & 0.000 & 0.002 \\
$\mathrm{Mg}$ & 0.001 & 0.000 & 0.000 & 0.001 & 0.005 & 0.007 & 0.005 & 0.005 & 0.009 & 0.007 \\
$\mathrm{Ca}$ & 0.880 & 0.755 & 0.856 & 0.616 & 0.560 & 0.512 & 0.545 & 0.568 & 0.620 & 0.573 \\
$\mathrm{Na}$ & 0.140 & 0.236 & 0.163 & 0.365 & 0.401 & 0.594 & 0.518 & 0.440 & 0.437 & 0.494 \\
$\mathrm{~K}$ & 0.004 & 0.004 & 0.002 & 0.014 & 0.017 & 0.017 & 0.017 & 0.017 & 0.008 & 0.010 \\
& & & & & & & & & & \\
\hline TOTAL & $\mathbf{5 . 0 1 5}$ & $\mathbf{5 . 0 0 4}$ & $\mathbf{5 . 0 2 2}$ & $\mathbf{4 . 9 9 8}$ & $\mathbf{4 . 9 9 3}$ & $\mathbf{5 . 1 0 0}$ & $\mathbf{5 . 0 7 0}$ & $\mathbf{5 . 0 2 5}$ & $\mathbf{5 . 0 6 3}$ & $\mathbf{5 . 0 6 8}$ \\
\hline & & & & & & & & & & \\
$\mathrm{An}$ & $\mathbf{8 5 . 9 4}$ & $\mathbf{7 5 . 8 8}$ & 83.84 & 61.91 & 57.26 & $\mathbf{4 5 . 5 8}$ & 50.46 & 55.42 & 58.22 & 53.20 \\
$\mathrm{Ab}$ & 13.67 & 23.72 & 15.96 & 36.68 & 41.00 & 52.87 & 47.96 & 42.91 & 41.03 & 45.87 \\
$\mathrm{Or}$ & 0.39 & 0.40 & 0.20 & 1.41 & 1.74 & 1.55 & 1.57 & 1.67 & 0.75 & 0.93 \\
& & & & & & & & & & \\
\hline
\end{tabular}


$\mathrm{SiO}_{2}$ contents of granulite plagioclase from sites 90041 and 90048 differ, ranging from 45.6-51.1 and 52.3-55.2 wt. \% $\mathrm{SiO}_{2}$ respectively. Pyroxenite plagioclase $\mathrm{SiO}_{2}$ contents are intermediate to these extremes, ranging from 51.7-52.9 wt. \% $\mathrm{SiO}_{2}$. A trend of increasing $\mathrm{SiO}_{2}$ with decreasing $\mathrm{Al}_{2} \mathrm{O}_{3}$ content (and An-content) is evident in plagioclase from the xenolith suite, reflecting an increased substitution of $\mathrm{Al}$ for $\mathrm{Si}$ in the lattice (Smith, 1975).

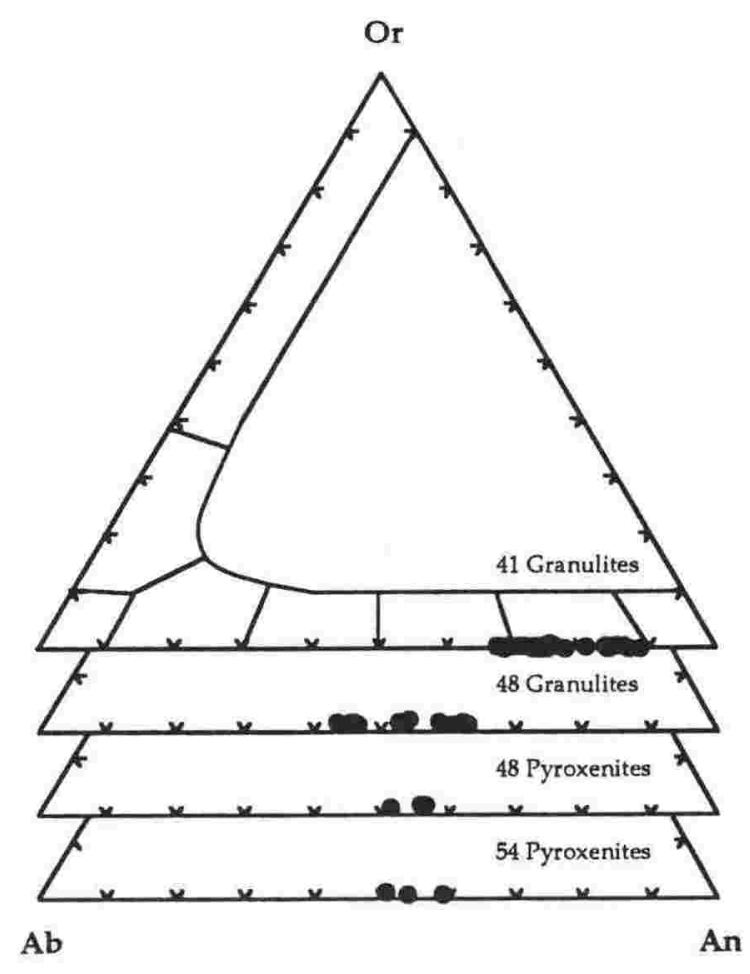

FIGURE 6.10: Composition of Mount Murphy xenolith plagioclase in the system $\mathrm{An}-\mathrm{Ab}$ Or. Plagioclase from site 90041 granulites have higher An-contents than those from site 90048 granulites. Pyroxenite plagioclase compositions resemble those of site 90048 granulites, although the small number of analyses of pyroxenite plagioclase due to their small abundances makes any direct comparisons difficult.

Minor components of xenolith plagioclase vary between xenolith types. $\mathrm{FeO}$ contents are higher in pyroxenite plagioclase $(0.43-0.71$ wt. \% $\mathrm{FeO}$ with plagioclase from site 90054 having the highest $\mathrm{FeO}$ contents), than in granulite plagioclase (0.04-0.49 wt. \% FeO in plagioclase from all sites). $\mathrm{K}_{2} \mathrm{O}$ contents range up to 0.14 wt. $\% \mathrm{~K}_{2} \mathrm{O}$ and from $0.24-0.41$ wt. $\% \mathrm{~K}_{2} \mathrm{O}$ in plagioclase from site 90041 and site 90048 granulites respectively. Pyroxenite plagioclase from site 90048 also have high $\mathrm{K}_{2} \mathrm{O}$ contents $\left(0.30-0.33 \mathrm{wt}\right.$. $\left.\% \mathrm{~K}_{2} \mathrm{O}\right)$ compared to other pyroxenites (0.150.19 wt. $\% \mathrm{~K}_{2} \mathrm{O}$ in plagioclase from site 90054$)$.

\subsubsection{Non-silicates}

The identification of primary oxides in the xenolith suite is difficult due to the widespread oxidation of the suite. Only oxides that are definitely primary in origin (occurring as inclusions, or in unoxidised xenoliths) are considered here, with representative analyses presented as Table 6.7. 
TABLE 6.7: Representative electron microprobe analyses of Mount Murphy primary oxides.

\begin{tabular}{|c|c|c|c|c|c|c|c|c|c|c|}
\hline $\begin{array}{l}\text { SAMPLE } \\
\text { TYPE } \\
\end{array}$ & $\begin{array}{c}\text { 90041B } \\
\text { Gran } \\
\end{array}$ & $\begin{array}{c}90041 C \\
\text { Gran }\end{array}$ & $\begin{array}{c}90048 \mathrm{E} \\
\text { Gran }\end{array}$ & $\begin{array}{c}\text { 90048G } \\
\text { Gran } \\
\end{array}$ & $\begin{array}{l}90048 B \\
\text { Pyxite } \\
\end{array}$ & $\begin{array}{l}\text { 90048B } \\
\text { Pyxite } \\
\end{array}$ & $\begin{array}{l}\text { 90048D } \\
\text { Pyxite }\end{array}$ & $\begin{array}{l}90054 \mathrm{C} \\
\text { Pyxite }\end{array}$ & $\begin{array}{l}90054 \mathrm{I} \\
\text { Pyxite }\end{array}$ & $\begin{array}{l}90054 \mathrm{~K} \\
\text { Pyxite }\end{array}$ \\
\hline $\mathrm{SiO} 2$ & 0.08 & 0.24 & 0.12 & 0.01 & 0.36 & 0.22 & 0.13 & 3.18 & 1.25 & 0.17 \\
\hline $\mathrm{Al} 2 \mathrm{O} 3$ & 53.76 & 16.22 & 7.18 & 0.49 & 0.14 & 50.30 & 8.75 & 7.47 & 0.72 & 58.33 \\
\hline TiO2 & 0.12 & 2.35 & 24.22 & 52.70 & 0.05 & 1.25 & 16.36 & 11.15 & 0.34 & 0.86 \\
\hline $\mathrm{Fe} 2 \mathrm{O} 3$ & & 45.91 & 24.93 & 6.19 & 67.45 & 6.52 & 29.47 & 33.01 & 52.91 & 5.65 \\
\hline $\mathrm{FeO}$ & 18.51 & 27.95 & 30.79 & 31.81 & 30.29 & 20.42 & 37.63 & 38.51 & 0.00 & 19.04 \\
\hline $\mathrm{MnO}$ & 0.02 & 0.04 & 0.33 & 0.63 & 0.12 & 0.14 & 0.42 & 0.43 & 0.00 & 0.09 \\
\hline $\mathrm{MgO}$ & 17.71 & 4.61 & 6.75 & 8.31 & 0.17 & 13.36 & 6.44 & 3.95 & 0.48 & 14.94 \\
\hline $\mathrm{CaO}$ & 0.04 & 0.59 & 0.08 & 0.07 & 0.15 & 0.14 & 0.05 & 1.37 & 0.34 & 0.06 \\
\hline $\mathrm{Cr} 2 \mathrm{O} 3$ & 10.63 & 0.28 & 3.43 & 0.02 & 0.24 & 7.56 & 1.18 & 0.49 & 0.11 & 0.91 \\
\hline $\mathrm{NiO}$ & 0.04 & 0.06 & 0.08 & 0.05 & 0.50 & 0.20 & 0.11 & 0.39 & 29.38 & 0.21 \\
\hline TOTAL & 100.90 & 98.25 & 97.91 & 100.28 & 99.47 & 100.10 & 100.53 & 99.95 & 85.53 & 100.26 \\
\hline
\end{tabular}

cations on the basis of 3 (spinel) or 2 (rhombehedral) sites

\begin{tabular}{lllllllllll} 
Si & 0.002 & 0.008 & 0.004 & 0.000 & 0.014 & 0.006 & 0.004 & 0.105 & 0.056 & 0.004 \\
Al & 1.690 & 0.661 & 0.183 & 0.014 & 0.006 & 1.636 & 0.354 & 0.310 & 0.038 & 1.825 \\
Ti & 0.002 & 0.061 & 0.909 & 0.938 & 0.001 & 0.026 & 0.422 & 0.296 & 0.012 & 0.017 \\
FeII & & 1.193 & 0.624 & 0.110 & 1.956 & 0.135 & 0.761 & 0.875 & 1.784 & 0.113 \\
FeII & 0.413 & 0.847 & 0.832 & 0.629 & 0.980 & 0.471 & 1.080 & 1.135 & 0.000 & 0.423 \\
Mn & 0.000 & 0.001 & 0.010 & 0.013 & 0.004 & 0.003 & 0.012 & 0.012 & 0.000 & 0.002 \\
Mg & 0.704 & 0.237 & 0.341 & 0.293 & 0.010 & 0.549 & 0.330 & 0.195 & 0.032 & 0.591 \\
Ca & 0.001 & 0.022 & 0.003 & 0.002 & 0.006 & 0.004 & 0.002 & 0.048 & 0.016 & 0.002 \\
Cr & 0.224 & 0.008 & 0.092 & 0.000 & 0.007 & 0.165 & 0.032 & 0.013 & 0.004 & 0.019 \\
Ni & 0.001 & 0.002 & 0.002 & 0.001 & 0.015 & 0.004 & 0.003 & 0.010 & 1.058 & 0.005 \\
& & & & & & & & & & \\
\hline TOTAL & 3.037 & 3.040 & 3.000 & 2.000 & 2.999 & 2.999 & 3.000 & 2.999 & 3.000 & 3.001 \\
\hline & & & & & & & & & & \\
X(Usp) & & 0.1075 & 0.5170 & & 0.0015 & 0.7140 & 0.5586 & 0.4283 & & 0.6858 \\
X(Il) & & & & 0.9204 & & & & & &
\end{tabular}

\section{Spinel series spinels}

Al-spinels are abundant in pyroxenite xenoliths, varying in colour from green to black, and occurring as early-formed cumulus phases. The spinels form a solid solution series between spinel sensu stricto $\left(\mathrm{MgAl}_{2} \mathrm{O}_{4}\right)$ and hercynite $\left(\mathrm{Fe}^{2+} \mathrm{Al}_{2} \mathrm{O}_{4}\right)$, with site 90048 pyroxenite spinels being closer to the hercynite endmember. These spinels are also more $\mathrm{Cr}_{2} \mathrm{O}_{3}$ - and $\mathrm{Fe}_{2} \mathrm{O}_{3}$-rich and less $\mathrm{Al}_{2} \mathrm{O}_{3}$-rich than those from site 90054 pyroxenites. 
Rare spinels also occur in the granulite suite, although these are subordinate in abundance to magnetite series spinels. Al-spinels from granulites are $\mathrm{Cr}$-rich, containing up to $23.98 \mathrm{wt}$. $\% \mathrm{Cr}_{2} \mathrm{O}_{3}$, compared with up to 7.56 wt. $\% \mathrm{Cr}_{2} \mathrm{O}_{3}$ in pyroxenite spinels.

\section{Magnetite series spinels}

Titanomagnetites are a common constituent of the granulite suite. Magnetite series spinels from the xenolith suite form a solid solution between pure magnetite $\left(\mathrm{Fe}_{3} \mathrm{O}_{4}\right)$ and ulvöspinel $\left(\mathrm{Fe}_{2} \mathrm{TiO}_{4}\right)$, with most compositions plotting closer to the magnetite end-member (Figure 6.11).

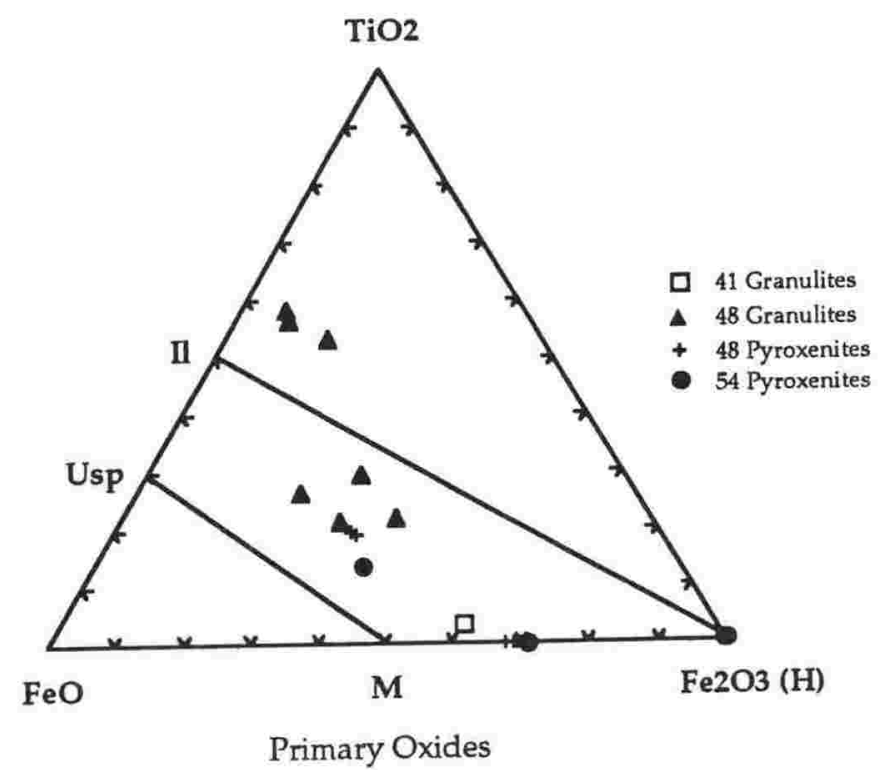

FIGURE 6.11: Primary magnetite-series spinel and ilmenite compositions of Mount Murphy xenolith oxides in the system $\mathrm{TiO}_{2}$ $\mathrm{FeO}-\mathrm{Fe}_{2} \mathrm{O}_{3}$. In addition to titanomagnetite and ilmenite, spinel series spinels sensu stricto are a common constituent of xenoliths, especially in site 90054 pyroxenites. $\mathrm{H}=$ hematite; $\mathrm{I}=$ ilmenite; $\mathrm{M}=$ magnetite; Usp = ulvöspinel.

Titanomagnetites also occur in the pyroxenite suite, where they constitute a minor spinel phase compared to Al-spinels. These magnetite spinels are similar in composition to those from the granulite suite (Figure 6.11).

\section{Other oxide phases}

Ilmenite occurs as a primary oxide phase with titanomagnetite in site 90048 granulites. The absence of hematite, and the coexistence of titanomagnetite, ilmenite and silicate minerals indicates that the xenoliths are sourced from a region with oxygen fugacities close to those of the FMQ (Buddington and Lindsley, 1964) buffer.

The only other oxide phase detected from the xenolith suite is Trevorite, which occurs as small microphenocrysts $(<100 \mu \mathrm{m})$ in site 90054 pyroxenites. In addition to the totals shown in Table 6.7 , trevorite contains approximately $1.5 \mathrm{wt}$. $\% \mathrm{ZnO}$, and 1.0 wt. \% CoO. The totals for these oxides however are low, suggesting the presence of other elements that have not been analysed. 
TABLE 6.8: Electron microprobe analyses of coexisting oxide pairs, and temperature-oxygen fugacity estimates for these pairs using the methods of Carmichael (1967), Anderson (1968), Lindsley and Spencer (1982), and Stormer (1983).

\begin{tabular}{lcccccc}
\hline SAMPLE & $\begin{array}{c}90048 \mathrm{E} \\
\text { TYPE }\end{array}$ & $\begin{array}{c}\text { Gran } \\
\text { Gran }\end{array}$ & $\begin{array}{c}90048 \mathrm{~F} \\
\text { Gran }\end{array}$ & $\begin{array}{c}90048 \mathrm{~F} \\
\text { Gran }\end{array}$ & $\begin{array}{c}90048 \mathrm{G} \\
\text { Gran }\end{array}$ & $\begin{array}{c}90048 \mathrm{G} \\
\text { Gran }\end{array}$ \\
\hline $\mathrm{SiO} 2$ & 0.11 & 0.02 & 0.24 & 0.02 & 0.08 & 0.01 \\
$\mathrm{Al2O} 3$ & 7.02 & 0.65 & 8.85 & 0.49 & 5.82 & 0.49 \\
$\mathrm{TiO} 2$ & 18.80 & 51.77 & 17.45 & 49.14 & 23.30 & 52.70 \\
$\mathrm{Fe} 2 \mathrm{O} 3$ & 35.12 & 7.52 & 27.04 & 14.26 & 21.43 & 6.19 \\
$\mathrm{FeO}$ & 31.84 & 32.92 & 37.53 & 28.88 & 43.14 & 31.81 \\
$\mathrm{MnO}$ & 0.34 & 0.09 & 0.63 & 0.39 & 0.53 & 0.63 \\
$\mathrm{MgO}$ & 5.66 & 7.06 & 6.84 & 8.26 & 6.77 & 8.31 \\
$\mathrm{CaO}$ & 0.01 & 0.08 & 0.05 & 0.07 & 0.09 & 0.07 \\
$\mathrm{Cr} 2 \mathrm{O} 3$ & 0.92 & 0.23 & 0.29 & 0.13 & 0.21 & 0.02 \\
$\mathrm{NiO}$ & 0.02 & 0.06 & 0.08 & 0.05 & 0.09 & 0.05 \\
& & & & & & \\
\hline TOTAL & 99.84 & 100.40 & 99.00 & $\mathbf{1 0 1 . 6 9}$ & $\mathbf{1 0 1 . 4 6}$ & $\mathbf{1 0 0 . 2 8}$ \\
\hline
\end{tabular}

cations on the basis of 3 (spinel) or 2 (rhombehedral) sites

\begin{tabular}{lllllll}
$\mathrm{Si}$ & 0.004 & 0.000 & 0.008 & 0.000 & 0.003 & 0.000 \\
$\mathrm{Al}$ & 0.176 & 0.018 & 0.361 & 0.014 & 0.235 & 0.014 \\
$\mathrm{Ti}$ & 0.737 & 0.921 & 0.454 & 0.866 & 0.601 & 0.938 \\
$\mathrm{FeIII}$ & 0.880 & 0.134 & 0.705 & 0.251 & 0.553 & 0.110 \\
$\mathrm{FeII}$ & 0.886 & 0.631 & 1.087 & 0.566 & 1.236 & 0.629 \\
$\mathrm{Mn}$ & 0.010 & 0.018 & 0.019 & 0.008 & 0.015 & 0.013 \\
$\mathrm{Mg}$ & 0.281 & 0.249 & 0.353 & 0.288 & 0.346 & 0.293 \\
$\mathrm{Ca}$ & 0.000 & 0.002 & 0.002 & 0.002 & 0.003 & 0.002 \\
$\mathrm{Cr}$ & 0.024 & 0.004 & 0.008 & 0.002 & 0.006 & 0.000 \\
$\mathrm{Ni}$ & 0.002 & 0.001 & 0.002 & 0.003 & 0.002 & 0.001 \\
& & & & & & \\
\hline TOTAL & 3.000 & 1.978 & 2.999 & 2.000 & 3.000 & 2.000 \\
\hline & & & & & & \\
X(Usp) & 0.6321 & & 0.5935 & & 0.7065 & \\
X(II) & & 0.9204 & & 0.8478 & & 0.9330 \\
& & & & & & \\
\hline
\end{tabular}

$\begin{array}{ccccc}\mathrm{T}\left({ }^{\circ} \mathrm{C}\right) & \mathbf{1} & 825.08 & 959.19 & 852.79 \\ & 2 & 885.80 & 1063.74 & 942.93 \\ & 3 & 1012.36 & 1193.85 & 1075.65 \\ & 4 & 906.36 & 1104.28 & 954.49 \\ & & & & \\ \mathrm{fO} 2 & \mathbf{1} & -14.23 & -10.89 & -14.07 \\ & \mathbf{2} & -12.97 & -9.14 & -12.15 \\ & 3 & -10.58 & -7.53 & -9.19 \\ & 4 & -13.00 & -9.00 & -12.36\end{array}$

1 = Stormer (1983); 2 = Anderson (1968);

3 = Carmichael (1967); 4 = Lindsley and Spencer (1982). 
Thermometry and oxygen fugacity calculations have been determined using coexisting spinel and rhombohedral oxide pairs. Compositions of oxide pairs used in these calculations are presented in Table 6.8, together with temperature- $\mathrm{fO}_{2}$ estimates using the methods of Carmichael (1967), Anderson (1968), Lindsley and Spencer (1982) and Stormer (1983).

Temperature and $\mathrm{fO}_{2}$ estimates using the method of Stormer (1983) have been plotted as Figure 6.12. This method is preferred, as it is the only method that takes into account minor elements in the oxides, although it should be noted that estimates using other methods do not differ substantially from those using the method of Stormer.

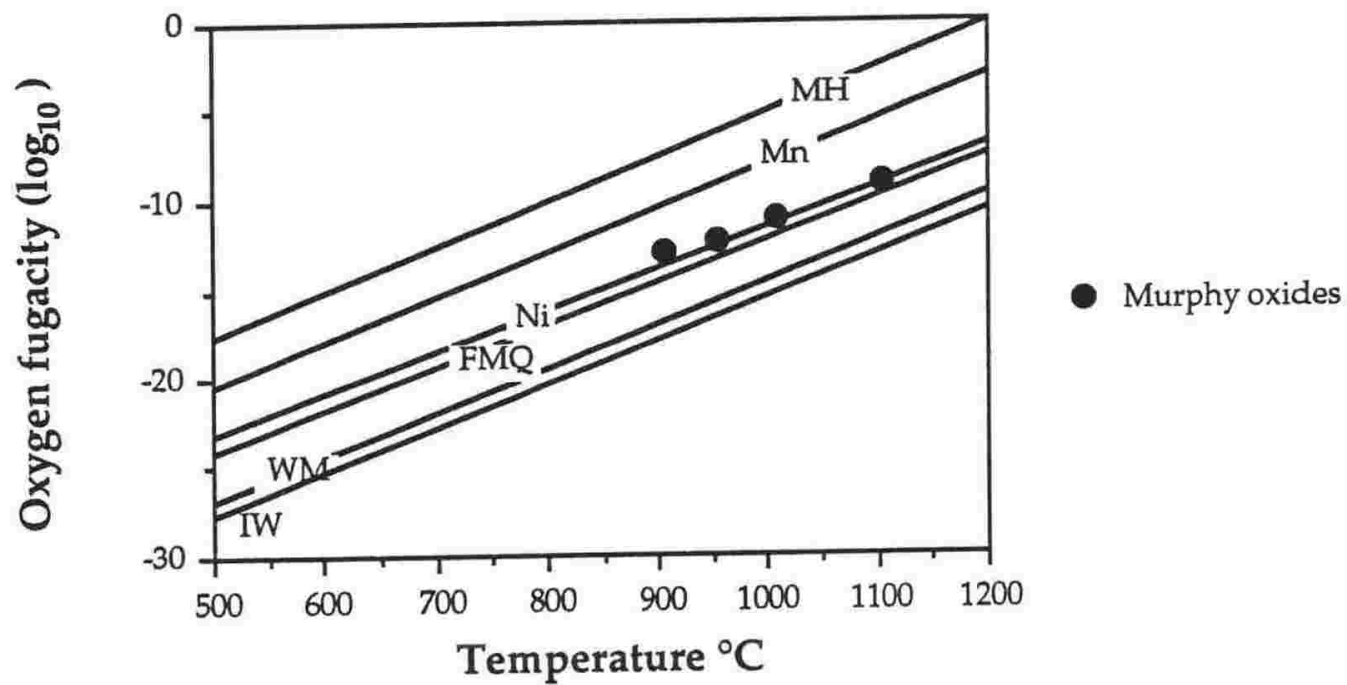

FIGURE 6.12: Oxide pair thermometry and oxygen fugacity calculations determined using the method of Stormer (1983). Redox conditions in the lower crust beneath Mount Murphy are similar to those of the FMQ buffer (Buddington and Lindsley, 1964), which is consistent with the mineral assemblage of coexisting silicate minerals, titanomagnetite and ilmenite. Temperature estimates indicate high (magmatic) temperatures, suggesting a high geothermal gradient for the lower crust in this region.

Temperature estimates give magmatic temperatures $\left(900-1100{ }^{\circ} \mathrm{C}\right)$, indicating a high geothermal gradient for the lower crust in this region. Oxygen fugacity estimates indicate conditions similar to those of the FMQ buffer, which are consistent with conditions expected for the lower crust, and similar to those found in the lower crust beneath Mount Sidley (Chapter 4.5.3).

\subsubsection{Summary and discussion of mineral chemistry}

The characteristics of the Mount Murphy xenolith textures and mineral assemblage are summarised in Table 6.9. The major features indicated by mineral chemistry are: 
- mineral compositions generally show good chemical trends, from site 90041 granulites, to site 90054 pyroxenites, site 90048 pyroxenites, and site 90048 granulites; e.g. decreasing Fo contents of olivine, En contents of clinopyroxene, and An content of plagioclase. These trends indicate that the xenolith suite is genetically related, having formed by the fractionation of related melts;

TABLE 6.9: Summary of the petrography and mineral chemistry of the Mount Murphy xenolith suite.

\begin{tabular}{|c|c|c|c|c|}
\hline TYPE & 90041 Granulites & 90048 Granulites & 90048 Pyroxenites & 90054 Pyroxenites \\
\hline ROCK TYPES & $\begin{array}{c}\text { Leucogabbros } \\
\text { Ol Leucogabbros } \\
\text { Ol Gabbros }\end{array}$ & $\begin{array}{c}\text { Leucogabbros } \\
\text { Ol Melagabbros } \\
\text { Ol Gabbros }\end{array}$ & $\begin{array}{l}\text { Clinopyroxenites } \\
\text { (Ol- and Pl-) }\end{array}$ & $\begin{array}{c}\text { Clinopyroxenites } \\
\text { (Ol-) }\end{array}$ \\
\hline TEXTURE & $\begin{array}{l}\text { Meta-Igneous } \\
\text { Granulites }\end{array}$ & $\begin{array}{l}\text { Meta-Igneous } \\
\text { Granulites }\end{array}$ & $\begin{array}{l}\text { Cumulate } \\
\text { Pyroxenites }\end{array}$ & $\begin{array}{l}\text { Cumulate } \\
\text { Pyroxenites }\end{array}$ \\
\hline $\begin{array}{l}\text { MINERALOGY } \\
\text { Olivine }\end{array}$ & Fo $81-84$ & Fo $55-71$ & Fo $69-75$ & Fo $73-87$ \\
\hline Clinopyroxene & $\begin{array}{l}\text { Wo } 45-50 \\
\text { En } 41-46 \\
\text { Fs } 6-112\end{array}$ & $\begin{array}{l}\text { Wo } 45-47 \\
\text { En } 38-40 \\
\text { Fs } 15-19\end{array}$ & $\begin{array}{l}\text { Wo } 43-48 \\
\text { En } 38-43 \\
\text { Fs } 12-16\end{array}$ & $\begin{array}{l}\text { Wo } 46-49 \\
\text { En } 40-47 \\
\text { Fs 5-13 }\end{array}$ \\
\hline Plagioclase & An $67-88$ & An $42-61$ & An $51-55$ & An $53-58$ \\
\hline Oxides & $\begin{array}{l}\text { Fe-Ti oxides } \\
\text { Al- spinels }\end{array}$ & $\begin{array}{c}\text { Fe-Ti oxides } \\
\text { Al-spinels }\end{array}$ & $\begin{array}{l}\text { Al- spinels } \\
\text { Fe-Ti oxides }\end{array}$ & $\begin{array}{l}\text { Al- spinels } \\
\text { Trevorite }\end{array}$ \\
\hline $\begin{array}{l}\text { Temperature }\left({ }^{\circ} \mathrm{C}\right) \\
\text { Pressure (kbars) }\end{array}$ & $\begin{array}{c}840-1070 \\
4.0-7.5\end{array}$ & $\begin{array}{c}1120-1210 \\
7.0-10.0\end{array}$ & $\begin{array}{c}1110-1230 \\
8.0-13.0\end{array}$ & $\begin{array}{c}1190-1320 \\
7.5-11.0\end{array}$ \\
\hline $\begin{array}{l}\text { SECONDARY } \\
\text { REACTIONS }\end{array}$ & $\begin{array}{c}\text { Oxidation } \\
\text { (intense) }\end{array}$ & $\begin{array}{l}\text { Oxidation } \\
\text { (moderate) }\end{array}$ & $\begin{array}{l}\text { Oxidation } \\
\text { (moderate) }\end{array}$ & $\begin{array}{l}\text { Oxidation } \\
\text { (moderate) }\end{array}$ \\
\hline
\end{tabular}

- clinopyroxene Al contents indicate that most site 90041 granulite, and some 90048 granulite clinopyroxenes crystallised after plagioclase, which depleted the melt in $\mathrm{Al}$ and resulted in lower $\mathrm{Al}$-contents in clinopyroxenes. Clinopyroxenes from the pyroxenite suite (and most from site 90048 granulites) are Al-rich, indicating that plagioclase fractionation has not affected them. These features are in agreement with xenolith textures, which indicate crystallisation of clinopyroxene after plagioclase in the granulite suite, and before plagioclase in the pyroxenite suite; 
- clinopyroxene $\mathrm{Al}^{\mathrm{IV}}$ and $\mathrm{Al}^{\mathrm{VI}}$ contents indicate that the clinopyroxenes have equilibrated to granulite facies conditions;

- P-T estimates using the Gasparik (1984) graphical geothermobarometer indicate that site 90041 granulites come from higher crustal levels than other xenoliths. Site 90048 granulites and pyroxenites come from deeper levels, with the pyroxenites having equilibrated at higher P-T conditions. Site 90054 pyroxenites also come from lower levels in the crust, similar to site 90048 pyroxenites, and consistent with their occurrence with upper mantle peridotites;

- P-T estimates of the granulite suite indicate that the variation in metamorphic recrystallisation decreases with depth, with fully recrystallised granulites yielding the lowest pressures and temperatures of equilibration;

- titanomagnetite is the major primary Fe-Ti oxide detected in the xenolith suite, although it is absent in pyroxenites from site 90054 . The presence of coexisting primary ilmenite with titanomagnetite in site 90048 granulites allows the calculation of temperature and oxygen fugacity conditions. Temperature estimations indicate magmatic $\left(900-1100{ }^{\circ} \mathrm{C}\right)$ temperatures, which are consistent with temperature estimations from pyroxene geothermometry. Oxygen fugacity conditions are similar to redox conditions of the FMQ buffer. Spinel series spinels (sensu stricto) also occur in the xenolith suite, and are most common in site 90054 pyroxenites;

- igneous mineral phases that have been recrystallised have similar compositions to primary igneous phases, indicating that metamorphism was closed system on the major-element scale;

- mineral compositions of site 90041 granulites are similar to site 90054 pyroxenites, and compositions of site 90048 granulites are similar to site 90048 pyroxenites. The xenolith suite may therefore represent two (or more) episodes of fractionation by a melt fractionating site 90041 granulites and pyroxenites, and by a more evolved melt fractionating site 90048 granulites and pyroxenites.

These factors are significant in establishing a stratigraphy of the lower crust in this region, as they indicate a layered crust of varying composition, formed as layered cumulates. As there is no relationship between primitive compositions of the xenolith suite and their depth of crystallisation (e.g. site 90048 pyroxenites have evolved compositions, but occur at the deepest depths), as there is in the Mount Sidley xenolith suite (Chapter 4.4.6), a single episode of crustal growth cannot have occurred. The multiple-episode growth model depicted by Figure $6.2 c$, or a variation thereof, is envisaged to have occurred in the lower crust beneath Mount Murphy. 


\subsection{Secondary Mineral Reactions}

The primary mineral assemblage of the xenolith suite has been altered by interaction with the host magma, and by oxidation of olivine. A number of case studies of these secondary mineral reactions are presented to document these processes, and to establish any connection between the two reactions. In secondary mineral reaction tables, minerals are identified by their association: 'core' or 'c' = primary mineral core; ' $m$ ' = primary. mineral between the core and rim; 'melt' = associated with the infiltrating melt; 'oxid.' = associated with oxidation; 'rim' or ' $r$ ' = primary mineral rim; 'symp' = symplectite minerals.

\subsubsection{Host melt - xenolith interactions}

Host melts react with the xenolith wherever the two come into contact. The rims of the xenoliths have been oxidised by the magma, 1-2 $\mathrm{mm}$ into the xenolith. Oxidised rims can be avoided, and have not been analysed here. In some cases however, host melts have infiltrated further into the xenolith, either through cracks or along grain boundaries, interacting with the xenolith mineral assemblage, and crystallising microphenocrysts.

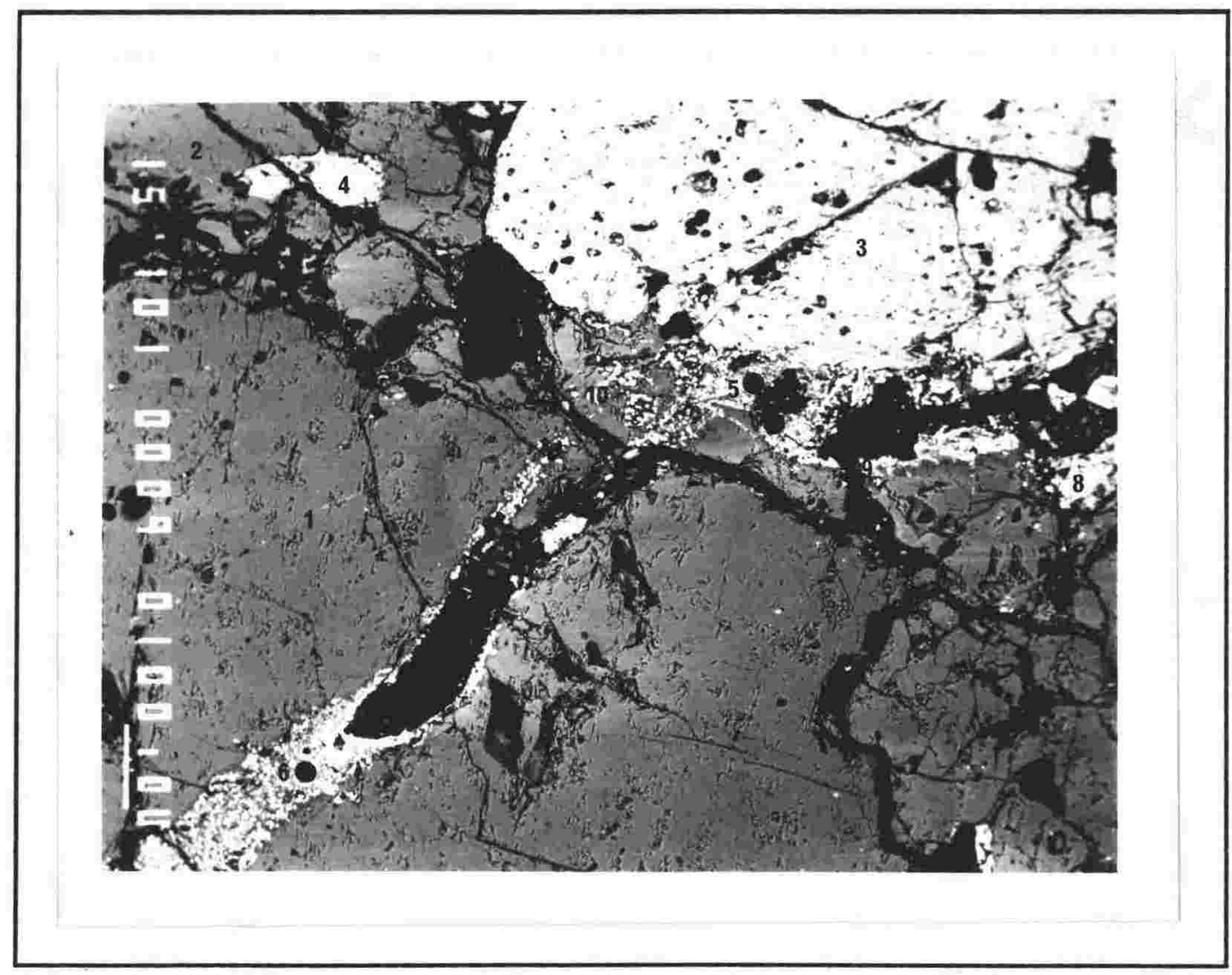

PLATE 6.6: Host melt in a vein through a granulite (sample 90041A). Glass fills the vein and also occurs between grain boundaries of a clinopyroxene (lgt grey) and plagioclase (dark grey). Analyses of sites 1-10 are presented as Table 6.10. See text for further explanation. Scale bar is $100 \mu \mathrm{m}$. 


\section{Sample 90041A: Granulite xenolith (Plate 6.6; Table 6.10)}

Host melts can infiltrate xenoliths through cracks, and along grain boundaries. The host plagioclase (1) has not been greatly affected by the melt, and is similar in composition to other plagioclase (2). However there is a very small rim ( $\mu \mathrm{m}$-scale) of plagioclase overgrowth on xenolith plagioclase in contact with the melt (dark plagioclase rim of Plate 6.6). The rim is too small to analyse, however its dark colour in back-scattered image indicates a Na-rich composition, reflecting crystallisation of a melt that was more Na-rich than the xenolith melts.

TABLE 6.10: Electron microprobe analyses of host melt - xenolith reactions in a granulite (sample 90041A). See Plate 6.6 for analyses sites.

\begin{tabular}{|c|c|c|c|c|c|c|c|c|c|c|}
\hline $\begin{array}{l}\text { PHASE } \\
\text { SITE }\end{array}$ & $\begin{array}{l}\text { Plag } \\
\text { core } \\
1\end{array}$ & $\begin{array}{c}\text { Plag } \\
\text { core } \\
2\end{array}$ & $\begin{array}{l}\text { Cpx } \\
\text { core } \\
3\end{array}$ & $\begin{array}{c}\text { Cpx } \\
\text { core } \\
4\end{array}$ & Melt & Melt & $\begin{array}{c}\text { Olivine } \\
\text { melt } \\
7\end{array}$ & $\begin{array}{c}\text { Cpx } \\
\text { melt } \\
8\end{array}$ & $\begin{array}{c}\text { Oxide } \\
\text { melt } \\
9\end{array}$ & $\begin{array}{c}\text { Oxide } \\
\text { melt } \\
10 \\
\end{array}$ \\
\hline $\mathrm{SiO} 2$ & 49.63 & 49.83 & 51.63 & 52.06 & 43.78 & 54.24 & 43.42 & 51.20 & 0.72 & 0.60 \\
\hline $\mathrm{Al} 2 \mathrm{O} 3$ & 31.61 & 31.47 & 2.97 & 2.78 & 13.92 & 15.04 & 0.04 & 1.95 & 1.14 & 1.81 \\
\hline TiO2 & 0.05 & 0.07 & 0.38 & 0.28 & 2.65 & 2.72 & 0.00 & 0.55 & 9.27 & 8.86 \\
\hline $\mathrm{Fe} 2 \mathrm{O} 3$ & & & 3.20 & 2.98 & & & & 7.97 & 47.40 & 47.59 \\
\hline $\mathrm{FeO}$ & 0.22 & 0.18 & 3.77 & 3.71 & 11.66 & 8.33 & 1.52 & 0.00 & 31.17 & 30.23 \\
\hline $\mathrm{MnO}$ & 0.06 & 0.00 & 0.20 & 0.22 & 0.61 & 0.21 & 0.27 & 0.23 & 0.49 & 0.62 \\
\hline $\mathrm{MgO}$ & 0.04 & 0.04 & 14.73 & 14.57 & 6.07 & 4.13 & 54.46 & 18.26 & 4.79 & 4.86 \\
\hline $\mathrm{CaO}$ & 14.93 & 14.14 & 22.56 & 22.96 & 13.68 & 7.62 & 0.08 & 18.45 & 0.31 & 0.45 \\
\hline $\mathrm{Na} 2 \mathrm{O}$ & 3.63 & 3.78 & 0.63 & 0.67 & 4.10 & 6.13 & 0.01 & 1.33 & 0.42 & 0.18 \\
\hline $\mathrm{K} 2 \mathrm{O}$ & 0.08 & 0.06 & 0.02 & 0.00 & 0.31 & 1.41 & 0.03 & 0.03 & 0.07 & 0.04 \\
\hline $\mathrm{Cr} 2 \mathrm{O} 3$ & 0.22 & 0.18 & 0.20 & 0.16 & 0.07 & 0.06 & 0.46 & 0.00 & 0.19 & 0.09 \\
\hline TOTAL & 100.47 & 99.75 & 100.29 & 100.39 & 96.84 & 99.88 & 100.29 & 99.97 & 95.96 & 95.33 \\
\hline $\mathrm{Si}$ & 2.268 & 2.282 & 1.914 & 1.924 & & & 1.019 & 1.898 & 0.027 & 0.023 \\
\hline Al & 1.713 & 1.698 & 0.131 & 0.123 & & & 0.001 & 0.085 & 0.051 & 0.081 \\
\hline $\mathrm{Ti}$ & 0.004 & 0.002 & 0.011 & 0.008 & & & 0.000 & 0.015 & 0.265 & 0.253 \\
\hline FeIII & & & 0.089 & 0.087 & & & & 0.247 & 1.358 & 1.363 \\
\hline FeII & 0.007 & 0.007 & 0.116 & 0.114 & & & 0.030 & 0.000 & 0.992 & 0.962 \\
\hline Mn & 0.001 & 0.000 & 0.006 & 0.007 & & & 0.006 & 0.007 & 0.016 & 0.020 \\
\hline $\mathrm{Mg}$ & 0.000 & 0.003 & 0.813 & 0.802 & & & 1.904 & 1.008 & 0.272 & 0.276 \\
\hline $\mathrm{Ca}$ & 0.690 & 0.694 & 0.896 & 0.909 & & & 0.002 & 0.733 & 0.013 & 0.018 \\
\hline $\mathrm{Na}$ & 0.331 & 0.335 & 0.045 & 0.049 & & & 0.000 & 0.096 & 0.000 & 0.000 \\
\hline K & 0.005 & 0.004 & 0.001 & 0.000 & & & 0.001 & 0.002 & 0.000 & 0.000 \\
\hline $\mathrm{Cr}$ & 0.008 & 0.007 & 0.006 & 0.005 & & & 0.009 & 0.000 & 0.006 & 0.003 \\
\hline TOTAL & 5.027 & 5.031 & 4.029 & 4.028 & & & 2.971 & 4.090 & 3.000 & 2.999 \\
\hline
\end{tabular}


The composition of the clinopyroxene (3) is similar to other clinopyroxenes (4) in the xenolith. This, and its unaltered appearance in Plate 6.6, indicates that it has not been affected by the melt.

The infiltrating melt near the clinopyroxene (5) differs in composition from the melt present in the crack in plagioclase (6). The melt has crystallised $\mathrm{Mg}$ rich olivine (7), clinopyroxene (8) poor in $\mathrm{Ca}$, and rich in $\mathrm{Mg}$, Fe and $\mathrm{Na}$ compared to xenolith clinopyroxene, and Fe-Ti oxides $(9,10)$. The differences in melt composition can be accounted for by the continued fractionation of these mineral phases, resulting in glass poor in $\mathrm{Mg}, \mathrm{Mn}, \mathrm{Fe}$ and $\mathrm{Ca}$, in the plagioclase vein. This melt is also rich in $\mathrm{Al}, \mathrm{Na}$ and $\mathrm{K}$ (elements that are not depleted during crystal fractionation), resulting in Na-rich plagioclase rims of xenolith plagioclase in contact with the melt.

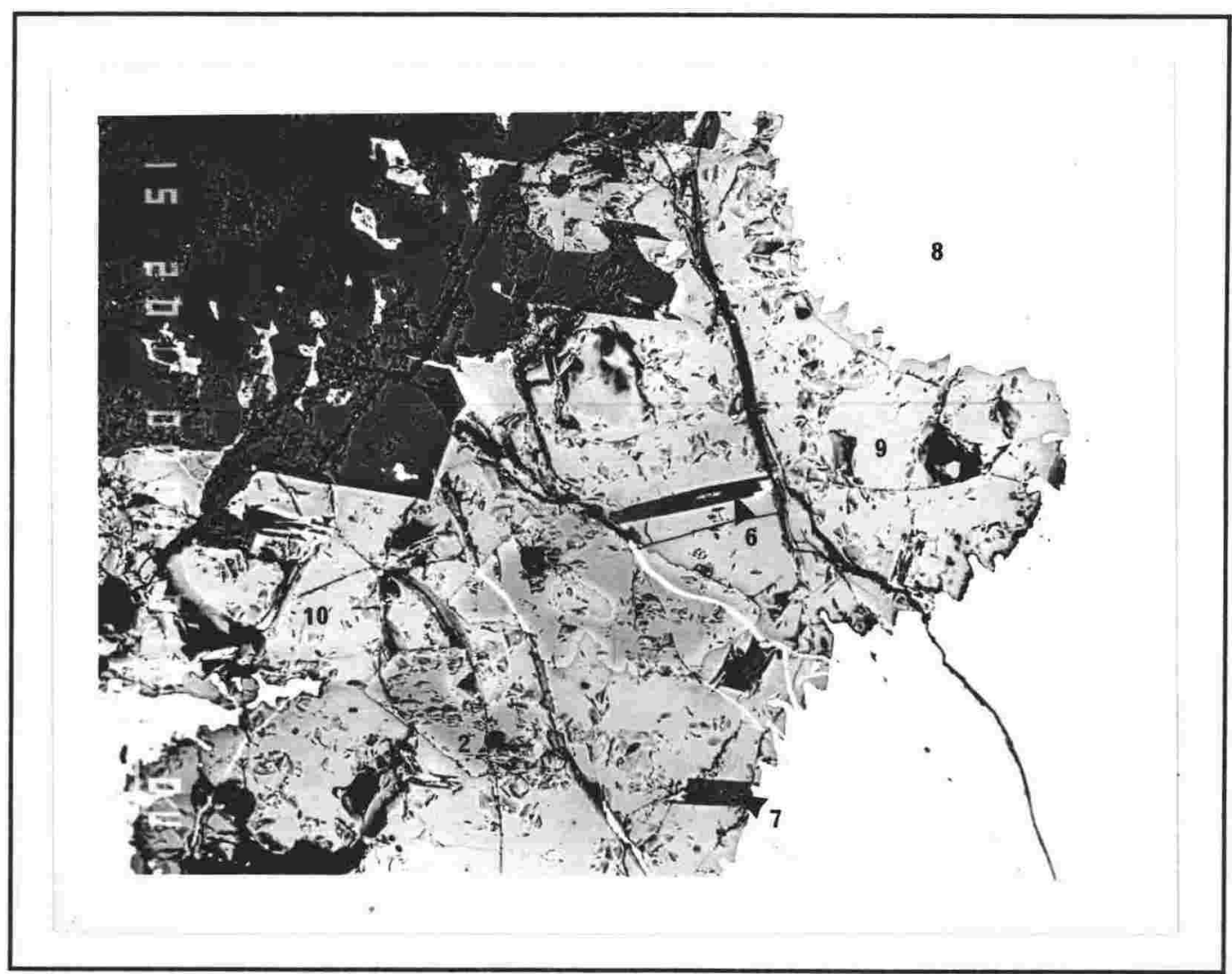

PLATE 6.7: Host melt infiltrating a granulite (sample 90048E). The melt (med grey) has crystallised olivine (euhedral grains in melt) and plagioclase (dark grey) microphenocrysts, and formed euhedral plagioclase and oxide (white) overgrowths on xenolith mineral phases. Analyses of sites 1-10 are presented as Table 6.11. See text for further explanation. Scale bar is $100 \mu \mathrm{m}$.

Sample 90048E: Granulite xenolith (Plate 6.7; Table 6.11)

Large amounts of host melt are capable of infiltrating the xenoliths along grain boundaries, reacting with xenolith minerals and crystallising microphenocrysts. Unaltered granulite olivine (1) is Fe-rich (Fo 61.7) compared to 
olivine that has crystallised from the infiltrating melt, such as the large skeletal olivine (2) at centre-bottom of Plate 6.7 (Fo 78.8). Melt olivine contains higher amounts of minor elements, such as $\mathrm{Ti}, \mathrm{Al}, \mathrm{Na}$, and especially $\mathrm{Ca}$, and lower amounts of $\mathrm{Mn}$. Abundances of $\mathrm{Mn}$ in olivine is dependant on fractionation and increases in abundance with decreasing $\mathrm{Mg}$ (Table 6.11). High Ca-contents of melt olivine indicate that they crystallised at lower pressures than xenolith olivine (Finnerty and Boyd, 1978), probably during ascent to the surface.

TABLE 6.11: Electron microprobe analyses of host melt - xenolith reactions in a granulite (sample 90048E). See Plate 6.7 for analyses sites.

\begin{tabular}{|c|c|c|c|c|c|c|c|c|c|c|}
\hline $\begin{array}{l}\text { PHASE } \\
\text { SITE }\end{array}$ & $\begin{array}{c}\text { Olivine } \\
\text { core } \\
1 \\
\end{array}$ & $\begin{array}{c}\text { Olivine } \\
\text { melt } \\
2\end{array}$ & $\begin{array}{c}\text { Plag } \\
\text { core } \\
3 \\
\end{array}$ & $\begin{array}{c}\text { Plag } \\
\text { melt c- } \\
4\end{array}$ & $\begin{array}{c}\text { Plag } \\
\text { melt } r \\
5 \\
\end{array}$ & $\begin{array}{c}\text { Plag } \\
\text { melt } \\
6 \\
\end{array}$ & $\begin{array}{c}\text { Plag } \\
\text { melt } \\
7 \\
\end{array}$ & $\begin{array}{c}\text { Oxide } \\
\text { melt } \\
8 \\
\end{array}$ & $\begin{array}{c}\text { Melt } \\
9 \\
\end{array}$ & $\begin{array}{c}\text { Melt } \\
10 \\
\end{array}$ \\
\hline $\mathrm{SiO} 2$ & 36.25 & 38.46 & 53.05 & 52.59 & 49.35 & 53.12 & 52.64 & 0.11 & 48.56 & 48.27 \\
\hline $\mathrm{Al} 2 \mathrm{O} 3$ & 0.01 & 0.10 & 29.99 & 29.78 & 32.10 & 29.45 & 29.09 & 7.02 & 14.94 & 13.79 \\
\hline $\mathrm{TiO} 2$ & 0.01 & 0.05 & 0.08 & 0.06 & 0.18 & 0.28 & 0.27 & 18.80 & 4.57 & 4.97 \\
\hline $\mathrm{Fe} 2 \mathrm{O} 3$ & & & & & & & & 35.12 & & \\
\hline $\mathrm{FeO}$ & 32.95 & 19.45 & 0.17 & 0.20 & 0.51 & 0.71 & 0.74 & 31.84 & 12.58 & 13.53 \\
\hline $\mathrm{MnO}$ & 0.57 & 0.20 & 0.00 & 0.09 & 0.02 & 0.00 & 0.00 & 0.34 & 0.19 & 0.24 \\
\hline $\mathrm{MgO}$ & 29.80 & 40.55 & 0.06 & 0.02 & 0.06 & 0.08 & 0.31 & 5.66 & 3.16 & 3.90 \\
\hline $\mathrm{CaO}$ & 0.18 & 0.34 & 12.34 & 12.65 & 15.08 & 12.05 & 12.26 & 0.01 & 8.22 & 6.88 \\
\hline $\mathrm{Na} 2 \mathrm{O}$ & 0.00 & 0.04 & 4.16 & 4.14 & 2.67 & 4.08 & 4.05 & 0.01 & 3.13 & 3.85 \\
\hline $\mathrm{K} 2 \mathrm{O}$ & 0.00 & 0.00 & 0.28 & 0.24 & 0.11 & 0.21 & 0.21 & 0.00 & 1.61 & 1.64 \\
\hline $\mathrm{Cr} 2 \mathrm{O} 3$ & 0.00 & 0.00 & 0.00 & 0.00 & 0.00 & 0.00 & 0.06 & 0.92 & 0.00 & 0.01 \\
\hline TOTAL & 99.77 & 99.19 & 100.12 & 99.77 & 100.08 & 99.98 & 99.63 & 99.84 & 96.96 & 97.08 \\
\hline $\mathrm{Si}$ & 0.998 & 0.996 & 2.399 & 2.392 & 2.255 & 2.407 & 2.400 & 0.004 & & \\
\hline $\mathrm{Al}$ & 0.000 & 0.003 & 1.599 & 1.596 & 1.729 & 1.573 & 1.563 & 0.176 & & \\
\hline $\mathrm{Ti}$ & 0.000 & 0.001 & 0.003 & 0.002 & 0.006 & 0.010 & 0.009 & 0.737 & & \\
\hline FeIII & & & & & & & & 0.880 & & \\
\hline FeII & 0.759 & 0.421 & 0.006 & 0.008 & 0.020 & 0.027 & 0.028 & 0.886 & & \\
\hline Mn & 0.013 & 0.004 & 0.000 & 0.004 & 0.001 & 0.000 & 0.000 & 0.010 & & \\
\hline $\mathbf{M g}$ & 1.223 & 1.566 & 0.004 & 0.001 & 0.004 & 0.006 & 0.021 & 0.281 & & \\
\hline $\mathrm{Ca}$ & 0.005 & 0.009 & 0.598 & 0.616 & 0.738 & 0.585 & 0.599 & 0.000 & & \\
\hline $\mathrm{Na}$ & 0.000 & 0.002 & 0.365 & 0.365 & 0.237 & 0.358 & 0.359 & 0.000 & & \\
\hline K & 0.000 & 0.000 & 0.016 & 0.014 & 0.006 & 0.012 & 0.012 & 0.000 & & \\
\hline $\mathrm{Cr}$ & 0.000 & 0.000 & 0.000 & 0.000 & 0.000 & 0.000 & 0.003 & 0.024 & & \\
\hline TOTAL & 2.998 & 3.002 & 4.990 & 4.998 & 4.996 & 4.978 & 4.993 & 2.998 & & \\
\hline
\end{tabular}

Primary plagioclase (3; not shown in Plate 6.7, and (4) at top left of Plate 6.7) shows severe signs of disequilibrium in contact with the melt, having melted 
prior to the growth of Ca-rich plagioclase overgrowths (5) from the melt. The secondary plagioclase (5) is euhedral, and changes in composition towards the rim (note the change in colour from lighter grey at site 5 to darker grey at the rim), reflecting a change in melt composition due to the fractionation of plagioclase and olivine. The rim is the same composition as euhedral plagioclase $(6,7)$ that has crystallised in the melt. Melt plagioclase has higher concentrations of minor elements, such as $\mathrm{Ti}$ and $\mathrm{Mg}$, and most notably $\mathrm{Fe}$, which ranges from 0.17-0.25 wt. $\% \mathrm{FeO}$ in xenolith plagioclase, and from $0.51-0.91 \mathrm{wt}$. \% $\mathrm{FeO}$ in melt plagioclase (Table 6.11).

Large euhedral-subhedral titanomagnetite has also crystallised from the melt (8). The titanomagnetite of Plate 6.7 sits entirely within the melt $(9,10)$. The melt is basaltic in composition, although one trachybasalt glass has been analysed.

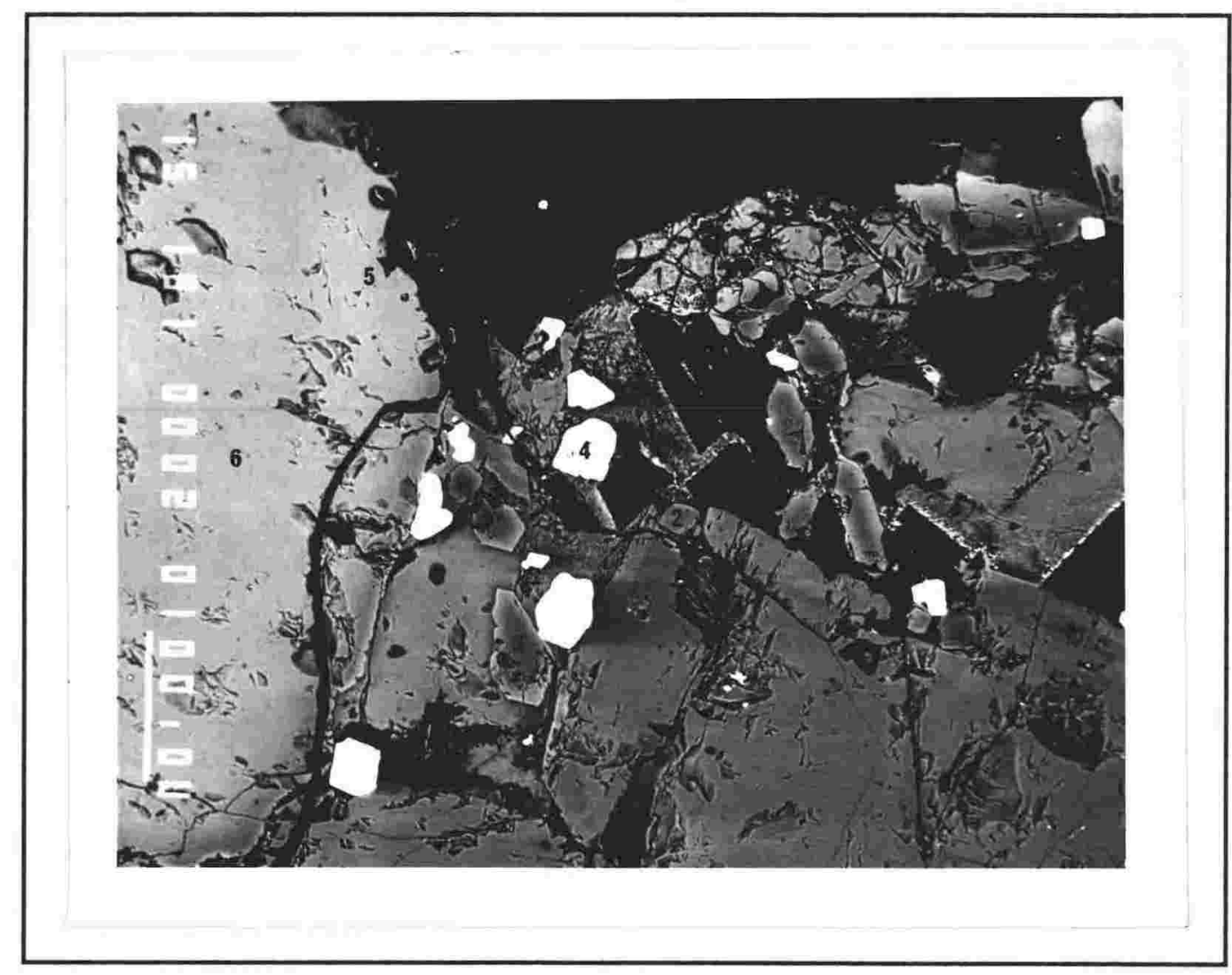

PLATE 6.8: Host melt infiltrating a pyroxenite (sample 90048D) has crystallised euhedral plagioclase (dark), olivine (grey) and Fe-oxides (white). Analyses of sites 1-10 are presented as Table 6.12. See text for further explanation. Scale bar is $100 \mu \mathrm{m}$.

\section{Sample 90048D: Pyroxenite xenolith (Plate 6.8; Table 6.12)}

Melt (1) has also infiltrated into pyroxenite xenoliths, although not as extensively as in the granulite suite. Euhedral plagioclase (2), olivine (3) and titanomagnetite (4) have crystallised from the host melt. Melt-derived plagioclase is variable in composition, but is generally more An-rich than xenolith 
plagioclase (5). Melt plagioclase also has higher contents of minor elements, such as $\mathrm{Ti}, \mathrm{Mg}$ and most notably $\mathrm{Fe}$ (e.g. 0.97 wt. \% FeO in melt plagioclase of Table 6.12, compared to 0.43 wt. \% FeO in xenolith plagioclase).

TABLE 6.12: Electron microprobe analyses of host melt-xenolith reactions in a pyroxenite (sample 90048D). See Plate 6.8 for analyses sites.

\begin{tabular}{|c|c|c|c|c|c|c|c|c|c|c|}
\hline $\begin{array}{l}\text { PHASE } \\
\text { SITE }\end{array}$ & Melt & $\begin{array}{l}\text { Plag } \\
\text { melt }\end{array}$ & $\begin{array}{c}\text { Olivine } \\
\text { melt }\end{array}$ & $\begin{array}{c}\text { Oxide } \\
\text { melt }\end{array}$ & $\begin{array}{l}\text { Plag } \\
\text { core }\end{array}$ & $\begin{array}{l}\text { Olivine } \\
\text { core }\end{array}$ & Melt & $\begin{array}{c}\text { Rhönite } \\
\text { melt }\end{array}$ & $\begin{array}{l}\text { Rhönite } \\
\text { melt }\end{array}$ & $\begin{array}{l}\text { Kaer } \\
\text { melt }\end{array}$ \\
\hline & 1 & 2 & 3 & 4 & 5 & 6 & 7 & 8 & 9 & 10 \\
\hline $\mathrm{SiO}_{2}$ & 44.63 & 50.86 & 38.78 & 0.17 & 52.26 & 37.48 & 45.83 & 26.61 & 24.57 & 37.50 \\
\hline $\mathrm{Al} 2 \mathrm{O} 3$ & 14.45 & 29.62 & 0.11 & 9.85 & 29.67 & 0.06 & 12.87 & 17.02 & 16.93 & 14.60 \\
\hline TiO2 & 5.47 & 0.37 & 0.22 & 19.09 & 0.18 & 0.08 & 3.87 & 11.02 & 10.87 & 6.23 \\
\hline $\mathrm{Fe} 2 \mathrm{O} 3$ & & & & 23.67 & & & & & & \\
\hline $\mathrm{FeO}$ & 10.99 & 0.97 & 20.55 & 38.75 & 0.43 & 26.71 & 9.73 & 16.46 & 19.95 & 16.17 \\
\hline $\mathrm{MnO}$ & 0.37 & 0.11 & 0.34 & 0.28 & 0.12 & 0.32 & 0.39 & 0.14 & 0.24 & 0.25 \\
\hline MgO & 5.50 & 0.17 & 39.63 & 7.59 & 0.04 & 35.07 & 7.88 & 16.45 & 13.88 & 7.10 \\
\hline $\mathrm{CaO}$ & 15.25 & 13.04 & 0.40 & 0.05 & 12.17 & 0.20 & 14.15 & 11.31 & 11.68 & 9.66 \\
\hline $\mathrm{Na} 2 \mathrm{O}$ & 1.35 & 4.49 & 0.01 & 0.08 & 5.39 & 0.10 & 4.39 & 1.52 & 1.21 & 2.98 \\
\hline $\mathrm{K} 2 \mathrm{O}$ & 0.83 & 0.23 & 0.02 & 0.03 & 0.33 & 0.02 & 1.64 & 0.05 & 0.01 & 1.74 \\
\hline $\mathrm{Cr} 2 \mathrm{O} 3$ & 0.11 & 0.17 & 0.23 & 0.76 & 0.08 & 0.01 & 0.17 & 0.13 & 0.46 & 0.05 \\
\hline TOTAL & 98.95 & 100.03 & 100.29 & 100.32 & 100.67 & 100.05 & 100.90 & 100.70 & 99.80 & 96.28 \\
\hline $\mathrm{Si}$ & & 2.332 & 1.001 & 0.006 & 2.371 & 0.997 & & 3.500 & 3.335 & 5.038 \\
\hline $\mathrm{Al}$ & & 1.602 & 0.003 & 0.393 & 1.587 & 0.002 & & 2.638 & 2.708 & 2.311 \\
\hline $\mathrm{Ti}$ & & 0.012 & 0.004 & 0.486 & 0.006 & 0.002 & & 1.090 & 1.109 & 0.629 \\
\hline FeIII & & & & 0.603 & & & & & & \\
\hline FeII & & 0.036 & 0.443 & 1.097 & 0.016 & 0.594 & & 1.809 & 2.264 & 1.816 \\
\hline $\mathrm{Mn}$ & & 0.004 & 0.007 & 0.008 & 0.005 & 0.007 & & 0.016 & 0.028 & 0.029 \\
\hline $\mathrm{Mg}$ & & 0.001 & 1.524 & 0.303 & 0.002 & 1.389 & & 3.223 & 2.806 & 1.420 \\
\hline $\mathrm{Ca}$ & & 0.641 & 0.001 & 0.001 & 0.592 & 0.005 & & 1.593 & 1.698 & 1.391 \\
\hline $\mathrm{Na}$ & & 0.400 & 0.000 & 0.001 & 0.474 & 0.005 & & 0.388 & 0.319 & 0.775 \\
\hline K & & 0.013 & 0.001 & 0.000 & 0.019 & 0.001 & & 0.008 & 0.002 & 0.298 \\
\hline $\mathrm{Cr}$ & & 0.006 & 0.005 & 0.100 & 0.003 & 0.000 & & 0.013 & 0.048 & 0.005 \\
\hline TOTAL & & 5.047 & 2.989 & 2.998 & 5.074 & 3.002 & & 14.278 & 14.315 & 13.710 \\
\hline
\end{tabular}

Olivine that has crystallised from the melt (3) is more Mg-rich than xenolith olivine (6) (Fo 77.5 compared to Fo 70.1), and also has higher contents of minor elements, such as $\mathrm{Ti}, \mathrm{Al}$, and $\mathrm{Ca}$.

In another area of this sample, the host magma (7) has crystallised rhönite $(8,9)$, and resulted in the small-scale $(10 \mu \mathrm{m}$-scale) replacement of clinopyroxene by kaersutite (10). One of the rhönite crystals is associated with this replacement 
(8), whereas the other (9) occurs in association with the kaersutite (Chapter 6.5.3). This is the only occurrence of these phases in the Mount Murphy xenolith suite.

\subsubsection{Oxidation of olivine}

Olivine in the xenolith suite has undergone various degrees of oxidation, from slight oxidation, resulting in a rusty appearance of olivine and highlighting cleavage planes, to complex multiple-layer symplectites of olivine, orthopyroxene and melt.

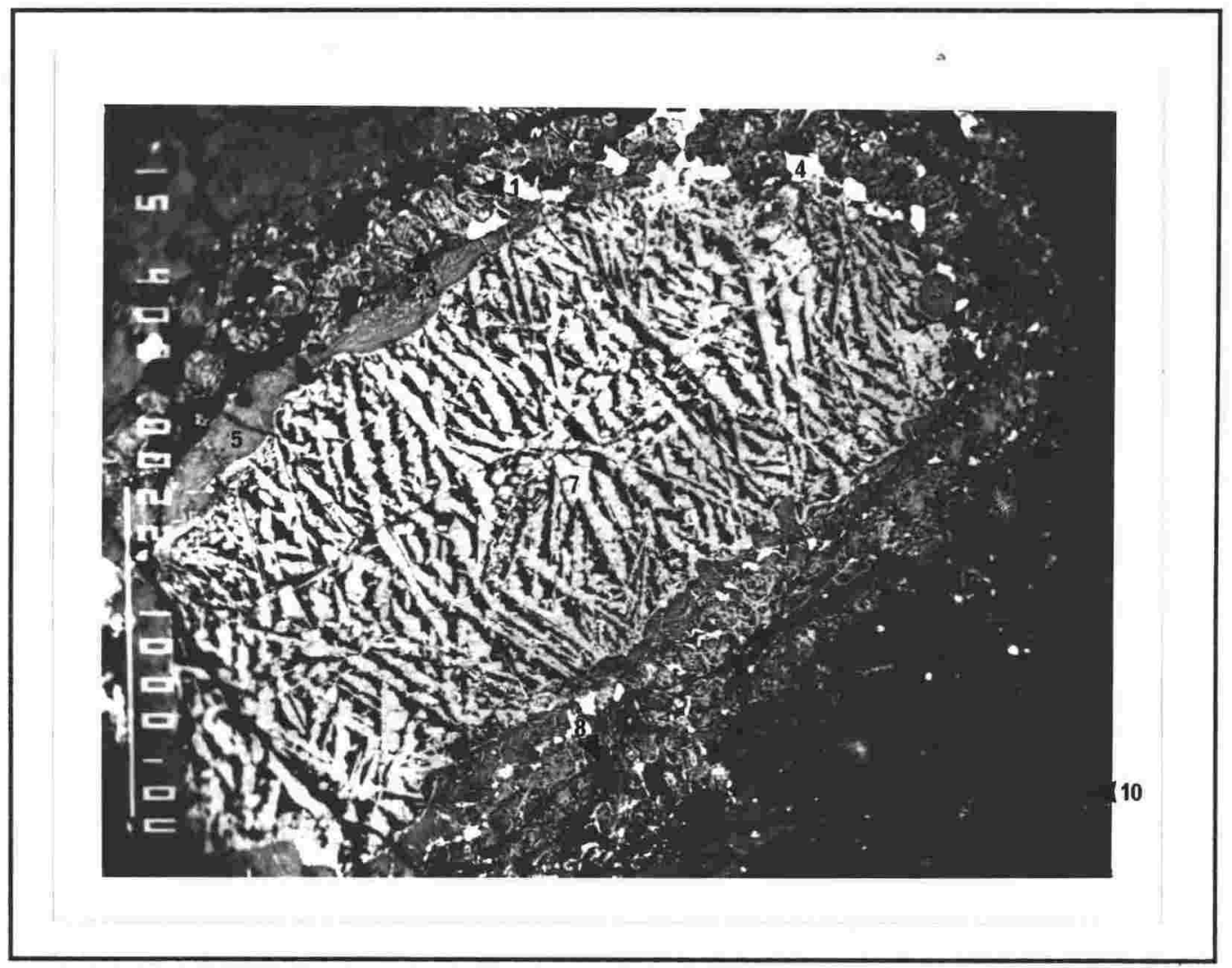

PLATE 6.9: Oxidation of olivine in a granulite (sample 90041A) has resulted in the formation of a symplectite of two phases of olivine in the core and outer rim (lgt grey and dark), with orthopyroxene (med grey) occurring between them. Fe-Ti oxides (white) also occur through the symplectite, but dominantly between the outer symplectite rim and orthopyroxene layer. Analyses of sites 1-10 are presented as Table 6.13. See text for further explanation. Scale bar is $100 \mu \mathrm{m}$.

\section{Sample 90041A: Granulite xenolith (Plate 6.9; Table 6.13)}

Olivine is this sample has been extensively oxidised to form a symplectite. The rim of the symplectite consists of two compositions of olivine and Fe-Ti oxides in a glass matrix. The melt (1) is a trachyandesite in composition, and is the most Si-rich glass analysed in the xenolith suite (Chapter 6.5.4).

Olivine on the symplectite rim consists of an Mg-rich olivine (2; Fo 99) and a more Fe-rich olivine (3; Fo 65). Magnetite (4) rich in $\mathrm{MgO}$ also occurs in the rim. 
Inside this outer rim is a layer of Mg-rich (En 88.1) orthopyroxene (5). The core of the olivine consists of an intergrown symplectite of two compositions of olivine, one Mg-rich (6; Fo 98) and one more Fe-rich (7; Fo 65), with slightly higher proportions (approximately $60 \%$ ) of the more Fe-rich olivine. Bulk composition calculations of the core symplectite indicates an initial olivine composition of approximately Fo 78-81, assuming no enrichment or depletion of Fe or Mg. An original olivine of this composition is similar to olivine compositions from other site 90041 granulites, which range from Fo 73-87.

TABLE 6.13: Electron microprobe analyses of oxidation reactions in a granulite (sample 90041A) resulting in symplectite growth from an olivine. See Plate 6.9 for analyses sites.

\begin{tabular}{|c|c|c|c|c|c|c|c|c|c|c|}
\hline $\begin{array}{l}\text { PHASE } \\
\text { SITE }\end{array}$ & $\begin{array}{c}\text { Melt } \\
\text { symp r } \\
1\end{array}$ & $\begin{array}{c}\text { Olivine } \\
\text { symp r } \\
2\end{array}$ & $\begin{array}{c}\text { Olivine } \\
\text { symp r } \\
3\end{array}$ & $\begin{array}{c}\text { Oxide } \\
\text { symp r } \\
4\end{array}$ & $\begin{array}{c}\text { Opx } \\
\text { symp m } \\
5\end{array}$ & $\begin{array}{c}\text { Olivine } \\
\text { symp c } \\
6\end{array}$ & $\begin{array}{c}\text { Olivine } \\
\text { symp c } \\
7\end{array}$ & $\begin{array}{c}\text { Plag } \\
\text { symp c } \\
8\end{array}$ & $\begin{array}{c}\text { Plag } \\
\text { core } \\
9\end{array}$ & $\begin{array}{c}\text { Cpx } \\
\text { core } \\
10\end{array}$ \\
\hline $\mathrm{SiO} 2$ & 57.69 & 42.63 & 39.41 & 0.39 & 55.35 & 43.01 & 39.47 & 51.11 & 49.70 & 51.51 \\
\hline $\mathrm{Al} 2 \mathrm{O} 3$ & 17.62 & 0.08 & 0.93 & 2.31 & 2.41 & 0.00 & 0.04 & 30.06 & 31.94 & 3.26 \\
\hline $\mathrm{TiO} 2$ & 0.46 & 0.04 & 0.26 & 0.16 & 0.06 & 0.00 & 0.00 & 0.03 & 0.01 & 0.58 \\
\hline $\mathrm{Fe} 2 \mathrm{O} 3$ & 0.00 & & & 74.62 & 2.81 & & & & & 1.89 \\
\hline $\mathrm{FeO}$ & 6.78 & 1.19 & 28.69 & 4.00 & 5.29 & 2.35 & 28.92 & 0.19 & 0.18 & 4.88 \\
\hline $\mathrm{MnO}$ & 0.17 & 0.31 & 0.57 & 0.66 & 0.33 & 0.22 & 0.39 & 0.00 & 0.05 & 0.20 \\
\hline $\mathrm{MgO}$ & 2.98 & 55.92 & 29.19 & 17.79 & 33.81 & 54.79 & 30.47 & 0.01 & 0.05 & 13.74 \\
\hline $\mathrm{CaO}$ & 5.80 & 0.17 & 0.76 & 0.06 & 0.28 & 0.00 & 0.04 & 14.28 & 14.46 & 22.85 \\
\hline $\mathrm{Na} 2 \mathrm{O}$ & 6.96 & 0.12 & 0.28 & 0.40 & 0.12 & 0.00 & 0.10 & 4.27 & 3.65 & 0.66 \\
\hline $\mathrm{K} 2 \mathrm{O}$ & 1.19 & 0.02 & 0.05 & 0.06 & 0.04 & 0.00 & 0.00 & 0.07 & 0.00 & 0.05 \\
\hline $\mathrm{Cr} 2 \mathrm{O} 3$ & 0.08 & 0.17 & 0.31 & 0.04 & 0.12 & 0.16 & 0.09 & 0.00 & 0.00 & 0.63 \\
\hline TOTAL & 99.71 & 100.63 & 100.44 & 100.48 & 100.61 & 100.53 & 99.52 & 100.02 & 100.04 & 100.24 \\
\hline Si & & 0.999 & 1.049 & 0.013 & 1.921 & 1.011 & 1.057 & 2.335 & 2.269 & 1.911 \\
\hline Al & & 0.002 & 0.028 & 0.091 & 0.097 & 0.000 & 0.001 & 1.618 & 1.718 & 0.142 \\
\hline $\mathrm{Ti}$ & & 0.001 & 0.005 & 0.004 & 0.001 & 0.000 & 0.000 & 0.001 & 0.000 & 0.016 \\
\hline FeIII & & & & 1.874 & 0.073 & & & & & 0.052 \\
\hline FeII & & 0.023 & 0.638 & 0.112 & 0.153 & 0.046 & 0.648 & 0.007 & 0.007 & 0.151 \\
\hline Mn & & 0.006 & 0.013 & 0.019 & 0.009 & 0.004 & 0.009 & 0.000 & 0.002 & 0.006 \\
\hline $\mathrm{Mg}$ & & 1.952 & 1.157 & 0.885 & 1.748 & 1.919 & 1.216 & 0.001 & 0.004 & 0.759 \\
\hline $\mathrm{Ca}$ & & 0.004 & 0.021 & 0.002 & 0.010 & 0.000 & 0.001 & 0.699 & 0.707 & 0.908 \\
\hline $\mathrm{Na}$ & & 0.005 & 0.014 & 0.000 & 0.008 & 0.000 & 0.005 & 0.378 & 0.323 & 0.047 \\
\hline K & & 0.000 & 0.002 & 0.000 & 0.002 & 0.000 & 0.000 & 0.004 & 0.000 & 0.002 \\
\hline $\mathrm{Cr}$ & & 0.003 & 0.006 & 0.001 & 0.003 & 0.003 & 0.002 & 0.000 & 0.000 & 0.018 \\
\hline TOTAL & & 2.996 & 2.933 & 3.001 & 4.026 & 2.983 & 2.939 & 5.041 & 5.031 & 4.014 \\
\hline
\end{tabular}


A small plagioclase (8) crystal on the rim of the symplectite has a sieved texture, showing signs of disequilibrium with the glass in the rim. The composition of this plagioclase is more Na-rich (An 65 compared to a range of An 67-74 for other plagioclase) than unaffected plagioclase elsewhere in the sample (e.g. 9; not shown in Plate 6.9).

Olivine has been oxidised throughout the sample, and clinopyroxene (10) is the only other mineral phase.

\section{Sample 90041I: Granulite xenolith (Plate 6.10; Table 6.14)}

Unlike the previous sample (90041A), olivine in this sample has only been mildly oxidised, without the formation of symplectites. In thin section they are easily recognisable as olivine, with opaque oxidised rims, and a rusty appearance that highlights their cleavage planes.

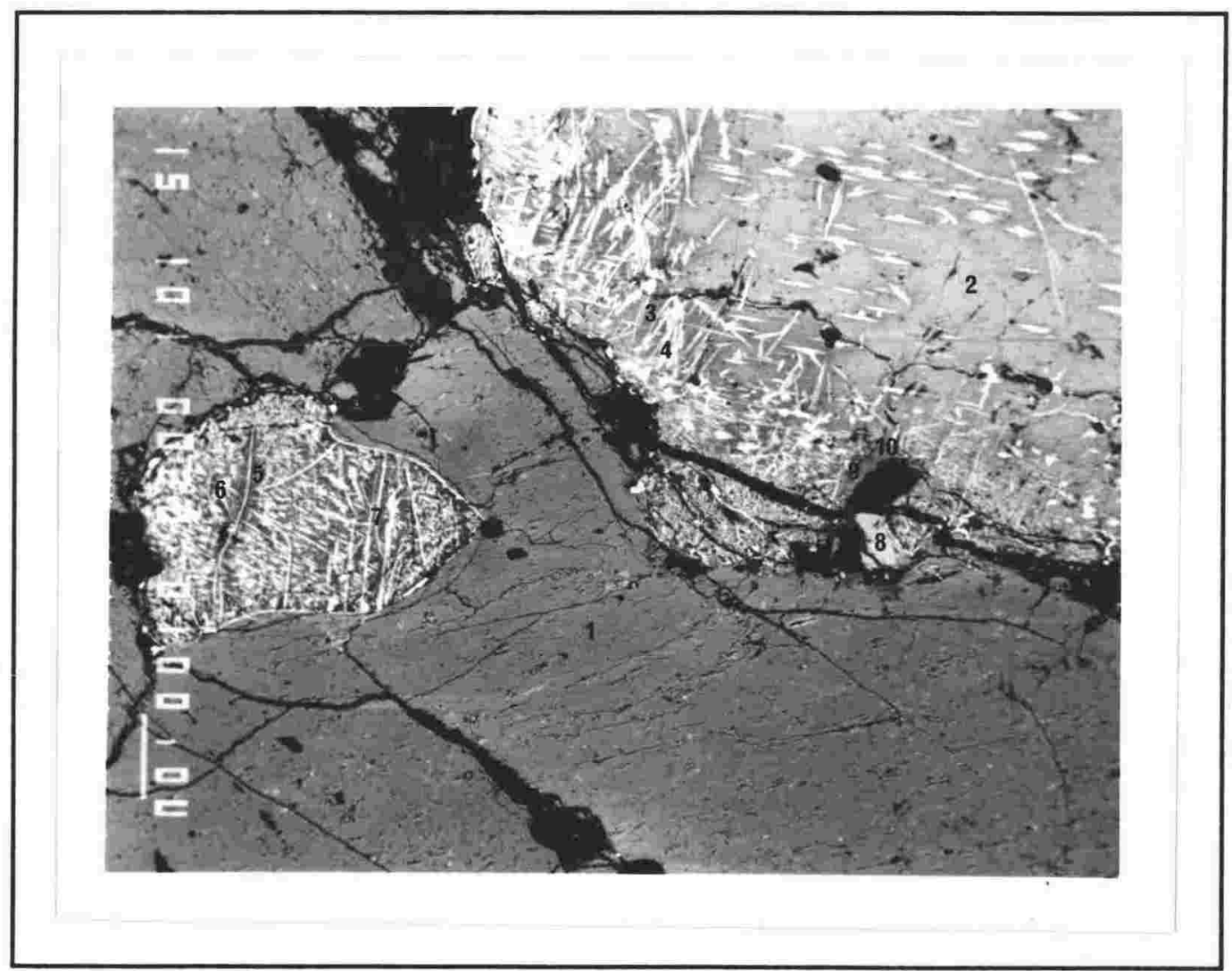

PLATE 6.10: Oxidation reactions of olivine (lgt grey) in a granulite (sample 90041I). A small olivine (centre left), and a large olivine (top right), have been oxidised, breaking down into two phases of olivine, one Mg-rich (white), and the other more Fe-rich (darker grey), as well as small Fe-oxides (bright white). Plagioclase (med grey) surrounds the olivines. Analyses of sites 1-10 are presented as Table 6.14. See text for further explanation. Scale bar is $100 \mu \mathrm{m}$.

In Plate 6.10, two oxidised olivine grains occur in plagioclase (1). The larger grain (top right) has an oxidised core (2), whereas the smaller olivine is oxidised 
throughout. Oxidation has resulted in the breakdown of the large olivines at its rim into two phases; one Mg-rich (3), and the other more Fe-rich (4). The smaller olivine has also broken down into two phases $(5,6)$.

TABLE 6.14: Electron microprobe analyses of oxidation reactions in a granulite (sample 90041I). See Plate 6.10 for analyses sites.

\begin{tabular}{|c|c|c|c|c|c|c|c|c|c|c|}
\hline $\begin{array}{l}\text { PHASE } \\
\text { SITE }\end{array}$ & $\begin{array}{c}\text { Plag } \\
\text { core } \\
1 \\
\end{array}$ & $\begin{array}{c}\text { Olivine } \\
\text { core } \\
2 \\
\end{array}$ & $\begin{array}{c}\text { Olivine } \\
\text { oxid. } \\
3 \\
\end{array}$ & $\begin{array}{c}\text { Olivine } \\
\text { oxid. } \\
4\end{array}$ & $\begin{array}{c}\text { Olivine } \\
\text { oxid. } \\
5\end{array}$ & $\begin{array}{c}\text { Olivine } \\
\text { oxid. } \\
6 \\
\end{array}$ & $\begin{array}{c}\text { Oxide } \\
\text { oxid. } \\
7 \\
\end{array}$ & $\begin{array}{c}\text { Cpx } \\
\text { oxid. } \\
8 \\
\end{array}$ & $\begin{array}{c}\text { Plag } \\
\text { oxid. } \\
9 \\
\end{array}$ & $\begin{array}{c}\text { Plag } \\
\text { oxid. } \\
10\end{array}$ \\
\hline $\mathrm{SiO}_{2}$ & 47.61 & 39.18 & 41.59 & 36.93 & 42.23 & 37.79 & 0.11 & 53.64 & 45.75 & 56.83 \\
\hline $\mathrm{A} 12 \mathrm{O} 3$ & 32.77 & 0.01 & 0.00 & 0.01 & 0.00 & 0.00 & 0.05 & 2.15 & 33.43 & 25.60 \\
\hline $\mathrm{TiO} 2$ & 0.03 & 0.04 & 0.00 & 0.01 & 0.00 & 0.01 & 0.08 & 0.11 & 0.03 & 0.11 \\
\hline $\mathrm{Fe} 2 \mathrm{O} 3$ & & & & & & & 79.86 & 1.49 & & \\
\hline $\mathrm{FeO}$ & 0.15 & 18.58 & 10.07 & 48.60 & 8.62 & 37.88 & 8.56 & 4.65 & 0.82 & 1.00 \\
\hline $\mathrm{MnO}$ & 0.04 & 0.31 & 0.10 & 0.18 & 0.10 & 0.25 & 0.24 & 0.24 & 0.09 & 0.01 \\
\hline $\mathrm{MgO}$ & 0.06 & 41.88 & 48.04 & 12.85 & 49.82 & 24.39 & 15.29 & 19.41 & 0.14 & 0.22 \\
\hline $\mathrm{CaO}$ & 16.66 & 0.05 & 0.01 & 0.14 & 0.03 & 0.04 & 0.07 & 18.07 & 17.40 & 8.65 \\
\hline $\mathrm{Na} 2 \mathrm{O}$ & 2.12 & 0.00 & 0.00 & 0.27 & 0.01 & 0.01 & 0.06 & 0.34 & 1.62 & 5.63 \\
\hline $\mathrm{K} 2 \mathrm{O}$ & 0.10 & 0.00 & 0.00 & 0.01 & 0.01 & 0.03 & 0.02 & 0.00 & 0.07 & 0.60 \\
\hline $\mathrm{Cr} 2 \mathrm{O} 3$ & 0.11 & 0.00 & 0.02 & 0.07 & 0.05 & 0.12 & 0.17 & 0.08 & 0.04 & 0.09 \\
\hline TOTAL & 99.65 & 100.05 & 99.83 & 99.07 & 100.87 & 100.52 & 104.51 & 100.17 & 99.39 & 98.74 \\
\hline $\mathrm{Si}$ & 2.194 & 1.000 & 1.018 & 1.100 & 1.017 & 1.049 & 0.003 & 1.948 & 2.129 & 2.591 \\
\hline $\mathrm{Al}$ & 1.780 & 0.000 & 0.000 & 0.000 & 0.000 & 0.000 & 0.002 & 0.094 & 1.833 & 1.375 \\
\hline $\mathrm{Ti}$ & 0.001 & 0.001 & 0.000 & 0.000 & 0.000 & 0.000 & 0.002 & 0.003 & 0.001 & 0.004 \\
\hline FeIII & & & & & & & 1.983 & 0.041 & & \\
\hline FeII & 0.006 & 0.397 & 0.206 & 1.210 & 0.173 & 0.879 & 0.236 & 0.141 & 0.032 & 0.038 \\
\hline $\mathrm{Mn}$ & 0.001 & 0.007 & 0.002 & 0.005 & 0.002 & 0.006 & 0.007 & 0.007 & 0.004 & 0.000 \\
\hline $\mathrm{Mg}$ & 0.004 & 1.592 & 1.752 & 0.570 & 1.787 & 1.009 & 0.752 & 1.050 & 0.010 & 0.015 \\
\hline $\mathrm{Ca}$ & 0.822 & 0.001 & 0.000 & 0.004 & 0.001 & 0.001 & 0.002 & 0.703 & 0.867 & 0.422 \\
\hline $\mathrm{Na}$ & 0.189 & 0.000 & 0.000 & 0.016 & 0.001 & 0.001 & 0.002 & 0.024 & 0.146 & 0.497 \\
\hline K & 0.006 & 0.000 & 0.000 & 0.000 & 0.000 & 0.001 & 0.002 & 0.000 & 0.004 & 0.035 \\
\hline $\mathrm{Cr}$ & 0.004 & 0.000 & 0.000 & 0.002 & 0.001 & 0.003 & 0.005 & 0.002 & 0.001 & 0.003 \\
\hline TO? & 5.007 & 2.998 & 2.978 & 2.907 & 2.982 & 2.949 & 2.996 & 4.012 & 5.026 & 4.980 \\
\hline
\end{tabular}

Fe-Ti oxides have formed along the rim of, and in veins through, the olivine (7). Small clinopyroxenes (8), and two phases of plagioclase (one Ca-rich (9), the other Ca-poor (10)) also occur along the rim of the larger olivine. The plagioclase is $\mathrm{Fe}$ - and $\mathrm{Mg}$-rich compared to xenolith plagioclase (1). 
Sample 90054I: Granulite xenolith (Plate 6.11; Table 6.15)

The oxidation of olivine in pyroxenites is similar to that in granulites (e.g. sample 90041I), resulting in the breakdown of the olivine (1) into two phases $(2,3)$, The extent of oxidation diminishes from the rim to the core of the olivine, which is unaffected by the oxidation e.g. the core of the oxidised olivine (1) is similar in composition to unoxidised olivine cores (4; not shown in Plate 6.11) elsewhere in the sample.

TABLE 6.15: Electron microprobe analyses of oxidation reactions in a pyroxenite (sample 90054A). See Plate 6.11 for analyses sites.

\begin{tabular}{|c|c|c|c|c|c|c|c|c|c|c|}
\hline $\begin{array}{l}\text { PHASE } \\
\text { SITE }\end{array}$ & $\begin{array}{c}\text { Olivine } \\
\text { core } \\
\mathbf{1}\end{array}$ & $\begin{array}{c}\text { Olivine } \\
\text { oxid. } \\
2\end{array}$ & $\begin{array}{c}\text { Olivine } \\
\text { oxid. } \\
3\end{array}$ & $\begin{array}{c}\text { Olivine } \\
\text { core } \\
4\end{array}$ & $\begin{array}{c}\text { Oxide } \\
\text { oxid. } \\
5\end{array}$ & $\begin{array}{c}\text { Oxide } \\
\text { oxid. } \\
6\end{array}$ & $\begin{array}{c}\text { Plag } \\
\text { oxid. } \\
7\end{array}$ & $\begin{array}{c}\text { Cpx } \\
\text { oxid. } \\
8\end{array}$ & $\begin{array}{c}\text { Cpx } \\
\text { core } \\
9\end{array}$ & $\begin{array}{c}\text { Cpx } \\
\text { core } \\
10\end{array}$ \\
\hline $\mathrm{SiO} 2$ & 38.62 & 40.19 & 37.52 & 38.80 & 0.48 & 6.05 & 54.41 & 48.27 & 48.74 & 49.07 \\
\hline $\mathrm{Al} 2 \mathrm{O} 3$ & 0.04 & 0.00 & 0.35 & 0.04 & 1.43 & 0.89 & 28.14 & 7.25 & 7.75 & 8.47 \\
\hline $\mathrm{TiO} 2$ & 0.04 & 0.02 & 0.05 & 0.11 & 0.49 & 0.16 & 0.21 & 1.89 & 1.38 & 1.67 \\
\hline $\mathrm{Fe} 2 \mathrm{O} 3$ & & & & & 73.99 & 53.72 & & 1.81 & 3.65 & 2.01 \\
\hline $\mathrm{FeO}$ & 19.61 & 13.65 & 44.62 & 17.66 & 1.61 & 31.78 & 0.62 & 4.43 & 2.83 & 3.68 \\
\hline $\mathrm{MnO}$ & 0.19 & 0.26 & 0.34 & 0.35 & 0.42 & 0.29 & 0.12 & 0.15 & 0.27 & 0.08 \\
\hline $\mathrm{MgO}$ & 41.68 & 45.38 & 16.03 & 43.30 & 18.91 & 3.87 & 0.12 & 13.70 & 14.22 & 14.05 \\
\hline $\mathrm{CaO}$ & 0.11 & 0.11 & 0.34 & 0.33 & 0.21 & 0.19 & 11.01 & 22.07 & 20.20 & 20.04 \\
\hline $\mathrm{Na} 2 \mathrm{O}$ & 0.01 & 0.00 & 0.23 & 0.09 & 0.15 & 0.49 & 5.33 & 0.46 & 1.07 & 1.22 \\
\hline $\mathrm{K} 2 \mathrm{O}$ & 0.04 & 0.00 & 0.05 & 0.06 & 0.04 & 0.12 & 0.26 & 0.05 & 0.04 & 0.00 \\
\hline $\mathrm{Cr} 2 \mathrm{O} 3$ & 0.10 & 0.10 & 0.21 & 0.20 & 0.09 & 0.19 & 0.09 & 0.39 & 0.43 & 0.04 \\
\hline TOTAL & 100.44 & 99.71 & 99.74 & 100.94 & 97.83 & 97.74 & 100.31 & 100.46 & 100.58 & 100.33 \\
\hline $\mathrm{Si}$ & 0.987 & 1.004 & 1.085 & 0.981 & 0.016 & 0.224 & 2.459 & 1.780 & 1.790 & 1.796 \\
\hline $\mathrm{Al}$ & 0.001 & 0.000 & 0.012 & 0.001 & 0.057 & 0.039 & 1.499 & 0.320 & 0.342 & 0.365 \\
\hline $\mathrm{Ti}$ & 0.001 & 0.000 & 0.001 & 0.002 & 0.012 & 0.004 & 0.007 & 0.053 & 0.039 & 0.045 \\
\hline FeIII & & & & & 1.883 & 1.499 & & 0.050 & 0.100 & 0.055 \\
\hline FeII & 0.419 & 0.285 & 1.079 & 0.373 & 0.045 & 0.985 & 0.024 & 0.136 & 0.086 & 0.112 \\
\hline Mn & 0.004 & 0.005 & 0.008 & 0.007 & 0.012 & 0.009 & 0.005 & 0.005 & 0.008 & 0.002 \\
\hline Mg & 1.588 & 1.689 & 0.691 & 1.631 & 0.953 & 0.214 & 0.008 & 0.753 & 0.778 & 0.766 \\
\hline $\mathrm{Ca}$ & 0.003 & 0.003 & 0.010 & 0.009 & 0.007 & 0.008 & 0.533 & 0.872 & 0.794 & 0.786 \\
\hline $\mathrm{Na}$ & 0.000 & 0.000 & 0.013 & 0.005 & 0.001 & 0.001 & 0.467 & 0.033 & 0.078 & 0.086 \\
\hline K & 0.001 & 0.000 & 0.002 & 0.002 & 0.000 & 0.000 & 0.015 & 0.002 & 0.002 & 0.000 \\
\hline $\mathrm{Cr}$ & 0.002 & 0.002 & 0.005 & 0.004 & 0.002 & 0.006 & 0.003 & 0.011 & 0.013 & 0.011 \\
\hline TOTAL & 3.006 & 2.988 & 2.906 & 3.015 & 2.988 & 2.989 & 5.019 & 4.014 & 4.030 & 4.024 \\
\hline
\end{tabular}

A variety of small microphenocrysts occur along the rim of the oxidised olivine, including Fe-Ti oxides (5) (which also occur as small microphenocrysts 
within the olivine and as veins along cleavage planes (6)), and plagioclase (7). A clinopyroxene associated with plagioclase on the olivine rim (8) is Ca-rich, and Aland Na-poor compared to its composition away from the plagioclase (9), which is similar to clinopyroxene elsewhere (10; not shown in Plate 6.11).

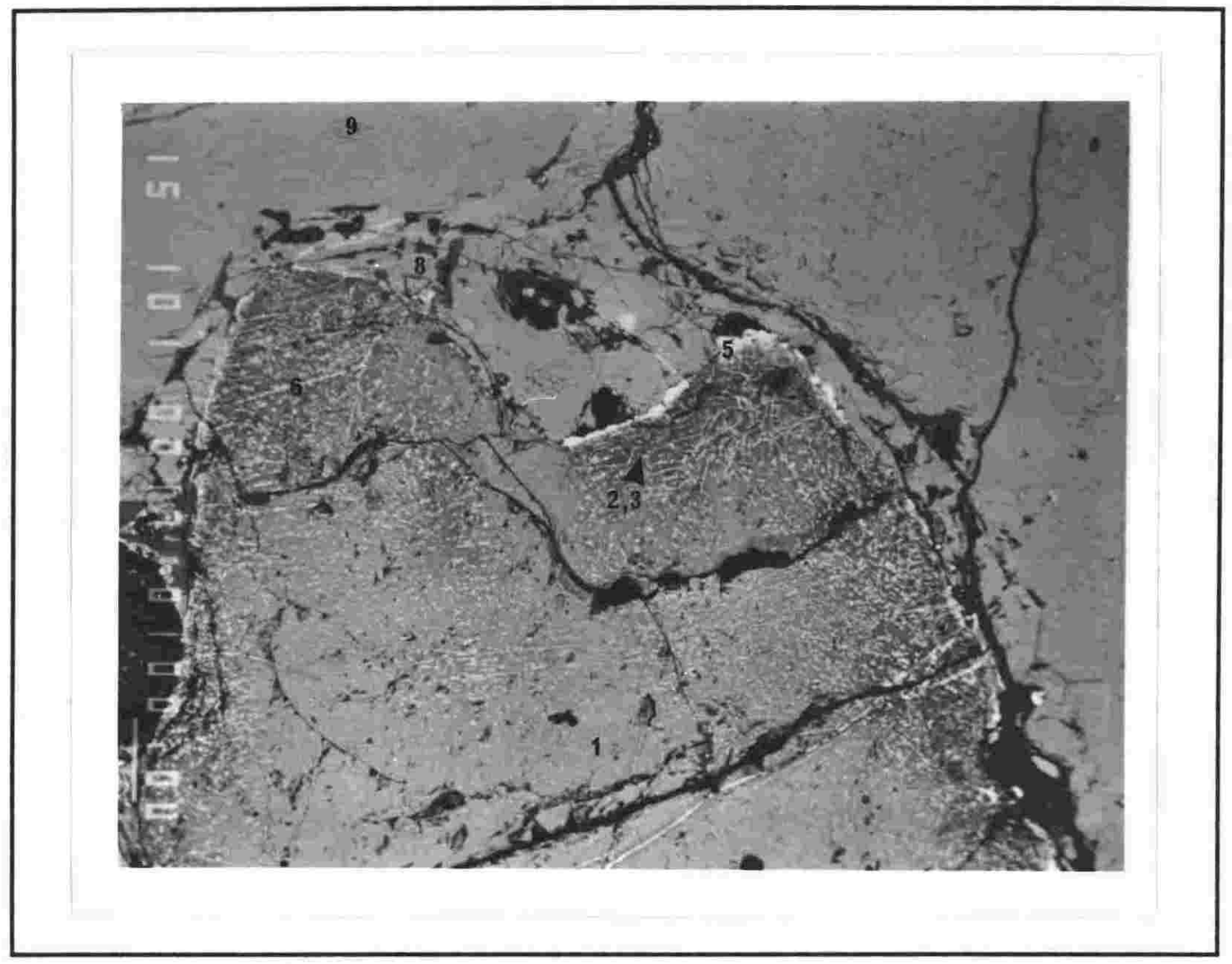

PLATE 6.11: Oxidation reactions of an olivine in a pyroxenite (sample 90054I). The olivine (med grey), has been oxidised at its rim into two phases; one Mg-rich (white), and the other more Fe-rich (darker grey). Small Fe-Ti oxides (bright white) also occur on olivine rims, as well as along cleavage planes. Plagioclase (darkest grey) forms at the rim between the olivine and clinopyroxene (light grey). Analyses of sites 1-10 are presented as Table 6.15. See text for explanation. Scale bar is $100 \mu \mathrm{m}$.

\subsubsection{Secondary mineral chemistry}

Oxidation processes and the reaction of the host melt with the xenoliths has altered the chemistry of primary minerals. This section seeks to determine the chemical changes brought about by oxidation and reactions with infiltrating host melts on the primary xenolith mineral assemblage. Compositions of phases that have crystallised directly from infiltrating host melts (plagioclase + olivine \pm oxides \pm rhönite) are also documented. Full analyses of these phases can be found in Tables relating to secondary mineral reactions (Tables 6.10 to 6.15), and in Appendix 3.3.

The oxidation of olivine has resulted in the breakdown of the olivine into two phases; one Mg-rich, and the other more Fe-rich (Chapter 6.5.2). Symplectite 
compositions of olivines from sample 90041 (Chapter 6.5.2) are plotted in Figure 6.13 , together with compositions of oxidised olivines from site 90041 granulites and site 90054 pyroxenites, as well as olivines that have crystallised from host melts that have infiltrated xenoliths from all sites. Fields of unoxidised olivines are also shown.

Mg-rich symplectite olivines from sample 90041 granulites are forsteritic (Fo 98-99), whereas more Fe-rich symplectite olivine compositions range from Fo 64-65. Both phases differ from original olivine compositions (Fo 81-84) by similar amounts, indicating breakdown into even amounts of each phase, maintaining the original bulk composition. In contrast, oxidised olivines that have not formed symplectites consist of one composition similar to the original olivine composition, and another composition far more Fo-poor than the original composition. The Fo-poor olivine is less abundant than Fo-rich olivine, maintaining the bulk composition of the original olivine phase.

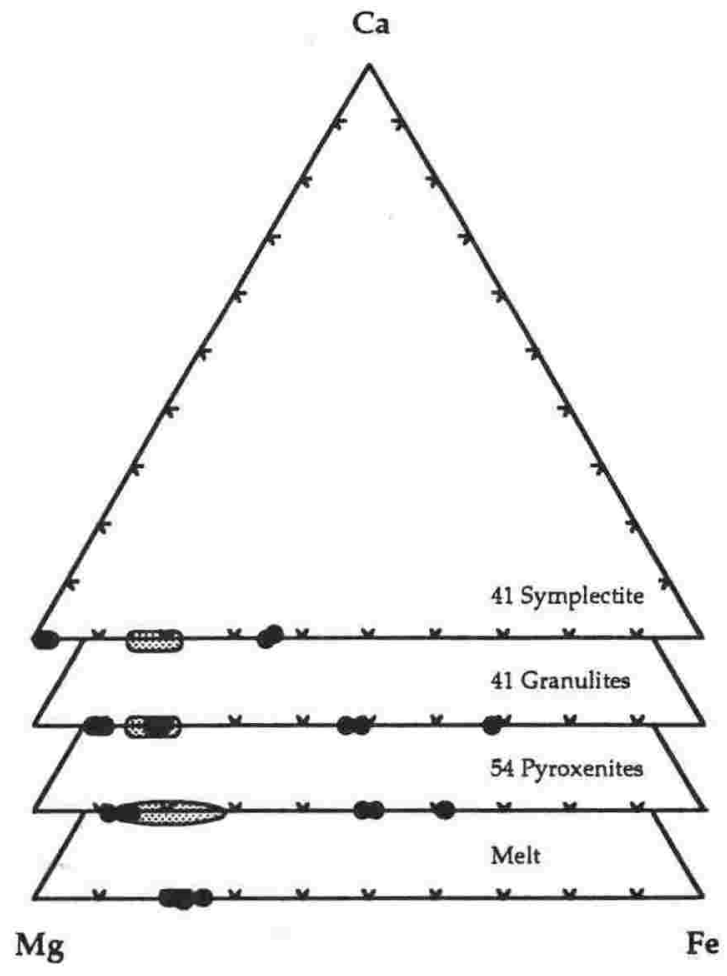

FIGURE 6.13: Compositions of secondary olivines in Mount Murphy xenoliths plotted in the system Ca-Mg-Fe. Shaded fields indicate compositional fields of primary olivines from site 90041 granulites and site 90054 pyroxenites. Symplectite olivines from site 90041 granulites have broken down into two compositions, that differ from the original olivine composition by similar amounts. In contrast, the products of slightly oxidised olivines include a Fo-rich olivine similar in composition to original olivine, and a Fo-poor olivine very different in composition. The two olivine phases include a Fo-poor exsolved olivine and a Fo-rich residual olivine. Olivines that have crystallised from host melts are similar in composition to pyroxenite olivines.

The difference in composition between olivines that have been fully oxidised to symplectites, and those that have only been slightly oxidised, suggests that with continued oxidation the two breakdown phases become more Fo-rich, maintaining bulk composition. This would further indicate that the Fo-rich olivine, which starts off closer to the original olivine in composition, is the residual olivine and that it is the Fo-poor olivine that has been exsolved. 
The composition of the olivine phases is otherwise identical to unoxidised olivines (e.g. similar $\mathrm{CaO}$ and $\mathrm{MnO}$ content). The breakdown of olivine into two phases is the only result of the oxidation process.

Olivines that have crystallised from infiltrating host melts range in composition from Fo 72-81. These are similar to pyroxenite olivines, indicating that the melt that crystallised the pyroxenite olivines may have been similar in $\mathrm{Mg} \#$ to the host melts. Olivines from host melts however have much higher $\mathrm{CaO}$ contents than xenolith olivines. This is probably a result of their lower pressures of formation, as low pressure olivines are able to incorporate greater amounts of Ca into their lattice (Finnerty and Boyd, 1978).

Minor amounts of secondary pyroxenes occur in the xenolith suite, as exsolutions in clinopyroxene, and associated with oxidised olivines. The compositions of both these phases are plotted in Figure 6.14.

a)

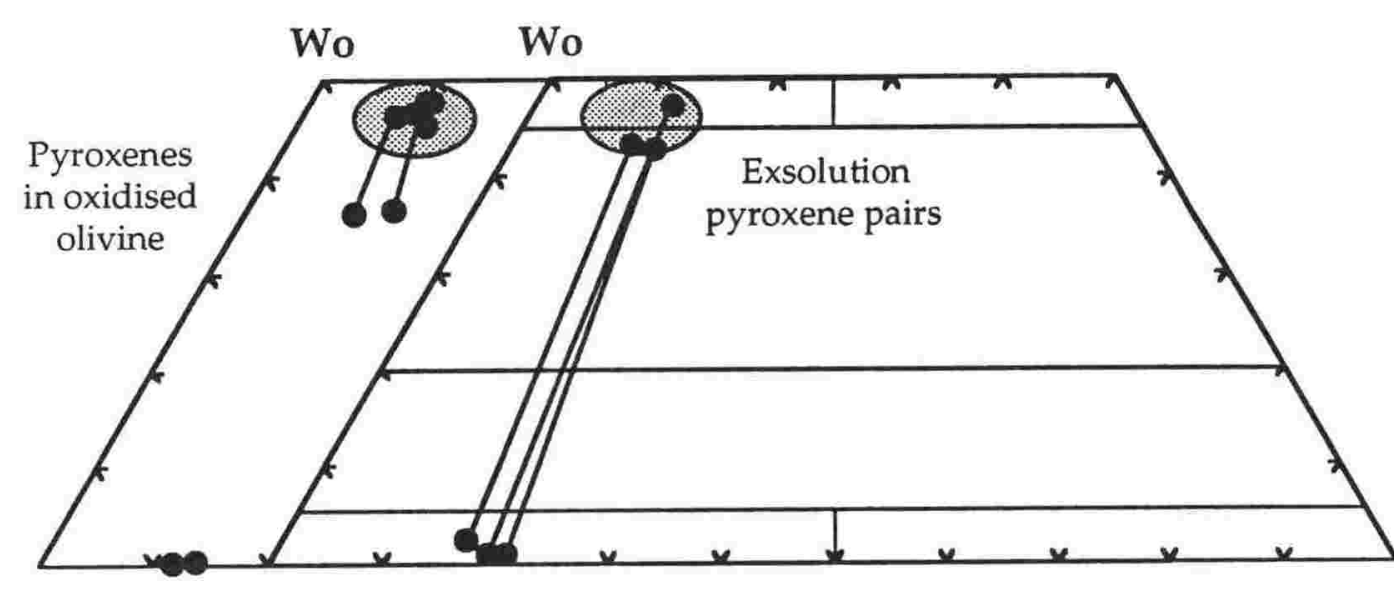

En

En b)

Fs

FIGURE 6.14: Compositions of secondary pyroxenes from the Mount Murphy xenolith suite in the system Wo-En-Fs (fields are those of Morimoto et al., 1988), including: a) pyroxenes associated with oxidised olivines; b) and coexisting clinopyroxene and exsolved orthopyroxene pairs, with tie-lines indicating pairs. The field of site 90041 granulite and site 90054 pyroxenite clinopyroxenes are shown for comparison. Oxidised pyroxenes include clinopyroxenes similar in composition to xenolith clinopyroxenes, indicating that they are also primary phases, and clinopyroxenes and orthopyroxenes significantly more Ca-poor, which are probably secondary in origin. Ca-rich clinopyroxenes have exsolved relatively Ca-poor orthopyroxenes, indicating a change in temperature during exsolution.

Clinopyroxenes associated with oxidised olivines include compositions identical to primary xenolith clinopyroxenes, indicating that they are primary in origin and have not been affected by oxidation, and compositions significantly more Ca-poor, including two orthopyroxenes. Tie lines between primary clinopyroxenes and their oxidised areas are shown in Figure 6.14a and indicate a 
depletion in $\mathrm{Ca}$ in oxidised clinopyroxenes, possibly due to unmixing. Compositions of xenolith clinopyroxenes that have exsolved orthopyroxene are also shown with tie-lines indicating pyroxene pairs (Figure 6.14b). Ca-rich clinopyroxenes coexist with more Ca-poor exsolved orthopyroxenes than clinopyroxenes that are not as Ca-rich. This suggests a change in temperature during exsolution, as with falling temperature clinopyroxenes become more $\mathrm{Ca}$ rich, and exsolved orthopyroxenes become progressively more Ca-poor.

Another major difference between oxidised clinopyroxenes and primary xenolith clinopyroxenes is the higher content of $\mathrm{Fe}^{3+}$ in oxidised clinopyroxene, as $\mathrm{Fe}^{2+}$ is oxidised to $\mathrm{Fe}^{3+}$.

Plagioclase has also been affected by secondary processes, notably by reactions with the infiltrating host melts. Anorthite contents of xenolith plagioclase are varied (An 42-88) (Figure 6.15). In contrast, plagioclase that has crystallised directly from the infiltrating host melts have a restricted range in An content (An 60-65). Melt-affected xenolith plagioclase have a similar range in An content (An 43-85) to primary xenolith plagioclase, indicating that their An composition has not been affected by host melt alteration.

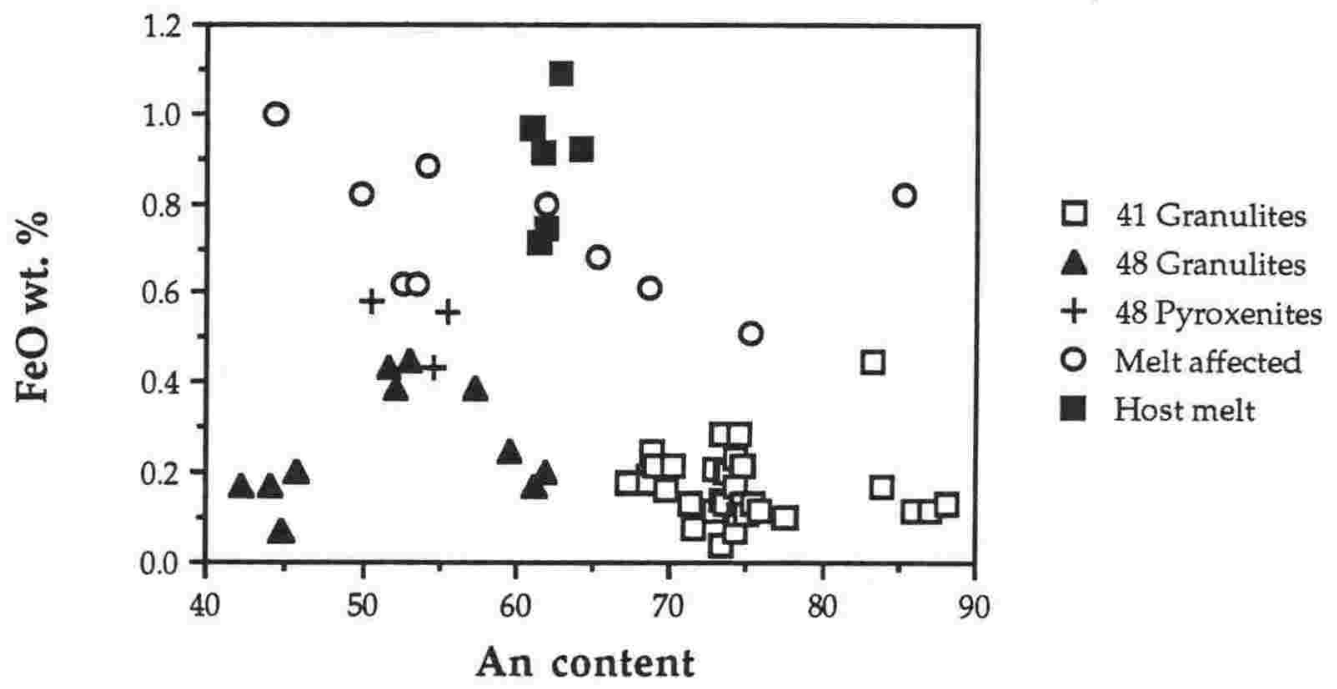

FIGURE 6.15: FeO and An contents of primary xenolith plagioclase that have been affected by infiltrating host melts (melt-affected), compared to unaltered xenolith plagioclase compositions (from site 41 granulites, 48 granulites and 48 pyroxenites), and plagioclase that has crystallised directly from the infiltrating melts (host melt). Melt-derived plagioclase have similar An contents to unaffected plagioclase, whereas host melt plagioclase have restricted An contents. FeO contents of melt-affected plagioclase however have higher $\mathrm{FeO}$ contents than unaltered plagioclase, which are similar to host melt plagioclase. Host-melt alteration of primary xenolith plagioclase does not alter their An content, but does result in an enrichment of $\mathrm{FeO}$.

The $\mathrm{FeO}$ content of melt-affected plagioclase however has been enriched by melt interaction (Figure 6.15). Xenolith plagioclase have low $\mathrm{FeO}$ contents of up to 


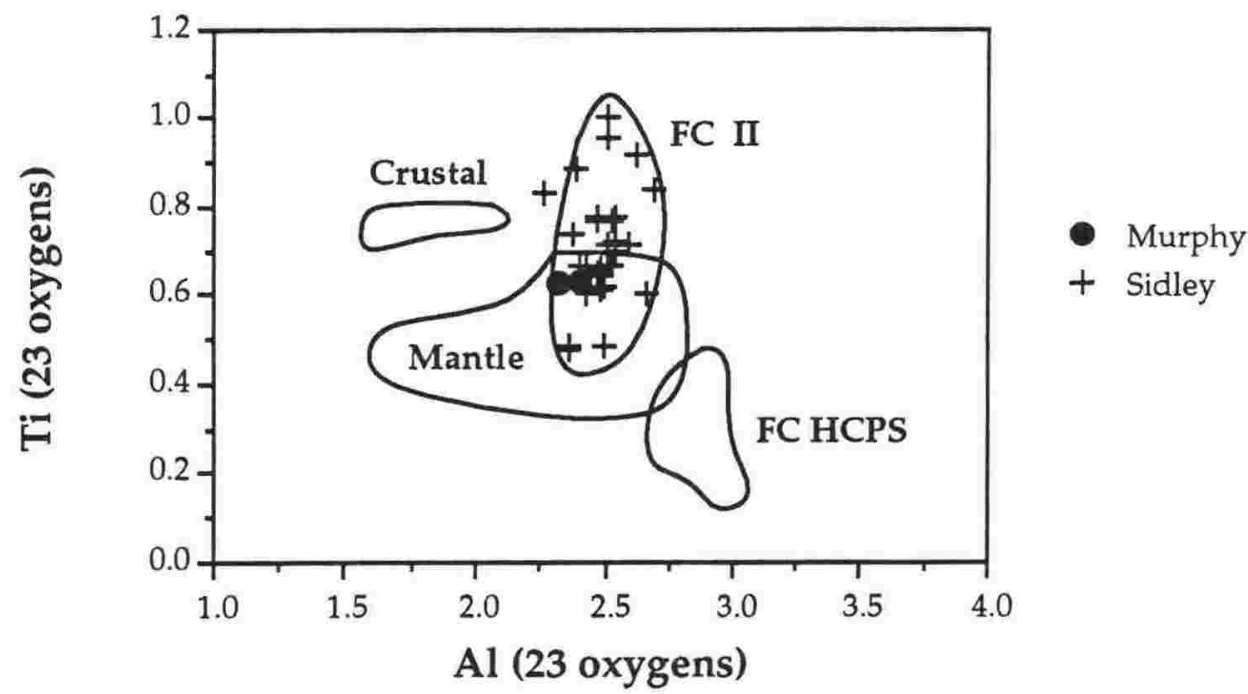

FIGURE 6.16: Kaersutite occurs in a single pyroxenite (sample 90048D), associated with infiltrating host melts, where it has partially replaced primary xenolith clinopyroxene. The composition of the kaersutite is similar to kaersutites that have replaced clinopyroxene in the Mount Sidley xenolith suite, and to kaersutites occurring in Group II xenoliths from Foster Crater (FC GPII field), in the Transantarctic Mountains (Gamble et al., 1988). Fields of crustal and mantle kaersutites are those of Vinx and Jung (1977). Note the composition of kaersutites from Mount Murphy, Mount Sidley and Foster Crater, which defines a lower crustal field, spanning into the mantle field.

0.60 wt. $\% \mathrm{FeO}$, whereas plagioclase that have crystallised from the host melts have higher $\mathrm{FeO}$ contents of 0.7-1.1 wt. \% FeO. Melt-affected xenolith plagioclase also have high $\mathrm{FeO}$ contents $(0.5-1.0$ wt. \% FeO), indicating that they have been enriched in $\mathrm{FeO}$ by the host melts.

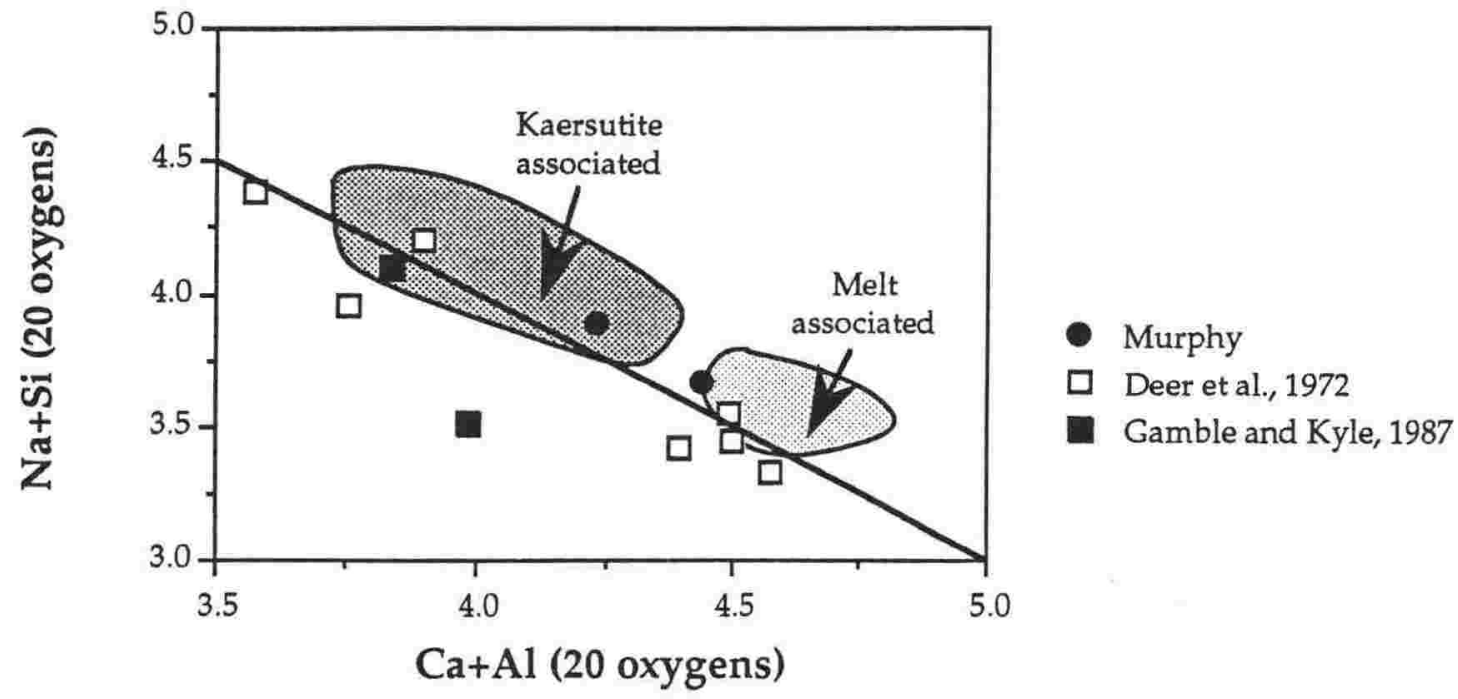

FIGURE 6.17: $\mathrm{Ca}+\mathrm{Al}$ and $\mathrm{Na}+\mathrm{Si}$ compositions of rhönites in a Mount Murphy pyroxenite (Sample 90048D), found in association with infiltrating host melts which have partially replaced clinopyroxene with kaersutite. Fields of rhönites from Mount Sidley found in association with kaersutite and of rhönites that have crystallised directly from the host melt are shown. One Mount Murphy rhönite crystallised directly from the host melt whereas the other is found in association with kaersutite; both plot in their respective fields. 
TABLE 6.16: Representative electron microprobe analyses of secondary oxides in the Mount Murphy xenolith suite, consisting of $\mathrm{Fe}-\mathrm{Ti}$ oxides that have crystallised from infiltrating host melts.

\begin{tabular}{|c|c|c|c|c|c|c|c|c|c|c|}
\hline $\begin{array}{l}\text { SAMPLE } \\
\text { TYPE }\end{array}$ & $\begin{array}{c}\text { 90041A } \\
\text { Gran } \\
\text { melt }\end{array}$ & $\begin{array}{c}90041 C \\
\text { Gran } \\
\text { melt }\end{array}$ & $\begin{array}{l}90044 \mathrm{~A} \\
\text { Pyxite } \\
\text { sp rim }\end{array}$ & $\begin{array}{c}90048 \mathrm{E} \\
\text { Gran } \\
\text { ox ol }\end{array}$ & $\begin{array}{c}90048 B \\
\text { Pyxite } \\
\text { melt }\end{array}$ & $\begin{array}{c}90048 \mathrm{D} \\
\text { Pyxite } \\
\text { melt }\end{array}$ & $\begin{array}{c}\text { 90048D } \\
\text { Pyxite } \\
\text { melt }\end{array}$ & $\begin{array}{l}90054 \mathrm{I} \\
\text { Pyxite } \\
\text { oxid. }\end{array}$ & $\begin{array}{l}90054 \mathrm{~K} \\
\text { Pyxite } \\
\text { sp rim }\end{array}$ & $\begin{array}{l}90054 \mathrm{~K} \\
\text { Pyxite } \\
\text { sp rim }\end{array}$ \\
\hline $\mathrm{SiO}_{2}$ & 0.72 & 0.28 & 3.29 & 0.11 & 0.26 & 0.17 & 0.29 & 0.48 & 0.86 & 0.49 \\
\hline $\mathrm{Al} 2 \mathrm{O} 3$ & 1.14 & 0.91 & 2.85 & 0.05 & 9.22 & 9.85 & 8.84 & 1.43 & 10.63 & 41.55 \\
\hline $\mathrm{TiO} 2$ & 9.27 & 11.03 & 3.09 & 0.08 & 22.11 & 19.09 & 10.26 & 0.49 & 3.36 & 1.16 \\
\hline $\mathrm{Fe} 2 \mathrm{O} 3$ & 47.40 & 45.03 & 46.94 & 75.48 & 15.38 & 23.67 & 42.73 & 73.99 & 48.65 & 22.34 \\
\hline $\mathrm{FeO}$ & 31.17 & 36.53 & 34.40 & 8.09 & 40.03 & 38.75 & 29.70 & 1.61 & 26.75 & 20.87 \\
\hline $\mathrm{MnO}$ & 0.49 & 0.13 & 0.32 & 0.24 & 0.45 & 0.28 & 0.56 & 0.42 & 0.23 & 0.16 \\
\hline MgO & 4.79 & 2.39 & 2.89 & 14.45 & 8.28 & 7.59 & 7.91 & 18.91 & 5.60 & 12.01 \\
\hline $\mathrm{CaO}$ & 0.31 & 0.38 & 0.54 & 0.07 & 0.11 & 0.05 & 0.25 & 0.21 & 0.32 & 0.32 \\
\hline $\mathrm{Cr} 2 \mathrm{O}_{3}$ & 0.19 & 0.08 & 5.81 & 0.17 & 3.67 & 0.76 & 0.16 & 0.09 & 0.25 & 0.90 \\
\hline $\mathrm{NiO}$ & 0.27 & 0.02 & & 0.32 & 0.15 & 0.08 & 0.00 & 0.39 & 0.23 & 0.04 \\
\hline TOTAL & 95.75 & 96.78 & 100.13 & 99.06 & 99.66 & 100.29 & 100.70 & 98.02 & 96.88 & 99.84 \\
\hline
\end{tabular}

cations on the basis of 3 (spinel) sites

\begin{tabular}{lllllllllll}
$\mathrm{Si}$ & 0.027 & 0.011 & 0.129 & 0.003 & 0.009 & 0.006 & 0.010 & 0.016 & 0.031 & 0.014 \\
$\mathrm{Al}$ & 0.051 & 0.041 & 0.132 & 0.002 & 0.367 & 0.393 & 0.355 & 0.057 & 0.447 & 1.418 \\
$\mathrm{Ti}$ & 0.265 & 0.318 & 0.091 & 0.002 & 0.562 & 0.486 & 0.262 & 0.012 & 0.090 & 0.024 \\
$\mathrm{FeIII}$ & 1.358 & 1.299 & 1.249 & 1.983 & 0.392 & 0.603 & 1.097 & 1.883 & 1.305 & 0.487 \\
FeII & 0.992 & 1.172 & 1.018 & 0.236 & 1.132 & 1.097 & 0.842 & 0.045 & 0.797 & 0.505 \\
$\mathrm{Mn}$ & 0.016 & 0.004 & 0.011 & 0.007 & 0.014 & 0.008 & 0.016 & 0.012 & 0.007 & 0.004 \\
$\mathrm{Mg}$ & 0.272 & 0.137 & 0.168 & 0.752 & 0.417 & 0.303 & 0.401 & 0.953 & 0.298 & 0.519 \\
$\mathrm{Ca}$ & 0.013 & 0.016 & 0.023 & 0.002 & 0.004 & 0.002 & 0.009 & 0.007 & 0.012 & 0.009 \\
$\mathrm{Cr}$ & 0.006 & 0.002 & 0.180 & 0.004 & 0.098 & 0.100 & 0.004 & 0.002 & 0.007 & 0.020 \\
$\mathrm{Ni}$ & 0.000 & 0.001 & & 0.009 & 0.004 & 0.002 & 0.004 & 0.011 & 0.007 & 0.001 \\
& & & & & & & & & & \\
\hline TOTAL & 3.000 & 3.001 & 3.001 & 3.000 & 2.999 & 3.000 & 3.000 & 2.998 & 3.001 & 3.001 \\
\hline & & & & & & & & & & \\
X(Usp) & 0.2382 & 0.3086 & 0.1016 & 0.0005 & 0.8192 & 0.6666 & 0.2960 & 0.0006 & 0.1170 & 0.6858 \\
& & & & & & & & & & \\
\hline
\end{tabular}

Kaersutite occurs in minor amounts in one pyroxenite (sample 90048D), where it replaces primary clinopyroxene (Table 6.12). This replacement reaction results from the interaction of xenolith clinopyroxene with the infiltrating host melts. The compositions of the kaersutites (Figure 6.16) are similar to lower crustal kaersutites from Mount Sidley (Chapter 4.5.2), and from Foster Crater (Gamble et al., 1988), reflecting their crystallisation at lower crustal conditions.

Rhönite is present in association with the replacement of clinopyroxene by kaersutite, and crystallising directly from infiltrating host melts. Compositions 
of these rhönites differ, with melt-derived rhönite being more $\mathrm{Ca}+\mathrm{Al}$-rich, and $\mathrm{Na}+\mathrm{Si}$-poor compared to rhönite associated with kaersutite (Figure 6.17).

These rhönite compositions are similar to those in the Mount Sidley xenolith suite (Chapter 4.5.2), with the melt-derived rhönite falling in the melt associated field of Figure 6.17, and the kaersutite associated rhönite falling in the kaersutite associated field.

Secondary oxides that have crystallised from infiltrating host melts consist of Fe-Ti oxides (Figure 6.18). Compositions of melt-derived secondary oxides are presented in Table 6.16.

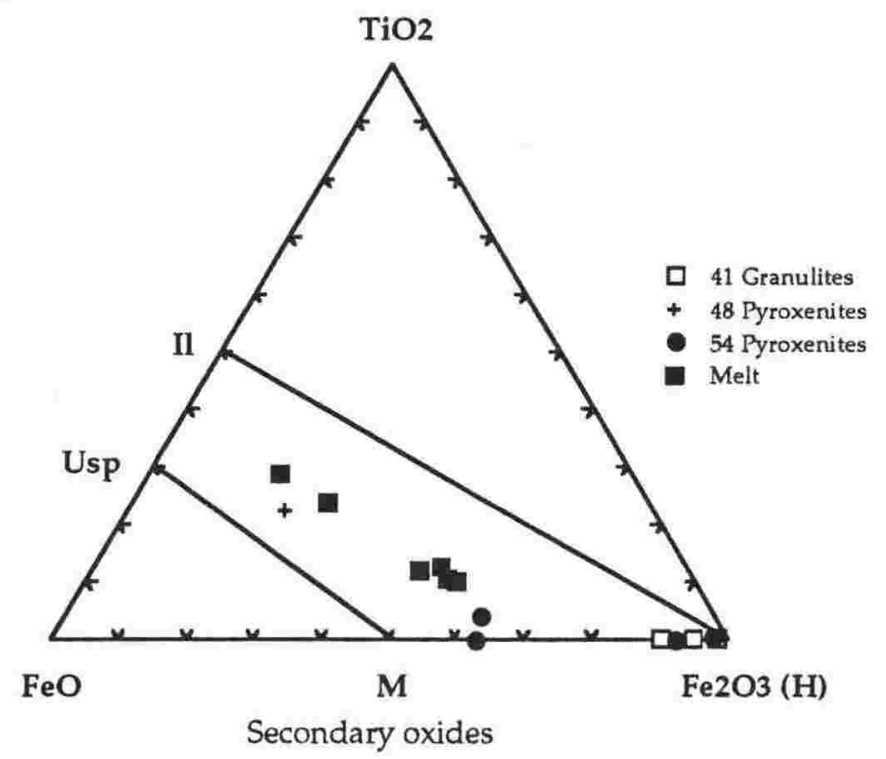

FIGURE 6.18: Secondary oxide compositions of Mount Murphy xenolith spinels in the system $\mathrm{TiO}_{2}-\mathrm{FeO}-\mathrm{Fe}_{2} \mathrm{O}_{3}$. Secondary oxides are dominantly titanomagnetites, that have crystallised from infiltrating host melts within the xenolith suite. $\mathrm{H}=$ hematite; I = ilmenite; $\mathrm{M}=$ magnetite; Usp = ulvöspinel.

The secondary oxides are all spinels; the absence of rhombohedral oxides makes the assemblage inappropriate for temperature and $\mathrm{fO}_{2}$ calculations (Carmichael, 1967; Anderson, 1968; Lindsley and Spencer, 1982; Stormer, 1983).

\subsubsection{Geochemistry and origin of glasses}

Glasses representing host melts that have infiltrated the xenolith suite occur in all xenolith types. Glass of any other origin (e.g. decompression melting) has not been detected in the xenolith suite. Representative analyses of glasses are presented as Table 6.17.

CIPW normative mineralogy's of the glasses are diverse, and include nepheline-, hypersthene- and quartz-normative compositions (Figure 6.19). There is a general trend defined by the glasses from nepheline- to quartz-normative.

Compositions of glasses plotted on a total alkali-silica (TAS) diagram (Le Bas et al., 1986), are highly varied, ranging from picrobasalts and basalts to benmoreites (Figure 6.20). The wide scatter in $\mathrm{Na}+\mathrm{K}$ content may in part reflect difficulties in analysing volatile elements by electron microscopy (approximately $5-10 \%$ ), however other elements should have little or no associated error 

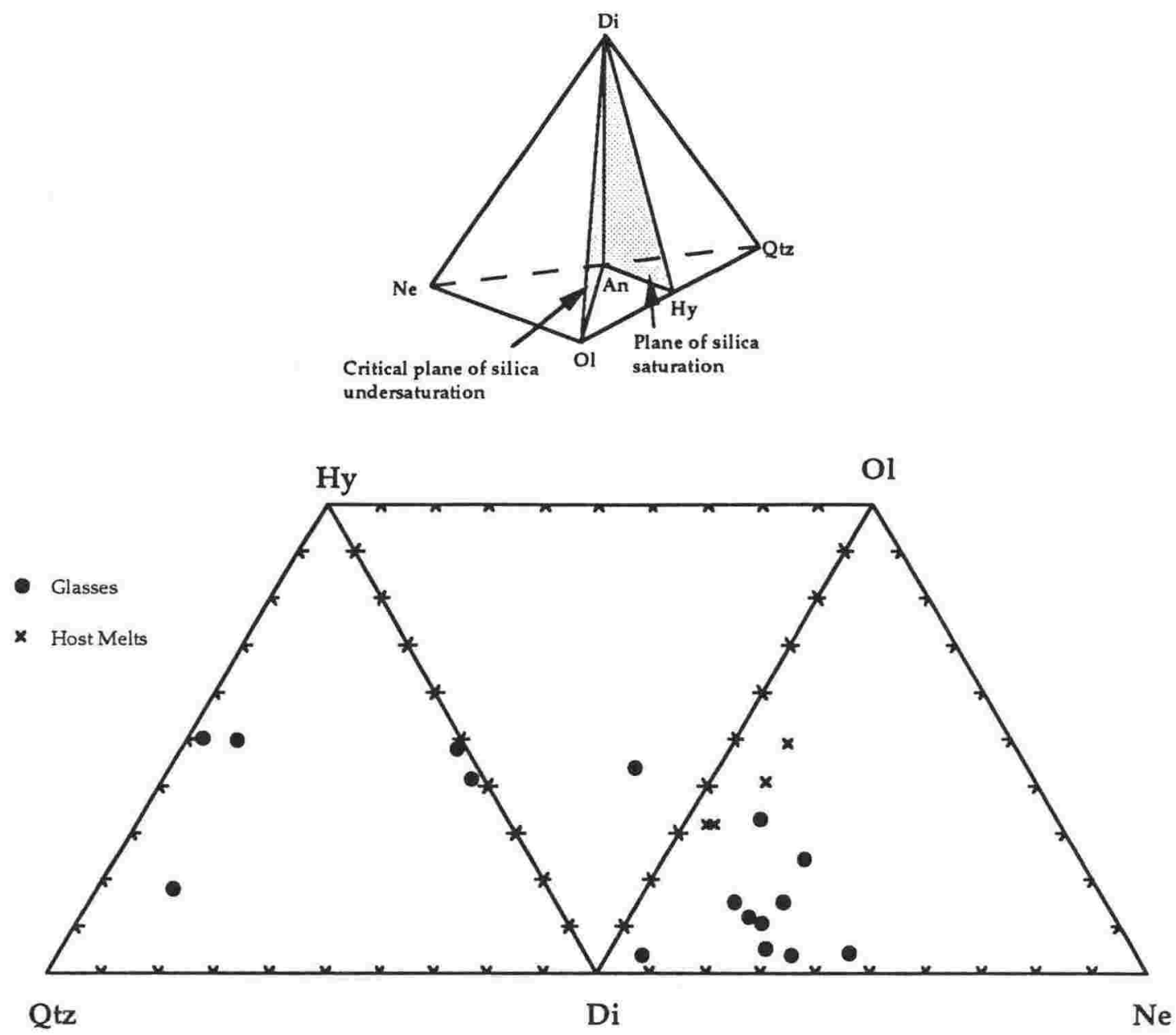

FIGURE 6.19: CIPW normative mineral assemblages of glasses occurring in the Mount Murphy xenolith suite. The glasses represent host melts that have infiltrated the xenoliths through cracks and along grain boundaries. The assemblage is highly varied, although a general trend is evident, from nepheline- to quartz-normative.

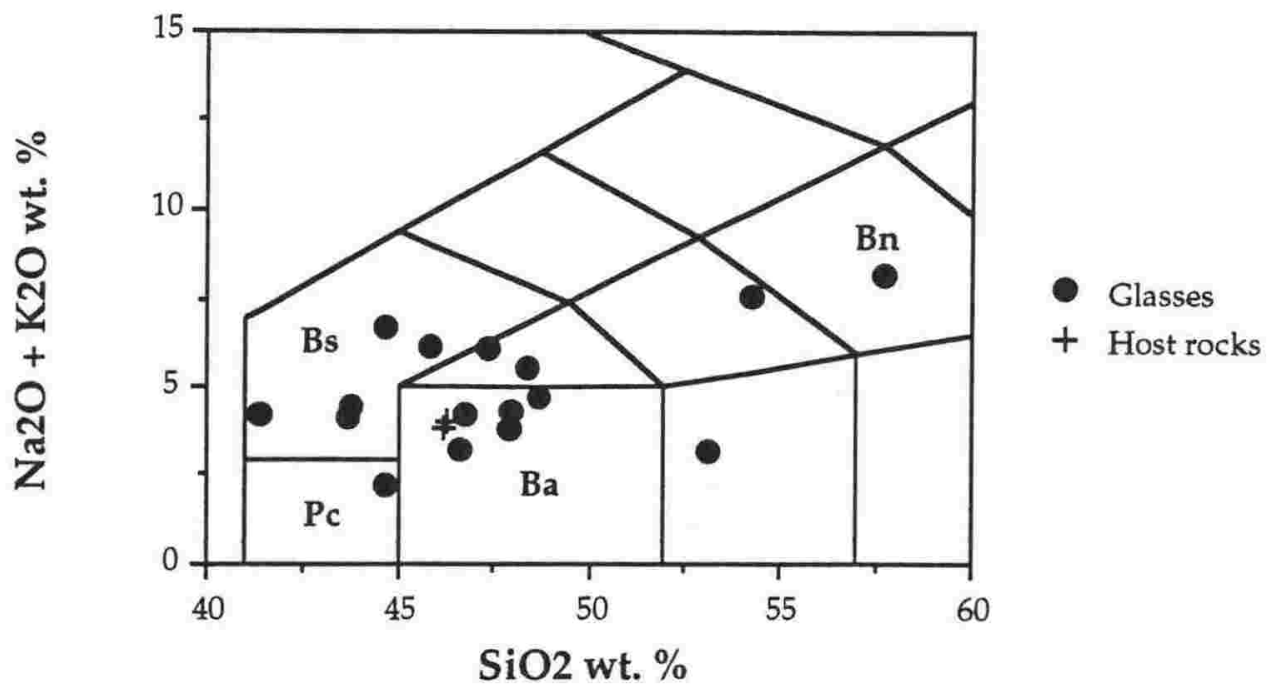

FIGURE 6.20: Total alkali-silica (TAS) diagram (Le Bas et al., 1986) of glasses, indicating a wide range in composition from picrobasalts and basalts to benmoreites. $\mathrm{Ba}=$ basalt; $\mathrm{Bn}=$ benmoreite; $\mathrm{Bs}=$ basanite; $\mathrm{Pc}=$ picrobasalt. See Figure 2.1 for other fields. 
TABLE 6.17: Representative electron microprobe analyses of single glass compositions occurring in the Mount Murphy xenolith suite.

\begin{tabular}{|c|c|c|c|c|c|c|c|c|c|c|}
\hline $\begin{array}{l}\text { Sample } \\
\text { Type }\end{array}$ & $\begin{array}{c}\text { 90041A } \\
\text { Gran } \\
\text { melt }\end{array}$ & $\begin{array}{c}\text { 90041A } \\
\text { Gran } \\
\text { symp }\end{array}$ & $\begin{array}{c}90048 \mathrm{~B} \\
\text { Pyx } \\
\text { melt }\end{array}$ & $\begin{array}{c}\text { 90048B } \\
\text { Pyx } \\
\text { melt }\end{array}$ & $\begin{array}{c}\text { 90048D } \\
\text { Pyx } \\
\text { melt }\end{array}$ & $\begin{array}{c}\text { 90048D } \\
\text { Pyx } \\
\text { melt }\end{array}$ & $\begin{array}{c}90048 \mathrm{E} \\
\text { Gran } \\
\text { melt } \\
\end{array}$ & $\begin{array}{c}90048 \mathrm{E} \\
\text { Gran } \\
\text { melt }\end{array}$ & $\begin{array}{c}90048 \mathrm{G} \\
\text { Gran } \\
\text { in plag } \\
\end{array}$ & $\begin{array}{c}\text { 90054I } \\
\text { Pyxite } \\
\text { with sp } \\
\end{array}$ \\
\hline $\mathrm{SiO} 2$ & 54.24 & 57.69 & 44.68 & 46.69 & 47.38 & 53.12 & 48.65 & 46.77 & 43.68 & 48.39 \\
\hline $\mathrm{Al} 2 \mathrm{O} 3$ & 15.04 & 17.62 & 15.20 & 13.39 & 15.75 & 18.81 & 14.94 & 14.26 & 13.32 & 16.19 \\
\hline $\mathrm{TiO} 2$ & 2.72 & 0.46 & 4.99 & 5.16 & 5.13 & 3.24 & 4.57 & 4.63 & 5.50 & 2.99 \\
\hline $\mathrm{FeO}$ & 8.33 & 6.78 & 13.01 & 10.52 & 12.41 & 9.69 & 12.58 & 12.99 & 13.24 & 10.47 \\
\hline $\mathrm{MnO}$ & 0.21 & 0.17 & 0.28 & 0.23 & 0.42 & 0.27 & 0.19 & 0.16 & 0.34 & 0.19 \\
\hline $\mathrm{MgO}$ & 4.13 & 2.98 & 3.65 & 5.80 & 3.50 & 4.29 & 3.16 & 3.75 & 3.25 & 4.46 \\
\hline $\mathrm{CaO}$ & 7.62 & 5.80 & 11.45 & 14.82 & 10.22 & 6.59 & 8.22 & 8.01 & 15.19 & 9.48 \\
\hline $\mathrm{Na} 2 \mathrm{O}$ & 6.13 & 6.96 & 5.02 & 2.05 & 4.03 & 1.86 & 3.13 & 2.75 & 2.29 & 4.56 \\
\hline $\mathrm{K} 2 \mathrm{O}$ & 1.41 & 1.19 & 1.60 & 1.19 & 2.00 & 1.31 & 1.61 & 1.49 & 1.79 & 1.08 \\
\hline TOTAL & 99.83 & 99.63 & 99.88 & 99.84 & 100.82 & 99.17 & 97.05 & 94.81 & 98.60 & 97.81 \\
\hline Mg\# & 46.92 & 43.96 & 33.32 & 49.56 & 33.42 & 44.09 & 30.92 & 33.99 & 30.43 & 43.15 \\
\hline$Q$ & 0.00 & 0.00 & 0.00 & 0.00 & 0.00 & 5.06 & 0.65 & 0.55 & 0.00 & 0.00 \\
\hline Or & 8.33 & 7.03 & 9.46 & 7.03 & 11.82 & 7.44 & 9.51 & 9.18 & 11.02 & 0.40 \\
\hline $\mathrm{Ab}$ & 40.79 & 53.31 & 7.53 & 12.38 & 18.14 & 15.13 & 26.49 & 24.25 & 3.48 & 28.09 \\
\hline An & 9.36 & 13.32 & 14.22 & 23.82 & 18.98 & 31.43 & 21.96 & 23.10 & 21.65 & 21.86 \\
\hline $\mathrm{Ne}$ & 6.00 & 3.03 & 18.93 & 2.69 & 8.65 & 0.00 & 0.00 & 0.00 & 9.05 & 7.05 \\
\hline Di & 23.38 & 12.90 & 35.56 & 40.33 & 26.46 & 25.93 & 15.78 & 15.29 & 40.78 & 23.37 \\
\hline Hy & 0.00 & 0.00 & 0.00 & 0.00 & 0.00 & 0.00 & 11.73 & 14.85 & 0.00 & 0.00 \\
\hline Ol & 5.31 & 7.97 & 2.39 & 1.92 & 4.84 & 6.86 & 0.00 & 0.00 & 0.00 & 8.98 \\
\hline Mt & 1.60 & 1.30 & 2.49 & 2.02 & 2.38 & 1.79 & 2.41 & 2.59 & 2.65 & 2.14 \\
\hline II & 5.17 & 0.87 & 9.48 & 9.80 & 9.74 & 5.91 & 8.68 & 9.16 & 10.88 & 6.05 \\
\hline TOTAL & 99.94 & 99.73 & 100.06 & 99.99 & 101.01 & 99.55 & 97.21 & 98.97 & 99.51 & 97.94 \\
\hline
\end{tabular}

(Appendix Three). The variation in silica does however emphasise a large range in glass composition.

Plots of major elements against silica are presented as Figure 6.21. Good negative trends are evident for $\mathrm{Fe}_{2} \mathrm{O}_{3}$ (total), $\mathrm{MnO}$ and $\mathrm{CaO}$, and a strong positive trend is evident for $\mathrm{Al}_{2} \mathrm{O}_{3}$. Host basalts plot within these trends, but do not form an end-member composition. This may be due to host lava compositions representing both melt and phenocryst compositions, rather than just liquid compositions.

The major element trends are consistent with the fractionation of the observed mineral assemblage in the glasses (olivine + plagioclase + oxides). 

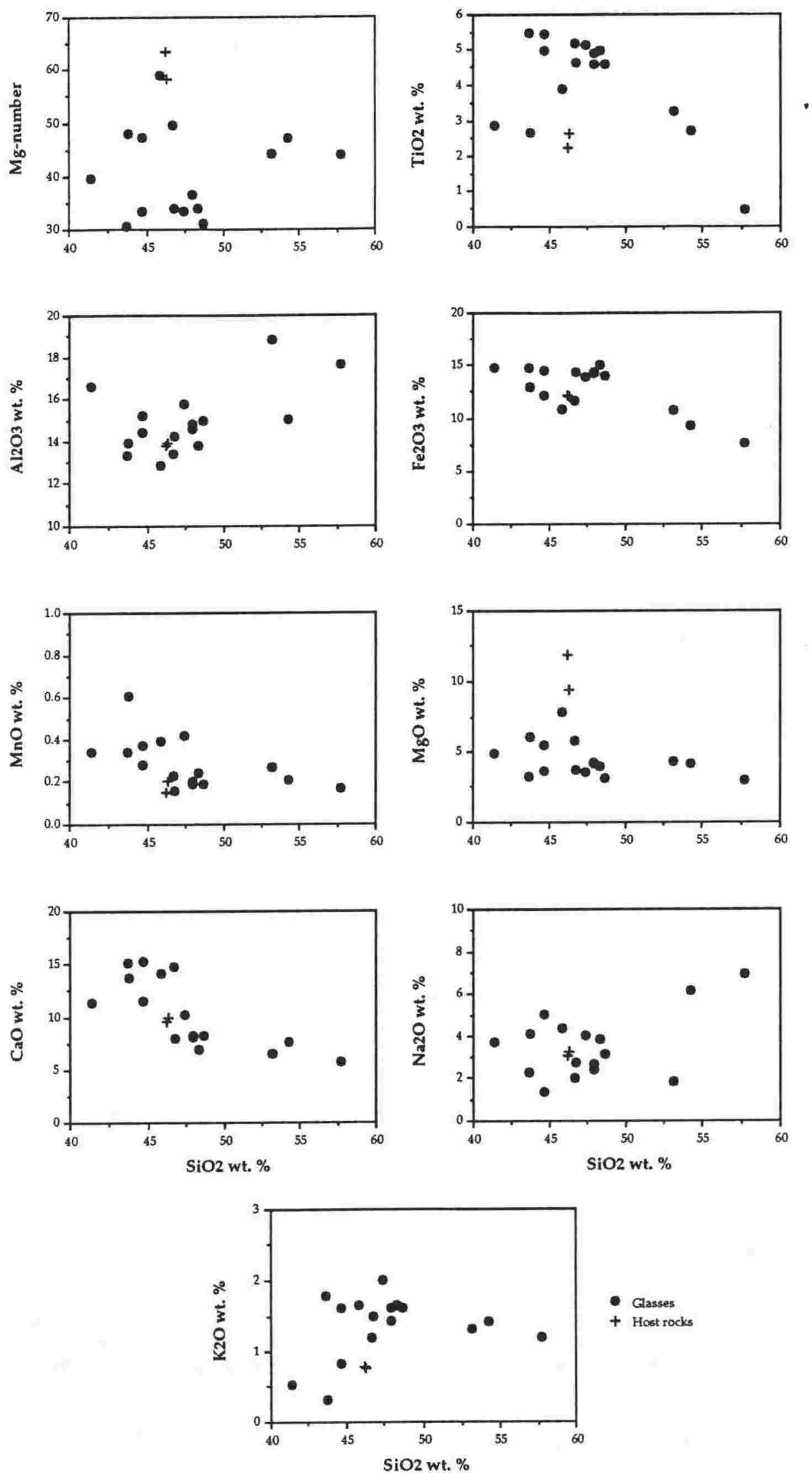

FIGURE 6.21: Major elements plotted against silica for glasses representing host melts that have infiltrated the xenolith suite. Host basalt compositions are plotted for comparison (from Le Masurier, 1990). 
Original glass compositions (presumably represented by host melt compositions) have evolved to more $\mathrm{Fe}$ - and $\mathrm{Mn}$-poor compositions with olivine fractionation, and more $\mathrm{Ca}$ - and $\mathrm{Si}$-poor compositions with plagioclase fractionation.

The scatter in $\mathrm{Mg} \#$ however indicates that other processes are occurring, as with simple fractionation the $\mathrm{Mg \#}$ should show a strong negative trend with silica. Interaction with xenolith mineral phases (Chapter 6.5) may have altered the xenolith compositions by providing an assimilant component to the melt. The crystallisation of mineral phases by the glass would provide the latent heat necessary to assimilate xenolith material, if the melts themselves were not initially heated enough to do so (Taylor, 1980), resulting in the modification of the melt in the lower crust by the AFC process.

\subsubsection{Summary and discussion of secondary mineral reactions}

Interaction between infiltrating melts and xenolith minerals is the dominant process responsible for the formation of secondary minerals. The host melt has crystallised microphenocrysts of plagioclase + olivine \pm oxides \pm kaersutite \pm rhönite. This crystallisation may have provided the latent heat to react with primary xenolith mineral phases (if the melts were not initially hot enough), assimilating xenolith material into the melt. The result is combined assimilation and fractional crystallisation (the AFC process) of the host melt within the xenolith suite.

Host melt interaction has resulted in the oxidation of the xenolith suite, particularly of the granulites. Oxidation varies in its extent. Minor oxidation has resulted in olivine rims breaking down into two phases of olivine (one $\mathrm{Mg}$-rich, the other relatively $\mathrm{Mg}$-poor), and the growth of small Fe-Ti oxides. Extensive oxidation has resulted in the development of complex symplectites, consisting of inner and outer cores of two phases of olivine, with orthopyroxene between these layers.

Analyses of the two phases of olivine indicate that relatively Fe-rich olivine has been exsolved from the original olivine in response to a change in equilibrium conditions, leaving behind a $\mathrm{Mg}$-rich residual olivine. Entrainment in high-temperature magmas, and subsequent lowering of pressure due to entrainment are likely to have caused the change in conditions and the oxidation of olivine.

Glass is not present in association with oxidised olivines, so a definite link between the host basalts and the oxidation process can not be established. However, given the strong relationship between host melts and oxidation processes evident in Mount Sidley (Chapter 4.5) and Mount Hampton (Chapter 
5.5) xenoliths, it is probable that the migration of hot silicate melts in the lower crust has oxidised the Mount Murphy xenolith suite, from lower crustal depths and during the ascent of the xenoliths to the surface, entrained in the host magmas.

Secondary oxides that have crystallised from the infiltrating melt in the xenolith suite consist of magnetite and Fe-Ti oxides. This is quite different from the primary assemblage which consists of magnetite and ilmenite, indicating differing redox conditions present at lower crustal depths to those present where oxidation and host interactions were occurring. Secondary oxide compositions indicate redox conditions similar to those at high crustal levels (Haggerty, 1990), indicating that oxidation occurred during ascent of the xenoliths from lower crustal depths to the surface.

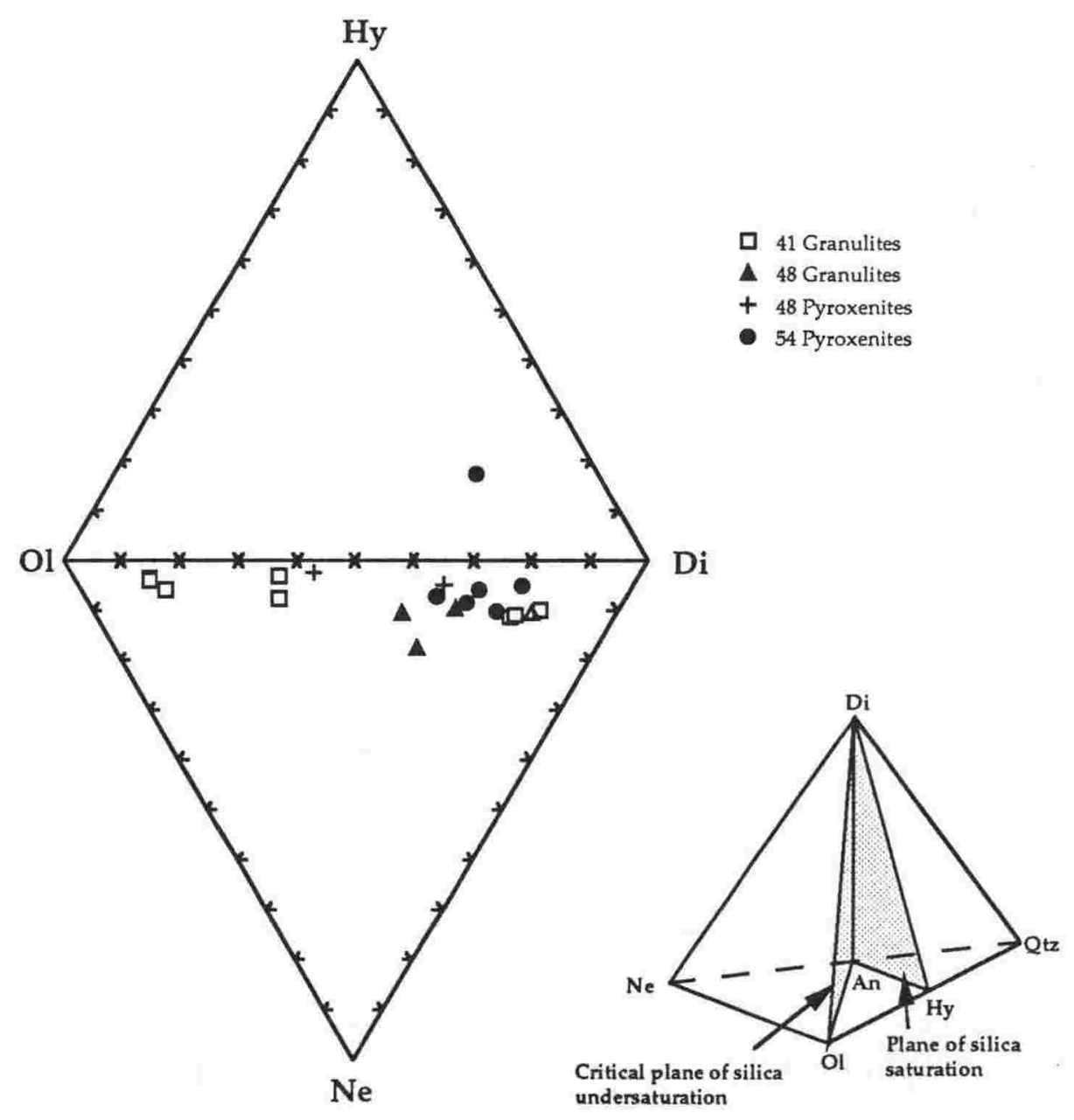

FIGURE 6.22: CIPW normative mineral compositions of xenoliths from Mount Murphy. With the exception of the only orthopyroxene-bearing pyroxenite from the xenolith suite (Sample 90044), all xenoliths are nepheline-normative, reflecting their silica poor modal mineral assemblage of olivine, clinopyroxene and plagioclase. 


\subsection{Whole Rock Geochemistry}

The Mount Murphy lower crustal xenolith suite consists of samples from four localities (Chapter 6.2). Only three granulites, and three pyroxenites have been sampled from site 90048, making it impossible to fully characterise the lower crust in this locality. Representative compositions of xenoliths from the major xenolith localities of Mount Murphy are given in Table 6.18, and a complete list of analyses can be found in Appendix 4.3. Mg\#s are calculated as $100 \mathrm{Mg} / \mathrm{Mg}+\Sigma \mathrm{Fe}$, with total $\Sigma \mathrm{Fe}$ taken as $\mathrm{FeO}$. CIPW normative compositions are calculated at an $\mathrm{Fe}_{2} \mathrm{O}_{3}: \mathrm{FeO}$ ratio of 0.15 .

\subsubsection{Major element geochemistry}

With the exception of one orthopyroxene-bearing pyroxenite (from site 90044) that is hypersthene-normative, the Mount Murphy xenolith suite is mildly nepheline-normative ( $\leq 7.61 \%$ normative nepheline; Figure 6.22). Phases which are silica-undersaturated are not present in modal mineral assemblages.

The granulite CIPW normative mineral assemblage ranges from olivinepoor to olivine-rich, in agreement with their modal assemblage (Table 6.1). Granulites from site 90048 have a more restricted normative range. The pyroxenite suite normative mineral assemblage is olivine-poor and diopside rich, also in agreement with their modal mineral assemblage (Table 6.1).

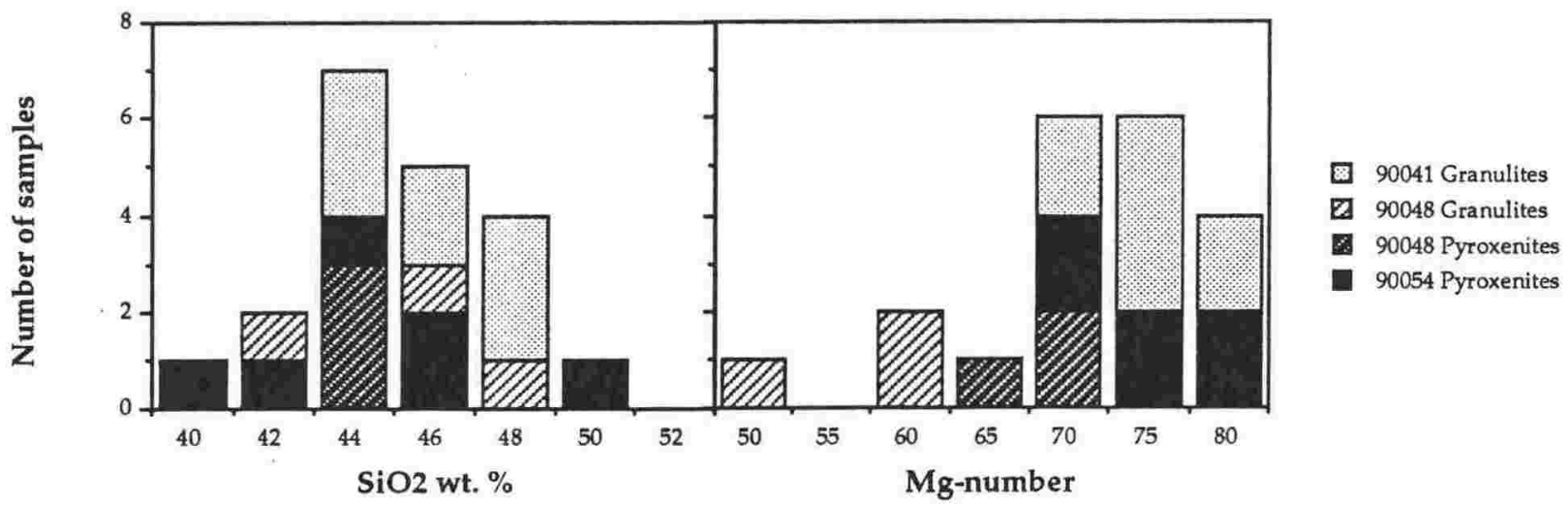

FIGURE 6.23: Silica and Mg\# histograms of Mount Murphy xenoliths. All xenoliths are mafic, with high Mg-numbers. Site 90041 granulites and site 90054 pyroxenites have the highest Mg-numbers, reflecting the higher $\mathrm{Mg}: \mathrm{Mg}+\mathrm{Fe}$ ratios of mafic minerals in these xenoliths. $\mathrm{SiO}_{2}$ abscissa is by 2 wt. $\%$ gradations (e.g. $40=40.0-41.9$ ), and $\mathrm{Mg \#}$ is by $5 \mathrm{Mg \#}$ gradations (e.g. $50=50.0-54.9$ ).

The xenolith suite is mafic, with a restricted silica range of $41.5-50.9$ wt. \% $\mathrm{SiO}_{2}$ (Figure 6.23). Mg\#s ( $\mathrm{Mg \#}=\mathrm{Mg} / \mathrm{Mg}+\Sigma \mathrm{Fe}$ as $\mathrm{FeO}$ ) are similar for granulites

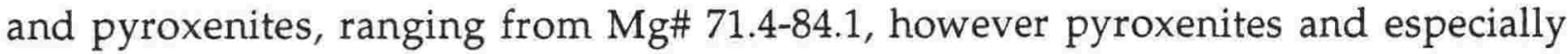
granulites from site 90048 have substantially lower Mg\#s (Figure 6.23). The orthopyroxene-bearing pyroxenite from site 90044 has the highest silica content 
TABLE 6.18: Representative analyses of xenoliths from four localities on Mount Murphy.

\begin{tabular}{|c|c|c|c|c|c|c|c|c|c|c|}
\hline $\begin{array}{l}\text { SAMPLE } \\
\text { TYPE } \\
\end{array}$ & $\begin{array}{c}90041 C \\
\text { Gran } \\
\end{array}$ & $\begin{array}{c}90041 \mathrm{H} \\
\text { Gran }\end{array}$ & $\begin{array}{c}90041 \mathrm{~J} \\
\text { Gran }\end{array}$ & $\begin{array}{c}90044 \mathrm{~A} \\
\text { Pyxite } \\
\end{array}$ & $\begin{array}{c}90048 \mathrm{~A} \\
\text { Pyxite } \\
\end{array}$ & $\begin{array}{c}90048 \mathrm{D} \\
\text { Pyxite }\end{array}$ & $\begin{array}{c}90048 \mathrm{E} \\
\text { Gran }\end{array}$ & $\begin{array}{c}90048 \mathrm{G} \\
\text { Gran }\end{array}$ & $\begin{array}{c}90054 \mathrm{~F} \\
\text { Pyxite }\end{array}$ & $\begin{array}{c}90054 G \\
\text { Pyxite }\end{array}$ \\
\hline $\mathrm{SiO} 2$ & 48.07 & 49.65 & 45.08 & 50.91 & 44.56 & 43.53 & 46.54 & 49.09 & 47.13 & 43.20 \\
\hline $\mathrm{TiO} 2$ & 0.34 & 0.58 & 0.12 & 0.59 & 0.72 & 3.04 & 1.75 & 2.30 & 1.25 & 1.51 \\
\hline $\mathrm{Al} 2 \mathrm{O} 3$ & 23.70 & 20.89 & 20.85 & 6.47 & 7.88 & 10.17 & 15.70 & 22.39 & 7.06 & 12.78 \\
\hline $\mathrm{Fe} 2 \mathrm{O} 3$ tot & 3.01 & 4.50 & 6.71 & 7.29 & 14.65 & 12.17 & 9.78 & 6.21 & 8.36 & 10.01 \\
\hline $\mathrm{MnO}$ & 0.06 & 0.08 & 0.09 & 0.15 & 0.20 & 0.16 & 0.14 & 0.09 & 0.16 & 0.16 \\
\hline $\mathrm{MgO}$ & 5.53 & 5.66 & 14.48 & 19.41 & 20.29 & 11.42 & 8.91 & 3.08 & 16.33 & 14.30 \\
\hline $\mathrm{CaO}$ & 16.25 & 15.42 & 11.05 & 14.36 & 10.55 & 17.41 & 13.59 & 10.73 & 18.56 & 17.14 \\
\hline $\mathrm{Na} 2 \mathrm{O}$ & 2.27 & 2.93 & 1.77 & 1.03 & 1.37 & 1.66 & 2.63 & 4.39 & 0.91 & 27 \\
\hline $\mathrm{K} 2 \mathrm{O}$ & 0.18 & 0.16 & 0.06 & 0.02 & 0.06 & 0.17 & 0.35 & 0.52 & 0.09 & 03 \\
\hline $\mathrm{P} 2 \mathrm{O} 5$ & 0.01 & 0.00 & 0.00 & 0.00 & 0.01 & 0.06 & 0.12 & 0.24 & 0.01 & 0.00 \\
\hline LOI & 0.22 & 0.47 & -0.19 & 0.06 & -0.73 & 0.25 & 0.79 & 1.37 & 0.17 & 0.07 \\
\hline TOTAL & 99.64 & 100.34 & 100.02 & 100.29 & 99.56 & 100.04 & 100.30 & 100.41 & 100.03 & 100.47 \\
\hline $\mathrm{Mg \#}$ & 78.44 & 71.35 & 81.04 & 84.06 & 73.28 & 65.02 & 64.34 & 49.55 & 79.46 & 73.88 \\
\hline $\mathrm{Sc}$ & 24 & 27 & 6 & 43 & 27 & 55 & 32 & 14 & 68 & 53 \\
\hline V & 69 & 142 & 21 & 238 & 170 & 446 & 251 & 137 & 328 & 464 \\
\hline $\mathrm{Cr}$ & 72 & 287 & 445 & 2022 & 1755 & 587 & 370 & 7 & 2603 & 232 \\
\hline $\mathrm{Ni}$ & 31 & 38 & 282 & 624 & 585 & 93 & 73 & 5 & 299 & 311 \\
\hline $\mathrm{Cu}$ & 5 & 33 & 18 & 62 & 222 & 33 & 26 & 13 & 33 & 40 \\
\hline $\mathrm{Zn}$ & 23 & 25 & 37 & 38 & 91 & 55 & 56 & 31 & 44 & 101 \\
\hline $\mathrm{Ga}$ & 16 & 20 & 15 & 8 & 9 & 17 & 17 & 20 & 12 & 26 \\
\hline $\mathrm{Rb}$ & 2 & 1 & $<1$ & $<1$ & 1 & 2 & 3 & 3 & $<1$ & 1 \\
\hline $\mathrm{Sr}$ & 588 & 547 & 579 & 30 & 340 & 310 & 891 & 1683 & 124 & 72 \\
\hline Y & 1 & 3 & $<1$ & 10 & 5 & 22 & 12 & 3 & 13 & 16 \\
\hline $\mathrm{Zr}$ & 27 & 25 & 15 & 14 & 27 & 90 & 98 & 54 & 55 & 45 \\
\hline $\mathrm{Nb}$ & 5 & 2 & 2 & 1 & 1 & 4 & 9 & 10 & 2 & 1 \\
\hline $\mathrm{Ba}$ & 37 & 75 & 40 & 2 & 28 & 27 & 79 & 243 & 14 & 4 \\
\hline $\mathrm{La}$ & 3 & 4 & 5 & 2 & 4 & 7 & 10 & 7 & 6 & 4 \\
\hline $\mathrm{Ce}$ & 8 & 8 & 9 & 6 & 10 & 22 & 34 & 22 & 18 & 14 \\
\hline $\mathrm{Pb}$ & 4 & 4 & 3 & 4 & 4 & 5 & 3 & 4 & 4 & 3 \\
\hline Th & 1 & 2 & $<1$ & 1 & $<1$ & 1 & 1 & 1 & 1 & $<1$ \\
\hline U & $<1$ & $<1$ & $<1$ & 1 & 2 & $<1$ & $<1$ & $<1$ & $<1$ & 1 \\
\hline Q & 0.00 & 0.00 & 0.00 & 0.00 & 0.00 & 0.00 & 0.00 & 0.00 & 0.00 & 0.00 \\
\hline Or & 1.06 & 0.95 & 0.35 & 0.12 & 0.35 & 0.00 & 2.07 & 3.07 & 0.00 & 0.00 \\
\hline $\mathrm{Ab}$ & 13.32 & 18.46 & 12.07 & 8.72 & 7.93 & 0.00 & 13.54 & 30.89 & 0.00 & 0.00 \\
\hline An & 53.95 & 43.38 & 48.77 & 12.97 & 15.18 & 19.80 & 30.00 & 39.85 & 14.91 & 29.08 \\
\hline $\mathrm{Ne}$ & 3.19 & 3.43 & 1.58 & 0.00 & 1.99 & 7.61 & 4.72 & 3.39 & 4.17 & 5.82 \\
\hline $\mathrm{Di}$ & 21.22 & 26.62 & 4.82 & 46.20 & 29.82 & 53.33 & 29.63 & 9.63 & 59.96 & 43.79 \\
\hline Hy & 0.00 & 0.00 & 0.00 & 13.20 & 0.00 & 0.00 & 0.00 & 0.00 & 0.00 & 0.00 \\
\hline $\mathrm{Ol}$ & 5.23 & 4.77 & 30.65 & 16.02 & 39.82 & 10.52 & 13.40 & 5.66 & 15.08 & 18.37 \\
\hline $\mathrm{Mt}$ & 0.52 & 0.78 & 1.16 & 1.26 & 2.53 & 2.10 & 1.69 & 1.07 & 1.44 & 1.73 \\
\hline II & 0.65 & 1.10 & 0.23 & 1.12 & 1.37 & 5.77 & 3.32 & 4.37 & 2.37 & 2.87 \\
\hline Ap & 0.02 & 0.00 & 0.00 & 0.00 & 0.02 & 0.79 & 0.28 & 0.57 & 0.02 & 0.00 \\
\hline OTAL & 99.16 & 99.49 & 99.63 & 99.61 & 99.01 & 99.92 & 98.65 & 98.50 & 97.95 & 101.66 \\
\hline
\end{tabular}



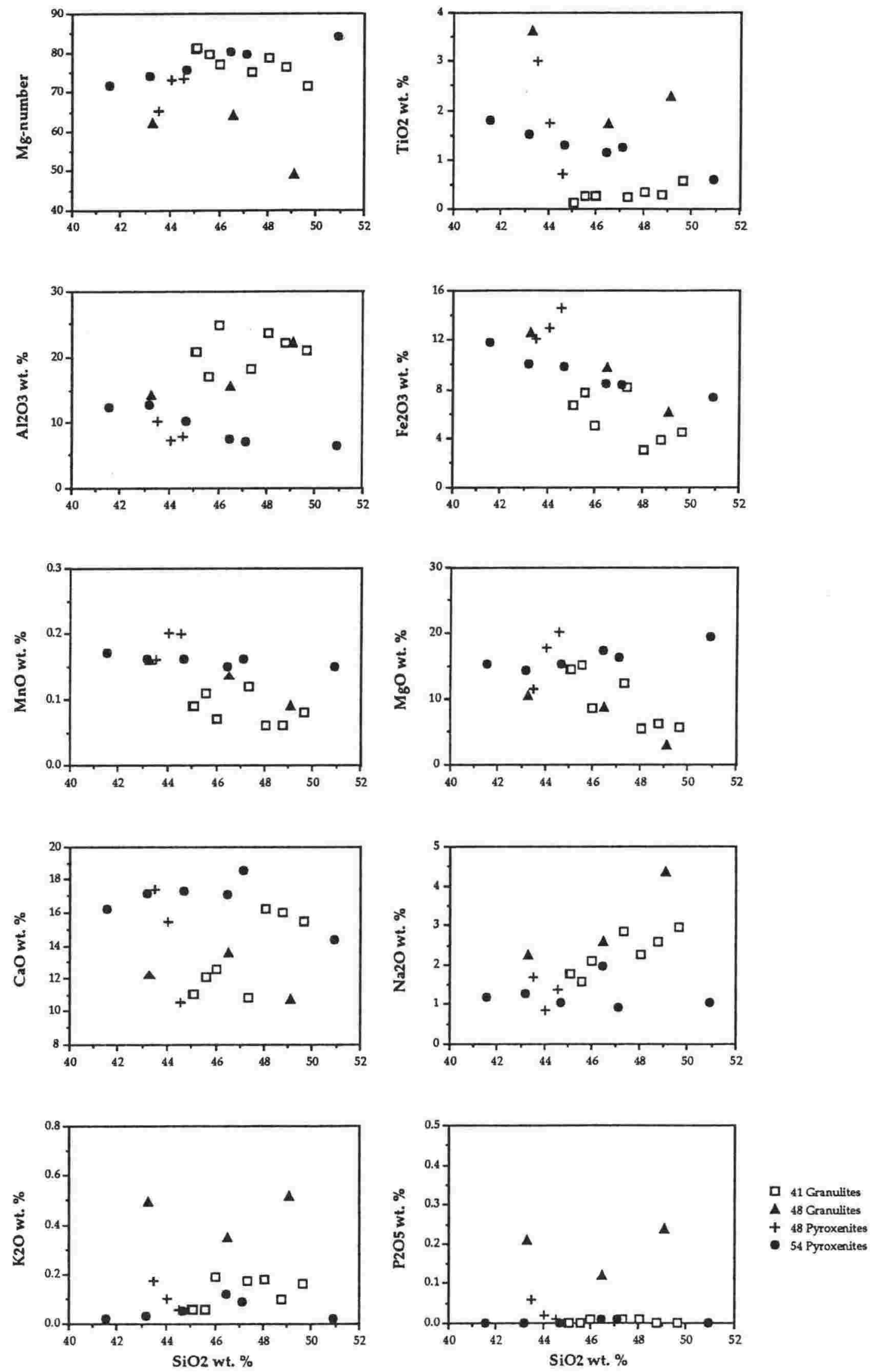

FIGURE 6.24: Major elements plotted against silica for xenoliths from Mount Murphy. Trends shown reflect the mineral assemblage, and the proportion of each mineral phase in the xenoliths. 
(50.9 wt. \% $\mathrm{SiO}_{2}$ compared to the next highest, a granulite with 49.5 wt. $\% \mathrm{SiO}_{2}$ ), and the highest Mg\# (Mg\# 84 compared to the next highest, a granulite with Mg\# 81) of the xenolith suite. $\mathrm{Mg \# s}$ reflect the $\mathrm{Mg}: \mathrm{Mg}+\mathrm{Fe}$ ratio of mafic minerals in these xenoliths, and suggest crystallisation of site 90048 xenoliths from more evolved melts than other xenoliths.

Major element abundances are controlled by the modal mineral abundances in the xenolith suite, reflecting their origin as igneous rocks with little or no trapped melt (Chapter 6.3). This results in well defined trends of major elements against silica (Figure 6.24) in the xenolith suite, reflecting simple mixing trends between modal mineral phases.

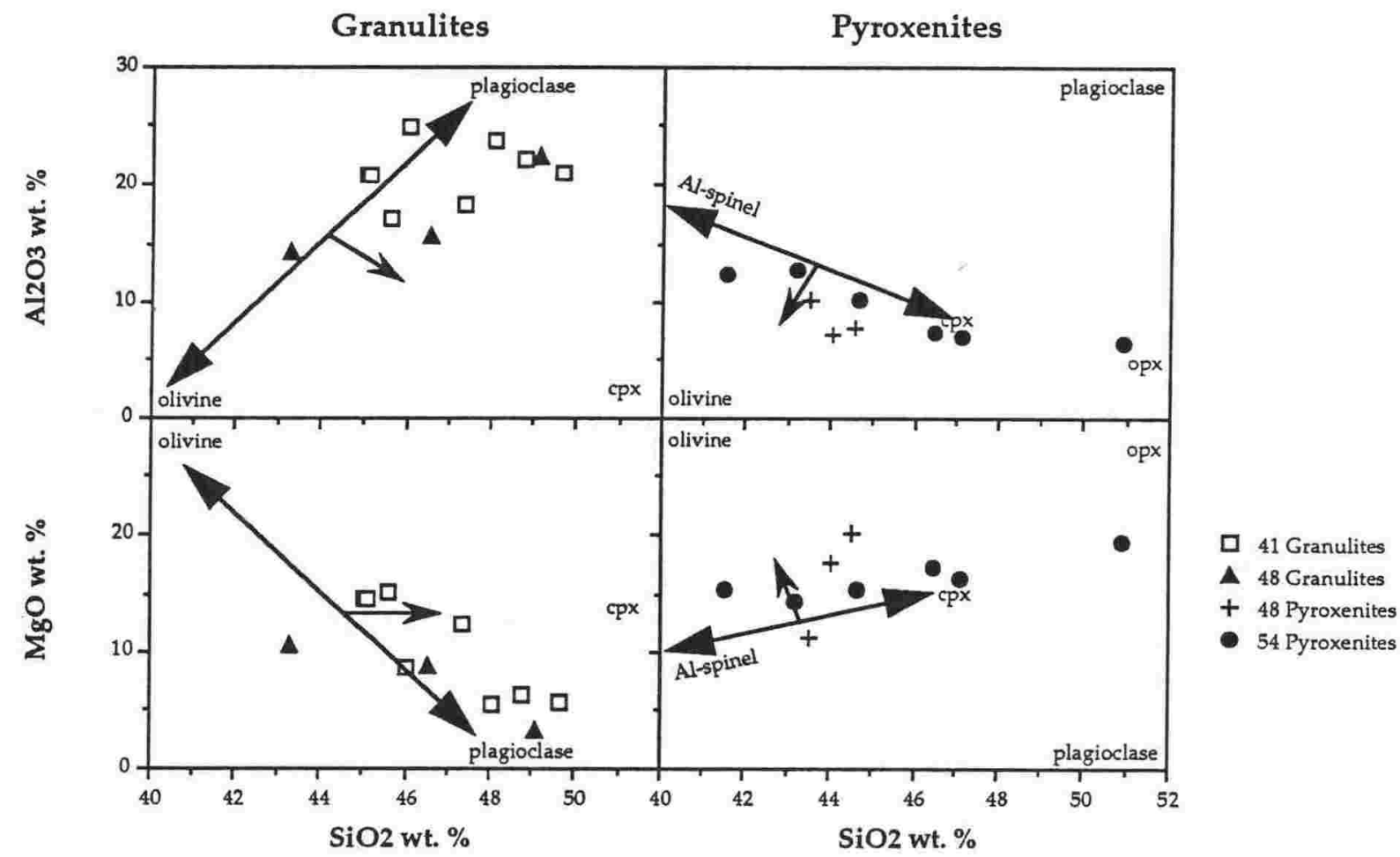

FIGURE 6.25: $\mathrm{Al}_{2} \mathrm{O}_{3}$ and $\mathrm{MgO} v \mathrm{SiO}_{2}$ plots of granulites and pyroxenites from Mount Murphy. Large double headed arrows reflect the control of plagioclase and olivine on whole rock trends in the granulite suites, and clinopyroxene and Al-spinel in the pyroxenite suites. Small single headed arrows reflect the minor influences of other modal mineral phases on xenolith composition. The orthopyroxene-bearing pyroxenite (sample 90044) plots at higher silica contents due to its high orthopyroxene content and the absence of olivine.

The dominance of the modal mineral assemblage on major element abundances can be seen in Figure 6.25, which shows $\mathrm{Al}_{2} \mathrm{O}_{3}$ and $\mathrm{MgO}$ contents plotted against $\mathrm{SiO}_{2}$ for mineral and whole-rock xenolith compositions. The position of the mineral phases is more variable than shown in Figure 6.25 , due to their large variation in composition. Large arrows depict the dominant major element trends in the xenolith suite, which are controlled by plagioclase and 
olivine in the granulite suites, and by clinopyroxene (and Al-spinel to a minor extent) in the pyroxenite suites. Small arrows indicate the minor influence of other minerals phases (that have low modal abundances), including clinopyroxene in granulites, and olivine in pyroxenites. Orthopyroxene also has an affect on the whole rock composition of the orthopyroxene-bearing pyroxenite (sample 90044).

Granulites and pyroxenites from site 90048 have markedly lower Mg\#s and $\mathrm{CaO}$ contents, and higher $\mathrm{TiO}_{2}, \mathrm{~K}_{2} \mathrm{O}$ and $\mathrm{P}_{2} \mathrm{O}_{5}$ contents than other xenoliths. These characteristics are also a product of the mineral assemblage, which consist of more evolved mineral compositions (e.g. lower $\mathrm{Mg}: \mathrm{Mg}+\mathrm{Fe}$ ratios) than other granulites and pyroxenites. In xenoliths from site 90048 , olivine is $\mathrm{Fe}_{2} \mathrm{O}_{3}$ (total)-rich and $\mathrm{MgO}$-poor, clinopyroxene has higher $\mathrm{Al}_{2} \mathrm{O}_{3}, \mathrm{TiO}_{2}, \mathrm{Fe}_{2} \mathrm{O}_{3}$ (total) and $\mathrm{NaO}$, and lower $\mathrm{CaO}, \mathrm{MgO}$ and $\mathrm{CaO}$ contents, and plagioclase has higher $\mathrm{SiO}_{2}, \mathrm{Fe}_{2} \mathrm{O}_{3}$ (total), $\mathrm{Na}_{2} \mathrm{O}$ and $\mathrm{K}_{2} \mathrm{O}$, and lower $\mathrm{Al}_{2} \mathrm{O}_{3}$ and $\mathrm{CaO}$ contents than in other granulite and pyroxenite mineral phases. These characteristics are reflected in their whole rock compositions.

\subsubsection{Trace element geochemistry}

Trace element abundances for pyroxenites and granulites are presented in Figure 6.26, and trace element compositions normalised to MORB (Pearce, 1983) are presented as Figure 6.27. As the xenoliths are cumulate in nature, absolute abundances normalised to MORB cannot be taken as a function of their source characteristics as they do not represent source melt compositions. The abundance of trace elements reflects their ability to partition in xenolith mineral phases. However, relative patterns are a good indication of differences in xenolith composition.

Trace element chemistry of the xenolith suite reflects the mineral assemblage of the xenolith suite, and the lack of residual melt in the cumulate protoliths. Sr and Ba are readily accommodated into the plagioclase structure, and as a result are present in higher concentrations in plagioclase bearing xenoliths (i.e. the granulite suites in Figure 6.26). $\mathrm{Ni}$ and $\mathrm{Cr}$ are generally more abundant in the pyroxenite suite (Figure 6.26), which contains higher proportions of spinel, clinopyroxene and olivine; phases that accommodate $\mathrm{Ni}$ and $\mathrm{Cr}$ into their structure. $\mathrm{Ni}$ and $\mathrm{Cr}$ contents in the granulite suite however are still reasonably high, reflecting lower but still significant proportions of spinel and clinopyroxene. $\mathrm{V}$ abundances are also high in the xenolith suite, showing a positive trend with silica in site 90041 granulites, and a negative trend in other xenoliths. These trends are identical to $\mathrm{Ti}$ trends, emphasising the parallel behaviour of these 

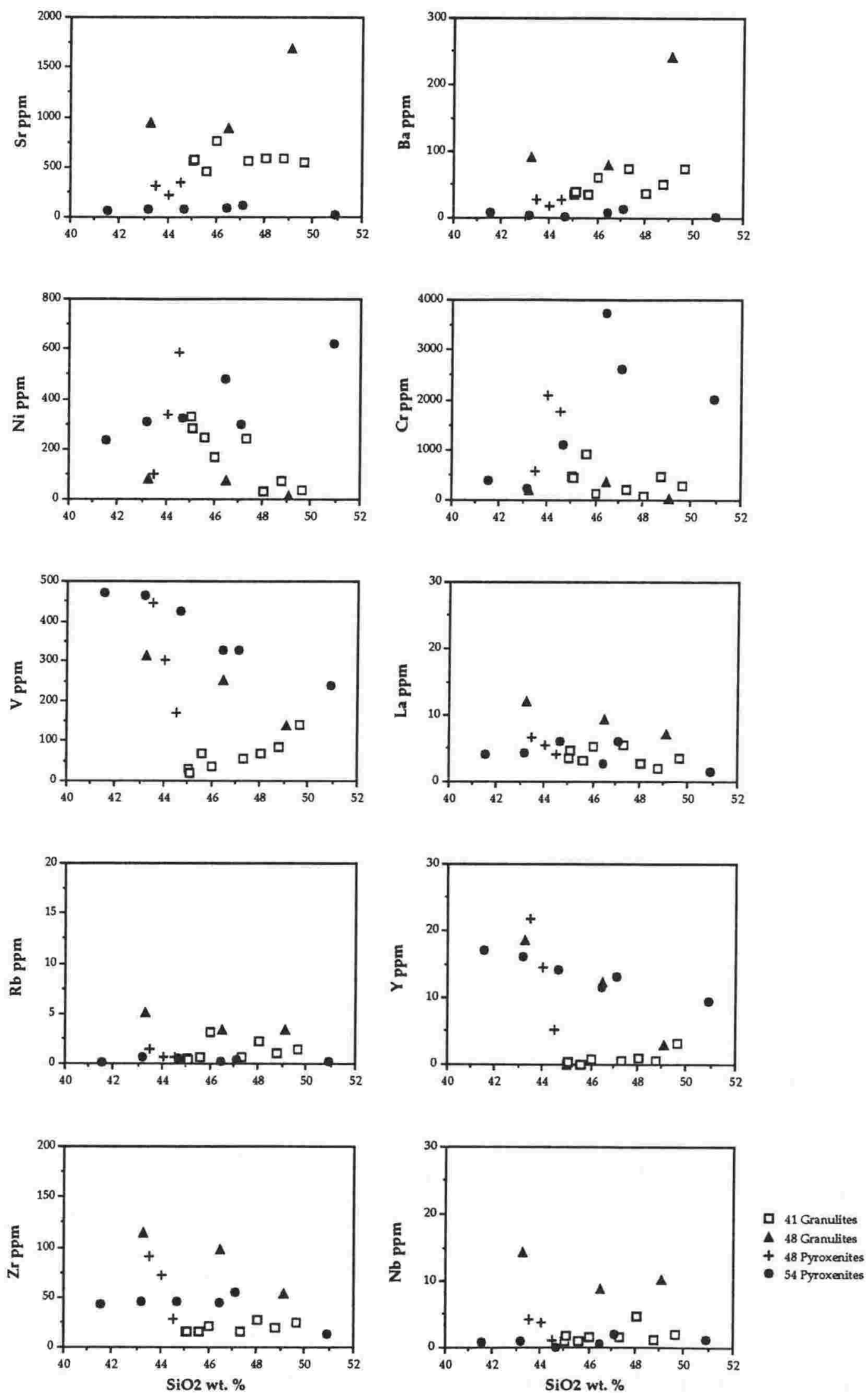

FIGURE 6.26: Trace elements plotted against silica for Mount Murphy xenoliths. Trace element abundances are highly dependant on the mineral assemblage. Only trace elements that readily partition into xenolith mineral phases are present in high abundances. 
elements in melting and crystallisation processes. The positive trend reflects the low abundance of spinels in site 90041 granulites, and the control of clinopyroxene on $\mathrm{Ti}$ and $\mathrm{V}$ contents. The negative trends represent spinel accumulation, increasing $\mathrm{Ti}$ and $\mathrm{V}$, and lowering silica contents in the xenoliths.

\section{Pearce plot (xenolith/MORB)}

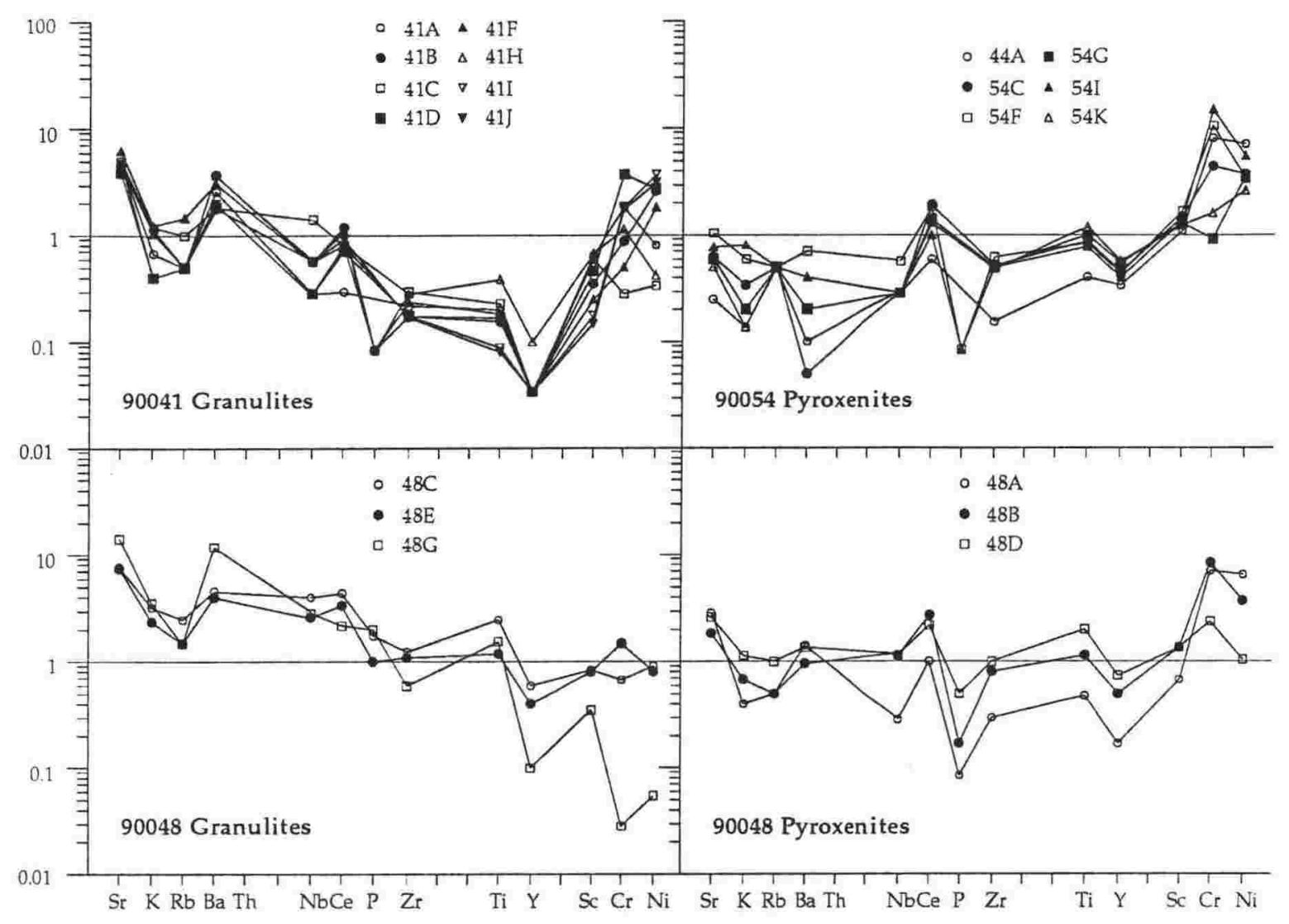

FIGURE 6.27: Multi-element variation diagrams normalised to MORB (Pearce, 1983) for Mount Murphy xenoliths. Patterns are dependant on the partitioning of elements in the xenolith assemblages. Granulites have higher LILE abundances, and lower HFSE abundances than pyroxenites. Site 90048 xenoliths have elevated patterns compared to site 90041 granulites and site 90054 pyroxenites respectively, but may indicate a gradation between them. This may be a product of their crystallisation from more evolved melts.

Elements that are not incorporated into xenolith mineral phases (e.g. La, $\mathrm{Rb}, \mathrm{Y}, \mathrm{Zr}$ and $\mathrm{Nb}$ ) are present in low abundances (Figure 6.26). The low contents of these elements further suggests that trapped melts representing the remnant of the crystallising melt were not present in significant quantities in the cumulate rocks; xenoliths retaining their igneous textures show no signs of trapped intercumulus melts (Chapter 6.3).

The above characteristics are also evident in Figure 6.27, which highlights the difference between xenolith types. Site 90041 granulites have the lowest 
overall abundances of trace elements in the xenolith suite, with only $\mathrm{Ba}$ and $\mathrm{Sr}$ being present in high abundances. In particular, HFSEs are low in abundance compared to in MORBs. Granulites from site 90048 have the highest trace element contents of all the xenolith suite, including high $\mathrm{Ba}$ and $\mathrm{Sr}$ contents reflecting their high content of modal plagioclase. Pyroxenite compositions are similar between sites, although site 90048 pyroxenites have slightly higher trace element abundances than site 90054 pyroxenites, especially in LILEs.

TABLE 6.19: Trace element, including rare earth element, analyses of Mount Murphy granulites, pyroxenites, and clinopyroxenes determined by INAA.

\begin{tabular}{|c|c|c|c|c|c|c|c|}
\hline $\begin{array}{l}\text { Sample } \\
\text { Type }\end{array}$ & $\begin{array}{c}\text { 90041B } \\
\text { Gran } \\
\text { rock }\end{array}$ & $\begin{array}{c}\text { 90041B } \\
\text { Gran } \\
\mathrm{cpx} \\
\end{array}$ & $\begin{array}{c}90041 C \\
\text { Gran } \\
\text { rock }\end{array}$ & $\begin{array}{c}90041 C \\
\text { Gran } \\
\text { cpx }\end{array}$ & $\begin{array}{c}90054 \mathrm{C} \\
\text { Pyxite } \\
\text { rock } \\
\end{array}$ & $\begin{array}{c}90054 \mathrm{~K} \\
\text { Pyxite } \\
\text { rock }\end{array}$ & $\begin{array}{c}90054 \mathrm{~K} \\
\text { Pyxite } \\
\text { cpx } \\
\end{array}$ \\
\hline Sc & 16.81 & 42.8 & 25.14 & 92.5 & 61.3 & 54.9 & 45.3 \\
\hline $\mathrm{Cr}$ & 228.8 & 572 & 79.4 & 292 & 985 & 335 & 439 \\
\hline $\mathrm{Ni}$ & 269 & 318 & 84 & 0 & 352 & 184 & 343 \\
\hline $\mathrm{Zn}_{\mathrm{n}}$ & 47 & 68 & 24 & 65 & 95 & 117 & 178 \\
\hline $\mathbf{R b}$ & 0 & 0 & 0 & 0 & - & - & - \\
\hline $\mathrm{Sr}$ & 611 & 273 & 628 & 0 & 0 & 0 & 0 \\
\hline $\mathrm{Ba}$ & 56 & 82 & 41 & 57 & - & - & - \\
\hline La & 1.62 & 2.1 & 2.9 & 2.92 & 2.98 & 2.19 & 1.69 \\
\hline $\mathrm{Ce}$ & 3.6 & 5.5 & 7 & 7.3 & 10.9 & 8.3 & 7.2 \\
\hline $\mathrm{Nd}$ & 2.4 & 0 & 0 & 0 & 0 & 0 & 6 \\
\hline $\mathrm{Sm}$ & 0.54 & 1.27 & 0.81 & 1.97 & 2.94 & 3.28 & 2.53 \\
\hline Eu & 0.437 & 0.68 & 0.448 & 0.57 & 1 & 1.24 & 0.99 \\
\hline $\mathrm{Tb}$ & 0.111 & 0.32 & 0.133 & 0.41 & 0.46 & 0.62 & 0.5 \\
\hline $\mathbf{Y b}$ & 0.23 & 0.72 & 0.4 & 1.23 & 1.15 & 1.38 & 1.01 \\
\hline Lu & 0.034 & 0.088 & 0.051 & 0.165 & 0.17 & 0.187 & 0.152 \\
\hline Hf & 0.2 & 0.61 & 0.64 & 1.28 & 1.96 & 2.07 & 1.35 \\
\hline $\mathrm{Ta}$ & 0.14 & 0.19 & 0.49 & 0.47 & 0.32 & 0.23 & 0.13 \\
\hline Th & 0 & 0 & 0.57 & 0.83 & 0 & 0.1 & 0.15 \\
\hline
\end{tabular}

Considering the control of xenolith minerals on the whole rock geochemistry of the xenolith suite, the differences in trace element patterns between site 90041 and site 90048 granulites (as well as site 90048 and site 90054 pyroxenites) is likely to be due to variations in mineral composition. The crystallisation of site 90048 xenoliths from more evolved melts (e.g. lower $\mathrm{Mg}: \mathrm{Mg}+\mathrm{Fe}$ ratios of mafic minerals), differences in mineral assemblages, or higher amounts of trapped melt (but still low in abundance) in site 90048 xenoliths, may be responsible for the observed variations. A comparison of trace element patterns is however suggestive of a gradation between xenolith types. 
Rare earth element patterns normalised to chondrite (Wheatley and Rock, 1988) have enriched patterns relative to chondrite, and differ between granulite and pyroxenite xenoliths from Mount Murphy (Figure 6.28). Analyses of REEs are presented as Table 6.19. Xenoliths from site 90048 have not been analysed for REE contents.

\section{REE plot (sample/chondrites)}

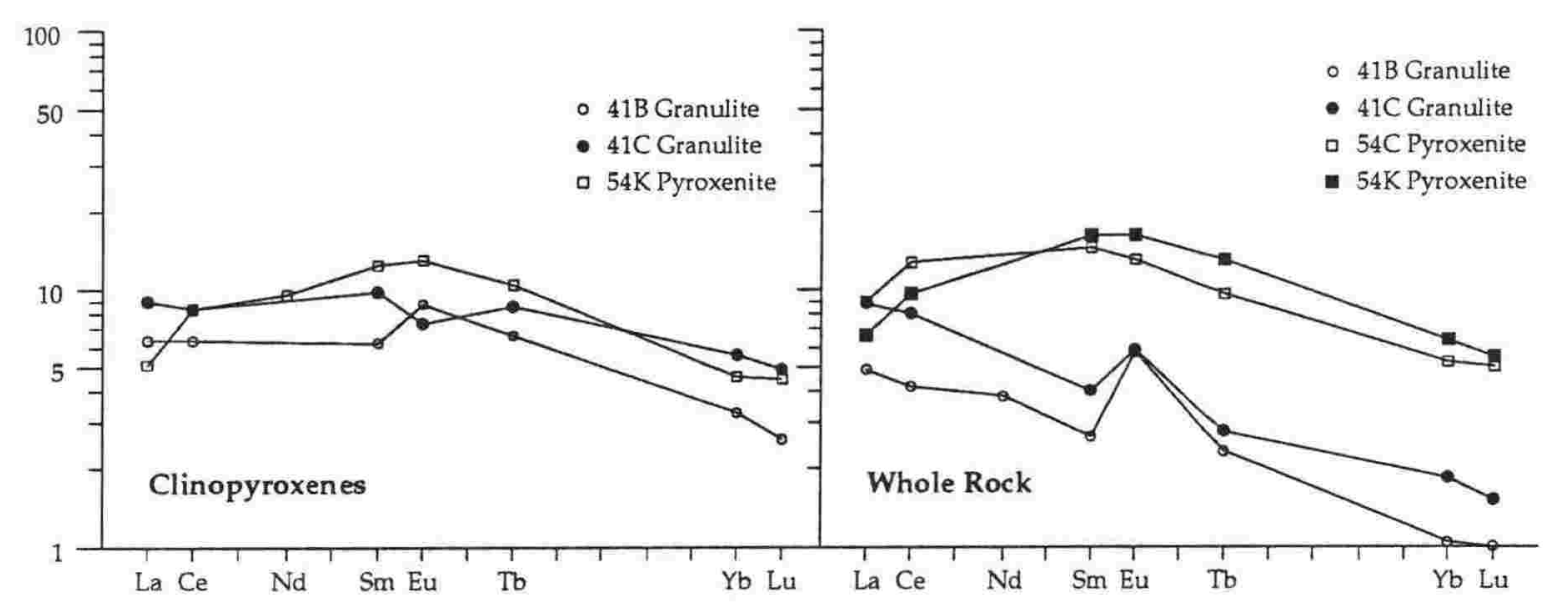

FIGURE 6.28: Rare earth element diagrams normalised to chondrite (Wheatley and Rock, 1988), for clinopyroxenes from site 90041 granulites and a site 90054 pyroxenite, and whole rock samples from two granulites and a pyroxenite. Granulite xenoliths have LREE-enriched patterns relative to HREEs, and a positive Eu anomaly, whereas pyroxenite xenoliths have LREE-depleted patterns relative to HREEs, and no Eu anomaly. These features reflect the control of plagioclase and clinopyroxene on granulite and pyroxenite REE abundances respectively.

Clinopyroxene from a pyroxenite (sample 90054K) shows a convex-up pattern (LREE-depleted relative to HREEs) similar to pyroxenite whole rock patterns, reflecting the control of clinopyroxene on pyroxenite REE compositions. Pyroxenite abundances are slightly lower than clinopyroxene abundances, indicating a dilution of the pattern by REE-deficient mineral phases (e.g. olivine).

Clinopyroxenes from two granulites are similar, with the exception of Eu. The clinopyroxene from sample $90041 \mathrm{C}$ shows a negative Eu-anomaly, suggesting crystallisation from a melt previously depleted in Eu by plagioclase crystallisation. This is consistent with textures (Chapter 6.3) and mineral chemistry (Chapter 6.4.2), which indicate that clinopyroxene crystallised after plagioclase in the granulite suite. The clinopyroxene from sample 90041B does not show a negative Eu-anomaly (in fact it has a slightly positive Eu-anomaly) indicating that it crystallised from a melt prior to plagioclase, as is the case for a minority of granulites (Chapter 6.3). 
A important feature of the trace element abundances in the xenolith suite is that metamorphosed granulites do not differ from granulites that are not metamorphosed, indicating that metamorphism did not produce a notable change in composition; i.e. it was closed system. Some affects of metamorphism however are difficult to determine, such as the affect on elements with low initial abundances. The similarity of xenoliths with documented host interaction (e.g. 41A, 48D, and 48E; Chapter 6.5.1) to other xenoliths in the suite further indicates that the xenoliths have not been enriched in trace elements by the host melt.

The granulite REE pattern differs markedly from the pyroxenite pattern, reflecting the dominance of plagioclase and olivine on whole rock geochemistry of the granulite suite (Chapter 6.6.1), rather than clinopyroxene. The pattern therefore probably mimics that of granulite plagioclase, which must have low REE abundances, and show a relative enrichment in LREEs compared to HREEs, with a strong positive Eu-anomaly, typical of melt-derived plagioclase (Kyle and Rankin, 1976).

TABLE 6.20: $87 \mathrm{Sr} / 86 \mathrm{Sr}$ ratios and $\mathrm{Rb}$ and $\mathrm{Sr}$ contents of Mount Murphy granulites and pyroxenites and one host basalt (from Le Masurier, 1990). For analytical details see Appendix Six. Rb and Sr errors are approximately $\pm 1 \mathrm{ppm}$.

\begin{tabular}{|c|c|c|c|c|c|}
\hline SAMPLE & Type & $\mathbf{R b}$ & $\mathrm{Sr}$ & Mg\# & $87 \mathrm{Sr} / 86 \mathrm{Sr}$ \\
\hline \multicolumn{6}{|c|}{ Mount Murphy Granulites } \\
\hline 90041B & Rock & 1 & 559 & 74.89 & $0.704416+-10$ \\
\hline $90041 C$ & Rock & 2 & 588 & 78.44 & $0.703283+-10$ \\
\hline \multicolumn{6}{|c|}{ Mount Murphy Pyroxenites } \\
\hline $90054 \mathrm{C}$ & Rock & 1 & 74 & 75.46 & $0.702688+-86$ \\
\hline $90054 \mathrm{~K}$ & Rock & 1 & 61 & 71.81 & $0.702820+-15$ \\
\hline \multicolumn{6}{|c|}{ Mount Murphy Volcanics } \\
\hline 67-62 & Basalt & 11 & 533 & 70.00 & 0.70288 \\
\hline
\end{tabular}

\subsubsection{Isotope geochemistry}

Only very limited isotopic data is available for the Mount Murphy xenolith suite, and this is presented as Table 6.20, together with a host basalt (from Le Masurier, 1990). The small number of analyses restricts the use of the isotopes as indicators of source characteristics and secondary processes. Details of isotopic analyses are presented in Appendix Six. 
Measured ${ }^{87} \mathrm{Sr} /{ }^{86} \mathrm{Sr}$ ratios of 0.702688 to 0.704416 are low, and consistent with ratios of mafic mantle derived rocks (Figure 6.29). The low ratios also suggest that if contamination by high ${ }^{87} \mathrm{Sr} /{ }^{86} \mathrm{Sr}$ rocks has occurred (i.e. by crustal rocks) it has been minimal.

$\mathrm{Rb} / \mathrm{Sr}$ ratios do not correlate with ${ }^{87} \mathrm{Sr} /{ }^{86} \mathrm{Sr}$ ratios for a variety of reasons. Foremost is the low $\mathrm{Rb}$ abundance in the xenolith suite, which combined with analytical errors of approximately $\pm 1 \mathrm{ppm}$ (at low $\mathrm{Rb}$ concentrations) does not allow the determination of accurate $\mathrm{Rb} / \mathrm{Sr}$ ratios. Furthermore, enrichment and/or depletion due to secondary processes may have affected the $\mathrm{Rb} / \mathrm{Sr}$ ratios. These limitations make any determinations of model $\mathrm{Rb}-\mathrm{Sr}$ ages meaningless.

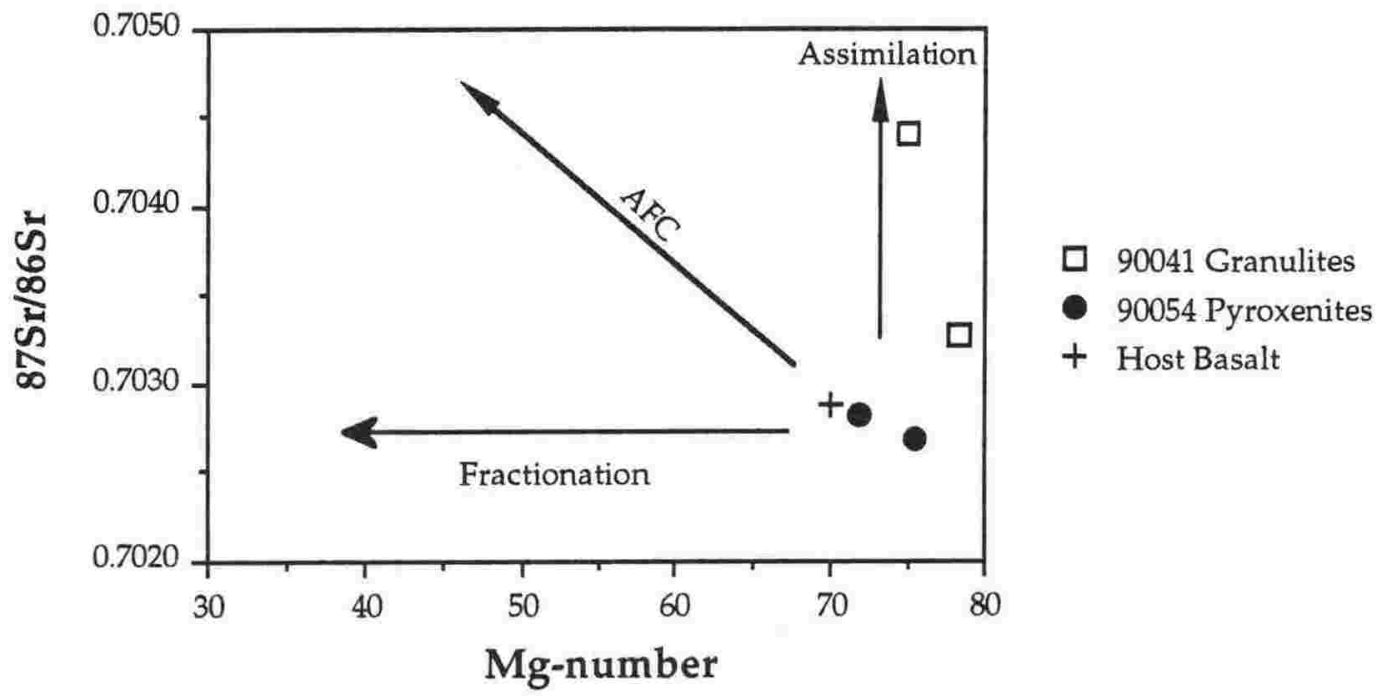

FIGURE 6.29: $\mathrm{Mg \#} \mathrm{v}^{87} \mathrm{Sr} /{ }^{86} \mathrm{Sr}$ ratios for xenoliths from Mount Murphy. Mg\#s remain constant with increasing ${ }^{87} \mathrm{Sr} /{ }^{86} \mathrm{Sr}$. This is most likely due to isotopic heterogeneity in the source region, and further indicates that assimilation of high ${ }^{87} \mathrm{Sr} /{ }^{86} \mathrm{Sr}$ evolved crustal material has not occurred. The low ${ }^{87} \mathrm{Sr} /{ }^{86} \mathrm{Sr}$ ratio of the host basalt (Le Masurier, 1990), which is similar to that of the pyroxenites, makes it difficult to determine if the xenolith suite has been affected by host-melt interaction.

$\mathrm{Mg}$-numbers are constant in the xenoliths with increasing ${ }^{87} \mathrm{Sr} /{ }^{86} \mathrm{Sr}$ ratios (Figure 6.29). This may reflect the assimilation of evolved crustal material. However the low ${ }^{87} \mathrm{Sr} /{ }^{86} \mathrm{Sr}$ and $\mathrm{Rb} / \mathrm{Sr}$ ratios does not support any assimilation of evolved material (which has high- ${ }^{87} \mathrm{Sr} /{ }^{86} \mathrm{Sr}$ and high- $\mathrm{Rb} / \mathrm{Sr}$ ratios). ${ }^{87} \mathrm{Sr} /{ }^{86} \mathrm{Sr}$ ratios of the host melts (Le Masurier, 1990) are similar to pyroxenite ratios, making it difficult to determine if host-melt interaction has affected the xenolith suite. It is unlikely that the present day ${ }^{87} \mathrm{Sr} /{ }^{86} \mathrm{Sr}$ ratios are time integrated, as $\mathrm{Rb} / \mathrm{Sr}$ ratios of the xenolith suite are very low, making it unlikely that present-day ratios would differ substantially from initial ratios (unless the xenoliths initially 
had higher $\mathrm{Rb}$ contents). A more likely explanation for the observed trend is isotopic heterogeneity in the source region.

A further discussion of the isotopic ratios of the Mount Murphy xenolith suite is presented in Chapter Seven, where the Mount Murphy xenolith suite is compared to the other xenolith suites world-wide, including other sites from MBL.

\subsubsection{Summary and discussion of whole rock geochemistry}

The whole rock geochemistry of the Mount Murphy is dominated by the modal mineral assemblage present in the xenolith suite. In particular, the whole rock geochemistry of the granulite suite is controlled by plagioclase and olivine contents, and the pyroxenite suite by the modal abundances of clinopyroxene, and to a less extent Al-spinel. The main features of the xenolith suite include;

- a mafic composition controlled by the mineral assemblage, which crystallised from a series of genetically related mafic mantle melts (41-51 wt. \% $\mathrm{SiO}_{2}$; original Mg\#s 71-86; $\left.{ }^{87} \mathrm{Sr} /{ }^{86} \mathrm{Sr} 0.702688-0.704416\right)$;

- site 90048 xenoliths have higher trace element abundances than other lower crustal xenoliths from Mount Murphy, which exhibit a gradation in trace elements between the suites. The difference in composition is due to differences in mineral chemistry, and modal abundances;

- REE abundances differ markedly between granulites and pyroxenites reflecting the dominance of plagioclase and clinopyroxene respectively in the two suites;

$-{ }^{87} \mathrm{Sr} /{ }^{86} \mathrm{Sr}$ ratios are low in the xenolith suite $(0.702688$ to 0.704416$)$, and are consistent with derivation from a mafic melt, and little or no crustal (high${ }^{87} \mathrm{Sr} /{ }^{86} \mathrm{Sr}$ ) contamination, including crystallisation uder AFC conditions. The ${ }^{87} \mathrm{Sr} /{ }^{86} \mathrm{Sr}$ ratios of host melts are similar to the xenolith suite, making it difficult to determine if the host melts have affected xenolith isotopic ratios. Variations in ${ }^{87} \mathrm{Sr} /{ }^{86} \mathrm{Sr}$ ratios evident in the xenolith suite probably reflect isotopic heterogeneity in the source region;

- the effects of metamorphism on an assemblage initially low in mobile element abundances (e.g. LILEs, and LREEs) is difficult to ascertain. However, as there has not been any notable large-scale depletion of the xenolith suites in trace element contents, metamorphism is believed to have occurred under essentially closed-system conditions;

- there is no evidence for chemical enrichment of the xenolith suite by the host melts (e.g. in LILEs or LREEs). 


\subsection{Summary and Conclusions}

\subsubsection{Summary of the xenolith suite}

Meta-igneous granulites and cumulate pyroxenites comprise the lower crust beneath Mount Murphy. The xenoliths are anhydrous, and consist of clinopyroxene, olivine, plagioclase (abundant in the granulites), spinels, and very rare orthopyroxene. The salient features of the xenolith suite are presented as Table 6.21.

TABLE 6.21: Summary of the main characteristics of the Mount Murphy xenolith suite for granulites and pyroxenites from three sites.

\begin{tabular}{|c|c|c|c|c|}
\hline TYPE & 90041 Granulites & 90048 Granulites & 90048 Pyroxenites & 90054 Pyroxenites \\
\hline TEXTURE & $\begin{array}{c}\text { Meta-Igneous } \\
\text { Layered } \\
\text { Granulites }\end{array}$ & $\begin{array}{c}\text { Igneous/ } \\
\text { Meta-Igneous } \\
\text { Granulites }\end{array}$ & $\begin{array}{l}\text { Cumulate } \\
\text { Pyroxenites }\end{array}$ & $\begin{array}{l}\text { Cumulate } \\
\text { Pyroxenites }\end{array}$ \\
\hline MINERALOGY & Y $\mathrm{Pl}+\mathrm{Ol}+\mathrm{Cp} x$ & $\mathrm{Plag}+\mathrm{Cpx}+\mathrm{Ol}$ & $\mathrm{Cpx}+\mathrm{Ol}+\mathrm{Plag}+\mathrm{Sp}$ & $\mathrm{Cpx}+\mathrm{Ol}+\mathrm{Sp}$ \\
\hline TEMP. $\left({ }^{\circ} \mathrm{C}\right)$ & $620-1070$ & $960-1210$ & $1110-1230$ & $1190-1320$ \\
\hline PRESSURE (kb) & $1.5-7.5$ & $3-10$ & $8-13$ & $7.5-11$ \\
\hline $\begin{array}{l}\text { SECONDARY } \\
\text { REACTIONS }\end{array}$ & $\begin{array}{c}\text { Oxidation } \\
\text { (extensive) }\end{array}$ & $\begin{array}{l}\text { Oxidation } \\
\text { (moderate) }\end{array}$ & $\begin{array}{l}\text { Oxidation } \\
\text { (moderate) }\end{array}$ & $\begin{array}{l}\text { Oxidation } \\
\text { (moderate) }\end{array}$ \\
\hline $\begin{array}{l}\text { MAJOR } \\
\text { ELEMENTS }\end{array}$ & $\begin{array}{l}\text { High } \mathrm{Mg} \# \text {, alkalis } \\
\text { Low } \mathrm{Mg}, \mathrm{Fe}\end{array}$ & $\begin{array}{l}\text { High } \mathrm{Ti} \text {, alkalis } \\
\text { Low } \mathrm{Mg \# ,} \mathrm{Mg}\end{array}$ & $\begin{array}{c}\text { High } \mathrm{Mg} \text {, Fe } \\
\text { Low } \mathrm{Mg \# ,} \mathrm{alkalis}\end{array}$ & $\begin{array}{c}\text { High } \mathrm{Mg}, \mathrm{Mg} \text {, } \mathrm{Fe} \\
\text { Low alkalis }\end{array}$ \\
\hline $\begin{array}{l}\text { TRACE } \\
\text { ELEMENTS }\end{array}$ & $\begin{array}{l}\text { High LILEs } \\
\text { Low HFSE }\end{array}$ & $\begin{array}{l}\text { High LILEs } \\
\text { Low } \mathrm{Cr}, \mathrm{Ni}\end{array}$ & $\begin{array}{l}\text { High } \mathrm{Cr}, \mathrm{Ni} \\
\text { Low LILEs }\end{array}$ & $\begin{array}{l}\text { High } \mathrm{Cr}, \mathrm{Ni} \\
\text { Low LILEs }\end{array}$ \\
\hline REEs & LREE-enriched & & & LREE-depleted \\
\hline ISOTOPES & Low $87 \mathrm{Sr} / 86 \mathrm{Sr}$ & & & Low $87 \mathrm{Sr} / 86 \mathrm{Sr}$ \\
\hline
\end{tabular}

Xenoliths from different sites on Mount Murphy are similar in texture and mineralogy, and have many similar geochemical characteristics, indicating a genetic relationship between the xenoliths. There is however some variation between xenoliths from different sites in mineral composition, with xenoliths from site 90048 having more evolved characteristics than those from other sites (e.g. low Fo content of olivine, and low En content of clinopyroxene). These differences have resulted from the crystallisation of the site 90048 xenoliths from a 
more evolved (but genetically related) melt than the other xenoliths. Geothermometry and geobarometry calculations indicate that samples from different sites are sourced from different levels of the crust, indicating vertical rather than lateral heterogeneity in the lower crust, although the latter may also be the case.

As the xenoliths are essentially cumulates (or metamorphosed cumulates), their whole rock geochemistry reflects their mineral chemistry. Xenoliths from site 90048 therefore differ from other sites (e.g. lower Mg\#s due to low Fo content of olivine and low En content of clinopyroxene). Major and trace elements that are readily partitioned into xenolith mineral phases are abundant in the xenoliths, and those that are not accommodated into mineral phases are low in abundance.

The lower crust beneath Mount Murphy, represented by the xenolith suite, has been affected by a number of processes subsequent to crystallisation. Many granulites have recrystallised metamorphic fabrics and show evidence of brittle deformation, indicating that metamorphic and deformational processes have affected the lower crust. Metamorphosed granulites are identical in composition to granulites that have not been metamorphosed, indicating that metamorphism was probably a closed-system process.

During entrainment in host basalts, and ascent to the surface, pockets of host basalt have infiltrated the xenolith suite, interacting with xenolith mineral phases. A striking affect of entrainment has been the oxidation of olivine to various degrees, ranging from the breakdown of olivine rims into two phases (one Mg-rich, the other more Fe-rich), to the formation of multi-layered symplectites of two phases of olivine and orthopyroxene. The extent of host melt xenolith interaction has been minor, with no obvious enrichment in major or trace elements, or isotopic signature.

\subsubsection{Nature of the crystallising melt and cumulate derivatives}

The composition of the crystallising melt cannot be directly determined, as melt in equilibrium with the cumulate xenoliths has not been found. Several characteristics of the xenolith suite indicate some of the parental melts features (Figure 6.30):

- mineral and whole rock compositions indicate that the xenolith suite is genetically related, and that site 90041 granulites have the most primitive compositions, and site 90048 granulites and pyroxenites the most evolved compositions. Several melts crystallised the xenolith suite; 
- the anhydrous and simple mineral assemblage of clinopyroxene \pm olivine \pm plagioclase \pm oxides, indicates that the parental melts were basaltic in composition;

- Fo contents of olivine in the cumulate derivatives of the melts (the xenolith suite) range from Fo 55-87, indicating equilibration from primitive to more evolved mantle melts;

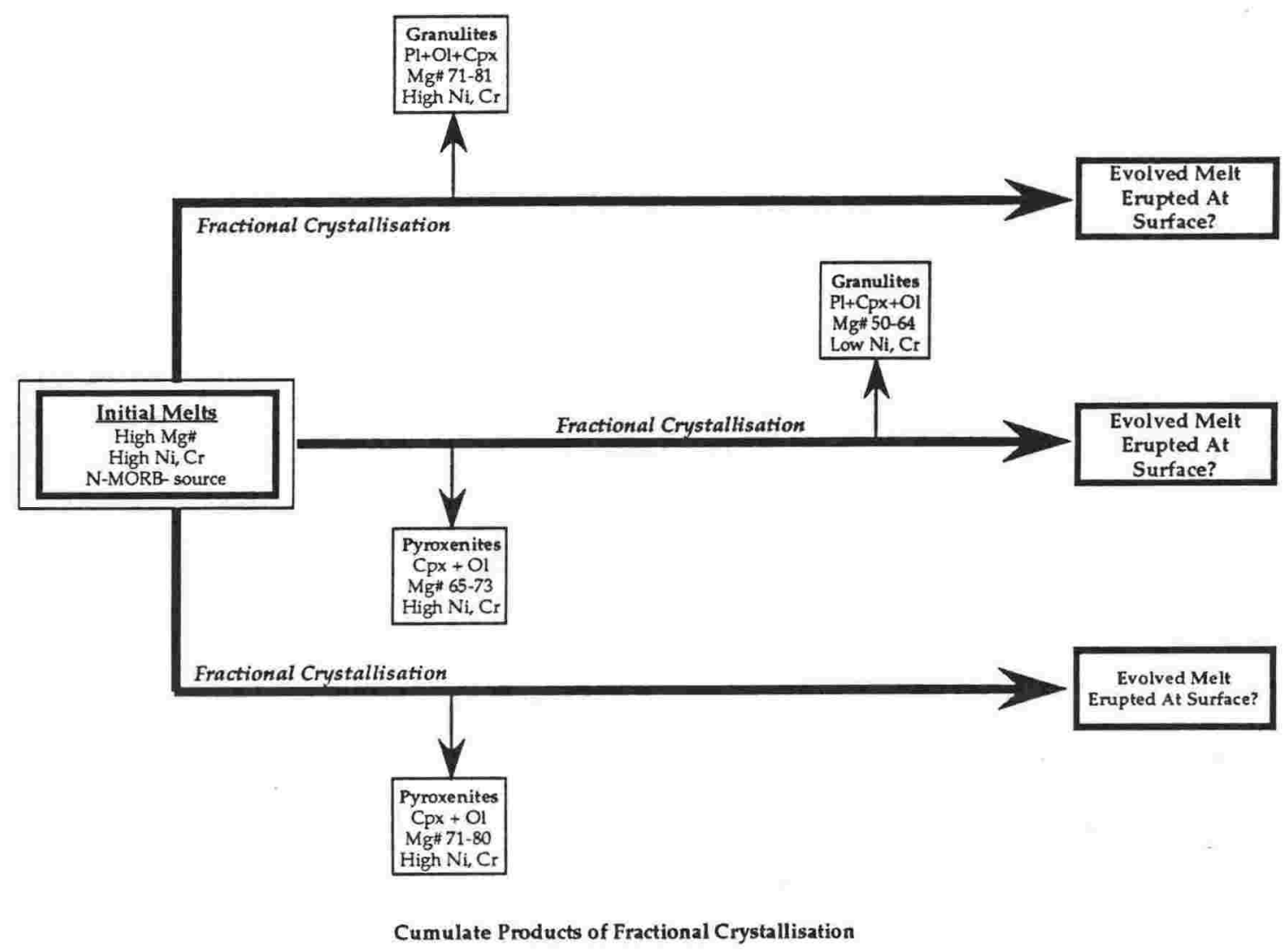

FIGURE 6.30: Inferred crystallisation sequence of the Mount Murphy xenolith suite from primitive melts sourced from the (depleted) mantle. Multiple episodes of fractionation from several melts best explain the relationship between genetically related xenoliths from different localities.

- the presence of large amounts of cumulate material (the xenolith suite), the variation of cumulus and intercumulus phases, and the composition of mineral phases (e.g. lower Fo content in olivine) between xenolith types, indicates that the parental melts evolved by crystal fractionation;

- present day ${ }^{87} \mathrm{Sr} /{ }^{86} \mathrm{Sr}$ ratios of the xenolith suite are low, indicating crystallisation from mantle-sourced melts. The low ratios further indicate that the melts were not contaminated by crustal rocks with high ${ }^{87} \mathrm{Sr} /{ }^{86} \mathrm{Sr}$ ratios.

The parental melts were primitive mantle (possibly depleted) melts that evolved by fractionation of the xenolith suite (Figure 6.30). These melts cannot have been the host magmas for a number of reasons; 
- metamorphic textures in some xenoliths indicate metamorphism prior to entrainment. They must therefore pre-date the host basalts;

- mineral and whole rock compositions indicate crystallisation from melts unlike the host melts;

- host melt that has infiltrated the xenolith has caused disequilibrium reactions with the xenolith assemblage, indicating that the xenoliths cannot have crystallised from these melts;

- the host lavas do not have the large negative Eu-anomalies required for the melts that crystallised the xenolith suite, which have positive Eu-anomalies.

As with the xenolith suite from Mount Sidley (Chapter 4.7.2) and Mount Hampton (Chapter 5.7.2), melts that have the characteristics required to be parental to the Mount Murphy xenolith suite have not been identified.

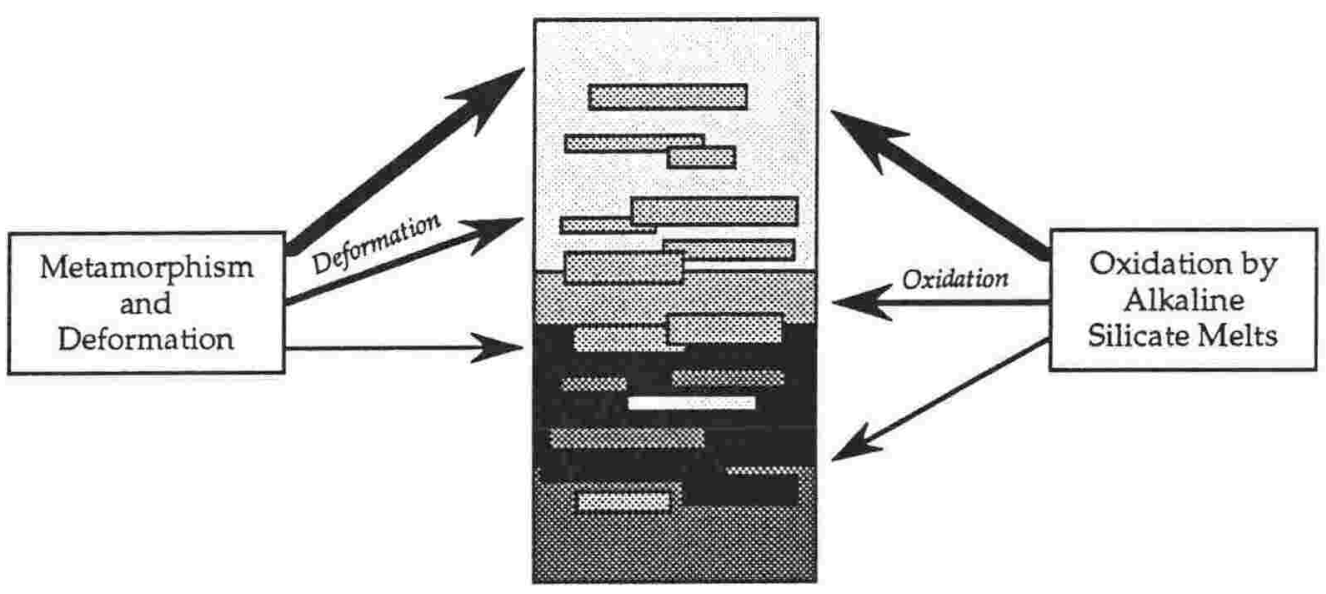

\section{METAMORPHISM \\ Recrystallisation of mineral phases to equant grains, with no apparant chemical change.}

90041 Granulites

\section{CRYSTALLISATION}

Crystallisation of cumulates from several genetically related primitive melts, sourced from the mantle.

\section{OXIDATION}

\section{Oxidation of olivine} to symplectites. No detectable chemical change to the xenolith suite.

90048 Pyroxenites

90054 Pyroxenites

FIGURE 6.31: Stylised stratigraphic sequence of the lower crust based on the Mount Murphy xenolith suite. The occurrence of xenoliths at different levels is based on relationships between the xenoliths, their occurrence with other xenoliths at the surface, and P-T estimates from pyroxene and oxide geothermometry and geobarometry. Metamorphic processes have recrystallised the upper levels of the lower crust, but have not resulted in any significant compositional change. Oxidation processes due to host melt infiltration have affected all xenoliths, especially xenoliths at higher levels in the crust, suggesting that these regions may be more perceptible to oxidation. The extent of these processes is shown by the thickness of the arrows, with large arrows indicating more intense metamorphism, deformation and oxidation. 


\subsubsection{Stratigraphy of the lower crust and secondary processes}

Possible models of the stratigraphy of the lower crust beneath Mount Murphy have been proposed in Chapter 6.3.3 (Figure 6.2). The preferred model of multiple-episodes of growth of the lower crust by basaltic mantle melts crystallising the xenolith suite, based on textures and occurrence of xenolith types (e.g. pyroxenites and peridotites at site 90054), remains the most likely model. In particular, the genetic relationship between the xenolith suites, and the P-T estimates based on pyroxene and oxide geothermometry and geobarometry indicate a stratified lower crust, with site 90041 granulites at higher levels, and site 90054 pyroxenites at intermediate to lower levels in the crust (Figure 6.31).

Metamorphic textures in the granulite suite indicates that the lower crust underwent metamorphism in these regions. Xenoliths from lower depths are not metamorphosed, indicating that metamorphism of the lower crust is confined to upper levels. Deformational features are widespread only in site 90041 granulites, suggesting that brittle deformation is only common at higher levels, which is under brittle mechanical boundary conditions (Parsons and McKenzie, 1978).

Finally, oxidation of the suite has occurred in all xenolith types, but is more intense in upper level granulites, where symplectites of olivine are well developed. The more extensive oxidation of higher level granulites indicates that either these xenoliths are more perceptible to the effects of oxidation, or that oxidation as a process is more extensive in the upper levels of the lower crust.

\subsubsection{Conclusion}

The Mount Murphy xenolith suite represents a suite of cumulates that formed by crystallisation from an evolving, primitive mantle melt. Metamorphic textures in some xenoliths, differences in composition, and disequilibrium reactions between the host melts and the xenoliths indicate that the xenoliths do not represent cumulate products of the host melt. Melts with the characteristics of the crystallising melt (primitive mantle (depleted) melt) have not been detected near Mount Murphy, or anywhere else in MBL.

The xenolith suite represents the lower crust beneath Mount Murphy, which is inferred to have grown by multiple episodes of fractional crystallisation of the parental melts. Subsequent to crystallisation, metamorphic and deformational processes have affected the higher levels of the lower crust, but there effects have been minimal in lower levels of the crust, which maintain their initial igneous textures. Metamorphism has resulted in recrystallisation of igneous mineral phases, but has not resulted in any detectable geochemical change in the lower crust. 
Part Three

\section{THE MARIE Byrd LAND LITHOSPHERE}

A comparison of the MBL xenolith suites with other xenolith localities world-wide, including a new estimate of the average composition of the lower crust, a discussion of the composition, structure, and processes influencing the MBL lithosphere, and implications for tectonic reconstructions. 


\section{Chapter seven \\ SYNTHESIS OF THE MARIE BYRD LAND LITHOSPHERE}

\section{Synopsis}

The Marie Byrd Land upper mantle is heterogeneous in composition, consisting of spinel lherzolites variably cut by Cr-diopside rich veins. Lherzolites from the USAS Escarpment are depleted in LREEs, possibly due to previous partial melting processes. Cr-diopside rich lherzolites occur at Mounts Hampton and Murphy. These lherzolites vary in composition (e.g. 38-54 wt. \% $\mathrm{SiO}_{2} ; \mathrm{Mg \# s}$ 75-92), compared to spinel lherzolites which have more restricted compositions (e.g. 44-46 wt. \% $\mathrm{SiO}_{2} ; \mathrm{Mg \# s}$ 87-92), and indicate a more fertile upper mantle in these regions. The geochemical similarity of $\mathrm{Cr}$-diopsides from spinel lherzolites, and from $\mathrm{Cr}$-diopside veins, indicates that the veins are related genetically.

Lower crustal xenoliths from Marie Byrd Land differ in composition geographically, indicating widespread geochemical heterogeneity in the lower crust. Lower crustal granulites from Mounts Sidley and Waesche are similar in composition to granulites from the Transantarctic Mountains (TM) and New Zealand, and together have been termed the TM Group. Granulites from Mounts Hampton, Cumming and Murphy are similar to granulites from the Ross Embayment (RE) and have been termed the RE Group. Southeastern Australia granulites vary in composition, overlapping with the RE and TM Groups.

$T M$ Group granulites are more evolved than RE Group granulites, with lower Mg\#s, higher Si, alkalis, $P$, most trace elements (including REE), and higher ${ }^{87} \mathrm{Sr} /{ }^{86} \mathrm{Sr}$ isotopic ratios. These features are interpreted to be due to differences in mineral chemistry resulting from their crystallisation from more evolved melts, and in some cases due to secondary enrichment by alkaline melts. Pyroxenites from these areas vary in composition, with no distinct similarities.

Integration of these new localities in terms of previous estimations of average world-wide lower crustal compositions leads to a more depleted, and primitive average lower crust. 


\subsection{Introduction}

Having documented the xenolith suites from MBL (Part Two), it is necessary to compare these suites to obtain a geochemical model for the MBL lithosphere. In this chapter, a three stage comparison of the xenolith suite will be made. First of all, the xenolith suites from MBL, including those from Mounts Sidley, Hampton and Murphy, as well as from Mount Waesche and Mount Cumming in the ECR, will be compared to more fully characterise the composition of the MBL lower crust. Secondly, the MBL lower crust is compared to the lower crust from other Gondwana continental fragments, namely the Ross Sea Embayment and Transantarctic Mountain regions (Antarctica), New Zealand and Australia. Finally, a comparison with average models for the composition of the lower crust is made in order to compare the MBL suite with localities world-wide. Lower crustal xenoliths from Antarctica and New Zealand discussed in this Chapter are then added to the existing data set of lower crustal xenoliths to establish a new average composition of the lower crust based on xenolith localities world-wide.

Prior to comparing the various lower crustal xenolith suites, a geochemical description of the upper mantle in MBL is presented in an attempt to document the MBL lithosphere. Upper mantle xenoliths from a number of localities from MBL, including Mount Murphy (on the Walgreen coast), Mt Aldaz (in the USAS Escarpment) and the ECR (Mounts Hampton and Cumming), will be discussed.

\subsection{The Marie Byrd Land Upper Mantle}

\subsubsection{Introduction}

The Upper Mantle, as previously discussed (Chapter 1.4), is considered here to consist of Type I peridotites (Frey and Prinz, 1978) while Type II pyroxenites are classified as lower crustal, due to their association with the granulite suites. Peridotites have not been found in lithological contact with pyroxenites or granulites. A detailed study of peridotitic xenoliths was not attempted in this study, however some discussion of the upper mantle is necessary in order to more fully understand the MBL lithosphere.

The mantle lithosphere in MBL consists of spinel lherzolites with granular textures consisting of olivine + clinopyroxene + orthopyroxene + spinel. In the Mount Hampton peridotite suite, $\mathrm{Cr}$-diopsides commonly occur as veins in lherzolites, and as whole samples on a cm-dm scale. The whole rock samples are 
interpreted to represent large veins in the upper mantle, as they are identical chemically to those found as veins in lherzolite.

\subsubsection{Major element geochemistry of upper mantle peridotites}

Representative whole rock compositions of MBL peridotites are presented as Table 7.1. Major element contents of Mount Cumming and USAS Escarpment lherzolites are restricted in range (e.g. 44-46 wt. \% $\mathrm{SiO}_{2}$ ). Lherzolites from Mount Hampton and Mount Cumming have similar compositions to Mount Cumming and USAS Escarpment lherzolites, however $\mathrm{Cr}$-diopside rich veins and dunites from these localities have a greater range in composition (e.g. 38-54 wt. \% $\mathrm{SiO}_{2}$ ).
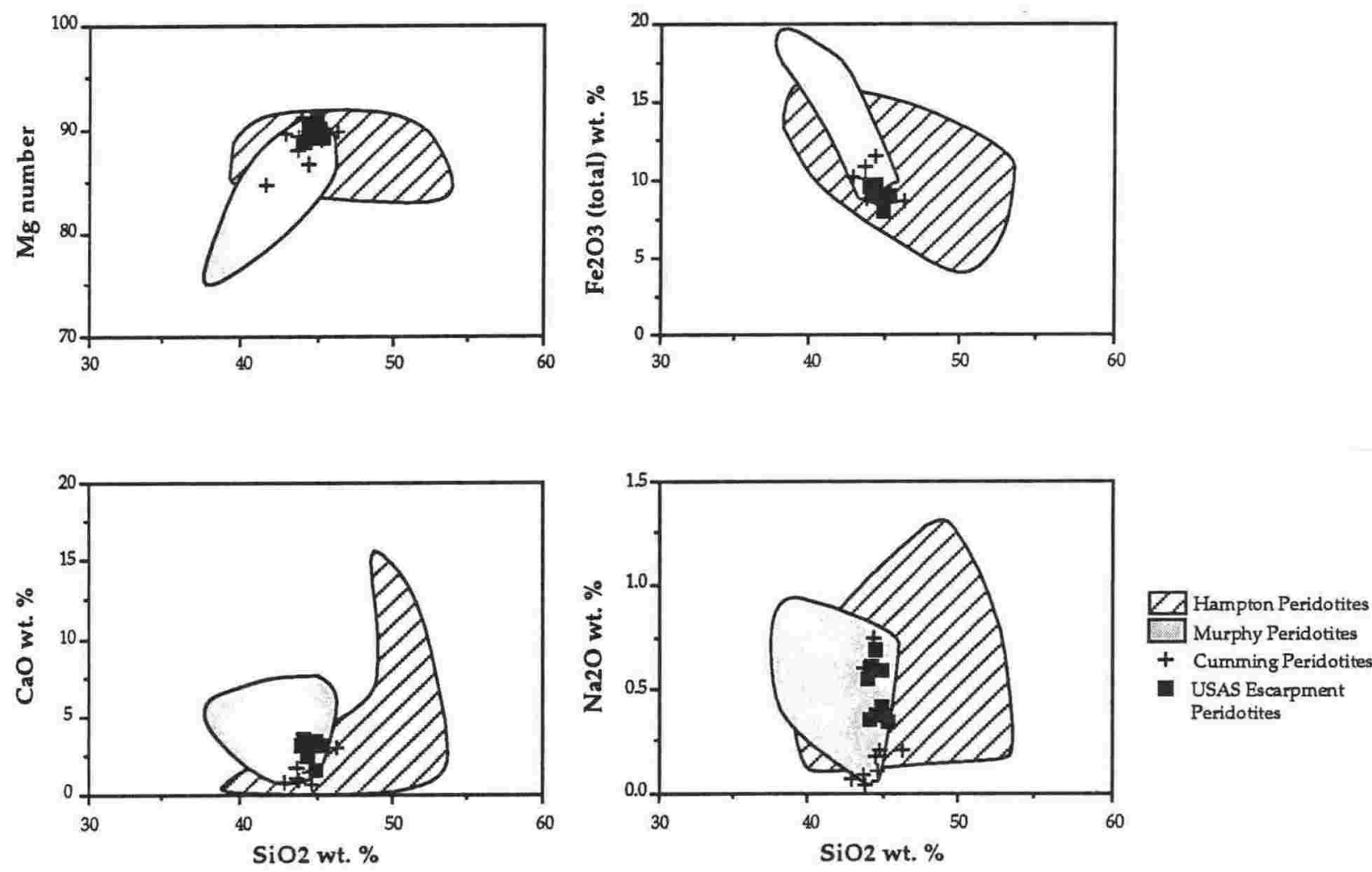

FIGURE 7.1: Selected $\mathrm{SiO}_{2} \mathrm{v}$ major element plots for Marie Byrd Land peridotites, with Hampton peridotites striped, and Murphy peridotites shaded. Note the variable Mount Hampton and Mount Murphy peridotite compositions, compared to the restricted compositions of peridotites from Mount Cumming and the USAS Escarpment.

Mount Hampton $\mathrm{Cr}$-diopside rich peridotites have higher $\mathrm{SiO}_{2}, \mathrm{TiO}_{2}, \mathrm{Al}_{2} \mathrm{O}_{3}$, $\mathrm{CaO}$ and $\mathrm{Na}_{2} \mathrm{O}$ contents, and lower $\mathrm{Fe}_{2} \mathrm{O}_{3}$ (total) and $\mathrm{MgO}$ contents, than Mount Hampton spinel lherzolites (Table 7.1). These variations, some of which are evident in Figure 7.1 (the $\mathrm{Cr}$-diopside veins are the high- $\mathrm{SiO}_{2}$ peridotites), reflect the increased $\mathrm{Cr}$-diopside abundance in these xenoliths and the consequent lack of olivine and orthopyroxene. 
TABLE 7.1: Representative compositions for peridotites from Marie Byrd Land, determined by XRF, including Mount Hampton (Ham), Mount Murphy (Mur), Mount Cumming (Cum) and the USAS Escarpment (USAS). Lherz = spinel lherzolite; $\mathrm{Cr}$-Diop $=\mathrm{Cr}$-diopside rich peridotite; Dun = dunite.

\begin{tabular}{|c|c|c|c|c|c|c|c|c|c|c|}
\hline $\begin{array}{l}\text { SAMPLE } \\
\text { TYPE } \\
\text { SUTTE } \\
\end{array}$ & $\begin{array}{c}\text { PK4E } \\
\text { Cr-Diop } \\
\text { Ham } \\
\end{array}$ & $\begin{array}{l}\text { PK4Z } \\
\text { Lherz } \\
\text { Ham } \\
\end{array}$ & $\begin{array}{c}\text { PK4A1 } \\
\text { Dun } \\
\text { Ham } \\
\end{array}$ & $\begin{array}{c}\text { 90040E } \\
\text { Lherz } \\
\text { Cum } \\
\end{array}$ & $\begin{array}{c}\text { 90040K } \\
\text { Lherz } \\
\text { Cum } \\
\end{array}$ & $\begin{array}{c}\text { 90054E } \\
\text { Lherz } \\
\text { Mur }\end{array}$ & $\begin{array}{c}900540 \\
\text { Dun } \\
\text { Mur } \\
\end{array}$ & $\begin{array}{c}\text { 90054Q } \\
\text { Lherz } \\
\text { Mur } \\
\end{array}$ & $\begin{array}{c}\text { MB69D } \\
\text { Lherz } \\
\text { USAS } \\
\end{array}$ & $\begin{array}{c}\text { MB69G } \\
\text { Lherz } \\
\text { USAS } \\
\end{array}$ \\
\hline $\mathrm{SiO} 2$ & 51.01 & 44.12 & 39.45 & 45.17 & 44.83 & 43.82 & 38.50 & 44.24 & 44.01 & 44.96 \\
\hline $\mathrm{TiO} 2$ & 0.14 & 0.03 & 0.04 & 0.14 & 0.04 & 0.09 & 0.55 & 0.04 & 0.12 & 0.01 \\
\hline $\mathrm{A} 12 \mathrm{O} 3$ & 4.76 & 1.15 & 0.28 & 3.59 & 1.62 & 2.31 & 4.87 & 1.65 & 3.34 & 1.76 \\
\hline $\mathrm{Fe} 2 \mathrm{O} 3$ tot & 4.70 & 8.44 & 15.69 & 9.31 & 8.35 & 10.01 & 19.57 & 11.62 & 9.51 & 8.07 \\
\hline $\mathrm{MnO}$ & 0.11 & 0.12 & 0.18 & 0.14 & 0.13 & 0.15 & 0.23 & 0.16 & 0.14 & 0.13 \\
\hline $\mathrm{MgO}$ & 24.80 & 44.11 & 43.96 & 37.93 & 42.88 & 41.05 & 31.54 & 40.94 & 38.11 & 42.48 \\
\hline $\mathrm{CaO}$ & 12.86 & 0.91 & 0.38 & 3.10 & 1.57 & 1.45 & 4.88 & 1.34 & 3.09 & 1.54 \\
\hline $\mathrm{Na} 2 \mathrm{O}$ & 1.06 & 0.58 & 0.55 & 0.40 & 0.21 & 0.37 & 0.89 & 0.07 & 0.55 & 0.41 \\
\hline $\mathrm{K} 2 \mathrm{O}$ & 0.01 & 0.05 & 0.04 & 0.03 & 0.01 & 0.02 & 0.06 & 0.02 & 0.02 & 0.02 \\
\hline $\mathrm{P} 2 \mathrm{O} 5$ & 0.00 & 0.01 & 0.02 & 0.01 & 0.01 & 0.03 & 0.04 & 0.00 & 0.01 & 0.01 \\
\hline LOI & 0.05 & 0.00 & 0.00 & 0.00 & 0.00 & 0.00 & 0.00 & 0.00 & 0.35 & 0.17 \\
\hline TOTAL & 99.50 & 99.52 & 100.59 & 99.82 & 99.65 & 99.30 & 101.13 & 100.08 & 99.25 & 99.56 \\
\hline Mg\# & 91.27 & 91.19 & 84.73 & 88.97 & 91.05 & 89.04 & 76.14 & 87.46 & 88.81 & 91.25 \\
\hline $\mathrm{Sc}$ & 40 & 6 & 3 & 13 & 8 & 10 & 13 & 8 & 16 & 8 \\
\hline V & 157 & 32 & 19 & 79 & 40 & 57 & 157 & 47 & 77 & 43 \\
\hline $\mathrm{Cr}$ & 6776 & 2491 & 219 & 2788 & 2615 & 3018 & 1641 & 3048 & 2459 & 3052 \\
\hline $\mathrm{Ni}$ & 1012 & 2598 & 2495 & 1936 & 2436 & 2205 & 1109 & 2203 & 2143 & 2319 \\
\hline $\mathrm{Cu}$ & 43 & $<1$ & 62 & 15 & 1 & 11 & 14 & 7 & 26 & $<1$ \\
\hline $\mathrm{Zn}$ & 29 & 50 & 103 & 53 & 47 & 66 & 135 & 81 & 57 & 48 \\
\hline $\mathrm{Ga}$ & 5 & 2 & 2 & 4 & 3 & 4 & 11 & 3 & 4 & 2 \\
\hline $\mathrm{Rb}$ & 1 & 1 & 1 & 1 & $<1$ & 1 & $<1$ & $<1$ & $<1$ & 1 \\
\hline $\mathrm{Sr}$ & 15 & 2 & 3 & 12 & 8 & 11 & 36 & 5 & 9 & 9 \\
\hline$Y$ & 4 & $<1$ & $<1$ & $<1$ & $<1$ & $<1$ & 2 & $<1$ & 1 & $<1$ \\
\hline $\mathrm{Zr}$ & 1 & $<1$ & 1 & 5 & 1 & 6 & 16 & 1 & 2 & $<1$ \\
\hline $\mathrm{Nb}$ & $<1$ & 1 & 1 & 2 & 1 & $<1$ & 2 & 1 & 1 & 1 \\
\hline $\mathrm{Ba}$ & 2 & 4 & 4 & 2 & 2 & 8 & 4 & 4 & $<1$ & 6 \\
\hline $\mathrm{La}$ & 2 & 1 & 3 & 2 & $<1$ & $<1$ & 3 & 3 & $<1$ & 1 \\
\hline $\mathrm{Ce}$ & 5 & $<1$ & 11 & 5 & $<1$ & 2 & 11 & 1 & $<1$ & $<1$ \\
\hline
\end{tabular}

Mount Murphy silica-poor peridotites are higher in $\mathrm{TiO}_{2}, \mathrm{Al}_{2} \mathrm{O}_{3}, \mathrm{MnO}$ and $\mathrm{Fe}_{2} \mathrm{O}_{3}$ (total), and lower in $\mathrm{Mg} \#$ and $\mathrm{MgO}$ than the rest of the Mount Murphy peridotite suite. These characteristics indicate the abundance of more silica-poor mineral phases such as olivine and spinels.

Peridotites from Mount Cumming and the USAS Escarpment have very consistent compositions. The trends defined by Mount Hampton and Mount 
Murphy peridotites intersect with Mount Cumming and Mount Murphy compositions.

\subsubsection{Trace element geochemistry of upper mantle peridotites}

Trace element concentrations are very low in the peridotite suite, with the exception of $\mathrm{Ni}$ and $\mathrm{Cr}$ (Table 7.1). The concentrations of these elements (Figure 7.2) are very high, and their abundances can be correlated with Cr-spinel, clinopyroxene and olivine contents. As discussed above, $\mathrm{Cr}$ content is highest in the $\mathrm{Cr}$-diopside rich xenoliths and its positive trend with $\mathrm{SiO}_{2}$ reflects the high proportions of clinopyroxene. The negative trend when plotted against $\mathrm{Ni}$ is consistent with a lower olivine content in the $\mathrm{Cr}$-diopside rich xenoliths.

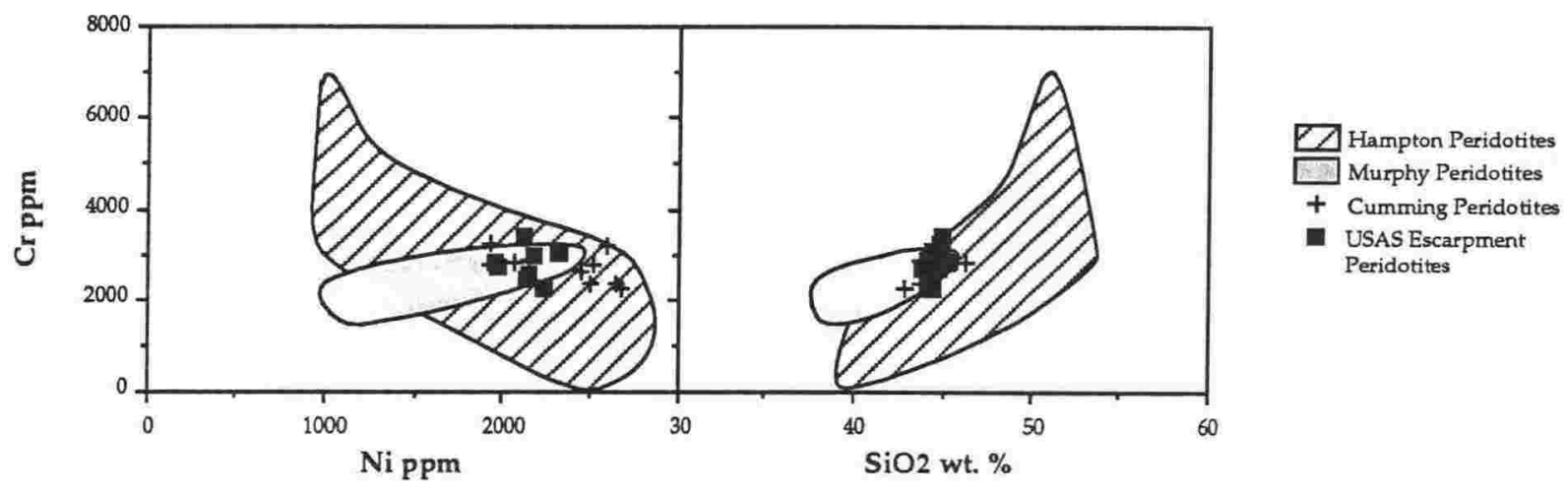

FIGURE 7.2: $\mathrm{Cr} v \mathrm{Ni}$ and $\mathrm{SiO}_{2}$ content for Marie Byrd Land peridotites. Cr-diopside rich peridotites have high $\mathrm{SiO}_{2}$ and $\mathrm{Cr}$ contents as a result of high $\mathrm{Cr}$-diopside abundances, and low Ni contents due to lower olivine abundances. Hampton peridotites are striped, and Murphy peridotites are shaded.

As with major element compositions, Mount Cumming and USAS Escarpment peridotites have similar and restricted trace element compositions, whereas Mount Hampton and Mount Murphy peridotites show more diverse compositions, although spinel lherzolites are similar to those from Mount Cumming and the USAS Escarpment.

REE normalised to chondrite (Wheatley and Rock, 1988) patterns of whole rocks and clinopyroxenes are presented for all localities as Figure 7.3, and representative REE compositions are given as Table 7.2. All peridotite patterns reflect their clinopyroxene compositions, having identical shapes, but with lower REE abundances due to a 'dilution' effect by REE-poor olivine and orthopyroxene. The shaded areas of Figure 7.3 highlight the similar patterns of clinopyroxenes (with higher REE abundances) and whole rock patterns (with lower REE abundances) from the same samples. 
TABLE 7.2: Trace element (including rare earth element) analyses of peridotites (whole rock (rock) and clinopyroxene (сpx) separates) from Marie Byrd Land, determined by INAA, including Mount Hampton (PK), Mount Murphy (54), Mount Cumming (40) and the USAS Escarpment (MB).

\begin{tabular}{|c|c|c|c|c|c|c|c|c|}
\hline $\begin{array}{l}\text { Sample } \\
\text { Type }\end{array}$ & $\begin{array}{c}90040 \mathrm{E} \\
\text { rock }\end{array}$ & $\begin{array}{c}90040 \mathrm{E} \\
\mathrm{cpx}\end{array}$ & $\begin{array}{c}90040 \mathrm{H} \\
\text { rock }\end{array}$ & $\begin{array}{c}90040 \mathrm{U} \\
\text { rock }\end{array}$ & $\begin{array}{c}90054 \mathrm{~A} \\
\text { cpx }\end{array}$ & $\begin{array}{c}90054 \mathrm{~A} \\
\text { rock }\end{array}$ & $\begin{array}{c}90054 \mathrm{~B} \\
\text { rock }\end{array}$ & $\begin{array}{c}90054 \mathrm{~B} \\
\mathrm{cpx}\end{array}$ \\
\hline $\mathrm{Sc}$ & 12.95 & 68.4 & 12.76 & 7 & 27.29 & 6.96 & 13.22 & 58.8 \\
\hline $\mathrm{Cr}$ & 2286 & 5025 & 657 & 3016 & 5951 & 1139 & 2806 & 6196 \\
\hline $\mathrm{Ni}$ & 1657 & 451 & 2047 & 2578 & 1798 & 2711 & 1984 & 450 \\
\hline $\mathrm{Zn}$ & 39 & 42 & 57 & 48 & 50 & 48 & 47 & 23 \\
\hline $\mathbf{R b}$ & 6 & 0 & 0 & 0 & 8 & 0 & - & - \\
\hline $\mathrm{Sr}$ & 0 & 0 & 0 & 0 & 0 & 0 & 0 & 243 \\
\hline $\mathrm{Ba}$ & 0 & 0 & 13 & 0 & 18 & 0 & - & - \\
\hline $\mathbf{L a}$ & 0.51 & 1.02 & 1.5 & 0.17 & 0.8 & 0.23 & 1.62 & 12.76 \\
\hline $\mathrm{Ce}$ & 2.2 & 1.9 & 3.8 & 0.8 & 3.1 & 0.48 & 4.8 & 40.1 \\
\hline $\mathrm{Nd}$ & 0 & 0 & 0 & 0.4 & 2.4 & 0 & 0 & 0 \\
\hline Sm & 0.23 & 1.38 & 0.75 & 0.01 & 0.57 & 0.1 & 0.55 & 4.93 \\
\hline Eu & 0.097 & 0.57 & 0.319 & 0 & 0.259 & 0.036 & 0.177 & 1.63 \\
\hline $\mathrm{Tb}$ & 0.07 & 0.38 & 0.145 & 0.035 & 0.161 & 0.02 & 0.072 & 0.7 \\
\hline $\mathbf{Y b}$ & 0.34 & 1.8 & 0.42 & 0.02 & 0.38 & 0.09 & 0.37 & 1.79 \\
\hline Lu & 0.04 & 0.312 & 0.043 & 0.004 & 0.065 & 0.009 & 0.052 & 0.277 \\
\hline $\mathrm{Hf}$ & 0.15 & 0.62 & 0.6 & 0 & 0.23 & 0.14 & 0.24 & 1.7 \\
\hline $\mathrm{Ta}$ & 0.49 & 0.08 & 0.35 & 0.23 & 0.19 & 0.3 & 0.24 & 0.27 \\
\hline Th & 0.14 & 0.44 & 0.1 & 0.05 & 0.12 & 0 & 0 & 0.18 \\
\hline Sample & $90054 \mathrm{E}$ & PK4G & PK4G1 & PK5D & PK5J & MB69F & MB69F & MB69H \\
\hline Type & rock & rock & rock & rock & rock & rock & cpx & rock \\
\hline $\mathrm{Sc}$ & 11.25 & 37.5 & 7.56 & 5.27 & 13.18 & 16.14 & 61.8 & 11.75 \\
\hline $\mathrm{Cr}$ & 2936 & 5399 & 2187 & 1535 & 2812 & 3214 & 5770 & 2124 \\
\hline $\mathrm{Ni}$ & 2185 & 1283 & 2216 & 2527 & 2047 & 2123 & 259 & 2177 \\
\hline $\mathrm{Zn}$ & 54 & 24 & 41 & 44 & 47 & 41 & 29 & 45 \\
\hline $\mathbf{R b}$ & - & - & - & - & - & 0 & 0 & 0 \\
\hline $\mathrm{Sr}$ & 0 & 163 & 0 & 137 & 0 & 0 & 0 & 0 \\
\hline $\mathbf{B a}$ & - & - & 0 & 0 & 0 & 0 & 0 & 0 \\
\hline $\mathrm{La}$ & 0.94 & 6.89 & 0.09 & 0.18 & 0 & 0.14 & 0.37 & 0.06 \\
\hline $\mathrm{Ce}$ & 2.7 & 12 & 0 & 0 & 0 & 0 & 0 & 0 \\
\hline Nd & 1.8 & 3.6 & - & - & - & 0 & 0 & 0 \\
\hline $\mathrm{Sm}$ & 0.33 & 0.46 & 0.03 & 0.04 & 0.12 & 0.19 & 0.93 & 0.18 \\
\hline Eu & 0.092 & 0.155 & 0.02 & 0.01 & 0.037 & 0.069 & 0.37 & 0 \\
\hline $\mathrm{Tb}$ & 0.092 & 0.086 & 0 & 0 & 0.042 & 0.07 & 0.29 & 0.074 \\
\hline $\mathrm{Yb}$ & 0.32 & 0.46 & 0.09 & 0 & 0.26 & 0.32 & 1.46 & 0.28 \\
\hline $\mathrm{Lu}$ & 0.056 & 0.07 & 0.012 & 0.013 & 0.041 & 0.052 & 0.222 & 0.049 \\
\hline $\mathrm{Hf}$ & 0.11 & 0.33 & 0 & 0 & 0.12 & 0 & 0.77 & 0.3 \\
\hline $\mathrm{Ta}$ & 0.23 & 0.49 & 0.22 & 0.17 & 0.15 & 0.18 & 0 & 0.12 \\
\hline Th & 0 & 0.56 & 0 & 0 & 0 & 0 & 0 & 0 \\
\hline
\end{tabular}

$\mathrm{cpx}=$ clinopyroxene; rock $=$ whole rock sample; 0 = not detected; $-=$ not analysed

Whole rock REE patterns are generally similar for Mount Hampton, Mount Murphy and Mount Cumming lherzolites, ranging from depleted chondritic patterns, to LREE-enriched. In contrast, USAS Escarpment spinel lherzolites are strongly LREE-depleted. The variation from REE-depleted to LREE-enriched abundances in the peridotites suggests a variably enriched upper mantle beneath 


\section{REE plot (peridotite/chondrites)}

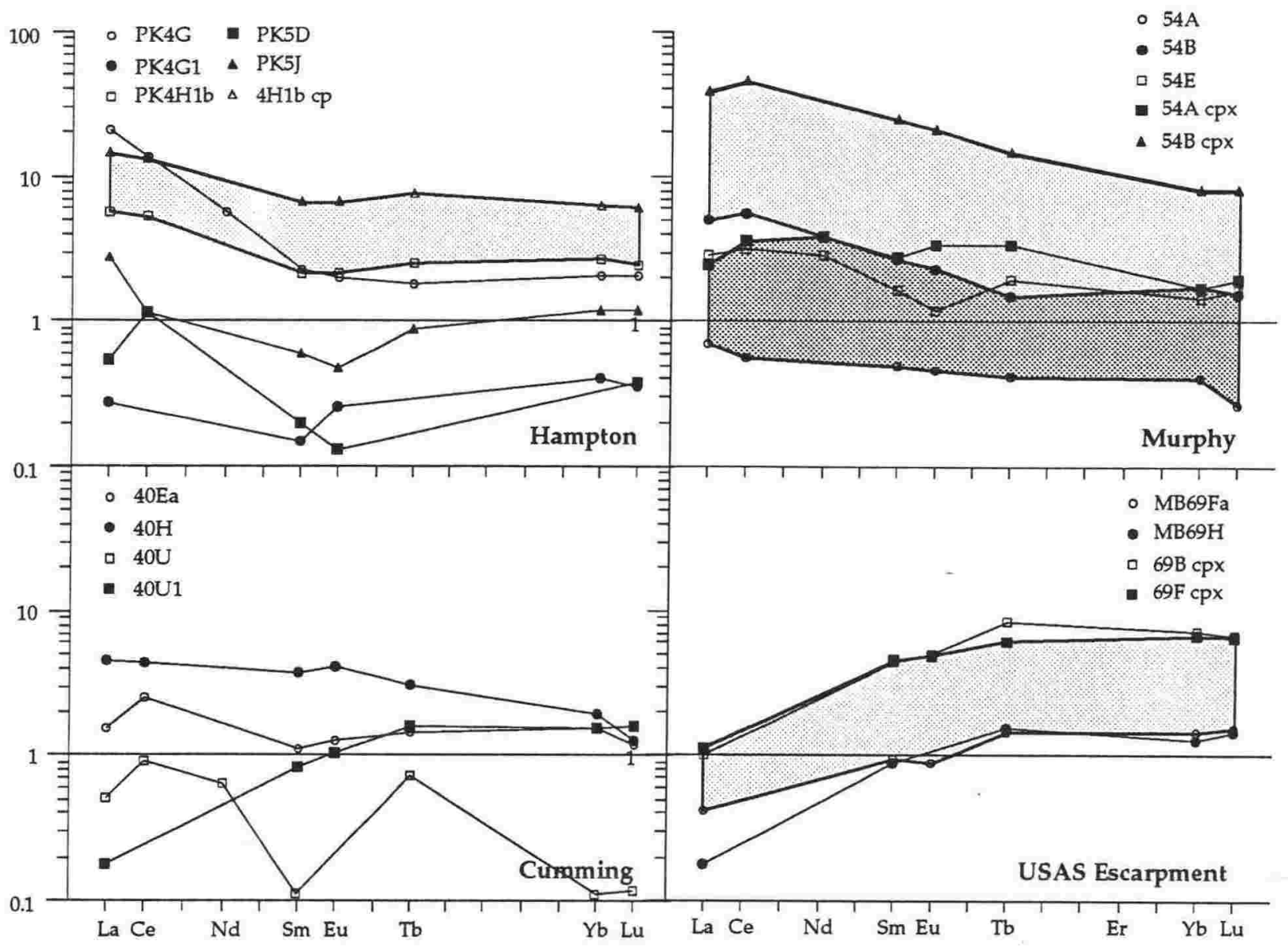

FIGURE 7.3: Rare earth elements normalised to chondrite (Wheatley and Rock, 1988) for peridotites from Marie Byrd Land. Shaded areas are between clinopyroxene compositions and whole rock compositions from the same sample. Note the similar patterns, indicating that whole rock compositions reflect clinopyroxene compositions. REE patterns are similar for most localities, with the exception of USAS Escarpment peridotites, which are LREE-depleted, possibly due to partial melting. $\mathrm{Cpx}=$ clinopyroxene separates; all other samples are whole rock analyses.

MBL. A comparison of the $\mathrm{Cr}$-diopside rich veins with spinel lherzolites may help to identify the nature of this chemical heterogeneity.

\subsubsection{Cr-diopside veins in $M B L$ peridotites}

Cr-diopside rich veins from two Mount Hampton spinel lherzolites and a USAS Escarpment spinel lherzolite have been analysed to ascertain any differences in trace element content between veins and host lherzolites. Sample PK4N1 from Mount Hampton consists of a Cr-diopside rich vein (PK4N1a) in a spinel lherzolite that has been sampled at one-cm intervals from the vein to six $\mathrm{cm}$ from the vein (samples (PK4N1b to PK4N1g). Sample PK4H1 is a cm-scale interlayered dunite (PK4H1a), Cr-diopside vein (PK4H1b) and $\mathrm{Cr}$-diopside rich 
spinel lherzolite (PK4H1c). The USAS Escarpment sample (MB69B) consists of a Cr-diopside vein $(\mathrm{MB} 69 \mathrm{Ba})$ with spinel lherzolite samples taken either side of the vein $(\mathrm{MB} 69 \mathrm{Bb}$ and $\mathrm{MB69BC})$.

\section{REE plot (peridotite/chondrites)}

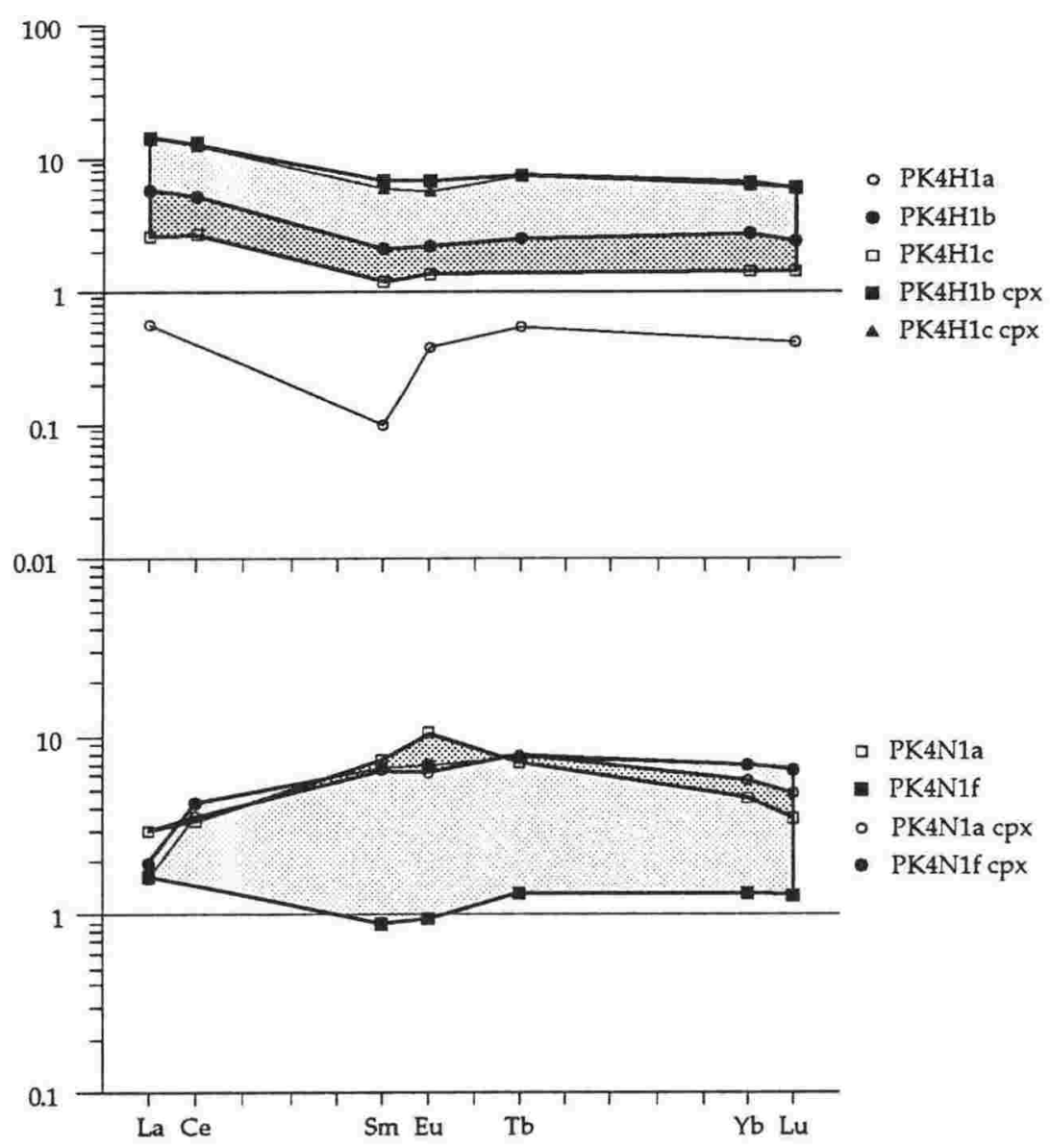

FIGURE 7.4: Rare earth elements normalised to chondrite (Wheatley and Rock, 1988) for Crdiopside peridotites and $\mathrm{Cr}$-diopsides from Marie Byrd Land. Shaded areas are between clinopyroxene compositions and whole rock compositions from the same sample, and their similar patterns reflect the controlling influence of clinopyroxene in determining REE patterns and abundances. Note the wide range in $\mathrm{Cr}$-diopside composition.

REE patterns for the two Mount Hampton veins and host rocks discussed above are presented as Figure 7.4. Sample PK4H1a (dunite) is depleted in REEs relative to the other samples, reflecting its high proportion of olivine. The $\mathrm{Cr}-$ diopside rich sample (PK4H1b) and the spinel lherzolite (PK4H1c) have similar LREE-enriched patterns, with the former having higher total concentrations. This similarity reflects the dependence of this pattern on $\mathrm{Cr}$-diopside composition, which is slightly LREE-enriched.

The Cr-diopside vein in sample PK4N1 is identical to clinopyroxene compositions from both the vein (PK4N1a) and the spinel lherzolite (e.g. 
PK4N1f). This similarity indicates no compositional difference in clinopyroxenes from the vein and the spinel lherzolite, and that the vein represents an accumulation of lherzolite $\mathrm{Cr}$-diopside. This is also the case for the vein from the USAS Escarpment (MB69B), where Cr-diopside REE patterns from the vein are identical to $\mathrm{Cr}$-diopsides from the lherzolite (Figure 7.3).

The similarity of vein $\mathrm{Cr}$-diopside compositions to lherzolite $\mathrm{Cr}$-diopside compositions indicates that the veins represent accumulations of $\mathrm{Cr}$-diopside. Similar samples from Australia have been interpreted to represent differentiated mantle wall-rock, while others represent recrystallised vein cumulate assemblages (O'Reilly et al., 1989). These interpretations are both consistent with melt transfer through lithospheric mantle.

Both vein and lherzolite clinopyroxenes show a wide range of REE compositions, from LREE-enriched to LREE-depleted. Variations like this are not uncommon in spinel lherzolite clinopyroxenes from elsewhere. Menzies et al. (1987) proposed that such variation may be due to mixing of a LREE-depleted component typical of MORB lithosphere, and LREE enriched components; i.e. mantle metasomatism (e.g. Bailey, 1982; Dawson, 1982; Menzies et al., 1985; Harte, 1987).

The peridotite suites beneath Mounts Hampton and Murphy show a much wider lithological and geochemical range than lherzolites from Mount Cumming and the USAS Escarpment, indicating a more 'fertile' lithosphere in these regions. Mantle metasomatic processes may have resulted in this enrichment, notably in LREEs. Cr-diopside rich veins however may represent the crystallised products of a migrating melt. Their similarity to host spinel lherzolites indicates that the lherzolites were also enriched by the migrating melts.

\subsubsection{Summary of the MBL upper mantle}

Peridotite compositions from Mount Cumming and the USAS Escarpment show little compositional variation in major elements, however Mount Murphy and Mount Hampton peridotite compositions show large variations. Trace element abundances (notably REE contents) vary considerably in the upper mantle xenolith suite, indicating widespread heterogeneities in the MBL upper mantle.

Characteristic features of the MBL upper mantle include:

- anhydrous mineral compositions of olivine, orthopyroxene, Cr-diopside and spinel;

- compositionally restricted spinel lherzolite compositions from all localities (e.g. $44-46$ wt. $\% \mathrm{SiO}_{2}$ ), and the presence of variable $\mathrm{Cr}$-diopside vein and dunite 
compositions (e.g. 38-54 wt. \% $\mathrm{SiO}_{2}$ ) from Mounts Hampton and Murphy, indicating a more 'fertile' lithosphere in these regions;

- low overall REE abundances, varying from LREE-depleted (USAS Escarpment) to LREE-enriched (Mount Hampton), further reflecting a geochemical heterogeneity in the upper mantle. LREE-enriched peridotites reflect the metasomatic enrichment of the upper mantle by silicate melts passing through the lithosphere, whereas LREE-depleted lherzolites indicate a mantle depleted by partial melting, particularly beneath the USAS Escarpment.

\subsection{The Marie Byrd Land Lower Crust}

\subsubsection{Introduction}

A summary of the main characteristics of the lower crustal xenolith suite from MBL is presented as Table 7.3. From these features it is evident that there are many similarities between the suites from various localities, but there are also many differences, reflecting a large-scale heterogeneity in the MBL lower crust. A direct comparison of the xenolith suites from MBL is made in this section.

\subsubsection{Textural and mineral characteristics}

Xenoliths from Mount Hampton differ petrographically from Mount Sidley and Mount Murphy xenoliths. Mount Hampton xenoliths are dominantly gabbros, norites and websterites, consisting of orthopyroxene + clinopyroxene + plagioclase. In contrast, xenoliths from Mounts Sidley and Murphy are mainly leucogabbros, gabbros and clinopyroxenites, consisting of olivine + clinopyroxene + plagioclase. The presence of orthopyroxene or olivine as a mineral phase is a major difference between the suites, and is responsible for many of the geochemical differences. It is important to note however that olivine also occurs in Mount Hampton xenoliths, and orthopyroxene occurs in Mount Murphy xenoliths, so the suites do not consist of only one of these phases.

Granulites from all localities are meta-igneous, with various degrees of metamorphic recrystallisation of protolith igneous cumulate textures. Granulites from Mount Murphy are generally less metamorphosed than those from the ECR (Mounts Sidley and Hampton), and include abundant igneous gabbros that are rare in the ECR xenolith suite. Pyroxenites from Mount Sidley and Mount Murphy have retained their original cumulate textures, with no evidence of recrystallisation. Mount Hampton pyroxenites however are metamorphic, with 
an almost complete recrystallisation of original cumulate textures to equant polygonal fabrics.

TABLE 7.3: Summary of the salient characteristics of the Marie Byrd Land lower crust, based on xenoliths from localities including Mount Sidley, Mount Hampton and Mount Murphy.

\begin{tabular}{|c|c|c|c|c|}
\hline & & Mount Sidley & Mount Hampton & Mount Murphy \\
\hline \multicolumn{5}{|c|}{ PETROGRAPHY } \\
\hline Texture & $\begin{array}{c}\text { Granulites } \\
\text { Pyroxenites }\end{array}$ & $\begin{array}{c}\text { Meta-Igneous } \\
\text { Igneous (cumulate) }\end{array}$ & $\begin{array}{l}\text { Meta-Igneous } \\
\text { Meta-Igneous }\end{array}$ & $\begin{array}{c}\text { Meta-Igneous } \\
\text { Igneous (cumulate) }\end{array}$ \\
\hline $\begin{array}{l}\text { Mineralogy } \\
\text { Dominant } \\
\text { Lithology }\end{array}$ & $\begin{array}{l}\text { Granulites } \\
\text { Pyroxenites }\end{array}$ & $\begin{array}{l}\text { Ol - Cpx - Plag } \\
\text { Leucogabbros } \\
\text { Clinopyroxenites }\end{array}$ & $\begin{array}{c}\text { Opx - Cpx - Plag } \\
\text { Gabbros and Norites } \\
\text { Websterites }\end{array}$ & $\begin{array}{l}\text { Ol - Cpx - Plag } \\
\text { Leucogabbros } \\
\text { Clinopyroxenites }\end{array}$ \\
\hline
\end{tabular}

\begin{tabular}{|c|c|c|c|c|}
\hline \multicolumn{2}{|c|}{$\begin{array}{l}\text { GEOCHEMICAL FEATURE } \\
\text { Elements }\end{array}$} & \multicolumn{3}{|c|}{ All element abundances dominated by the mineral assemblage } \\
\hline \multirow[t]{2}{*}{ Mg number } & Granulites & $\mathrm{Mg} \# 32-59$ & $\mathrm{Mg} \# 69-73$ & $\mathrm{Mg} \# 50-81$ \\
\hline & Pyroxenites & $\mathrm{Mg} \# 55-80$ & $\mathrm{Mg} \# 67-77$ & $\mathrm{Mg \#} 65-84$ \\
\hline \multirow[t]{2}{*}{ Trace Elements } & Granulites & LILE-enriched & High $\mathrm{Sr}, \mathrm{K}, \mathrm{Ba}$ & LILE enriched \\
\hline & Pyroxenites & High $\mathrm{Ni}, \mathrm{Cr}$ & High $\mathrm{Ni}, \mathrm{Cr}$ & Depleted (Ni, Cr rich) \\
\hline \multirow[t]{2}{*}{ REEs } & Granulites & LREE-enriched & LREE-depleted & LREE-enriched \\
\hline & Pyroxenites & LREE-depleted & LREE-depleted & LREE-depleted \\
\hline Sr isotopes & & $0.70286-0.70376$ & $0.70420-0.70458$ & $0.70270-0.70442$ \\
\hline $\mathrm{Nd}$ isotopes & & $0.512864-0.512870$ & $0.512771-0.512819$ & \\
\hline $206 \mathrm{~Pb} / 204 \mathrm{~Pb}$ & & $17.653-19.589$ & $19.048-19.179$ & \\
\hline $207 \mathrm{~Pb} / 204 \mathrm{~Pb}$ & & $15.539-15.660$ & $15.647-15.650$ & \\
\hline $208 \mathrm{~Pb} / 204 \mathrm{~Pb}$ & & $37.378-39.182$ & $38.830-38.883$ & \\
\hline SECONDARY & & Metasomatism & Oxidation & Oxidation \\
\hline PROCESSES & & $\begin{array}{l}\text { Kaersutitisation } \\
\text { Oxidation }\end{array}$ & & \\
\hline
\end{tabular}

\section{NATURE OF THE LOWER CRUST}

\begin{tabular}{|c|c|c|c|c|}
\hline Crystallisation & & $\begin{array}{l}\text { Cumulates from an } \\
\text { evolving melt (or melts) }\end{array}$ & $\begin{array}{l}\text { Cumulates from an } \\
\text { evolving melt }\end{array}$ & $\begin{array}{c}\text { Cumulates from multiple, } \\
\text { evolving melts }\end{array}$ \\
\hline Structure & & Stratified (interlayered) & Stratified (interlayered) & Stratified (interlayered?) \\
\hline \multirow[t]{2}{*}{ Pressure * } & Granulites & $4.0-6.5 \mathrm{~kb}$ & $6.5-9.5 \mathrm{~kb}$ & $4.0-10.0 \mathrm{~kb}$ \\
\hline & Pyroxenites & $8.0-12.0 \mathrm{~kb}$ & $7.0-8.5 \mathrm{~kb}$ & $7.5-13 \mathrm{~kb}$ \\
\hline \multirow[t]{2}{*}{ Temperature * } & Granulites & $980-1160^{\circ} \mathrm{C}$ & $1150-1215^{\circ} \mathrm{C}$ & $840-1210^{\circ} \mathrm{C}$ \\
\hline & Pyroxenites & $1080-1240^{\circ} \mathrm{C}$ & $1150-1225^{\circ} \mathrm{C}$ & $1110-1320^{\circ} \mathrm{C}$ \\
\hline Source & & $\begin{array}{l}\text { Primitive alkaline } \\
\text { mantle melt }\end{array}$ & $\begin{array}{l}\text { Primitive sub-alkaline } \\
\text { mantle melt }\end{array}$ & $\begin{array}{c}\text { Primitive sub-alkaline (?) } \\
\text { mantle melt }\end{array}$ \\
\hline
\end{tabular}

- Estimates using the method of Gasparik (1984) for each suite. Temperatures are likely to be high for granulite rocks using this method.

Mineral compositions from all three localities indicate crystallisation from primitive mafic melts. Variations in mineral composition within the suites (e.g Fo content of olivine and An content of plagioclase) from Mount Sidley and Mount Murphy indicate that the parental melts evolved by several episodes of crystal fractionation. Mount Murphy xenoliths may have crystallised from several 
such melts. In contrast, compositions of Mount Hampton granulite and pyroxenite minerals are identical, and indicate synchronous crystallisation from the same parental magma.

\subsubsection{Major element comparison of the xenolith suite}

All MBL xenoliths were initially crystallised as cumulate rocks, so their geochemical characteristics are largely a function of their mineral assemblage. The dominance of olivine or orthopyroxene as the Ca-poor mafic phase has resulted in many of the chemical differences between Mount Hampton and Mounts Sidley and Murphy xenoliths; e.g. the former are generally more silica rich than the latter.

The influence of the mineral assemblage, and of secondary processes on whole rock composition, can be seen in the selected plots of major elements against silica in Figure 7.5. Differences in composition between granulites from various localities are largely a function of the composition of their mineral assemblages. Mount Sidley granulites differ from other granulites as they crystallised from more evolved melts. Their higher $\mathrm{Fe}_{2} \mathrm{O}_{3}$ (total) and $\mathrm{Na}_{2} \mathrm{O}$ contents, and low Mg\#s are inherited from the low $\mathrm{Mg}: \mathrm{Mg}+\mathrm{Fe}$ ratios of their mafic mineral phases (e.g. Mount Sidley olivines have low Fo contents compared to olivines from other xenoliths), and low An content of plagioclase compared to other granulites. Mount Murphy granulites from site 90048 also formed from evolved melts, and are similar to Mount Sidley granulites. However, Mount Murphy granulites from site 90041 crystallised from primitive (high-Mg\#) melts, and are geochemically similar to Mount Hampton granulites. This indicates an intermediate nature of the Mount Murphy granulites to Mount Sidley and Mount Hampton granulites.

Pyroxenite compositions are also dominated by their mineral assemblage. Orthopyroxene-bearing pyroxenites from Mount Hampton, and the orthopyroxene-bearing pyroxenite from Mount Murphy are high in silica compared to other pyroxenites, which are olivine-bearing. The dominance of olivine or orthopyroxene is best seen in the different trends of $\mathrm{Fe}_{2} \mathrm{O}_{3}$ against $\mathrm{SiO}_{2}$ (Figure 7.5). Mount Hampton pyroxenites (orthopyroxene-bearing) form a positive trend of $\mathrm{Fe}_{2} \mathrm{O}_{3}$ (total) with silica (due to the higher $\mathrm{SiO}_{2}$ content of orthopyroxene), whereas olivine-bearing pyroxenites (including the olivinebearing pyroxenites from Mount Hampton) form a negative trend of $\mathrm{Fe}_{2} \mathrm{O}_{3}$ (total) with silica (due to the low $\mathrm{SiO}_{2}$ content of olivine). $\mathrm{Na}_{2} \mathrm{O}$ contents are similar in all pyroxenites as $\mathrm{Na}_{2} \mathrm{O}$ is not present in large abundance in either olivine or orthopyroxene. 


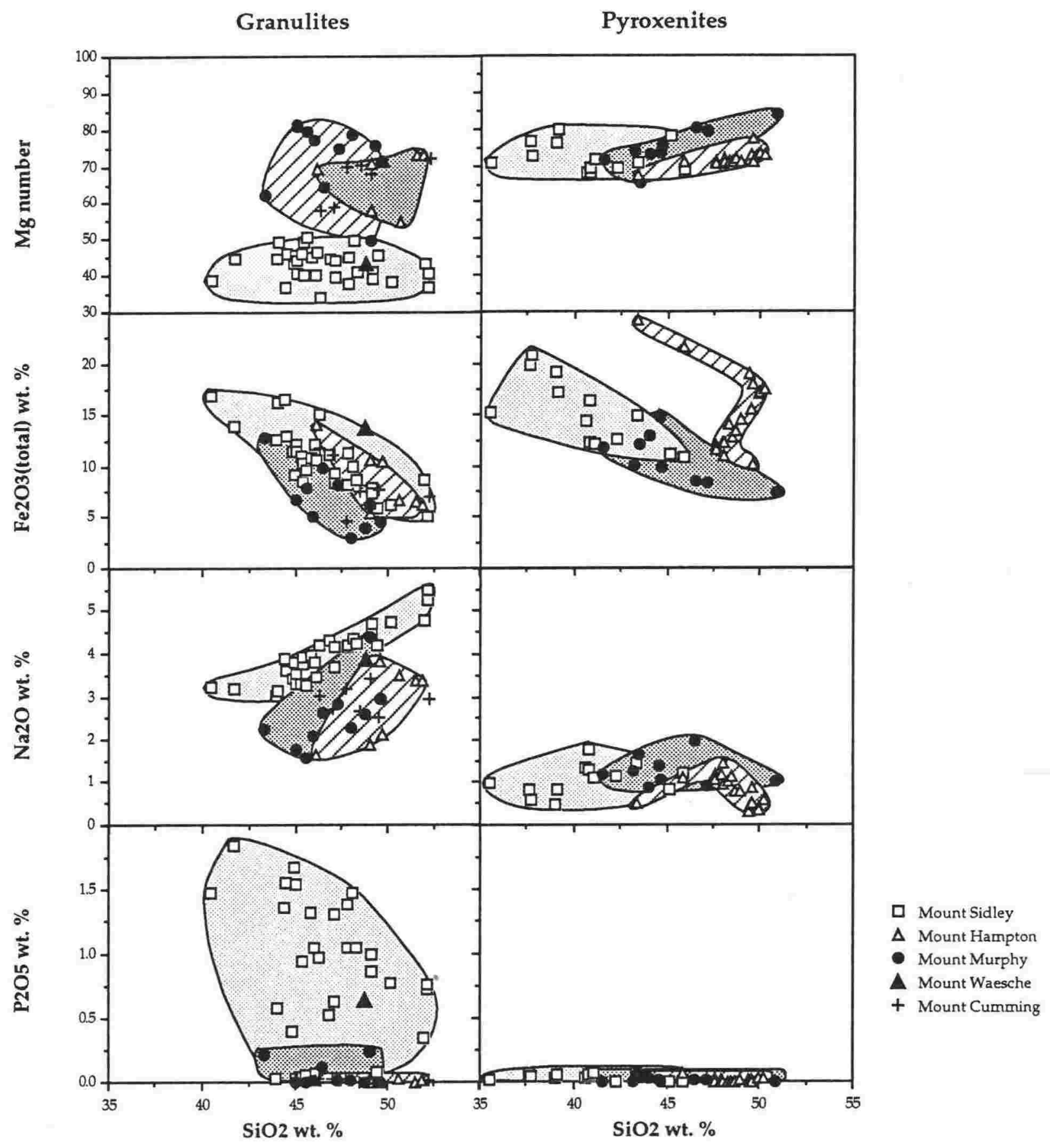

FIGURE 7.5: Selected major elements against $\mathrm{SiO}_{2}$ indicates a similarity between Mount Sidley (light shade) and Mount Waesche xenoliths, and between Mount Hampton (striped), Mount Murphy (with the exception of site 90048 xenoliths) (dark shade) and Mount Cumming xenoliths.

The reliance of whole rock geochemical composition on the mineral assemblage, and the influence of secondary processes on whole rock geochemistry is highlighted in $\mathrm{P}_{2} \mathrm{O}_{5}$ contents in the xenolith suite. Mount Sidley granulites, and the Mount Waesche granulite, have high and variable $\mathrm{P}_{2} \mathrm{O}_{5}$ contents, due to the presence of apatite that crystallised as a secondary mineral phase from infiltrating host melts in the granulites (secondary processes also resulted in enrichment of 
many other elements (Chapter 4.5) in the Mount Sidley xenoliths). The three Mount Murphy granulites from site 90048 also have elevated $\mathrm{P}_{2} \mathrm{O}_{5}$ contents compared to other xenoliths, indicating higher apatite contents.

Despite the dominance of the mineral assemblage, whole rock compositions are still useful in identifying xenoliths with similar characteristics. The similarity of the Mount Waesche granulite with the Mount Sidley granulites is evident, as is the similarity of the Mounts Hampton, Murphy and Cumming granulites (although site 90048 granulites are closer to Mount Sidley granulites).

\subsubsection{Trace element comparison of the xenolith suite}

Trace element contents also reflect the composition and modal abundance of the mineral assemblage. Elements that are accommodated into mineral phases are present in higher abundances than elements that are not partitioned into the mineral phases. As such, trace elements can not reveal a great deal about the source of the xenoliths. They can however characterise features of xenoliths from different localities.

Figure 7.6 consists of three selected trace element plots that highlight the characteristics of the xenolith suite. The abundance of elements that do or do not partition into xenolith mineral phases can be seen in the plot of $\mathrm{Ba} \mathrm{v} \mathrm{Ni} \mathrm{(Figure}$ 7.6a). As $\mathrm{Ba}$ is readily partitioned into plagioclase, it is present in higher concentrations in granulites, compared to pyroxenites. The converse is true for $\mathrm{Ni}$ contents. Mount Sidley granulites have especially high $\mathrm{Ba}$ contents, as a result of secondary enrichment by alkaline host melts, with Ba contents exceeding $430 \mathrm{ppm}$ (plotting off the scale of Figure 7.6a).

$\mathrm{La}$ and $\mathrm{Ce}$ are present in higher concentrations in plagioclase than in other minerals, resulting in their higher content in the granulite suite compared to the pyroxenite suite (Figure 7.6b). All xenoliths have low $\mathrm{La}$ and $\mathrm{Ce}$ abundances (compared to melts), but similar La:Ce ratios of approximately 0.5. Mount Sidley and Mount Waesche granulites have higher abundances than other xenoliths, due to enrichment by the host melts: host basanites contain approximately $40 \mathrm{ppm}$ $\mathrm{La}$ and $80 \mathrm{ppm} \mathrm{Ce}(\mathrm{La}: \mathrm{Ce}$ ratios of 0.5 ), which plot on the trend shown by the granulite suite.

$\mathrm{Nb}$ and $\mathrm{Zr}$ are elements which are not accommodated into mineral phases, and therefore have low abundances in the xenolith suite (Figure 7.6c). There is however much evidence to suggest that the $\mathrm{Zr} / \mathrm{Nb}$ ratio is fractionated in the xenolith suite, with $\mathrm{Zr}$ being preferentially incorporated into clinopyroxene (Irving and Price, 1981; Le Marchand et al., 1987; Wilson, 1989). This makes the $\mathrm{Zr} / \mathrm{Nb}$ ratio unsuitable as an indicator of source characteristics. 


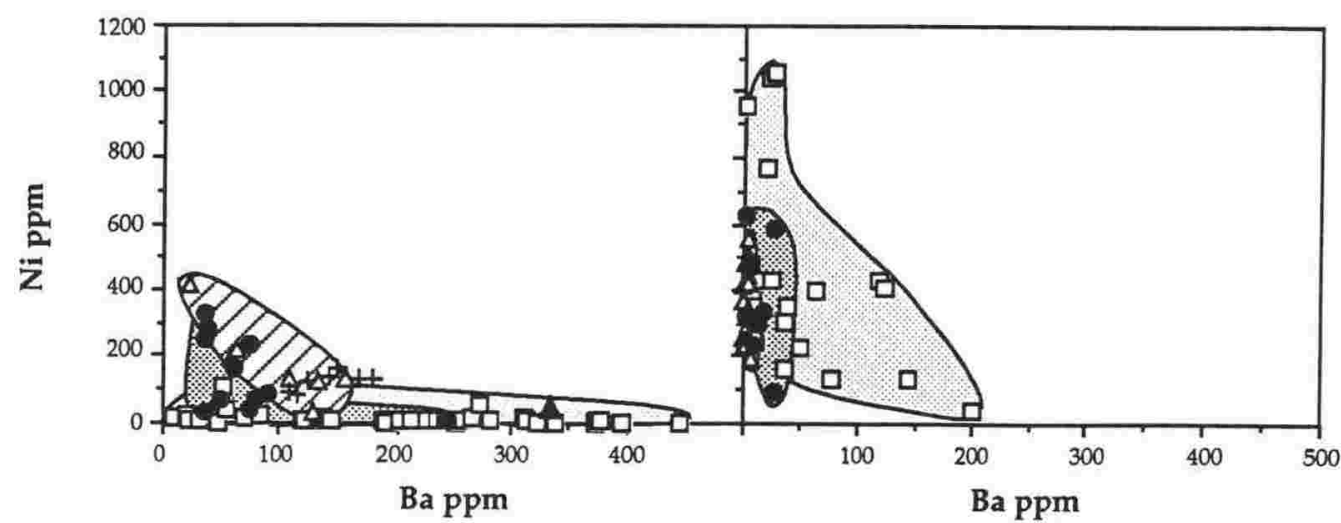

a)

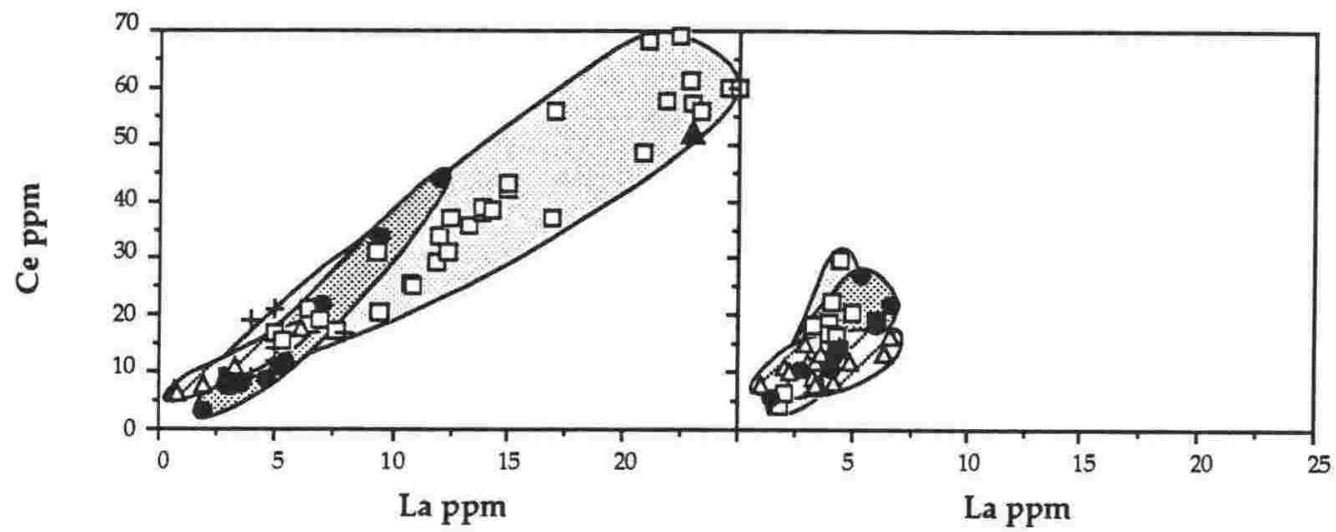

b)

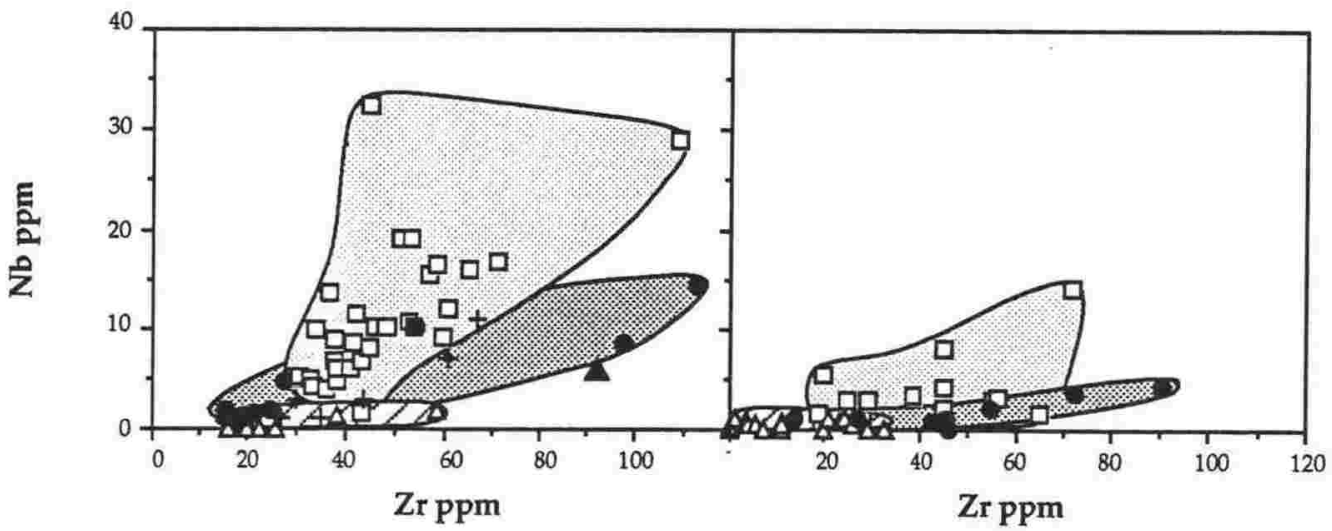

c)

ㅁ Mount Sidley

$\Delta$ Mount Hampton

- Mount Murphy

A Mount Waesche

+ Mount Cumming

FIGURE 7.6: Selected trace element plots of Marie Byrd Land xenoliths, including a) Ba v Ni, b) La v $\mathrm{Ce}$, and c) $\mathrm{Zr} \mathrm{v} \mathrm{Nb}$, highlighting characteristics of the xenolith suite. Note the similarity of Mounts Sidley (light shade) and Waesche, and Mounts Hampton (striped) and Cumming xenoliths, and the intermediate nature of Mount Murphy (dark shade) xenoliths.

$\mathrm{Nb}$ and $\mathrm{Zr}$ have been enriched in the Mount Sidley xenolith suite by the host melts (with concentrations of approximately $60 \mathrm{ppm} \mathrm{Nb}$, and $240 \mathrm{ppm} \mathrm{Zr}$ ), and trend towards host melt values and host melt $\mathrm{Zr} / \mathrm{Nb}$ ratios of approximately 4 (Figure 7.6c). Other xenoliths however do not appear to have been affected by the host melts and have similar, and low $\mathrm{Nb}$ abundances, indicating that $\mathrm{Nb}$ does behave as an incompatible element in the xenolith mineral phases. $\mathrm{Zr}$ contents 
are similar in the granulite suite and variable in the pyroxenites, with clinopyroxene-rich xenoliths having higher $\mathrm{Zr}$ contents.

Trace element characteristics of the MBL xenolith suite are best seen in multi-element plots normalised to MORB (Pearce, 1983); Figure 7.7 is a plot of representative xenoliths from each locality. All xenoliths have low abundances of trace elements, reflecting their cumulate nature. Only elements that are high in concentration in mineral phases are present in any quantity e.g. $\mathrm{Sr}$ and $\mathrm{Ba}$ in granulites, and $\mathrm{Ni}$ and $\mathrm{Cr}$ in pyroxenites (Figures 7.6 and 7.7).

\section{Pearce plot (MBL xenolith/MORB)}

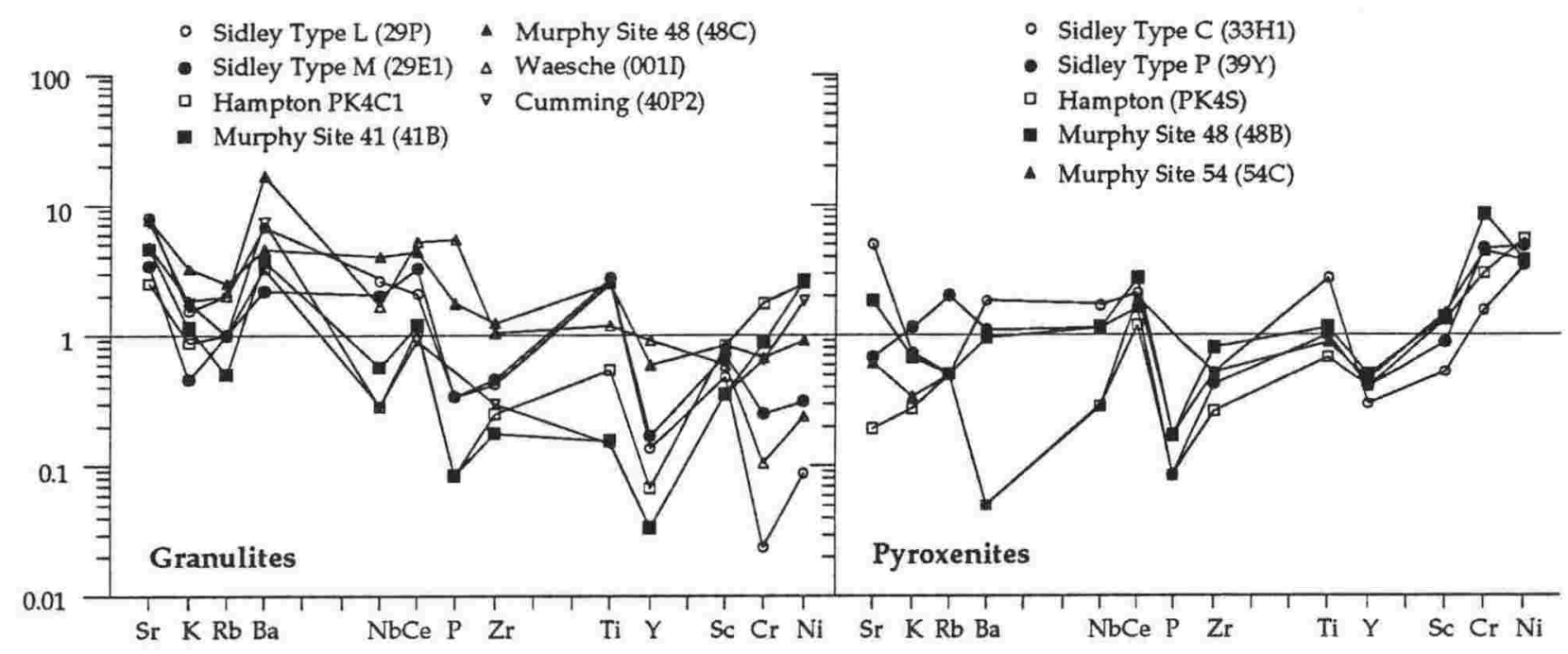

FIGURE 7.7: Representative multi-element plots of Marie Byrd Land xenoliths normalised to MORB (Pearce, 1983). Granulites from Mount Sidley, Mount Waesche, and site 90048 Mount Murphy granulites are distinct from the other granulites, reflecting their more evolved melts mineral compositions and assemblage. The pyroxenites are all similar in composition.

Mount Waesche and Mount Murphy site 90048 granulites have the highest trace element abundances (with the exception of $\mathrm{Ni}$ and $\mathrm{Cr}$ ), followed by Mount Sidley granulites, and Mount Hampton and Mount Murphy site 90041 granulites, which have the lowest trace element abundances. These characteristics can be attributed to crystallisation from more evolved (and trace element rich) melts. Furthermore, the Mount Sidley suite crystallised from an alkaline melt, whereas the Mount Hampton suite crystallised from a sub-alkaline parental melts. The parental melt of the Mount Murphy xenolith suite is uncertain. High LILE contents of Mount Sidley granulites is also due to their enrichment by host alkaline melts; their relatively low HFSE abundances (with the exception of $\mathrm{Ti}$ ) indicates that these elements have not been enriched.

The pyroxenites are similar in trace element abundance, with notably high $\mathrm{Cr}$ and Ni contents. Mount Sidley and Mount Murphy site 90048 pyroxenites have 
the highest, and Mount Hampton and Mount Murphy site 90054 pyroxenites have the lowest trace element abundances, as is the case for the granulite suite.

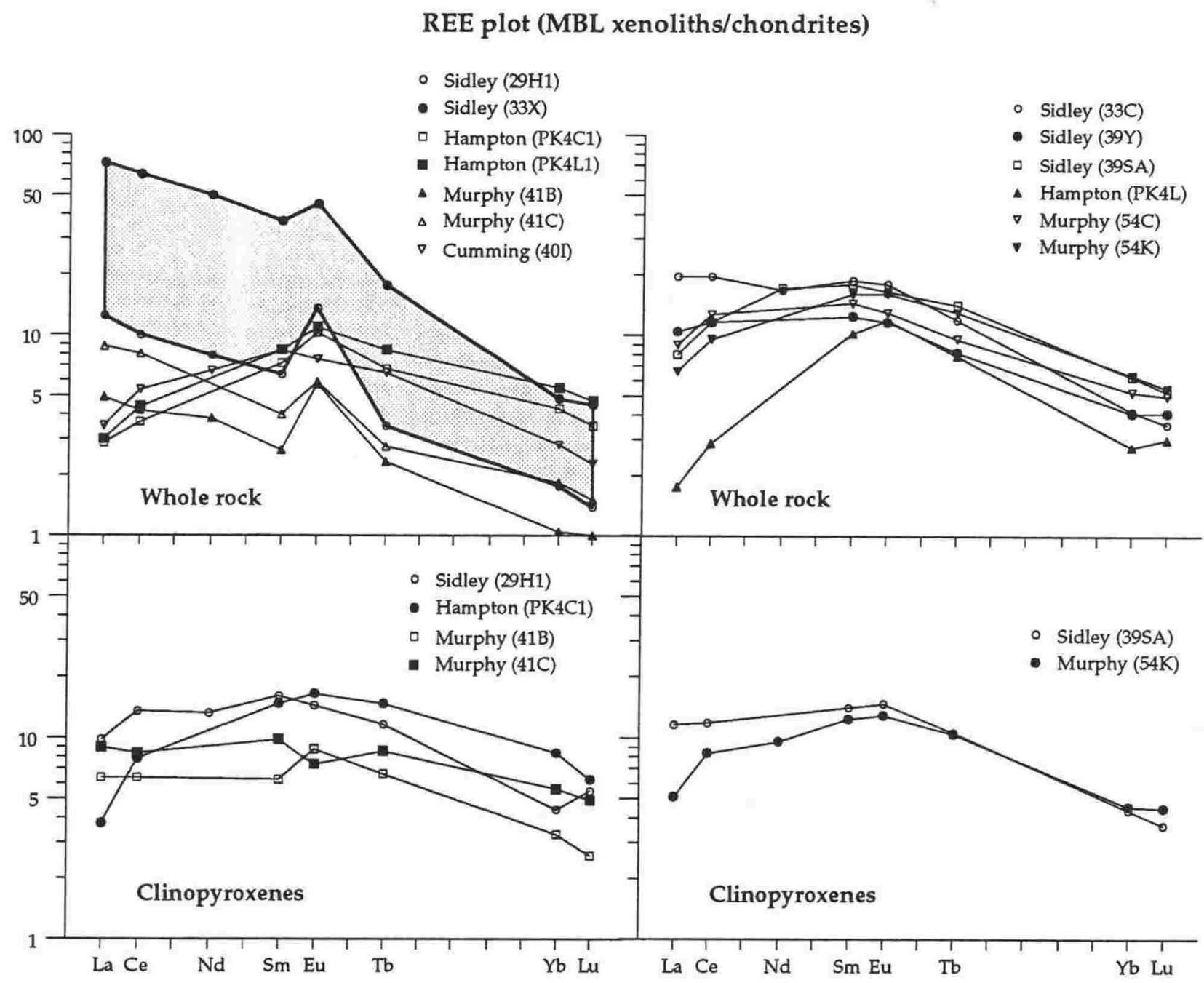

Granulites

Pyroxenites

FIGURE 7.8: Representative REE normalised to chondrite plots (Wheatley and Rock, 1988) of Marie Byrd Land xenoliths. Mount Sidley and Mount Murphy granulites have similar patterns, as do Mount Hampton and Mount Cumming xenoliths. Note the LREE-depletion of the Mount Hampton pyroxenite compared to other pyroxenites.

Rare earth elements normalised to chondrite (Wheatley and Rock, 1988) also reveal a number of similarities (Figure 7.8). Granulites from Mounts Sidley and Murphy have similar LREE-enriched patterns with higher abundances of REEs in the Mount Sidley xenoliths compared to Mount Murphy, resulting from their crystallisation from alkaline (as opposed to sub-alkaline) parental melts. Furthermore, they have been enrichment by the host alkaline melts. The overall pattern however is the same. Mount Hampton and Mount Cumming granulites have convex-up patterns, with lower LREE/HREE ratios compared to the Mount 
Sidley and Mount Murphy granulites. REE abundances of the latter are controlled by their clinopyroxene compositions.

Pyroxenites from all localities have similar REE abundances, reflecting the composition of clinopyroxene. The Mount Hampton pyroxenite however has a very low LREE abundance, possibly due to depletion during metamorphic recrystallisation; the other pyroxenite suites have not been recrystallised.

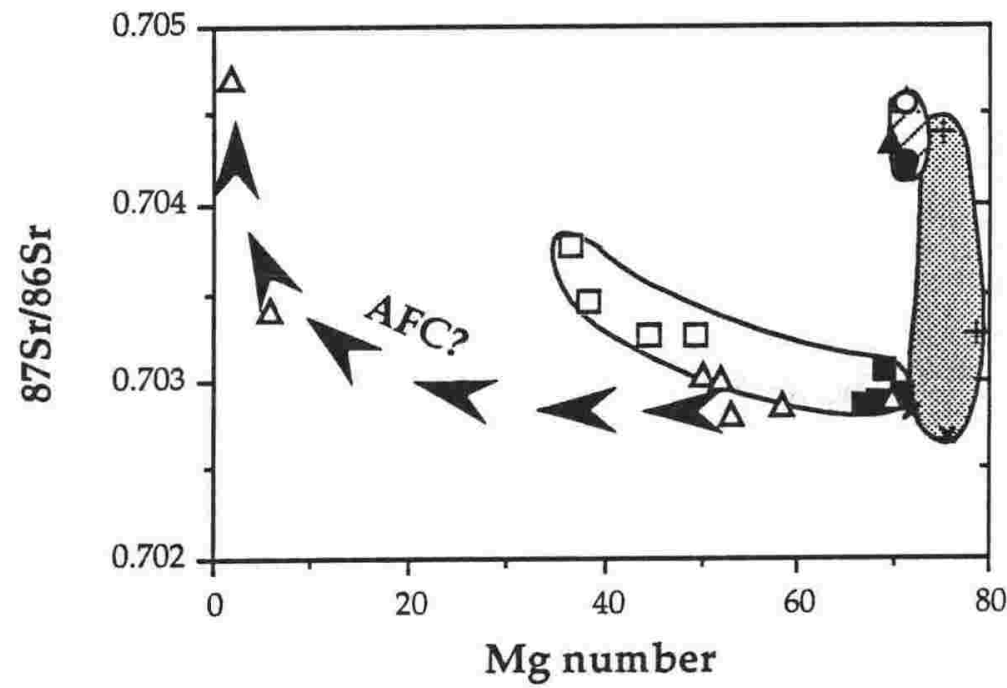

$\square$ Sidley Granulites

- Hampton Granulites

+ Murphy Granulites

A Cumming Granulite

- Sidley Pyroxenites

- Hampton Pyroxenite

× Murphy Pyroxenites

$\triangle$ MBL volcanics

FIGURE 7.9: Plot of ${ }^{87} \mathrm{Sr} /{ }^{86} \mathrm{Sr}$ v Mg\#, showing the low ${ }^{87} \mathrm{Sr} /{ }^{86} \mathrm{Sr}$ ratios of the xenolith suite. Mount Hampton (striped) xenoliths have high ${ }^{87} \mathrm{Sr} /{ }^{86} \mathrm{Sr}$ ratios, compared to the lower ratios of the Mount Sidley (light shade) xenoliths. The Mount Cumming granulite has a ${ }^{87} \mathrm{Sr} /{ }^{86} \mathrm{Sr}$ ratio similar to those from Mount Hampton, and Mount Murphy (dark shade) ${ }^{87} \mathrm{Sr} /{ }^{86} \mathrm{Sr}$ ratios span the range of other xenoliths. Marie Byrd Land volcanics (Le Masurier, 1990; Panter pers. comm.) differ from the xenolith suite, and indicate that the xenolith suite have not been affected by the host rocks.

Isotopic ratios also show similarities between xenolith suites (Figure 7.9). All suites show low ${ }^{87} \mathrm{Sr} /{ }^{86} \mathrm{Sr}$ ratios, indicating crystallisation from mafic melts with little or no contamination by isotopically evolved material. Mount Sidley xenoliths have lower ${ }^{87} \mathrm{Sr} /{ }^{86} \mathrm{Sr}$ ratios than Mount Hampton xenoliths. The Mount Cumming granulite has a ${ }^{87} \mathrm{Sr} /{ }^{86} \mathrm{Sr}$ ratio similar to Mount Hampton ratios, and Mount Murphy xenoliths have ratios that span the range from Mount Sidley to Mount Hampton xenoliths, further indicating their intermediate composition between the Mount Sidley and Mount Hampton xenolith suites.

A plot of ${ }^{87} \mathrm{Sr} /{ }^{86} \mathrm{Sr} v \mathrm{Mg} \#$ reveals two distinct trends (Figure 7.9). A trend to higher ${ }^{87} \mathrm{Sr} /{ }^{86} \mathrm{Sr}$ and lower $\mathrm{Mg \#}$ is shown by Mount Sidley xenoliths. Similar trends have been interpreted to represent AFC processes (Rudnick et al., 1986; Chapter 4.6.3). MBL volcanics fall along a similar trend, with evolved volcanics having high ${ }^{87} \mathrm{Sr} /{ }^{86} \mathrm{Sr}$ ratios and low $\mathrm{Mg \# s}$. They can not have mixed with the xenoliths as their high $\mathrm{Rb} / \mathrm{Sr}$ ratios $(20+)$, should also be inherited by the xenoliths, which have low $\mathrm{Rb} / \mathrm{Sr}$ ratios (Chapter 4.6.3). The exhibited trend is due 
to some processes other than mixing with evolved volcanics, although AFC with a pre-existing mafic crust can not be discounted, as a mafic crust would have had low ${ }^{87} \mathrm{Sr} /{ }^{86} \mathrm{Sr}$ (and $\mathrm{Rb} / \mathrm{Sr}$ ) ratios.

The trend to high ${ }^{87} \mathrm{Sr} /{ }^{86} \mathrm{Sr}$ at constant $\mathrm{Mg} \#$ shown by other xenoliths (Mounts Hampton, Cumming and Murphy) is more easily explicable as reflecting source heterogeneity. The ratios may have also developed as time-integrated ratios, however the presently low $\mathrm{Rb} / \mathrm{Sr}$ ratios in the xenolith suite are not capable of producing such variation, unless $\mathrm{Rb}$ was initially present in higher abundances, and was depleted to its present concentration (Chapters 5.6.3 and 6.6.3). These affects may also in part be responsible for the Mount Sidley trend.

\subsubsection{Summary of the MBL lower crust.}

A comparison of the lower crustal xenoliths from several localities in MBL (Table 7.3) indicates that the lower crust is extremely heterogeneous. Many of these heterogeneities reflect variation in composition of the mineral phases, which crystallised from different melts (notably Mount Sidley xenoliths crystallised from alkaline melts, whereas Mount Hampton xenoliths crystallised from sub-alkaline melts). Other differences are a result of secondary processes, such as metamorphic recrystallisation and melt enrichment.

Some regions of the lower crust are similar in composition. Mounts Sidley and Waesche have similar geochemical characteristics, and Mounts Hampton and Cumming are also similar in composition, having more primitive characteristics than the former group (e.g. higher Mg\#s reflecting higher $\mathrm{Mg}: \mathrm{Mg}+\mathrm{Fe}$ ratios of mafic minerals). Mount Murphy, further away from these sites, has attributes of both of these groups, reflecting its intermediate nature between Mounts Sidley and Hampton.

A full discussion of the composition of the MBL lower crust, of its structure and its modification by secondary processes, is presented as Chapter Eight. Prior to this, a comparison of the MBL lower crust with other localities, both from Gondwana, and a more general world-wide comparison, will be useful to more fully understand the MBL lithosphere.

\subsection{Comparison with Other Gondwana Lower Crustal Xenolith Suites}

\subsubsection{Introduction}

Lower crustal xenoliths have been documented from localities world-wide. This section seeks to compare the MBL suites with lower crustal xenoliths from 
the Ross Embayment and the Transantarctic Mountains of the McMurdo Sound region (Antarctica), from Fiordland (a granulite terrain) and the Central North Island of New Zealand, and from Eastern Australia. These regions were once joined in the supercontinent of Gondwana, prior to the Mesozoic break-up.

\subsubsection{McMurdo Sound xenoliths}

Lower crustal xenoliths have been described from a number of localities in the McMurdo Sound area. The lower crust in this region, on the basis of xenolith studies, has been divided into two adjoining sectors; the Ross Embayment (RE) and the Transantarctic Mountains (TM) (Kalamarides et. al, 1987).

Samples from a number of sites either side of the inferred RE-TM boundary are compared here to the MBL suites. Data from McMurdo Sound localities is from Kalamarides and Berg (1991), and Berg (pers comm) (various localities); Gamble and Kyle (1987), and Gamble et al. (1988) (pyroxenites from Foster Crater (TM)); Gamble and Kyle (pers. comm) (pyroxenites from Foster Crater (TM) and Sulphur Cones (RE), and granulites from Half Moon Crater, Hut Point Peninsula (RE)); and from Berg and Wu (1992) (granulites from Cape McCormick, considered here to be aligned with the RE suite). The xenolith suite from Foster Crater consists of pyroxenites similar to Group II (GPII) pyroxenites (Frey and Prinz, 1978), as well as an unual high-calcium pyroxenite suite (HCPS; Gamble et al., 1988)).

In addition to these localities, lower crustal suites from Black Island, Sulphur Cones and Turtle Rock in the RE, and Foster Crater in the TM, have been collected in the 1992-93 field season, and will be compared to the MBL suite at a later date (Chapter Two).

The RE lower crust consists of basic cumulates, which are believed to be derived from tholeiitic or alkaline melts, whereas the TM lower crust is dominated by basic melts (or near melts) of calc-alkaline affinity (Kalamarides and Berg, 1991).

\subsubsection{New Zealand xenoliths}

Ultramafic nodules have been collected from various localities in New Zealand (Reay and Sipiera, 1987; Duggan et al., 1989; Sewell et al., 1993). Granulite xenoliths have been detailed from only one locality in New Zealand; from Mount Ruapehu, an andesitic stratovolcano in the Central North Island of New Zealand (Graham et al., 1990). In addition to the Mount Ruapehu xenolith suite, granulites from a mafic terrain in Fiordland, in the lower South Island of New Zealand (McCulloch et al., 1987), will also be discussed. 
The Fiordland suite consists of a terrain of granulite facies orthogneisses, that have been U-Pb zircon dated at 118-120 Ma (Mattinson et al., 1986), and Rb-Sr dated at $120 \pm 15 \mathrm{Ma}$ (McCulloch et al., 1987). Another suite of leucogabbros (Darran Complex) from eastern Fiordland (which have not been metamorphosed) show similar geochemical properties to the western Fiordland orthogneisses, but are not correlative with them. Both suites show geochemical characteristics of Phanerozoic calc-alkaline island-arc suites. Due to the similarity of the two suites, they are treated here as one suite in this chapter.

Mount Ruapehu xenoliths are unusual as they have been entrained by andesitic melts, and provide the only samples of the lower crust beneath the Taupo Volcanic Zone of New Zealand. The suite consists of meta-igneous granulites that are believed to represent either altered oceanic crust (basalts and gabbros), or igneous rocks of unknown origin that have been hydrothermally altered by lower crustal fluids circulating into or from the overlying metasedimentary basement (Graham et al., 1990).

\subsubsection{Eastern Australia xenoliths}

Lower crustal and upper mantle xenoliths occur in many localities throughout Australia. All are hosted by alkali basalt-basanite lavas of intraplate character.

Only granulites from SE Australia (O'Reilly et al., 1988) have been selected here, due to the close proximity of SE Australia with other regions in the Gondwana supercontinent. These samples include granulites from The Anakies in Victoria, the Sydney Basin, Delgate and Gloucester in New South Wales.

Pyroxenites to be compared to the MBL suite have been selected from across Eastern Australia (O'Reilly and Griffin, 1987). Localities include: Lake Bullenmerri, Anakie (O'Reilly and Griffin, 1987) and Mt Shadwell (Irving, 1980) from Victoria; Delegate (Griffin and O'Reilly, 1986) and Kiama (Wass and Rogers, 1980) from New South Wales; and Lake Eacham and Sapphire Hill (Irving, 1980) from North Queensland.

The xenoliths were all formed as cumulates derived from basaltic magmas, with diverse compositions and various petrogenetic histories, including as intrusives of basaltic magmas, by basaltic underplating, and by mixing with crustal material.

\subsubsection{A geochemical comparison}

A comparison of the geochemistry of xenoliths from these localities allows the identification of xenoliths with similar characteristics. It must be stressed 
however that any similarities between suites in no way links the lower crust of these regions, other than in the similarity of rock types. While it is possible that the similarities stem from their formation in the same region by the same melts, it is also probable that they simply reflect formation in similar environments, with similar subsequent histories, much as unrelated basalts from identical tectonic settings may resemble each other.
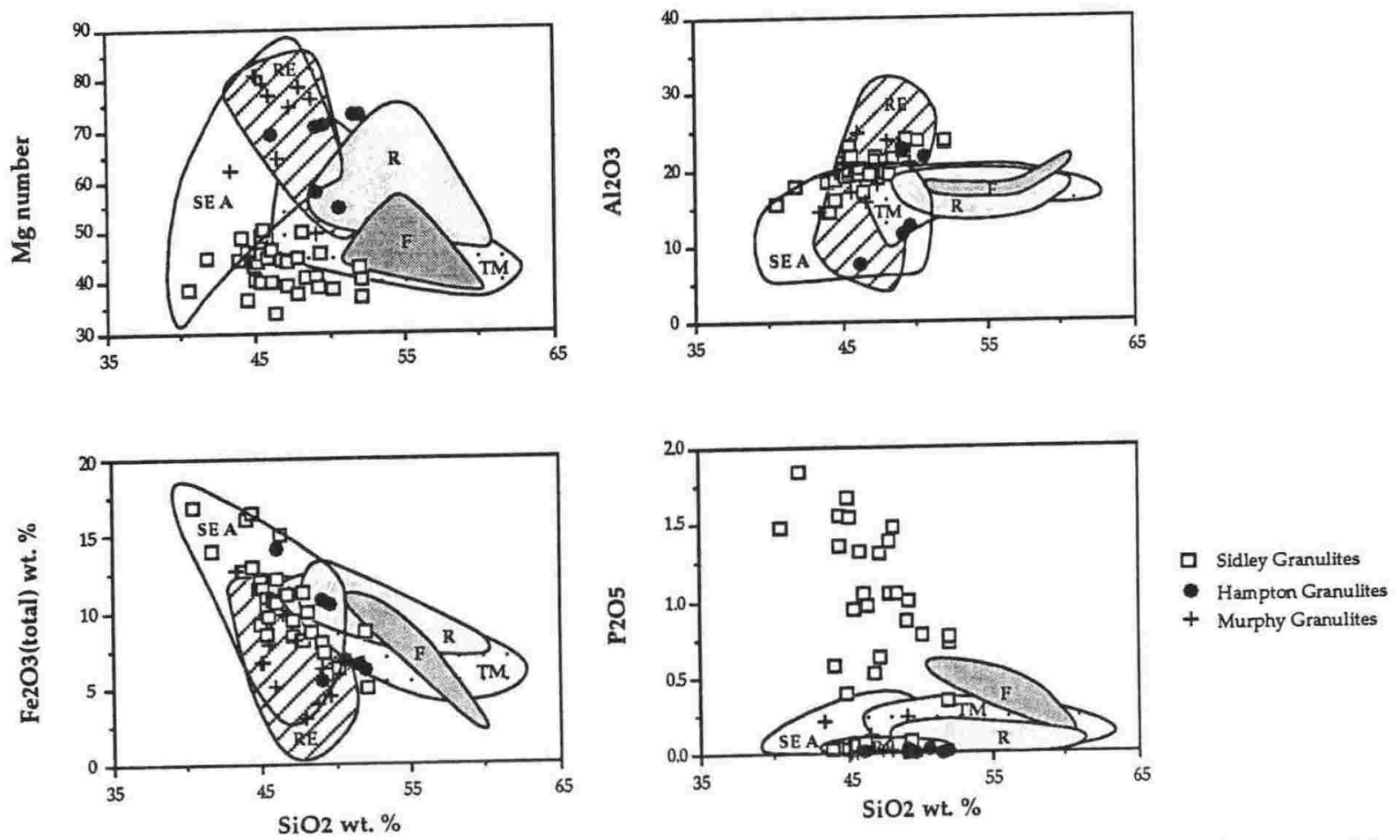

FIGURE 7.10: Selected major elements plotted against $\mathrm{SiO}_{2}$ highlight the similarities between Ross Embayment (RE), Mount Hampton and Mount Murphy granulites, and Transantarctic Mountain (TM), New Zealand (Ruapehu (R) and Fiordland (F)) and Mount Sidley granulites. Southeast Australia (SE A) granulites overlap with RE and Mounts Hampton and Murphy granulites.

Mount Murphy and Mount Hampton granulites have similar major element compositions to RE granulites (Figure 7.10). Southeastern Australia granulites show larger ranges in composition, which overlap those of the RE. Granulites from the TM, Fiordland and Mount Ruapehu have similar compositions, and are distinct from the other localities. Mount Sidley granulites are unique, due mainly to their low silica content, also reflected in the absence of orthopyroxene. In other elements they have similar compositions to TM and New Zealand granulites, notably in their low Mg\#s, and high $\mathrm{P}_{2} \mathrm{O}_{5}$ contents.

MBL pyroxenites show a wide range in $\mathrm{SiO}_{2}$ content, reflecting the occurrence of olivine or orthopyroxene as a major mineral phase (Figure 7.11). An example of the control of the mineral assemblage on whole rock compositions, is the bimodal distribution of $\mathrm{CaO}$ contents. Pyroxenites with low clinopyroxene abundances have low $\mathrm{CaO}$ content, and those with high abundances of 
clinopyroxene have high $\mathrm{CaO}$ contents. There are no strong similarities between any of the pyroxenite suites.
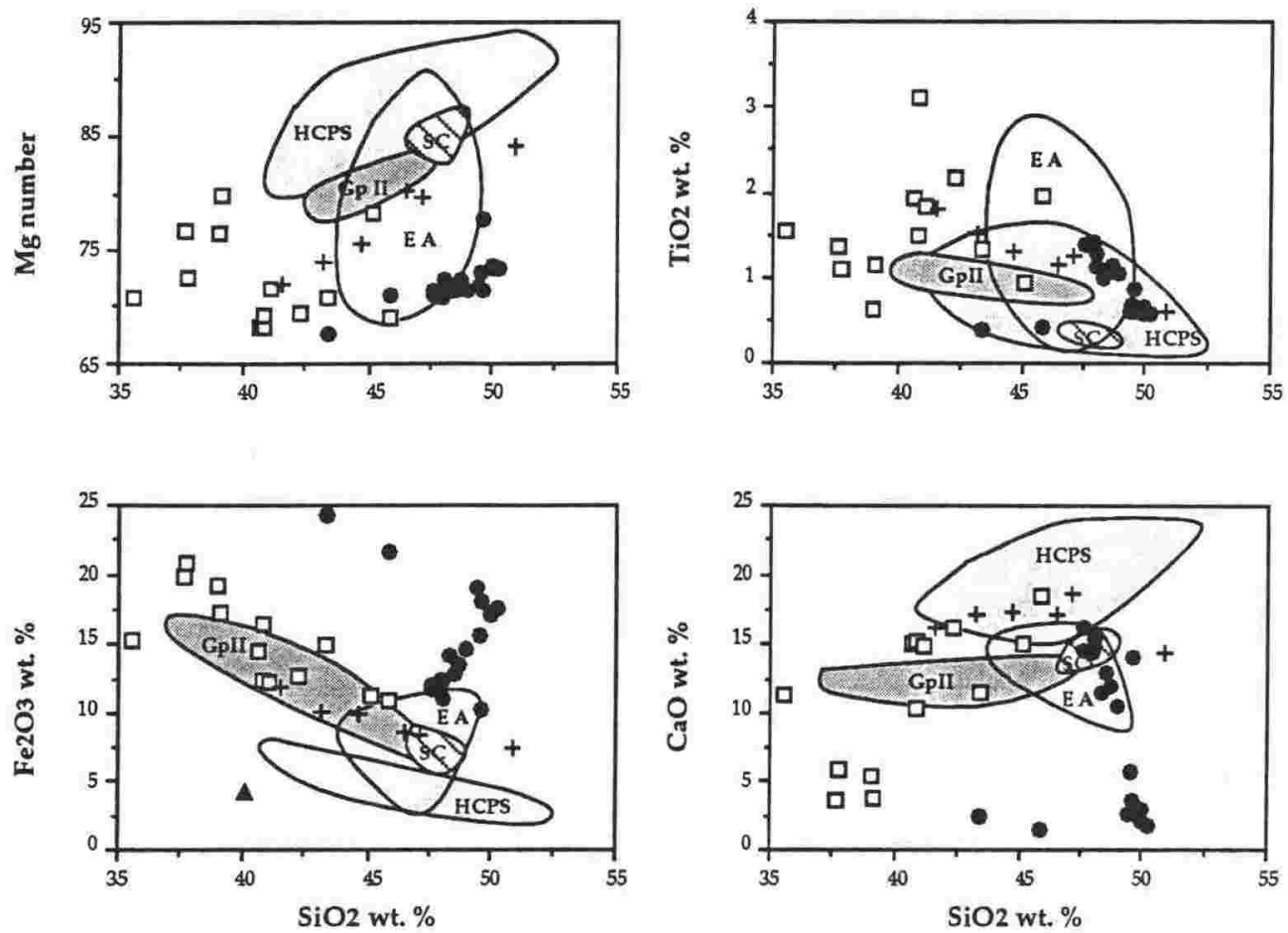

口 Sidley Pyroxenites

- Hampton Pyroxenites

+ Murphy Pyroxenites

FIGURE 7.11: Selected major elements plotted against $\mathrm{SiO}_{2}$ for pyroxenites from Mounts Sidley, Hampton and Murphy, compared to pyroxenites from Foster Crater (Group II xenoliths (GPII) and High Calcium Pyroxenite Suite (HCPS) pyroxenites) in the Transantarctic Mountains, Sulphur Cones (SC) in the Ross Embayment, and Eastern Australia (EA). Pyroxenite compositions are highly varied with no similarities evident.

Trace element contents are less reliant on the mineral assemblage, so trace element-trace element plots are more useful than major element plots in identifying geochemical characteristics between the xenolith suites.

The similarity of TM and New Zealand granulites shown by major elements is even more apparent in trace element plots (Figure 7.12). Mount Sidley granulites also consistently plot within this group, and the three localities are here termed the TM Group. Mount Murphy and Mount Hampton granulites have similar trace element characteristics to RE granulites. These granulites are here termed the RE Group. SE Australia granulites show large variations in trace element composition, overlapping all other fields.

Pyroxenite trace element plots (Figure 7.12), as with major element plots, show wide ranges in composition, with no strong similarities between any of the suites. The unique character of the HCPS xenolith suite from Foster Crater (Gamble et al., 1988; McGibbon, 1991) is especially evident compared to other xenolith suites, including the Group II pyroxenite suite from Foster Crater. The 
Granulites
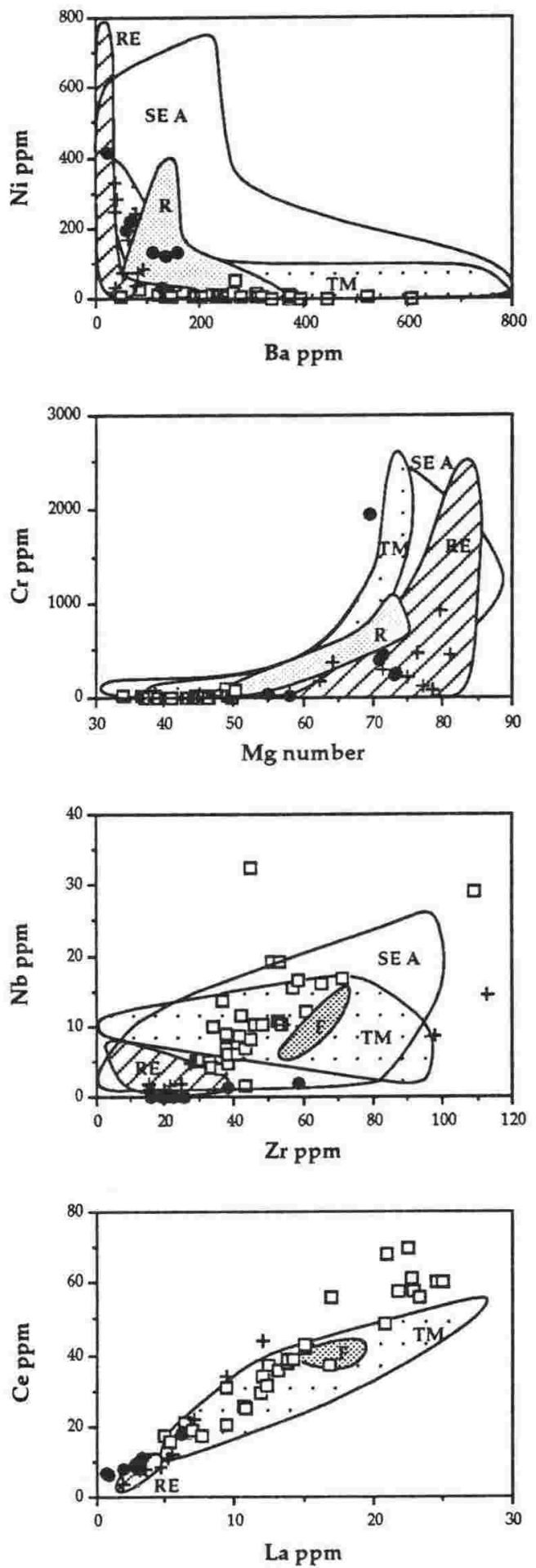

Pyroxenites
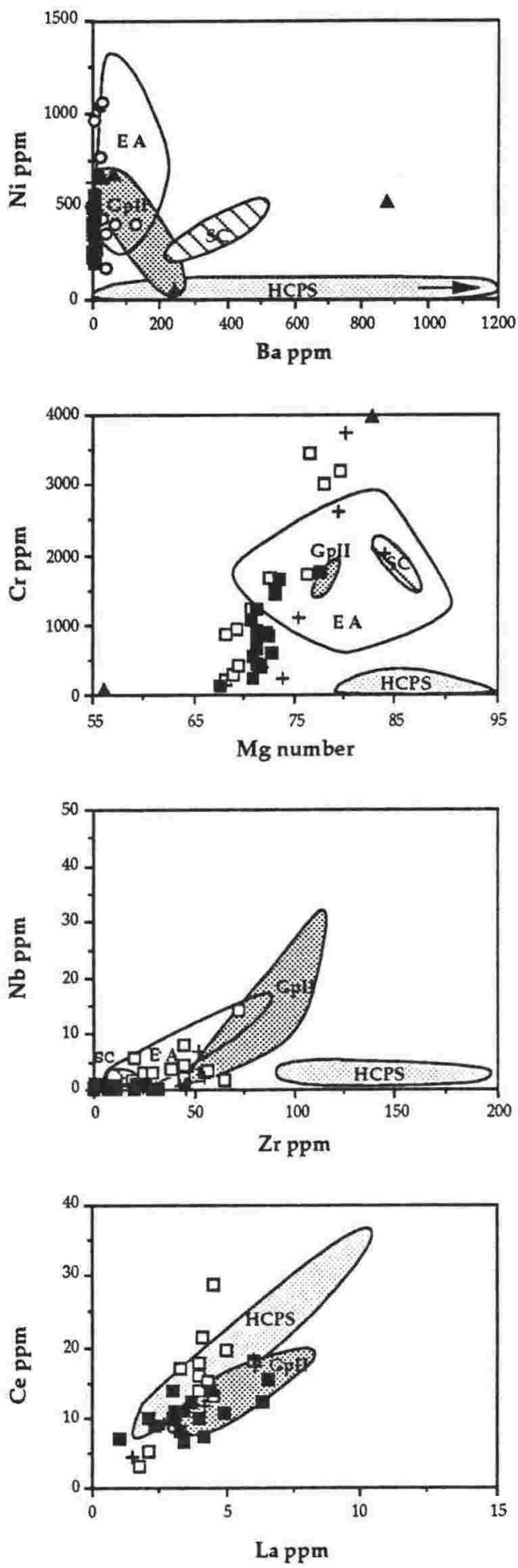

- Sidley Granulites

- Hampton Granulites + Murphy Granulites

FIGURE 7.12: Selected trace elements plotted against $\mathrm{SiO}_{2}$ for xenoliths from Mounts Sidley, Hampton and Murphy, compared to xenoliths from other Gondwana localities (symbols and fields as for Figures 7.10 and 7.11). Pyroxenite compositions are varied and do not overlap, but granulite compositions can be broadly divided into two groups; the TM Group consisting of the TM, NZ and Mount Sidley granulites, and the RE Group consisting of the RE, Mounts Hampton and Murphy granulites. SE Australia granulites overlap both groups. Abbreviations for granulite and pyroxenite localities are as for Figure 7.10 and Figure 7.11 respectively. 
HCPS xenolith suite has notably high $\mathrm{Ba}$ and $\mathrm{Zr}$ contents, and low $\mathrm{Cr}$ contents compared to other pyroxenites.

The trace element similarities between granulites from Mount Sidley, the TM, and New Zealand are highlighted in multi-element plots normalised to MORB (Pearce, 1983). Figure 7.13 shows representative plots from the RE, the TM, SE Australia, Mount Ruapehu, and Fiordland (small plots), with average compositions of these localities compared to MBL granulite average compositions (large plot).

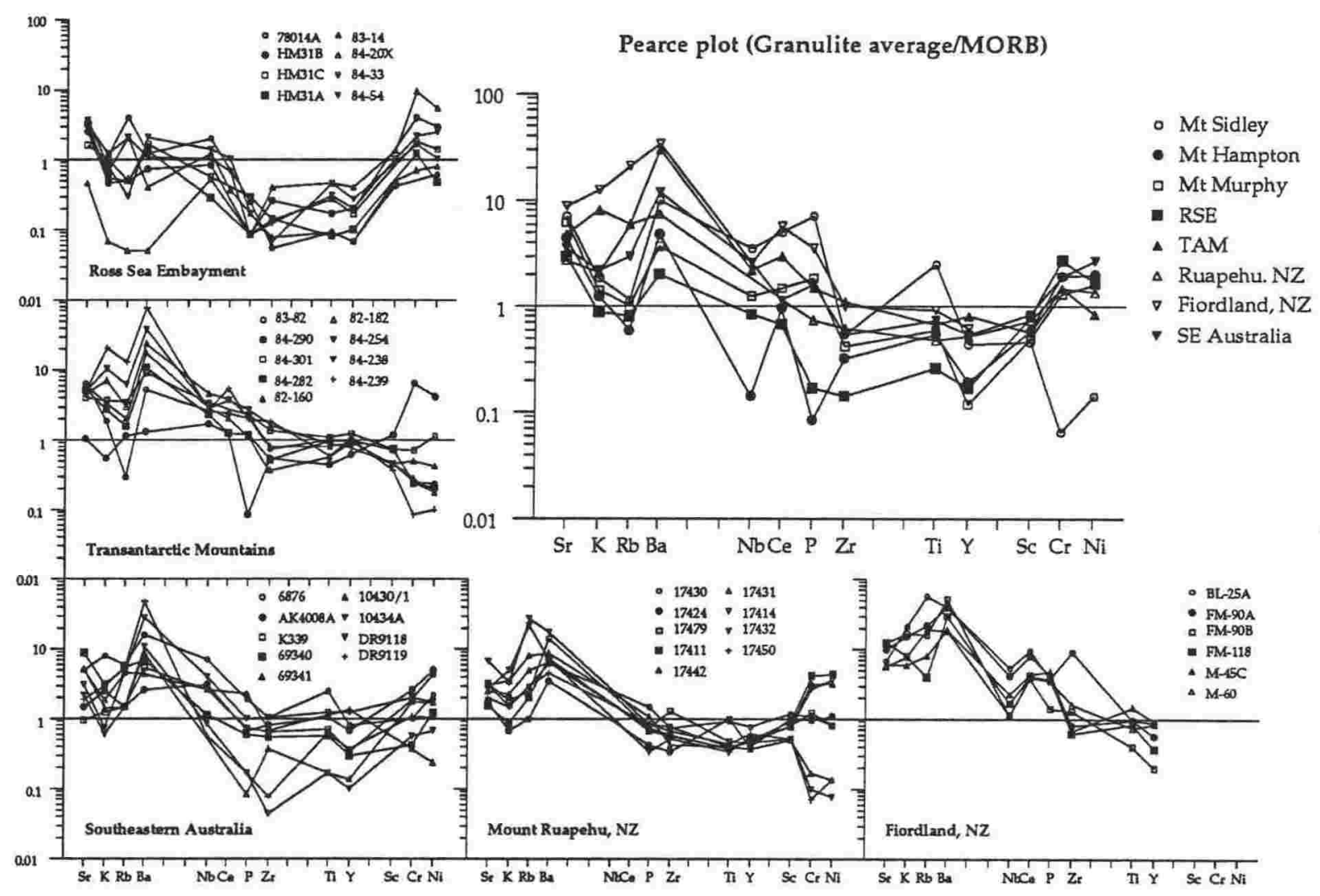

FIGURE 7.13: Multi-element plots normalised to MORB (Pearce, 1983) of Gondwana granulites for individual localities (small plots) and average analyses of each locality (large plot). The similarity of TM Group granulites and of the RE Group granulites, as well as the trace-element rich character of the TM Group compared to the RE Group, is emphasised.

The TM Group and SE Australia granulites show higher abundances of trace elements than other granulites; in particular high LILE contents. The very low $\mathrm{Cr}$ and $\mathrm{Ni}$ contents of Mount Sidley granulites is a distinguishing feature, correlating

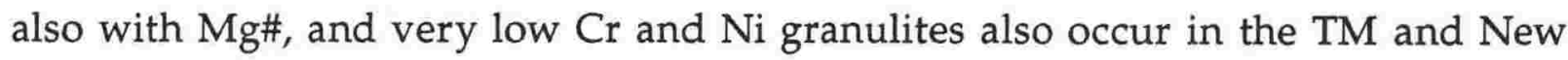
Zealand localities. RE Group granulites show similar trace element characteristics.

Pyroxenites from all localities show similar trace element patterns (Figure 7.14; small plots are of individual localities, and the large plot of average compositions from each locality), although Mount Hampton and Mount Murphy 
pyroxenites are generally more depleted than other pyroxenites. Some Eastern Australia pyroxenites (from Victoria) are also depleted in trace elements, reflecting the large variation in composition of these pyroxenites. The HCPS suite from Foster Crater (Gamble et al., 1988; McGibbon, 1991) is again markedly different to all other pyroxenites, especially in their higher LILE contents, and lower $\mathrm{Cr}$ and $\mathrm{Ni}$ contents.

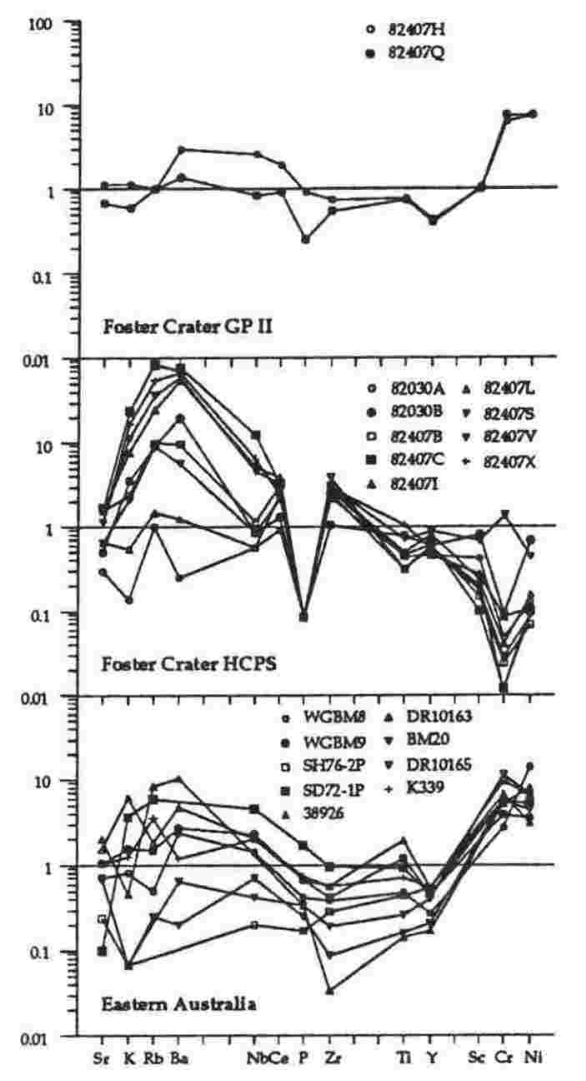

Pearce plot (pyroxenite average/MORB)

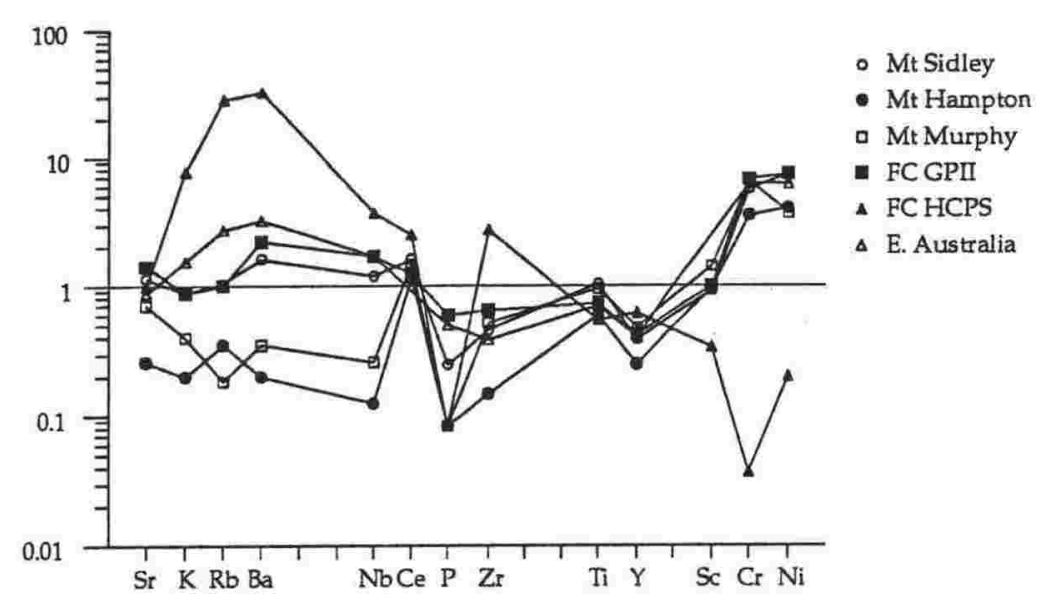

FIGURE 7.14: Multi-element plots normalised to MORB (Pearce, 1983) of Gondwana pyroxenites for individual localities (small plots) and average analyses of each locality (large plot). Mount Hampton and Mount Murphy pyroxenites have low trace element abundances compared to other localities. The HCPS suite (from Foster Crater; Gamble et al., 1988; McGibbon, 1991) is quite different to other pyroxenites, and includes relatively LILE-rich, and $\mathrm{Cr}$ - and $\mathrm{Ni}$-poor pyroxenites.

The TM Group granulites have high LREE contents compared to other granulites (Figure 7.15). RE Group granulites have similar REE contents, with low REE abundances, and no LREE-enrichment. Mount Murphy granulites have low REE abundances and are LREE-enriched.

Pyroxenites from all localities have similar REE patterns (Figure 7.15), except for the LREE-depleted pattern of the Mount Hampton pyroxenite, and distinctive 'humped' REE pattern of the HCPS suite. 


\section{REE plot (xenolith average/chondrites)}

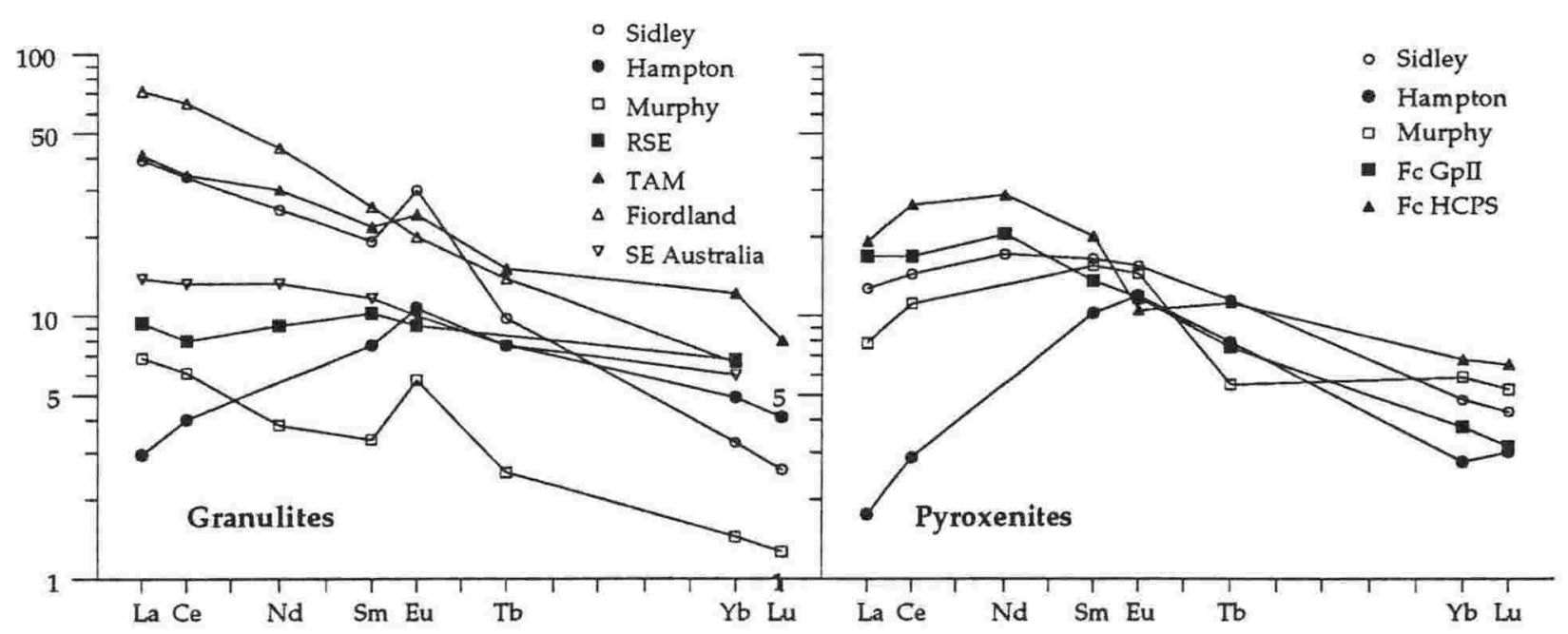

FIGURE 7.15: Rare earth element plots normalised to chondrite of average xenolith compositions from Gondwana localities. TM Group granulites are all LREE-enriched, as are Mount Murphy granulites, although with lower REE abundances. Other RE Group granulites have convex-up patterns similar to clinopyroxenes. HCPS Pyroxenites are especially unlike other pyroxenites.

Isotopic signatures of the xenolith suites show some similarities (Figure 7.16). MBL xenoliths have low ${ }^{87} \mathrm{Sr} /{ }^{86} \mathrm{Sr}(\leq 0.70458)$ and high ${ }^{143} \mathrm{Nd} / \mathrm{Nd}^{144}(\geq$ 0.512771 ) ratios compared to many other granulites.

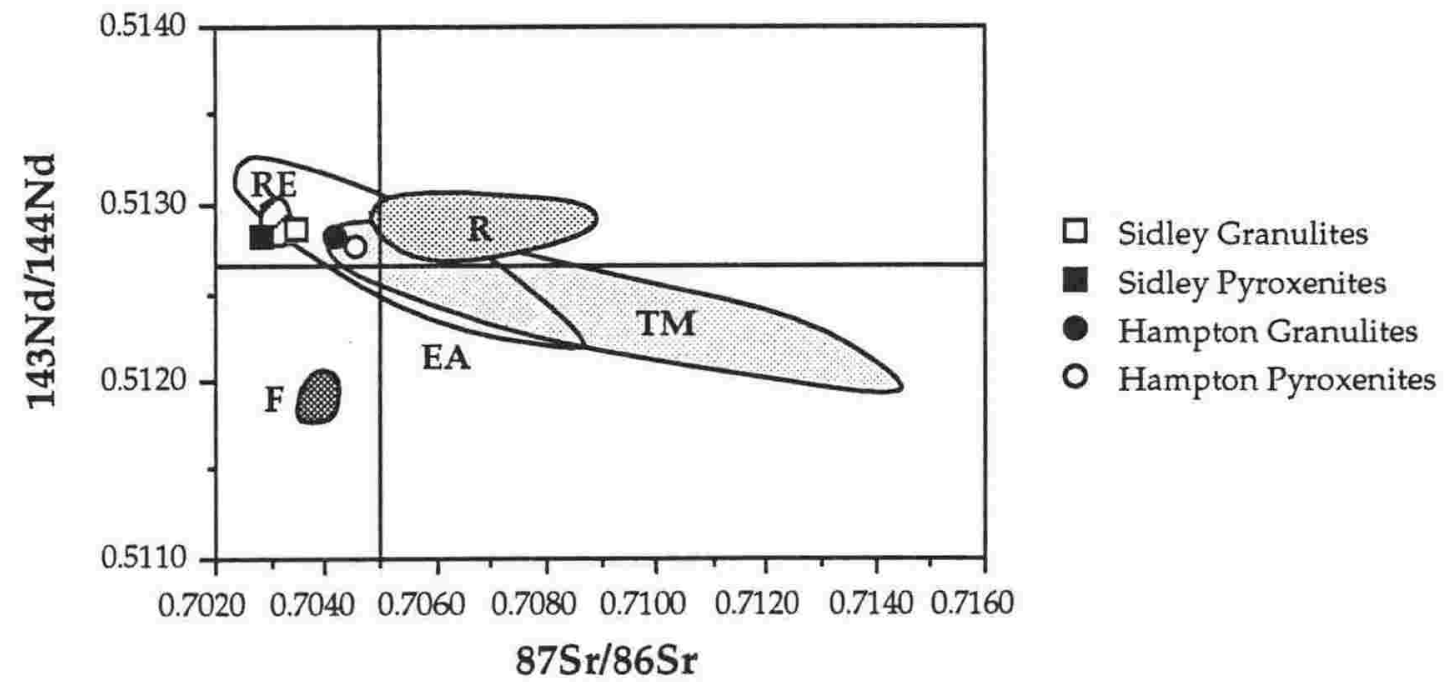

FIGURE 7.16: Plot of ${ }^{87} \mathrm{Sr} /{ }^{86} \mathrm{Sr}$ against ${ }^{143} \mathrm{Nd} /{ }^{144} \mathrm{Nd}$ for Gondwana xenoliths. TM Group xenoliths have high generally ${ }^{87} \mathrm{Sr} /{ }^{86} \mathrm{Sr}$ and lower ${ }^{143} \mathrm{Nd} /{ }^{144} \mathrm{Nd}$ ratios compared to RE Group xenoliths. Ruapehu granulites have high ${ }^{87} \mathrm{Sr} /{ }^{86} \mathrm{Sr}$ ratios as a result of contamination by sea-water and trench sediments, and Fiordland granulites have acquired low ${ }^{143} \mathrm{Nd} /{ }^{144} \mathrm{Nd}$ ratios.

TM granulites and SE Australia granulites show significantly larger ranges in isotopic composition than other granulites. Both the Fiordland and Mount Ruapehu granulites have decoupled $\mathrm{Sr}-\mathrm{Nd}$ isotopic ratios. Ruapehu granulites 
possibly having acquired their higher ${ }^{87} \mathrm{Sr} /{ }^{86} \mathrm{Sr}$ ratios through contamination by sea-water and trench sediments (Graham et al., 1990). Fiordland granulites have also inherited lower $\mathrm{Nd}$ ratios from secondary processes (McCulloch et al., 1987).

\subsubsection{Summary and discussion}

A geochemical comparison between xenoliths from MBL and other Gondwana localities has distinguished two main characteristics:

- Granulites from all localities generally fall within one of two groups consisting of: the Transantarctic Mountain, New Zealand and Mount Sidley granulites; and the Ross Embayment, Mount Hampton and Mount Murphy granulites. As these two groups were first identified in the McMurdo Sound region of Antarctica (Kalamarides et. al, 1987), they are here termed the TM (Transantarctic Mountain) Group, and the RE (Ross Embayment) Group. SE Australia granulites show a wide diversity in composition, overlapping with both groups;

- Pyroxenites from all localities show a large range in composition, with no apparent similarities between pyroxenites from different localities. The HCPS suite from Foster Crater is distinctive from all other pyroxenites, notably in its enriched LREE contents, and elevated $\mathrm{Zr}$.

TM Group granulites are distinguished from RE Group granulites by their more evolved composition e.g. lower $\mathrm{Mg \# s,} \mathrm{Cr}$ and $\mathrm{Ni}$, higher $\mathrm{SiO}_{2}$, alkalis, $\mathrm{P}_{2} \mathrm{O}_{5}$, trace elements (especially LILEs), REEs (especially LREEs), and larger ranges in ${ }^{87} \mathrm{Sr} /{ }^{86} \mathrm{Sr}$ and ${ }^{143} \mathrm{Nd} /{ }^{144} \mathrm{Nd}$ ratios. These characteristics suggest that the TM Group granulites formed from more evolved melts, and RE Group granulites formed from more primitive melts.

The melts that originally crystallised xenoliths from the two groups were compositionally distinct, with TM Group xenoliths having crystallised from relatively more evolved, alkaline melts, and RE Group xenoliths having crystallised from primitive sub-alkaline.

The lower crustal discontinuity identified between the Ross Embayment and the Transantarctic Mountains (Kalamarides et. al, 1987) may have relevance to the other regions discussed here. Any genetic relationship between the lower crustal segments that make up the TM and RE Groups is difficult to determine, however it is possible that these segments (e.g. the lower crust of the Transantarctic Mountains, Mount Sidley and New Zealand) formed at the same time, and were once joined as the same initial lower crustal block. Alternatively, their similarities may simply reflect their crystallisation from similar, but unrelated melts. 


\subsection{Comparison with Lower Crustal Xenolith Suites World-Wide}

\subsubsection{Introduction}

Having compared the MBL xenolith suites with other areas from Gondwana, it is desirable to compare the suite as a new locality to xenoliths world-wide. Rather than give a detailed comparison between sites that are laterally separated by vast distances, it is more appropriate to compare the MBL lower crust to average world-wide compositions. Only granulites are compared, due to the uncertainty and debate as to whether pyroxenites are lower crustal or upper mantle samples (Chapter 1.3).

Several estimates of average lower crust in the published literature have been collated, using crustal evolution models, granulite terrains and granulite xenoliths (Weaver and Tarney, 1984; Taylor and McLennan, 1985; Shaw et al., 1986; Rudnick and Presper, 1990; Rudnick, 1992). The MBL xenolith suite is compared to the calculation of Rudnick (1992), which is based on averages from 20 localities world-wide. The composition of this average is presented in Tables 7.4 and 7.6, and is discussed in full in Chapter 7.5.3.

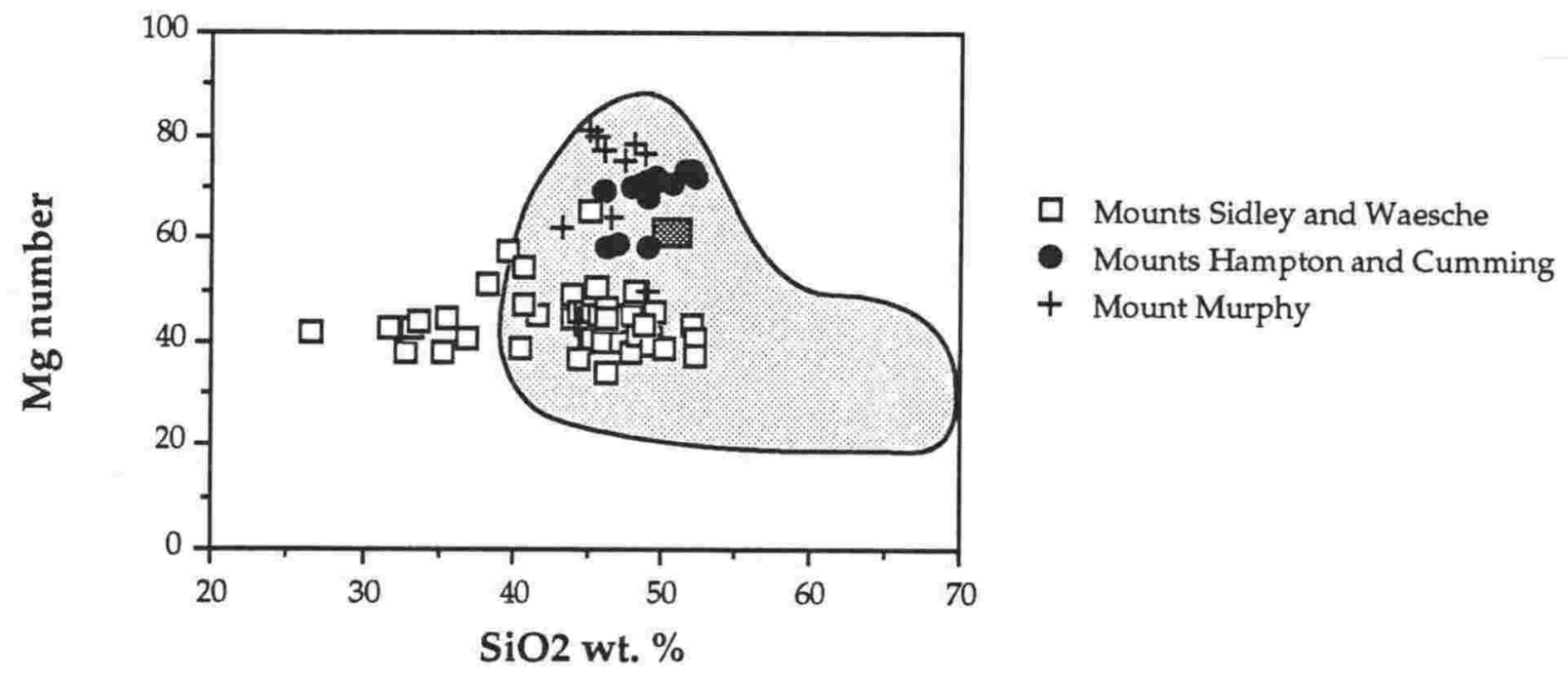

FIGURE 7.17: $\mathrm{Mg \#} \mathrm{v} \mathrm{SiO}_{2}$ for Marie Byrd Land granulites compared to granulite localities worldwide (shaded field). Average Marie Byrd Land granulite compositions are less $\mathrm{SiO}_{2}$-rich and variable in $\mathrm{Mg \#} \mathrm{compared} \mathrm{to} \mathrm{other} \mathrm{granulites} \mathrm{(dark} \mathrm{rectangle} \mathrm{is} \mathrm{the} \mathrm{average} \mathrm{composition} \mathrm{of} \mathrm{Rudnick,}$ 1992).

\subsubsection{A geochemical comparison}

The composition of the MBL lower crust varies in both $\mathrm{Mg \#}$ and in $\mathrm{SiO}_{2}$ content (Figure 7.17). Most $\mathrm{MBL}$ granulites have lower than average $\mathrm{SiO}_{2}$ (especially Type $\mathrm{M}$ granulites, due to their large secondary $\mathrm{Fe}-\mathrm{Ti}$ oxide contents). Mount Sidley granulites also have very low Mg\#s compared to other xenoliths. 
Mount Hampton and Mount Murphy granulites have Mg\#s typical of xenoliths world-wide, and $\mathrm{SiO}_{2}$ contents similar to other granulites, but somewhat lower than the average, reflecting their simple and primitive (high $\mathrm{Mg}: \mathrm{Mg}+\mathrm{Fe}$ ) mafic mineral assemblage.

\section{MBL Granulite average/ Lower Crustal average}

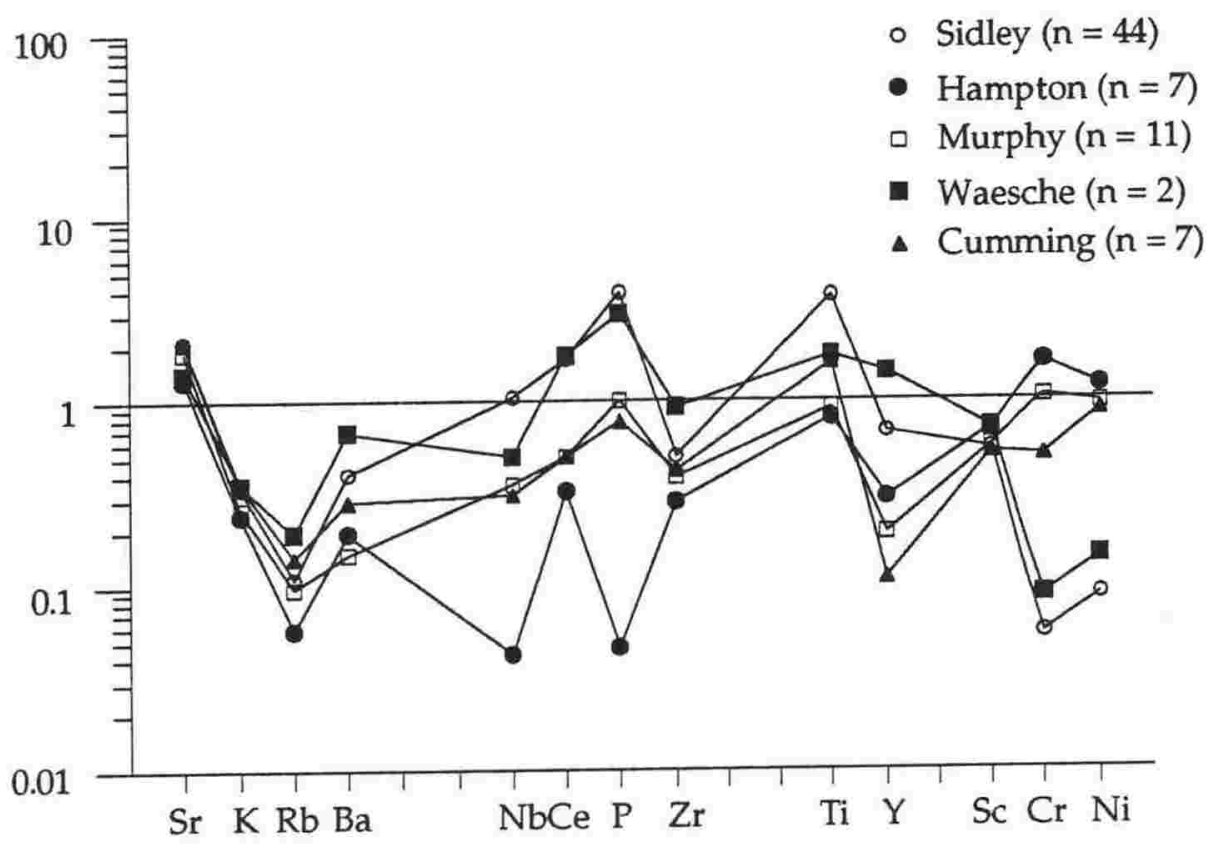

FIGURE 7.18: Multi-element plots of average granulite compositions from five sites in Marie Byrd Land, normalised to average lower crustal compositions of Rudnick (1992). Marie Byrd Land granulites are generally trace element poor (but rich in $\mathrm{Sr}$, reflecting high plagioclase abundances). Mount Sidley granulites are also rich in $\mathrm{Ti}$ and $\mathrm{P}$, due to enrichment by alkaline melts.

MBL granulites have low trace element abundances (Figure 7.18) compared with an average lower crust, with the exception of $\mathrm{Sr}$, reflecting a higher than average modal plagioclase content. Mount Sidley and Mount Waesche granulites also have high $\mathrm{P}$ and Ti contents, as a result of secondary apatite and oxide growth resulting from melt infiltration, and Mount Hampton and Mount Murphy granulites have slightly higher than average $\mathrm{Cr}$ and $\mathrm{Ni}$.

REEs are also depleted in MBL granulites (Figure 7.19) compared to average lower crust, with the exception of LREE contents in Mount Sidley granulites, which is a result of enrichment by alkaline melts. Eu in Mount Sidley granulites is higher than average, due to high plagioclase contents.

The low REE contents in MBL xenoliths reflect the primitive, and mafic mineral assemblage, with more evolved parental melts (i.e. TM Group melts) crystallising xenoliths with higher REE contents. The low REE abundances compared with average granulite compositions may also be an indication that the 


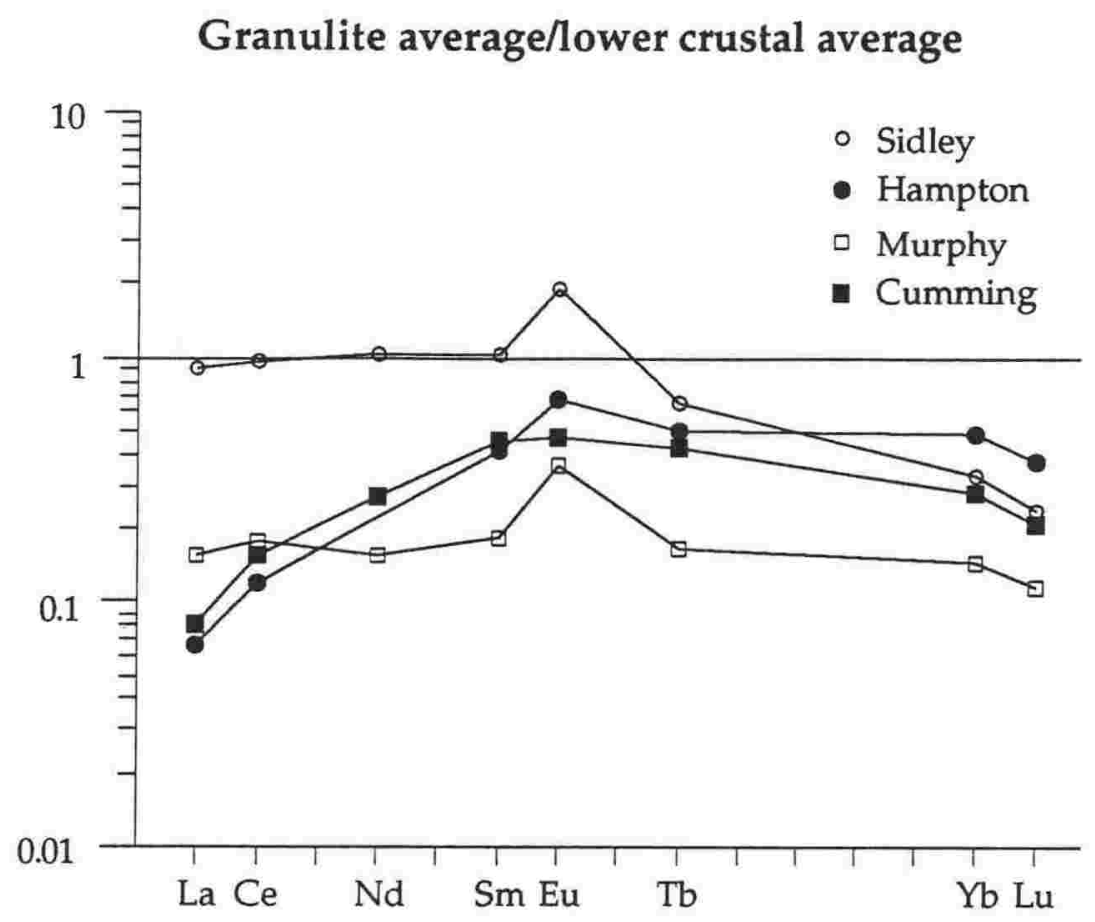

FIGURE 7.19: REE plots of average Marie Byrd Land granulite compositions normalised to average lower crustal compositions of Rudnick (1992). Marie Byrd Land granulites are REE-depleted compared to average lower crustal compositions.

crystallising melts were in equilibrium with garnet, and therefore crystallised relatively REE-depleted mineral phases.

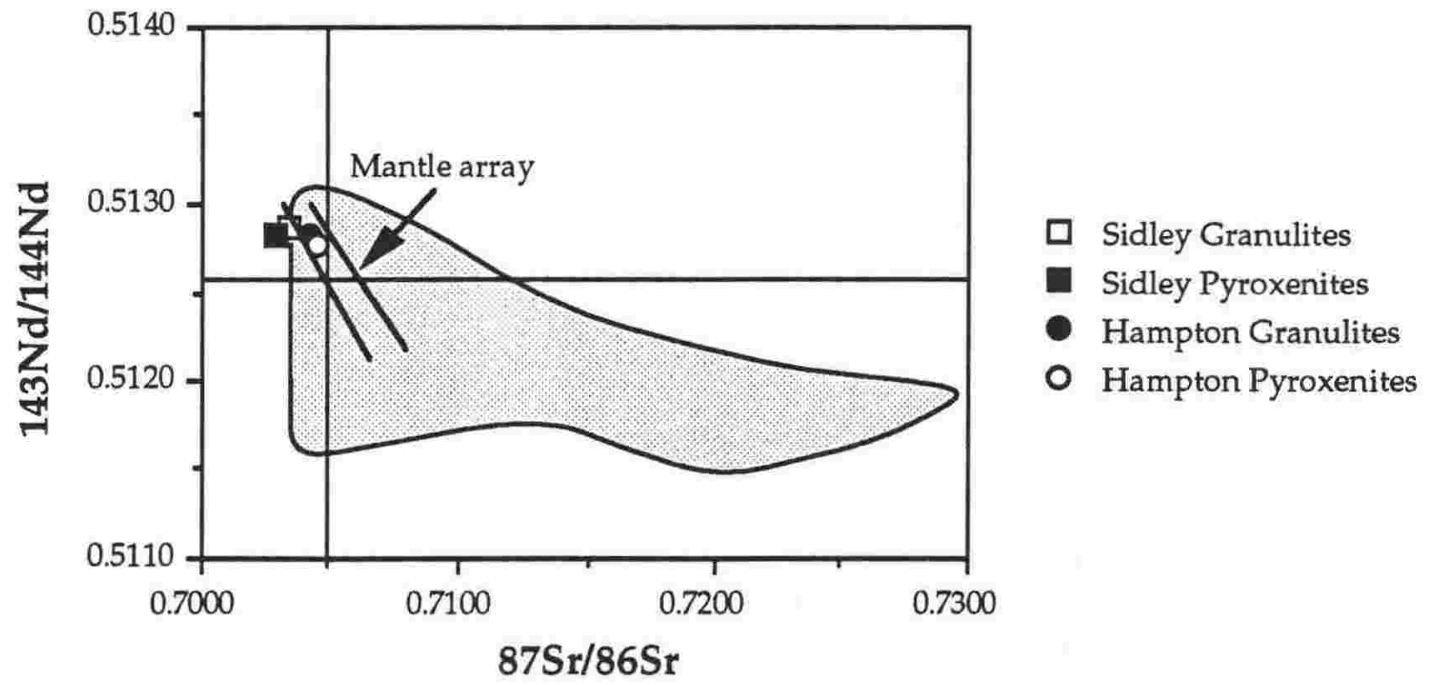

FIGURE 7.20: $\mathrm{Plot}$ of ${ }^{87} \mathrm{Sr} /{ }^{86} \mathrm{Sr}$ against ${ }^{143} \mathrm{Nd} /{ }^{144} \mathrm{Nd}$ for Marie Byrd Land xenoliths compared to xenolith localities world-wide (shaded area). Marie Byrd Land xenoliths have low ${ }^{87} \mathrm{Sr} /{ }^{86} \mathrm{Sr}$ and high ${ }^{143} \mathrm{Nd} /{ }^{144} \mathrm{Nd}$ ratios compared to most localities.

$\mathrm{Sr}-\mathrm{Nd}$ isotopic ratios are primitive compared to granulites world-wide, plotting in depleted mantle fields. The Sr-Nd isotopic ratios reflect their mafic and 
primitive nature compared to other granulites world-wide (e.g. low ${ }^{87} \mathrm{Sr} /{ }^{86} \mathrm{Sr}$ and higher ${ }^{143} \mathrm{Nd} /{ }^{144} \mathrm{Nd}$ ratios than average (Figure 7.20)).

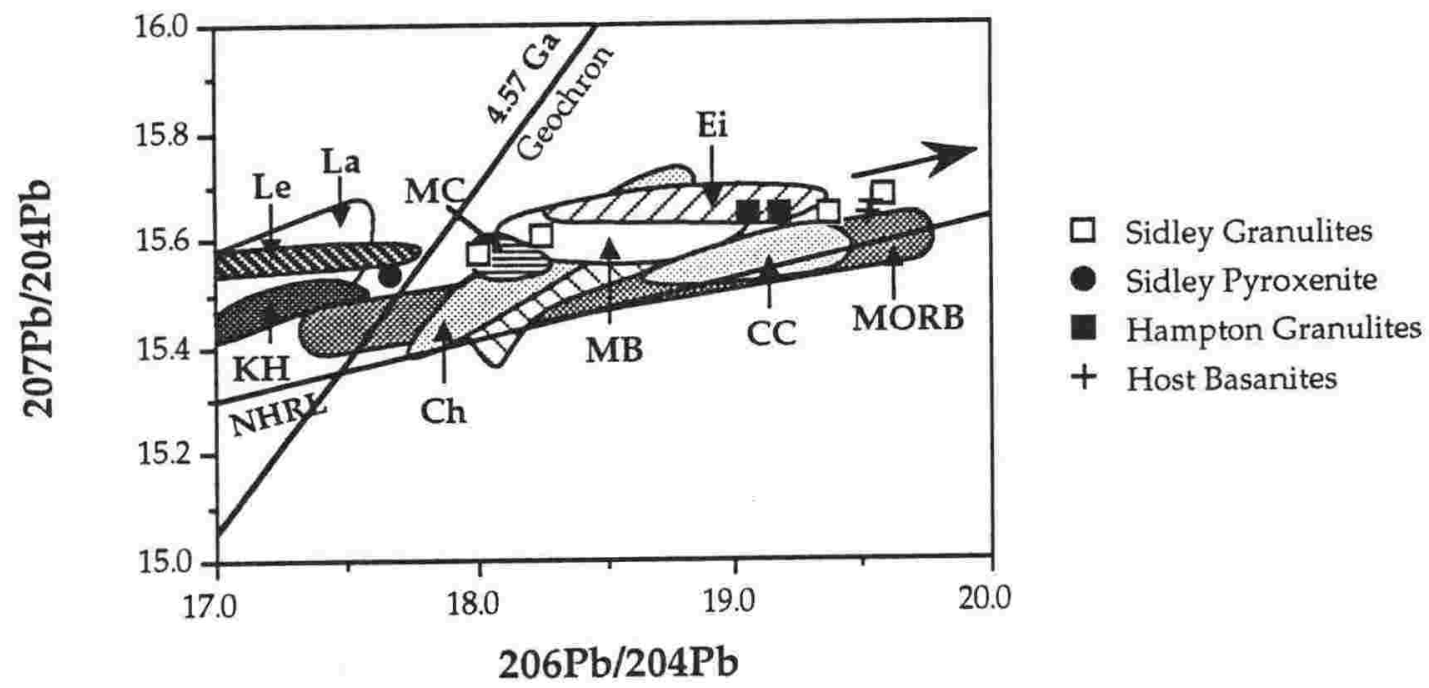

FIGURE 7.21: Plot of ${ }^{206} \mathrm{~Pb} /{ }^{204} \mathrm{~Pb}$ against ${ }^{207} \mathrm{~Pb} /{ }^{204} \mathrm{~Pb}$ for Marie Byrd Land xenoliths compared to xenolith localities world-wide (from Rudnick and Goldstein, 1990), showing a wide range in $\mathrm{Pb}$ isotopic compositions due to mixing between initially unradiogenic $\mathrm{Pb}$ ratios (as for Mount Sidley pyroxenites) and alkaline melts with radiogenic $\mathrm{Pb}$ ratios. $\mathrm{CC}=$ Camp Creek, $\mathrm{AZ}, \mathrm{U} . \mathrm{S} . \mathrm{A} ; \mathrm{Ch}=$ Chudleigh, Queensland, Australia; Ei = Eifel, Germany; $\mathrm{KH}=$ Kilbourne Hole, NM, U.S.A; La = Lashaine, Tanzania; Le = Lesotho, Sth Africa; $\mathrm{MB}=$ McBride Province, Queensland, Australia; MC = Massif Central, France. See Table 7.4 for references.

Despite the limited number of analyses, $\mathrm{Pb}$ isotopic compositions show an extremely wide range in composition compared to other granulites, and indeed basaltic melts (Figure 7.21). The exceptionally large range is most likely the result of mixing between the granulites, which have initial ratios represented by the pyroxenite suite, and the host magmas. Melt affected granulites have $\mathrm{Pb}$ isotopic ratios similar to the host-melts, reflecting the infiltration of melt into these xenoliths (Figure 7.21).

\subsubsection{A lower crustal average composition}

Previous lower crustal averages based on xenoliths include that of Rudnick and Presper (1990), which is based on an average of all granulite analyses, and of Rudnick (1992), which is based on suite-by-suite averages. The later, shown in Table 7.4, has been preferred as a comparison with MBL averages as it is not heavily weighted towards localities with many analyses (e.g. the Massif Central in France (Leyreloup et al., 1977; Dostal et al., 1980) has 366 published analyses compared to only two from the Erebus Volcanic Field, Antarctica (Kyle et al., 1987). Average compositions of the individual sites used by Rudnick (1992) to calculate an average composition for the lower crust world-wide are also 
presented in Table 7.4. The average of each locality is combined to give the average world-wide composition (last column of Table 7.4).

TABLE 7.4: Average compositions of lower crustal xenoliths by locality world-wide. The last column is an average of all the localities, and represents an average composition for the lower crust worldwide (from Rudnick, 1992).

Average compositions of lower crustal xenolith by locality

\begin{tabular}{|c|c|c|c|c|c|c|c|c|c|c|c|c|c|c|c|c|c|c|c|c|c|}
\hline & 1 & 2 & 3 & 4 & 5 & 6 & 7 & 8 & 9 & 10 & 11 & 12 & 13 & 14 & 15 & 16 & 17 & 18 & 19 & 20 & $\bar{X}$ \\
\hline $\mathrm{SiO}_{2}$ & 54.93 & 50.44 & 48.31 & 49.63 & 47.22 & 55.69 & 47.97 & 49.70 & 49.87 & 54.53 & 48.65 & 49.70 & 49.86 & 46.70 & 46.21 & 50.52 & 45.36 & 53.15 & 59.08 & 49.84 & 50.4 \\
\hline $\mathrm{TiO}_{2}$ & 1.01 & 0.65 & 0.86 & 0.68 & 1.13 & 1.08 & 0.33 & 1.27 & 0.99 & 1.20 & - & 0.82 & 1.31 & 1.37 & 0.95 & 1.02 & 1.22 & 0.88 & I.11 & 1.23 & 1.0 \\
\hline $\mathrm{Al}_{2} \mathrm{O}_{3}$ & 16.75 & 17.17 & 15.95 & 19.26 & 17.42 & 16.93 & 17.53 & 17.67 & 13.61 & 17.34 & 17,11 & 17.56 & 16.40 & 17.64 & 14.28 & 14.94 & 13.09 & 18.50 & 21.80 & 15.70 & 16.8 \\
\hline $\mathrm{FeO} \cdot$ & 8.51 & 10.15 & 9.59 & 7.64 & 9.11 & 8.04 & 4.27 & 9.85 & 8.57 & 7.66 & 6.71 & 8.19 & 11.24 & 9.65 & 9.67 & 11.75 & 11.55 & 6.26 & 10.46 & 10.95 & 9.0 \\
\hline Mno & 0.14 & 0.15 & 0.16 & 0.14 & 0.20 & 0.10 & 0.09 & 0.15 & 0.14 & 0.13 & - & 0.15 & 0.22 & 0.16 & 0.17 & 0.16 & 0.20 & 0.11 & 0.15 & 0.17 & 0.15 \\
\hline $\mathrm{MgO}$ & 5.80 & 8.15 & 8.08 & 5.45 & 8.09 & 5.47 & 11.61 & 5.79 & 9.31 & 5.74 & 10.59 & 9.86 & 8.21 & 7.94 & 10.76 & 7.27 & 11.33 & 5.47 & 2.15 & 7.14 & 7.7 \\
\hline $\mathrm{CaO}$ & 6.98 & 10.88 & 10.40 & 12.24 & 12.28 & 5.50 & 15.97 & 9.08 & 1287 & 8.31 & 14.53 & 10.65 & 9.47 & 10.45 & 12.39 & 9.77 & 14.01 & 9.39 & 1.08 & 9.58 & 10.3 \\
\hline $\mathrm{Na}_{2} \mathrm{O}$ & 2.82 & 2.56 & 2.94 & 3.22 & 2.44 & 2.20 & 1.74 & 2.84 & 202 & 2.87 & 0.75 & 2.61 & 2.01 & 2.73 & 2.06 & 1.56 & 1.11 & 3.41 & 0.78 & 2.82 & 2.27 \\
\hline $\mathrm{K}_{2} \mathrm{O}$ & 0.82 & 0.39 & 0.99 & 1.23 & 0.33 & 1.48 & 0.11 & 1.00 & 0.55 & 1.00 & 0.19 & 0.19 & 0.44 & 0.48 & 0.27 & 0.90 & 0.35 & 1.14 & 3.16 & 1.10 & 0.81 \\
\hline $\mathrm{P}_{2} \mathrm{O}_{5}$ & 0.18 & 0.16 & 0.16 & 0.15 & 0.40 & 0.17 & 0.03 & 0.43 & 0.25 & 0.13 & - & 0.37 & 0.25 & 0.39 & 0.15 & 0.08 & 0.53 & 0.17 & 0.05 & 0.06 & 0.22 \\
\hline$n$ & 12 & 9 & 19 & 17 & 16 & 72 & 2 & 14 & 6 & 17 & 3 & 21 & 28 & 18 & so & 10 & 19 & 22 & 3 & 5 & 336 \\
\hline $\mathrm{Mg} \#$ & 51.6 & 59.2 & 60.2 & 57.1 & 61.0 & 48.3 & 82.3 & 50.3 & 61.3 & 55.8 & 73.6 & 67.6 & 54.5 & 58.0 & 65.7 & 51.2 & 62.9 & 57.4 & 26.8 & 53.5 & 57.9 \\
\hline
\end{tabular}

$n=$ number of analyses averaged.

1 Hoggar, Algeria (Leyreloup et al., 1982)

Fon Portal, Uganda (Thomas and Nixon, 1987)

3 Lesotho, south Africa (Grifin et al., 1979; Rogers and Hawkseworth, 1982)

4 Man Shield, Liberia (Totl et at., 1989)

Eifel, West Germany (Stosch et al., 1986)

Massif Central, France (Leyreloup et al., 1977; Dostal et al., 1980)

Erebus Volcanic Field, Antaratica (Kylc et al., 1987)

Chinese Peak, Sierra Nevada, U.S.A. (Dodge el al., 1986)

9 Big Creek, Sierra Nevada, U.S.A. (Dodge et al., 1988)

10 Mexico (Roberts et al., 1989)
11 Pali Aike, Chile (Setverstone and Stern, 1983)

Chudleigh, Queensland, Australia (Kay and Kay, 1983; Rudnick et al., 1986)

13 McBride, Queensland (Kay and Kay, 1983; Rudnick and Taylor, 1987; Stolz and Davies, 1989)

14 Central Queensiand (Griftin et al., 1987)

15 SE Australia (Wilkinson and Thylor, 1980; Arculus et al., 1988; O'Reilly et at., 1988)

16 South Australia (Arculus et al., 1988)

17 Camp Creek, AZ, U.S.A. (Esperança et al., 1988)

18 Geronimo, NM (Kempton et al., 1990)

19 Kilbourne Hole, NM, U.S.A. (Padovani and Carter, 1977; Reid et al., 1989)

20 Colorado/Wyoming border (Bradley and McCallum, 1986).

\begin{tabular}{|c|c|c|c|c|c|c|c|c|c|c|c|c|c|c|c|c|c|c|c|c|c|}
\hline & 1 & 2 & 3 & 4 & 5 & 6 & 7 & 8 & 9 & 10 & 11 & 12 & 13 & 14 & 15 & 16 & 17 & 18 & 19 & 20 & $\bar{X}$ \\
\hline $\mathrm{Sc}$ & - & 29 & - & - & 34 & - & - & - & - & - & - & - & 38 & - & 34 & 44 & 46 & 18 & 28 & - & 34 \\
\hline v & 180 & 211 & 198 & - & - & 170 & - & - & - & - & - & 104 & 222 & 316 & 237 & 281 & 362 & 141 & - & - & 220 \\
\hline $\mathrm{Cr}_{\mathrm{r}}$ & 137 & - & 285 & - & 166 & 241 & 738 & 226 & 437 & - & - & 301 & 390 & 76 & 587 & 375 & 343 & 114 & 115 & - & 302 \\
\hline Co & 48 & 38 & 77 & - & 35 & 40 & - & - & - & - & - & - & 33 & - & 62 & 65 & 82 & - & - & - & 53 \\
\hline $\mathrm{Ni}$ & 95 & - & 103 & - & - & 70 & 194 & $n 1$ & 360 & - & - & 154 & 199 & 88 & 234 & 124 & 141 & 77 & - & - & 147 \\
\hline $\mathrm{Cu}$ & 17 & - & 54 & - & - & 23 & 28 & - & - & - & - & 31 & 80 & 109 & 74 & 58 & 92 & 20 & - & - & 53 \\
\hline $\mathrm{Zn}$ & - & - & - & 77 & - & - & 91 & 24 & - & - & - & - & 53 & 107 & 104 & 105 & 94 & 105 & 67 & - & 83 \\
\hline $\mathrm{Ga}$ & - & - & - & - & - & - & - & 12 & - & - & - & - & - & - & - & 15 & 15 & - & - & - & 14 \\
\hline $\mathrm{Rb}$ & - & 10 & 18 & - & 2 & 32 & - & - & - & 17 & - & 1 & 10 & 4 & 6 & 37 & 9 & 31 & 94 & - & 21 \\
\hline $\mathrm{Sr}$ & 522 & 277 & 863 & - & 589 & 298 & 243 & 513 & 302 & 383 & - & 426 & 235 & 608 & 420 & 180 & 187 & 715 & 119 & - & 405 \\
\hline$Y$ & 42 & 12 & 11 & - & - & 18 & 6 & - & - & - & - & 8 & 26 & 18 & 15 & 27 & 24 & 19 & - & - & 19 \\
\hline $\mathrm{Zr}$ & 124 & 194 & 43 & - & - & 97 & 18 & 130 & 72 & 105 & - & 27 & 175 & 38 & 41 & 83 & 71 & 98 & 268 & - & 99 \\
\hline $\mathrm{Nb}$ & 10.3 & - & 53 & - & - & 7.0 & 2.5 & - & - & - & - & 0.7 & 11.7 & 3.8 & 7.3 & 60.0 & - & 7.5 & - & - & 12 \\
\hline Cs & - & - & - & - & - & - & - & - & - & - & - & 0.2 & 0.1 & - & 4.7 & 0.1 & - & 0.8 & 0.1 & - & 1.0 \\
\hline $\mathrm{Ba}$ & 515 & 292 & 2144 & - & - & 648 & 24 & 729 & 567 & - & - & 152 & 218 & 119 & 238 & 885 & 66 & 435 & - & - & 502 \\
\hline $\mathrm{La}$ & 17.3 & 5.84 & 8.33 & - & 19.9 & 16.6 & - & - & - & 15.1 & - & 2.28 & 12.6 & - & 4.60 & 15.0 & - & 15.1 & 42.1 & - & 14.6 \\
\hline $\mathrm{Ce}$ & 35.2 & 12.1 & 18.7 & - & 45.8 & 34.9 & - & - & - & 32.3 & - & 4.92 & 2.92 & - & 11.4 & 33.9 & - & 32.4 & 72.3 & - & 29.9 \\
\hline $\mathrm{Nd}$ & - & 6.58 & 9.47 & - & 26.0 & - & - & - & - & 18.5 & - & 3.71 & 3.41 & - & 8.44 & 16.5 & 17.6 & 17.9 & 32.7 & - & 15.6 \\
\hline $\mathrm{Sm}$ & 3.21 & 1.55 & 2.54 & - & 5.27 & 4.08 & - & - & - & 4.09 & - & 1.12 & 1.25 & - & 2.37 & 4.72 & 4.29 & 3.73 & 8.93 & - & 3.79 \\
\hline Eu & 1.47 & 0.71 & 1.13 & - & 1.51 & 1.39 & - & - & - & 1.32 & - & 0.86 & - & - & 0.77 & 1.39 & - & 1.31 & 1.63 & - & 1.23 \\
\hline Gd & - & 1.89 & - & - & - & - & - & - & - & 4.75 & - & 1.26 & 4.11 & - & 2.46 & 5.40 & - & - & 9.14 & - & 4.14 \\
\hline $\mathrm{Tb}$ & 0.54 & - & 0.47 & - & 0.71 & 0.54 & - & - & - & 0.70 & - & 0.16 & 0.86 & - & 0.37 & 1.40 & - & 0.55 & 1.70 & - & 0.73 \\
\hline Ho & - & 0.48 & 0.68 & - & - & - & - & - & - & 0.87 & - & 0.30 & 1.05 & - & 0.53 & 1.11 & - & - & - & - & 0.72 \\
\hline Er & - & 1.37 & - & - & - & - & - & - & - & 2.56 & - & 0.78 & 3.62 & - & 1.45 & 3.10 & - & - & - & - & 2.15 \\
\hline$Y_{b}$ & 1.56 & 1.30 & 1.77 & - & 2.00 & 1.64 & - & - & - & 2.09 & - & 0.69 & 3.13 & - & 1.30 & 2.87 & - & 1.00 & 7.52 & - & 2.24 \\
\hline Lu & 0.24 & 0.20 & 0.27 & - & 0.31 & - & - & - & - & 0.32 & - & - & 0.40 & - & - & - & - & 0.15 & 1.06 & - & 0.37 \\
\hline $\mathrm{HI}$ & 2.21 & - & 1.63 & - & 2.33 & - & - & - & - & 2.88 & - & 0.54 & 6.39 & - & 0.76 & 2.38 & - & 2.44 & 7.24 & - & 2,88 \\
\hline $\mathrm{Pb}$ & - & - & - & - & - & - & 3.00 & - & - & 4.16 & - & 1.12 & 3.86 & - & 3.87 & 8.11 & - & 9.67 & 13.8 & - & 5.9 \\
\hline Th & 0.77 & - & - & - & 2.20 & - & 2.00 & - & - & 2.85 & - & 0.06 & 0.68 & - & 0.44 & 6.09 & - & 1.74 & 10.9 & - & 2.77 \\
\hline U & - & - & - & - & - & - & - & - & - & - & - & 0.03 & 0.25 & - & 0.11 & 0.52 & - & 0.85 & 0.48 & - & 0.37 \\
\hline
\end{tabular}

As the MBL suite is a new locality, and represents a large land mass, the region should be included in any lower crustal average compositions. The Ross Sea Embayment, Transantarctic Mountain and Mount Ruapehu granulites have 
TABLE 7.5: Average compositions of granulite xenoliths from the three main localities discussed in this study (Mounts Sidley, Hampton and Murphy), from the Ross Embayment and the Transantarctic Mountains, Antarctica, and from Mount Ruapehu, New Zealand.

\begin{tabular}{|c|c|c|c|c|c|c|}
\hline $\begin{array}{l}\text { AREA } \\
\text { SOURCE }\end{array}$ & $\begin{array}{l}\text { Mount } \\
\text { Sidley§ }\end{array}$ & $\begin{array}{c}\text { Mount } \\
\text { Hampton§ }\end{array}$ & $\begin{array}{c}\text { Mount } \\
\text { Murphy§ }\end{array}$ & $\begin{array}{c}\text { Ross } \\
\text { Embaymentt }\end{array}$ & $\begin{array}{c}\text { Transant. } \\
\text { Mountainst }\end{array}$ & $\begin{array}{c}\text { Mount } \\
\text { Ruapehuf }\end{array}$ \\
\hline $\mathrm{SiO} 2$ & 43.6 & 49.7 & 46.8 & 47.9 & 53.1 & 54.5 \\
\hline TiO2 & 3.7 & 0.8 & 0.9 & 0.4 & 1.0 & 0.7 \\
\hline $\mathrm{Al} 2 \mathrm{O} 3$ & 17.1 & 16.4 & 20.1 & 18.8 & 16.7 & 16.5 \\
\hline $\mathrm{FeO}^{*}$ & 13.0 & 7.7 & 6.1 & 4.8 & 8.1 & 8.5 \\
\hline $\mathrm{MnO}$ & 0.19 & 0.13 & 0.10 & 0.09 & 0.13 & 0.16 \\
\hline $\mathrm{MgO}$ & 5.7 & 10.3 & 9.6 & 10.8 & 6.3 & 8.1 \\
\hline $\mathrm{CaO}$ & 11.0 & 11.1 & 12.9 & 14.9 & 9.3 & 8.8 \\
\hline $\mathrm{Na} 2 \mathrm{O}$ & 3.3 & 2.8 & 2.5 & 1.8 & 2.8 & 2.2 \\
\hline $\mathrm{K} 2 \mathrm{O}$ & 0.27 & 0.19 & 0.21 & 0.13 & 1.20 & 0.32 \\
\hline P2O5 & 0.86 & 0.01 & 0.22 & 0.02 & 0.18 & 0.09 \\
\hline Mg\#* & 43.51 & 69.50 & 72.30 & 77.0 & 51.3 & 59.8 \\
\hline Sc & 18 & 24 & 20 & 33 & 23 & 30 \\
\hline v & 226 & 173 & 110 & 103 & 145 & 227 \\
\hline $\mathrm{Cr}$ & 16 & 478 & 321 & 672 & 362 & 363 \\
\hline $\mathrm{Ni}$ & 13 & 178 & 143 & 153 & 77 & 120 \\
\hline $\mathrm{Cu}$ & 22 & 31 & 28 & 43 & 20 & 39 \\
\hline $\mathrm{Zn}$ & 63 & 46 & 38 & 31 & 88 & 91 \\
\hline $\mathrm{Ga}$ & 21 & 15 & 16 & 11 & - & 18 \\
\hline $\mathbf{R b}$ & 2 & 1 & 2 & 2 & 12 & 12 \\
\hline Sr & 861 & 532 & 740 & 360 & 576 & 324 \\
\hline $\mathbf{Y}$ & 13 & 6 & 4 & 5 & 24 & 16 \\
\hline $\mathbf{Z r}_{\mathbf{r}}$ & 49 & 29 & 38 & 13 & 99 & 56 \\
\hline $\mathrm{Nb}$ & 12 & 1 & 4 & 3 & 8 & - \\
\hline $\mathrm{Ba}$ & 204 & 97 & 75 & 40 & 590 & 150 \\
\hline La & 14 & 3 & 6 & 3 & 13 & - \\
\hline $\mathrm{Ce}$ & 50 & 10 & 15 & 7 & 30 & - \\
\hline $\mathrm{Nd}^{* *}$ & 18.0 & - & 1.2 & 5.7 & 18.0 & - \\
\hline $\mathrm{Sm}^{* *}$ & 3.30 & 1.60 & 0.68 & 1.18 & 4.46 & - \\
\hline $\mathrm{Eu}^{* *}$ & 1.20 & 0.81 & 0.44 & 0.70 & 1.86 & - \\
\hline $\mathrm{Gd}^{* *}$ & - & - & - & 3.01 & 4.93 & - \\
\hline $\mathrm{Tb}^{* *}$ & 0.43 & 0.37 & 0.12 & 0.11 & 0.73 & - \\
\hline $\mathrm{Er}^{* *}$ & - & - & - & 1.07 & 2.40 & - \\
\hline $\mathrm{Yb}^{* *}$ & 1.20 & 0.90 & 0.32 & 1.49 & 2.68 & - \\
\hline $\mathbf{L u}^{* *}$ & 0.09 & 0.14 & 0.04 & 0.04 & 0.28 & - \\
\hline $\mathrm{Hf}^{* *}$ & 3.60 & 1.00 & 0.42 & 0.33 & 2.96 & - \\
\hline $\mathrm{Pb}$ & 4.7 & 3.1 & 3.6 & 2.8 & 5.1 & 6.5 \\
\hline $\mathrm{Th}^{* *}$ & - & - & - & 0.16 & 0.12 & - \\
\hline$n$ & 44 & 7 & 11 & 11 & 14 & 16 \\
\hline${ }^{* *} n$ & 5 & 2 & 2 & 3 & 8 & \\
\hline
\end{tabular}

$\S$ source $=$ this study; + source $=$ Berg (pers. comm.); $\ddagger$ source $=$ Graham et al., 1990 .

* all Fe calculated as $\mathrm{FeO}$, and a ratio of $\mathrm{Fe} 2 \mathrm{O} 3: \mathrm{FeO}=0.15$ is used for $\mathrm{Mg}$-number calculations.

** number of analyses is smaller for these elements (see **n row). 
also not been incorporated into any previous calculations of average lower crust composition (the Fiordland granulites are from a terrain, and therefore should not be included in any calculations based on xenoliths only). Average compositions for the three major MBL granulite localities discussed in this study (Mounts Sidley, Hampton and Murphy), as well as average compositions for the Ross Embayment and Transantarctic Mountains (Berg, pers. comm.), and for Mount Ruapehu (Graham et al., 1990) are presented as Table 7.5. A new computation of an average composition for the lower crust, taking into account these new localities, is presented as Table 7.6. The xenolith models of Rudnick and Presper (1990) and Rudnick (1992), and two terrain averages (Weaver and Tarney, 1984 - Lewisian granulites, and Shaw et al., 1986 - Canadian Shield) are also shown.

Compared to the other lower crustal averages, the new average differs only slightly in major element compositions. There are however some substantial changes to trace element values. As these were previously based on an average of only 10 localities; adding a further five localities has substantially changed these estimates, and made them more representative of an average lower crust. In particular, the new estimate has higher $\mathrm{Cr}$ and $\mathrm{Sr}$ contents than previous averages, and lower contents of most other trace elements, indicating a more depleted and primitive lower crust than previous averages.

Xenolith averages differ significantly from terrain averages, which have higher incompatible element concentrations and more silicic compositions (Chapter 1.4). Certainly the MBL lower crustal xenolith suite is mafic compared to granulite terrains (Weaver and Tarney, 1984; Shaw et al., 1986). The most likely explanation for this discrepancy, based on the MBL xenolith suite, is that the MBL granulites were crystallised from mafic primitive mantle-derived melts, with no assimilation of evolved crustal material. The result is a mafic rather that a felsic lower crust. In contrast, lower crustal granulite terrains typically have a large proportion of felsic material.

An example of this discrepancy from MBL is the granulite suite discussed here compared to the amphibolite-granulite terrain from the Fosdick Metamorphic Complex, which has a protolith of deep marine sediments and granitoid rocks (Bradshaw et al., 1983; Weaver et al., 1991; Luyendyk et al., 1992). As the Fosdick Metamorphic Complex granulites come from higher crustal levels than the xenolith suite (Luyendyk et al., 1992), the compositional difference between granulite xenoliths and terrains can be explained by granulite xenoliths and terrains representing different levels of the crust (Bohlen, 1987; Rushmer, 1993). 
TABLE 7.6: Estimates of average lower crustal compositions as deduced from granulite terrains, and from granulite xenolith compositions, including from this study.

\begin{tabular}{|c|c|c|c|c|c|}
\hline $\begin{array}{l}\text { TYPE } \\
\text { METHOD }\end{array}$ & $\begin{array}{c}\text { Terrain } \\
\text { Weaver and } \\
\text { Tarney, 1984 }\end{array}$ & $\begin{array}{c}\text { Terrain } \\
\text { Shaw et al., } \\
1986 \\
\end{array}$ & $\begin{array}{c}\text { Xenolith } \\
\text { Rudnick and } \\
\text { Presper, } 1990\end{array}$ & $\begin{array}{c}\text { Xenolith } \\
\text { Rudnick, } \\
1992 \\
\end{array}$ & $\begin{array}{c}\text { Xenolith } \\
\text { This Study, } \\
1993\end{array}$ \\
\hline $\mathrm{SiO} 2$ & 61.2 & 61.2 & 50.5 & 50.4 & 50.1 \\
\hline TiO2 & 0.5 & 0.8 & 1.0 & 1.0 & 1.1 \\
\hline $\mathrm{Al} 2 \mathrm{O} 3$ & 15.6 & 14.9 & 16.5 & 16.8 & 17.0 \\
\hline $\mathrm{FeO}$ & 5.3 & 7.2 & 9.0 & 9.0 & 8.8 \\
\hline $\mathrm{MnO}$ & 0.10 & 0.12 & 0.15 & 0.15 & 0.15 \\
\hline MgO & 3.4 & 4.1 & 7.8 & 7.7 & 7.9 \\
\hline $\mathrm{CaO}$ & 5.6 & 5.2 & 9.7 & 10.3 & 10.5 \\
\hline $\mathrm{Na} 2 \mathrm{O}$ & 4.4 & 3.1 & 2.4 & 2.3 & 2.4 \\
\hline $\mathrm{K} 2 \mathrm{O}$ & 1.00 & 1.60 & 0.79 & 0.81 & 0.71 \\
\hline $\mathrm{P} 2 \mathrm{O} 5$ & 0.18 & 0.13 & 0.23 & 0.22 & 0.22 \\
\hline Mg\# & 53.34 & 50.37 & 60.70 & 60.4 & 60.8 \\
\hline Sc & - & 19 & 34 & 34 & 30 \\
\hline V & - & 139 & 214 & 220 & 200 \\
\hline $\mathrm{Cr}$ & 88 & 144 & 308 & 302 & 321 \\
\hline Co & - & 39 & 51 & 53 & 53 \\
\hline $\mathrm{Ni}$ & 58 & 89 & 137 & 147 & 137 \\
\hline $\mathrm{Cu}$ & - & 38 & 53 & 53 & 45 \\
\hline $\mathrm{Zn}$ & - & - & - & 83 & 74 \\
\hline $\mathrm{Ga}$ & - & - & - & 14 & 15 \\
\hline $\mathbf{R b}$ & 11 & 41 & 17 & 21 & 16 \\
\hline $\mathrm{Sr}$ & 569 & 317 & 403 & 405 & 447 \\
\hline$Y$ & 7 & 30 & 20 & 19 & 16 \\
\hline $\mathbf{Z r}$ & 202 & 169 & 84 & 99 & 85 \\
\hline $\mathrm{Nb}$ & 5 & 14 & 11 & 12 & 10 \\
\hline Cs & - & - & 1 & 1.0 & 1.0 \\
\hline $\mathrm{Ba}$ & 757 & 458 & 384 & 502 & 409 \\
\hline La & 22 & - & 13 & 14.6 & 13 \\
\hline $\mathrm{Ce}$ & 44 & - & 28 & 29.9 & 28 \\
\hline $\mathrm{Nd}$ & 18 & - & 15 & 15.6 & 14.1 \\
\hline $\mathrm{Sm}$ & 3.3 & - & 3.6 & 3.79 & 3.39 \\
\hline Eu & 1.2 & - & 1.3 & 1.23 & 1.23 \\
\hline $\mathrm{Gd}$ & - & - & - & 4.14 & 4.10 \\
\hline $\mathrm{Tb}$ & 0.43 & - & 0.58 & 0.73 & 0.61 \\
\hline Ho & - & - & - & 0.72 & 0.72 \\
\hline $\mathrm{Er}$ & - & - & - & 2.15 & 2.05 \\
\hline $\mathrm{Yb}$ & 1.2 & - & 1.9 & 2.24 & 1.94 \\
\hline Lu & - & - & - & 0.37 & 0.27 \\
\hline Hf & 3.6 & 4 & 2.5 & 2.88 & 0.46 \\
\hline $\mathrm{Pb}$ & 13 & 23 & 5 & 5.9 & 5.2 \\
\hline Th & 0.42 & 7.7 & 1.6 & 2.77 & 2.33 \\
\hline $\mathbf{U}$ & 0.05 & 1.1 & 0.4 & 0.37 & 0.37 \\
\hline
\end{tabular}


Averages based on model calculations (e.g. Taylor and McLennan, 1985) are closer to xenolith averages than terrain averages. These differences highlight the wide diversity of granulite xenoliths compared to granulite terrains world-wide (O'Reilly et al., 1988; Rudnick, 1992; Rushmer, 1993).

\subsection{Conclusion}

The MBL lithosphere, which includes upper mantle spinel lherzolites with Cr-diopside veins, and lower crustal granulites and pyroxenites, is diverse in its composition. In the region of the ECR, a lithospheric discontinuity has been identified, between an evolved alkaline (e.g. lower $\mathrm{Mg \# )} \mathrm{lower} \mathrm{crust} \mathrm{in} \mathrm{the} \mathrm{south}$ (Mounts Sidley and Mount Waesche) and a more primitive (e.g. higher Mg\#s) sub-alkaline lower crust to the north (Mounts Hampton and Cumming). The lower crust beneath Mount Murphy, on the MBL coast, is similar to the lower crust in the north of the ECR, although it does have some of the characteristics of the south ECR lower crust.

The lower crustal composition of other regions once joined as a part of the Gondwana supercontinent, show compositional similarities to the MBL lower crust. Granulite xenoliths from the Transantarctic Mountains in the McMurdo Sound region, and from Mount Ruapehu in New Zealand, as well as a granulite terrain in Fiordland, New Zealand, are compositionally similar to the southern ECR lower crust. Lower crustal granulites from the Ross Embayment are similar to granulites from the northern ECR. Granulites from these regions have been termed the TM and RE Groups respectively, after the lower crustal discontinuity previously inferred by xenoliths from the McMurdo Sound region (Kalamarides et al., 1987).

The composition of the MBL lower crust is depleted in trace elements (including rare earth elements) relative to an average lower crustal composition world-wide. They are however more mafic than average compositions, and have a mantle-like isotopic signature, reflecting their formation as cumulates from primitive mantle melts. 


\section{Chapter eight \\ LOWER CRUSTAL ARCHITECTURE AND PROCESSES}

\section{Synopsis}

The lower crust of Marie Byrd Land, represented by granulite and pyroxenite xenoliths, was initially formed by crystallisation from primitive subalkaline and alkaline mantle derived melts. This has resulted in a stratified lower crust that varies in composition across Marie Byrd Land. Geothermometry and geobarometry estimates indicate a high rift-like geotherm, similar to that beneath the Transantarctic Mountains (Berg and Herz, 1986), and are consistent with the xenoliths having equilibrated to lower crustal conditions.

Cenozoic alkaline volcanism has resulted in two closely linked styles of metasomatism that have modified the lower crust. Hydrous fluids and/or melts have seeped through the pyroxenite-dominated lower crust (as water through blotting paper), resulting in kaersutite replacement of clinopyroxene. Silicate melt metasomatism has infiltrated the granulite-dominated lower crust along grain boundaries, resulting in the crystallisation of secondary minerals, including $\mathrm{Fe}-\mathrm{Ti}$ oxides, apatite and plagioclase, in a manner similar to the precipitation of solids from water flowing through pipes ('plumbing' style). Both have resulted in an enrichment of the lower crust in mobile elements (e.g. LILEs and LREEs), and the two processes are probably related, occurring in different regions of the lower crust. This enrichment process has also resulted in the modification of the infiltrating melts by percolative fractional crystallisation (Harte et al., 1993).

The composition of the lower crust, together with exposed lithologies in Marie Byrd Land, are consistent with the growth of Marie Byrd Land as oceanic crust that subsequently experienced periods of sedimentation and magmatism. Marie Byrd Land sutured on to Antarctica in Paleozoic times, and together with other allochthonous terranes presently forms the West Antarctic tectonostratigraphic region. 


\subsection{Introduction}

The lower crustal and upper mantle xenolith suites from geographically distinct regions of MBL, have been documented and discussed in Part Two of this thesis, and are compared to other Gondwana localities in Chapter Seven. This chapter presents a discussion of the geological structure of the MBL lithosphere, and of the secondary processes occurring within the lithosphere, based upon the different xenolith suites and constrained by the limitations of the thermobarometric data. In conclusion, the implications of this study in reconstructing the geologic and tectonic history of MBL since Paleozoic times are discussed. A series of models are presented that best integrate our current knowledge.

\subsection{Structure of the Lower Crust}

\subsubsection{Heterogeneity in the MBL lithosphere}

The MBL xenolith suite, as documented in Part Two of this work, indicates a lower crust that is compositionally heterogeneous both vertically and laterally. This is similar to models based on xenolith suites world-wide (Griffin and O'Reilly, 1987a). An example of the lateral variation in the MBL lower crust occurs along the ECR, where crust in the northern part of the range (Mounts Hampton and Cumming) differs significantly to that in the southern part (Mounts Sidley and Waesche). This has previously been termed the ECR discontinuity (Wysoczanski and Gamble, 1992).

Granulites from MBL have been divided into two groups, on the basis of their geochemical similarity to granulites from the Transantarctic Mountains, and the Ross Embayment (Chapter 7.4). The Transantarctic Mountain (TM) Group, consists of xenoliths from Mounts Sidley and Waesche. The Ross Embayment (RE) Group consists of xenoliths from Mounts Hampton, Cumming, and Murphy. These groups are distinguished geochemically by the more evolved nature of the TM Group (lower Mg\#s, $\mathrm{Cr}$ and $\mathrm{Ni}$, and higher trace element and LREE contents). To understand the significance of this compositional variation, it is appropriate to consider the source of the lower crust in these regions.

\subsubsection{The origin of the lower crustal xenoliths}

The cumulate nature of the MBL xenolith suite, as estimated from whole rock chemistry and textural relations, controls the geochemistry of the xenoliths, 
which have been affected by secondary processes, such as enrichment by alkaline melts, to various degrees. Metamorphic recrystallisation of the xenolith suite was largely closed-system, although some geochemical features (e.g. depletion of LILEs and other mobile elements) may have been altered. This has made it difficult to characterise fully the composition of the parental crystallising melts. However some of the parental melts characteristics can be ascertained from the xenolith suite:

- the simple mineral assemblage of olivine and/or orthopyroxene + clinopyroxene + plagioclase are consistent with crystallisation from basaltic melts;

- high Mg\#s of the xenoliths are inherited from the high $\mathrm{Mg}: \mathrm{Mg}+\mathrm{Fe}$ ratios of the mafic minerals (olivine and pyroxenes), which indicate crystallisation from a primitive melt with high $(>60) \mathrm{Mg \# s;}$

- isotopic ratios indicate crystallisation from mantle melts, with little or no assimilation of isotopically evolved crustal material;

- the two-pyroxene assemblage of the Mounts Hampton, Cumming and Murphy xenolith suites is consistent with crystallisation from an alkaline melt. However, the single-pyroxene Mount Sidley xenoliths may have crystallised from an alkaline melt; the absence of orthopyroxene, presence of $\mathrm{Ti}$ - and Ca-rich clinopyroxene, $\mathrm{Cr}$-poor spinels, late crystallising plagioclase and generally higher LILE and LREE contents than Hampton, Cumming and Murphy xenoliths at similar Mg\#s, is consistent with an alkaline melt source for these xenoliths. The MBL xenolith suite also shows no signs of an arc signature (e.g. high $\mathrm{Ba}$ and low $\mathrm{Nb}$ ), so it is unlikely that the xenoliths crystallised from subduction-related melts;

- a complete lack of meta-sedimentary xenoliths associated with the lower crustal xenoliths suggests that either meta-sedimentary lithologies were not sampled by the ascending melts (due to rapid ascent), or that the xenolith suite did not crystallise in thick continental crust. The absence of geochemical features associated with assimilation of felsic crust (e.g. high ${ }^{87} \mathrm{Sr} /{ }^{86} \mathrm{Sr}$ ratios) further suggest crystallisation in a region with no felsic material. If the xenolith suite did not form within felsic crust, they may represent underplated mafic intrusives at the base of pre-existing crust, or new crust formed in an oceanic environment (i.e. at a mid ocean ridge or in an extensional rift).

Geochemical similarities of MBL xenoliths to other localities may also be applicable in determining the source characteristics of the xenoliths (Chapter 7.3). RE Group granulites are inferred to have been crystallised from tholeiitic or alkaline melts (Kalamarides and Berg, 1991). As MBL RE Group granulites (from Mounts Hampton, Cumming and Murphy) were not sourced from an alkaline melt, the RE Group xenoliths may represent tholeiitic cumulates. 
Some TM Group granulites (from Fiordland, and the Transantarctic Mountains) show calc-alkaline island-arc characteristics (McCulloch et al., 1987; Kalamarides and Berg, 1991), while Mount Ruapehu granulites are interpreted to represent oceanic crust (Graham et al., 1990). As discussed above, it is unlikely that the Mounts Sidley and Waesche xenoliths represent subduction related cumulates. The common characteristic of TM Group xenoliths is their crystallisation from more evolved melts than RE Group xenoliths (e.g. lower $\mathrm{Mg}: \mathrm{Mg}+\mathrm{Fe}$ ratios of mafic minerals). However, they did not necessarily crystallise from melts of similar composition, with some crystallising from alkaline melts, and others from sub-alkaline melts.

The characteristics discussed above are not definitive, but do represent the most probable source for the MBL xenolith suites; i.e. crystallisation as cumulates from primitive sub-alkaline (RE Group) and more evolved alkaline and subalkaline (TM Group) melts, that evolved by crystal fractionation, possibly in an oceanic setting.

\subsubsection{A stratified lower crustal model}

Geochemical and petrographic relationships between xenolith types in all the xenolith localities suggest that the lower crust formed as cumulates from fractionating melts at various levels in the crust. Geothermometry and geochemical relationships infer that granulites from Mounts Sidley and Mount Murphy formed at higher crustal levels than the associated pyroxenites. Mount Hampton granulites and pyroxenites formed at similar crustal levels, from primitive melts. These relationships indicate a stratified lower crust, with some interlayering between granulites and pyroxenites. This is consistent with deep seismic data from localities world-wide, which indicate a layered lower crust on a scale of tens to hundreds of metres, formed by the interlayering of lower crustal rocks, which have been variously interpreted as underplated melts, sills, and fluids (Hale and Thompson, 1982; Blundell and Raynard, 1985; Hall, 1986; Matthews, 1986).

\section{The MBL geothermal gradient}

From geothermometry and geobarometry estimations of granulite, pyroxenite and peridotite xenoliths (Table 8.1), a geothermal gradient can be estimated for MBL (Figure 8.1).

Geobarometric calculations using the method of Gasparik (1984) yield pressure estimates approximately one $\mathrm{kb}$ too high for single-pyroxene assemblages (see Chapter 5.4 .5 for the limitations of various geothermometers applied to 
granulites). Similarly, geothermometric estimates using the Gasparik method are approximately $100-200^{\circ} \mathrm{C}$ too high (Chapter 6.4). To compensate for these errors, all P-T estimates used to construct the geotherm are based on the Gasparik method with a modification of $-150^{\circ} \mathrm{C}$ to bring temperature estimates down to estimates similar to other methods (Wood and Banno, 1973; Wells, 1977).

TABLE 8.1: Pressure and temperature estimations used to construct a geothermal gradient for Marie Byrd Land (Figure 8.1). P-T estimates using the method of Gasparik (1984) yield estimates approximately $1 \mathrm{~kb}$ and $150^{\circ} \mathrm{C}$ too high, so both the original estimates and modified estimates are shown. The modified estimates have been used in constructing the geotherm.

\begin{tabular}{lcccc}
\hline LOCATION & $\begin{array}{c}\text { Gasparik } \\
\text { Temperature }\end{array}$ & $\begin{array}{c}\text { Gasparik } \\
\text { Pressure }\end{array}$ & $\begin{array}{c}\text { Modified } \\
\text { Temperature }\end{array}$ & $\begin{array}{c}\text { Modified } \\
\text { Pressure }\end{array}$ \\
\hline Mount Sidley & & & & \\
L Granulites & $980-1160$ & $4.0-6.5$ & $830-1010$ & $3.0-5.5$ \\
M Granulites & $1060-1150$ & $4.5-6.5$ & $910-1000$ & $3.5-5.5$ \\
C Pyroxenites & $1080-1140$ & $9.0-11.5$ & $930-990$ & $8.0-10.5$ \\
P Pyroxenites & $1160-1240$ & $8.0-12.0$ & $1010-1090$ & $7.0-11.0$ \\
& & & & \\
\hline
\end{tabular}

\section{Mount Hampton}

Granulites

1150 - 1215

$6.5-9.5$

$1000-1065$

$5.5-8.5$

Pyroxenites

$1150-1225$

$7.0-8.5$

$1000-1075$

$6.0-7.5$

Opx Pyroxenite

1140 - 1210

$8.0-9.0$

$990-1060$

$7.0-8.0$

\section{Mount Murphy}

41 Granulites

$840-1070$

$4.0-7.5$

$690-920$

$3.0-6.5$

48 Granulites

$1120-1210$

$7.0-10.0$

$970-1060$

$6.0-9.0$

48 Pyroxenites

$1110-1230$

$8.0-13.0$

$960-1080$

$7.0-12.0$

54 Pyroxenites

$1190-1320$

$7.5-11.0$

$1040-1170$

$6.5-10.0$

Peridotites
Mt Hampton
Mt Murphy
Mt Cumming
USAS Escarpment

$1180-1320$
$1170-1270$
$1120-1170$
$1260-1320$

$17.0-21.0$
$15.0-17.5$
$14.0-16.0$
$19.0-21.0$

$1030-1170$

$16.0-20.0$

$1020-1120$

$14.0-16.5$

$980-1020$

$13.0-15.0$

USAS Escarpment

$1120-1170$
$1260-1320$

$1110-1170$

$18.0-20.0$

Geobarometric estimates have been calculated on clinopyroxene compositions only, with the subtraction of $1 \mathrm{~kb}$ to compensate for the high pressures that result from single pyroxene calculations for the xenolith suite compared to two-pyroxene assemblages (the ideal assemblage for this method). 
Table 8.1 presents the initial data using the Gasparik (1984) method (from calculations in Part Two), together with the modified estimates used in constructing the geotherm.

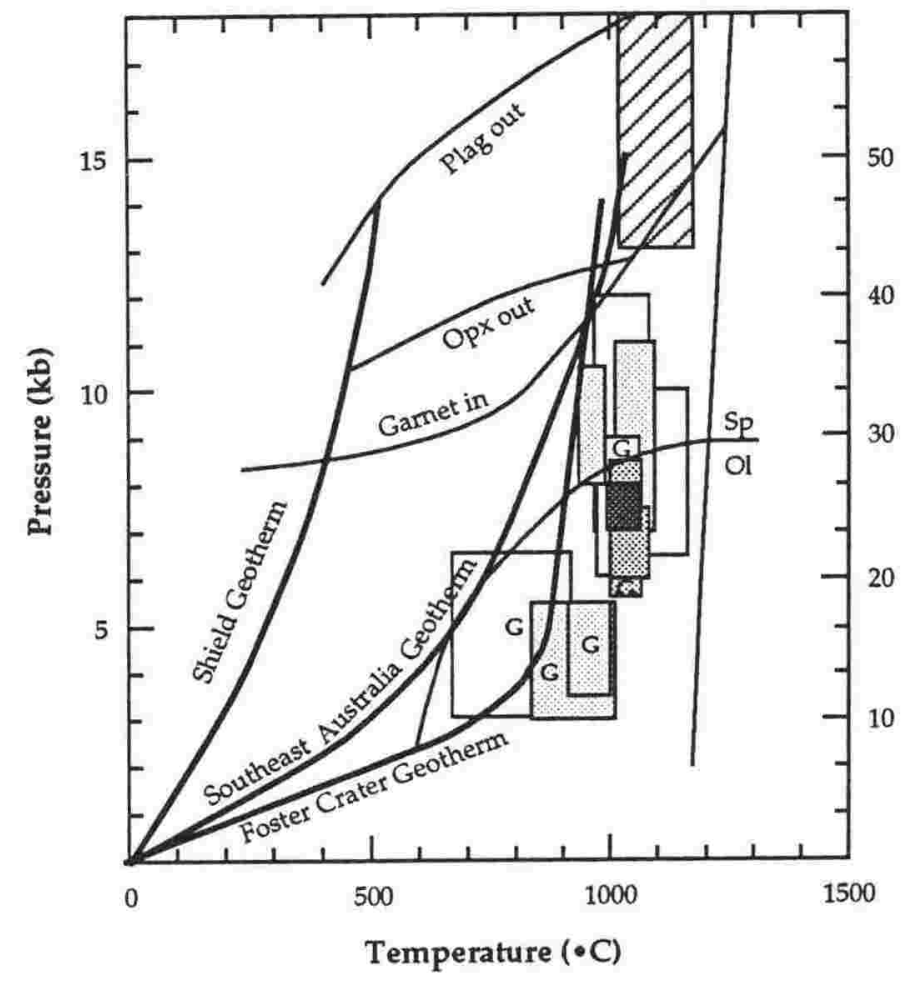

FIGURE 8.1: A model for the geothermal gradient in Marie Byrd Land constructed using modified P-T estimates for the Marie Byrd Land xenolith suite (no shade = Mount Sidley; light shade $=$ Mount Murphy; dark shade $=$ Mount Hampton (with black representing two-pyroxene xenolith from Mount Hampton); striped $=$ peridotites from all Marie Byrd Land localities; and $\mathrm{G}=$ granulites, with other fields being pyroxenites). The olivine-spinel stability field is that of Herzberg (1978), and the garnet, plagioclase and orthopyroxene stability fields are those of Wood (1987). The Marie Byrd Land geotherm is higher than a typical shield geotherm (e.g. western Australia) and southeast Australia (both from O'Reilly and Griffin, 1985), and similar to the Foster Crater geotherm (Berg and Herz, 1986; Gamble et al., 1988), reflecting the high temperature rift environment in Marie Byrd Land.

Stability fields of mineral assemblages, such as those of Herzberg (1978) and Wood (1987) shown in Figure 8.1, provide constraints on P-T determinations. The MBL xenolith assemblages fall within these fields: e.g. olivine coexisting with plagioclase occurs only in a few granulites that plot above the olivine-spinel stability field of Herzberg (1978); garnet-free assemblages plot below the garnet stability field, and the xenoliths fall below the opx-out field of Wood (1987). These agreements between experimentally determined stability fields and xenolith mineral assemblages give added confidence to the P-T determinations of the xenolith suite.

The calculated geotherm for MBL is higher than typical shield geotherms (e.g. western Australia; O'Reilly and Griffin, 1985), and similar to the rift-like geotherm of Foster Crater (Berg and Herz, 1986; Gamble et al., 1988), but with somewhat higher temperatures. The high temperatures however may be a result of the problems associated with temperature estimates using the MBL mineral assemblages as discussed above. 


\section{The petrologic Moho}

As discussed in Chapter 1.3, the precise definition of the Moho is uncertain, especially when defined by seismic means (Hall, 1986; Matthews, 1986; White, 1988), and compared to that defined by petrologic methodology (Malapas, 1978; Griffin and O'Reilly, 1986). The relationships between the granulites and pyroxenites discussed above are relevant to identifying a petrologic Moho in MBL.

P-T estimates from the xenolith suite indicate a crustal thickness of up to 40 $\mathrm{km}$ beneath Mount Murphy, and up to $35 \mathrm{~km}$ beneath the ECR, if the pyroxenite suites are considered to be lower crustal rather than upper mantle (as they have been in this study). This agrees with crustal thickness estimates based on gravity anomaly data (Groushinsky and Sazhina, 1982), which indicate a thickness of 30$35 \mathrm{~km}$ beneath central MBL, extending to $40 \mathrm{~km}$ at the coast (e.g. Mount Murphy). However, if only granulites are considered to represent the lower crust, a crustal thickness of up to $30 \mathrm{~km}$ is inferred from the xenoliths. This estimate agrees with seismic studies, which place the crustal thickness at 25-30 km (Davey and Cooper, 1987; Bentley, 1991).

Differences in crustal thickness estimates by geophysical methods may be explained by consideration of this petrologic data. The xenolith suite indicates a depth of $30 \mathrm{~km}$ to the granulite-pyroxenite boundary, and up to $40 \mathrm{~km}$ to the base of the pyroxenites; a difference ranging from $5-10 \mathrm{~km}$ (Figure 8.2). Crustal thicknesses in MBL, as deduced by the xenolith suite, will therefore vary depending on the acceptance of the base of the granulites, or the base of the pyroxenites as the base of the lower crust (the Moho). Geophysical estimations may also have (albeit unintentionally) identified one or other of either of these layers as the Moho. In this way, the method of Groushinsky and Sazhina (1982) may have calculated a crustal thickness to the base of the pyroxenites, whereas the method of Davey and Cooper (1987) and Bentley (1991) may have calculated a crustal thickness to the base of the granulites.

If pyroxenites are also considered to represent the lower crust, then estimates of an average lower crustal composition (Chapter 7.5) would be significantly more mafic that estimates based solely on granulites, given that mafic pyroxenites accompany many felsic granulites (e.g. McCulloch et al., 1987). The occurrence of pyroxenites at lower crustal depths would further widen the observed rift between lower crustal compositions based on xenolith studies, which show a mafic lower crust, and studies of granulite terrains that show a more felsic lower crust.

It has been suggested that this contention reflects the occurrence of mafic and felsic layers in different levels of the lower crust (Bohlen, 1987; Rushmer, 


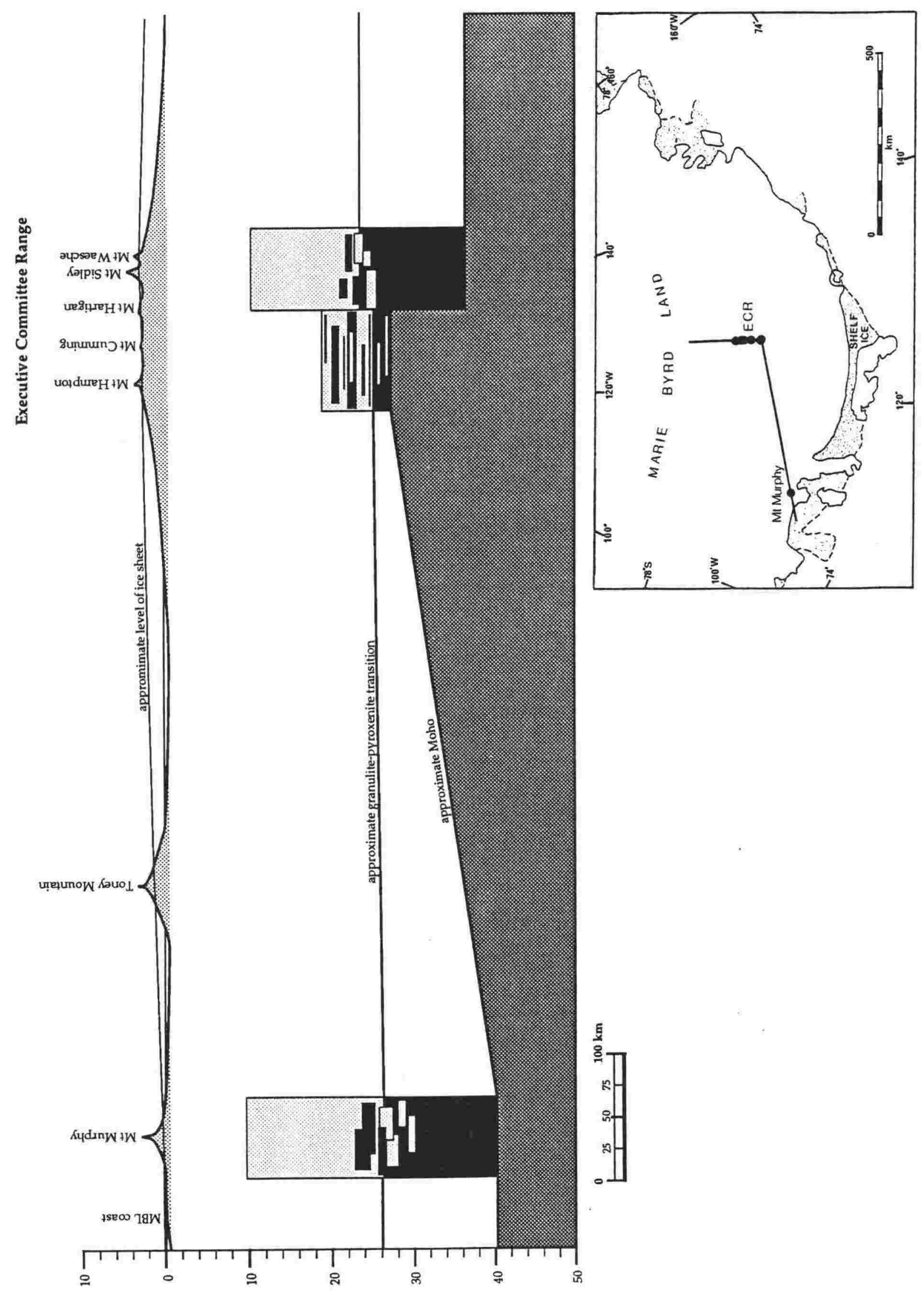


1993). P-T estimates for lower crustal assemblages from MBL support this, as metasedimentary amphibolites from the Fosdick Metamorphic Complex, which have been locally metamorphosed to granulite facies, come from higher crustal levels at the middle-lower crustal boundary (5-6 kb or 15-18 km; Luyendyk et al., 1992; Smith, 1992), whereas mafic granulitic xenoliths appear to be sourced from deeper levels of the lower crust (Table 8.1; Figure 8.1). Each crustal level may locally reach higher or lower depths due to burial or exhumation (e.g. a minority of xenolith granulites record depths as shallow as $10 \mathrm{~km}$ ). The paradox between lower crustal compositions based on xenoliths and terrains may largely be explicable in terms of this relationship.

\section{Cross section of the MBL lithosphere}

Stratigraphic models for the lower crust have been presented for Mounts Sidley, Hampton and Murphy (Part Two). By integrating these models with thermobarometric calculations, a cross section for the lithosphere across MBL can be established (Figure 8.2). Topographic heights representing the basement surface, and lateral distances are from Drewry (1982) and Le Masurier (1990).

A number of assumptions and limitations have been made in constructing this model:

- the crust sampled by xenoliths beneath Mounts Hampton and Cumming, and Mounts Sidley and Waesche, are compositionally similar (Chapter 7.4). It is assumed that they represent the same crustal segment and are therefore stratigraphically similar;

- the absence of felsic xenoliths is taken to reflect an absence of continental type lower crust. The Swanson Formation is the oldest lithologic unit identified in MBL (Adams, 1986). Metamorphosed amphibolites and granulites from the Fosdick Metamorphic Complex (Bradshaw et al., 1983; Weaver et al., 1991) have a Swanson Formation and granite protolith. These are the highest grade metamorphic rocks in MBL, and as they have reached the granulite-amphibolite boundary, are interpreted to represent the middle crust in the Fosdick Mountains (Luyendyk et al., 1992; Smith, 1992);

FIGURE 8.2 (opposite): A cross section of the Marie Byrd Land lithosphere from Mount Murphy at the coast to the Executive Committee Range (see inset for transect), showing the surface (medium shade $=$ basement above sea level), approximate level of the ice sheet, the lower crust (light shade $=$ granulites, black $=$ pyroxenites) with an approximate boundary between granulites and pyroxenites, the Moho (defined as the base of the pyroxenites) and the upper mantle (dark shade). Depths are based on P-T estimates of the xenolith suite. Note the variation in the lower crustal across the ECR, with a major discontinuity between Mounts Cumming and Sidley, and the constant level of the granulite-pyroxenite boundary. Vertical exaggeration of approximately $x 6$. 
- the base of the crust is represented by the lowermost extent of the lower crustal xenolith suite (granulites and pyroxenites);

- no attempt has been made to link the crust between sites. The approximate transition from granulite to pyroxenite dominated segments of the crust is shown for reference;

- the stratigraphy above the lower crust has not been represented. This is discussed with the evolution of the crust and tectonic models in Chapter 8.4.

A feature of the cross section is the constant level of the granulitepyroxenite boundary across MBL, despite the lateral variation in composition, produced by the variation in source melt compositions and crystallisation sequences across MBL.

The variation in the crust between Mounts Sidley and Cumming in the ECR (the ECR discontinuity) is also shown; it is unclear whether this is an abrupt change representing a crustal suture, or if it is a transitional change reflecting a change in source melts laterally. The difference in crustal thickness between these segments is large (approximately $10 \mathrm{~km}$ ), however there are no large gravity or magnetic anomalies associated with this (Bentley, 1991), suggesting that the crust is thicker than indicated by the xenolith suite (with xenoliths from lower levels not having been sampled), or that the difference in crustal thickness has been compensated for by an unidentified feature.

\subsection{Modification Processes in the Lower Crust}

Secondary processes that have affected the xenolith suite have been documented and discussed in Part Two (Chapters 4.5, 5.5 and 6.5). This section is a summary of these processes, and seeks to provide a model for late Cenozoic lithospheric processes.

\subsubsection{Entrainment of the xenoliths and ascent to the surface}

The entrainment of the xenoliths in the host alkaline melts, and their ascent to the surface appears to have been rapid. Narrow oxidised rims on the xenoliths, the small amount of rounding, and the absence of appreciable decompression melting of mineral phases all indicate rapid ascent to the surface. Previous estimates of no longer than 50 hours ascent time for mantle and lower crustal xenoliths (Kushiro et al., 1976; Spera, 1980) also appear to be applicable to the MBL xenolith suite. 
Reactions between xenoliths and host melt have been minimal during ascent, although pockets of melt have infiltrated some xenoliths. These are easily identifiable by their limited extent (small pools of glass rather than pervasive infiltration), and the growth of microphenocrysts identical in assemblage, size and composition to those in the host magma. Only narrow reaction rims with xenolith minerals are evident, and xenolith compositions do not appear to have been affected by the host melts during ascent to any great extent.

\subsubsection{Metamorphism and deformation in the lower crust}

Metamorphic fabrics are common in granulites from all localities, and some pyroxenites (notably those from Mount Hampton) also show distinctive textural evidence for metamorphic recrystallisation.

The major affect of metamorphism on the xenoliths has been the recrystallisation of the mineral phases from large igneous grains to smaller equant polygonal grains with $120^{\circ}$ triple junctions. Layering evident in many granulites is interpreted to be a relic of primary igneous layering, which has been enhanced by metamorphism (Chapter 2.2.4). Recrystallisation varies from none at all to complete recrystallisation. Relict igneous textures (such as inclusions of minerals in other minerals, and zoning of phenocrysts) are evident in xenoliths that have not been fully recrystallised.

Where igneous minerals have been recrystallised, there is no apparent difference in composition between the metamorphic minerals and their igneous parents. In terms of major element chemistry at least, metamorphism appears to have been closed system.

The affect of metamorphism on elements incompatible in mineral phases is difficult to estimate. As the xenoliths are cumulate in origin, they have only small concentrations of elements that are incompatible in xenolith minerals. While metamorphism may have depleted the xenoliths in mobile elements, the initially low concentrations of these elements (e.g. Rb, K, Th, U) in the xenoliths makes it impossible to ascertain if this has taken place. Depletion of some elements may have occurred: e.g. some recrystallised Mount Hampton pyroxenites have very low LREE element concentrations compared to other pyroxenites. Other elements however (e.g. mobile trace elements) do not appear to have been affected. The origin of this depletion is uncertain, however metamorphism of the xenoliths may have been responsible.

Many xenoliths show no signs of recrystallisation. While they may not have been metamorphosed at all, it is possible that they have been depleted in mobile elements by heating that was not sufficient to cause recrystallisation. This 
is particularly possible in high-temperature pyroxenites which are unlikely to be heated enough to be recrystallised.

Deformation processes are also evident in the xenolith suite, particularly in the granulite suites, and less so in the pyroxenite suites. In the granulite suite, large plagioclase are typically broken, due to brittle deformation either at lower crustal depths or during ascent. Brittle deformation however is not evident in recrystallised plagioclase, or in pyroxenite plagioclase suggesting that deformation occurred at lower crustal depths, prior to recrystallisation.

In the pyroxenite suite, ductile deformation is evident as curved exsolution bands. Ductile deformation in the lower crust has been documented from other localities (McCarthy et al., 1988; White et al., 1990; Salisbury and Keen, 1993) and shearing and faulting has been described in the upper mantle (Peddy, 1984; McGeary and Warner, 1985; Warner and McGeary, 1987; Goleby et al., 1988; Vissers et al., 1991).

The variation in deformation with depth may be a result of the higher temperatures present at lower depths. The change in deformation style may be gradational, or occur at a transitional boundary, signifying a change from one regime to another. One such boundary could be the change from the mechanical boundary layer, to the thermal boundary layer in the lithosphere (Parsons and McKenzie, 1978; White, 1988; Chapter 1.3.1). The boundary between granulites and pyroxenites from geothermometric estimations (Figure 8.2) is at a remarkably constant depth, and may correspond with a mechanical layer / thermal layer boundary.

\subsubsection{Metasomatism and PFC processes in the lower crust}

Metasomatic process in the upper mantle have been well documented through xenolith studies, and the combined isotopic and trace element study of volcanic rocks (e.g. Bailey, 1970, 1972; Frey and Prinz, 1978; Bailey, 1982; Dawson, 1982; Menzies et al., 1985; Harte, 1987; Menzies et al., 1987; Harte et al., 1993). Lower crustal metasomatism however has not been widely recognised, although it has been documented to occur in the lower crust beneath the Eifel, West Germany (Stosch et al., 1986), and Foster Crater, Antarctica (Gamble and Kyle, 1987; Gamble et al., 1988). This is unusual, as if lithospheric mantle has been metasomatised then it is realistic to expect juxtaposed lower crust to also have been affected by these processes, if only to a minor extent. This section summarises the process and effects of metasomatism on the lower crust in MBL. 


\section{Definition of metasomatic processes}

Lower crustal xenoliths from Mount Sidley have been extensively enriched by their host alkaline melts. This process has resulted in the oxidation of olivine, disequilibrium sieved textures in plagioclase adjacent to the melt, growth of large secondary minerals (plagioclase, $\mathrm{Fe}-\mathrm{Ti}$ oxides and apatite), replacement of clinopyroxene by kaersutite, and an enrichment in mobile elements (e.g. Rb, K, LILEs, LREEs).

There is increasing evidence that the metasomatic process was an in situ process, and did not occur simply as a result of infiltration by the transporting melt during and/or after eruption (Harte, 1983, 1987; Menzies, 1983; Dawson, 1984; Gamble and Kyle, 1987). Harte (1987) considers simple intrusions of melt into rocks as separate from metasomatism. However, when a fluid penetrates a solid body along grain boundaries and reacts with minerals of the solid to produce new minerals, then the process can be considered as metasomatic. The pervasive infiltration of melts at lower crustal depths along grain boundaries in the Mount Sidley xenolith suite is therefore considered to be a metasomatic process.

\section{Metasomatism evident in the MBL xenolith suite}

A major consequence of infiltration by the alkaline melts has been the growth of large secondary minerals (Fe-Ti oxides, plagioclase, apatite and kaersutite; e.g. Plates 4.15 and 4.16), i.e. modal (or patent; Dawson, 1982) metasomatism (Harte, 1987; Menzies et al., 1987). Two types of modal metasomatism occur here: the growth of mineral phases from silicate melts, which is dominant in the granulite suite (Chapters 4.5.3, 5.5.1 and 6.5.2); and the replacement of clinopyroxene by kaersutite (kaersutitisation; Chapter 4.5.2), typically without any or only minor amounts of residual melt present, dominant in the pyroxenite suite. The chemical result of this process is the enrichment of the xenoliths in elements that partition readily into these phases (e.g. $\mathrm{Fe}, \mathrm{Ti}, \mathrm{Na}$, $\mathrm{K}, \mathrm{P}, \mathrm{H}_{2} \mathrm{O}$, HFSEs).

In addition to enrichment by these elements, there is evidence for the enrichment of mobile elements in the lower crust by the melt; i.e. cryptic metasomatism (Harte, 1987; Menzies et al., 1987). Elevated LILE and LREE element concentrations are evident in many metasomatised xenoliths. $\mathrm{Pb}$ isotopic ratios have also been affected by enrichment, with the xenolith suite showing a wide variation in $\mathrm{Pb}$ composition from unradiogenic (initial) ratios to radiogenic (inherited) values. ${ }^{87} \mathrm{Sr} /{ }^{86} \mathrm{Sr}$ and ${ }^{143} \mathrm{Nd} /{ }^{144} \mathrm{Nd}$ ratios do not appear to have been affected, possibly due to the insensitivity of $\mathrm{Sr}-\mathrm{Nd}$ isotopic systematics to enrichment by a St Helena-like (HIMU) component (Wilson, 1989; Chapter 4.6.3). 
This is in agreement with studies that have shown that while LREE, $\mathrm{Rb}$ and $\mathrm{Sr}$ compositions may change due to melt infiltration, ${ }^{87} \mathrm{Sr} /{ }^{86} \mathrm{Sr}$ and especially ${ }^{143} \mathrm{Nd} /{ }^{144} \mathrm{Nd}$ ratios are typically not affected (Lee et al., 1993).

Metasomatism in the granulite suite (with secondary Fe-Ti oxide, apatite and plagioclase growth) has resulted in the enrichment of elements such as $\mathrm{Fe}, \mathrm{Ti}$, $\mathrm{P}, \mathrm{Na}, \mathrm{K}$, HFSEs, LILEs, LREEs, whereas metasomatism by replacement of clinopyroxene by kaersutite in the pyroxenite suite has resulted in enrichment in elements such as $\mathrm{K}, \mathrm{H}_{2} \mathrm{O}, \mathrm{Rb}$ and LREEs. The first process is very similar in affect to $\mathrm{Fe}-\mathrm{Ti}$ metasomatism by silicate melts in the upper mantle, and the second process is similar to $\mathrm{K}$-metasomatism by hydrous fluids in the upper mantle (Menzies et al., 1987). There is however some debate as to whether the second process is due to hydrous fluids or to silicate melts. Harte et al. (1993) considers both types of metasomatism to be due to silicate melts, and Gamble and Kyle (1987) have shown kaersutitisation at Foster Crater to be due to silicate melts. Small amounts of silicate melt have been detected in association with kaersutitisation in the Mount Sidley xenolith suite (Chapter 4.5.2), suggesting that this process is also related to silicate melts. The two metasomatic processes may therefore be linked.

\section{Models for the metasomatism of the MBL lithosphere}

The contrasting styles of metasomatism can be represented in the two models of Figure 8.3. Kaersutitisation is associated with only minor amounts of melt, and results in the replacement of an anhydrous mineral phase (clinopyroxene) with a hydrous one (kaersutite), indicating that hydrous melts are involved. Replacement occurs along well defined boundaries, with the formation of intermediate phases (rhönite, plagioclase K-feldspar and olivine may all be involved), through the clinopyroxene as an advancing front, rather than around grain boundaries or through cracks. This style of metasomatism is similar to water seeping through paper; i.e. the 'blotting paper' model of Figure 8.3a.

Metasomatism in the granulite suite involves a melt infiltrating along grain boundaries, crystallising secondary minerals (Figure $8.3 \mathrm{~b}$ ). The secondary minerals are larger than minerals that crystallised from melts at the surface, indicating longer growth times than is available during ascent. Their large size suggests that the small amount of mafic melt associated with the minerals could not have crystallised them. A constant flow of melt crystallising the minerals, is necessary. Furthermore, the mafic composition of the minerals (e.g. calcic plagioclase) indicates that the melts have not become too evolved (i.e. felsic), and so could not have crystallised the minerals by themselves; greater volumes of 
melt were necessary. These features, as well as the form of the secondary minerals (joining on the xenolith minerals, with typically euhedral faces on the melt side; Figure $8.3 \mathrm{~b}$ ), can be likened to precipitates that form on the walls of pipes, from fluids that continue to flow; i.e. a 'plumbing' style of metasomatism (Figure 8.3b).

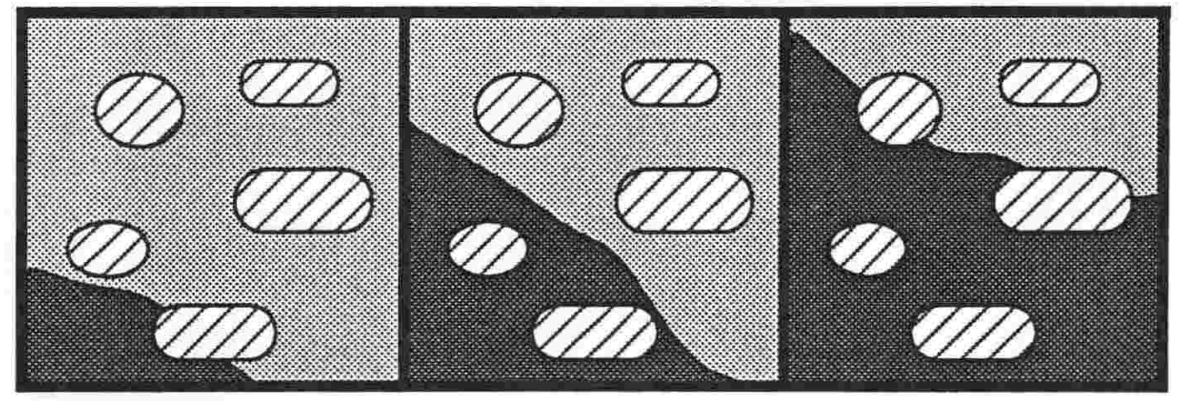

a) Blotting paper model

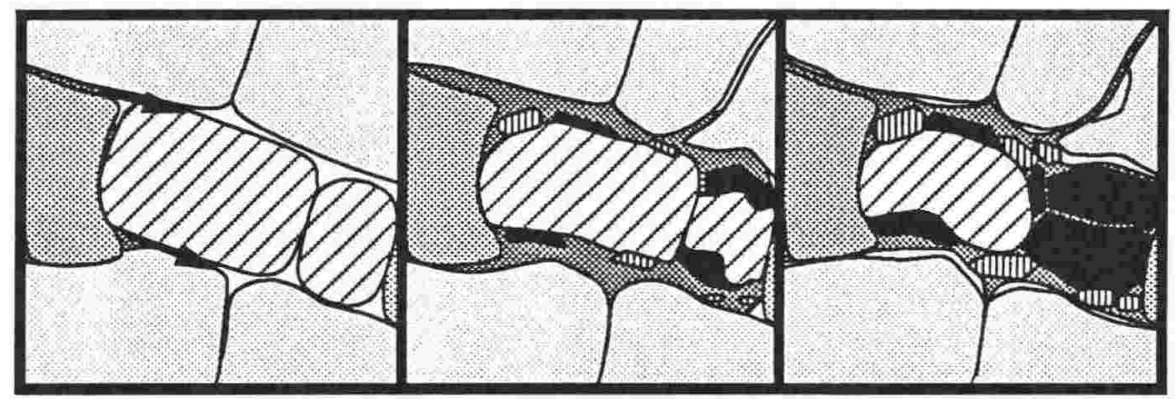

b) Plumbing model

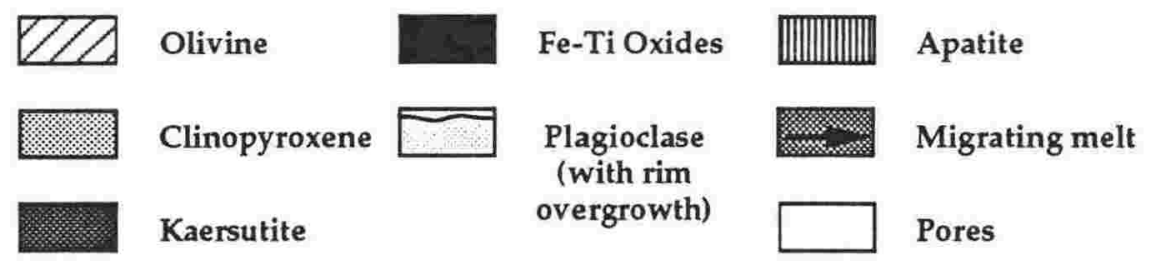

FIGURE 8.3: Styles of metasomatic processes in the Marie Byrd Land lithosphere, include the 'blotting paper' and 'plumbing system' styles. a) Metasomatism by hydrous silicate melts results in the replacement of clinopyroxene by kaersutite from hydrous fluids seeping through the clinopyroxene along an advancing front, rather than along grain boundaries, as water absorbs through blotting paper. b) Metasomatism by silicate melts occurs along grain boundaries, resulting in the crystallisation of secondary minerals (Fe-Ti oxides, plagioclase, apatite) from migrating melts, similar to precipitates forming from fluids in pipes.

The occurrence of differing styles of metasomatism in the granulite and the pyroxenite suites may explain the contrasting styles. Melts do not appear to be capable of infiltrating the dense pyroxenites other than through veins (which are not common), making the pyroxenites virtually impervious to melt metasomatism. Dihedral angles of the minerals determine if pores are linked 
(angles $<60^{\circ}$ make a rock permeable), allowing melts to migrate through them, or separate (angles $>60^{\circ}$ make a rock impermeable), trapping any melt present (Bulau et al., 1979; McKenzie, 1984; Cheadle, 1989; Harte et al., 1993). Compression of the pyroxenites following expulsion of the crystallising melt may have resulted in high dihedral angles, and the closing of pores, resulting in the impermeability of the pyroxenites (Harte et al., 1993).

Silicate melts have pervasively infiltrated the mafic layers of granulites, but not plagioclase layers. The layering of the granulites may act as permeable and impermeable layers, allowing the melt to pass through much as an artesian system or petroleum reservoir, resulting in a plumbing style of metasomatism along grain boundaries. Vertical ascent of the melt can then occur up-dip through the layers, along cracks and conduits, allowing the melts to reach higher crustal levels, and ultimately the surface.

The contrasting styles of metasomatism may therefore reflect the different physical properties of the pyroxenite and granulite suites, rather than two separate and contrasting processes. The composition of melts associated with both styles are similar, further indicating that they are the result of the same agent (Chapter 4.5.4), as suggested by Gamble and Kyle (1987) and Harte et al., (1993), and not mutually exclusive processes.

\section{Affects of metasomatism on the infiltrating melts}

The crystallisation of secondary minerals from the melt, and its reaction with the lower crust and upper mantle, will have an affect on the composition of the melt as well as the lithosphere. Crystallisation of plagioclase, apatite and Fe-Ti oxides in the MBL xenoliths equates to fractionation of these minerals by the infiltrating melt, and reactions of the melt with xenolith phases results in assimilation of lithospheric material by the melt by percolative processes (McKenzie, 1984; Navon and Stolper, 1987; McKenzie and O'Nions, 1991). The combination of these processes has been previously recognised in upper mantle peridotites, and termed 'percolative fractional crystallisation' (PFC) by Harte et al. (1993). This differs from normal crystal fractionation, as the melt maintains at least partial equilibrium with the host rock phases; e.g. equilibrium with olivine will maintain high $\mathrm{Ni}$ and Co contents in the melt.

If the infiltrating melt subsequently escapes the lower crust and erupts at the surface, and if the volume of lower crust affected is large, PFC processes will have a major influence on the composition of the melt by the time it reaches the surface. This process has been documented in oceanic crust in Newfoundland, Canada, which has acted as a reactive filter to primary magmas. The evolution of 
these magmas owes as much to assimilation and reaction with older cumulates than to fractional crystallisation (Bedard, 1993). One consequence of PFC in the MBL xenolith suite is that the melt may actually become more mafic in composition with PFC: plagioclase fractionation would lower the $\mathrm{SiO} 2$ content of the melt, and Fe-Ti oxide crystallisation may increase its Mg-number (provided olivine crystallisation did not occur).

\subsubsection{Plume-lithosphere interaction}

The presence of a mantle plume beneath MBL has been suggested mainly from the geochemical characteristics of the late Cenozoic volcanic rocks, and their age ranges and trends (Hole and Le Masurier, 1990; Behrendt et al., 1991; Kyle et al., 1991; Storey and Alabaster, 1991; Behrendt et al., 1992). The plume is responsible for the vast amount of alkaline magmatism that has erupted in MBL in the late Cenozoic.

A mantle plume beneath the MBL is likely to have an affect on the crust. The enrichment of the lower crust beneath Mount Sidley is attributable to the volcanism generated by the plume. Only Mount Sidley however has been greatly affected by enrichment from alkaline melts. $\mathrm{Pb}$ isotopic ratios in the Mount Hampton xenoliths seem to have been affected by the plume, but no other enrichment has occurred. This is unusual considering the similarity in xenolith types across MBL.

Metasomatism of the lower crust beneath Mount Sidley may be due to a close proximity of the plume head, or at least of pathways for metasomatic fluids to traverse the lithosphere. However, the present position of the plume axis is considered to be beneath the USAS Escarpment, i.e. closer to Mount Hampton than Mount Sidley. Furthermore, the upper mantle peridotites from the USAS Escarpment show signs of being depleted in LREEs compared to HREEs, and not enriched. Perhaps further work on the systematics of the plume will provide an answer to this apparent paradox.

\subsection{Evolution of the Marie Byrd Land Crust}

The examination of the structure of the MBL lower crust is important in ascertaining the evolution of the crust and its tectonic history. This section seeks to examine the geologic history of MBL and present a model for the evolution of MBL since its origin as oceanic crust. 


\subsubsection{Stratigraphy of the $M B L$ crust}

A stratigraphic column for MBL has been established on the basis of lithological units exposed at the surface (e.g. Laird, 1991a and 1991b; Figure 1.5). The incomplete stratigraphic record is partially a result of the limited exposure of rock in MBL, and partially a record of periods of erosion and non-deposition.

In summary, the stratigraphy of the upper crust is as follows (see Chapter 1.2.3; Figure 1.5):

- the Swanson Formation (mudstone and sandstone submarine turbidites) is the oldest (up to c. $593 \mathrm{Ma}$; Adams, 1986) exposed unit in MBL and constitutes the basement rock;

- the Ford Granodiorite intruded the Swanson Formation in Late Devonian-Carboniferous times (360-390 Ma; Adams, 1987). Calc-alkaline metavolcanics from the Ruppert Coast may be correlative with the Ford Granodiorite;

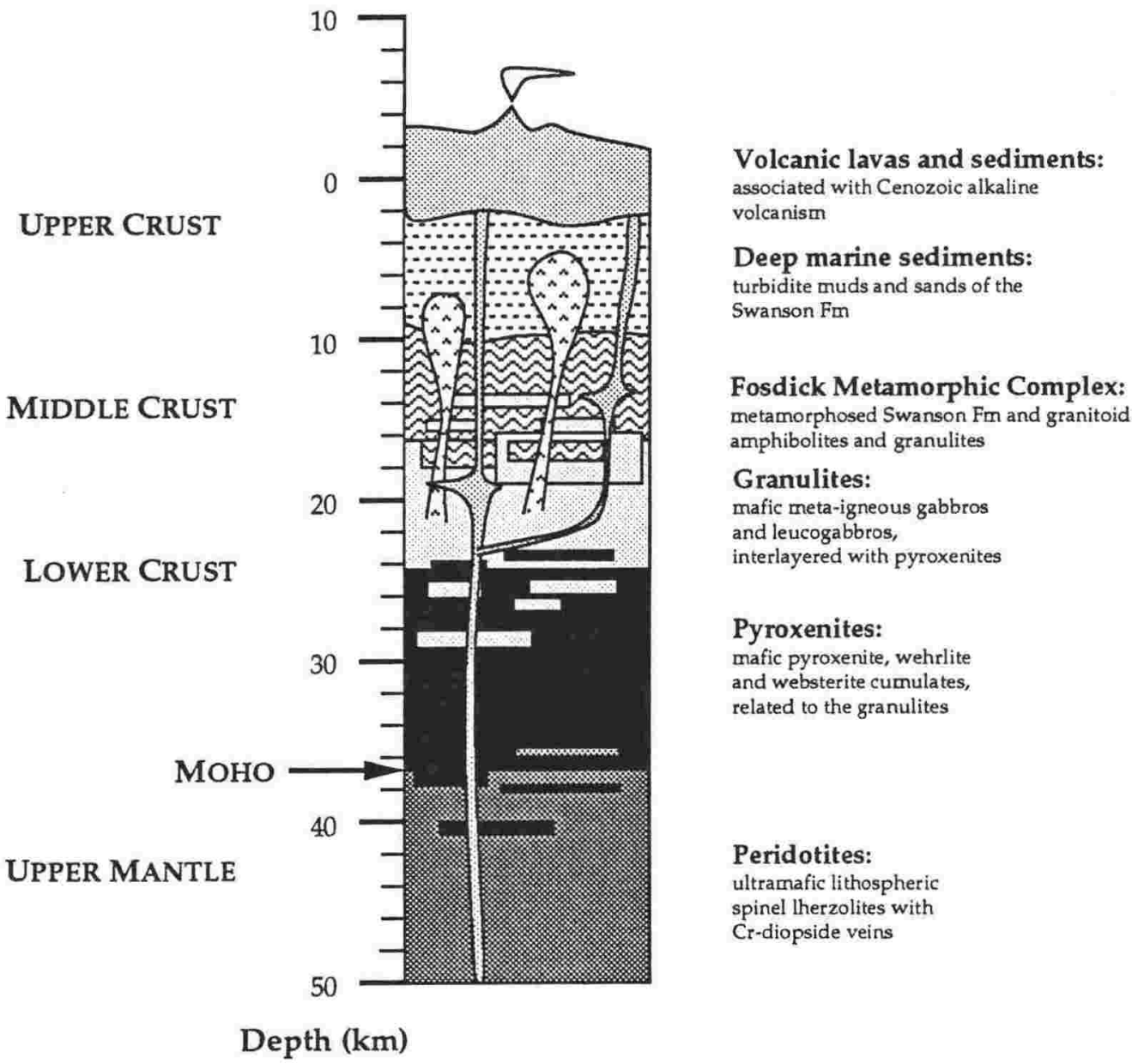

FIGURE 8.4: Idealised section through the Marie Byrd Land lithosphere based on outcrops at the surface and xenoliths entrained in basanitic magmas. This model assumes that as other lithologies are not exposed at the surface, or entrained in magmas, that they are not present. Depths are obtained from P-T calculations. 
- the Byrd Coast Granites were emplaced into the crust as two pulses at c. $140 \mathrm{Ma}$ and c. $110 \mathrm{Ma}$ (Adams, 1987), in response to extension and uplift;

- late Cenozoic alkaline volcanics associated with the West Antarctic Rift system constitute present growth of the crust.

The composition of the upper crust therefore has been dominated by igneous activity, with virtually no sedimentary processes recorded since deposition of the Swanson Formation in Ordovician times.

Middle crustal rocks have been exposed in the Fosdick Mountains, where meta-sedimentary amphibolites (locally granulites) of the Fosdick Metamorphic Complex formed from a Swanson Formation and granite protolith (Bradshaw et al., 1983; Weaver et al., 1991; Luyendyk et al., 1992; Richard, 1992; Smith, 1992). P-T estimates on meta-sediments from the Fosdick Metamorphic Complex indicate equilibration at $725-780{ }^{\circ} \mathrm{C}$ and 5-6 kbs, equivalent to middle crustal depths (Luyendyk et al., 1992). These conditions suggest that the xenolith suite, representing the MBL lower crust and upper mantle, underlies the Fosdick Metamorphic Complex and Swanson Formation sediments. On the basis of these observations, a stratigraphic model for the MBL lithosphere can be established (Figure 8.4).

\subsubsection{Crustal growth}

Various models, depicted in Figure 8.5, have been proposed for the growth of continental crust (Dewey, 1986). A number of the features of the tectonostratigraphic history of MBL are pertinent in considering the evolution and growth of the MBL crust:

- the lower crust, as defined by xenolith studies, consists of mafic subalkaline cumulates that formed in an oceanic (possibly ridge) environment, and alkaline mafic cumulates of less certain origin;

- deep marine turbidites (Ordovician Swanson Formation) constitute the basement in MBL (Adams, 1986). These have been metamorphosed to amphibolite and granulite facies, indicating burial to middle crustal levels (Smith, 1992);

- two periods of granitic magmatism, associated with metavolcanics and deformation (Late Devonian-Carboniferous and Cretaceous), are the main events to have affected MBL, prior to more recent volcanism associated with rifting of the West Antarctic Rift. The crust was built up by a combination of magmatism and compression associated with deformation during these periods;

- long intervals are not represented by the stratigraphic record, and may represent periods of quiescence and erosion. In particular, there was a period of 
tectonic inactivity between Devonian and Cretaceous times. During this period, erosion of MBL is thought to have occurred, resulting in the deposition of the Torlesse Supergroup turbidites offshore of MBL in New Zealand (Bradshaw et al., 1981).

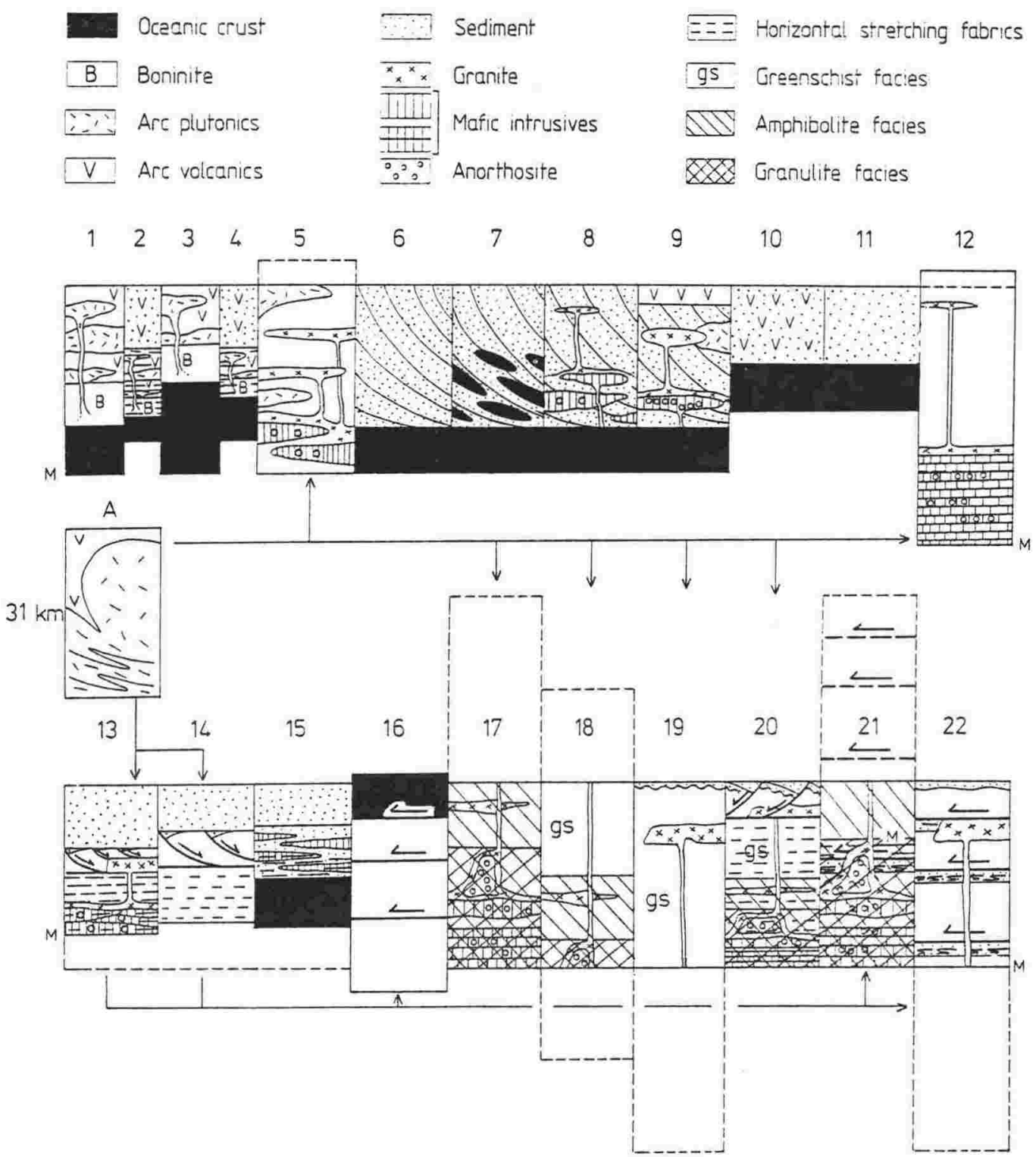

FIGURE 8.5: The classification of types of continental crust according to tectonic environment and process (from Dewey, 1986). $\mathrm{A}=$ Archean protolith; 1 = volcanic arc nucleated on oceanic crust; $2=$ intra-arc pull-apart in 1;3 = volcanic arc nucleated on oceanic plateau; $4=$ intra-arc pull-apart in 3;5 $=$ continental margin arc; $6=$ subduction-accretion prism; $7=$ subduction-accretion prism with clippedoff seamounts and oceanic slithers; $8=$ subduction-accretion prism with trench-ridge interaction; $9=$ subduction-accretion prism overprinted by volcanic arc; $10=$ back-arc basin; $11=$ oceanic deltas; $12=$ crust underplated by mafic igneous rocks; $13=$ crustal extension to beta $>2 ; 14=$ crustal extension to beta $<2 ; 15=$ ridge blanketed by sediment; $16=$ thrust stacked crust with high-level ophiolite nappe; $17-19=$ crusts thickened by vertical stretching; 21 and $22=$ thickened by thrust stacking; 17 and 21 = denuded back to normal thickness; 18 = denuded and delaminated back to normal thickness; 19 and 22 = delaminated back to normal thickness; $20=$ stretched back to normal thickness. The Marie Byrd Land crust had an origin as oceanic crust with deep sea sediments and subsequent stacking due to subduction and thickening of the crust. 
These relationships suggest that the most probable model for the formation of the MBL lithosphere is as oceanic crust. In particular, the sub-alkaline cumulate nature of the lower crust of the northern ECR and the presence of deep-marine turbidites as the oldest basement rock is reminiscent of oceanic crust. Subsequent growth of the crust has occurred due to a number of igneous and tectonic events that have thickened the crust, including the deformation and metamorphism of Swanson Formation sediments, the intrusion of granites, and the eruption of calcalkaline (subduction related) and alkaline (rift related) volcanics (an origin similar to numbers 8 and 9 of Figure 8.5).

\subsubsection{Tectonic reconstructions of $M B L$}

A model for MBL forming as oceanic crust and its subsequent growth has important implications in reconstructing the tectonic evolution of MBL since Paleozoic times. As the geologic and tectonic history of MBL is related to the Transantarctic Mountains and Ross Embayment of Antarctica, SE Australia, New Zealand, and the Campbell Plateau (Chapter 1.2), a summary of the geology and tectonic history of other regions once adjacent to MBL will be helpful in understanding its tectonic history (Figure 8.6).

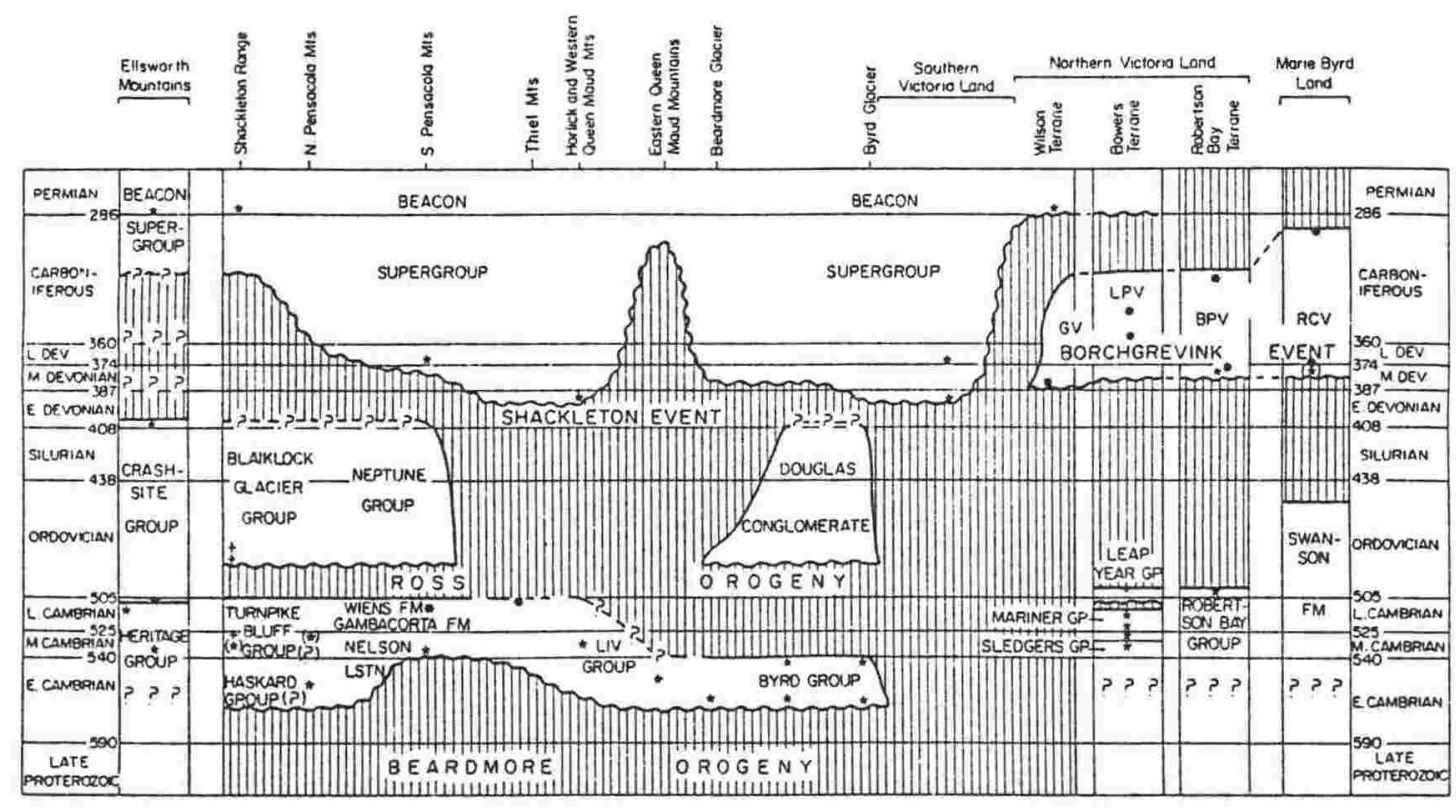

FIGURE 8.6: Chronostratigraphy of the Transantarctic Mountains, Ellsworth Mountains and Marie Byrd Land in Paleozoic times (from Laird, 1991a and 1991b). Vertical lines show periods of nondeposition or erosion; wavy lines depict unconformable relationships. Unconformities within the Beacon Supergroup are not shown. GV = Gallipoli Volcanics; LPV = Lawerence Peaks Volcanics; BPV $=$ Black Prince Volcanics; RBC $=$ Ruppert Coast Metavolcanics; ${ }^{*}=$ fossil horizons $\left({ }^{*}\right)=$ fossils not in situ; $+=$ isotopic ages (diagenesis) on sediments; star $=$ isotopic ages on volcanics. The time scale is that of Harland et al. (1982). 


\section{Paleozoic history of the paleo-Pacific margin of Gondwana}

Pre-Cambrian and Cambrian sedimentation in the Transantarctic Mountains consisted of shallow marine and shelf sediments and silicic volcanics along the late Proterozoic paleo-Pacific margin of Antarctica, which trended along the present day Transantarctic Mountains. Deposition ceased with a period of uplift, metamorphism and emplacement of granitoid intrusions along the length of the Transantarctic Mountains in Ordovician times (approximately $500 \mathrm{Ma}$ ). This event, termed the Ross Orogeny (Gunn and Warren, 1962), has been interpreted to be associated with a cratonisation event with west-dipping subduction along the Cambro-Ordovician paleo-Pacific continental margin of Antarctica (Stump, 1982; Borg, 1983; Schmidt, 1983; Weaver et al., 1984; Borg et al., 1987). The Ross Orogeny was followed by non-marine deposition of the Late Devonian to Late Triassic - Early Jurassic Beacon Supergroup, in an intracratonic environment (Barrett, 1981; Woolfe, 1991). Westward subduction continued to the east of the craton from Devonian times, with the Devonian paleo-Pacific margin being close to the present day Northern Victoria Land and MBL coasts (Dalziel and Elliot, 1982; Elliot, 1986; St John, 1986; Woolfe, 1991).

In Northern Victoria Land, three terranes separated by tectonic boundaries can be identified; these are (from the Transantarctic Mountains to the Ross Embayment) the Wilson, Bowers and Robertson Bay terranes. The Wilson terrane is autochthonous to the Transantarctic Mountains, but the Bowers and Robertson Bay terranes are allochthonous (Weaver et al., 1984; Borg et al., 1987; Bradshaw, 1987; Laird, 1991a and 1991b), and consist of Cambrian deep marine fan and/or island arc sediments. Granitoids associated with the Ross Orogeny are present in the Wilson terrane, but not in the Bowers or Robertson Bay terranes. While the Wilson and the Bowers and Robertson Bay terranes were not immediately adjacent during the Ross Orogeny, they may have been subjected to a common tectonic (but not magmatic) event at this time (Adams, 1986; Laird, 1991a and 1991b). Sedimentation ceased in the Bowers and Robertson Bay terranes from Early Ordovician times until the Devonian, when I-type (using the terminology of White and Chappell, 1983) granites (the Admiralty Intrusives; Borg et al., 1986), dated at 390-360 Ma (Borg et al., 1987) were intruded. These granites do not occur in the Wilson terrane. Calc-alkaline volcanism, and a period of post-Middle Devonian deformation, followed granite emplacement, and preceded the deposition of the Beacon Supergroup in all three terranes.

Similar lithologies to those of the Bowers and Robertson Bay terranes are present in New Zealand and in MBL. Cambro-Ordovician deep marine sediments (the Greenland group of New Zealand, and the Swanson Formation of MBL) have 
been tentatively correlated with the Robertson Bay Group turbidites (Adams, 1981; Grindley and Davey, 1982; Wade and Couch, 1982; Adams, 1986; Laird, 1991a and 1991b; Woolfe, 1991). Deep marine sedimentation ceased with an Ordovician deformational event, dated at c. $450 \mathrm{Ma}$ (Adams, 1986). This is $50 \mathrm{Ma}$ after the Ross Orogeny in the Transantarctic Mountains, which has not been identified in either New Zealand or MBL. The Middle Devonian to Early Carboniferous period saw the intrusion of granitoids, including the broadly S-type Karamea Batholith of New Zealand (Tulloch, 1983), and the I-type Ford Granodiorite of MBL (Wade et al., 1977b; Adams, 1987; Weaver et al., 1991), followed by calc-alkaline volcanism (Grindley et al., 1980) and deposition of carbonaceous sediments, that have since been strongly deformed.

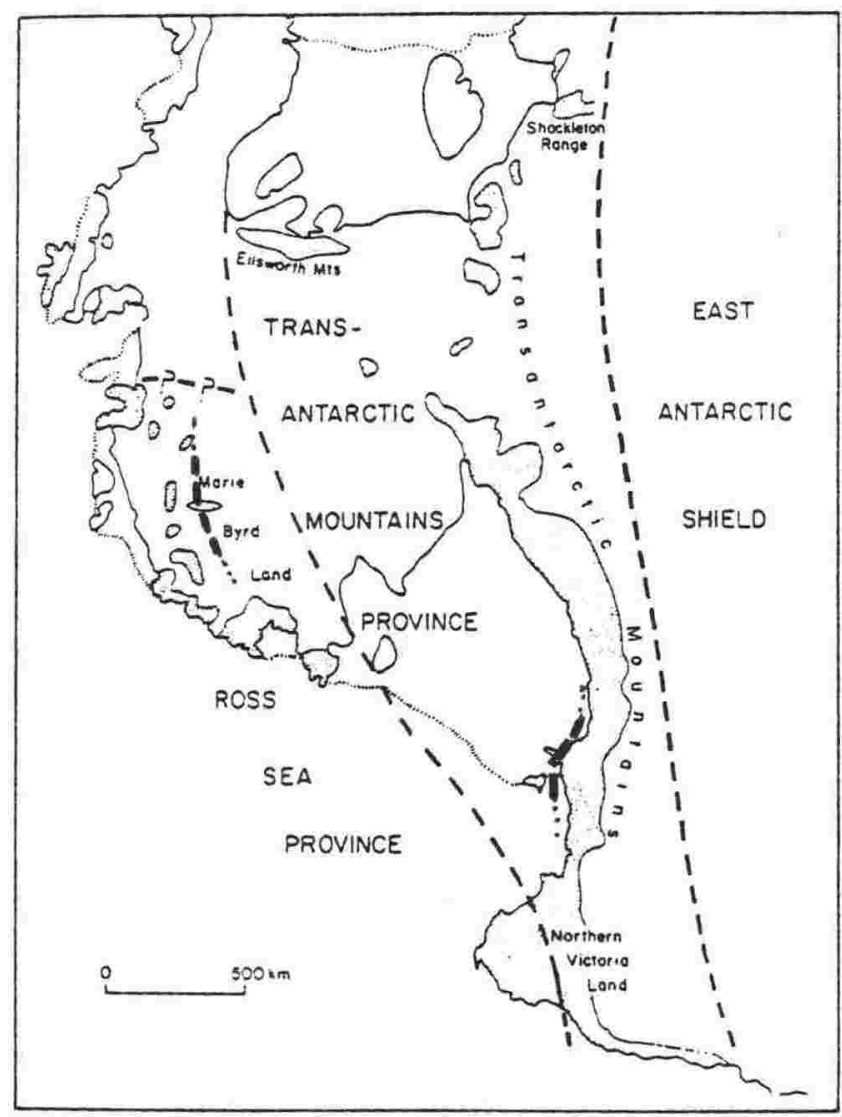

FIGURE 8.7: Early-middle Paleozoic tectono-stratigraphic provinces of Antarctica, consisting of the Transantarctic Mountain and Ross Sea provinces (after Laird, 1991a and 1991b). Dashed line shows the estimated boundary between these provinces of Laird (1991a and 1991b). Thick dashed lines show discontinuities defined by xenoliths in the Transantarctic Mountains and the Ross Embayment of the McMurdo Sound region (Kalamarides et al., 1987), and in the Executive Committee Range in Marie Byrd Land (Wysoczanski and Gamble, 1992); a dotted line is an estimated continuation of these boundaries, which are interpreted to represent the province boundary. The McMurdo Sound and ECR crustal boundaries do not join up due to tectonic movements (mainly rifting) since the Paleozoic.

From the stratigraphy of Antarctica, two early-middle Paleozoic tectonostratigraphic provinces (Figure 8.7) can be identified ( Laird, 1991a and 1991b). These consist of Northern Victoria Land (Bowers and Robertson Bay Group) and MBL, which comprise the Ross Sea Province, and the Transantarctic Mountains (including the Wilson Terrane), which comprise the Transantarctic Mountains province. 
The boundary between these provinces is vague, and an estimate is shown as a dashed line in Figure 8.7. The lower crustal discontinuity between the Ross Embayment and the Transantarctic Mountains in the McMurdo Sound region (Kalamarides et al., 1987) is also shown, and is taken here to represent the best possibility for the boundary between the tectono-stratigraphic provinces. If the lower crustal discontinuity in the ECR (Wysoczanski and Gamble, 1992; this study) also defines a major crustal suture, then the province boundary can be inferred to coincide with the ECR discontinuity. The geochemical similarity between the northern ECR and Ross Embayment lower crusts, and the southern ECR and TM lower crusts (Chapter 7.4) supports extending the province boundary to the ECR. The boundaries do not join, probably as a result of rifting and rotation of MBL from the Antarctic continent since Paleozoic times (Chapter 1.2.2).

\section{Paleozoic accretion of allochthonous terranes to East Antarctica}

The differences in geologic and tectonic evolution between the different provinces is considered to represent the allochthonous nature of Northern Victoria Land and MBL (as well as SE Australia, New Zealand and the Campbell Plateau), to East Antarctica, and their suturing some time in the Paleozoic (Cooper et al., 1982; Bradshaw et al., 1983; Adams, 1986; Laird, 1991a and 1991b; Weaver et al., 1991).

In terms of Paleozoic reconstructions, there are four main events that are important in reconstructing this region: firstly, the absence of the Ordovician granites associated with the Ross Orogeny (c. $500 \mathrm{Ma}$ ) in the Bowers and Robertson Bay terranes of Northern Victoria Land, in New Zealand and in MBL, and the presence of a deformational event at c. $450 \mathrm{Ma}$ in New Zealand and MBL; secondly the presence of a subduction system along the paleo-Pacific margin of Antarctica from Ordovician times; thirdly the absence of Devonian granitoids and a deformational event in the Transantarctic Mountains province; and fourthly the tectonically inactive environment from Late Devonian times evidenced by the deposition of the Beacon Supergroup in Victoria Land (Woolfe, 1991), and of the Torlesse Supergroup in New Zealand (sourced from MBL; Bradshaw et al., 1981), in deformation-free environments.

Two models (with some variations) have been proposed for the accretion of the allochthonous blocks to Antarctica; in Ordovician, and in Devonian times.

\section{a) Ordovician accretion of allochthonous terranes to East Antarctica}

The Ross Orogeny has been proposed to be a collisional event, representing the suturing of allochthonous terranes to East Antarctica in Ordovician times 
(Vetter and Tessenshon, 1987; Findlay, 1987; Woolfe, 1991). The absence of Ordovician granites in the Bowers and Robertson Bay terranes, and in New Zealand and MBL, combined with the later period of deformation (at c. $450 \mathrm{Ma}$ ) in New Zealand and MBL, is problematic. This model requires the suturing of New Zealand and MBL to Antarctica some 50 Ma later than Northern Victoria Land.

Such a model allows the Devonian granites (Ford Granodiorite, Karamea Granite and Admiralty Intrusives) to be Caledonian-type (Pitcher, 1983) posttectonic magmatism granites, generated during uplift and adiabatic melting of igneous underplate. This can account for the presence of both I-type and S-type granites at this time (Weaver et al., 1991). The oceanic lower crust beneath MBL (as well as the Ross Embayment (Berg and Wu, 1992) and probably New Zealand (Graham et al., 1990) would have been capable of generating such melts.

\section{b) Devonian accretion of allochthonous terranes to East Antarctica}

Devonian suturing of the exotic terranes to East Antarctica prior to deposition of the undeformed Beacon Supergroup has also been proposed (Borg et al., 1987; Weaver et al., 1991). This is an attractive model as it explains the similar geological histories of the Ross Sea province blocks up to and beyond Devonian magmatism. In particular, the absence of Devonian granites in the Wilson terrane, and the presence of Beacon Supergroup sediments in both the Wilson terrane and the Bowers and Robertson Bay terranes, suggests that they were joined at this time, and not before.

This model requires the Devonian granites to be subduction-related Cordilleran-type granites. The S-type granites from New Zealand may be problematic in this respect, but need not be. Weaver et al., (1991) suggested that they may represent the continental inboard side of the active margin of the allochthonous block. The S-type granites would therefore delineate thicker continental crust beneath New Zealand, and thinner crust beneath Northern Victoria Land, the Ross Embayment, and MBL. The MBL crust is thin (this study), as is the Ross Embayment crust (Berg and $\mathrm{Wu}, 1992$ ). While this does not necessarily support the Devonian suture model, it does not dispute it.

The lack of a widespread Devonian orogeny indicates that accretion was generally passive. However, there is some evidence of Middle Devonian magmatism and deformation in MBL and Northern Victoria Land. Deformed metavolcanics and sediments that post-date granite intrusion (Middle Devonian) are present in Northern Victoria Land and MBL (the Borchgrevink Event; Craddock, 1972; Laird, 1991a and 1991b). This was followed by deposition of the Beacon Supergroup during a tectonically inactive period in Northern Victoria 
Land, and a period of erosion in MBL, resulting in deposition of the Torlesse Supergroup in New Zealand (Bradshaw et al, 1981). In the Transantarctic Mountains, there is also evidence for a Devonian deformational event (the Shackleton Event; Rowell et al., 1988; Laird, 1991a and 1991b). This event however was probably prior to the Borchgrevink Event, and was not associated with magmatism. The lack of deformation in East Antarctica and deformation in the allochthonous blocks is a major problem yet to be reconciled with this model.

\section{Tectonic reconstructions for MBL since Lower Paleozoic times}

On the basis of the structure of the crust, the difference in crustal blocks, and the geologic and tectonic events recorded by the stratigraphy, a model for the post-Cambrian evolution of $\mathrm{MBL}$ can be established. While there are many possibilities for such reconstructions, the model proposed in Figure 8.8 is preferred, as it is simple, fits in with other areas of Gondwana, and best explains the observed stratigraphy.

Pre-Cambrian reconstructions for this region of Gondwana are unresolved, mainly due to the incomplete pre-Cambrian stratigraphic record in Antarctica. Borg and DePaolo (1990) have proposed a model based on the identification of crustal provinces in East Antarctica from model ages of granite sources. This model involves the accretion of the Beardmore microcontinent to east Antarctica in late Proterozoic times, possibly resulting in the Beardmore Orogeny (Grindley and McDougall, 1969; Stump, 1981; Stump et al., 1988) some time between 800-550 Ma.

More recently, it has been proposed that southwest United States was joined to East Antarctica and Australia in pre-Cambrian times (Moores, 1991; Dalziel, 1991; Hoffman, 1991). In such reconstructions, MBL is placed between southwest United States and East Antarctica, whereas New Zealand and Northern Victoria Land are not constrained. Rifting of East Antarctica and southwest United States is thought to have occurred in latest pre-Cambrian times.

FIGURE 8.8 (opposite): A model for tectonic reconstructions of Marie Byrd Land (MBL; consisting of Mount Sidley (S) crust in the south, and Mount Hampton $(\mathrm{H})$ crust in the north) and the Campbell Plateau/New Zealand (CP/NZ) since Paleozoic times. a) The similarity in the lower crust between MBL, CP/NZ and the Transantarctic Mountains (East Antarctica; EA) suggests that these provinces may have been joined in Cambro-Ordovician times, when Swanson Formation sediments were deposited in MBL and CP/NZ as turbidites on oceanic crust. Southwest United States (SW US) is depicted as rifting away from EA. b) Alternatively, MBL and CP/NZ may have accreted to EA in Ordovician times (during the Ross Orogeny), or as a passive accretion in Late Devonian times, prior to deposition of the Beacon Supergroup. c) Subduction in Devonian times resulted in the intrusion of granites, eruption of volcanics and deformation in MBL and NZ/CP, but had no effect in EA, possibly due to its distance from the trench. d) The Mesozoic was a period of tectonic inactivity, with erosion of MBL sourcing deep marine sediments of the Torlesse Supergroup in NZ. e) MBL and NZ/CP rifted apart in the Cretaceous (approximately $100 \mathrm{Ma}$ ), associated with granite emplacement. 
a) Cambro-Ordovician

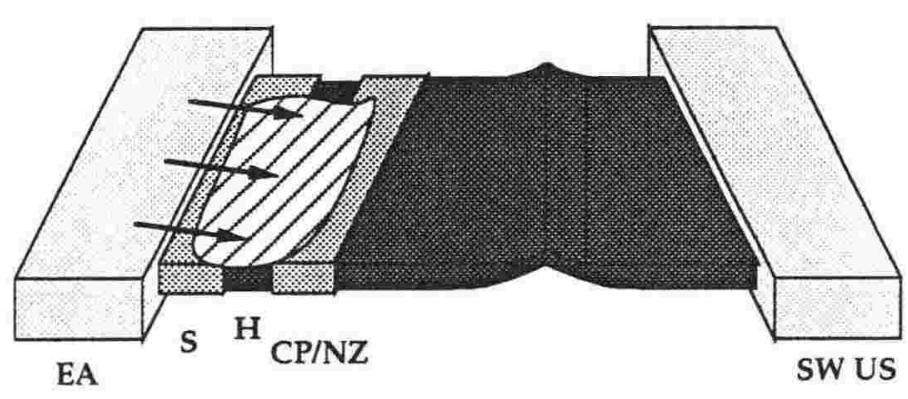

c) Late Devonian - Carboniferous

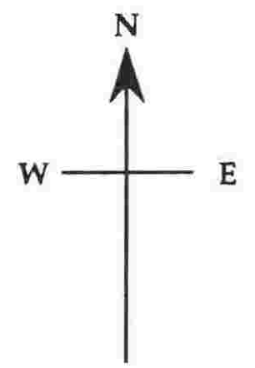

$\mathrm{s}$

Continental Crust

Old Oceanic Crust

New Oceanic Crust

Subducting Crust

Devonian Volcanics

Devonian Granites

Cretaceous Granites

Cambro-Ordovician Sediments

Mesozoic Sediments

$\mathrm{EA}=$ East Antarctica

$\mathrm{H}=\mathrm{Mt}$ Hampton

$\mathrm{NZ} / \mathrm{CP}=$ New Zealand $/$ Campbell Plateau

$\mathrm{S}=\mathrm{M}$ t Sidley

SW US = Southwest

United States

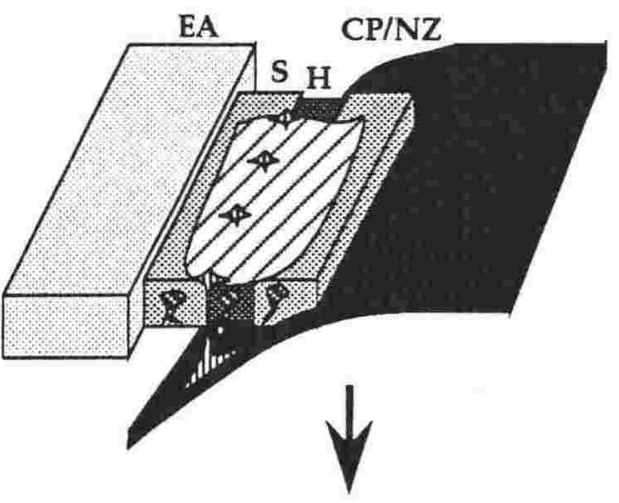

d) Mesozoic

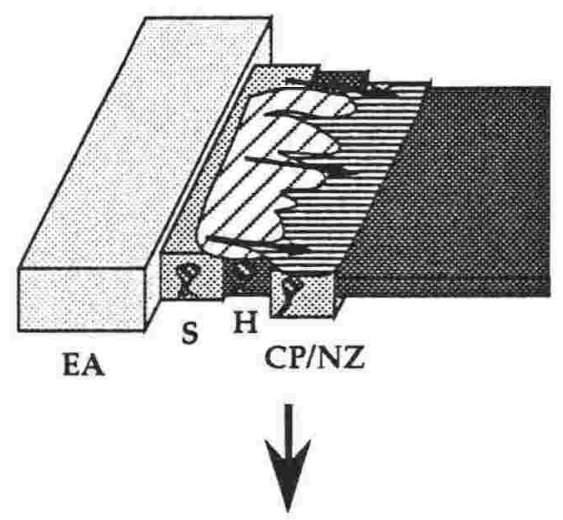

e) Cretaceous

b) Ordovician or Late Devonian
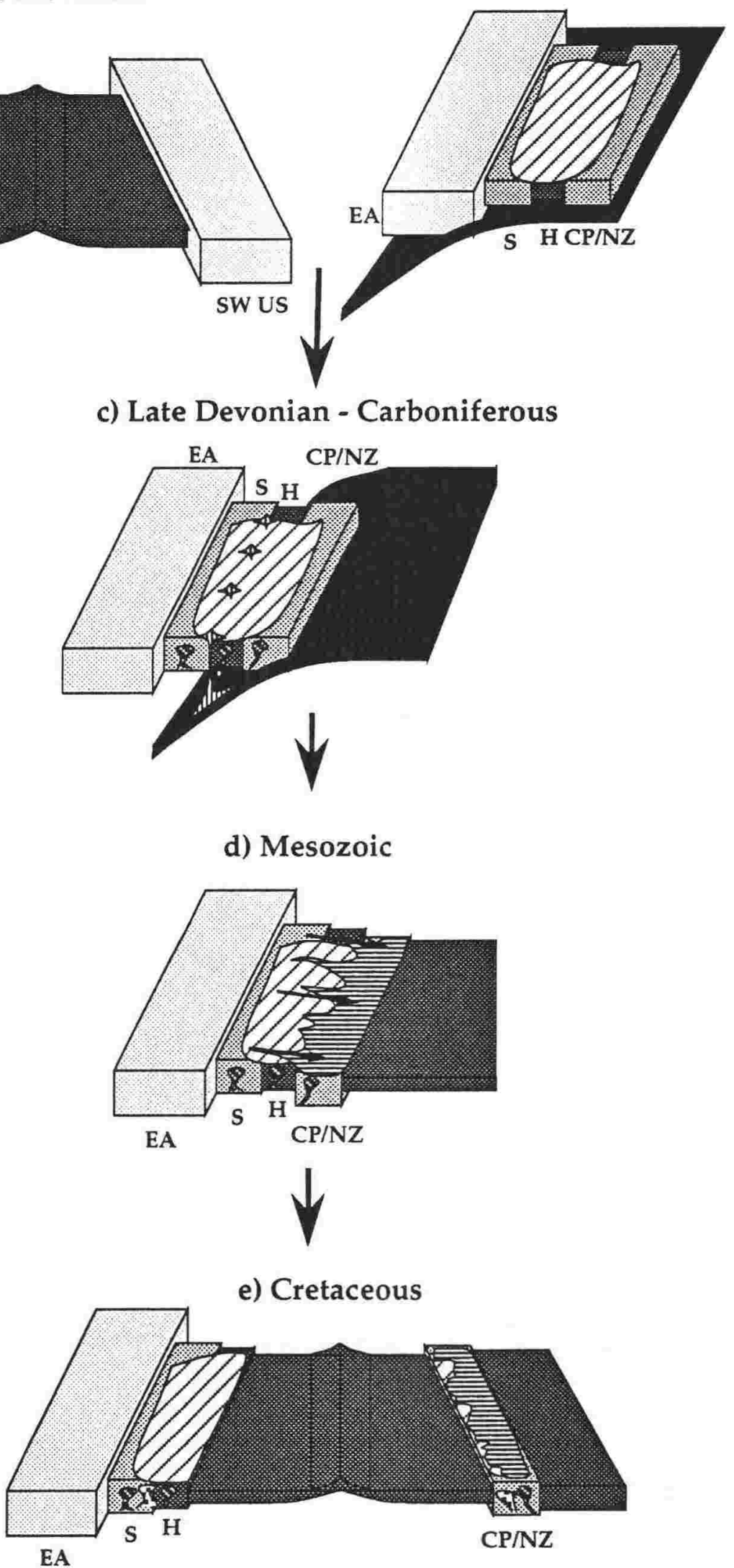
The reconstruction presented here shows southwest United States rifting from East Antarctica during Cambro-Ordovician times, although this is not essential to the model (Figure 8.8a). More importantly is the similarity between the southern ECR and the Transantarctic Mountains lower crusts, which suggests that they may belong to the same crustal block. The northern ECR crust would simply represent oceanic crust, offshore from the continents, where Swanson Formation sediments were being deposited in a deep marine environment, sourced from the East Antarctic craton. Turbidites were also deposited in New Zealand at this time (Greenland Group).

Alternatively, MBL and New Zealand may still have been offshore from East Antarctica, and have sutured to the craton in Ordovician or Devonian times (Figure $8.8 \mathrm{~b}$ ). As previously discussed, this suturing is still a contentious issue. If suturing was Devonian, Swanson Formation sediments would have to have been deposited from an unknown source, not Antarctica.

Subduction occurred during Late Devonian-Carboniferous times, and coincided with a period of granitic emplacement, volcanism and deformation in the allochthonous blocks, resulting in thickening of the MBL crust (Figure 8.8c). East Antarctica was unaffected by this event due to its distance from the trench. As discussed above (Devonian accretion of allochthonous blocks to. East Antarctica), subduction may have been accompanied by a collisional event. However, if this was the case, and subduction was west-dipping as seems likely, then the trench would have to have moved offshore from MBL and New Zealand for magmatism to have affected the allochthonous blocks.

Following subduction, there was a period of quiescence, with erosion in MBL resulting in the deposition of deep marine turbidites of the Torlesse Supergroup in New Zealand (Figure 8.8d). This period was interrupted by the rifting of MBL and New Zealand in the Mesozoic (Figure 8.8e), and finally late Cenozoic alkaline volcanism in MBL associated with a mantle plume, and the opening of the West Antarctic Rift.

\subsection{Conclusion}

The stratigraphy of the MBL crust has led to a model for the formation of the MBL crust as oceanic crust, represented by the lower crustal granulite and pyroxenite xenolith suites, overlain by deep water turbidites (the Swanson Formation), probably in latest pre-Cambrian or Early Cambrian times. Two earlymiddle Paleozoic tectono-stratigraphic provinces can be recognised in Antarctica, 
which consist of autochthonous East Antarctica, and the allochthonous blocks of Northern Victoria Land, New Lealand and MBL. It is proposea that the lower crustal discontinuities identified in the Ross Sea and in the ECR represent the boundary between these provinces. Suturing of the allochthonous blocks to East Antarctica occurred in the Paleozoic, and several tectono-magmatic events including granite emplacement, volcanism, and deformation associated with subduction and rifting, has resulted in the growth of MBL.

The most recent event in MBL, the late Cenozoic alkaline volcanism related to a mantle plume, has modified the composition of some parts of the lower crust, particularly beneath Mount Sidley. Alkaline melts have resulted in two styles of metasomatism, one dominant in the pyroxenite suite, and one in the granulite suite. The composition of the melts will also have been modified by these metasomatic processes, resulting in percolative fractional crystallisation of the melt; the extent of this process can not be ascertained by this study, but is a compelling reason to extend this work to a more detailed isotopic study. 


\section{Chapter nine \\ SUMMARY AND CONCLUSIONS}

\subsection{The Xenolith Suite}

The study of a suite of xenoliths from the lower crust and upper mantle of MBL, which includes granulites, pyroxenites and peridotites, has brought an insight into the composition and processes occurring within the lithosphere of MBL, and has enabled comparison with xenolith suites world-wide. The xenolith suite has been documented in Part Two of this study, and the results discussed in Part Three. A brief summary of the main conclusions is presented here.

\subsection{Composition of the Marie Byrd Land Lithosphere}

Upper mantle peridotites from MBL were collected from Mount Cumming and Mount Hampton in the ECR, from the USAS Escarpment to the north of the ECR, and from Mount Murphy, some $450 \mathrm{~km}$ east of the ECR, on the MBL coast. Lower crustal xenoliths from three major sites have been documented: Mount Sidley, in the south of the ECR; Mount Hampton, approximately $100 \mathrm{~km}$ north of Mount Sidley at the northern end of the ECR; and Mount Murphy.

The upper mantle beneath Mount Hampton and Mount Murphy consists of dunites, spinel lherzolites (with variable amounts of $\mathrm{Cr}$-diopside), and $\mathrm{Cr}$ diopside veins, and shows a large variation in composition. This compositional range is largely a reflection of the variable amounts of $\mathrm{Cr}$-diopside in the peridotites, and indicates a generally 'fertile' upper mantle in these regions. Some peridotites are LREE-enriched, and may have been enriched by mantle metasomatic processes. In contrast, peridotites from Mount Cumming and the USAS Escarpment consist of spinel lherzolites, with little variation in 
composition. USAS Escarpment peridotites are LREE-depleted, and indicate a more 'infertile' upper mantle, depleted by partial melting.

Mount Sidley lower crustal xenoliths consist of a suite of granulites and pyroxenites that crystallised as cumulates from one or more related (probably alkaline) mantle melts. A plagioclase-poor pyroxenite suite (termed Type $\mathrm{P}$ pyroxenites) crystallised at the greatest depth, and from the most primitive melt. Successive cumulates crystallised from more evolved melts and at higher levels, and include plagioclase-bearing pyroxenites (Type $C$ pyroxenites), mafic-rich plagioclase granulites (Type $\mathrm{M}$ granulites), and well layered mafic-poor plagioclase granulites (Type L granulites). The primary mineral assemblage consists of clinopyroxene + olivine + plagioclase + spinel, which occur in variable abundances in each xenolith type. A single granulite from Mount Waesche is compositionally similar to Mount Sidley granulites.

The Mount Hampton lower crustal xenolith suite consists of granulites and pyroxenites that crystallised as cumulates from a sub-alkaline mantle melt (or melts). The mineral assemblage consists of orthopyroxene + clinopyroxene + plagioclase + spinel, with olivine occurring (together with orthopyroxene) in a minority of xenoliths. Mineral P-T equilibria suggest the granulites and pyroxenites crystallised at similar levels in the crust, with the only difference between them being the dominance of plagioclase in the former. Mount Cumming granulites are compositionally similar to Mount Hampton granulites.

Mount Murphy xenoliths consist of granulites and pyroxenites that crystallised as cumulates from evolving mantle melts. Granulites generally formed at higher crustal levels and pyroxenites at lower levels. Site 90041 granulites crystallised from the most primitive melt, followed by site 90054 pyroxenites and site 90048 granulites and pyroxenites, which have more evolved characteristics. The mineral assemblage consists of olivine and/or orthopyroxene + clinopyroxene + plagioclase + spinel. While the majority of xenoliths consist of olivine, orthopyroxene is present in some xenoliths, and pyroxenites from site 90044 consist entirely of orthopyroxene + clinopyroxene, with no olivine.

These differences between sites reflect the large scale heterogeneities evident in the MBL lithosphere, particularly in the ECR. The lower crust beneath the southern ECR, as represented by the Mounts Sidley and Waesche xenoliths, is quite different from that in the north, which underlies Mounts Hampton and Cumming; this apparent hiatus has been previously termed the ECR discontinuity (Wysoczanski and Gamble, 1992). Mount Murphy xenoliths represent a lower crust that is essentially transitional in composition to the lower crust beneath Mount Hampton and Mount Sidley. 
The ECR discontinuity is similar to the discontinuity identified in the McMurdo Sound region, between xenoliths from the Transantarctic Mountains, and the Ross Embayment (Kalamarides et al., 1987). The Mount Sidley lower crust is compositionally similar to that beneath the Transantarctic Mountains (and New Zealand), and the Mount Hampton and Mount Murphy lower crusts are similar to the Ross Embayment lower crust. The difference between these lower crustal segments (the TM Group and RE Group crusts respectively) is interpreted to represent an ancient crustal suturing of distinctive terranes.

In summary, the MBL lower crust is mafic in composition, having formed as cumulates from both sub-alkaline and alkaline melts. These melts were primitive mantle melts that had not been contaminated by felsic crustal material, and evolved through fractional crystallisation of the xenolith suite. This is similar to lower crustal xenolith suites from other localities which indicate a mafic lower crust world-wide (Griffin and O'Reilly, 1986; Rudnick, 1992).

\subsection{Metasomatic Processes in the Marie Byrd Land Lithosphere}

Plume related alkaline volcanism has resulted in the enrichment of some regions of the MBL lithosphere, particularly the lower crust beneath Mount Sidley. Enrichment has occurred in two styles; one dominant in pyroxenite xenoliths, and one in granulite xenoliths:

- kaersutitisation associated with hydrous silicate melts occurs in the pyroxenite suite, resulting in the replacement of clinopyroxene by kaersutite (i.e. an anhydrous phase by a hydrous phase). This style of metasomatism occurs through the minerals rather than along grain boundaries, much like water through blotting paper, resulting in an enrichment in mobile elements (e.g. LILEs and LREEs), as well as elements that partition readily into kaersutite (e.g. $\mathrm{K}, \mathrm{H}_{2} \mathrm{O}$, $\mathrm{Na})$;

- enrichment associated with infiltration of silicate melts occurs in the granulite suite, resulting in the growth of secondary minerals, such as Fe-Ti oxides, apatite and plagioclase from the migrating melt. The mechanism envisaged is similar to precipitates forming from fluids in pipes of a plumbing system. The plagioclase and mafic mineral layering of the granulites appears to have provided permeable and impermeable layers respectively, channelling the flow of the melts through the lower crust, as in petroleum reservoirs and artesian systems. The xenoliths have been enriched in elements that partition into the 
secondary mineral phases (e.g. Fe, Ti, P, Sr), as well as in mobile elements (e.g. LILEs and LREEs).

Infiltrating melts have also enriched the lower crust, by fractionating microphenocrysts in the lower crust. The melts themselves evolve by crystal fractionation, and by interaction with the xenolith mineral assemblage; a process termed 'percolative fractional crystallisation' (Harte et al., 1993). The extent of this process is uncertain and depends on the amount of melt that has come into contact with the xenolith suite; it may be restricted to conduit walls, or be a pervasive reaction through the lower crust.

\subsection{Lithospheric Structure and Evolution}

The formation of the MBL lower crust by mafic melts crystallising cumulates at various lower crustal levels has resulted in its present vertical stratification. Geothermometry and geobarometry estimates indicate a high riftlike geothermal gradient in MBL, similar to that in the Transantarctic Mountains (Berg and Herz, 1986; Gamble et al., 1988), and an average crustal thickness of 30 $\mathrm{km}$ to the base of the granulites, and $30-35 \mathrm{~km}$ to the base of the pyroxenites. Both of these estimates agree with varying estimates of the thickness of the crust based on geophysical methods. The genetic relationship between the granulites and pyroxenites, and their difference to the peridotites, is taken here to indicate that the base of the pyroxenites corresponds to the petrologic Moho in MBL.

The mafic lower crust, in the absence of other lithologies, and from mineral $\mathrm{P}-\mathrm{T}$ equilibria, is presumed to be overlain by Swanson Formation deep marine turbidites, metamorphosed to amphibolite-granulite facies (the Fosdick Metamorphic Complex, exposed in the Ford Ranges; Luyendyk et al., 1992). This relationship suggests an origin for the lower crust as oceanic crust in latest preCambrian or Early Cambrian times. MBL was allochthonous to East Antarctica, and suturing of the two blocks occurred in Paleozoic times (Ordovician or Late Devonian). Several subsequent periods of magmatism, metamorphism and deformation associated with both subduction and rifting, have resulted in the growth of the MBL crust. Pre-Cambrian reconstructions of Gondwana must therefore allow for MBL being oceanic crust at this time, and not a continental allochthonous block. 
Part Four

\section{APPENDICES, GLOSSARY AND REFERENCES}

Appendices of xenolith samples, mineral assemblages and compositions, whole rock compositions (including rare earth elements and isotopic analyses), a glossary of keywords and anagrams, and a list of references. 


\section{Appendix one \\ SAMPLE LISTS}

\section{Introduction}

A full list of xenoliths collected from MBL (Chapter Three) is presented here, including upper crustal rocks that have not been discussed in this study. Localities are presented in order of their discussion in the thesis text; i.e. Mounts Sidley, Hampton and Murphy, followed by Mounts Cumming, Waesche and the USAS Escarpment. Samples from each locality are listed according to type: granulite, pyroxenite, peridotite and upper crustal (host rocks and upper crustal rocks) xenoliths. Locations of individual site numbers for each locality are shown in the appropriate location maps of Chapter Three.

\section{Descriptions and abbreviations}

Field No. The number given to each sample in the field (e.g. 89001A). The first two digits represent the year (e.g. 89). The following three digits represent the site number (e.g. 001). The final characters represent sample numbers for that site, from $A$ to $Z$ and then $A 1, B 1$ etc (e.g. A). Sample numbers are in no particular order.

V.U.W. No. The sample number given to each sample stored in the Victoria University of Wellington rock collection. Rocks, powders and thin sections are all stored in this collection.

Lithology. The nomenclature for each sample according to the classification schemes used in this study (Chapter Two). Abbreviations are: 


$\begin{array}{llll}\text { Cpx } & \text { - Clinopyroxene } & \text { Cpxite } & \text { - Clinopyroxenite } \\ \text { Ka } & \text { - Kaersutite } & \text { Kaerite } & \text { - Kaersutitite } \\ \text { Leugb } & \text { - Leucogabbro } & \text { Leutroct } & \text { - Leucotroctolite } \\ \text { Melgb } & \text { - Melagabbro } & \text { Ol } & \text { - Olivine } \\ \text { Opx } & \text { - Orthopyroxene } & \text { Pl } & \text { - Plagioclase } \\ \text { Webst } & \text { - Websterite } & \text { Wehr } & \text { - Wehrlite }\end{array}$

Analyses. The analytical methods used on each sample in this study. While some samples under the heading "Upper crustal" have been prepared, they may not have been analysed in this study. All other rock types have been both prepared and analysed in this study. Abbreviations are:

I - Isotopic analyses

$\mathbf{P}$ - Probe section (includes $\mathbf{S}$ )

S - Thin section
M - Major element analyses

R - Rare Earth Element analyses

T - Trace element analyses 


\section{A1.1 Mount Sidley Xenoliths}

\begin{tabular}{|c|c|c|c|c|c|c|c|}
\hline Field No & VLW No & Lithology & Analyses & Field No & VUW No & Lithology & Analyses \\
\hline \multicolumn{8}{|c|}{ Type L Granulites } \\
\hline 90029D & 32590 & Ol Gabbro & $\mathrm{P}$ & $90031 \mathrm{P}$ & 32642 & Ka Gabbro & $M, T, S$ \\
\hline $90029 \mathrm{~K}$ & 32597 & Ol Gabbro & $\mathrm{M}, \mathrm{T}$ & $90031 \mathrm{R}$ & 32644 & Ol Gabbro & $S$ \\
\hline $90029 \mathrm{~L}$ & 32598 & Ol Gabbro & $\mathrm{S}$ & 900330 & 32660 & Troctolite & $\mathrm{P}$ \\
\hline $90029 \mathrm{M}$ & 32599 & Ol Gabbro & $\mathrm{M}, \mathrm{T}$ & 900335 & 32664 & Ol Gabbro & M,T,P \\
\hline 900290 & 32601 & Ol Gabbro & $\mathrm{M}, \mathrm{T}, \mathrm{P}$ & $90033 U$ & 32666 & Ol Gabbro & $\mathrm{M}, \mathrm{T}, \mathrm{P}$ \\
\hline $90029 \mathrm{P}$ & 32602 & Ol Gabbro & $M, T, S$ & $90033 \mathrm{~V}$ & 32667 & Ol Gabbro & $\mathrm{M}, \mathrm{T}, \mathrm{P}$ \\
\hline $90029 R$ & 32604 & Ol Gabbro & $\mathrm{S}$ & $90033 \mathrm{~W}$ & 32668 & Ol Gabbro & $M, T, P$ \\
\hline $90029 S$ & 32605 & Ol Gabbro & $\mathrm{S}$ & $90033 x$ & 32669 & Ol Gabbro & $M, T, I, R, P$ \\
\hline $90029 \mathrm{~T}$ & 32606 & Anorthosite & $\mathrm{S}$ & $90033 \mathrm{~B} 1$ & 32673 & Ka Gabbro & $M, T, S$ \\
\hline $90029 \mathrm{U}$ & 32607 & Ol Gabbro & $M, T, S$ & $90033 \mathrm{Cl}$ & 32674 & Ol Gabbro & $\mathrm{M}, \mathrm{T}$ \\
\hline $90029 \mathrm{~W}$ & 32609 & Ol Gabbro & $\mathrm{S}$ & $90033 \mathrm{EI}$ & 32676 & Gabbro & $\mathrm{M}, \mathrm{T}, \mathrm{P}$ \\
\hline $90029 x$ & 32610 & Gabbro & $\mathrm{M}, \mathrm{T}, \mathrm{P}$ & 90033F1 & 32677 & Ol Gabbro & $M, T, P$ \\
\hline $90029 Y$ & 32611 & Ol Gabbro & $M, T, S$ & $90033 \mathrm{G1}$ & 32678 & Ol Gabbro & P \\
\hline $90029 Z$ & 32612 & Ol Gabbro & S & $90033 \mathrm{~K} 1$ & 32682 & Ka Gabbro & $\mathrm{T}, \mathrm{P}$ \\
\hline $90029 \mathrm{~A} 1$ & 32613 & Ol Gabbro & $\mathrm{S}$ & $90033 \mathrm{Ll}$ & 32683 & Ka Gabbro & $\mathrm{T}, \mathrm{S}$ \\
\hline 90029B1 & 32614 & Ol Gabbro & $\mathrm{P}$ & 9003301 & 32686 & Ol Gabbro & $\mathrm{T}, \mathrm{S}$ \\
\hline $90029 \mathrm{Cl}$ & 32615 & Ol Gabbro & $\mathrm{M}, \mathrm{T}, \mathrm{S}$ & $90038 \mathrm{~F}$ & 32716 & Ol Gabbro & $\mathrm{T}$ \\
\hline 90029D1 & 32616 & Ol Gabbro & $\mathrm{M}, \mathrm{T}, \mathrm{P}$ & $90038 \mathrm{G}$ & 32717 & Ol Gabbro & $\mathrm{T}$ \\
\hline $90029 \mathrm{~F} 1$ & 32618 & Ol Gabbro & M,T,S & $90039 \mathrm{~A}$ & 32724 & Ol Gabbro & $\mathrm{M}, \mathrm{T}$ \\
\hline $90029 \mathrm{G} 1$ & 32619 & Ol Gabbro & $\mathrm{M}, \mathrm{T}, \mathrm{I}, \mathrm{R}, \mathrm{S}$ & $90039 \mathrm{C}$ & 32726 & Ol Gabbro & $\mathrm{M}, \mathrm{T}, \mathrm{P}$ \\
\hline $90029 \mathrm{H} 1$ & 32620 & Ol Gabbro & $M, T, I, R, S$ & $90039 D$ & 32727 & Troctolite & M,T,P \\
\hline $90029 J 1$ & 32622 & Ol Gabbro & $\mathrm{T}$ & $90039 E$ & 32728 & Troctolite & M,T,P \\
\hline 90029L1 & 32624 & Ol Gabbro & $\mathrm{T}, \mathrm{P}$ & $90039 \mathrm{G}$ & 32730 & Ol Gabbro & $M, I, I, R, P$ \\
\hline 90029M1 & 32625 & Ol Gabbro & $\mathrm{T}$ & 900391 & 32732 & Ol Cabbro & $M, T, S$ \\
\hline $90031 \mathrm{~A}$ & 32627 & Ol Gabbro & $\mathrm{T}, \mathrm{S}$ & $90039 \mathrm{~J}$ & 32733 & Ol Gabbro & $\mathrm{T}, \mathrm{P}$ \\
\hline 90031D & 32630 & Ka Gabbro & $\mathrm{T}, \mathrm{I}, \mathrm{R}, \mathrm{S}$ & $90039 \mathrm{~K}$ & 32734 & Ol Gabbro & $\mathrm{M}, \mathrm{T}$ \\
\hline $90031 \mathrm{~F}$ & 32632 & Ol Gabbro & $\mathrm{T}, \mathrm{S}$ & $90039 \mathrm{~L}$ & 32735 & Ol Gabbro & $M, T, S$ \\
\hline $90031 \mathrm{G}$ & 32633 & Ka Gabbro & $\mathrm{M}, \mathrm{T}, \mathrm{S}$ & $90039 \mathrm{M}$ & 32736 & Gabbro & $\mathrm{M}, \mathrm{T}, \mathrm{P}$ \\
\hline $90031 \mathrm{~L}$ & 32638 & Ka Gabbro & $\mathrm{M}, \mathrm{T}$ & $90039 \mathrm{P}$ & 32739 & Anorthosite & $\mathrm{P}$ \\
\hline 900310 & 32641 & Ka Gabbro & $M, T, S$ & & & & \\
\hline \multicolumn{8}{|c|}{ Type M Granulites } \\
\hline $90029 \mathrm{C}$ & 32589 & Ol Gabbro & $M, T, P$ & $90033 G$ & 32652 & Ol Gabbro & $\mathrm{M}, \mathrm{T}$ \\
\hline $90029 \mathrm{H}$ & 32594 & Ol Gabbro & $\mathrm{M}, \mathrm{T}, \mathrm{P}$ & $90033 \mathrm{~K}$ & 32656 & Ol Gabbro & $\mathrm{M}, \mathrm{T}, \mathrm{P}$ \\
\hline $90029 Q$ & 32603 & Ol Gabbro & $M, T, S$ & $90033 Q$ & 32662 & $\mathrm{Ka}$ Gabbro & $\mathrm{T}, \mathrm{P}$ \\
\hline $90029 \mathrm{~V}$ & 32608 & Ol Gabbro & $\mathrm{M}, \mathrm{T}, \mathrm{P}$ & $90039 \mathrm{~B}$ & 32725 & Ol Gabbro & $M, T, P$ \\
\hline 90029EI & 32617 & Ol Gabbro & $M, T, P$ & $90039 \mathrm{~F}$ & 32729 & Ol Gabbro & $M, T, P$ \\
\hline 9002911 & 32621 & Ol Gabbro & $\mathrm{T}, \mathrm{S}$ & $90039 \mathrm{R}$ & 32741 & Ol Gabbro & M,T,P \\
\hline $90031 \mathrm{C}$ & 32629 & Ka Gabbro & $\mathrm{M}, \mathrm{T}, \mathrm{S}$ & $90039 \mathrm{~V}$ & 32745 & Ol Gabbro & $\mathrm{M}, \mathrm{T}, \mathrm{P}$ \\
\hline \multicolumn{8}{|c|}{ Type C Pyroxenites } \\
\hline $90029 B$ & 32588 & Gabbro & $\mathrm{M}, \mathrm{T}$ & $90033 \mathrm{M} 1$ & 32684 & Gabbro & $\mathrm{T}, \mathrm{P}$ \\
\hline $90033 \mathrm{~J}$ & 32655 & Ka Gabbro & $\mathrm{M}, \mathrm{T}, \mathrm{P}$ & $90033 \mathrm{P} 1$ & 32687 & Ka Gabbro & $\mathrm{M}, \mathrm{T}, \mathrm{P}$ \\
\hline $90033 \mathrm{P}$ & 32661 & Ka Gabbro & $\mathrm{M}, \mathrm{T}, \mathrm{P}$ & 900390 & 32738 & Ol Gabbro & $\mathrm{P}$ \\
\hline $90033 Z$ & 32671 & Ka Gabbro & $\mathrm{T}, \mathrm{S}$ & $90039 \mathrm{Sb}$ & 32742 & Gabbro & $M, T, I, R, P$ \\
\hline $90033 \mathrm{H} 1$ & 32679 & Gabbro & $\mathrm{M}, \mathrm{T}, \mathrm{P}$ & $90039 \mathrm{~T}$ & 32743 & Ka Gabbro & $\mathrm{T}, \mathrm{S}$ \\
\hline \multicolumn{8}{|c|}{ Type P Pyroxenites } \\
\hline $90031 Q$ & 32643 & Wehrlite & $\mathrm{M}, \mathrm{T}$ & $90033 \mathrm{~N}$ & 32659 & Wehrlite & $\mathrm{S}$ \\
\hline $90033 \mathrm{~A}$ & 32646 & Ol Cpxite & $M, T, P$ & $90033 \mathrm{R}$ & 32663 & Gabbro & $\mathrm{P}$ \\
\hline $90033 B$ & 32647 & Ol Cpxite & $M, T, P$ & 90033D1 & 32675 & Ol Cpxite & $\mathrm{T}, \mathrm{S}$ \\
\hline $90033 C$ & 32648 & Ol Kaerite & $M, T, R, P$ & $90033 \mathrm{~N} 1$ & 32685 & Wehrlite & $\mathrm{T}, \mathrm{P}$ \\
\hline
\end{tabular}




\begin{tabular}{|c|c|c|c|c|c|c|c|}
\hline Field No & VUW No & Lithology & Analyses & Field No & VUW No & Lithology & Analyses \\
\hline $\begin{array}{l}\text { 90033D } \\
90033 \mathrm{E} \\
90033 \mathrm{~F} \\
90033 \mathrm{C} \\
90033 \mathrm{H} \\
90033 \mathrm{I} \\
90033 \mathrm{~L} \\
90033 \mathrm{M}\end{array}$ & $\begin{array}{l}32649 \\
32650 \\
32651 \\
32652 \\
32653 \\
32654 \\
32657 \\
32658\end{array}$ & $\begin{array}{l}\text { Wehrlite } \\
\text { Ol Gabbro } \\
\text { Ka Wehr } \\
\text { Ol Cpxite } \\
\text { Ka Wehr } \\
\text { Wehrlite } \\
\text { Wehrlite } \\
\text { Cpxite }\end{array}$ & $\begin{array}{l}\mathrm{T}, \mathrm{S} \\
\mathrm{M}, \mathrm{T}, \mathrm{P} \\
\mathrm{M}, \mathrm{T}, \mathrm{P} \\
\mathrm{P} \\
\mathrm{M}, \mathrm{T}, \mathrm{P} \\
\mathrm{M}, \mathrm{T}, \mathrm{P} \\
\mathrm{S} \\
\mathrm{T}, \mathrm{S}\end{array}$ & $\begin{array}{l}\text { 90033Q1 } \\
90033 \mathrm{R} 1 \\
90033 \mathrm{~S} 1 \\
90039 \mathrm{Sa} \\
90039 \mathrm{U} \\
90039 \mathrm{X} \\
90039 \mathrm{Y}\end{array}$ & $\begin{array}{l}32688 \\
32689 \\
32690 \\
32742 \\
32744 \\
32747 \\
32748\end{array}$ & $\begin{array}{l}\text { Wehrlite } \\
\text { Wehrlite } \\
\text { Wehrlite } \\
\text { Wehrlite } \\
\text { Ol Cpxite } \\
\text { Ol Cpxite } \\
\text { Ol Cpxite }\end{array}$ & $\begin{array}{l}\mathrm{P} \\
\mathrm{T}, \mathrm{P} \\
\mathrm{M}, \mathrm{T}, \mathrm{P} \\
\mathrm{M}, \mathrm{T}, \mathrm{I}, \mathrm{R}, \mathrm{P} \\
\mathrm{M}, \mathrm{T} \\
\mathrm{M}, \mathrm{T}, \mathrm{S} \\
\mathrm{M}, \mathrm{T}, \mathrm{I}, \mathrm{R}, \mathrm{S}\end{array}$ \\
\hline & Field No & VUW No & Application & Field No & VUW No & \multicolumn{2}{|l|}{ Application } \\
\hline \multicolumn{8}{|c|}{$\begin{array}{l}\text { Upper Crustal } \\
\mid \quad 90033 \mathrm{~J} 1\end{array}$} \\
\hline & $\begin{array}{l}90025 \\
90026 \mathrm{~A}\end{array}$ & $\begin{array}{l}32580 \\
32581\end{array}$ & & $90034 \mathrm{~A}$ & 32691 & $\mathrm{~T}, \mathrm{~S}$ & \\
\hline & $\begin{array}{l}90026 \mathrm{~A} \\
90026 \mathrm{~B}\end{array}$ & $\begin{array}{l}32581 \\
32582\end{array}$ & & $90034 \mathrm{~B}$ & 32692 & $\mathrm{~s}$ & \\
\hline & $\begin{array}{l}90026 \mathrm{~B} \\
90027\end{array}$ & $\begin{array}{l}32582 \\
32583\end{array}$ & $\mathrm{P}$ & $90034 \mathrm{C}$ & 32693 & $\mathrm{~T}, \mathrm{~S}$ & \\
\hline & $\begin{array}{l}90027 \\
90028 \mathrm{~A}\end{array}$ & $\begin{array}{l}32583 \\
32584\end{array}$ & & $90035 \mathrm{~A}$ & 32694 & $\mathrm{~T}$ & \\
\hline & $90028 B$ & $\begin{array}{l}32584 \\
32585\end{array}$ & & $90035 \mathrm{~B}$ & 32695 & $\mathrm{~s}$ & \\
\hline & $90028 C$ & $\begin{array}{l}32585 \\
32586\end{array}$ & & $90035 \mathrm{C}$ & 32696 & $\mathrm{~T}, \mathrm{~S}$ & \\
\hline & $90029 \mathrm{~A}$ & $\begin{array}{l}32586 \\
32587\end{array}$ & $M, T, P$ & 90035D & $\begin{array}{l}32697 \\
32698\end{array}$ & $\begin{array}{l}\mathrm{T}, \mathrm{S} \\
\mathrm{S}\end{array}$ & \\
\hline & $90029 \mathrm{E}$ & 32591 & $\begin{array}{l}\mathrm{M}, \mathrm{T}, \mathrm{P} \\
\mathrm{S}\end{array}$ & $\begin{array}{l}90035 \mathrm{E} \\
90035 \mathrm{~F}\end{array}$ & $\begin{array}{l}32698 \\
32699\end{array}$ & & \\
\hline & $90029 \mathrm{~F}$ & 32592 & $\begin{array}{l}\mathrm{S} \\
\mathrm{M}, \mathrm{T}, \mathrm{P}\end{array}$ & $\begin{array}{l}90035 \mathrm{~F} \\
90036 \mathrm{~A}\end{array}$ & 32700 & & \\
\hline & $90029 \mathrm{G}$ & 32593 & $\mathrm{M}, \mathrm{T}$ & $90036 \mathrm{~B}$ & 32701 & $\mathrm{~T}, \mathrm{~S}$ & \\
\hline & 90029I & 32595 & & $90036 \mathrm{C}$ & 32702 & $\mathrm{~T}, \mathrm{~S}$ & \\
\hline & $90029 \mathrm{~J}$ & 32596 & & $90036 \mathrm{D}$ & 32703 & & \\
\hline & $90029 \mathrm{~N}$ & 32600 & $\mathrm{~T}, \mathrm{~S}$ & $90036 \mathrm{E}$ & 32704 & & \\
\hline & $90029 \mathrm{~K} 1$ & 32623 & & $90036 \mathrm{~F}$ & 32705 & & \\
\hline & 90030 & 32626 & $\mathrm{~T}, \mathrm{P}$ & $90036 \mathrm{G}$ & 32706 & $\mathrm{~T}, \mathrm{~S}$ & \\
\hline & $90031 \mathrm{~B}$ & 32628 & $\mathrm{~s}$ & $90036 \mathrm{H}$ & 32707 & & \\
\hline & $90031 \mathrm{E}$ & 32631 & $\mathrm{~T}, \mathrm{~S}$ & $90036 \mathrm{I}$ & 32708 & $T, S$ & \\
\hline & $90031 \mathrm{H}$ & 32634 & & $90036 \mathrm{~J}$ & 32709 & $\mathrm{~T}, \mathrm{~S}$ & \\
\hline & 900311 & 32635 & & $90038 \mathrm{D}$ & 32714 & $\mathrm{~S}$ & \\
\hline & 90031J & 32636 & $\mathrm{~T}, \mathrm{~S}$ & $90038 \mathrm{E}$ & 32715 & $\mathrm{~T}, \mathrm{~S}$ & \\
\hline & $90031 \mathrm{~K}$ & 32637 & $\mathrm{~T}, \mathrm{~S}$ & $90038 \mathrm{~F}$ & 32716 & $\mathrm{~T}, \mathrm{~S}$ & \\
\hline & $90031 \mathrm{M}$ & 32639 & $\mathrm{~T}, \mathrm{~S}$ & $90038 \mathrm{G}$ & 32717 & $\mathrm{~T}, \mathrm{~S}$ & \\
\hline & $90031 \mathrm{~N}$ & 32640 & $\mathrm{~T}, \mathrm{~S}$ & $90038 \mathrm{H}$ & 32718 & $\mathrm{~T}, \mathrm{~S}$ & \\
\hline & 90032 & 32645 & & $90038 \mathrm{I}$ & 32719 & $\mathrm{~T}, \mathrm{~S}$ & \\
\hline & $90033 \mathrm{~T}$ & 32665 & $\mathrm{~T}, \mathrm{P}$ & $90038 \mathrm{~J}$ & 32720 & $\mathrm{~T}, \mathrm{~S}$ & \\
\hline & $90033 \mathrm{Y}$ & 32670 & $\mathrm{~T}, \mathrm{~S}$ & $90038 \mathrm{~K}$ & 32721 & $\mathrm{~T}, \mathrm{~S}$ & \\
\hline & $90033 Z$ & 32671 & $\mathrm{~T}, \mathrm{~S}$ & $90038 \mathrm{~L}$ & 32722 & $\mathrm{~T}, \mathrm{~S}$ & \\
\hline & $90033 \mathrm{~A} 1$ & 32672 & $\mathrm{M}, \mathrm{T}, \mathrm{P}$ & $90038 \mathrm{M}$ & 32723 & $\mathrm{~T}, \mathrm{~S}$ & \\
\hline & $90033 \mathrm{II}$ & 32680 & $\mathrm{P}$ & $90039 \mathrm{H}$ & 32731 & $\mathrm{P}$ & \\
\hline
\end{tabular}




\section{A1.2 Mount Hampton Xenoliths}

\begin{tabular}{|c|c|c|c|c|c|c|c|}
\hline Field No & VUW No & Lithology & Analyses & Field No & VUW No & Lithology & Analyses \\
\hline \multicolumn{8}{|c|}{ Granulites } \\
\hline PK4A & 32875 & Norite & $\mathrm{M}, \mathrm{T}, \mathrm{P}$ & PK4Y & 32903 & Cpx Norite & $\mathrm{M}, \mathrm{T}, \mathrm{P}$ \\
\hline PK4R & 32896 & Opx Melgb & $\mathrm{M}, \mathrm{T}, \mathrm{P}$ & PK4C1 & 32907 & Melgb & $\mathrm{M}, \mathrm{T}, \mathrm{I}, \mathrm{R}, \mathrm{P}$ \\
\hline PK4V & 32900 & Opx Leugb & $\mathrm{M}, \mathrm{T}, \mathrm{P}$ & PK4LI & 32916 & Melgb & $\mathrm{M}, \mathrm{T}, \mathrm{I}, \mathrm{R}$ \\
\hline PK $4 \mathrm{X}$ & 32902 & Cpx Norite & M,T & & & & \\
\hline \multicolumn{8}{|c|}{ Pyroxenites } \\
\hline PK4B & 32876 & Pl Webst & $\mathrm{M}, \mathrm{T}, \mathrm{P}$ & PK4Q & 32895 & Websterite $\mathrm{N}$ & $\mathrm{M}, \mathrm{T}, \mathrm{P}$ \\
\hline PK4C & 32877 & Websterite & $\mathrm{M}, \mathrm{T}$ & PK4S & 32897 & Websterite $N$ & $\mathrm{M}, \mathrm{T}, \mathrm{P}$ \\
\hline PK4D & 32878 & Pl Webst & $\mathrm{M}, \mathrm{T}, \mathrm{P}$ & PK4T & 32898 & Pl Webst & $\mathrm{M}, \mathrm{T}, \mathrm{P}$ \\
\hline PK4I & 32879 & Websterite & $\mathrm{M}, \mathrm{T}$ & PK4B1 & 32906 & Cpxite & $\mathrm{P}$ \\
\hline PK4J & 32888 & Websterite & $\mathrm{M}, \mathrm{T}, \mathrm{P}$ & PK4D1 & 32908 & Websterite & $\mathrm{M}, \mathrm{T}, \mathrm{P}$ \\
\hline PK4K & 32889 & Websterite & $\mathrm{M}, \mathrm{T}$ & PK4O1 & 32919 & Pl Webst & $\mathrm{M}, \mathrm{T}, \mathrm{P}$ \\
\hline PK4L & 32890 & Websterite & $\mathrm{M}, \mathrm{T}, \mathrm{I}, \mathrm{R}, \mathrm{P}$ & PK4Q1 & 32879 & Websterite & $\mathrm{M}, \mathrm{T}$ \\
\hline PK4M & 32891 & Websterite & $\mathrm{M}, \mathrm{T}, \mathrm{P}$ & PK5E & 32925 & Websterite & $\mathrm{M}, \mathrm{T}, \mathrm{P}$ \\
\hline PK4N & 32892 & Websterite & $\mathrm{M}, \mathrm{T}, \mathrm{P}$ & PK5G & 32927 & Websterite $\mathrm{N}$ & $\mathrm{M}, \mathrm{T}, \mathrm{P}$ \\
\hline PK4P & 32879 & Websterite & $\mathrm{M}, \mathrm{T}$ & & & & \\
\hline & Field No & VUW No & Application & Field No & VUW No & Application & \\
\hline \multicolumn{8}{|c|}{ Peridotites } \\
\hline & PK1A & 32874 & $\mathrm{M}, \mathrm{T}$ & PK4K1 & 32915 & $\mathrm{M}, \mathrm{T}, \mathrm{S}$ & \\
\hline & PK4E & 32879 & $\mathrm{M}, \mathrm{T}$ & PK4M1 & 32917 & $\mathrm{M}, \mathrm{T}, \mathrm{S}$ & \\
\hline & PK4F & 32880 & M,T,S & PK4N1 & 32918 & $\mathrm{M}, \mathrm{T}, \mathrm{R}$ & \\
\hline & PK4G & 32881 & $\mathrm{M}, \mathrm{T}, \mathrm{R}, \mathrm{P}$ & PK4P1 & 32920 & $\mathrm{M}, \mathrm{T}$ & \\
\hline & PK4H & 32882 & $\mathrm{M}, \mathrm{T}$ & PK5A & 32921 & M,T,S & \\
\hline & PK4O & 32893 & $\mathrm{M}, \mathrm{T}, \mathrm{P}$ & PK5B & 32922 & M,TS & \\
\hline & PK4U & 32899 & $\mathrm{M}, \mathrm{T}$ & PK5C & 32923 & $\mathrm{M}, \mathrm{T}, \mathrm{S}$ & \\
\hline & PK4W & 32901 & $\mathrm{M}, \mathrm{T}, \mathrm{S}$ & PK5D & 32924 & $M, T, R, S$ & \\
\hline & PK4Z & 32904 & M,T,P & PK5F & 32926 & $\mathrm{M}, \mathrm{T}, \mathrm{S}$ & \\
\hline & PK4A1 & 32905 & $\mathrm{M}, \mathrm{T}, \mathrm{P}$ & PK5H & 32928 & $\mathrm{M}, \mathrm{T}, \mathrm{S}$ & \\
\hline & PK4E1 & 32909 & M,T,S & PK5I & 32929 & $\mathrm{M}, \mathrm{T}, \mathrm{S}$ & \\
\hline & PK4F1 & 32910 & $\mathrm{M}, \mathrm{T}, \mathrm{P}$ & PK5J & 32930 & $M, T, R, S$ & \\
\hline & PK4G1 & 32911 & M,T,R,P & PK5K & 32931 & $\mathrm{~S}$ & \\
\hline & PK4H1 & 32912 & $\mathrm{M}, \mathrm{T}, \mathrm{R}, \mathrm{P}$ & PK5L & 32932 & $\mathrm{M}, \mathrm{T}$ & \\
\hline & PK4I1 & 32913 & $\mathrm{M}, \mathrm{T}, \mathrm{S}$ & PK5M & 32933 & $\mathrm{M}, \mathrm{T}$ & \\
\hline & PK4J1 & 32914 & $\mathrm{M}, \mathrm{T}, \mathrm{S}$ & & & & \\
\hline
\end{tabular}




\section{A1.3 Mount Murphy Xenoliths}

\begin{tabular}{|c|c|c|c|c|c|c|c|}
\hline Field No & VUW No & Lithology & Analyses & Field No & VUW No & Lithology & Analyses \\
\hline \multicolumn{8}{|c|}{90041 Granulites } \\
\hline $90041 \mathrm{~A}$ & 32834 & Leugb & M,T,P & $90041 \mathrm{~F}$ & 32839 & Ol Leugb & $\mathrm{M}, \mathrm{T}, \mathrm{S}$ \\
\hline 90041B & 32835 & Leutroct & $\mathrm{M}, \mathrm{T}, \mathrm{I}, \mathrm{R}, \mathrm{P}$ & $90041 G$ & 32840 & Ol Leugb & $\mathrm{P}$ \\
\hline $90041 \mathrm{C}$ & 32836 & Leugb & $\mathrm{M}, \mathrm{T}, \mathrm{I}, \mathrm{R}, \mathrm{P}$ & $90041 \mathrm{H}$ & 32841 & Leugb & $\mathrm{M}, \mathrm{T}$ \\
\hline 90041D & 32837 & Leutroct & $\mathrm{M}, \mathrm{T}$ & 900411 & 32842 & Troctolite & $\mathrm{M}, \mathrm{T}, \mathrm{P}$ \\
\hline $90041 \mathrm{E}$ & 32838 & Ol Gabbro & $\mathrm{S}$ & $90041 \mathrm{~J}$ & 32843 & Troctolite & $\mathrm{M}, \mathrm{T}$ \\
\hline \multicolumn{8}{|c|}{90048 Granulites } \\
\hline $90048 \mathrm{C}$ & 32847 & Ol Melgb & M,T,S & $90048 \mathrm{~F}$ & 32850 & Ol Gabbro & $\mathrm{T}, \mathrm{P}$ \\
\hline $90048 \mathrm{E}$ & 32849 & Leugb & $\mathrm{M}, \mathrm{T}, \mathrm{P}$ & $90048 \mathrm{G}$ & 32851 & Leugb & $\mathrm{M}, \mathrm{T}, \mathrm{P}$ \\
\hline \multicolumn{8}{|c|}{90044 Pyroxenites } \\
\hline $90044 \mathrm{~A}$ & 32844 & Cpxite & $\mathrm{M}, \mathrm{T}, \mathrm{P}$ & & & & \\
\hline \multicolumn{8}{|c|}{90048 Pyroxenites } \\
\hline $90048 \mathrm{~A}$ & 32845 & Ol Cpxite & $\mathrm{M}, \mathrm{T}$ & $90048 \mathrm{D}$ & 32848 & PI Cpxite & $\mathrm{M}, \mathrm{T}, \mathrm{P}$ \\
\hline $90048 \mathrm{~B}$ & 32846 & Ol Cpxite & $\mathrm{M}, \mathrm{T}, \mathrm{P}$ & & & & \\
\hline \multicolumn{8}{|c|}{90054 Pyroxenites } \\
\hline $90054 \mathrm{C}$ & 32855 & Ol Cpxite & $\mathrm{M}, \mathrm{T}, \mathrm{I}, \mathrm{R}, \mathrm{P}$ & $90054 \mathrm{~K}$ & 32863 & Ol Cpxite & M,T,I,R,P \\
\hline $90054 \mathrm{~F}$ & 32858 & Ol Cpxite & $\mathrm{M}, \mathrm{T}$ & $90054 \mathrm{P}$ & 32868 & Ol Cpxite & $\mathrm{T}, \mathrm{S}$ \\
\hline $90054 \mathrm{G}$ & 32859 & Cpxite & $M, T, S$ & $90054 \mathrm{~S}$ & 32871 & Ol Cpxite & $\mathrm{T}, \mathrm{P}$ \\
\hline $90054 \mathrm{I}$ & 32861 & Ol Cpxite & $\mathrm{M}, \mathrm{T}, \mathrm{P}$ & & & & \\
\hline & Field No & VUW No & Application & Field No & VUW No & Application & \\
\hline \multicolumn{8}{|c|}{ Peridotites } \\
\hline & $90054 \mathrm{~A}$ & 32853 & $\mathrm{~T}, \mathrm{R}, \mathrm{S}$ & $90054 \mathrm{M}$ & 32865 & $M, T, S$ & \\
\hline & $90054 \mathrm{~B}$ & 32854 & $\mathrm{M}, \mathrm{T}, \mathrm{R}, \mathrm{S}$ & $90054 \mathrm{~N}$ & 32866 & $M, T, S$ & \\
\hline & $90054 \mathrm{D}$ & 32856 & $\mathrm{M}, \mathrm{T}$ & 900540 & 32867 & $M, T, S$ & \\
\hline & $90054 \mathrm{E}$ & 32857 & $M, T, R, S$ & $90054 Q$ & 32869 & $\mathrm{M}, \mathrm{T}, \mathrm{S}$ & \\
\hline & $90054 \mathrm{H}$ & 32860 & $M, T, S$ & $90054 \mathrm{R}$ & 32870 & M,T,S & \\
\hline & 90054J & 32862 & $\mathrm{M}, \mathrm{T}, \mathrm{P}$ & $90054 \mathrm{~T}$ & 32872 & M,T,S & \\
\hline & $90054 \mathrm{~L}$ & 32863 & $\mathrm{M}, \mathrm{T}, \mathrm{S}$ & $90065 \mathrm{U}$ & 32873 & $\mathrm{M}, \mathrm{T}$ & \\
\hline
\end{tabular}




\section{A1.4 Mount Cumming Xenoliths}

\begin{tabular}{|c|c|c|c|c|c|c|c|}
\hline Field No & VUW No & Lithology & Analyses & Field No & VUW No & Lithology & Analyses \\
\hline \multicolumn{8}{|c|}{ Granulites } \\
\hline $90040 \mathrm{I}$ & 32770 & Gabbro & $\mathrm{M}, \mathrm{T}, \mathrm{I}, \mathrm{R}, \mathrm{P}$ & $90040 \mathrm{~N} 2$ & 32827 & Gabbro & $\mathrm{M}, \mathrm{T}, \mathrm{S}$ \\
\hline $90040 \mathrm{~J}$ & 32771 & Gabbro & $\mathrm{S}$ & 9004002 & 32828 & Gabbro & $M, T, S$ \\
\hline $90040 \mathrm{~W}$ & 32784 & Gabbro & M,T,P & 90040P2 & 32829 & Gabbro & $\mathrm{M}, \mathrm{T}, \mathrm{S}$ \\
\hline $90040 Y$ & 32786 & Gabbro & $\mathrm{M}, \mathrm{T}, \mathrm{P}$ & $90040 \mathrm{Q} 2$ & 32830 & Gabbro & $\mathrm{S}$ \\
\hline $90040 \mathrm{~F} 1$ & 32793 & Gabbro & & 90040R2 & 32831 & Gabbro & $\mathrm{S}$ \\
\hline $90040 \mathrm{M} 2$ & 32826 & Gabbro & $M, T, S$ & & & & \\
\hline & Field No & VUW No & Application & Field No & VUW No & Application & \\
\hline \multicolumn{8}{|c|}{ Perid otites } \\
\hline & $90040 \mathrm{~A}$ & 32762 & $\mathrm{~S}$ & $90040 \mathrm{~K} 1$ & 32798 & & \\
\hline & $90040 \mathrm{~B}$ & 32763 & $\mathrm{~S}$ & $90040 \mathrm{M} 1$ & 32800 & $\mathrm{P}$ & \\
\hline & $90040 \mathrm{C}$ & 32764 & P & 9004001 & 32802 & $\mathrm{~T}, \mathrm{P}$ & \\
\hline & $90040 \mathrm{D}$ & 32765 & $\mathrm{~T}$ & 90040P1 & 32803 & $\mathrm{~T}$ & \\
\hline & $90040 \mathrm{E}$ & 32766 & $\mathrm{M}, \mathrm{T}, \mathrm{R}, \mathrm{S}$ & $90040 \mathrm{Q} 1$ & 32804 & $\mathrm{~S}$ & \\
\hline & $90040 \mathrm{~F}$ & 32767 & $\mathrm{~T}, \mathrm{~S}$ & 90040R1 & 32805 & & \\
\hline & $90040 \mathrm{G}$ & 32768 & $\mathrm{M}, \mathrm{T}, \mathrm{P}$ & $90040 \$ 1$ & 32806 & $\mathrm{M}, \mathrm{T}, \mathrm{S}$ & \\
\hline & $90040 \mathrm{H}$ & 32769 & $\mathrm{M}, \mathrm{T}, \mathrm{I}, \mathrm{R}, \mathrm{S}$ & $90040 \mathrm{~T} 1$ & 32807 & $\mathrm{~T}, \mathrm{~S}$ & \\
\hline & $90040 \mathrm{~K}$ & 32772 & $\mathrm{M}, \mathrm{T}$ & $90040 \mathrm{U1}$ & 32808 & M,T,R,S & \\
\hline & $90040 \mathrm{M}$ & 32774 & $\mathrm{~T}, \mathrm{~S}$ & $90040 \mathrm{~V} 1$ & 32809 & $\mathrm{~T}, \mathrm{~S}$ & \\
\hline & $90040 \mathrm{~N}$ & 32775 & M,T,S & $90040 W 1$ & 32810 & $\mathrm{~T}, \mathrm{~S}$ & \\
\hline & 900400 & 32776 & $\mathrm{~S}$ & $90040 \times 1$ & 32811 & $\mathrm{~T}, \mathrm{~S}$ & \\
\hline & $90040 \mathrm{P}$ & 32777 & M,T,P & $90040 Y 1$ & 32812 & $\mathrm{~T}$ & \\
\hline & $90040 Q$ & 32778 & $\mathrm{P}$ & $90040 \mathrm{Z1}$ & 32813 & $\mathrm{~T}, \mathrm{~S}$ & \\
\hline & $90040 \mathrm{R}$ & 32779 & P & $90040 \mathrm{~A} 2$ & 32814 & $\mathrm{~T}, \mathrm{~S}$ & \\
\hline & $90040 \mathrm{~S}$ & 32780 & $\mathrm{P}$ & $90040 \mathrm{~B} 2$ & 32815 & $\mathrm{~T}$ & \\
\hline & $90040 \mathrm{~T}$ & 32781 & $\mathrm{~T}, \mathrm{P}$ & $90040 \mathrm{C} 2$ & 32816 & $\mathrm{~T}$ & \\
\hline & $90040 \mathrm{U}$ & 32782 & $\mathrm{M}, \mathrm{T}, \mathrm{R}$ & $90040 \mathrm{D} 2$ & 32817 & $\mathrm{~T}$ & \\
\hline & $90040 X$ & 32785 & & $90040 F 2$ & 32818 & $\mathrm{~T}, \mathrm{~S}$ & \\
\hline & $90040 Z$ & 32787 & $T, P$ & $90040 \mathrm{~F} 2$ & 32819 & $\mathrm{~T}, \mathrm{~S}$ & \\
\hline & $90040 \mathrm{~A} 1$ & 32788 & $\mathrm{P}$ & $90040 \mathrm{G} 2$ & 32820 & M,T,P & \\
\hline & $9004 \mathrm{~B} 1$ & 32789 & & $90040 \mathrm{H} 2$ & 32821 & $\mathrm{~S}$ & \\
\hline & $90040 \mathrm{C} 1$ & 32790 & $\mathrm{P}$ & $90040 \mathrm{I} 2$ & 32822 & $\mathrm{~S}$ & \\
\hline & $90040 \mathrm{D} 1$ & 32791 & $\mathrm{P}$ & $90040 J 2$ & 32823 & $\mathrm{~S}$ & \\
\hline & $90040 \mathrm{EI}$ & 32792 & $\mathrm{P}$ & $90040 \mathrm{~K} 2$ & 32824 & $\mathrm{~S}$ & \\
\hline & $90040 \mathrm{G} 1$ & 32794 & $\mathrm{P}$ & 90040L2 & 32825 & $\mathrm{~T}, \mathrm{~S}$ & \\
\hline & $90040 \mathrm{H} 1$ & 32795 & & $90040 \mathrm{~A} 3$ & 32833 & $\mathrm{M}, \mathrm{T}, \mathrm{S}$ & \\
\hline \multicolumn{8}{|c|}{ Upper crustal } \\
\hline & $90040 \mathrm{~L}$ & 32773 & $\mathrm{M}, \mathrm{T}, \mathrm{S}$ & $90040 \mathrm{~J} 1$ & 32797 & $\mathrm{~T}, \mathrm{P}$ & \\
\hline & $90040 \mathrm{~V}$ & 32783 & T,P & 90040L1 & 32799 & $\mathrm{~T}, \mathrm{P}$ & \\
\hline & $90040 \mathrm{I} 1$ & 32796 & & $90040 S 2$ & 32832 & $\mathrm{~S}$ & \\
\hline
\end{tabular}




\section{A1.5 Mount Waesche Xenoliths}

\begin{tabular}{|c|c|c|c|c|c|c|}
\hline Field No & VUW No & Lithology & Analyses & Field No & VUW No & Lithology Analyses \\
\hline \multicolumn{7}{|c|}{ Granulites } \\
\hline 890011 & 32564 & Gabbro & $\mathrm{M}, \mathrm{T}, \mathrm{P}$ & $89001 \mathrm{~L}$ & 32567 & Gabbro \\
\hline & Field No & VUW No & Application & Field No & VUW No & Application \\
\hline \multicolumn{7}{|c|}{ Upper crustal } \\
\hline & $89001 \mathrm{~A}$ & 32556 & $\mathrm{P}$ & 89003 & 32573 & \\
\hline & $89001 B$ & 32557 & & 89004 & 32574 & \\
\hline & $89001 C$ & 32558 & $\mathrm{~T}, \mathrm{P}$ & 89005 & 32575 & \\
\hline & 89001D & 32559 & $\mathrm{~T}$ & 89006 & 32576 & \\
\hline & $89001 \mathrm{E}$ & 32560 & $\mathrm{M}, \mathrm{T}, \mathrm{P}$ & 89007 & 32577 & $\mathrm{M}, \mathrm{T}, \mathrm{P}$ \\
\hline & $89001 \mathrm{~F}$ & 32561 & M,T,P & 89008 & 32578 & \\
\hline & $89001 \mathrm{G}$ & 32562 & $\mathrm{P}$ & 89009 & 32579 & $\mathrm{M}, \mathrm{T}, \mathrm{P}$ \\
\hline & $89001 \mathrm{H}$ & 32563 & $P$ & 89010 & 32580 & T,P \\
\hline & $89001 \mathrm{~J}$ & 32565 & $P$ & 89011 & 32581 & $\mathrm{P}$ \\
\hline & $89001 \mathrm{~K}$ & 32566 & & 89012 & 32582 & \\
\hline & $89001 \mathrm{M}$ & 32568 & S & 89013 & 32583 & \\
\hline & $89001 \mathrm{~N}$ & 32569 & S & 89014 & 32584 & \\
\hline & 890010 & 32570 & P & 89015 & 32585 & \\
\hline & $89002 \mathrm{~A}$ & 32571 & $\mathrm{~T}, \mathrm{P}$ & 89017 & 32586 & \\
\hline & $89002 B$ & 32572 & $\mathrm{M}, \mathrm{T}, \mathrm{P}$ & 89018 & 32587 & \\
\hline
\end{tabular}

\section{A1.6 USAS Escarpment Xenoliths}

\begin{tabular}{llll|lll}
\hline Field No & VUW No & Application & Field No & VUW No & Application \\
\hline \multicolumn{7}{c}{ Peridotites } \\
MB69A & 32934 & M,T,S & MB69F & 32939 & M,T,R,S \\
MB69B & 32935 & T,R,S & MB69G & 32940 & M,T,S \\
MB69C & 32936 & M,T,P & MB69H & 32941 & M,T,R,S \\
MB69D & 32937 & M,T,S & MB69I & 32942 & M,T,S \\
MB69E & 32938 & M,T,S & & & \\
\end{tabular}




\section{Appendix two \\ MODAL ANALYSES}

\section{Introduction}

Modal point counts were made on representative slides of the xenolith suite; for granulites and pyroxenites from Mounts Sidley, Hampton and Murphy. Each slide was subjected to 500 point counts, with a spacing of $2 \mathrm{~mm}$ to entirely cover the whole slide.

Errors associated with point counting vary depending on mainly on the number of counts and the proportion of mineral phases. At 500 point counts, for minerals consisting of: $1 \%$ of the mineral assemblage, errors are approximately \pm $0.5 \%$; for $10 \%$ of the mineral assemblage, errors are approximately $\pm 2.5 \%$; for 20 $\%$ of the mineral assemblage, errors are approximately $\pm 3.5 \%$; for $30 \%$ of the mineral assemblage, errors are approximately $\pm 4.0 \%$; and for $40 \%$ of the mineral assemblage, errors are approximately $\pm 4.3 \%$. Other factors that contribute to errors include the grain size and spacing of the grid, the refractive index and opacity of the minerals, and mistakes made in mineral identification. For a full description of errors associated with point counting, see van der Plas and Tobi (1965).

The large grain size of the xenolith suite requires a number of slides to be counted to obtain more accurate analyses. However, in many cases, the xenoliths are too small for multiple slides, and only one slide from each xenolith was counted to maintain consistency in point counting. Due to the large grain size, real errors associated with point counting on the xenolith suite are likely to be higher than the estimates given above.

Modal counts are of total mineral phases only, and minerals have not been distinguished between igneous and metamorphic phases, or primary or secondary minerals. Furthermore, the large extent of oxidation has resulted in a sometimes large proportion of opaque minerals (olivine and orthopyroxene) that are 
optically difficult to distinguish from oxides. All opaque minerals are grouped together as 'opaques' in the following tables. Accessory minerals are primarily apatite and rhönite, although other unidentified minerals may also be present; e.g. zircon. 
A2.1 Mount Sidley xenolith modes

\begin{tabular}{|c|c|c|c|c|c|c|c|c|}
\hline SAMPLE & $90029 \mathrm{C}$ & $90029 \mathrm{H}$ & 90029P & $90029 \mathrm{~V}$ & $90029 X$ & 90029D1 & 90029G1 & 90031D \\
\hline TYPE & Type M & Type M & Type L & Type M & Type L & Type L & & \\
\hline Olivine & 6.0 & 22.2 & 2.0 & 2.6 & $\operatorname{Tr}$ & 6.8 & 3.2 & - \\
\hline Clinopyroxene & 25.2 & 3.0 & 20.6 & 18.2 & 10.2 & 3.4 & 0.6 & 5.0 \\
\hline Orthopyroxene & - & - & - & - & - & - & - & - \\
\hline Plagioclase & 31.8 & 52.0 & 64.4 & 28.2 & 73.0 & 83.0 & 83.0 & 78.8 \\
\hline Kaersutite & 0.2 & - & 0.6 & - & 0.4 & $\operatorname{Tr}$ & - & 4.2 \\
\hline Opaques & 35.4 & 20.8 & 12.4 & 50.8 & 15.6 & 6.4 & 14.8 & 10.0 \\
\hline Accessories & 1.4 & 0.2 & - & 2.2 & 0.8 & 0.4 & 0.4 & 2.0 \\
\hline
\end{tabular}

\begin{tabular}{|c|c|c|c|c|c|c|c|c|}
\hline $\begin{array}{l}\text { SAMPLE } \\
\text { TYPE }\end{array}$ & $\begin{array}{l}\text { 90031G } \\
\text { Type C }\end{array}$ & $\begin{array}{l}\text { 90033A } \\
\text { Type P }\end{array}$ & $\begin{array}{l}90033 \mathrm{~B} \\
\text { Type P }\end{array}$ & $\begin{array}{l}90033 \mathrm{C} \\
\text { Type P }\end{array}$ & $\begin{array}{l}\text { 90033D } \\
\text { Type P }\end{array}$ & $\begin{array}{l}\text { 90033E } \\
\text { Type P }\end{array}$ & $\begin{array}{l}\text { 90033F } \\
\text { Type P }\end{array}$ & $\begin{array}{l}\text { 90033G } \\
\text { Type P }\end{array}$ \\
\hline Olivine & - & 12.8 & 7.8 & 34.2 & 58.4 & 17.8 & 69.8 & 9.8 \\
\hline Clinopyroxene & 34.4 & 79.8 & 64.8 & 32.0 & 35.0 & 57.2 & 10.4 & 65.0 \\
\hline Orthopyroxene & - & - & - & - & - & - & - & - \\
\hline Plagioclase & 36.4 & - & 7.4 & 0.2 & - & 16.2 & 1.8 & 5.6 \\
\hline Kaersutite & 23.2 & 4.0 & 3.6 & 31.6 & - & 3.4 & 11.6 & - \\
\hline Opaques & 5.6 & 3.4 & 16.4 & 2.0 & 6.6 & 5.4 & 6.4 & 20.6 \\
\hline Accessories & 0.4 & - & - & - & - & - & - & - \\
\hline
\end{tabular}

\begin{tabular}{|c|c|c|c|c|c|c|c|c|}
\hline $\begin{array}{l}\text { SAMPLE } \\
\text { TYPE }\end{array}$ & $\begin{array}{l}90033 \mathrm{~J} \\
\text { Type P }\end{array}$ & $\begin{array}{c}\text { 90033K } \\
\text { Type M }\end{array}$ & $\begin{array}{l}\text { 90033L } \\
\text { Type P }\end{array}$ & $\begin{array}{c}\text { 90033H1 } \\
\text { Type C }\end{array}$ & $\begin{array}{c}\text { 90033P1 } \\
\text { Type C }\end{array}$ & $\begin{array}{c}\text { 90039D } \\
\text { Type L }\end{array}$ & $\begin{array}{l}\text { 90039G } \\
\text { Type P }\end{array}$ & $\begin{array}{l}\text { 90039M } \\
\text { Type L }\end{array}$ \\
\hline Olivine & 29.8 & 6.2 & 69.0 & 15.6 & 7.6 & 27.8 & 4.2 & $\operatorname{Tr}$ \\
\hline Clinopyroxene & 33.8 & 47.8 & 23.0 & 34.8 & 51.2 & 0.2 & 19.0 & 9.0 \\
\hline Orthopyroxene & - & - & - & - & - & - & - & - \\
\hline Plagioclase & 11.6 & 24.0 & 0.6 & 39.0 & 26.4 & 69.6 & 59.6 & 62.6 \\
\hline Kaersutite & 22.6 & - & - & 3.8 & 6.6 & 0.9 & 5.0 & 0.2 \\
\hline Opaques & 2.2 & 21.4 & 7.4 & 6.2 & 8.2 & 1.2 & 12.2 & 23.8 \\
\hline Accessories & 1.2 & 0.2 & - & - & - & 0.4 & - & 8.8 \\
\hline
\end{tabular}


A2.2 Mount Hampton xenolith modes

\begin{tabular}{lcccccccc}
\hline SAMPLE & $\begin{array}{c}\text { PK4J } \\
\text { TYPE }\end{array}$ & $\begin{array}{c}\text { PK4Q } \\
\text { Pyrox }\end{array}$ & $\begin{array}{c}\text { PK4S } \\
\text { Pyrox }\end{array}$ & $\begin{array}{c}\text { PK4V } \\
\text { Gran }\end{array}$ & $\begin{array}{c}\text { PK4Y } \\
\text { Gran }\end{array}$ & $\begin{array}{c}\text { PK4B1 } \\
\text { Pyrox }\end{array}$ & $\begin{array}{c}\text { PK4C1 } \\
\text { Gran }\end{array}$ & $\begin{array}{c}\text { PK4D1 } \\
\text { Pyrox }\end{array}$ \\
\hline Olivine & - & - & - & - & - & - & - & - \\
Clinopyroxene & 64.6 & 73.4 & 65.6 & 21.0 & 15.4 & 84.4 & 40.0 & 30.2 \\
Orthopyroxene & 33.2 & 17.0 & 26.0 & - & 12.2 & 9.6 & 14.2 & 54.6 \\
Plagioclase & - & - & - & 70.0 & 59.4 & - & 27.6 & - \\
Kaersutite & - & - & - & - & - & - & - & - \\
Opaques & 2.0 & 8.8 & 7.8 & $8.2^{*}$ & 12.2 & 5.2 & 17.2 & 14.2 \\
Accessories & 0.2 & 0.8 & 0.6 & 0.8 & 0.8 & 0.8 & 1.0 & 0.4 \\
& & & & & & & & \\
\hline
\end{tabular}

A2.3 Mount Murphy xenolith modes

\begin{tabular}{lcccccccc}
\hline SAMPLE & $\begin{array}{c}90041 \mathrm{~B} \\
\text { TYPE }\end{array}$ & $\begin{array}{c}90041 \mathrm{C} \\
\text { Gran }\end{array}$ & $\begin{array}{c}90048 \mathrm{G} \\
\text { Gran }\end{array}$ & $\begin{array}{c}90048 \mathrm{~F} \\
\text { Gran }\end{array}$ & $\begin{array}{c}90044 \\
\text { Pyxite }\end{array}$ & $\begin{array}{c}90048 \mathrm{D} \\
\text { Pyxite }\end{array}$ & $\begin{array}{c}90054 \mathrm{C} \\
\text { Pyxite }\end{array}$ & $\begin{array}{c}90054 \mathrm{~K} \\
\text { Pyxite }\end{array}$ \\
\hline Olivine & 29.4 & - & 0.5 & 8.8 & - & 26.2 & 11.2 & 12.2 \\
Clinopyroxene & 3.6 & 23.6 & 8.4 & 30.6 & 66.2 & 54.4 & 87.6 & 78.0 \\
Orthopyroxene & - & - & - & - & 31.6 & - & - & - \\
Plagioclase & 61.0 & 68.8 & 83.4 & 54.6 & - & 10.8 & - & 0.4 \\
Kaersutite & - & 4.4 & - & - & - & - & - & - \\
Opaques & 4.8 & 3.2 & 6.4 & 5.2 & 2.2 & 8.2 & 1.2 & 8.8 \\
Accessories & 1.2 & - & 1.4 & 0.8 & - & 0.4 & - & 0.6 \\
& & & & & & & & \\
\hline
\end{tabular}




\section{Appendix three \\ MICROPROBE MINERAL ANALYSES}

\section{Introduction}

Polished thin sections of selected xenoliths were analysed for mineral compositions on a JEOL-733 Superprobe at Victoria University of Wellington. The initial method used was modified from that of Bence and Albee (1969). For the later part of this work, the full ZAF correction was used.

Anhydrous silicates were analysed at $15 \mathrm{kV}$ and $1.2 \times 10-8 \mathrm{~A}$, and hydrous minerals, oxides and glasses were analysed at $0.8 \times 10^{-8} \mathrm{~A}$ with a defocused beam (10-20 $\mu \mathrm{m}$ diameter). Precision of analyses is approximately $1 \%$ for elements with abundances $>10 \%$, and from $5-10 \%$ for low abundance elements.

\section{Abbreviations}

Abbreviations for sample types can be found in Appendix Four. Other abbreviations used here are as follows:

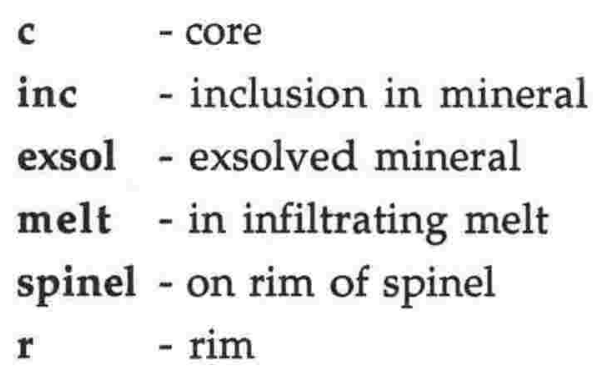
dk - dark part of oxidised olivine kaerst - in kaersutitisation reaction lgt - light part of oxidised olivine oxid - in oxidation reaction symp - in olivine symplectite " - " - relates this analysis to the following analysis


A3.1 Mount Sidley xenolith mineral analyses: olivine

\begin{tabular}{|c|c|c|c|c|c|c|c|c|c|c|c|c|c|c|}
\hline $\begin{array}{l}\text { Sample } \\
\text { Type }\end{array}$ & $\begin{array}{c}90029 \mathrm{C} \\
\text { Type M } \\
\text { core }\end{array}$ & $\begin{array}{c}90029 \mathrm{C} \\
\text { Type M } \\
\text { core }\end{array}$ & $\begin{array}{c}90029 \mathrm{C} \\
\text { Type M } \\
\text { core } \\
\end{array}$ & $\begin{array}{c}90029 \mathrm{C} \\
\text { Type M } \\
\text { core }\end{array}$ & $\begin{array}{c}90029 \mathrm{~V} \\
\text { Type M } \\
\text { oxid }\end{array}$ & $\begin{array}{c}90029 B 1 \\
\text { Type L } \\
\text { core }\end{array}$ & $\begin{array}{c}\text { 90029B1 } \\
\text { Type L } \\
\text { core }\end{array}$ & $\begin{array}{c}\text { 90033A } \\
\text { Type P } \\
\text { oxid }\end{array}$ & $\begin{array}{c}90033 \mathrm{~A} \\
\text { Type } \mathrm{P} \\
\text { core }\end{array}$ & $\begin{array}{c}90033 \mathrm{~A} \\
\text { Type P } \\
\text { core }\end{array}$ & $\begin{array}{c}90033 B \\
\text { Type P } \\
\text { oxid }\end{array}$ & $\begin{array}{c}90033 \mathrm{C} \\
\text { Type P } \\
\text { core } \\
\end{array}$ & $\begin{array}{l}90033 \mathrm{C} \\
\text { Type P } \\
\text { kaerst }\end{array}$ & $\begin{array}{c}90033 \mathrm{C} \\
\text { Type P } \\
\text { core } \\
\end{array}$ \\
\hline $\mathrm{SiO}_{2}$ & 35.55 & 35.84 & 35.63 & 35.79 & 43.18 & 36.36 & 35.67 & 38.12 & 37.86 & 37.23 & 37.55 & 37.55 & 3751 & 3758 \\
\hline $\mathrm{A} 12 \mathrm{O} 3$ & 0.18 & 0.11 & 0.19 & 0.00 & 0.30 & 0.19 & 0.00 & 0.02 & 0.05 & 0.02 & 0.08 & 0.03 & 0.70 & 0.03 \\
\hline $\mathrm{TiO}_{2}$ & 0.05 & 0.04 & 0.19 & 0.00 & 0.07 & 0.12 & 0.09 & 0.02 & 0.08 & 0.02 & 0.00 & 0.03 & 3.08 & 0.08 \\
\hline $\mathrm{FeO}$ & 40.24 & 39.04 & 39.56 & 39.73 & 23.75 & 36.24 & 39.84 & 27.40 & 21.50 & 26,80 & 29.54 & 24.10 & 17.06 & 25.34 \\
\hline $\mathrm{MnO}$ & 1.07 & 0.84 & 0.87 & 0.86 & 1.03 & 0.84 & 0.91 & 0.28 & 0.26 & 0.29 & 0.31 & 0.29 & 0.37 & 0.46 \\
\hline $\mathrm{MgO}$ & 23.43 & 22.97 & 23.66 & 23.21 & 31.98 & 25.96 & 2283 & 34.05 & 39.05 & 35.15 & 31.45 & 36.79 & 40.09 & 35.79 \\
\hline $\mathrm{CaO}$ & 0.13 & 0.16 & 0.09 & 0.20 & 0.37 & 0.16 & 0.19 & 0.10 & 0.32 & 0.12 & 0.17 & 0.28 & 0.23 & 0.18 \\
\hline $\mathrm{Na} 2 \mathrm{O}$ & 0.00 & 0.00 & 0.00 & 0.00 & 0.20 & 0.00 & 0.00 & 0.00 & 0.03 & 0.03 & 0.02 & 0.00 & 0.01 & 0.00 \\
\hline $\mathrm{K} 2 \mathrm{O}$ & 0.06 & 0.04 & 0.05 & 0.00 & 0.10 & 0.00 & 0.00 & 0.00 & 0.01 & 0.01 & 0.00 & 0.00 & 0.13 & 0.01 \\
\hline TOTAL & 100.71 & 99.04 & 100.24 & 99.79 & 100.99 & 99.87 & 99.52 & 99.99 & 99.15 & 99.66 & 99.12 & 99.06 & 99.17 & 99.46 \\
\hline $\mathrm{Si}$ & 1.007 & 1.030 & 1.011 & 1.020 & 1.107 & 1.016 & 1.020 & 1.014 & 0.992 & 0.994 & 1.018 & 0.996 & 0.964 & 0.999 \\
\hline Al & 0.006 & 0.003 & 0.006 & 0.000 & 0.009 & 0.006 & 0.000 & 0.001 & 0.004 & 0.001 & 0.003 & 0.001 & 0.021 & 0.004 \\
\hline $\mathbf{T i}$ & 0.001 & 0.000 & 0.000 & 0.000 & 0.001 & 0.000 & 0.000 & 0.001 & 0.004 & 0.001 & 0.000 & 0.001 & 0.060 & 0.008 \\
\hline $\mathrm{Fe}$ & 0.953 & 0.933 & 0.939 & 0.945 & 0.509 & 0.846 & 0.953 & 0.610 & 0.471 & 0.599 & 0.670 & 0.535 & 0.367 & 0.563 \\
\hline $\mathrm{Mn}$ & 0.026 & 0.020 & 0.021 & 0.021 & 0.022 & 0.019 & 0.022 & 0.006 & 0.006 & 0.007 & 0.007 & 0.007 & 0.008 & 0.010 \\
\hline $\mathbf{M g}$ & 0.989 & 0.979 & 1.000 & 0.984 & 1.221 & 1.080 & 0.973 & 1.351 & 1.525 & 1.400 & 1.271 & 1.455 & 1.537 & 1.418 \\
\hline $\mathrm{Ca}$ & 0.004 & 0.005 & 0.003 & 0.006 & 0.010 & 0.005 & 0.006 & 0.003 & 0.009 & 0.005 & 0.005 & 0.012 & 0.060 & 0.005 \\
\hline $\mathrm{Na}$ & 0.000 & 0.001 & 0.000 & 0.000 & 0.010 & 0.000 & 0.000 & 0.000 & 0.003 & 0.002 & 0.001 & 0.000 & 0.001 & 0.000 \\
\hline $\mathbf{K}$ & 0.002 & 0.000 & 0.000 & 0.000 & 0.000 & 0.000 & 0.000 & 0.000 & 0.001 & 0.000 & 0.000 & 0.000 & 0.040 & 0.001 \\
\hline TOTAL & 2988 & 2.971 & 2.980 & 2.976 & 2.889 & 2.972 & 2.974 & 2986 & 3.015 & 3.009 & 2975 & 3.007 & 3.058 & 3.008 \\
\hline Mg\# & 50.93 & 51.20 & 51.57 & 51.01 & 70.58 & 56.07 & 50.52 & 68.89 & 76.40 & 70.04 & 65.48 & 73.12 & 80.72 & 71.58 \\
\hline
\end{tabular}

\begin{tabular}{|c|c|c|c|c|c|c|c|c|c|c|c|c|c|c|}
\hline Sample & $90033 \mathrm{G} 1$ & $90033 \mathrm{CI}$ & $90033 \mathrm{G} 1$ & $90033 \mathrm{G1}$ & $90033 \mathrm{P} 1$ & $90033 \mathrm{P} 1$ & $90033 \mathrm{P} 1$ & $90033 \mathrm{P} 1$ & $90033 \mathrm{P} 1$ & $90033 \mathrm{Q} 1$ & $90033 \mathrm{Q} 1$ & $90033 Q 1$ & $90033 \mathrm{Q} 1$ & $90033 \mathrm{Q} 1$ \\
\hline Type & $\begin{array}{c}\text { Type L } \\
\text { oxid }\end{array}$ & $\begin{array}{c}\text { Type L } \\
\text { core }\end{array}$ & $\begin{array}{c}\text { Type L } \\
\text { core }\end{array}$ & $\begin{array}{c}\text { Type L } \\
\text { core }\end{array}$ & $\begin{array}{c}\text { Type C } \\
\text { oxid }\end{array}$ & $\begin{array}{c}\text { Type C } \\
\text { oxid }\end{array}$ & $\begin{array}{c}\text { Type C } \\
\text { oxid }\end{array}$ & $\begin{array}{c}\text { Type C } \\
\text { oxid }\end{array}$ & $\begin{array}{c}\text { Type C } \\
\text { oxid } \\
\end{array}$ & $\begin{array}{c}\text { Type } \mathbf{P} \\
\text { core } \\
\end{array}$ & $\begin{array}{c}\text { Type } P \\
\text { core }\end{array}$ & $\begin{array}{c}\text { Type } \mathbf{P} \\
\text { rim }\end{array}$ & $\begin{array}{c}\text { Type } \mathrm{P} \\
\text { core }\end{array}$ & $\begin{array}{c}\text { Type } \mathbf{P} \\
\text { oxid } \\
\end{array}$ \\
\hline $\mathrm{SiO}_{2}$ & 41.22 & 34.79 & 35.31 & 34.52 & 36.34 & 39.09 & 39.92 & 41.03 & 40.35 & 38.54 & 37.85 & 39.16 & 38.26 & 38.17 \\
\hline $\mathrm{Al} 2 \mathrm{O} 3$ & 0.00 & 0.05 & 0.00 & 0.00 & 0.05 & 0.04 & 0.01 & 0.00 & 0.08 & 0.02 & 0.00 & 0.06 & 0.03 & 0.00 \\
\hline $\mathrm{TiO}_{2}$ & 0.09 & 0.03 & 0.07 & 0.01 & 0.06 & 0.06 & 0.02 & 0.04 & 0.09 & 0.01 & 0.00 & 0.02 & 0.00 & 0.00 \\
\hline $\mathrm{FeO}$ & 16.81 & 40.80 & 36.98 & 42.25 & 40.00 & 14.24 & 13.48 & 15.25 & 16.72 & 22.00 & 22.37 & 14.89 & 22.65 & 21.96 \\
\hline $\mathrm{MnO}$ & 0.64 & 0.81 & 1.01 & 0.91 & 0.50 & 0.55 & 0.56 & 0.47 & 0.34 & 0.26 & 0.26 & 0.12 & 0.22 & 0.30 \\
\hline $\mathrm{MgO}_{\mathrm{g}}$ & 41.20 & 23.92 & 26.46 & 22.27 & 22.83 & 45.09 & 45.86 & 43.55 & 42.12 & 39.87 & 39.69 & 45.25 & 39.73 & 39.16 \\
\hline $\mathrm{CaO}$ & 0.22 & 0.23 & 0.15 & 0.21 & 0.18 & 0.16 & 0.12 & 0.16 & 0.14 & 0.11 & 0.10 & 0.28 & 0.11 & 0.12 \\
\hline $\mathrm{Na}_{2} \mathrm{O}$ & 0.04 & 0.00 & 0.03 & 0.00 & 0.03 & 0.00 & 0.03 & 0.00 & 0.00 & 0.00 & 0.00 & 0.00 & 0.00 & 0.03 \\
\hline $\mathrm{K} 2 \mathrm{O}$ & 0.12 & 0.00 & 0.00 & 0.00 & 0.00 & 0.00 & 0.00 & 0.00 & 0.00 & 0.00 & 0.01 & 0.00 & 0.00 & 0.00 \\
\hline TOTAL & 100.33 & 100.63 & 100.01 & 100.17 & 100.00 & 99.22 & 100.00 & 100.50 & 99.84 & 100.80 & 100.27 & 99.78 & 100.99 & 99.74 \\
\hline Si & 1.037 & 0.991 & 0.994 & 0.996 & 1.031 & 0.988 & 0.996 & 1.023 & 1.020 & 0.993 & 0.984 & 0.985 & 0.987 & 0.994 \\
\hline Al & 0.000 & 0.002 & 0.000 & 0.000 & 0.002 & 0.001 & 0.000 & 0.000 & 0.000 & 0.001 & 0.000 & 0.002 & 0.002 & 0.000 \\
\hline $\mathrm{Ti}$ & 0.004 & 0.001 & 0.004 & 0.001 & 0.001 & 0.001 & 0.000 & 0.000 & 0.000 & 0.000 & 0.000 & 0.000 & 0.000 & 0.000 \\
\hline $\mathbf{F e}$ & 0.354 & 0.972 & 0.870 & 1.020 & 0.949 & 0.301 & 0.281 & 0.318 & 0.353 & 0.474 & 0.486 & 0.313 & 0.489 & 0.478 \\
\hline Mn & 0.014 & 0.019 & 0.024 & 0.022 & 0.012 & 0.012 & 0.012 & 0.010 & 0.007 & 0.006 & 0.006 & 0.003 & 0.005 & 0.007 \\
\hline Mg & 1.546 & 1.016 & 1.110 & 0.958 & 0.965 & 1.700 & 1.706 & 1.617 & 1.585 & 1.531 & 1.538 & 1.697 & 1.528 & 1.521 \\
\hline $\mathrm{Ca}$ & 0.006 & 0.007 & 0.040 & 0.006 & 0.006 & 0.004 & 0.003 & 0.004 & 0.000 & 0.003 & 0.003 & 0.007 & 0.003 & 0.003 \\
\hline $\mathrm{Na}$ & 0.005 & 0.000 & 0.004 & 0.000 & 0.002 & 0.000 & 0.001 & 0.000 & 0.000 & 0.000 & 0.000 & 0.000 & 0.000 & 0.002 \\
\hline $\mathrm{K}$ & 0.004 & 0.000 & 0.000 & 0.000 & 0.000 & 0.000 & 0.000 & 0.000 & 0.000 & 0.000 & 0.000 & 0.000 & 0.000 & 0.000 \\
\hline TOTAL & 2970 & 3.008 & 3.046 & 3.003 & 2.968 & 3.007 & 2.999 & 2972 & 2.965 & 3.008 & 3.017 & 3.007 & 3.014 & 3.005 \\
\hline Mg & 81.37 & 51.11 & 56.06 & 48.43 & 50.42 & 84.96 & 85.86 & 83.57 & 81.79 & 76.36 & 75.99 & 84.43 & 75.76 & 76.09 \\
\hline
\end{tabular}




\begin{tabular}{|c|c|c|c|c|c|c|c|c|c|c|c|c|c|c|}
\hline Sample & $90033 \mathrm{C}$ & $90033 \mathrm{C}$ & $90033 \mathrm{~F}$ & $90033 \mathrm{~F}$ & $90033 \mathrm{~F}$ & $90033 \mathrm{~F}$ & $90033 \mathrm{~F}$ & $90033 \mathrm{~F}$ & $90033 \mathrm{~F}$ & $90033 \mathrm{~F}$ & $90033 \mathrm{~F}$ & $90033 \mathrm{~F}$ & $90033 \mathrm{C}$ & $90033 \mathrm{H}$ \\
\hline Type & $\begin{array}{c}\text { Type } P \\
\text { core } \\
\end{array}$ & $\begin{array}{c}\text { Type P } \\
\text { core }\end{array}$ & $\begin{array}{c}\text { Type P } \\
\text { oxid } \\
\end{array}$ & $\begin{array}{c}\text { Type P } \\
\text { oxid } \\
\end{array}$ & $\begin{array}{c}\text { Type } \mathrm{P} \\
\text { oxid } \\
\end{array}$ & $\begin{array}{c}\text { Type P } \\
\text { oxid } \\
\end{array}$ & $\begin{array}{c}\text { Type } \mathbf{P} \\
\text { oxid } \\
\end{array}$ & $\begin{array}{c}\text { Type P } \\
\text { oxid } \\
\end{array}$ & $\begin{array}{c}\text { Type P } \\
\text { oxid }\end{array}$ & $\begin{array}{c}\text { Type } \mathrm{P} \\
\text { core }\end{array}$ & $\begin{array}{c}\text { Type P } \\
\text { core } \\
\end{array}$ & $\begin{array}{c}\text { Type P } \\
\text { core }\end{array}$ & $\begin{array}{c}\text { Type P } \\
\text { core } \\
\end{array}$ & $\begin{array}{c}\text { Type P } \\
\text { core }\end{array}$ \\
\hline $\mathrm{SiO}_{2}$ & 37.22 & 37.38 & 39.17 & 39.18 & 4226 & 40.63 & 41.63 & 39.21 & 38.22 & 39.62 & 40.72 & 39.08 & 38.03 & 38.69 \\
\hline $\mathrm{A} / 2 \mathrm{O} 3$ & 0.02 & 0.03 & 1.93 & 1.93 & 0.11 & 0.10 & 0.01 & 0.21 & 0.22 & 0.07 & 0.01 & 0.00 & 0.11 & 0.00 \\
\hline $\mathrm{TiO}_{2}$ & 0.00 & 0.00 & 1.47 & 1.47 & 0.07 & 0.09 & 0.04 & 0.16 & 0.07 & 0.04 & 0.07 & 0.08 & 0.10 & 0.01 \\
\hline $\mathrm{FeO}$ & 27.29 & 26.52 & 6.68 & 6.68 & 9.45 & 13.84 & 31.24 & 35.77 & 39.94 & 21.63 & 20.47 & 21.89 & 23.08 & 17.28 \\
\hline $\mathrm{MnO}$ & 0.38 & 0.34 & 0.16 & 0.16 & 0.20 & 0.21 & 0.29 & 0.34 & 0.32 & 0.33 & 0.27 & 39.23 & 0.58 & 0.26 \\
\hline $\mathrm{MgO}$ & 35.09 & 35.14 & 48.84 & 48.85 & 48.16 & 45.57 & 25.41 & 25.14 & 21.03 & 39.17 & 38.33 & 0.13 & 37.66 & 4289 \\
\hline $\mathrm{CaO}$ & 0.11 & 0.14 & 0.39 & 0.39 & 0.06 & 0.13 & 0.18 & 0.30 & 0.32 & 0.13 & 0.15 & 0.00 & 0.41 & 0.06 \\
\hline $\mathrm{Na} 2 \mathrm{O}$ & 0.00 & 0.00 & 0.00 & 0.00 & 0.00 & 0.00 & 0.00 & 0.00 & 0.00 & 0.00 & 0.00 & 0.00 & 0.03 & 0.03 \\
\hline $\mathrm{K}_{2} \mathrm{O}$ & 0.00 & 0.00 & 0.01 & 0.10 & 0.00 & 0.02 & 0.08 & 0.03 & 0.04 & 0.06 & 0.02 & 0.00 & 0.00 & 0.02 \\
\hline TOTAL & 100.10 & 99.56 & 98.65 & 98.75 & 100.31 & 100.57 & 98.89 & 101.15 & 100.16 & 101.05 & 100.03 & 100.40 & 100.00 & 99.23 \\
\hline $\mathrm{Si}$ & 0.992 & 0.998 & 0.949 & 0.949 & 1.025 & 1.005 & 1.123 & 1.063 & 1.071 & 1.014 & 1.043 & 1.007 & 0.995 & 0.991 \\
\hline Al & 0.001 & 0.001 & 0.055 & 0.055 & 0.003 & 0.003 & 0.000 & 0.007 & 0.007 & 0.002 & 0.000 & 0.000 & 0.003 & 0.000 \\
\hline $\mathrm{Ti}$ & 0.000 & 0.000 & 0.027 & 0.027 & 0.001 & 0.002 & 0.001 & 0.003 & 0.001 & 0.000 & 0.000 & 0.002 & 0.002 & 0.001 \\
\hline $\mathrm{Fe}$ & 0.608 & 0.592 & 0.135 & 0.135 & 0.191 & 0.286 & 0.704 & 0.811 & 0.935 & 0.463 & 0.438 & 0.472 & 0.505 & 0.370 \\
\hline $\mathrm{Mn}$ & 0.009 & 0.008 & 0.003 & 0.003 & 0.004 & 0.004 & 0.007 & 0.008 & 0.008 & 0.007 & 0.006 & 0.003 & 0.013 & 0.006 \\
\hline $\mathrm{Mg}$ & 1.394 & 1.399 & 1.763 & 1.763 & 1.740 & 1.680 & 1.020 & 1.016 & 0.878 & 1.493 & 1.462 & 1.507 & 1.469 & 1.638 \\
\hline $\mathrm{Ca}_{\mathrm{a}}$ & 0.004 & 0.004 & 0.010 & 0.010 & 0.002 & 0.003 & 0.005 & 0.009 & 0.010 & 0.003 & 0.004 & 0.000 & 0.011 & 0.002 \\
\hline $\mathrm{Na}$ & 0.000 & 0.000 & 0.000 & 0.000 & 0.000 & 0.001 & 0.000 & 0.001 & 0.000 & 0.000 & 0.000 & 0.000 & 0.004 & 0.007 \\
\hline K & 0.000 & 0.000 & 0.003 & 0.003 & 0.000 & 0.000 & 0.003 & 0.001 & 0.000 & 0.000 & 0.000 & 0.000 & 0.000 & 0.004 \\
\hline TOTAL & 3.008 & 3.002 & 2945 & 2.945 & 2.966 & 2.984 & 2863 & 2919 & 2910 & 2.982 & 2.953 & 2.991 & 3.002 & 3.019 \\
\hline $\mathrm{Mg} \#$ & 69.63 & 70.27 & 9289 & 92.89 & 90.11 & 85.45 & 59.16 & 55.61 & 48.43 & 76.33 & 76.95 & 76.15 & 74.42 & 81.57 \\
\hline
\end{tabular}

\begin{tabular}{|c|c|c|c|c|c|c|c|c|c|c|c|c|c|c|}
\hline Sample & $90033 \mathrm{Q} 1$ & $90033 \mathrm{Q} 1$ & $90033 \mathrm{S1}$ & $90033 \mathrm{~S} 1$ & $90033 S_{1}$ & $90033 \mathrm{~S} 1$ & $90033 \mathrm{~S} 1$ & $90033 \mathrm{~S} 1$ & $90039 \mathrm{~B}$ & $90039 \mathrm{~B}$ & $90039 \mathrm{~B}$ & 90039D & $90039 \mathrm{D}$ & $90039 \mathrm{D}$ \\
\hline Type & $\begin{array}{c}\text { Type P } \\
\text { core } \\
\end{array}$ & $\begin{array}{c}\text { Type P } \\
\text { core } \\
\end{array}$ & $\begin{array}{c}\text { Type P } \\
\text { oxid } \\
\end{array}$ & $\begin{array}{c}\text { Type P } \\
\text { oxid }\end{array}$ & $\begin{array}{c}\text { Type P } \\
\text { core } \\
\end{array}$ & $\begin{array}{c}\text { Type } P \\
\text { core } \\
\end{array}$ & $\begin{array}{c}\text { Type P } \\
\text { core } \\
\end{array}$ & $\begin{array}{c}\text { Type } \mathrm{P} \\
\text { core } \\
\end{array}$ & $\begin{array}{c}\text { Type M } \\
\text { core } \\
\end{array}$ & $\begin{array}{c}\text { Type } \mathrm{M} \\
\text { core } \\
\end{array}$ & $\begin{array}{c}\text { Type } \mathrm{M} \\
\text { core }\end{array}$ & $\begin{array}{c}\text { Type L } \\
\text { oxid } \\
\end{array}$ & $\begin{array}{c}\text { Type L } \\
\text { oxid } \\
\end{array}$ & $\begin{array}{c}\text { Type L } \\
\text { oxid } \\
\end{array}$ \\
\hline $\mathrm{SiO}_{2}$ & 38.47 & 38.71 & 37.85 & 40.11 & 38.36 & 38.45 & 38.10 & 37.66 & 36.65 & 36.66 & 36.48 & 35.69 & 36.07 & 37.55 \\
\hline $\mathrm{Al}_{2} \mathrm{O}_{3}$ & 0.01 & 0.22 & 0.23 & 0.00 & 0.00 & 0.00 & 0.00 & 0.01 & 0.11 & 0.16 & 0.00 & 0.05 & 0.07 & 0.00 \\
\hline $\mathrm{TiO}_{2}$ & 0.04 & 0.06 & 0.04 & 0.00 & 0.05 & 0.00 & 0.02 & 0.01 & 0.00 & 0.00 & 0.00 & 0.00 & 0.00 & 0.00 \\
\hline $\mathrm{FeO}$ & 21.71 & 20,17 & 39.70 & 1210 & 23.19 & 23.35 & 23.75 & 23.21 & 35.70 & 35.51 & 34.86 & 33.65 & 34.19 & 26.84 \\
\hline MnO & 0.21 & 0.20 & 0.27 & 0.34 & 0.27 & 0.27 & 0.30 & 0.32 & 0.62 & 0.69 & 0.57 & 0.55 & 0.50 & 0.66 \\
\hline $\mathrm{MgO}$ & 39.58 & 40.61 & 21.12 & 48.06 & 38.75 & 38.55 & 38.34 & 37.97 & 26.92 & 27.48 & 28.00 & 29.20 & 29.10 & 34.82 \\
\hline $\mathrm{CaO}$ & 0.11 & 0.18 & 0.27 & 0.09 & 0.12 & 0.13 & 0.09 & 0.11 & 0.08 & 0.08 & 0.10 & 0.07 & 0.07 & 0.12 \\
\hline $\mathrm{Na}_{2} \mathrm{O}$ & 0.01 & 0.13 & 0.00 & 0.00 & 0.00 & 0.00 & 0.00 & 0.00 & 0.00 & 0.00 & 0.00 & 0.00 & 0.00 & 0.00 \\
\hline $\mathrm{K} 2 \mathrm{O}$ & 0.00 & 0.00 & 0.00 & 0.01 & 0.00 & 0.02 & 0.01 & 0.02 & 0.03 & 0.03 & 0.00 & 0.00 & 0.01 & 0.00 \\
\hline TOTAL & 100.14 & 100.28 & 99.48 & 100.72 & 100.75 & 100.78 & 100.60 & 99.30 & 100.11 & 100.61 & 100.01 & 99.21 & 100.01 & 99.99 \\
\hline $\mathrm{Si}$ & 0.995 & 0.994 & 1.071 & 0.988 & 0.993 & 0.995 & 0.991 & 0.992 & 1.017 & 1.012 & 1.010 & 0.993 & 0.996 & 0.999 \\
\hline Al & 0.000 & 0.007 & 0.008 & 0.000 & 0.000 & 0.000 & 0.000 & 0.000 & 0.000 & 0.010 & 0.000 & 0.002 & 0.002 & 0.000 \\
\hline $\mathrm{Ti}$ & 0.001 & 0.002 & 0.002 & 0.000 & 0.001 & 0.000 & 0.000 & 0.000 & 0.000 & 0.000 & 0.000 & 0.000 & 0.000 & 0.000 \\
\hline $\mathrm{Fe}$ & 0.470 & 0.433 & 0.939 & 0.249 & 0.502 & 0.506 & 0.517 & 0.511 & 0.828 & 0.819 & 0.807 & 0.783 & 0.790 & 0.597 \\
\hline $\mathrm{Mn}$ & 0.005 & 0.004 & 0.006 & 0.007 & 0.006 & 0.006 & 0.007 & 0.007 & 0.010 & 0.010 & 0.010 & 0.013 & 0.012 & 0.015 \\
\hline Mg & 1.526 & 1.534 & 0.891 & 1.765 & 1.496 & 1.489 & 1.487 & 1.491 & 1.114 & 1.130 & 1.155 & 1.211 & 1.198 & 1.382 \\
\hline $\mathrm{Ca}$ & 0.003 & 0.005 & 0.008 & 0.002 & 0.003 & 0.004 & 0.002 & 0.003 & 0.000 & 0.000 & 0.000 & 0.002 & 0.002 & 0.003 \\
\hline $\mathrm{Na}$ & 0.000 & 0.006 & 0.000 & 0.000 & 0.000 & 0.000 & 0.000 & 0.000 & 0.000 & 0.000 & 0.000 & 0.000 & 0.000 & 0.000 \\
\hline K & 0.000 & 0.000 & 0.000 & 0.001 & 0.000 & 0.000 & 0.000 & 0.001 & 0.000 & 0.000 & 0.000 & 0.000 & 0.000 & 0.000 \\
\hline TOTAL & 3.000 & 2.985 & 2.925 & 3.012 & 3.001 & 3.000 & 3.004 & 3.005 & 2969 & 2.981 & 2.982 & 3.004 & 3.000 & 2.996 \\
\hline Mg & 76.45 & 77.99 & 48.69 & 87.64 & 74.87 & 74.64 & 74.20 & 74.48 & 57.36 & 57.98 & 58.87 & 60.73 & 60.26 & 69.83 \\
\hline
\end{tabular}




\begin{tabular}{|c|c|c|c|c|c|c|c|c|c|c|c|c|c|c|}
\hline Sample & $90033 \mathrm{H}$ & $90033 \mathrm{H}$ & $90033 \mathrm{H}$ & 900331 & 900331 & 900331 & 900331 & 900331 & 900331 & $90033 \mathrm{~J}$ & $90033 \mathrm{~J}$ & $90033 \mathrm{~J}$ & $90033 \mathrm{~J}$ & $90033 \mathrm{~J}$ \\
\hline Type & $\begin{array}{c}\text { Type P } \\
\text { core }\end{array}$ & $\begin{array}{c}\text { Type } \mathrm{P} \\
\text { core }\end{array}$ & $\begin{array}{c}\text { Type P } \\
\text { core } \\
\end{array}$ & $\begin{array}{c}\text { Type } \mathrm{P} \\
\text { core } \\
\end{array}$ & $\begin{array}{c}\text { Type P } \\
\text { core } \\
\end{array}$ & $\begin{array}{c}\text { Type P } \\
\text { core }\end{array}$ & $\begin{array}{c}\text { Type P } \\
\text { core- }\end{array}$ & $\begin{array}{c}\text { Type P } \\
\text { rim } \\
\end{array}$ & $\begin{array}{c}\text { Type } \mathrm{P} \\
\text { core } \\
\end{array}$ & $\begin{array}{c}\text { Type C } \\
\text { core } \\
\end{array}$ & $\begin{array}{l}\text { Type C } \\
\text { kaerst }\end{array}$ & $\begin{array}{l}\text { Type C } \\
\text { kaerst }\end{array}$ & $\begin{array}{c}\text { Type C } \\
\text { core } \\
\end{array}$ & $\begin{array}{c}\text { Type C } \\
\text { core } \\
\end{array}$ \\
\hline $\mathrm{SiO}_{2}$ & 38.48 & 38.73 & 38.82 & 38.73 & 38.29 & 38.49 & 39.03 & 38.60 & 38.69 & 38.20 & 38.80 & 39.63 & 37.88 & 38.58 \\
\hline $\mathrm{A} 12 \mathrm{O} 3$ & 0.01 & 0.04 & 0.03 & 0.04 & 0.05 & 0.01 & 0.04 & 0.07 & 0.02 & 0.04 & 0.00 & 0.08 & 0.01 & 0.02 \\
\hline $\mathrm{TiO}_{2}$ & $0 . \infty$ & 0.03 & 0.01 & 0.01 & 0.04 & 0.01 & 0.06 & 0.02 & 0.00 & 0.01 & 0.04 & 0.12 & 0.03 & 0.04 \\
\hline $\mathrm{FeO}$ & 17.35 & 17.41 & 18.06 & 19.97 & 20.68 & 20.33 & 20.51 & 19.81 & 20.35 & 22.01 & 18.21 & 15.41 & 28.25 & 29.45 \\
\hline $\mathrm{MnO}$ & 0.31 & 0.29 & 0.21 & 0.26 & 0.22 & 0.28 & 0.31 & 0.22 & 0.25 & 0.44 & 0.44 & 0.25 & 0.50 & 0.50 \\
\hline $\mathrm{MgO}$ & 42.83 & 42.48 & 43.20 & 40.18 & 40.37 & 40.15 & 40.26 & 40.32 & 40.27 & 34.46 & 41.64 & 44.27 & 34.23 & 34.32 \\
\hline $\mathrm{CaO}$ & 0.11 & 0.08 & 0.07 & 0.13 & 0.16 & 0.11 & 0.18 & 0.15 & 0.10 & 0.23 & 0.24 & 0.19 & 0.11 & 0.14 \\
\hline $\mathrm{Na} 2 \mathrm{O}$ & 0.00 & 0.03 & 0.00 & 0.00 & 0.00 & 0.00 & 0.03 & 0.00 & 0.00 & 0.00 & 0.03 & 0.03 & 0.00 & 0.01 \\
\hline $\mathrm{K} 2 \mathrm{O}$ & 0.00 & 0.00 & 0.00 & 0.00 & 0.00 & 0.03 & 0.02 & 0.01 & 0.01 & 0.00 & $0 . \infty$ & 0.02 & 0.02 & 0.01 \\
\hline TOTAL & 99.09 & 99.10 & 100.41 & 99.32 & 99.81 & 99.40 & 100.45 & 99.20 & 99.70 & 100.39 & 99.40 & 99.99 & 101.04 & 103.07 \\
\hline $\mathrm{Si}$ & 0.986 & 0.994 & 0.986 & 1.002 & 0.990 & 0.998 & 1.001 & 1.000 & 0.999 & 1.011 & 0.997 & 0.998 & 1.000 & 1.005 \\
\hline Al & 0.000 & 0.002 & 0.001 & & 0.002 & 0.000 & 0.001 & 0.006 & 0.001 & 0.002 & 0.000 & 0.006 & 0.000 & 0.000 \\
\hline $\mathrm{Ti}$ & 0.000 & 0.001 & 0.000 & 0.000 & 0.001 & 0.000 & 0.001 & 0.001 & 0.000 & 0.000 & 0.001 & 0.006 & 0.000 & 0.000 \\
\hline $\mathrm{Fe}$ & 0.372 & 0.374 & 0.384 & 0.432 & 0.447 & 0.441 & 0.440 & 0.429 & 0.439 & 0.598 & 0.391 & 0.324 & 0.625 & 0.641 \\
\hline $\mathrm{Mn}$ & 0.007 & 0.006 & 0.005 & 0.006 & 0.005 & 0.006 & 0.007 & 0.005 & 0.005 & 0.010 & 0.010 & 0.005 & 0.010 & 0.011 \\
\hline $\mathrm{Mg}$ & 1.636 & 1.626 & 1.636 & 1.549 & 1.556 & 1.532 & 1.538 & 1.557 & 1.550 & 1.360 & 1.595 & 1.661 & 1.350 & 1.332 \\
\hline $\mathrm{Ca}_{2}$ & 0.003 & 0.003 & 0.002 & 0.004 & 0.004 & 0.005 & 0.005 & 0.004 & 0.003 & 0.007 & 0.007 & 0.005 & 0.004 & 0.004 \\
\hline $\mathrm{Na}$ & 0.000 & 0.002 & 0.000 & 0.000 & 0.000 & 0.000 & 0.001 & 0.000 & 0.000 & 0.000 & 0.001 & 0.004 & 0.000 & 0.000 \\
\hline K & 0.000 & 0.000 & 0.000 & 0.000 & 0.000 & 0.001 & 0.001 & 0.001 & 0.000 & 0.000 & 0.000 & 0.001 & 0.001 & 0.000 \\
\hline TOTAL & 3.004 & 3.008 & 3.014 & 2.994 & 3.005 & 2.983 & 2.995 & 3.003 & 2997 & 2988 & 3.002 & 3.010 & 2990 & 2.993 \\
\hline ng" & 81.47 & 81.30 & 80.99 & 78.19 & 77.68 & 77.65 & 77.76 & 78.40 & 77.93 & 69.46 & 80.31 & 83.68 & 68.35 & 67.51 \\
\hline
\end{tabular}

\begin{tabular}{|c|c|c|c|c|c|c|c|c|c|c|c|c|c|c|}
\hline Sample & $90039 \mathrm{D}$ & $90039 D$ & $90039 \mathrm{D}$ & 90039D & $90039 \mathrm{E}$ & $90039 \mathrm{~F}$ & $90039 \mathrm{~F}$ & $90039 \mathrm{~F}$ & $90039 \mathrm{~F}$ & $90039 \mathrm{G}$ & $90039 \mathrm{M}$ & $90039 \mathrm{M}$ & $90039 \mathrm{M}$ & $90039 \mathrm{M}$ \\
\hline Type & $\begin{array}{c}\text { Type L } \\
\text { oxid } \\
\end{array}$ & $\begin{array}{c}\text { Type L } \\
\text { oxid }\end{array}$ & $\begin{array}{c}\text { Type L } \\
\text { oxid } \\
\end{array}$ & $\begin{array}{c}\text { Type L } \\
\text { oxid }\end{array}$ & $\begin{array}{c}\text { Type L } \\
\text { melt }\end{array}$ & $\begin{array}{c}\text { Type M } \\
\text { core } \\
\end{array}$ & $\begin{array}{c}\text { Type } \mathbf{M} \\
\text { core } \\
\end{array}$ & $\begin{array}{c}\text { Type } M \\
\text { core } \\
\end{array}$ & $\begin{array}{c}\text { Type } M \\
\text { core } \\
\end{array}$ & $\begin{array}{c}\text { Type L } \\
\text { melt }\end{array}$ & $\begin{array}{c}\text { Type L } \\
\text { oxid }\end{array}$ & $\begin{array}{l}\text { Type L } \\
\text { oxid }\end{array}$ & $\begin{array}{c}\text { Type L } \\
\text { oxid }\end{array}$ & $\begin{array}{c}\text { Type L } \\
\text { oxid }\end{array}$ \\
\hline $\mathrm{SiO}_{2}$ & 36.44 & 36.52 & 36.19 & 35.97 & 37.96 & 35.10 & 35.23 & 35.92 & 35.93 & 40.59 & 38.77 & 37.76 & 40.51 & 38.11 \\
\hline $\mathrm{A} 12 \mathrm{O} 3$ & 0.06 & 0.08 & 0.08 & 0.00 & 0.00 & 0.07 & 0.04 & 0.08 & 0.04 & 0.06 & 0.00 & 0.04 & 0.05 & 0.13 \\
\hline $\mathrm{TiO}_{2}$ & 0.05 & 0.02 & 0.00 & 0.00 & 0.15 & 0.06 & 0.01 & 0.12 & 0.05 & 0.09 & 0.03 & 0.05 & 0.06 & 0.05 \\
\hline $\mathrm{FeO}$ & 31.78 & 38.29 & 34.33 & 35.37 & 25.99 & 39.60 & 40.81 & 40.40 & 40.67 & 6.89 & 28.61 & 38.25 & 28.63 & 37.35 \\
\hline $\mathrm{MnO}$ & 0.60 & 0.49 & 0.68 & 0.49 & 0.48 & 0.74 & 0.68 & 0.63 & 0.70 & 0.37 & 0.54 & 0.65 & 0.74 & 0.68 \\
\hline $\mathrm{MgO}$ & 30.97 & 24,30 & 28.98 & 28.44 & 34.67 & 24.38 & 23.10 & 23.53 & 23.28 & 51.55 & 32.44 & 22.73 & 29.64 & 23.79 \\
\hline $\mathrm{CaO}$ & 0.06 & 0.11 & 0.08 & 0.04 & 0.36 & 0.16 & 0.12 & 0.13 & 0.15 & 0.42 & 0.09 & 0.12 & 0.14 & 0.13 \\
\hline $\mathrm{Na}_{2} \mathrm{O}$ & 0.03 & 0.00 & 0.00 & 0.00 & 0.00 & 0.00 & 0.04 & 0.08 & 0.06 & 0.03 & $0 . \infty$ & 0.00 & 0.10 & 0.01 \\
\hline $\mathrm{K} 2 \mathrm{O}$ & 0.00 & 0.01 & 0.00 & 0.00 & 0.00 & 0.01 & 0.03 & 0.03 & 0.02 & 0.00 & 0.00 & 0.01 & 0.08 & 0.04 \\
\hline TOTAL & 99.97 & 100.02 & 100.34 & 100.31 & 99.60 & 100.12 & 100.07 & 100.91 & 100.89 & 100,00 & 100.48 & 99.60 & 99.94 & 100.29 \\
\hline Si & 0.995 & 1.027 & 0.998 & 0.997 & 1.012 & 0.998 & 1.008 & 1.014 & 1.016 & 0.985 & 1.031 & 1.062 & 1.078 & 1.059 \\
\hline A! & 0.002 & 0.000 & 0.005 & 0.000 & 0.000 & 0.002 & 0.001 & 0.003 & 0.001 & 0.004 & 0.000 & 0.003 & 0.011 & 0.004 \\
\hline $\mathrm{Ti}$ & 0.001 & 0.001 & 0.000 & 0.000 & 0.003 & 0.001 & 0.000 & 0.003 & 0.001 & 0.003 & 0.005 & 0.003 & 0.010 & 0.001 \\
\hline $\mathrm{Fe}$ & 0.726 & 0.900 & 0.792 & 0.820 & 0.579 & 0.941 & 0.976 & 0.953 & 0.961 & 0.140 & 0.636 & 0.900 & 0.637 & 0.867 \\
\hline $\mathrm{Mn}$ & 0.014 & 0.012 & 0.016 & 0.011 & 0.010 & 0.018 & 0.017 & 0.015 & 0.017 & 0.008 & 0.012 & 0.015 & 0.017 & 0.016 \\
\hline $\mathrm{Mg}$ & 1.261 & 1.027 & 1.191 & 1.175 & 1.377 & 1.033 & 0.984 & 0.989 & 0.980 & 1.865 & 1.286 & 0.953 & 1.176 & 0.984 \\
\hline $\mathrm{Ca}_{a}$ & 0.002 & 0.003 & 0.004 & 0.002 & 0.010 & 0.005 & 0.004 & 0.004 & 0.005 & 0.011 & 0.0003 & 0.004 & 0.004 & 0.004 \\
\hline $\mathrm{Na}$ & 0.001 & 0.000 & 0.000 & 0.000 & 0.000 & 0.000 & 0.002 & 0.004 & 0.003 & 0.003 & 0.000 & 0.000 & 0.005 & 0.001 \\
\hline $\mathrm{K}$ & 0.000 & 0.000 & 0.000 & 0.000 & 0.000 & 0.000 & 0.001 & 0.001 & 0.001 & 0.000 & 0.006 & 0.000 & 0.022 & 0.001 \\
\hline TOTAL & 3.002 & 2.973 & 3.006 & 3.005 & 2.991 & 2.998 & 2.993 & 2986 & 2985 & 3.019 & 2978 & 2.940 & 2.960 & 2.937 \\
\hline $\mathrm{Mg}$ & 63.46 & 53.30 & 60.06 & 58.90 & 70.40 & 5233 & 50.20 & 50.93 & 50.49 & 93.02 & 66.91 & 51.43 & 64.86 & 53.16 \\
\hline
\end{tabular}




\begin{tabular}{|c|c|c|c|c|c|c|c|c|c|c|c|c|c|c|}
\hline $\begin{array}{l}\text { Sample } \\
\text { Type }\end{array}$ & $\begin{array}{c}\text { 90033J } \\
\text { Type C } \\
\text { core }\end{array}$ & $\begin{array}{l}90033 \mathrm{~K} \\
\text { Type M T } \\
\text { oxid }\end{array}$ & $\begin{array}{c}90033 \mathrm{~K} \\
\text { Type M } \\
\text { oxid }\end{array}$ & $\begin{array}{c}90033 \mathrm{~K} \\
\text { Type } \mathrm{M} \\
\text { oxid }\end{array}$ & $\begin{array}{c}90033 \mathrm{~K} \\
\text { Type M } \\
\text { oxid }\end{array}$ & $\begin{array}{c}900330 \\
\text { Type L } \\
\text { oxid }\end{array}$ & $\begin{array}{c}900330 \\
\text { Type L } \\
\text { core } \\
\end{array}$ & $\begin{array}{c}90033 P \\
\text { Type C } \\
\text { oxid } \\
\end{array}$ & $\begin{array}{c}\text { 90033P } \\
\text { Type C } \\
\text { melt }\end{array}$ & $\begin{array}{c}90033 R \\
\text { Type } P \\
\text { core }\end{array}$ & $\begin{array}{c}90033 R \\
\text { Type P } \\
\text { oxid } \\
\end{array}$ & $\begin{array}{c}90033 \mathrm{R} \\
\text { Type } \mathrm{P} \\
\text { oxid } \\
\end{array}$ & $\begin{array}{c}90033 S \\
\text { Type L } \\
\text { oxid } \\
\end{array}$ & $\begin{array}{c}90033 \mathrm{~S} \\
\text { Type L } \\
\text { oxid } \\
\end{array}$ \\
\hline $\mathrm{SiO}_{2}$ & 38.99 & 38.94 & 39.87 & 39.17 & 38.56 & 38.67 & 38.84 & 41.52 & 40.06 & 39.98 & 39.61 & 39.85 & 39.54 & 39.67 \\
\hline $\mathrm{Al}_{2} \mathrm{O}_{3}$ & 0.05 & 0.00 & 0.00 & 0.14 & 0.00 & 0.37 & 0.07 & 0.01 & 0.22 & 0.20 & 0.05 & 0.05 & 0.00 & 0.02 \\
\hline $\mathrm{TiO}_{2}$ & 0.03 & 0.03 & 0.01 & 0.04 & 0.01 & 0.03 & 0.04 & 0.10 & 0.29 & 0.07 & 0.09 & 0.10 & 0.00 & 0.00 \\
\hline $\mathrm{FeO}$ & 28.85 & 20.25 & 15.92 & 16.15 & 20.97 & 36.32 & 38.09 & 4.25 & 21.60 & 17.85 & 17.14 & 19.60 & 30.34 & 3.58 \\
\hline $\mathrm{MnO}$ & 0.45 & 0.24 & 0.25 & 0.36 & 0.30 & 1.24 & 1.56 & 0.45 & 0.42 & 0.16 & 0.19 & 0.27 & 0.71 & 0.44 \\
\hline $\mathrm{MgO}$ & 34.59 & 40.70 & 44.79 & 43.42 & 40.56 & 23.44 & 21.82 & 53.78 & 37.69 & 41.24 & 42.19 & 39.71 & 29.12 & 55.40 \\
\hline $\mathrm{CaO}$ & 0.16 & 0.12 & 0.12 & 0.06 & 0.10 & 0.28 & 0.23 & 0.23 & 0.49 & 0.27 & 0.35 & 0.34 & 0.29 & 0.03 \\
\hline $\mathrm{Na}_{2} \mathrm{O}$ & 0.27 & 0.00 & 0.00 & 0.00 & 0.00 & 0.05 & 0.20 & 0.02 & 0.05 & 0.00 & 0.02 & 0.05 & 0.00 & 0.00 \\
\hline $\mathrm{K} 2 \mathrm{O}$ & 0.04 & 0.00 & 0.00 & 0.02 & 0.00 & 0.18 & 0.01 & 0.01 & 0.00 & 0.00 & 0.01 & 0.02 & 0.00 & 0.02 \\
\hline TOTAL & 103.42 & 100.27 & 100.96 & 99.35 & 100.49 & 100.58 & 100.86 & 100.37 & 100.82 & 99.77 & 99.65 & 99.99 & 100.00 & 99.15 \\
\hline Si & 1.010 & 0.998 & 0.994 & 0.995 & 0.991 & 1.068 & 1.076 & 0.991 & 1.030 & 1.020 & 1.006 & 1.021 & 1.063 & 0.959 \\
\hline Al & 0.000 & 0.000 & 0.000 & 0.004 & 0.000 & 0.012 & 0.002 & 0.000 & 0.007 & 0.010 & 0.002 & 0.002 & 0.000 & 0.001 \\
\hline $\mathrm{Ti}$ & 0.000 & 0.001 & 0.000 & 0.001 & 0.000 & 0.001 & 0.001 & 0.002 & 0.006 & 0.000 & 0.003 & 0.003 & 0.000 & 0.000 \\
\hline $\mathrm{Fe}$ & 0.624 & 0.434 & 0.332 & 0.343 & 0.451 & 0.839 & 0.882 & 0.085 & 0.462 & 0.379 & 0.370 & 0.420 & 0.682 & 0.072 \\
\hline Mn & 0.010 & 0.005 & 0.005 & 0.008 & 0.006 & 0.029 & 0.037 & 0.009 & 0.010 & 0.004 & 0.004 & 0.006 & 0.016 & 0.009 \\
\hline $\mathrm{Mg}$ & 1.333 & 1.556 & 1.665 & 1.644 & 1.554 & 0.965 & 0.900 & 1.913 & 1.437 & 1.561 & 1.598 & 1.516 & 1.167 & 1.997 \\
\hline $\mathrm{Ca}$ & 0.010 & 0.003 & 0.003 & 0.002 & 0.003 & 0.008 & 0.007 & 0.006 & 0.014 & 0.007 & 0.010 & 0.009 & 0.008 & 0.001 \\
\hline $\mathrm{Na}$ & 0.010 & 0.000 & 0.000 & 0.000 & 0.000 & 0.003 & 0.011 & 0.001 & 0.003 & 0.000 & 0.002 & 0.003 & 0.000 & 0.000 \\
\hline $\mathbf{K}$ & 0.000 & 0.000 & 0.000 & 0.001 & 0.000 & 0.006 & 0.000 & 0.000 & 0.000 & 0.000 & 0.000 & 0.001 & 0.000 & 0.000 \\
\hline TOTAL & 2.997 & 2.997 & 2.999 & 2.998 & 3.005 & 2.931 & 2.916 & 3.007 & 2969 & 2.981 & 2.995 & 2.981 & 2.936 & 3.039 \\
\hline Mg\# & 68.11 & 78.19 & 83.38 & 82.74 & 77.51 & 53.49 & 50.51 & 95.75 & 75.67 & 80.46 & 81.20 & 78.31 & 63.12 & 96.52 \\
\hline
\end{tabular}

\begin{tabular}{|c|c|c|c|c|c|c|c|c|c|c|c|c|c|c|}
\hline $\begin{array}{l}\text { Sample } \\
\text { Type }\end{array}$ & $\begin{array}{c}900390 \\
\text { Type L } \\
\text { core }\end{array}$ & $\begin{array}{c}900390 \\
\text { Type L } \\
\text { core }\end{array}$ & $\begin{array}{c}900390 \\
\text { Type L } \\
\text { core }\end{array}$ & $\begin{array}{c}900390 \\
\text { Type C } \\
\text { core }\end{array}$ & $\begin{array}{c}900390 \\
\text { Type C } \\
\text { core }\end{array}$ & $\begin{array}{c}90039 \mathrm{Sb} 9 \\
\text { Type C } \\
\text { core }\end{array}$ & $\begin{array}{c}90039 \mathrm{Sb} 9 \\
\text { Type C } \\
\text { core }\end{array}$ & $\begin{array}{c}90039 \mathrm{Sb} \\
\text { Type } \mathbf{P} \\
\text { core }\end{array}$ & $\begin{array}{c}90039 \mathrm{Sb} 9 \\
\text { Type C } \\
\text { oxid }\end{array}$ & $\begin{array}{c}90039 \text { Sb } \\
\text { Type P } \\
\text { core }\end{array}$ & $\begin{array}{c}90039 \mathrm{Sb} \\
\text { Type C } \\
\text { core }\end{array}$ & $\begin{array}{c}90039 \mathrm{Sb} 9 \\
\text { Type C } \\
\text { core }\end{array}$ & $\begin{array}{c}90039 \mathrm{Sb} \\
\text { Type P } \\
\text { core }\end{array}$ & $\begin{array}{c}90039 S b \\
\text { Type P } \\
\text { core } \\
\end{array}$ \\
\hline $\mathrm{SiO}_{2}$ & 35.52 & 36.83 & 35.25 & 37.23 & 37.16 & 35.08 & 34.93 & 35.22 & 33.69 & 35.37 & 35.05 & 35.38 & 36.64 & 36.94 \\
\hline $\mathrm{Al}_{2} \mathrm{O}_{3}$ & 0.06 & 0.00 & 0.08 & 0.09 & 0.04 & 0.00 & 0.00 & 0.01 & 0.03 & 0.02 & 0.00 & 0.02 & 0.01 & 0.00 \\
\hline $\mathrm{TiO}_{2}$ & 0.06 & 0.06 & 0.09 & 0.11 & 0.01 & 0.00 & 0.00 & 0.06 & 0.03 & 0.08 & 0.02 & 0.00 & 0.11 & 0.08 \\
\hline $\mathrm{FeO}$ & 38.99 & 39.99 & 40.30 & 33.28 & 3239 & 39.84 & 39.91 & 37.00 & 38.95 & 29.41 & 39.72 & 37.86 & 28.76 & 26.97 \\
\hline $\mathrm{MnO}$ & 0.78 & 0.72 & 0.85 & 0.68 & 0.70 & 0.79 & 0.69 & 0.71 & 0.85 & 0.93 & 0.69 & 0.75 & 0.44 & 0.51 \\
\hline $\mathrm{MgO}$ & 24.62 & 23.87 & 24.40 & 30.07 & 30.01 & 25.04 & 24,78 & 26.72 & 26.37 & 34.08 & 24.73 & 25.71 & 33.55 & 35.52 \\
\hline $\mathrm{CaO}$ & 0.20 & 0.14 & 0.11 & 0.12 & 0.13 & 0.06 & 0.07 & 0.07 & 0.07 & 0.10 & 0.05 & 0.09 & 0.40 & 0.40 \\
\hline $\mathrm{Na} 2 \mathrm{O}$ & 0.07 & 0.07 & 0.00 & 0.07 & 0.00 & 0.00 & 0.00 & 0.00 & 0.00 & 0.00 & 0.00 & 0.00 & 0.00 & 0.00 \\
\hline $\mathrm{K} 2 \mathrm{O}$ & 0.03 & 0.01 & 0.02 & 0.08 & 0.03 & 0.03 & 0.00 & 0.00 & 0.01 & 0.00 & 0.00 & 0.00 & 0.01 & 0.01 \\
\hline TOTAL & 100.33 & 101.68 & 101.08 & 101.74 & 100.46 & 100.84 & 100.38 & 99.78 & 99.99 & 99.99 & 100.27 & 99.80 & 99.90 & 100.42 \\
\hline Si & 1.004 & 1.025 & 0.993 & 1.003 & 1.010 & 0.991 & 0.992 & 1.045 & 0.961 & 0.961 & 0.995 & 1.000 & 0.988 & 0.983 \\
\hline Al & 0.000 & 0.000 & 0.002 & 0.002 & 0.000 & 0.000 & 0.000 & 0.000 & 0.001 & 0.001 & 0.000 & 0.001 & 0.000 & 0.002 \\
\hline $\mathrm{Ti}$ & 0.000 & 0.000 & 0.002 & 0.002 & 0.000 & 0.000 & 0.000 & 0.001 & 0.001 & 0.002 & 0.000 & 0.000 & 0.003 & 0.002 \\
\hline $\mathrm{Fe}$ & 0.921 & 0.930 & 0.949 & 0.750 & 0.737 & 0.942 & 0.948 & 0.704 & 0.929 & 0.668 & 0.943 & 0.895 & 0.649 & 0.600 \\
\hline $\mathrm{Mn}$ & 0.019 & 0.017 & 0.020 & 0.016 & 0.016 & 0.019 & 0.017 & 0.018 & 0.021 & 0.021 & 0.017 & 0.018 & 0.010 & 0.011 \\
\hline $\mathrm{Mg}$ & 1.036 & 0.989 & 1.024 & 1.207 & 1.215 & 1.055 & 1.049 & 1.182 & 1.121 & 1.381 & 1.047 & 1.083 & 1.349 & 1.408 \\
\hline $\mathrm{Ca}$ & 0.006 & 0.004 & 0.003 & 0,004 & 0.004 & 0.002 & 0.002 & 0.002 & 0.002 & 0.003 & 0.002 & 0.004 & 0.012 & 0.011 \\
\hline $\mathrm{Na}$ & 0.004 & 0.004 & 0.000 & 0.004 & 0.000 & 0.000 & 0.000 & 0.000 & 0.000 & 0.000 & 0.000 & 0.000 & 0.000 & 0.000 \\
\hline $\mathbf{K}$ & 0.001 & 0.000 & 0.000 & 0.003 & 0.000 & 0.000 & 0.000 & 0.000 & 0.000 & 0.000 & 0.000 & 0.000 & 0.001 & 0.001 \\
\hline TOTAL & 2.991 & 2.969 & 2.993 & 2.991 & 2.982 & 3.009 & 3.008 & 2952 & 3.036 & 3.037 & 3.004 & 3.001 & 3.012 & 3.018 \\
\hline $\mathrm{Mg}^{\#}$ & 52.94 & 51.54 & 51.90 & 61.68 & 62.24 & 52.83 & 52.53 & 62.67 & 54.68 & 67.40 & 52.61 & 54.75 & 67.52 & 70.12 \\
\hline
\end{tabular}




\begin{tabular}{|c|c|c|c|c|c|c|c|c|c|c|c|c|c|c|}
\hline Sample & & $90033 \mathrm{U}$ & $90033 \mathrm{U}$ & $90033 \mathrm{U}$ & $90033 \mathrm{U}$ & $90033 \mathrm{~V}$ & $90033 \mathrm{~V}$ & $90033 \mathrm{~V}$ & $90033 \mathrm{~V}$ & $90033 \mathrm{~V}$ & $90033 x$ & $90033 X$ & $90033 X$ & $90033 X$ \\
\hline Type & $\begin{array}{c}\text { Type L } \\
\text { melt }\end{array}$ & $\begin{array}{c}\text { Type L } \\
\text { core }\end{array}$ & $\begin{array}{c}\text { Type L } \\
\text { core }\end{array}$ & $\begin{array}{c}\text { Type L } \\
\text { core } \\
\end{array}$ & $\begin{array}{c}\text { Type L } \\
\text { melt }\end{array}$ & $\begin{array}{c}\text { Type L } \\
\text { core }\end{array}$ & $\begin{array}{c}\text { Type L } \\
\text { core }\end{array}$ & $\begin{array}{c}\text { Type L } \\
\text { melt }\end{array}$ & $\begin{array}{c}\text { Type L } \\
\text { melt } \\
\end{array}$ & $\begin{array}{c}\text { Type L } \\
\text { core } \\
\end{array}$ & $\begin{array}{c}\text { Type L } \\
\text { core } \\
\end{array}$ & $\begin{array}{c}\text { Type L } \\
\text { core }\end{array}$ & $\begin{array}{c}\text { Type L } \\
\text { core } \\
\end{array}$ & $\begin{array}{c}\text { Type L } \\
\text { core } \\
\end{array}$ \\
\hline $\mathrm{SiO}_{2}$ & 39.17 & 36.21 & 34.55 & 38.98 & 39.67 & 34.50 & 34.54 & 36.17 & 38.07 & 34.09 & 35.35 & 33.96 & 34.74 & 33.44 \\
\hline $\mathrm{A} 12 \mathrm{O} 3$ & 0.28 & 0.00 & 0.00 & 0.06 & 0.02 & 0.06 & 0.04 & 0.02 & 0.08 & 0.02 & 0.04 & 0.01 & 0.03 & 0.03 \\
\hline $\mathrm{TiO}_{2}$ & 0.06 & 0.02 & 0.03 & 0.12 & 0.09 & 0.01 & 0.01 & 0.15 & 0.17 & 0.03 & 0.17 & 0.06 & 0.03 & 0.09 \\
\hline $\mathrm{FeO}$ & 39.59 & 36.11 & 39.25 & 33.22 & 8.91 & 43.27 & 4245 & 33.21 & 29.11 & 43.62 & 38.65 & 45.70 & 44.39 & 44.88 \\
\hline $\mathrm{MnO}$ & 0.81 & 0.82 & 0.88 & 0.75 & 0.88 & 0.70 & 0.76 & 0.52 & 0.52 & 0.75 & 0.85 & 1.15 & 1.10 & 1.10 \\
\hline $\mathrm{MgO}$ & 19.57 & 26.96 & 24.93 & 27.34 & 47.61 & 21.55 & 22.32 & 29.41 & 31.05 & 21.06 & 25.10 & 19.85 & 20.25 & 19.21 \\
\hline $\mathrm{CaO}$ & 0.44 & 0.08 & 0.28 & 0.14 & 0.19 & 0.21 & 0.20 & 0.48 & 0.45 & 0.20 & 0.38 & 0.33 & 0.30 & 0.29 \\
\hline $\mathrm{Na}_{2} \mathrm{O}$ & 0.01 & 0.02 & 0.00 & 0.00 & 0.00 & 0.00 & 0.00 & 0.00 & 0.00 & 0.00 & 0.00 & 0.00 & 0.02 & 0.02 \\
\hline $\mathrm{K}_{2} \mathrm{O}$ & 0.06 & 0.00 & 0.00 & 0.06 & 0.01 & 0.00 & 0.02 & 0.00 & 0.01 & 0.03 & 0.02 & 0.01 & 0.00 & 0.02 \\
\hline TOTAL & 99.99 & 100.21 & 99.91 & 100.65 & 97.37 & 100.30 & 100.33 & 99.96 & 99.47 & 99.79 & 100.54 & 101.06 & 100.85 & 99.07 \\
\hline $\mathrm{Si}$ & 1.100 & 1.008 & 0.986 & 1.055 & 0.998 & 0.998 & 0.995 & 0.997 & 1.028 & 0.995 & 0.996 & 0.990 & 1.047 & 0.994 \\
\hline Al & 0.009 & 0.000 & 0.000 & 0.002 & 0.000 & 0.003 & 0.001 & 0.002 & 0.007 & 0.002 & 0.001 & 0.001 & 0.002 & 0.001 \\
\hline $\mathrm{ri}$ & 0.003 & 0.001 & 0.001 & 0.002 & 0.000 & 0.000 & 0.000 & 0.008 & 0.008 & 0.001 & 0.004 & 0.001 & 0.002 & 0.002 \\
\hline $\mathbf{F e}$ & 0.930 & 0.841 & 0.937 & 0.752 & 0.187 & 1.047 & 1.023 & 0.765 & 0.658 & 1.065 & 0.911 & 1.115 & 1.030 & 1.116 \\
\hline Mn & 0.019 & 0.019 & 0.021 & 0.017 & 0.019 & 0.017 & 0.019 & 0.012 & 0.012 & 0.019 & 0.020 & 0.028 & 0.026 & 0.028 \\
\hline $\mathrm{Mg}$ & 0.819 & 1.119 & 1.060 & 1.104 & 1.785 & 0.929 & 0.959 & 1.108 & 1.250 & 0.917 & 1.055 & 0.863 & 0.838 & 0.852 \\
\hline $\mathrm{Ca}^{a}$ & 0.013 & 0.004 & 0.009 & 0.004 & 0.010 & 0.007 & 0.006 & 0.014 & 0.013 & 0.006 & 0.011 & 0.010 & 0.009 & 0.009 \\
\hline $\mathrm{Na}$ & 0.001 & 0.001 & 0.000 & 0.000 & 0.000 & 0.000 & 0.000 & 0.000 & 0.000 & 0.000 & 0.000 & 0.000 & 0.003 & 0.001 \\
\hline K & 0.006 & 0.000 & 0.000 & 0.002 & 0.000 & 0.000 & 0.001 & 0.000 & 0.001 & 0.003 & 0.001 & 0.001 & 0.000 & 0.001 \\
\hline TOTAL & 2900 & 2.993 & 3.014 & 2.938 & 2.999 & 3.001 & 3.004 & 2906 & 2977 & 3.008 & 2999 & 3.009 & 2.957 & 3.004 \\
\hline Mg & 46.83 & 57.09 & 53.08 & 59.48 & 90.52 & 47.01 & 48.39 & 59.16 & 65.51 & 46.27 & 53.66 & 43.63 & 44.86 & 43.29 \\
\hline
\end{tabular}

\begin{tabular}{|c|c|c|c|c|c|c|c|c|c|c|c|c|c|c|}
\hline Sample & $0039 \mathrm{Sb}$ & $90039 \mathrm{Sb}$ & $90039 \mathrm{Sb}$ & $90039 \mathrm{Sa}$ & $90039 \mathrm{Sa}$ & $90039 \mathrm{Sa}$ & $90039 \mathrm{Sa}$ & $90039 \mathrm{Sa}$ & $90039 \mathrm{Sa}$ & $90039 \mathrm{Sa}$ & $90039 \mathrm{Sa}$ & $90039 \mathrm{~V}$ & $90039 \mathrm{~V}$ & $90039 \mathrm{~V}$ \\
\hline Type & $\begin{array}{c}\text { Type } P \\
\text { core } \\
\end{array}$ & $\begin{array}{c}\text { Type } \mathbf{P} \\
\text { core }\end{array}$ & $\begin{array}{c}\text { Type P } \\
\text { core }\end{array}$ & $\begin{array}{c}\text { Type } \mathrm{P} \\
\text { core }\end{array}$ & $\begin{array}{c}\text { Type } \mathrm{P} \\
\text { core }\end{array}$ & $\begin{array}{c}\text { Type P } \\
\text { core }\end{array}$ & $\begin{array}{c}\text { Type } \mathbf{P} \\
\text { core }\end{array}$ & $\begin{array}{c}\text { Type } \mathrm{P} \\
\text { core }\end{array}$ & $\begin{array}{c}\text { Type } \mathbf{P} \\
\text { core }\end{array}$ & $\begin{array}{c}\text { Type } \mathrm{P} \\
\text { core }\end{array}$ & $\begin{array}{c}\text { Type } \mathbf{P} \\
\text { core }\end{array}$ & $\begin{array}{c}\text { Type } \mathbf{M} \\
\text { core } \\
\end{array}$ & $\begin{array}{c}\text { Type } \mathbf{M} \\
\text { oxid } \\
\end{array}$ & $\begin{array}{c}\text { Type } \mathrm{M} \\
\text { core } \\
\end{array}$ \\
\hline $\mathrm{SiO}_{2}$ & 37.09 & 37.10 & 37.22 & 36.52 & 37.31 & 37.14 & 37.06 & 37.36 & 37.04 & 37.12 & 37.25 & 36.07 & 35.80 & 35.06 \\
\hline $\mathrm{Al}_{2} \mathrm{O} 3$ & 0.04 & 0.05 & 0.04 & 0.04 & 0.00 & 0.05 & 0.05 & 0.03 & 0.03 & 0.03 & 0.08 & 0.04 & 0.02 & 0.00 \\
\hline $\mathrm{TiO}_{2}$ & 0.07 & 0.05 & 0.14 & 0.05 & 0.01 & 0.00 & 0.00 & 0.03 & 0.00 & 0.04 & 0.04 & 0.02 & 0.07 & 0.11 \\
\hline $\mathrm{FeO}$ & 26.48 & 26.46 & 26.41 & 29.83 & 27.51 & 28.69 & 28.98 & 27.20 & 28.47 & 27.36 & 28.40 & 39.73 & 39.31 & 40.19 \\
\hline $\mathrm{MnO}$ & 0.42 & 0.39 & 0.39 & 0.43 & 0.40 & 0.23 & 0.34 & 0.36 & 0.38 & 0.39 & 0.28 & 0.68 & 0.83 & 0.69 \\
\hline MgO & 34.55 & 35.38 & 35.17 & 32.59 & 33.83 & 33.69 & 33.77 & 34.55 & 34.35 & 34.50 & 34.57 & 23.52 & 23.79 & 24.22 \\
\hline $\mathrm{CaO}$ & 0.36 & 0.33 & 0.41 & 0.12 & 0.18 & 0.11 & 0.11 & 0.16 & 0.09 & 0.12 & 0.15 & 0.29 & 0.20 & 0.18 \\
\hline $\mathrm{Na} 2 \mathrm{O}$ & 0.00 & 0.01 & 0.05 & 0.04 & 0.03 & 0.00 & 0.00 & 0.00 & 0.00 & 0.00 & 0.00 & 0.21 & 0.05 & 0.08 \\
\hline $\mathrm{K} 2 \mathrm{O}$ & 0.01 & 0.00 & 0.03 & 0.00 & 0.01 & 0.00 & 0.00 & 0.01 & 0.00 & 0.02 & 0.00 & 0.06 & 0.05 & 0.06 \\
\hline TOTAL & 99.02 & 99.77 & 99.85 & 99.61 & 99.28 & 99.91 & 100.31 & 99.70 & 100.37 & 99.58 & 100.72 & 100.61 & 100.12 & 100.59 \\
\hline Si & 0.997 & 0.990 & 0.992 & 0.992 & 1.003 & 0.996 & 0.993 & 0.999 & 0.990 & 0.996 & 0.991 & 1.015 & 1.012 & 0.991 \\
\hline Al & 0.002 & 0.002 & 0.002 & 0.007 & 0.000 & 0.002 & 0.002 & 0.001 & 0.001 & 0.002 & 0.001 & 0.001 & 0.000 & 0.000 \\
\hline $\mathrm{Ti}$ & 0.002 & 0.002 & 0.004 & 0.006 & 0.000 & 0.000 & 0.000 & 0.001 & 0.000 & 0.001 & 0.001 & 0.000 & 0.002 & 0.002 \\
\hline $\mathrm{Fe}$ & 0.596 & 0.590 & 0.589 & 0.678 & 0.619 & 0.644 & 0.649 & 0.608 & 0.636 & 0.614 & 0.632 & 0.935 & 0.929 & 0.950 \\
\hline Mn & 0.010 & 0.009 & 0.009 & 0.010 & 0.009 & 0.005 & 0.008 & 0.008 & 0.009 & 0.009 & 0.006 & 0.016 & 0.020 & 0.016 \\
\hline $\mathrm{Mg}$ & 1.385 & 1.407 & 1.397 & 1.320 & 1.356 & 1.347 & 1.349 & 1.377 & 1.368 & 1.379 & 1.371 & 0.986 & 1.002 & 1.020 \\
\hline $\mathrm{Ca}$ & 0.010 & 0.009 & 0.012 & 0.019 & 0.005 & 0.003 & 0.003 & 0.005 & 0.003 & 0.005 & 0.004 & 0.009 & 0.006 & 0.006 \\
\hline $\mathbf{N a}$ & 0.000 & 0.000 & 0.004 & 0.011 & 0.002 & 0.000 & 0.000 & 0.000 & 0.000 & 0.000 & 0.000 & 0.011 & 0.005 & 0.004 \\
\hline K & 0.001 & 0.000 & 0.001 & 0.000 & 0.000 & 0.000 & 0.000 & 0.000 & 0.000 & 0.001 & 0.000 & 0.002 & 0.001 & 0.002 \\
\hline TOTAL & 3.003 & 3.009 & 3.010 & 3.043 & 2.994 & 2.997 & 3.004 & 2999 & 3.007 & 3.007 & 3.006 & 2.975 & 2.977 & 2.991 \\
\hline $\mathbf{M g}^{*}$ & 69.91 & 70.46 & 70.34 & 66.07 & 68.66 & 67.65 & 67.52 & 69.37 & 68.26 & 69.19 & 68.45 & 51.33 & 51.89 & 51.78 \\
\hline
\end{tabular}




\begin{tabular}{|c|c|c|c|}
\hline Sample & $90033 x$ & $90033 x$ & $90033 \mathrm{~F} 1$ \\
\hline Type & $\begin{array}{c}\text { Type L } \\
\text { core }\end{array}$ & $\begin{array}{c}\text { Type L } \\
\text { core }\end{array}$ & $\begin{array}{c}\text { Type L } \\
\text { core }\end{array}$ \\
\hline $\mathrm{SiO}_{2}$ & 34.68 & 35.08 & 35.36 \\
\hline $\mathrm{A} 12 \mathrm{O} 3$ & 0.01 & 0.01 & 0.00 \\
\hline $\mathrm{TiO}_{2}$ & 0.07 & 0.06 & 0.00 \\
\hline $\mathrm{FeO}$ & 39.67 & 38.85 & 38.56 \\
\hline $\mathrm{MnO}$ & 0.99 & 0.76 & 0.76 \\
\hline $\mathrm{MgO}$ & 23.46 & 24.75 & 25.13 \\
\hline $\mathrm{CaO}$ & 0.42 & 0.34 & 0.11 \\
\hline $\mathrm{Na} 2 \mathrm{O}$ & 0.00 & 0.06 & 0.00 \\
\hline $\mathrm{K}_{2} \mathrm{O}$ & 0.00 & 0.00 & 0.01 \\
\hline TOTAL & 99.29 & 99.90 & 99.93 \\
\hline $\mathrm{Si}$ & 0.999 & 0.997 & 1.002 \\
\hline Al & 0.000 & 0.001 & 0.000 \\
\hline $\mathrm{Ti}$ & 0.004 & 0.003 & 0.000 \\
\hline $\mathrm{Fe}$ & 0.955 & 0.924 & 0.914 \\
\hline Mn & 0.024 & 0.018 & 0.018 \\
\hline $\mathbf{M g}$ & 1.007 & 1.049 & 1.061 \\
\hline $\mathrm{Ca}$ & 0.013 & 0.010 & 0.008 \\
\hline $\mathrm{Na}$ & 0.000 & 0.008 & 0.000 \\
\hline $\mathbf{K}$ & 0.000 & 0.000 & 0.001 \\
\hline TOTAL & 3.002 & 3.010 & 3.004 \\
\hline Mg* & 51.33 & 53.17 & 53.72 \\
\hline
\end{tabular}

\begin{tabular}{|c|c|c|c|c|}
\hline Sample & $90039 \mathrm{~V}$ & $90039 \mathrm{~V}$ & $90039 \mathrm{~V}$ & $90039 \mathrm{~V}$ \\
\hline Type & Type M & Type M & Type M & Type M \\
\hline & core & core & core & oxid \\
\hline $\mathrm{SiO}_{2}$ & 35.61 & 36.21 & 35.95 & 36.80 \\
\hline $\mathrm{Al}_{2} \mathrm{O}_{3}$ & 0.02 & 0.02 & 0.01 & 0.14 \\
\hline $\mathrm{TiO}_{2}$ & 0.08 & 0.12 & 0.13 & 0.32 \\
\hline $\mathrm{FeO}$ & 39.71 & 38.10 & 40.04 & 29.83 \\
\hline $\mathrm{MnO}$ & 0.65 & 0.75 & 0.70 & 0.52 \\
\hline $\mathrm{MgO}$ & 23.65 & 23.78 & 23.64 & 31.82 \\
\hline $\mathrm{CaO}$ & 0.15 & 0.24 & 0.22 & 0.48 \\
\hline $\mathrm{Na} 2 \mathrm{O}$ & 0.04 & 0.75 & 0.00 & 0.09 \\
\hline $\mathrm{K}_{2} \mathrm{O}$ & 0.05 & 0.06 & 0.03 & 0.05 \\
\hline TOTAL & 99.96 & 100.03 & 100.72 & 100.03 \\
\hline $\mathrm{Si}$ & 1.007 & 0.998 & 1.013 & 0.992 \\
\hline $\mathrm{Al}$ & 0.000 & 0.000 & 0.000 & 0.004 \\
\hline $\mathrm{Ti}$ & 0.001 & 0.003 & 0.003 & 0.006 \\
\hline $\mathrm{Fe}$ & 0.939 & 0.878 & 0.943 & 0.672 \\
\hline Mn & 0.016 & 0.018 & 0.017 & 0.012 \\
\hline $\mathbf{M g}$ & 0.996 & 0.976 & 0.992 & 1.278 \\
\hline $\mathrm{Ca}$ & 0.005 & 0.007 & 0.007 & 0.014 \\
\hline $\mathrm{Na}$ & 0.002 & 0.040 & 0.000 & 0.005 \\
\hline $\mathbf{K}$ & 0.002 & 0.002 & 0.001 & 0.002 \\
\hline TOTAL & 2.968 & 2.922 & 2.976 & 2.985 \\
\hline Mg* & 51.47 & 52.64 & 51.27 & 65.54 \\
\hline
\end{tabular}




\section{A3.1 Mount Sidley xenolith mineral analyses: pyroxenes}

\begin{tabular}{|c|c|c|c|c|c|c|c|c|c|c|c|c|c|c|}
\hline $\begin{array}{l}\text { Sample } \\
\text { Type }\end{array}$ & $\begin{array}{c}90029 \mathrm{C} \\
\text { Type M } \\
\text { core }\end{array}$ & $\begin{array}{c}90029 \mathrm{C} \\
\text { Type M } \\
\text { core }\end{array}$ & $\begin{array}{c}90029 \mathrm{~V} \\
\text { Type M } \\
\text { core }\end{array}$ & $\begin{array}{c}90029 \mathrm{~V} \\
\text { Type M } \\
\text { core }\end{array}$ & $\begin{array}{c}90029 \mathrm{~V} \\
\text { Type M } \\
\text { core }\end{array}$ & $\begin{array}{l}90029 \mathrm{~V} \\
\text { Type M } \\
\text { oxid ol }\end{array}$ & $\begin{array}{l}90029 \mathrm{~V} \\
\text { Type M } \\
\text { oxid ol }\end{array}$ & $\begin{array}{c}90029 X \\
\text { Type L } \\
\text { core } \\
\end{array}$ & $\begin{array}{c}90029 X \\
\text { Type L } \\
\text { core }\end{array}$ & $\begin{array}{c}90029 X \\
\text { Type L } \\
\text { core }\end{array}$ & $\begin{array}{c}90029 X \\
\text { Type L } \\
\text { core }\end{array}$ & $\begin{array}{c}90029 X \\
\text { Type L } \\
\text { core }\end{array}$ & $\begin{array}{c}90029 \mathrm{~B} 19 \\
\text { Type L } \\
\text { core }\end{array}$ & $\begin{array}{c}90029 \mathrm{~B} 1 \\
\text { Type L } \\
\text { core } \\
\end{array}$ \\
\hline $\mathrm{SiO}_{2}$ & 50.16 & 50.39 & 51.30 & 50.41 & 49.32 & 54.33 & 55.58 & 50.14 & 48.93 & 49.48 & 48.76 & 49.47 & 50.54 & 50.24 \\
\hline $\mathrm{A} 12 \mathrm{O} 3$ & 4.15 & 4.43 & 3.64 & 3.99 & 3.90 & 0.07 & 0.26 & 3.52 & 5.35 & 3.95 & 4.72 & 4.17 & 3.53 & 3.16 \\
\hline $\mathrm{TiO} 2$ & 1.41 & 1.54 & 1.05 & 1.47 & 0.83 & 0.06 & 0.03 & 1.19 & 2.02 & 1.51 & 2.01 & 1.61 & 1.04 & 0.98 \\
\hline $\mathrm{FeO}$ total & 9.73 & 9.86 & 9.73 & 10.00 & 11.03 & 7.20 & 7.89 & 10.00 & 9.14 & 10.13 & 9.42 & 9.71 & 10.20 & 10.19 \\
\hline $\mathrm{MnO}$ & 0.40 & 0.31 & 0.28 & 0.40 & 0.38 & 0.81 & 0.60 & 0.23 & 0.28 & 0.37 & 0.30 & 0.24 & 0.40 & 0.30 \\
\hline $\mathrm{MgO}$ & 12.55 & 12.18 & 12.83 & 12.59 & 1242 & 35.73 & 35.16 & 12.82 & 14.01 & 12.17 & 12.17 & 12.18 & 12.59 & 12.70 \\
\hline $\mathrm{CaO}$ & 21.15 & 21.27 & 20.92 & 21.64 & 20.82 & 0.26 & 0.68 & 22.08 & 19.95 & 21.51 & 21.46 & 21.99 & 21.07 & 20.96 \\
\hline $\mathrm{Na} 2 \mathrm{O}$ & 0.00 & 0.00 & 0.58 & 0.60 & 0.54 & 0.12 & 0.37 & 0.47 & 0.31 & 0.60 & 0.60 & 0.62 & 0.64 & 0.54 \\
\hline $\mathrm{K} 2 \mathrm{O}$ & 0.00 & 0.00 & 0.03 & 0.02 & 0.01 & 0.03 & 0.20 & 0.00 & 0.00 & 0.00 & 0.00 & 0.01 & 0.00 & 0.00 \\
\hline $\mathrm{Fe} 2 \mathrm{O} 3$ & 0.00 & 0.00 & 0.22 & 204 & 3.40 & 0.00 & 8.76 & 7.45 & 1.24 & 2.26 & 1.79 & 2.36 & 1.85 & 1.72 \\
\hline $\mathrm{FeO}$ & 9.73 & 9.86 & 4.53 & 8.17 & 7.97 & 7.20 & 0.01 & 2.83 & 8.02 & 8.12 & 7.87 & 7.58 & 8.53 & 8.64 \\
\hline TOTAL & 99.55 & 99.98 & 100.33 & 101.09 & 99.23 & 98.57 & 100.56 & 100.44 & 99.99 & 99.71 & 99.45 & 99.99 & 100.01 & 99.08 \\
\hline $\mathrm{Si}$ & 1.890 & 1.880 & 1.910 & 1.875 & 1.877 & 1.926 & 1.935 & 1.878 & 1.825 & 1.869 & 1.843 & 1.862 & 1.899 & 1.904 \\
\hline AlIV & 0.110 & 0.120 & 0.090 & 0.120 & 0.120 & 0.002 & 0.010 & 0.122 & 0.175 & 0.131 & 0.157 & 0.138 & 0.101 & 0.096 \\
\hline AlVI & 0.070 & 0.080 & 0.070 & 0.050 & 0.050 & 0.000 & 0.000 & 0.030 & 0.060 & 0.050 & 0.050 & 0.050 & 0.060 & 0.050 \\
\hline $\mathrm{Ti}$ & 0.040 & 0.040 & 0.030 & 0.040 & 0.023 & 0.002 & 0.000 & 0.034 & 0.057 & 0.043 & 0.057 & 0.046 & 0.029 & 0.028 \\
\hline FellI & 0.000 & 0.000 & 0.006 & 0.013 & 0.097 & 0.000 & 0.230 & 0.080 & 0.040 & 0.070 & 0.050 & 0.067 & 0.052 & 0.049 \\
\hline FelI & 0.300 & 0.310 & 0.303 & 0.250 & 0.252 & 0.213 & 0.000 & 0.230 & 0.250 & 0.260 & 0.246 & 0.237 & 0.267 & 0.273 \\
\hline $\mathrm{Mn}$ & 0.010 & 0.010 & 0.010 & 0.012 & 0.012 & 0.024 & 0.010 & 0.007 & 0.009 & 0.012 & 0.010 & 0.008 & 0.012 & 0.010 \\
\hline $\mathbf{M g}_{\mathbf{g}}$ & 0.700 & 0.680 & 0.712 & 0.698 & 0.704 & 1.887 & 1.824 & 0.716 & 0.779 & 0.685 & 0.686 & 0.684 & 0.705 & 0.718 \\
\hline $\mathrm{Ca}$ & 0.850 & 0.850 & 0.835 & 0.862 & 0.829 & 0.010 & 0.020 & 0.886 & 0.797 & 0.870 & 0.869 & 0.887 & 0.848 & 0.851 \\
\hline $\mathrm{Na}$ & 0.000 & 0.000 & 0.042 & 0.043 & 0.040 & 0.010 & 0.020 & 0.034 & 0.023 & 0.044 & 0.044 & 0.045 & 0.046 & 0.040 \\
\hline $\mathbf{K}$ & 0.000 & 0.000 & 0.000 & 0.001 & 0.000 & 0.000 & 0.010 & 0.000 & 0.000 & 0.000 & 0.000 & 0.001 & 0.000 & 0.000 \\
\hline TOTAL & 3.970 & 3.970 & 4.008 & 3.964 & 4.004 & 4.074 & 4.059 & 4.017 & 4.015 & 4.034 & 4.012 & 4.025 & 4.019 & 4.019 \\
\hline Wo & 45.95 & 46.20 & 44.99 & 47.28 & 44.05 & 0.47 & 0.96 & 46.34 & 42.71 & 46.15 & 46.95 & 47.31 & 45.30 & 45.00 \\
\hline En & 37.84 & 36.96 & 38.36 & 38.29 & 37.41 & 89.43 & 87.95 & 37.45 & 41.75 & 36.34 & 37.06 & 36.48 & 37.66 & 37.97 \\
\hline Fs & 16.22 & 16.85 & 16.65 & 14.43 & 18.54 & 10.09 & 11.09 & 16.21 & 15.54 & 17.51 & 15.99 & 16.21 & 17.04 & 17.03 \\
\hline Sample & $90033 \mathrm{U}$ & $90033 \mathrm{U}$ & $90033 \mathrm{U}$ & $90033 \mathrm{U}$ & $90033 \mathrm{U}$ & $90033 \mathrm{~V}$ & $90033 \mathrm{~V}$ & $90033 X$ & $90033 X$ & $90033 X$ & $90033 \mathrm{X}$ & $90033 X$ & 90033 F1 & $90033 \mathrm{~F} 1$ \\
\hline Type & $\begin{array}{c}\text { Type L } \\
\text { oxid } \\
\end{array}$ & $\begin{array}{c}\text { Type L } \\
\text { oxid } \\
\end{array}$ & $\begin{array}{c}\text { Type L } \\
\text { core } \\
\end{array}$ & $\begin{array}{c}\text { Type L } \\
\text { core }\end{array}$ & $\begin{array}{c}\text { Type L } \\
\text { core } \\
\end{array}$ & $\begin{array}{c}\text { Type L } \\
\text { oxid } \\
\end{array}$ & $\begin{array}{c}\text { Type L } \\
\text { oxid } \\
\end{array}$ & $\begin{array}{c}\text { Type L } \\
\text { core- }\end{array}$ & $\begin{array}{c}\text { Type L } \\
\text { rim }\end{array}$ & $\begin{array}{c}\text { Type L } \\
\text { core }\end{array}$ & $\begin{array}{c}\text { Type L } \\
\text { core }\end{array}$ & $\begin{array}{c}\text { Type L } \\
\text { core }\end{array}$ & $\begin{array}{c}\text { Type L } \\
\text { oxid } \\
\end{array}$ & $\begin{array}{c}\text { Type L } \\
\text { oxid } \\
\end{array}$ \\
\hline $\mathrm{SiO}_{2}$ & 49.22 & 54.55 & 48.46 & 50.38 & 50.79 & 50.10 & 50.40 & 49.53 & 50.18 & 49.76 & 49.62 & 48.05 & 48.77 & 44.68 \\
\hline $\mathrm{Al} 2 \mathrm{O} 3$ & 4.78 & 0.36 & 6.18 & 3.88 & 4.16 & 4.25 & 5.48 & 4.16 & 2.60 & 3.75 & 4.00 & 4.38 & 5.20 & 10.25 \\
\hline $\mathrm{TiO} 2$ & 1.32 & 0.12 & 1.55 & 1.34 & 1.05 & 0.98 & 1.56 & 1.18 & 1.43 & 1.26 & 1.06 & 2.22 & 1.78 & 3.34 \\
\hline $\mathrm{FeO}$ total & 10.99 & 15.31 & 10.08 & 9.78 & 9.65 & 11.96 & 7.93 & 13.25 & 11.63 & 12.73 & 12.76 & 10.95 & 9.69 & 8.70 \\
\hline $\mathrm{MnO}$ & 0.17 & 0.67 & 0.34 & 0.26 & 0.29 & 0.31 & 0.18 & 0.47 & 0.30 & 0.43 & 0.42 & 0.07 & 0.26 & 0.26 \\
\hline $\mathrm{MgO}$ & 11.28 & 28.11 & 11.00 & 12.43 & 11.77 & 11.12 & 1204 & 10.97 & 13.02 & 10.98 & 11.14 & 11.94 & 13.21 & 11.03 \\
\hline $\mathrm{CaO}$ & 21.87 & 0.88 & 21.88 & 21.08 & 21.45 & 20.50 & 20.84 & 20.10 & 20.94 & 19.88 & 20.02 & 20.73 & 20.67 & 20.68 \\
\hline $\mathrm{Na} 2 \mathrm{O}$ & 0.80 & 0.00 & 0.92 & 0.49 & 0.84 & 0.98 & 0.75 & 0.91 & 0.43 & 0.86 & 0.78 & 0.76 & 0.56 & 0.72 \\
\hline $\mathrm{K} 2 \mathrm{O}$ & 0.00 & 0.00 & 0.00 & 0.00 & 0.00 & 0.02 & 0.10 & 0.00 & 0.00 & 0.00 & 0.00 & 0.08 & 0.00 & 0.05 \\
\hline $\mathrm{Fe} 2 \mathrm{O} 3$ & 3.30 & 2.09 & 2.76 & 0.05 & 0.70 & 244 & 0.00 & 3.39 & 2.99 & 1.75 & 2.26 & 3.28 & 283 & 2.44 \\
\hline $\mathrm{FeO}$ & 8.02 & 13.42 & 7.59 & 9.73 & 9.02 & 9.77 & 7.93 & 10.20 & 8.94 & 11.15 & 10.72 & 8.00 & 7.02 & 6.50 \\
\hline TOTAL & 100.42 & 100.00 & 100.41 & 99.65 & 100.00 & 100.18 & 99.18 & 100.56 & 100.52 & 99.65 & 99.80 & 99.09 & 100.14 & 99.65 \\
\hline Si & 1.840 & 1.961 & 1.814 & 1.893 & 1.902 & 1.880 & 1.890 & 1.876 & 1.889 & 1.894 & 1.887 & 1.818 & 1.843 & 1.673 \\
\hline AlIV & 0.160 & 0.040 & 0.190 & 0.110 & 0.100 & 0.120 & 0.110 & 0.120 & 0.110 & 0.110 & 0.110 & 0.180 & 0.160 & 0.330 \\
\hline AlVI & 0.050 & 0.000 & 0.090 & 0.070 & 0.090 & 0.070 & 0.130 & 0.060 & 0.000 & 0.060 & 0.070 & 0.010 & 0.080 & 0.130 \\
\hline $\mathrm{Ti}$ & 0.037 & 0.003 & 0.044 & 0.038 & 0.030 & 0.028 & 0.044 & 0.034 & 0.041 & 0.036 & 0.030 & 0.063 & 0.050 & 0.094 \\
\hline FeIII & 0.093 & 0.057 & 0.078 & 0.002 & 0.020 & 0.069 & 0.299 & 0.096 & 0.084 & 0.050 & 0.064 & 0.101 & 0.029 & 0.069 \\
\hline FelI & 0.251 & 0.403 & 0.238 & 0.306 & 0.282 & 0.307 & 0.000 & 0.321 & 0.279 & 0.354 & 0.339 & 0.245 & 0.273 & 0.204 \\
\hline $\mathrm{Mn}$ & 0.005 & 0.021 & 0.011 & 0.008 & 0.009 & 0.010 & 0.006 & 0.015 & 0.010 & 0.014 & 0.014 & 0.002 & 0.008 & 0.008 \\
\hline $\mathrm{Mg}$ & 0.629 & 1.506 & 0.614 & 0.696 & 0.657 & 0.622 & 0.673 & 0.619 & 0.730 & 0.623 & 0.632 & 0.674 & 0.744 & 0.616 \\
\hline $\mathrm{Ca}$ & 0.877 & 0.034 & 0.862 & 0.849 & 0.861 & 0.825 & 0.838 & 0.816 & 0.844 & 0.811 & 0.815 & 0.841 & 0.785 & 0.830 \\
\hline $\mathrm{Na}$ & 0.058 & 0.000 & 0.067 & 0.036 & 0.061 & 0.071 & 0.055 & 0.067 & 0.031 & 0.064 & 0.057 & 0.056 & 0.041 & 0.050 \\
\hline $\mathbf{K}$ & 0.000 & 0.000 & 0.000 & 0.000 & 0.001 & 0.001 & 0.005 & 0.000 & 0.000 & 0.000 & 0.000 & 0.004 & 0.000 & 0.002 \\
\hline TOTAL & 4.000 & 4.025 & 4.008 & 4.008 & 4.013 & 4.003 & 4.050 & 4.024 & 4.018 & 4.016 & 4.018 & 3.994 & 4.013 & 4.006 \\
\hline Wo & 47.41 & 1.70 & 48.10 & 45.82 & 47.31 & 45.26 & 46.30 & 44.06 & 43.57 & 44.12 & 44.05 & 45.19 & 42.87 & 48.28 \\
\hline En & 34.00 & 75.30 & 34.26 & 37.56 & 36.10 & 34.12 & 37.18 & 33.42 & 37.69 & 33.90 & 34.16 & 36.22 & 40.63 & 35.83 \\
\hline Fs & 18.59 & 23.00 & 17.63 & 16.62 & 16.59 & 20.63 & 16.52 & 22.52 & 18.74 & 21.98 & 21.78 & 18.59 & 16.49 & 15.88 \\
\hline
\end{tabular}




\begin{tabular}{|c|c|c|c|c|c|c|c|c|c|c|c|c|c|c|}
\hline $\begin{array}{l}\text { Sample } \\
\text { Type }\end{array}$ & $\begin{array}{c}90029 \mathrm{~B} 1 \\
\text { Type L } \\
\text { core }\end{array}$ & $\begin{array}{c}90029 \mathrm{~B} 1 \\
\text { Type L } \\
\text { melt }\end{array}$ & $\begin{array}{c}90029 \mathrm{~B} 1 \\
\text { Type L } \\
\text { core }\end{array}$ & $\begin{array}{c}90029 \mathrm{D} 1 \\
\text { Type L } \\
\text { core } \\
\end{array}$ & $\begin{array}{c}90033 \mathrm{~A} \\
\text { Type P } \\
\text { core } \\
\end{array}$ & $\begin{array}{c}90033 \mathrm{~A} \\
\text { Type P } \\
\text { core } \\
\end{array}$ & $\begin{array}{c}90033 \mathrm{~A} \\
\text { Type P } \\
\text { core } \\
\end{array}$ & $\begin{array}{c}90033 \mathrm{~A} \\
\text { Type P } \\
\text { core } \\
\end{array}$ & $\begin{array}{c}90033 \mathrm{~B} \\
\text { Type P } \\
\text { core }\end{array}$ & $\begin{array}{c}90033 \mathrm{~B} \\
\text { Type P } \\
\text { core } \\
\end{array}$ & $\begin{array}{c}90033 \mathrm{~B} \\
\text { Type P } \\
\text { core } \\
\end{array}$ & $\begin{array}{c}90033 \mathrm{~B} \\
\text { Type P } \\
\text { core } \\
\end{array}$ & $\begin{array}{c}90033 \mathrm{~B} \\
\text { Type P } \\
\text { core }\end{array}$ & $\begin{array}{c}90033 \text { B } \\
\text { Type P } \\
\text { core } \\
\end{array}$ \\
\hline $\mathrm{SiO}_{2}$ & 51.22 & 59.53 & 50.74 & 50.43 & 47.24 & 48.42 & 48.66 & 48.27 & 48.61 & 48.90 & 48.50 & 48.43 & 48.95 & 48.31 \\
\hline $\mathrm{Al}_{2} \mathrm{O}_{3}$ & 3.27 & 0.75 & 3.59 & 2.99 & 8.38 & 7.84 & 7.33 & 8.37 & 7.91 & 7.67 & 8.04 & 7.83 & 8.00 & 8.43 \\
\hline TiO2 & 1.05 & 0.00 & 1.01 & 1.12 & 1.81 & 1.68 & 2.00 & 1.84 & 1.39 & 1.18 & 1.23 & 1.23 & 1.32 & 1.37 \\
\hline $\mathrm{FeO}$ total & 10.40 & 6.06 & 10.48 & 11.07 & 7.92 & 8.25 & 7.33 & 7.92 & 7.85 & 7.67 & 8.21 & 8.03 & 8.18 & 8.08 \\
\hline $\mathrm{MnO}$ & 0.27 & 0.60 & 0.25 & 0.33 & 0.18 & 0.12 & 0.12 & 0.11 & 0.16 & 0.15 & 0.24 & 0.18 & 0.23 & 0.29 \\
\hline $\mathrm{MgO}$ & 12.51 & 30.06 & 12.75 & 12.72 & 1262 & 12.64 & 11.83 & 12.89 & 12.93 & 12.73 & 12.59 & 12.77 & 1284 & 1245 \\
\hline $\mathrm{CaO}$ & 20.92 & 0.36 & 21.39 & 21.77 & 19.97 & 20.12 & 22.26 & 19.66 & 20.54 & 20.34 & 19.80 & 19.73 & 20.24 & 20.09 \\
\hline $\mathrm{Na}_{2} \mathrm{O}$ & 0.53 & 2.04 & 0.61 & & 0.89 & 0.93 & 0.42 & 0.92 & 0.92 & 0.94 & 0.95 & 0.86 & 0.92 & 0.85 \\
\hline $\mathrm{K} 2 \mathrm{O}$ & 0.00 & 0.60 & 0.00 & & 0.01 & 0.00 & 0.03 & 0.02 & 0.01 & 0.01 & 0.00 & 0.02 & 0.01 & 0.00 \\
\hline $\mathrm{Fe} 2 \mathrm{O} 3$ & 0.06 & 0.91 & 2.37 & 0.75 & 2.49 & 1.78 & 0.00 & 1.31 & 2.57 & 1.60 & 1.79 & 1.45 & 203 & 0.88 \\
\hline $\mathrm{FeO}$ & 10.34 & 5.24 & 8.35 & 10.39 & 5.68 & 6.65 & 7.33 & 6.74 & 5.54 & 6.23 & 6.60 & 6.73 & 6.36 & 7.29 \\
\hline TOTAL & 100.17 & 99.40 & 100.82 & 100.43 & 99.01 & 100.00 & 99.98 & 100.00 & 100.33 & 99.59 & 99.56 & 99.09 & 100.69 & 99.87 \\
\hline $\mathrm{Si}$ & 1.917 & 2.034 & 1.893 & 1.895 & 1.773 & 1.791 & 1.812 & 1.788 & 1.798 & 1.811 & 1.807 & 1.805 & 1.803 & 1.794 \\
\hline AlIV & 0.083 & 0.000 & 0.107 & 0.105 & 0.227 & 0.209 & 0.188 & 0.212 & 0.202 & 0.189 & 0.193 & 0.195 & 0.197 & 0.206 \\
\hline AIVI & 0.060 & 0.030 & 0.050 & 0.030 & 0.140 & 0.130 & 0.130 & 0.150 & 0.140 & 0.150 & 0.160 & 0.150 & 0.150 & 0.160 \\
\hline $\mathrm{Ti}$ & 0.029 & 0.000 & 0.028 & 0.032 & 0.051 & 0.047 & 0.056 & 0.051 & 0.039 & 0.033 & 0.035 & 0.034 & 0.037 & 0.038 \\
\hline FelII & 0.002 & 0.024 & 0.066 & 0.021 & 0.070 & 0.049 & 0.000 & 0.036 & 0.071 & 0.045 & 0.050 & 0.041 & 0.056 & 0.015 \\
\hline FeII & 0.324 & 0.151 & 0.259 & 0.326 & 0.177 & 0.206 & 0.255 & 0.208 & 0.170 & 0.193 & 0.205 & 0.210 & 0.195 & 0.227 \\
\hline Mn & 0.009 & 0.017 & 0.008 & 0.010 & 0.006 & 0.004 & 0.004 & 0.003 & 0.005 & 0.005 & 0.008 & 0.006 & 0.007 & 0.009 \\
\hline $\mathrm{Mg}$ & 0.698 & 1.546 & 0.709 & 0.712 & 0.706 & 0.697 & 0.657 & 0.712 & 0.713 & 0.703 & 0.699 & 0.709 & 0.705 & 0.689 \\
\hline $\mathrm{Ca}_{\mathrm{a}}$ & 0.839 & 0.013 & 0.855 & 0.876 & 0.803 & 0.798 & 0.889 & 0.780 & 0.814 & 0.808 & 0.790 & 0.788 & 0.799 & 0.799 \\
\hline $\mathrm{Na}$ & 0.038 & 0.136 & 0.044 & & 0.064 & 0.067 & 0.031 & 0.066 & 0.066 & 0.068 & 0.068 & 0.062 & 0.065 & 0.061 \\
\hline $\mathbf{K}$ & 0.000 & 0.026 & 0.000 & & 0.000 & 0.000 & 0.001 & 0.001 & 0.000 & 0.000 & 0.000 & 0.001 & 0.001 & 0.000 \\
\hline TOTAL & 3.999 & 3.977 & 4.019 & 4.007 & 4.017 & 3.998 & 4.023 & 4.007 & 4.018 & 4.005 & 4.015 & 4.001 & 4.015 & 3.998 \\
\hline Wo & 45.03 & 0.75 & 45.26 & 45.27 & 45.73 & 45.60 & 49.36 & 44.93 & 46.04 & 46.20 & 45.30 & 45.08 & 45.53 & 46.18 \\
\hline En & 37.47 & 89.16 & 37.53 & 36.80 & 40.21 & 39.83 & 36.48 & 41.01 & 40.33 & 40.19 & 40.08 & 40.56 & 40.17 & 39.83 \\
\hline Fs & 17.50 & 10.09 & 17.20 & 17.93 & 14.07 & 14.57 & 14.16 & 14.06 & 13.63 & 13.61 & 14.62 & 14.36 & 14.30 & 13.99 \\
\hline
\end{tabular}

\begin{tabular}{|c|c|c|c|c|c|c|c|c|c|c|c|c|c|c|}
\hline Sample & $t$ & 331 & $90033 \mathrm{G} 1 \mathrm{c}$ & $33 \mathrm{G} 1$ & 90033P1 & 90033P1 & 90033P1 & 90033P1 9 & $90033 \mathrm{P} 1$ & 90033P1 9 & $90033 \mathrm{P} 19$ & $90033 \mathrm{Q} 1 \mathrm{~s}$ & 90033Q19 & $90033 Q 1$ \\
\hline Type & $\begin{array}{c}\text { Type L } \\
\text { core }\end{array}$ & $\begin{array}{c}\text { Type L } \\
\text { core }\end{array}$ & $\begin{array}{c}\text { Type L } \\
\text { core }\end{array}$ & $\begin{array}{c}\text { Type L } \\
\text { core }\end{array}$ & $\begin{array}{c}\text { Type C } \\
\text { core }\end{array}$ & $\begin{array}{c}\text { Type C } \\
\text { core }\end{array}$ & $\begin{array}{c}\text { Type C } \\
\text { core }\end{array}$ & $\begin{array}{c}\text { Type C } \\
\text { oxid }\end{array}$ & $\begin{array}{c}\text { Type C } \\
\text { core } \\
\end{array}$ & $\begin{array}{c}\text { Type C } \\
\text { core }\end{array}$ & $\begin{array}{c}\text { Type C } \\
\text { oxid }\end{array}$ & $\begin{array}{l}\text { Type P } \\
\text { oxid c- }\end{array}$ & $\begin{array}{c}\text { Type P } \\
\text { rim }\end{array}$ & $\begin{array}{c}\text { Type } \mathrm{P} \\
\text { core } \\
\end{array}$ \\
\hline $\mathrm{SiO}_{2}$ & 49.96 & 49.90 & 51.81 & 49.55 & 46.94 & 48.05 & 47.84 & 44.56 & 48.10 & 48.02 & 41.06 & 38.84 & 40.97 & 47.09 \\
\hline $\mathrm{Al} 2 \mathrm{O}_{3}$ & 3.64 & 4.03 & 280 & 4.28 & 8.18 & 7.73 & 6.90 & 8.49 & 7.38 & 8.05 & 13.92 & 15.23 & 1243 & 7.22 \\
\hline $\mathrm{TiO}_{2}$ & 1.41 & 1.32 & 0.48 & 205 & 2.23 & 1.85 & 1.81 & 4.20 & 1.76 & 2.27 & 6.11 & 7.03 & 6.22 & 3.79 \\
\hline $\mathrm{FeO}$ total & 10.34 & 10.01 & 10.91 & 8.75 & 8.55 & 8.05 & 8.64 & 6.98 & 8.17 & 7.45 & 6.11 & 6.78 & 5.69 & 6.10 \\
\hline $\mathrm{MnO}$ & 0.26 & 0.27 & 0.33 & 0.20 & 0.13 & 0.21 & 0.20 & 0.08 & 0.17 & 0.22 & 0.18 & 0.07 & 0.08 & 0.11 \\
\hline $\mathrm{MgO}$ & 12.87 & 12.87 & 1249 & 13.25 & 12.17 & 12.23 & 12.22 & 12.25 & 12.32 & 11.92 & 10.26 & 9.38 & 10.99 & 13.41 \\
\hline $\mathrm{CaO}$ & 20.97 & 21.32 & 20.48 & 20.74 & 20.95 & 21.06 & 20.68 & 22.27 & 21.21 & 21.30 & 22.31 & 21.90 & 22.58 & 21.90 \\
\hline $\mathrm{Na} 2 \mathrm{O}$ & 0.55 & 0.45 & 0.72 & 0.69 & 0.83 & 0.81 & 0.91 & 0.55 & 0.88 & 0.78 & & 0.77 & 0.56 & 0.20 \\
\hline $\mathrm{K}_{2} \mathrm{O}$ & 0.00 & 0.00 & 0.01 & 0.00 & 0.02 & 0.01 & 0.00 & 0.01 & 0.00 & 0.00 & 0.00 & 0.01 & 0.00 & 0.01 \\
\hline $\mathrm{Fe} 2 \mathrm{O} 3$ & 2.23 & 1.99 & 0.83 & 1.41 & 3.35 & 1.92 & 2.80 & 3.30 & 2.75 & 0.41 & 0.00 & 273 & 258 & 0.00 \\
\hline $\mathrm{FeO}$ & 8.53 & 8.22 & 10.16 & 7.48 & 5.53 & 6.32 & 6.12 & 4.01 & 5.70 & 7.04 & 6.11 & 4.33 & 3.37 & 6.10 \\
\hline TOTAL & 100.00 & 100.18 & 100.03 & 99.52 & 99.98 & 99.99 & 99.19 & 99.39 & 99.99 & 100.01 & 99.95 & 100.00 & 99.52 & 99.82 \\
\hline $\mathrm{Si}$ & 1.879 & 1.871 & 1.939 & 1.853 & 1.755 & 1.782 & 1.802 & 1.680 & 1.793 & 1.783 & 1.540 & 1.464 & 1.543 & 1.752 \\
\hline AllV & 0.120 & 0.130 & 0.060 & 0.150 & 0.240 & 0.220 & 0.200 & 0.320 & 0.210 & 0.220 & 0.460 & 0.540 & 0.460 & 0.250 \\
\hline AIVI & 0.040 & 0.050 & 0.060 & 0.040 & 0.120 & 0.120 & 0.110 & 0.060 & 0.120 & 0.130 & 0.160 & 0.140 & 0.100 & 0.070 \\
\hline $\mathrm{Ti}$ & 0.040 & 0.037 & 0.014 & 0.058 & 0.063 & 0.052 & 0.051 & 0.119 & 0.049 & 0.060 & 0.170 & 0.199 & 0.176 & 0.106 \\
\hline FeIII & 0.062 & 0.056 & 0.023 & 0.040 & 0.094 & 0.054 & 0.079 & 0.093 & 0.077 & 0.010 & 0.000 & 0.077 & 0.073 & 0.003 \\
\hline Fell & 0.262 & 0.257 & 0.318 & 0.234 & 0.172 & 0.196 & 0.191 & 0.126 & 0.17 & 0.220 & 0.190 & 0.136 & 0.106 & 0.200 \\
\hline Mn & 0.008 & 0.008 & 0.010 & 0.006 & 0.004 & 0.007 & 0.006 & 0.002 & 0.005 & 0.007 & 0.010 & 0.002 & 0.003 & 0.000 \\
\hline $\mathrm{Mg}$ & 0.721 & 0.720 & 0.697 & 0.739 & 0.678 & 0.676 & 0.686 & 0.689 & 0.684 & 0.660 & 0.570 & 0.527 & 0.617 & 0.740 \\
\hline $\mathrm{Ca}$ & 0.845 & 0.857 & 0.822 & 0.832 & 0.840 & 0.837 & 0.835 & 0.900 & 0.847 & 0.848 & 0.890 & 0.884 & 0.911 & 0.873 \\
\hline $\mathrm{Na}$ & 0.040 & 0.033 & 0.052 & 0.050 & 0.060 & 0.058 & 0.066 & 0.040 & 0.064 & 0.056 & & 0.056 & 0.041 & 0.014 \\
\hline K & 0.000 & 0.000 & 0.000 & 0.000 & 0.001 & 0.000 & 0.000 & 0.001 & 0.000 & 0.000 & 0.000 & 0.000 & 0.000 & 0.000 \\
\hline TOTAL & 4.017 & 4.019 & 3.995 & 4.002 & 4.027 & 4.002 & 4.026 & 4.030 & 4.026 & 3.994 & 3.990 & 4.025 & 4.030 & 4.008 \\
\hline Wo & 44.71 & 45.34 & 44.19 & 45.09 & 47.09 & 47.48 & 46.62 & 49.78 & 47.45 & 48.79 & 53.94 & 54.43 & 53.37 & 48.07 \\
\hline En & 38.15 & 38.10 & 37.47 & 40.05 & 38.00 & 38.34 & 38.30 & 38.11 & 38.32 & 37.97 & 34.55 & 32.45 & 36.15 & 40.75 \\
\hline Fs & 17.14 & 16.56 & 18.33 & 14.85 & 14.91 & 14.18 & 15.08 & 12.11 & 14.23 & 13.23 & 11.52 & 13.12 & 10.49 & 11.18 \\
\hline
\end{tabular}




\begin{tabular}{|c|c|c|c|c|c|c|c|c|c|c|c|c|c|c|}
\hline rype & $\begin{array}{c}90033 \mathrm{C} \\
\text { Type P } \\
\text { core } \\
\end{array}$ & $\begin{array}{c}90033 \mathrm{C} \\
\text { Type P } \\
\text { core } \\
\end{array}$ & $\begin{array}{c}90033 \mathrm{C} \\
\text { Type P } \\
\text { core } \\
\end{array}$ & $\begin{array}{c}90033 \mathrm{C} \\
\text { Type P } \\
\text { core } \\
\end{array}$ & $\begin{array}{c}90033 \mathrm{C} \\
\text { Type P } \\
\text { core } \\
\end{array}$ & $\begin{array}{c}90033 \mathrm{~F} \\
\text { Type P } \\
\text { core } \\
\end{array}$ & $\begin{array}{c}90033 G \\
\text { Type P } \\
\text { core } \\
\end{array}$ & $\begin{array}{l}90033 \mathrm{G} \\
\text { Type P } \\
\text { oxid c } \\
\end{array}$ & $\begin{array}{c}90033 G \\
\text { Type P } \\
\text { core } \\
\end{array}$ & $\begin{array}{l}\text { 90033G } \\
\text { Type P } \\
\text { oxid c } \\
\end{array}$ & $\begin{array}{c}90033 \mathrm{G} \\
\text { Type P } \\
\text { core } \\
\end{array}$ & $\begin{array}{c}90033 \mathrm{C} \\
\text { Type P } \\
\text { core } \\
\end{array}$ & $\begin{array}{c}90033 \mathrm{H} \\
\text { Type P } \\
\text { core } \\
\end{array}$ & $\begin{array}{c}90033 \mathrm{H} \\
\text { Type P } \\
\text { core } \\
\end{array}$ \\
\hline $\mathrm{iO}_{2}$ & .17 & 47.60 & 47.17 & 47.08 & 51.42 & 49.97 & 44.57 & 45.38 & 46.61 & 95 & 47.10 & 47.13 & 49.28 & 49.45 \\
\hline & & 8.52 & & 9.17 & 3.04 & 7.87 & 10.46 & & 9.29 & 8.3 & 6.88 & 5.61 & 7.43 & 7.07 \\
\hline $\mathrm{TiO}_{2}$ & 1.44 & 2.23 & & 2.82 & 0.64 & 2.11 & 3.93 & 3.3 & 2.25 & 2.84 & & 2.34 & & 1.79 \\
\hline $\mathrm{FeO}$ to & 6.82 & 7.56 & 7.36 & 7.31 & 6.99 & 6.44 & 8.22 & 6.90 & 8.92 & & & & 4.99 & 5.26 \\
\hline Ino & 0.17 & 0.14 & 0.15 & 0.17 & 0.23 & 0.10 & 0.00 & 0.10 & 0.19 & & 0.15 & 0.27 & 0.11 & 0.16 \\
\hline 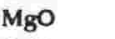 & & 12.04 & 12.10 & 11.89 & 14.64 & 1290 & 10.32 & 12.41 & 11.67 & 12.47 & 12.78 & 11.29 & 14.52 & 14.81 \\
\hline $\mathrm{aO}$ & & 20.62 & 20.63 & 20.81 & 21.53 & 20.32 & 21.60 & & 19.74 & 22.23 & 22.34 & 2.30 & 20.84 & 20.58 \\
\hline $\mathrm{Na} 2$ & 1. & 1.22 & 1.18 & 1.35 & 0.68 & 0.93 & 0.89 & 0.62 & 1.06 & & & & & 0.88 \\
\hline 20 & 0.0 & 0.00 & 0.01 & 0.01 & 0.02 & 0.02 & 0.00 & 0.01 & 0.01 & 0.03 & 0.02 & 0.06 & 0.00 & 0.00 \\
\hline & & & & & & 0.00 & & & & & & & & 1.69 \\
\hline 0 & & 23 & 6 & 4. & 4.92 & 6.44 & 62 & 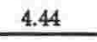 & 6.5 & ? & 4.38 & 3.56 & 3.7 & 3.74 \\
\hline OTA & 51 & 99.93 & 27 & 1 & 9.1 & 00.66 & 99.9 & 99.20 & 2 & 99. & 9.98 & 99.58 & & 100.00 \\
\hline & & 1. & & $\ldots$ & 1.91 & 1.824 & 1. & 1.090 & 1.7 & 1.7 & , & 1.7 & 1.8 & 1.806 \\
\hline IV & & 0.240 & 0.236 & 0.261 & 0.083 & 0.176 & & 0.304 & 0.255 & & 0 & 6 & 6 & 0.194 \\
\hline & & 0.130 & & 140 & 0.050 & 0.160 & 0.130 & & 0160 & & 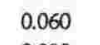 & & & 0.110 \\
\hline & 10 & 0.062 & 0.060 & 0.078 & 0.018 & 0.058 & 0. & 0.095 & 0.0 & 0.0 & 0.080 & 0.066 & 0.047 & 0.049 \\
\hline eIII & & 0.072 & & 0.086 & 0.064 & 0.000 & 0.050 & 0.077 & 0.07 & 0.1 & 9 & 0.190 & 0.037 & 0.046 \\
\hline 11 & & 0.162 & & 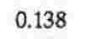 & 0.153 & 0.197 & 0307 & & 0.20 & & & & & 0.114 \\
\hline & & 0.004 & 0 & 0 & 0.007 & 0.003 & & & 0.0 & & & & & 0.005 \\
\hline & & 0.664 & & & & 0.701 & 0.575 & 0.692 & 0.651 & 0.6 & 2 & 0.6 & 2 & 0.806 \\
\hline & & & & & 0.860 & 0.794 & & & 0.7 & & & & & 0.806 \\
\hline & & & & & & & & & 0.077 & & & 0.078 & & 0.062 \\
\hline & 0.000 & 0.001 & 0.000 & 0.001 & 0.001 & 0.001 & 0.000 & 0.000 & 0.000 & 0.001 & 0.001 & 0.003 & 0.000 & 0.000 \\
\hline TAL & 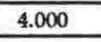 & 77 & 8.022 & 8.020 & 4.010 & 3.979 & 4.003 & 3.999 & 4.027 & 0.978 & .023 & 3.996 & 4.003 & 3.998 \\
\hline & & & & & & & & & & & & & & \\
\hline & & & & 38 & & & & & 37. & 38.37 & 86 & 34.51 & 44.95 & 45.49 \\
\hline & 12.12 & 13.64 & 13.23 & 13.16 & 11.48 & 1.64 & 15.14 & 12.02 & 16.15 & 12.49 & 12.28 & 16.41 & 8.63 & 9.03 \\
\hline
\end{tabular}

\begin{tabular}{|c|c|c|c|c|c|c|c|c|c|c|c|c|c|c|}
\hline $\begin{array}{l}\text { Sample } \\
\text { Type }\end{array}$ & $\begin{array}{c}90033 \mathrm{Q} 1 \\
\text { Type P } \\
\text { core } \\
\end{array}$ & $\begin{array}{l}90033 \text { Q1 } \\
\text { Type P } \\
\text { oxid c- }\end{array}$ & $\begin{array}{c}90033 \mathrm{Q} 1 \\
\text { Type P } \\
\text { rim }\end{array}$ & $\begin{array}{c}\text { Type P P } \\
\text { core }\end{array}$ & $\begin{array}{c}90033 \mathrm{Q1} \\
\text { Type P } \\
\text { rim } \\
\end{array}$ & $\begin{array}{c}190033 \mathrm{Q1} \\
\text { Type } \mathrm{P} \\
\text { core }\end{array}$ & $\begin{array}{c}190033 \mathrm{~S} 1 \\
\text { Type P } \\
\text { oxid }\end{array}$ & $\begin{array}{c}\text { Ty0033S1 } \\
\text { Type P } \\
\text { core }\end{array}$ & $\begin{array}{c}90033 \mathrm{~S} 1 \\
\text { Type } \mathrm{P} \\
\text { core } \\
\end{array}$ & $\begin{array}{c}90033 \mathrm{~S} 1 \\
\text { Type } \mathrm{P} \\
\text { core } \\
\end{array}$ & $\begin{array}{c}90033 \mathrm{S1} \\
\text { Type P } \\
\text { core } \\
\end{array}$ & $\begin{array}{c}190033 \mathrm{~S} 1 \\
\text { Type P } \\
\text { core } \\
\end{array}$ & $\begin{array}{c}190033 \mathrm{~S} 1 \\
\text { Type P } \\
\text { core } \\
\end{array}$ & $\begin{array}{c}90039 \mathrm{~B} \\
\text { Type M } \\
\text { core } \\
\end{array}$ \\
\hline $\mathrm{HO}_{2}$ & 43.21 & 38.44 & 42.37 & 49.36 & 41.39 & 48.14 & 45.62 & 46.07 & 40.29 & 42.47 & 42.67 & 47.98 & 48.25 & 50.44 \\
\hline $\mathrm{Al} 2 \mathrm{O} 3$ & 11.45 & 15.30 & 11.46 & 7.86 & 12.68 & 8.67 & 8.92 & 6.58 & 12.91 & 11.50 & 11.79 & 9.22 & 8.72 & 4.49 \\
\hline $\mathrm{TiO}_{2}$ & 4.66 & 7.19 & 5.56 & 1.53 & 6.01 & 1.83 & 4.67 & 3.99 & 6.86 & 5.36 & 5.35 & 2.14 & 1.55 & 1.47 \\
\hline $\mathrm{FeO}$ total & 5.47 & 7.33 & 5.50 & 6.65 & 5.52 & 6.34 & 5.33 & 6.51 & 5.72 & 5.02 & 5.35 & 6.92 & 6.80 & 8.67 \\
\hline $\mathrm{MnO}$ & 0.01 & 0.02 & 0.09 & 0.10 & 0.07 & 0.17 & 0.03 & 0.05 & 0.02 & 0.12 & 0.09 & 0.18 & 0.18 & 0.27 \\
\hline MgO & 11.83 & 9.08 & 11.51 & 13.56 & 11.13 & 13.25 & 1284 & 14.78 & 10.94 & 11.92 & 11.89 & 13.19 & 13.24 & 12.95 \\
\hline $\mathrm{CaO}$ & 22.07 & 21.46 & 22.48 & 20.67 & 2273 & 20.42 & 21.91 & 20.48 & 22.30 & 22.37 & 22.04 & 19.59 & 19.70 & 20.95 \\
\hline $\mathrm{Na} 2 \mathrm{O}$ & 0.55 & 0.81 & 0.59 & 1.04 & 0.54 & 1.08 & 0.66 & 0.53 & 0.55 & 0.55 & 0.42 & 0.78 & 0.66 & 0.47 \\
\hline $\mathrm{K} 2 \mathrm{O}$ & 0.00 & 0.00 & 0.02 & 0.00 & 0.01 & 0.01 & 0.02 & 0.01 & 0.00 & 0.00 & 0.01 & 0.00 & 0.00 & 0.00 \\
\hline $\mathrm{Fe} 2 \mathrm{O3}$ & 1.72 & 2.64 & 229 & 2.05 & 2.45 & 238 & 0.78 & 3.30 & 2.26 & 2.24 & 2.25 & 0.04 & 0.00 & 0.00 \\
\hline $\mathrm{FeO}$ & 3.92 & 4.92 & 3.44 & 4.81 & 3.31 & 4.20 & 4.63 & 3.54 & 3.69 & 3.01 & 3.32 & 6.89 & 6.80 & 8.67 \\
\hline TOTAL & 99.26 & 99.61 & 99.55 & 100.77 & 100.06 & 99.89 & 99.98 & 98.99 & 99.59 & 99.32 & 99.59 & 100.00 & 99.10 & 99.71 \\
\hline Si & 1.613 & 1.449 & 1.581 & 1.798 & 1.539 & 1.776 & 1.688 & 1.730 & 1.516 & 1.585 & 1.582 & 1.766 & 1.790 & 1.890 \\
\hline AlIV & 0.390 & 0.550 & 0.420 & 0.200 & 0.460 & 0.220 & 0.310 & 0.270 & 0.480 & 0.410 & 0.420 & 0.230 & 0.210 & 0.110 \\
\hline Alv1 & 0.120 & 0.130 & 0.090 & 0.140 & 0.100 & 0.150 & 0.080 & 0.020 & 0.090 & 0.090 & 0.100 & 0.170 & 0.170 & 0.090 \\
\hline $\mathrm{Ti}$ & 0.131 & 0.204 & 0.156 & 0.042 & 0.168 & 0.051 & 0.130 & 0.113 & 0.194 & 0.150 & 0.149 & 0.059 & 0.043 & 0.040 \\
\hline FelII & 0.048 & 0.075 & 0.064 & 0.056 & 0.069 & 0.066 & 0.022 & 0.093 & 0.064 & 0.063 & 0.063 & 0.010 & 0.000 & 0.000 \\
\hline Fell & 0.122 & 0.156 & 0.107 & 0.146 & 0.103 & 0.129 & 0.143 & 0.110 & 0.116 & 0.094 & 0.103 & 0.212 & 0.217 & 0.270 \\
\hline Mn & 0.000 & 0.001 & 0.003 & 0.003 & 0.002 & 0.005 & 0.001 & 0.001 & 0.001 & 0.004 & 0.011 & 0.006 & 0.005 & 0.010 \\
\hline Mg & 0.658 & 0.510 & 0.640 & 0.736 & 0.617 & 0.728 & 0.709 & 0.827 & 0.614 & 0.663 & 0.657 & 0.724 & 0.732 & 0.720 \\
\hline $\mathrm{Ca}$ & 0.883 & 0.867 & 0.900 & 0.807 & 0.906 & 0.807 & 0.869 & 0.824 & 0.899 & 0.895 & 0.889 & 0.773 & 0.783 & 0.840 \\
\hline $\mathrm{Na}$ & 0.040 & 0.059 & 0.043 & 0.073 & 0.039 & 0.077 & 0.047 & 0.039 & 0.040 & 0.040 & 0.040 & 0.056 & 0.047 & 0.030 \\
\hline $\mathbf{K}$ & 0.000 & 0.000 & 0.001 & 0.000 & 0.001 & 0.000 & 0.001 & 0.001 & 0.000 & 0.000 & 0.003 & 0.000 & 0.000 & 0.000 \\
\hline TOTAL & 4.005 & 4.001 & 4.005 & 4.001 & 4.004 & 4.009 & 4.000 & 4.028 & 4.014 & 3.994 & 4.017 & 4.006 & 3.997 & 4.000 \\
\hline Wo & 51.61 & 53.92 & 52.60 & 46.25 & 53.45 & 46.65 & 49.86 & 44.44 & 53.10 & 52.19 & 51.93 & 44.97 & 45.21 & 45.90 \\
\hline 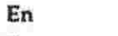 & 38.46 & 31.72 & 37.41 & 42.18 & 36.40 & 42.08 & 40.68 & 44.61 & 36.27 & 38.66 & 38.38 & 42.12 & 42.26 & 39.34 \\
\hline $\mathrm{Fs}$ & 9.94 & 14.37 & 9.99 & 11.58 & 10.15 & 11.27 & 9.47 & 10.95 & 10.63 & 9.15 & 9.70 & 12.91 & 12.53 & 14.75 \\
\hline
\end{tabular}




\begin{tabular}{|c|c|c|c|c|c|c|c|c|c|c|c|c|c|c|}
\hline Sample & 900331 & 900331 & $90033 I$ & 900331 & $90033 \mathrm{~J}$ & $90033 \mathrm{~J}$ & $90033 \mathrm{~J}$ & $90033 \mathrm{~J}$ & $90033 \mathrm{~J}$ & $90033 \mathrm{~J}$ & $90033 \mathrm{~K}$ & $90033 \mathrm{~K}$ & $90033 \mathrm{~K}$ & $90033 \mathrm{R}$ \\
\hline Type & $\begin{array}{c}\text { Type P } \\
\text { core }\end{array}$ & $\begin{array}{c}\text { Type } \mathrm{P} \\
\text { core }\end{array}$ & $\begin{array}{c}\text { Type P } \\
\text { core } \\
\end{array}$ & $\begin{array}{c}\text { Type P } \\
\text { core }\end{array}$ & $\begin{array}{c}\text { Type C } \\
\text { core }\end{array}$ & $\begin{array}{c}\text { Type C } \\
\text { core }\end{array}$ & $\begin{array}{c}\text { Type C } \\
\text { core }\end{array}$ & $\begin{array}{c}\text { Type C } \\
\text { core }\end{array}$ & $\begin{array}{c}\text { Type C } \\
\text { core }\end{array}$ & $\begin{array}{c}\text { Type C } \\
\text { core }\end{array}$ & $\begin{array}{c}\text { Type } M \\
\text { core- }\end{array}$ & $\begin{array}{c}\text { Type } M \\
\text { rim }\end{array}$ & $\begin{array}{c}\text { Type } M \\
\text { core }\end{array}$ & $\begin{array}{c}\text { Type P } \\
\text { core }\end{array}$ \\
\hline $\mathrm{SiO}_{2}$ & 48.21 & 48.24 & 49.31 & 48.96 & 48.76 & 48.58 & 45.30 & 48.22 & 50.16 & 50.53 & 48.78 & 44.55 & 47.52 & 45.30 \\
\hline $\mathrm{Al}_{2} \mathrm{O}_{3}$ & 8.73 & 8.56 & 7.90 & 8.55 & 8.14 & 7.98 & 7.79 & 8.51 & 6.98 & 7.19 & 8.29 & 10.29 & 8.51 & 8.93 \\
\hline $\mathrm{TiO}_{2}$ & 2.02 & 1.95 & 1.47 & 1.43 & 1.70 & 1.86 & 3.87 & 1.92 & 1.28 & 1.53 & 2.20 & 5.01 & 257 & 279 \\
\hline FeO total & 5.83 & 6.25 & 5.64 & 5.70 & 7.38 & 7.39 & 6.94 & 7.38 & 7.74 & 8.14 & 5.58 & 4.71 & 5.99 & 6.51 \\
\hline $\mathrm{MnO}$ & 0.12 & 0.19 & 0.16 & 0.29 & 0.14 & 0.20 & 0.12 & 0.20 & 0.27 & 0.06 & 0.12 & 0.06 & 0.19 & 0.14 \\
\hline $\mathrm{MgO}$ & 13.17 & 13.11 & 13.73 & 13.53 & 1217 & 12.40 & 12.41 & 12.27 & 13.07 & 13.23 & 13.84 & 12.62 & 13.35 & 1205 \\
\hline $\mathrm{CaO}$ & 20.41 & 20.05 & 20.61 & 20.65 & 21.89 & 21.70 & 22.29 & 21.69 & 21.61 & 21.08 & 20,37 & 21.95 & 20.91 & 2268 \\
\hline $\mathrm{Na} 2 \mathrm{O}$ & 1.06 & 1.05 & 0.92 & 0.88 & 0.73 & 0.82 & 0.87 & 0.77 & 0.83 & 0.84 & 0.76 & 0.63 & 0.91 & 0.56 \\
\hline $\mathrm{K} 2 \mathrm{O}$ & 0.02 & 0.02 & 0.00 & 0.02 & 0.00 & 0.00 & 0.01 & 0.02 & 0.03 & 0.02 & 0.00 & 0.00 & 0.00 & 0.01 \\
\hline$\overline{\mathrm{Fe} 2 \mathrm{O} 3}$ & 1.23 & 1.12 & 0.82 & 0.98 & 0.09 & 1.73 & $2 . \pi$ & 1.67 & 2.03 & 1.07 & 0.00 & 0.61 & 208 & 3.24 \\
\hline $\mathrm{FeO}$ & 4.73 & 5.24 & 4.90 & 4.81 & 6.55 & 5.84 & 4.64 & 5.82 & 5.92 & 7.17 & 5.58 & 4.16 & 4.12 & 3.59 \\
\hline TOTAL & 99.57 & 99.42 & 99.74 & 100.01 & 100.91 & 100.94 & 99.61 & 100.97 & 101.96 & 10261 & 99.94 & 99.83 & 99.95 & 99.17 \\
\hline $\mathrm{Si}$ & 1.776 & 1.785 & 1.811 & 1.795 & 1.794 & 1.787 & 1.687 & 1.775 & 1.830 & 1.826 & 1.791 & 1.650 & 1.751 & 1.712 \\
\hline AIIV & 0.224 & 0.215 & 0.189 & 0.205 & 0.206 & 0.213 & 0.313 & 0.220 & 0.170 & 0.170 & 0.209 & 0.350 & 0.249 & 0.288 \\
\hline AlVI & 0.160 & 0.160 & 0.150 & 0.160 & 0.150 & 0.130 & 0.030 & 0.150 & 0.130 & 0.140 & 0.150 & 0.100 & 0.120 & 0.110 \\
\hline $\mathrm{Ti}$ & 0.056 & 0.054 & 0.042 & 0.039 & 0.047 & 0.052 & 0.108 & 0.053 & 0.035 & 0.041 & 0.061 & 0.140 & 0.071 & 0.079 \\
\hline FellI & 0.034 & 0.031 & 0.023 & 0.027 & 0.025 & 0.048 & 0.130 & 0.050 & 0.050 & 0.030 & 0.004 & 0.017 & 0.058 & 0.091 \\
\hline FeII & 0.146 & 0.162 & 0.150 & 0.148 & 0.201 & 0.179 & 0.086 & 0.180 & 0.180 & 0.220 & 0.130 & 0.129 & 0.127 & 0.112 \\
\hline $\mathrm{Mn}$ & 0.004 & 0.006 & 0.005 & 0.009 & 0.004 & 0.006 & 0.004 & 0.006 & 0.010 & 0.002 & 0.000 & 0.002 & 0.006 & 0.005 \\
\hline $\mathbf{M g}$ & 0.723 & 0.722 & 0.752 & 0.740 & 0.667 & 0.680 & 0.689 & 0.673 & 0.709 & 0.712 & 0.760 & 0.697 & 0.733 & 0.676 \\
\hline $\mathrm{Ca}_{\mathrm{a}}$ & 0.806 & 0.794 & 0.811 & 0.811 & 0.863 & 0.855 & 0.890 & 0.855 & 0.843 & 0.816 & 0.800 & 0.871 & 0.825 & 0.914 \\
\hline $\mathrm{Na}$ & 0.076 & 0.075 & 0.066 & 0.063 & 0.052 & 0.059 & 0.063 & 0.055 & 0.059 & 0.059 & 0.050 & 0.045 & 0.065 & 0.041 \\
\hline $\mathbf{K}$ & 0.001 & 0.001 & 0.000 & 0.001 & 0.000 & 0.000 & 0.001 & 0.000 & 0.001 & 0.000 & 0.000 & 0.000 & 0.000 & 0.000 \\
\hline TOTAL & 4.006 & 4.005 & 3.999 & 3.998 & 4.009 & 4.009 & 4.001 & 4.017 & 4.017 & 4.016 & 3.955 & 4.001 & 4.005 & 4.028 \\
\hline Wo & 47.16 & 46.46 & 46.72 & 46.99 & 49.15 & 48.52 & 49.58 & 48.63 & 47.31 & 45.89 & 46.23 & 50.82 & 47.33 & 50.98 \\
\hline En & 42.31 & 42.25 & 43.32 & 4287 & 37.98 & 38.59 & 38.38 & 38.28 & 39.79 & 40.04 & 43.68 & 40.67 & 4205 & 37.70 \\
\hline Fs & 10.53 & 11.29 & 9.97 & 10.14 & 1287 & 1288 & 12.03 & 13.08 & 12.91 & 14.06 & 10.09 & 8.52 & 10.61 & 11.32 \\
\hline Sample & $90039 \mathrm{~B}$ & $90039 \mathrm{~B}$ & $90039 \mathrm{D}$ & $90039 \mathrm{~F}$ & $90039 \mathrm{~F}$ & $90039 \mathrm{~F}$ & $90039 \mathrm{~F}$ & $90039 \mathrm{~F}$ & $90039 \mathrm{C}$ & $90039 \mathrm{C}$ & $90039 \mathrm{M}$ & $90039 \mathrm{M}$ & $90039 \mathrm{M}$ & $90039 \mathrm{M}$ \\
\hline Type & $\begin{array}{c}\text { Type } \mathrm{M} \\
\text { core } \\
\end{array}$ & $\begin{array}{c}\text { Type } M \\
\text { core } \\
\end{array}$ & $\begin{array}{l}\text { Type L } \\
\text { oxid ol }\end{array}$ & $\begin{array}{c}\text { Type M } \\
\text { core }\end{array}$ & $\begin{array}{c}\text { Type } M \\
\text { core } \\
\end{array}$ & $\begin{array}{c}\text { Type } \mathbf{M} \\
\text { core }\end{array}$ & $\begin{array}{c}\text { Type M } \\
\text { sore } \\
\end{array}$ & $\begin{array}{c}\text { Type M } \\
\text { core } \\
\end{array}$ & $\begin{array}{c}\text { Type L } \\
\text { core }\end{array}$ & $\begin{array}{c}\text { Type L } \\
\text { oxid }\end{array}$ & $\begin{array}{c}\text { Type L } \\
\text { core }\end{array}$ & $\begin{array}{c}\text { Type L } \\
\text { core }\end{array}$ & $\begin{array}{c}\text { Type L } \\
\text { core }\end{array}$ & $\begin{array}{c}\text { Type L } \\
\text { core }\end{array}$ \\
\hline $\mathrm{SiO}_{2}$ & 49.91 & 51.29 & 53.59 & 49.75 & 50.02 & 49.94 & 50.65 & 50.32 & 44.54 & 39.72 & 49.75 & 49.59 & 50.19 & 49.87 \\
\hline $\mathrm{A}_{2} 2 \mathrm{O}_{3}$ & 4.69 & 4.65 & 2.33 & 3.62 & 3.69 & 3.98 & 3.79 & 3.62 & 9.15 & 10.51 & 4.23 & 4.31 & 3.71 & 4.09 \\
\hline $\mathrm{TiO}_{2}$ & 1.58 & 1.55 & 0.06 & 1.30 & 1.19 & 1.23 & 1.22 & $0 . \pi$ & 4.38 & 5.93 & 1.55 & 1.58 & 1.23 & 1.27 \\
\hline $\mathrm{FeO}$ total & 9.26 & 8.49 & 19.04 & 10.23 & 10.24 & 9.68 & 9.86 & 10.41 & 7.34 & 16.45 & 9.50 & 9.47 & 9.95 & 9.64 \\
\hline MnO & 0.40 & 0.23 & 0.53 & 0.32 & 0.24 & 0.33 & 0.34 & 0.35 & 0.09 & 0.22 & 0.23 & 0.22 & 0.26 & 0.25 \\
\hline $\mathrm{MgO}$ & 12.69 & 13.23 & 23.67 & 1268 & 1275 & 1272 & 12.73 & 13.03 & 11.82 & 8.43 & 12.66 & 12.85 & 1275 & 1269 \\
\hline $\mathrm{CaO}$ & 20.92 & 20.04 & 0.78 & 21.20 & 21.38 & 20.22 & 20.77 & 20.58 & 22.17 & 17.34 & 21.39 & 21.83 & 21.62 & 2203 \\
\hline $\mathrm{Na} 2 \mathrm{O}$ & 0.43 & 0.63 & 0.00 & 0.53 & 0.50 & 0.64 & 0.71 & 0.46 & 0.50 & 0.97 & 0.59 & 0.55 & 0.52 & 0.42 \\
\hline $\mathrm{K} 2 \mathrm{O}$ & 0.00 & 0.23 & 0.00 & 0.00 & 0.00 & 0.04 & 0.01 & 0.00 & 0.01 & 0.12 & 0.03 & 0.02 & 0.03 & 0.01 \\
\hline $\mathrm{Fe} 2 \mathrm{O} 3$ & 0.00 & 0.00 & 0.00 & 238 & 2.28 & 0.97 & 1.31 & 1.83 & 2.28 & 10.47 & 1.85 & 275 & 2.26 & 218 \\
\hline $\mathrm{FeO}$ & 9.26 & 8.49 & 19.04 & 8.13 & 8.19 & 8.80 & 8.68 & $8 . \pi$ & 5.28 & 6.66 & 7.83 & 6.99 & 7.91 & 7.68 \\
\hline TOTAL & 99.88 & 100.09 & 100.00 & 99.62 & 100.01 & 98.73 & 100.07 & 99.55 & 99.99 & 99.57 & 99.90 & 100.39 & 100.23 & 100.25 \\
\hline Si & 1.870 & 1.900 & 1.969 & 1.879 & 1.881 & 1.892 & 1.900 & 1.900 & 1.662 & 1.551 & 1.859 & 1.843 & 1.882 & 1.859 \\
\hline AlIV & 0.130 & 0.100 & 0.030 & 0.120 & 0.120 & 0.110 & 0.100 & 0.100 & 0.340 & 0.450 & 0.140 & 0.140 & 0.120 & 0.140 \\
\hline AlVI & 0.080 & 0.100 & 0.070 & 0.040 & 0.050 & 0.070 & 0.070 & 0.060 & 0.070 & 0.050 & 0.050 & 0.030 & 0.050 & 0.040 \\
\hline $\mathrm{Ti}$ & 0.040 & 0.040 & 0.002 & 0.037 & 0.034 & 0.030 & 0.034 & 0.022 & 0.123 & 0.174 & 0.044 & 0.044 & 0.035 & 0.036 \\
\hline FeIII & 0.000 & 0.000 & 0.000 & 0.067 & 0.064 & 0.030 & 0.040 & 0.050 & 0.064 & 0.336 & 0.052 & 0.077 & 0.064 & 0.061 \\
\hline Fell & 0.290 & 0.263 & 0.627 & 0.254 & 0.256 & 0.280 & 0.270 & 0.280 & 0.165 & 0.192 & 0.245 & 0.217 & 0.247 & 0.240 \\
\hline Mn & 0.010 & 0.007 & 0.016 & 0.010 & 0.008 & 0.010 & 0.011 & 0.011 & 0.003 & 0.007 & 0.007 & 0.007 & 0.008 & 0.008 \\
\hline $\mathrm{Mg}$ & 0.710 & 0.731 & 1.296 & 0.714 & 0.715 & 0.718 & 0.710 & 0.732 & 0.887 & 0.491 & 0.705 & 0.712 & 0.712 & 0.705 \\
\hline $\mathrm{Ca}$ & 0.840 & 0.796 & 0.031 & 0.858 & 0.862 & 0.820 & 0.833 & 0.831 & 0.657 & 0.725 & 0.857 & 0.870 & 0.869 & 0.881 \\
\hline $\mathrm{Na}$ & 0.030 & 0.050 & 0.000 & 0.039 & 0.036 & 0.047 & 0.052 & 0.034 & 0.036 & 0.073 & 0.043 & 0.040 & 0.038 & 0.030 \\
\hline K & 0.000 & 0.011 & 0.000 & 0.000 & 0.000 & 0.002 & 0.000 & 0.000 & 0.000 & 0.006 & 0.002 & 0.001 & 0.001 & 0.001 \\
\hline TOTAL & 4.000 & 3.998 & 4.041 & 4.018 & 4.026 & 4.009 & 4.020 & 4.020 & 4.007 & 4.055 & 4.004 & 3.981 & 4.026 & 4.001 \\
\hline Wo & 45.65 & 44.47 & 1.59 & 45.32 & 45.44 & 44.37 & 44.95 & 43.90 & 37.06 & 41.57 & 46.10 & 46.38 & 45.93 & 46.69 \\
\hline En & 38.59 & 40.83 & 66.33 & 37.72 & 37.69 & 38.85 & 38.32 & 38.67 & 50.03 & 28.15 & 37.92 & 37.95 & 37.63 & 37.36 \\
\hline Fs & 15.76 & 14.69 & 3209 & 16.96 & 16.87 & 16.77 & 16.73 & 17.43 & 12.92 & 30.28 & 15.98 & 15.67 & 16.44 & 15.95 \\
\hline
\end{tabular}




\begin{tabular}{|c|c|c|c|c|c|c|c|c|c|c|c|c|c|c|}
\hline Sample & $90033 R$ & $90033 \mathrm{R}$ & $90033 R$ & $90033 R$ & $90033 R$ & $90033 R$ & $90033 R$ & $90033 R$ & $90033 R$ & $90033 \mathrm{~S}$ & $90033 \mathrm{~S}$ & $90033 \mathrm{~S}$ & $90033 \mathrm{~S}$ & $90033 \mathrm{~S}$ \\
\hline Type & $\begin{array}{c}\text { Type } P \\
\text { oxid } \\
\end{array}$ & $\begin{array}{c}\text { Type P } \\
\text { oxid }\end{array}$ & $\begin{array}{c}\text { Type P } \\
\text { oxid } \\
\end{array}$ & $\begin{array}{c}\text { Type P } \\
\text { oxid } \\
\end{array}$ & $\begin{array}{c}\text { Type P } \\
\text { core } \\
\end{array}$ & $\begin{array}{c}\text { Type P } \\
\text { core }\end{array}$ & $\begin{array}{c}\text { Type P } \\
\text { oxid } \\
\end{array}$ & $\begin{array}{c}\text { Type } P \\
\text { oxid } \\
\end{array}$ & $\begin{array}{c}\text { Type P } \\
\text { core } \\
\end{array}$ & $\begin{array}{c}\text { Type L } \\
\text { core } \\
\end{array}$ & $\begin{array}{c}\text { Type L } \\
\text { core } \\
\end{array}$ & $\begin{array}{c}\text { Type L } \\
\text { core }\end{array}$ & $\begin{array}{c}\text { Type L } \\
\text { core- }\end{array}$ & $\begin{array}{c}\text { Type L } \\
\text { rim } \\
\end{array}$ \\
\hline $\mathrm{SiO}_{2}$ & 46.30 & 51.52 & 41.07 & 47.24 & 47.50 & 49.49 & 46.04 & 42.92 & 47.98 & 46.71 & 48.40 & 49.10 & 48.11 & 44.10 \\
\hline $\mathrm{Al} 2 \mathrm{O}_{3}$ & 8.21 & 3.95 & 12.78 & 5.72 & 9.08 & 7.81 & 9.10 & 11.05 & 9.46 & 7.84 & 5.73 & 6.37 & 6.44 & 9.28 \\
\hline $\mathrm{TiO}_{2}$ & 3.85 & 1.66 & 6.04 & 3.24 & 1.89 & 1.12 & 3.64 & 5.16 & 2.16 & 1.70 & 1.76 & 2.17 & 1.32 & 3.51 \\
\hline FeO total & 6.54 & 5.85 & 6.87 & 8.55 & 8.74 & 8.15 & 6.00 & 6.74 & 8.09 & 8.89 & 8.73 & 9.28 & 9.00 & 8.42 \\
\hline $\mathrm{MnO}$ & 0.08 & 0.14 & 0.04 & 0.20 & 0.12 & 0.13 & 0.13 & 0.01 & 0.19 & 0.23 & 0.22 & 0.23 & 0.11 & 0.12 \\
\hline $\mathrm{MgO}$ & 14.50 & 18.05 & 11.06 & 10.90 & 11.92 & 1295 & 14.23 & 12.18 & 12.20 & 11.35 & 12.62 & 11.93 & 11.70 & 11.10 \\
\hline $\mathrm{CaO}$ & 19.37 & 18.47 & 21.88 & 23.25 & 19.47 & 19.95 & 20.31 & 20.97 & 19.87 & 22.44 & 21.82 & 21.94 & 23.73 & 23.49 \\
\hline $\mathrm{Na} 2 \mathrm{O}$ & 0.67 & 0.38 & 0.68 & 0.98 & 1.17 & 0.95 & 0.69 & 0.73 & 0.00 & 0.63 & 0.70 & 0.73 & 0.43 & 0.50 \\
\hline $\mathrm{K} 2 \mathrm{O}$ & 0.00 & 0.00 & 0.01 & 0.05 & 0.01 & 0.01 & 0.01 & 0.00 & 0.05 & 0.00 & 0.02 & 0.00 & 0.00 & 0.01 \\
\hline $\mathrm{Fe} 2 \mathrm{O3}$ & 1.76 & 0.56 & 3.69 & 3.65 & 225 & 1.32 & 2.71 & 3.07 & 0.00 & 4.07 & 3.62 & 2.75 & 4.07 & 5.45 \\
\hline $\mathrm{FeO}$ & 4.96 & 5.34 & 3.55 & 5.27 & 6.71 & 6.96 & 3.56 & 3.97 & 8.09 & 5.23 & 5.47 & 6.75 & 5.33 & 3.52 \\
\hline TOTAL & 99.52 & 100.03 & 100.43 & 100.14 & 99.90 & 100.55 & 100.17 & 99.76 & 99.95 & 99.79 & 99.98 & 100.75 & 100.84 & 100.51 \\
\hline $\mathrm{Si}$ & 1.721 & 1.877 & 1.538 & 1.783 & 1.769 & 1.821 & 1.699 & 1.608 & 1.770 & 1.762 & 1.800 & 1.816 & 1.798 & 1.662 \\
\hline AIIV & 0.279 & 0.123 & 0.462 & 0.217 & 0.231 & 0.179 & 0.301 & 0.392 & 0.230 & 0.238 & 0.200 & 0.184 & 0.202 & 0.338 \\
\hline AlVI & 0.080 & 0.050 & 0.100 & 0.040 & 0.170 & 0.160 & 0.100 & 0.100 & 0.180 & 0.110 & 0.050 & 0.090 & 0.080 & 0.070 \\
\hline $\mathrm{Ti}$ & 0.108 & 0.046 & 0.170 & 0.092 & 0.053 & 0.031 & 0.101 & 0.145 & 0.060 & 0.048 & 0.049 & 0.033 & 0.037 & 0.099 \\
\hline FeIII & 0.049 & 0.015 & 0.103 & 0.103 & 0.062 & 0.037 & 0.075 & 0.086 & 0.000 & 0.114 & 0.101 & 0.077 & 0.114 & 0.152 \\
\hline FelI & 0.154 & 0.163 & 0.110 & 0.165 & 0.209 & 0.214 & 0.109 & 0.124 & 0.250 & 0.165 & 0.170 & 0.209 & 0.165 & 0.109 \\
\hline $\mathrm{Mn}$ & 0.002 & 0.004 & 0.001 & 0.007 & 0.004 & 0.004 & 0.004 & 0.000 & 0.010 & 0.007 & 0.007 & 0.007 & 0.003 & 0.004 \\
\hline $\mathrm{Mg}$ & 0.803 & 0.981 & 0.617 & 0.613 & 0.664 & 0.710 & 0.783 & 0.680 & 0.670 & 0.638 & 0.700 & 0.658 & 0.652 & 0.624 \\
\hline $\mathrm{Ca}$ & 0.771 & 0.721 & 0.878 & 0.940 & $0 . \pi 7$ & 0.786 & 0.803 & 0.841 & 0.790 & 0.907 & 0.870 & 0.870 & 0.950 & 0.948 \\
\hline $\mathrm{Na}$ & 0.048 & 0.027 & 0.050 & 0.072 & 0.084 & 0.068 & 0.050 & 0.053 & 0.000 & 0.046 & 0.050 & 0.052 & 0.031 & 0.036 \\
\hline K & 0.000 & 0.000 & 0.001 & 0.002 & 0.001 & 0.001 & 0.001 & 0.000 & 0.020 & 0.000 & 0.002 & 0.000 & 0.000 & 0.000 \\
\hline TOTAL & 4.015 & 4.007 & 4.030 & 4.034 & 4.024 & 4.011 & 4.026 & 4.029 & 3.980 & 4.035 & 3.999 & 3.996 & 4.032 & 4.042 \\
\hline Wo & 43.39 & 38.35 & 51.41 & 51.62 & 45.39 & 44.99 & 45.37 & 48.58 & 46.20 & 49.73 & 47.26 & 47.96 & 50.51 & 51.72 \\
\hline En & 45.19 & 52.18 & 36.12 & 33.66 & 38.79 & 40.64 & 44.24 & 39.28 & 39.18 & 34.98 & 38.02 & 36.27 & 34.66 & 34.04 \\
\hline Fs & 11.42 & 9.47 & 12.47 & 14.72 & 15.83 & 14.37 & 10.40 & 12.13 & 14.62 & 15.30 & 14.72 & 15.77 & 14.83 & 14.24 \\
\hline
\end{tabular}

\begin{tabular}{|c|c|c|c|c|c|c|c|c|c|c|c|c|c|c|}
\hline $\begin{array}{l}\text { Sample } \\
\text { Type }\end{array}$ & $\begin{array}{c}90039 \mathrm{M} \\
\text { Type L } \\
\text { core }\end{array}$ & $\begin{array}{c}900390 \\
\text { Type L } \\
\text { core }\end{array}$ & $\begin{array}{c}900390 \\
\text { Type L } \\
\text { core }\end{array}$ & $\begin{array}{l}900390 \\
\text { Type L } \\
\text { core }\end{array}$ & $\begin{array}{c}900390 \\
\text { Type L } \\
\text { core }\end{array}$ & $\begin{array}{c}900390 \\
\text { Type C } \\
\text { core }\end{array}$ & $\begin{array}{l}900390 \\
\text { Type C } \\
\text { core }\end{array}$ & $\begin{array}{c}90039 \mathrm{Sa} \\
\text { Type C } \\
\text { core }\end{array}$ & $\begin{array}{c}90039 \mathrm{Sa} \\
\text { Type C } \\
\text { core }\end{array}$ & $\begin{array}{c}90039 \mathrm{Sa} \\
\text { Type C } \\
\text { core }\end{array}$ & $\begin{array}{c}90039 S a \\
\text { Type C } \\
\text { core }\end{array}$ & $\begin{array}{c}90039 \mathrm{Sa} 9 \\
\text { Type C } \\
\text { core }\end{array}$ & $\begin{array}{c}90039 S a \\
\text { Type P } \\
\text { core }\end{array}$ & $\begin{array}{c}90039 \mathrm{Sa} \\
\text { Type P } \\
\text { core } \\
\end{array}$ \\
\hline $\mathrm{SiO}_{2}$ & 48.75 & 51.41 & 52.01 & 50.23 & 49.96 & 5234 & 50.72 & 49.10 & 46.57 & 46.43 & 46.84 & 47.58 & 46.92 & 46.83 \\
\hline $\mathrm{A} 1203$ & 4.98 & 3.37 & 3.03 & 3.43 & 3.40 & 229 & 2.86 & 8.05 & 8.95 & 9.14 & 8.75 & 8.08 & 8.68 & 8.60 \\
\hline $\mathrm{TiO}_{2}$ & 1.72 & 1.14 & 1.10 & 1.16 & 1.33 & 0.47 & 1.02 & 1.68 & 2.32 & 2.57 & 2.30 & 1.96 & 2.11 & 230 \\
\hline FeO total & 9.42 & 10.98 & 10.89 & 10.19 & 10.17 & 8.13 & 7.93 & 8.66 & 8.73 & 8.22 & 8.68 & 8.74 & 8.36 & 7.61 \\
\hline $\mathrm{MnO}$ & 0.20 & 0.31 & 0.27 & 0.47 & 0.36 & 0.39 & 0.21 & 0.12 & 0.10 & 0.15 & 0.13 & 0.14 & 0.17 & 0.16 \\
\hline $\mathrm{MgO}_{\mathrm{g}}$ & 13.91 & 12.90 & 12.98 & 12.74 & 1266 & 15.02 & 14.05 & 10.68 & 11.85 & 11.71 & 11.85 & 12.23 & 11.71 & 12.55 \\
\hline $\mathrm{CaO}$ & 21.65 & 21.04 & 21.41 & 21.47 & 21.01 & 21.12 & 20.93 & 20.99 & 20.28 & 20.16 & 20.10 & 20.20 & 20.87 & 21.05 \\
\hline $\mathrm{Na} 2 \mathrm{O}$ & 0.34 & 0.66 & 0.47 & 0.59 & 0.57 & 0.62 & 0.56 & 0.73 & 0.73 & 0.72 & 0.78 & 0.68 & 0.69 & 0.76 \\
\hline $\mathrm{K} 2 \mathrm{O}$ & 0.06 & 0.07 & 0.06 & 0.05 & 0.05 & 0.03 & 0.01 & 0.00 & 0.02 & 0.00 & 0.00 & 0.02 & 0.00 & 0.01 \\
\hline $\mathrm{Fe} 2 \mathrm{O} 3$ & 4.55 & 2.26 & 1.03 & 298 & 211 & 2.59 & 1.20 & 0.00 & 1.81 & 0.66 & 1.38 & 1.26 & 1.51 & 291 \\
\hline $\mathrm{FeO}$ & 5.33 & 8.94 & 9.96 & 7.51 & 8.28 & 5.80 & 6.85 & 8.66 & 7.10 & 7.62 & 7,44 & 7.60 & 7.00 & 4.99 \\
\hline TOTAL & 100.97 & 101.81 & 102.14 & 100.28 & 99.45 & 100.38 & 98.29 & 100.01 & 99.52 & 99.09 & 99.42 & 99.61 & 99.51 & 99.85 \\
\hline Si & 1.795 & 1.890 & 1.900 & 1.884 & 1.890 & 1.932 & 1.913 & 1.835 & 1.746 & 1.744 & 1.756 & 1.780 & 1.760 & 1.745 \\
\hline AlIV & 0.200 & 0.140 & 0.130 & 0.120 & 0.110 & 0.070 & 0.090 & 0.160 & 0.250 & 0.260 & 0.240 & 0.220 & 0.240 & 0.250 \\
\hline AlvI & 0.010 & 0.030 & 0.030 & 0.030 & 0.040 & 0.030 & 0.040 & 0.190 & 0.140 & 0.150 & 0.140 & 0.140 & 0.140 & 0.120 \\
\hline $\mathrm{Ti}$ & 0.048 & 0.031 & 0.030 & 0.030 & 0.038 & 0.013 & 0.030 & 0.047 & 0.065 & 0.073 & 0.065 & 0.055 & 0.059 & 0.064 \\
\hline FellI & 0.126 & 0.060 & 0.030 & 0.080 & 0.060 & 0.070 & 0.030 & 0.000 & 0.051 & 0.019 & 0.039 & 0.035 & 0.042 & 0.081 \\
\hline Fell & 0.164 & 0.280 & 0.310 & 0.230 & 0.260 & 0.170 & 0.220 & 0.270 & 0.222 & 0.239 & 0.233 & 0.237 & 0.219 & 0.155 \\
\hline $\mathrm{Mn}$ & 0.006 & 0.010 & 0.008 & 0.015 & 0.011 & 0.012 & 0.010 & 0.004 & 0.003 & 0.005 & 0.004 & 0.006 & 0.005 & 0.005 \\
\hline $\mathrm{Mg}$ & 0.765 & 0.696 & 0.697 & 0.712 & 0.712 & 0.826 & 0.790 & 0.595 & 0.662 & 0.655 & 0.662 & 0.682 & 0.654 & 0.697 \\
\hline $\mathrm{Ca}$ & 0.855 & 0.816 & 0.827 & 0.863 & 0.849 & 0.835 & 0.846 & 0.841 & 0.814 & 0.811 & 0.807 & 0.810 & 0.838 & 0.840 \\
\hline $\mathrm{Na}$ & 0.024 & 0.046 & 0.033 & 0.043 & 0.042 & 0.044 & 0.041 & 0.053 & 0.053 & 0.052 & 0.057 & 0.049 & 0.050 & 0.055 \\
\hline K & 0.003 & 0.003 & 0.003 & 0.002 & 0.002 & 0.001 & 0.000 & 0.000 & 0.001 & 0.000 & 0.000 & 0.001 & 0.000 & 0.000 \\
\hline TOTAL & 3.996 & 4.002 & 3.998 & 4.009 & 4.014 & 4.003 & 4.010 & 3.995 & 4.007 & 4.008 & 4.003 & 4.014 & 4.007 & 4.012 \\
\hline Wo & 44.76 & 44.06 & 44.37 & 45.78 & 45.14 & 43.92 & 44.86 & 49.30 & 46.54 & 47.04 & 46.35 & 45.92 & 47.80 & 47.38 \\
\hline En & 40.06 & 37.58 & 37.39 & 37.77 & 37.85 & 43.45 & 41.89 & 34.88 & 37.85 & 37.99 & 38.02 & 38.66 & 37.31 & 39.31 \\
\hline Fs & 15.18 & 18.36 & 18.24 & 16.45 & 17.01 & 1262 & 13.26 & 15.83 & 15.61 & 14.97 & 15.62 & 15.42 & 14.89 & 13.31 \\
\hline
\end{tabular}




\begin{tabular}{|c|c|c|c|c|c|}
\hline $\begin{array}{l}\text { Sample } \\
\text { Type }\end{array}$ & $\begin{array}{c}90033 \mathrm{~S} \\
\text { Type L } \\
\text { core } \\
\end{array}$ & $\begin{array}{c}90033 \mathrm{~S} \\
\text { Type L } \\
\text { rim } \\
\end{array}$ & $\begin{array}{c}90033 \mathrm{~S} \\
\text { Type L } \\
\text { rim } \\
\end{array}$ & $\begin{array}{c}90033 \mathrm{U} \\
\text { Type L } \\
\text { core } \\
\end{array}$ & \\
\hline $\mathrm{SiO}_{2}$ & 48.51 & 46.73 & 46.01 & 49.95 & \\
\hline $\mathrm{Al}_{2} \mathrm{O}_{3}$ & 6.95 & 9.06 & 9.72 & 4.43 & \\
\hline TiO2 & 1.03 & 1.86 & 2.98 & 1.22 & \\
\hline $\mathrm{FeO}$ total & 9.55 & 10.07 & 7.17 & 9.72 & \\
\hline $\mathrm{MnO}$ & 0.17 & 0.30 & 0.12 & 0.48 & \\
\hline $\mathrm{MgO}$ & 11.33 & 10.12 & 1236 & 11.68 & \\
\hline $\mathrm{CaO}$ & 21.66 & 20.85 & 21.05 & 21.64 & \\
\hline $\mathrm{Na} 2 \mathrm{O}$ & 0.79 & 1.01 & 0.73 & 0.89 & \\
\hline $\mathrm{K}_{2} \mathrm{O}$ & 0.00 & 0.00 & 0.00 & 0.00 & \\
\hline$\overline{\mathrm{Fe} 2 \mathrm{O} 3}$ & 2.69 & 253 & 222 & 2.27 & \\
\hline $\mathrm{FeO}$ & 7.15 & 7.79 & 5.17 & 7.68 & \\
\hline TOTAL & 99.99 & 100.00 & 100.14 & 100.01 & \\
\hline $\mathrm{Si}$ & 1.819 & 1.759 & 1.701 & 1.878 & \\
\hline AlIV & 0.181 & 0.241 & 0.299 & 0.122 & \\
\hline AlVI & 0.130 & 0.160 & 0.130 & 0.070 & \\
\hline $\mathrm{Ti}$ & 0.029 & 0.052 & 0.083 & 0.034 & \\
\hline FeIII & 0.075 & 0.071 & 0.052 & 0.064 & \\
\hline FelI & 0.223 & 0.244 & 0.160 & 0.240 & \\
\hline Mn & 0.006 & 0.010 & 0.004 & 0.015 & \\
\hline Mg & 0.633 & 0.567 & 0.681 & 0.654 & \\
\hline $\mathrm{Ca}$ & 0.870 & 0.841 & 0.834 & 0.872 & \\
\hline $\mathrm{Na}$ & 0.057 & 0.073 & 0.052 & 0.065 & \\
\hline K & 0.000 & 0.001 & 0.006 & 0.000 & \\
\hline TOTAL & 4.023 & 4.019 & 4.012 & 4.014 & \\
\hline Wo & 48.31 & 48.81 & 48.01 & 47.65 & \\
\hline En & 35.15 & 32.91 & 39.21 & 35.74 & \\
\hline Fs & 16.55 & 18.28 & 1278 & 16.61 & \\
\hline Sample & $90039 \mathrm{Sa}$ & $90039 \mathrm{~V}$ & $90039 \mathrm{~V}$ & $90039 \mathrm{~V}$ & $90039 \mathrm{~V}$ \\
\hline Type & $\begin{array}{c}\text { Type P } \\
\text { core } \\
\end{array}$ & $\begin{array}{c}\text { Type M } \\
\text { core } \\
\end{array}$ & $\begin{array}{c}\text { Type M } \\
\text { core }\end{array}$ & $\begin{array}{c}\text { Type M } \\
\text { core }\end{array}$ & $\begin{array}{c}\text { Type M } \\
\text { core } \\
\end{array}$ \\
\hline $\mathrm{SiO}_{2}$ & 46.86 & 47.06 & 50.28 & 50.49 & 49.67 \\
\hline $\mathrm{Al}_{2} \mathrm{O}_{3}$ & 8.41 & 6.03 & 4.54 & 4.15 & 4.05 \\
\hline TiO2 & 2.12 & 284 & 1.16 & 1.31 & 1.47 \\
\hline $\mathrm{FeO}$ total & 8.29 & 9.78 & 9.26 & 9.28 & 9.11 \\
\hline MnO & 0.13 & 0.18 & 0.28 & 0.32 & 0.35 \\
\hline MgO & 12.51 & 11.62 & 12.66 & 1290 & 12.90 \\
\hline $\mathrm{CaO}$ & 20.07 & 22.07 & 21.26 & 21.75 & 21.98 \\
\hline $\mathrm{Na} 2 \mathrm{O}$ & 0.80 & 0.41 & 0.47 & 0.69 & 0.45 \\
\hline $\mathrm{K} 2 \mathrm{O}$ & 0.00 & 0.06 & 0.03 & 0.06 & 0.02 \\
\hline$\overline{\mathrm{Fe} 2 \mathrm{O} 3}$ & 2.47 & 2.74 & 0.57 & 0.00 & 2.27 \\
\hline $\mathrm{FeO}$ & 6.07 & 7.50 & 8.74 & 9.28 & 7.07 \\
\hline TOTAL & 99.18 & 99.99 & 99.91 & 100.87 & 99.98 \\
\hline $\mathrm{Si}$ & 1.750 & 1.766 & 1.875 & 1.866 & 1.860 \\
\hline AlIV & 0.250 & 0.230 & 0.120 & 0.130 & 0.140 \\
\hline AlVI & 0.120 & 0.040 & 0.080 & 0.050 & 0.040 \\
\hline $\mathrm{Ti}$ & 0.060 & 0.080 & 0.032 & 0.040 & 0.040 \\
\hline FelII & 0.069 & 0.072 & 0.016 & 0.000 & 0.064 \\
\hline Fell & 0.190 & 0.236 & 0.273 & 0.287 & 0.221 \\
\hline $\mathrm{Mn}$ & 0.004 & 0.001 & 0.009 & 0.010 & 0.011 \\
\hline $\mathrm{Mg}$ & 0.696 & 0.650 & 0.703 & 0.710 & 0.720 \\
\hline $\mathrm{Ca}$ & 0.803 & 0.888 & 0.849 & 0.861 & 0.882 \\
\hline $\mathrm{Na}$ & 0.058 & 0.030 & 0.084 & 0.050 & 0.033 \\
\hline K & 0.000 & 0.003 & 0.002 & 0.000 & 0.001 \\
\hline TOTAL & 4.000 & 3.996 & 3.993 & 4.004 & 4.012 \\
\hline Wo & 45.68 & 48.10 & 46.12 & 46.34 & 46.74 \\
\hline En & 39.59 & 35.21 & 38.19 & 38.21 & 38.16 \\
\hline Fs & 14.73 & 16.68 & 15.70 & 15.45 & 15.10 \\
\hline
\end{tabular}




\section{A3.1 Mount Sidley xenolith mineral analyses: plagioclase}

\begin{tabular}{|c|c|c|c|c|c|c|c|c|c|c|c|c|c|c|}
\hline $\begin{array}{l}\text { Sample } \\
\text { Type }\end{array}$ & $\begin{array}{c}90029 \mathrm{C} \\
\text { Type L } \\
\text { core } \\
\end{array}$ & $\begin{array}{c}90029 \mathrm{C} \\
\text { Type L } \\
\text { core }\end{array}$ & $\begin{array}{c}90029 \mathrm{C} \\
\text { Type L } \\
\text { core } \\
\end{array}$ & $\begin{array}{l}90029 \mathrm{~V} \\
\text { Type M } \\
\text { core- }\end{array}$ & $\begin{array}{c}90029 \mathrm{~V} \\
\text { Type M } \\
\text { rim } \\
\end{array}$ & $\begin{array}{c}90029 \mathrm{~V} \\
\text { Type M } \\
\text { core- } \\
\end{array}$ & $\begin{array}{c}90029 \mathrm{~V} \\
\text { Type M } \\
\text { rim }\end{array}$ & $\begin{array}{c}90029 X \\
\text { Type L } \\
\text { core }\end{array}$ & $\begin{array}{c}90029 X \\
\text { Type L } \\
\text { core }\end{array}$ & $\begin{array}{c}90029 X \\
\text { Type L } \\
\text { core }\end{array}$ & $\begin{array}{c}90029 X \\
\text { Type L } \\
\text { core }\end{array}$ & $\begin{array}{c}90029 X \\
\text { Type L } \\
\text { core- }\end{array}$ & $\begin{array}{l}\text { 90029X } \\
\text { Type L } \\
\text { rim } \\
\end{array}$ & $\begin{array}{c}90029 \mathrm{~B} 1 \\
\text { Type L } \\
\text { rim } \\
\end{array}$ \\
\hline $\mathrm{SiO}_{2}$ & 53.69 & 54.26 & 54.06 & 56.63 & 48.41 & 56.20 & 48.28 & 53.76 & 54.43 & 53.70 & 52.96 & 54.47 & 53.01 & 52.82 \\
\hline $\mathrm{A} 12 \mathrm{O} 3$ & 29.41 & 29.10 & 28.65 & 28.58 & 33.56 & 29.24 & 33.47 & 29.10 & 28.98 & 29.60 & 29.72 & 29.43 & 30.07 & 28.80 \\
\hline $\mathrm{TiO}_{2}$ & 0.09 & 0.09 & 0.01 & 0.01 & 0.20 & 0.02 & 0.15 & 0.05 & 0.04 & 0.03 & 0.01 & 0.01 & 0.08 & 0.32 \\
\hline $\mathrm{FeO}$ & 0.18 & 0.20 & 0.26 & 0.27 & 0.71 & 0.23 & 0.59 & 0.11 & 0.20 & 0.16 & 0.15 & 0.16 & 0.24 & 1.22 \\
\hline $\mathrm{MnO}$ & 0.15 & 0.04 & 0.07 & 0.09 & 0.00 & 0.13 & 0.15 & 0.12 & 0.03 & 0.00 & 0.00 & 0.05 & 0.00 & 0.00 \\
\hline $\mathrm{MgO}$ & 0.00 & 0.00 & 0.00 & 0.01 & 0.04 & 0.10 & 0.02 & 0.00 & 0.00 & 0.01 & 0.03 & 0.00 & 0.03 & 0.01 \\
\hline $\mathrm{CaO}$ & 12.26 & 11.52 & 11.64 & 10.81 & 16.39 & 10.69 & 17.25 & 11.83 & 11.14 & 11.47 & 11.68 & 10.99 & 11.95 & 12.22 \\
\hline $\mathrm{Na}_{2} \mathrm{O}$ & 4.40 & 4.73 & 4.63 & 3.74 & 1.88 & 3.83 & 2.17 & 4.66 & 5.09 & 4.85 & 4.77 & 5.03 & 4.57 & 4.71 \\
\hline $\mathrm{K} 2 \mathrm{O}$ & 0.11 & 0.10 & 0.13 & 0.36 & 0.12 & 0.34 & 0.11 & 0.22 & 0.28 & 0.26 & 0.19 & 0.28 & 0.21 & 0.26 \\
\hline TOTAL & 100.28 & 100.04 & 99.44 & 100.49 & 101.31 & 100.79 & 102.18 & 99.85 & 100.17 & 100.07 & 99.51 & 100.40 & 100.16 & 100.36 \\
\hline $\mathbf{S i}$ & 2.420 & 2.448 & 2.456 & 2.520 & 2.190 & 2.500 & 2.180 & 2435 & 2.455 & 2.426 & 2.405 & 2.448 & 2.397 & 2.402 \\
\hline A.1 & 1.562 & 1.547 & 1.534 & 1.500 & 1.790 & 1.530 & 1.780 & 1.554 & 1.540 & 1.576 & 1.591 & 1.559 & 1.602 & 1.545 \\
\hline $\mathrm{Ti}$ & 0.006 & 0.003 & 0.000 & 0.000 & 0.010 & 0.000 & 0.010 & 0.002 & 0.001 & 0.001 & 0.000 & 0.000 & 0.003 & 0.011 \\
\hline $\mathrm{Fe}$ & 0.007 & 0.007 & 0.010 & 0.010 & 0.030 & 0.010 & 0.020 & 0.004 & 0.008 & 0.006 & 0.006 & 0.006 & 0.009 & 0.046 \\
\hline $\mathrm{Mn}$ & 0.006 & 0.001 & 0.003 & 0.000 & 0.000 & 0.000 & 0.010 & 0.005 & 0.001 & 0.000 & 0.000 & 0.002 & 0.000 & 0.000 \\
\hline $\mathrm{Mg}$ & 0.000 & 0.000 & 0.000 & 0.000 & 0.000 & 0.010 & 0.000 & 0.000 & 0.000 & 0.000 & 0.002 & 0.000 & 0.002 & 0.001 \\
\hline $\mathrm{Ca}$ & 0.592 & 0.556 & 0.567 & 0.516 & 0.795 & 0.509 & 0.833 & 0.574 & 0.538 & 0.555 & 0.568 & 0.529 & 0.579 & 0.596 \\
\hline $\mathrm{Na}$ & 0.385 & 0.413 & 0.407 & 0.323 & 0.165 & 0.330 & 0.190 & 0.409 & 0.445 & 0.425 & 0.420 & 0.438 & 0.401 & 0.415 \\
\hline $\mathbf{K}$ & 0.006 & 0.006 & 0.008 & 0.021 & 0.010 & 0.020 & 0.010 & 0.013 & 0.016 & 0.015 & 0.011 & 0.016 & 0.012 & 0.015 \\
\hline TOTAL & 4.981 & 4.981 & 4.985 & 4.890 & 4.990 & 4.909 & 5.033 & 4.996 & 5.004 & 5.004 & 5.003 & 4.998 & 5.005 & 5.031 \\
\hline An & 60.22 & 57.03 & 57.74 & 60.00 & 81.96 & 59.25 & 80.64 & 57.63 & 53.85 & 55.78 & 56.86 & 53.81 & 58.37 & 58.09 \\
\hline $\mathbf{A b}$ & 39.17 & 42.36 & 41.45 & 37.56 & 17.01 & 38.42 & 18.39 & 41.06 & 44.54 & 42.71 & 42.04 & 44.56 & 40.42 & 40.45 \\
\hline Or & 0.61 & 0.62 & 0.81 & 244 & 1.03 & 2.33 & 0.97 & 1.31 & 1.60 & 1.51 & 1.10 & 1.63 & 1.21 & 1.46 \\
\hline
\end{tabular}

\begin{tabular}{|c|c|c|c|c|c|c|c|c|c|c|c|c|c|c|}
\hline Sample & $90033 \mathrm{U}$ & $90033 \mathrm{~V}$ & $90033 \mathrm{~V}$ & $90033 \mathrm{~V}$ & $90033 \mathrm{~V}$ & $90033 X$ & $90033 \mathrm{X}$ & $90033 X$ & $90033 X$ & $90033 X$ & $90033 x$ & $90033 \mathrm{~F} 1$ & $90033 \mathrm{~F} 1$ & $90033 \mathrm{~F} 1$ \\
\hline Type & $\begin{array}{c}\text { Type L } \\
\text { core }\end{array}$ & $\begin{array}{c}\text { Type } \mathrm{L} \\
\text { core }\end{array}$ & $\begin{array}{c}\text { Type L } \\
\text { melt }\end{array}$ & $\begin{array}{c}\text { Type L } \\
\text { melt }\end{array}$ & $\begin{array}{c}\text { Type L } \\
\text { core }\end{array}$ & $\begin{array}{c}\text { Type L } \\
\text { core }\end{array}$ & $\begin{array}{c}\text { Type L } \\
\text { core }\end{array}$ & $\begin{array}{c}\text { Type L } \\
\text { core }\end{array}$ & $\begin{array}{c}\text { Type L } \\
\text { core }\end{array}$ & $\begin{array}{c}\text { Type L } \\
\text { core- }\end{array}$ & $\begin{array}{c}\text { Type L } \\
\text { rim }\end{array}$ & $\begin{array}{c}\text { Type L } \\
\text { core }\end{array}$ & $\begin{array}{c}\text { Type L } \\
\text { core }\end{array}$ & $\begin{array}{c}\text { Type L } \\
\text { core }\end{array}$ \\
\hline $\mathrm{SiO}_{2}$ & 54.21 & 56.92 & 51.78 & 54.09 & 59.41 & 58.24 & 58.03 & 58.46 & 58.11 & 58.26 & 54.68 & 54.56 & 54.94 & 55.27 \\
\hline $\mathrm{A} 12 \mathrm{O} 3$ & 28.54 & 27.49 & 30.15 & 28.65 & 26.40 & 26.84 & 26.73 & 26.78 & 26.49 & 26.01 & 28.55 & 28.96 & 29.15 & 28.55 \\
\hline $\mathrm{TiO}_{2}$ & 0.00 & 0.00 & 0.11 & 0.11 & 0.01 & 0.08 & 0.03 & 0.06 & 0.03 & 0.05 & 0.08 & 0.02 & 0.07 & 0.01 \\
\hline $\mathrm{FeO}$ & 0.19 & 0.11 & 0.59 & 0.47 & 0.15 & 0.15 & 0.27 & 0.23 & 0.20 & 0.20 & 0.57 & 0.19 & 0.04 & 0.18 \\
\hline $\mathrm{MnO}$ & 0.00 & 0.00 & 0.02 & 0.04 & 0.09 & 0.00 & 0.01 & 0.09 & 0.00 & 0.00 & 0.01 & 0.00 & 0.02 & 0.00 \\
\hline $\mathrm{MgO}$ & 0.00 & 0.09 & 0.04 & 0.08 & 0.00 & 0.02 & 0.03 & 0.03 & 0.00 & 0.02 & 0.06 & 0.00 & 0.01 & 0.00 \\
\hline $\mathrm{CaO}$ & 11.69 & 9.20 & 13.45 & 11.89 & 8.34 & 8.73 & 8.12 & 8.20 & 8.05 & 8.17 & 10.62 & 11.36 & 11.71 & 10.95 \\
\hline $\mathrm{Na} 2 \mathrm{O}$ & 5.09 & 6.22 & 3.81 & 4.54 & 5.12 & 6.22 & 6.30 & 6.33 & 6.47 & 6.41 & 5.11 & 4.91 & 4.71 & 5.25 \\
\hline $\mathrm{K}_{2} \mathrm{O}$ & 0.29 & 0.51 & 0.25 & 0.41 & 0.57 & 0.47 & 0.51 & 0.50 & 0.44 & 0.47 & 0.18 & 0.28 & 0.28 & 0.25 \\
\hline TOTAL & 100.01 & 100.55 & 100.18 & 100.29 & 100.09 & 100.74 & 100.01 & 100.68 & 99.78 & 99.59 & 99.84 & 100.27 & 100.92 & 100.45 \\
\hline $\mathrm{Si}$ & 2453 & 2.545 & 2.355 & 2.445 & 2.641 & 2.590 & 2.597 & 2.599 & 2.604 & 2618 & 2471 & 2.457 & 2.456 & 2.482 \\
\hline Al & 1.522 & 1.448 & 1.617 & 1.527 & 1.383 & 1.407 & 1.410 & 1.404 & 1.399 & 1.377 & 1.521 & 1.537 & 1.536 & 1.511 \\
\hline $\mathrm{Ti}$ & 0.000 & 0.000 & 0.004 & 0.005 & 0.000 & 0.003 & 0.001 & 0.002 & 0.001 & 0.002 & 0.003 & 0.001 & 0.002 & 0.000 \\
\hline $\mathrm{Fe}$ & 0.007 & 0.004 & 0.022 & 0.018 & 0.006 & 0.006 & 0.010 & 0.009 & 0.007 & 0.008 & 0.021 & 0.007 & 0.002 & 0.007 \\
\hline $\mathrm{Mn}$ & 0.002 & 0.000 & 0.001 & 0.002 & 0.004 & 0.000 & 0.001 & 0.003 & 0.000 & 0.000 & 0.000 & 0.000 & 0.001 & 0.000 \\
\hline $\mathbf{M g}$ & 0.001 & 0.006 & 0.003 & 0.005 & 0.000 & 0.001 & 0.002 & 0.002 & 0.000 & 0.001 & 0.004 & 0.000 & 0.001 & 0.000 \\
\hline $\mathrm{Ca}^{a}$ & 0.567 & 0.441 & 0.656 & 0.576 & 0.397 & 0.416 & 0.389 & 0.391 & 0.387 & 0.394 & 0.514 & 0.548 & 0.561 & 0.527 \\
\hline $\mathrm{Na}$ & 0.446 & 0.539 & 0.336 & 0.398 & 0.441 & 0.537 & 0.546 & 0.546 & 0.562 & 0.558 & 0.447 & 0.428 & 0.409 & 0.457 \\
\hline $\mathbf{K}$ & 0.017 & 0.029 & 0.015 & 0.024 & 0.032 & 0.027 & 0.029 & 0.029 & 0.025 & 0.027 & 0.010 & 0.016 & 0.016 & 0.014 \\
\hline TOTAL & 5.015 & 5.012 & 5.009 & 5.000 & 4.904 & 4.987 & 4.985 & 4.985 & 4.985 & 4.985 & 4.991 & 4.994 & 4.984 & 4.998 \\
\hline An & 55.06 & 43.71 & 65.14 & 57.72 & 45.63 & 4245 & 40.35 & 40.48 & 39.73 & 40.25 & 52.94 & 55.24 & 56.90 & 52.81 \\
\hline $\mathrm{Ab}$ & 43.30 & 53.42 & 33.37 & 39.88 & 50.69 & 54.80 & 56.64 & 56.52 & 57.70 & 57.00 & 46.04 & 43.15 & 41.48 & 45.79 \\
\hline Or & 1.65 & 2.87 & 1.49 & 240 & 3.68 & 2.76 & 3.01 & 3.00 & 2.57 & 2.76 & 1.08 & 1.61 & 1.62 & 1.40 \\
\hline
\end{tabular}




\begin{tabular}{|c|c|c|c|c|c|c|c|c|c|c|c|c|c|c|}
\hline $\begin{array}{l}\text { Sample } \\
\text { Type }\end{array}$ & $\begin{array}{c}90029 \mathrm{~B} 1 \\
\text { Type L } \\
\text { core }\end{array}$ & $\begin{array}{c}90029 \mathrm{B1} \\
\text { Type L } \\
\text { core }\end{array}$ & $\begin{array}{c}90029 \mathrm{~B} 1 \\
\text { Type L } \\
\text { core }\end{array}$ & $\begin{array}{c}\text { 90029B1 } \\
\text { Type L } \\
\text { core }\end{array}$ & $\begin{array}{c}\text { 90029B1 } \\
\text { Type L } \\
\text { core }\end{array}$ & $\begin{array}{c}\text { 90029B1 } \\
\text { Type L } \\
\text { core }\end{array}$ & $\begin{array}{c}90029 B 1 \\
\text { Type L } \\
\text { core }\end{array}$ & $\begin{array}{c}\text { 90029B1 } \\
\text { Type L } \\
\text { core }\end{array}$ & $\begin{array}{c}90033 \mathrm{~A} \\
\text { Type P } \\
\text { melt }\end{array}$ & $\begin{array}{c}90033 \mathrm{~A} \\
\text { Type P } \\
\text { melt }\end{array}$ & $\begin{array}{c}90033 \mathrm{~A} \\
\text { Type P } \\
\text { melt } \\
\end{array}$ & $\begin{array}{c}90033 \mathrm{~B} \\
\text { Type P } \\
\text { core } \\
\end{array}$ & $\begin{array}{c}90033 \mathrm{~B} \\
\text { Type P } \\
\text { core }\end{array}$ & $\begin{array}{c}\text { 90033B } \\
\text { Type P } \\
\text { core } \\
\end{array}$ \\
\hline $\mathrm{SiO}_{2}$ & 56.52 & 56.10 & 56.54 & 56.21 & 56.97 & 56.80 & 57.32 & 56.64 & 53.76 & 55.92 & 52.20 & 50.62 & 53.06 & 52.34 \\
\hline $\mathrm{Al} 2 \mathrm{O}_{3}$ & 27.68 & 27.61 & 27.53 & 27.86 & 27.59 & 27.35 & 27.56 & 27.43 & 27.53 & 25.99 & 29.40 & 31.03 & 29.88 & 29.65 \\
\hline $\mathrm{TiO}_{2}$ & 0.04 & 0.03 & 0.07 & 0.02 & 0.07 & 0.13 & 0.12 & 0.04 & 0.25 & 0.47 & 0.20 & 0.17 & 0.03 & 0.13 \\
\hline $\mathrm{FeO}$ & 0.07 & 0.24 & 0.14 & 0.14 & 0.20 & 0.27 & 0.16 & 0.27 & 1.03 & 1.15 & 0.80 & 0.54 & 0.29 & 0.52 \\
\hline $\mathrm{MnO}$ & 0.00 & 0.00 & 0.00 & 0.01 & 0.03 & 0.07 & 0.08 & 0.05 & 0.02 & 0.00 & 0.05 & 0.00 & 0.00 & 0.00 \\
\hline $\mathrm{MgO}$ & 0.03 & 0.01 & 0.02 & 0.00 & 0.00 & 0.00 & 0.00 & 0.00 & 1.17 & 0.13 & 0.01 & 0.12 & 0.03 & 0.09 \\
\hline $\mathrm{CaO}$ & 9.91 & 10.04 & 9.90 & 9.85 & 9.78 & 9.65 & 9.91 & 9.91 & 11.57 & 10.51 & 12.40 & 14.41 & 12.51 & 1290 \\
\hline $\mathrm{Na} 2 \mathrm{O}$ & 6.01 & 6.07 & 6.29 & 6.38 & 5.51 & 5.44 & 5.21 & 5.40 & 4.49 & 5.46 & 4.19 & 3.38 & 4.48 & 4.08 \\
\hline $\mathrm{K}_{2} \mathrm{O}$ & 0.44 & 0.41 & 0.44 & 0.39 & 0.28 & 0.35 & 0.36 & 0.32 & 0.25 & 0.36 & 0.30 & 0.16 & 0.25 & 0.22 \\
\hline TOTAL & 100.70 & 100.50 & 100.92 & 100.88 & 100.42 & 100.06 & 100.72 & 100.06 & 100.07 & 99.99 & 99.53 & 100.43 & 100.53 & 99.92 \\
\hline Si & 2.528 & 2.519 & 2.527 & 2.515 & 2.545 & 2.549 & & 2.543 & 2442 & 2.535 & 2.387 & 2.301 & 2.396 & \\
\hline Al & 1.460 & 1.462 & 1.451 & 1.470 & 1.452 & 1.446 & 1.445 & 1.451 & 1.475 & 1.390 & 1.585 & 1.662 & 1.591 & $\begin{array}{l}2.381 \\
1.590\end{array}$ \\
\hline $\mathrm{Ti}$ & 0.001 & 0.001 & 0.001 & 0.001 & 0.002 & 0.005 & 0.004 & 0.001 & 0.009 & 0.016 & 0.007 & 0,006 & 0.001 & 0.004 \\
\hline $\mathrm{Fe}$ & 0.002 & 0.009 & 0.065 & 0.005 & 0.007 & 0.010 & 0.006 & 0.010 & 0.039 & 0.044 & 0.031 & 0.020 & 0.011 & 0.020 \\
\hline Mn & 0.000 & 0.000 & 0.000 & 0.000 & 0.001 & 0.002 & 0.003 & 0.001 & 0.004 & 0.000 & 0.002 & 0.000 & 0.000 & 0.000 \\
\hline $\mathrm{Mg}$ & 0.001 & 0.001 & 0.001 & 0.000 & 0.000 & 0.000 & 0.000 & 0.000 & 0.079 & 0.009 & 0.001 & 0.008 & 0.002 & 0.006 \\
\hline $\mathrm{Ca}$ & 0.475 & 0.483 & 0.474 & 0.472 & 0.468 & 0.464 & 0.472 & 0.476 & 0.563 & 0.511 & 0.608 & 0.702 & 0.606 & 0.629 \\
\hline $\mathrm{Na}$ & 0.521 & 0.528 & 0.545 & 0.553 & 0.477 & 0.473 & 0.450 & 0.470 & 0.395 & 0.480 & 0.371 & 0.298 & 0.392 & 0.360 \\
\hline $\mathbf{K}$ & 0.025 & 0.023 & 0.025 & 0.022 & 0.016 & 0.020 & 0.020 & 0.018 & 0.014 & 0.021 & 0.018 & 0.009 & 0.014 & 0.013 \\
\hline An & 46.52 & 46.71 & 45.40 & 45.08 & 48.70 & 48.48 & 50.11 & 49.38 & 57.92 & 50.49 & 60.98 & 69.57 & 59.88 & 6277 \\
\hline $\mathbf{A b}$ & 51.03 & 51.06 & 52.20 & 52.82 & 49.64 & 49.43 & 47.77 & 48.76 & 40.64 & 47.43 & 37.21 & 29.53 & 38.74 & 35.93 \\
\hline Or & 2.45 & 2.22 & 239 & 210 & 1.66 & 2.09 & 2.12 & 1.87 & 1.44 & 2.08 & 1.81 & 0.89 & 1.38 & 1.30 \\
\hline
\end{tabular}

\begin{tabular}{|c|c|c|c|c|c|c|c|c|c|c|c|c|c|c|}
\hline $\begin{array}{l}\text { Sample } \\
\text { Type }\end{array}$ & $\begin{array}{c}90033 \mathrm{~F} 1 \\
\text { Type L } \\
\text { core }\end{array}$ & $\begin{array}{c}90033 \mathrm{G} 1 \\
\text { Type L } \\
\text { core }\end{array}$ & $\begin{array}{c}19003361 \\
\text { Type L } \\
\text { core }\end{array}$ & $\begin{array}{c}\text { Type } \mathrm{L} \\
\text { core }\end{array}$ & $\begin{array}{c}\text { Type L } \\
\text { core }\end{array}$ & $\begin{array}{c}\text { Type C } \\
\text { core }\end{array}$ & $\begin{array}{c}\text { T0033P1 } \\
\text { Type C } \\
\text { core }\end{array}$ & $\begin{array}{c}90033 \mathrm{P} 1 \\
\text { Type C } \\
\text { core }\end{array}$ & $\begin{array}{c}90033 \mathrm{P} 1 \\
\text { Type C } \\
\text { core }\end{array}$ & $\begin{array}{c}\text { Type C } \\
\text { core } \\
\end{array}$ & $\begin{array}{c}\text { Type C } \\
\text { core } \\
\end{array}$ & $\begin{array}{c}\text { Type C } \\
\text { core } \\
\end{array}$ & $\begin{array}{c}\text { Type P } \\
\text { melt }\end{array}$ & $\begin{array}{c}\text { Type } \mathbf{P} \\
\text { melt }\end{array}$ \\
\hline $\mathrm{SiO}_{2}$ & 54.69 & 53.69 & 52.75 & 55.61 & 57.12 & 5248 & 54.09 & 51.08 & 54.94 & 52.32 & 52.56 & 51.09 & 52.50 & 51.02 \\
\hline $\mathrm{Al} 2 \mathrm{O}_{3}$ & 28.95 & 29.46 & 29.40 & 28.33 & 27.51 & 29.77 & 28.90 & 30.29 & 28.29 & 29.83 & 29.84 & 30.46 & 30.13 & 31.12 \\
\hline $\mathrm{TiO}_{2}$ & 0.06 & 0.03 & 0.13 & 0.10 & 0.10 & 0.05 & 0.09 & 0.20 & 0.06 & 0.13 & 0.09 & 0.19 & 0.22 & 0.28 \\
\hline $\mathrm{FeO}$ & 0.13 & 0.18 & 0.60 & 0.18 & 0.13 & 0.24 & 0.20 & 0.52 & 0.28 & 0.15 & 0.20 & 0.50 & 0,47 & 0.74 \\
\hline MnO & 0.00 & 0.08 & 0.00 & 0.00 & 0.05 & 0.00 & 0.00 & 0.00 & 0.03 & 0.00 & 0.04 & 0.00 & 0.00 & 0.03 \\
\hline $\mathrm{MgO}$ & 0.02 & 0.04 & 0.05 & 0.02 & 0.01 & 0.04 & 0.03 & 0.05 & 0.06 & 0.06 & 0.04 & 0.03 & 0.09 & 0.02 \\
\hline $\mathrm{CaO}$ & 11.50 & 11.72 & 12.20 & 10.16 & 8.95 & 1247 & 11.79 & 13.62 & 10.78 & 12.72 & 12.67 & 13.60 & 1262 & 13.35 \\
\hline $\mathrm{Na} 2 \mathrm{O}$ & 4.80 & 5.02 & 4.65 & 5.76 & 6.28 & 4.53 & 4.96 & 3.76 & 5.38 & 4.36 & 4.31 & 4.08 & 4.26 & 3.81 \\
\hline $\mathrm{K} 2 \mathrm{O}$ & 0.25 & 0.36 & 0.35 & 0.44 & 0.51 & 0.24 & 0.27 & 0.30 & 0.45 & 0.29 & 0.32 & 0.23 & 0.32 & 0.27 \\
\hline TOTAL & 100.39 & 100.57 & 100.12 & 100.60 & 100.66 & 99.81 & 100.33 & 99.80 & 100.26 & 99.85 & 100.07 & 100.17 & 100.61 & 100.62 \\
\hline Si & 2.459 & & 2.396 & 2.494 & 2.550 & 2.386 & & 2335 & 2477 & 2.381 & & & & \\
\hline Al & $\begin{array}{l}2.459 \\
1.534\end{array}$ & $\begin{array}{l}2.421 \\
1.565\end{array}$ & $\begin{array}{l}2.396 \\
1.574\end{array}$ & 1.498 & 1.448 & $\begin{array}{l}2.386 \\
1.595\end{array}$ & $\begin{array}{l}2440 \\
1.537\end{array}$ & 1.632 & 1.503 & $\begin{array}{l}2.381 \\
1.600\end{array}$ & $\begin{array}{l}2.386 \\
1.596\end{array}$ & $\begin{array}{l}2.329 \\
1.637\end{array}$ & $\begin{array}{l}2.368 \\
1.603\end{array}$ & $\begin{array}{l}2.314 \\
1.663\end{array}$ \\
\hline $\mathrm{Ti}$ & 0.002 & 0.001 & 0.004 & 0.004 & 0.004 & 0.002 & 0.003 & 0.007 & 0.002 & 0.004 & $\begin{array}{l}1.596 \\
0.003\end{array}$ & $\begin{array}{l}1.637 \\
0.007\end{array}$ & 0.007 & $\begin{array}{l}1.663 \\
0.010\end{array}$ \\
\hline $\mathrm{Fe}$ & 0.005 & 0.007 & 0.023 & 0.007 & 0.005 & 0.009 & 0.007 & 0.020 & 0.011 & 0.006 & $\begin{array}{l}0.003 \\
0.008\end{array}$ & $\begin{array}{l}0.007 \\
0.019\end{array}$ & 0.018 & $\begin{array}{l}0.010 \\
0.028\end{array}$ \\
\hline $\mathrm{Mn}$ & 0.000 & 0.003 & 0.000 & 0.000 & 0.002 & 0.000 & 0.000 & 0.000 & 0.001 & 0.000 & 0.002 & 0.000 & 0.000 & $\begin{array}{l}0.028 \\
0.001\end{array}$ \\
\hline $\mathrm{Mg}$ & 0.000 & 0.003 & 0.004 & 0.002 & 0.001 & 0.003 & 0.000 & 0.003 & 0.004 & 0.004 & 0.003 & 0.002 & 0.006 & $\begin{array}{l}0.001 \\
0.002\end{array}$ \\
\hline $\mathrm{Ca}$ & 0.554 & 0.566 & 0.594 & 0.488 & 0.428 & 0.608 & 0.570 & 0.667 & 0.521 & 0.620 & 0.616 & 0.664 & $\begin{array}{l}0.006 \\
0.610\end{array}$ & $\begin{array}{l}0.002 \\
0.648\end{array}$ \\
\hline $\mathrm{Na}$ & 0.418 & 0.438 & 0.409 & 0.501 & 0.544 & 0.399 & 0.433 & 0.333 & 0.470 & 0.385 & 0.379 & 0.360 & $\begin{array}{l}0.610 \\
0.404\end{array}$ & $\begin{array}{l}0.648 \\
0.335\end{array}$ \\
\hline K & 0.014 & 0.021 & 0.020 & 0.025 & 0.029 & 0.014 & 0.016 & 0.018 & 0.026 & 0.017 & 0.018 & 0.014 & $\begin{array}{l}0.404 \\
0.018\end{array}$ & $\begin{array}{l}0.335 \\
0.015\end{array}$ \\
\hline & & & & & & & & & & & & & & 0.015 \\
\hline TOTAL & 4.986 & 5.025 & 5.024 & 5.019 & 5.011 & 5.016 & 5.006 & 5.015 & 5.015 & 5.017 & 5.011 & 5.032 & 5.034 & 5.016 \\
\hline An & 56.19 & 55.22 & 58.06 & 48.13 & 42.76 & 59.55 & 55.94 & 65.52 & 51.23 & 60.67 & 60.81 & 63.97 & 59.11 & \\
\hline $\mathbf{A b}$ & 42.39 & 42.73 & 39.98 & 49.41 & 54.35 & 39.08 & 42.49 & 32.71 & 46.21 & 37.67 & 37.41 & 34.68 & 39.15 & $\begin{array}{l}64.93 \\
33.57\end{array}$ \\
\hline Or & 1.42 & 205 & 1.96 & 247 & 2.90 & 1.37 & 1.57 & 1.77 & 2.56 & 1.66 & 1.78 & 1.35 & 1.74 & $\begin{array}{r}33.57 \\
1.50\end{array}$ \\
\hline & & & & & & & & & & & & & & 1.50 \\
\hline
\end{tabular}




\begin{tabular}{|c|c|c|c|c|c|c|c|c|c|c|c|c|c|c|}
\hline Sample & $90033 \mathrm{C}$ & $90033 \mathrm{G}$ & $90033 \mathrm{G}$ & $90033 \mathrm{G}$ & $90033 \mathrm{G}$ & $90033 \mathrm{C}$ & $90033 \mathrm{G}$ & $90033 \mathrm{G}$ & $90033 \mathrm{G}$ & $90033 \mathrm{H}$ & $90033 \mathrm{~J}$ & $90033 \mathrm{~J}$ & $90033 \mathrm{~J}$ & 900330 \\
\hline Type & $\begin{array}{l}\text { Type P } \\
\text { kaerst }\end{array}$ & $\begin{array}{c}\text { Type P } \\
\text { melt }\end{array}$ & $\begin{array}{c}\text { Type P } \\
\text { melt }\end{array}$ & $\begin{array}{c}\text { Type P } \\
\text { core }\end{array}$ & $\begin{array}{c}\text { Type P } \\
\text { melt }\end{array}$ & $\begin{array}{c}\text { Type P } \\
\text { melt }\end{array}$ & $\begin{array}{c}\text { Type } \mathbf{P} \\
\text { core }\end{array}$ & $\begin{array}{c}\text { Type P } \\
\text { oxid }\end{array}$ & $\begin{array}{c}\text { Type P } \\
\text { oxid }\end{array}$ & $\begin{array}{c}\text { Type } P \\
\text { core }\end{array}$ & $\begin{array}{c}\text { Type C } \\
\text { core }\end{array}$ & $\begin{array}{l}\text { Type C } \\
\text { kaerst }\end{array}$ & $\begin{array}{l}\text { Type C } \\
\text { kaerst }\end{array}$ & $\begin{array}{c}\text { Type L } \\
\text { core }\end{array}$ \\
\hline $\mathrm{SiO}_{2}$ & 61.50 & 51.65 & 47.62 & 50.60 & 64.65 & 60.46 & 47.76 & 48.54 & 51.84 & 50.99 & 50.28 & 57.62 & 54.49 & 59.56 \\
\hline $\mathrm{A} 12 \mathrm{O} 3$ & 25.01 & 30.39 & 32.28 & 30.55 & 19.71 & 25.01 & 33.05 & 32.01 & 29.79 & 30.78 & 30.78 & 26.08 & 26.57 & 25.94 \\
\hline $\mathrm{TiO}_{2}$ & 1.01 & 0.09 & 0.13 & 0.17 & 0.25 & 0.10 & 0.16 & 0.08 & 0.14 & 0.20 & 0.21 & 0.28 & 0.76 & 0.06 \\
\hline $\mathrm{FeO}$ & 1.12 & 0.39 & 0.43 & 0.61 & 0.34 & 0.40 & 0.56 & 0.60 & 0.55 & 0.32 & 0.37 & 0.77 & 1.07 & 0.27 \\
\hline MnO & 0.04 & 0.00 & 0.04 & 0.00 & 0.00 & 0.03 & 0.00 & 0.00 & 0.00 & 0.02 & 0.01 & 0.00 & 0.00 & 0.04 \\
\hline $\mathrm{MgO}$ & 1.60 & 0.00 & 0.02 & 0.01 & 0.04 & 0.00 & 0.00 & 0.02 & 0.02 & 0.04 & 0.01 & 0.01 & 0.84 & 0.03 \\
\hline $\mathrm{CaO}$ & 0.53 & 13.26 & 16.06 & 13.19 & 1.23 & 6.66 & 15.70 & 14.97 & 12.65 & 13.60 & 13.45 & 7.90 & 10.17 & 7.53 \\
\hline $\mathrm{Na} 2 \mathrm{O}$ & 1.95 & 4.04 & 244 & 3.67 & 3.69 & 7.13 & 2.48 & 2.81 & 4.20 & 3.76 & 3.61 & 5.76 & 5.53 & 6.70 \\
\hline $\mathrm{K} 2 \mathrm{O}$ & 5.38 & 0.33 & 0.16 & 0.21 & 9.58 & 1.07 & 0.11 & 0.18 & 0.42 & 0.28 & 0.35 & 1.37 & 0.57 & 0.55 \\
\hline TOTAL & 98.13 & 100.15 & 99.18 & 99.00 & 99.48 & 100.86 & 99.81 & 99.21 & 99.62 & 99.98 & 99.07 & 99.78 & 100.00 & 100.68 \\
\hline $\mathrm{Si}$ & 2.764 & 2.350 & 2.205 & 2.329 & 2.938 & 2.678 & 2.195 & 2234 & 2369 & 2.323 & 2.315 & 2.599 & 2.478 & 2.642 \\
\hline Al & 1.326 & 1.630 & 1.761 & 1.657 & 1.056 & 1.306 & 1.790 & 1.736 & 1.604 & 1.653 & 1.671 & 1.386 & 1.424 & 1.357 \\
\hline $\mathrm{Ti}$ & 0.034 & 0.003 & 0.005 & 0.006 & 0.009 & 0.003 & 0.006 & 0.003 & 0.005 & 0.007 & 0.007 & 0.009 & 0.026 & 0.002 \\
\hline $\mathrm{Fe}$ & 0.042 & 0.015 & 0.017 & 0.023 & 0.013 & 0.015 & 0.021 & 0.023 & 0.021 & 0.012 & 0.014 & 0.029 & 0.041 & 0.010 \\
\hline Mn & 0.000 & 0.000 & 0.002 & 0.000 & 0.000 & 0.000 & 0.000 & 0.000 & 0.000 & 0.001 & 0.000 & 0.000 & 0.000 & 0.001 \\
\hline Mg & 0.107 & 0.000 & 0.002 & 0.001 & 0.002 & 0.000 & 0.000 & 0.001 & 0.001 & 0.003 & 0.000 & 0.001 & 0.067 & 0.002 \\
\hline $\mathrm{Ca}$ & 0.026 & 0.647 & 0.797 & 0.651 & 0.060 & 0.316 & 0.773 & 0.738 & 0.619 & 0.664 & 0.664 & 0.382 & 0.495 & 0.358 \\
\hline $\mathrm{Na}$ & 0.170 & 0.357 & 0.219 & 0.328 & 0.325 & 0.612 & 0.221 & 0.250 & 0.372 & 0.331 & 0.322 & 0.503 & 0.488 & 0.576 \\
\hline K & 0.308 & 0.019 & 0.010 & 0.012 & 0.555 & 0.061 & 0.007 & 0.011 & 0.024 & 0.016 & 0.021 & 0.079 & 0.033 & 0.031 \\
\hline TOTAL & 4.777 & 5.021 & 5.018 & 5.007 & 4.958 & 4.991 & 5.013 & 4.996 & 5.015 & 5.010 & 5.014 & 4.988 & 5.042 & 4.979 \\
\hline An & 5.16 & 63.25 & 77.68 & 65.69 & 6.38 & 31.95 & 77.22 & 73.87 & 60.99 & 65.68 & 65.94 & 39.63 & 48.72 & 37.10 \\
\hline $\mathbf{A b}$ & 33.73 & 34.90 & 21.35 & 33.10 & 34.57 & 61.88 & 22.08 & 25.03 & 36.65 & 32.74 & 31.98 & 52.18 & 48.03 & 59.69 \\
\hline Or & 61.11 & 1.86 & 0.97 & 1.21 & 59.04 & 6.17 & 0.70 & 1.10 & 2.36 & 1.58 & 2.09 & 8.20 & 3.25 & 3.21 \\
\hline
\end{tabular}

\begin{tabular}{|c|c|c|c|c|c|c|c|c|c|c|c|c|c|c|}
\hline $\begin{array}{l}\text { Sample } \\
\text { Type }\end{array}$ & $\begin{array}{c}90033 \mathrm{Q} 1 \\
\text { Type P } \\
\text { melt }\end{array}$ & $\begin{array}{c}90033 Q 19 \\
\text { Type P } \\
\text { melt }\end{array}$ & $\begin{array}{c}\text { 190033Q1 } \\
\text { Type P } \\
\text { melt }\end{array}$ & $\begin{array}{c}90033 \mathrm{Q} 1 \\
\text { Type P } \\
\text { melt }\end{array}$ & $\begin{array}{c}90033 Q 1 \\
\text { Type P } \\
\text { core } \\
\end{array}$ & $\begin{array}{l}\text { 90039D } \\
\text { Type L } \\
\text { core }\end{array}$ & $\begin{array}{l}\text { 90039D } \\
\text { Type L } \\
\text { core }\end{array}$ & $\begin{array}{c}\text { 90039D } \\
\text { Type L } \\
\text { core }\end{array}$ & $\begin{array}{c}\text { 90039D } \\
\text { Type L } \\
\text { core }\end{array}$ & $\begin{array}{c}\text { 90039D } \\
\text { Type L } \\
\text { core }\end{array}$ & $\begin{array}{c}\text { 90039D } \\
\text { Type L } \\
\text { core }\end{array}$ & $\begin{array}{c}\text { 90039D } \\
\text { Type L } \\
\text { core } \\
\end{array}$ & $\begin{array}{c}90039 E \\
\text { Type L } \\
\text { melt }\end{array}$ & $\begin{array}{c}90039 \mathrm{E} \\
\text { Type L } \\
\text { core- }\end{array}$ \\
\hline $\mathrm{SiO}_{2}$ & 58.04 & 52.77 & 52.77 & 52.69 & 52.01 & 53.38 & 52.35 & 52.68 & 52.55 & 53.23 & 52.09 & 52.73 & 55.00 & 57.96 \\
\hline $\mathrm{A} 12 \mathrm{O} 3$ & 25.09 & 20.66 & 29.68 & 29.72 & 30.14 & 29.44 & 30.35 & 30.19 & 29.85 & 29.82 & 30.21 & 30.00 & 27.26 & 28.43 \\
\hline $\mathrm{TiO}_{2}$ & 0.43 & 2.20 & 0.27 & 0.19 & 0.16 & 0.05 & 0.06 & 0.09 & 0.00 & 0.07 & 0.04 & 0.10 & 0.31 & 0.14 \\
\hline $\mathrm{FeO}$ & 0.81 & 4.82 & 0.35 & 0.39 & 0.50 & 0.30 & 0.20 & 0.04 & 0.18 & 0.15 & 0.13 & 0.16 & 1.02 & 0.00 \\
\hline $\mathrm{MnO}$ & 0.00 & 0.06 & 0.00 & 0.02 & 0.00 & 0.00 & 0.01 & 0.00 & 0.01 & 0.00 & 0.02 & 0.00 & 0.00 & 0.00 \\
\hline MgO & 0.50 & 2.21 & 0.07 & 0.07 & 0.09 & 0.01 & 0.04 & 0.00 & 0.00 & 0.11 & 0.00 & 0.00 & 0.00 & 0.00 \\
\hline $\mathrm{CaO}$ & 8.07 & 9.23 & 12.71 & 12.76 & 1294 & 11.99 & 13.05 & 12.95 & 12.69 & 12.15 & 12.76 & 12.21 & 10.34 & 11.12 \\
\hline $\mathrm{Na} 2 \mathrm{O}$ & 6.09 & 5.69 & 4.28 & 4.44 & 3.97 & 4.63 & 3.93 & 4.09 & 4.04 & 4.41 & 4.12 & 4.31 & 4.92 & 5.64 \\
\hline $\mathrm{K} 2 \mathrm{O}$ & 1.29 & 1.19 & 0.36 & 0.23 & 0.28 & 0.28 & 0.23 & 0.23 & 0.26 & 0.31 & 0.27 & 0.26 & 0.44 & 0.24 \\
\hline TOTAL & 100.32 & 98.82 & 100.47 & 100.52 & 100.10 & 100.09 & 100.21 & 100.25 & 99.57 & 100.25 & 99.63 & 99.76 & 99.28 & 103.53 \\
\hline Si & 2610 & 2.499 & 2.388 & 2.384 & 2.363 & 2.417 & 2.369 & 2382 & 2.392 & 2405 & 2.372 & 2.394 & 2.499 & 2.518 \\
\hline Al & 1.329 & 1.154 & 1.583 & 1.585 & 1.614 & 1.571 & 1.619 & 1.609 & 1.601 & 1.588 & 1.622 & 1.605 & 1.460 & 1.456 \\
\hline $\mathrm{Ti}$ & 0.014 & 0.078 & 0.009 & 0.006 & 0.006 & 0.002 & 0.002 & 0.003 & 0.000 & 0.002 & 0.001 & 0.003 & 0.010 & 0.005 \\
\hline $\mathrm{Fe}$ & 0.030 & 0.191 & 0.013 & 0.015 & 0.019 & 0.011 & 0.007 & 0.002 & 0.007 & 0.006 & 0.005 & 0.006 & 0.038 & 0.000 \\
\hline Mn & 0.000 & 0.003 & 0.000 & 0.001 & 0.000 & 0.000 & 0.000 & 0.000 & 0.000 & 0.000 & 0.001 & 0.000 & 0.000 & 0.000 \\
\hline $\mathrm{Mg}$ & 0.033 & 0.156 & 0.005 & 0.004 & 0.006 & 0.001 & 0.003 & 0.000 & 0.000 & 0.008 & 0.000 & 0.000 & 0.000 & 0.000 \\
\hline $\mathrm{Ca}$ & 0.389 & 0.469 & 0.616 & 0.619 & 0.630 & 0.582 & 0.633 & 0.627 & 0.619 & 0.588 & 0.623 & 0.594 & 0.503 & 0.517 \\
\hline $\mathrm{Na}$ & 0.531 & 0.523 & 0.375 & 0.389 & 0.350 & 0.407 & 0.345 & 0.358 & 0.356 & 0.386 & 0.364 & 0.379 & 0.433 & 0.474 \\
\hline K & 0.074 & 0.072 & 0.021 & 0.013 & 0.016 & 0.016 & 0.013 & 0.013 & 0.015 & 0.018 & 0.015 & 0.015 & 0.026 & 0.014 \\
\hline TOTAL & 5.010 & 5.145 & 5.010 & 5.016 & 5.004 & 5.007 & 4.991 & 4.994 & 4.990 & 5.001 & 5.003 & 4.996 & 4.969 & 4.984 \\
\hline An & 39.13 & 44.08 & 60.87 & 60.63 & 63.25 & 57.91 & 63.87 & 62.83 & 62.53 & 59.27 & 62.18 & 60.12 & 52.29 & 51.44 \\
\hline $\mathbf{A b}$ & 53.42 & 49.15 & 37.06 & 38.10 & 35.14 & 40.50 & 34.81 & 35.87 & 35.96 & 38.91 & 36.33 & 38.36 & 45.01 & 47.16 \\
\hline Or & 7.44 & 6.77 & 208 & 1.27 & 1.61 & 1.59 & 1.31 & 1.30 & 1.52 & 1.81 & 1.50 & 1.52 & 270 & 1.39 \\
\hline
\end{tabular}




\begin{tabular}{|c|c|c|c|c|c|c|c|c|c|c|c|c|c|c|}
\hline $\begin{array}{l}\text { Sample } \\
\text { Type }\end{array}$ & $\begin{array}{c}90033 \mathrm{P} \\
\text { Type C } \\
\text { core }\end{array}$ & $\begin{array}{c}90033 \mathrm{P} \\
\text { Type C } \\
\text { core } \\
\end{array}$ & $\begin{array}{l}90033 \mathrm{P} \\
\text { Type C } \\
\text { kaerst }\end{array}$ & $\begin{array}{c}90033 \mathrm{P} \\
\text { Type C } \\
\text { core }\end{array}$ & $\begin{array}{c}90033 \mathrm{P} \\
\text { Type C } \\
\text { core }\end{array}$ & $\begin{array}{c}90033 \mathrm{P} \\
\text { Type C } \\
\text { core } \\
\end{array}$ & $\begin{array}{c}90033 P \\
\text { Type C } \\
\text { core } \\
\end{array}$ & $\begin{array}{c}90033 \mathrm{P} \\
\text { Type C } \\
\text { melt - }\end{array}$ & $\begin{array}{c}90033 \mathrm{P} \\
\text { Type C } \\
\text { melt }\end{array}$ & $\begin{array}{c}\text { 90033R } \\
\text { Type C } \\
\text { melt }\end{array}$ & $\begin{array}{c}90033 \mathrm{R} \\
\text { Type C } \\
\text { core } \\
\end{array}$ & $\begin{array}{c}90033 \mathrm{R} \\
\text { Type C } \\
\text { core- }\end{array}$ & $\begin{array}{c}90033 \mathrm{R} \\
\text { Type C } \\
\text { rim }\end{array}$ & $\begin{array}{c}\text { 90033R } \\
\text { Type C } \\
\text { melt }\end{array}$ \\
\hline $\mathrm{SiO}_{2}$ & 55.01 & 55.61 & 61.55 & 53.81 & 52.14 & 5286 & 55.13 & 50.51 & 49.43 & 58.31 & 55.86 & 56.12 & 51.21 & 49.61 \\
\hline $\mathrm{Al} 2 \mathrm{O}_{3}$ & 28.16 & 28.57 & 22.21 & 29.56 & 30.12 & 29.89 & 28.54 & 30.81 & 32.24 & 25.69 & 27.62 & 27.61 & 30.98 & 31.67 \\
\hline Tí2 & 0.01 & 0.05 & 0.20 & 0.05 & 0.07 & 0.09 & 0.04 & 0.15 & 0.15 & 0.23 & 0.05 & 0.07 & 0.06 & 0.23 \\
\hline $\mathrm{FeO}$ & 0.17 & 0.16 & 1.69 & 0.17 & 0.27 & 0.12 & 0.14 & 0.40 & 0.29 & 0.62 & 0.17 & 0.00 & 0.44 & 0.61 \\
\hline MnO & 0.02 & 0.03 & 0.08 & 0.00 & 0.00 & 0.05 & 0.00 & 0.03 & 0.00 & 0.00 & 0.05 & 0.00 & 0.01 & 0.00 \\
\hline $\mathrm{MgO}$ & 0.03 & 0.00 & 1.14 & 0.03 & 0.05 & 0.02 & 0.08 & 0.07 & 0.06 & 0.00 & 0.03 & 0.07 & 0.05 & 0.03 \\
\hline $\mathrm{CaO}$ & 10.64 & 10.57 & 1.73 & 11.55 & 13.04 & 1265 & 10.84 & 14.21 & 15.18 & 8.12 & 9.65 & 10.08 & 13.62 & 15.01 \\
\hline $\mathrm{Na} 2 \mathrm{O}$ & 6.00 & 5.79 & 3.99 & 5.10 & 4.61 & 4.62 & 5.21 & 3.55 & 2.85 & 6.23 & 5.72 & 5.69 & 3.58 & 293 \\
\hline $\mathrm{K}_{2} \mathrm{O}$ & 0.26 & 0.22 & 7.84 & 0.17 & 0.34 & 0.15 & 0.18 & 0.15 & 0.11 & 0.08 & 0.47 & 0.35 & 0.34 & 0.21 \\
\hline TOTAL & 100.29 & 101.01 & 100.41 & 100.42 & 100.63 & 100.46 & 100.11 & 99.89 & 100.29 & 99.29 & 99.62 & 100.00 & 100.29 & 100.30 \\
\hline Si & 2.481 & 2.485 & 2.789 & 2.424 & 2.362 & 2389 & 2481 & 2309 & 2253 & 2.618 & 2.524 & 2.577 & 2.327 & 2.266 \\
\hline Al & 1.498 & 1.505 & 1.187 & 1.569 & 1.609 & 1.592 & 1.514 & 1.660 & 1.732 & 1.359 & 1.471 & 1.418 & 1.659 & 1.705 \\
\hline $\mathrm{Ti}$ & 0.000 & 0.001 & 0.007 & 0.002 & 0.002 & 0.003 & 0.001 & 0.005 & 0.005 & 0.008 & 0.002 & 0.000 & 0.002 & 0.008 \\
\hline $\mathrm{Fe}$ & 0.006 & 0.006 & 0.064 & 0.006 & 0.010 & 0.004 & 0.005 & 0.015 & 0.011 & 0.023 & 0.006 & 0.000 & 0.017 & 0.023 \\
\hline Mn & 0.000 & 0.001 & 0.007 & 0.000 & 0.000 & 0.002 & 0.000 & 0.001 & 0.000 & 0.000 & 0.002 & 0.000 & 0.000 & 0.000 \\
\hline Mg & 0.001 & 0.000 & 0.077 & 0.002 & 0.003 & 0.001 & 0.002 & 0.005 & 0.004 & 0.002 & 0.002 & 0.000 & 0.004 & 0.002 \\
\hline $\mathrm{Ca}$ & 0.514 & 0.506 & 0.084 & 0.557 & 0.633 & 0.613 & 0.523 & 0.696 & 0.741 & 0.390 & 0.467 & 0.471 & 0.663 & 0.735 \\
\hline $\mathrm{Na}$ & 0.525 & 0.502 & 0.351 & 0.446 & 0.405 & 0.405 & 0.455 & 0.315 & 0.252 & 0.543 & 0.501 & 0.481 & 0.316 & 0.260 \\
\hline K & 0.015 & 0.013 & 0.453 & 0.010 & 0.020 & 0.008 & 0.010 & 0.009 & 0.006 & 0.047 & 0.027 & 0.020 & 0.019 & 0.012 \\
\hline TOTAL & 5.040 & 5.019 & 5.019 & 5.016 & 5.044 & 5.017 & 4.991 & 5.015 & 5.004 & 4.990 & 5.002 & 4.967 & 5.007 & 5.011 \\
\hline An & 48.77 & 49.56 & 9.46 & 54.99 & 59.83 & 59.75 & 52.94 & 68.24 & 74.17 & 39.80 & 46.93 & 48.46 & 66.43 & 72.99 \\
\hline$A b$ & 49.81 & 49.17 & 39.53 & 44.03 & 38.28 & 39.47 & 46.05 & 30.88 & 25.23 & 55.41 & 50.35 & 49.49 & 31.66 & 25.82 \\
\hline Or & 1.42 & 1.27 & 51.01 & 0.99 & 1.89 & 0.78 & 1.01 & 0.88 & 0.60 & 4.80 & 2.71 & 2.06 & 1.90 & 1.19 \\
\hline
\end{tabular}

\begin{tabular}{|c|c|c|c|c|c|c|c|c|c|c|c|c|c|c|}
\hline $\begin{array}{l}\text { Sample } \\
\text { Type }\end{array}$ & $\begin{array}{c}90039 \mathrm{E} \\
\text { Type L } \\
\text { rim }\end{array}$ & $\begin{array}{c}90039 \mathrm{~F} \\
\text { Type M } \\
\text { core }\end{array}$ & $\begin{array}{c}90039 \mathrm{M} \\
\text { Type L } \\
\text { core- }\end{array}$ & $\begin{array}{c}90039 \mathrm{M} \\
\text { Type L } \\
\text { rim }\end{array}$ & $\begin{array}{c}90039 \mathrm{M} \\
\text { Type L } \\
\text { core }\end{array}$ & $\begin{array}{c}90039 \mathrm{M} \\
\text { Type L } \\
\text { core }\end{array}$ & $\begin{array}{c}90039 \mathrm{M} \\
\text { Type L } \\
\text { core }\end{array}$ & $\begin{array}{c}90039 \mathrm{M} \\
\text { Type L } \\
\text { core } \\
\end{array}$ & $\begin{array}{c}90039 \mathrm{M} \\
\text { Type L } \\
\text { core }\end{array}$ & $\begin{array}{c}90039 \mathrm{M} \\
\text { Type L } \\
\text { core }\end{array}$ & $\begin{array}{c}90039 \mathrm{M} \\
\text { Type L } \\
\text { core }\end{array}$ & $\begin{array}{c}900390 \\
\text { Type L. } \\
\text { core }\end{array}$ & $\begin{array}{c}900390 \\
\text { Type L } \\
\text { core }\end{array}$ & $\begin{array}{c}900390 \\
\text { Type C } \\
\text { core }\end{array}$ \\
\hline $\mathrm{SiO}_{2}$ & 54.60 & 55.68 & 54.12 & 49.28 & 54.89 & 54.56 & 54.76 & 53.97 & 54.82 & 54.23 & 55.02 & 55.52 & 57.16 & 57.92 \\
\hline $\mathrm{A} \mid 2 \mathrm{O}_{3}$ & 29.94 & 28.61 & 29.25 & 3222 & 29.02 & 29.25 & 28.89 & 28.76 & 29.05 & 29.37 & 28.89 & 28.59 & 28.56 & 27.40 \\
\hline $\mathrm{TiO}_{2}$ & 0.21 & 0.05 & 0.00 & 0.05 & 0.07 & 0.01 & 0.11 & 0.08 & 0.08 & 0.08 & 0.02 & 0.07 & 0.00 & 0.30 \\
\hline $\mathrm{FeO}$ & 0.70 & 0.20 & 0.19 & 0.58 & 0.15 & 0.25 & 0.13 & 0.17 & 0.15 & 0.14 & 0.12 & 0.13 & 0.17 & 0.29 \\
\hline $\mathrm{MnO}$ & 0.00 & 0.05 & 0.00 & 0.09 & 0.00 & 0.00 & 0.00 & 0.00 & 0.03 & 0.05 & 0.00 & 0.00 & 0.14 & 0.10 \\
\hline $\mathrm{MgO}$ & 0.08 & 0.01 & 0.00 & 0.02 & 0.00 & 0.03 & 0.05 & 0.00 & 0.02 & 0.06 & 0.00 & 0.05 & 0.03 & 0.01 \\
\hline $\mathrm{CaO}$ & 14.60 & 10.50 & 11.36 & 14.79 & 10.90 & 11.42 & 10.79 & 11.45 & 11.10 & 11.53 & 11.05 & 10.07 & 10.47 & 9.27 \\
\hline $\mathrm{Na} 2 \mathrm{O}$ & 3.76 & 4.52 & 4.84 & 281 & 5.16 & 4.98 & 5.13 & 5.05 & 5.38 & 5.07 & 5.06 & 5.38 & 5.38 & 5.83 \\
\hline $\mathrm{K}_{2} \mathrm{O}$ & 0.27 & 0.25 & 0.25 & 0.16 & 0.34 & 0.24 & 0.25 & 0.23 & 0.24 & 0.23 & 0.29 & 0.31 & 0.26 & 0.33 \\
\hline TOTAL & 104.16 & 99.87 & 100.01 & 100.00 & 100.53 & 100.73 & 100.10 & 99.65 & 100.86 & 100.76 & 100.45 & 100.11 & 102.17 & 107.43 \\
\hline $\mathrm{Si}$ & 2.388 & 2.501 & 2.443 & 2.255 & 2.464 & 2.448 & 2465 & 2449 & 2456 & 2.434 & 2.470 & 2.490 & 2.514 & 2.561 \\
\hline Al & 1.543 & 1.515 & 1.556 & 1.737 & 1.535 & 1.547 & 1.533 & 1.538 & 1.534 & 1.554 & 1.529 & 1.512 & 1.480 & 1.428 \\
\hline $\mathrm{Ti}$ & 0.007 & 0.000 & 0.000 & 0.002 & 0.002 & 0.000 & 0.004 & 0.001 & 0.003 & 0.003 & 0.001 & 0.002 & 0.000 & 0.010 \\
\hline $\mathrm{Fe}$ & 0.025 & 0.000 & 0.007 & 0.022 & 0.006 & 0.009 & 0.005 & 0.007 & 0.006 & 0.005 & 0.005 & 0.005 & 0.010 & 0.010 \\
\hline Mn & 0.000 & 0.000 & 0.000 & 0.003 & 0.000 & 0.000 & 0.000 & 0.000 & 0.000 & 0.002 & 0.000 & 0.000 & 0.010 & 0.000 \\
\hline Mg & 0.000 & 0.000 & 0.000 & 0.001 & 0.000 & 0.000 & 0.003 & 0.000 & 0.000 & 0.004 & 0.000 & 0.000 & 0.000 & 0.000 \\
\hline $\mathrm{Ca}$ & 0.684 & 0.507 & 0.549 & 0.725 & 0.524 & 0.549 & 0.520 & 0.557 & 0.533 & 0.554 & 0.531 & 0.484 & 0.493 & 0.439 \\
\hline $\mathrm{Na}$ & 0.318 & 0.392 & 0.424 & 0.250 & 0.449 & 0.433 & 0.447 & 0.444 & 0.468 & 0.441 & 0.441 & 0.467 & 0.458 & 0.499 \\
\hline $\mathbf{K}$ & 0.015 & 0.013 & 0.014 & 0.009 & 0.019 & 0.014 & 0.015 & 0.013 & 0.014 & 0.013 & 0.017 & 0.018 & 0.014 & 0.019 \\
\hline TOTAL & 4.980 & 4.928 & 4.993 & 5.004 & 4.999 & 5.000 & 4.992 & 5.009 & 5.013 & 5.010 & 4.994 & 4.978 & 4.979 & 4.966 \\
\hline An & 67.26 & 55.59 & 55.62 & 73.68 & 5282 & 55.12 & 52.95 & 54.93 & 52.51 & 54.96 & 53.69 & 49.95 & 51.09 & 45.87 \\
\hline$A b$ & 31.27 & 42.98 & 42.96 & 25.41 & 45.26 & 43.47 & 45.52 & 43.79 & 46.11 & 43.75 & 44.59 & 48.19 & 47.46 & 52.14 \\
\hline Or & 1.47 & 1.43 & 1.42 & 0.91 & 1.92 & 1.41 & 1.53 & 1.28 & 1.38 & 1.29 & 1.72 & 1.86 & 1.45 & 1.99 \\
\hline
\end{tabular}




\begin{tabular}{|c|c|c|c|c|c|c|c|c|c|c|c|c|}
\hline Sample & $90033 \mathrm{~S}$ & $90033 \mathrm{~S}$ & $90033 S$ & $90033 S$ & $90033 \mathrm{~S}$ & $90033 \mathrm{~S}$ & $90033 \mathrm{~S}$ & $90033 \mathrm{~S}$ & $90033 \mathrm{~S}$ & $90033 \mathrm{~S}$ & $90033 \mathrm{~S}$ & 900335 \\
\hline Type & $\begin{array}{c}\text { Type L } \\
\text { core } \\
\end{array}$ & $\begin{array}{c}\text { Type L } \\
\text { core } \\
\end{array}$ & $\begin{array}{c}\text { Type L } \\
\text { core- }\end{array}$ & $\begin{array}{c}\text { Type L } \\
\text { rim }\end{array}$ & $\begin{array}{c}\text { Type L } \\
\text { core }\end{array}$ & $\begin{array}{c}\text { Type L } \\
\text { core }\end{array}$ & $\begin{array}{c}\text { Type L } \\
\text { melt }\end{array}$ & $\begin{array}{c}\text { Type L } \\
\text { core }\end{array}$ & $\begin{array}{c}\text { Type L } \\
\text { core }\end{array}$ & $\begin{array}{c}\text { Type L } \\
\text { core }\end{array}$ & $\begin{array}{c}\text { Type L } \\
\text { core }\end{array}$ & $\begin{array}{l}\text { Type L } \\
\text { kaerst } \\
\end{array}$ \\
\hline $\mathrm{SiO}_{2}$ & 54.64 & 51.57 & 53.67 & 49.19 & 53.59 & 51.95 & 49.87 & 52.59 & 53.45 & 50.61 & 49.88 & 56.53 \\
\hline $\mathrm{A} 12 \mathrm{O} 3$ & 28.20 & 29.83 & 28.86 & 31.36 & 29.62 & 29.78 & 30.98 & 29.70 & 28.79 & 30.86 & 31.30 & 27.56 \\
\hline $\mathrm{TiO}_{2}$ & 0.05 & 0.00 & 0.03 & 0.09 & 0.04 & 0.01 & 0.21 & 0.01 & 0.15 & 0.17 & 0.15 & 0.13 \\
\hline $\mathrm{FeO}$ & 0.23 & 0.28 & 0.22 & 0.72 & 0.16 & 0.22 & 1.08 & 0.16 & 0.45 & 0.56 & 0.57 & 0.53 \\
\hline $\mathrm{MnO}$ & 0.00 & 0.04 & 0.00 & 0.02 & 0.00 & 0.00 & 0.00 & 0.00 & 0.09 & 0.00 & 0.00 & 0.00 \\
\hline $\mathrm{MgO}$ & 0.01 & 0.07 & 0.14 & 0.00 & 0.05 & 0.04 & 0.07 & 0.01 & 0.08 & 0.00 & 0.00 & 0.00 \\
\hline $\mathrm{CaO}$ & 11.08 & 13.68 & 12.09 & 14.85 & 12.92 & 13.25 & 14.47 & 12.71 & 12.38 & 13.97 & 14.67 & 9.86 \\
\hline $\mathrm{Na} 2 \mathrm{O}$ & 5.27 & 4.18 & 4.25 & 290 & 4.30 & 3.99 & 2.97 & 4.31 & 4.13 & 3.62 & 2.90 & 5.46 \\
\hline K2O & 0.23 & 0.15 & 0.22 & 0.21 & 0.18 & 0.16 & 0.18 & 0.14 & 0.38 & 0.00 & 0.17 & 0.45 \\
\hline TOTAL & 99.72 & 99.79 & 99.48 & 99.34 & 100.86 & 99.40 & 99.82 & 99.62 & 99.89 & 99.79 & 99.64 & 100.52 \\
\hline Si & 2.475 & 2.356 & 2.439 & 2.269 & 2.409 & 2.375 & 2.288 & 2394 & 2.428 & 2.318 & 2.287 & 2.533 \\
\hline Al & 1.506 & 1.606 & 1.545 & 1.705 & 1.570 & 1.605 & 1.676 & 1.594 & 1.541 & 1.657 & 1.693 & 1.455 \\
\hline $\mathrm{Ti}$ & 0.002 & 0.000 & 0.001 & 0.003 & 0.001 & 0.000 & 0.007 & 0.000 & 0.005 & 0.006 & 0.005 & 0.004 \\
\hline Fe & 0.009 & 0.011 & 0.008 & 0.028 & 0.006 & 0.008 & 0.041 & 0.006 & 0.017 & 0.021 & 0.022 & 0.020 \\
\hline Mn & 0.000 & 0.001 & 0.000 & 0.001 & 0.000 & 0.000 & 0.000 & 0.000 & 0.003 & 0.000 & 0.000 & 0.000 \\
\hline Mg & 0.000 & 0.004 & 0.010 & 0.000 & 0.003 & 0.002 & 0.005 & 0.001 & 0.005 & 0.000 & 0.000 & 0.000 \\
\hline $\mathrm{Ca}$ & 0.538 & 0.670 & 0.588 & 0.734 & 0.623 & 0.649 & 0.712 & 0.620 & 0.603 & 0.686 & 0.721 & 0.473 \\
\hline $\mathrm{Na}$ & 0.463 & 0.370 & 0.375 & 0.259 & 0.375 & 0.353 & 0.264 & 0.380 & 0.364 & 0.321 & 0.258 & 0.474 \\
\hline $\mathbf{K}$ & 0.013 & 0.009 & 0.013 & 0.013 & 0.010 & 0.009 & 0.011 & 0.008 & 0.022 & 0.000 & 0.010 & 0.026 \\
\hline TOTAL & 5.006 & 5.027 & 4.979 & 5.012 & 4.997 & 5.001 & 5.004 & 5.003 & 4.988 & 5.009 & 4.996 & 4.985 \\
\hline An & 53.06 & 63.87 & 60.25 & 72.96 & 61.81 & 64.19 & 72.14 & 61.51 & 60.97 & 68.12 & 72.90 & 48.61 \\
\hline $\mathbf{A b}$ & 45.66 & 35.27 & 38.42 & 25.75 & 37.20 & 34.92 & 26.75 & 37.70 & 36.80 & 31.88 & 26.09 & 48.72 \\
\hline Or & 1.28 & 0.86 & 1.33 & 1.29 & 0.99 & 0.89 & 1.11 & 0.79 & 2.22 & 0.00 & 1.01 & 2.67 \\
\hline
\end{tabular}

\begin{tabular}{|c|c|c|c|c|c|c|c|c|c|c|c|c|}
\hline Sample & $90039 \mathrm{Sb}$ & $90039 \mathrm{Sb}$ & $90039 \mathrm{Sb}$ & $90039 \mathrm{Sb}$ & $90039 \mathrm{Sb}$ & $90039 \mathrm{Sb}$ & $90039 \mathrm{Sa}$ & $90039 \mathrm{Sa}$ & $90039 \mathrm{~V}$ & $90039 \mathrm{~V}$ & $90039 \mathrm{~V}$ & $90039 \mathrm{~V}$ \\
\hline Type & $\begin{array}{c}\text { Type C } \\
\text { core }\end{array}$ & $\begin{array}{c}\text { Type C } \\
\text { core }\end{array}$ & $\begin{array}{c}\text { Type C } \\
\text { core } \\
\end{array}$ & $\begin{array}{c}\text { Type } P \\
\text { core }\end{array}$ & $\begin{array}{c}\text { Type C } \\
\text { core } \\
\end{array}$ & $\begin{array}{c}\text { Type P } \\
\text { core }\end{array}$ & $\begin{array}{c}\text { Type C } \\
\text { core } \\
\end{array}$ & $\begin{array}{c}\text { Type P } \\
\text { core } \\
\end{array}$ & $\begin{array}{c}\text { Type } \mathrm{M} \\
\text { core } \\
\end{array}$ & $\begin{array}{c}\text { Type } \mathrm{M} \\
\text { rim } \\
\end{array}$ & $\begin{array}{c}\text { Type } \mathrm{M} \\
\text { core }\end{array}$ & $\begin{array}{c}\text { Type } \mathbf{M} \\
\text { core } \\
\end{array}$ \\
\hline $\mathrm{SiO}_{2}$ & 55.46 & 55.12 & 52.15 & 50.50 & 52.07 & 51.33 & 54.48 & 49.63 & 54.62 & 49.06 & 53.37 & 53.59 \\
\hline $\mathrm{A} 12 \mathrm{O} 3$ & 29.04 & 28.40 & 30.41 & 31.27 & 30.36 & 30.67 & 28.56 & 31.93 & 29.30 & 31.92 & 29.50 & 29.45 \\
\hline $\mathrm{TiO}_{2}$ & 0.02 & 0.07 & 0.14 & 0.18 & 0.17 & 0.17 & 0.05 & 0.06 & 0.08 & 0.21 & 0.13 & 0.09 \\
\hline $\mathrm{FeO}$ & 0.15 & 0.09 & 0.44 & 0.51 & 0.66 & 0.48 & 0.24 & 0.29 & 0.18 & 0.55 & 0.24 & 0.25 \\
\hline MnO & 0.01 & 0.10 & 0.00 & 0.01 & 0.00 & 0.00 & 0.00 & 0.02 & 0.09 & 0.11 & 0.11 & 0.02 \\
\hline $\mathrm{MgO}$ & 0.02 & 0.00 & 0.08 & 0.06 & 0.10 & 0.09 & 0.07 & 0.03 & 0.00 & 0.08 & 0.10 & 0.06 \\
\hline $\mathrm{CaO}$ & 10.59 & 10.43 & 12.98 & 14.21 & 12.97 & 13.72 & 11.13 & 15.06 & 11.79 & 14.92 & 11.76 & 11.83 \\
\hline $\mathrm{Na} 2 \mathrm{O}$ & 5.44 & 5.57 & 4.24 & 3.47 & 4.09 & 3.65 & 4.81 & 2.91 & 3.89 & 2.71 & 4.65 & 4.91 \\
\hline $\mathrm{K} 2 \mathrm{O}$ & 0.25 & 0.27 & 0.24 & 0.18 & 0.24 & 0.22 & 0.18 & 0.04 & 0.14 & 0.10 & 0.12 & 0.13 \\
\hline TOTAL & 100.97 & 100.06 & 100.68 & 100.38 & 100.64 & 100.33 & 99.50 & 99.96 & 100.09 & 99.66 & 99.98 & 100.33 \\
\hline Si & 2476 & 2.485 & 2.357 & 2.298 & 2.357 & 2.333 & 2.469 & 2267 & 2447 & 2.243 & 2409 & 2.414 \\
\hline Al & 1.528 & 1.590 & 1.620 & 1.677 & 1.619 & 1.642 & 1.526 & 1.720 & 1.547 & 1.719 & 1.570 & 1.563 \\
\hline $\mathrm{Ti}$ & 0.000 & 0.000 & 0.010 & 0.010 & 0.010 & 0.010 & 0.002 & 0.001 & 0.002 & 0.007 & 0.004 & 0.003 \\
\hline $\mathrm{Fe}$ & 0.006 & 0.000 & 0.017 & 0.020 & 0.025 & 0.018 & 0.009 & 0,011 & 0.007 & 0.020 & 0.009 & 0.009 \\
\hline Mn & 0.000 & 0.000 & 0.000 & 0.000 & 0.000 & 0.000 & 0.000 & 0.001 & 0.003 & 0.004 & 0.004 & 0.000 \\
\hline $\mathbf{M g}$ & 0.000 & 0.000 & 0.010 & 0.000 & 0.010 & 0.010 & 0.004 & 0.002 & 0.000 & 0.005 & 0.006 & 0.000 \\
\hline $\mathrm{Ca}_{2}$ & 0.507 & 0.504 & 0.629 & 0.693 & 0.629 & 0.668 & 0.540 & 0.738 & 0.566 & 0.730 & 0.568 & 0.571 \\
\hline $\mathrm{Na}$ & 0.471 & 0.487 & 0.371 & 0.306 & 0.359 & 0.321 & 0.422 & 0.258 & 0.338 & 0.240 & 0.407 & 0.428 \\
\hline $\mathbf{K}$ & 0.014 & 0.016 & 0.014 & 0.010 & 0.014 & 0.013 & 0.010 & 0.002 & 0.008 & 0.006 & 0.007 & 0.008 \\
\hline TOTAL & 5.002 & 5.082 & 5.028 & 5.014 & 5.023 & 5.015 & 4.982 & 5.000 & 4.918 & 4.974 & 4.984 & 4.996 \\
\hline An & 51.11 & 50.05 & 62.03 & 68.68 & 62.77 & 66.67 & 55.56 & 73.95 & 62.06 & 74.80 & 57.84 & 56.70 \\
\hline$A b$ & 47.48 & 48.36 & 36.59 & 30.33 & 35.83 & 32.04 & 43.42 & 25.85 & 37.06 & 24.59 & 41.45 & 42.50 \\
\hline Or & 1.41 & 1.59 & 1.38 & 0.99 & 1.40 & 1.30 & 1.03 & 0.20 & 0.88 & 0.61 & 0.71 & 0.79 \\
\hline
\end{tabular}




\section{A3.1 Mount Sidley xenolith mineral analyses: kaersutite}

\begin{tabular}{|c|c|c|c|c|c|c|c|c|c|c|c|c|c|c|}
\hline $\begin{array}{l}\text { Sample } \\
\text { Type }\end{array}$ & $\begin{array}{c}90033 \mathrm{C} \\
\text { Type } \mathrm{P} \\
\text { core }\end{array}$ & $\begin{array}{c}90033 \mathrm{C} \\
\text { Type P } \\
\text { core }\end{array}$ & $\begin{array}{c}90033 \mathrm{C} \\
\text { Type } \mathrm{P} \\
\text { core }\end{array}$ & $\begin{array}{c}90033 \mathrm{C} \\
\text { Type P } \\
\text { core }\end{array}$ & $\begin{array}{c}90033 \mathrm{C} \\
\text { Type P } \\
\text { core } \\
\end{array}$ & $\begin{array}{c}90033 \mathrm{C} \\
\text { Type } \mathrm{P} \\
\text { core } \\
\end{array}$ & $\begin{array}{c}90033 \mathrm{C} \\
\text { Type P } \\
\text { core } \\
\end{array}$ & $\begin{array}{c}90033 \mathrm{C} \\
\text { Type } \mathrm{P} \\
\text { core }\end{array}$ & $\begin{array}{c}90033 \mathrm{C} \\
\text { Type P } \\
\text { core }\end{array}$ & $\begin{array}{c}90033 \mathrm{C} \\
\text { Type P } \\
\text { core } \\
\end{array}$ & $\begin{array}{c}90033 \mathrm{H} \\
\text { Type P } \\
\text { core }\end{array}$ & $\begin{array}{c}90033 \mathrm{H} \\
\text { Type } \mathrm{P} \\
\text { core }\end{array}$ & $\begin{array}{c}90033 \mathrm{~J} \\
\text { Type C } \\
\text { core }\end{array}$ & $\begin{array}{c}90033 \mathrm{~J} \\
\text { Type C } \\
\text { core }\end{array}$ \\
\hline $\mathrm{SiO}_{2}$ & 39.31 & 39.04 & 40.37 & 39.11 & 40.19 & 39.31 & 39.58 & 39.23 & 39.08 & 38.30 & 38.71 & 40.61 & 38.94 & 37.13 \\
\hline $\mathrm{Al}_{2} \mathrm{O} 3$ & 14.74 & 15.04 & 14.53 & 15.36 & 14.07 & 14.35 & 14.39 & 14.61 & 14.81 & 14.78 & 14.39 & 14.24 & 14.70 & 14.40 \\
\hline $\mathrm{TiO}_{2}$ & 7.08 & 6,42 & 5.68 & 5.47 & 5.43 & 6.97 & 5.99 & 6.99 & 7.11 & 6.10 & 7.08 & 6.21 & 5.66 & 5.98 \\
\hline $\mathrm{FeO}$ & 8.94 & 10.29 & 9.92 & 10.72 & 11.10 & 9.75 & 11.01 & 9.89 & 9.50 & 10.95 & 9.12 & 6.77 & 12.18 & 13.54 \\
\hline $\mathrm{MnO}$ & 0.08 & 0.10 & 0.07 & 0.10 & 0.14 & 0.04 & 0.07 & 0.08 & 0.14 & 0.07 & 0.12 & 0.10 & 0.15 & 0.15 \\
\hline $\mathrm{MgO}$ & 12.51 & 12.24 & 12.78 & 12.07 & 12.48 & 1266 & 12.50 & 12.31 & 12.36 & 12.25 & 13.20 & 14.66 & 1252 & 12.44 \\
\hline $\mathrm{CaO}$ & 11.54 & 11.30 & 10.97 & 11.21 & 10.66 & 11.40 & 11.16 & 11.37 & 11.61 & 11.10 & 12.02 & 11.16 & 11.23 & 11.15 \\
\hline $\mathrm{Na} 2 \mathrm{O}$ & 2.90 & 3.16 & 3.22 & 3.02 & 3.26 & 2.97 & 3.13 & 2.93 & 3.03 & 2.83 & 2.95 & 3.15 & 3.04 & 3.04 \\
\hline $\mathrm{K}_{2} \mathrm{O}$ & 1.06 & 1.14 & 0.88 & 1.08 & 0.93 & 1.03 & 0.94 & 1.09 & 1.10 & 1.08 & 0.60 & 0.71 & 0.75 & 0.73 \\
\hline $\mathrm{Cr} 2 \mathrm{O}_{3}$ & 0.24 & 0.24 & 0.25 & 0.26 & 0.09 & 0.22 & 0.14 & 0.15 & 0.16 & 0.20 & 0.62 & 0.75 & 0.18 & 0.16 \\
\hline TOTAL & 98.40 & 98.97 & 98.67 & 98.40 & 98.35 & 98.70 & 98.91 & 98.65 & 98.90 & 97.65 & 98.81 & 98.36 & 99.34 & 98.72 \\
\hline Si & 5.720 & 5.700 & 5.870 & 5.740 & 5.900 & 5.740 & 5.790 & 5.720 & 5.690 & 5.682 & 5.640 & 5.850 & 5.576 & 5.400 \\
\hline Al & 2.530 & 2.590 & 2.490 & 2.660 & 2.430 & 2.470 & 2.480 & 2.520 & 2.540 & 2.584 & 2.470 & 2.420 & 2.481 & 2.470 \\
\hline $\mathrm{Ti}$ & 0.780 & 0.710 & 0.620 & 0.600 & 0.600 & 0.770 & 0.660 & 0.770 & 0.780 & 0.680 & 0.780 & 0.670 & 0.610 & 0.650 \\
\hline $\mathrm{Fe}$ & 1.090 & 1.260 & 1.210 & 1.320 & 1.360 & 1.190 & 1.350 & 1.210 & 1.160 & 1.359 & 1.110 & 0.820 & 1.313 & 1.480 \\
\hline Mn & 0.010 & 0.010 & 0.010 & 0.010 & 0.020 & 0.010 & 0.010 & 0.010 & 0.020 & 0.009 & 0.020 & 0.010 & 0.018 & 0.020 \\
\hline $\mathbf{M g}$ & 2.720 & 2.670 & 2.770 & 2.640 & 2.730 & 2.760 & 2720 & 2.680 & 2690 & 2.709 & 2.870 & 3.150 & 2.673 & 2.700 \\
\hline $\mathrm{Ca}$ & 1.800 & 1.770 & 1.710 & 1.760 & 1.680 & 1.780 & 1.750 & 1.780 & 1.810 & 1.765 & 1.880 & 1.720 & 1.723 & 1.740 \\
\hline $\mathrm{Na}$ & 0.820 & 0.890 & 0.910 & 0.860 & 0.930 & 0.840 & 0.890 & 0.830 & 0.860 & 0.815 & 0.830 & 0.880 & 0.845 & 0.860 \\
\hline K & 0.200 & 0.210 & 0.160 & 0.200 & 0.170 & 0.190 & 0.180 & 0.200 & 0.210 & 0.203 & 0.110 & 0.130 & 0.136 & 0.140 \\
\hline $\mathrm{C}_{\mathrm{r}}$ & 0.030 & 0.030 & 0.030 & 0.030 & 0.010 & 0.030 & 0.020 & 0.020 & 0.020 & 0.023 & 0.070 & 0.090 & 0.020 & 0.020 \\
\hline TOTAL & 15.700 & 15.840 & 15.780 & 15.820 & 15.830 & 15.780 & 15.850 & 15.740 & 15.780 & 15.829 & 15.780 & 15.740 & 15.395 & 15.480 \\
\hline Mg\# & 0.71 & 0.68 & 0.70 & 0.67 & 0.67 & 0.70 & 0.67 & 0.69 & 0.70 & 0.67 & 0.72 & 0.79 & 0.67 & 0.65 \\
\hline
\end{tabular}

\begin{tabular}{|c|c|c|c|c|c|c|c|c|c|c|c|c|c|c|}
\hline Sample & $90033 \mathrm{~J}$ & $90033 \mathrm{P}$ & $90033 P$ & $90033 \mathrm{P}$ & $90033 P$ & $90033 \mathrm{~S}$ & $90033 \mathrm{~S}$ & $90033 \mathrm{~S}$ & $90033 \mathrm{Q} 19$ & 90033Q1 & $90033 \mathrm{~S} 1$ & $90033 \mathrm{~S} 1$ & $90033 S 1$ & $90033 S 1$ \\
\hline Type & $\begin{array}{c}\text { Type C } \\
\text { core }\end{array}$ & $\begin{array}{c}\text { Type C } \\
\text { core }\end{array}$ & $\begin{array}{c}\text { Type C } \\
\text { core }\end{array}$ & $\begin{array}{c}\text { Type C } \\
\text { core } \\
\end{array}$ & $\begin{array}{c}\text { Type C } \\
\text { core } \\
\end{array}$ & $\begin{array}{c}\text { Type } L \\
\text { oxid } \\
\end{array}$ & $\begin{array}{c}\text { Type L } \\
\text { core }\end{array}$ & $\begin{array}{c}\text { Type L } \\
\text { core } \\
\end{array}$ & $\begin{array}{c}\text { Type } \mathbf{P} \\
\text { core }\end{array}$ & $\begin{array}{c}\text { Type } \mathbf{P} \\
\text { core }\end{array}$ & $\begin{array}{c}\text { Type P } \\
\text { core- }\end{array}$ & $\begin{array}{c}\text { Type } P \\
\text { rim } \\
\end{array}$ & $\begin{array}{c}\text { Type } \mathrm{P} \\
\text { core- }\end{array}$ & $\begin{array}{c}\text { Type P } \\
\text { rim } \\
\end{array}$ \\
\hline $\mathrm{SiO}_{2}$ & 38.94 & 40.23 & 40.45 & 41.00 & 39.94 & 38.85 & 38.36 & 37.39 & 38.29 & 40.72 & 39.95 & 37.47 & 39.76 & 37.44 \\
\hline $\mathrm{Al} 2 \mathrm{O} 3$ & 14.70 & 13.20 & 14.84 & 13.53 & 13.35 & 14.24 & 14.58 & 14.90 & 13.83 & 14.49 & 14.56 & 14.35 & 14.71 & 14.51 \\
\hline $\mathrm{TiO}_{2}$ & 5.66 & 7.65 & 6.55 & 4.35 & 4.39 & 5.75 & 6.46 & 6.49 & 8.09 & 4.43 & 6.13 & 8.62 & 6.10 & 9.08 \\
\hline $\mathrm{FeO}$ & 12.18 & 9.37 & 8.41 & 14.54 & 13.94 & 11.21 & 9.96 & 12.71 & 10.09 & 9.08 & 9.60 & 8.75 & 9.78 & 8.50 \\
\hline MnO & 0.15 & 0.15 & 0.11 & 0.18 & 0.24 & 0.15 & 0.09 & 0.07 & 0.08 & 0.09 & 0.09 & 0.08 & 0.13 & 0.01 \\
\hline $\mathrm{MgO}$ & 12.52 & 12.86 & 14.10 & 10.84 & 11.09 & 1237 & 12.32 & 12.03 & 12.57 & 14.28 & 13.32 & 12.61 & 13.44 & 12.80 \\
\hline $\mathrm{CaO}$ & 11.23 & 11.95 & 11.36 & 10.64 & 11.30 & 12.38 & 12.67 & 12.41 & 12.20 & 10.82 & 10.83 & 11.96 & 10.77 & 1239 \\
\hline $\mathrm{Na} 2 \mathrm{O}$ & 3.04 & 3.00 & 2.95 & 3.07 & 2.88 & 2.82 & 2.80 & 2.64 & 2.84 & 3.58 & 2.84 & 2.61 & 2.87 & 264 \\
\hline $\mathrm{K} 2 \mathrm{O}$ & 0.75 & 0.44 & 0.82 & 0.81 & 0.81 & 0.69 & 0.69 & 0.62 & 0.83 & 0.33 & 0.87 & 0.60 & 0.81 & 0.60 \\
\hline $\mathrm{Cr} 2 \mathrm{O} 3$ & 0.18 & 0.05 & 0.07 & 0.00 & 0.01 & 0.01 & 0.07 & 0.01 & 0.05 & 0.26 & 0.21 & 0.00 & 0.19 & 0.04 \\
\hline TOTAL & 99.35 & 98.90 & 99.66 & 98.96 & 97.95 & 98.46 & 98.00 & 99.27 & 98.86 & 98.07 & 98.41 & 97.06 & 98.56 & 98.01 \\
\hline Si & 5.580 & 5.840 & 5.790 & 6.050 & 5.970 & 5.731 & 5.662 & 5.390 & 5.616 & 5.929 & 5.813 & 5.553 & 5.780 & 54.500 \\
\hline Al & 2.480 & 2.260 & 2.500 & 2.350 & 2.350 & 2.476 & 2.537 & 2.530 & 2392 & 2.488 & 2.497 & 2.506 & 2.520 & 2.510 \\
\hline $\mathrm{Ti}$ & 0.610 & 0.830 & 0.710 & 0.480 & 0.490 & 0.638 & 0.717 & 0.700 & 0.892 & 0.485 & 0.671 & 0.961 & 0.670 & 1.000 \\
\hline $\mathrm{Fe}$ & 1.310 & 1.140 & 1.010 & 1.800 & 1.740 & 1.384 & 1.230 & 1.380 & 1.238 & 1.106 & 1.168 & 1.084 & 1.190 & 1.040 \\
\hline Mn & 0.020 & 0.020 & 0.010 & 0.020 & 0.030 & 0.019 & 0.011 & 0.010 & 0.010 & 0.011 & 0.011 & 0.011 & 0.020 & 0.000 \\
\hline $\mathrm{Mg}_{\mathrm{g}}$ & 2.670 & 2.780 & 3.010 & 2.390 & 2.470 & 2.719 & 2.712 & 2590 & 2.748 & 3.100 & 2.890 & 2.786 & 2.910 & 2.800 \\
\hline $\mathrm{Ca}$ & 1.720 & 1.860 & 1.740 & 1.680 & 1.810 & 1.956 & 2.004 & 1.920 & 1.918 & 1.689 & 1.689 & 1.899 & 1.680 & 1.950 \\
\hline $\mathrm{Na}$ & 0.850 & 0.840 & 0.820 & 0.880 & 0.840 & 0.808 & 0.800 & 0.740 & 0.808 & 1.011 & 0.800 & 0.749 & 0.810 & 0.750 \\
\hline K & 0.140 & 0.080 & 0.150 & 0.150 & 0.150 & 0.130 & 0.131 & 0.120 & 0.155 & 0.061 & 0.162 & 0.113 & 0.150 & 0.110 \\
\hline $\mathrm{Cr}$ & 0.020 & 0.010 & 0.010 & 0.000 & 0.000 & 0.001 & 0.008 & 0.000 & 0.0003 & 0.013 & 0.024 & 0.000 & 0.020 & 0.010 \\
\hline TOTAL & 15.400 & 15.660 & 15.750 & 15.800 & 15.850 & 15.862 & 15.812 & 15.380 & 15.780 & 15.893 & 15.725 & 15.662 & 15.750 & 64.670 \\
\hline $\mathrm{Mg}^{\#}$ & 0.67 & 0.71 & 0.75 & 0.57 & 0.59 & 0.66 & 0.69 & 0.65 & 0.69 & 0.74 & 0.71 & 0.72 & 0.71 & 0.73 \\
\hline
\end{tabular}




\section{A3.1 Mount Sidley xenolith mineral analyses: rhönite}

\begin{tabular}{|c|c|c|c|c|c|c|c|c|c|c|c|c|}
\hline $\begin{array}{l}\text { Sample } \\
\text { Type }\end{array}$ & $\begin{array}{c}90033 \mathrm{~A} \\
\text { Type P } \\
\text { core } \\
\end{array}$ & $\begin{array}{l}90033 \mathrm{~A} \\
\text { Type P } \\
\text { inc spx }\end{array}$ & $\begin{array}{c}90033 \mathrm{~A} \\
\text { Type P } \\
\text { melt }\end{array}$ & $\begin{array}{l}90033 C \\
\text { Type P } \\
\text { inc cpx }\end{array}$ & $\begin{array}{l}90033 \mathrm{C} \\
\text { Type P } \\
\text { kaerst }\end{array}$ & $\begin{array}{l}90033 \mathrm{C} \\
\text { Type P } \\
\text { kaerst }\end{array}$ & $\begin{array}{l}90033 \mathrm{C} \\
\text { Type P } \\
\text { kaerst }\end{array}$ & $\begin{array}{l}90033 G \\
\text { Type P } \\
\text { inc cpx }\end{array}$ & $\begin{array}{l}90033 G \\
\text { Type P } \\
\text { inc cpx }\end{array}$ & $\begin{array}{c}90033 G \\
\text { Type P } \\
\text { oxr }\end{array}$ & $\begin{array}{l}90033 \mathrm{H} \\
\text { Type P } \\
\text { kaerst }\end{array}$ & $\begin{array}{l}\text { 90033J } \\
\text { Type C } \\
\text { kaerst }\end{array}$ \\
\hline $\mathrm{SiO}_{2}$ & 26.34 & 25.67 & 23.73 & 28.02 & 28.37 & 28.89 & 28.49 & 26.27 & 26.26 & 23.96 & 24.78 & 24.84 \\
\hline $\mathrm{A} 12 \mathrm{O} 3$ & 16.93 & 17.25 & 17.62 & 14.61 & 15.64 & 15.93 & 14.86 & 16.83 & 16.41 & 17.87 & 17.08 & 15.97 \\
\hline $\mathrm{TiO}_{2}$ & 11.14 & 12.01 & 11.26 & 9.72 & 9.62 & 9.80 & 9.88 & 11.36 & 11.52 & 11.08 & 11.02 & 9.83 \\
\hline $\mathrm{FeO}$ & 18.10 & 16.16 & 20.08 & 16.89 & 16.58 & 16.89 & 17.18 & 18.70 & 20.04 & 21.69 & 18.63 & 22.97 \\
\hline Mno & 0.11 & 0.01 & 0.14 & 0.22 & 0.11 & 0.11 & 0.22 & 0.19 & 0.22 & 0.00 & 0.13 & 0.07 \\
\hline $\mathrm{MgO}$ & 14.33 & 15.03 & 13.00 & 15.90 & 15.01 & 15.29 & 16.17 & 13.88 & 13.04 & 12.17 & 13.36 & 13.33 \\
\hline $\mathrm{CaO}$ & 12.37 & 11.56 & 12.00 & 9.86 & 10.61 & 10.81 & 10.03 & 11.58 & 11.15 & 11.64 & 10.86 & 10.54 \\
\hline $\mathrm{Na} 2 \mathrm{O}$ & 0.76 & 1.16 & 0.89 & 253 & 2.23 & 223 & 2.53 & 1.18 & 1.35 & 0.93 & 1.81 & 1.68 \\
\hline $\mathrm{K} 2 \mathrm{O}$ & 0.00 & 0.02 & 0.01 & 0.01 & 0.02 & 0.02 & 0.01 & 0.02 & 0.01 & 0.00 & 0.02 & 0.02 \\
\hline $\mathrm{Cr} 2 \mathrm{O}_{3}$ & 0.07 & 0.06 & 0.27 & 0.58 & 0.34 & 0.34 & 0.58 & 0.03 & 0.03 & 0.11 & 1.44 & 0.53 \\
\hline TOTAL & 100.15 & 98.91 & 99.00 & 98.32 & 98.51 & 100.30 & 99.95 & 100.04 & 100.02 & 99.45 & 99.12 & 99.76 \\
\hline Si & 3.511 & 3.436 & 3.253 & 3.781 & 3.610 & 3.803 & 3.781 & 3.516 & 3.537 & 3.283 & 3.368 & 3.417 \\
\hline Al & 2661 & 2.723 & 2.848 & 2.325 & 2.347 & 2.470 & 2.325 & 2656 & 2606 & 2888 & 2.737 & 2.590 \\
\hline $\mathrm{Ti}$ & 1.117 & 1.209 & 1.161 & 0.986 & 0.922 & 0.970 & 0.986 & 1.143 & 1.166 & 1.140 & 1.126 & 1.017 \\
\hline $\mathrm{Fe}$ & 2.018 & 1.809 & 2.302 & 1.906 & 1.767 & 1.860 & 1.906 & 2.093 & 2.257 & 2.486 & 2.118 & 2.642 \\
\hline $\mathbf{M n}$ & 0.012 & 0.000 & 0.016 & 0.025 & 0.013 & 0.013 & 0.025 & 0.022 & 0.025 & 0.000 & 0.015 & 0.008 \\
\hline Mg & 2847 & 2.999 & 2.657 & 3.198 & 2.850 & 3.000 & 3.198 & 2768 & 2617 & 2.486 & 2.707 & 2.733 \\
\hline $\mathrm{Ca}$ & 1.768 & 1.659 & 1.764 & 1.426 & 1.447 & 1.523 & 1.426 & 1.662 & 1.610 & 1.710 & 1.582 & 1.554 \\
\hline $\mathrm{Na}$ & 0.196 & 0.301 & 0.237 & 0.662 & 0.551 & 0.580 & 0.662 & 0.306 & 0.352 & 0.247 & 0.478 & 0.448 \\
\hline K & 0.000 & 0.003 & 0.002 & 0.002 & 0.003 & 0.003 & 0.002 & 0.003 & 0.001 & 0.000 & 0.004 & 0.004 \\
\hline $\mathrm{Cr}_{\mathrm{r}}$ & 0.007 & 0.006 & 0.029 & 0.062 & 0.011 & 0.036 & 0.062 & 0.001 & 0.002 & 0.012 & 0.155 & 0.058 \\
\hline TOTAL & 14.137 & 14.145 & 14.269 & 14.373 & 13.521 & 14.258 & 14.373 & 14.170 & 14.173 & 14.252 & 14.290 & 14.471 \\
\hline $\mathrm{Ca}+\mathrm{Al}$ & 4.43 & 4.38 & 4.61 & 3.75 & 3.79 & 3.99 & 3.75 & 4.32 & 4.22 & 4.60 & 4.32 & 4.14 \\
\hline $\mathrm{Na}+\mathrm{Si}$ & 3.71 & 3.74 & 3.49 & 4.44 & 4.16 & 4.38 & 4.44 & 3.82 & 3.89 & 3.53 & 3.85 & 3.87 \\
\hline
\end{tabular}

\begin{tabular}{|c|c|c|c|c|c|c|c|c|c|c|c|c|c|}
\hline Sample & $90033 R$ & $90033 \mathrm{R}$ & $90033 \mathrm{R}$ & $90033 \mathrm{R}$ & $90033 \mathrm{~S}$ & $90033 \mathrm{~S}$ & 90033Q1 & $90033 \mathrm{Q} 1$ & $90033 Q 1$ & $90033 \mathrm{Q} 1$ & 190033Q1 & $90033 \mathrm{Q} 1$ & 9003351 \\
\hline Type & $\begin{array}{c}\text { Type C } \\
\text { core }\end{array}$ & $\begin{array}{c}\text { Type C } \\
\text { core }\end{array}$ & $\begin{array}{c}\text { Type C } \\
\text { core }\end{array}$ & $\begin{array}{c}\text { Type C } \\
\text { core }\end{array}$ & $\begin{array}{l}\text { Type L } \\
\text { kaerst }\end{array}$ & $\begin{array}{c}\text { Type L } \\
\text { melt }\end{array}$ & $\begin{array}{c}\text { Type P } \\
\text { core }\end{array}$ & $\begin{array}{c}\text { Type P } \\
\text { core }\end{array}$ & $\begin{array}{c}\text { Type } \mathbf{P} \\
\text { core } \\
\end{array}$ & $\begin{array}{c}\text { Type P } \\
\text { melt }\end{array}$ & $\begin{array}{c}\text { Type } \mathbf{P} \\
\text { core }\end{array}$ & $\begin{array}{c}\text { Type } \mathbf{P} \\
\text { core }\end{array}$ & $\begin{array}{c}\text { Type } \mathbf{P} \\
\text { core } \\
\end{array}$ \\
\hline $\mathrm{SiO}_{2}$ & 23.77 & 23.91 & 23.62 & 24.31 & 27.55 & 25.29 & 25.68 & 24.36 & 24.55 & 24.02 & 24.43 & 24.41 & 25.46 \\
\hline $\mathrm{Al}_{2} \mathrm{O}_{3}$ & 18.15 & 17.60 & 18.76 & 17.96 & 17.31 & 15.88 & 17.87 & 18.59 & 19.43 & 18.73 & 18.57 & 18.22 & 16.70 \\
\hline $\mathrm{TiO}_{2}$ & 12.53 & 12.53 & 12.90 & 11.97 & 9.12 & 9.93 & 10.78 & 11.68 & 11.58 & 12.13 & 12.64 & 12.41 & 12.56 \\
\hline $\mathrm{FeO}$ & 19.43 & 19.01 & 18.26 & 19.49 & 13.32 & 25.63 & 17.97 & 18.52 & 16.45 & 17.84 & 17.65 & 17.62 & 17.01 \\
\hline Mno & 0.16 & 0.10 & 0.03 & 0.17 & 0.24 & 0.28 & 0.10 & 0.11 & 0.11 & 0.07 & 0.11 & 0.08 & 0.10 \\
\hline $\mathrm{MgO}$ & 13.36 & 13.45 & 13.45 & 13.32 & 18.78 & 1240 & 14.14 & 12.85 & 14.08 & 13.51 & 13.68 & 13.68 & 14.24 \\
\hline $\mathrm{CaO}$ & 11.60 & 11.40 & 11.73 & 12.00 & 12.30 & 8.07 & 11.61 & 12.03 & 12.20 & 11.97 & 12.00 & 12.04 & 11.32 \\
\hline $\mathrm{Na} 2 \mathrm{O}$ & 0.89 & 1.42 & 1.02 & 0.95 & 1.34 & 2.33 & 1.14 & 0.99 & 0.99 & 0.99 & 1.12 & 1.05 & 1.43 \\
\hline $\mathrm{K} 2 \mathrm{O}$ & 0.01 & 0.04 & 0.00 & 0.01 & 0.03 & 0.11 & 0.00 & 0.00 & 0.00 & 0.01 & 0.00 & 0.00 & 0.01 \\
\hline $\mathrm{Cr} 2 \mathrm{O} 3$ & 0.00 & 0.11 & 0.01 & 0.14 & 0.00 & 0.08 & 0.05 & 0.12 & 0.39 & 0.32 & 0.03 & 0.29 & 0.16 \\
\hline TOTAL & 99.88 & 99.57 & 99.76 & 100.33 & 99.99 & 100.00 & 99.34 & 99.25 & 99.79 & 99.60 & 100.23 & 99.81 & 98.99 \\
\hline Si & 3.210 & 3.240 & 3.173 & 3.271 & 3.595 & 3.493 & 3.448 & 3.294 & 3.269 & 3.231 & 3.257 & 3.272 & 3.424 \\
\hline Al & 2890 & 2.813 & 2.970 & 2.848 & 2.664 & 2.586 & 2.829 & 2965 & 3.051 & 2.971 & 2.919 & 2.879 & 2.648 \\
\hline $\mathrm{Ti}$ & 1.273 & 1.27 & 1.303 & 1.211 & 0.895 & 1.031 & 1.088 & 1.188 & 1.160 & 1.221 & 1.267 & 1.251 & 1.271 \\
\hline $\mathrm{Fe}$ & 2195 & 2.155 & 2.051 & 2.193 & 1.454 & 2.960 & 2.018 & 2.095 & 1.832 & 2007 & 1.968 & 1.974 & 1.914 \\
\hline Mn & 0.018 & 0.011 & 0.003 & 0.019 & 0.027 & 0.033 & 0.011 & 0.013 & 0.012 & 0.008 & 0.013 & 0.009 & 0.012 \\
\hline $\mathrm{Mg}$ & 2.690 & 2.717 & 2.694 & 2.672 & 3.653 & 2.553 & 2.830 & 2.590 & 2795 & 2709 & 2.719 & 2.733 & 2.856 \\
\hline $\mathrm{Ca}$ & 1.680 & 1.656 & 1.688 & 1.730 & 1.721 & 1.194 & 1.671 & 1.744 & 1.741 & 1.726 & 1.714 & 1.729 & 1.632 \\
\hline $\mathrm{Na}$ & 0.233 & 0.373 & 0.265 & 0.248 & 0.338 & 0.624 & 0.297 & 0.260 & 0.256 & 0.258 & 0.291 & 0.273 & 0.373 \\
\hline K & 0.002 & 0.007 & 0.000 & 0.001 & 0.005 & 0.020 & 0.000 & 0.000 & 0.000 & 0.002 & 0.000 & 0.000 & 0.001 \\
\hline $\mathrm{Cr}$ & 0.000 & 0.012 & 0.015 & 0.015 & 0.000 & 0.009 & 0.005 & 0.013 & 0.041 & 0.034 & 0.003 & 0.031 & 0.017 \\
\hline TOTAL & 14.191 & 14.261 & 14.162 & 14.208 & 14.352 & 14.503 & 14.197 & 14.162 & 14.157 & 14.167 & 14.151 & 14.151 & 14.148 \\
\hline $\mathrm{Ca}+\mathrm{Al}$ & 4.57 & 4.47 & 4.66 & 4.58 & 4.39 & 3.78 & 4.50 & 4.71 & 4.79 & 4.70 & 4.63 & 4.61 & 4.28 \\
\hline $\mathrm{Na}+\mathrm{Si}$ & 3.44 & 3.61 & 3.44 & 3.52 & 3.93 & 4.12 & 3.75 & 3.55 & 3.53 & 3.49 & 3.55 & 3.55 & 3.80 \\
\hline
\end{tabular}




\section{A3.1 Mount Sidley xenolith mineral analyses: oxides}

\begin{tabular}{|c|c|c|c|c|c|c|c|c|c|c|c|c|c|c|}
\hline $\begin{array}{l}\text { Sample } \\
\text { Type }\end{array}$ & $\begin{array}{c}90029 X \\
\text { Type L } \\
\text { core }\end{array}$ & $\begin{array}{c}90029 X \\
\text { Type L } \\
\text { oxid }\end{array}$ & $\begin{array}{c}90029 X \\
\text { Type L } \\
\text { oxid- }\end{array}$ & $\begin{array}{c}90029 \mathrm{~B} 1 \\
\text { Type L } \\
\text { core }\end{array}$ & $\begin{array}{c}90029 B 1 \\
\text { Type L } \\
\text { core }\end{array}$ & $\begin{array}{c}\text { 90029B1 } \\
\text { Type L } \\
\text { core }\end{array}$ & $\begin{array}{c}\text { 90029B1 } \\
\text { Type L } \\
\text { oxid- }\end{array}$ & $\begin{array}{c}\text { 90029B19 } \\
\text { Type L } \\
\text { oxid }\end{array}$ & $\begin{array}{c}\text { 90029D1 } \\
\text { Type L } \\
\text { core }\end{array}$ & $\begin{array}{c}\text { 90029D1 } \\
\text { Type L } \\
\text { oxid }\end{array}$ & $\begin{array}{c}90033 \mathrm{~A} \\
\text { Type P } \\
\text { core }\end{array}$ & $\begin{array}{c}90033 \mathrm{~A} \\
\text { Type P } \\
\text { core }\end{array}$ & $\begin{array}{c}\text { 90033A } \\
\text { Type P } \\
\text { core }\end{array}$ & $\begin{array}{c}90033 \mathrm{~A} \\
\text { Type P } \\
\text { oxid }\end{array}$ \\
\hline $\mathrm{SiO}_{2}$ & 0.09 & 0.00 & 0.00 & 0.06 & 0.10 & 0.06 & 0.01 & 0.04 & 0.11 & 0.07 & 0.00 & 0.17 & 0.11 & 0.29 \\
\hline $\mathrm{Al}_{2} \mathrm{O}_{3}$ & 0.84 & 1.75 & 3.02 & 0.77 & 3.31 & 3.24 & 0.45 & 0.26 & 10.69 & 0.52 & 60.23 & 58.99 & 59.34 & 1.52 \\
\hline $\mathrm{TiO}_{2}$ & 29.08 & 50.67 & 8.96 & 47.76 & 8.14 & 12.53 & 0.52 & 50.01 & 1.84 & 27.67 & 0.58 & 0.59 & 0.45 & 1279 \\
\hline $\mathrm{Fe} 2 \mathrm{O} 3$ & 13.13 & 5.24 & 49.95 & 10.24 & 50.93 & 38.13 & 61.37 & 7.20 & 53.62 & 37.59 & 4.25 & 4.76 & 4.64 & 4298 \\
\hline $\mathrm{FeO}$ & 46.63 & 36.14 & 33.73 & 3241 & 27.20 & 39.05 & 27.97 & 33.50 & 26.82 & 13.93 & 20.47 & 2057 & 19.60 & 38.53 \\
\hline MnO & 0.32 & 0.35 & 0.52 & 0.35 & 1.16 & 0.17 & 0.25 & 0.42 & 0.84 & 0.69 & 0.12 & 0.18 & 0.14 & 0.26 \\
\hline $\mathrm{MgO}$ & 6.63 & 5.06 & 3.51 & 5.72 & 6.19 & 1.61 & 0.36 & 6.22 & 4.24 & 5.78 & 14.07 & 13.83 & 14.28 & 2.49 \\
\hline $\mathrm{CaO}$ & 0.23 & 0.04 & 0.00 & 0.05 & 0.56 & 0.02 & 0.02 & 0.01 & 0.00 & 0.03 & 0.02 & 0.01 & 0.01 & 0.23 \\
\hline $\mathrm{Cr} 2 \mathrm{O}_{3}$ & 0.06 & 0.11 & 0.00 & 0.00 & 0.00 & 0.00 & 0.02 & 0.03 & 0.00 & 0.04 & 0.60 & 0.48 & 0.47 & 0.03 \\
\hline TOTAL & 97.00 & 99.35 & 99.69 & 97.35 & 97.59 & 94.80 & 90.98 & 97.69 & 98.16 & 86.32 & 100.34 & 99.57 & 99.05 & 99.12 \\
\hline $\mathbf{S i}$ & 0.003 & 0.000 & 0.000 & 0.001 & 0.004 & 0.002 & 0.000 & 0.000 & 0.003 & 0.003 & 0.000 & 0.005 & 0.003 & 0.012 \\
\hline Al & 0.036 & 0.050 & 0.130 & 0.023 & 0.143 & 0.148 & 0.021 & 0.008 & 0.460 & 0.02 & 1.880 & 1.861 & 1.873 & 0.078 \\
\hline $\mathrm{Ti}$ & 0.797 & 0.926 & 0.240 & 0.892 & 0.224 & 0.366 & 0.015 & 0.930 & 0.048 & 0.882 & 0.012 & 0.012 & 0.009 & 0.354 \\
\hline FellI & 0.361 & 0.096 & 1.371 & 0.191 & 1.402 & 1.115 & 1.944 & 0.140 & 1.443 & 1.200 & 0.085 & 0.096 & 0.093 & 1.190 \\
\hline Fell & 1.421 & 0.730 & 1.029 & 0.673 & 0.832 & 1.269 & 0.984 & 0.690 & 0.801 & 0.495 & 0.453 & 0.460 & 0.439 & 1.190 \\
\hline Mn & 0.010 & 0.008 & 0.018 & 0.007 & 0.036 & 0.006 & 0.009 & 0.008 & 0.024 & 0.024 & 0.003 & 0.004 & 0.003 & 0.009 \\
\hline $\mathbf{M g}$ & 0.360 & 0.184 & 0.210 & 0.212 & 0.337 & 0.093 & 0.024 & 0.228 & 0.220 & 0.366 & 0.555 & 0.552 & 0.570 & 0.150 \\
\hline $\mathrm{Ca}$ & 0.009 & 0.002 & 0.000 & 0.001 & 0.022 & 0.001 & 0.000 & 0.000 & 0.000 & 0.000 & 0.001 & 0.000 & 0.000 & 0.012 \\
\hline $\mathrm{Cr}$ & 0.002 & 0.002 & 0.000 & 0.000 & 0.000 & 0.000 & 0.000 & 0.000 & 0.000 & 0.000 & 0.013 & 0.010 & 0.010 & 0.000 \\
\hline TOTAL & 2.999 & 1.998 & 2.998 & 2000 & 3.000 & 3.000 & 2997 & 2004 & 2999 & 2.997 & 3.002 & 3.000 & 3.000 & 2.995 \\
\hline
\end{tabular}

\begin{tabular}{|c|c|c|c|c|c|c|c|c|c|c|c|c|c|c|}
\hline Sample & $90033 \mathrm{~S}$ & $90033 \mathrm{~S}$ & $90033 S$ & $90033 \mathrm{~S}$ & $90033 \mathrm{~S}$ & $90033 \mathrm{~S}$ & $90033 S$ & $90033 \mathrm{U}$ & $90033 \mathrm{U}$ & $90033 x$ & $90033 \mathrm{~F} 1$ & $90033 \mathrm{~F} 1$ & $90033 \mathrm{~F} 1$ & $90033 F 1$ \\
\hline Type & $\begin{array}{c}\text { Type L. } \\
\text { core }\end{array}$ & $\begin{array}{c}\text { Type L } \\
\text { oxid }\end{array}$ & $\begin{array}{c}\text { Type L } \\
\text { oxid }\end{array}$ & $\begin{array}{c}\text { Type L } \\
\text { oxid }\end{array}$ & $\begin{array}{c}\text { Type L } \\
\text { oxid }\end{array}$ & $\begin{array}{c}\text { Type L } \\
\text { oxid }\end{array}$ & $\begin{array}{c}\text { Type L } \\
\text { oxid- }\end{array}$ & $\begin{array}{c}\text { Type L } \\
\text { oxid } \\
\end{array}$ & $\begin{array}{c}\text { Type L } \\
\text { oxid }\end{array}$ & $\begin{array}{c}\text { Type } \mathrm{L} \\
\text { core } \\
\end{array}$ & $\begin{array}{l}\text { Type L } \\
\text { oxid } r\end{array}$ & $\begin{array}{l}\text { Type L } \\
\text { oxid r }\end{array}$ & $\begin{array}{c}\text { Type L } \\
\text { oxid- }\end{array}$ & $\begin{array}{c}\text { Type L } \\
\text { oxid } \\
\end{array}$ \\
\hline $\mathrm{SiO}_{2}$ & 0.43 & 0.43 & 0.35 & 0.09 & 0.32 & 0.14 & 0.02 & 0.07 & 0.13 & 0.13 & 0.06 & 0.03 & 0.00 & 0.10 \\
\hline $\mathrm{A} / 2 \mathrm{O} 3$ & 2.16 & 2.16 & 246 & 1.28 & 2.81 & 5.91 & 2.16 & 1.26 & 0.68 & 4.76 & 1.28 & 4.89 & 0.32 & 5.56 \\
\hline $\mathrm{TiO}_{2}$ & 14.37 & 14.37 & 9.72 & 43.70 & 39.97 & 7.73 & 7.72 & 31.29 & 0.24 & 27.34 & 1.37 & 1.08 & 47.55 & 7.30 \\
\hline $\mathrm{Fe} 2 \mathrm{O} 3$ & 35.98 & 35.98 & 43.55 & 21.07 & 2260 & 52.56 & 50.05 & 41.45 & 61.09 & 10.04 & 61.58 & 64.28 & 12.24 & 48.14 \\
\hline $\mathrm{FeO}$ & 41.85 & 41.85 & 31.95 & 31.38 & 28.19 & 32.30 & 31.36 & 22.27 & 28.58 & 51.56 & 30.30 & 16.79 & 3262 & 30.58 \\
\hline Mno & 0.25 & 0.25 & 0.38 & 0.22 & 0.20 & 0.44 & 0.46 & 0.44 & 0.00 & 0.53 & 0.05 & 3.16 & 0.49 & 0.45 \\
\hline $\mathrm{MgO}$ & 1.25 & 1.25 & 3.98 & 4.37 & 4.26 & 5.07 & 3.46 & 3.06 & 0.05 & 2.92 & 0.48 & 8.02 & 5.39 & 4.44 \\
\hline $\mathrm{CaO}$ & 0.20 & 0.20 & 0.18 & 0.01 & 0.27 & 0.23 & 0.05 & 0.04 & 0.03 & 0.04 & 0.03 & 0.08 & 0.03 & 0.05 \\
\hline $\mathrm{Cr}_{2} \mathrm{O}_{3}$ & 0.01 & 0.01 & 0.02 & 0.00 & 0.08 & 0.05 & 0.18 & 0.05 & 0.00 & 0.00 & 0.06 & 0.00 & 0.02 & 0.14 \\
\hline TOTAL & 96.49 & 96.49 & 9260 & 102.11 & 98.70 & 104.43 & 95.45 & 99.94 & 90.79 & 97.30 & 95.20 & 98.33 & 98.65 & 96.75 \\
\hline $\mathbf{S i}$ & 0.017 & 0.018 & 0.015 & 0.002 & 0.008 & 0.006 & 0.000 & 0.003 & 0.006 & 0.050 & 0.003 & 0.000 & 0.000 & 0.003 \\
\hline Al & 0.098 & 0.099 & 0.114 & 0.036 & 0.082 & 0.237 & 0.090 & 0.057 & 0.033 & 0.206 & 0.060 & 0.207 & 0.010 & 0.243 \\
\hline $\mathrm{Ti}$ & 0.415 & 0.414 & 0.288 & 0.790 & 0.740 & 0.198 & 0.210 & 0.882 & 0.009 & 0.740 & 0.042 & 0.036 & 0.882 & 0.204 \\
\hline FellI & 1.039 & 1.038 & 1.284 & 0.380 & 0.420 & 1.353 & 1.460 & 1.170 & 1.941 & 0.270 & 1.851 & 1.720 & 0.228 & 1.341 \\
\hline Fell & 1.343 & 1.344 & 1.047 & 0.630 & 0.582 & 0.924 & 1.020 & 0.699 & 1.008 & 1.560 & 1.011 & 1.512 & 0.672 & 0.945 \\
\hline Mn & 0.008 & 0.009 & 0.012 & 0.004 & 0.004 & 0.012 & 0.015 & 0.015 & 0.000 & 0.016 & 0.000 & 0.288 & 0.010 & 0.015 \\
\hline $\mathrm{Mg}$ & 0.072 & 0.072 & 0.234 & 0.156 & 0.156 & 0.258 & 0.200 & 0.171 & 0.003 & 0.160 & 0.030 & 0.230 & 0.198 & 0.246 \\
\hline Ca & 0.008 & 0.009 & 0.003 & 0.000 & 0.008 & 0.010 & 0.001 & 0.001 & 0.000 & 0.000 & 0.000 & 0.003 & 0.000 & 0.003 \\
\hline $\mathrm{Cr}$ & 0.000 & 0.000 & 0.000 & 0.000 & 0.001 & 0.000 & 0.002 & 0.000 & 0.000 & 0.000 & 0.001 & 0.000 & 0.000 & 0.001 \\
\hline TOTAL & 3.000 & 3.003 & 2.997 & 1.998 & 2.001 & 2.998 & 2998 & 2998 & 3.000 & 3.002 & 3.001 & 3.996 & 2.000 & 3.001 \\
\hline
\end{tabular}




\begin{tabular}{|c|c|c|c|c|c|c|c|c|c|c|c|c|c|c|}
\hline Sample & $90033 \mathrm{~A}$ & $90033 \mathrm{C}$ & $90033 \mathrm{C}$ & $90033 \mathrm{C}$ & $90033 \mathrm{C}$ & $90033 \mathrm{G}$ & $90033 \mathrm{G}$ & $90033 \mathrm{G}$ & $90033 \mathrm{G}$ & $90033 \mathrm{~K}$ & $90033 \mathrm{~K}$ & $90033 \mathrm{~K}$ & $90033 \mathrm{~K}$ & $90033 \mathrm{~K}$ \\
\hline Type & $\begin{array}{c}\text { Type } \mathrm{P} \\
\text { oxid }\end{array}$ & $\begin{array}{c}\text { Type } P \\
\text { core } \\
\end{array}$ & $\begin{array}{c}\text { Type } \mathbf{P} \\
\text { core }\end{array}$ & $\begin{array}{c}\text { Type } \mathbf{P} \\
\text { core } \\
\end{array}$ & $\begin{array}{c}\text { Type } \mathbf{P} \\
\text { core } \\
\end{array}$ & $\begin{array}{c}\text { Type P } \\
\text { oxid- }\end{array}$ & $\begin{array}{l}\text { Type P } \\
\text { oxid } r \\
\end{array}$ & $\begin{array}{c}\text { Type P } \\
\text { oxid } \\
\end{array}$ & $\begin{array}{c}\text { Type P } \\
\text { oxid }\end{array}$ & $\begin{array}{c}\text { Type } M \\
\text { core } \\
\end{array}$ & $\begin{array}{c}\text { Type M } \\
\text { core }\end{array}$ & $\begin{array}{c}\text { Type M } \\
\text { core } \\
\end{array}$ & $\begin{array}{c}\text { Type M } \\
\text { core } \\
\end{array}$ & $\begin{array}{l}\text { Type } \mathrm{M} \\
\text { oxid }\end{array}$ \\
\hline $\mathrm{SiO}_{2}$ & 0.11 & 0.05 & 0.12 & 0.14 & 0.13 & 0.09 & 0.09 & 0.22 & 0.12 & 0.23 & 0.19 & 0.00 & 0.17 & 0.05 \\
\hline $\mathrm{A} 12 \mathrm{O} 3$ & 0.19 & 54.24 & 52.81 & 55.76 & 55.79 & 55.26 & 8.91 & 55.83 & 7.47 & 32.87 & 50.76 & 53.14 & 52.60 & 0.35 \\
\hline $\mathrm{TiO}_{2}$ & 46.93 & 0.97 & 4.33 & 0.85 & 1.45 & 1.29 & 20.34 & 1.22 & 35.58 & 0.21 & 0.92 & 1.09 & 1.11 & 37.66 \\
\hline $\mathrm{Fe}_{2} \mathrm{O} 3$ & $13.86^{\circ}$ & 5.76 & 0.14 & 4.73 & 6.21 & 8.33 & 55.57 & 6.72 & 27.86 & 25.95 & 4.97 & 4.10 & 3.88 & 20,11 \\
\hline $\mathrm{FeO}$ & 34.00 & 21.28 & 21.33 & 21.94 & 17.75 & 23.31 & 8.47 & 23.82 & 19.61 & 20.62 & 16.48 & 17.10 & 18.37 & 23.26 \\
\hline $\mathrm{MnO}$ & 0.41 & 0.19 & 0.04 & 0.23 & 0.18 & 0.22 & 0.28 & 0.11 & 0.60 & 0.08 & 0.12 & 0.15 & 0.08 & 0.58 \\
\hline $\mathrm{MgO}$ & 4.15 & 13.05 & 14.08 & 12.50 & 15.63 & 1218 & 5.34 & 11.95 & 6.56 & 11.06 & 15.47 & 15.93 & 15.32 & 5.65 \\
\hline $\mathrm{CaO}$ & 0.08 & 0.02 & 0.09 & 0.02 & 0.08 & 0.00 & 0.10 & 0.01 & 0.18 & 0.01 & 0.00 & 0.00 & 0.03 & 0.01 \\
\hline $\mathrm{Cr} 2 \mathrm{O}_{3}$ & 0.00 & 4.38 & 257 & 250 & 1.80 & 0.22 & 0.00 & 0.30 & 0.21 & 9.84 & 8.57 & 9.27 & 9.67 & 0.00 \\
\hline TOTAL & 99.74 & 99.93 & 95.51 & 98.66 & 99.01 & 100.89 & 99.08 & 100.17 & 98.19 & 100.87 & 97.48 & 100.78 & 101.22 & 87.67 \\
\hline $\mathrm{Si}$ & 0.002 & 0.000 & 0.001 & 0.004 & 0.003 & 0.003 & 0.003 & 0.006 & 0.002 & 0.007 & 0.005 & 0.000 & 0.005 & 0.002 \\
\hline Al & 0.006 & 1.746 & 1.750 & 1.805 & 1.770 & 1.773 & 0.378 & 1.790 & 0.210 & 1.160 & 1.660 & 1.677 & 1.663 & 0.012 \\
\hline $\mathbf{T i}$ & 0.866 & 0.021 & 0.092 & 0.018 & 0.029 & 0.027 & 0.552 & 0.020 & 0.640 & 0.005 & 0.019 & 0.022 & 0.022 & 0.780 \\
\hline FelII & 0.256 & 0.117 & 0.003 & 0.098 & 0.126 & 0.171 & 1.510 & 0.150 & 0.502 & 0.584 & 0.104 & 0.083 & 0.078 & 0.420 \\
\hline FeII & 0.698 & 0.486 & 0.501 & 0.504 & 0.400 & 0.531 & 0.255 & 0.543 & 0.392 & 0.516 & 0.382 & 0.383 & 0.412 & 0.540 \\
\hline Mn & 0.004 & 0.003 & 0.001 & 0.005 & 0.004 & 0.006 & 0.009 & 0.003 & 0.012 & 0.002 & 0.003 & 0.003 & 0.002 & 0.014 \\
\hline $\mathrm{Mg}_{\mathrm{g}}$ & 0.170 & 0.531 & 0.590 & 0.512 & 0.627 & 0.490 & 0.290 & 0.486 & 0.234 & 0.493 & 0.639 & 0.636 & 0.612 & 0.232 \\
\hline $\mathrm{Ca}$ & 0.002 & 0.000 & 0.003 & 0.001 & 0.002 & 0.000 & 0.001 & 0.000 & 0.006 & 0.000 & 0.000 & 0.000 & 0.001 & 0.000 \\
\hline $\mathrm{Cr}_{\mathrm{r}}$ & 0.000 & 0.093 & 0.057 & 0.054 & 0.038 & 0.000 & 0.000 & 0.002 & 0.004 & 0.233 & 0.188 & 0.196 & 0.205 & 0.000 \\
\hline OTAL & 2.004 & 2.997 & 2.998 & 3.001 & 2.999 & 3.001 & 2.998 & 3.000 & 2002 & 3.000 & 3.000 & 3.000 & 3.000 & 2.000 \\
\hline
\end{tabular}

\begin{tabular}{|c|c|c|c|c|c|c|c|c|c|c|c|c|c|c|}
\hline Sample & $90033 \mathrm{~F} 1$ & $90033 \mathrm{~F} 1$ & $90033 \mathrm{G} 1$ & $90033 \mathrm{Gl}$ & $190033 \mathrm{G}_{1}$ & $90033 \mathrm{G} 15$ & $190033 \mathrm{G} 1$ & $190033 \mathrm{G} 1$ & 190033P1 & $190033 \mathrm{P} 1$ & $90033 \mathrm{Q} 1$ & $90033 \mathrm{Q} 1$ & 9003301 & $90033 \mathrm{Q} 1$ \\
\hline Type & $\begin{array}{c}\text { Type L } \\
\text { oxid- }\end{array}$ & $\begin{array}{c}\text { Type L } \\
\text { oxid } r\end{array}$ & $\begin{array}{c}\text { Type L } \\
\text { oxid }\end{array}$ & $\begin{array}{c}\text { Type L } \\
\text { oxid }\end{array}$ & $\begin{array}{c}\text { Type L } \\
\text { oxid }\end{array}$ & $\begin{array}{c}\text { Type L } \\
\text { oxid } \\
\end{array}$ & $\begin{array}{c}\text { Type L } \\
\text { oxid } \\
\end{array}$ & $\begin{array}{c}\text { Type L } \\
\text { oxid } \\
\end{array}$ & $\begin{array}{c}\text { Type C } \\
\text { oxid- }\end{array}$ & $\begin{array}{c}\text { Type C } \\
\text { oxid } \\
\end{array}$ & $\begin{array}{c}\text { Type } \mathbf{P} \\
\text { core } \\
\end{array}$ & $\begin{array}{c}\text { Type } \mathbf{P} \\
\text { core }\end{array}$ & $\begin{array}{c}\text { Type } P \\
\text { core }\end{array}$ & $\begin{array}{c}\text { Type } \mathbf{P} \\
\text { core } \\
\end{array}$ \\
\hline $\mathrm{SiO}_{2}$ & 0.08 & 0.28 & 0.58 & 1.72 & 0.65 & 0.21 & 0.11 & 0.10 & 0.04 & 0.06 & 0.13 & 0.09 & 0.10 & 0.07 \\
\hline $\mathrm{Al} 2 \mathrm{O} 3$ & 0.24 & 2.22 & 0.46 & 8.11 & 213 & 3.67 & 1.72 & 0.40 & 0.70 & 1.61 & 60.17 & 60.64 & 58.76 & 59.89 \\
\hline $\mathrm{TiO}_{2}$ & 52.39 & 0.75 & 37.32 & 40.14 & 14.62 & 4.98 & 15.31 & 48.87 & 18.97 & 48.65 & 0.23 & 0.24 & 0.41 & 0.45 \\
\hline $\mathrm{Fe} 2 \mathrm{O} 3$ & 0.89 & 62.56 & 33.42 & 18.54 & 36.24 & 54.16 & 35.07 & 7.76 & 34.08 & 10.08 & 4.63 & 3.71 & 3.65 & 3.60 \\
\hline $\mathrm{FeO}$ & 38.18 & 26.16 & 5.32 & 20.25 & 39.65 & 32.04 & 41.05 & 36.85 & 40.40 & 33.68 & 14.96 & 16.67 & 17.36 & 16.85 \\
\hline $\mathrm{MnO}$ & 0.50 & 1.22 & 0.26 & 0.41 & 0.49 & 0.17 & 0.38 & 0.46 & 0.40 & 0.18 & 0.13 & 0.15 & 0.06 & 0.06 \\
\hline $\mathrm{MgO}$ & 4.74 & 2.41 & 15.98 & 8.60 & 3.10 & 2.18 & 1.91 & 3.79 & 4.90 & 5.28 & 17.31 & 16.26 & 15.58 & 16.21 \\
\hline $\mathrm{CaO}$ & 0.01 & 0.03 & 0.15 & 1.03 & 0.00 & 0.26 & 0.00 & 0.00 & 0.03 & 0.01 & 0.00 & 0.00 & 0.00 & 0.02 \\
\hline $\mathrm{Cr} 2 \mathrm{O}_{3}$ & 0.00 & 0.00 & 0.03 & 0.07 & 0.03 & 0.04 & 0.11 & 0.09 & 0.13 & 0.09 & 1.52 & 1.57 & 244 & 214 \\
\hline TOTAL & 96.99 & 95.63 & 93.53 & 98.87 & 96.91 & 97.72 & 95.66 & 98.32 & 99.66 & 99.63 & 99.08 & 99.33 & 98.37 & 99.28 \\
\hline Si & 0.000 & 0.012 & 0.014 & 0.042 & 0.024 & 0.009 & 0.003 & 0.002 & 0.003 & 0.002 & 0.003 & 0.002 & 0.003 & 0.002 \\
\hline Al & 0.008 & 0.102 & 0.014 & 0.230 & 0.096 & 0.170 & 0.078 & 0.012 & 0.033 & 0.048 & 1.861 & 1.880 & 1.853 & 1.862 \\
\hline $\mathrm{Ti}$ & 0.988 & 0.021 & 0.676 & 0.686 & 0.414 & 0.141 & 0.444 & 0.920 & 0.516 & 0.882 & 0.005 & 0.005 & 0.008 & 0.009 \\
\hline FeIII & 0.016 & 1.833 & 0.606 & 0.316 & 1.026 & 0.000 & 1.020 & 0.146 & 0.927 & 0.184 & 0.092 & 0.073 & 0.074 & 0.072 \\
\hline Fell & 0.800 & 0.852 & 0.108 & 0.384 & 1.248 & 1.536 & 1.326 & 0.770 & 1.224 & 0.680 & 0.328 & 0.367 & 0.388 & 0.372 \\
\hline Mn & 0.010 & 0.039 & 0.006 & 0.008 & 0.015 & 1.011 & 0.012 & 0.010 & 0.012 & 0.004 & 0.003 & 0.003 & 0.001 & 0.001 \\
\hline $\mathbf{M g}$ & 0.178 & 0.141 & 0.574 & 0.308 & 0.174 & 0.006 & 0.111 & 0.140 & 0.282 & 0.200 & 0.677 & 0.637 & 0.621 & 0.637 \\
\hline $\mathrm{Ca}$ & 0.000 & 0.000 & 0.004 & 0.026 & 0.000 & 0.123 & 0.000 & 0.000 & 0.000 & 0.000 & 0.000 & 0.000 & 0.000 & 0.001 \\
\hline $\mathrm{Cr}_{\mathrm{r}}$ & 0.000 & 0.000 & 0.000 & 0.000 & 0.000 & 0.000 & 0.001 & 0.001 & 0.003 & 0.001 & 0.032 & 0.033 & 0.052 & 0.045 \\
\hline TOTAL & 2000 & 3.000 & 2.002 & 2.000 & 2.997 & 2.996 & 2.995 & 2001 & 3.000 & 2001 & 3.001 & 3.000 & 3.000 & 3.001 \\
\hline
\end{tabular}




\begin{tabular}{|c|c|c|c|c|c|c|c|c|c|c|c|c|c|c|}
\hline $\begin{array}{l}\text { ample } \\
\text { ype }\end{array}$ & $\begin{array}{c}90033 \mathrm{~K} \\
\text { Type M } \\
\text { oxid }\end{array}$ & $\begin{array}{c}90033 \mathrm{~K} \\
\text { Type } \mathrm{M} \\
\text { oxid r }\end{array}$ & $\begin{array}{l}900330 \\
\text { Type L } \\
\text { oxid r }\end{array}$ & $\begin{array}{c}900330 \\
\begin{array}{c}\text { Type L } \\
\text { oxid }\end{array} \\
\end{array}$ & $\begin{array}{l}900330 \\
\text { Type L } \\
\text { oxid. }\end{array}$ & $\begin{array}{c}900330 \\
\text { Type L } \\
\text { oxid } \\
\end{array}$ & $\begin{array}{c}900030 \\
\text { Type L } \\
\text { oxid- }\end{array}$ & $\begin{array}{c}900330 \\
\text { Type L } \\
\text { oxid } \\
\end{array}$ & $\begin{array}{c}90033 \mathrm{P} \\
\text { Type C } \\
\text { oxid } \\
\end{array}$ & $\begin{array}{c}90033 \mathrm{R} \\
\text { Type C } \\
\text { core } \\
\end{array}$ & $\begin{array}{c}90033 \mathrm{R} \\
\text { Type C } \\
\text { oxid } \\
\end{array}$ & $\begin{array}{c}90033 \mathrm{R} \\
\text { Type C } \\
\text { oxid }\end{array}$ & $\begin{array}{c}90033 R \\
\text { Type C } \\
\text { oxid }\end{array}$ & $\begin{array}{c}\text { 90033R } \\
\text { Type C } \\
\text { oxid } \\
\end{array}$ \\
\hline $\mathrm{OO} 2$ & & & & & & & & & & 0.04 & 0.13 & 10 & 06 & 6.77 \\
\hline & & & & & & & & & 2.89 & 56.84 & 1.45 & 8.70 & 0.24 & 7.59 \\
\hline & & & & & & & & & & 0.69 & 19.48 & 36.17 & 51.16 & 15.16 \\
\hline e2 & & & 93 & & 49. & 12.95 & & & 43.24 & 0.20 & 23.99 & 31.54 & 7.94 & 13.89 \\
\hline $\mathrm{eO}$ & & & & & 34. & 34 & & 41.59 & 34.07 & 22.37 & 44.28 & 14.79 & 34.30 & 41.07 \\
\hline In & & & & & & & & & 08 & 0.0 & & & & 0.40 \\
\hline & & & & & & & & & 1.73 & 12.39 & 1.49 & 9.61 & 6.32 & 6.71 \\
\hline a & & & & & & & 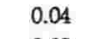 & & 0.7 & 0.00 & 0.1 & 3 & 10 & 1.33 \\
\hline 12 & & & & & & 0 & 0.02 & .24 & 01 & 0.69 & 0.19 & 33 & .07 & 0.17 \\
\hline OTAL & & 9 & & 9220 & 96.8 & 99.94 & 98.42 & 98.15 & 90.99 & 99.37 & 1.2 & 8 & 100.56 & 93.10 \\
\hline & & & & & & & & & & 0.0 & & 002 & 12 & 0.240 \\
\hline & & & & & & & & & 0.138 & 26 & 69 & 0 & 0.006 & 0.320 \\
\hline & & & & & & & & & & 0.0 & 1 & 2 & 0.920 & 0.408 \\
\hline FeIII & & & & & & 238 & 0.300 & & 1.305 & 0.128 & & & 0.146 & 0.375 \\
\hline eII & & & & & & & & & & 0 & & 78 & 88 & 1.230 \\
\hline & & & & & & & & & & 2 & & 6 & 08 & 112 \\
\hline & & & & & & & & & $\infty 0$ & .503 & & 320 & 26 & 60 \\
\hline 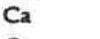 & & & & & & & & & & & & 10 & 0.001 & 1.050 \\
\hline$C_{-}$ & 210 & 0 & 0. & & 0.001 & 0.000 & 0.000 & 0.002 & 0.000 & 0.015 & 0.006 & 0.003 & 0.001 & 0.002 \\
\hline & & & 02 & 3.000 & 2.999 & 1.999 & 2002 & 2997 & 3.001 & 2.999 & 2.997 & 1.995 & 1.998 & 2.997 \\
\hline
\end{tabular}

\begin{tabular}{|c|c|c|c|c|c|c|c|c|c|c|c|c|c|c|}
\hline ample & $90033 \varnothing$ & 35 & 336 & 1330 & 9003351 & $90033 \mathrm{~S} 1$ & $90033 \mathrm{~S} 1$ & $90033 \mathrm{~S} 1$ & $90033 \mathrm{~S} 1$ & $90033 \mathrm{~S} 1$ & $90039 \mathrm{C}$ & $90039 \mathrm{G}$ & $90039 \mathrm{M}$ & $90039 \mathrm{M}$ \\
\hline Type & $\begin{array}{c}\text { Type P } \\
\text { core }\end{array}$ & $\begin{array}{c}\text { Type P } \\
\text { core }\end{array}$ & $\begin{array}{c}\text { Type P } \\
\text { oxid } \\
\end{array}$ & $\begin{array}{c}\text { Type P } \\
\text { oxid }\end{array}$ & $\begin{array}{c}\text { Type P } \\
\text { core }\end{array}$ & $\begin{array}{c}\text { Type P } \\
\text { core }\end{array}$ & $\begin{array}{c}\text { Type P } \\
\text { core }\end{array}$ & $\begin{array}{c}\text { Type P } \\
\text { core }\end{array}$ & $\begin{array}{c}\text { Type } \mathbf{P} \\
\text { core } \\
\end{array}$ & $\begin{array}{c}\text { Type P } \\
\text { core }\end{array}$ & $\begin{array}{c}\text { Type L } \\
\text { core }\end{array}$ & $\begin{array}{c}\text { Type L } \\
\text { oxid- } \\
\end{array}$ & $\begin{array}{c}\text { Type L } \\
\text { oxid }\end{array}$ & $\begin{array}{c}\text { Type L } \\
\text { oxid } \\
\end{array}$ \\
\hline $\mathrm{SiO}_{2}$ & 0.08 & 0.19 & 0.33 & 6.38 & 0.07 & 0.09 & 0.22 & 0.01 & 0.11 & 0.87 & 0.05 & 0.01 & 0.33 & 0.36 \\
\hline $\mathrm{Al} 2 \mathrm{O}_{3}$ & 61.19 & 59.74 & 0.43 & 4.84 & 58.23 & 58.09 & 58.06 & 58.25 & 59.24 & 0.13 & 2.95 & 9.29 & 1.99 & 3.30 \\
\hline $\mathrm{TiO}_{2}$ & 0.24 & 1.04 & 24.16 & 1.07 & 0.69 & 0.80 & 0.24 & 0.45 & 0.42 & 0.02 & 8.78 & 1.75 & 46.61 & 5.08 \\
\hline $\mathrm{Fe} 2 \mathrm{O} 3$ & 2.34 & 3.47 & 48.08 & 41.79 & 4.98 & 4.95 & 5.05 & 6.19 & 4.34 & 96.86 & 46.16 & 56.97 & 7.29 & 49.64 \\
\hline $\mathrm{FeO}$ & 17.16 & 15.10 & 15.61 & 30.71 & 17.92 & 18.06 & 18.15 & 15.57 & 17.14 & 0.47 & 30.71 & 28.88 & 35.83 & 30.28 \\
\hline $\mathrm{MnO}$ & 0.14 & 0.12 & 0.40 & 0.49 & 0.17 & 0.17 & 0.10 & 0.10 & 0.14 & 0.00 & 0.48 & 0.57 & 0.17 & 0.53 \\
\hline $\mathrm{MgO}$ & 15.90 & 18.04 & 3.16 & 4.08 & 15.47 & 15.52 & 15.38 & 15.48 & 15.93 & 0.26 & 4.10 & 3.33 & 3.53 & 2.03 \\
\hline $\mathrm{CaO}$ & 0.00 & 0.13 & 0.37 & 1.08 & 0.00 & 0.05 & 0.00 & 0.02 & 0.04 & 0.10 & 0.22 & 0.01 & 0.01 & 0.18 \\
\hline $\mathrm{Cr} 2 \mathrm{O} 3$ & 1.76 & 3.26 & 0.00 & 0.98 & 2.05 & 2.40 & 3.19 & 2.54 & 2.11 & 0.00 & 0.06 & 0.12 & 0.01 & 0.02 \\
\hline TOTAL & 98.80 & 101.08 & 9255 & 91.41 & 99.59 & 100.14 & 100.40 & 98.60 & 99.47 & 98.71 & 93.51 & 100.92 & 95.77 & 91.41 \\
\hline $\mathrm{Si}$ & 0.002 & 0.005 & 0.012 & 0.243 & 0.002 & 0.002 & 0.006 & 0.002 & 0.003 & 0.023 & 0.002 & 0.000 & 0.008 & 0.015 \\
\hline Al & 1.908 & 1.816 & 0.021 & 0.219 & 1.826 & 1.815 & 1.812 & 1.815 & 1.847 & 0.004 & 0.135 & 0.387 & 0.060 & 0.156 \\
\hline $\mathrm{Ti}$ & 0.005 & 0.020 & 0.741 & 0.030 & 0.014 & 0.016 & 0.005 & 0.004 & 0.008 & 0.000 & 0.256 & 0.048 & 0.892 & 0.153 \\
\hline FelII & 0.047 & 0.067 & 1.473 & 1.203 & 0.100 & 0.098 & 0.100 & 0.122 & 0.086 & 1.949 & 1.347 & 1.515 & 0.140 & 1.506 \\
\hline FelI & 0.379 & 0.326 & 0.531 & 0.981 & 0.399 & 0.400 & 0.402 & 0.342 & 0.379 & 0.010 & 0.996 & 0.855 & 0.762 & 1.020 \\
\hline Mn & 0.003 & 0.003 & 0.015 & 0.015 & 0.004 & 0.004 & 0.002 & 0.004 & 0.003 & 0.000 & 0.016 & 0.018 & 0.004 & 0.018 \\
\hline $\mathrm{Mg}$ & 0.625 & 0.693 & 0.190 & 0.234 & 0.613 & 0.613 & 0.607 & 0.661 & 0.628 & 1.010 & 0.237 & 0.174 & 0.134 & 0.123 \\
\hline $\mathrm{Ca}$ & 0.000 & 0.004 & 0.015 & 0.045 & 0.000 & 0.001 & 0.000 & 0.000 & 0.001 & 0.003 & 0.009 & 0.000 & 0.000 & 0.010 \\
\hline $\mathrm{Cr}$ & 0.037 & 0.066 & 0.000 & 0.030 & 0.043 & 0.050 & 0.067 & 0.050 & 0.044 & 0.000 & 0.002 & 0.001 & 0.000 & 0.000 \\
\hline TOTAL & 3.001 & 3.000 & 2.998 & 3.000 & 3.001 & 2.999 & 3.001 & 3.000 & 2999 & 2.999 & 3.000 & 2.998 & 2.000 & 3.001 \\
\hline
\end{tabular}




\begin{tabular}{|c|c|c|c|c|}
\hline Sample & $90033 S$ & $90033 \mathrm{~S}$ & $90033 \mathrm{~S}$ & $90033 \mathrm{~S}$ \\
\hline Type & $\begin{array}{c}\text { Type L } \\
\text { core }\end{array}$ & $\begin{array}{c}\text { Type L } \\
\text { core }\end{array}$ & $\begin{array}{c}\text { Type L } \\
\text { core }\end{array}$ & $\begin{array}{c}\text { Type L } \\
\text { core }\end{array}$ \\
\hline $\mathrm{SiO}_{2}$ & 0.24 & 0.03 & 0.21 & 0.08 \\
\hline $\mathrm{Al} 2 \mathrm{O} 3$ & 64.29 & 63.41 & 0.84 & 263 \\
\hline $\mathrm{TiO}_{2}$ & 0.13 & 0.11 & 13.90 & 25.33 \\
\hline $\mathrm{Fe} 2 \mathrm{O} 3$ & 3.65 & 7.37 & 40.19 & 13.25 \\
\hline $\mathrm{FeO}$ & 9.62 & 5.42 & 31.12 & 45.82 \\
\hline $\mathrm{MnO}$ & 0.88 & 0.88 & 0.40 & 0.09 \\
\hline $\mathrm{MgO}$ & 20.95 & 23.56 & 6.76 & 4.10 \\
\hline $\mathrm{CaO}$ & 0.00 & 0.02 & 0.47 & 0.29 \\
\hline $\mathrm{Cr} 2 \mathrm{O} 3$ & 0.17 & 0.10 & 0.00 & 0.05 \\
\hline TOTAL & 99.92 & 100.91 & 93.89 & 91.63 \\
\hline $\mathrm{Si}$ & 0.006 & 0.001 & 0.008 & 0.003 \\
\hline Al & 1.910 & 1.855 & 0.038 & 0.121 \\
\hline $\mathbf{T i}$ & 0.002 & 0.002 & 0.398 & 0.742 \\
\hline FelII & 0.069 & 0.138 & 0.151 & 0.388 \\
\hline Fell & 0.203 & 0.113 & 0.990 & 1.492 \\
\hline Mn & 0.019 & 0.018 & 0.013 & 0.003 \\
\hline $\mathbf{M g}$ & 0.787 & 0.871 & 0.383 & 0.238 \\
\hline $\mathrm{Ca}$ & 0.000 & 0.001 & 0.019 & 0.012 \\
\hline $\mathrm{Cr}$ & 0.003 & 0.002 & 0.000 & 0.002 \\
\hline TOTAL & 2999 & 3.001 & 2.000 & 3.001 \\
\hline
\end{tabular}

\begin{tabular}{|c|c|c|c|c|c|}
\hline Sample & $90039 \mathrm{M}$ & $90039 \mathrm{M}$ & $90039 \mathrm{M}$ & $90039 \mathrm{~V}$ & $90039 \mathrm{~V}$ \\
\hline Type & $\begin{array}{c}\text { Type L } \\
\text { oxid }\end{array}$ & $\begin{array}{c}\text { Type L } \\
\text { oxid- }\end{array}$ & $\begin{array}{c}\text { Type L } \\
\text { oxid }\end{array}$ & $\begin{array}{c}\text { Type M } \\
\text { oxid }\end{array}$ & $\begin{array}{c}\text { Type } M \\
\text { oxid }\end{array}$ \\
\hline $\mathrm{SiO}_{2}$ & 0.97 & 0.00 & 0.55 & 0.18 & 0.01 \\
\hline $\mathrm{A} 12 \mathrm{O} 3$ & 1.22 & 1.66 & 3.07 & 5.60 & 0.46 \\
\hline $\mathrm{TiO}_{2}$ & 6.54 & 51.91 & 4.42 & 18.58 & 51.97 \\
\hline $\mathrm{Fe} 2 \mathrm{O} 3$ & 50.60 & 3.56 & 54.37 & 27.60 & 5.66 \\
\hline $\mathrm{FeO}$ & 30.06 & 38.29 & 32.50 & 45.23 & 37.12 \\
\hline $\mathrm{MnO}$ & 0.70 & 0.25 & 0.39 & 0.58 & 0.66 \\
\hline $\mathrm{MgO}$ & 3.65 & 4.54 & 1.64 & 247 & 4.99 \\
\hline $\mathrm{CaO}$ & 0.34 & 0.04 & 0.07 & 0.06 & 0.05 \\
\hline $\mathrm{Cr} 2 \mathrm{O}_{3}$ & 0.00 & 0.00 & 0.04 & 0.10 & 0.00 \\
\hline TOTAL & 94.08 & 100.24 & 97.04 & 100.39 & 100.92 \\
\hline $\mathrm{Si}$ & 0.039 & 0.000 & 0.021 & 0.006 & 0.000 \\
\hline Al & 0.057 & 0.048 & 0.138 & 0.228 & 0.014 \\
\hline $\mathrm{Ti}$ & 0.192 & 0.944 & 0.126 & 0.504 & 0.942 \\
\hline FelII & 1.480 & 0.064 & 1.563 & 0.750 & 0.100 \\
\hline Fell & 0.981 & 0.774 & 1.038 & 1.365 & 0.748 \\
\hline Mn & 0.024 & 0.006 & 0.012 & 0.018 & 0.014 \\
\hline $\mathbf{M g}$ & 0.213 & 0.164 & 0.100 & 0.126 & 0.180 \\
\hline $\mathrm{Ca}$ & 0.015 & 0.002 & 0.003 & 0.001 & 0.002 \\
\hline $\mathrm{Cr}$ & 0.000 & 0.000 & 0.000 & 0.001 & 0.000 \\
\hline TOTAL & 3.001 & 2.002 & 3.001 & 2.999 & 2.000 \\
\hline
\end{tabular}




\section{A3.1 Mount Sidley xenolith mineral analyses: glasses}

\begin{tabular}{|c|c|c|c|c|c|c|c|c|c|c|}
\hline Sample & 900330 & 900330 & $90033 P$ & $90033 \mathrm{P}$ & $90033 \mathrm{P}$ & $90033 P$ & $90033 P$ & $90033 \mathrm{P}$ & $90033 X$ & $90033 X$ \\
\hline Type & Type L & Type L & Type C & Type C & Type C & Type C & Type C & Type C & Type L & Type L \\
\hline $\mathrm{SiO}_{2}$ & 50.18 & 50.63 & 47.86 & 48.00 & 54.63 & 46.23 & 47.35 & 44.70 & 45.13 & 42.94 \\
\hline $\mathrm{Al}_{2} \mathrm{O}_{3}$ & 18.38 & 18.08 & 17.29 & 18.72 & 16.62 & 16.15 & 18.28 & 15.97 & 10.49 & 10.34 \\
\hline $\mathrm{TiO}_{2}$ & 2.57 & 1.96 & 4.75 & 3.99 & 2.62 & 4.53 & 2.90 & 4.69 & 2.68 & 3.21 \\
\hline $\mathrm{FeO}$ & 11.05 & 10.39 & 11.25 & 12.23 & 9.59 & 13.49 & 10.65 & 14.01 & 21.39 & 22.42 \\
\hline $\mathrm{MnO}$ & 0.12 & 0.14 & 0.10 & 0.01 & 0.22 & 0.13 & 0.07 & 0.15 & 0.65 & 0.61 \\
\hline $\mathrm{MgO}$ & 0.87 & 3.61 & 2.47 & 3.43 & 4.40 & 2.94 & 6.03 & 2.98 & 9.59 & 6.60 \\
\hline $\mathrm{CaO}$ & 6.23 & 6.88 & 8.61 & 3.20 & 4.35 & 7.63 & 1.97 & 10.49 & 7.75 & 8.25 \\
\hline $\mathrm{Na} 2 \mathrm{O}$ & 4.66 & 3.69 & 5.07 & 3.80 & 2.96 & 5.43 & 6.62 & 4.00 & 0.36 & 2.52 \\
\hline $\mathrm{K}_{2} \mathrm{O}$ & 2.76 & 1.28 & 1.54 & 6.16 & 4.18 & 1.52 & 5.42 & 1.11 & 1.17 & 0.67 \\
\hline $\mathrm{Cr} 2 \mathrm{O} 3$ & 0.07 & 0.53 & 0.00 & 0.02 & 0.00 & 0.10 & 0.07 & 0.06 & 0.00 & \\
\hline $\mathrm{Cl}$ & & & 0.22 & 0.23 & 0.28 & 0.30 & 0.18 & 0.16 & 0.00 & 0.03 \\
\hline P2O5 & 3.33 & 3.03 & & & & 1.24 & 0.64 & 0.77 & & 2.12 \\
\hline TOTAL & 100.22 & 100.22 & 99.16 & 99.80 & 99.85 & 99.68 & 100.17 & 99.08 & 99.21 & 99.72 \\
\hline Mg\#" & 12.26 & 38.24 & 28.12 & 33.32 & 44.96 & 27.96 & 50.20 & 27.50 & 44.41 & 34.41 \\
\hline Q & 0.00 & 3.80 & 0.00 & 0.00 & 1.13 & 0.00 & 0.00 & 0.00 & 0.00 & 0.00 \\
\hline Or & 16.31 & 7.56 & 9.10 & 36.40 & 24.70 & 8.98 & 32.03 & 6.56 & 6.91 & 3.96 \\
\hline $\mathbf{A b}$ & 43.43 & 36.22 & 26.60 & 10.78 & 25.05 & 29.29 & 7.00 & 21.20 & 3.05 & 21.32 \\
\hline An & 9.17 & 14.36 & 19.87 & 15.83 & 19.72 & 15.20 & 4.16 & 22.34 & 23.55 & 14.92 \\
\hline $\mathrm{Ne}$ & 0.00 & 0.00 & 8.83 & 11.58 & 0.00 & 9.02 & 26.55 & 6.85 & 0.00 & 0.00 \\
\hline $\mathrm{Di}$ & 7.99 & 12.02 & 19.17 & 0.04 & 1.54 & 12.28 & 4.23 & 20.84 & 12.41 & 10.27 \\
\hline $\mathrm{Hy}$ & 8.59 & 15.67 & 0.00 & 0.00 & 20.75 & 0.00 & 0.00 & 0.00 & 37.67 & 14.43 \\
\hline $\mathrm{Ol}$ & 1.57 & 0.00 & 4.34 & 15.15 & 0.00 & 10.63 & 17.82 & 7.89 & 6.72 & 19.77 \\
\hline Mt & 0.00 & 0.00 & 0.00 & 0.00 & 0.00 & 0.00 & 0.00 & 0.00 & 0.00 & 0.00 \\
\hline Il & 4.88 & 3.72 & 9.02 & 7.58 & 4.98 & 8.60 & 5.51 & 8.91 & 5.09 & 6.10 \\
\hline Ap & 7.88 & 7.17 & 0.00 & 0.00 & 0.00 & 2.94 & 0.17 & 1.82 & 0.00 & 5.02 \\
\hline TOTAL & 99.82 & 100.52 & 96.93 & 97.36 & 97.87 & 96.94 & 97.47 & 96.41 & 95.40 & 95.79 \\
\hline
\end{tabular}

\begin{tabular}{|c|c|c|c|c|c|c|c|c|c|c|}
\hline Sample & $90033 x$ & $90033 Q 1$ & $90039 \mathrm{G}$ & $90039 \mathrm{~V}$ & $90039 \mathrm{~V}$ & $90039 \mathrm{E}$ & 90039E & $90039 \mathrm{E}$ & $90039 \mathrm{E}$ & $90039 \mathrm{E}$ \\
\hline Type & Type L & Type P & Type L & Type $\mathbf{M}$ & Type M & Type L & Type L & Type L & Type L & Type L \\
\hline $\mathrm{SiO}_{2}$ & 43.58 & 46.83 & 48.99 & 38.46 & 50.97 & 47.69 & 46.13 & 45.73 & 51.93 & 45.32 \\
\hline $\mathrm{Al}_{2} \mathrm{O} 3$ & 10.52 & 17.68 & 18.99 & 5.61 & 1210 & 16.11 & 16.31 & 14.79 & 17.05 & 14.97 \\
\hline $\mathrm{TiO}_{2}$ & 4.63 & 3.65 & 4.69 & 8.36 & 2.64 & 3.44 & 4.07 & 4.09 & 2.93 & 4.35 \\
\hline $\mathrm{FeO}$ & 23.08 & 9.70 & 9.84 & 22.60 & 15.52 & 9.78 & 11.12 & 14.47 & 7.97 & 14.54 \\
\hline $\mathrm{MnO}$ & 0.60 & 0.18 & 0.18 & 0.50 & 0.60 & 0.33 & 0.32 & 0.30 & 0.27 & 0.33 \\
\hline $\mathrm{MgO}$ & 3.43 & 4.73 & 274 & 8.04 & 4.34 & 5.33 & 3.09 & 4.76 & 3.15 & 3.38 \\
\hline $\mathrm{CaO}$ & 10.01 & 10.67 & 7.96 & 13.72 & 11.28 & 9.64 & 11.22 & 8.61 & 7.39 & 7.43 \\
\hline $\mathrm{Na} 2 \mathrm{O}$ & 2.72 & 3.94 & 4.81 & 1.32 & 0.79 & 3.91 & 3.99 & 4.23 & 1.79 & 4.39 \\
\hline $\mathrm{K}_{2} \mathrm{O}$ & 0.76 & 0.90 & 1.43 & 0.44 & 0.66 & 1.67 & 0.70 & 1.32 & 4.70 & 2.24 \\
\hline $\mathrm{Cr}_{2} \mathrm{O}_{3}$ & 0.04 & 0.00 & 0.11 & 0.03 & 0.03 & 0.00 & 0.03 & 0.03 & 0.04 & 0.03 \\
\hline $\mathrm{Cl}$ & 0.00 & & 0.02 & & & & 0.06 & & & \\
\hline P2O5 & & & & & 1.03 & 2.66 & 2.98 & 3.24 & 3.06 & 3.22 \\
\hline TOTAL & 99.37 & 98.28 & 99.76 & 99.08 & 99.96 & 100.56 & 100.01 & 101.56 & 100.28 & 100.20 \\
\hline Mg & 20.94 & 46.49 & 33.16 & 38.80 & 33.26 & 49.27 & 33.11 & 36.96 & 41.32 & 29.30 \\
\hline Q & 0.00 & 0.00 & 0.00 & 0.00 & 11.60 & 0.00 & 0.00 & 0.00 & 4.75 & 0.00 \\
\hline Or & 4.49 & 5.32 & 8.45 & 260 & 3.90 & 9.87 & 4.14 & 7.80 & 27.78 & 13.24 \\
\hline $\mathrm{Ab}$ & 19.17 & 21.86 & 32.41 & 1.02 & 6.68 & 33.09 & 33.76 & 35.79 & 15.15 & 34.16 \\
\hline An & 14.25 & 27.90 & 26.00 & 8.08 & 27.53 & 21.48 & 24.53 & 17.47 & 16.69 & 14.53 \\
\hline $\mathrm{Ne}$ & 2.08 & 6.22 & 4.49 & 5.50 & 0.00 & 0.00 & 0.00 & 0.00 & 0.00 & 1.02 \\
\hline $\mathrm{Di}$ & 30.39 & 20.53 & 11.19 & 49.73 & 18.35 & 7.36 & 9.78 & 3.42 & 13.77 & 1.11 \\
\hline Hy & 0.00 & 0.00 & 0.00 & 0.00 & 21.70 & 0.69 & 4.39 & 0.84 & 8.23 & 0.00 \\
\hline OI & 16.02 & 7.80 & 6.42 & 12.22 & 0.00 & 13.64 & 6.72 & 18.07 & 0.00 & 16.87 \\
\hline Mt & 0.00 & 0.00 & 0.00 & 0.00 & 0.00 & 0.00 & 0.00 & 0.00 & 0.00 & 0.00 \\
\hline II & 8.79 & 6.93 & 8.91 & 15.88 & 5.01 & 6.53 & 7.73 & 7.77 & 5.56 & 8.26 \\
\hline Ap & 0.00 & 0.00 & 0.00 & 0.00 & 2.44 & 6.30 & 7.05 & 7.67 & 7.24 & 7.62 \\
\hline TOTAL & 95.19 & 96.56 & 97.87 & 95.03 & 97.21 & 98.96 & 98.10 & 98.83 & 99.17 & 96.81 \\
\hline
\end{tabular}




\section{A3.2 Mount Hampton xenolith mineral analyses: olivine}

\begin{tabular}{|c|c|c|c|c|c|c|c|c|c|c|c|c|c|c|}
\hline $\begin{array}{l}\text { Sample } \\
\text { Type }\end{array}$ & $\begin{array}{c}\text { PK4A } \\
\text { Gran } \\
\text { symp }\end{array}$ & $\begin{array}{c}\text { PK4A } \\
\text { Gran } \\
\text { symp }\end{array}$ & $\begin{array}{l}\text { PK4B } \\
\text { Pyxite } \\
\text { symp }\end{array}$ & $\begin{array}{l}\text { PK4B } \\
\text { Pyxite } \\
\text { symp }\end{array}$ & $\begin{array}{l}\text { PK4L } \\
\text { Pyxite } \\
\text { symp }\end{array}$ & $\begin{array}{l}\text { PK4L } \\
\text { Pyxite } \\
\text { symp }\end{array}$ & $\begin{array}{l}\text { PK4L } \\
\text { Pyxite } \\
\text { symp }\end{array}$ & $\begin{array}{l}\text { PK4L } \\
\text { Pyxite } \\
\text { symp }\end{array}$ & $\begin{array}{l}\text { PK4S } \\
\text { Pyxite } \\
\text { symp }\end{array}$ & $\begin{array}{l}\text { PK4S } \\
\text { Pyxite } \\
\text { symp }\end{array}$ & $\begin{array}{c}\text { PK4S } \\
\text { Pyxite } \\
\text { vein } \\
\end{array}$ & $\begin{array}{c}\text { PK4S } \\
\text { Pyxite } \\
\text { vein }\end{array}$ & $\begin{array}{c}\text { PK4Y } \\
\text { Gran } \\
\text { symp }\end{array}$ & $\begin{array}{l}\text { PK4Y } \\
\text { Gran } \\
\text { symp }\end{array}$ \\
\hline $\mathrm{SiO}_{2}$ & 43.47 & 35.85 & 42.20 & 38.12 & 39.96 & 42.07 & 38.60 & 39.57 & 42.96 & 39.18 & 28.10 & 31.90 & 42.79 & 40.80 \\
\hline $\mathrm{A} 12 \mathrm{O} 3$ & 0.02 & 0.15 & 0.08 & 0.11 & 0.10 & 0.07 & 0.23 & 0.62 & 0.05 & 0.12 & 3.44 & 3.90 & 0.02 & 0.13 \\
\hline $\mathrm{TiO}_{2}$ & 0.08 & 0.09 & 0.08 & 0.13 & 0.14 & 0.04 & 0.25 & 0.02 & 0.11 & 0.11 & 0.25 & 0.27 & 0.06 & 0.13 \\
\hline $\mathrm{FeO}$ & 1.63 & 37.10 & 8.18 & 43.64 & 34.45 & 4.86 & 35.34 & 28.78 & 1.04 & 30.99 & 45.30 & 39.45 & 247 & 27.16 \\
\hline MnO & 0.33 & 0.23 & 0.44 & 0.44 & 0.26 & 0.31 & 0.30 & 0.44 & 0.26 & 0.44 & 0.50 & 0.37 & 0.33 & 0.52 \\
\hline $\mathrm{MgO}$ & 55.73 & 24.52 & 49.90 & 16.11 & 24.60 & 52.28 & 24.18 & 28.68 & 56.39 & 27.63 & 21.49 & 22.89 & 54.35 & 30.47 \\
\hline $\mathrm{CaO}$ & 0.14 & 0.51 & 0.16 & 0.27 & 0.33 & 0.14 & 0.76 & 0.35 & 0.10 & 0.35 & 0.65 & 0.76 & 0.18 & 0.47 \\
\hline $\mathrm{Na} 2 \mathrm{O}$ & 0.03 & 0.00 & 0.09 & 0.24 & 0.07 & 0.06 & 0.00 & 0.11 & 0.00 & 0.00 & 0.23 & 0.42 & 0.10 & 0.06 \\
\hline $\mathrm{K} 2 \mathrm{O}$ & 0.00 & 0.08 & 0.00 & 0.15 & 0.03 & 0.02 & 0.04 & 0.01 & 0.02 & 0.02 & 0.03 & 0.04 & 0.05 & 0.13 \\
\hline TOTAL & 101.42 & 98.54 & 101.13 & 99.19 & 99.95 & 99.83 & 99.70 & 98.55 & 100.92 & 98.85 & 99.97 & 99.99 & 100.35 & 99.88 \\
\hline Si & 1.517 & 1.532 & 1.010 & 1.100 & 1.090 & 1.009 & 1.067 & 1.070 & 1.003 & 1.069 & 0.837 & 0.912 & 1.010 & 1.079 \\
\hline Al & 0.001 & 0.008 & 0.002 & 0.003 & 0.000 & 0.000 & 0.007 & 0.019 & 0.002 & 0.003 & 0.120 & 0.136 & 0.000 & 0.003 \\
\hline $\mathrm{Ti}$ & 0.000 & 0.003 & 0.001 & 0.002 & 0.000 & 0.000 & 0.005 & 0.000 & 0.001 & 0.002 & 0.000 & 0.005 & 0.000 & 0.002 \\
\hline $\mathrm{Fe}$ & 0.048 & 1.324 & 0.164 & 1.053 & 0.786 & 0.097 & 0.816 & 0.650 & 0.020 & 0.706 & 1.128 & 0.941 & 0.048 & 0.600 \\
\hline Mn & 0.010 & 0.008 & 0.010 & 0.010 & 0.006 & 0.006 & 0.007 & 0.010 & 0.005 & 0.010 & 0.012 & 0.008 & 0.007 & 0.011 \\
\hline $\mathbf{M g}$ & 2.898 & 1.560 & 1.784 & 0.692 & 1.000 & 1.868 & 0.996 & 1.155 & 1.962 & 1.123 & 0.954 & 0.965 & 1.912 & 1.200 \\
\hline $\mathrm{Ca}$ & 0.005 & 0.024 & 0.004 & 0.008 & 0.009 & 0.003 & 0.022 & 0.010 & 0.002 & 0.010 & 0.020 & 0.022 & 0.004 & 0.013 \\
\hline $\mathrm{Na}$ & 0.002 & 0.000 & 0.004 & 0.013 & 0.000 & 0.002 & 0.000 & 0.010 & 0.000 & 0.000 & 0.013 & 0.022 & 0.004 & 0.003 \\
\hline K & 0.000 & 0.004 & 0.001 & 0.005 & 0.000 & 0.000 & 0.000 & 0.000 & 0.000 & 0.000 & 0.000 & 0.001 & 0.001 & 0.004 \\
\hline TOTAL & 4.481 & 4.463 & 2.980 & 2.886 & 2.891 & 2.985 & 2.920 & 2924 & 2995 & 2.923 & 3.084 & 3.012 & 2.986 & 2.915 \\
\hline $\mathrm{Mg}^{\prime \prime}$ & 98.37 & 54.09 & 91.58 & 39.66 & 55.99 & 95.06 & 54.97 & 63.99 & 98.99 & 61.40 & 45.82 & 50.63 & 97.55 & 66.67 \\
\hline
\end{tabular}

\begin{tabular}{|c|c|c|c|c|c|c|c|c|c|c|c|c|c|c|}
\hline $\begin{array}{l}\text { Sample } \\
\text { Type }\end{array}$ & $\begin{array}{l}\text { PK4Y } \\
\text { Gran } \\
\text { symp }\end{array}$ & $\begin{array}{l}\text { PK4Y } \\
\text { Gran } \\
\text { symp }\end{array}$ & $\begin{array}{l}\text { PK4Y } \\
\text { Gran } \\
\text { symp }\end{array}$ & $\begin{array}{l}\text { PK4Y } \\
\text { Gran } \\
\text { symp }\end{array}$ & $\begin{array}{l}\text { PK4Y } \\
\text { Gran } \\
\text { symp }\end{array}$ & $\begin{array}{l}\text { PK4Y } \\
\text { Gran } \\
\text { symp }\end{array}$ & $\begin{array}{l}\text { PK4B1 } \\
\text { Pyxite } \\
\text { symp } \\
\end{array}$ & $\begin{array}{l}\text { PK4C1 } \\
\text { Gran } \\
\text { opx r }\end{array}$ & $\begin{array}{c}\text { PK4Cl } \\
\text { Gran } \\
\text { symp }\end{array}$ & $\begin{array}{c}\text { PK4C1 } \\
\text { Gran } \\
\text { symp } \\
\end{array}$ & $\begin{array}{c}\text { PK4C1 } \\
\text { Gran } \\
\text { symp } \\
\end{array}$ & $\begin{array}{c}\text { PK4C1 } \\
\text { Gran } \\
\text { symp }\end{array}$ & $\begin{array}{l}\text { PK4C1 } \\
\text { Gran } \\
\text { symp } \\
\end{array}$ & $\begin{array}{c}\text { PK4C1 } \\
\text { Gran } \\
\text { symp } \\
\end{array}$ \\
\hline $\mathrm{SiO}_{2}$ & 42.91 & 37.00 & 42.71 & 38.39 & 43.80 & 37.83 & 41.44 & 42.86 & 37.63 & 42.34 & 39.70 & 43.23 & 42.19 & 38.20 \\
\hline $\mathrm{Al}_{2} \mathrm{O}_{3}$ & 0.00 & 0.16 & 0.00 & 0.32 & 0.00 & 0.20 & 2.51 & 0.20 & 0.26 & 0.00 & 0.27 & 0.05 & 0.00 & 0.08 \\
\hline $\mathrm{TiO}_{2}$ & 0.02 & 0.20 & 0.04 & 0.20 & 0.00 & 0.09 & 0.24 & 0.46 & 0.18 & 0.11 & 0.49 & 0.07 & 0.05 & 0.15 \\
\hline $\mathrm{FeO}$ & 1.85 & 36.53 & 1.43 & 33.96 & 1.35 & 36.44 & 26.84 & 25.82 & 33.05 & 0.90 & 31.43 & 1.19 & 3.22 & 38.24 \\
\hline $\mathrm{MnO}$ & 0.37 & 0.40 & 0.35 & 0.37 & 0.34 & 0.33 & 0.54 & 0.59 & 0.46 & 0.37 & 0.43 & 0.39 & 0.32 & 0.35 \\
\hline $\mathrm{MgO}$ & 54.67 & 24.15 & 55.86 & 26.17 & 54.49 & 24.41 & 28.04 & 31.08 & 26.05 & 56.93 & 27.27 & 56.24 & 54.05 & 21.94 \\
\hline $\mathrm{CaO}$ & 0.07 & 0.38 & 0.25 & 0.38 & 0.09 & 0.24 & 0.46 & 0.66 & 0.43 & 0.08 & 1.05 & 0.09 & 0.19 & 0.88 \\
\hline $\mathrm{Na} 2 \mathrm{O}$ & 0.09 & 0.35 & 0.03 & 0.31 & 0.04 & 0.31 & 0.11 & 0.05 & 0.19 & 0.00 & 0.12 & 0.03 & 0.01 & 0.17 \\
\hline $\mathrm{K} 2 \mathrm{O}$ & 0.04 & 0.10 & 0.02 & 0.08 & 0.04 & 0.01 & 0.06 & 0.02 & 0.05 & 0.03 & 0.03 & 0.02 & 0.02 & 0.05 \\
\hline TOTAL & 100.01 & 98.54 & 101.13 & 99.19 & 99.95 & 99.83 & 99.70 & 98.55 & 100.92 & 98.85 & 99.97 & 99.99 & 100.35 & 99.88 \\
\hline $\mathrm{Si}$ & 1.013 & 1.040 & 1.503 & 1.576 & 1.542 & 1.578 & 1.082 & 1.644 & 1.049 & 0.991 & 1.065 & 1.006 & 1.004 & 1.056 \\
\hline Al & 0.000 & 0.005 & 0.000 & 0.015 & 0.000 & 0.010 & 0.077 & 0.000 & 0.008 & 0.000 & 0.010 & 0.001 & 0.000 & 0.002 \\
\hline $\mathrm{Ti}$ & 0.004 & 0.004 & 0.000 & 0.000 & 0.000 & 0.000 & 0.004 & 0.010 & 0.004 & 0.002 & 0.008 & 0.001 & 0.010 & 0.003 \\
\hline Fe & 0.037 & 0.858 & 0.042 & 1.166 & 0.039 & 1.270 & 0.586 & 0.828 & 0.770 & 0.018 & 0.705 & 0.023 & 0.064 & 0.907 \\
\hline Mn & 0.007 & 0.009 & 0.010 & 0.012 & 0.010 & 0.010 & 0.012 & 0.019 & 0.010 & 0.007 & 0.010 & 0.008 & 0.006 & 0.008 \\
\hline $\mathrm{Mg}$ & 1.925 & 1.011 & 2.928 & 1.601 & 2.858 & 1.516 & 1.091 & 1.776 & 1.082 & 1.986 & 1.090 & 1.949 & 1.917 & 0.927 \\
\hline $\mathrm{Ca}$ & 0.002 & 0.011 & 0.010 & 0.016 & 0.003 & 0.010 & 0.012 & 0.027 & 0.012 & 0.002 & 0.030 & 0.002 & 0.005 & 0.026 \\
\hline $\mathrm{Na}$ & 0.004 & 0.018 & 0.000 & 0.024 & 0.000 & 0.024 & 0.005 & 0.004 & 0.010 & 0.000 & 0.006 & 0.001 & 0.002 & 0.009 \\
\hline K & 0.007 & 0.003 & 0.000 & 0.000 & 0.000 & 0.000 & 0.002 & 0.001 & 0.002 & 0.001 & 0.001 & 0.001 & 0.006 & 0.000 \\
\hline TOTAL & 2999 & 2.959 & 4.493 & 4.410 & 4.452 & 4.418 & 2.871 & 4.309 & 2947 & 3.007 & 2.925 & 2.992 & 3.014 & 2.938 \\
\hline Mg\# & 98.11 & 54.09 & 98.59 & 57.86 & 98.65 & 54.41 & 65.06 & 68.20 & 58.42 & 99.10 & 60.72 & 98.83 & 96.77 & 50.55 \\
\hline
\end{tabular}




\section{A3.2 Mount Hampton xenolith mineral analyses: pyroxenes}

\begin{tabular}{|c|c|c|c|c|c|c|c|c|c|c|c|c|c|c|}
\hline $\begin{array}{l}\text { Sample } \\
\text { Type }\end{array}$ & $\begin{array}{l}\text { PK4A } \\
\text { Gran } \\
\text { core }\end{array}$ & $\begin{array}{c}\text { PK4A } \\
\text { Gran } \\
\text { core }\end{array}$ & $\begin{array}{l}\text { PK4A } \\
\text { Gran } \\
\text { core }\end{array}$ & $\begin{array}{l}\text { PK4A } \\
\text { Gran } \\
\text { core }\end{array}$ & $\begin{array}{l}\text { PK4A } \\
\text { Gran } \\
\text { core }\end{array}$ & $\begin{array}{l}\text { PK4A } \\
\text { Gran } \\
\text { core }\end{array}$ & $\begin{array}{l}\text { PK4B } \\
\text { Pyxite } \\
\text { core }\end{array}$ & $\begin{array}{l}\text { PK4B } \\
\text { Pyxite } \\
\text { core }\end{array}$ & $\begin{array}{l}\text { PK4B } \\
\text { Pyxite } \\
\text { core }\end{array}$ & $\begin{array}{c}\text { PK4B } \\
\text { Pyxite } \\
\text { core } \\
\end{array}$ & $\begin{array}{l}\text { PK4B } \\
\text { Pyxite } \\
\text { core }\end{array}$ & $\begin{array}{l}\text { PK4B } \\
\text { Pyxite } \\
\text { core }\end{array}$ & $\begin{array}{l}\text { PK4B } \\
\text { Pyxite } \\
\text { core }\end{array}$ & $\begin{array}{l}\text { PK4B } \\
\text { Pyxite } \\
\text { core }\end{array}$ \\
\hline $\mathrm{SiO}_{2}$ & 48.97 & 48.74 & 50.82 & 49.66 & 50.51 & 48.80 & 47.49 & 51.05 & 48.23 & 47.90 & 50.60 & 48.29 & 47.73 & 51.37 \\
\hline $\mathrm{Al}_{2} \mathrm{O}_{3}$ & 8.67 & 8.59 & 6.69 & 6.03 & 6.64 & 5.63 & 7.67 & 5.22 & 8.31 & 8.39 & 5.71 & 8.11 & 8.22 & 5.76 \\
\hline $\mathrm{TiO} 2$ & 0.77 & 0.89 & 0.15 & 0.92 & 0.15 & 1.14 & 1.44 & 0.42 & 1.43 & 1.52 & 0.28 & 1.49 & 1.45 & 0.37 \\
\hline $\mathrm{FeO}$ total & 7.90 & 7.89 & 16.86 & 8.47 & 17.25 & 7.95 & 8.27 & 16.89 & 7.95 & 8.25 & 17.09 & 8.27 & 8.59 & 16.71 \\
\hline $\mathrm{MnO}$ & 0.19 & 0.15 & 0.34 & 0.17 & 0.37 & 0.25 & 0.21 & 0.37 & 0.22 & 0.20 & 0.21 & 0.21 & 0.24 & 0.45 \\
\hline MgO & 12.47 & 12.52 & 24.30 & 15.16 & 24.02 & 14.39 & 12.49 & 24.78 & 12.72 & 12.59 & 24.92 & 12.96 & 1291 & 24.68 \\
\hline $\mathrm{CaO}$ & 21.04 & 20.17 & 0.73 & 19.29 & 0.96 & 21.53 & 20.24 & 0.95 & 19.51 & 19.54 & 1.29 & 19.94 & 20.57 & 0.88 \\
\hline $\mathrm{Na} 2 \mathrm{O}$ & 1.07 & 1.11 & 0.12 & 0.34 & 0.15 & 0.32 & 1.07 & 0.15 & 1.04 & 1.07 & 0.58 & 1.09 & 1.09 & 0.16 \\
\hline $\mathrm{K}_{2} \mathrm{O}$ & 0.01 & 0.00 & 0.01 & 0.00 & 0.04 & 0.04 & 0.02 & 0.01 & 0.07 & 0.04 & 0.12 & 0.04 & 0.08 & 0.07 \\
\hline$\overline{\mathrm{Fe} 2 \mathrm{O} 3}$ & 3.37 & 2,42 & 1.21 & 1.93 & 1.98 & 3.93 & 4.02 & 2.13 & 2.12 & 2.67 & 6.31 & 3.46 & 5.69 & 0.66 \\
\hline $\mathrm{FeO}$ & 4.86 & 5.71 & 15.77 & 6.74 & 15.47 & 4.41 & 4.65 & 14.97 & 6.04 & 5.85 & 11.41 & 5.15 & 3.47 & 16.12 \\
\hline
\end{tabular}

\begin{tabular}{lllllllllllllll}
\hline TOTAL & 101.09 & 100.06 & 100.02 & 100.04 & 100.08 & 100.05 & 98.89 & 99.84 & 99.48 & 99.50 & 100.80 & 100.40 & 100.87 & 100.46 \\
\hline
\end{tabular}

\begin{tabular}{|c|c|c|c|c|c|c|c|c|c|c|c|c|c|c|}
\hline Si & 1.799 & 1.805 & 1.846 & 1.840 & 1.840 & 1.819 & 1.789 & 1.859 & 1.791 & 1.785 & 1.830 & 1.785 & 1.765 & 1.862 \\
\hline AlIV & 0.200 & 0.190 & 0.150 & 0.160 & 0.160 & 0.180 & 0.210 & 0.140 & 0.210 & 0.210 & 0.170 & 0.210 & 0.230 & 0.140 \\
\hline AlVI & 0.180 & 0.180 & 0.140 & 0.100 & 0.130 & 0.070 & 0.130 & 0.080 & 0.150 & 0.160 & 0.070 & 0.140 & 0.130 & 0.110 \\
\hline $\mathrm{Ti}$ & 0.020 & 0.024 & 0.004 & 0.025 & 0.004 & 0.032 & 0.040 & 0.010 & 0.040 & 0.042 & 0.010 & 0.040 & 0.040 & 0.010 \\
\hline FeIII & 0.093 & 0.067 & 0.033 & 0.010 & 0.054 & 0.109 & 0.113 & 0.058 & 0.059 & 0.075 & 0.170 & 0.096 & 0.156 & 0.018 \\
\hline FelI & 0.148 & 0.176 & 0.478 & 0.053 & 0.469 & 0.136 & 0.145 & 0.454 & 0.187 & 0.181 & 0.341 & 0.158 & 0.106 & 0.489 \\
\hline Mn & 0.006 & 0.004 & 0.010 & 0.007 & 0.015 & 0.008 & 0.010 & 0.010 & 0.010 & 0.010 & 0.010 & 0.010 & 0.010 & 0.013 \\
\hline $\mathrm{Mg}$ & 0.682 & 0.691 & 1.315 & 0.836 & 1.305 & 0.799 & 0.701 & 1.345 & 0.703 & 0.699 & 1.345 & 0.713 & 0.711 & 1.312 \\
\hline $\mathrm{Ca}$ & 0.828 & 0.800 & 0.028 & 0.765 & 0.037 & 0.860 & 0.817 & 0.037 & 0.776 & 0.780 & 0.050 & 0.789 & 0.814 & 0.034 \\
\hline $\mathrm{Na}$ & 0.076 & 0.077 & 0.008 & 0.024 & 0.014 & 0.022 & 0.077 & 0.010 & 0.074 & 0.077 & 0.040 & 0.078 & 0.078 & 0.011 \\
\hline K & 0.000 & 0.000 & 0.001 & 0.000 & 0.002 & 0.002 & 0.000 & 0.000 & 0.000 & 0.000 & 0.010 & 0.000 & 0.000 & 0.000 \\
\hline TOTAL & 4.032 & 4.014 & 4.013 & 3.820 & 4.030 & 4.037 & 4.032 & 4.003 & 4.000 & 4.019 & 4.046 & 4.019 & 4.040 & 3.999 \\
\hline Wo & 47.29 & 46.14 & 1.51 & 45,97 & 1.98 & 45.17 & 46.00 & 1.95 & 44.99 & 44.96 & 2.62 & 44.93 & 45.55 & 1.83 \\
\hline En & 38.95 & 39.85 & 70.93 & 50.24 & 69.97 & 41.96 & 39.47 & 71.01 & 40.75 & 40.29 & 70.57 & 40.60 & 39.79 & 70.80 \\
\hline Fs & 13.76 & 14.01 & 27.56 & 3.79 & 28.04 & 1287 & 14.53 & 27.03 & 14.26 & 14.76 & 26.81 & 14.46 & 14.66 & 27.36 \\
\hline
\end{tabular}

\begin{tabular}{|c|c|c|c|c|c|c|c|c|c|c|c|c|c|c|}
\hline $\begin{array}{l}\text { Sample } \\
\text { Type }\end{array}$ & $\begin{array}{c}\text { PK4T } \\
\text { Pyxite } \\
\text { core } \\
\end{array}$ & $\begin{array}{c}\text { PK4T } \\
\text { Pyxite } \\
\text { core } \\
\end{array}$ & $\begin{array}{c}\text { PK4T } \\
\text { Pyxite } \\
\text { core } \\
\end{array}$ & $\begin{array}{c}\text { PK4T } \\
\text { Pyxite } \\
\text { core } \\
\end{array}$ & $\begin{array}{c}\text { PK4T } \\
\text { Pyxite } \\
\text { core } \\
\end{array}$ & $\begin{array}{c}\text { PK4T } \\
\text { Pyxite } \\
\text { core } \\
\end{array}$ & $\begin{array}{c}\text { PK4T } \\
\text { Pyxite } \\
\text { core } \\
\end{array}$ & $\begin{array}{c}\text { PK4T } \\
\text { Pyxite } \\
\text { core } \\
\end{array}$ & $\begin{array}{c}\text { PK4V } \\
\text { Gran } \\
\text { core } \\
\end{array}$ & $\begin{array}{c}\text { PK4V } \\
\text { Gran } \\
\text { core } \\
\end{array}$ & $\begin{array}{l}\text { PK4V } \\
\text { Gran } \\
\text { core } \\
\end{array}$ & $\begin{array}{l}\text { PK4Y } \\
\text { Gran } \\
\text { core } \\
\end{array}$ & $\begin{array}{l}\text { PK4Y } \\
\text { Gran } \\
\text { symp }\end{array}$ & $\begin{array}{c}\text { PK4Y } \\
\text { Gran } \\
\text { core } \\
\end{array}$ \\
\hline $\mathrm{SiO}_{2}$ & 47.87 & 49.97 & 47.56 & 48.21 & 48.04 & 50.21 & 51.10 & 51.74 & 46.60 & 46.58 & 47.79 & 50.84 & 53.16 & 50.09 \\
\hline $\mathrm{A} 12 \mathrm{O} 3$ & 8.40 & 5.76 & 7.48 & 8.21 & 7.34 & 4.83 & 5.23 & 5.35 & 8.60 & 7.14 & 8.98 & 6.32 & 1.99 & 8.31 \\
\hline $\mathrm{TiO}_{2}$ & 1.41 & 0.38 & 1.52 & 1.45 & 1.43 & 0.37 & 0.39 & 0.44 & 1.19 & 2.45 & 1.41 & 0.25 & 0.63 & 0.91 \\
\hline $\mathrm{FeO}$ total & 9.14 & 18.18 & 9.12 & 8.84 & 8.87 & 18.31 & 18.45 & 17.76 & 9.64 & 7.56 & 9.33 & 16.63 & 7.66 & 8.38 \\
\hline $\mathrm{MnO}$ & 0.22 & 0.51 & 0.25 & 0.26 & 0.28 & 0.43 & 0.38 & 0.33 & 0.22 & 0.11 & 0.21 & 0.40 & 0.26 & 0.21 \\
\hline $\mathrm{MgO}$ & 12.67 & 23.88 & 12.52 & 1260 & 12.44 & 23.37 & 23.97 & 24.06 & 11.12 & 12.60 & 11.51 & 24.93 & 17.89 & 13.19 \\
\hline $\mathrm{CaO}$ & 19.01 & 1.12 & 20.21 & 19.06 & 19.22 & 1.21 & 1.07 & 1.13 & 20.39 & 22.36 & 19.72 & 0.91 & 19.04 & 17.55 \\
\hline $\mathrm{Na} 2 \mathrm{O}$ & 1.00 & 0.06 & 1.04 & 1.14 & 1.05 & 0.19 & 0.14 & 0.13 & 1.06 & 0.43 & 0.99 & 0.16 & 0.38 & 1.40 \\
\hline $\mathrm{K}_{2} \mathrm{O}$ & 0.00 & 0.02 & 0.02 & 0.04 & 0.03 & 0.05 & 0.03 & 0.05 & 0.01 & 0.00 & 0.00 & 0.01 & 0.02 & 0.03 \\
\hline $\mathrm{Fe} 2 \mathrm{O} 3$ & 2.70 & 3.25 & 4.70 & 2.69 & 2.42 & 2.95 & 2.48 & 1.02 & 4.39 & 3.21 & 1.78 & 2.63 & 2.06 & 0.33 \\
\hline $\mathrm{FeO}$ & 6.70 & 15.25 & 4.89 & 6.43 & 6.69 & 15.66 & 16.22 & 16.83 & 5.69 & 4.67 & 7.72 & 14.26 & 5.81 & 8.08 \\
\hline TOTAL & 99.71 & 99.88 & 99.71 & 99.82 & 98.70 & 98.98 & 100.75 & 100.98 & 98.82 & 99.23 & 99.94 & 100.45 & 101.03 & 100.07 \\
\hline Si & 1.783 & 1.834 & 1.784 & 1.793 & 1.808 & 1.863 & 1.858 & 1.869 & 1.771 & 1.756 & 1.781 & 1.840 & 1.935 & 1.842 \\
\hline AIIV & 0.220 & 0.170 & 0.220 & 0.210 & 0.190 & 0.140 & 0.140 & 0.130 & 0.230 & 0.240 & 0.220 & 0.160 & 0.060 & 0.160 \\
\hline AlVI & 0.150 & 0.080 & 0.110 & 0.150 & 0.140 & 0.070 & 0.080 & 0.100 & 0.160 & 0.060 & 0.170 & 0.110 & 0.030 & 0.200 \\
\hline $\mathrm{Ti}$ & 0.039 & 0.010 & 0.040 & 0.040 & 0.040 & 0.010 & 0.010 & 0.010 & 0.034 & 0.069 & 0.041 & 0.007 & 0.017 & 0.025 \\
\hline FelII & 0.075 & 0.089 & 0.131 & 0.075 & 0.068 & 0.082 & 0.067 & 0.028 & 0.124 & 0.090 & 0.050 & 0.071 & 0.056 & 0.009 \\
\hline FeII & 0.208 & 0.465 & 0.152 & 0.199 & 0.210 & 0.483 & 0.491 & 0.508 & 0.179 & 0.146 & 0.240 & 0.429 & 0.176 & 0.248 \\
\hline Mn & 0.010 & 0.015 & 0.010 & 0.010 & 0.010 & 0.010 & 0.010 & 0.010 & 0.007 & 0.003 & 0.007 & 0.012 & 0.008 & 0.007 \\
\hline $\mathbf{M g}$ & 0.702 & 1.305 & 0.699 & 0.697 & 0.697 & 1.292 & 1.298 & 1.295 & 0.630 & 0.708 & 0.639 & 1.344 & 0.970 & 0.722 \\
\hline $\mathrm{Ca}$ & 0.758 & 0.043 & 0.812 & 0.759 & 0.774 & 0.048 & 0.041 & 0.043 & 0.830 & 0.903 & 0.787 & 0.035 & 0.742 & 0.691 \\
\hline $\mathrm{Na}$ & 0.072 & 0.000 & 0.075 & 0.081 & 0.070 & 0.013 & 0.010 & 0.010 & 0.078 & 0.032 & 0.074 & 0.011 & 0.027 & 0.098 \\
\hline K & 0.000 & 0.000 & 0.000 & 0.000 & 0.000 & 0.000 & 0.000 & 0.000 & 0.001 & 0.000 & 0.000 & 0.001 & 0.001 & 0.001 \\
\hline TOTAL & 4.017 & 4.011 & 4.033 & 4.014 & 4.007 & 4.011 & 4.005 & 4.003 & 4.044 & 4.007 & 4.009 & 4.020 & 4.022 & 4.003 \\
\hline Wo & 43.49 & 2.26 & 45.26 & 43.87 & 44.25 & 2.52 & 2.16 & 2.29 & 47.08 & 48.89 & 45.86 & 1.86 & 38.17 & 41.38 \\
\hline En & 40.28 & 68.61 & 38.96 & 40.29 & 39.85 & 67.82 & 68.42 & 69.10 & 35.73 & 38.33 & 37.24 & 71.53 & 49.90 & 43.23 \\
\hline Fs & 16.24 & 29.13 & 15.77 & 15.84 & 15.89 & 29.66 & 29.41 & 28.60 & 17.19 & 12.78 & 16.90 & 26.61 & 11.93 & 15.39 \\
\hline
\end{tabular}




\begin{tabular}{|c|c|c|c|c|c|c|c|c|c|c|c|c|c|c|}
\hline $\begin{array}{l}\text { Sample } \\
\text { Type }\end{array}$ & $\begin{array}{c}\text { PK4B } \\
\text { Pyxite } \\
\text { core }\end{array}$ & $\begin{array}{c}\text { PK4B } \\
\text { Pyxite } \\
\text { core }\end{array}$ & $\begin{array}{c}\text { PK4D } \\
\text { Pyxite } \\
\text { core }\end{array}$ & $\begin{array}{l}\text { PK4D } \\
\text { Pyxite } \\
\text { core } \\
\end{array}$ & $\begin{array}{c}\text { PK4D } \\
\text { Pyxite } \\
\text { core } \\
\end{array}$ & $\begin{array}{l}\text { PK4D } \\
\text { Pyxite } \\
\text { core } \\
\end{array}$ & $\begin{array}{c}\text { PK4D } \\
\text { Pyxite } \\
\text { core } \\
\end{array}$ & $\begin{array}{c}\text { PK4D } \\
\text { Pyxite } \\
\text { core }\end{array}$ & $\begin{array}{c}\text { PK4D } \\
\text { Pyxite } \\
\text { core }\end{array}$ & $\begin{array}{c}\text { PK4D } \\
\text { Pyxite } \\
\text { core }\end{array}$ & $\begin{array}{c}\text { PK4D } \\
\text { Pyxite } \\
\text { core }\end{array}$ & $\begin{array}{c}\text { PK4D } \\
\text { Pyxite } \\
\text { core }\end{array}$ & $\begin{array}{c}\text { PK4D } \\
\text { Pyxite } \\
\text { core } \\
\end{array}$ & $\begin{array}{c}\text { PK4D } \\
\text { Pyxite } \\
\text { core } \\
\end{array}$ \\
\hline $\mathrm{SiO}_{2}$ & 51.21 & 48.81 & 48.03 & 51.57 & 48.42 & 50.86 & 47.86 & 48.59 & 51.81 & 51.46 & 51.37 & 47.04 & 51.38 & 47.88 \\
\hline $\mathrm{A}_{12} \mathrm{O} 3$ & 5.83 & 8.51 & 8.09 & 5.40 & 8.16 & 5.49 & 8.43 & 7.86 & 5.65 & 5.46 & 5.41 & 8.06 & 5.61 & 8.25 \\
\hline $\mathrm{TiO} 2$ & 0.34 & 1.54 & 1.59 & 0.38 & 1.56 & 0.38 & 1.56 & 1.54 & 0.42 & 0.42 & 0.36 & 1.62 & 0.37 & 1.58 \\
\hline $\mathrm{FeO}$ total & 17.20 & 7.98 & 7.70 & 15.74 & 7.60 & 16.80 & 8.84 & 8.32 & 16.04 & 16.08 & 16.68 & 8.90 & 16.42 & 8.34 \\
\hline $\mathrm{MnO}$ & 0.34 & 0.21 & 0.27 & 0.38 & 0.20 & 0.27 & 0.18 & 0.17 & 0.27 & 0.30 & 0.25 & 0.23 & 0.31 & 0.24 \\
\hline $\mathrm{MgO}$ & 24.17 & 12.50 & 12.78 & 25.29 & 1274 & 25.27 & 1262 & 12.70 & 24.71 & 25.01 & 24.88 & 12.89 & 24.77 & 12.91 \\
\hline $\mathrm{CaO}$ & 0.94 & 19.81 & 19.23 & 0.97 & 19.90 & 1.02 & 19.92 & 19.81 & 0.99 & 0.99 & 0.94 & 20.15 & 1.03 & 19.77 \\
\hline $\mathrm{Na} 2 \mathrm{O}$ & 0.09 & 1.07 & 1.14 & 0.15 & 1.01 & 0.13 & 1.04 & 1.05 & 0.13 & 0.30 & 0.12 & 1.10 & 0.11 & 1.09 \\
\hline $\mathrm{K} 2 \mathrm{O}$ & 0.04 & 0.04 & 0.08 & 0.03 & 0.04 & 0.04 & 0.02 & 0.05 & 0.02 & 0.11 & 0.03 & 0.05 & 0.02 & 0.01 \\
\hline $\mathrm{Fe} 2 \mathrm{O} 3$ & 0.30 & 1.12 & 231 & 1.35 & 1.67 & 3.30 & 3.65 & 2.30 & 0.00 & 1.86 & 1.44 & 6.03 & 1.05 & 3.67 \\
\hline $\mathrm{FeO}$ & 16.93 & 6.97 & 5.63 & 14.53 & 6.10 & 13.83 & 5.56 & 6.26 & 16.04 & 14.40 & 15.38 & 3.48 & 15.47 & 5.01 \\
\hline TOTAL & 100.16 & 100.47 & 98.93 & 99.90 & 99.62 & 100.25 & 100.46 & 100.09 & 100.04 & 100.13 & 100.03 & 100.04 & 100.02 & 100.07 \\
\hline $\mathrm{Si}$ & 1.860 & 1.805 & 1.798 & 1.866 & 1.797 & 1.834 & 1.773 & 1.801 & 1.871 & 1.860 & 1.860 & 1.758 & 1.862 & 1.780 \\
\hline AlIV & 0.140 & 0.190 & 0,200 & 0.130 & 0.200 & 0.170 & 0.230 & 0.200 & 0.130 & 0.140 & 0.140 & 0.240 & 0.140 & 0.220 \\
\hline AlVI & 0.110 & 0.160 & 0.160 & 0.100 & 0.160 & 0.060 & 0.140 & 0.140 & 0.110 & 0.090 & 0.090 & 0.110 & 0.100 & 0.140 \\
\hline $\mathbf{T i}$ & 0.010 & 0.040 & 0.040 & 0.010 & 0.043 & 0.010 & 0.040 & 0.040 & 0.010 & 0.010 & 0.010 & 0.040 & 0.010 & 0.040 \\
\hline FeIII & 0.008 & 0.031 & 0.065 & 0.037 & 0.047 & 0.090 & 0.101 & 0.064 & 0.000 & 0.051 & 0.039 & 0.167 & 0.029 & 0.102 \\
\hline Fell & 0.515 & 0.215 & 0.175 & 0.444 & 0.189 & 0.417 & 0.171 & 0.193 & 0.484 & 0.435 & 0.466 & 0.107 & 0.468 & 0.155 \\
\hline $\mathrm{Mn}$ & 0.010 & 0.010 & 0.008 & 0.010 & 0.010 & 0.010 & 0.010 & 0.010 & 0.010 & 0.010 & 0.010 & 0.010 & 0.010 & 0.010 \\
\hline $\mathrm{Mg}$ & 1.308 & 0.689 & 0.712 & 1.363 & 0.704 & 1.358 & 0.696 & 0.701 & 1.329 & 1.348 & 1.344 & 0.717 & 1.337 & 0.714 \\
\hline $\mathrm{Ca}$ & 0.035 & 0.784 & 0.771 & 0.037 & 0.790 & 0.039 & 0.790 & 0.786 & 0.038 & 0.038 & 0.036 & 0.806 & 0.039 & 0.786 \\
\hline $\mathrm{Na}$ & 0.010 & 0.075 & 0.082 & 0.010 & 0.072 & 0.010 & 0.074 & 0.075 & 0.010 & 0.020 & 0.010 & 0.080 & 0.010 & 0.080 \\
\hline $\mathbf{K}$ & 0.000 & 0.000 & 0.003 & 0.000 & 0.000 & 0.000 & 0.000 & 0.002 & 0.000 & 0.000 & 0.000 & 0.000 & 0.000 & 0.000 \\
\hline TOTAL & 4.006 & 3.999 & 4.014 & 4.007 & 4.012 & 3.998 & 4.025 & 4.012 & 3.992 & 4.002 & 4.005 & 4.035 & 4.005 & 4.027 \\
\hline Wo & 1.88 & 45.61 & 44.75 & 1.97 & 45.66 & 205 & 44.94 & 45.07 & 2.05 & 2.03 & 1.91 & 44.85 & 208 & 44.74 \\
\hline En & 70.10 & 40.08 & 41.32 & 72.46 & 40.69 & 71.32 & 39.59 & 40.19 & 71.80 & 72.01 & 71.30 & 39.90 & 71.38 & 40.64 \\
\hline Fs & 28.03 & 14.31 & 13.93 & 25.57 & 13.64 & 26.63 & 15.47 & 14.74 & 26.15 & 25.96 & 26.79 & 15.25 & 26.53 & 14.63 \\
\hline $\begin{array}{l}\text { Sample } \\
\text { Type }\end{array}$ & $\begin{array}{c}\text { PK4Y } \\
\text { Gran } \\
\text { core } \\
\end{array}$ & $\begin{array}{c}\text { PK4Y } \\
\text { Gran } \\
\text { core } \\
\end{array}$ & $\begin{array}{l}\text { PK4Y } \\
\text { Gran } \\
\text { core } \\
\end{array}$ & $\begin{array}{l}\text { PK4Y } \\
\text { Gran } \\
\text { core } \\
\end{array}$ & $\begin{array}{l}\text { PK4Y } \\
\text { Gran } \\
\text { core } \\
\end{array}$ & $\begin{array}{l}\text { PK4Y } \\
\text { Gran } \\
\text { core } \\
\end{array}$ & $\begin{array}{l}\text { PK4Y } \\
\text { Gran } \\
\text { core } \\
\end{array}$ & $\begin{array}{l}\text { PK4Y } \\
\text { Gran } \\
\text { core } \\
\end{array}$ & $\begin{array}{c}\text { PK4Y } \\
\text { Gran } \\
\text { core } \\
\end{array}$ & $\begin{array}{l}\text { PK4X } \\
\text { Gran } \\
\text { core } \\
\end{array}$ & $\begin{array}{c}\text { PK4Y } \\
\text { Gran } \\
\text { core } \\
\end{array}$ & $\begin{array}{l}\text { PK4Y } \\
\text { Gran } \\
\text { core } \\
\end{array}$ & $\begin{array}{l}\text { PK4Y } \\
\text { Gran } \\
\text { core } \\
\end{array}$ & $\begin{array}{r}\text { PK4Y } \\
\text { Gran } \\
\text { symp } \\
\end{array}$ \\
\hline $\mathrm{SiO}_{2}$ & 51.44 & 49.88 & 50.78 & 50.63 & 47.74 & 51.55 & 52.05 & 51.39 & 48.00 & 50.54 & 47.52 & 49.76 & 49.22 & 54.35 \\
\hline $\mathrm{Al}_{2} \mathrm{O}_{3}$ & 5.99 & 6.80 & 8.37 & 8.26 & 7.07 & 6.47 & 5.89 & 6.27 & 8.17 & 6.14 & 8.47 & 8.57 & 8.79 & 1.20 \\
\hline $\mathrm{TiO}_{2}$ & 0.16 & 0.22 & 1.16 & 0.98 & 2.53 & 0.20 & 0.20 & 0.22 & 0.89 & 0.23 & 1.12 & 0.88 & 0.82 & 0.31 \\
\hline FeO total & 16.23 & 16.47 & 7.87 & 8.21 & 7.93 & 15.93 & 15.79 & 16.48 & 8.25 & 16.50 & 8.19 & 8.24 & 8.56 & 13.56 \\
\hline $\mathrm{MnO}$ & 0.37 & 0.33 & 0.19 & 0.23 & 0.21 & 0.34 & 0.40 & 0.26 & 0.28 & 0.31 & 0.28 & 0.30 & 0.26 & 0.42 \\
\hline $\mathrm{MgO}$ & 25.09 & 25.42 & 12.88 & 12.84 & 14.04 & 25.26 & 24.47 & 24.67 & 12.52 & 24.39 & 12.13 & 12.44 & 12.35 & 27.62 \\
\hline $\mathrm{CaO}$ & 0.83 & 0.75 & 18.85 & 18.44 & 20.19 & 0.87 & 1.05 & 0.97 & 19.83 & 0.88 & 20.08 & 19.91 & 19.63 & 1.92 \\
\hline $\mathrm{Na} 2 \mathrm{O}$ & 0.09 & 0.14 & 1.19 & 1.17 & 0.54 & 0.08 & 0.09 & 0.08 & 1.24 & 0.25 & 1.22 & 1.27 & 1.15 & 0.21 \\
\hline $\mathrm{K} 2 \mathrm{O}$ & 0.01 & 0.01 & 0.03 & 0.04 & 0.09 & 0.09 & 0.01 & 0.27 & 0.02 & 0.07 & 0.05 & 0.04 & 0.04 & 0.08 \\
\hline$\overline{\mathrm{Fe} 2 \mathrm{O} 3}$ & 1.29 & 4.29 & 0.00 & 0.00 & 244 & 1.07 & 0.00 & 0.08 & 4.34 & 2.36 & 4.23 & 2.21 & 1.66 & 1.77 \\
\hline $\mathrm{FeO}$ & 15.07 & 12.61 & 7.87 & 8.21 & 5.73 & 14.96 & 15.79 & 16.42 & 4.34 & 14.37 & 4.38 & 6.25 & 7.07 & 11.97 \\
\hline OTAL & 100.21 & 100.02 & 101.32 & 100.79 & 100.32 & 100.77 & 99.95 & 100.62 & 99.21 & 99.30 & 99.05 & 101.42 & 100.82 & 99.66 \\
\hline Si & 1.860 & 1.818 & 1.842 & 1.848 & 1.772 & 1.851 & 1.881 & 1.854 & 1.799 & 1.850 & 1.786 & 1.817 & 1.820 & 1.959 \\
\hline Allv & 0.140 & 0.180 & 0.160 & 0.150 & 0.230 & 0.150 & 0.120 & 0.150 & 0.200 & 0.150 & 0.210 & 0.180 & 0.180 & 0.040 \\
\hline AlVI & 0.120 & 0.100 & 0.200 & 0.210 & 0.080 & 0.120 & 0.130 & 0.120 & 0.160 & 0.110 & 0.170 & 0.190 & 0.180 & 0.010 \\
\hline $\mathrm{Ti}$ & 0.004 & 0.006 & 0.031 & 0.027 & 0.070 & 0.005 & 0.005 & 0.006 & 0.026 & 0.007 & 0.031 & 0.024 & 0.022 & 0.009 \\
\hline FelII & 0.035 & 0.116 & 0.000 & 0.000 & 0.068 & 0.029 & 0.000 & 0.002 & 0.121 & 0.065 & 0.118 & 0.060 & 0.046 & 0.048 \\
\hline FeII & 0.454 & 0.380 & 0.240 & 0.250 & 0.177 & 0.448 & 0.480 & 0.497 & 0.135 & 0.438 & 0.136 & 0.190 & 0.218 & 0.359 \\
\hline $\mathbf{M n}$ & 0.011 & 0.010 & 0.006 & 0.007 & 0.006 & 0.010 & 0.012 & 0.008 & 0.008 & 0.009 & 0.008 & 0.009 & 0.008 & 0.012 \\
\hline Mg & 1.351 & 1.380 & 0.696 & 0.697 & 0.776 & 1.350 & 1.317 & 1.327 & 0.699 & 1.330 & 0.679 & 0.676 & 0.680 & 1.483 \\
\hline $\mathrm{Ca}$ & 0.032 & 0.029 & 0.732 & 0.721 & 0.802 & 0.033 & 0.039 & 0.038 & 0.796 & 0.034 & 0.808 & 0.778 & 0.777 & 0.073 \\
\hline $\mathrm{Na}$ & 0.007 & 0.010 & 0.084 & 0.082 & 0.038 & 0.005 & 0.006 & 0.006 & 0.090 & 0.017 & 0.089 & 0.090 & 0.082 & 0.014 \\
\hline K & 0.000 & 0.000 & 0.002 & 0.002 & 0.004 & 0.004 & 0.000 & 0.012 & 0.000 & 0.003 & 0.002 & 0.001 & 0.001 & 0.003 \\
\hline TOTAL & 4.014 & 4.029 & 3.993 & 3.994 & 4.023 & 4.005 & 3.990 & 4.020 & 4.034 & 4.013 & 4.037 & 4.015 & 4.014 & 4.010 \\
\hline Wo & 1.71 & 152 & 43.88 & 43.23 & 43.99 & 1.77 & 2.12 & 2.04 & 45.46 & 1.82 & 46.41 & 45.66 & 45.15 & 3.72 \\
\hline En & 72.17 & 72.44 & 41.73 & 41.79 & 4257 & 72.58 & 71.73 & 71.19 & 39.92 & 71.24 & 39.00 & 39.67 & 39.51 & 75.55 \\
\hline Fs & 26.12 & 26.04 & 14.39 & 14.99 & 13.44 & 25.65 & 26.14 & 26.77 & 14.62 & 26.94 & 14.59 & 14.67 & 15.34 & 20.73 \\
\hline
\end{tabular}




\begin{tabular}{|c|c|c|c|c|c|c|c|c|c|c|c|c|c|c|}
\hline $\begin{array}{l}\text { Sample } \\
\text { Type }\end{array}$ & $\begin{array}{c}\text { PK4D } \\
\text { Pyxite } \\
\text { core }\end{array}$ & $\begin{array}{c}\text { PK4L } \\
\text { Pyxite } \\
\text { core }\end{array}$ & $\begin{array}{l}\text { PK4L } \\
\text { Pyxite } \\
\text { core } \\
\end{array}$ & $\begin{array}{c}\text { PK4L } \\
\text { Pyxite } \\
\text { core } \\
\end{array}$ & $\begin{array}{c}\text { PK4L } \\
\text { Pyxite } \\
\text { core }\end{array}$ & $\begin{array}{l}\text { PK4L } \\
\text { Pyxite } \\
\text { host- }\end{array}$ & $\begin{array}{l}\text { PK4L } \\
\text { Pyxite } \\
\text { exsol }\end{array}$ & $\begin{array}{c}\text { PK4L } \\
\text { Pyxite } \\
\text { host- }\end{array}$ & $\begin{array}{l}\text { PK4L } \\
\text { Pyxite } \\
\text { exsol } \\
\end{array}$ & $\begin{array}{l}\text { PK4R } \\
\text { Gran } \\
\text { core } \\
\end{array}$ & $\begin{array}{l}\text { PK4R } \\
\text { Gran } \\
\text { core } \\
\end{array}$ & $\begin{array}{l}\text { PK4R } \\
\text { Gran } \\
\text { core }\end{array}$ & $\begin{array}{l}\text { PK4R } \\
\text { Gran } \\
\text { core }\end{array}$ & $\begin{array}{l}\text { PK4R } \\
\text { Gran } \\
\text { core }\end{array}$ \\
\hline $\mathrm{SiO}_{2}$ & 50.70 & 46.68 & 47.77 & 49.03 & 50.17 & 49.03 & 51.49 & 47.63 & 50.87 & 50.69 & 52.53 & 50.07 & 51.52 & 49.63 \\
\hline $\mathrm{Al} 2 \mathrm{O}_{3}$ & 5.73 & 9.39 & 9.24 & 9.08 & 6.53 & 8.73 & 6.15 & 9.00 & 6.57 & 4.57 & 4.17 & 7.17 & 3.98 & 7.05 \\
\hline $\mathrm{THO}_{2}$ & 0.40 & 1.71 & 1.69 & 1.64 & 0.40 & 1.46 & 0.45 & 1.79 & 0.48 & 0.20 & 0.23 & 1.26 & 1.05 & 1.43 \\
\hline $\mathrm{FeO}$ total & 16.53 & 8.54 & 8.31 & 8.43 & 16.85 & 8.50 & 16.52 & 8.92 & 16.98 & 19.68 & 18.53 & 8.42 & 9.66 & 8.28 \\
\hline $\mathrm{MnO}$ & 0.27 & 0.21 & 0.25 & 0.15 & 0.33 & 0.15 & 0.32 & 0.26 & 0.39 & 0.44 & 0.45 & 0.17 & 0.28 & 0.17 \\
\hline $\mathrm{MgO}$ & 25.34 & 12.42 & 12.56 & 1230 & 24.33 & 12.05 & 23.84 & 12.16 & 23.78 & 23.51 & 23.39 & 12.25 & 14.77 & 12.08 \\
\hline $\mathrm{CaO}$ & 0.93 & 18.49 & 19.05 & 17.97 & 1.03 & 19.28 & 1.14 & 18.99 & 1.12 & 0.80 & 0.74 & 20.32 & 18.50 & 20.01 \\
\hline $\mathrm{Na} 2 \mathrm{O}$ & 0.10 & 1.32 & 1.33 & 1.36 & 0.11 & 1.35 & 0.11 & 1.28 & 0.16 & 0.11 & 0.06 & 1.39 & 0.70 & 1.39 \\
\hline K2O & 0.05 & 0.01 & 0.04 & 0.00 & 0.03 & 0.00 & 0.03 & 0.00 & 0.03 & 0.03 & 0.03 & 0.05 & 0.06 & 0.02 \\
\hline$\overline{\mathrm{Fe} 2 \mathrm{O} 3}$ & 2.92 & 4.41 & 3.31 & 0.00 & 0.00 & 1.27 & 0.00 & 2.71 & 0.04 & 3.13 & 0.00 & 2.30 & 0.99 & 1.60 \\
\hline $\mathrm{FeO}$ & 13.90 & 4.58 & 5.33 & 8.43 & 16.85 & 7.35 & 16.52 & 6.50 & 16.61 & 16.86 & 18.53 & 6.35 & 8.77 & 6.84 \\
\hline
\end{tabular}

\begin{tabular}{lllllllllllllll}
\hline TOTAL & 100.05 & 98.76 & 100.19 & 99.95 & 99.75 & 100.55 & 100.02 & 100.03 & 100.35 & 99.99 & 100.09 & 101.05 & 100.47 & 100.04 \\
\hline
\end{tabular}

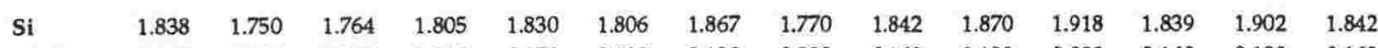

$\begin{array}{lllllllllllllll}\text { AIIV } & 0.160 & 0.250 & 0.240 & 0.190 & 0.170 & 0.190 & 0.130 & 0.230 & 0.160 & 0.130 & 0.080 & 0.160 & 0.100 & 0.160\end{array}$

$\begin{array}{lllllllllllllll}\text { AlVI } & 0.090 & 0.160 & 0.160 & 0.200 & 0.110 & 0.190 & 0.130 & 0.160 & 0.120 & 0.070 & 0.100 & 0.150 & 0.070 & 0.150\end{array}$

$\begin{array}{lllllllllllllll}\text { Ti } & 0.010 & 0.040 & 0.046 & 0.045 & 0.011 & 0.040 & 0.012 & 0.049 & 0.013 & 0.005 & 0.006 & 0.034 & 0.029 & 0.039\end{array}$

$\begin{array}{lllllllllllllll}\text { FelII } & 0.079 & 0.124 & 0.092 & 0.000 & 0.000 & 0.035 & 0.000 & 0.075 & 0.011 & 0.086 & 0.000 & 0.063 & 0.027 & 0.045\end{array}$

\begin{tabular}{llllllllllllllll} 
Fell & 0.420 & 0.143 & 0.164 & 0.259 & 0.513 & 0.226 & 0.500 & 0.201 & 0.504 & 0.516 & 0.565 & 0.194 & 0.270 & 0.211 \\
\hline
\end{tabular}

$\begin{array}{lllllllllllllll}\text { Mn } & 0.010 & 0.010 & 0.007 & 0.004 & 0.010 & 0.004 & 0.009 & 0.007 & 0.011 & 0.012 & 0.013 & 0.005 & 0.008 & 0.005\end{array}$

$\begin{array}{lllllllllllllll}\mathrm{Mg} & 1.368 & 0.694 & 0.690 & 0.674 & 1.321 & 0.661 & 1.287 & 0.673 & 1.282 & 1.290 & 1.272 & 0.670 & 0.812 & 0.668\end{array}$

$\begin{array}{llllllllllllllll}\mathrm{Ca} & 0.036 & 0.743 & 0.753 & 0.708 & 0.040 & 0.761 & 0.043 & 0.755 & 0.043 & 0.030 & 0.028 & 0.799 & 0.731 & 0.795 \\ \mathrm{Na} & 0.010 & 0.096 & 0.094 & 0.097 & 0.008 & 0.096 & 0.007 & 0.089 & 0.011 & 0.010 & 0.004 & 0.099 & 0.050 & 0.098\end{array}$

$\begin{array}{lllllllllllllll}\mathrm{Na} & 0.010 & 0.096 & 0.094 & 0.097 & 0.008 & 0.096 & 0.007 & 0.089 & 0.011 & 0.010 & 0.004 & 0.099 & 0.050 & 0.098\end{array}$

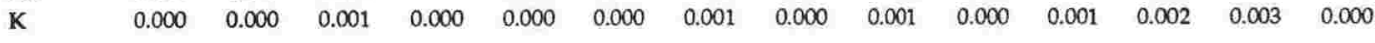

\begin{tabular}{|c|c|c|c|c|c|c|c|c|c|c|c|c|c|c|}
\hline TOTAL & 4.021 & 4.010 & 4.011 & 3.982 & 4.013 & 4.009 & 3.986 & 4.009 & 3.998 & 4.019 & 3.987 & 4.015 & 4.002 & 4.013 \\
\hline Wo & 1.89 & 43.60 & 44.32 & 43.14 & 2.13 & 45.22 & 2.35 & 44.31 & 2.34 & 1.56 & 1.50 & 46.29 & 39.73 & 46.25 \\
\hline En & 71.89 & 40.73 & 40.61 & 41.07 & 70.49 & 39.28 & 70.33 & 39.50 & 69.67 & 67.12 & 68.20 & 38.82 & 44.13 & 38.86 \\
\hline Fs & 26.22 & 15.67 & 15.07 & 15.78 & 27.37 & 15.51 & 27.32 & 16.20 & 27.99 & 31.32 & 30.29 & 14.89 & 16.14 & 14.89 \\
\hline
\end{tabular}

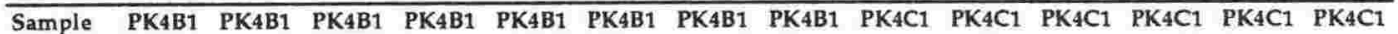

Type Pyxite Pyxite Pyxite Pyxite Pyxite Pyxite Pyxite Pyxite Gran Gran Gran Gran Gran Gran

\begin{tabular}{|c|c|c|c|c|c|c|c|c|c|c|c|c|c|c|}
\hline & core & core & core & core & core & core & core & core & core & core & core & core & core & core \\
\hline $\mathrm{SiO}_{2}$ & 46.73 & 47.38 & 50.59 & 47.22 & 50.20 & 50.32 & 49.68 & 47.07 & 50.51 & 48.43 & 47.64 & 49.83 & 50.88 & 50.43 \\
\hline $\mathrm{Al}_{2} \mathrm{O}_{3}$ & 9.18 & 9.15 & 6.83 & 9.14 & 6.49 & 7.12 & 6.64 & 8.67 & 5.85 & 6.76 & 8.44 & 6.03 & 5.88 & 6.15 \\
\hline $\mathrm{TiO}_{2}$ & 1.54 & 1.62 & 0.50 & 1.54 & 0.43 & 0.47 & 0.41 & 1.51 & 0.30 & 1.70 & 1.28 & 0.26 & 0.26 & 0.30 \\
\hline FeO total & 8.68 & 8.94 & 15.93 & 8.61 & 16.50 & 16.43 & 17.35 & 8.45 & 17.45 & 8.58 & 8.33 & 17.90 & 17.38 & 17.49 \\
\hline Mno & 0.22 & 0.17 & 0.38 & 0.24 & 0.36 & 0.32 & 0.25 & 0.25 & 0.26 & 0.20 & 0.21 & 0.38 & 0.35 & 0.32 \\
\hline $\mathrm{MgO}$ & 12.51 & 12.70 & 24.55 & 1269 & 24.93 & 24.36 & 24.11 & 12.64 & 24.85 & 13.34 & 13.41 & 24.68 & 24.18 & 24.50 \\
\hline $\mathrm{CaO}$ & 19.19 & 19.11 & 1.22 & 19.27 & 1.11 & 1.16 & 1.22 & 19.87 & 1.05 & 19.81 & 19.94 & 0.94 & 0.87 & 0.94 \\
\hline $\mathrm{Na} 2 \mathrm{O}$ & 1.02 & 1.10 & 0.10 & 1.30 & 0.21 & 0.15 & 0.15 & 0.86 & 0.11 & 0.89 & 0.99 & 0.10 & 0.01 & 0.06 \\
\hline $\mathrm{K} 2 \mathrm{O}$ & 0.00 & 0.01 & 0.05 & 0.03 & 0.08 & 0.02 & 0.04 & 0.04 & 0.06 & 0.01 & 0.02 & 0.00 & 0.00 & 0.04 \\
\hline
\end{tabular}

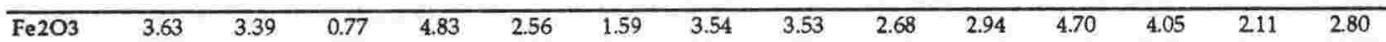

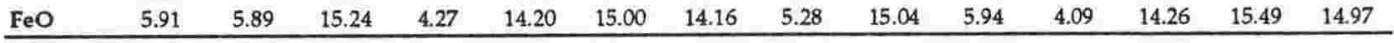

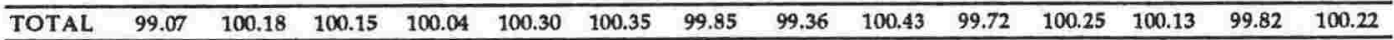

\begin{tabular}{|c|c|c|c|c|c|c|c|c|c|c|c|c|c|c|}
\hline Si & 1.752 & 1.756 & 1.825 & 1.754 & 1.819 & 1.822 & 1.815 & 1.762 & 1.838 & 1.809 & 1.770 & 1.820 & 1.858 & 1.838 \\
\hline AlIV & 0.250 & 0.240 & 0.170 & 0.250 & 0.180 & 0.180 & 0.180 & 0.240 & 0.160 & 0.190 & 0.230 & 0.180 & 0.140 & 0.160 \\
\hline AlVI & 0.160 & 0.160 & 0.120 & 0.150 & 0.100 & 0.120 & 0.110 & 0.140 & 0.090 & 0.110 & 0.140 & 0.080 & 0.110 & 0.100 \\
\hline $\mathrm{Ti}$ & 0.040 & 0.050 & 0.014 & 0.043 & 0.011 & 0.010 & 0.010 & 0.040 & 0.010 & 0.050 & 0.035 & 0.010 & 0.007 & 0.010 \\
\hline FeIII & 0.102 & 0.094 & 0.021 & 0.134 & 0.070 & 0.043 & 0.097 & 0.099 & 0.073 & 0.082 & 0.130 & 0.111 & 0.058 & 0.076 \\
\hline Fell & 0.169 & 0.182 & 0.461 & 0.131 & 0.429 & 0.454 & 0.430 & 0.164 & 0.456 & 0.184 & 0.126 & 0.433 & 0.470 & 0.453 \\
\hline Mn & 0.007 & 0.005 & 0.011 & 0.007 & 0.010 & 0.010 & 0.008 & 0.008 & 0.008 & 0.006 & 0.006 & 0.012 & 0.010 & 0.010 \\
\hline $\mathrm{Mg}$ & 0.699 & 0.701 & 1.320 & 0.702 & 1.345 & 1.314 & 1.312 & 0.705 & 1.347 & 0.742 & 0.742 & 1.346 & 1.315 & 1.330 \\
\hline $\mathrm{Ca}$ & 0.770 & 0.759 & 0.047 & 0.767 & 0.042 & 0.044 & 0.048 & 0.797 & 0.041 & 0.793 & 0.794 & 0.037 & 0.034 & 0.037 \\
\hline $\mathrm{Na}$ & 0.074 & 0.078 & 0.007 & 0.093 & 0.014 & 0.011 & 0.010 & 0.062 & 0.007 & 0.064 & 0.070 & 0.007 & 0.001 & 0.004 \\
\hline K & 0.000 & 0.000 & 0.002 & 0.001 & 0.004 & 0.001 & 0.002 & 0.002 & 0.003 & 0.001 & 0.001 & 0.000 & 0.000 & 0.002 \\
\hline TOTAL & 4.023 & 4.025 & 3.998 & 4.032 & 4.024 & 4.009 & 4.022 & 4.019 & 4.033 & 4.031 & 4.044 & 4.036 & 4.003 & 4.020 \\
\hline Wo & 44.25 & 43.72 & 2.54 & 44.23 & 2.23 & 2.37 & 2.54 & 45.16 & 2.14 & 44.03 & 44.31 & 1.92 & 1.81 & 1.95 \\
\hline En & 40.17 & 40.38 & 71.39 & 40.48 & 71.31 & 70.84 & 69.53 & 39.94 & 70.27 & 41.20 & 41.41 & 69.85 & 70.06 & 70.15 \\
\hline Fs & 15.57 & 15.90 & 26.07 & 15.28 & 26.46 & 26.79 & 27.93 & 14.90 & 27.60 & 14.77 & 14.29 & 28.23 & 28.13 & 27.90 \\
\hline
\end{tabular}




\begin{tabular}{|c|c|c|c|c|c|c|c|c|c|c|c|c|c|c|}
\hline $\begin{array}{l}\text { Sample } \\
\text { Type }\end{array}$ & $\begin{array}{c}\text { PK4R } \\
\text { Gran } \\
\text { core } \\
\end{array}$ & $\begin{array}{l}\text { PK4R } \\
\text { Gran } \\
\text { core } \\
\end{array}$ & $\begin{array}{l}\text { PK4R } \\
\text { Gran } \\
\text { core } \\
\end{array}$ & $\begin{array}{c}\text { PK4S } \\
\text { Pyxite } \\
\text { core } \\
\end{array}$ & $\begin{array}{c}\text { PK4S } \\
\text { Pyxite } \\
\text { core } \\
\end{array}$ & $\begin{array}{c}\text { PK4S } \\
\text { Pyxite } \\
\text { core } \\
\end{array}$ & $\begin{array}{c}\text { PK4S } \\
\text { Pyxite } \\
\text { core } \\
\end{array}$ & $\begin{array}{c}\text { PK4S } \\
\text { Pyxite } \\
\text { core } \\
\end{array}$ & $\begin{array}{l}\text { PK4S } \\
\text { Pyxite } \\
\text { core } \\
\end{array}$ & $\begin{array}{c}\text { PK4S } \\
\text { Pyxite } \\
\text { core } \\
\end{array}$ & $\begin{array}{c}\text { PK4S } \\
\text { Pyxite } \\
\text { core }\end{array}$ & $\begin{array}{c}\text { PK4S } \\
\text { Pyxite } \\
\text { core } \\
\end{array}$ & $\begin{array}{c}\text { PK4S } \\
\text { Pyxite } \\
\text { core } \\
\end{array}$ & $\begin{array}{l}\text { PK4S } \\
\text { Pyxite } \\
\text { symp } \\
\end{array}$ \\
\hline $\mathrm{SiO}_{2}$ & 49.77 & 49.15 & 49.23 & 50.46 & 51.41 & 48.39 & 52.00 & 48.19 & 49.35 & 52.08 & 51.75 & 50.96 & 51.07 & 48.84 \\
\hline $\mathrm{A} 12 \mathrm{O} 3$ & 7.45 & 7.57 & 7.69 & 7.18 & 5.31 & 7.15 & 5.31 & 7.25 & 7.32 & 5.02 & 5.06 & 4.95 & 5.16 & 4.48 \\
\hline $\mathrm{TiO}_{2}$ & 1.47 & 1.47 & 1.46 & 1.43 & 0.35 & 1.50 & 0.39 & 1.33 & 1.44 & 0.29 & 0.26 & 0.34 & 0.36 & 1.90 \\
\hline $\mathrm{FeO}$ total & 8.28 & 8.12 & 8.19 & 8.27 & 17.34 & 8.34 & 16.93 & 8.45 & 8.88 & 17.27 & 17.05 & 17.64 & 17.05 & 10.20 \\
\hline $\mathrm{MnO}$ & 0.30 & 0.23 & 0.22 & 0.37 & 0.31 & 0.26 & 0.45 & 0.20 & 0.24 & 0.57 & 0.33 & 0.37 & 0.36 & 0.28 \\
\hline $\mathrm{MgO}$ & 12.22 & 11.95 & 12.32 & 12.94 & 24.86 & 13.52 & 24.39 & 12.88 & 13.02 & 24.54 & 25.09 & 25.17 & 24.69 & 18.31 \\
\hline $\mathrm{CaO}$ & 19.80 & 20.56 & 20.05 & 18.01 & 1.15 & 19.74 & 1.00 & 20.56 & 18.74 & 0.98 & 1.00 & 0.93 & 1.14 & 15.36 \\
\hline $\mathrm{Na} 2 \mathrm{O}$ & 1.49 & 1.42 & 1.45 & 0.88 & 0.13 & 1.08 & 0.12 & 0.91 & 0.94 & 0.13 & 0.15 & 0.10 & 0.16 & 0.56 \\
\hline $\mathrm{K} 2 \mathrm{O}$ & 0.05 & 0.02 & 0.02 & 0.04 & 0.06 & 0.09 & 0.05 & 0.04 & 0.07 & 0.05 & 0.01 & 0.04 & 0.03 & 0.04 \\
\hline $\mathrm{Fe} 2 \mathrm{O} 3$ & 2.15 & 2.84 & 2.96 & 0.00 & 270 & 4.53 & 0.31 & 3.89 & 0.73 & 1.15 & 2.22 & 3.78 & 258 & 6.10 \\
\hline $\mathrm{FeO}$ & 6.35 & 5.56 & 5.53 & 8.27 & 14.90 & 4.26 & 16.64 & 4.95 & 8.22 & 16.23 & 15.06 & 14.24 & 14.73 & 4.71 \\
\hline TOTAL & 100.78 & 100.47 & 100.60 & 99.53 & 100.86 & 99.97 & 100.56 & 99.78 & 99.93 & 100.87 & 100.69 & 100.45 & 99.98 & 99.93 \\
\hline $\mathrm{Si}$ & 1.832 & 1.819 & 1.817 & 1.864 & 1.859 & 1.800 & 1.877 & 1.799 & 1.826 & 1.879 & 1.871 & 1.854 & 1.863 & 1.800 \\
\hline AlIV & 0.170 & 0.180 & 0.180 & 0.140 & 0.140 & 0.200 & 0.120 & 0.200 & 0.170 & 0.120 & 0.130 & 0.150 & 0.140 & 0.200 \\
\hline AlvI & 0.150 & 0.150 & 0.150 & 0.170 & 0.070 & 0.110 & 0.110 & 0.120 & 0.150 & 0.090 & 0.080 & 0.060 & 0.080 & 0.000 \\
\hline $\mathrm{Ti}$ & 0.040 & 0.040 & 0.040 & 0.039 & 0.009 & 0.041 & 0.010 & 0.037 & 0.040 & 0.007 & 0.007 & 0.009 & 0.009 & 0.050 \\
\hline FeIII & 0.059 & 0.079 & 0.082 & 0.000 & 0.000 & 0.126 & 0.009 & 0.108 & 0.020 & 0.031 & 0.060 & 0.103 & 0.070 & 0.168 \\
\hline Fell & 0.194 & 0.171 & 0.169 & 0.260 & 0.524 & 0.131 & 0.503 & 0.153 & 0.254 & 0.489 & 0.453 & 0.430 & 0.446 & 0.144 \\
\hline $\mathrm{Mn}$ & 0.009 & 0.007 & 0.006 & 0.011 & 0.009 & 0.008 & 0.013 & 0.006 & 0.007 & 0.017 & 0.010 & 0.011 & 0.010 & 0.009 \\
\hline Mg & 0.670 & 0.658 & 0.677 & 0.712 & 1.339 & 0.749 & 1.311 & 0.716 & 0.718 & 1.319 & 1.350 & 1.364 & 1.341 & 1.006 \\
\hline $\mathrm{Ca}$ & 0.780 & 0.815 & 0.792 & 0.712 & 0.044 & 0.786 & 0.038 & 0.822 & 0.742 & 0.037 & 0.038 & 0.036 & 0.044 & 0.607 \\
\hline $\mathrm{Na}$ & 0.105 & 0.101 & 0.103 & 0.063 & 0.009 & 0.078 & 0.008 & 0.065 & 0.067 & 0.009 & 0.010 & 0.007 & 0.011 & 0.040 \\
\hline $\mathbf{K}$ & 0.002 & 0.001 & 0.001 & 0.000 & 0.002 & 0.004 & 0.002 & 0.001 & 0.003 & 0.002 & 0.000 & 0.001 & 0.001 & 0.001 \\
\hline TOTAL & 4.011 & 4.021 & 4.017 & 3.971 & 4.005 & 4.033 & 4.001 & 4.027 & 3.997 & 4.000 & 4.009 & 4.025 & 4.015 & 4.025 \\
\hline Wo & 45.80 & 47.30 & 46.05 & 42.28 & 2.31 & 43.86 & 2.04 & 45.69 & 42.79 & 1.97 & 2.00 & 1.86 & 2.31 & 31.53 \\
\hline En & 39.34 & 38.19 & 39.36 & 42.28 & 70.21 & 41.80 & 70.45 & 39.80 & 41.41 & 70.31 & 71.02 & 70.56 & 70.54 & 52.26 \\
\hline Fs & 14.86 & 14.51 & 14.59 & 15.44 & 27.48 & 14.34 & 27.51 & 14.51 & 15.80 & 27.72 & 26.99 & 27.57 & 27.14 & 16.21 \\
\hline Sample & PK4C1 & PK4C1 & PK4C1 & PK4C1 & $\mathrm{PK} 4 \mathrm{Cl}$ & PK4C1 & $\mathrm{PK} 4 \mathrm{C} 1$ & PK4C1 & PK4D1 & PK4D1 & PK4D1 & PKAD1 & PK4D1 & PK4D1 \\
\hline Type & $\begin{array}{l}\text { Gran } \\
\text { core }\end{array}$ & $\begin{array}{l}\text { Gran } \\
\text { core }\end{array}$ & $\begin{array}{l}\text { Gran } \\
\text { core }\end{array}$ & $\begin{array}{l}\text { Gran } \\
\text { core }\end{array}$ & $\begin{array}{l}\text { Gran } \\
\text { core }\end{array}$ & $\begin{array}{l}\text { Gran } \\
\text { core }\end{array}$ & $\begin{array}{c}\text { Gran } \\
\text { core }\end{array}$ & $\begin{array}{l}\text { Gran } \\
\text { core } \\
\end{array}$ & $\begin{array}{c}\text { Pyxite } \\
\text { core } \\
\end{array}$ & $\begin{array}{c}\text { Pyxite } \\
\text { core } \\
\end{array}$ & $\begin{array}{c}\text { Pyxite } \\
\text { core }\end{array}$ & $\begin{array}{c}\text { Pyxite } \\
\text { core }\end{array}$ & $\begin{array}{c}\text { Pyxite } \\
\text { core }\end{array}$ & $\begin{array}{c}\text { Pyxite } \\
\text { core } \\
\end{array}$ \\
\hline $\mathrm{SiO}_{2}$ & 48.41 & 50,96 & 47.61 & 47.17 & 48.03 & 51.05 & 47.88 & 50.61 & 48.57 & 50.38 & 50.53 & 50.80 & 51.23 & 48.52 \\
\hline $\mathrm{Al} 2 \mathrm{O} 3$ & 8.54 & 6.01 & 8.74 & 8.78 & 8.72 & 6.17 & 8.69 & 6.18 & 7.81 & 5.43 & 5.63 & 5.39 & 5.65 & 7.87 \\
\hline $\mathrm{TiO}_{2}$ & 1.37 & 0.29 & 1.55 & 1.38 & 1.41 & 0.26 & 1.34 & 0.35 & 1.46 & 0.30 & 0.32 & 0.35 & 0.35 & 1.39 \\
\hline $\mathrm{FeO}$ total & 8.33 & 17.88 & 8.28 & 8.32 & 8.06 & 17.06 & 8.27 & 17.02 & 8.29 & 16.87 & 16.35 & 15.62 & 16.80 & 8.39 \\
\hline $\mathrm{MnO}$ & 0.34 & 0.41 & 0.27 & 0.26 & 0.27 & 0.43 & 0.31 & 0.28 & 0.16 & 0.34 & 0.21 & 0.28 & 0.27 & 0.20 \\
\hline $\mathrm{MgO}$ & 12.74 & 24.11 & 12.81 & 12.79 & 12.54 & 24.10 & 12.49 & 24.62 & 12.71 & 24.74 & 24.96 & 25.59 & 24.47 & 12.61 \\
\hline $\mathrm{CaO}$ & 20.24 & 0.94 & 20.54 & 19.84 & 19.89 & 0.95 & 19.99 & 0.96 & 20.12 & 1.00 & 0.97 & 1.03 & 1.05 & 20.15 \\
\hline $\mathrm{Na} 2 \mathrm{O}$ & 1.17 & 0.11 & 1.22 & 1.05 & 1.09 & 0.14 & 1.09 & 0.08 & 1.01 & 0.03 & 0.05 & 0.12 & 0.06 & 1.05 \\
\hline $\mathrm{K} 2 \mathrm{O}$ & 0.05 & 0.01 & 0.05 & 0.03 & 0.01 & 0.01 & 0.02 & 0.00 & 0.00 & 0.00 & 0.00 & 0.00 & 0.01 & 0.01 \\
\hline $\mathrm{Fe} 2 \mathrm{O} 3$ & 4.04 & 1.99 & 5.61 & 4.81 & 2.84 & 0.42 & 3.32 & 1.79 & 2.30 & 0.34 & 2.02 & 2.60 & 0.84 & 2.55 \\
\hline $\mathrm{FeO}$ & 4.69 & 16.09 & 3.23 & 4.17 & 5.50 & 16.68 & 5.29 & 15.41 & 6.21 & 14.65 & 14.53 & 13.28 & 16.05 & 6.09 \\
\hline TOTAL & 101.18 & 100.72 & 101.07 & 99.62 & 100.02 & 100.16 & 100.08 & 100.10 & 100.14 & 99.08 & 99.02 & 99.19 & 99.88 & 100.18 \\
\hline $\mathrm{Si}$ & 1.782 & 1.850 & 1.759 & 1.763 & 1.781 & 1.852 & 1.777 & 1.840 & 1.800 & 1.852 & 1.852 & 1.854 & 1.860 & 1.800 \\
\hline Allv & 0.220 & 0.150 & 0.240 & 0.240 & 0.220 & 0.150 & 0.220 & 0.160 & 0.200 & 0.150 & 0.150 & 0.150 & 0.140 & 0.200 \\
\hline AlVI & 0.150 & 0.110 & 0.140 & 0.150 & 0.160 & 0.110 & 0.160 & 0.100 & 0.140 & 0.090 & 0.090 & 0.080 & 0.100 & 0.140 \\
\hline $\mathrm{Ti}$ & 0.040 & 0.010 & 0.040 & 0.039 & 0.039 & 0.007 & 0.037 & 0.010 & 0.041 & 0.008 & 0.009 & 0.010 & 0.010 & 0.039 \\
\hline FelII & 0.111 & 0.054 & 0.154 & 0.128 & 0.079 & 0.012 & 0.092 & 0.049 & 0.064 & 0.068 & 0.056 & 0.009 & 0.023 & 0.071 \\
\hline FeII & 0.143 & 0.486 & 0.098 & 0.129 & 0.170 & 0.507 & 0.163 & 0.467 & 0.198 & 0.448 & 0.443 & 0.403 & 0.487 & 0.188 \\
\hline $\mathrm{Mn}$ & 0.011 & 0.013 & 0.008 & 0.011 & 0.008 & 0.013 & 0.010 & 0.008 & 0.005 & 0.011 & 0.006 & 0.009 & 0.008 & 0.006 \\
\hline $\mathbf{M g}$ & 0.698 & 1.304 & 0.705 & 0.713 & 0.693 & 1.303 & 0.690 & 1.333 & 0.702 & 1.356 & 1.363 & 1.392 & 1.333 & 0.697 \\
\hline $\mathrm{Ca}$ & 0.798 & 0.037 & 0.812 & 0.795 & 0.791 & 0.037 & 0.794 & 0.037 & 0.799 & 0.039 & 0.038 & 0.040 & 0.042 & 0.801 \\
\hline $\mathrm{Na}$ & 0.083 & 0.008 & 0.087 & 0.076 & 0.078 & 0.010 & 0.076 & 0.006 & 0.074 & 0.002 & 0.004 & 0.009 & 0.004 & 0.075 \\
\hline $\mathbf{K}$ & 0.002 & 0.001 & 0.002 & 0.002 & 0.000 & 0.000 & 0.001 & 0.000 & 0.000 & 0.000 & 0.000 & 0.000 & 0.000 & 0.001 \\
\hline TOTAL & 4.038 & 4.023 & 4.045 & 4.046 & 4.019 & 4.001 & 4.020 & 4.010 & 4.023 & 4.024 & 4.011 & 3.956 & 4.007 & 4.018 \\
\hline Wo & 45.60 & 1.97 & 45.90 & 45.04 & 45.64 & 1.99 & 45.66 & 1.96 & 45.32 & 2.04 & 2.00 & 2.17 & 2.23 & 45.59 \\
\hline En & 39.89 & 69.32 & 39.85 & 40.40 & 39.99 & 70.09 & 39.68 & 70.68 & 39.82 & 70.96 & 71.74 & 75.49 & 70.72 & 39.67 \\
\hline Fs & 14.51 & 28.71 & 14.25 & 14.56 & 14.37 & 27.92 & 14.66 & 27.36 & 14.86 & 27.00 & 26.26 & 22.34 & 27.06 & 14.74 \\
\hline
\end{tabular}




\begin{tabular}{|c|c|c|c|c|c|c|}
\hline $\begin{array}{l}\text { Sample } \\
\text { Type }\end{array}$ & $\begin{array}{l}\text { PK4S } \\
\text { Pyxite } \\
\text { symp }\end{array}$ & $\begin{array}{c}\text { PK4S } \\
\text { Pyxite } \\
\text { symp }\end{array}$ & $\begin{array}{c}\text { PK4S } \\
\text { Pyxite } \\
\text { oxid } \\
\end{array}$ & $\begin{array}{l}\text { PK4T } \\
\text { Pyxite } \\
\text { core } \\
\end{array}$ & $\begin{array}{c}\text { PK4T } \\
\text { Pyxite } \\
\text { core } \\
\end{array}$ & \\
\hline $\mathrm{SiO}_{2}$ & 50.42 & 48.76 & 51.28 & 47.78 & 49.93 & \\
\hline $\mathrm{Al} 2 \mathrm{O}_{3}$ & 4.67 & 7.29 & 4.90 & 7.88 & 5.54 & \\
\hline $\mathrm{TiO}_{2}$ & 1.77 & 1.24 & 0.33 & 1.51 & 0.35 & \\
\hline $\mathrm{FeO}$ total & 7.09 & 8.98 & 12.37 & 8.94 & 17.40 & \\
\hline $\mathrm{MnO}$ & 0.17 & 0.18 & 0.46 & 0.26 & 0.51 & \\
\hline $\mathrm{MgO}$ & 15.84 & 13.16 & 29.14 & 12.58 & 24.33 & \\
\hline $\mathrm{CaO}$ & 19.57 & 19.87 & 1.36 & 19.48 & 0.99 & \\
\hline $\mathrm{Na} 2 \mathrm{O}$ & 0.49 & 0.97 & 0.09 & 1.17 & 0.21 & \\
\hline $\mathrm{K}_{2} \mathrm{O}$ & 0.00 & 0.01 & 0.06 & 0.06 & 0.05 & \\
\hline $\mathrm{Fe} 2 \mathrm{O} 3$ & 1.09 & 3.54 & 6.10 & 3.94 & 3.90 & \\
\hline $\mathrm{FeO}$ & 6.11 & 5.73 & 6.88 & 5.39 & 13.89 & \\
\hline TOTAL & 100.03 & 100.44 & 99.93 & 99.61 & 99.27 & \\
\hline $\mathbf{S i}$ & 1.846 & 1.806 & 1.834 & 1.785 & 1.837 & \\
\hline Allv & 0.150 & 0.190 & 0.170 & 0.210 & 0.160 & \\
\hline AlVI & 0.050 & 0.130 & 0.040 & 0.130 & 0.080 & \\
\hline $\mathrm{Ti}$ & 0.048 & 0.034 & 0.009 & 0.040 & 0.010 & \\
\hline FelII & 0.030 & 0.098 & 0.162 & 0.110 & 0.107 & \\
\hline Fell & 0.188 & 0.178 & 0.203 & 0.167 & 0.424 & \\
\hline Mn & 0.005 & 0.005 & 0.013 & 0.010 & 0.016 & \\
\hline Mg & 0.863 & 0.726 & 1.553 & 0.700 & 1.334 & \\
\hline $\mathrm{Ca}$ & 0.767 & 0.788 & 0.051 & 0.779 & 0.038 & \\
\hline $\mathrm{Na}$ & 0.034 & 0.069 & 0.006 & 0.084 & 0.014 & \\
\hline K & 0.000 & 0.000 & 0.003 & 0.000 & 0.000 & \\
\hline TOTAL & 3.981 & 4.024 & 4.044 & 4.015 & 4.020 & \\
\hline Wo & 41.50 & 44.02 & 2.59 & 44.36 & 2.00 & \\
\hline En & 46.70 & 40.56 & 78.87 & 39.86 & 70.10 & \\
\hline Fs & 11.80 & 15.42 & 18.54 & 15.77 & 27.90 & \\
\hline Sample & PK5G & PK5G & PK5G & PKSG & PK5G & PK5G \\
\hline Type & $\begin{array}{c}\text { Pyxite } \\
\text { core }\end{array}$ & $\begin{array}{c}\text { Pyxite } \\
\text { core }\end{array}$ & $\begin{array}{c}\text { Pyxite } \\
\text { core }\end{array}$ & $\begin{array}{c}\text { Pyxite } \\
\text { core }\end{array}$ & $\begin{array}{c}\text { Pyxite } \\
\text { core }\end{array}$ & $\begin{array}{c}\text { Pyxite } \\
\text { core }\end{array}$ \\
\hline $\mathrm{SiO}_{2}$ & 49.71 & 52.15 & 50.92 & 51.36 & 49.70 & 52.75 \\
\hline $\mathrm{Al}_{2} \mathrm{O}_{3}$ & 7.34 & 5.39 & 6.87 & 5.01 & 6.92 & 4.72 \\
\hline $\mathrm{TiO}_{2}$ & 1.11 & 0.30 & 1.11 & 0.33 & 1.21 & 0.31 \\
\hline $\mathrm{FeO}$ total & 7.17 & 14.13 & 6.76 & 14.06 & 7.40 & 13.41 \\
\hline $\mathrm{MnO}$ & 0.11 & 0.43 & 0.13 & 0.20 & 0.09 & 0.33 \\
\hline $\mathrm{MgO}$ & 14.04 & 27.42 & 13.88 & 26.93 & 14.13 & 27.28 \\
\hline $\mathrm{CaO}$ & 20.05 & 1.02 & 19.89 & 0.94 & 19.59 & 0.98 \\
\hline $\mathrm{Na} 2 \mathrm{O}$ & 0.96 & 0.13 & 0.93 & 0.19 & 1.00 & 0.24 \\
\hline K2O & 0.01 & 0.00 & 0.00 & 0.00 & 0.02 & 0.02 \\
\hline$\overline{\mathrm{Fe} 2 \mathrm{O} 3}$ & 2.26 & 2.99 & 0.00 & 291 & 2.18 & 1.53 \\
\hline $\mathrm{FeO}$ & 5.14 & 11.44 & 6.76 & 11.44 & 5.58 & 12.03 \\
\hline TOTAL & 100.51 & 100.94 & 100.48 & 99.00 & 100.07 & 100.03 \\
\hline $\mathrm{Si}$ & 1.818 & 1.854 & 1.855 & 1.864 & 1.833 & 1.878 \\
\hline AlIV & 0.180 & 0.150 & 0.140 & 0.140 & 0.170 & 0.120 \\
\hline AlVI & 0.140 & 0.080 & 0.150 & 0.070 & 0.130 & 0.080 \\
\hline $\mathrm{Ti}$ & 0.030 & 0.010 & 0.030 & 0.010 & 0.030 & 0.010 \\
\hline FeIII & 0.062 & 0.080 & 0.000 & 0.079 & 0.059 & 0.041 \\
\hline FeII & 0.157 & 0.338 & 0.205 & 0.345 & 0.168 & 0.359 \\
\hline Mn & 0.000 & 0.010 & 0.000 & 0.010 & 0.000 & 0.010 \\
\hline $\mathbf{M g}$ & 0.764 & 1.452 & 0.753 & 1.456 & 0.776 & 1.446 \\
\hline $\mathrm{Ca}_{\mathrm{a}}$ & 0.785 & 0.038 & 0.776 & 0.036 & 0.773 & 0.037 \\
\hline $\mathrm{Na}$ & 0.068 & 0.010 & 0.065 & 0.013 & 0.070 & 0.016 \\
\hline K & 0.000 & 0.000 & 0.000 & 0.000 & 0.000 & 0.000 \\
\hline TOTAL & 4.004 & 4.022 & 3.974 & 4.023 & 4.009 & 3.997 \\
\hline Wo & 44.40 & 1.99 & 44.75 & 1.88 & 43.52 & 1.96 \\
\hline En & 43.21 & 76.10 & 43.43 & 75.99 & 43.69 & 76.79 \\
\hline Fs & 12.39 & 21.91 & 11.82 & 22.13 & 12.78 & 21.24 \\
\hline
\end{tabular}




\section{A3.2 Mount Hampton xenolith mineral analyses: plagioclase}

\begin{tabular}{|c|c|c|c|c|c|c|c|c|c|c|c|c|c|c|}
\hline $\begin{array}{l}\text { Sample } \\
\text { Type }\end{array}$ & $\begin{array}{c}\text { PK4A } \\
\text { Gran } \\
\text { core } \\
\end{array}$ & $\begin{array}{c}\text { PK4A } \\
\text { Gran } \\
\text { core } \\
\end{array}$ & $\begin{array}{c}\text { PK4A } \\
\text { Gran } \\
\text { core } \\
\end{array}$ & $\begin{array}{l}\text { PK4A } \\
\text { Gran } \\
\text { core } \\
\end{array}$ & $\begin{array}{l}\text { PK4A } \\
\text { Gran } \\
\text { core } \\
\end{array}$ & $\begin{array}{c}\text { PK4B } \\
\text { Pyxite } \\
\text { core } \\
\end{array}$ & $\begin{array}{c}\text { PK4B } \\
\text { Pyxite } \\
\text { core } \\
\end{array}$ & $\begin{array}{c}\text { PK4B } \\
\text { Pyxite } \\
\text { core } \\
\end{array}$ & $\begin{array}{c}\text { PK4B } \\
\text { Pyxite } \\
\text { core } \\
\end{array}$ & $\begin{array}{c}\text { PK4B } \\
\text { Pyxite } \\
\text { core } \\
\end{array}$ & $\begin{array}{c}\text { PK4D } \\
\text { Pyxite } \\
\text { core } \\
\end{array}$ & $\begin{array}{c}\text { PK4D } \\
\text { Pyxite } \\
\text { core } \\
\end{array}$ & $\begin{array}{c}\text { PK4D } \\
\text { Pyxite } \\
\text { core } \\
\end{array}$ & $\begin{array}{c}\text { PK4D } \\
\text { Pyxite } \\
\text { core } \\
\end{array}$ \\
\hline $\mathrm{SiO}_{2}$ & 55.28 & 54.57 & 56.69 & 55.05 & 54.30 & 54.48 & 54.91 & 54.82 & 54.97 & 54.67 & 55.68 & 52.77 & 55.14 & 55.85 \\
\hline $\mathrm{A} 12 \mathrm{O} 3$ & 28.08 & 28.40 & 28.71 & 29.38 & 29.34 & 29.08 & 0.08 & 28.48 & 28.38 & 28.63 & 28.42 & 29.11 & 28.03 & 28.27 \\
\hline $\mathrm{TiO}_{2}$ & 0.03 & 0.08 & 0.10 & 0.07 & 0.04 & 0.12 & 27.92 & 0.07 & 0.06 & 0.05 & 0.04 & 0.15 & 0.08 & 0.01 \\
\hline $\mathrm{FeO}$ & 0.35 & 0.15 & 0.19 & 0.12 & 0.18 & 0.23 & 0.22 & 0.18 & 0.23 & 0.21 & 0.33 & 0.42 & 0.21 & 0.19 \\
\hline $\mathrm{MnO}$ & 0.08 & 0.02 & 0.00 & 0.14 & 0.02 & 0.07 & 0.04 & 0.05 & 0.06 & 0.07 & 0.00 & 0.06 & 0.00 & 0.05 \\
\hline $\mathrm{MgO}$ & 0.03 & 0.04 & 0.03 & 0.00 & 0.06 & 0.07 & 0.08 & 0.03 & 0.04 & 0.04 & 0.11 & 0.12 & 0.08 & 0.04 \\
\hline $\mathrm{CaO}$ & 10.52 & 9.94 & 10.29 & 10.60 & 10.38 & 11.23 & 11.38 & 10.95 & 10.94 & 10.86 & 10.48 & 12.23 & 10.80 & 10.66 \\
\hline $\mathrm{Na} 2 \mathrm{O}$ & 5.21 & 5.49 & 3.74 & 4.57 & 5.70 & 5.17 & 5.14 & 5.03 & 5.04 & 5.24 & 5.40 & 4.84 & 5.62 & 5.36 \\
\hline $\mathrm{K} 2 \mathrm{O}$ & 0.45 & 0.54 & 0.46 & 0.44 & 0.46 & 0.42 & 0.35 & 0.48 & 0.36 & 0.39 & 0.50 & 0.28 & 0.57 & 0.51 \\
\hline TOTAL & 100.03 & 99.23 & 100.21 & 100.36 & 100.48 & 100.86 & 100.12 & 100.09 & 100.08 & 100.16 & 100.95 & 99.98 & 100.53 & 100.95 \\
\hline $\mathrm{Si}$ & 2.495 & 2.481 & 2.533 & 2.466 & 2.454 & 2.444 & 2.479 & 2.474 & 2479 & 2.464 & 2.488 & 2.400 & 2.482 & 2.495 \\
\hline Al & 1.493 & 1.522 & 1.506 & 1.550 & 1.537 & 1.537 & 1.490 & 1.514 & 1.508 & 1.521 & 1.496 & 1.560 & 1.486 & 1.488 \\
\hline $\mathrm{Ti}$ & 0.001 & 0.003 & 0.000 & 0.002 & 0.001 & 0.000 & 0.000 & 0.000 & 0.000 & 0.000 & 0.001 & 0.010 & 0.000 & 0.000 \\
\hline $\mathrm{Fe}$ & 0.013 & 0.006 & 0.005 & 0.004 & 0.006 & 0.010 & 0.010 & 0.010 & 0.010 & 0.010 & 0.010 & 0.010 & 0.010 & 0.007 \\
\hline $\mathrm{Mn}$ & 0.003 & 0.001 & 0.000 & 0.005 & 0.000 & 0.000 & 0.000 & 0.000 & 0.000 & 0.000 & 0.000 & 0.000 & 0.000 & 0.000 \\
\hline $\mathrm{Mg}$ & 0.002 & 0.003 & 0.000 & 0.000 & 0.004 & 0.000 & 0.010 & 0.000 & 0.000 & 0.000 & 0.010 & 0.010 & 0.010 & 0.000 \\
\hline $\mathrm{Ca}$ & 0.509 & 0.484 & 0.492 & 0.508 & 0.502 & 0.539 & 0.550 & 0.529 & 0.528 & 0.524 & 0.501 & 0.596 & 0.520 & 0.509 \\
\hline $\mathrm{Na}$ & 0.455 & 0.483 & 0.420 & 0.396 & 0.499 & 0.449 & 0.449 & 0.439 & 0.440 & 0.457 & 0.467 & 0.426 & 0.490 & 0.463 \\
\hline $\mathrm{K}$ & 0.026 & 0.031 & 0.030 & 0.025 & 0.026 & 0.020 & 0.020 & 0.027 & 0.020 & 0.023 & 0.028 & 0.016 & 0.032 & 0.029 \\
\hline TOTAL & 4.997 & 5.014 & 4.986 & 4.956 & 5.029 & 4.999 & 5.008 & 4.993 & 4.985 & 4.999 & 5.001 & 5.028 & 5.030 & 4.991 \\
\hline An & 51.41 & 48.50 & 52.23 & 54.68 & 48.88 & 53.47 & 53.97 & 53.17 & 53,44 & 52.19 & 50.30 & 57.42 & 49.90 & 50.85 \\
\hline$A b$ & 45.96 & 48.40 & 44.59 & 42.63 & 48.59 & 44.54 & 44.06 & 44.12 & 44.53 & 45.52 & 46.89 & 41.04 & 47.02 & 46.25 \\
\hline Or & 2.63 & 3.11 & 3.18 & 2.69 & 2.53 & 1.98 & 1.96 & 2.71 & 2.02 & 2.29 & 2.81 & 1.54 & 3.07 & 290 \\
\hline
\end{tabular}

\begin{tabular}{|c|c|c|c|c|c|c|c|c|c|c|c|c|c|c|}
\hline $\begin{array}{l}\text { Sample } \\
\text { Type }\end{array}$ & $\begin{array}{c}\text { PK4R } \\
\text { Gran } \\
\text { core } \\
\end{array}$ & $\begin{array}{l}\text { PK4S } \\
\text { Pyxite } \\
\text { symp } \\
\end{array}$ & $\begin{array}{l}\text { PK4S } \\
\text { Pyxite } \\
\text { symp } \\
\end{array}$ & $\begin{array}{l}\text { PK4V } \\
\text { Gran } \\
\text { core } \\
\end{array}$ & $\begin{array}{l}\text { PK4V } \\
\text { Gran } \\
\text { core } \\
\end{array}$ & $\begin{array}{l}\text { PK4V } \\
\text { Gran } \\
\text { core } \\
\end{array}$ & $\begin{array}{l}\text { PK4V } \\
\text { Gran } \\
\text { core } \\
\end{array}$ & $\begin{array}{l}\text { PK4Y } \\
\text { Gran } \\
\text { core } \\
\end{array}$ & $\begin{array}{l}\text { PK4Y } \\
\text { Gran } \\
\text { core } \\
\end{array}$ & $\begin{array}{l}\text { PKAY } \\
\text { Gran } \\
\text { core } \\
\end{array}$ & $\begin{array}{l}\text { PK4Y } \\
\text { Gran } \\
\text { core } \\
\end{array}$ & $\begin{array}{l}\text { PK4Y } \\
\text { Gran } \\
\text { core } \\
\end{array}$ & $\begin{array}{l}\text { PK4Y } \\
\text { Gran } \\
\text { core } \\
\end{array}$ & $\begin{array}{l}\text { PK4Y } \\
\text { Gran } \\
\text { core } \\
\end{array}$ \\
\hline $\mathrm{SiO}_{2}$ & 58.21 & 53.87 & 53.22 & 54.13 & 54.57 & 52.02 & 54.59 & 55.54 & 55.90 & 55.70 & 56.29 & 56.26 & 55.59 & 55.65 \\
\hline $\mathrm{A} 12 \mathrm{O} 3$ & 28.07 & 26.82 & 26.87 & 28.38 & 29.21 & 29.89 & 28.55 & 28.51 & 27.82 & 28.55 & 28.16 & 28.17 & 27.79 & 27.05 \\
\hline $\mathrm{TiO}_{2}$ & 0.18 & 0.26 & 1.27 & 0.04 & 0.02 & 0.01 & 0.04 & 0.07 & 0.05 & 0.04 & 0.03 & 0.03 & 0.04 & 0.07 \\
\hline $\mathrm{FeO}$ & 0.19 & 1.90 & 245 & 0.21 & 0.22 & 0.20 & 0.23 & 0.29 & 0.16 & 0.15 & 0.25 & 0.17 & 0.27 & 0.25 \\
\hline $\mathrm{MnO}$ & 0.03 & 0.01 & 0.06 & 0.00 & 0.00 & 0.00 & 0.00 & 0.05 & 0.00 & 0.02 & 0.02 & 0.05 & 0.06 & 0.00 \\
\hline $\mathrm{MgO}$ & 0.01 & 1.08 & 0.34 & 0.02 & 0.01 & 0.00 & 0.03 & 0.07 & 0.09 & 0.08 & 0.08 & 0.07 & 0.08 & 0.04 \\
\hline $\mathrm{CaO}$ & 9.75 & 10.78 & 10.66 & 11.14 & 11.58 & 12.24 & 11.39 & 11.61 & 10.48 & 10.84 & 10.31 & 10.65 & 10.43 & 10.39 \\
\hline $\mathrm{Na}_{2} \mathrm{O}$ & 4.25 & 5.44 & 5.05 & 4.96 & 4.92 & 5.07 & 4.93 & 3.87 & 5.69 & 5.02 & 5.26 & 4.38 & 5.88 & 5.78 \\
\hline $\mathrm{K} 2 \mathrm{O}$ & 0.24 & 0.25 & 0.09 & 0.27 & 0.27 & 0.27 & 0.23 & 0.37 & 0.41 & 0.34 & 0.29 & 0.32 & 0.30 & 0.35 \\
\hline TOTAL & 100.92 & 100.39 & 100.01 & 99.15 & 100.80 & 99.71 & 99.99 & 100.36 & 100.59 & 100.74 & 100.69 & 100.09 & 100.44 & 99.57 \\
\hline Si & 2.570 & 2.447 & 2.433 & 2.465 & 2.447 & 2.374 & 2.466 & 2.491 & 2.508 & 2491 & 2.515 & 2.519 & 2.500 & 2.524 \\
\hline Al & 1.460 & 1.436 & 1.447 & 1.523 & 1.545 & 1.609 & 1.521 & 1.507 & 1.470 & 1.504 & 1.482 & 1.486 & 1.473 & 1.445 \\
\hline $\mathrm{Ti}$ & 0.005 & 0.008 & 0.043 & 0.001 & 0.000 & 0.000 & 0.001 & 0.002 & 0.002 & 0.001 & 0.001 & 0.000 & 0.001 & 0.002 \\
\hline $\mathbf{F e}$ & 0.006 & 0.071 & 0.093 & 0.008 & 0.008 & 0.008 & 0.007 & 0.010 & 0.006 & 0.006 & 0.009 & 0.006 & 0.010 & 0.009 \\
\hline $\mathrm{Mn}$ & 0.001 & 0.000 & 0.000 & 0.000 & 0.000 & 0.000 & 0.000 & 0.002 & 0.000 & 0.000 & 0.001 & 0.002 & 0.002 & 0.000 \\
\hline $\mathbf{M g}$ & 0.000 & 0.072 & 0.023 & 0.001 & 0.001 & 0.000 & 0.000 & 0.005 & 0.006 & 0.005 & 0.006 & 0.004 & 0.006 & 0.002 \\
\hline $\mathrm{Ca}$ & 0.460 & 0.524 & 0.521 & 0.544 & 0.557 & 0.599 & 0.552 & 0.557 & 0.504 & 0.519 & 0.493 & 0.510 & 0.503 & 0.505 \\
\hline $\mathrm{Na}$ & 0.363 & 0.478 & 0.446 & 0.438 & 0.428 & 0.449 & 0.432 & 0.336 & 0.495 & 0.435 & 0.456 & 0.397 & 0.517 & 0.507 \\
\hline K & 0.013 & 0.014 & 0.005 & 0.016 & 0.015 & 0.016 & 0.014 & 0.021 & 0.023 & 0.019 & 0.017 & 0.018 & 0.018 & 0.020 \\
\hline TOTAL & 4.878 & 5.050 & 5.011 & 4.996 & 5.001 & 5.055 & 4.993 & 4.931 & 5.014 & 4.980 & 4.980 & 4.942 & 5.030 & 5.014 \\
\hline An & 55.02 & 51.57 & 53.60 & 54.51 & 55.70 & 56.30 & 55.31 & 60.94 & 49.32 & 53.34 & 51.04 & 55.14 & 48.46 & 48.93 \\
\hline $\mathbf{A b}$ & 43.42 & 47.05 & 45.88 & 43.89 & 42.80 & 42.20 & 43.29 & 36.76 & 48.43 & 44.71 & 47.20 & 42.92 & 49.81 & 49.13 \\
\hline Or & 1.56 & 1.38 & 0.51 & 1.60 & 1.50 & 1.50 & 1.40 & 2.30 & 2.25 & 1.95 & 1.76 & 1.95 & 1.73 & 1.94 \\
\hline
\end{tabular}




\begin{tabular}{|c|c|c|c|c|c|c|c|c|c|c|c|c|c|c|}
\hline $\begin{array}{l}\text { Sample } \\
\text { Type }\end{array}$ & $\begin{array}{c}\text { PK4D } \\
\text { Pyxite } \\
\text { core }\end{array}$ & $\begin{array}{c}\text { PK4D } \\
\text { Pyxite } \\
\text { core } \\
\end{array}$ & $\begin{array}{l}\text { PK4L } \\
\text { Pyxite } \\
\text { symp }\end{array}$ & $\begin{array}{l}\text { PK4L } \\
\text { Pyxite } \\
\text { symp }\end{array}$ & $\begin{array}{l}\text { PK4L } \\
\text { Pyxite } \\
\text { symp }\end{array}$ & $\begin{array}{l}\text { PK4L } \\
\text { Pyxite } \\
\text { symp }\end{array}$ & $\begin{array}{l}\text { PK4L } \\
\text { Pyxite } \\
\text { symp }\end{array}$ & $\begin{array}{c}\text { PK4R } \\
\text { Gran } \\
\text { core } \\
\end{array}$ & $\begin{array}{c}\text { PK4R } \\
\text { Gran } \\
\text { core } \\
\end{array}$ & $\begin{array}{c}\text { PK4R } \\
\text { Gran } \\
\text { core } \\
\end{array}$ & $\begin{array}{c}\text { PK4R } \\
\text { Gran } \\
\text { core } \\
\end{array}$ & $\begin{array}{c}\text { PK4R } \\
\text { Gran } \\
\text { core } \\
\end{array}$ & $\begin{array}{c}\text { PK4R } \\
\text { Gran } \\
\text { core } \\
\end{array}$ & $\begin{array}{c}\text { PK4R } \\
\text { Gran } \\
\text { core } \\
\end{array}$ \\
\hline $\mathrm{SiO}_{2}$ & 55.76 & 54.75 & 49.87 & 52.84 & 51.00 & 51.08 & 50.54 & 56.91 & 51.71 & 58.00 & 57.44 & 58.19 & 58.28 & 58.39 \\
\hline $\mathrm{A} 12 \mathrm{O} 3$ & 28.98 & 0.07 & 30.67 & 29.17 & 30.25 & 29.59 & 30.62 & 27.14 & 29.55 & 27.68 & 27.68 & 27.05 & 27.64 & 26.96 \\
\hline $\mathrm{TiO}_{2}$ & 0.11 & 28.57 & 0.14 & 0.15 & 0.10 & 0.22 & 0.21 & 0.06 & 0.22 & 0.06 & 0.05 & 0.05 & 0.05 & 0.05 \\
\hline $\mathrm{FeO}$ & 0.29 & 0.10 & 0.77 & 0.73 & 0.66 & 1.06 & 0.81 & 0.22 & 0.61 & 0.14 & 0.06 & 0.13 & 0.17 & 0.22 \\
\hline MnO & 0.00 & 0.04 & 0.03 & 0.02 & 0.11 & 0.04 & 0.14 & 0.09 & 0.05 & 0.08 & 0.07 & 0.09 & 0.00 & 0.07 \\
\hline $\mathrm{MgO}$ & 0.05 & 0.04 & 0.19 & 0.19 & 0.12 & 0.20 & 0.19 & 0.07 & 0.17 & 0.07 & 0.05 & 0.06 & 0.00 & 0.01 \\
\hline $\mathrm{CaO}$ & 10.63 & 10.67 & 15.17 & 1264 & 14.48 & 14.07 & 14.50 & 9.50 & 13.85 & 9.76 & 9.38 & 9.48 & 9.89 & 9.91 \\
\hline $\mathrm{Na} 2 \mathrm{O}$ & 4.71 & 5.42 & 3.18 & 4.41 & 3.44 & 3.19 & 3.32 & 4.75 & 3.77 & 4.45 & 5.11 & 4.88 & 3.77 & 5.03 \\
\hline $\mathrm{K} 2 \mathrm{O}$ & 0.44 & 0.53 & 0.04 & 0.08 & 0.08 & 0.07 & 0.05 & 0.22 & 0.36 & 0.35 & 0.33 & 0.28 & 0.26 & 0.33 \\
\hline TOTAL & 100.97 & 100.19 & 100.06 & 100.23 & 100.23 & 99.52 & 100.36 & 98.94 & 100.29 & 100.58 & 100.17 & 100.21 & 100.06 & 100.97 \\
\hline Si & 2.482 & 2.470 & 2.287 & 2.398 & 2.327 & 2.336 & 2306 & 2570 & 2357 & 2.573 & 2.563 & 2.592 & 2.589 & 2.588 \\
\hline Al & 1.520 & 1.519 & 1.657 & 1.560 & 1.626 & 1.594 & 1.646 & 1.444 & 1.587 & 1.447 & 1.455 & 1.419 & 1.447 & 1.408 \\
\hline $\mathbf{T i}$ & 0.003 & 0.000 & 0.004 & 0.004 & 0.003 & 0.007 & 0.007 & 0.002 & 0.007 & 0.001 & 0.001 & 0.001 & 0.001 & 0.001 \\
\hline $\mathrm{Fe}$ & 0.010 & 0.000 & 0.028 & 0.027 & 0.024 & 0.039 & 0.029 & 0.008 & 0.022 & 0.005 & 0.002 & 0.004 & 0.006 & 0.008 \\
\hline $\mathrm{Mn}$ & 0.000 & 0.000 & 0.000 & 0.000 & 0.004 & 0.001 & 0.005 & 0.003 & 0.001 & 0.002 & 0.002 & 0.003 & 0.000 & 0.002 \\
\hline $\mathbf{M g}$ & 0.000 & 0.000 & 0.012 & 0.012 & 0.010 & 0.013 & 0.012 & 0.004 & 0.011 & 0.004 & 0.003 & 0.003 & 0.000 & 0.000 \\
\hline $\mathrm{Ca}$ & 0.507 & 0.515 & 0.745 & 0.614 & 0.707 & 0.689 & 0.708 & 0.459 & 0.676 & 0.463 & 0.448 & 0.452 & 0.470 & 0.470 \\
\hline $\mathrm{Na}$ & 0.405 & 0.473 & 0.282 & 0.388 & 0.304 & 0.348 & 0.293 & 0.415 & 0.332 & 0.382 & 0.442 & 0.421 & 0.320 & 0.431 \\
\hline $\mathrm{K}$ & 0.025 & 0.030 & 0.002 & 0.004 & 0.005 & 0.004 & 0.002 & 0.012 & 0.021 & 0.019 & 0.018 & 0.015 & 0.014 & 0.018 \\
\hline TOTAL & 4.952 & 5.007 & 5.017 & 5.007 & 5.010 & 5.031 & 5.008 & 4.917 & 5.014 & 4.896 & 4.934 & 4.910 & 4.847 & 4.926 \\
\hline An & 54.11 & 50.59 & 72.40 & 61.03 & 69.59 & 66.19 & 70.59 & 51.81 & 65.69 & 53.59 & 49.34 & 50.90 & 58.46 & 51.14 \\
\hline$A \mathbf{b}$ & 43.22 & 46.46 & 27.41 & 38.57 & 29.92 & 33.43 & 29.21 & 46.84 & 32.26 & 44.21 & 48.68 & 47.41 & 39.80 & 46.90 \\
\hline Or & 2.67 & 2.95 & 0.19 & 0.40 & 0.49 & 0.38 & 0.20 & 1.35 & 2.04 & 2.20 & 1.98 & 1.69 & 1.74 & 1.96 \\
\hline
\end{tabular}

\begin{tabular}{|c|c|c|c|c|c|c|c|c|c|c|c|c|c|c|}
\hline $\begin{array}{l}\text { Sample } \\
\text { Type }\end{array}$ & $\begin{array}{l}\text { PK4Y } \\
\text { Gran } \\
\text { core } \\
\end{array}$ & $\begin{array}{l}\text { PK4Y } \\
\text { Gran } \\
\text { symp } \\
\end{array}$ & $\begin{array}{l}\text { PK4Y } \\
\text { Gran } \\
\text { symp }\end{array}$ & $\begin{array}{l}\text { PK4Y } \\
\text { Gran } \\
\text { core } \\
\end{array}$ & $\begin{array}{c}\text { PK4Y } \\
\text { Gran } \\
\text { rim } \\
\end{array}$ & $\begin{array}{l}\text { PK4Y } \\
\text { Gran } \\
\text { core } \\
\end{array}$ & $\begin{array}{l}\text { PK4Y } \\
\text { Gran } \\
\text { core } \\
\end{array}$ & $\begin{array}{c}\text { PK4Y } \\
\text { Gran } \\
\text { core } \\
\end{array}$ & $\begin{array}{l}\text { PK4Y } \\
\text { Gran } \\
\text { melt } \\
\end{array}$ & $\begin{array}{l}\text { PK4Y } \\
\text { Gran } \\
\text { melt } \\
\end{array}$ & $\begin{array}{c}\text { PKAY } \\
\text { Gran } \\
\text { rim } \\
\end{array}$ & $\begin{array}{c}\text { PK4C1 } \\
\text { Gran } \\
\text { core } \\
\end{array}$ & $\begin{array}{c}\text { PK4C1 } \\
\text { Gran } \\
\text { core } \\
\end{array}$ & $\begin{array}{c}\text { PK4C1 } \\
\text { Gran } \\
\text { core } \\
\end{array}$ \\
\hline $\mathrm{SiO}_{2}$ & 56.24 & 53.49 & 54.67 & 55.05 & 50.79 & 54.89 & 55.74 & 55.80 & 54.12 & 53.80 & 54.50 & 54.64 & 54.46 & 52.87 \\
\hline $\mathrm{Al}_{2} \mathrm{O}_{3}$ & 28.39 & 27.84 & 28.27 & 28.25 & 30.60 & 28.16 & 28.07 & 27.95 & 28.07 & 28.60 & 28.36 & 28.16 & 28.49 & 29.87 \\
\hline $\mathrm{TiO}_{2}$ & 0.07 & 0.15 & 0.19 & 0.00 & 0.11 & 0.05 & 0.07 & 0.00 & 0.38 & 0.29 & 0.23 & 0.01 & 0.04 & 0.22 \\
\hline $\mathrm{FeO}$ & 0.29 & 1.26 & 1.11 & 0.20 & 0.66 & 0.17 & 0.26 & 0.43 & 1.15 & 0.85 & 0.76 & 0.13 & 0.20 & 0.54 \\
\hline $\mathrm{MnO}$ & 0.00 & 0.00 & 0.09 & 0.09 & 0.03 & 0.02 & 0.00 & 0.00 & 0.00 & 0.06 & 0.00 & 0.05 & 0.01 & 0.10 \\
\hline $\mathrm{MgO}$ & 0.06 & 0.01 & 0.00 & 0.01 & 0.05 & 0.01 & 0.00 & 0.00 & 0.18 & 0.10 & 0.00 & 0.01 & 0.16 & 0.08 \\
\hline $\mathrm{CaO}$ & 10.87 & 11.56 & 10.88 & 10.43 & 14.33 & 11.21 & 11.20 & 10.90 & 11.68 & 11.68 & 12.11 & 10.91 & 11.03 & 1281 \\
\hline $\mathrm{Na} 2 \mathrm{O}$ & 4.50 & 5.37 & 5.28 & 5.86 & 3.72 & 4.94 & 5.63 & 5.64 & 5.26 & 4.74 & 5.02 & 4.72 & 5.36 & 4.21 \\
\hline $\mathrm{K}_{2} \mathrm{O}$ & 0.31 & 0.34 & 0.43 & 0.37 & 0.17 & 0.33 & 0.34 & 0.45 & 0.35 & 0.32 & 0.44 & 0.41 & 0.33 & 0.26 \\
\hline TOTAL & 100.73 & 100.03 & 100.91 & 100.26 & 100.44 & 99.77 & 101.31 & 101.17 & 101.19 & 100.43 & 101.41 & 99.04 & 100.07 & 100.96 \\
\hline Si & 2.509 & 2.414 & 2.462 & 2.482 & 2.314 & 2.483 & 2490 & 2.495 & 2439 & 2.434 & 2.446 & 2.487 & 2.462 & 2.383 \\
\hline $\mathrm{Al}$ & 1.493 & 1.498 & 1.500 & 1.502 & 1.640 & 1.501 & 1.477 & 1.473 & 1.490 & 1.525 & 1.500 & 1.510 & 1.510 & 1.587 \\
\hline $\mathrm{Ti}$ & 0.002 & 0.005 & 0.006 & 0.000 & 0.003 & 0.001 & 0.002 & 0.000 & 0.012 & 0.009 & 0.007 & 0.000 & 0.000 & 0.007 \\
\hline $\mathrm{Fe}$ & 0.010 & 0.047 & 0.041 & 0.007 & 0.025 & 0.006 & 0.009 & 0.016 & 0.043 & 0.030 & 0.028 & 0.005 & 0.007 & 0.020 \\
\hline Mn & 0.000 & 0.000 & 0.003 & 0.003 & 0.001 & 0.000 & 0.000 & 0.000 & 0.000 & 0.000 & 0.000 & 0.002 & 0.003 & 0.004 \\
\hline Mg & 0.004 & 0.000 & 0.000 & 0.000 & 0.003 & 0.000 & 0.000 & 0.000 & 0.012 & 0.006 & 0.000 & 0.001 & 0.011 & 0.006 \\
\hline $\mathrm{Ca}$ & 0.520 & 0.566 & 0.524 & 0.504 & 0.699 & 0.543 & 0.535 & 0.522 & 0.563 & 0.566 & 0.582 & 0.532 & 0.534 & 0.618 \\
\hline $\mathrm{Na}$ & 0.389 & 0.475 & 0.460 & 0.512 & 0.328 & 0.432 & 0.486 & 0.488 & 0.459 & 0.415 & 0.436 & 0.416 & 0.470 & 0.368 \\
\hline K & 0.017 & 0.020 & 0.024 & 0.021 & 0.009 & 0.018 & 0.019 & 0.025 & 0.020 & 0.018 & 0.025 & 0.024 & 0.019 & 0.015 \\
\hline TOTAL & 4.944 & 5.025 & 5.020 & 5.031 & 5.022 & 4.984 & 5.018 & 5.019 & 5.038 & 5.003 & 5.024 & 4.977 & 5.016 & 5.008 \\
\hline An & 56.16 & 53.35 & 51.98 & 48.60 & 67.47 & 54.68 & 51.44 & 50.43 & 54.03 & 56.66 & 55.80 & 54.73 & 52.20 & 61.74 \\
\hline $\mathbf{A b}$ & 42.01 & 44.77 & 45.63 & 49.37 & 31.66 & 43.50 & 46.73 & 47.15 & 44.05 & 41.54 & 41.80 & 42.80 & 45.94 & 36.76 \\
\hline Or & 1.84 & 1.89 & 238 & 203 & 0.87 & 1.81 & 1.83 & 2.42 & 1.92 & 1.80 & 2.40 & 2.47 & 1.86 & 1.50 \\
\hline
\end{tabular}




\begin{tabular}{|c|c|c|c|}
\hline $\begin{array}{l}\text { Sample } \\
\text { Type }\end{array}$ & $\begin{array}{c}\text { PK4R } \\
\text { Gran } \\
\text { core } \\
\end{array}$ & $\begin{array}{c}\text { PK4R } \\
\text { Gran } \\
\text { core } \\
\end{array}$ & $\begin{array}{c}\text { PK4R } \\
\text { Gran } \\
\text { core } \\
\end{array}$ \\
\hline $\mathrm{SiO}_{2}$ & 57.10 & 57.94 & 56.99 \\
\hline $\mathrm{A} 12 \mathrm{O} 3$ & 2.88 & 27.32 & 27.99 \\
\hline $\mathrm{TiO}_{2}$ & 0.04 & 0.07 & 0.10 \\
\hline $\mathrm{FeO}$ & 0.23 & 0.14 & 0.13 \\
\hline $\mathrm{MnO}$ & 0.00 & 0.05 & 0.00 \\
\hline $\mathrm{MgO}$ & 0.00 & 0.03 & 0.04 \\
\hline $\mathrm{CaO}$ & 9.29 & 10.17 & 9.81 \\
\hline $\mathrm{Na} 2 \mathrm{O}$ & 5.49 & 4.11 & 4.71 \\
\hline $\mathrm{K} 2 \mathrm{O}$ & 0.31 & 0.26 & 0.24 \\
\hline TOTAL & 100.32 & 100.09 & 100.01 \\
\hline $\mathrm{Si}$ & 2.549 & 2.582 & 2.547 \\
\hline Al & 1.466 & 1.434 & 1.474 \\
\hline $\mathrm{Ti}$ & 0.001 & 0.002 & 0.003 \\
\hline $\mathrm{Fe}$ & 0.008 & 0.005 & 0.004 \\
\hline Mn & 0.000 & 0.001 & 0.000 \\
\hline $\mathrm{Mg}$ & 0.000 & 0.001 & 0.002 \\
\hline $\mathrm{Ca}$ & 0.444 & 0.485 & 0.469 \\
\hline $\mathrm{Na}$ & 0.474 & 0.354 & 0.407 \\
\hline $\mathbf{K}$ & 0.017 & 0.014 & 0.013 \\
\hline TOTAL & 4.959 & 4.878 & 4.919 \\
\hline An & 47.49 & 56.86 & 52.76 \\
\hline$A b$ & 50.70 & 41.50 & 45.78 \\
\hline Or & 1.82 & 1.64 & 1.46 \\
\hline
\end{tabular}

\begin{tabular}{|c|c|c|c|c|}
\hline $\begin{array}{l}\text { Sample } \\
\text { Type }\end{array}$ & $\begin{array}{c}\text { PK4C1 } \\
\text { Gran } \\
\text { core }\end{array}$ & $\begin{array}{c}\text { PKAC1 } \\
\text { Gran } \\
\text { core }\end{array}$ & $\begin{array}{c}\text { PK4C1 } \\
\text { Gran } \\
\text { rim }\end{array}$ & $\begin{array}{c}\text { PK4C1 } \\
\text { Gran } \\
\text { core } \\
\end{array}$ \\
\hline $\mathrm{SiO}_{2}$ & 50.25 & 56.22 & 50.65 & 55.76 \\
\hline $\mathrm{Al}_{2} \mathrm{O}_{3}$ & 30.69 & 28.46 & 30.25 & 28.38 \\
\hline $\mathrm{TiO}_{2}$ & 0.19 & 0.09 & 0.11 & 0.07 \\
\hline $\mathrm{FeO}$ & 1.03 & 0.12 & 0.76 & 0.17 \\
\hline $\mathrm{MnO}$ & 0.06 & 0.08 & 0.07 & 0.08 \\
\hline $\mathrm{MgO}$ & 0.11 & 0.08 & 0.14 & 0.04 \\
\hline $\mathrm{CaO}$ & 14.47 & 10.69 & 13.89 & 10.77 \\
\hline $\mathrm{Na} 2 \mathrm{O}$ & 3.39 & 4.26 & 3.61 & 4.76 \\
\hline $\mathrm{K} 2 \mathrm{O}$ & 0.18 & 0.37 & 0.21 & 0.33 \\
\hline TOTAL & 100.37 & 100.37 & 99.69 & 100.36 \\
\hline Si & 2.298 & 2.513 & 2.325 & 2.500 \\
\hline Al & 1.653 & 1.499 & 1.635 & 1.501 \\
\hline Ti & 0.007 & 0.003 & 0.004 & 0.002 \\
\hline $\mathrm{Fe}$ & 0.039 & 0.004 & 0.028 & 0.006 \\
\hline Mn & 0.002 & 0.003 & 0.003 & 0.003 \\
\hline $\mathrm{Mg}$ & 0.007 & 0.005 & 0.010 & 0.003 \\
\hline $\mathrm{Ca}$ & 0.708 & 0.512 & 0.682 & 0.517 \\
\hline $\mathrm{Na}$ & 0.300 & 0.369 & 0.321 & 0.414 \\
\hline $\mathbf{K}$ & 0.010 & 0.021 & 0.012 & 0.019 \\
\hline TOTAL & 5.024 & 4.929 & 5.020 & 4.965 \\
\hline An & 69.55 & 56.76 & 67.19 & 54.42 \\
\hline$A b$ & 29.47 & 40.91 & 31.63 & 43.58 \\
\hline Or & 0.98 & 2.33 & 1.18 & 200 \\
\hline
\end{tabular}




\section{A3.2 Mount Hampton xenolith mineral analyses: oxides}

\begin{tabular}{|c|c|c|c|c|c|c|c|c|c|c|c|c|c|}
\hline $\begin{array}{l}\text { Sample } \\
\text { Type }\end{array}$ & $\begin{array}{c}\text { PK4A } \\
\text { Gran } \\
\text { symp } \\
\end{array}$ & $\begin{array}{c}\text { PK4A } \\
\text { Gran } \\
\text { vein } \\
\end{array}$ & $\begin{array}{c}\text { PK4B } \\
\text { Pyxite } \\
\text { core } \\
\end{array}$ & $\begin{array}{c}\text { PK4D } \\
\text { Pyxite } \\
\text { core } \\
\end{array}$ & $\begin{array}{l}\text { PK4L } \\
\text { Pyxite } \\
\text { symp }\end{array}$ & $\begin{array}{l}\text { PK4L } \\
\text { Pyxite } \\
\text { symp }\end{array}$ & $\begin{array}{l}\text { PK4L } \\
\text { Pyxite } \\
\text { symp }\end{array}$ & $\begin{array}{c}\text { PK4L } \\
\text { Pyxite } \\
\text { core } \\
\end{array}$ & $\begin{array}{l}\text { PK4S } \\
\text { Pyxite } \\
\text { symp }\end{array}$ & $\begin{array}{l}\text { PK4S } \\
\text { Pyxite } \\
\text { symp }\end{array}$ & $\begin{array}{l}\text { PK4S } \\
\text { Pyxite } \\
\text { symp }\end{array}$ & $\begin{array}{l}\text { PK4S } \\
\text { Pyxite } \\
\text { symp }\end{array}$ & $\begin{array}{c}\text { PK4T } \\
\text { Pyxite } \\
\text { core } \\
\end{array}$ \\
\hline $\mathrm{SiO}_{2}$ & 4 & 6.22 & 0.12 & 0.11 & 2.71 & 0.05 & 0.12 & 0.06 & 0.06 & 0.63 & 0.17 & 0.70 & 0.11 \\
\hline $\mathrm{Al}_{2} \mathrm{O}_{3}$ & 1.42 & 3.89 & 1.40 & 0.11 & 0.19 & 0.15 & 0.54 & 58.13 & 0.24 & 0.38 & 3.84 & 0.97 & 0.23 \\
\hline TiO2 & 0.08 & 1.91 & 51.09 & 51.28 & 0.27 & 0.07 & 0.02 & 0.40 & 1.12 & 6.77 & 0.02 & 7.37 & 46.89 \\
\hline $\mathrm{Fe} 2 \mathrm{O} 3$ & 76.66 & 50.04 & 1.19 & 5.58 & 6278 & 69.34 & 66.52 & 5.67 & 66.19 & 55.97 & 71.06 & 53.29 & 13.56 \\
\hline $\mathrm{FeO}$ & 0.22 & 30.86 & 39.14 & 32.26 & 28.50 & 26.88 & 30.20 & 19.24 & 31.53 & 31.83 & 5.53 & 31.29 & 31.72 \\
\hline $\mathrm{MnO}$ & 0.55 & 0.30 & 0.19 & 0.37 & 0.07 & 0.04 & 0.09 & 0.16 & 0.07 & 0.35 & 1.15 & 0.33 & 0.38 \\
\hline $\mathrm{MgO}$ & 19.73 & 6.15 & 3.67 & 7.47 & 3.70 & 2.54 & 0.15 & 13.99 & 0.28 & 3.61 & 13.28 & 4.12 & 5.83 \\
\hline $\mathrm{CaO}$ & 0.08 & 0.18 & 0.04 & 0.09 & 0.13 & 0.08 & 0.06 & 0.04 & 0.04 & 0.18 & 0.06 & 0.17 & 0.14 \\
\hline $\mathrm{Cr} 2 \mathrm{O}$ & 0.13 & 0.12 & 0.16 & 0.31 & & & & & 0.00 & & 0.29 & 0.81 & 0.03 \\
\hline $\mathrm{NiO}$ & 0.18 & 0.11 & 0.16 & 0.19 & & & & & 0.44 & & 3.19 & 0.45 & 0.11 \\
\hline TOTAL & 99.28 & 99.76 & 97.16 & 97.77 & 98.33 & 99.17 & 97.69 & 97.68 & 99.97 & 99.73 & 98.58 & 99.51 & 98.25 \\
\hline $\mathrm{Si}$ & 0.008 & 0.211 & 0.003 & 0.003 & 0.102 & 0.002 & & & 0.002 & & & 0.027 & 0.003 \\
\hline Al & 0.056 & 0.155 & 0.041 & 0.003 & 0.008 & 0.007 & 0.025 & 1.864 & 0.011 & 0.018 & 0.164 & 0.045 & 0.007 \\
\hline $\mathbf{T i}$ & 0.002 & 0.049 & 0.967 & 0.946 & 0.008 & 0.002 & 0.000 & 0.008 & 0.033 & 0.188 & 0.000 & 0.203 & 0.869 \\
\hline FeIII & 1.924 & 0.934 & 0.019 & 0.099 & 1.774 & 1.985 & 1.965 & 0.116 & 1.920 & 1.557 & 1.823 & 1.469 & 0.251 \\
\hline FelI & 0.009 & 1.326 & 0.827 & 0.666 & 0.895 & 0.855 & 0.991 & 0.438 & 1.016 & 0.984 & 0.158 & 0.958 & 0.653 \\
\hline Mn & 0.016 & 0.009 & 0.004 & 0.008 & 0.002 & 0.001 & 0.003 & 0.004 & 0.002 & 0.012 & 0.035 & 0.011 & 0.008 \\
\hline $\mathbf{M g}$ & 0.982 & 0.311 & 0.138 & 0.273 & 0.207 & 0.144 & 0.009 & 0.567 & 0.016 & 0.210 & 0.718 & 0.240 & 0.207 \\
\hline $\mathrm{Ca}$ & 0.003 & 0.006 & 0.001 & 0.003 & 0.005 & 0.003 & 0.002 & 0.001 & 0.000 & 0.007 & 0.000 & 0.007 & 0.003 \\
\hline $\mathrm{Cr}$ & 0.003 & 0.000 & 0.003 & 0.000 & & & & & 0.000 & & 0.000 & 0.025 & 0.000 \\
\hline $\mathrm{Ni}$ & 0.006 & 0.000 & 0.003 & 0.000 & & & & & 0.010 & & 0.092 & 0.014 & 0.010 \\
\hline OTAL & 3.008 & 3.001 & 2.006 & 2.001 & 3.001 & 2.999 & 3.000 & 3.000 & 3.010 & 3.000 & 2.996 & 2.999 & 2.004 \\
\hline
\end{tabular}

\begin{tabular}{|c|c|c|c|c|c|c|c|c|c|c|c|c|c|}
\hline $\begin{array}{l}\text { Sample } \\
\text { Type }\end{array}$ & $\begin{array}{c}\text { PK4T } \\
\text { Pyxite } \\
\text { core }\end{array}$ & $\begin{array}{l}\text { PK4V } \\
\text { Gran } \\
\text { core }\end{array}$ & $\begin{array}{l}\text { PK4V } \\
\text { Gran } \\
\text { core } \\
\end{array}$ & $\begin{array}{l}\text { PK4Y } \\
\text { Gran } \\
\text { symp }\end{array}$ & $\begin{array}{l}\text { PK4Y } \\
\text { Gran } \\
\text { symp }\end{array}$ & $\begin{array}{l}\text { PK4Y } \\
\text { Gran } \\
\text { symp }\end{array}$ & $\begin{array}{l}\text { PK4Y } \\
\text { Gran } \\
\text { symp }\end{array}$ & $\begin{array}{l}\text { PK4Y } \\
\text { Gran } \\
\text { vein }\end{array}$ & $\begin{array}{l}\text { PK4Y } \\
\text { Gran } \\
\text { vein }\end{array}$ & $\begin{array}{l}\text { PK4Y } \\
\text { Gran } \\
\text { vein }\end{array}$ & $\begin{array}{c}\text { PK4CI } \\
\text { Gran } \\
\text { symp }\end{array}$ & $\begin{array}{l}\text { PK4C1 } \\
\text { Gran } \\
\text { core } \\
\end{array}$ & $\begin{array}{c}\text { PK4D1 } \\
\text { Pyxite } \\
\text { core } \\
\end{array}$ \\
\hline $\mathrm{SiO}_{2}$ & 0.17 & 0.03 & 0.82 & 0.36 & 0.70 & 0.11 & 0.21 & 0.23 & 0.42 & 1.06 & 1.34 & 0.13 & 0.08 \\
\hline $\mathrm{Al} 2 \mathrm{O} 3$ & 0.41 & 2.27 & 0.75 & 2.78 & 3.37 & 1.28 & 0.31 & 4.55 & 2.07 & 0.40 & 0.45 & 61.42 & 0.50 \\
\hline $\mathrm{TiO}_{2}$ & 48.89 & 53.44 & 50.59 & 0.14 & 0.17 & 2.78 & 0.16 & 0.79 & 16.53 & 7.94 & 0.57 & 0.23 & 48.37 \\
\hline $\mathrm{Fe} 2 \mathrm{O}_{3}$ & 9.25 & 0.96 & 3.42 & 73.94 & 73.16 & 64.44 & 67.46 & 63.99 & 35.78 & 52.99 & 65.07 & 4.10 & 10.81 \\
\hline $\mathrm{FeO}$ & 33.37 & 36.87 & 40.28 & 1.59 & 2.15 & 23.22 & 29.53 & 24.53 & 39.05 & 32.40 & 28.69 & 20.21 & 31.31 \\
\hline MnO & 0.41 & 0.14 & 0.24 & 1.16 & 1.16 & 0.58 & 0.26 & 0.44 & 0.54 & 0.49 & 0.37 & 0.25 & 0.22 \\
\hline $\mathrm{MgO}$ & 5.75 & 6.03 & 2.72 & 19.56 & 18.85 & 6.30 & 0.78 & 4.82 & 4.21 & 4.22 & 2.59 & 14.24 & 6.75 \\
\hline $\mathrm{CaO}$ & 0.32 & 0.02 & 0.15 & 0.10 & 0.14 & 0.12 & 0.14 & 0.15 & 0.19 & 0.18 & 0.12 & 0.01 & 0.02 \\
\hline $\mathrm{Cr}_{2} \mathrm{O}_{3}$ & 0.24 & 0.00 & 0.01 & 0.35 & 0.37 & & & & & & & & 0.17 \\
\hline $\mathrm{NiO}$ & 0.12 & 0.01 & 0.03 & & & & & & & & & & 0.03 \\
\hline TOTAL & 98.93 & 99.75 & 99.01 & 99.98 & 100.06 & 98.83 & 98.84 & 99.50 & 98.78 & 99.67 & 99.20 & 100.59 & 98.25 \\
\hline Si & 0.004 & 0.001 & 0.024 & 0.011 & 0.022 & 0.004 & 0.008 & 0.009 & 0.017 & 0.041 & 0.051 & 0.005 & 0.002 \\
\hline Al & 0.011 & 0.066 & 0.026 & 0.105 & 0.124 & 0.056 & 0.014 & 0.206 & 0.102 & 0.018 & 0.020 & 1.903 & 0.014 \\
\hline $\mathrm{Ti}$ & 0.900 & 0.958 & 0.931 & 0.004 & 0.004 & 0.077 & 0.005 & 0.021 & 0.447 & 0.219 & 0.016 & 0.005 & 0.889 \\
\hline FeIII & 0.171 & 0.017 & 0.063 & 1.864 & 1.825 & 1.782 & 1.961 & 1.734 & 0.969 & 1.463 & 1.846 & 0.081 & 0.204 \\
\hline FeII & 0.687 & 0.734 & 0.824 & 0.045 & 0.060 & 0.714 & 0.954 & 0.733 & 1.175 & 0.994 & 0.905 & 0.440 & 0.635 \\
\hline Mn & 0.008 & 0.003 & 0.006 & 0.032 & 0.030 & 0.018 & 0.008 & 0.014 & 0.019 & 0.016 & 0.012 & 0.006 & 0.004 \\
\hline $\mathbf{M g}$ & 0.205 & 0.221 & 0.120 & 0.935 & 0.931 & 0.345 & 0.045 & 0.276 & 0.262 & 0.242 & 0.145 & 0.558 & 0.246 \\
\hline $\mathrm{Ca}$ & 0.008 & 0.000 & 0.005 & 0.003 & 0.005 & 0.005 & 0.006 & 0.006 & 0.009 & 0.007 & 0.005 & & 0.006 \\
\hline $\mathrm{Cr}$ & 0.003 & 0.000 & 0.000 & 0.004 & 0.002 & & & & & & & & 0.003 \\
\hline Ni & 0.003 & 0.000 & 0.000 & & & & & & & & & & 0.001 \\
\hline TOTAL & 2.000 & 2.000 & 1.999 & 3.003 & 3.000 & 3.001 & 3.001 & 2797 & 3.000 & 3.000 & 3.000 & 2.998 & 2.004 \\
\hline
\end{tabular}


A3.2 Mount Hampton xenolith mineral analyses: glasses

\begin{tabular}{|c|c|c|c|c|c|c|c|c|c|}
\hline $\begin{array}{l}\text { Sample } \\
\text { Type }\end{array}$ & $\begin{array}{c}\text { PK4A } \\
\text { Gran } \\
\text { symp }\end{array}$ & $\begin{array}{c}\text { PK4A } \\
\text { Gran } \\
\text { symp }\end{array}$ & $\begin{array}{c}\text { PK4A } \\
\text { Gran } \\
\text { vein }\end{array}$ & $\begin{array}{c}\text { PK4A } \\
\text { Gran } \\
\text { vein } \\
\end{array}$ & $\begin{array}{l}\text { PKAL } \\
\text { Pyxite } \\
\text { symp }\end{array}$ & $\begin{array}{l}\text { PK4S } \\
\text { Pyxite } \\
\text { symp }\end{array}$ & $\begin{array}{l}\text { PK4Y } \\
\text { Gran } \\
\text { symp }\end{array}$ & $\begin{array}{l}\text { PK4Y } \\
\text { Gran } \\
\text { symp }\end{array}$ & $\begin{array}{c}\text { PK4Y } \\
\text { Gran } \\
\text { symp }\end{array}$ \\
\hline $\mathrm{SiO}_{2}$ & 56.02 & 58.27 & 58.93 & 60.77 & 49.95 & 47.70 & 56.34 & 55.67 & 56.41 \\
\hline $\mathrm{Al} 2 \mathrm{O}_{3}$ & 11.27 & 17.23 & 15.25 & 15.10 & 17.80 & 17.02 & 14.98 & 14.80 & 15.37 \\
\hline $\mathrm{TiO}_{2}$ & 3.27 & 1.61 & 2.97 & 232 & 0.97 & 3.47 & 3.08 & 2.83 & 2.73 \\
\hline $\mathrm{FeO}$ & 12.04 & 5.09 & 8.87 & 9.13 & 4.38 & 10.78 & 9.60 & 8.97 & 7.58 \\
\hline $\mathrm{MnO}$ & 0.22 & 0.14 & 0.19 & 0.03 & 0.12 & 0.23 & 0.10 & 0.11 & 0.21 \\
\hline $\mathrm{MgO}$ & 4.65 & 2.41 & 2.36 & 299 & 7.50 & 9.38 & 3.77 & 3.72 & 3.41 \\
\hline $\mathrm{CaO}$ & 9.94 & 8.03 & 2.87 & 4.31 & 17.54 & 8.36 & 4.57 & 6.58 & 5.50 \\
\hline $\mathrm{Na} 2 \mathrm{O}$ & 2.99 & 5.69 & 4.60 & 4.77 & 1.84 & 3.72 & 6.48 & 5.97 & 5.53 \\
\hline $\mathrm{K} 2 \mathrm{O}$ & 0.76 & 1.69 & 4.50 & 0.76 & 0.02 & 0.09 & 2.16 & 2.27 & 1.97 \\
\hline TOTAL & 101.16 & 100.16 & 100.54 & 100.17 & 100.12 & 100.76 & 101.07 & 100.92 & 98.70 \\
\hline Mg\# & 40.76 & 45.74 & 32.12 & 36.88 & 75.32 & 60.78 & 41.15 & 42.52 & 44.51 \\
\hline $\mathbf{Q}$ & 9.70 & 0.88 & 3.31 & 13.32 & 0.00 & 0.00 & 0.00 & 0.00 & 0.47 \\
\hline Or & 4.49 & 9.99 & 26.59 & 4.49 & 0.12 & 0.53 & 12.76 & 13.42 & 11.64 \\
\hline $\mathbf{A b}$ & 25.30 & 48.15 & 38.93 & 40.36 & 15.57 & 31.43 & 50.00 & 42.67 & 46.80 \\
\hline An & 15.09 & 16.48 & 7.67 & 17.55 & 40.25 & 29.48 & 5.41 & 6.88 & 11.30 \\
\hline $\mathrm{Ne}$ & 0.00 & 0.00 & 0.00 & 0.00 & 0.00 & 0.02 & 2.62 & 4.25 & 0.00 \\
\hline $\mathrm{Di}$ & 28.30 & 19.15 & 5.48 & 3.19 & 37.24 & 9.66 & 14.22 & 21.19 & 13.09 \\
\hline $\mathrm{Hy}$ & 8.94 & 1.14 & 10.59 & 14.49 & 3.97 & 0.00 & 0.00 & 0.00 & 8.27 \\
\hline OI & 0.00 & 0.00 & 0.00 & 0.00 & 0.00 & 20.23 & 7.73 & 4.81 & 0.00 \\
\hline Mt & 0.00 & 0.00 & 0.00 & 0.00 & 0.00 & 0.00 & 0.00 & 0.00 & 0.00 \\
\hline II & 6.21 & 3.06 & 5.64 & 4.41 & 1.84 & 6.59 & 5.85 & 5.37 & 5.18 \\
\hline Ap & 0.00 & 0.00 & 0.00 & 0.00 & 0.00 & 0.00 & 0.00 & 0.00 & 0.00 \\
\hline TOTAL & 98.03 & 98.85 & 98.21 & 97.81 & 98.99 & 97.94 & 98.59 & 98.59 & 96.75 \\
\hline
\end{tabular}

\begin{tabular}{|c|c|c|c|c|c|c|c|c|c|}
\hline $\begin{array}{l}\text { Sample } \\
\text { Type }\end{array}$ & $\begin{array}{l}\text { PK4Y } \\
\text { Gran } \\
\text { vein } \\
\end{array}$ & $\begin{array}{l}\text { PK4Y } \\
\text { Gran } \\
\text { vein } \\
\end{array}$ & $\begin{array}{l}\text { PK4Y } \\
\text { Gran } \\
\text { vein }\end{array}$ & $\begin{array}{l}\text { PK4Y } \\
\text { Gran } \\
\text { vein } \\
\end{array}$ & $\begin{array}{l}\text { PK4Y } \\
\text { Gran } \\
\text { symp }\end{array}$ & $\begin{array}{l}\text { PK4Y } \\
\text { Gran } \\
\text { symp }\end{array}$ & $\begin{array}{c}\text { PK4C1 } \\
\text { Gran } \\
\text { symp }\end{array}$ & $\begin{array}{c}\text { PK4CI } \\
\text { Gran } \\
\text { symp }\end{array}$ & $\begin{array}{c}\mathrm{PK} 4 \mathrm{Cl} \\
\text { Gran } \\
\text { symp } \\
\end{array}$ \\
\hline $\mathrm{SiO}_{2}$ & 52.59 & 56.01 & 51.70 & 56.25 & 56.84 & 57.80 & 56.96 & 56.43 & 49.25 \\
\hline $\mathrm{A}_{12} \mathrm{O}_{3}$ & 16.57 & 15.05 & 14.94 & 13.54 & 15.76 & 15.45 & 17.09 & 15.17 & 10.58 \\
\hline $\mathrm{TiO} 2$ & 2.82 & 4.42 & 4.20 & 3.41 & 3.19 & 3.39 & 3.65 & 6.17 & 3.08 \\
\hline $\mathrm{FeO}$ & 9.09 & 11.51 & 12.09 & 9.78 & 6.04 & 6.14 & 7.32 & 5.37 & 11.43 \\
\hline $\mathrm{MnO}$ & 0.16 & 0.23 & 0.27 & 0.15 & 0.19 & 0.08 & 0.17 & 0.05 & 0.14 \\
\hline $\mathrm{MgO}$ & 2.41 & 3.14 & 276 & 3.52 & 3.80 & 3.90 & 3.54 & 2.00 & 15.19 \\
\hline $\mathrm{CaO}$ & 6.31 & 5.25 & 4.78 & 4.11 & 8.65 & 5.33 & 6.88 & 3.66 & 5.86 \\
\hline $\mathrm{Na} 2 \mathrm{O}$ & 7.49 & 4.33 & 5.89 & 5.14 & 4.49 & 5.79 & 3.74 & 3.42 & 3.16 \\
\hline $\mathrm{K} 2 \mathrm{O}$ & 3.32 & 1.28 & 3.13 & 3.52 & 1.34 & 1.95 & 1.50 & 4.34 & 1.30 \\
\hline TOTAL & 100.76 & 101.23 & 99.75 & 99.44 & 100.29 & 99.83 & 100.85 & 96.61 & 99.99 \\
\hline Mg\# & 32.10 & 32.73 & 28.93 & 39.09 & 52.85 & 53.09 & 46.32 & 39.85 & 70.31 \\
\hline $\mathbf{Q}$ & 0.00 & 7.77 & 0.00 & 0.00 & 5.08 & 1.56 & 9.39 & 10.17 & 0.00 \\
\hline Or & 19.62 & 7.56 & 18.50 & 20.80 & 7.92 & 11.52 & 8.86 & 25.65 & 7.68 \\
\hline $\mathbf{A b}$ & 24.89 & 36.64 & 34.33 & 43.50 & 37.99 & 49.00 & 31.65 & 28.94 & 26.74 \\
\hline An & 1.79 & 17.85 & 5.08 & 3.48 & 18.89 & 10.41 & 25.42 & 13.22 & 10.85 \\
\hline $\mathrm{Ne}$ & 20.85 & 0.00 & 8.40 & 0.00 & 0.00 & 0.00 & 0.00 & 0.00 & 0.00 \\
\hline $\mathrm{Di}$ & 24.66 & 6.81 & 15.61 & 13.95 & 19.27 & 1282 & 7.05 & 3.84 & 14.55 \\
\hline $\mathrm{Hy}$ & 0.00 & 13.19 & 0.00 & 5.52 & 3.53 & 6.49 & 9.65 & 3.20 & 5.44 \\
\hline Ol & 1.23 & 0.00 & 6.92 & 3.16 & 0.00 & 0.00 & 0.00 & 0.00 & 25.91 \\
\hline Mt & 0.00 & 0.00 & 0.00 & 0.00 & 0.00 & 0.00 & 0.00 & 3.38 & 0.00 \\
\hline II & 5.36 & 8.39 & 7.98 & 6.48 & 6.06 & 6.44 & 6.93 & 11.72 & 5.85 \\
\hline Ap & 0.00 & 0.00 & 0.00 & 0.00 & 0.00 & 0.00 & 0.00 & 0.00 & 0.00 \\
\hline TOTAL & 98.4 & 98.21 & 96.82 & 96.89 & 98.74 & 98.24 & 98.95 & 100.12 & 97.02 \\
\hline
\end{tabular}




\section{A3.3 Mount Murphy xenolith mineral analyses: olivine}

\begin{tabular}{|c|c|c|c|c|c|c|c|c|c|c|c|c|c|c|}
\hline $\begin{array}{l}\text { Sample } \\
\text { Type }\end{array}$ & $\begin{array}{c}90041 \mathrm{~A} \\
\text { Gran } \\
\text { oxid r }\end{array}$ & $\begin{array}{c}90041 \mathrm{~A} \\
\text { Gran } \\
\text { symp c- }\end{array}$ & $\begin{array}{c}\text { 90041A } \\
\text { Gran } \\
\text { symp c- }\end{array}$ & $\begin{array}{c}90041 \mathrm{~A} \\
\text { Gran } \\
\text { symp z- }\end{array}$ & $\begin{array}{c}90041 \mathrm{~A} \\
\text { Gran } \\
\text { symp r- }\end{array}$ & $\begin{array}{c}\text { 90041B } \\
\text { Gran } \\
\text { core } \\
\end{array}$ & $\begin{array}{c}90041 B \\
\text { Gran } \\
\text { core }\end{array}$ & $\begin{array}{c}90041 B \\
\text { Gran } \\
\text { core }\end{array}$ & $\begin{array}{c}90041 B \\
\text { Gran } \\
\text { core }\end{array}$ & $\begin{array}{c}90041 B \\
\text { Gran } \\
\text { core }\end{array}$ & $\begin{array}{l}\text { 90041B } \\
\text { Gran } \\
\text { core }\end{array}$ & $\begin{array}{c}90041 B \\
\text { Gran } \\
\text { core }\end{array}$ & $\begin{array}{c}\text { 90041B } \\
\text { Gran } \\
\text { core }\end{array}$ & $\begin{array}{c}90041 B \\
\text { Gran } \\
\text { core } \\
\end{array}$ \\
\hline $\mathrm{SiO}_{2}$ & 43.42 & 39.47 & 43.01 & 39.41 & 42.63 & 39.52 & 39.35 & 39.44 & 39.39 & 39.35 & 38.75 & 39.08 & 39.80 & 39.95 \\
\hline $\mathrm{A} 12 \mathrm{O}$ & 0.04 & 0.04 & 0.00 & 0.93 & 0.08 & 0.01 & 0.05 & 0.06 & 0.00 & 0.04 & 0.07 & 0.06 & 0.04 & 0.00 \\
\hline TiO2 & 0.00 & 0.00 & 0.00 & 0.26 & 0.04 & 0.03 & 0.05 & 0.07 & 0.06 & 0.00 & 0.00 & 0.05 & 0.08 & 0.08 \\
\hline $\mathrm{FeO}$ & 1.52 & 28.92 & 2.35 & 28.69 & 1.19 & 17.47 & 17.78 & 17.00 & 17.90 & 17.42 & 17.40 & 17.95 & 17.08 & 17.12 \\
\hline $\mathrm{MnO}$ & 0.27 & 0.39 & 0.22 & 0.57 & 0.31 & 0.36 & 0.49 & 0.48 & 0.27 & 0.27 & 0.29 & 0.32 & 0.33 & 0.45 \\
\hline $\mathrm{MgO}$ & 54.46 & 30.47 & 54.79 & 29.19 & 55.92 & 42.91 & 43.17 & 42.81 & 42.62 & 42.76 & 43.50 & 42.53 & 43.32 & 43.03 \\
\hline $\mathrm{CaO}$ & 0.08 & 0.04 & 0.00 & 0.76 & 0.17 & 0.05 & 0.02 & 0.04 & 0.02 & 0.07 & 0.02 & 0.03 & 0.02 & 0.03 \\
\hline $\mathrm{Na}_{2} \mathrm{O}$ & 0.01 & 0.10 & 0.00 & 0.28 & 0.12 & 0.08 & 0.00 & 0.03 & 0.07 & 0.00 & 0.16 & 0.06 & 0.12 & 0.10 \\
\hline $\mathrm{K} 2 \mathrm{O}$ & 0.03 & 0.00 & 0.00 & 0.05 & 0.02 & 0.01 & 0.00 & 0.00 & 0.01 & 0.00 & 0.00 & 0.02 & 0.03 & 0.02 \\
\hline $\mathrm{Cr} 2 \mathrm{O} 3$ & 0.46 & 0.09 & 0.16 & 0.31 & 0.17 & & & & & & & & & \\
\hline TOTAL & 100.29 & 99.52 & 100.53 & 100.44 & 100.63 & 100.45 & 100.92 & 99.95 & 100.34 & 99.91 & 100.19 & 100.10 & 100.82 & 100.78 \\
\hline Si & 1.019 & 1.057 & 1.011 & 1.049 & 0.999 & 0.998 & 0.991 & 1.000 & 1.000 & 0.997 & 0.981 & 0.992 & 0.999 & 1.002 \\
\hline Al & 0.001 & 0.001 & 0.000 & 0.028 & 0.002 & 0.000 & 0.000 & 0.000 & 0.000 & 0.000 & 0.002 & 0.001 & 0.001 & 0.000 \\
\hline $\mathrm{Ti}$ & 0.000 & 0.000 & 0.000 & 0.005 & 0.001 & 0.000 & 0.000 & 0.000 & 0.001 & 0.000 & 0.000 & 0.000 & 0.001 & 0.000 \\
\hline $\mathbf{F e}$ & 0.030 & 0.648 & 0.046 & 0.638 & 0.023 & 0.369 & 0.374 & 0.360 & 0.371 & 0.369 & 0.368 & 0.381 & 0.358 & 0.359 \\
\hline Mn & 0.006 & 0.009 & 0.004 & 0.013 & 0.006 & 0.007 & 0.010 & 0.010 & 0.006 & 0.005 & 0.006 & 0.006 & 0.007 & 0.009 \\
\hline Mg & 1.904 & 1.216 & 1.919 & 1.157 & 1.952 & 1.615 & 1.619 & 1.617 & 1.611 & 1.615 & 1.641 & 1.609 & 1.620 & 1.609 \\
\hline $\mathrm{Ca}$ & 0.002 & 0.001 & 0.000 & 0.021 & 0.004 & 0.001 & 0.000 & 0.000 & 0.000 & 0.001 & 0.000 & 0.000 & 0.000 & 0.000 \\
\hline $\mathrm{Na}$ & 0.000 & 0.005 & 0.000 & 0.014 & 0.005 & 0.003 & 0.000 & 0.000 & 0.000 & 0.000 & 0.007 & 0.003 & 0.006 & 0.005 \\
\hline K & 0.001 & 0.000 & 0.000 & 0.002 & 0.000 & 0.000 & 0.000 & 0.000 & 0.000 & 0.000 & 0.000 & 0.000 & 0.000 & 0.000 \\
\hline $\mathrm{Cr}$ & 0.009 & 0.002 & 0.003 & 0.006 & 0.003 & & & & & & & & & \\
\hline TOTAL & 2971 & 2.938 & 2.982 & 2.933 & 2.997 & 2.993 & 2.994 & 2987 & 2.989 & 2.987 & 3.005 & 2.992 & 2.992 & 2.984 \\
\hline Mg\# & 98.46 & 65.25 & 97.66 & 64.46 & 98.82 & 81.40 & 81.23 & 81.79 & 81.28 & 81.40 & 81.68 & 80.85 & 81.90 & 81.76 \\
\hline
\end{tabular}

\begin{tabular}{|c|c|c|c|c|c|c|c|c|c|c|c|c|c|c|}
\hline $\begin{array}{l}\text { Sample } \\
\text { Type }\end{array}$ & $\begin{array}{c}\text { 90048D } \\
\text { Pyxite } \\
\text { core }\end{array}$ & $\begin{array}{c}\text { 90048D } \\
\text { Pyxite } \\
\text { core }\end{array}$ & $\begin{array}{c}\text { 90048D } \\
\text { Pyxite } \\
\text { melt }\end{array}$ & $\begin{array}{c}90048 D \\
\text { Pyxite } \\
\text { melt }\end{array}$ & $\begin{array}{c}\text { 90048E } \\
\text { Gran } \\
\text { core }\end{array}$ & $\begin{array}{c}90048 E \\
\text { Gran } \\
\text { melt }\end{array}$ & $\begin{array}{c}90048 E \\
\text { Gran } \\
\text { melt }\end{array}$ & $\begin{array}{c}90048 E \\
\text { Gran } \\
\text { core } \\
\end{array}$ & $\begin{array}{c}90048 \mathrm{E} \\
\text { Gran } \\
\text { melt }\end{array}$ & $\begin{array}{c}\text { 90048E } \\
\text { Gran } \\
\text { melt }\end{array}$ & $\begin{array}{c}90048 \mathrm{~F} \\
\text { Gran } \\
\text { core }\end{array}$ & $\begin{array}{c}90048 \mathrm{~F} \\
\text { Gran } \\
\text { core }\end{array}$ & $\begin{array}{c}90048 F \\
\text { Gran } \\
\text { core }\end{array}$ & $\begin{array}{c}90048 \mathrm{~F} \\
\text { Gran } \\
\text { core } \\
\end{array}$ \\
\hline $\mathrm{SiO}_{2}$ & 36.98 & 37.48 & 38.78 & 38.33 & 37.00 & 38.18 & 38.46 & 36.25 & 38.37 & 39.03 & 37.05 & 38.20 & 37.38 & 38.40 \\
\hline $\mathrm{A} 12 \mathrm{O} 3$ & 0.06 & 0.06 & 0.11 & 0.07 & 0.03 & 0.09 & 0.10 & 0.01 & 0.07 & 0.05 & 0.07 & 0.13 & 0.07 & 0.09 \\
\hline $\mathrm{TiO}_{2}$ & 0.08 & 0.08 & 0.22 & 0.27 & 0.02 & 0.06 & 0.05 & 0.01 & 0.10 & 0.08 & 0.02 & 0.07 & 0.08 & 0.13 \\
\hline $\mathrm{FeO}$ & 27.12 & 26.71 & 20.55 & 22.36 & 30.51 & 19.24 & 19.45 & 32.95 & 20.67 & 19.79 & 26.22 & 25.62 & 24.94 & 26.06 \\
\hline $\mathrm{MnO}$ & 0.38 & 0.32 & 0.34 & 0.56 & 0.32 & 0.24 & 0.20 & 0.57 & 0.21 & 0.24 & 0.54 & 0.40 & 0.33 & 0.36 \\
\hline MgO & 35.67 & 35.07 & 39.63 & 38.00 & 32.81 & 40.94 & 40.55 & 29.80 & 39.32 & 40.93 & 35.71 & 35.25 & 34.09 & 34.63 \\
\hline $\mathrm{CaO}$ & 0.22 & 0.20 & 0.40 & 0.42 & 0.37 & 0.27 & 0.34 & 0.18 & 0.42 & 0.31 & 0.17 & 0.23 & 0.23 & 0.22 \\
\hline $\mathrm{Na}_{2} \mathrm{O}$ & 0.04 & 0.10 & 0.01 & 0.00 & 0.00 & 0.04 & 0.04 & 0.00 & 0.02 & 0.00 & 0.00 & 0.04 & 0.27 & 0.14 \\
\hline $\mathrm{K} 2 \mathrm{O}$ & 0.01 & 0.02 & 0.02 & 0.03 & 0.00 & 0.00 & 0.00 & 0.00 & 0.02 & 0.00 & 0.00 & 0.00 & 0.33 & 0.04 \\
\hline $\mathrm{Cr} 2 \mathrm{O}_{3}$ & 0.04 & 0.01 & 0.23 & 0.04 & & & & & & & & 0.08 & 2.24 & 0.05 \\
\hline TOTAL & 100.59 & 100.06 & 100.29 & 100.08 & 101.06 & 99.06 & 99.19 & 99.77 & 99.20 & 100.43 & 99.78 & 100.03 & 99.96 & 100.12 \\
\hline Si & 0.982 & 0.997 & 1.001 & 0.999 & 0.992 & 0.989 & 0.996 & 0.998 & 0.999 & 0.998 & 0.987 & 1.009 & 0.995 & 1.015 \\
\hline Al & 0.002 & 0.002 & 0.003 & 0.002 & 0.000 & 0.000 & 0.003 & 0.000 & 0.002 & 0.004 & 0.002 & 0.004 & 0.002 & 0.003 \\
\hline $\mathrm{Ti}$ & 0.002 & 0.002 & 0.004 & 0.005 & 0.000 & 0.000 & 0.001 & 0.000 & 0.002 & 0.001 & 0.000 & 0.001 & 0.001 & 0.002 \\
\hline $\mathrm{Fe}$ & 0.602 & 0.594 & 0.443 & 0.487 & 0.684 & 0.417 & 0.421 & 0.759 & 0.450 & 0.423 & 0.584 & 0.566 & 0.555 & 0.576 \\
\hline Mn & 0.008 & 0.007 & 0.007 & 0.012 & 0.010 & 0.010 & 0.004 & 0.013 & 0.005 & 0.005 & 0.012 & 0.009 & 0.007 & 0.008 \\
\hline $\mathbf{M g}$ & 1.411 & 1.389 & 1.524 & 1.476 & 1.311 & 1.582 & 1.566 & 1.223 & 1.526 & 1.561 & 1.418 & 1.387 & 1.352 & 1.363 \\
\hline $\mathrm{Ca}$ & 0.006 & 0.005 & 0.001 & 0.011 & 0.010 & 0.010 & 0.009 & 0.005 & 0.012 & 0.008 & 0.005 & 0.006 & 0.006 & 0.006 \\
\hline $\mathrm{Na}$ & 0.002 & 0.005 & 0.000 & 0.000 & 0.000 & 0.000 & 0.002 & 0.000 & 0.001 & 0.000 & 0.000 & 0.002 & 0.013 & 0.007 \\
\hline $\mathbf{K}$ & 0.000 & 0.001 & 0.001 & 0.001 & 0.000 & 0.000 & 0.000 & 0.000 & 0.001 & 0.000 & 0.000 & 0.000 & 0.011 & 0.001 \\
\hline $\mathrm{Cr}$ & 0.001 & 0.000 & 0.005 & 0.001 & & & & & & & & 0.002 & 0.047 & 0.001 \\
\hline TOTAL & 3.015 & 3.002 & 2.989 & 2.994 & 3.007 & 3.008 & 3.002 & 2998 & 2.998 & 3.000 & 3.008 & 2.986 & 2.988 & 2.981 \\
\hline Mg\# & 70.09 & 70.05 & 77.48 & 75.18 & 65.71 & 79.14 & 78.81 & 61.71 & 77.23 & 78.68 & 70.83 & 71.04 & 70.90 & 70.30 \\
\hline
\end{tabular}




\begin{tabular}{|c|c|c|c|c|c|c|c|c|c|c|c|c|c|c|}
\hline $\begin{array}{l}\text { Sample } \\
\text { Type }\end{array}$ & $\begin{array}{c}90041 \mathrm{G} \\
\text { Gran } \\
\text { oxid dk- }\end{array}$ & $\begin{array}{c}90041 \mathrm{C} \\
\text { Gran } \\
\text {-oxid lgt }\end{array}$ & $\begin{array}{c}90041 \mathrm{G} \\
\text { Gran } \\
\text { t oxid dk- }\end{array}$ & $\begin{array}{c}90041 \mathrm{C} \\
\text { Gran } \\
\text { - oxid lgt }\end{array}$ & $\begin{array}{c}90041 \mathrm{G} \\
\text { Gran } \\
\text { core }\end{array}$ & $\begin{array}{c}900411 \\
\text { Gran } \\
\text { core } \\
\end{array}$ & $\begin{array}{c}90041 \mathrm{II} \\
\text { Gran } \\
\text { core } \\
\end{array}$ & $\begin{array}{c}900411 \\
\text { Gran } \\
\text { core } \\
\end{array}$ & $\begin{array}{c}900411 \\
\text { Gran } \\
\text { core } \\
\end{array}$ & $\begin{array}{c}90041 I \\
\text { Gran } \\
\text { core }\end{array}$ & $\begin{array}{c}90041 I \\
\text { Gran } \\
\text { oxid lgt- }\end{array}$ & $\begin{array}{c}900411 \\
\text { Gran } \\
\text { oxid dk }\end{array}$ & $\begin{array}{c}90041 \mathrm{I} \\
\text { Gran } \\
\text { oxid dk }\end{array}$ & $\begin{array}{l}900411 \\
\text { Gran } \\
\text { oxid lgt- }\end{array}$ \\
\hline $\mathrm{SiO}_{2}$ & 39.12 & 37.13 & 39.67 & 38.16 & 39.34 & 40.92 & 39.83 & 39.73 & 39.50 & 39.18 & 36.93 & 41.59 & 41.25 & 37.79 \\
\hline $\mathrm{Al} 2 \mathrm{O} 3$ & 0.12 & 0.01 & 0.01 & 0.04 & 0.02 & 0.05 & 0.11 & 0.08 & 0.04 & 0.01 & 0.01 & 0.00 & 0.00 & 0.00 \\
\hline $\mathrm{TiO}_{2}$ & 0.01 & 0.03 & 0.08 & 0.03 & 0.08 & 0.01 & 0.02 & 0.00 & 0.00 & 0.04 & 0.01 & 0.00 & 0.00 & 0.01 \\
\hline $\mathrm{FeO}$ & 17.55 & 37.58 & 16.44 & 38.70 & 17.87 & 16.50 & 16.82 & 14.94 & 16.72 & 18.58 & 48.60 & 10.07 & 9.40 & 37.88 \\
\hline $\mathrm{MnO}$ & 0.31 & 0.27 & 0.34 & 0.30 & 0.31 & 0.24 & 0.33 & 0.27 & 0.45 & 0.31 & 0.18 & 0.10 & 0.26 & 0.25 \\
\hline $\mathrm{MgO}$ & 42.32 & 24.30 & 43.24 & 2271 & 41.96 & 42.34 & 42.70 & 44.79 & 43.78 & 41.88 & 12.85 & 48.04 & 48.82 & 24.39 \\
\hline $\mathrm{CaO}$ & 0.03 & 0.07 & 0.03 & 0.05 & 0.09 & 0.01 & 0.08 & 0.04 & 0.01 & 0.05 & 0.14 & 0.01 & 0.04 & 0.04 \\
\hline $\mathrm{Na} 2 \mathrm{O}$ & 0.11 & 0.10 & 0.00 & 0.10 & 0.12 & 0.01 & 0.07 & 0.04 & 0.01 & 0.00 & 0.27 & 0.00 & 0.00 & 0.01 \\
\hline $\mathrm{K} 2 \mathrm{O}$ & 0.09 & 0.01 & 0.05 & 0.01 & 0.02 & 0.03 & 0.01 & 0.03 & 0.00 & 0.00 & 0.01 & 0.00 & 0.00 & 0.03 \\
\hline $\mathrm{Cr} 2 \mathrm{O}_{3}$ & 0.35 & 0.31 & 0.13 & 0.04 & 0.07 & 0.17 & 0.04 & 0.11 & 0.12 & 0.00 & 0.07 & 0.02 & 0.09 & 0.12 \\
\hline TOTAL & 100.01 & 99.79 & 99.99 & 100.13 & 99.87 & 100.29 & 100.02 & 100.01 & 100.65 & 100.05 & 99.05 & 99.83 & 99.86 & 100.52 \\
\hline $\mathrm{Si}$ & 0.996 & 1.039 & 1.003 & 1.066 & 1.002 & 1.027 & 1.008 & 0.997 & 0.994 & 1.000 & 1.100 & 1.018 & 1.009 & 1.049 \\
\hline Al & 0.003 & 0.000 & 0.000 & 0.001 & 0.000 & 0.000 & 0.000 & 0.002 & 0.001 & 0.000 & 0.000 & 0.000 & 0.000 & 0.000 \\
\hline $\mathrm{Ti}$ & 0.000 & 0.000 & 0.001 & 0.000 & 0.001 & 0.000 & 0.000 & 0.000 & 0.000 & 0.001 & 0.000 & 0.000 & 0.000 & 0.000 \\
\hline $\mathrm{Fe}$ & 0.737 & 0.879 & 0.347 & 0.904 & 0.380 & 0.346 & 0.355 & 0.313 & 0.352 & 0.397 & 1.210 & 0.206 & 0.192 & 0.879 \\
\hline $\mathrm{Mn}$ & 0.006 & 0.006 & 0.007 & 0.007 & 0.006 & 0.005 & 0.006 & 0.005 & 0.009 & 0.007 & 0.005 & 0.002 & 0.005 & 0.006 \\
\hline $\mathrm{Mg}$ & 1.606 & 1.014 & 1.628 & 0.945 & 1.593 & 1.584 & 1.609 & 1.676 & 1.642 & 1.592 & 0.570 & 1.752 & 1.778 & 1.009 \\
\hline $\mathrm{Ca}$ & 0.000 & 0.002 & 0.000 & 0.001 & 0.002 & 0.000 & 0.002 & 0.000 & 0.000 & 0.001 & 0.004 & 0.000 & 0.001 & 0.001 \\
\hline $\mathrm{Na}$ & 0.006 & 0.005 & 0.000 & 0.005 & 0.005 & 0.000 & 0.000 & 0.001 & 0.000 & 0.000 & 0.016 & 0.000 & 0.000 & 0.001 \\
\hline K & 0.002 & 0.000 & 0.001 & 0.000 & 0.000 & 0.001 & 0.000 & 0.000 & 0.000 & 0.000 & 0.000 & 0.000 & 0.000 & 0.001 \\
\hline $\mathrm{Cr}_{\mathrm{r}}$ & 0.004 & 0.007 & 0.002 & 0.000 & 0.001 & 0.003 & 0.000 & 0.002 & 0.002 & 0.000 & 0.002 & 0.000 & 0.002 & 0.003 \\
\hline TOTAL & 3.359 & 2.952 & 2.989 & 2.929 & 2.990 & 2.966 & 2980 & 2996 & 3.000 & 2.998 & 2.906 & 2.978 & 2.987 & 2.949 \\
\hline$M$ & 68.54 & 53.57 & 82.43 & 51.11 & 80.74 & 82.07 & 81.92 & 84.26 & 82.35 & 80.06 & 32.03 & 89.48 & 90.25 & 53.43 \\
\hline
\end{tabular}

\begin{tabular}{|c|c|c|c|c|c|c|c|c|c|c|c|c|c|c|}
\hline $\begin{array}{l}\text { Sample } \\
\text { Type }\end{array}$ & $\begin{array}{c}90048 \mathrm{G} \\
\text { Gran } \\
\text { core }\end{array}$ & $\begin{array}{c}900486 \\
\text { Gran } \\
\text { core } \\
\end{array}$ & $\begin{array}{c}0054 \mathrm{C} \\
\text { Pyxite } \\
\text { core } \\
\end{array}$ & $\begin{array}{c}90054 \mathrm{C} \\
\text { Pyxite } \\
\text { core } \\
\end{array}$ & $\begin{array}{c}90054 \mathrm{C} \\
\text { Pyxite } \\
\text { core } \\
\end{array}$ & $\begin{array}{c}90054 \mathrm{C} \\
\text { Pyxite } \\
\text { core } \\
\end{array}$ & $\begin{array}{c}90054 \mathrm{I} \\
\text { Pyxite } \\
\text { core- } \\
\end{array}$ & $\begin{array}{l}90054 I \\
\text { Pyxite } \\
\text { oxid dk-0 }\end{array}$ & $\begin{array}{c}90054 I \\
\text { Pyxite } \\
\text { oxid Igt }\end{array}$ & $\begin{array}{c}900541 \\
\text { Pyxite } \\
\text { core } \\
\end{array}$ & $\begin{array}{c}90054 \mathrm{I} \\
\text { Pyxite } \\
\text { oxid dk- }\end{array}$ & $\begin{array}{c}90054 \mathrm{I} \\
\text { Pyxite } \\
\text { oxid lgt }\end{array}$ & $\begin{array}{c}90054 \mathrm{I} \\
\text { Pyxite } \\
\text { core } \\
\end{array}$ & $\begin{array}{c}900541 \\
\text { Pyxite } \\
\text { core }\end{array}$ \\
\hline $\mathrm{SiO}_{2}$ & 34.63 & 34.96 & 38.24 & 38.60 & 38.75 & 38.26 & 38.62 & 40.19 & 37.52 & 38.80 & 40.11 & 37.17 & 39.23 & 39.93 \\
\hline $\mathrm{Al} 2 \mathrm{O}_{3}$ & 0.08 & 0.07 & 0.05 & 0.15 & 0.12 & 0.11 & 0.04 & 0.00 & 0.35 & 0.04 & 0.05 & 0.29 & 0.05 & 0.05 \\
\hline $\mathrm{TiO}_{2}$ & 0.06 & 0.10 & 0.28 & 0.07 & 0.04 & 0.11 & 0.04 & 0.02 & 0.05 & 0.11 & 0.01 & 0.06 & 0.01 & 0.04 \\
\hline $\mathrm{FeO}$ & 36.12 & 37.64 & 21.83 & 21.19 & 21.06 & 21.80 & 19.61 & 13.65 & 44.62 & 17.66 & 12.93 & 39.88 & 18.07 & 16.99 \\
\hline $\mathrm{MnO}$ & 0.74 & 0.86 & 0.30 & 0.38 & 0.35 & 0.34 & 0.19 & 0.26 & 0.34 & 0.35 & 0.26 & 0.34 & 0.22 & 0.35 \\
\hline $\mathrm{MgO}$ & 28.23 & 25.96 & 38.82 & 39.33 & 39.02 & 38.93 & 41.68 & 45.38 & 16.03 & 43.30 & 46.72 & 21.76 & 42.38 & 43.28 \\
\hline $\mathrm{CaO}$ & 0.19 & 0.18 & 0.22 & 0.11 & 0.17 & 0.15 & 0.11 & 0.11 & 0.34 & 0.33 & 0.08 & 0.32 & 0.11 & 0.13 \\
\hline $\mathrm{Na} 2 \mathrm{O}$ & 0.00 & 0.28 & 0.00 & 0.00 & 0.07 & 0.12 & 0.01 & 0.00 & 0.23 & 0.09 & 0.00 & 0.48 & 0.00 & 0.07 \\
\hline $\mathrm{K}_{2} \mathrm{O}$ & 0.02 & 0.06 & 0.00 & 0.04 & 0.00 & 0.00 & 0.04 & 0.00 & 0.05 & 0.06 & 0.02 & 0.08 & 0.01 & 0.03 \\
\hline $\mathrm{Cr} 2 \mathrm{O}_{3}$ & 0.26 & 0.00 & 0.00 & 0.15 & 0.22 & 0.08 & 0.10 & 0.10 & 0.21 & 0.20 & & & & \\
\hline TOTAL & 100.32 & 100.10 & 99.74 & 100.02 & 99.80 & 99.90 & 100.42 & 99.71 & 99.75 & 100.93 & 100.18 & 100.37 & 100.07 & 100.86 \\
\hline $\mathrm{Si}$ & 0.970 & 0.988 & 0.995 & 0.998 & 1.003 & 0.995 & 0.987 & 1.004 & 1.085 & 0.981 & 0.996 & 1.048 & 0.998 & 1.003 \\
\hline Al & 0.008 & 0.002 & 0.002 & 0.004 & 0.004 & 0.003 & 0.001 & 0.000 & 0.012 & 0.001 & 0.001 & 0.009 & 0.001 & 0.001 \\
\hline Ti & 0.001 & 0.002 & 0.005 & 0.001 & 0.001 & 0.002 & 0.001 & 0.000 & 0.001 & 0.002 & 0.000 & 0.001 & 0.000 & 0.000 \\
\hline Fe & 0.846 & 0.890 & 0.475 & 0.458 & 0.456 & 0.474 & 0.419 & 0.285 & 1.079 & 0.373 & 0.268 & 0.940 & 0.384 & 0.356 \\
\hline Mn & 0.017 & 0.020 & 0.006 & 0.008 & 0.007 & 0.007 & 0.004 & 0.005 & 0.008 & 0.007 & 0.005 & 0.008 & 0.004 & 0.007 \\
\hline $\mathrm{Mg}$ & 1.177 & 1.093 & 1.504 & 1.515 & 1.505 & 1.508 & 1.588 & 1.689 & 0.691 & 1.631 & 1.728 & 0.914 & 1.607 & 1.619 \\
\hline $\mathrm{Ca}$ & 0.005 & 0.005 & 0.006 & 0.003 & 0.005 & 0.004 & 0.003 & 0.003 & 0.010 & 0.009 & 0.002 & 0.009 & 0.002 & 0.003 \\
\hline $\mathrm{Na}$ & 0.000 & 0.015 & 0.000 & 0.000 & 0.003 & 0.006 & 0.000 & 0.000 & 0.013 & 0.005 & 0.000 & 0.025 & 0.000 & 0.003 \\
\hline K & 0.001 & 0.002 & 0.000 & 0.001 & 0.000 & 0.000 & 0.001 & 0.000 & 0.002 & 0.002 & 0.000 & 0.002 & 0.000 & 0.001 \\
\hline $\mathrm{Cr}_{\mathrm{r}}$ & 0.006 & 0.000 & 0.000 & 0.003 & 0.004 & 0.002 & 0.002 & 0.002 & 0.006 & 0.004 & & & & \\
\hline TOTAL & 3.025 & 3.017 & 2.993 & 2.993 & 2.988 & 3.000 & 3.006 & 2988 & 2906 & 3.014 & 3.000 & 2.956 & 2.996 & 2.993 \\
\hline Mg\# & 58.20 & 55.14 & 76.01 & 76.79 & 76.76 & 76.09 & 79.12 & 85.56 & 39.03 & 81.38 & 86.57 & 49.30 & 80.71 & 81.97 \\
\hline
\end{tabular}




\begin{tabular}{|c|c|c|c|c|c|c|c|c|}
\hline $\begin{array}{l}\text { Sample } \\
\text { Type }\end{array}$ & $\begin{array}{c}90041 I \\
\text { Gran } \\
\text { oxid dk } \\
\end{array}$ & $\begin{array}{c}90048 B \\
\text { Pyxite } \\
\text { core }\end{array}$ & $\begin{array}{c}90048 B \\
\text { Pyxite } \\
\text { core }\end{array}$ & $\begin{array}{c}90048 B \\
\text { Pyxite } \\
\text { core } \\
\end{array}$ & $\begin{array}{c}90048 B \\
\text { Pyxite } \\
\text { core }\end{array}$ & $\begin{array}{c}90048 B \\
\text { Pyxite } \\
\text { core }\end{array}$ & $\begin{array}{c}90048 \mathrm{~B} \\
\text { Pyxite } \\
\text { melt }\end{array}$ & $\begin{array}{c}\text { 90048B } \\
\text { Pyxite } \\
\text { melt }\end{array}$ \\
\hline $\mathrm{SiO}_{2}$ & 42.23 & 37.12 & 37.50 & 37.43 & 37.29 & 37.73 & 40.13 & 38.37 \\
\hline $\mathrm{A} 12 \mathrm{O} 3$ & 0.00 & 0.06 & 0.01 & 0.02 & 0.14 & 0.09 & 0.15 & 0.24 \\
\hline $\mathrm{TiO}_{2}$ & 0.00 & 0.01 & 0.13 & 0.05 & 0.10 & 0.03 & 0.14 & 0.11 \\
\hline $\mathrm{FeO}$ & 8.62 & 27.45 & 26.76 & 26.61 & 26.86 & 25.29 & 18.30 & 20.29 \\
\hline $\mathrm{MnO}$ & 0.10 & 0.42 & 0.47 & 0.51 & 0.34 & 0,42 & 0.16 & 0.30 \\
\hline MgO & 49.82 & 35.25 & 34.48 & 35.10 & 34.92 & 36.02 & 41.08 & 39.76 \\
\hline $\mathrm{CaO}$ & 0.03 & 0.15 & 0.18 & 0.17 & 0.19 & 0.19 & 0.33 & 0.33 \\
\hline $\mathrm{Na} 2 \mathrm{O}$ & 0.01 & 0.04 & 0.17 & 0.06 & 0.00 & 0.00 & 0.13 & 0.09 \\
\hline $\mathrm{K} 2 \mathrm{O}$ & 0.01 & 0.04 & 0.01 & 0.01 & 0.03 & 0.03 & 0.03 & 0.02 \\
\hline $\mathrm{Cr}_{2} \mathrm{O} 3$ & 0.05 & 0.21 & 0.00 & 0.12 & 0.07 & 0.20 & 0.21 & 0.29 \\
\hline TOTAL & 100.85 & 100.75 & 99.71 & 100.07 & 99.94 & 99.99 & 100.65 & 99.80 \\
\hline Si & 1.017 & 0.989 & 1.000 & 0.995 & 0.993 & 0.996 & 1.014 & 0.991 \\
\hline Al & 0.000 & 0.001 & 0.000 & 0.000 & 0.004 & 0.003 & 0.004 & 0.007 \\
\hline $\mathrm{Ti}$ & 0.000 & 0.000 & 0.002 & 0.001 & 0.001 & 0.001 & 0.002 & 0.002 \\
\hline $\mathrm{Fe}$ & 0.173 & 0.611 & 0.596 & 0.591 & 0.598 & 0.558 & 0.386 & 0.438 \\
\hline Mn & 0.002 & 0.009 & 0.010 & 0.011 & 0.007 & 0.009 & 0.003 & 0.007 \\
\hline Mg & 1.787 & 1.378 & 1.370 & 1.390 & 1.385 & 1.417 & 1.547 & 1.531 \\
\hline $\mathrm{Ca}$ & 0.001 & 0.004 & 0.005 & 0.004 & 0.005 & 0.005 & 0.009 & 0.009 \\
\hline $\mathrm{Na}$ & 0.001 & 0.002 & 0.008 & 0.002 & 0.000 & 0.000 & 0.007 & 0.004 \\
\hline K & 0.000 & 0.001 & 0.000 & 0.000 & 0.001 & 0.000 & 0.001 & 0.000 \\
\hline $\mathrm{Cr}_{\mathrm{r}}$ & 0.001 & 0.004 & 0.000 & 0.002 & 0.001 & 0.004 & 0.004 & 0.005 \\
\hline TOTAL & 2981 & 2.999 & 2.991 & 2.996 & 2.995 & 2.993 & 2.977 & 2994 \\
\hline Mg\# & 91.15 & 69.28 & 69.68 & 70.17 & 69.84 & 71.75 & 80.03 & 77.76 \\
\hline
\end{tabular}

\begin{tabular}{|c|c|c|c|c|c|c|c|c|c|}
\hline $\begin{array}{l}\text { Sample } \\
\text { Type }\end{array}$ & $\begin{array}{l}90054 I \\
\text { Pyxite } \\
\text { core }\end{array}$ & $\begin{array}{c}90054 I \\
\text { Pyxite } \\
\text { core } \\
\end{array}$ & $\begin{array}{c}90054 I \\
\text { Pyxite } \\
\text { core }\end{array}$ & $\begin{array}{c}90054 \mathrm{~K} \\
\text { Pyxite } \\
\text { core }\end{array}$ & $\begin{array}{c}90054 \mathrm{~K} \\
\text { Pyxite } \\
\text { core }\end{array}$ & $\begin{array}{l}\text { 90054K } \\
\text { Pyxite } \\
\text { oxid dk- }\end{array}$ & $\begin{array}{l}90054 \mathrm{~K} \\
\text { Pyxite } \\
\text { oxid lgt }\end{array}$ & $\begin{array}{c}90054 K \\
\text { Pyxite } \\
\text { core }\end{array}$ & $\begin{array}{c}90054 K \\
\text { Pyxite } \\
\text { core }\end{array}$ \\
\hline $\mathrm{SiO}_{2}$ & 39.88 & 40.19 & 41.10 & 37.95 & 38.38 & 40.19 & 37.16 & 38.22 & 38.44 \\
\hline $\mathrm{A} 12 \mathrm{O} 3$ & 0.04 & 0.07 & 0.02 & 0.06 & 0.07 & 0.01 & 0.01 & 0.05 & 0.06 \\
\hline $\mathrm{TiO}_{2}$ & 0.04 & 0.01 & 0.07 & 0.05 & 0.02 & 0.01 & 0.11 & 0.04 & 0.05 \\
\hline $\mathrm{FeO}$ & 15.79 & 14.13 & 12.98 & 23.79 & 24.03 & 10.53 & 38.96 & 23.67 & 21.78 \\
\hline Mno & 0.22 & 0.33 & 0.30 & 0.39 & 0.38 & 0.36 & 0.37 & 0.38 & 0.38 \\
\hline $\mathrm{MgO}$ & 43.97 & 44.93 & 45.46 & 37.64 & 36.89 & 47.56 & 22.84 & 37.38 & 39.08 \\
\hline $\mathrm{CaO}$ & 0.15 & 0.23 & 0.06 & 0.10 & 0.15 & 0.09 & 0.24 & 0.13 & 0.17 \\
\hline $\mathrm{Na} 2 \mathrm{O}$ & 0.00 & 0.06 & 0.00 & 0.05 & 0.04 & 0.00 & 0.12 & 0.01 & 0.01 \\
\hline $\mathrm{K}_{2} \mathrm{O}$ & 0.03 & 0.03 & 0.07 & 0.05 & 0.02 & 0.07 & 0.08 & 0.02 & 0.00 \\
\hline $\mathrm{Cr} 2 \mathrm{O}_{3}$ & & & & 0.07 & 0.05 & 0.06 & 0.06 & 0.02 & 0.00 \\
\hline TOTAL & 100.12 & 99.98 & 100.04 & 100.15 & 100.03 & 98.87 & 99.95 & 99.92 & 99.98 \\
\hline Si & 1.003 & 1.004 & 1.019 & 0.994 & 1.005 & 1.000 & 1.046 & 1.001 & 0.997 \\
\hline Al & 0.001 & 0.002 & 0.000 & 0.001 & 0.002 & 0.000 & 0.000 & 0.001 & 0.002 \\
\hline $\mathrm{Ti}$ & 0.000 & 0.000 & 0.001 & 0.000 & 0.000 & 0.000 & 0.002 & 0.000 & 0.001 \\
\hline $\mathrm{Fe}$ & 0.332 & 0.299 & 0.269 & 0.520 & 0.526 & 0.218 & 0.917 & 0.518 & 0.472 \\
\hline $\mathrm{Mn}$ & 0.004 & 0.007 & 0.006 & 0.008 & 0.008 & 0.007 & 0.009 & 0.008 & 0.008 \\
\hline $\mathbf{M g}_{\mathbf{g}}$ & 1.648 & 1.672 & 1.679 & 1.468 & 1.440 & 1.763 & 0.958 & 1.459 & 1.510 \\
\hline $\mathrm{Ca}$ & 0.003 & 0.006 & 0.001 & 0.002 & 0.004 & 0.002 & 0.007 & 0.003 & 0.004 \\
\hline $\mathrm{Na}$ & 0.000 & 0.002 & 0.000 & 0.002 & 0.002 & 0.000 & 0.006 & 0.000 & 0.000 \\
\hline $\mathbf{K}$ & 0.001 & 0.000 & 0.002 & 0.001 & 0.000 & 0.002 & 0.003 & 0.000 & 0.000 \\
\hline $\mathrm{Cr}$ & & & & 0.001 & 0.001 & 0.001 & 0.001 & 0.000 & 0.000 \\
\hline TOTAL & 2992 & 2.992 & 2.977 & 2.997 & 2.988 & 2.993 & 2.949 & 2990 & 2994 \\
\hline $\mathrm{M}_{3} \#$ & 83.23 & 84.83 & 86.19 & 73.84 & 73.25 & 89.00 & 51.09 & 73.80 & 76.19 \\
\hline
\end{tabular}




\section{A3.3 Mount Murphy xenolith mineral analyses: pyroxenes}

\begin{tabular}{|c|c|c|c|c|c|c|c|c|c|c|c|c|c|c|}
\hline $\begin{array}{l}\text { Sample } \\
\text { Type }\end{array}$ & $\begin{array}{c}90041 \mathrm{~A} \\
\text { Gran } \\
\text { core } \\
\end{array}$ & $\begin{array}{c}90041 \mathrm{~A} \\
\text { Gran } \\
\text { core }\end{array}$ & $\begin{array}{c}90041 \mathrm{~A} \\
\text { Gran } \\
\text { core }\end{array}$ & $\begin{array}{c}90041 \mathrm{~A} \\
\text { Gran } \\
\text { core } \\
\end{array}$ & $\begin{array}{c}90041 \mathrm{~A} \\
\text { Gran } \\
\text { core } \\
\end{array}$ & $\begin{array}{c}\text { 90041A } \\
\text { Gran } \\
\text { oxid r }\end{array}$ & $\begin{array}{c}90041 \mathrm{~A} \\
\text { Gran } \\
\text { core }\end{array}$ & $\begin{array}{c}\text { 90041A } \\
\text { Gran } \\
\text { core }\end{array}$ & $\begin{array}{c}90041 \mathrm{~A} \\
\text { Gran } \\
\text { core }\end{array}$ & $\begin{array}{c}90041 \mathrm{~A} \\
\text { Gran } \\
\text { core }\end{array}$ & $\begin{array}{c}90041 \mathrm{~A} \\
\text { Gran } \\
\text { core }\end{array}$ & $\begin{array}{c}90041 \mathrm{~A} \\
\text { Gran } \\
\text { core }\end{array}$ & $\begin{array}{c}90041 A \\
\text { Gran } \\
\text { symp }\end{array}$ & $\begin{array}{c}90041 C \\
\text { Gran } \\
\text { core } \\
\end{array}$ \\
\hline $\mathrm{SiO}_{2}$ & 51.47 & 51.82 & 51.77 & 51.51 & 51.63 & 51.20 & 52.06 & 49.51 & 52.35 & 51.80 & 51.28 & 51.54 & 55.35 & 52.99 \\
\hline $\mathrm{Al}_{2} \mathrm{O}_{3}$ & 3.30 & 251 & 2.36 & 3.26 & 2.97 & 1.95 & 2.78 & 4.45 & 2.34 & 2.93 & 2.77 & 264 & 241 & 1.64 \\
\hline TiO2 & 0.37 & 0.27 & 0.29 & 0.58 & 0.38 & 0.55 & 0.28 & 0.85 & 0.35 & 0.46 & 0.34 & 0.28 & 0.06 & 0.35 \\
\hline $\mathrm{FeO}$ total & 6.90 & 6.84 & 6.27 & 6.58 & 6.64 & 7.97 & 6.39 & 7.16 & 6.46 & 6.64 & 6.38 & 6.52 & 7.82 & 5.41 \\
\hline $\mathrm{MnO}$ & 0.21 & 0.17 & 0.28 & 0.20 & 0.20 & 0.23 & 0.22 & 0.34 & 0.27 & 0.25 & 0.18 & 0.22 & 0.33 & 0.20 \\
\hline $\mathrm{MgO}$ & 14.42 & 15.18 & 14.84 & 13.74 & 14.73 & 18.26 & 14.57 & 14.65 & 14.71 & 14.09 & 14.22 & 14.68 & 33.81 & 15.44 \\
\hline $\mathrm{CaO}$ & 22.72 & 22.49 & 23.53 & 2285 & 22.56 & 18.45 & 22.96 & 21.55 & 23.11 & 23.06 & 22.87 & 23.41 & 0.28 & 24.47 \\
\hline $\mathrm{Na} 2 \mathrm{O}$ & 0.66 & 0.66 & 0.50 & 0.66 & 0.63 & 1.33 & 0.67 & 0.79 & 0.56 & 0.68 & 0.66 & 0.66 & 0.12 & 0.41 \\
\hline K2O & 0.00 & 0.02 & 0.04 & 0.05 & 0.02 & 0.03 & 0.00 & 0.02 & 0.01 & 0.03 & 0.01 & 0.02 & 0.04 & 0.01 \\
\hline $\mathrm{Cr}_{2} \mathrm{O}_{3}$ & 0.08 & 0.11 & 0.20 & 0.63 & 0.20 & 0.00 & 0.16 & 0.23 & 0.19 & 0.41 & 0.22 & 0.23 & 0.12 & \\
\hline $\mathrm{Fe} 2 \mathrm{O} 3$ & 3.46 & 4.24 & 3.92 & 1.89 & 3.20 & 8.86 & 2.98 & 5.66 & 2.58 & 2.70 & 3.18 & 4.61 & 281 & 3.09 \\
\hline $\mathrm{FeO}$ & 3.79 & 3.03 & 274 & 4.88 & 3.77 & 0.00 & 3.71 & 2.06 & 4.14 & 4.21 & 3.52 & 2.38 & 5.29 & 2.63 \\
\hline TOTAL & 100.12 & 100.07 & 100.08 & 100.04 & 99.96 & 99.97 & 100.09 & 99.53 & 100.34 & 100.35 & 98.92 & 100.19 & 100.33 & 100.93 \\
\hline $\mathrm{Si}$ & 1.916 & 1.920 & 1.917 & 1.911 & 1.914 & 1.898 & 1.924 & 1.851 & 1.934 & 1.915 & 1.921 & 1.912 & 1.921 & 1.940 \\
\hline AlIV & 0.080 & 0.080 & 0.080 & 0.090 & 0.090 & 0.085 & 0.080 & 0.150 & 0.070 & 0.080 & 0.080 & 0.090 & 0.080 & 0.060 \\
\hline AlVI & 0.061 & 0.031 & 0.026 & 0.052 & 0.041 & 0.000 & 0.043 & 0.046 & 0.032 & 0.050 & 0.042 & 0.027 & 0.017 & 0.010 \\
\hline $\mathbf{T i}$ & 0.010 & 0.007 & 0.008 & 0.016 & 0.011 & 0.015 & 0.008 & 0.024 & 0.010 & 0.013 & 0.010 & 0.008 & 0.001 & 0.009 \\
\hline FeIII & 0.096 & 0.117 & 0.108 & 0.052 & 0.089 & 0.000 & 0.082 & 0.157 & 0.071 & 0.075 & 0.089 & 0.127 & 0.073 & 0.085 \\
\hline FeII & 0.117 & 0.093 & 0.084 & 0.151 & 0.116 & 0.247 & 0.114 & 0.064 & 0.127 & 0.130 & 0.109 & 0.073 & 0.153 & 0.080 \\
\hline Mn & 0.006 & 0.005 & 0.009 & 0.006 & 0.006 & 0.007 & 0.007 & 0.011 & 0.008 & 0.008 & 0.006 & 0.007 & 0.009 & 0.006 \\
\hline $\mathrm{Mg}_{\mathrm{g}}$ & 0.792 & 0.837 & 0.819 & 0.759 & 0.813 & 1.008 & 0.802 & 0.816 & 0.809 & 0.776 & 0.794 & 0.811 & 1.748 & 0.842 \\
\hline $\mathrm{Ca}$ & 0.897 & 0.892 & 0.933 & 0.908 & 0.896 & 0.733 & 0.909 & 0.863 & 0.914 & 0.913 & 0.917 & 0.930 & 0.010 & 0.959 \\
\hline $\mathrm{Na}$ & 0.047 & 0.048 & 0.037 & 0.047 & 0.045 & 0.096 & 0.049 & 0.057 & 0.040 & 0.049 & 0.048 & 0.048 & 0.002 & 0.029 \\
\hline $\mathbf{K}$ & 0.000 & 0.001 & 0.002 & 0.002 & 0.001 & 0.002 & 0.000 & 0.007 & 0.000 & 0.001 & 0.000 & 0.001 & 0.003 & 0.000 \\
\hline $\mathrm{Cr}$ & 0.002 & 0.003 & 0.006 & 0.018 & 0.006 & 0.000 & 0.005 & 0.007 & 0.006 & 0.012 & 0.007 & 0.007 & 0.007 & \\
\hline TOTAL & 4.023 & 4.034 & 4.029 & 4.013 & 4.028 & 4.090 & 4.023 & 4.052 & 4.020 & 4.024 & 4.022 & 4.040 & 4.024 & 4.020 \\
\hline Wo & 47.16 & 46.00 & 48.01 & 48.55 & 46.80 & 36.86 & 47.67 & 45.42 & 47.57 & 48.20 & 48.06 & 47.92 & 0.50 & 48.78 \\
\hline En & 41.64 & 43.17 & 42.12 & 40.59 & 42.49 & 50.72 & 42.05 & 42.94 & 42.12 & 40.98 & 41.57 & 41.78 & 88.11 & 42.83 \\
\hline Fs & 11.20 & 10.83 & 9.88 & 10.86 & 10.71 & 12.42 & 10.28 & 11.64 & 10.31 & 10.82 & 10.37 & 10.30 & 11.39 & 8.39 \\
\hline Sample & $90048 \mathrm{~B}$ & $90048 B$ & $90048 \mathrm{D}$ & $90048 \mathrm{D}$ & $90048 \mathrm{D}$ & $90048 D$ & $90048 \mathrm{D}$ & $90048 D$ & 90048D & $90048 \mathrm{D}$ & $90048 D$ & 90048D & $90048 \mathrm{D}$ & $90048 \mathrm{D}$ \\
\hline Type & $\begin{array}{c}\text { Pyxite } \\
\text { core }\end{array}$ & $\begin{array}{c}\text { Pyxite } \\
\text { core }\end{array}$ & $\begin{array}{c}\text { Pyxite } \\
\text { core }\end{array}$ & $\begin{array}{c}\text { Pyxite } \\
\text { core }\end{array}$ & $\begin{array}{c}\text { Pyxite } \\
\text { core }\end{array}$ & $\begin{array}{c}\text { Pyxite } \\
\text { core }\end{array}$ & $\begin{array}{c}\text { Pyxite } \\
\text { core }\end{array}$ & $\begin{array}{c}\text { Pyxite } \\
\text { core }\end{array}$ & $\begin{array}{c}\text { Pyxite } \\
\text { core }\end{array}$ & $\begin{array}{c}\text { Pyxite } \\
\text { core }\end{array}$ & $\begin{array}{c}\text { Pyxite } \\
\text { core }\end{array}$ & $\begin{array}{c}\text { Pyxite } \\
\text { core }\end{array}$ & $\begin{array}{c}\text { Pyxite } \\
\text { core } \\
\end{array}$ & $\begin{array}{c}\text { Pyxite } \\
\text { core }\end{array}$ \\
\hline $\mathrm{SiO}_{2}$ & 47.86 & 48.54 & 45.52 & 47.49 & 46.37 & 47.11 & 45.91 & 47.29 & 46.69 & 45.56 & 47.44 & 47.42 & 46.40 & 46.26 \\
\hline $\mathrm{Al}_{2} \mathrm{O}_{3}$ & 7.62 & 7.47 & 8.59 & 7.73 & 0.04 & 9.21 & 8.77 & 8.34 & 8.63 & 8.81 & 7.91 & 8.48 & 8.24 & 8.81 \\
\hline $\mathrm{TiO}_{2}$ & 1.78 & 1.57 & 261 & 2.37 & 2.31 & 3.10 & 2.86 & 2.61 & 2.67 & 2.65 & 2.36 & 2.75 & 286 & 254 \\
\hline $\mathrm{FeO}$ total & 7.77 & 7.65 & 8.69 & 8.51 & 8.75 & 8.37 & 8.92 & 8.26 & 8.74 & 8.10 & 7.97 & 7.91 & 8.45 & 8.26 \\
\hline $\mathrm{MnO}$ & 0.16 & 0.34 & 0.30 & 0.01 & 0.29 & 0.16 & 0.21 & 0.21 & 0.34 & 0.36 & 0.24 & 0.22 & 0.26 & 0.23 \\
\hline $\mathrm{MgO}$ & 12.67 & 12.63 & 12.55 & 12.52 & 12.55 & 11.81 & 12.18 & 12.07 & 12.09 & 12.51 & 12.02 & 12.09 & 12.48 & 12.20 \\
\hline $\mathrm{CaO}$ & 19.98 & 20.35 & 20.65 & 20.36 & 20.72 & 20.01 & 20.42 & 20.16 & 20.00 & 20.30 & 21.08 & 20.56 & 20.41 & 20.53 \\
\hline $\mathrm{Na} 2 \mathrm{O}$ & 1.04 & 1.01 & 1.04 & 0.97 & 0.99 & 1.02 & 1.07 & 1.06 & 1.01 & 1.18 & 0.98 & 1.02 & 0.98 & 1.18 \\
\hline $\mathrm{K} 2 \mathrm{O}$ & 0.01 & 0.02 & 0.04 & 0.02 & 0.02 & 0.03 & 0.03 & 0.00 & 0.01 & 0.01 & 0.08 & 0.01 & 0.02 & 0.01 \\
\hline $\mathrm{Cr} 2 \mathrm{O}_{3}$ & 0.41 & 0.33 & 0.16 & 0.00 & 0.17 & 0.13 & 0.11 & 0.26 & 0.29 & 0.12 & 0.13 & 0.20 & 0.42 & 0.18 \\
\hline $\mathrm{Fe} 2 \mathrm{O}_{3}$ & 2.46 & 2.18 & 6.48 & 291 & 5.58 & 0.97 & 5.11 & 2.05 & 2.99 & 6.03 & 2.54 & 1.80 & 4.21 & 494 \\
\hline $\mathrm{FeO}$ & 5.55 & 5.69 & 2.85 & 5.90 & 3.73 & 7.50 & 4.32 & 6.42 & 6.04 & 2.68 & 5.69 & 6.29 & 4.66 & 3.81 \\
\hline TOTAL & 99.31 & 99.91 & 100.15 & 99.97 & 9222 & 100.95 & 100.46 & 100.26 & 100.44 & 99.59 & 100.21 & 100.65 & 100.53 & 100.20 \\
\hline Si & 1.791 & 1.804 & 1.710 & 1.773 & 1.739 & 1.740 & 1.716 & 1.760 & 1.740 & 1.713 & 1.768 & 1.755 & 1.730 & 1.729 \\
\hline AlIV & 0.210 & 0.200 & 0.290 & 0.230 & 0.260 & 0.260 & 0.280 & 0.240 & 0.260 & 0.290 & 0.230 & 0.240 & 0.270 & 0.270 \\
\hline AlVI & 0.126 & 0.127 & 0.090 & 0.110 & 0.095 & 0.140 & 0.106 & 0.125 & 0.139 & 0.100 & 0.117 & 0.129 & 0.092 & 0.118 \\
\hline $\mathrm{Ti}$ & 0.050 & 0.043 & 0.075 & 0.066 & 0.065 & 0.086 & 0.080 & 0.073 & 0.075 & 0.075 & 0.066 & 0.076 & 0.080 & 0.071 \\
\hline FeIII & 0.069 & 0.050 & 0.181 & 0.081 & 0.156 & 0.027 & 0.142 & 0.057 & 0.084 & 0.168 & 0.071 & 0.050 & 0.117 & 0.138 \\
\hline FeII & 0.173 & 0.176 & 0.088 & 0.183 & 0.116 & 0.231 & 0.134 & 0.199 & 0.187 & 0.083 & 0.177 & 0.194 & 0.144 & 0.118 \\
\hline $\mathrm{Mn}$ & 0.005 & 0.010 & 0.010 & 0.000 & 0.009 & 0.005 & 0.007 & 0.007 & 0.011 & 0.011 & 0.008 & 0.007 & 0.008 & 0.007 \\
\hline $\mathrm{Mg}$ & 0.706 & 0.699 & 0.702 & 0.696 & 0.701 & 0.650 & 0.678 & 0.669 & 0.671 & 0.701 & 0.668 & 0.666 & 0.693 & 0.679 \\
\hline $\mathrm{Ca}$ & 0.800 & 0.810 & 0.830 & 0.814 & 0.832 & 0.792 & 0.817 & 0.804 & 0.798 & 0.817 & 0.842 & 0.815 & 0.815 & 0.822 \\
\hline $\mathrm{Na}$ & 0.075 & 0.071 & 0.073 & 0.070 & 0.071 & 0.073 & 0.078 & 0.076 & 0.073 & 0.086 & 0.069 & 0.073 & 0.071 & 0.086 \\
\hline K & 0.000 & 0.001 & 0.002 & 0.001 & 0.001 & 0.001 & 0.001 & 0.000 & 0.000 & 0.000 & 0.003 & 0.001 & 0.001 & 0.000 \\
\hline $\mathrm{Cr}$ & 0.012 & 0.009 & 0.005 & 0.000 & 0.005 & 0.004 & 0.003 & 0.007 & 0.008 & 0.003 & 0.004 & 0.006 & 0.012 & 0.005 \\
\hline TOTAL & 4.017 & 4.000 & 4.055 & 4.024 & 4.050 & 4.008 & 4.041 & 4.016 & 4.046 & 4.048 & 4.022 & 4.012 & 4.033 & 4.043 \\
\hline Wo & 45.77 & 46.69 & 46.09 & 45.88 & 46.09 & 46.58 & 46.14 & 46.49 & 45.87 & 46.21 & 47.89 & 47.24 & 46.08 & 46.78 \\
\hline En & 40.39 & 40.29 & 38.98 & 39.24 & 38.84 & 38.24 & 38.28 & 38.70 & 38.56 & 39.60 & 37.99 & 38.62 & 39.16 & 38.65 \\
\hline Fs & 13.84 & 13.03 & 14.93 & 14.88 & 15.07 & 15.18 & 15.58 & 14.81 & 15.57 & 14.19 & 14.11 & 14.14 & 14.76 & 14.57 \\
\hline
\end{tabular}




\begin{tabular}{|c|c|c|c|c|c|c|c|c|c|c|c|c|c|c|}
\hline $\begin{array}{l}\text { SAMPLE } \\
\text { Type }\end{array}$ & $\begin{array}{l}90041 \mathrm{C} \\
\text { Gran } \\
\text { core }\end{array}$ & $\begin{array}{c}90041 \mathrm{C} \\
\text { Gran } \\
\text { core }\end{array}$ & $\begin{array}{c}90041 \mathrm{C} \\
\text { Gran } \\
\text { core } \\
\end{array}$ & $\begin{array}{c}90041 \mathrm{G} \\
\text { Gran } \\
\text { core }\end{array}$ & $\begin{array}{c}90041 \mathrm{G} \\
\text { Gran } \\
\text { core }\end{array}$ & $\begin{array}{c}90041 \mathrm{C} \\
\text { Gran } \\
\text { core }\end{array}$ & $\begin{array}{c}90041 \mathrm{C} \\
\text { Gran } \\
\text { core } \\
\end{array}$ & $\begin{array}{l}90041 \mathrm{G} \\
\text { Gran } \\
\text { core } \\
\end{array}$ & $\begin{array}{c}90041 \mathrm{G} \\
\text { Gran } \\
\text { core } \\
\end{array}$ & $\begin{array}{c}90041 \mathrm{G} \\
\text { Gran } \\
\text { core }\end{array}$ & $\begin{array}{c}90041 \mathrm{G} \\
\text { Gran } \\
\text { core } \\
\end{array}$ & $\begin{array}{c}90041 \mathrm{G} \\
\text { Gran } \\
\text { core } \\
\end{array}$ & $\begin{array}{c}900411 \\
\text { Gran } \\
\text { oxid r }\end{array}$ & $\begin{array}{c}900411 \\
\text { Gran } \\
\text { oxid r }\end{array}$ \\
\hline $\mathrm{SiO}_{2}$ & 52.66 & 53.26 & 51.07 & 51.75 & 51,24 & 52.33 & 51.41 & 54.20 & 54.33 & 50.62 & 49.54 & 53.57 & 47.37 & 53.64 \\
\hline $\mathrm{A}\left[2 \mathrm{O}_{3}\right.$ & 1.83 & 1.49 & 3.67 & 3.98 & 3.80 & 3.85 & 3.63 & 2.09 & 2.27 & 2.68 & 5.54 & 2.45 & 9.39 & 2.15 \\
\hline TiO2 & 0.40 & 0.36 & 0.95 & 0.94 & 0.78 & 0.73 & 0.75 & 0.09 & 0.13 & 0.16 & 1.39 & 0.21 & 0.42 & 0.11 \\
\hline $\mathrm{FeO}$ total & 5.70 & 4.76 & 5.30 & 4.70 & 4.74 & 4.17 & 4.51 & 12.06 & 12.53 & 5.09 & 6.95 & 4.21 & 5.70 & 5.99 \\
\hline $\mathrm{MnO}$ & 0.19 & 0.27 & 0.19 & 0.11 & 0.08 & 0.00 & 0.21 & 0.34 & 0.32 & 0.05 & 0.21 & 0.20 & 0.19 & 0.24 \\
\hline $\mathrm{MgO}$ & 15.26 & 15.39 & 15.65 & 14.83 & 15.50 & 15.07 & 15.69 & 29.50 & 29.54 & 16.21 & 14.66 & 15.81 & 13.78 & 19.41 \\
\hline $\mathrm{CaO}$ & 23.43 & 24.55 & 22.14 & 22.55 & 2286 & 22.08 & 23.42 & 0.64 & 0.63 & 24.69 & 20.97 & 22.91 & 21.76 & 18.07 \\
\hline $\mathrm{Na} 2 \mathrm{O}$ & 0.49 & 0.45 & 0.61 & 0.69 & 0.65 & 0.52 & 0.60 & 0.10 & 0.07 & 0.44 & 0.52 & 0.40 & 0.57 & 0.34 \\
\hline $\mathrm{K}_{2} \mathrm{O}$ & 0.04 & 0.02 & 0.01 & 0.01 & 0.02 & 0.31 & 0.00 & 0.03 & 0.03 & 0.01 & 0.06 & 0.03 & 0.04 & 0.00 \\
\hline $\mathrm{Cr} 2 \mathrm{O}_{3}$ & & & & 0.49 & 0.60 & 0.78 & 0.68 & 0.35 & 0.22 & 0.01 & 0.10 & 0.18 & 0.07 & 0.08 \\
\hline$\overline{\mathrm{Fe} 2 \mathrm{O} 3}$ & 2.38 & 2.32 & 3.01 & 0.74 & 3.20 & 0.00 & 3.7 & 1.73 & 1.87 & 5.66 & 2.69 & 0.00 & 4.55 & 1.49 \\
\hline $\mathrm{FeO}$ & 3.56 & 2.67 & 259 & 4.04 & 1.86 & 4.17 & 1.12 & 10.50 & 10.87 & 0.00 & 4.53 & 4.21 & 1.60 & 4.65 \\
\hline TOTAL & 100.01 & 100.55 & 99.59 & 100.04 & 100.27 & 99.84 & 100.90 & 99.40 & 100.05 & 99.96 & 99.93 & 99.96 & 99.27 & 100.02 \\
\hline $\mathrm{Si}$ & 1.943 & 1.952 & 1.885 & 1.901 & 1.882 & 1.916 & 1.878 & 1.937 & 1.934 & 1.880 & 1.836 & 1.958 & 1.761 & 1.948 \\
\hline AlIV & 0.060 & 0.050 & 0.110 & 0.100 & 0.120 & 0.080 & 0.120 & 0.060 & 0.070 & 0.120 & 0.160 & 0.050 & 0.240 & 0.060 \\
\hline AIVI & 0.020 & 0.014 & 0.050 & 0.069 & 0.044 & 0.086 & 0.036 & 0.027 & 0.022 & 0.000 & 0.078 & 0.054 & 0.171 & 0.033 \\
\hline $\mathrm{Ti}$ & 0.010 & 0.009 & 0.026 & 0.025 & 0.021 & 0.019 & 0.020 & 0.002 & 0.003 & 0.005 & 0.038 & 0.006 & 0.011 & 0.003 \\
\hline FelII & 0.066 & 0.064 & 0.083 & 0.020 & 0.088 & 0.000 & 0.103 & 0.046 & 0.049 & 0.158 & 0.074 & 0.000 & 0.126 & 0.041 \\
\hline FelI & 0.109 & 0.082 & 0.079 & 0.124 & 0.057 & 0.127 & 0.034 & 0.321 & 0.322 & 0.000 & 0.140 & 0.129 & 0.049 & 0.141 \\
\hline Mn & 0.010 & 0.008 & 0.006 & 0.003 & 0.002 & 0.000 & 0.006 & 0.010 & 0.009 & 0.001 & 0.006 & 0.006 & 0.006 & 0.007 \\
\hline $\mathrm{Mg}$ & 0.838 & 0.840 & 0.860 & 0.811 & 0.847 & 0.822 & 0.854 & 1.570 & 1.567 & 0.897 & 0.809 & 0.861 & 0.763 & 1.050 \\
\hline $\mathrm{Ca}_{\mathrm{a}}$ & 0.925 & 0.964 & 0.875 & 0.887 & 0.899 & 0.866 & 0.916 & 0.024 & 0.023 & 0.982 & 0.833 & 0.897 & 0.866 & 0.703 \\
\hline $\mathrm{Na}$ & 0.036 & 0.032 & 0.043 & 0.047 & 0.046 & 0.037 & 0.042 & 0.006 & 0.004 & 0.031 & 0.037 & 0.028 & 0.041 & 0.024 \\
\hline K & 0.002 & 0.000 & 0.000 & 0.000 & 0.000 & 0.014 & 0.000 & 0.001 & 0.001 & 0.000 & 0.003 & 0.001 & 0.002 & 0.000 \\
\hline $\mathrm{Cr}_{\mathrm{r}}$ & & & & 0.013 & 0.017 & 0.022 & 0.019 & 0.009 & 0.005 & 0.000 & 0.003 & 0.005 & 0.002 & 0.002 \\
\hline TOTAL & 4.019 & 4.015 & 4.017 & 4.000 & 4.023 & 3.989 & 4.028 & 4.013 & 4.009 & 4.074 & 4.017 & 3.993 & 4.037 & 4.012 \\
\hline W & 47 & 49. & $4 \epsilon$ & 48. & 47 & & & & & & & 47 & 48.02 & 36.33 \\
\hline Er & 43.24 & 43.08 & 45.33 & 44.03 & 44.79 & 45.29 & 44.78 & 80.05 & 79.91 & 44.03 & 43.61 & 45.63 & 42.28 & 54.26 \\
\hline Fs & 9.03 & 7.49 & 8.54 & 7.82 & 7.67 & 7.00 & 7.18 & 18.73 & 18.92 & 7.75 & 11.53 & 6.82 & 9.70 & 9.41 \\
\hline
\end{tabular}

\begin{tabular}{|c|c|c|c|c|c|c|c|c|c|c|c|c|c|c|}
\hline $\begin{array}{l}\text { SAMPLE } \\
\text { Type }\end{array}$ & $\begin{array}{l}90048 \mathrm{D} \\
\text { Pyxite } \\
\text { core }\end{array}$ & $\begin{array}{c}90048 \mathrm{D} \\
\text { Pyxite } \\
\text { core } \\
\end{array}$ & $\begin{array}{c}0048 \mathrm{D} \\
\text { Pyxite } \\
\text { core } \\
\end{array}$ & $\begin{array}{c}90048 \mathrm{D} \\
\text { Pyxite } \\
\text { core } \\
\end{array}$ & $\begin{array}{c}90048 \mathrm{E} \\
\text { Gran } \\
\text { core } \\
\end{array}$ & $\begin{array}{c}90048 \mathrm{~F} \\
\text { Gran } \\
\text { core } \\
\end{array}$ & $\begin{array}{c}90048 \mathrm{~F} \\
\text { Gran } \\
\text { core } \\
\end{array}$ & $\begin{array}{c}90048 F \\
\text { Gran } \\
\text { core }\end{array}$ & $\begin{array}{c}90048 \mathrm{G} \\
\text { Gran } \\
\text { core }\end{array}$ & $\begin{array}{c}90048 \mathrm{G} \\
\text { Gran } \\
\text { core }\end{array}$ & $\begin{array}{l}90048 G \\
\text { Gran } \\
\text { core }\end{array}$ & $\begin{array}{l}90054 \mathrm{C} \\
\text { Pyxite } \\
\text { core } \\
\end{array}$ & $\begin{array}{c}90054 \mathrm{C} \\
\text { Pyxite } \\
\text { core } \\
\end{array}$ & $\begin{array}{c}90054 \mathrm{C} \\
\text { Pyxite } \\
\text { core } \\
\end{array}$ \\
\hline $\mathrm{SiO}_{2}$ & 45.54 & 46.09 & 46.25 & 46.03 & 48.67 & 46.32 & 46.50 & 47.21 & 49.94 & 47.54 & 49.99 & 48.47 & 49.19 & 47.75 \\
\hline Al2O3 & 8.54 & 8.51 & 8.67 & 8.75 & 7.04 & 8.48 & 8.62 & 7.59 & 3.20 & 6.12 & 2.49 & 8.52 & 6.85 & 8.80 \\
\hline TiO2 & 2.75 & 2.88 & 2.63 & 269 & 1.84 & 2.61 & 2.73 & 2.51 & 0.76 & 1.60 & 0.50 & 1.61 & 0.86 & 1.79 \\
\hline $\mathrm{FeO}$ total & 8.88 & 7.87 & 8.54 & 8.89 & 8.91 & 8.32 & 8.43 & 8.62 & 9.84 & 9.30 & 10.54 & 7.13 & 6.50 & 7.76 \\
\hline $\mathrm{MnO}$ & 0.30 & 0.26 & 0.12 & 0.15 & 0.21 & 0.29 & 0.17 & 0.31 & 0.30 & 0.34 & 0.59 & 0.20 & 0.17 & 0.46 \\
\hline $\mathrm{MgO}$ & 12.24 & 12.53 & 12.12 & 12.00 & 11.93 & 12.37 & 12.18 & 12.63 & 13.22 & 13.40 & 13.24 & 13.42 & 14.83 & 13.47 \\
\hline $\mathrm{CaO}$ & 20.54 & 20.48 & 20.92 & 20.30 & 20.57 & 20.00 & 19.90 & 19.90 & 22.16 & 20.79 & 21.59 & 19.90 & 21.23 & 19.20 \\
\hline $\mathrm{Na} 2 \mathrm{O}$ & 1.08 & 1.09 & 1.07 & 1.17 & 0.83 & 1.19 & 1.24 & 1.06 & 0.27 & 0.81 & 0.69 & 0.84 & 0.43 & 1.03 \\
\hline K2O & 0.00 & 0.01 & 0.01 & 0.04 & 0.02 & 0.00 & 0.01 & 0.04 & 0.01 & 0.05 & 0.01 & 0.00 & 0.02 & 0.06 \\
\hline $\mathrm{Cr}_{2} \mathrm{O}_{3}$ & 0.09 & 0.13 & 0.30 & 0.26 & & 0.14 & 0.17 & 0.05 & 0.05 & 0.00 & 0.30 & 0.22 & 0.30 & 0.21 \\
\hline $\mathrm{Fe} 2 \mathrm{O} 3$ & 6.02 & 4.59 & 4.97 & 5.05 & 0.09 & 0.00 & 3.80 & 3.63 & 3.35 & 6.32 & 6.07 & 1.35 & 3.06 & 3.33 \\
\hline $\mathrm{FeO}$ & 3.47 & 3.74 & 4.07 & 4.34 & 8.10 & 8.32 & 5.01 & 5.35 & 6.82 & 3.61 & 5.08 & 5.91 & 3.75 & 4.77 \\
\hline TOTAL & 99.95 & 99.83 & 100.64 & 100.28 & 100.01 & 99.71 & 99.95 & 99.92 & 99.76 & 99.96 & 99.94 & 100.31 & 100.38 & 100.54 \\
\hline $\mathrm{Si}$ & 1.714 & 1.726 & 1.724 & 1.727 & 1.815 & 1.738 & 1.739 & 1.766 & 1.885 & 1.787 & 1.894 & 1.786 & 1.812 & 1.768 \\
\hline AlIV & 0.290 & 0.270 & 0.280 & 0.270 & 0.180 & 0.260 & 0.260 & 0.230 & 0.110 & 0.210 & 0.110 & 0.220 & 0.190 & 0.240 \\
\hline AlVI & 0.089 & 0.106 & 0.101 & 0.117 & 0.130 & 0.115 & 0.120 & 0.105 & 0.032 & 0.064 & 0.000 & 0.147 & 0.104 & 0.134 \\
\hline $\mathrm{Ti}$ & 0.078 & 0.081 & 0.074 & 0.076 & 0.050 & 0.074 & 0.077 & 0.071 & 0.022 & 0.046 & 0.014 & 0.044 & 0.024 & 0.049 \\
\hline FeIII & 0.108 & 0.128 & 0.138 & 0.141 & 0.025 & 0.000 & 0.106 & 0.101 & 0.094 & 0.176 & 0.171 & 0.037 & 0.064 & 0.092 \\
\hline FelI & 0.108 & 0.116 & 0.125 & 0.135 & 0.252 & 0.261 & 0.155 & 0.166 & 0.214 & 0.112 & 0.159 & 0.182 & 0.115 & 0.147 \\
\hline Mn & 0.010 & 0.008 & 0.004 & 0.005 & 0.007 & 0.009 & 0.005 & 0.009 & 0.009 & 0.011 & 0.019 & 0.006 & 0.005 & 0.014 \\
\hline Mg & 0.687 & 0.699 & 0.673 & 0.671 & 0.663 & 0.691 & 0.678 & 0.704 & 0.744 & 0.750 & 0.747 & 0.736 & 0.813 & 0.743 \\
\hline $\mathrm{Ca}_{\mathrm{a}}$ & 0.829 & 0.822 & 0.836 & 0.816 & 0.822 & 0.804 & 0.797 & 0.797 & 0.896 & 0.837 & 0.876 & 0.785 & 0.837 & 0.761 \\
\hline $\mathrm{Na}$ & 0.079 & 0.071 & 0.077 & 0.085 & 0.061 & 0.086 & 0.087 & 0.075 & 0.020 & 0.060 & 0.050 & 0.059 & 0.030 & 0.072 \\
\hline K & 0.000 & 0.000 & 0.000 & 0.002 & 0.001 & 0.000 & 0.001 & 0.002 & 0.000 & 0.003 & 0.001 & 0.000 & 0.001 & 0.003 \\
\hline $\mathrm{Cr}$ & 0.003 & 0.004 & 0.009 & 0.007 & & 0.004 & 0.005 & 0.001 & 0.002 & 0.000 & 0.009 & 0.006 & 0.009 & 0.006 \\
\hline TOTAL & 3.995 & 4.031 & 4.041 & 4.052 & 4.006 & 4.041 & 4.029 & 4.027 & 4.027 & 4.056 & 4.051 & 4.009 & 4.004 & 4.028 \\
\hline Wo & 47.86 & 46.57 & 47.18 & 46.28 & 46.65 & 45.78 & 45.90 & 45.09 & 46.01 & 44.64 & 44.85 & 45.11 & 45.76 & 43.67 \\
\hline En & 39.67 & 39.60 & 37.98 & 38.06 & 37.63 & 39.36 & 39.07 & 39.81 & 38.18 & 40.01 & 38.26 & 42.31 & 44.46 & 42.61 \\
\hline Fs & 12.47 & 13.82 & 14.84 & 15.66 & 15.72 & 14.86 & 15.03 & 15.10 & 15.81 & 15.36 & 16.89 & 12.58 & 9.78 & 13.71 \\
\hline
\end{tabular}




\begin{tabular}{|c|c|c|c|c|c|c|c|c|c|c|c|c|c|c|}
\hline $\begin{array}{l}\text { SAMPLE } \\
\text { Type }\end{array}$ & $\begin{array}{c}900411 \\
\text { Gran } \\
\text { core }\end{array}$ & $\begin{array}{l}900411 \\
\text { Gran } \\
\text { core }\end{array}$ & $\begin{array}{l}90041 I \\
\text { Gran } \\
\text { core }\end{array}$ & $\begin{array}{l}900411 \\
\text { Gran } \\
\text { core }\end{array}$ & $\begin{array}{l}90041 \mathrm{I} \\
\text { Gran } \\
\text { core }\end{array}$ & $\begin{array}{c}90044 \mathrm{~A} \\
\text { Pyxite } \\
\text { core }\end{array}$ & $\begin{array}{c}90044 \mathrm{~A} \\
\text { Pyxite } \\
\text { core }\end{array}$ & $\begin{array}{l}90044 \mathrm{~A} \\
\text { Pyxite } \\
\text { core }\end{array}$ & $\begin{array}{c}90044 \mathrm{~A} \\
\text { Pyxite } \\
\text { core }\end{array}$ & $\begin{array}{c}90044 \mathrm{~A} \\
\text { Pyxite } \\
\text { core }\end{array}$ & $\begin{array}{c}90044 \mathrm{~A} \\
\text { Pyxite } \\
\text { core }\end{array}$ & $\begin{array}{c}90044 \mathrm{~A} \\
\text { Pyxite } \\
\text { core }\end{array}$ & $\begin{array}{l}90044 \mathrm{~A} \\
\text { Pyxite } \\
\text { core }\end{array}$ & $\begin{array}{c}90044 \mathrm{~A} \\
\text { Pyxite } \\
\text { core }\end{array}$ \\
\hline $\mathrm{SiO}_{2}$ & 52.28 & 48.49 & 46.44 & 47.97 & 50.43 & 53.43 & 50.30 & 53.16 & 50.42 & 51.17 & 53.89 & 50.36 & 50.65 & 53.17 \\
\hline $\mathrm{Al} 2 \mathrm{O}_{3}$ & 3.50 & 7.01 & 9.03 & 8.22 & 3.90 & 5.17 & 6.97 & 5.25 & 6.64 & 6.68 & 5.27 & 6.74 & 6.90 & 5.34 \\
\hline $\mathrm{TiO}_{2}$ & 0.60 & 1.63 & 1.77 & 1.46 & 0.87 & 0.27 & 0.80 & 0.19 & 0.87 & 0.81 & 0.16 & 0.72 & 0.85 & 0.19 \\
\hline FeO total & 3.50 & 3.89 & 4.77 & 3.42 & 4.45 & 9.97 & 4.84 & 9.65 & 4.62 & 4.55 & 9.90 & 4.77 & 4.78 & 10.16 \\
\hline $\mathrm{MnO}$ & 0.14 & 0.10 & 0.06 & 0.10 & 0.10 & 0.18 & 0.17 & 0.29 & 0.06 & 0.27 & 0.29 & 0.14 & 0.17 & 0.32 \\
\hline $\mathrm{MgO}$ & 16.00 & 15.14 & 13.88 & 15.29 & 15.18 & 28.99 & 14.64 & 29.49 & 14.76 & 14.67 & 29.11 & 14.53 & 14.78 & 29.34 \\
\hline $\mathrm{CaO}$ & 23.39 & 22.39 & 2281 & 22.12 & 23.48 & 0.91 & 20.45 & 0.92 & 20.95 & 20.53 & 0.99 & 20.96 & 20.27 & 0.85 \\
\hline $\mathrm{Na} 2 \mathrm{O}$ & 0.50 & 0.59 & 0.61 & 0.65 & 0.84 & 0.15 & 1.07 & 0.12 & 1.15 & 1.06 & 0.17 & 1.11 & 1.12 & 0.12 \\
\hline $\mathrm{K} 2 \mathrm{O}$ & 0.03 & 0.04 & 0.01 & 0.00 & 0.02 & 0.00 & 0.02 & 0.08 & 0.01 & 0.01 & 0.04 & 0.03 & 0.00 & 0.04 \\
\hline $\mathrm{Cr} 2 \mathrm{O} 3$ & 0.69 & 0.79 & 0.69 & 0.81 & 0.61 & 0.21 & 0.45 & 0.28 & 0.39 & 0.59 & 0.29 & 0.68 & 0.56 & 0.40 \\
\hline $\mathrm{Fe} 2 \mathrm{O} 3$ & 1.66 & 3.36 & 4.99 & 3.80 & 4.94 & 0.00 & 1.62 & 0.65 & 2.38 & 0.37 & 0.00 & 2.23 & 1.24 & 0.89 \\
\hline $\mathrm{FeO}$ & 2.00 & 0.87 & 0.28 & 0.00 & 0.00 & 9.97 & 3.38 & 9.06 & 2.48 & 4.21 & 9.90 & 285 & 3.66 & 9.26 \\
\hline TOTAL & 100.63 & 100.06 & 100.07 & 100.03 & 99.87 & 99.28 & 99.69 & 99.36 & 99.88 & 100.33 & 100.11 & 100.04 & 100.07 & 99.93 \\
\hline Si & 1.902 & 1.783 & 1.720 & 1.759 & 1.866 & 1.891 & 1.844 & 1.880 & 1.846 & 1.860 & 1.893 & 1.845 & 1.848 & 1.874 \\
\hline Allv & 0.100 & 0.220 & 0.280 & 0.240 & 0.130 & 0.110 & 0.160 & 0.120 & 0.150 & 0.140 & 0.110 & 0.150 & 0.150 & 0.130 \\
\hline AlVI & 0.050 & 0.080 & 0.110 & 0.120 & 0.040 & 0.110 & 0.140 & 0.100 & 0.140 & 0.150 & 0.100 & 0.140 & 0.150 & 0.090 \\
\hline $\mathbf{T i}$ & 0.016 & 0.044 & 0.048 & 0.039 & 0.024 & 0.007 & 0.021 & 0.005 & 0.020 & 0.021 & 0.000 & 0.019 & 0.023 & 0.005 \\
\hline FelII & 0.045 & 0.096 & 0.137 & 0.116 & 0.152 & 0.000 & 0.045 & 0.017 & 0.065 & 0.010 & 0.000 & 0.060 & 0.034 & 0.024 \\
\hline FelI & 0.061 & 0.026 & 0.009 & 0.000 & 0.000 & 0.295 & 0.104 & 0.268 & 0.076 & 0.128 & 0.290 & 0.085 & 0.112 & 0.275 \\
\hline Mn & 0.004 & 0.002 & 0.002 & 0.003 & 0.003 & 0.005 & 0.005 & 0.008 & 0.001 & 0.008 & 0.010 & 0.004 & 0.005 & 0.009 \\
\hline Mg & 0.867 & 0.829 & 0.765 & 0.835 & 0.836 & 1.529 & 0.799 & 1.554 & 0.806 & 0.794 & 1.524 & 0.792 & 0.803 & 1.541 \\
\hline $\mathrm{Ca}$ & 0.911 & 0.881 & 0.904 & 0,868 & 0.930 & 0.034 & 0.803 & 0.034 & 0.821 & 0.799 & 0.036 & 0.822 & 0.792 & 0.032 \\
\hline $\mathrm{Na}$ & 0.035 & 0.040 & 0.042 & 0.045 & 0.060 & 0.010 & 0.075 & 0.008 & 0.081 & 0.074 & 0.010 & 0.077 & 0.079 & 0.008 \\
\hline $\mathbf{K}$ & 0.001 & 0.001 & 0.000 & 0.000 & 0.000 & 0.000 & 0.000 & 0.001 & 0.000 & 0.000 & 0.001 & 0.001 & 0.000 & 0.001 \\
\hline $\mathrm{Cr}_{\mathrm{r}}$ & 0.019 & 0.022 & 0.019 & 0.023 & 0.017 & 0.005 & 0.012 & 0.007 & 0.011 & 0.016 & 0.010 & 0.019 & 0.016 & 0.011 \\
\hline TOTAL & 4.011 & 4.024 & 4.036 & 4.048 & 4.058 & 3.996 & 4.008 & 4.002 & 4.017 & 4.000 & 3.984 & 4.014 & 4.012 & 4.000 \\
\hline Wo & 48.35 & 48.0 & 49.81 & 47.72 & 48.49 & & 45.86 & 1.82 & 46.44 & 46.16 & 1.95 & 46.73 & 45.49 & 1.71 \\
\hline En & 46.02 & 45.25 & 42.15 & 45.90 & 43.59 & 82.29 & 45.63 & 82.97 & 45.59 & 45.87 & 82.38 & 45.03 & 46.12 & 8232 \\
\hline Fs & 5.63 & 6.66 & 8.04 & 6.38 & 7.92 & 15.88 & 8.51 & 15.22 & 7.98 & 7.97 & 15.68 & 8.24 & 8.39 & 15.97 \\
\hline
\end{tabular}

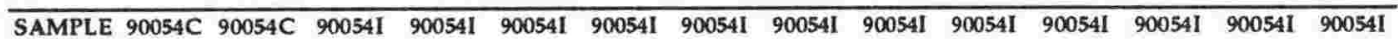

Type Pyxite Pyxite Pyxite Pyxite Pyxite Pyxite Pyxite Pyxite Pyxite Pyxite Pyxite Pyxite Pyxite Pyxite core core oxid oxid core oxid core- exsol core core core core core core

$\begin{array}{lcccccccccccccc}\mathrm{SiO2} & 48.42 & 47.91 & 48.97 & 48.33 & 48.74 & 48.27 & 48.75 & 53.41 & 47.71 & 49.08 & 48.39 & 48.87 & 49.07 & 50.61 \\ \mathrm{Al2O} 3 & 8.28 & 8.62 & 5.34 & 6.35 & 7.75 & 7.25 & 6.49 & 4.99 & 8.46 & 7.72 & 6.60 & 8.06 & 8.47 & 5.69 \\ \mathrm{TiO2} & 1.43 & 1.74 & 1.56 & 1.55 & 1.38 & 1.89 & 0.98 & 0.28 & 1.65 & 1.44 & 1.78 & 1.32 & 1.67 & 1.30 \\ \mathrm{FeO} \text { total } & 6.92 & 6.75 & 5.74 & 6.65 & 6.12 & 6.05 & 6.17 & 10.50 & 5.74 & 6.02 & 7.10 & 5.86 & 5.50 & 5.11 \\ \mathrm{MnO} & 0.26 & 0.20 & 0.15 & 0.13 & 0.27 & 0.15 & 0.19 & 0.23 & 0.21 & 0.17 & 0.17 & 0.20 & 0.08 & 0.16 \\ \mathrm{MgO} & 13.81 & 13.36 & 14.88 & 14.44 & 14.22 & 13.70 & 14.91 & 29.27 & 13.98 & 14.00 & 13.63 & 14.17 & 14.05 & 15.31 \\ \mathrm{CaO} & 19.88 & 20.30 & 22.22 & 20.91 & 20.20 & 22.07 & 19.41 & 1.25 & 19.99 & 20.19 & 21.77 & 20.26 & 20.04 & 21.14 \\ \mathrm{Na2O} & 1.07 & 1.04 & 0.42 & 0.56 & 1.07 & 0.46 & 0.97 & 0.11 & 1.32 & 1.41 & 0.82 & 1.19 & 1.22 & 0.54 \\ \mathrm{~K} 2 \mathrm{O} & 0.19 & 0.02 & 0.02 & 0.14 & 0.04 & 0.05 & 0.06 & 0.00 & 0.03 & 0.03 & 0.03 & 0.00 & 0.00 & 0.02\end{array}$

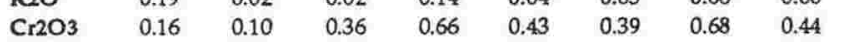

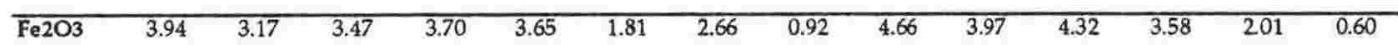

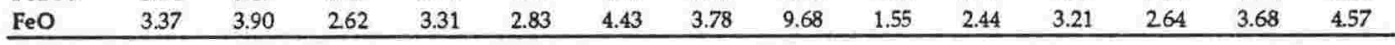

\begin{tabular}{lllllllllllllll}
\hline TOTAL & 100.41 & 100.05 & 99.65 & 99.71 & 100.20 & 100.27 & 98.60 & 100.48 & 99.09 & 100.05 & 100.28 & 99.94 & 100.10 & 99.86 \\
\hline Si & 1.789 & 1.771 & 1.815 & 1.798 & 1.790 & 1.780 & 1.831 & 1.879 & 1.773 & 1.807 & 1.796 & 1.798 & 1.796 & 1.853 \\
AlIV & 0.220 & 0.230 & 0.190 & 0.210 & 0.210 & 0.220 & 0.170 & 0.130 & 0.230 & 0.190 & 0.200 & 0.200 & 0.200 & 0.150 \\
AlVI & 0.133 & 0.146 & 0.048 & 0.068 & 0.132 & 0.100 & 0.117 & 0.077 & 0.140 & 0.144 & 0.088 & 0.149 & 0.165 & 0.099 \\
Ti & 0.039 & 0.048 & 0.044 & 0.043 & 0.039 & 0.053 & 0.028 & 0.007 & 0.045 & 0.039 & 0.049 & 0.036 & 0.045 & 0.036 \\
FeIII & 0.109 & 0.087 & 0.096 & 0.103 & 0.100 & 0.050 & 0.073 & 0.024 & 0.129 & 0.109 & 0.120 & 0.081 & 0.055 & 0.016 \\
FelI & 0.103 & 0.120 & 0.080 & 0.102 & 0.086 & 0.136 & 0.116 & 0.286 & 0.048 & 0.075 & 0.099 & 0.006 & 0.112 & 0.140 \\
Mn & 0.008 & 0.006 & 0.005 & 0.004 & 0.008 & 0.005 & 0.006 & 0.007 & 0.006 & 0.005 & 0.005 & 0.098 & 0.002 & 0.004 \\
Mg & 0.760 & 0.736 & 0.822 & 0.800 & 0.778 & 0.753 & 0.818 & 1.534 & 0.774 & 0.767 & 0.753 & 0.777 & 0.766 & 0.834 \\
Ca & 0.786 & 0.804 & 0.882 & 0.833 & 0.794 & 0.872 & 0.765 & 0.046 & 0.796 & 0.796 & 0.865 & 0.798 & 0.786 & 0.828 \\
Na & 0.075 & 0.075 & 0.031 & 0.040 & 0.078 & 0.033 & 0.070 & 0.007 & 0.095 & 0.098 & 0.058 & 0.084 & 0.086 & 0.038 \\
K & 0.009 & 0.001 & 0.001 & 0.007 & 0.002 & 0.002 & 0.003 & 0.000 & 0.001 & 0.001 & 0.001 & 0.000 & 0.000 & 0.000 \\
Cr & 0.004 & 0.003 & 0.011 & 0.019 & 0.013 & 0.011 & 0.020 & 0.012 & & & & & & \\
& & & & & & & & & & & & & \\
TOTAL & 4.034 & 4.026 & 4.024 & 4.026 & 4.029 & 4.015 & 4.017 & 4.008 & 4.037 & 4.031 & 4.034 & 4.027 & 4.013 & 3.998 \\
\hline & & & & & & & & & & & & & & \\
Wo & 44.73 & 46.01 & 46.92 & 45.31 & 45.17 & 48.15 & 43.19 & 2.43 & 45.56 & 45.56 & 47.09 & 48.01 & 45.72 & 45.54 \\
En & 43.22 & 42.14 & 43.71 & 43.53 & 44.25 & 41.57 & 46.15 & 81.16 & 44.30 & 43.90 & 40.99 & 46.75 & 44.56 & 45.87 \\
Fs & 12.06 & 11.85 & 9.36 & 11.16 & 10.58 & 10.28 & 10.67 & 16.41 & 10.13 & 10.53 & 11.92 & 5.23 & 9.71 & 8.58
\end{tabular}




\begin{tabular}{|c|c|c|c|c|c|c|c|c|}
\hline $\begin{array}{l}\text { SAMPLE } \\
\text { Type }\end{array}$ & $\begin{array}{c}90044 \mathrm{~A} \\
\text { Pyxite } \\
\text { core }\end{array}$ & $\begin{array}{c}90044 \mathrm{~A} \\
\text { Pyxite } \\
\text { core }\end{array}$ & $\begin{array}{c}90044 \mathrm{~A} \\
\text { Pyxite } \\
\text { core }\end{array}$ & $\begin{array}{c}\text { 90048B } \\
\text { Pyxite } \\
\text { core }\end{array}$ & $\begin{array}{c}\text { 90048B } \\
\text { Pyxite } \\
\text { core }\end{array}$ & $\begin{array}{c}\text { 90048B } \\
\text { Pyxite } \\
\text { core }\end{array}$ & $\begin{array}{c}90048 B \\
\text { Pyxite } \\
\text { core }\end{array}$ & $\begin{array}{c}90048 B \\
\text { Pyxite } \\
\text { core }\end{array}$ \\
\hline $\mathrm{SiO}_{2}$ & 52.49 & 49.57 & 49.74 & 48.05 & 48.18 & 49.22 & 46.55 & 48.62 \\
\hline $\mathrm{Al} 2 \mathrm{O} 3$ & 5.31 & 7.14 & 6.98 & 7.41 & 7.13 & 7.25 & 9.05 & 7.88 \\
\hline $\mathrm{TiO}_{2}$ & 0.25 & 0.95 & 0.83 & 1.96 & 1.82 & 1.59 & 2.00 & 1.53 \\
\hline FeO total & 10.33 & 4.81 & 4.69 & 8.43 & 7.92 & 7.69 & 6.58 & 7.09 \\
\hline $\mathrm{MnO}$ & 0.38 & 0.19 & 0.04 & 0.19 & 0.26 & 0.25 & 0.15 & 0.12 \\
\hline $\mathrm{MgO}$ & 29.66 & 14.66 & 9 & 12 & 12 & 12.48 & 1271 & 13.66 \\
\hline $\mathrm{CaO}$ & 0.96 & 21.11 & 20.46 & 20.54 & 20.50 & 20.57 & 21.39 & 20.23 \\
\hline $\mathrm{Na} 2 \mathrm{O}$ & 0. & 1.26 & 1.20 & 1.15 & 1.07 & 1.10 & 1.02 & 1.05 \\
\hline $\mathrm{K} 2 \mathrm{O}$ & 0.02 & 0.0 & 0. & 0.00 & 0.02 & 0.02 & 0.02 & 0.05 \\
\hline $\mathrm{Cr} 2 \mathrm{O} 3$ & 0.34 & 0.55 & 0.58 & 0.20 & 0.01 & 0.72 & 0.44 & 0.67 \\
\hline$\overline{\mathrm{Fe} 2 \mathrm{O} 3}$ & 2.59 & 4.38 & 299 & 3.80 & 3.87 & 1.63 & 4.66 & 3.41 \\
\hline $\mathrm{FeO}$ & 8.00 & 0.86 & 200 & 5.01 & 4.44 & 6.22 & 2.39 & 4.02 \\
\hline TOTAL & 99.83 & 100.27 & 99.33 & 100.43 & 99.90 & 100.89 & 99.90 & 100.89 \\
\hline $\mathrm{Si}$ & 1.859 & 1.816 & 1.832 & 1.786 & 1.795 & 1.813 & 1.732 & 1.785 \\
\hline AlIV & 0.140 & 0.180 & 0.170 & 0.210 & 0.200 & 0.190 & 0.270 & 0.210 \\
\hline AlVI & 0.080 & 0.130 & 0.130 & 0.114 & 0.113 & 0.124 & 0.126 & 0.131 \\
\hline $\mathrm{Ti}$ & 0.006 & 0.026 & 0.023 & 0.054 & 0.0 & & & 0.042 \\
\hline FeIII & 0.069 & 0.120 & 0.0 & 0.1 & 0.107 & 0.045 & 0.129 & 0.093 \\
\hline FeII & 0.236 & & 0.0 & 0.154 & 0.137 & 0.191 & 0.074 & 0.122 \\
\hline $\mathrm{Mn}$ & 0.011 & 0.006 & 0.001 & 0.0 & 8 & 0.007 & 0.004 & 0.003 \\
\hline $\mathrm{Mg}$ & 1.564 & 0.800 & 0.811 & 0.692 & 0 & 0.685 & 0.704 & 0.747 \\
\hline $\mathrm{Ca}$ & 0.036 & 8 & 0.807 & 0.817 & 0.818 & 0.811 & 0.852 & 0.795 \\
\hline $\mathrm{Na}$ & 0.008 & 39 & 0.085 & 0.082 & 0.077 & 0.078 & 0.074 & 0.074 \\
\hline $\mathbf{K}$ & 0.000 & 0.000 & 0.000 & 0.000 & 0,000 & 0.001 & 0.000 & 0.002 \\
\hline $\mathrm{Cr}_{\mathrm{r}}$ & 0.009 & 0.015 & 0.017 & 0.005 & 0.000 & 0.020 & 0.013 & 0.019 \\
\hline TC & 4.017 & 4.036 & 4.019 & 4.024 & 4.026 & 4.009 & 4.034 & 4.023 \\
\hline Wo & 1.89 & 40.08 & 45.83 & 46.21 & 4.5 .90 & 46.82 & 48.44 & 45.25 \\
\hline En & 82.10 & 45.10 & 46.05 & 39.14 & 40.40 & 39.55 & 40.02 & 42.52 \\
\hline Fs & 16.01 & 8.23 & 8.12 & 14.65 & 13.69 & 13.63 & 11.54 & 12.24 \\
\hline
\end{tabular}

SAMPLE 90054I 90054I 90054K 90054K 90054K 90054K 90054K 90054K

Type Pyxite Pyxite Pyxite Pyxite Pyxite Pyxite Pyxite Pyxite

\begin{tabular}{|c|c|c|c|c|c|c|c|c|}
\hline & core & core & core & core & core & core & core & core \\
\hline $\mathrm{SiO}_{2}$ & 48.87 & 50.25 & 46.83 & 47.46 & 47.70 & 47.09 & 47.79 & 46.90 \\
\hline $\mathrm{A} 12 \mathrm{O} 3$ & 8.44 & 7.74 & 8.21 & 8.36 & 7.18 & 8.45 & 8.41 & 8.32 \\
\hline $\mathrm{TiO} 2$ & 1.36 & 1.37 & 2.05 & 2.05 & 1.98 & 1.95 & 1.74 & 1.87 \\
\hline FeO total & 5.52 & 5.33 & 6.27 & 7.51 & 6.70 & 7.26 & 7.20 & 7.64 \\
\hline $\mathrm{MnO}$ & 0.20 & 0.12 & 0.14 & 0.22 & 0.16 & 0.18 & 0.22 & 0.28 \\
\hline $\mathrm{MgO}$ & 14.03 & 14.13 & 13.19 & 12.43 & 13.35 & 1281 & 13.13 & 12.92 \\
\hline $\mathrm{CaO}$ & 20.15 & 20.60 & 21.80 & 20.54 & 22.66 & 21.06 & 20.88 & 20.88 \\
\hline $\mathrm{Na} 2 \mathrm{O}$ & 1.33 & 1.32 & 0.45 & 0.99 & 0.42 & 1.00 & 0.87 & 0.84 \\
\hline $\mathrm{K} 2 \mathrm{O}$ & 0.06 & 0.04 & 0.04 & 0.00 & 0.03 & 0.02 & 0.01 & 0.03 \\
\hline $\mathrm{Cr} 2 \mathrm{O}_{3}$ & & & 0.03 & 0.17 & 0.19 & 0.04 & 0.12 & 0.20 \\
\hline $\mathrm{Fe2O3}$ & 3.70 & 2.19 & 249 & 2.63 & 3.24 & 4.50 & 4.09 & 4.52 \\
\hline $\mathrm{FeO}$ & 2.19 & 3.36 & 4.02 & 5.14 & 3.78 & 3.21 & 3.52 & 3.58 \\
\hline TOTAL & 99.96 & 100.90 & 99.00 & 99.74 & 100.35 & 99.86 & 100.37 & 99.88 \\
\hline $\mathrm{Si}$ & 1.794 & 1.824 & 1.754 & 1.768 & 1.771 & 1.754 & 1.758 & 1.750 \\
\hline AlIV & 0.210 & 0.180 & 0.250 & 0.230 & 0.230 & 0.250 & 0.240 & 0.250 \\
\hline AIVI & 0.155 & 0.151 & 0.112 & 0.137 & 0.084 & 0.121 & 0.128 & 0.115 \\
\hline $\mathbf{T i}$ & 0.037 & 0.037 & 0.057 & 0.057 & 0.065 & 0.055 & 0.049 & 0.053 \\
\hline FelII & 0.101 & 0.060 & 0.070 & 0.073 & 0.090 & 0.125 & 0.113 & 0.126 \\
\hline FelI & 0.067 & 0.102 & 0.125 & 0.159 & 0.117 & 0.099 & 0.108 & 0.111 \\
\hline Mn & 0.006 & 0.003 & 0.004 & 0.006 & 0.004 & 0.005 & 0.006 & 0.009 \\
\hline $\mathrm{Mg}$ & 0.766 & 0.764 & 0.736 & 0.690 & 0.738 & 0.710 & 0.727 & 0.718 \\
\hline $\mathrm{Ca}$ & 0.792 & 0.801 & 0.874 & 0.819 & 0.901 & 0.839 & 0.831 & 0.834 \\
\hline $\mathrm{Na}$ & 0.096 & 0.092 & 0.032 & 0.071 & 0.030 & 0.073 & 0.064 & 0.062 \\
\hline $\mathbf{K}$ & 0.002 & 0.001 & 0.001 & 0.000 & 0.001 & 0.000 & 0.000 & 0.001 \\
\hline $\mathrm{Cr}$ & & & 0.001 & 0.005 & 0.005 & 0.001 & 0.003 & 0.006 \\
\hline TOTAL & 4.026 & 4.015 & 4.016 & 4.015 & 4.026 & 4.032 & 4.027 & 4.035 \\
\hline Wo & 45.89 & 46.38 & 48.42 & 47.04 & 48.81 & 47.32 & 46.71 & 46.62 \\
\hline En & 44.38 & 44.24 & 40.78 & 39.63 & 39.98 & 40.05 & 40.87 & 40.13 \\
\hline Fs & 9.73 & 9.38 & 10.80 & 13.33 & 11.21 & 1263 & 12.42 & 13.25 \\
\hline
\end{tabular}


A3.3 Mount Murphy xenolith mineral analyses: plagioclase

\begin{tabular}{|c|c|c|c|c|c|c|c|c|c|c|c|c|c|c|}
\hline $\begin{array}{l}\text { Sample } \\
\text { Type }\end{array}$ & $\begin{array}{c}90041 \mathrm{~A} \\
\text { Gran } \\
\text { core }\end{array}$ & $\begin{array}{c}90041 \mathrm{~A} \\
\text { Gran } \\
\text { core }\end{array}$ & $\begin{array}{c}90041 A \\
\text { Gran } \\
\text { core }\end{array}$ & $\begin{array}{c}90041 \mathrm{~A} \\
\text { Gran } \\
\text { core }\end{array}$ & $\begin{array}{c}90041 \mathrm{~A} \\
\text { Gran } \\
\text { core } \\
\end{array}$ & $\begin{array}{c}90041 \mathrm{~A} \\
\text { Gran } \\
\text { core }\end{array}$ & $\begin{array}{c}\text { 90041A } \\
\text { Gran } \\
\text { vein } \\
\end{array}$ & $\begin{array}{c}90041 \mathrm{~A} \\
\text { Gran } \\
\text { core } \\
\end{array}$ & $\begin{array}{c}90041 \mathrm{~A} \\
\text { Gran } \\
\text { melt }\end{array}$ & $\begin{array}{c}\text { 90041B } \\
\text { Gran } \\
\text { core }\end{array}$ & $\begin{array}{c}90041 B \\
\text { Gran } \\
\text { core }\end{array}$ & $\begin{array}{c}\text { 90041B } \\
\text { Gran } \\
\text { core }\end{array}$ & $\begin{array}{c}90041 B \\
\text { Gran } \\
\text { core }\end{array}$ & $\begin{array}{c}90041 \mathrm{~B} \\
\text { Gran } \\
\text { core }\end{array}$ \\
\hline $\mathrm{SiO}_{2}$ & 49.73 & 49.63 & 49.70 & 48.73 & 49.83 & 48.63 & 49.63 & 47.92 & 51.11 & 47.06 & 44.99 & 47.87 & 45.94 & 45.91 \\
\hline $\mathrm{A} 12 \mathrm{O} 3$ & 31.59 & 31.61 & 31.94 & 32.33 & 31.47 & 32.09 & 31.83 & 33.11 & 30.06 & 32.71 & 34.95 & 33.34 & 34.53 & 34.50 \\
\hline $\mathrm{TiO}_{2}$ & 0.09 & 0.05 & 0.01 & 0.05 & 0.07 & 0.08 & 0.14 & 0.00 & 0.03 & 0.05 & 0.00 & 0.03 & 0.00 & 0.00 \\
\hline $\mathrm{FeO}$ & 0.19 & 0.22 & 0.18 & 0.25 & 0.18 & 0.08 & 0.19 & 0.23 & 0.19 & 0.14 & 0.13 & 0.20 & 0.12 & 0.12 \\
\hline $\mathrm{MnO}$ & 0.02 & 0.06 & 0.05 & 0.03 & 0.00 & 0.07 & 0.04 & 0.01 & 0.00 & 0.22 & 0.10 & 0.02 & 0.01 & 0.10 \\
\hline $\mathrm{MgO}$ & 0.07 & 0.04 & 0.05 & 0.11 & 0.04 & 0.00 & 0.01 & 0.03 & 0.01 & 0.04 & 0.03 & 0.06 & 0.01 & 0.02 \\
\hline $\mathrm{CaO}$ & 14.66 & 14.93 & 14.46 & 14.88 & 14.14 & 15.44 & 14.10 & 15.70 & 14.28 & 15.94 & 18.12 & 15.93 & 18.45 & 17.87 \\
\hline $\mathrm{Na} 2 \mathrm{O}$ & 3.69 & 3.63 & 3.65 & 3.65 & 3.78 & 3.34 & 3.75 & 2.97 & 4.27 & 3.16 & 1.31 & 3.10 & 1.50 & 1.58 \\
\hline $\mathrm{K} 2 \mathrm{O}$ & 0.05 & 0.08 & 0.00 & 0.12 & 0.06 & 0.09 & 0.08 & 0.06 & 0.07 & 0.04 & 0.04 & 0.04 & 0.04 & 0.07 \\
\hline TOTAL & 100.09 & 100.25 & 100.04 & 100.14 & 99.57 & 99.80 & 99.78 & 100.04 & 100.02 & 99.35 & 99.66 & 100.59 & 100.60 & 100.17 \\
\hline Si & 2.269 & 2.265 & 2.269 & 2.232 & 2.282 & 2.235 & 2.268 & 2199 & 2.334 & 2.178 & 2.081 & 2.184 & 2.108 & 2.112 \\
\hline Al & 1.698 & 1.700 & 1.718 & 1.745 & 1.698 & 1.738 & 1.714 & 1.790 & 1.618 & 1.784 & 1.905 & 1.792 & 1.867 & 1.870 \\
\hline $\mathrm{Ti}$ & 0.003 & 0.002 & 0.000 & 0.002 & 0.002 & 0.003 & 0.005 & 0.000 & 0.001 & 0.001 & 0.000 & 0.001 & 0.000 & 0.000 \\
\hline $\mathrm{Fe}$ & 0.007 & 0.009 & 0.007 & 0.009 & 0.007 & 0.003 & 0.007 & 0.001 & 0.007 & 0.005 & 0.004 & 0.007 & 0.004 & 0.004 \\
\hline Mn & 0.001 & 0.002 & 0.002 & 0.001 & 0.000 & 0.003 & 0.002 & 0.000 & 0.000 & 0.008 & 0.003 & 0.000 & 0.000 & 0.004 \\
\hline $\mathbf{M g}$ & 0.005 & 0.002 & 0.004 & 0.008 & 0.003 & 0.000 & 0.001 & 0.002 & 0.001 & 0.002 & 0.002 & 0.004 & 0.000 & 0.001 \\
\hline $\mathrm{Ca}$ & 0.716 & 0.730 & 0.707 & 0.730 & 0.694 & 0.760 & 0.690 & 0.771 & 0.699 & 0.789 & 0.897 & 0.778 & 0.906 & 0.880 \\
\hline $\mathrm{Na}$ & 0.326 & 0.320 & 0.323 & 0.324 & 0.335 & 0.297 & 0.332 & 0.264 & 0.378 & 0.283 & 0.117 & 0.273 & 0.133 & 0.140 \\
\hline $\mathbf{K}$ & 0.003 & 0.005 & 0.000 & 0.007 & 0.004 & 0.005 & 0.005 & 0.004 & 0.004 & 0.002 & 0.002 & 0.002 & 0.002 & 0.004 \\
\hline TOTAL & 5.027 & 5.034 & 5.031 & 5.057 & 5.025 & 5.042 & 5.023 & 5.031 & 5.041 & 5.052 & 5.011 & 5.041 & 5.020 & 5.015 \\
\hline An & 68.54 & 69.19 & 68.64 & 68.80 & 67.18 & 71.52 & 67.22 & 74.26 & 64.66 & 73.46 & 88.29 & 73.88 & 87.03 & 85.94 \\
\hline$A b$ & 31.20 & 30.38 & 31.36 & 30.55 & 3248 & 27.97 & 32.31 & 25.39 & 34.96 & 26.35 & 11.52 & 25.93 & 1278 & 13.67 \\
\hline Or & 0.26 & 0.44 & 0.00 & 0.65 & 0.34 & 0.51 & 0.47 & 0.36 & 0.38 & 0.19 & 0.20 & 0.19 & 0.19 & 0.39 \\
\hline
\end{tabular}

\begin{tabular}{|c|c|c|c|c|c|c|c|c|c|c|c|c|c|c|}
\hline $\begin{array}{l}\text { Sample } \\
\text { Type }\end{array}$ & $\begin{array}{l}\text { 90041I } \\
\text { Gran } \\
\text { core }\end{array}$ & $\begin{array}{c}900411 \\
\text { Gran } \\
\text { core }\end{array}$ & $\begin{array}{l}90041 I \\
\text { Gran } \\
\text { core }\end{array}$ & $\begin{array}{l}\text { 90041I } \\
\text { Gran } \\
\text { oxid }\end{array}$ & $\begin{array}{l}900411 \\
\text { Gran } \\
\text { oxid }\end{array}$ & $\begin{array}{l}90044 A \\
\text { Pyxite } \\
\text { spinel r }\end{array}$ & $\begin{array}{c}\text { 90048B } \\
\text { Pyxite } \\
\text { core }\end{array}$ & $\begin{array}{c}\text { 90048B } \\
\text { Pyxite } \\
\text { oxid }\end{array}$ & $\begin{array}{c}\text { 90048B } \\
\text { Pyxite } \\
\text { melt }\end{array}$ & $\begin{array}{c}\text { 90048B } \\
\text { Pyxite } \\
\text { melt }\end{array}$ & $\begin{array}{c}\text { 90048D } \\
\text { Pyxite } \\
\text { melt }\end{array}$ & $\begin{array}{c}90048 D \\
\text { Pyxite } \\
\text { oxid }\end{array}$ & $\begin{array}{c}\text { 90048D } \\
\text { Pyxite } \\
\text { core }\end{array}$ & $\begin{array}{c}\text { 90048D } \\
\text { Pyxite } \\
\text { core }\end{array}$ \\
\hline $\mathrm{SiO}_{2}$ & 48.03 & 48.79 & 47.61 & 56.83 & 45.75 & 53.24 & 52.63 & 50.36 & 50.51 & 49.69 & 50.86 & 52.44 & 5294 & 5226 \\
\hline $\mathrm{Al}_{2} \mathrm{O}_{3}$ & 33.49 & 32.41 & 32.77 & 25.60 & 33.43 & 28.57 & 29.08 & 30.37 & 30.44 & 31.15 & 29.62 & 28.84 & 29.01 & 29.67 \\
\hline $\mathrm{TiO}_{2}$ & 0.01 & 0.07 & 0.03 & 0.11 & 0.03 & 0.11 & 0.07 & 0.16 & 0.19 & 0.17 & 0.37 & 0.31 & 0.19 & 0.18 \\
\hline $\mathrm{FeO}$ & 0.12 & 0.13 & 0.15 & 1.00 & 0.82 & 0.82 & 0.58 & 0.61 & 0.92 & 1.09 & 0.97 & 0.88 & 0.56 & 0.43 \\
\hline $\mathrm{MnO}$ & 0.00 & 0.05 & 0.04 & 0.01 & 0.09 & 0.07 & 0.01 & 0.03 & 0.05 & 0.08 & 0.11 & 0.09 & 0.17 & 0.12 \\
\hline $\mathrm{MgO}$ & 0.04 & 0.05 & 0.06 & 0.22 & 0.14 & 0.21 & 0.08 & 0.14 & 0.14 & 0.15 & 0.17 & 0.07 & 0.08 & 0.04 \\
\hline $\mathrm{CaO}$ & 15.54 & 15.55 & 16.66 & 8.65 & 17.40 & 11.07 & 11.18 & 14.44 & 13.54 & 13.31 & 13.04 & 11.77 & 11.66 & 12.17 \\
\hline $\mathrm{Na}_{2} \mathrm{O}$ & 3.19 & 2.77 & 2.12 & 5.63 & 1.62 & 5.99 & 5.88 & 3.56 & 4.07 & 4.26 & 4.49 & 5.26 & 4.99 & 5.39 \\
\hline $\mathrm{K} 2 \mathrm{O}$ & 0.03 & 0.07 & 0.10 & 0.60 & 0.07 & 0.26 & 0.30 & 0.13 & 0.21 & 0.21 & 0.23 & 0.40 & 0.30 & 0.33 \\
\hline TOTAL & 100.45 & 99.88 & 99.54 & 98.66 & 99.35 & 100.33 & 99.81 & 99.80 & 100.07 & 100.11 & 99.86 & 100.06 & 99.90 & 100.58 \\
\hline Si & 2.193 & 2.233 & 2,194 & 2.591 & 2.129 & 2.416 & 2399 & 2306 & 2.313 & 2.275 & 2.332 & 2.391 & 2.407 & 2.371 \\
\hline Al & 1.802 & 1.748 & 1.780 & 1.375 & 1.833 & 1.527 & 1.562 & 1.638 & 1.642 & 1.680 & 1.602 & 1.549 & 1.554 & 1.587 \\
\hline $\mathrm{Ti}$ & 0.000 & 0.002 & 0.001 & 0.004 & 0.001 & 0.003 & 0.002 & 0.005 & 0.006 & 0.005 & 0.012 & 0.010 & 0.007 & 0.006 \\
\hline $\mathrm{Fe}$ & 0.004 & 0.004 & 0.006 & 0.038 & 0.032 & 0.030 & 0.022 & 0.022 & 0.034 & 0.040 & 0.036 & 0.032 & 0.021 & 0.016 \\
\hline Mn & 0.000 & 0.002 & 0.001 & 0.000 & 0.004 & 0.002 & 0.000 & 0.001 & 0.001 & 0.002 & 0.004 & 0.003 & 0.007 & 0.005 \\
\hline $\mathbf{M g}$ & 0.002 & 0.003 & 0.004 & 0.015 & 0.010 & 0.014 & 0.005 & 0.009 & 0.009 & 0.010 & 0.001 & 0.005 & 0.005 & 0.002 \\
\hline $\mathrm{Ca}$ & 0.760 & 0.762 & 0.822 & 0.422 & 0.867 & 0.538 & 0.545 & 0.708 & 0.664 & 0.652 & 0.641 & 0.575 & 0.568 & 0.592 \\
\hline $\mathrm{Na}$ & 0.282 & 0.245 & 0.189 & 0.497 & 0.146 & 0.526 & 0.518 & 0.315 & 0.361 & 0.377 & 0.400 & 0.464 & 0.440 & 0.474 \\
\hline $\mathbf{K}$ & 0.001 & 0.003 & 0.006 & 0.035 & 0.004 & 0.015 & 0.017 & 0.007 & 0.012 & 0.012 & 0.013 & 0.022 & 0.017 & 0.019 \\
\hline TOTAL & 5.044 & 5.002 & 5.003 & 4.978 & 5.026 & 5.071 & 5.070 & 5.011 & 5.042 & 5.053 & 5.041 & 5.052 & 5.025 & 5.071 \\
\hline An & 72.87 & 75.45 & 80.83 & 44.24 & 85.28 & 49.86 & 50.46 & 68.74 & 64.03 & 62.63 & 60.82 & 54.17 & 55.42 & 54.55 \\
\hline $\mathbf{A b}$ & 27.04 & 24.26 & 18.59 & 52.11 & 14.33 & 48.75 & 47.96 & 30.58 & 34.81 & 36.22 & 37.95 & 43.75 & 4291 & 43.70 \\
\hline Or & 0.10 & 0.30 & 0.58 & 3.66 & 0.39 & 1.39 & 1.57 & 0.68 & 1.16 & 1.15 & 1.23 & 2.07 & 1.67 & 1.75 \\
\hline
\end{tabular}




\begin{tabular}{|c|c|c|c|c|c|c|c|c|c|c|c|c|c|c|}
\hline $\begin{array}{l}\text { Sample } \\
\text { Type }\end{array}$ & $\begin{array}{c}90041 \mathrm{~B} \\
\text { Gran } \\
\text { core }\end{array}$ & $\begin{array}{c}90041 B \\
\text { Gran } \\
\text { core }\end{array}$ & $\begin{array}{c}90041 B \\
\text { Gran } \\
\text { core } \\
\end{array}$ & $\begin{array}{c}90041 \mathrm{~B} \\
\text { Gran } \\
\text { core }\end{array}$ & $\begin{array}{c}90041 C \\
\text { Gran } \\
\text { core }\end{array}$ & $\begin{array}{c}90041 C \\
\text { Gran } \\
\text { core }\end{array}$ & $\begin{array}{c}90041 C \\
\text { Gran } \\
\text { core }\end{array}$ & $\begin{array}{c}90041 C \\
\text { Gran } \\
\text { core }\end{array}$ & $\begin{array}{c}90041 C \\
\text { Gran } \\
\text { core }\end{array}$ & $\begin{array}{c}90041 C \\
\text { Gran } \\
\text { core }\end{array}$ & $\begin{array}{c}90041 \mathrm{G} \\
\text { Gran } \\
\text { core }\end{array}$ & $\begin{array}{c}90041 G \\
\text { Gran } \\
\text { core }\end{array}$ & $\begin{array}{c}90041 G \\
\text { Gran } \\
\text { core } \\
\end{array}$ & $\begin{array}{c}90041 G \\
\text { Gran } \\
\text { core } \\
\end{array}$ \\
\hline $\mathrm{SiO}_{2}$ & 46.67 & 47.98 & 47.95 & 48.38 & 48.53 & 48.94 & 48.44 & 48.18 & 49.19 & 46.57 & 45.48 & 49.16 & 48.66 & 48.80 \\
\hline $\mathrm{Al} 2 \mathrm{O} 3$ & 33.26 & 32.89 & 32.86 & 32.90 & 33.33 & 32.38 & 3289 & 33.38 & 32.21 & 34.00 & 34.37 & 32.30 & 32.34 & 32.49 \\
\hline $\mathrm{TiO}_{2}$ & 0.00 & 0.01 & 0.06 & 0.03 & 0.04 & 0.04 & 0.07 & 0.00 & 0.00 & 0.02 & 0.05 & 0.00 & 0.00 & 0.09 \\
\hline $\mathrm{FeO}$ & 0.10 & 0.13 & 0.04 & 0.07 & 0.12 & 0.22 & 0.11 & 0.11 & 0.17 & 0.45 & 0.24 & 0.21 & 0.22 & 0.16 \\
\hline Mno & 0.13 & 0.10 & 0.08 & 0.16 & 0.04 & 0.01 & 0.04 & 0.07 & 0.08 & 0.00 & 0.01 & 0.07 & 0.05 & 0.05 \\
\hline $\mathrm{MgO}$ & 0.05 & 0.04 & 0.05 & 0.04 & 0.03 & 0.07 & 0.08 & 0.06 & 0.06 & 0.06 & 0.06 & 0.00 & 0.07 & 0.05 \\
\hline $\mathrm{CaO}$ & 16.68 & 15.81 & 15.82 & 15.78 & 15.47 & 15.72 & 15.64 & 15.42 & 15.75 & 17.06 & 17.87 & 15.30 & 15.15 & 14.88 \\
\hline $\mathrm{Na} 2 \mathrm{O}$ & 2.68 & 3.06 & 3.13 & 299 & 267 & 290 & 2.80 & 2.86 & 2.96 & 1.87 & 1.72 & 3.08 & 3.49 & 3.35 \\
\hline $\mathrm{K} 2 \mathrm{O}$ & 0.02 & 0.13 & 0.08 & 0.06 & 0.09 & 0.06 & 0.14 & 0.08 & 0.07 & 0.07 & 0.06 & 0.09 & 0.09 & 0.06 \\
\hline TOTAL & 99.58 & 100.14 & 100.06 & 100.40 & 100.32 & 100.33 & 100.20 & 100.15 & 100.50 & 100.10 & 99.86 & 100.21 & 100.06 & 99.93 \\
\hline Si & 2.156 & 2.200 & 2.200 & 2.209 & 2.213 & 2.235 & 2.215 & 2.200 & 2.243 & 2142 & 2.100 & 2.244 & 2.230 & 2.232 \\
\hline Al & 1.810 & 1.777 & 1.777 & 1.770 & 1.791 & 1.742 & 1.772 & 1.798 & 1.731 & 1.843 & 1.872 & 1.737 & 1.746 & 1.751 \\
\hline $\mathrm{Ti}$ & 0.000 & 0.000 & 0.002 & 0.001 & 0.001 & 0.001 & 0.002 & 0.000 & 0.000 & 0.000 & 0.002 & 0.000 & 0.000 & 0.003 \\
\hline $\mathrm{Fe}$ & 0.003 & 0.004 & 0.001 & 0.002 & 0.004 & 0.008 & 0.004 & 0.004 & 0.006 & 0.016 & 0.009 & 0.007 & 0.008 & 0.006 \\
\hline Mn & 0.005 & 0.003 & 0.003 & 0.005 & 0.000 & 0.000 & 0.001 & 0.003 & 0.003 & 0.000 & 0.000 & 0.002 & 0.001 & 0.001 \\
\hline $\mathbf{M g}$ & 0.003 & 0.002 & 0.003 & 0.002 & 0.000 & 0.000 & 0.005 & 0.003 & 0.004 & 0.004 & 0.004 & 0.000 & 0.004 & 0.003 \\
\hline $\mathrm{Ca}$ & 0.825 & 0.776 & 0.777 & 0.771 & 0.755 & 0.769 & 0.765 & 0.755 & 0.769 & 0.840 & 0.885 & 0.748 & 0.744 & 0.728 \\
\hline $\mathrm{Na}$ & 0.239 & 0.272 & 0.278 & 0.264 & 0.236 & 0.256 & 0.248 & 0.253 & 0.261 & 0.166 & 0.154 & 0.272 & 0.310 & 0.314 \\
\hline $\mathbf{K}$ & 0.001 & 0.007 & 0.004 & 0.003 & 0.004 & 0.003 & 0.008 & 0.004 & 0.004 & 0.004 & 0.004 & 0.005 & 0.005 & 0.003 \\
\hline TOTAL & 5.042 & 5.041 & 5.045 & 5.027 & 5.004 & 5.014 & 5.020 & 5.020 & 5.021 & 5.015 & 5.032 & 5.015 & 5.048 & 5.041 \\
\hline An & 77.46 & 73.55 & 73.37 & 74.28 & 75.88 & 74.81 & 74.93 & 74.60 & 74.37 & 83.17 & 84.89 & 72.98 & 70.25 & 69.67 \\
\hline$A b$ & 22.44 & 25.78 & 26.25 & 25.43 & 23.72 & 24.90 & 24.29 & 25.00 & 25.24 & 16.44 & 14.78 & 26.54 & 29.27 & 30.05 \\
\hline Or & 0.09 & 0.66 & 0.38 & 0.29 & 0.40 & 0.29 & 0.78 & 0.40 & 0.39 & 0.40 & 0.34 & 0.49 & 0.47 & 0.29 \\
\hline
\end{tabular}

\begin{tabular}{|c|c|c|c|c|c|c|c|c|c|c|c|c|c|c|}
\hline $\begin{array}{l}\text { Sample } \\
\text { Type }\end{array}$ & $\begin{array}{c}90048 E \\
\text { Gran } \\
\text { core }\end{array}$ & $\begin{array}{c}90048 \mathrm{E} \\
\text { Gran } \\
\text { melt }\end{array}$ & $\begin{array}{c}90048 \mathrm{E} \\
\text { Gran } \\
\text { melt }\end{array}$ & $\begin{array}{c}\text { 90048E } \\
\text { Gran } \\
\text { core } \\
\end{array}$ & $\begin{array}{c}90048 E \\
\text { Gran } \\
\text { core } \\
\end{array}$ & $\begin{array}{c}90048 \mathrm{E} \\
\text { Gran } \\
\text { melt }\end{array}$ & $\begin{array}{c}90048 E \\
\text { Gran } \\
\text { core }\end{array}$ & $\begin{array}{c}90048 \mathrm{~F} \\
\text { Gran } \\
\text { core }\end{array}$ & $\begin{array}{c}90048 \mathrm{~F} \\
\text { Gran } \\
\text { core }\end{array}$ & $\begin{array}{c}90048 \mathrm{~F} \\
\text { Gran } \\
\text { core }\end{array}$ & $\begin{array}{c}90048 \mathrm{~F} \\
\text { Gran } \\
\text { core }\end{array}$ & $\begin{array}{c}90048 G \\
\text { Gran } \\
\text { core- }\end{array}$ & $\begin{array}{c}90048 G \\
\text { Gran } \\
\text { rim }\end{array}$ & $\begin{array}{c}90048 \mathrm{G} \\
\text { Gran } \\
\text { core } \\
\end{array}$ \\
\hline $\mathrm{SiO}_{2}$ & 53.44 & 52.64 & 53.12 & 49.35 & 53.05 & 52.93 & 52.59 & 53.32 & 52.98 & 53.20 & 53.59 & 55.09 & 49.46 & 55.19 \\
\hline $\mathrm{A} 12 \mathrm{O}_{3}$ & 30.40 & 29.09 & 29.45 & 32.10 & 29.99 & 29.21 & 29.78 & 28.85 & 29.49 & 29.27 & 29.17 & 28.08 & 30.76 & 27.87 \\
\hline $\mathrm{TiO}_{2}$ & 0.04 & 0.27 & 0.28 & 0.18 & 0.08 & 0.28 & 0.06 & 0.11 & 0.12 & 0.10 & 0.18 & 0.02 & 0.22 & 0.00 \\
\hline $\mathrm{FeO}$ & 0.25 & 0.74 & 0.71 & 0.51 & 0.17 & 0.91 & 0.20 & 0.39 & 0.43 & 0.39 & 0.45 & 0.07 & 0.68 & 0.17 \\
\hline $\mathrm{MnO}$ & 0.02 & 0.00 & 0.00 & 0.02 & 0.00 & 0.00 & 0.09 & 0.05 & 0.00 & 0.10 & 0.00 & 0.15 & 0.00 & 0.11 \\
\hline $\mathrm{MgO}$ & 0.05 & 0.31 & 0.08 & 0.06 & 0.06 & 0.12 & 0.02 & 0.07 & 0.08 & 0.14 & 0.06 & 0.00 & 0.15 & 0.03 \\
\hline $\mathrm{CaO}$ & 12.31 & 12.26 & 12.05 & 15.08 & 1234 & 12.31 & 1265 & 11.45 & 11.12 & 11.02 & 11.00 & 10.18 & 14.16 & 10.17 \\
\hline $\mathrm{Na} 2 \mathrm{O}$ & 4.48 & 4.05 & 4.08 & 267 & 4.16 & 4.07 & 4.14 & 4.53 & 5.56 & 5.40 & 5.14 & 6.70 & 4.11 & 6.84 \\
\hline $\mathrm{K} 2 \mathrm{O}$ & 0.25 & 0.21 & 0.21 & 0.11 & 0.28 & 0.25 & 0.24 & 0.29 & 0.33 & 0.33 & 0.41 & 0.36 & 0.11 & 0.39 \\
\hline TOTAL & 101.24 & 99.57 & 99.98 & 100.08 & 100.12 & 100.08 & 99.77 & 99.05 & 100.12 & 99.94 & 100.00 & 100.65 & 99.65 & 100.75 \\
\hline Si & 2392 & 2.400 & 2.407 & 2.255 & 2.399 & 2.403 & 2.392 & 2.436 & 2403 & 2415 & 2.427 & 2.479 & 2.273 & 2.481 \\
\hline Al & 1.604 & 1.562 & 1.573 & 1.729 & 1.599 & 1.562 & 1.596 & 1.553 & 1.576 & 1.566 & 1.557 & 1.489 & 1.665 & 1.476 \\
\hline $\mathbf{T i}$ & 0.001 & 0.010 & 0.010 & 0.006 & 0.003 & 0.010 & 0.002 & 0.004 & 0.004 & 0.003 & 0.006 & 0.001 & 0.008 & 0.000 \\
\hline $\mathrm{Fe}$ & 0.009 & 0.028 & 0.027 & 0.020 & 0.006 & 0.036 & 0.008 & 0.015 & 0.016 & 0.014 & 0.017 & 0.003 & 0.026 & 0.006 \\
\hline Mn & 0.001 & 0.000 & 0.000 & 0.001 & 0.000 & 0.000 & 0.004 & 0.002 & 0.000 & 0.003 & 0.000 & 0.006 & 0.000 & 0.004 \\
\hline $\mathbf{M g}$ & 0.006 & 0.021 & 0.006 & 0.004 & 0.004 & 0.009 & 0.001 & 0.005 & 0.005 & 0.009 & 0.004 & 0.000 & 0.010 & 0.002 \\
\hline $\mathrm{Ca}$ & 0.591 & 0.598 & 0.585 & 0.738 & 0.598 & 0.599 & 0.616 & 0.560 & 0.540 & 0.536 & 0.534 & 0.491 & 0.697 & 0.489 \\
\hline $\mathrm{Na}$ & 0.389 & 0.358 & 0.358 & 0.237 & 0.365 & 0.358 & 0.365 & 0.401 & 0.488 & 0.475 & 0.452 & 0.584 & 0.366 & 0.596 \\
\hline $\mathbf{K}$ & 0.014 & 0.012 & 0.012 & 0.006 & 0.016 & 0.015 & 0.014 & 0.017 & 0.019 & 0.019 & 0.024 & 0.020 & 0.006 & 0.022 \\
\hline TOTAL & 5.004 & 4.989 & 4.978 & 4.996 & 4.990 & 4.992 & 4.998 & 4.993 & 5.051 & 5.040 & 5.020 & 5.072 & 5.050 & 5.076 \\
\hline An & 59.46 & 61.78 & 61.26 & 75.23 & 61.08 & 61.63 & 61.91 & 57.26 & 51.56 & 52.02 & 52.90 & 44.83 & 65.19 & 44.18 \\
\hline $\mathbf{A b}$ & 39.13 & 36.98 & 37.49 & 24.16 & 37.28 & 36.83 & 36.68 & 41.00 & 46.64 & 46.12 & 44.75 & 53.34 & 34.22 & 53.80 \\
\hline Or & 1.41 & 1.24 & 1.26 & 0.61 & 1.63 & 1.54 & 1.41 & 1.74 & 1.80 & 1.85 & 2.35 & 1.83 & 0.59 & 202 \\
\hline
\end{tabular}




\begin{tabular}{|c|c|c|c|c|c|c|}
\hline $\begin{array}{l}\text { Sample } \\
\text { Type }\end{array}$ & $\begin{array}{c}\text { 90041G } \\
\text { Gran } \\
\text { core } \\
\end{array}$ & $\begin{array}{c}900416 \\
\text { Gran } \\
\text { core }\end{array}$ & $\begin{array}{c}90041 I \\
\text { Gran } \\
\text { core } \\
\end{array}$ & $\begin{array}{c}90041 \mathrm{I} \\
\text { Gran } \\
\text { core } \\
\end{array}$ & $\begin{array}{l}900411 \\
\text { Gran } \\
\text { core } \\
\end{array}$ & $\begin{array}{c}900411 \\
\text { Gran } \\
\text { core } \\
\end{array}$ \\
\hline $\mathrm{SiO}_{2}$ & 45.64 & 47.27 & 47.30 & 48.15 & 48.28 & 47.50 \\
\hline $\mathrm{Al}_{2} \mathrm{O} 3$ & 34.84 & 33.43 & 33.05 & 32.44 & 33.03 & 3299 \\
\hline $\mathrm{TiO}_{2}$ & 0.04 & 0.05 & 0.10 & 0.00 & 0.04 & 0.05 \\
\hline $\mathrm{FeO}$ & 0.17 & 0.20 & 0.29 & 0.29 & 0.13 & 0.13 \\
\hline $\mathrm{MnO}$ & 0.10 & 0.12 & 0.03 & 0.05 & 0.03 & 0.06 \\
\hline MgO & 0.00 & 0.05 & 0.00 & 0.05 & 0.08 & 0.01 \\
\hline $\mathrm{CaO}$ & 17.38 & 15.84 & 15.89 & 15.71 & 15.04 & 16.20 \\
\hline $\mathrm{Na} 2 \mathrm{O}$ & 1.83 & 3.07 & 2.95 & 3.12 & 3.30 & 3.03 \\
\hline $\mathrm{K}_{2} \mathrm{O}$ & 0.04 & 0.07 & 0.11 & 0.06 & 0.07 & 0.03 \\
\hline TOTAL & 100.04 & 100.10 & 99.71 & 99.87 & 100.00 & 100.01 \\
\hline $\mathrm{Si}$ & 2.101 & 2.170 & 2.178 & 2.213 & 2.212 & 2.185 \\
\hline Al & 1.889 & 1.809 & 1.793 & 1.756 & 1.783 & 1.788 \\
\hline $\mathrm{Ti}$ & 0.001 & 0.001 & 0.003 & 0.000 & 0.001 & 0.001 \\
\hline $\mathrm{Fe}$ & 0.006 & 0.070 & 0.010 & 0.010 & 0.005 & 0.004 \\
\hline Mn & 0.004 & 0.005 & 0.001 & 0.002 & 0.001 & 0.002 \\
\hline Mg & 0.000 & 0.003 & 0.000 & 0.003 & 0.005 & 0.000 \\
\hline $\mathrm{Ca}$ & 0.856 & 0.778 & 0.783 & 0.773 & 0.737 & 0.798 \\
\hline $\mathrm{Na}$ & 0.163 & 0.273 & 0.262 & 0.277 & 0.292 & 0.269 \\
\hline $\mathbf{K}$ & 0.002 & 0.004 & 0.006 & 0.003 & 0.004 & 0.001 \\
\hline TOTAL & 5.022 & 5.113 & 5.036 & 5.037 & 5.040 & 5.048 \\
\hline An & 83.84 & 73.74 & 74.50 & 73.41 & 71.35 & 74.72 \\
\hline$A b$ & 15.96 & 25.88 & 24.93 & 26.31 & 28.27 & 25.19 \\
\hline Or & 0.20 & 0.38 & 0.57 & 0.28 & 0.39 & 0.09 \\
\hline
\end{tabular}


A3.3 Mount Murphy xenolith mineral analyses: oxides

\begin{tabular}{|c|c|c|c|c|c|c|c|c|c|c|c|c|c|c|}
\hline $\begin{array}{l}\text { Sample } \\
\text { Type }\end{array}$ & $\begin{array}{c}90041 \text { A } \\
\text { Gran } \\
\text { melt }\end{array}$ & $\begin{array}{c}90041 \mathrm{~A} \\
\text { Gran } \\
\text { melt }\end{array}$ & $\begin{array}{c}90041 A \\
\text { Gran } \\
\text { symp }\end{array}$ & $\begin{array}{c}90041 C \\
\text { Gran } \\
\text { melt }\end{array}$ & $\begin{array}{c}90041 C \\
\text { Gran } \\
\text { core } \\
\end{array}$ & $\begin{array}{c}900411 \\
\text { Gran } \\
\text { oxid } \\
\end{array}$ & $\begin{array}{c}900411 \\
\text { Gran } \\
\text { oxid } \\
\end{array}$ & $\begin{array}{c}90044 \mathrm{~A} \\
\text { Pyxite } \\
\text { core- }\end{array}$ & $\begin{array}{l}90044 \mathrm{~A} \\
\text { Pyxite } \\
\text { rim } \\
\end{array}$ & $\begin{array}{c}\text { 90048B } \\
\text { Pyxite } \\
\text { core }\end{array}$ & $\begin{array}{c}\text { 90048B } \\
\text { Pyxite } \\
\text { core }\end{array}$ & $\begin{array}{c}\text { 90048B } \\
\text { Pyxite } \\
\text { core }\end{array}$ & $\begin{array}{c}\text { 90048B } \\
\text { Pyxite } \\
\text { core }\end{array}$ & $\begin{array}{c}90048 B \\
\text { Pyxite } \\
\text { oxid } \\
\end{array}$ \\
\hline $\mathrm{SiO}_{2}$ & 0.72 & 0.60 & 0.39 & 0.28 & 0.24 & 0. & & & & 0.71 & 0.36 & 0.22 & 0.88 & 0.25 \\
\hline $\mathrm{Al}_{2} \mathrm{O}_{3}$ & 1.14 & 1.81 & 2.31 & 0.91 & 16.22 & 0.1 & 0.05 & 60.14 & 2.85 & 0.14 & 0.14 & 50.30 & 0.39 & 8.75 \\
\hline $\mathrm{TiO} 2$ & 9.27 & 8.86 & 0.16 & 11.03 & 235 & 0.05 & 0.08 & 0.22 & 3.09 & 0.09 & 0.05 & 1.25 & 0.04 & 21.00 \\
\hline $\mathrm{Fe}_{2} \mathrm{O}_{3}$ & 47.40 & 47.59 & 74.62 & 45.03 & 45.91 & 84.06 & 79.86 & 0.59 & 42 & 62.94 & 67.45 & 6.52 & 61.09 & 14.61 \\
\hline $\mathrm{FeO}$ & 31.17 & 30.23 & 4.00 & 36.53 & 27.95 & 1.25 & 8.56 & 13.17 & 31.08 & 27.70 & 30.29 . & 20.42 & 28.96 & 38.02 \\
\hline $\mathrm{MnO}$ & 0.49 & 0.62 & 0.66 & 0.13 & 0.04 & 0.28 & 0.24 & 0.10 & 0.32 & 0.03 & 0.12 & 0.14 & & \\
\hline $\mathrm{MgO}$ & 4.79 & 4.86 & 17.79 & 239 & 4.61 & 20.60 & 15.29 & 18.50 & 2.89 & & 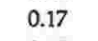 & 13.36 & 0.25 & 7.86 \\
\hline $\mathrm{CaO}$ & 0.31 & 0.45 & 0.06 & 0.38 & 0.59 & 0.09 & 0.07 & 0.10 & 0.54 & 0.45 & 0.15 & 0.14 & 0.22 & 0.11 \\
\hline $\mathrm{Cr} 2 \mathrm{O}$ & 0.19 & 0.09 & 0.04 & 0.08 & 0.28 & 0.03 & 0.17 & 6.10 & 5.81 & 0.06 & 0.24 & & & \\
\hline $\mathrm{NiO}$ & 0.27 & 0.24 & 0.42 & 0.02 & 0.06 & 0.25 & 0.32 & & & 1.33 & 0.50 & 0.20 & 0.34 & 0.15 \\
\hline TOT & 75 & 95.35 & 100.45 & 9 & 3.25 & 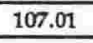 & . & 99.11 & 근 & 93.87 & 99.46 & 100.10 & 92.37 & 94.69 \\
\hline $6 i$ & & & & 0.011 & 0.008 & 0.007 & 0.003 & 0.005 & 0.129 & 0.0 & 0.0 & 0.0 & 0.0 & \\
\hline Al & 0.051 & 0.081 & 0.091 & 0.041 & 0.661 & 0.007 & 0.002 & 1.845 & 0.132 & 0.007 & 0.006 & & & \\
\hline $\mathrm{Ti}$ & 0.265 & 0.253 & 0.004 & 0.318 & 0.061 & 0.001 & & & 0.091 & 0.003 & 0.001 & 0.026 & 0.001 & 0.562 \\
\hline FelII & & 1.363 & 1.874 & 1.299 & 1.193 & 1.976 & 1.983 & 0.011 & 1.249 & 1.927 & 1.956 & 0.135 & 1.899 & 0.392 \\
\hline FeII & 0.992 & 0.962 & 0.112 & 1.172 & 0.847 & 0.033 & 0.236 & 0.257 & 1.018 & 0.943 & 0.980 & & & \\
\hline $\mathrm{Mn}$ & 0.016 & 0.020 & 0.019 & 0.004 & 0.001 & 0.007 & & & & & 0.004 & 0.003 & 0.000 & 0.014 \\
\hline Mg & 0.272 & 0.276 & 0.885 & 0.137 & 0.237 & 0.959 & 0.752 & 0.717 & 0.168 & 0.025 & 0.010 & 0.549 & 0.015 & 0.417 \\
\hline $\mathrm{Ca}$ & 0.013 & 0.018 & 0.002 & 0.016 & 0.022 & 0.003 & 0.002 & 0.003 & 0.023 & 0.020 & 0.006 & 0.004 & & \\
\hline Cr & 0.006 & 0.000 & 0.001 & & 0.008 & 0.001 & 0.004 & 0.126 & 0.180 & & 0.007 & 0.165 & 0.006 & 0.098 \\
\hline $\mathrm{Ni}$ & 0.000 & 0.000 & 0.000 & 0.001 & 0.002 & 0.006 & 0.009 & & & 0.044 & 0.015 & 0.004 & 0.011 & 0.004 \\
\hline 21 & 000 & 2.999 & .001 & 3.001 & 3.040 & 3.000 & 3.000 & 2970 & 3.001 & 3.001 & 2999 & 2.999 & 2.999 & 2.999 \\
\hline
\end{tabular}

\begin{tabular}{|c|c|c|c|c|c|c|c|c|c|c|c|c|c|c|}
\hline $\begin{array}{l}\text { Sample } \\
\text { Type }\end{array}$ & $\begin{array}{c}900486 \\
\text { Gran } \\
\text { oxid }\end{array}$ & $\begin{array}{c}90054 C \\
\text { Pyxite } \\
\text { core- }\end{array}$ & $\begin{array}{c}90054 C \\
\text { Pyxite } \\
\text { rim }\end{array}$ & $\begin{array}{c}90054 C \\
\text { Pyxite } \\
\text { core }\end{array}$ & $\begin{array}{c}90054 C \\
\text { Pyxite } \\
\text { core }\end{array}$ & $\begin{array}{c}900541 \\
\text { Pyxite } \\
\text { oxid }\end{array}$ & $\begin{array}{l}900541 \\
\text { Pyxite } \\
\text { oxid } \\
\end{array}$ & $\begin{array}{c}900541 \\
\text { Pyxite } \\
\text { oxid } \\
\end{array}$ & $\begin{array}{l}90054 I \\
\text { Pyxite } \\
\text { oxid c- }\end{array}$ & $\begin{array}{l}90054 I \\
\text { Pyxite } \\
\text { oxid r } \\
\end{array}$ & $\begin{array}{c}900541 \\
\text { Pyxite } \\
\text { core }\end{array}$ & $\begin{array}{c}90054 I \\
\text { Pyxite } \\
\text { oxid }\end{array}$ & $\begin{array}{c}90054 I \\
\text { Pyxite } \\
\text { core }\end{array}$ & $\begin{array}{c}900541 \\
\text { Pyxite } \\
\text { oxid }\end{array}$ \\
\hline $\mathrm{SiO}_{2}$ & 0.02 & 0.15 & 0.04 & 1.00 & 3.18 & 0.19 & 6.05 & 0.48 & 0.20 & 1.12 & 0.36 & 0.09 & 0.44 & 0.92 \\
\hline $\mathrm{Al} 2 \mathrm{O} 3$ & 0.65 & 58.83 & 0.13 & 0.54 & 7.96 & 1.48 & 0.89 & 1.43 & 54.93 & 5.29 & 48.69 & 27.77 & 56.19 & 3.12 \\
\hline $\mathrm{TiO}_{2}$ & 51.77 & 0.54 & 0.00 & 0.23 & 11.88 & 0.11 & 0.16 & 0.49 & 1.80 & 36.63 & 0.85 & 0.37 & 0.27 & 0.84 \\
\hline $\mathrm{Fe} 2 \mathrm{O} 3$ & 7.52 & 7.67 & 47.01 & 55.02 & 35.17 & 76.85 & 53.72 & 73.99 & 3.14 & 19.24 & 7.28 & 10.49 & 6.54 & 80.65 \\
\hline $\mathrm{FeO}$ & 32.92 & 16.74 & 19.52 & 0.00 & 41.03 & 6.44 & 31.78 & 1.61 & 17.13 & 25.99 & 16.33 & 11.05 & 13.92 & \\
\hline MnO & 0.09 & 0.21 & 0.21 & 0.20 & 0.43 & 0.64 & 0.29 & 0.42 & 0.20 & 0.16 & 0.15 & 0.13 & 0.19 & 0.22 \\
\hline $\mathrm{MgO}$ & 7.06 & 16.50 & 0.14 & 0.63 & 3.95 & 16.00 & 3.87 & 18.91 & 15.93 & 4.12 & 16.20 & 12.25 & 16.76 & 0.74 \\
\hline $\mathrm{CaO}$ & 0.08 & 0.02 & 0.11 & 0.66 & 1.37 & 0.28 & 0.19 & 0.21 & 0.23 & 0.43 & 0.17 & 0.27 & 0.08 & 0.30 \\
\hline $\mathrm{C} 22 \mathrm{O}_{3}$ & 0.23 & 1.15 & 0.30 & 32.00 & 0.49 & 0.11 & 0.19 & 0.09 & 5.17 & 2.47 & 12.26 & 17.80 & & \\
\hline $\mathrm{NiO}$ & 0.06 & 0.20 & 1.42 & 28.17 & 0.39 & 0.40 & 0.42 & 0.39 & 0.28 & 0.23 & 0.23 & 0.24 & & \\
\hline TOTAL & 100.38 & 102.01 & 68.87 & 118.45 & 105.85 & 102.49 & 97.55 & 98.02 & 99.00 & 95.68 & 10252 & 80.47 & 94.39 & 86.78 \\
\hline Si & 0.000 & 0.004 & 0.000 & 0.045 & 0.105 & 0.006 & 0.224 & 0.016 & 0.005 & 0.028 & 0.010 & 0.003 & 0.012 & \\
\hline Al & 0.018 & 1.806 & 0.009 & 0.025 & 0.310 & 0.058 & 0.039 & 0.057 & 1.743 & 0.156 & 1.539 & 1.181 & 1.829 & \\
\hline $\mathrm{Ti}$ & 0.921 & 0.011 & 0.000 & 0.008 & 0.296 & 0.003 & 0.004 & 0.012 & 0.036 & 0.689 & 0.017 & 0.010 & 0.006 & \\
\hline FelII & 0.134 & 0.141 & 1.974 & 1.855 & 0.875 & 1.921 & 1.499 & 1.883 & 0.064 & 0.364 & 0.147 & 0.285 & 0.136 & \\
\hline FelI & 0.631 & 0.365 & 0.911 & 0.000 & 1.135 & 0.179 & 0.985 & 0.045 & 0.386 & 0.544 & 0.366 & 0.333 & 0.321 & \\
\hline Mn & 0.018 & 0.005 & 0.010 & 0.005 & 0.012 & 0.018 & 0.009 & 0.012 & 0.004 & 0.003 & 0.003 & 0.004 & 0.005 & \\
\hline $\mathrm{Mg}$ & 0.249 & 0.641 & 0.012 & 0.042 & 0.195 & 0.792 & 0.214 & 0.953 & 0.639 & 0.154 & 0.647 & 0.659 & 0.689 & \\
\hline $\mathrm{Ca}$ & 0.002 & 0.000 & 0.007 & 0.002 & 0.048 & 0.010 & 0.008 & 0.007 & 0.007 & 0.011 & 0.005 & 0.010 & 0.002 & \\
\hline $\mathrm{Cr}$ & 0.004 & 0.024 & 0.013 & 0.011 & 0.013 & 0.003 & 0.006 & 0.002 & 0.110 & 0.049 & 0.260 & 0.508 & & \\
\hline $\mathrm{Ni}$ & 0.001 & 0.004 & 0.064 & 1.015 & 0.010 & 0.011 & 0.012 & 0.011 & 0.006 & 0.005 & 0.005 & 0.007 & & \\
\hline TOTAL & 1.978 & 3.001 & 3.000 & 3.008 & 2.999 & 3.001 & 3.000 & 2998 & 3.000 & 2003 & 2999 & 3.000 & 3.000 & 0.000 \\
\hline
\end{tabular}




\begin{tabular}{|c|c|c|c|c|c|c|c|c|c|c|c|c|}
\hline $\begin{array}{l}\text { Sample } \\
\text { Type }\end{array}$ & $\begin{array}{c}\text { 90048B } \\
\text { Pyxite } \\
\text { oxid }\end{array}$ & $\begin{array}{c}\text { 90048D } \\
\text { Pyxite } \\
\text { melt }\end{array}$ & $\begin{array}{c}\text { 90048D } \\
\text { Pyxite } \\
\text { melt }\end{array}$ & $\begin{array}{c}\text { 90048D } \\
\text { Pyxite } \\
\text { melt }\end{array}$ & $\begin{array}{c}90048 D \\
\text { Pyxite } \\
\text { core }\end{array}$ & $\begin{array}{c}\text { 90048D } \\
\text { Pyxite } \\
\text { core }\end{array}$ & $\begin{array}{c}90048 E \\
\text { Gran } \\
\text { core }\end{array}$ & $\begin{array}{l}90048 \mathrm{E} \\
\text { Gran } \\
\text { core } \\
\end{array}$ & $\begin{array}{l}0048 \mathrm{~F} \\
\text { Gran } \\
\text { oxid }\end{array}$ & $\begin{array}{c}\text { 90048F } \\
\text { Gran } \\
\text { oxid }\end{array}$ & $\begin{array}{c}900486 \\
\text { Gran } \\
\text { oxid c- }\end{array}$ & $\begin{array}{c}90048 \mathrm{G} \\
\text { Gran } \\
\text { oxid } r\end{array}$ \\
\hline $\mathrm{SiO}_{2}$ & 0.46 & 0.17 & 0.13 & 0.29 & 0.12 & 0.13 & 0.11 & 0.12 & 0.24 & 0.02 & 0.01 & 0.08 \\
\hline $\mathrm{Al}_{2} \mathrm{O}_{3}$ & 7.76 & 9.85 & 4.96 & 8.84 & 9.39 & 8.75 & 7.02 & 7.18 & 8.85 & 0.49 & 0.49 & 5.82 \\
\hline $\mathrm{TiO}_{2}$ & 17.15 & 19.09 & 25.11 & 10.26 & 15.86 & 16.36 & 18.80 & 22.72 & 17.45 & 49.14 & 52.70 & 23.30 \\
\hline $\mathrm{Fe} 2 \mathrm{O} 3$ & 18.05 & 23.67 & 17.13 & 42.73 & 30.37 & 29.47 & 35.12 & 24.43 & 27.04 & 14.26 & 6.19 & 21.43 \\
\hline $\mathrm{FeO}$ & 41.99 & 38.75 & 45.02 & 29.70 & 37.14 & 37.63 & 31.84 & 29.29 & 37.53 & 28.88 & 31.81 & 43.14 \\
\hline $\mathrm{MnO}$ & 0.19 & 0.28 & 0.36 & 0.56 & 0.22 & 0.42 & 0.34 & 0.33 & 0.63 & 0.39 & 0.63 & 0.53 \\
\hline $\mathrm{MgO}$ & 3.05 & 7.59 & 6.43 & 7.91 & 6.66 & 6.44 & 5.66 & 6.75 & 6.84 & 8.26 & 8.31 & 6.77 \\
\hline $\mathrm{CaO}$ & 0.23 & 0.05 & 0.13 & 0.25 & 0.11 & 0.05 & 0.01 & 0.08 & 0.05 & 0.07 & 0.07 & 0.09 \\
\hline $\mathrm{Cr}_{2} \mathrm{O}_{3}$ & 5.20 & 0.76 & 1.10 & 0.16 & 0.82 & 1.18 & 0.92 & 3.43 & 0.29 & 0.13 & 0.02 & 0.21 \\
\hline $\mathrm{NiO}$ & 0.11 & 0.08 & 0.18 & 0.00 & 0.11 & 0.11 & 0.02 & 0.08 & 0.08 & 0.05 & 0.05 & 0.09 \\
\hline TOTAL & 94.19 & 100.29 & 100.55 & 100.69 & 100.80 & 100.53 & 99.85 & 94.40 & 99.00 & 101.69 & 100.28 & 101.46 \\
\hline Si & 0.017 & 0.006 & 0.004 & 0.010 & 0.005 & 0.004 & 0.004 & 0.004 & 0.008 & 0.000 & 0.000 & 0.003 \\
\hline Al & 0.341 & 0.393 & 0.203 & 0.355 & 0.377 & 0.354 & 0.176 & 0.183 & 0.361 & 0.014 & 0.014 & 0.235 \\
\hline $\mathrm{Ti}$ & 0.482 & 0.486 & 0.655 & 0.262 & 0.407 & 0.422 & 0.737 & 0.909 & 0.454 & 0.866 & 0.938 & 0.601 \\
\hline FeIII & 0.507 & 0.603 & 0.447 & 1.097 & 0.779 & 0.761 & 0.880 & 0.624 & 0.705 & 0.251 & 0.110 & 0.553 \\
\hline FelI & 1.311 & 1.097 & 1.307 & 0.842 & 1.059 & 1.080 & 0.886 & 0.832 & 1.087 & 0.566 & 0.629 & 1.236 \\
\hline Mn & 0.006 & 0.008 & 0.011 & 0.016 & 0.006 & 0.012 & 0.010 & 0.010 & 0.019 & 0.008 & 0.013 & 0.015 \\
\hline $\mathrm{Mg}$ & 0.169 & 0.303 & 0.333 & 0.401 & 0.338 & 0.330 & 0.281 & 0.341 & 0.353 & 0.288 & 0.293 & 0.346 \\
\hline $\mathrm{Ca}$ & 0.009 & 0.002 & 0.005 & 0.009 & 0.004 & 0.002 & 0.000 & 0.003 & 0.002 & 0.002 & 0.002 & 0.003 \\
\hline $\mathrm{Cr}$ & 0.154 & 0.100 & 0.030 & 0.004 & 0.022 & 0.032 & 0.024 & 0.092 & 0.008 & 0.002 & 0.000 & 0.006 \\
\hline $\mathrm{Ni}$ & 0.003 & 0.002 & 0.005 & 0.004 & 0.003 & 0.003 & 0.002 & 0.002 & 0.002 & 0.003 & 0.001 & 0.002 \\
\hline TOTAL & 2.999 & 3.000 & 3.000 & 3.000 & 3.000 & 3.000 & 3.000 & 3.000 & 2999 & 2.000 & 2.000 & 3.000 \\
\hline
\end{tabular}

\begin{tabular}{|c|c|c|c|c|c|c|c|c|c|c|c|c|}
\hline $\begin{array}{l}\text { Sample } \\
\text { Type }\end{array}$ & $\begin{array}{c}90054 I \\
\text { Pyxite } \\
\text { core } \\
\end{array}$ & $\begin{array}{c}900541 \\
\text { Pyxite } \\
\text { core } \\
\end{array}$ & $\begin{array}{c}\text { 90054I } \\
\text { Pyxite } \\
\text { core } \\
\end{array}$ & $\begin{array}{c}90054 K \\
\text { Pyxite } \\
\text { core- }\end{array}$ & $\begin{array}{c}90054 K \\
\text { Pyxite } \\
\text { rim }\end{array}$ & $\begin{array}{c}90054 \mathrm{~K} \\
\text { Pyxite } \\
\text { core }\end{array}$ & $\begin{array}{c}90054 \mathrm{~K} \\
\text { Pyxite } \\
\text { core }\end{array}$ & $\begin{array}{l}90054 \mathrm{~K} \\
\text { Pyxite } \\
\text { oxid c- }\end{array}$ & $\begin{array}{l}90054 \mathrm{~K} \\
\text { Pyxite } \\
\text { oxid } \mathrm{r} \\
\end{array}$ & $\begin{array}{c}90054 \mathrm{~K} \\
\text { Pyxite } \\
\text { core }\end{array}$ & $\begin{array}{c}90054 \mathrm{~K} \\
\text { Pyxite } \\
\text { core }\end{array}$ & $\begin{array}{c}90054 \mathrm{~K} \\
\text { Pyxite } \\
\text { core }\end{array}$ \\
\hline $\mathrm{SiO}_{2}$ & 0.13 & 0.40 & 1.25 & 0.18 & 0.86 & 0.20 & 0.22 & 0.26 & 0.49 & 0.19 & 0.17 & 0.11 \\
\hline $\mathrm{Al}_{2} \mathrm{O}_{3}$ & 58.39 & 43.66 & 0.72 & 63.36 & 10.63 & 64.45 & 59.13 & 64.57 & 43.61 & 59.16 & 58.33 & 59.44 \\
\hline $\mathrm{TiO}_{2}$ & 0.74 & 1.18 & 0.34 & 0.33 & 3.36 & 0.69 & 0.75 & 0.65 & 1.16 & 0.90 & 0.86 & 0.29 \\
\hline $\mathrm{Fe} 2 \mathrm{O} 3$ & 3.51 & 9.42 & 52.91 & 3.20 & 48.65 & 0.00 & 6.01 & 0.00 & 23.44 & 4.73 & 5.65 & 5.73 \\
\hline $\mathrm{FeO}$ & 14.43 & 12.70 & 0.00 & 10.47 & 26.75 & 15.31 & 19.31 & 19.35 & 21.90 & 19.69 & 19.04 & 19.11 \\
\hline $\mathrm{MnO}$ & 0.13 & 0.13 & 0.00 & 0.23 & 0.23 & 0.22 & 0.15 & 0.13 & 0.16 & 0.17 & 0.09 & 0.15 \\
\hline $\mathrm{MgO}$ & 16.69 & 13.93 & 0.48 & 20.37 & 5.60 & 16.03 & 15.10 & 12.99 & 12.61 & 14.64 & 14.94 & 14.65 \\
\hline $\mathrm{CaO}$ & 0.05 & 0.33 & 0.34 & 0.08 & 0.32 & 0.08 & 0.11 & 0.10 & 0.32 & 0.12 & 0.06 & 0.03 \\
\hline $\mathrm{Cr} 2 \mathrm{O}_{3}$ & & & 0.11 & 0.42 & 0.25 & 0.73 & 0.83 & 1.10 & 0.90 & 0.76 & 0.91 & 0.46 \\
\hline $\mathrm{NiO}$ & & & 29.38 & 0.23 & 0.23 & 0.23 & 0.16 & 0.16 & 0.04 & 0.16 & 0.21 & 0.25 \\
\hline TOTAL & 94.06 & 81.74 & 85.53 & 98.86 & 96.89 & 97.93 & 101.78 & 99.31 & 104.63 & 100,51 & 100.26 & 100.21 \\
\hline $\mathrm{Si}$ & 0.004 & 0.013 & 0.056 & 0.005 & 0.031 & 0.005 & 0.006 & 0.007 & 0.014 & 0.005 & 0.004 & 0.003 \\
\hline Al & 0.015 & 1.684 & 0.038 & 1.908 & 0.447 & 1.992 & 1.823 & 2010 & 1.418 & 1.844 & 1.825 & 1.859 \\
\hline $\mathrm{Ti}$ & 0.331 & 0.029 & 0.012 & 0.006 & 0.090 & 0.014 & 0.015 & 0.013 & 0.024 & 0.018 & 0.017 & 0.006 \\
\hline FeIII & 1.890 & 0.232 & 1.784 & 0.062 & 1.305 & 0.000 & 0.118 & 0.000 & 0.487 & 0.094 & 0.113 & 0.114 \\
\hline FeII & 0.072 & 0.348 & 0.000 & 0.224 & 0.797 & 0.340 & 0.422 & 0.427 & 0.506 & 0.435 & 0.423 & 0.424 \\
\hline $\mathrm{Mn}$ & 0.003 & 0.003 & 0.000 & 0.005 & 0.007 & 0.005 & 0.003 & 0.003 & 0.004 & 0.004 & 0.002 & 0.003 \\
\hline $\mathbf{M g}$ & 0.683 & 0.679 & 0.032 & 0.775 & 0.298 & 0.626 & 0.588 & 0.511 & 0.519 & 0.577 & 0.591 & 0.579 \\
\hline $\mathrm{Ca}$ & 0.001 & 0.012 & 0.016 & 0.002 & 0.012 & 0.002 & 0.003 & 0.003 & 0.009 & 0.003 & 0.002 & 0.001 \\
\hline $\mathrm{Cr}$ & & & 0.004 & 0.009 & 0.007 & 0.015 & 0.017 & 0.023 & 0.020 & 0.016 & 0.019 & 0.010 \\
\hline $\mathrm{Ni}$ & & & 1.058 & 0.004 & 0.007 & 0.004 & 0.003 & 0.003 & 0.001 & 0.003 & 0.005 & 0.001 \\
\hline TOTA & 2.999 & 3.000 & 3.000 & 3.000 & 3.001 & 3.003 & 2998 & 3.000 & 3.001 & 2.999 & 3.001 & 3.000 \\
\hline
\end{tabular}


A3.3 Mount Murphy xenolith mineral analyses: glasses

\begin{tabular}{|c|c|c|c|c|c|c|c|c|c|}
\hline $\begin{array}{l}\text { Sample } \\
\text { Type }\end{array}$ & $\begin{array}{c}90048 E \\
\text { Gran }\end{array}$ & $\begin{array}{c}90048 \mathrm{E} \\
\text { Gran }\end{array}$ & $\begin{array}{c}90048 \mathrm{E} \\
\text { Gran }\end{array}$ & $\begin{array}{c}90048 E \\
\text { Gran }\end{array}$ & $\begin{array}{c}90048 \mathrm{E} \\
\text { Gran }\end{array}$ & $\begin{array}{c}90048 B \\
\text { Pyxite }\end{array}$ & $\begin{array}{c}90048 B \\
\text { Pyxite }\end{array}$ & $\begin{array}{c}90041 \mathrm{~A} \\
\text { Gran }\end{array}$ & $\begin{array}{c}90041 \mathrm{~A} \\
\text { Gran }\end{array}$ \\
\hline $\mathrm{SiO}_{2}$ & 48.27 & 48.65 & 46.77 & 47.94 & 47.90 & 44.68 & 46.69 & 54.24 & 43.78 \\
\hline $\mathrm{A} \mid 2 \mathrm{O}_{3}$ & 13.79 & 14.94 & 14.26 & 14.83 & 14.56 & 15.20 & 13.39 & 15.04 & 13.92 \\
\hline $\mathrm{TiO} 2$ & 4.97 & 4.57 & 4.63 & 4.91 & 4.58 & 4.99 & 5.16 & 2.72 & 2.65 \\
\hline $\mathrm{FeO}$ & 13.53 & 12.58 & 12.99 & 12.81 & 1290 & 13.01 & 10.52 & 8.33 & 11.66 \\
\hline $\mathrm{MnO}$ & 0.24 & 0.19 & 0.16 & 0.19 & 0.20 & 0.28 & 0.23 & 0.21 & 0.61 \\
\hline $\mathrm{MgO}$ & 3.90 & 3.16 & 3.75 & 4.14 & 4.17 & 3.65 & 5.80 & 4.13 & 6.07 \\
\hline $\mathrm{CaO}$ & 6.88 & 8.22 & 8.01 & 8.24 & 8.14 & 11.45 & 14.82 & 7.62 & 13.68 \\
\hline $\mathrm{Na} 2 \mathrm{O}$ & 3.85 & 3.13 & 275 & 240 & 2.67 & 5.02 & 2.05 & 6.13 & 4.10 \\
\hline $\mathrm{K} 2 \mathrm{O}$ & 1.64 & 1.61 & 1.49 & 1.44 & 1.61 & 1.60 & 1.19 & 1.41 & 0.31 \\
\hline TOTAL & 97.07 & 97.05 & 94.81 & 96.89 & 96.73 & 99.88 & 99.84 & 99.83 & 96.77 \\
\hline Mg* & 33.92 & 30.92 & 33.99 & 36.53 & 36.53 & 33.32 & 49.56 & 46.92 & 48.13 \\
\hline Q & 0.00 & 0.65 & 0.55 & 2.70 & 0.71 & 0.00 & 0.00 & 0.00 & 0.00 \\
\hline Or & 9.89 & 9.51 & 9.18 & 8.51 & 9.51 & 9.46 & 7.03 & 8.33 & 1.83 \\
\hline $\mathbf{A b}$ & 32.58 & 26.49 & 24.25 & 20.31 & 22.59 & 7.53 & 12.38 & 40.79 & 6.22 \\
\hline An & 15.50 & 21.96 & 23.10 & 25.44 & 22.99 & 14.22 & 23.82 & 9.36 & 18.66 \\
\hline $\mathrm{Ne}$ & 0.00 & 0.00 & 0.00 & 0.00 & 0.00 & 18.93 & 2.69 & 6.00 & 15.43 \\
\hline $\mathrm{Di}_{\mathrm{i}}$ & 15.55 & 15.78 & 15.29 & 12.82 & 14.47 & 35.56 & 40.33 & 23.38 & 40.64 \\
\hline Hy & 4.16 & 11.73 & 14.85 & 15.51 & 15.45 & 0.00 & 0.00 & 0.00 & 0.00 \\
\hline Ol & 7.73 & 0.00 & 0.00 & 0.00 & 0.00 & 2.39 & 1.92 & 5.31 & 6.90 \\
\hline Mt & 2.59 & 2.41 & 2.59 & 2.45 & 2.47 & 249 & 2.02 & 1.60 & 2.23 \\
\hline Il & 9.44 & 8.68 & 9.16 & 9.33 & 8.70 & 9.48 & 9.80 & 5.17 & 5.03 \\
\hline Ap & 0.00 & 0.00 & 0.00 & 0.00 & 0.00 & 0.00 & 0.00 & 0.00 & 0.00 \\
\hline TOTAL & 97.44 & 97.21 & 98.97 & 97.07 & 96.89 & 100.06 & 99.99 & 99.94 & 96.94 \\
\hline
\end{tabular}

Sample 90041A 90048D 90048D 90048D 90048D 90048D 90048D 90048G 90054I

Type Gran Pyxite Pyxite Pyxite Pyxite Pyxite Pyxite Gran Pyxite

\begin{tabular}{lccccccccc}
$\mathrm{SiO2}$ & 57.69 & 47.35 & 44.63 & 47.38 & 53.12 & 45.83 & 41.33 & 43.68 & 48.39 \\
$\mathrm{Al2O} 3$ & 17.62 & 15.86 & 14.45 & 15.75 & 18.81 & 12.87 & 16.58 & 13.32 & 16.19 \\
$\mathrm{TiO2}$ & 0.46 & 4.78 & 5.47 & 5.13 & 3.24 & 3.87 & 2.86 & 5.50 & 2.99 \\
$\mathrm{FeO}$ & 6.78 & 12.78 & 10.99 & 12.41 & 9.69 & 9.73 & 13.26 & 13.24 & 10.47 \\
$\mathrm{MnO}$ & 0.17 & 0.35 & 0.37 & 0.42 & 0.27 & 0.39 & 0.34 & 0.34 & 0.19 \\
$\mathrm{MgO}$ & 2.98 & 3.91 & 5.50 & 3.50 & 4.29 & 7.88 & 4.90 & 3.25 & 4.46 \\
$\mathrm{CaO}$ & 5.80 & 9.62 & 15.25 & 10.22 & 6.59 & 14.15 & 11.31 & 15.19 & 9.48 \\
$\mathrm{Na2O}$ & 6.96 & 4.50 & 1.35 & 4.03 & 1.86 & 4.39 & 3.70 & 2.29 & 4.56 \\
$\mathrm{K2O}$ & 1.19 & 2.06 & 0.83 & 2.00 & 1.31 & 1.64 & 0.53 & 1.79 & 1.08 \\
& & & & & & & & & \\
\hline TOTAL & 99.63 & 101.20 & 98.84 & 100.82 & 99.17 & 100.73 & 94.81 & 98.60 & 97.81 \\
\hline $\mathrm{Mg \#}$ & 43.96 & 35.29 & 47.14 & 33.42 & 44.09 & 59.05 & 39.72 & 30.43 & 43.15 \\
& & & & & & & & & \\
\hline & & & & & & & & & \\
$\mathrm{Q}$ & 0.00 & 0.00 & 0.00 & 0.00 & 5.06 & 0.00 & 0.00 & 0.00 & 0.00 \\
$\mathrm{Or}$ & 7.03 & 12.17 & 4.91 & 11.82 & 7.44 & 6.13 & 3.26 & 11.02 & 0.40 \\
$\mathrm{Ab}$ & 53.31 & 16.99 & 10.93 & 18.14 & 15.13 & 0.00 & 8.52 & 3.48 & 28.09 \\
$\mathrm{An}$ & 13.32 & 16.99 & 30.92 & 18.98 & 31.43 & 10.57 & 28.21 & 21.65 & 21.86 \\
$\mathrm{Ne}$ & 3.03 & 11.42 & 0.27 & 8.65 & 0.00 & 20.12 & 13.06 & 9.05 & 7.05 \\
$\mathrm{Di}$ & 12.90 & 25.61 & 36.42 & 26.46 & 25.93 & 48.17 & 25.27 & 40.78 & 23.37 \\
$\mathrm{Hy}$ & 0.00 & 0.00 & 0.00 & 0.00 & 0.00 & 0.00 & 0.00 & 0.00 & 0.00 \\
$\mathrm{OI}$ & 7.97 & 6.66 & 3.06 & 4.84 & 6.86 & 3.89 & 12.36 & 0.00 & 8.98 \\
$\mathrm{Mt}$ & 1.30 & 2.45 & 211 & 2.38 & 1.79 & 1.86 & 2.65 & 2.65 & 2.14 \\
$\mathrm{II}$ & 0.87 & 9.08 & 10.39 & 9.74 & 5.91 & 7.35 & 5.66 & 10.88 & 6.05 \\
$\mathrm{Ap}$ & 0.00 & 0.00 & 0.00 & 0.00 & 0.00 & 0.00 & 0.00 & 0.00 & 0.00 \\
\hline $\mathrm{TOTAL}$ & 99.73 & 101.37 & 99.01 & 101.01 & 99.55 & 98.09 & 98.99 & 99.51 & 97.94 \\
\hline & & & & & & & & & \\
\hline
\end{tabular}




\section{Appendix four \\ WHOLE ROCK GEOCHEMISTRY}

\section{Introduction}

A representative selection of xenoliths based on size, degree of freshness and suitability for sample preparation were selected for major and trace element analyses. Samples were first split using a tungsten carbide ROCKLABS hydraulic splitter, and crushed to powder using in a TEMA tungsten carbide swing mill. The use of tungsten carbide equipment precluded the determination of $\mathrm{W}$ and $\mathrm{Co}$. Whole rock samples and powders are stored in the Victoria University of Wellington rock collection.

Major and trace elements were determined using a PHILIPS PW1404 automatic sequential X-ray spectrometer, at Victoria University of Wellington. Fused disks for major element analyses were prepared using procedures modified after Norrish and Hutton (1969). One half gram of rock powder, $0.60 \mathrm{~g}$ of AR ammonium nitrate, and a determined weight of Norrish formula X-ray flux (usually between $2.6800 \mathrm{~g}$ and $2.7000 \mathrm{~g}$ depending on atmospheric moisture at the time of fusing) were melted together and pressed as a fused disk. Loss on ignition (LOI) was determined by heating approximately two grams of sample at $1,100{ }^{\circ} \mathrm{C}$ for one hour. Full details of this technique can be found in Palmer (1990).

$\mathrm{Fe}_{2} \mathrm{O}_{3}$ (total) listed in tables represents total iron measured as $\mathrm{Fe}_{2} \mathrm{O}_{3}$; discrete $\mathrm{FeO}$ and $\mathrm{Fe}_{2} \mathrm{O}_{3}$ contents were not determined. For purposes of normative mineralogy calculations, total iron was adjusted to $\mathrm{Fe}_{2} \mathrm{O}_{3}: \mathrm{FeO}=0.15 . \mathrm{Mg}$ numbers (Mg\#) are determined by the ratio: $100 \mathrm{MgO} / \mathrm{MgO}+\mathrm{FeO}$, where $\mathrm{FeO}$ is total iron $\left(\mathrm{FeO}+\mathrm{Fe}_{2} \mathrm{O}_{3}\right)$ measured as $\mathrm{FeO}$. These ratios are preferred as they allow direct comparisons with the majority of published normative mineralogy's and $\mathrm{Mg}$ numbers.

Trace element concentrations were determined on boric acid-backed pressed pellets using procedures modified after Norrish and Chappell (1977). Four grams 
of rock powder were combined with boric acid to form a four centimetre pressed pellet, which was then analysed by $X$-ray spectrometry for selected trace elements. Quoted trace element abundances are accurate to approximately $\pm 1-2 \mathrm{ppm}$. The exact errors depend on the element, and its abundance, with lower concentrations having higher associated errors. For a more complete discussion of XRF analyses, and errors involved, see Roser (1983).

Results of all major element analyses, together with trace element analyses and calculated normative mineralogy are presented in Appendices 3.1 to 3.6, with localities in order of their discussion in the thesis text.

\section{Abbreviations}

The full list of abbreviations used in this appendix, and for sample names in all appendices is as follows:

$\begin{array}{llll}\text { Gran } & \text { - Granulite } & \text { Perid } & \text { - Peridotite } \\ \text { Pyrox } & \text { - Pyroxenite } & \text { Type L } & \text { - Type L granulite } \\ \text { Type M } & \text { - Type M granulite } & \text { Type C } & \text { - Type C pyroxenite } \\ \text { Type P } & \text { - Type P pyroxenite } & \text { U.C. } & \text { - Upper crustal rock }\end{array}$

Xenoliths named Type L to Type $\mathrm{P}$ refer to xenoliths from Mount Sidley only. 


\section{A4.1 Mount Sidley xenolith analyses}

\begin{tabular}{|c|c|c|c|c|c|c|c|c|c|c|}
\hline Sample & $90029 \mathrm{~A}$ & $90029 B$ & $90029 \mathrm{C}$ & $90029 \mathrm{~F}$ & $90029 \mathrm{G}$ & $90029 \mathrm{H}$ & $90029 \mathrm{~K}$ & $90029 \mathrm{M}$ & 900290 & $90029 \mathrm{P}$ \\
\hline Type & U.C. & Type C & Type M & U.C. & U.C. & Type $\mathrm{M}$ & Type L & Type L & Type L & Type L \\
\hline $\mathrm{SiO}_{2}$ & 55.12 & 44.65 & 33.28 & 56.06 & 63.89 & 35.29 & 52.15 & 41.68 & 45.02 & 45.35 \\
\hline TiO2 & 1.66 & 0.67 & 6.40 & 1.67 & 0.19 & 5.14 & 1.32 & 3.62 & 3.27 & 3.77 \\
\hline $\mathrm{Al} 2 \mathrm{O} 3$ & 15.76 & 18.54 & 8.87 & 16.30 & 18.09 & 12.54 & 23.50 & 17.70 & 20.13 & 19.64 \\
\hline $\mathrm{Fe} 2 \mathrm{O} 3$ total & 8.65 & 14.30 & 25.74 & 8.67 & 3.47 & 29.28 & 5.01 & 13.93 & 12.01 & 10.90 \\
\hline $\mathrm{MnO}$ & 0.15 & 0.22 & 0.37 & 0.14 & 0.09 & 0.36 & 0.06 & 0.16 & 0.12 & 0.13 \\
\hline $\mathrm{MgO}$ & 4.14 & 10.08 & 9.58 & 2.61 & 0.39 & 9.09 & 1.72 & 5.72 & 4.14 & 4.65 \\
\hline $\mathrm{CaO}$ & 5.18 & 8.19 & 12.13 & 4.22 & 1.38 & 6.03 & 9.87 & 11.14 & 11.97 & 12.10 \\
\hline $\mathrm{Na} 2 \mathrm{O}$ & 5.30 & 2.77 & 1.63 & 5.87 & 7.59 & 2.23 & 5.24 & 3.18 & 3.31 & 3.31 \\
\hline $\mathrm{K} 2 \mathrm{O}$ & 3.22 & 0.20 & 0.07 & 3.65 & 4.37 & 0.15 & 0.31 & 0.19 & 0.19 & 0.23 \\
\hline $\mathrm{P} 2 \mathrm{O} 5$ & 0.32 & 0.15 & 2.45 & 0.51 & 0.09 & 0.40 & 0.72 & 1.84 & 0.02 & 0.04 \\
\hline LOI & 0.36 & -0.23 & -0.42 & 0.28 & 0.28 & -0.56 & 0.37 & 0.88 & -0.08 & 0.09 \\
\hline TOTAL & 99.86 & 99.54 & 100.10 & 99.98 & 99.83 & 99.95 & 100.27 & 100.04 & 100.10 & 100.21 \\
\hline Mg\# & 48.66 & 58.26 & 42.43 & 37.35 & 18.21 & 38.07 & 40.47 & 44.85 & 40.57 & 45.80 \\
\hline
\end{tabular}

\begin{tabular}{|c|c|c|c|c|c|c|c|c|c|c|}
\hline Sc & 8 & 3 & 23 & 3 & 2 & 7 & 10 & 12 & 16 & 19 \\
\hline V & 118 & 45 & 376 & 88 & 14 & 393 & 47 & 305 & 334 & 258 \\
\hline $\mathrm{Cr}$ & 126 & 66 & 7 & 8 & 1 & 13 & $<1$ & 4 & 7 & 6 \\
\hline $\mathrm{Ni}$ & 63 & 136 & 12 & 15 & 1 & 12 & 1 & 4 & 8 & 8 \\
\hline $\mathrm{Cu}$ & 20 & 15 & 29 & 19 & 12 & 15 & 8 & 17 & 35 & 36 \\
\hline $\mathrm{Zn}$ & 82 & 70 & 113 & 81 & 22 & 123 & 21 & 49 & 43 & 49 \\
\hline $\mathrm{Ga}$ & 24 & 18 & 18 & 25 & 24 & 21 & 23 & 21 & 24 & 22 \\
\hline As & 1 & $<1$ & $<1$ & $<1$ & 1 & 1 & $<1$ & $<1$ & $<1$ & $<1$ \\
\hline $\mathbf{R b}$ & 122 & 2 & 2 & 134 & 61 & 2 & 1 & 1 & 2 & 4 \\
\hline $\mathrm{Sr}$ & 475 & 754 & 481 & 647 & 200 & 694 & 1325 & 915 & 949 & 976 \\
\hline$Y$ & 35 & $<1$ & 35 & 34 & 10 & 3 & 5 & 13 & 2 & 4 \\
\hline $\mathrm{Zr}$ & 357 & 21 & 48 & 304 & 515 & 36 & 29 & 38 & 41 & 38 \\
\hline $\mathrm{Nb}$ & 93 & 3 & 17 & 90 & 28 & 9 & 5 & 9 & 6 & 9 \\
\hline $\mathrm{Ba}$ & 525 & 143 & 47 & 492 & 565 & 135 & 446 & 143 & 137 & 135 \\
\hline La & 52 & 8 & 45 & 64 & 26 & 5 & 10 & 17 & 5 & 7 \\
\hline $\mathrm{Ce}$ & 97 & 19 & 171 & 118 & 40 & 38 & 21 & 56 & 17 & 21 \\
\hline $\mathrm{Pb}$ & 10 & 5 & 6 & 10 & 9 & 6 & 3 & 3 & 4 & 5 \\
\hline Th & 12 & 2 & 1 & 18 & 13 & 1 & $<1$ & 1 & $<1$ & 2 \\
\hline $\mathrm{U}$ & 4 & $<1$ & $<1$ & 5 & 4 & $<1$ & $<1$ & 1 & $<1$ & $<1$ \\
\hline$Q$ & 0.00 & 0.00 & 0.00 & 0.00 & 0.00 & 0.00 & 0.00 & 0.00 & 0.00 & 0.00 \\
\hline Or & 19.03 & 1.18 & 0.41 & 21.57 & 25.83 & 0.89 & 1.83 & 1.12 & 1.12 & 1.36 \\
\hline $\mathrm{Ab}$ & 40.64 & 21.45 & 1.93 & 43.97 & 62.91 & 10.76 & 43.24 & 21.56 & 19.18 & 19.86 \\
\hline An & 9.70 & 37.57 & 16.68 & 7.35 & 2.39 & 23.76 & 39.69 & 33.46 & 39.51 & 38.05 \\
\hline $\mathrm{Ne}$ & 2.28 & 1.08 & 6.42 & 3.09 & 0.72 & 4.39 & 0.60 & 2.90 & 4.78 & 4.41 \\
\hline $\mathrm{Di}$ & 11.47 & 1.71 & 22.81 & 8.59 & 2.36 & 2.97 & 3.80 & 8.08 & 16.37 & 17.81 \\
\hline Hy & 0.00 & 0.00 & 0.00 & 0.00 & 0.00 & 0.00 & 0.00 & 0.00 & 0.00 & 0.00 \\
\hline Ol & 10.24 & 31.45 & 27.73 & 8.52 & 2.90 & 39.42 & 5.26 & 17.26 & 9.81 & 8.54 \\
\hline Mt & 1.49 & 2.47 & 4.44 & 1.50 & 0.60 & 5.05 & 0.86 & 2.40 & 2.07 & 1.88 \\
\hline Il & 3.15 & 1.27 & 12.16 & 3.17 & 0.36 & 9.76 & 2.51 & 6.88 & 6.21 & 7.16 \\
\hline Ap & 0.76 & 0.36 & 5.80 & 1.21 & 0.21 & 0.95 & 1.70 & 4.36 & 0.05 & 0.09 \\
\hline TOTAL & 98.76 & 98.54 & 98.38 & 98.97 & 98.28 & 97.95 & 99.49 & 98.02 & 99.10 & 99.16 \\
\hline
\end{tabular}




\begin{tabular}{|c|c|c|c|c|c|c|c|c|c|c|}
\hline$\overline{\text { Sample }}$ & $90029 Q$ & $90029 \mathrm{U}$ & $90029 \mathrm{~V}$ & $90029 X$ & $90029 \mathrm{Y}$ & $90029 \mathrm{C} 1$ & 90029D1 & 90029EI & 90029F1 & $90029 \mathrm{G} 1$ \\
\hline Type & Type M & Type L & Type M & Type L & Type L & Type L & Type L & Type $\mathbf{M}$ & Type L & Type L \\
\hline $\mathrm{SiO} 2$ & 31.73 & 48.37 & 33.65 & 44.85 & 48.13 & 49.14 & 49.19 & 38.17 & 45.87 & 50.18 \\
\hline $\mathrm{TiO} 2$ & 7.04 & 2.08 & 6.74 & 3.65 & 1.46 & 1.59 & 1.90 & 4.14 & 2.75 & 1.48 \\
\hline $\mathrm{A} 12 \mathrm{O} 3$ & 7.31 & 21.51 & 8.91 & 19.49 & 19.42 & 22.37 & 22.90 & 8.84 & 20.22 & 23.71 \\
\hline $\mathrm{Fe} 2 \mathrm{O} 3$ total & 27.23 & 8.64 & 25.10 & 11.48 & 9.99 & 7.91 & 7.38 & 25.19 & 10.73 & 6.28 \\
\hline $\mathrm{MnO}$ & 0.39 & 0.12 & 0.32 & 0.16 & 0.15 & 0.12 & 0.10 & 0.33 & 0.17 & 0.10 \\
\hline $\mathrm{MgO}$ & 10.06 & 3.04 & 9.63 & 4.45 & 5.01 & 2.77 & 2.39 & 13.33 & 4.44 & 1.98 \\
\hline $\mathrm{CaO}$ & 11.81 & 10.98 & 11.13 & 10.98 & 10.20 & 10.54 & 10.38 & 9.25 & 9.80 & 10.20 \\
\hline $\mathrm{Na} 2 \mathrm{O}$ & 1.42 & 4.25 & 2.14 & 3.42 & 4.37 & 4.49 & 4.72 & 1.47 & 3.96 & 4.73 \\
\hline $\mathrm{K} 2 \mathrm{O}$ & 0.07 & 0.24 & 0.22 & 0.25 & 0.25 & 0.26 & 0.26 & 0.07 & 0.24 & 0.36 \\
\hline $\mathrm{P} 2 \mathrm{O} 5$ & 3.25 & 1.05 & 2.34 & 0.39 & 1.48 & 0.86 & 1.00 & 0.04 & 1.32 & 0.77 \\
\hline LOI & -0.14 & 0.01 & 0.12 & 0.23 & -0.22 & 0.20 & 0.02 & 0.00 & 0.00 & 0.22 \\
\hline TOTAL & 100.17 & 100.29 & 100.30 & 99.35 & 100.24 & 100.25 & 100.24 & 100.83 & 99.50 & 100.01 \\
\hline $\mathrm{Mg \#}$ & 42.25 & 41.07 & 43.18 & 43.43 & 49.83 & 40.95 & 39.07 & 51.17 & 45.04 & 38.44 \\
\hline Sc & 25 & 14 & 20 & 16 & 9 & 10 & 8 & 28 & 5 & 6 \\
\hline $\mathrm{V}$ & 324 & 124 & 291 & 221 & 35 & 81 & 58 & 415 & 95 & 58 \\
\hline $\mathrm{Cr}$ & 11 & 4 & 10 & 3 & 2 & $<1$ & 1 & 63 & 1 & 1 \\
\hline $\mathrm{Ni}$ & 9 & 3 & 9 & 8 & 4 & 1 & 1 & 28 & 4 & 2 \\
\hline $\mathrm{Cu}$ & 26 & 12 & 38 & 21 & 19 & 10 & 12 & 31 & 18 & 16 \\
\hline $\mathrm{Zn}$ & 123 & 37 & 119 & 61 & 35 & 38 & 28 & 113 & 47 & 34 \\
\hline $\mathrm{Ga}$ & 15 & 23 & 18 & 21 & 18 & 23 & 22 & 16 & 19 & 23 \\
\hline As & $<1$ & $<1$ & $<1$ & $<1$ & $<1$ & $<1$ & $<1$ & 1 & $<1$ & $<1$ \\
\hline $\mathrm{Rb}$ & $<1$ & 2 & 2 & 2 & 2 & 2 & 1 & 2 & 1 & 2 \\
\hline $\mathrm{Sr}$ & 419 & 1102 & 461 & 1041 & 1111 & 1201 & 1282 & 404 & 1109 & 1190 \\
\hline$Y$ & 37 & 9 & 25 & 7 & 13 & 9 & 8 & 5 & 9 & 7 \\
\hline $\mathrm{Zr}$ & 43 & 38 & 47 & 51 & 31 & 39 & 29 & 42 & 37 & 34 \\
\hline $\mathrm{Nb}$ & 18 & 5 & 20 & 19 & 5 & 6 & 5 & 7 & 14 & 10 \\
\hline $\mathrm{Ba}$ & 31 & 322 & 20 & 204 & 313 & 338 & 372 & 43 & 250 & 394 \\
\hline La & 31 & 12 & 14 & 9 & 21 & 13 & 12 & 5 & 14 & 12 \\
\hline $\mathrm{Ce}$ & 158 & 31 & 109 & 31 & 48 & 36 & 29 & 32 & 38 & 34 \\
\hline $\mathrm{Pb}$ & 8 & 5 & 7 & 5 & 4 & 3 & 4 & 3 & 6 & 4 \\
\hline Th & 2 & 1 & 1 & $<1$ & 1 & $<1$ & $<1$ & 1 & 2 & $<1$ \\
\hline $\mathrm{U}$ & $<1$ & $<1$ & $<1$ & $<1$ & 1 & 1 & $<1$ & 1 & $<1$ & $<1$ \\
\hline $\mathrm{Q}$ & 0.00 & 0.00 & 0.00 & 0.00 & 0.00 & 0.00 & 0.00 & 0.00 & 0.00 & 0.00 \\
\hline Or & 0.41 & 1.42 & 1.30 & 1.48 & 1.48 & 1.54 & 1.54 & 0.41 & 1.42 & 2.13 \\
\hline $\mathrm{Ab}$ & 3.76 & 33.55 & 3.62 & 23.72 & 33.98 & 34.96 & 36.45 & 2.38 & 32.04 & 37.93 \\
\hline An & 13.37 & 38.91 & 14.06 & 37.09 & 32.64 & 40.12 & 40.53 & 17.32 & 36.69 & 42.40 \\
\hline $\mathrm{Ne}$ & 4.47 & 1.31 & 7.85 & 2.83 & 1.63 & 1.64 & 1.89 & 5.45 & 0.80 & 1.14 \\
\hline $\mathrm{Di}$ & 19.90 & 7.24 & 21.41 & 12.22 & 6.86 & 5.46 & 3.69 & 23.30 & 2.73 & 2.65 \\
\hline $\mathrm{Hy}$ & 0.00 & 0.00 & 0.00 & 0.00 & 0.00 & 0.00 & 0.00 & 0.00 & 0.00 & 0.00 \\
\hline $\mathrm{Ol}$ & 30.42 & 9.23 & 27.20 & 10.95 & 15.10 & 9.26 & 8.27 & 36.45 & 14.75 & 7.32 \\
\hline Mt & 4.70 & 1.49 & 4.33 & 1.98 & 1.72 & 1.36 & 1.27 & 4.34 & 1.85 & 0.00 \\
\hline II & 13.37 & 3.95 & 12.80 & 6.93 & 2.77 & 3.02 & 3.61 & 7.86 & 5.22 & 2.81 \\
\hline Ap & 7.69 & 2.49 & 5.54 & 0.92 & 3.50 & 2.04 & 2.37 & 0.09 & 3.12 & 1.82 \\
\hline TOTAL & 98.09 & 99.59 & 98.11 & 98.12 & 99.68 & 99.40 & 99.62 & 97.60 & 98.62 & 98.20 \\
\hline
\end{tabular}




\begin{tabular}{|c|c|c|c|c|c|c|c|c|c|c|}
\hline Sample & $90029 \mathrm{H} 1$ & $90031 \mathrm{C}$ & $90031 \mathrm{G}$ & $90031 \mathrm{~L}$ & 900310 & $90031 \mathrm{P}$ & $90031 Q$ & $90033 \mathrm{~A}$ & $90033 \mathrm{~B}$ & $90033 C$ \\
\hline Type & Type L & Type $\mathbf{M}$ & Type L & Type L & Type L & Type L & Type $\mathrm{P}$ & Type P & Type P & Type $\mathrm{P}$ \\
\hline $\mathrm{SiO} 2$ & 45.40 & 40.89 & 47.27 & 44.96 & 45.43 & 46.16 & 43.43 & 42.27 & 40.80 & 40.89 \\
\hline $\mathrm{TiO} 2$ & 3.41 & 7.10 & 1.51 & 2.96 & 2.78 & 3.44 & 1.34 & 2.17 & 1.49 & 3.11 \\
\hline $\mathrm{Al} 2 \mathrm{O} 3$ & 19.82 & 13.29 & 18.69 & 20.87 & 23.07 & 20.02 & 9.29 & 11.53 & 15.77 & 8.91 \\
\hline $\mathrm{Fe} 2 \mathrm{O} 3$ total & 10.24 & 16.43 & 7.87 & 9.18 & 8.54 & 10.60 & 14.81 & 12.56 & 12.27 & 16.29 \\
\hline $\mathrm{MnO}$ & 0.12 & 0.25 & 0.11 & 0.12 & 0.09 & 0.12 & 0.20 & 0.16 & 0.16 & 0.18 \\
\hline $\mathrm{MgO}$ & 5.01 & 7.31 & 7.58 & 3.89 & 2.90 & 4.63 & 18.09 & 14.36 & 13.22 & 18.46 \\
\hline $\mathrm{CaO}$ & 11.80 & 11.49 & 13.25 & 11.69 & 11.50 & 11.00 & 11.38 & 16.15 & 15.18 & 10.37 \\
\hline $\mathrm{Na} 2 \mathrm{O}$ & 3.75 & 2.73 & 3.03 & 3.81 & 3.94 & 3.47 & 1.45 & 1.12 & 1.28 & 1.76 \\
\hline $\mathrm{K} 2 \mathrm{O}$ & 0.27 & 0.30 & 0.31 & 0.34 & 0.44 & 0.34 & 0.21 & 0.04 & 0.09 & 0.46 \\
\hline $\mathrm{P} 2 \mathrm{O} 5$ & 0.04 & 0.10 & 0.07 & 1.67 & 0.94 & 0.06 & 0.07 & 0.00 & 0.04 & 0.05 \\
\hline LOI & 0.14 & 0.34 & 0.29 & 0.46 & 0.49 & 0.22 & -0.26 & -0.30 & -0.18 & -0.43 \\
\hline TOTAL & 100.00 & 100.23 & 99.98 & 99.95 & 100.12 & 100.06 & 100.01 & 100.06 & 100.12 & 100.05 \\
\hline Mg\# & 49.21 & 46.84 & 65.61 & 45.63 & 40.21 & 46.38 & 70.75 & 69.37 & 68.09 & 69.18 \\
\hline Sc & 21 & 25 & 26 & 14 & 14 & 17 & 33 & 54 & 43 & 31 \\
\hline V & 298 & 273 & 186 & 187 & 201 & 215 & 246 & 440 & 444 & 375 \\
\hline $\mathrm{Cr}$ & 11 & 6 & 170 & 1 & 3 & 3 & 1224 & 417 & 205 & 942 \\
\hline $\mathrm{Ni}$ & 10 & 15 & 80 & 3 & 6 & 5 & 399 & 246 & 166 & 405 \\
\hline $\mathrm{Cu}$ & 28 & 46 & 31 & 18 & 19 & 26 & 29 & 63 & 32 & 69 \\
\hline $\mathrm{Zn}$ & 43 & 73 & 34 & 57 & 47 & 41 & 109 & 82 & 122 & 78 \\
\hline $\mathrm{Ga}$ & 22 & 19 & 20 & 22 & 24 & 23 & 12 & 20 & 27 & 12 \\
\hline As & $<1$ & $<1$ & $<1$ & $<1$ & $<1$ & $<1$ & $<1$ & $<1$ & $<1$ & $<1$ \\
\hline $\mathrm{Rb}$ & 1 & 5 & 2 & 2 & 6 & 3 & 4 & $<1$ & 3 & 3 \\
\hline $\mathrm{Sr}$ & 903 & 674 & 825 & 1095 & 1161 & 993 & 282 & 97 & 114 & 420 \\
\hline$Y$ & 2 & 10 & 9 & 17 & 15 & 7 & 12 & 18 & 15 & 13 \\
\hline $\mathrm{Zr}$ & 45 & 67 & 58 & 53 & 65 & 61 & 45 & 55 & 45 & 72 \\
\hline $\mathrm{Nb}$ & 8 & 35 & 7 & 19 & 16 & 12 & 8 & 3 & 4 & 14 \\
\hline $\mathrm{Ba}$ & 120 & 71 & 114 & 192 & 212 & 147 & 65 & 13 & 37 & 123 \\
\hline $\mathrm{La}$ & 3 & 4 & 6 & 15 & 15 & 7 & 6 & 3 & 4 & 5 \\
\hline $\mathrm{Ce}$ & 9 & 35 & 15 & 43 & 42 & 19 & 19 & 18 & 23 & 30 \\
\hline $\mathrm{Pb}$ & 3 & 4 & 5 & 9 & 5 & 4 & 6 & 6 & 5 & 5 \\
\hline Th & $<1$ & 1 & 1 & 2 & 1 & $<1$ & 2 & 1 & 1 & 1 \\
\hline$U$ & $<1$ & $<1$ & $<1$ & $<1$ & 2 & $<1$ & 1 & $<1$ & $<1$ & $<1$ \\
\hline$Q$ & 0.00 & 0.00 & 0.00 & 0.00 & 0.00 & 0.00 & 0.00 & 0.00 & 0.00 & 0.00 \\
\hline Or & 1.60 & 1.77 & 1.83 & 2.01 & 2.60 & 2.01 & 1.24 & 0.00 & 0.00 & 1.90 \\
\hline $\mathrm{Ab}$ & 18.79 & 12.51 & 16.49 & 26.49 & 24.14 & 23.97 & 4.50 & 0.00 & 0.00 & 0.00 \\
\hline An & 36.45 & 23.12 & 36.48 & 38.84 & 43.97 & 38.05 & 18.22 & 26.32 & 37.02 & 15.05 \\
\hline $\mathrm{Ne}$ & 7.01 & 5.74 & 4.96 & 3.11 & 4.98 & 2.92 & 4.21 & 5.13 & 5.87 & 8.07 \\
\hline $\mathrm{Di}$ & 17.84 & 27.05 & 23.24 & 6.78 & 5.75 & 13.24 & 30.42 & 34.20 & 28.69 & 28.98 \\
\hline Hy & 0.00 & 0.00 & 0.00 & 0.00 & 0.00 & 0.00 & 0.00 & 0.00 & 0.00 & 0.00 \\
\hline $\mathrm{Ol}$ & 8.94 & 11.70 & 11.62 & 10.38 & 8.51 & 10.22 & 35.12 & 26.61 & 23.57 & 35.57 \\
\hline Mt & 0.00 & 0.00 & 0.00 & 0.00 & 0.00 & 0.00 & 0.00 & 2.74 & 2.12 & 2.81 \\
\hline II & 6.48 & 13.48 & 2.87 & 5.62 & 5.28 & 6.53 & 2.54 & 4.12 & 2.83 & 5.91 \\
\hline Ap & 0.09 & 0.24 & 0.17 & 3.95 & 2.23 & 0.14 & 0.17 & 0.00 & 0.09 & 0.12 \\
\hline TOTAL & 97.20 & 95.61 & 97.66 & 97.18 & 97.46 & 97.08 & 96.42 & 99.12 & 100.19 & 98.41 \\
\hline
\end{tabular}




\begin{tabular}{|c|c|c|c|c|c|c|c|c|c|c|}
\hline Sample & $90033 \mathrm{E}$ & $90033 \mathrm{~F}$ & $90033 \mathrm{G}$ & $90033 \mathrm{H}$ & $90033 I$ & $90033 \mathrm{~K}$ & $90033 \mathrm{~J}$ & $90033 P$ & $90033 \mathrm{~S}$ & $90033 \mathrm{U}$ \\
\hline Type & Type $\mathrm{P}$ & Type $\mathbf{P}$ & Type M & Type $\mathbf{P}$ & Type P & Type $\mathbf{M}$ & Type C & Type C & Type L & Type L \\
\hline $\mathrm{SiO} 2$ & 41.08 & 37.69 & 39.69 & 39.15 & 39.06 & 35.55 & 41.85 & 41.89 & 45.60 & 47.13 \\
\hline $\mathrm{TiO} 2$ & 1.83 & 1.36 & 5.59 & 1.15 & 0.64 & 7.25 & 2.51 & 4.73 & 2.02 & 2.53 \\
\hline $\mathrm{Al} 2 \mathrm{O} 3$ & 13.57 & 4.86 & 13.20 & 4.72 & 4.97 & 8.10 & 9.73 & 16.52 & 21.57 & 21.64 \\
\hline $\mathrm{Fe} 2 \mathrm{O} 3$ total & 12.16 & 19.74 & 15.57 & 17.09 & 19.11 & 24.30 & 15.12 & 13.17 & 9.62 & 8.35 \\
\hline $\mathrm{MnO}$ & 0.14 & 0.24 & 0.20 & 0.23 & 0.22 & 0.32 & 0.21 & 0.16 & 0.10 & 0.12 \\
\hline $\mathrm{MgO}$ & 15.35 & 32.40 & 10.75 & 33.89 & 31.21 & 9.88 & 17.98 & 8.26 & 4.93 & 3.32 \\
\hline $\mathrm{CaO}$ & 14.87 & 3.65 & 13.17 & 3.82 & 5.40 & 12.71 & 11.48 & 10.32 & 12.62 & 12.24 \\
\hline $\mathrm{Na} 2 \mathrm{O}$ & 1.11 & 0.83 & 1.94 & 0.82 & 0.48 & 1.40 & 1.69 & 3.70 & 3.24 & 3.68 \\
\hline $\mathrm{K} 2 \mathrm{O}$ & 0.09 & 0.13 & 0.30 & 0.13 & 0.03 & 0.10 & 0.31 & 0.81 & 0.24 & 0.25 \\
\hline $\mathrm{P} 2 \mathrm{O} 5$ & 0.06 & 0.06 & 0.12 & 0.05 & 0.02 & 0.07 & 0.11 & 0.16 & 0.05 & 0.63 \\
\hline LOI & -0.29 & -1.20 & -0.46 & -0.91 & -1.27 & -0.17 & -0.73 & 0.44 & 0.07 & 0.29 \\
\hline TOTAL & 99.97 & 99.76 & 100.07 & 100.14 & 99.87 & 99.51 & 100.26 & 100.16 & 100.06 & 100.18 \\
\hline Mg\# & 71.43 & 76.47 & 57.76 & 79.70 & 76.38 & 44.60 & 70.19 & 55.40 & 50.37 & 44.05 \\
\hline $\mathrm{Sc}$ & 56 & 7 & 30 & 11 & 17 & 46 & 41 & 44 & 19 & 17 \\
\hline V & 457 & 153 & 461 & 139 & 169 & 580 & 306 & 395 & 317 & 166 \\
\hline $\mathrm{Cr}$ & 415 & 3428 & 63 & 3188 & 1726 & 26 & 911 & 22 & 69 & 16 \\
\hline $\mathrm{Ni}$ & 351 & 1050 & 112 & 1038 & 959 & 26 & 429 & 42 & 25 & 7 \\
\hline $\mathrm{Cu}$ & 268 & 14 & 55 & 9 & 47 & 55 & 77 & 33 & 11 & 12 \\
\hline $\mathrm{Zn}$ & 127 & 116 & 107 & 104 & 120 & 134 & 91 & 62 & 49 & 35 \\
\hline $\mathrm{Ga}$ & 28 & 10 & 24 & 8 & 13 & 20 & 13 & 19 & 22 & 19 \\
\hline As & $<1$ & $<1$ & $<1$ & $<1$ & $<1$ & $<1$ & $<1$ & $<1$ & $<1$ & $<1$ \\
\hline $\mathrm{Rb}$ & 2 & 2 & 5 & 1 & 1 & 1 & 2 & 17 & 1 & 3 \\
\hline $\mathrm{Sr}$ & 148 & 103 & 305 & 93 & 43 & 285 & 352 & 761 & 867 & 1061 \\
\hline$Y$ & 14 & 4 & 20 & 4 & 3 & 16 & 20 & 31 & 5 & 8 \\
\hline $\mathrm{Zr}$ & 57 & 20 & 77 & 25 & 19 & 70 & 74 & 162 & 43 & 46 \\
\hline $\mathrm{Nb}$ & 3 & 6 & 14 & 3 & 2 & 17 & 15 & 53 & 2 & 10 \\
\hline $\mathrm{Ba}$ & 40 & 28 & 53 & 28 & 3 & 24 & 118 & 201 & 85 & 253 \\
\hline La & 4 & 2 & 7 & 2 & 5 & 4 & 7 & 24 & 7 & 11 \\
\hline $\mathrm{Ce}$ & 19 & 6 & 35 & 4 & 14 & 36 & 27 & 69 & 18 & 25 \\
\hline $\mathrm{Pb}$ & 5 & 5 & 5 & 6 & 5 & 6 & 2 & 4 & 4 & 6 \\
\hline Th & $<1$ & 1 & 1 & 1 & $<1$ & 2 & $<1$ & 1 & $<1$ & $<1$ \\
\hline $\mathrm{U}$ & 1 & $<1$ & $<1$ & 2 & $<1$ & $<1$ & $<1$ & $<1$ & $<1$ & 2 \\
\hline$Q$ & 0.00 & 0.00 & 0.00 & 0.00 & 0.00 & 0.00 & 0.00 & 0.00 & 0.00 & 0.00 \\
\hline Or & 0.00 & 0.00 & 1.77 & 0.16 & 0.00 & 0.00 & 1.82 & 4.79 & 1.42 & 1.77 \\
\hline $\mathrm{Ab}$ & 0.00 & 0.00 & 0.44 & 0.00 & 0.00 & 0.00 & 0.00 & 8.80 & 16.54 & 26.44 \\
\hline An & 31.78 & 9.15 & 26.42 & 8.81 & 11.32 & 15.52 & 18.05 & 26.08 & 43.61 & 40.08 \\
\hline $\mathrm{Ne}$ & 5.09 & 3.80 & 8.66 & 3.76 & 2.20 & 6.42 & 7.75 & 12.19 & 5.89 & 3.79 \\
\hline $\mathrm{Di}$ & 31.40 & 6.85 & 30.80 & 7.82 & 12.29 & 38.79 & 30.68 & 19.69 & 15.35 & 12.18 \\
\hline $\mathrm{Hy}$ & 0.00 & 0.00 & 0.00 & 0.00 & 0.00 & 0.00 & 0.00 & 0.00 & 0.00 & 0.00 \\
\hline $\mathrm{Ol}$ & 25.87 & 73.51 & 17.50 & 73.27 & 69.78 & 19.90 & 33.72 & 15.58 & 10.73 & 6.73 \\
\hline Mt & 2.10 & 3.40 & 2.69 & 2.95 & 3.30 & 4.19 & 2.61 & 2.27 & 1.66 & 1.40 \\
\hline Il & 3.48 & 2.58 & 10.62 & 2.18 & 1.22 & 13.77 & 4.77 & 8.98 & 3.84 & 4.90 \\
\hline Ap & 0.14 & 0.14 & 0.28 & 0.12 & 0.05 & 0.17 & 0.26 & 0.38 & 0.12 & 1.54 \\
\hline TOTAL & 99.86 & 99.43 & 99.18 & 99.07 & 100.16 & 98.76 & 99.66 & 98.76 & 99.16 & 98.83 \\
\hline
\end{tabular}




\begin{tabular}{|c|c|c|c|c|c|c|c|c|c|c|}
\hline Sample & $90033 \mathrm{~V}$ & $90033 \mathrm{~W}$ & $90033 X$ & $90033 \mathrm{~A}$ & $90033 \mathrm{~B} 1$ & $90033 \mathrm{C} 1$ & 90033EI & 90033F1 & $90033 \mathrm{H} 1$ & $90033 \mathrm{P} 1$ \\
\hline Type & Type L & Type L & Type L & U.C. & Type L & Type L & Type L & Type L & Type C & Type C \\
\hline $\mathrm{SiO}_{2}$ & 47.15 & 52.17 & 44.44 & 65.43 & 46.83 & 44.02 & 49.43 & 52.00 & 43.01 & 45.72 \\
\hline $\mathrm{TiO} 2$ & 2.34 & 1.12 & 3.09 & 0.19 & 2.44 & 2.88 & 1.67 & 1.53 & 4.07 & 1.86 \\
\hline $\mathrm{Al} 2 \mathrm{O} 3$ & 21.07 & 23.84 & 15.83 & 16.67 & 19.33 & 14.25 & 24.06 & 18.55 & 13.53 & 14.10 \\
\hline $\mathrm{Fe} 2 \mathrm{O} 3$ total & 9.37 & 5.01 & 16.44 & 3.19 & 11.17 & 16.11 & 5.92 & 8.67 & 14.94 & 10.21 \\
\hline $\mathrm{MnO}$ & 0.11 & 0.09 & 0.27 & 0.08 & 0.14 & 0.23 & 0.07 & 0.20 & 0.16 & 0.14 \\
\hline $\mathrm{MgO}$ & 3.10 & 1.49 & 4.80 & 0.31 & 4.53 & 7.82 & 2.51 & 3.31 & 11.44 & 10.38 \\
\hline $\mathrm{CaO}$ & 11.37 & 9.50 & 10.11 & 0.87 & 9.58 & 10.71 & 11.64 & 9.42 & 11.11 & 14.32 \\
\hline $\mathrm{Na} 2 \mathrm{O}$ & 4.15 & 5.50 & 3.89 & 7.05 & 4.31 & 3.15 & 4.20 & 4.80 & 2.37 & 2.13 \\
\hline $\mathrm{K} 2 \mathrm{O}$ & 0.30 & 0.37 & 0.30 & 5.29 & 0.43 & 0.53 & 0.26 & 0.64 & 0.11 & 0.19 \\
\hline P2O5 & 1.31 & 0.76 & 1.36 & 0.05 & 0.52 & 0.58 & 0.08 & 0.34 & 0.02 & 0.07 \\
\hline LOI & -0.27 & -0.13 & -0.72 & 0.20 & -0.10 & -0.31 & 0.18 & -0.19 & -0.61 & 0.19 \\
\hline TOTAL & 100.00 & 99.72 & 99.81 & 99.33 & 99.18 & 99.97 & 100.02 & 99.27 & 100.15 & 99.31 \\
\hline Mg\# & 39.58 & 37.07 & 36.64 & 16.14 & 44.54 & 49.01 & 45.64 & 43.06 & 60.26 & 66.81 \\
\hline Sc & 12 & 6 & 22 & $<1$ & 14 & 21 & 11 & 17 & 21 & 39 \\
\hline V & 100 & 26 & 164 & 9 & 149 & 244 & 140 & 74 & 305 & 279 \\
\hline $\mathrm{Cr}$ & 5 & $<1$ & 19 & 4 & 10 & 99 & 10 & 3 & 388 & 376 \\
\hline $\mathrm{Ni}$ & 3 & $<1$ & 14 & $<1$ & 16 & 53 & 6 & 7 & 304 & 133 \\
\hline $\mathrm{Cu}$ & 26 & 11 & 27 & 13 & 22 & 55 & 13 & 16 & 130 & 53 \\
\hline $\mathrm{Zn}$ & 34 & 25 & 81 & 35 & 56 & 96 & 28 & 53 & 67 & 52 \\
\hline Ga & 23 & 22 & 21 & 25 & 20 & 18 & 22 & 22 & 17 & 17 \\
\hline As & $<1$ & $<1$ & $<1$ & 3 & $<1$ & $<1$ & $<1$ & $<1$ & $<1$ & $<1$ \\
\hline $\mathrm{Rb}$ & 3 & 1 & 1 & 175 & 3 & 6 & 1 & 1 & 1 & 3 \\
\hline $\mathrm{Sr}$ & 1098 & 1383 & 869 & 46 & 1154 & 420 & 1044 & 757 & 597 & 557 \\
\hline$Y$ & 11 & 5 & 22 & 24 & 9 & 13 & $<1$ & 14 & 9 & 14 \\
\hline $\mathrm{Zr}$ & 43 & 36 & 38 & 494 & 71 & 109 & 34 & 45 & 47 & 67 \\
\hline $\mathrm{Nb}$ & 7 & 4 & 7 & 87 & 17 & 29 & 4 & 33 & 6 & 7 \\
\hline $\mathrm{Ba}$ & 284 & 606 & 311 & 170 & 266 & 271 & 236 & 523 & 36 & 78 \\
\hline La & 12 & 11 & 22 & 28 & 14 & 21 & 8 & 17 & 5 & 4 \\
\hline $\mathrm{Ce}$ & 37 & 26 & 69 & 46 & 39 & 68 & 17 & 37 & 21 & 16 \\
\hline $\mathrm{Pb}$ & 5 & 4 & 5 & 10 & 3 & 7 & 5 & 5 & 3 & 4 \\
\hline Th & $<1$ & $<1$ & $<1$ & 28 & $<1$ & 1 & $<1$ & $<1$ & $<1$ & 1 \\
\hline $\mathrm{U}$ & $<1$ & $<1$ & $<1$ & 9 & 0 & $<1$ & $<1$ & $<1$ & $<1$ & $<1$ \\
\hline Q & 0.00 & 0.00 & 0.00 & 30.00 & 0.00 & 0.00 & 0.00 & 0.00 & 0.00 & 0.00 \\
\hline Or & 1.95 & 2.19 & 1.77 & 0.30 & 2.54 & 3.13 & 1.54 & 3.78 & 0.65 & 1.12 \\
\hline $\mathbf{A b}$ & 29.18 & 43.44 & 26.36 & 56.30 & 28.55 & 16.52 & 29.85 & 39.78 & 12.42 & 10.20 \\
\hline An & 36.54 & 39.27 & 24.85 & 4.32 & 32.13 & 23.18 & 46.03 & 27.18 & 25.96 & 28.35 \\
\hline $\mathrm{Ne}$ & 4.68 & 1.68 & 3.55 & 0.00 & 4.29 & 5.49 & 3.09 & 0.46 & 4.13 & 4.24 \\
\hline $\mathrm{Di}$ & 9.20 & 2.42 & 13.78 & 3.48 & 9.94 & 21.58 & 9.22 & 14.42 & 23.49 & 34.05 \\
\hline $\mathrm{Hy}$ & 0.00 & 0.00 & 0.00 & 4.69 & 0.00 & 0.00 & 0.00 & 0.00 & 0.00 & 0.00 \\
\hline O1 & 9.01 & 5.66 & 16.92 & 0.00 & 13.09 & 19.37 & 5.22 & 7.90 & 22.44 & 14.81 \\
\hline Mt & 1.58 & 0.87 & 2.83 & 0.70 & 1.93 & 2.78 & 1.02 & 1.50 & 2.58 & 1.76 \\
\hline II & 4.43 & 2.13 & 5.87 & 0.36 & 4.63 & 5.47 & 3.17 & 2.91 & 7.73 & 3.53 \\
\hline Ap & 3.24 & 1.80 & 3.22 & 0.12 & 1.23 & 1.37 & 0.19 & 0.80 & 0.05 & 0.17 \\
\hline TOTAL & 99.81 & 99.46 & 99.15 & 100.27 & 98.33 & 98.89 & 99.33 & 98.73 & 99.45 & 98.23 \\
\hline
\end{tabular}




\begin{tabular}{|c|c|c|c|c|c|c|c|c|c|c|}
\hline Sample & $90033 S 1$ & $90034 \mathrm{C}$ & $90035 \mathrm{C}$ & $90036 \mathrm{C}$ & $90036 \mathrm{G}$ & $90038 \mathrm{~L}$ & 90039A & $90039 \mathrm{~B}$ & $90039 \mathrm{C}$ & 90039D \\
\hline Type & Type $\mathrm{P}$ & U.C. & U.C. & U.C. & U.C. & U.C. & Type L & Type $\mathrm{M}$ & Type L & Type L \\
\hline $\mathrm{SiO}_{2}$ & 37.72 & 73.54 & 65.69 & 62.10 & 66.25 & 62.74 & 50.84 & 40.89 & 45.08 & 47.86 \\
\hline TiO2 & 1.09 & 0.05 & 0.60 & 0.48 & 0.56 & 0.33 & 0.54 & 3.21 & 3.33 & 2.30 \\
\hline $\mathrm{Al} 2 \mathrm{O} 3$ & 6.96 & 14.12 & 14.96 & 16.05 & 15.76 & 15.77 & 25.93 & 8.87 & 19.10 & 19.60 \\
\hline $\mathrm{Fe} 2 \mathrm{O} 3$ total & 20.80 & 0.80 & 5.75 & 7.39 & 3.64 & 6.63 & 3.90 & 21.35 & 11.49 & 11.22 \\
\hline $\mathrm{MnO}$ & 0.24 & 0.02 & 0.14 & 0.22 & 0.05 & 0.19 & 0.06 & 0.31 & 0.14 & 0.19 \\
\hline $\mathrm{MgO}$ & 27.63 & 0.29 & 0.09 & 0.27 & 1.68 & 0.19 & 2.69 & 12.86 & 4.60 & 3.44 \\
\hline $\mathrm{CaO}$ & 5.82 & 1.50 & 0.78 & 2.01 & 4.19 & 1.31 & 11.15 & 11.87 & 11.63 & 10.18 \\
\hline $\mathrm{Na} 2 \mathrm{O}$ & 0.59 & 4.47 & 6.53 & 6.13 & 4.65 & 6.47 & 4.11 & 1.51 & 3.51 & 4.15 \\
\hline $\mathrm{K}_{2} \mathrm{O}$ & 0.11 & 3.50 & 5.57 & 5.52 & 2.56 & 5.52 & 0.35 & 0.12 & 0.27 & 0.37 \\
\hline $\mathrm{P} 2 \mathrm{O} 5$ & 0.04 & 0.25 & 0.02 & 0.08 & 0.12 & 0.05 & 0.02 & 0.02 & 1.54 & 1.04 \\
\hline LOI & -0.89 & 0.92 & 0.11 & -0.07 & 0.29 & 0.10 & 0.00 & -0.74 & -0.52 & -0.49 \\
\hline TOTAL & 100.11 & 99.46 & 100.24 & 100.18 & 99.75 & 99.30 & 99.59 & 100.27 & 100.17 & 99.86 \\
\hline Mg\# & 72.46 & 41.79 & 3.01 & 6.75 & 47.75 & 5.37 & 57.73 & 54.40 & 44.22 & 37.78 \\
\hline $\mathrm{Sc}$ & 13 & 2 & $<1$ & 3 & 3 & $<1$ & 6 & 36 & 14 & 10 \\
\hline V & 212 & 8 & 9 & 10 & 50 & 5 & 29 & 347 & 148 & 43 \\
\hline $\mathrm{Cr}$ & 1671 & $<1$ & 1 & 2 & 51 & 3 & 11 & 106 & 7 & 4 \\
\hline $\mathrm{Ni}$ & 765 & $<1$ & 3 & 3 & 12 & 3 & 28 & 41 & 6 & 4 \\
\hline $\mathrm{Cu}$ & 47 & 4 & 10 & 13 & 12 & 9 & 25 & 62 & 18 & 15 \\
\hline $\mathrm{Zn}$ & 122 & 33 & 112 & 96 & 58 & 91 & 22 & 92 & 44 & 45 \\
\hline $\mathrm{Ga}$ & 16 & 18 & 40 & 28 & 24 & 33 & 21 & 15 & 22 & 24 \\
\hline As & $<1$ & $<1$ & 2 & 2 & 3 & 1 & $<1$ & $<1$ & $<1$ & $<1$ \\
\hline $\mathrm{Rb}$ & 2 & 159 & 243 & 106 & 108 & 160 & 2 & 2 & 3 & 4 \\
\hline $\mathrm{Sr}$ & 79 & 122 & 2 & 36 & 356 & 15 & 1034 & 386 & 1104 & 1201 \\
\hline $\mathrm{Y}$ & 6 & 3 & 89 & 42 & 16 & 48 & $<1$ & 11 & 13 & 17 \\
\hline $\mathrm{Zr}$ & 29 & 23 & 861 & 302 & 128 & 359 & 29 & 43 & 53 & 54 \\
\hline $\mathrm{Nb}$ & 3 & 16 & 176 & 69 & 7 & 76 & 5 & 5 & 11 & 10 \\
\hline $\mathrm{Ba}$ & 20 & 159 & 33 & 384 & 388 & 203 & 185 & 55 & 190 & 377 \\
\hline $\mathrm{La}$ & 4 & 4 & 110 & 45 & 19 & 59 & 7 & 5 & 22 & 25 \\
\hline $\mathrm{Ce}$ & 17 & 6 & 190 & 86 & 39 & 100 & 13 & 23 & 58 & 60 \\
\hline $\mathrm{Pb}$ & 5 & 26 & 22 & 13 & 24 & 10 & 4 & 6 & 3 & 5 \\
\hline Th & 1 & 1 & 28 & 8 & 15 & 12 & $<1$ & 1 & 1 & 1 \\
\hline $\mathrm{U}$ & 1 & 3 & 7 & 4 & 6 & 3 & $<1$ & $<1$ & 1 & $<1$ \\
\hline Q & & 29.47 & 6.46 & 0.00 & 17.55 & 0.00 & 0.00 & 0.00 & 0.00 & 0.00 \\
\hline Or & & 20.68 & 32.92 & 32.62 & 15.13 & 32.62 & 2.07 & 0.71 & 1.60 & 2.19 \\
\hline $\mathrm{Ab}$ & & 37.83 & 45.94 & 51.53 & 39.35 & 50.39 & 32.90 & 3.30 & 26.57 & 33.47 \\
\hline An & & 5.81 & 0.00 & 0.00 & 14.57 & 0.00 & 51.27 & 17.07 & 35.57 & 33.76 \\
\hline $\mathrm{Ne}$ & & 0.00 & 0.00 & 0.16 & 0.00 & 0.00 & 1.02 & 5.13 & 1.70 & 0.89 \\
\hline $\mathrm{Di}$ & & 3.51 & 3.32 & 8.35 & 4.49 & 5.46 & 3.19 & 34.18 & 9.96 & 8.32 \\
\hline Hy & & 0.00 & 7.88 & 0.00 & 6.08 & 4.93 & 0.00 & 0.00 & 0.00 & 0.00 \\
\hline $\mathrm{Ol}$ & & 0.00 & 0.00 & 4.58 & 0.00 & 3.84 & 7.04 & 28.91 & 12.42 & 12.01 \\
\hline Mt & & 0.14 & 1.51 & 1.25 & 0.63 & 0.26 & 0.67 & 3.68 & 1.98 & 1.93 \\
\hline Il & & 0.09 & 1.14 & 0.91 & 1.06 & 0.63 & 1.03 & 6.10 & 6.32 & 4.37 \\
\hline Ap & & 0.59 & 0.05 & 0.19 & 0.28 & 0.12 & 0.05 & 0.05 & 3.65 & 2.46 \\
\hline TOTAL & 0.00 & 98.12 & 99.22 & 99.59 & 99.14 & 98.25 & 99.24 & 99.13 & 99.77 & 99.40 \\
\hline
\end{tabular}




\begin{tabular}{|c|c|c|c|c|c|c|c|c|c|c|}
\hline $\begin{array}{l}\text { Sample } \\
\text { Type } \\
\end{array}$ & $\begin{array}{l}90039 \mathrm{E} \\
\text { Type L }\end{array}$ & $\begin{array}{c}90039 \mathrm{~F} \\
\text { Type M }\end{array}$ & $\begin{array}{l}\text { 90039G } \\
\text { Type L }\end{array}$ & $\begin{array}{r}900391 \\
\text { Type L } \\
\end{array}$ & $\begin{array}{l}90039 \mathrm{~J} \\
\text { Type L } \\
\end{array}$ & $\begin{array}{l}90039 \mathrm{~K} \\
\text { Type L }\end{array}$ & $\begin{array}{l}\text { 90039L } \\
\text { Type L }\end{array}$ & $\begin{array}{c}90039 \mathrm{M} \\
\text { Type L }\end{array}$ & $\begin{array}{c}90039 \mathrm{R} \\
\text { Type M }\end{array}$ & $\begin{array}{l}\text { 90039Sa } \\
\text { Type } \mathrm{P}\end{array}$ \\
\hline $\mathrm{SiO}_{2}$ & 44.50 & 36.91 & 43.91 & 47.87 & 46.24 & 46.32 & 46.03 & 40.48 & 26.67 & 40.65 \\
\hline $\mathrm{TiO} 2$ & 2.86 & 6.22 & 4.21 & 2.12 & 0.50 & 2.73 & 3.00 & 5.19 & 8.67 & 1.93 \\
\hline $\mathrm{Al} 2 \mathrm{O} 3$ & 18.49 & 10.98 & 18.34 & 21.16 & 20.18 & 17.00 & 19.44 & 15.54 & 2.04 & 10.73 \\
\hline $\mathrm{Fe} 2 \mathrm{O} 3$ total & 12.95 & 22.93 & 12.65 & 8.12 & 11.92 & 15.00 & 12.15 & 16.80 & 36.71 & 14.43 \\
\hline $\mathrm{MnO}$ & 0.18 & 0.29 & 0.14 & 0.10 & 0.18 & 0.27 & 0.18 & 0.21 & 0.52 & 0.18 \\
\hline $\mathrm{MgO}$ & 5.56 & 7.92 & 5.16 & 3.35 & 9.55 & 3.89 & 4.11 & 5.32 & 13.30 & 15.60 \\
\hline $\mathrm{CaO}$ & 10.38 & 12.08 & 11.65 & 11.07 & 8.86 & 9.74 & 10.34 & 11.56 & 10.50 & 15.02 \\
\hline $\mathrm{Na} 2 \mathrm{O}$ & 3.59 & 1.80 & 3.01 & 4.18 & 2.79 & 4.21 & 3.82 & 3.22 & 0.59 & 1.34 \\
\hline $\mathrm{K}_{2} \mathrm{O}$ & 0.27 & 0.13 & 0.21 & 0.33 & 0.24 & 0.42 & 0.44 & 0.28 & 0.08 & 0.07 \\
\hline $\mathrm{P} 2 \mathrm{O} 5$ & 1.56 & 1.36 & 0.03 & 1.38 & 0.13 & 0.97 & 1.05 & 1.48 & 3.17 & 0.02 \\
\hline LOI & -0.45 & -0.39 & 0.07 & -0.51 & -0.53 & -0.19 & -0.42 & -0.65 & -2.24 & -0.55 \\
\hline TOTAL & 99.89 & 100.23 & 99.38 & 99.17 & 100.06 & 100.36 & 100.14 & 99.43 & 100.01 & 99.42 \\
\hline Mg\# & 45.95 & 40.62 & 44.69 & 44.97 & 61.34 & 33.93 & 40.12 & 38.54 & 41.78 & 68.16 \\
\hline Sc & 9 & 32 & 19 & 12 & 3 & 15 & 10 & 23 & 21 & 44 \\
\hline V & 158 & 324 & 377 & 103 & 29 & 118 & 170 & 288 & 177 & 463 \\
\hline $\mathrm{Cr}$ & 23 & 18 & 13 & 8 & 41 & 14 & 8 & 9 & 7 & 870 \\
\hline $\mathrm{Ni}$ & 7 & 12 & 12 & 6 & 139 & 9 & 10 & 8 & 15 & 350 \\
\hline $\mathrm{Cu}$ & 26 & 25 & 31 & 13 & 27 & 17 & 30 & 16 & 40 & 74 \\
\hline $\mathrm{Zn}$ & 54 & 86 & 52 & 32 & 62 & 66 & 59 & 72 & 176 & 108 \\
\hline Ga & 19 & 21 & 23 & 20 & 17 & 23 & 22 & 21 & 15 & 23 \\
\hline As & $<1$ & $<1$ & $<1$ & $<1$ & $<1$ & $<1$ & $<1$ & 1 & 2 & $<1$ \\
\hline $\mathbf{R b}$ & 2 & 1 & 1 & 3 & 2 & 3 & 4 & 4 & 1 & $<1$ \\
\hline $\mathrm{Sr}$ & 1082 & 554 & 849 & 1091 & 777 & 801 & 995 & 775 & 101 & 67 \\
\hline Y & 15 & 23 & 4 & 10 & $<1$ & 17 & 14 & 19 & 44 & 16 \\
\hline $\mathrm{Zr}$ & 42 & 46 & 48 & 42 & 25 & 33 & 59 & 54 & 44 & 45 \\
\hline $\mathrm{Nb}$ & 12 & 14 & 10 & 9 & 4 & 5 & 17 & 16 & 24 & 2 \\
\hline $\mathrm{Ba}$ & 241 & 139 & 122 & 281 & 145 & 374 & 243 & 213 & 8 & 8 \\
\hline $\mathrm{La}$ & 23 & 21 & 5 & 14 & 7 & 25 & 23 & 22 & 25 & 4 \\
\hline $\mathrm{Ce}$ & 57 & 76 & 16 & 39 & 17 & 60 & 56 & 66 & 188 & 15 \\
\hline $\mathrm{Pb}$ & 4 & 4 & 4 & 4 & 6 & 6 & 5 & 7 & 5 & 3 \\
\hline Th & $<1$ & 1 & $<1$ & 2 & 1 & 1 & 2 & 2 & 2 & 1 \\
\hline $\mathrm{U}$ & $<1$ & $<1$ & $<1$ & $<1$ & $<1$ & $<1$ & $<1$ & 1 & $<1$ & $<1$ \\
\hline Q & 0.00 & 0.00 & 0.00 & 0.00 & 0.00 & 0.00 & 0.00 & 0.00 & 0.00 & 0.00 \\
\hline Or & 0.71 & 0.77 & 1.24 & 1.95 & 1.42 & 2.48 & 2.60 & 1.65 & 0.00 & 0.00 \\
\hline $\mathbf{A b}$ & 28.09 & 7.17 & 18.54 & 33.32 & 23.43 & 29.42 & 28.44 & 16.33 & 0.00 & 0.00 \\
\hline An & 33.98 & 21.50 & 35.91 & 38.00 & 41.83 & 26.25 & 34.60 & 27.12 & 2.68 & 23.06 \\
\hline $\mathrm{Ne}$ & 1.24 & 4.37 & 3.75 & 1.11 & 0.10 & 3.36 & 2.10 & 5.91 & 2.70 & 6.14 \\
\hline Di & 6.05 & 24.52 & 17.83 & 6.52 & 1.04 & 13.25 & 8.19 & 17.08 & 21.84 & 39.39 \\
\hline Hy & 0.00 & 0.00 & 0.00 & 0.00 & 0.00 & 0.00 & 0.00 & 0.00 & 0.00 & 0.00 \\
\hline $\mathrm{Ol}$ & 17.70 & 21.36 & 10.67 & 9.44 & 28.41 & 14.45 & 13.33 & 14.33 & 42.64 & 25.74 \\
\hline Mt & 2.23 & 3.95 & 2.18 & 1.40 & 2.06 & 2.59 & 2.10 & 2.90 & 6.33 & 2.49 \\
\hline II & 5.43 & 11.81 & 8.00 & 4.03 & 0.95 & 5.18 & 5.70 & 9.86 & 16.47 & 3.67 \\
\hline Ap & 3.69 & 3.22 & 0.07 & 3.27 & 0.31 & 2.30 & 2.49 & 3.50 & 7.34 & 0.05 \\
\hline TOTAL & 99.12 & 98.67 & 98.19 & 99.04 & 99.55 & 99.28 & 99.55 & 98.68 & 100.00 & 100.54 \\
\hline
\end{tabular}




\begin{tabular}{|c|c|c|c|c|c|c|}
\hline & $90039 \mathrm{Sb}$ & $90039 \mathrm{~T}$ & $90039 \mathrm{U}$ & $90039 \mathrm{~V}$ & $90039 X$ & $90039 Y$ \\
\hline Type & Type C & Type C & Type $\mathrm{P}$ & Type M & Type $\mathrm{P}$ & Type $\mathrm{P}$ \\
\hline $\mathrm{SiO} 2$ & 44.66 & 44.99 & 45.16 & 32.68 & 45.90 & 35.58 \\
\hline $\mathrm{TiO} 2$ & 1.70 & 0.67 & 0.94 & 8.62 & 1.96 & 1.53 \\
\hline $\mathrm{Al} 2 \mathrm{O} 3$ & 16.58 & 18.10 & 7.25 & 7.10 & 9.56 & 16.90 \\
\hline $\mathrm{Fe} 2 \mathrm{O} 3$ total & 10.81 & 15.30 & 11.12 & 30.39 & 10.80 & 15.22 \\
\hline $\mathrm{MnO}$ & 0.13 & 0.24 & 0.18 & 0.36 & 0.18 & 0.17 \\
\hline $\mathrm{MgO}$ & 11.08 & 10.84 & 20.00 & 9.29 & 12.05 & 18.56 \\
\hline $\mathrm{CaO}$ & 13.28 & 7.76 & 15.07 & 11.77 & 18.47 & 11.35 \\
\hline $\mathrm{Na} 2 \mathrm{O}$ & 2.19 & 2.64 & 0.84 & 1.08 & 1.20 & 0.97 \\
\hline $\mathrm{K} 2 \mathrm{O}$ & 0.15 & 0.20 & 0.08 & 0.11 & 0.10 & 0.17 \\
\hline $\mathrm{P} 2 \mathrm{O} 5$ & 0.05 & 0.02 & 0.00 & 0.10 & 0.00 & 0.01 \\
\hline LOI & -0.32 & -1.06 & -0.33 & -1.55 & -0.01 & -0.34 \\
\hline TOTAL & 100.31 & 99.70 & 100.31 & 99.95 & 100.21 & 100.12 \\
\hline Mg\# & 67.00 & 58.39 & 78.08 & 37.71 & 68.84 & 70.72 \\
\hline Sc & 32 & 2 & 54 & 33 & 75 & 35 \\
\hline $\mathrm{V}$ & 311 & 53 & 280 & 689 & 508 & 431 \\
\hline $\mathrm{Cr}$ & 360 & 65 & 3004 & 16 & 296 & 1120 \\
\hline $\mathrm{Ni}$ & 225 & 153 & 428 & 16 & 70 & 429 \\
\hline $\mathrm{Cu}$ & 34 & 13 & 33 & 30 & 16 & 17 \\
\hline $\mathrm{Zn}$ & 80 & 75 & 63 & 157 & 44 & 184 \\
\hline $\mathrm{Ga}$ & 22 & 17 & 12 & 22 & 16 & 34 \\
\hline As & $<1$ & $<1$ & $<1$ & 1 & $<1$ & $<1$ \\
\hline $\mathrm{Rb}$ & 1 & 1 & 1 & 3 & 3 & 4 \\
\hline $\mathrm{Sr}$ & 529 & 758 & 84 & 245 & 180 & 80 \\
\hline$Y$ & 12 & $<1$ & 10 & 14 & 19 & 12 \\
\hline $\mathrm{Zr}$ & 48 & 21 & 28 & 68 & 65 & 38 \\
\hline $\mathrm{Nb}$ & 4 & 3 & 1 & 20 & 2 & 4 \\
\hline $\mathrm{Ba}$ & 51 & 127 & 14 & 10 & 25 & 22 \\
\hline $\mathrm{La}$ & 4 & 3 & 3 & 2 & 5 & 4 \\
\hline $\mathrm{Ce}$ & 14 & 13 & 8 & 49 & 21 & 16 \\
\hline $\mathrm{Pb}$ & 5 & 5 & 3 & 6 & 5 & 5 \\
\hline Th & 1 & 1 & 1 & 1 & 1 & 1 \\
\hline $\mathrm{U}$ & $<1$ & 1 & $<1$ & $<1$ & 1 & $<1$ \\
\hline$Q$ & 0.00 & 0.00 & 0.00 & 0.00 & 0.00 & 0.00 \\
\hline Or & 0.89 & 1.18 & 0.00 & 0.00 & 0.00 & 0.00 \\
\hline $\mathrm{Ab}$ & 8.31 & 21.87 & 0.00 & 0.00 & 0.00 & 0.00 \\
\hline An & 34.97 & 36.95 & 15.78 & 14.20 & 20.40 & 41.26 \\
\hline $\mathrm{Ne}$ & 5.54 & 0.25 & 3.85 & 4.95 & 5.50 & 4.45 \\
\hline $\mathrm{Di}$ & 24.67 & 1.16 & 47.08 & 34.24 & 57.30 & 12.06 \\
\hline $\mathrm{Hy}$ & 0.00 & 0.00 & 0.00 & 0.00 & 0.00 & 0.00 \\
\hline OI & 20.09 & 34.05 & 29.54 & 24.24 & 10.26 & 36.15 \\
\hline Mt & 1.86 & 2.64 & 1.92 & 5.24 & 1.86 & 2.62 \\
\hline Il & 3.23 & 1.27 & 1.79 & 16.37 & 3.72 & 2.91 \\
\hline Ap & 0.12 & 0.05 & 0.00 & 0.24 & 0.00 & 0.02 \\
\hline TOTAL & 99.68 & 99.42 & 99.96 & 99.48 & 99.04 & 99.47 \\
\hline
\end{tabular}




\section{A4.2 Mount Hampton xenolith analyses}

\begin{tabular}{|c|c|c|c|c|c|c|c|c|c|c|}
\hline $\begin{array}{l}\text { Sample } \\
\text { Type }\end{array}$ & $\begin{array}{l}\text { PK1A } \\
\text { Perid } \\
\end{array}$ & $\begin{array}{c}\text { PK4A } \\
\text { Gran }\end{array}$ & $\begin{array}{l}\text { PK4B } \\
\text { Pyxite }\end{array}$ & $\begin{array}{l}\text { PK4C } \\
\text { Pyxite }\end{array}$ & $\begin{array}{l}\text { PK4D } \\
\text { Pyxite }\end{array}$ & $\begin{array}{l}\text { PK4E } \\
\text { Perid } \\
\end{array}$ & $\begin{array}{l}\text { PK4F } \\
\text { Perid }\end{array}$ & $\begin{array}{l}\text { PK4G } \\
\text { Perid }\end{array}$ & $\begin{array}{l}\text { PK4H } \\
\text { Perid }\end{array}$ & $\begin{array}{l}\text { PK4Ia } \\
\text { Pyxite }\end{array}$ \\
\hline $\mathrm{SiO} 2$ & 43.81 & 50.62 & 48.52 & 45.85 & 49.56 & 51.01 & 44.91 & 49.80 & 43.69 & 48.73 \\
\hline $\mathrm{TiO}_{2}$ & 0.07 & 0.22 & 1.11 & 0.42 & 0.68 & 0.14 & 0.14 & 0.14 & 0.02 & 1.16 \\
\hline $\mathrm{Al} 2 \mathrm{O} 3$ & 1.90 & 21.78 & 7.86 & 3.67 & 7.00 & 4.76 & 3.65 & 4.36 & 0.62 & 7.04 \\
\hline $\mathrm{Fe} 2 \mathrm{O} 3$ total & 9.22 & 6.74 & 12.67 & 21.65 & 15.53 & 4.70 & 8.79 & 5.30 & 8.50 & 13.43 \\
\hline $\mathrm{MnO}$ & 0.14 & 0.08 & 0.22 & 0.29 & 0.25 & 0.11 & 0.14 & 0.12 & 0.12 & 0.23 \\
\hline $\mathrm{MgO}$ & 42.52 & 8.19 & 15.83 & 26.70 & 20.97 & 24.80 & 38.00 & 27.11 & 45.92 & 17.61 \\
\hline $\mathrm{CaO}$ & 1.62 & 8.88 & 12.95 & 1.39 & 5.46 & 12.86 & 3.49 & 11.04 & 0.54 & 11.88 \\
\hline $\mathrm{Na} 2 \mathrm{O}$ & 0.22 & 3.50 & 1.15 & 1.10 & 0.46 & 1.06 & 0.54 & 1.17 & 0.22 & 0.79 \\
\hline $\mathrm{K} 2 \mathrm{O}$ & 0.00 & 0.31 & 0.03 & 0.08 & 0.05 & 0.01 & 0.01 & 0.05 & 0.00 & 0.02 \\
\hline $\mathrm{P} 2 \mathrm{O} 5$ & 0.01 & 0.02 & 0.00 & 0.06 & 0.00 & 0.00 & 0.01 & 0.01 & 0.02 & 0.00 \\
\hline LOI & -0.20 & 0.04 & -0.12 & -0.90 & -0.32 & 0.05 & -0.35 & 0.40 & -0.26 & -0.39 \\
\hline TOTAL & 99.31 & 100.38 & 100.22 & 100.31 & 99.64 & 99.50 & 99.33 & 99.50 & 99.39 & 100.50 \\
\hline Mg\# & 90.13 & 70.64 & 71.22 & 70.95 & 72.78 & 91.27 & 89.54 & 91.02 & 91.45 & 72.20 \\
\hline
\end{tabular}

$\begin{array}{lcccccccccc}\mathrm{Sc} & 5 & 7 & 50 & 19 & 35 & 40 & 13 & 37 & 4 & 49 \\ \mathrm{~V} & 58 & 45 & 364 & 177 & 266 & 157 & 81 & 126 & 24 & 369 \\ \mathrm{Cr} & 3082 & 45 & 735 & 236 & 598 & 6776 & 2975 & 5559 & 2806 & 896 \\ \mathrm{Ni} & 2349 & 130 & 274 & 499 & 303 & 1012 & 2086 & 1184 & 2705 & 235 \\ \mathrm{Cu} & 6 & 5 & 53 & 28 & 46 & 43 & 28 & 35 & 2 & 25 \\ \mathrm{Zn} & 55 & 38 & 70 & 153 & 102 & 29 & 56 & 29 & 49 & 77 \\ \mathrm{Ga} & 2 & 15 & 14 & 8 & 12 & 5 & 3 & 5 & <1 & 13 \\ \mathrm{As} & <1 & <1 & <1 & <1 & <1 & <1 & <1 & <1 & <1 & <1 \\ \mathrm{Rb} & 1 & 2 & <1 & 1 & 1 & 1 & <1 & 1 & 0 & 1 \\ \mathrm{Sr} & 10 & 719 & 62 & 3 & 65 & 15 & 9 & 178 & 2 & 32 \\ \mathrm{Y} & <1 & <1 & 14 & 1 & 4 & 4 & 1 & 2 & <1 & 14 \\ \mathrm{Zr} & <1 & 19 & 25 & 3 & 11 & 1 & 2 & 13 & 2 & 24 \\ \mathrm{Nb} & 1 & <1 & <1 & 1 & 1 & <1 & 1 & 3 & 1 & 1 \\ \mathrm{Ba} & 3 & 158 & 11 & 5 & 12.3 & 2 & 2 & 5 & 5 & 3 \\ \mathrm{La} & 1 & 2 & 2 & 7 & 2 & 2 & 1 & 6 & 1 & 4 \\ \mathrm{Ce} & 3 & 8 & 8 & 17 & 11 & 5 & 2 & 5 & 2 & 11 \\ \mathrm{~Pb} & 3 & 3 & 5 & 4 & 3 & 4 & 3 & 3 & 3 & 4 \\ \mathrm{Th} & <1 & 1 & 1 & 1 & <1 & 1 & 2 & 1 & <1 & 1 \\ \mathrm{U} & 1 & <1 & 1 & <1 & 1 & <1 & <1 & <1 & 1 & <1\end{array}$

\begin{tabular}{|c|c|c|c|c|c|c|c|c|c|c|}
\hline$Q$ & 0.00 & 0.00 & 0.00 & 0.00 & 0.00 & 0.00 & 0.00 & 0.00 & 0.00 & 0.00 \\
\hline Or & 0.00 & 1.83 & 0.18 & 0.47 & 0.30 & 0.06 & 0.06 & 0.30 & 0.00 & 0.12 \\
\hline$A b$ & 1.86 & 29.62 & 9.73 & 9.31 & 3.89 & 8.97 & 4.57 & 9.90 & 1.86 & 6.68 \\
\hline An & 4.20 & 42.80 & 16.20 & 4.84 & 16.89 & 8.20 & 7.51 & 6.50 & 0.70 & 15.60 \\
\hline $\mathrm{Ne}$ & 0.00 & 0.00 & 0.00 & 0.00 & 0.00 & 0.00 & 0.00 & 0.00 & 0.00 & 0.00 \\
\hline $\mathrm{Di}$ & 2.98 & 0.90 & 38.67 & 1.22 & 8.92 & 43.74 & 7.69 & 37.94 & 1.45 & 34.84 \\
\hline Hy & 16.87 & 7.49 & 13.49 & 35.88 & 55.60 & 11.33 & 14.71 & 8.65 & 15.75 & 22.69 \\
\hline OI & 71.05 & 15.48 & 16.66 & 42.79 & 9.20 & 25.67 & 62.57 & 34.15 & 77.60 & 15.26 \\
\hline Mt & 1.59 & 1.16 & 2.18 & 3.73 & 2.68 & 0.81 & 1.52 & 0.92 & 1.47 & 2.32 \\
\hline II & 0.13 & 0.42 & 2.11 & 0.80 & 1.29 & 0.27 & 0.27 & 0.27 & 0.04 & 2.20 \\
\hline Ap & 0.02 & 0.05 & 0.00 & 0.14 & 0.00 & 0.00 & 0.02 & 0.02 & 0.05 & 0.00 \\
\hline TOTAL & 98.70 & 99.75 & 99.22 & 99.18 & 98.77 & 99.05 & 98.92 & 98.65 & 98.92 & 99.71 \\
\hline
\end{tabular}




\begin{tabular}{|c|c|c|c|c|c|c|c|c|c|c|}
\hline Sample & PK4Ib & PK4Ic & PK4Id & PK4Ie & PK4J & PK4K & PK4L & PK4M & PK4N & PK4O \\
\hline Type & Pyxite & Pyxite & Pyxite & Pyxite & Pyxite & Pyxite & Pyxite & Pyxite & Pyxite & Perid \\
\hline $\mathrm{SiO} 2$ & 40.25 & 48.95 & 49.96 & 40.63 & 48.06 & 50.25 & 47.57 & 49.39 & 43.40 & 44.63 \\
\hline $\mathrm{TiO} 2$ & 2.20 & 1.05 & 0.66 & 2.10 & 1.28 & 0.57 & 1.39 & 0.59 & 0.40 & 0.12 \\
\hline $\mathrm{Al} 2 \mathrm{O} 3$ & 15.26 & 6.23 & 6.00 & 14.29 & 7.12 & 5.82 & 8.52 & 4.71 & 4.28 & 3.26 \\
\hline $\mathrm{Fe} 2 \mathrm{O} 3$ total & 13.45 & 14.51 & 17.00 & 13.06 & 12.27 & 17.45 & 11.94 & 18.94 & 24.26 & 8.98 \\
\hline $\mathrm{MnO}$ & 0.17 & 0.25 & 0.23 & 0.18 & 0.23 & 0.24 & 0.20 & 0.28 & 0.28 & 0.14 \\
\hline $\mathrm{MgO}$ & 12.82 & 18.19 & 23.41 & 13.25 & 15.42 & 24.02 & 14.91 & 24.13 & 25.54 & 39.84 \\
\hline $\mathrm{CaO}$ & 14.74 & 10.49 & 2.91 & 14.79 & 14.87 & 1.82 & 14.57 & 2.58 & 2.51 & 2.95 \\
\hline $\mathrm{Na} 2 \mathrm{O}$ & 1.59 & 0.78 & 0.39 & 1.62 & 0.95 & 0.58 & 1.16 & 0.32 & 0.51 & 0.33 \\
\hline $\mathrm{K} 2 \mathrm{O}$ & 0.03 & 0.03 & 0.03 & 0.05 & 0.01 & 0.03 & 0.01 & 0.01 & 0.03 & 0.00 \\
\hline $\mathrm{P} 2 \mathrm{O} 5$ & 0.00 & 0.01 & 0.02 & 0.00 & 0.00 & 0.03 & 0.02 & 0.01 & 0.04 & 0.01 \\
\hline LOI & -0.19 & -0.24 & -0.55 & -0.07 & 0.00 & -0.37 & -0.33 & -0.67 & -1.10 & -0.48 \\
\hline TOTAL & 100.32 & 100.25 & 100.06 & 99.90 & 100.21 & 100.44 & 99.96 & 100.29 & 100.15 & 99.78 \\
\hline Mg\# & 65.37 & 71.29 & 73.17 & 66.77 & 71.34 & 73.16 & 71.21 & 71.62 & 67.58 & 89.78 \\
\hline
\end{tabular}

\begin{tabular}{|c|c|c|c|c|c|c|c|c|c|c|}
\hline Sc & 42 & 50 & 25 & 38 & 58 & 24 & 43 & 31 & 14 & 11 \\
\hline V & 492 & 357 & 231 & 479 & 421 & 217 & 381 & 239 & 120 & 71 \\
\hline $\mathrm{Cr}$ & 28 & 644 & 1436 & 49 & 926 & 1509 & 1235 & 403 & 144 & 2816 \\
\hline $\mathrm{Ni}$ & 115 & 257 & 415 & 153 & 248 & 450 & 371 & 346 & 421 & 2131 \\
\hline $\mathrm{Cu}$ & 42 & 35 & 45 & 73 & 44 & 59 & 78 & 16 & 7 & 23 \\
\hline $\mathrm{Zn}$ & 123 & 89 & 98 & 112 & 64 & 100 & 51 & 132 & 127 & 55 \\
\hline $\mathrm{Ga}$ & 27 & 14 & 10 & 24 & 13 & 8.4 & 11 & 11 & 6 & 4 \\
\hline As & $<1$ & $<1$ & $<1$ & $<1$ & $<1$ & $<1$ & $<1$ & $<1$ & $<1$ & $<1$ \\
\hline $\mathrm{Rb}$ & 1 & 2 & 2 & 1 & 1 & $<1$ & $<1$ & $<1$ & $<1$ & $<1$ \\
\hline $\mathrm{Sr}$ & 132 & 34 & 12 & 131 & 33 & 3 & 37 & 4 & 22 & 8 \\
\hline$Y$ & 15 & 12 & $<1$ & 15 & 16 & $<1$ & 8 & 2 & $<1$ & $<1$ \\
\hline $\mathrm{Zr}$ & 44 & 21 & 1 & 42 & 29 & $<1$ & 4 & 7 & 10 & 2 \\
\hline $\mathrm{Nb}$ & 1 & 1 & $<1$ & $<1$ & $<1$ & $<1$ & 1 & $<1$ & $<1$ & $<1$ \\
\hline $\mathrm{Ba}$ & 8 & $<1$ & 1 & 10 & 2 & 4 & $<1$ & 4 & 5 & $<1$ \\
\hline $\mathrm{La}$ & 4 & 3 & 3 & 5 & 3 & 3 & 3 & 6 & 4 & 2 \\
\hline $\mathrm{Ce}$ & 19 & 15 & 11 & 17 & 9 & 8 & 11 & 13 & 15 & 3 \\
\hline $\mathrm{Pb}$ & 5 & 5 & 3 & 4 & 5 & 2 & 5 & 5 & 5 & 4 \\
\hline Th & 1 & 2 & 2 & 1 & $<1$ & $<1$ & 2 & 2 & 1 & 1 \\
\hline $\mathrm{U}$ & $<1$ & 1 & 1 & 1 & $<1$ & 1 & 1 & $<1$ & 1 & 1 \\
\hline$Q$ & 0.00 & 0.00 & 0.00 & 0.00 & 0.00 & 0.00 & 0.00 & 0.00 & 0.00 & 0.00 \\
\hline Or & 0.00 & 0.18 & 0.18 & 0.00 & 0.06 & 0.18 & 0.06 & 0.06 & 0.18 & 0.00 \\
\hline $\mathrm{Ab}$ & 0.00 & 6.60 & 3.30 & 0.00 & 8.04 & 4.91 & 9.82 & 2.71 & 4.32 & 2.79 \\
\hline An & 34.41 & 13.41 & 14.31 & 31.57 & 15.13 & 8.83 & 18.01 & 11.39 & 9.30 & 7.41 \\
\hline $\mathrm{Ne}$ & 7.29 & 0.00 & 0.00 & 7.43 & 0.00 & 0.00 & 0.00 & 0.00 & 0.00 & 0.00 \\
\hline $\mathrm{Di}$ & 31.28 & 31.05 & 11.50 & 33.73 & 47.17 & 7.10 & 43.54 & 1.08 & 2.35 & 5.64 \\
\hline $\mathrm{Hy}$ & 0.00 & 29.64 & 50.85 & 0.00 & 7.37 & 60.50 & 3.92 & 66.16 & 32.22 & 16.14 \\
\hline Ol & 22.98 & 13.82 & 17.55 & 22.65 & 16.83 & 13.78 & 19.16 & 13.49 & 45.71 & 65.68 \\
\hline Mt & 2.32 & 2.50 & 2.93 & 2.25 & 2.12 & 3.01 & 2.06 & 3.27 & 4.18 & 1.55 \\
\hline II & 4.18 & 1.99 & 1.25 & 3.99 & 2.43 & 1.08 & 2.64 & 1.12 & 0.76 & 0.23 \\
\hline Ap & 0.00 & 0.02 & 0.05 & 0.00 & 0.00 & 0.07 & 0.05 & 0.02 & 0.09 & 0.02 \\
\hline TOTAL & 102.46 & 99.21 & 101.92 & 101.62 & 99.15 & 99.46 & 99.26 & 99.30 & 99.11 & 99.46 \\
\hline
\end{tabular}




\begin{tabular}{|c|c|c|c|c|c|c|c|c|c|c|}
\hline $\begin{array}{l}\text { Sample } \\
\text { Type }\end{array}$ & $\begin{array}{l}\text { PK4Q } \\
\text { Pyxite }\end{array}$ & $\begin{array}{c}\text { PK4R } \\
\text { Gran } \\
\end{array}$ & $\begin{array}{l}\text { PK4S } \\
\text { Pyxite } \\
\end{array}$ & $\begin{array}{l}\text { PK4T } \\
\text { Pyxite }\end{array}$ & $\begin{array}{l}\text { PK4U } \\
\text { Perid } \\
\end{array}$ & $\begin{array}{l}\text { PK4V } \\
\text { Gran }\end{array}$ & $\begin{array}{c}\text { PK4W } \\
\text { Perid }\end{array}$ & $\begin{array}{l}\text { PK4X } \\
\text { Gran }\end{array}$ & $\begin{array}{l}\text { PK4Y } \\
\text { Gran }\end{array}$ & $\begin{array}{l}\text { PK4Z } \\
\text { Perid } \\
\end{array}$ \\
\hline $\mathrm{SiO}_{2}$ & 47.93 & 46.13 & 48.37 & 47.60 & 40.22 & 49.08 & 43.81 & 51.55 & 51.93 & 44.12 \\
\hline $\mathrm{TiO}_{2}$ & 1.40 & 1.31 & 1.00 & 1.38 & 0.05 & 1.58 & 0.02 & 0.34 & 0.44 & 0.03 \\
\hline $\mathrm{Al} 2 \mathrm{O} 3$ & 8.22 & 7.58 & 6.26 & 7.53 & 0.52 & 22.65 & 1.00 & 18.72 & 19,62 & 1.15 \\
\hline $\mathrm{Fe} 2 \mathrm{O} 3$ total & 12.22 & 14.12 & 14.10 & 11.65 & 13.74 & 5.43 & 8.76 & 6.60 & 6.15 & 8.44 \\
\hline $\mathrm{MnO}$ & 0.21 & 0.23 & 0.23 & 0.21 & 0.17 & 0.06 & 0.12 & 0.11 & 0.10 & 0.12 \\
\hline $\mathrm{MgO}$ & 14.86 & 16.14 & 17.68 & 14.29 & 45.51 & 3.77 & 46.12 & 9.11 & 8.44 & 44.11 \\
\hline $\mathrm{CaO}$ & 14.46 & 13.36 & 11.51 & 16.12 & 0.56 & 13.30 & 0.68 & 9.48 & 9.59 & 0.91 \\
\hline $\mathrm{Na} 2 \mathrm{O}$ & 1.16 & 1.63 & 1.03 & 1.06 & 0.40 & 3.86 & 0.29 & 3.37 & 3.37 & 0.58 \\
\hline $\mathrm{K} 2 \mathrm{O}$ & 0.02 & 0.08 & 0.04 & 0.01 & 0.02 & 0.23 & 0.01 & 0.22 & 0.26 & 0.05 \\
\hline $\mathrm{P} 2 \mathrm{O} 5$ & 0.01 & 0.01 & 0.00 & 0.00 & 0.02 & 0.02 & 0.01 & 0.00 & 0.01 & 0.01 \\
\hline LOI & -0.25 & -0.55 & -0.37 & -0.10 & -0.89 & 0.15 & -0.41 & -0.11 & -0.08 & -0.41 \\
\hline TOTAL & 100.24 & 100.04 & 99.85 & 99.75 & 100.32 & 100.13 & 100.41 & 99.39 & 99.83 & 99.11 \\
\hline Mg\# & 70.66 & 69.36 & 71.29 & 70.84 & 86.77 & 57.89 & 91.25 & 73.22 & 73.10 & 91.19 \\
\hline
\end{tabular}

\begin{tabular}{|c|c|c|c|c|c|c|c|c|c|c|}
\hline $\mathrm{Sc}$ & 48 & 40 & 51 & 59 & 6 & 19 & 5 & 16 & 18 & 6 \\
\hline V & 396 & 259 & 366 & 439 & 29 & 155 & 30 & 110 & 115 & 32 \\
\hline $\mathrm{Cr}$ & 1084 & 1940 & 732 & 545 & 658 & 28 & 2332 & 265 & 233 & 2491 \\
\hline $\mathrm{Ni}$ & 294 & 414 & 487 & 226 & 2779 & 32 & 2681 & 132 & 122 & 2598 \\
\hline $\mathrm{Cu}$ & 44 & 66 & 163 & 44 & 25 & 38 & $<1$ & 18 & 15 & $<1$ \\
\hline $\mathrm{Zn}$ & 56 & 73 & 81 & 61 & 91 & 22 & 51 & 40 & 36 & 50 \\
\hline $\mathrm{Ga}$ & 13 & 10 & 11 & 15 & 2 & 20 & 2 & 16 & 15 & 2 \\
\hline As & $<1$ & $<1$ & $<1$ & $<1$ & $<1$ & $<1$ & $<1$ & $<1$ & $<1$ & $<1$ \\
\hline $\mathrm{Rb}$ & $<1$ & $<1$ & 1 & $<1$ & $<1$ & 2 & $<1$ & 1 & 1 & 1 \\
\hline $\mathrm{Sr}$ & 38 & 164 & 23 & 39 & 3 & 1065 & 2 & 589 & 635 & 2 \\
\hline $\mathbf{Y}$ & 12 & 17 & 12 & 20 & $<1$ & 3 & $<1$ & $<1$ & 1 & $<1$ \\
\hline $\mathrm{Zr}_{\mathbf{r}}$ & 11 & 59 & 23 & 32 & $<1$ & 38 & 1 & 16 & 20 & $<1$ \\
\hline $\mathrm{Nb}$ & $<1$ & 2 & 1 & $<1$ & $<1$ & 1 & 1 & $<1$ & $<1$ & 1 \\
\hline $\mathrm{Ba}$ & 6 & 23 & 1 & $<1$ & 1 & 129 & 6 & 109 & 136 & 4 \\
\hline La & 3 & 6 & 3 & 5 & 3 & 3 & $<1$ & 1 & 1 & 1 \\
\hline $\mathrm{Ce}$ & 12 & 18 & 12 & 12 & 8 & 9 & $<1$ & 7 & 6 & $<1$ \\
\hline $\mathrm{Pb}$ & 4 & 3 & 5 & 5 & 3 & 5 & 2 & 2 & 5 & 4 \\
\hline Th & 1 & $<1$ & 2 & $<1$ & $<1$ & $<1$ & $<1$ & $<1$ & $<1$ & 1 \\
\hline U & $<1$ & 1 & $<1$ & $<1$ & 1 & $<1$ & $<1$ & $<1$ & 1 & 1 \\
\hline$Q$ & 0.00 & 0.00 & 0.00 & 0.00 & 0.00 & 0.00 & 0.00 & 0.00 & 0.00 & 0.00 \\
\hline Or & 0.12 & 0.47 & 0.24 & 0.06 & 0.12 & 1.36 & 0.06 & 1.30 & 1.54 & 0.30 \\
\hline $\mathrm{Ab}$ & 9.82 & 8.28 & 8.72 & 8.89 & 0.12 & 23.63 & 2.45 & 28.52 & 28.52 & 4.91 \\
\hline An & 17.16 & 13.13 & 12.34 & 15.76 & 0.00 & 43.80 & 1.40 & 35.30 & 37.64 & 0.39 \\
\hline $\mathrm{Ne}$ & 0.00 & 2.99 & 0.00 & 0.05 & 1.33 & 4.89 & 0.00 & 0.00 & 0.00 & 0.00 \\
\hline $\mathrm{Di}$ & 43.86 & 42.82 & 36.04 & 51.66 & 2.10 & 17.83 & 1.51 & 9.43 & 7.93 & 3.20 \\
\hline $\mathrm{Hy}$ & 5.79 & 0.00 & 18.42 & 0.00 & 0.00 & 0.00 & 12.88 & 11.82 & 13.59 & 12.12 \\
\hline Ol & 17.87 & 26.72 & 18.89 & 17.79 & 93.48 & 3.78 & 80.29 & 10.76 & 8.23 & 76.33 \\
\hline Mt & 2.11 & 2.43 & 2.43 & 2.01 & 2.01 & 1.18 & 1.51 & 1.14 & 1.06 & 1.46 \\
\hline II & 2.66 & 2.49 & 1.90 & 2.62 & 0.09 & 3.00 & 0.04 & 0.65 & 0.84 & 0.06 \\
\hline Ap & 0.02 & 0.02 & 0.00 & 0.00 & 0.05 & 0.05 & 0.02 & 0.00 & 0.02 & 0.02 \\
\hline TOTAL & 99.41 & 99.35 & 98.98 & 98.84 & 99.30 & 99.52 & 100.16 & 98.92 & 99.37 & 98.79 \\
\hline
\end{tabular}




\begin{tabular}{|c|c|c|c|c|c|c|c|c|c|c|}
\hline $\begin{array}{l}\text { Sample } \\
\text { Type }\end{array}$ & $\begin{array}{c}\text { PK4A1 } \\
\text { Perid }\end{array}$ & $\begin{array}{c}\text { PK4C1 } \\
\text { Gran }\end{array}$ & $\begin{array}{c}\text { PK4D1 } \\
\text { Pyxite }\end{array}$ & $\begin{array}{c}\text { PK4E1 } \\
\text { Perid } \\
\end{array}$ & $\begin{array}{c}\text { PK4F1 } \\
\text { Perid } \\
\end{array}$ & $\begin{array}{c}\text { PK4G1 } \\
\text { Perid }\end{array}$ & $\begin{array}{c}\text { PK4H1 } \\
\text { Perid } \\
\end{array}$ & $\begin{array}{l}\text { PK4H1b } \\
\text { Perid }\end{array}$ & $\begin{array}{c}\text { PK4HIc } \\
\text { Perid }\end{array}$ & $\begin{array}{l}\text { PK4I1 } \\
\text { Perid }\end{array}$ \\
\hline $\mathrm{SiO}_{2}$ & 39.45 & 49.68 & 49.57 & 44.20 & 44.48 & 43.93 & 40.34 & 49.35 & 45.09 & 44.83 \\
\hline $\mathrm{TiO} 2$ & 0.04 & 0.81 & 0.59 & 0.03 & 0.08 & 0.03 & 0.03 & 0.18 & 0.12 & 0.11 \\
\hline $\mathrm{Al} 2 \mathrm{O} 3$ & 0.28 & 12.64 & 5.93 & 0.91 & 3.22 & 1.59 & 0.73 & 4.86 & 3.45 & 3.37 \\
\hline $\mathrm{Fe} 2 \mathrm{O} 3$ total & 15.69 & 10.43 & 17.92 & 8.46 & 9.11 & 9.00 & 10.94 & 7.23 & 9.13 & 9.18 \\
\hline $\mathrm{MnO}$ & 0.18 & 0.17 & 0.26 & 0.13 & 0.14 & 0.13 & 0.14 & 0.13 & 0.14 & 0.14 \\
\hline $\mathrm{MgO}$ & 43.96 & 13.10 & 22.37 & 45.47 & 39.38 & 44.66 & 47.88 & 31.57 & 39.10 & 39.28 \\
\hline $\mathrm{CaO}$ & 0.38 & 11.15 & 3.52 & 0.69 & 2.74 & 0.78 & 0.56 & 5.97 & 2.90 & 2.93 \\
\hline $\mathrm{Na} 2 \mathrm{O}$ & 0.55 & 2.11 & 0.50 & 0.25 & 0.61 & 0.23 & 0.14 & 0.65 & 0.41 & 0.44 \\
\hline $\mathrm{K} 2 \mathrm{O}$ & 0.04 & 0.13 & 0.02 & 0.01 & 0.03 & 0.00 & 0.00 & 0.00 & 0.01 & 0.00 \\
\hline $\mathrm{P} 2 \mathrm{O} 5$ & 0.02 & 0.00 & 0.01 & 0.01 & 0.01 & 0.01 & 0.01 & 0.00 & 0.01 & 0.01 \\
\hline LOI & -1.05 & -0.13 & -0.59 & -0.31 & -0.45 & -0.51 & -0.55 & -0.15 & -0.34 & -0.53 \\
\hline TOTAL & 99.54 & 100.09 & 100.10 & 99.85 & 99.35 & 99.85 & 100.22 & 99.79 & 100.02 & 99.76 \\
\hline Mg\# & 84.73 & 71.33 & 71.20 & 91.41 & 89.54 & 90.76 & 89.66 & 89.63 & 89.45 & 89.44 \\
\hline
\end{tabular}

\begin{tabular}{|c|c|c|c|c|c|c|c|c|c|c|}
\hline $\mathrm{Sc}$ & 3 & 33 & 30 & 8 & 10 & 6 & 3 & 25 & 13 & 10 \\
\hline V & 19 & 251 & 265 & 33 & 71 & 42 & 18 & 126 & 78 & 72 \\
\hline $\mathrm{Cr}$ & 219 & 448 & 435 & 2681 & 2911 & 2347 & 1633 & 4564 & 2750 & 2750 \\
\hline $\mathrm{Ni}$ & 2495 & 222 & 415 & 2594 & 2154 & 2342 & 2892 & 1414 & 2053 & 2064 \\
\hline $\mathrm{Cu}$ & 62 & 36 & 106 & 1 & 17 & 2 & 1 & 55 & 20 & 15 \\
\hline $\mathrm{Zn}$ & 103 & 57 & 118 & 49 & 55 & 51 & 60 & 44 & 56 & 55 \\
\hline $\mathrm{Ga}$ & 2 & 15 & 13 & 2 & 3 & 2 & 1 & 5 & 3 & 4 \\
\hline As & $<1$ & $<1$ & $<1$ & $<1$ & $<1$ & $<1$ & $<1$ & $<1$ & $<1$ & $<1$ \\
\hline $\mathrm{Rb}$ & 1 & 2 & 1 & $<1$ & $<1$ & $<1$ & $<1$ & $<1$ & $<1$ & $<1$ \\
\hline $\mathrm{Sr}$ & 3 & 302 & 8 & 3 & 1 & 2 & 3 & 22 & 10 & 4 \\
\hline Y & $<1$ & 9 & 2 & $<1$ & $<1$ & $<1$ & $<1$ & 3 & $<1$ & $<1$ \\
\hline $\mathrm{Zr}$ & 1 & 22 & 5 & $<1$ & $<1$ & $<1$ & $<1$ & 6 & 6 & 1 \\
\hline $\mathrm{Nb}$ & 1 & $<1$ & 1 & $<1$ & $<1$ & 1 & $<1$ & 1 & 1 & 1 \\
\hline $\mathrm{Ba}$ & 4 & 65 & $<1$ & 7 & 4 & 4 & $<1$ & 1 & $<1$ & 2 \\
\hline La & 3 & 3 & 4 & $<1$ & $<1$ & 1 & $<1$ & 2 & 1 & 2 \\
\hline $\mathrm{Ce}$ & 11 & 11 & 13 & 1 & $<1$ & $<1$ & 3 & 3 & $<1$ & 1 \\
\hline $\mathrm{Pb}$ & 4 & 2 & 4 & 2 & 2 & 5 & 5 & 2 & 3 & 4 \\
\hline Th & 1 & $<1$ & $<1$ & 1 & $<1$ & 1 & $<1$ & 1 & 1 & $<1$ \\
\hline U & 1 & 2 & $<1$ & $<1$ & $<1$ & $<1$ & 1 & 1 & 1 & $<1$ \\
\hline$Q$ & 0.00 & 0.00 & 0.00 & 0.00 & 0.00 & 0.00 & 0.00 & 0.00 & 0.00 & 0.00 \\
\hline Or & 0.00 & 0.77 & 0.12 & 0.06 & 0.18 & 0.00 & 0.00 & 0.00 & 0.06 & 0.00 \\
\hline $\mathrm{Ab}$ & 0.00 & 17.85 & 4.23 & 2.12 & 5.16 & 1.95 & 0.00 & 5.50 & 3.47 & 3.72 \\
\hline An & 0.00 & 24.64 & 13.88 & 1.33 & 5.96 & 3.31 & 1.36 & 10.34 & 7.54 & 7.22 \\
\hline $\mathrm{Ne}$ & 0.66 & 0.00 & 0.00 & 0.00 & 0.00 & 0.00 & 0.64 & 0.00 & 0.00 & 0.00 \\
\hline $\mathrm{Di}$ & 3.03 & 24.69 & 2.84 & 1.60 & 5.97 & 0.40 & 1.06 & 15.20 & 5.35 & 5.72 \\
\hline $\mathrm{Hy}$ & 0.00 & 12.81 & 62.44 & 16.83 & 12.33 & 16.73 & 0.00 & 31.24 & 17.97 & 16.04 \\
\hline Ol & 93.58 & 15.19 & 11.37 & 75.94 & 67.65 & 75.57 & 94.85 & 35.43 & 63.35 & 64.97 \\
\hline Mt & 1.89 & 1.80 & 3.09 & 1.46 & 1.57 & 1.55 & 1.89 & 1.25 & 1.57 & 1.58 \\
\hline Il & 0.08 & 1.54 & 1.12 & 0.06 & 0.15 & 0.06 & 0.06 & 0.34 & 0.23 & 0.21 \\
\hline Ap & 0.05 & 0.00 & 0.02 & 0.02 & 0.02 & 0.02 & 0.02 & 0.00 & 0.02 & 0.02 \\
\hline TOTAL & 99.29 & 99.29 & 99.11 & 99.42 & 98.99 & 99.59 & 99.88 & 99.30 & 99.56 & 99.48 \\
\hline
\end{tabular}




\begin{tabular}{|c|c|c|c|c|c|c|c|c|c|c|}
\hline $\begin{array}{l}\text { Sample } \\
\text { Type }\end{array}$ & $\begin{array}{l}\text { PK4J1 } \\
\text { Perid }\end{array}$ & $\begin{array}{c}\text { PK4K1 } \\
\text { Perid }\end{array}$ & $\begin{array}{c}\text { PK4L1 } \\
\text { Gran }\end{array}$ & $\begin{array}{c}\text { PK4M1 } \\
\text { Perid }\end{array}$ & $\begin{array}{c}\text { PK4N1a } \\
\text { Perid }\end{array}$ & $\begin{array}{c}\text { PK4N1f } \\
\text { Perid }\end{array}$ & $\begin{array}{l}\text { PK4O1 } \\
\text { Pyxite }\end{array}$ & $\begin{array}{c}\text { PK4P1 } \\
\text { Perid }\end{array}$ & $\begin{array}{l}\text { PK5A } \\
\text { Perid }\end{array}$ & $\begin{array}{l}\text { PK5B } \\
\text { Perid }\end{array}$ \\
\hline $\mathrm{SiO}_{2}$ & 43.69 & 44.51 & 49.08 & 43.87 & 49.08 & 44.97 & 48.02 & 44.59 & 46.07 & 46.34 \\
\hline $\mathrm{TiO}_{2}$ & 0.07 & 0.11 & 0.90 & 0.12 & 0.48 & 0.11 & 1.12 & 0.15 & 0.08 & 0.20 \\
\hline $\mathrm{Al} 2 \mathrm{O} 3$ & 2.33 & 3.40 & 11.59 & 3.64 & 6.31 & 3.23 & 8.37 & 4.07 & 1.87 & 3.61 \\
\hline $\mathrm{Fe} 2 \mathrm{O} 3$ total & 9.62 & 9.12 & 10.66 & 9.28 & 5.11 & 9.41 & 10.95 & 8.85 & 7.45 & 8.93 \\
\hline $\mathrm{MnO}$ & 0.14 & 0.15 & 0.18 & 0.14 & 0.12 & 0.14 & 0.20 & 0.14 & 0.12 & 0.14 \\
\hline $\mathrm{MgO}$ & 42.12 & 39.62 & 13.14 & 38.58 & 21.51 & 38.12 & 14.43 & 38.73 & 39.57 & 36.08 \\
\hline $\mathrm{CaO}$ & 1.58 & 3.30 & 11.77 & 3.48 & 15.07 & 2.75 & 15.29 & 3.17 & 4.40 & 4.46 \\
\hline $\mathrm{Na} 2 \mathrm{O}$ & 0.35 & 0.48 & 1.90 & 0.31 & 1.28 & 0.40 & 1.44 & 0.47 & 0.36 & 0.36 \\
\hline $\mathrm{K} 2 \mathrm{O}$ & 0.01 & 0.01 & 0.13 & 0.02 & 0.04 & 0.04 & 0.05 & 0.02 & 0.01 & 0.04 \\
\hline P2O5 & 0.01 & 0.01 & 0.00 & 0.00 & 0.00 & 0.00 & 0.00 & 0.01 & 0.00 & 0.01 \\
\hline LOI & -0.47 & -0.40 & -0.15 & 0.26 & 0.85 & 0.04 & 0.33 & -0.43 & -0.24 & 0.05 \\
\hline TOTAL & 99.45 & 100.31 & 99.20 & 99.70 & 99.85 & 99.21 & 100.20 & 99.77 & 99.69 & 100.22 \\
\hline Mg\# & 89.66 & 89.59 & 70.94 & 89.17 & 89.29 & 88.92 & 72.30 & 89.66 & 91.32 & 88.89 \\
\hline
\end{tabular}

\begin{tabular}{|c|c|c|c|c|c|c|c|c|c|c|}
\hline $\mathrm{Sc}$ & 7 & 14 & 38 & 14 & 43 & 13 & 61 & 14 & 14 & 18 \\
\hline V & 56 & 84 & 273 & 78 & 204 & 74 & 343 & 79 & 72 & 85 \\
\hline $\mathrm{Cr}$ & 2372 & 2915 & 387 & 2877 & 4604 & 2741 & 824 & 3165 & 3455 & 2554 \\
\hline $\mathrm{Ni}$ & 2291 & 2188 & 194 & 2278 & 1422 & 2229 & 197 & 2174 & 2358 & 2139 \\
\hline $\mathrm{Cu}$ & 2 & 41 & 40 & 41 & 158 & 42 & 32 & 35 & 80 & 35 \\
\hline $\mathrm{Zn}$ & 54 & 56 & 58 & 58 & 30 & 55 & 54 & 58 & 42 & 51 \\
\hline $\mathrm{Ga}$ & 4 & 4 & 16 & 3 & 6 & 4 & 13 & 5 & 2 & 4 \\
\hline As & $<1$ & $<1$ & $<1$ & $<1$ & $<1$ & $<1$ & $<1$ & $<1$ & $<1$ & $<1$ \\
\hline $\mathbf{R b}$ & $<1$ & 1 & $<1$ & $<1$ & 1 & $<1$ & 1 & $<1$ & $<1$ & 1 \\
\hline Sr & 4 & 5 & 259 & 5 & 33 & 6 & 98 & 4 & 7 & 31 \\
\hline$Y$ & $<1$ & $<1$ & 10 & 1 & 11 & $<1$ & 17 & $<1$ & $<1$ & 2 \\
\hline $\mathrm{Zr}$ & 1 & 1 & 26 & 2 & 15 & 1 & 26 & 1 & $<1$ & 9 \\
\hline $\mathrm{Nb}$ & 1 & $<1$ & $<1$ & $<1$ & $<1$ & $<1$ & 1 & $<1$ & $<1$ & 2 \\
\hline $\mathrm{Ba}$ & 5 & 4 & 59 & 1 & 5 & 4 & 6 & 6 & 3 & $<1$ \\
\hline $\mathrm{La}$ & $<1$ & $<1$ & 3 & 1 & 2 & 2 & 2 & 1 & $<1$ & 2 \\
\hline $\mathrm{Ce}$ & $<1$ & 1 & 8 & 4 & 3 & $<1$ & 10 & $<1$ & 2 & 4 \\
\hline $\mathrm{Pb}$ & 3 & 2 & 2 & 3 & 4 & 1 & 4 & 3 & 3 & 3 \\
\hline Th & $<1$ & $<1$ & $<1$ & $<1$ & $<1$ & $<1$ & $<1$ & 1 & $<1$ & $<1$ \\
\hline $\mathrm{U}$ & 1 & 1 & $<1$ & $<1$ & 1 & 1 & $<1$ & 1 & $<1$ & $<1$ \\
\hline Q & 0.00 & 0.00 & 0.00 & 0.00 & 0.00 & 0.00 & 0.00 & 0.00 & 0.00 & 0.00 \\
\hline Or & 0.06 & 0.06 & 0.77 & 0.12 & 0.24 & 0.24 & 0.30 & 0.12 & 0.06 & 0.24 \\
\hline $\mathbf{A b}$ & 2.96 & 4.06 & 16.08 & 2.62 & 7.66 & 3.38 & 10.70 & 3.98 & 3.05 & 3.05 \\
\hline An & 4.76 & 7.09 & 22.71 & 8.48 & 11.35 & 6.90 & 16.23 & 8.94 & 3.46 & 8.12 \\
\hline $\mathrm{Ne}$ & 0.00 & 0.00 & 0.00 & 0.00 & 1.72 & 0.00 & 0.80 & 0.00 & 0.00 & 0.00 \\
\hline Di & 2.38 & 7.27 & 28.73 & 6.93 & 49.96 & 5.33 & 47.91 & 5.31 & 14.45 & 11.00 \\
\hline $\mathrm{Hy}$ & 14.35 & 13.76 & 11.96 & 13.21 & 0.00 & 20.58 & 0.00 & 14.18 & 15.97 & 22.12 \\
\hline Ol & 72.76 & 64.87 & 14.62 & 65.44 & 25.84 & 60.08 & 18.96 & 65.08 & 60.86 & 52.93 \\
\hline Mt & 1.66 & 1.57 & 1.84 & 1.60 & 0.88 & 1.62 & 1.89 & 1.53 & 1.29 & 1.54 \\
\hline Il & 0.13 & 0.21 & 1.71 & 0.23 & 0.91 & 0.21 & 2.13 & 0.28 & 0.15 & 0.38 \\
\hline Ap & 0.02 & 0.02 & 0.00 & 0.00 & 0.00 & 0.00 & 0.00 & 0.02 & 0.00 & 0.02 \\
\hline TOTAL & 99.08 & 98.91 & 98.42 & 98.63 & 98.56 & 98.34 & 98.92 & 99.44 & 99.29 & 99.40 \\
\hline
\end{tabular}




\begin{tabular}{|c|c|c|c|c|c|c|c|c|c|c|}
\hline $\begin{array}{l}\text { Sample } \\
\text { Type }\end{array}$ & $\begin{array}{l}\text { PK5C } \\
\text { Perid } \\
\end{array}$ & $\begin{array}{l}\text { PK5D } \\
\text { Perid } \\
\end{array}$ & $\begin{array}{l}\text { PK5E } \\
\text { Pyxite }\end{array}$ & $\begin{array}{l}\text { PK5F } \\
\text { Pyxite } \\
\end{array}$ & $\begin{array}{l}\text { PK5G } \\
\text { Pyxite } \\
\end{array}$ & $\begin{array}{l}\text { PK5H } \\
\text { Perid } \\
\end{array}$ & $\begin{array}{l}\text { PK5I } \\
\text { Perid } \\
\end{array}$ & $\begin{array}{l}\text { PK5J } \\
\text { Perid } \\
\end{array}$ & $\begin{array}{l}\text { PK5L } \\
\text { Pyxite }\end{array}$ & $\begin{array}{l}\text { PK5M } \\
\text { Perid } \\
\end{array}$ \\
\hline $\mathrm{SiO} 2$ & 42.25 & 45.24 & 49.96 & 53.02 & 49.65 & 45.72 & 44.27 & 45.23 & 53.17 & 43.78 \\
\hline $\mathrm{TiO} 2$ & 0.04 & 0.17 & 0.58 & 0.26 & 0.86 & 0.10 & 0.03 & 0.09 & 0.27 & 0.02 \\
\hline $\mathrm{Al} 2 \mathrm{O} 3$ & 0.84 & 2.41 & 5.95 & 4.49 & 6.35 & 3.43 & 2.09 & 3.16 & 4.63 & 0.85 \\
\hline $\mathrm{Fe} 2 \mathrm{O} 3$ total & 9.27 & 10.58 & 17.19 & 10.81 & 10.13 & 8.81 & 8.31 & 9.00 & 10.92 & 8.63 \\
\hline $\mathrm{MnO}$ & 0.13 & 0.15 & 0.23 & 0.18 & 0.19 & 0.14 & 0.13 & 0.14 & 0.19 & 0.13 \\
\hline $\mathrm{MgO}$ & 46.45 & 39.94 & 24.09 & 28.57 & 17.76 & 37.75 & 43.54 & 39.26 & 28.86 & 45.98 \\
\hline $\mathrm{CaO}$ & 0.39 & 1.92 & 2.05 & 1.92 & 14.07 & 3.15 & 1.09 & 2.56 & 1.96 & 0.64 \\
\hline $\mathrm{Na} 2 \mathrm{O}$ & 0.23 & 0.33 & 0.35 & 0.22 & 0.87 & 0.39 & 0.35 & 0.48 & 0.24 & 0.57 \\
\hline $\mathrm{K} 2 \mathrm{O}$ & 0.01 & 0.01 & 0.02 & 0.00 & 0.03 & 0.01 & 0.01 & 0.01 & 0.00 & 0.03 \\
\hline $\mathrm{P} 2 \mathrm{O} 5$ & 0.01 & 0.01 & 0.02 & 0.01 & 0.00 & 0.00 & 0.01 & 0.00 & 0.01 & 0.02 \\
\hline LOI & -0.31 & -0.43 & -0.55 & -0.14 & 0.10 & -0.24 & -0.25 & -0.15 & -0.38 & -0.37 \\
\hline TOTAL & 99.31 & 100.33 & 99.89 & 99.34 & 100.01 & 99.26 & 99.58 & 99.78 & 99.87 & 100.28 \\
\hline $\mathrm{Mg} \#$ & 90.85 & 88.20 & 73.51 & 83.96 & 77.64 & 89.46 & 91.21 & 89.63 & 83.96 & 91.34 \\
\hline $\mathrm{Sc}$ & 10 & 1 & 26 & 24 & 51 & 17 & 6 & 14 & 4 & 4 \\
\hline V & 83 & 26 & 227 & 148 & 313 & 91 & 38 & 76 & 30 & 32 \\
\hline $\mathrm{Cr}$ & 2432 & 1660 & 1636 & 3280 & 1746 & 2935 & 2547 & 2827 & 2977 & 2620 \\
\hline $\mathrm{Ni}$ & 2085 & 2542 & 555 & 996 & 484 & 2053 & 2548 & 2117 & 2658 & 2637 \\
\hline $\mathrm{Cu}$ & 18 & 2 & 49 & 68 & 68 & 36 & $<1$ & 12 & $<1$ & 1 \\
\hline $\mathrm{Zn}$ & 67 & 50 & 98 & 71 & 58 & 54 & 50 & 53 & 53 & 52 \\
\hline Ga & 3 & 1 & 9 & 8 & 10 & 4 & 3 & 4 & 1 & 2 \\
\hline As & $<1$ & $<1$ & $<1$ & $<1$ & $<1$ & $<1$ & $<1$ & $<1$ & $<1$ & $<1$ \\
\hline $\mathrm{Rb}$ & 1 & $<1$ & 1 & 1 & 1 & 1 & 1 & 1 & $<1$ & $<1$ \\
\hline $\mathrm{Sr}$ & 7 & 2 & 6 & 3 & 35 & 2 & 2 & 2 & 2 & 2 \\
\hline$Y$ & $<1$ & $<1$ & $<1$ & $<1$ & 11 & $<1$ & $<1$ & $<1$ & $<1$ & $<1$ \\
\hline $\mathrm{Zr}$ & 1 & $<1$ & $<1$ & $<1$ & 20 & $<1$ & 2 & $<1$ & 1 & $<1$ \\
\hline $\mathrm{Nb}$ & 1 & $<1$ & $<1$ & $<1$ & $<1$ & 1 & 1 & $<1$ & $<1$ & $<1$ \\
\hline $\mathrm{Ba}$ & 5 & 1 & 4 & 7 & 7 & 6 & 7 & 4 & 4 & 7 \\
\hline $\mathrm{La}$ & $<1$ & $<1$ & 4 & $<1$ & 1 & 1 & 1 & 1 & $<1$ & 1 \\
\hline $\mathrm{Ce}$ & $<1$ & 3 & 8 & $<1$ & 8 & 1 & 1 & 1 & $<1$ & 2 \\
\hline $\mathrm{Pb}$ & 3 & 5 & 3 & 3 & 4 & 4 & 2 & 4 & 4 & 3 \\
\hline Th & $<1$ & 1 & $<1$ & $<1$ & $<1$ & $<1$ & $<1$ & $<1$ & $<1$ & $<1$ \\
\hline $\mathrm{U}$ & $<1$ & 1 & $<1$ & 1 & $<1$ & 1 & 1 & 1 & 1 & 1 \\
\hline$Q$ & 0.00 & 0.00 & 0.00 & 0.00 & 0.00 & 0.00 & 0.00 & 0.00 & 0.00 & 0.00 \\
\hline Or & 0.06 & 0.06 & 0.12 & 0.00 & 0.18 & 0.06 & 0.06 & 0.06 & 0.00 & 0.18 \\
\hline$A b$ & 1.95 & 2.79 & 2.96 & 1.86 & 7.36 & 3.30 & 2.96 & 4.06 & 2.03 & 4.21 \\
\hline An & 1.23 & 5.07 & 10.04 & 9.46 & 13.33 & 7.58 & 4.10 & 6.44 & 9.66 & 0.00 \\
\hline $\mathrm{Ne}$ & 0.00 & 0.00 & 0.00 & 0.00 & 0.00 & 0.00 & 0.00 & 0.00 & 0.00 & 0.00 \\
\hline $\mathrm{Di}$ & 0.50 & 2.48 & 8.07 & 7.51 & 45.10 & 6.35 & 0.97 & 4.93 & 7.67 & 2.40 \\
\hline $\mathrm{Hy}$ & 8.93 & 22.84 & 61.20 & 69.57 & 15.15 & 22.84 & 16.95 & 18.94 & 68.30 & 8.49 \\
\hline Ol & 84.44 & 63.43 & 12.77 & 8.99 & 14.52 & 56.89 & 72.54 & 62.98 & 10.47 & 82.78 \\
\hline Mt & 1.60 & 1.82 & 2.96 & 1.86 & 1.75 & 1.52 & 1.43 & 1.55 & 1.88 & 1.22 \\
\hline II & 0.08 & 0.32 & 1.10 & 0.49 & 1.63 & 0.19 & 0.06 & 0.17 & 0.51 & 0.04 \\
\hline Ap & 0.02 & 0.02 & 0.05 & 0.02 & 0.00 & 0.00 & 0.02 & 0.00 & 0.02 & 0.05 \\
\hline TOTAL & 98.81 & 98.83 & 99.27 & 99.76 & 99.02 & 98.73 & 99.09 & 99.13 & 100.54 & 99.37 \\
\hline
\end{tabular}


A4.3 Mount Murphy xenolith analyses

\begin{tabular}{|c|c|c|c|c|c|c|c|c|c|c|}
\hline $\begin{array}{l}\text { Sample } \\
\text { Type }\end{array}$ & $\begin{array}{c}90041 \mathrm{~A} \\
\text { Gran }\end{array}$ & $\begin{array}{c}90041 B \\
\text { Gran }\end{array}$ & $\begin{array}{c}90041 C \\
\text { Gran }\end{array}$ & $\begin{array}{c}\text { 90041D } \\
\text { Gran }\end{array}$ & $\begin{array}{c}\text { 90041F } \\
\text { Gran }\end{array}$ & $\begin{array}{c}90041 \mathrm{H} \\
\text { Gran }\end{array}$ & $\begin{array}{c}90041 I \\
\text { Gran }\end{array}$ & $\begin{array}{c}90041 J \\
\text { Gran }\end{array}$ & $\begin{array}{l}\text { 90044A } \\
\text { Pyxite }\end{array}$ & $\begin{array}{c}90048 \mathrm{~A} \\
\text { Pyxite }\end{array}$ \\
\hline $\mathrm{SiO}_{2}$ & 48.79 & 47.34 & 48.07 & 45.58 & 46.00 & 49.65 & 45.03 & 45.08 & 50.91 & 44.56 \\
\hline $\mathrm{TiO}_{2}$ & 0.30 & 0.23 & 0.34 & 0.25 & 0.27 & 0.58 & 0.13 & 0.12 & 0.59 & 0.72 \\
\hline $\mathrm{Al} 2 \mathrm{O} 3$ & 22.14 & 18.16 & 23.70 & 17.07 & 24.88 & 20.89 & 20.77 & 20.85 & 6.47 & 7.88 \\
\hline $\mathrm{Fe} 2 \mathrm{O} 3$ total & 3.89 & 8.14 & 3.01 & 7.78 & 5.06 & 4.50 & 6.72 & 6.71 & 7.29 & 14.65 \\
\hline $\mathrm{MnO}$ & 0.06 & 0.12 & 0.06 & 0.11 & 0.07 & 0.08 & 0.09 & 0.09 & 0.15 & 0.20 \\
\hline $\mathrm{MgO}$ & 6.28 & 12.26 & 5.53 & 15.19 & 8.58 & 5.66 & 14.43 & 14.48 & 19.41 & 20.29 \\
\hline $\mathrm{CaO}$ & 15.98 & 10.86 & 16.25 & 12.11 & 12.58 & 15.42 & 11.03 & 11.05 & 14.36 & 10.55 \\
\hline $\mathrm{Na} 2 \mathrm{O}$ & 2.58 & 2.84 & 2.27 & 1.57 & 2.08 & 2.93 & 1.75 & 1.77 & 1.03 & 1.37 \\
\hline $\mathrm{K} 2 \mathrm{O}$ & 0.10 & 0.17 & 0.18 & 0.06 & 0.19 & 0.16 & 0.06 & 0.06 & 0.02 & 0.06 \\
\hline $\mathrm{P} 2 \mathrm{O} 5$ & 0.00 & 0.01 & 0.01 & 0.00 & 0.01 & 0.00 & 0.00 & 0.00 & 0.00 & 0.01 \\
\hline LOI & 0.17 & 0.20 & 0.22 & 0.25 & 0.43 & 0.47 & 0.08 & -0.19 & 0.06 & -0.73 \\
\hline TOTAL & 100.29 & 100.33 & 99.64 & 99.97 & 100.15 & 100.34 & 100.09 & 100.02 & 100.29 & 99.56 \\
\hline Mg\# & 76.17 & 74.89 & 78.44 & 79.45 & 77.05 & 71.35 & 80.96 & 81.04 & 84.06 & 73.28 \\
\hline Sc & 26 & 14 & 24 & 18 & 10 & 27 & 7 & 6 & 43 & 27 \\
\hline V & 85 & 57 & 69 & 70 & 36 & 142 & 31 & 21 & 238 & 170 \\
\hline $\mathrm{Cr}$ & 462 & 220 & 72 & 914 & 126 & 287 & 460 & 445 & 2022 & 1755 \\
\hline $\mathrm{Ni}$ & 72 & 239 & 31 & 248 & 168 & 38 & 331 & 282 & 624 & 585 \\
\hline $\mathrm{Cu}$ & 23 & 66 & 5 & 55 & 29 & 33 & 4 & 18 & 62 & 222 \\
\hline $\mathrm{Zn}$ & 19 & 50 & 23 & 48 & 34 & 25 & 41 & 37 & 38 & 91 \\
\hline $\mathrm{Ga}$ & 14 & 16 & 16 & 12 & 18 & 20 & 14 & 15 & 8 & 9 \\
\hline As & $<1$ & $<1$ & $<1$ & $<1$ & $<1$ & $<1$ & $<1$ & $<1$ & $<1$ & $<1$ \\
\hline $\mathrm{Rb}$ & 1 & 1 & 2 & 1 & 3 & 1 & 1 & $<1$ & $<1$ & 1 \\
\hline Sr & 582 & 559 & 588 & 453 & 754 & 547 & 566 & 579 & 30 & 340 \\
\hline$Y$ & 1 & 1 & 1 & $<1$ & 1 & 3 & $<1$ & $<1$ & 10 & 5 \\
\hline $\mathrm{Zr}_{\mathrm{r}}$ & 20 & 16 & 27 & 16 & 21 & 25 & 16 & 15 & 14 & 27 \\
\hline $\mathrm{Nb}$ & 1 & 2 & 5 & $<1$ & 2 & 2 & $<1$ & 2 & 1 & 1 \\
\hline $\mathrm{Ba}$ & 51 & 75 & 37 & 36 & 61 & 75 & 35 & 40 & 2 & 28 \\
\hline La & 2 & 6 & 3 & 3 & 5 & 4 & 4 & 5 & 2 & 4 \\
\hline $\mathrm{Ce}$ & 3 & 12 & 8 & 7 & 11 & 8 & 8 & 9 & 6 & 10 \\
\hline $\mathrm{Pb}$ & 4 & 5 & 4 & 3 & 5 & 4 & 3 & 3 & 4 & 4 \\
\hline Th & 1 & 2 & 1 & $<1$ & $<1$ & 2 & 1 & $<1$ & 1 & $<1$ \\
\hline $\mathrm{U}$ & $<1$ & $<1$ & $<1$ & $<1$ & 1 & $<1$ & $<1$ & $<1$ & 1 & 2 \\
\hline$Q$ & 0.00 & 0.00 & 0.00 & 0.00 & 0.00 & 0.00 & 0.00 & 0.00 & 0.00 & 0.00 \\
\hline Or & 0.59 & 1.00 & 1.06 & 0.35 & 1.12 & 0.95 & 0.35 & 0.35 & 0.12 & 0.35 \\
\hline$A b$ & 14.58 & 17.91 & 13.32 & 10.72 & 15.03 & 18.46 & 12.23 & 12.07 & 8.72 & 7.93 \\
\hline An & 48.54 & 36.30 & 53.95 & 39.35 & 57.99 & 43.38 & 48.64 & 48.77 & 12.97 & 15.18 \\
\hline $\mathrm{Ne}$ & 3.93 & 3.31 & 3.19 & 1.39 & 1.39 & 3.43 & 1.40 & 1.58 & 0.00 & 1.99 \\
\hline $\mathrm{Di}$ & 24.61 & 14.05 & 21.22 & 16.53 & 3.48 & 26.62 & 4.84 & 4.82 & 46.20 & 29.82 \\
\hline Hy & 0.00 & 0.00 & 0.00 & 0.00 & 0.00 & 0.00 & 0.00 & 0.00 & 13.20 & 0.00 \\
\hline Ol & 6.30 & 24.97 & 5.23 & 28.86 & 18.85 & 4.77 & 30.55 & 30.65 & 16.02 & 39.82 \\
\hline Mt & 0.67 & 1.40 & 0.52 & 1.34 & 0.87 & 0.78 & 1.16 & 1.16 & 1.26 & 2.53 \\
\hline II & 0.57 & 0.44 & 0.65 & 0.47 & 0.51 & 1.10 & 0.25 & 0.23 & 1.12 & 1.37 \\
\hline Ap & 0.00 & 0.02 & 0.02 & 0.00 & 0.02 & 0.00 & 0.00 & 0.00 & 0.00 & 0.02 \\
\hline TOTAL & 99.79 & 99.40 & 99.16 & 99.01 & 99.26 & 99.49 & 99.42 & 99.63 & 99.61 & 99.01 \\
\hline
\end{tabular}




\begin{tabular}{|c|c|c|c|c|c|c|c|c|c|c|}
\hline $\begin{array}{l}\text { Sample } \\
\text { Type }\end{array}$ & $\begin{array}{l}90048 \mathrm{~B} \\
\text { Pyxite } \\
\end{array}$ & $\begin{array}{c}90048 \mathrm{C} \\
\text { Gran }\end{array}$ & $\begin{array}{c}90048 D \\
\text { Pyxite }\end{array}$ & $\begin{array}{c}90048 \mathrm{E} \\
\text { Gran }\end{array}$ & $\begin{array}{c}90048 \mathrm{G} \\
\text { Gran }\end{array}$ & $\begin{array}{l}90050 \mathrm{~A} \\
\text { Pyxite }\end{array}$ & $\begin{array}{c}90054 B \\
\text { Perid } \\
\end{array}$ & $\begin{array}{c}90054 \mathrm{C} \\
\text { Pyxite }\end{array}$ & $\begin{array}{c}\text { 90054D } \\
\text { Perid } \\
\end{array}$ & $\begin{array}{c}\text { 90054E } \\
\text { Perid }\end{array}$ \\
\hline $\mathrm{SiO}_{2}$ & 44.07 & 43.29 & 43.53 & 46.54 & 49.09 & 44.94 & 45.22 & 44.66 & 45.65 & 43.82 \\
\hline $\mathrm{TiO}_{2}$ & 1.74 & 3.67 & 3.04 & 1.75 & 2.30 & 0.85 & 0.11 & 1.32 & 0.29 & 0.09 \\
\hline $\mathrm{Al} 2 \mathrm{O} 3$ & 7.33 & 14.25 & 10.17 & 15.70 & 22.39 & 7.27 & 2.48 & 10.26 & 4.30 & 2.31 \\
\hline $\mathrm{Fe} 2 \mathrm{O} 3$ total & 12.95 & 12.68 & 12.17 & 9.78 & 6.21 & 14.79 & 9.88 & 9.80 & 10.35 & 10.01 \\
\hline $\mathrm{MnO}$ & 0.20 & 0.16 & 0.16 & 0.14 & 0.09 & 0.44 & 0.16 & 0.16 & 0.16 & 0.15 \\
\hline $\mathrm{MgO}$ & 17.66 & 10.56 & 11.42 & 8.91 & 3.08 & 12.73 & 39.02 & 15.22 & 31.42 & 41.05 \\
\hline $\mathrm{CaO}$ & 15.42 & 12.31 & 17.41 & 13.59 & 10.73 & 11.82 & 2.17 & 17.31 & 6.79 & 1.45 \\
\hline $\mathrm{Na} 2 \mathrm{O}$ & 0.86 & 2.25 & 1.66 & 2.63 & 4.39 & 0.90 & 0.30 & 1.05 & 0.72 & 0.37 \\
\hline $\mathrm{K} 2 \mathrm{O}$ & 0.10 & 0.49 & 0.17 & 0.35 & 0.52 & 0.77 & 0.05 & 0.05 & 0.02 & 0.02 \\
\hline $\mathrm{P} 2 \mathrm{O} 5$ & 0.02 & 0.21 & 0.06 & 0.12 & 0.24 & 0.01 & 0.03 & 0.00 & 0.01 & 0.03 \\
\hline LOI & 0.05 & 0.18 & 0.25 & 0.79 & 1.37 & 4.80 & -0.24 & 0.00 & -0.38 & -0.39 \\
\hline TOTAL & 100.40 & 100.05 & 100.04 & 100.30 & 100.41 & 99.32 & 99.18 & 99.83 & 99.33 & 98.91 \\
\hline $\mathrm{Mg} \#$ & 72.98 & 62.25 & 65.02 & 64.34 & 49.55 & 63.03 & 88.66 & 75.46 & 85.74 & 89.04 \\
\hline $\mathrm{Sc}$ & 54 & 33 & 55 & 32 & 14 & 41 & 10 & 60 & 19 & 10 \\
\hline V & 302 & 313 & 446 & 251 & 137 & 177 & 62 & 424 & 130 & 57 \\
\hline $\mathrm{Cr}$ & 2081 & 171 & 587 & 370 & 7 & 2729 & 2991 & 1092 & 2896 & 3018 \\
\hline $\mathrm{Ni}$ & 334 & 84 & 93 & 73 & 5 & 329 & 2088 & 325 & 1645 & 2205 \\
\hline $\mathrm{Cu}$ & 46 & 37 & 33 & 26 & 13 & 8 & 18 & 63 & 23 & 11 \\
\hline $\mathrm{Zn}$ & 65 & 56 & 55 & 56 & 31 & 260 & 61 & 67 & 62 & 66 \\
\hline $\mathrm{Ga}$ & 14 & 17 & 17 & 17 & 20 & 20 & 5 & 18 & 5 & 4 \\
\hline As & $<1$ & $<1$ & $<1$ & $<1$ & $<1$ & 1 & $<1$ & $<1$ & $<1$ & $<1$ \\
\hline $\mathrm{Rb}$ & 1 & 5 & 2 & 3 & 3 & 20 & 1 & 1 & $<1$ & 1 \\
\hline $\mathrm{Sr}$ & 219 & 939 & 310 & 891 & 1683 & 130 & 18 & 74 & 21 & 11 \\
\hline$Y$ & 15 & 18 & 22 & 12 & 3 & 64 & $<1$ & 14 & 5 & $<1$ \\
\hline $\mathrm{Zr}$ & 72 & 113 & 90 & 98 & 54 & 74 & 11 & 46 & 12 & 6 \\
\hline $\mathrm{Nb}$ & 4 & 14 & 4 & 9 & 10 & 13 & 1 & $<1$ & 1 & $<1$ \\
\hline $\mathrm{Ba}$ & 19 & 91 & 27 & 79 & 243 & 458 & 4 & 1 & 6 & 8 \\
\hline $\mathrm{La}$ & 5 & 12 & 7 & 10 & 7 & 27 & 6 & 6 & $<1$ & $<1$ \\
\hline $\mathrm{Ce}$ & 27 & 44 & 22 & 34 & 22 & 73 & 3 & 19 & 6 & 2 \\
\hline $\mathrm{Pb}$ & 3 & 3 & 5 & 3 & 4 & 7 & 3 & 4 & 4 & 4 \\
\hline Th & 1 & 2 & 1 & 1 & 1 & 2 & $<1$ & $<1$ & $<1$ & $<1$ \\
\hline $\mathrm{U}$ & $<1$ & $<1$ & $<1$ & $<1$ & $<1$ & $<1$ & 1 & 1 & $<1$ & $<1$ \\
\hline$Q$ & 0.00 & 0.00 & 0.00 & 0.00 & 0.00 & 0.00 & 0.00 & 0.00 & 0.00 & 0.00 \\
\hline Or & 0.00 & 2.90 & 0.00 & 2.07 & 3.07 & 4.79 & 0.30 & 0.00 & 0.12 & 0.12 \\
\hline $\mathrm{Ab}$ & 0.00 & 9.34 & 0.00 & 13.54 & 30.89 & 8.04 & 2.54 & 0.00 & 6.09 & 3.13 \\
\hline An & 15.85 & 27.34 & 19.80 & 30.00 & 39.85 & 14.16 & 5.27 & 23.14 & 8.44 & 4.58 \\
\hline $\mathrm{Ne}$ & 3.94 & 5.26 & 7.61 & 4.72 & 3.39 & 0.00 & 0.00 & 4.81 & 0.00 & 0.00 \\
\hline Di & 48.53 & 26.10 & 53.33 & 29.63 & 9.63 & 38.53 & 4.18 & 50.17 & 19.94 & 1.91 \\
\hline $\mathrm{Hy}$ & 0.00 & 0.00 & 0.00 & 0.00 & 0.00 & 10.06 & 24.53 & 0.00 & 10.40 & 17.56 \\
\hline $\mathrm{Ol}$ & 25.74 & 18.18 & 10.52 & 13.40 & 5.66 & 17.85 & 59.76 & 18.20 & 51.46 & 69.17 \\
\hline Mt & 2.23 & 2.19 & 2.10 & 1.69 & 1.07 & 3.38 & 1.70 & 1.69 & 1.79 & 1.73 \\
\hline II & 3.30 & 6.97 & 5.77 & 3.32 & 4.37 & 1.69 & 0.21 & 2.51 & 0.55 & 0.17 \\
\hline Ap & 0.05 & 0.50 & 0.79 & 0.28 & 0.57 & 0.02 & 0.07 & 0.00 & 0.02 & 0.07 \\
\hline TOTAL & 99.64 & 98.78 & 99.92 & 98.65 & 98.50 & 98.52 & 98.56 & 100.52 & 98.81 & 98.44 \\
\hline
\end{tabular}




\begin{tabular}{|c|c|c|c|c|c|c|c|c|c|c|}
\hline $\begin{array}{l}\text { Sample } \\
\text { Type }\end{array}$ & $\begin{array}{l}\text { 90054F } \\
\text { Pyxite }\end{array}$ & $\begin{array}{l}90054 G \\
\text { Pyxite }\end{array}$ & $\begin{array}{c}90054 \mathrm{H} \\
\text { Perid }\end{array}$ & $\begin{array}{l}\text { 90054I } \\
\text { Pyxite }\end{array}$ & $\begin{array}{l}90054 J \\
\text { Perid }\end{array}$ & $\begin{array}{l}90054 \mathrm{~K} \\
\text { Pyxite }\end{array}$ & $\begin{array}{c}\text { 90054L } \\
\text { Perid }\end{array}$ & $\begin{array}{c}90054 \mathrm{M} \\
\text { Perid }\end{array}$ & $\begin{array}{c}90054 \mathrm{~N} \\
\text { Perid }\end{array}$ & $\begin{array}{c}900540 \\
\text { Perid }\end{array}$ \\
\hline $\mathrm{SiO}_{2}$ & 47.13 & 43.20 & 43.08 & 46.48 & 38.10 & 41.55 & 42.26 & 43.56 & 42.08 & 38.50 \\
\hline $\mathrm{TiO}_{2}$ & 1.25 & 1.51 & 0.10 & 1.15 & 0.68 & 1.81 & 0.32 & 0.09 & 0.19 & 0.55 \\
\hline $\mathrm{Al} 2 \mathrm{O} 3$ & 7.06 & 12.78 & 2.22 & 7.37 & 5.40 & 12.34 & 3.31 & 1.90 & 2.89 & 4.87 \\
\hline $\mathrm{Fe} 2 \mathrm{O} 3$ total & 8.36 & 10.01 & 12.47 & 8.44 & 19.24 & 11.82 & 12.68 & 12.27 & 17.18 & 19.57 \\
\hline $\mathrm{MnO}$ & 0.16 & 0.16 & 0.17 & 0.15 & 0.23 & 0.17 & 0.20 & 0.17 & 0.23 & 0.23 \\
\hline $\mathrm{MgO}$ & 16.33 & 14.30 & 39.41 & 17.22 & 30.70 & 15.20 & 35.66 & 39.90 & 34.47 & 31.54 \\
\hline $\mathrm{CaO}$ & 18.56 & 17.14 & 1.94 & 17.13 & 5.55 & 16.20 & 5.26 & 1.29 & 2.90 & 4.88 \\
\hline $\mathrm{Na} 2 \mathrm{O}$ & 0.91 & 1.27 & 0.21 & 1.97 & 0.54 & 1.17 & 0.29 & 0.68 & 0.21 & 0.89 \\
\hline $\mathrm{K} 2 \mathrm{O}$ & 0.09 & 0.03 & 0.07 & 0.12 & 0.07 & 0.02 & 0.03 & 0.05 & 0.02 & 0.06 \\
\hline $\mathrm{P} 2 \mathrm{O} 5$ & 0.01 & 0.00 & 0.03 & 0.01 & 0.01 & 0.00 & 0.00 & 0.05 & 0.01 & 0.04 \\
\hline LOI & 0.17 & 0.07 & -0.28 & 0.08 & -1.10 & -0.23 & -0.48 & -0.63 & -0.85 & -1.17 \\
\hline TOTAL & 100.03 & 100.47 & 99.42 & 100.12 & 99.42 & 100.05 & 99.53 & 99.33 & 99.33 & 99.96 \\
\hline Mg\# & 79.46 & 73.88 & 86.22 & 80.16 & 75.96 & 71.81 & 84.78 & 86.56 & 79.89 & 76.14 \\
\hline $\mathrm{Sc}$ & 68 & 53 & 9 & 54 & 20 & 50 & 20 & 8 & 13 & 13 \\
\hline V & 328 & 464 & 64 & 328 & 202 & 472 & 130 & 57 & 88 & 157 \\
\hline $\mathrm{Cr}$ & 2603 & 232 & 2902 & 3745 & 2300 & 399 & 2520 & 2525 & 2547 & 1641 \\
\hline $\mathrm{Ni}$ & 299 & 311 & 2263 & 483 & 1037 & 236 & 1731 & 2075 & 1611 & 1109 \\
\hline $\mathrm{Cu}$ & 33 & 40 & 27 & 72 & 16 & 36 & 41 & 7 & 10 & 14 \\
\hline $\mathrm{Zn}$ & 44 & 101 & 91 & 43 & 112 & 91 & 90 & 78 & 106 & 135 \\
\hline $\mathrm{Ga}$ & 12 & 26 & 4 & 12 & 13 & 21 & 7 & 3 & 4 & 11 \\
\hline As & $<1$ & $<1$ & $<1$ & $<1$ & $<1$ & $<1$ & $<1$ & $<1$ & $<1$ & $<1$ \\
\hline $\mathrm{Rb}$ & $<1$ & 1 & 1 & $<1$ & $<1$ & $<1$ & 1 & 1 & $<1$ & $<1$ \\
\hline $\mathrm{Sr}$ & 124 & 72 & 18 & 94 & 35 & 61 & 20 & 7 & 18 & 36 \\
\hline$Y$ & 13 & 16 & $<1$ & 12 & 4 & 17 & 2 & $<1$ & $<1$ & 2 \\
\hline $\mathrm{Zr}$ & 55 & 45 & 13 & 45 & 20 & 43 & 10 & 4 & 5 & 16 \\
\hline $\mathrm{Nb}$ & 2 & 1 & 2 & 1 & 1 & 1 & 1 & $<1$ & $<1$ & 2 \\
\hline $\mathrm{Ba}$ & 14 & 4 & 5 & 8 & 2 & 8 & 2 & 6 & 2 & 4 \\
\hline $\mathrm{La}$ & 6 & 4 & 2 & 3 & 1 & 4 & 2 & $<1$ & 2 & 3 \\
\hline $\mathrm{Ce}$ & 18 & 14 & 6 & 10 & 6 & 13 & 6 & $<1$ & 6 & 11 \\
\hline $\mathrm{Pb}$ & 4 & 3 & 3 & 2 & 5 & 4 & 5 & 3 & 4 & 3 \\
\hline Th & 1 & $<1$ & $<1$ & 1 & $<1$ & 1 & 1 & 1 & $<1$ & 1 \\
\hline $\mathbf{U}$ & $<1$ & 1 & $<1$ & $<1$ & 1 & $<1$ & $<1$ & $<1$ & 1 & $<1$ \\
\hline$Q$ & 0.00 & 0.00 & 0.00 & 0.00 & 0.00 & 0.00 & 0.00 & 0.00 & 0.00 & 0.00 \\
\hline Or & 0.00 & 0.00 & 0.41 & 0.00 & 0.00 & 0.00 & 0.18 & 0.30 & 0.12 & 0.00 \\
\hline $\mathrm{Ab}$ & 0.00 & 0.00 & 1.78 & 0.00 & 0.00 & 0.00 & 2.45 & 5.75 & 1.78 & 0.00 \\
\hline An & 14.91 & 29.08 & 4.91 & 10.91 & 12.10 & 28.36 & 7.64 & 1.98 & 6.88 & 9.12 \\
\hline $\mathrm{Ne}$ & 4.17 & 5.82 & 0.00 & 9.03 & 2.48 & 5.36 & 0.00 & 0.00 & 0.00 & 4.08 \\
\hline $\mathrm{Di}$ & 59.96 & 43.79 & 3.58 & 58.79 & 12.31 & 40.74 & 14.64 & 3.34 & 5.94 & 11.89 \\
\hline $\mathrm{Hy}$ & 0.00 & 0.00 & 16.43 & 0.00 & 0.00 & 0.00 & 2.48 & 12.51 & 15.39 & 0.00 \\
\hline Ol & 15.08 & 18.37 & 69.09 & 17.30 & 68.99 & 21.45 & 68.71 & 72.63 & 65.21 & 71.12 \\
\hline Mt & 1.44 & 1.73 & 2.15 & 1.46 & 3.32 & 2.04 & 2.19 & 2.12 & 2.96 & 3.38 \\
\hline Il & 2.37 & 2.87 & 0.19 & 2.87 & 1.29 & 3.44 & 0.61 & 0.17 & 0.36 & 1.04 \\
\hline Ap & 0.02 & 0.00 & 0.07 & 0.02 & 0.02 & 0.00 & 0.00 & 0.07 & 0.02 & 0.09 \\
\hline TOTAL & 97.95 & 101.66 & 98.61 & 100.38 & 100.51 & 101.39 & 98.90 & 98.87 & 98.66 & 100.72 \\
\hline
\end{tabular}




\begin{tabular}{|c|c|c|c|c|}
\hline $\begin{array}{l}\text { Sample } \\
\text { Type }\end{array}$ & $\begin{array}{c}\text { 90054Q } \\
\text { Perid } \\
\end{array}$ & $\begin{array}{c}\text { 90054R } \\
\text { Perid } \\
\end{array}$ & $\begin{array}{c}90054 \mathrm{~T} \\
\text { Perid }\end{array}$ & $\begin{array}{c}90054 \mathrm{U} \\
\text { Perid }\end{array}$ \\
\hline $\mathrm{SiO}_{2}$ & 44.24 & 43.65 & 42.47 & 42.11 \\
\hline $\mathrm{TiO} 2$ & 0.04 & 0.04 & 0.12 & 0.08 \\
\hline $\mathrm{A} 12 \mathrm{O} 3$ & 1.65 & 1.59 & 1.73 & 1.61 \\
\hline $\mathrm{Fe} 2 \mathrm{O} 3$ total & 11.62 & 9.16 & 16.24 & 13.30 \\
\hline $\mathrm{MnO}$ & 0.16 & 0.14 & 0.21 & 0.17 \\
\hline $\mathrm{MgO}$ & 40.94 & 42.67 & 37.63 & 40.95 \\
\hline $\mathrm{CaO}$ & 1.34 & 1.18 & 1.97 & 1.32 \\
\hline $\mathrm{Na} 2 \mathrm{O}$ & 0.07 & 0.10 & 0.56 & 0.37 \\
\hline $\mathrm{K}_{2} \mathrm{O}$ & 0.02 & 0.02 & 0.02 & 0.03 \\
\hline $\mathrm{P} 2 \mathrm{O} 5$ & 0.00 & 0.00 & 0.04 & 0.02 \\
\hline LOI & -0.69 & 0.90 & -0.81 & -0.64 \\
\hline TOTAL & 99.39 & 99.45 & 100.18 & 99.32 \\
\hline Mg\# & 87.46 & 90.22 & 82.11 & 85.91 \\
\hline Sc & 8 & 9 & 4 & 4 \\
\hline V & 47 & 49 & 59 & 52 \\
\hline $\mathrm{Cr}$ & 3048 & 3104 & 2431 & 2550 \\
\hline $\mathrm{Ni}$ & 2203 & 2422 & 1784 & 2189 \\
\hline $\mathrm{Cu}$ & 7 & 3 & 10 & 26 \\
\hline $\mathrm{Zn}$ & 81 & 58 & 98 & 91 \\
\hline $\mathrm{Ga}$ & 3 & 3 & 3 & 4 \\
\hline As & $<1$ & $<1$ & $<1$ & $<1$ \\
\hline $\mathrm{Rb}$ & $<1$ & 1 & 1 & 1 \\
\hline $\mathrm{Sr}$ & 5 & 5 & 10 & 7 \\
\hline $\mathrm{Y}$ & $<1$ & $<1$ & $<1$ & $<1$ \\
\hline $\mathrm{Zr}$ & 1 & 1 & 4 & $<1$ \\
\hline $\mathrm{Nb}$ & 1 & $<1$ & $<1$ & 2 \\
\hline $\mathrm{Ba}$ & 4 & 3 & 4 & 5 \\
\hline $\mathrm{La}$ & 3 & 2 & $<1$ & 1 \\
\hline $\mathrm{Ce}$ & 1 & $<1$ & 3 & 3 \\
\hline $\mathrm{Pb}$ & 4 & 4 & 6 & 4 \\
\hline Th & 1 & $<1$ & 3 & $<1$ \\
\hline $\mathrm{U}$ & $<1$ & 1 & 1 & 1 \\
\hline$Q$ & 0.00 & 0.00 & 0.00 & 0.00 \\
\hline Or & 0.12 & 0.12 & 0.12 & 0.18 \\
\hline$A b$ & 0.59 & 0.85 & 4.74 & 3.13 \\
\hline An & 4.13 & 3.83 & 2.15 & 2.64 \\
\hline $\mathrm{Ne}$ & 0.00 & 0.00 & 0.00 & 0.00 \\
\hline $\mathrm{Di}$ & 1.99 & 1.59 & 5.86 & 2.99 \\
\hline $\mathrm{Hy}$ & 24.15 & 20.58 & 9.49 & 9.70 \\
\hline $\mathrm{Ol}$ & 66.00 & 69.13 & 74.08 & 77.65 \\
\hline Mt & 2.01 & 1.58 & 2.80 & 2.30 \\
\hline Il & 0.08 & 0.08 & 0.23 & 0.15 \\
\hline Ap & 0.00 & 0.00 & 0.09 & 0.05 \\
\hline TOTAL & 99.07 & 97.76 & 99.56 & 98.79 \\
\hline
\end{tabular}




\section{A4.4 Mount Cumming xenolith analyses}

\begin{tabular}{|c|c|c|c|c|c|c|c|c|c|c|}
\hline $\begin{array}{l}\text { Sample } \\
\text { Type }\end{array}$ & $\begin{array}{c}90040 \mathrm{E} \\
\text { Perid }\end{array}$ & $\begin{array}{c}90040 G \\
\text { Perid }\end{array}$ & $\begin{array}{c}90040 \mathrm{H} \\
\text { Perid }\end{array}$ & $\begin{array}{c}90040 I \\
\text { Gran }\end{array}$ & $\begin{array}{c}90040 \mathrm{~K} \\
\text { Perid }\end{array}$ & $\begin{array}{c}90040 \mathrm{~L} \\
\text { U.C. }\end{array}$ & $\begin{array}{c}90040 N \\
\text { Perid }\end{array}$ & $\begin{array}{c}90040 P \\
\text { Perid }\end{array}$ & $\begin{array}{c}90040 U \\
\text { Perid }\end{array}$ & $\begin{array}{c}90040 W \\
\text { Gran }\end{array}$ \\
\hline $\mathrm{SiO} 2$ & 45.17 & 42.90 & 41.61 & 47.83 & 44.83 & 71.10 & 44.51 & 43.89 & 44.70 & 47.02 \\
\hline TiO2 & 0.14 & 0.04 & 0.29 & 0.46 & 0.04 & 0.09 & 0.05 & 0.01 & 0.02 & 4.66 \\
\hline $\mathrm{Al} 2 \mathrm{O} 3$ & 3.59 & 0.97 & 2.58 & 26.12 & 1.62 & 14.88 & 1.60 & 0.89 & 0.78 & 16.10 \\
\hline $\mathrm{Fe} 2 \mathrm{O} 3$ total & 9.31 & 10.25 & 13.85 & 4.59 & 8.35 & 1.38 & 8.75 & 8.73 & 8.69 & 11.05 \\
\hline $\mathrm{MnO}$ & 0.14 & 0.15 & 0.19 & 0.06 & 0.13 & 0.08 & 0.13 & 0.13 & 0.14 & 0.15 \\
\hline $\mathrm{MgO}$ & 37.93 & 44.40 & 38.55 & 5.39 & 42.88 & 0.18 & 43.06 & 45.05 & 44.76 & 8.04 \\
\hline $\mathrm{CaO}$ & 3.10 & 0.78 & 3.34 & 12.09 & 1.57 & 0.80 & 1.46 & 0.86 & 0.71 & 10.24 \\
\hline $\mathrm{Na} 2 \mathrm{O}$ & 0.40 & 0.07 & 0.35 & 3.17 & 0.21 & 4.53 & 0.18 & 0.04 & 0.11 & 2.70 \\
\hline $\mathrm{K} 2 \mathrm{O}$ & 0.03 & 0.04 & 0.31 & 0.23 & 0.01 & 5.02 & 0.04 & 0.02 & 0.02 & 0.26 \\
\hline $\mathrm{P} 2 \mathrm{O} 5$ & 0.01 & 0.01 & 0.02 & 0.03 & 0.01 & 0.03 & 0.01 & 0.00 & 0.00 & 0.02 \\
\hline LOI & -0.38 & -0.38 & -0.61 & 0.20 & -0.45 & 1.52 & -0.19 & -0.24 & -0.27 & 0.00 \\
\hline TOTAL & 99.44 & 99.23 & 100.48 & 100.17 & 99.20 & 99.61 & 99.60 & 99.38 & 99.66 & 100.24 \\
\hline Mg\# & 88.97 & 89.56 & 84.64 & 69.93 & 91.05 & 20.53 & 90.69 & 91.09 & 91.07 & 59.03 \\
\hline
\end{tabular}

\begin{tabular}{lcccccccccc}
\hline $\mathrm{Sc}$ & 13 & $<1$ & 4 & 5 & 8 & 4 & 6 & 4 & 6 & 27 \\
$\mathrm{~V}$ & 79 & 29 & 68 & 32 & 40 & 8 & 39 & 27 & 29 & 267 \\
$\mathrm{Cr}$ & 2788 & 2268 & 669 & 11 & 2615 & 1 & 2793 & 2342 & 3165 & 208 \\
$\mathrm{Ni}$ & 1936 & 2667 & 1865 & 98 & 2436 & 1 & 2511 & 2643 & 2587 & 143 \\
$\mathrm{Cu}$ & 15 & 3 & 24 & 9 & 1 & 2 & 4 & 1 & 3 & 50 \\
$\mathrm{Zn}$ & 53 & 63 & 84 & 35 & 47 & 39 & 52 & 50 & 53 & 59 \\
$\mathrm{Ga}$ & 4 & 3 & 5 & 17 & 3 & 22 & 2 & 2 & 2 & 20 \\
$\mathrm{As}$ & $<1$ & $<1$ & $<1$ & $<1$ & $<1$ & 1 & $<1$ & $<1$ & $<1$ & $<1$ \\
$\mathrm{Rb}$ & 1 & 1 & 2 & 2 & $<1$ & 330 & 1 & $<1$ & $<1$ & 2 \\
$\mathrm{Sr}$ & 12 & 11 & 41 & 771 & 8 & 55 & 12 & 4 & 3 & 714 \\
$\mathrm{Y}$ & $<1$ & $<1$ & 3 & $<1$ & $<1$ & 44 & $<1$ & $<1$ & 1 & $<1$ \\
$\mathrm{Zr}$ & 5 & 3 & 16 & 30 & 1 & 117 & 1 & 1 & $<1$ & 61 \\
$\mathrm{Nb}$ & 2 & 2 & 2 & 3 & 1 & 23 & 1 & 1 & 1 & 7 \\
$\mathrm{Ba}$ & 2 & 9 & 10 & 109 & 2 & 174 & 1 & 5 & 4 & 144 \\
$\mathrm{La}$ & 2 & 2 & 4 & 5 & $<1$ & 20 & 1 & 1 & 3 & 5 \\
$\mathrm{Ce}$ & 5 & 2 & 11 & 12 & $<1$ & 42 & 1 & 3 & 3 & 21 \\
$\mathrm{~Pb}$ & 4 & 6 & 4 & 5 & 4 & 36 & 3 & 3 & 4 & 5 \\
$\mathrm{Th}$ & 1 & $<1$ & 1 & $<1$ & $<1$ & 27 & $<1$ & $<1$ & 2 & $<1$ \\
$\mathrm{U}$ & 1 & $<1$ & 1 & $<1$ & $<1$ & 9 & 1 & $<1$ & $<1$ & $<1$
\end{tabular}

\begin{tabular}{lcccccccccc}
\hline $\mathrm{Q}$ & 0.00 & 0.00 & 0.00 & 0.00 & 0.00 & 21.96 & 0.00 & 0.00 & 0.00 & 0.00 \\
$\mathrm{Or}$ & 0.18 & 0.24 & 0.35 & 1.36 & 0.06 & 29.67 & 0.24 & 0.12 & 0.12 & 1.54 \\
$\mathrm{Ab}$ & 3.38 & 0.59 & 2.96 & 21.94 & 1.78 & 38.33 & 1.52 & 0.34 & 0.93 & 22.85 \\
$\mathrm{An}$ & 7.91 & 2.21 & 5.29 & 56.36 & 3.45 & 3.77 & 3.44 & 2.19 & 1.58 & 31.04 \\
$\mathrm{Ne}$ & 0.00 & 0.00 & 0.00 & 2.65 & 0.00 & 0.00 & 0.00 & 0.00 & 0.00 & 0.00 \\
$\mathrm{Di}$ & 5.83 & 1.25 & 8.83 & 2.76 & 3.37 & 3.26 & 2.94 & 1.63 & 1.53 & 15.78 \\
$\mathrm{Hy}$ & 19.79 & 15.64 & 1.59 & 0.00 & 20.92 & 0.64 & 19.77 & 19.26 & 22.48 & 10.12 \\
$\mathrm{Ol}$ & 60.00 & 76.91 & 77.61 & 12.77 & 67.81 & 0.00 & 69.49 & 73.79 & 70.99 & 7.14 \\
$\mathrm{Mt}$ & 1.61 & 1.77 & 2.39 & 0.79 & 1.44 & 0.24 & 1.51 & 1.51 & 1.50 & 1.91 \\
$\mathrm{Il}$ & 0.27 & 0.08 & 0.55 & 0.87 & 0.08 & 0.17 & 0.09 & 0.02 & 0.04 & 8.85 \\
$\mathrm{Ap}$ & 0.02 & 0.02 & 0.05 & 0.07 & 0.02 & 0.07 & 0.02 & 0.00 & 0.00 & 0.05 \\
& & & & & & & & & & \\
\hline TOTAL & 98.99 & 98.71 & 99.62 & 99.57 & 98.93 & 98.11 & 99.02 & 98.86 & 99.17 & 99.28 \\
\hline
\end{tabular}




\begin{tabular}{|c|c|c|c|c|c|c|c|c|c|}
\hline Sample & $90040 Y$ & $90040 \mathrm{~S} 1$ & $90040 \mathrm{U1}$ & $90040 \mathrm{G} 2$ & $90040 \mathrm{M} 2$ & $90040 \mathrm{~N} 2$ & $90040 \mathrm{O} 2$ & $90040 \mathrm{P} 2$ & $90040 \mathrm{A3}$ \\
\hline Type & Gran & Perid & Perid & Perid & Gran & Gran & Gran & Gran & Perid \\
\hline $\mathrm{SiO}_{2}$ & 52.22 & 43.65 & 46.29 & 44.32 & 49.03 & 46.28 & 48.56 & 49.55 & 43.74 \\
\hline $\mathrm{TiO} 2$ & 0.26 & 0.05 & 0.09 & 0.10 & 0.24 & 5.04 & 0.44 & 0.22 & 0.21 \\
\hline $\mathrm{Al} 2 \mathrm{O} 3$ & 19.51 & 1.63 & 3.38 & 2.85 & 23.86 & 15.67 & 17.66 & 19.75 & 1.70 \\
\hline $\mathrm{Fe} 2 \mathrm{O} 3$ total & 7.05 & 10.11 & 8.66 & 11.51 & 5.92 & 11.80 & 7.51 & 7.63 & 10.83 \\
\hline $\mathrm{MnO}$ & 0.11 & 0.15 & 0.14 & 0.20 & 0.07 & 0.15 & 0.12 & 0.10 & 0.18 \\
\hline $\mathrm{MgO}$ & 9.11 & 43.36 & 38.51 & 37.71 & 6.41 & 8.22 & 9.02 & 9.90 & 40.44 \\
\hline $\mathrm{CaO}$ & 8.47 & 1.03 & 3.02 & 2.78 & 10.75 & 9.61 & 13.55 & 10.51 & 1.71 \\
\hline $\mathrm{Na} 2 \mathrm{O}$ & 2.96 & 0.09 & 0.21 & 0.75 & 3.43 & 3.03 & 2.67 & 2.51 & 0.60 \\
\hline $\mathrm{K} 2 \mathrm{O}$ & 0.30 & 0.02 & 0.02 & 0.11 & 0.31 & 0.35 & 0.24 & 0.26 & 0.17 \\
\hline $\mathrm{P} 2 \mathrm{O} 5$ & 0.01 & 0.00 & 0.00 & 0.01 & 0.03 & 0.03 & 0.00 & 0.00 & 0.02 \\
\hline LOI & 0.14 & -0.30 & -0.16 & -0.20 & 0.16 & -0.09 & 0.27 & -0.09 & -0.54 \\
\hline TOTAL & 100.14 & 99.79 & 100.16 & 100.14 & 100.21 & 100.09 & 100.04 & 100.34 & 99.06 \\
\hline$M g \#$ & 71.90 & 89.47 & 89.80 & 86.65 & 68.20 & 57.98 & 70.40 & 71.99 & 88.09 \\
\hline Sc & 16 & 8 & 14 & 15 & 10 & 26 & 26 & 14 & 9 \\
\hline V & 52 & 45 & 73 & 68 & 28 & 117 & 273 & 51 & 47 \\
\hline $\mathrm{Cr}$ & 198 & 2348 & 2803 & 3216 & 33 & 182 & 261 & 165 & 2897 \\
\hline $\mathrm{Ni}$ & 131 & 2495 & 2067 & 1933 & 137 & 87 & 129 & 167 & 2148 \\
\hline $\mathrm{Cu}$ & 27 & 1 & 21 & 4 & 13 & 17 & 49 & 14 & 29 \\
\hline $\mathrm{Zn}$ & 53 & 57 & 50 & 82 & 48 & 53 & 76 & 56 & 69 \\
\hline $\mathrm{Ga}$ & 20 & 3 & 3 & 3 & 19 & 19 & 21 & 17 & 3 \\
\hline As & $<1$ & $<1$ & $<1$ & $<1$ & $<1$ & $<1$ & $<1$ & $<1$ & $<1$ \\
\hline $\mathrm{Rb}$ & 2 & $<1$ & $<1$ & 1 & 3 & 3 & 7 & 2 & 12 \\
\hline Sr & 931 & 4 & 2 & 12 & 1478 & 567 & 636 & 888 & 12 \\
\hline$Y$ & 1 & $<1$ & $<1$ & $<1$ & $<1$ & 6 & 7 & $<1$ & $<1$ \\
\hline $\mathrm{Zr}$ & 26 & 3 & 1 & 3 & 44 & 35 & 67 & 27 & 8 \\
\hline $\mathrm{Nb}$ & 1 & 1 & $<1$ & $<1$ & 3 & 1 & 11 & $<1$ & 3 \\
\hline $\mathrm{Ba}$ & 168 & 2 & 3 & 3 & 180 & 117 & 126 & 150 & 28 \\
\hline La & 5 & 2 & 1 & 3 & 8 & 5 & 4 & 4 & 4 \\
\hline $\mathrm{Ce}$ & 12 & $<1$ & 2 & 3 & 17 & 14 & 19 & 9 & 2 \\
\hline $\mathrm{Pb}$ & 4 & 3 & 4 & 2 & 5 & 5 & 6 & 6 & 4 \\
\hline Th & 1 & $<1$ & $<1$ & $<1$ & $<1$ & $<1$ & 1 & 2 & $<1$ \\
\hline $\mathrm{U}$ & $<1$ & $<1$ & $<1$ & $<1$ & $<1$ & 1 & $<1$ & $<1$ & $<1$ \\
\hline$Q$ & 0.00 & 0.00 & 0.00 & 0.00 & 0.00 & 0.00 & 0.00 & 0.00 & 0.00 \\
\hline Or & 1.77 & 0.12 & 0.12 & 0.65 & 1.83 & 2.07 & 1.42 & 1.54 & 1.00 \\
\hline $\mathrm{Ab}$ & 25.05 & 0.76 & 1.78 & 6.35 & 26.54 & 25.64 & 17.29 & 21.24 & 5.08 \\
\hline An & 39.06 & 3.98 & 8.22 & 4.09 & 48.79 & 28.12 & 35.50 & 41.86 & 1.44 \\
\hline $\mathrm{Ne}$ & 0.00 & 0.00 & 0.00 & 0.00 & 1.35 & 0.00 & 2.87 & 0.00 & 0.00 \\
\hline $\mathrm{Di}$ & 2.33 & 0.89 & 5.33 & 7.63 & 3.51 & 15.57 & 25.59 & 8.28 & 5.45 \\
\hline $\mathrm{Hy}$ & 25.59 & 18.80 & 26.92 & 10.16 & 0.00 & 3.39 & 0.00 & 10.22 & 11.19 \\
\hline OI & 3.84 & 72.82 & 55.52 & 68.26 & 15.96 & 12.67 & 14.31 & 14.89 & 72.17 \\
\hline Mt & 1.22 & 1.75 & 1.49 & 1.98 & 1.02 & 2.04 & 1.30 & 1.32 & 1.87 \\
\hline Il & 0.49 & 0.09 & 0.17 & 0.19 & 0.46 & 9.57 & 0.84 & 0.42 & 0.40 \\
\hline Ap & 0.02 & 0.00 & 0.00 & 0.02 & 0.07 & 0.07 & 0.00 & 0.00 & 0.05 \\
\hline TOTAL & 99.37 & 99.21 & 99.55 & 99.33 & 99.53 & 99.14 & 99.12 & 99.77 & 98.65 \\
\hline
\end{tabular}


A4.5 Mount Waesche xenolith analyses

\begin{tabular}{|c|c|c|c|c|c|c|}
\hline $\begin{array}{l}\text { Sample } \\
\text { Type }\end{array}$ & $\begin{array}{c}89001 \mathrm{E} \\
\text { U.C. }\end{array}$ & $\begin{array}{c}89001 \mathrm{~F} \\
\text { U.C. }\end{array}$ & $\begin{array}{c}89001 I \\
\text { Gran }\end{array}$ & $\begin{array}{c}\text { 89002B } \\
\text { U.C. }\end{array}$ & $\begin{array}{c}890007 \\
\text { U.C. }\end{array}$ & $\begin{array}{c}890009 \\
\text { U.C. }\end{array}$ \\
\hline $\mathrm{SiO}_{2}$ & 60.43 & 62.51 & 48.78 & 45.03 & 38.31 & 46.19 \\
\hline $\mathrm{TiO} 2$ & 0.61 & 0.24 & 1.79 & 1.91 & 7.75 & 2.40 \\
\hline $\mathrm{Al} 2 \mathrm{O} 3$ & 17.35 & 19.82 & 15.19 & 14.00 & 8.89 & 16.32 \\
\hline Fe2O3total & 7.12 & 2.74 & 13.77 & 12.80 & 25.71 & 13.22 \\
\hline $\mathrm{MnO}$ & 0.15 & 0.05 & $0.31^{\circ}$ & 0.20 & 0.35 & 0.19 \\
\hline $\mathrm{MgO}$ & 0.70 & 0.20 & 5.26 & 12.15 & 5.08 & 5.35 \\
\hline $\mathrm{CaO}$ & 2.67 & 1.52 & 10.34 & 9.88 & 10.06 & 10.82 \\
\hline $\mathrm{Na} 2 \mathrm{O}$ & 7.19 & 7.21 & 4.30 & 2.99 & 3.06 & 3.39 \\
\hline $\mathrm{K} 2 \mathrm{O}$ & 3.49 & 5.20 & 0.28 & 0.67 & 0.81 & 0.70 \\
\hline $\mathrm{P} 2 \mathrm{O} 5$ & 0.14 & 0.04 & 0.64 & 0.37 & 0.42 & 0.35 \\
\hline LOI & 0.39 & 0.71 & -0.39 & 0.22 & -0.32 & 1.34 \\
\hline TOTAL & 100.24 & 100.24 & 100.27 & 100.22 & 100.12 & 100.27 \\
\hline Mg\# & 16.30 & 12.63 & 43.07 & 65.28 & 28.13 & 44.49 \\
\hline $\mathrm{Sc}$ & $<1$ & 4 & 24 & 22 & 31 & 23 \\
\hline V & 15 & 15 & 160 & 188 & 485 & 272 \\
\hline $\mathrm{Cr}$ & 5 & 1 & 26 & 565 & 10 & 71 \\
\hline $\mathrm{Ni}$ & 3 & 9 & 21 & 272 & 17 & 35 \\
\hline $\mathrm{Cu}$ & 9 & 5 & 24 & 77 & 92 & 69 \\
\hline $\mathrm{Zn}$ & 61 & 31 & 92 & 74 & 127 & 73 \\
\hline $\mathrm{Ga}$ & 22 & 25 & 23 & 18 & 25 & 24 \\
\hline As & $<1$ & 1 & $<1$ & $<1$ & 2 & $<1$ \\
\hline $\mathrm{Rb}$ & 22 & 109 & 4 & 17 & 19 & 14 \\
\hline $\mathrm{Sr}$ & 132 & 196 & 562 & 462 & 281 & 455 \\
\hline$Y$ & 32 & 23 & 27 & 24 & 41 & 26 \\
\hline $\mathrm{Zr}$ & 197 & 1726 & 92 & 152 & 216 & 141 \\
\hline $\mathrm{Nb}$ & 123 & 18 & 6 & 35 & 51 & 25 \\
\hline $\mathrm{Ba}$ & 1204 & 257 & 333 & 293 & 274 & 235 \\
\hline La & 46 & 47 & 23 & 32 & 27 & 23 \\
\hline $\mathrm{Ce}$ & 100 & 76 & 52 & 67 & 124 & 59 \\
\hline $\mathrm{Pb}$ & 5 & 15 & 6 & 6 & 7 & 6 \\
\hline Th & 1 & 13 & 2 & 4 & 2 & 3 \\
\hline U & 1 & 4 & 1 & 2 & 1 & 1 \\
\hline$Q$ & 0.00 & 0.00 & 0.00 & 0.00 & 0.00 & 0.00 \\
\hline Or & 20.62 & 30.73 & 1.65 & 3.96 & 4.79 & 4.14 \\
\hline$A b$ & 56.87 & 53.79 & 30.91 & 14.68 & 9.05 & 22.01 \\
\hline An & 4.76 & 6.36 & 21.32 & 22.80 & 8.13 & 27.25 \\
\hline $\mathrm{Ne}$ & 2.15 & 3.91 & 2.97 & 5.76 & 9.12 & 3.61 \\
\hline $\mathrm{Di}$ & 6.58 & 0.80 & 21.50 & 19.25 & 32.95 & 20.03 \\
\hline Hy & 0.00 & 0.00 & 0.00 & 0.00 & 0.00 & 0.00 \\
\hline Ol & 5.53 & 2.68 & 13.83 & 25.74 & 14.01 & 13.08 \\
\hline Mt & 1.23 & 0.47 & 2.37 & 2.21 & 4.43 & 2.28 \\
\hline Il & 1.16 & 0.46 & 3.40 & 3.63 & 14.72 & 4.56 \\
\hline Ap & 0.33 & 0.09 & 1.52 & 0.88 & 0.99 & 0.83 \\
\hline TOTAL & 99.23 & 99.29 & 99.47 & 98.91 & 98.19 & 97.79 \\
\hline
\end{tabular}




\section{A4.6 USAS Escarpment xenolith analyses}

\begin{tabular}{|c|c|c|c|c|c|c|c|c|}
\hline $\begin{array}{l}\text { Sample } \\
\text { Type }\end{array}$ & $\begin{array}{c}\text { MB69A } \\
\text { Perid } \\
\end{array}$ & $\begin{array}{c}\text { MB69C } \\
\text { Perid }\end{array}$ & $\begin{array}{c}\text { MB69D } \\
\text { Perid }\end{array}$ & $\begin{array}{c}\text { MB69E } \\
\text { Perid }\end{array}$ & $\begin{array}{c}\text { MB69F } \\
\text { Perid }\end{array}$ & $\begin{array}{c}\text { MB69G } \\
\text { Perid }\end{array}$ & $\begin{array}{c}\text { MB69H } \\
\text { Perid }\end{array}$ & $\begin{array}{c}\text { MB69I } \\
\text { Perid }\end{array}$ \\
\hline $\mathrm{SiO}_{2}$ & 44.48 & 44.13 & 44.01 & 44.26 & 44.91 & 44.96 & 44.32 & 45.28 \\
\hline $\mathrm{TiO} 2$ & 0.15 & 0.13 & 0.12 & 0.10 & 0.10 & 0.01 & 0.12 & 0.12 \\
\hline $\mathrm{Al} 2 \mathrm{O} 3$ & 3.68 & 3.24 & 3.34 & 3.24 & 3.36 & 1.76 & 2.76 & 3.82 \\
\hline $\mathrm{Fe} 2 \mathrm{O} 3$ total & 8.94 & 9.32 & 9.51 & 9.01 & 8.03 & 8.07 & 9.62 & 8.91 \\
\hline $\mathrm{MnO}$ & 0.14 & 0.15 & 0.14 & 0.14 & 0.13 & 0.13 & 0.14 & 0.14 \\
\hline $\mathrm{MgO}$ & 37.18 & 37.38 & 38.11 & 38.75 & 38.28 & 42.48 & 40.52 & 37.23 \\
\hline $\mathrm{CaO}$ & 3.29 & 3.57 & 3.09 & 3.08 & 3.38 & 1.54 & 2.47 & 3.17 \\
\hline $\mathrm{Na} 2 \mathrm{O}$ & 0.69 & 0.35 & 0.55 & 0.61 & 0.59 & 0.41 & 0.36 & 0.34 \\
\hline $\mathrm{K} 2 \mathrm{O}$ & 0.05 & 0.05 & 0.02 & 0.03 & 0.02 & 0.02 & 0.01 & 0.03 \\
\hline $\mathrm{P} 2 \mathrm{O} 5$ & 0.01 & 0.01 & 0.01 & 0.01 & 0.01 & 0.01 & 0.01 & 0.00 \\
\hline LOI & 1.10 & 1.77 & 0.35 & 0.47 & 0.61 & 0.17 & 0.00 & 1.12 \\
\hline TOTAL & 99.71 & 100.10 & 99.25 & 99.70 & 99.42 & 99.56 & 100.33 & 100.16 \\
\hline Mg\# & 89.17 & 88.82 & 88.81 & 89.49 & 90.42 & 91.25 & 89.30 & 89.22 \\
\hline Sc & 12 & 16 & 16 & 11 & 12 & 8 & 10 & 20 \\
\hline V & 77 & 79 & 77 & 72 & 85 & 43 & 64 & 81 \\
\hline $\mathrm{Cr}$ & 2736 & 2564 & 2459 & 2998 & 3403 & 3052 & 2246 & 2808 \\
\hline $\mathrm{Ni}$ & 1978 & 2152 & 2143 & 2183 & 2130 & 2319 & 2235 & 1962 \\
\hline $\mathrm{Cu}$ & 24 & 23 & 26 & 20 & 32 & $<1$ & 22 & 23 \\
\hline $\mathrm{Zn}$ & 55 & 54 & 57 & 53 & 51 & 48 & 55 & 55 \\
\hline $\mathrm{Ga}$ & 4 & 3 & 4 & 3 & 4 & 2 & 3 & 3 \\
\hline As & $<1$ & $<1$ & $<1$ & $<1$ & $<1$ & $<1$ & $<1$ & $<1$ \\
\hline $\mathrm{Rb}$ & $<1$ & 2 & $<1$ & $<1$ & $<1$ & 1 & $<1$ & 1 \\
\hline $\mathrm{Sr}$ & 15 & 20 & 9 & 5 & 6 & 9 & 10 & 34 \\
\hline$Y$ & 1 & $<1$ & 1 & 1 & $<1$ & $<1$ & $<1$ & 1 \\
\hline $\mathrm{Zr}$ & 5 & 5 & 2 & 2 & $<1$ & $<1$ & 10 & 3 \\
\hline $\mathrm{Nb}$ & 2 & 2 & 1 & 2 & $<1$ & 1 & $<1$ & 2 \\
\hline $\mathrm{Ba}$ & $<1$ & 7 & $<1$ & $<1$ & $<1$ & 6 & 3 & $<1$ \\
\hline $\mathrm{La}$ & $<1$ & 1 & $<1$ & $<1$ & $<1$ & 1 & $<1$ & 5 \\
\hline $\mathrm{Ce}$ & 1 & 3 & $<1$ & $<1$ & 1 & $<1$ & 5 & 6 \\
\hline $\mathrm{Pb}$ & 3 & 4 & 3 & 1 & 4 & 3 & 3 & 4 \\
\hline Th & $<1$ & 1 & $<1$ & $<1$ & $<1$ & $<1$ & $<1$ & 2 \\
\hline U & $<1$ & $<1$ & 1 & $<1$ & $<1$ & 1 & $<1$ & $<1$ \\
\hline Q & 0.00 & 0.00 & 0.00 & 0.00 & 0.00 & 0.00 & 0.00 & 0.00 \\
\hline Or & 0.30 & 0.30 & 0.12 & 0.18 & 0.12 & 0.12 & 0.06 & 0.18 \\
\hline $\mathrm{Ab}$ & 5.84 & 2.96 & 4.65 & 5.16 & 4.99 & 3.47 & 3.05 & 2.88 \\
\hline An & 6.80 & 7.12 & 6.59 & 6.01 & 6.46 & 2.90 & 5.89 & 8.81 \\
\hline $\mathrm{Ne}$ & 0.00 & 0.00 & 0.00 & 0.00 & 0.00 & 0.00 & 0.00 & 0.00 \\
\hline $\mathrm{Di}$ & 7.46 & 8.30 & 6.85 & 7.26 & 8.07 & 3.67 & 4.97 & 5.46 \\
\hline Hy & 13.04 & 16.03 & 12.79 & 11.43 & 14.60 & 18.89 & 15.16 & 22.76 \\
\hline Ol & 62.54 & 60.92 & 65.17 & 66.63 & 62.27 & 68.19 & 68.47 & 56.41 \\
\hline Mt & 1.54 & 1.61 & 1.64 & 1.55 & 1.38 & 1.39 & 1.66 & 1.54 \\
\hline Il & 0.28 & 0.25 & 0.23 & 0.19 & 0.19 & 0.02 & 0.23 & 0.23 \\
\hline AP & 0.02 & 0.02 & 0.02 & 0.02 & 0.02 & 0.02 & 0.02 & 0.00 \\
\hline TOTAL & 97.82 & 97.51 & 98.06 & 98.43 & 98.10 & 98.67 & 99.51 & 98.27 \\
\hline
\end{tabular}




\section{Appendix five \\ RARE EARTH ELEMENT ANALYSES AND MINERAL SEPARATION TECHNIQUES}

\section{Introduction}

Trace Elements for selected rocks were also determined using the instrumental neutron activation analysis (INAA) method, in the Department of Geoscience, New Mexico Institute of Mining and Technology. Where elements were determined by X-Ray Fluorescence (XRF) as well as INAA, XRF data was used for all plots, with the exception of REE normalised diagrams, where INAA data was used. Using only a single dataset for plots provides internal consistency in the data set.

INAA samples were prepared as for XRF analyses (Appendix Four). Sample sixes ranged from 30 and $120 \mathrm{mg}$, depending on rock type and sample type as follows;
Granulite rock $\quad 70-110 \mathrm{mg}$
Pyroxenite rock $50-70 \mathrm{mg}$
Peridotite rock $\quad 80-120 \mathrm{mg}$
Granulite Clinopyroxene $\quad 40-60 \mathrm{mg}$ Pyroxenite Clinopyroxene $40-50 \mathrm{mg}$ Peridotite Clinopyroxene $30-50 \mathrm{mg}$

The samples were irradiated and counted after 7 days, and again after 40 days. A full detail of the method can be found in Gamble and Kyle (1987).

The estimated accuracy (P.R. Kyle, writ. comm.) of analyses determined by INAA is as follows:

$\begin{array}{lll}\text { very good } & \mathbf{2} \% \text { or less } & \mathrm{La}, \mathrm{Eu}, \mathrm{Tb}, \mathrm{Th} \\ \text { good } & 2-4 \% & \mathrm{Sc}, \mathrm{Cr}, \mathrm{Rb}, \mathrm{Ce}, \mathrm{Sm}, \mathrm{Yb}, \mathrm{Lu}, \mathrm{Hf}, \mathrm{Ta} \\ \text { rough } & \mathbf{5 - 1 0} \% & \mathrm{Zn}, \mathrm{As}, \mathrm{Br}, \mathrm{Ba}, \mathrm{Nd}, \\ \text { very rough } & \text { up to } 25 \% & \mathrm{Ni}, \mathrm{Sr}\end{array}$




\section{Abbreviations}

Rock sample abbreviations are presented in Appendix Four. Others used here are:

$$
\begin{aligned}
& \text { cpx - clinopyroxene sample re - repeat analysis } \\
& \text { wr - whole rock sample }
\end{aligned}
$$

\section{Mineral Separation Techniques}

Xenoliths from Antarctica are commonly well preserved and unweathered due to the desert environment. However, the oxidised nature of the xenoliths has resulted in some minerals with oxide inclusions and coatings. Along with their high densities this makes the separation of some minerals difficult.

To overcome the difficulties with coated or altered minerals, a suitable grain size for mineral separations must be established. Typically a fraction of $1 / 5$ to $1 / 10$ the mean grainsize is suitable. In the case of Antarctic xenoliths, a grain size of $2-3 ø(0.25-0.125 \mathrm{~mm})$ was selected. This is the largest grain size whereby samples are large enough to examine easily under a microscope and allow easy hand picking, while being small enough to produce monomineralic grains without any coatings of oxides.

Minimising the number of analytical techniques is preferred so as to restrict the possibility of contamination. With further 'handling' of samples the possibility of contamination is increased. This is especially important when dealing with small amounts of sample as for isotopic and REE analyses. Equipment used must be thoroughly cleaned at each step; especially the sieve stack and the frantz magnetic separator which easily produce contaminants.

\section{Sample Crushing}

Rock chips of samples for mineral separation were crushed in a tema for a few seconds to produce the required grain size before mineral separations were undertaken. Further discussion of techniques used for crushing minerals can be found in Appendix Four.

\section{Dry Sieving}

To obtain a uniform grain size of 2-3 ø, all samples were dry sieved using a Fritsch shaker. Full details of procedures for grain size analyses can be found in Barrett and Brooker (1989). The steps taken were: 
1. Samples were sieved for 18 minutes ( 6 mins on intermediate setting, 6 mins on micro setting, 6 mins on intermediate) at amplitude 6;

2. Fractions were collected for 1.5-2.0 , and for 2.0-3.0 ø. All other fractions were discarded.

3. Both fractions were then placed in beakers and washed of adhering fine grains by squirting distilled water into the beakers, stirring, and pouring off the clouded water. This was continued until the water ran clear.

4. Samples were then oven dried at $40{ }^{\circ} \mathrm{C}$ overnight before placing in vials ready for mineral separation.

\section{Magnetic Separations}

Mineral separations were undertaken using a Frantz isodynamic magnetic separator. As a knowledge of the magnetic susceptibilities of the minerals concerned is needed for this method, experiments were undertaken on a number of samples at many settings to determine the optimum conditions for separating minerals from granulites, pyroxenites and peridotites. A hand magnet in a plastic bag was passed over all samples to remove grains of magnetic oxides which can easily clog the Frantz separator, and provide contaminants. A slope of $20^{\circ}$ for the magnetic separator was used in all cases. The procedures for different rock types are outlined below.

\section{Granulites}

1. At a current of 0.5 amps, plagioclase is the only mineral phase not affected by the magnetic field. A sample containing only plagioclase grains (the residual; i.e. unaffected grains) was obtained.

2. The sample was then passed through a $0.1 \mathrm{amp}$ current. Highly magnetic grains and grains well coated with oxides (oxidised olivine and orthopyroxene) were separated off and discarded. The unaffected residual sample was then separated for clinopyroxene.

3. Experiments in separations failed to obtain a sample rich in clinopyroxene. As the oxides had already been separated off, only clinopyroxene and the more susceptible plagioclase (and unoxidised olivine and orthopyroxene) grains were affected by the current. The greatest concentration of clinopyroxene 
(approximately $70 \%$ ) was obtained at a current of 2.5 amps. The residual grains (rich in plagioclase) were discarded. Further runs at 2.5 amps failed to increase the proportion of clinopyroxene significantly, and only succeeded in reducing the size of the separation. Multiple runs are therefore discouraged unless there is sufficient sample to do so.

4. In order to purify the samples, both were floated in heavy liquids and hand picked of impurities (other mineral phases and altered minerals). The resultant samples were almost (if not totally) $100 \%$ pure.

\section{Pyroxenites}

The problems encountered in separating granulite minerals were compounded for separating pyroxenite minerals, which are often oxidised, and contain mineral phases with similar magnetic properties. For isotopic and REE analyses only clinopyroxenes were separated. Other mineral phases were not separated in this study, but because of similar magnetic susceptibilities of the other grains the use of heavy liquids is recommended.

N.B. Kaersutite was not a major phase in any of the pyroxenites. Separating kaersutite from clinopyroxene by magnetic properties and their identification under the microscope at the grain size was considered too difficult, and the use of heavy liquids is again recommended for their separation.

1. Any plagioclase present was separated out at 0.5 amps as per the granulite procedure.

2. Highly magnetically susceptible phases were then separated out at a current of 0.1 amps and discarded.

3. A current of 0.25 amps was again found to be the best for separating clinopyroxenes. Unlike the granulite samples however, it is the residue (grains unaffected by the current) that was rich in clinopyroxene. The other split is a mix of clinopyroxene and olivine or orthopyroxene.

4. The sample was then hand picked of any undesirable material.

\section{Peridotites}

Peridotites were only separated for clinopyroxenes (for REE analyses). Optimum conditions for the separation of other phases were also determined. 
1. A current of 0.4 amps was used to separate clinopyroxenes, which were unaffected by the current. This split was not totally impurity free as splits using a 0.5 amp current are, but as clinopyroxene is not an abundant phase, the lower current was preferred to obtain a larger sample.

2. The sample was then passed through a 0.1 amp current to isolate highly magnetic minerals.

3. A run at 0.25 amps resulted in a split that was a mix of olivine and orthopyroxene (rich in the latter). At 3.0 amps a split that was also a mix of olivine and orthopyroxene was obtained, as well as a split almost purely olivine. A run at 0.3 amps for olivine (magnetic split), followed by 0.25 amps for orthopyroxene (magnetic split), is therefore recommended.

4. Samples were then hand picked of any impurities.

\section{Summary of magnetic separations}

Granulites:

$0.5 \mathrm{~A}$ - plagioclase (n)

$0.1 \mathrm{~A}$ - discard (m)

$0.25 \mathrm{~A}$ - Clinopyroxene $(\mathrm{m})$
Pyroxenites:

$0.5 \mathrm{~A}$ - plagioclase $(\mathrm{n})$

$0.1 \mathrm{~A}$ - discard (m)
Peridotites:

$0.4 \mathrm{~A}$ - clinopyroxene ( $\mathrm{n}$ )

$0.1 \mathrm{~A}$ - discard $(\mathrm{m})$

$0.3 \mathrm{~A}$ - olivine $(\mathrm{m})$

$0.25 \mathrm{~A}$ - Orthopyroxene $(\mathrm{m})$

$(\mathrm{n})=$ non-magnetic split, $(\mathrm{m})=$ magnetic split

\section{Heavy Liquids}

Sodium polytungstate was the preferred heavy liquid as it is non toxic. Although it is generally only useful for densities up to approximately $3.1 \mathrm{~g} / \mathrm{cc}$, and has problems with densities above $2.7 \mathrm{~g} / \mathrm{cc}$, it could still be used if sufficient sample was present.

Densities of $3 \mathrm{~g} / \mathrm{cc}$ were used to float off plagioclase in granulites and pyroxenites. Such a high density was necessary because of the oxidised nature of the grains, which makes them denser than unoxidised grains. At this high density, settling of grains in the liquid was not complete. The heavy fraction was filtered off and washed. This was a pure clinopyroxene fraction and was used for analyses. The remaining liquid, except for the very top containing the floated fraction, was then filtered and evaporated for reuse. The grains were a mixture of heavy and light, and were discarded. The float was then filtered off and washed. 
This was a pure plagioclase fraction and was added to that produced by magnetic separation. 
A5.1 MBL xenolith trace and rare earth element analyses

\begin{tabular}{|c|c|c|c|c|c|c|c|c|c|c|}
\hline $\begin{array}{l}\text { Sample } \\
\text { Type }\end{array}$ & $\begin{array}{c}9002961 \\
\text { Gran } \\
\text { rock }\end{array}$ & $\begin{array}{c}\text { 190029H1 } \\
\text { Gran } \\
\text { rock }\end{array}$ & $\begin{array}{c}190029 \mathrm{H} \\
\text { Gran } \\
\text { cpx }\end{array}$ & $\begin{array}{c}190029 \mathrm{H} 1 \\
\text { Gran } \\
\text { cpx re }\end{array}$ & $\begin{array}{c}90031 \mathrm{D} \\
\text { Gran } \\
\text { rock }\end{array}$ & $\begin{array}{c}90033 \mathrm{C} \\
\text { Pyxite } \\
\text { rock }\end{array}$ & $\begin{array}{c}90033 \mathrm{C} \\
\text { Pyxite } \\
\text { rock re }\end{array}$ & $\begin{array}{c}90033 \mathrm{C} \\
\text { Pyxite } \\
\text { rock re }\end{array}$ & $\begin{array}{c}90033 X \\
\text { Gran } \\
\text { rock }\end{array}$ & $\begin{array}{c}90039 \mathrm{G} \\
\text { Gran } \\
\text { rock }\end{array}$ \\
\hline Sc & 5.75 & 24.86 & 87.8 & 24.79 & 20.32 & 34.6 & 34.7 & 34.4 & 23.99 & 29.08 \\
\hline $\mathrm{Cr}$ & 2.3 & 10 & 16 & 11.6 & 3.8 & 872 & 875 & 872 & 24.3 & 10.4 \\
\hline $\mathrm{Ni}$ & 0 & 49 & 0. & 0 & 58 & 482 & 472 & 450 & 0 & 0 \\
\hline $\mathrm{Zn}$ & 32 & 48 & 108 & 50 & 61 & 88 & 85 & 70 & 101 & 80 \\
\hline As & 0 & 0 & 1.7 & 0 & 0 & 0 & 0 & 0 & 0 & 0 \\
\hline $\mathrm{Br}$ & 0.3 & 0 & 0 & 0 & 0 & 0.24 & 0 & 0 & 0 & 0 \\
\hline $\mathbf{R b}$ & 7 & 0 & 0 & 0 & 0 & 0 & 0 & 0 & 0 & 0 \\
\hline $\mathrm{Sr}$ & 1110 & 848 & 0 & 850 & 1111 & 530 & 417 & 400 & 780 & 816 \\
\hline $\mathrm{Sb}$ & - & - & - & 0 & - & - & 0 & 0 & - & - \\
\hline Cs & - & - & - & 0.08 & - & - & 0 & 0 & - & - \\
\hline $\mathrm{Ba}$ & 417 & 149 & 0 & 99 & 192 & 142 & 170 & 43 & 268 & 124 \\
\hline $\mathrm{La}$ & 14.94 & 4.07 & 3.24 & 4.18 & 17.83 & 6.52 & 6.61 & 6.49 & 23.78 & 4.35 \\
\hline $\mathrm{Ce}$ & 31.5 & 8.7 & 11.7 & 8.1 & 40.4 & 17.1 & 20.3 & 18.7 & 54.9 & 9.3 \\
\hline Nd & 17 & 5 & 8.3 & 3.9 & 21.1 & 10.7 & 12.8 & 11 & 31.5 & 5 \\
\hline $\mathrm{Sm}$ & 3.49 & 1.3 & 3.3 & 1.31 & 5.61 & 3.85 & 3.93 & 3.87 & 7.45 & 1.53 \\
\hline $\mathrm{Eu}$ & 3.26 & 1.05 & 1.11 & 1.064 & 2.7 & 1.38 & 1.36 & 1.373 & 3.47 & 1.184 \\
\hline $\mathrm{Tb}$ & 0.414 & 0.171 & 0.56 & 0.219 & 0.686 & 0.57 & 0.57 & 0.566 & 0.837 & 0.248 \\
\hline $\mathrm{Yb}$ & 0.56 & 0.39 & 0.97 & 0.4 & 1.14 & 0.93 & 0.99 & 0.93 & 1.05 & 0.47 \\
\hline Lu & 0.063 & 0.047 & 0.187 & 0.077 & 0.128 & 0.122 & 0.138 & 0.131 & 0.151 & 0.053 \\
\hline Hf & 0.37 & 0.94 & 2.95 & 0.93 & 1.02 & 2.26 & 2.29 & 2.11 & 0.67 & 1.17 \\
\hline $\mathrm{Ta}$ & 1.2 & 1 & 3.73 & 0.97 & 1.03 & 1.23 & 1.21 & 1.19 & 0.94 & 1.17 \\
\hline Th & 0.29 & 0.18 & 0 & 0.11 & 0.34 & 0.37 & 0.43 & 0.39 & 0.42 & 0.18 \\
\hline $\begin{array}{l}\text { Sample } \\
\text { Type }\end{array}$ & $\begin{array}{c}90039 \mathrm{G} \\
\text { Gran } \\
\text { cpx }\end{array}$ & $\begin{array}{c}90039 S a \\
\text { Pyxite } \\
\text { rock }\end{array}$ & $\begin{array}{c}90039 \text { Sa } \\
\text { Pyxite } \\
\text { cpx }\end{array}$ & $\begin{array}{c}90039 \mathrm{Sb} \\
\text { Pyxite } \\
\text { rock }\end{array}$ & $\begin{array}{c}90039 Y \\
\text { Pyxite } \\
\text { rock }\end{array}$ & $\begin{array}{c}90040 \mathrm{E} \\
\text { Perid } \\
\text { rock }\end{array}$ & $\begin{array}{c}\text { 90040E } \\
\text { Perid } \\
\text { cpx }\end{array}$ & $\begin{array}{c}90040 \mathrm{H} \\
\text { Perid } \\
\text { rock }\end{array}$ & $\begin{array}{c}90040 \mathrm{I} \\
\text { Gran } \\
\text { rock }\end{array}$ & $\begin{array}{c}90040 \mathrm{U} \\
\text { Perid } \\
\text { rock } \\
\end{array}$ \\
\hline Sc & 87.7 & 51 & 33.6 & 4.11 & 38.8 & 12.95 & 68.4 & 12.76 & 23.64 & 7 \\
\hline $\mathrm{Cr}$ & 17.9 & 795 & 314 & 14.9 & 947 & 2286 & 5025 & 657 & 226 & 3016 \\
\hline $\mathrm{Ni}$ & 252 & 449 & 188 & 173 & 556 & 1657 & 451 & 2047 & 181 & 2578 \\
\hline $\mathrm{Zn}$ & 83 & 119 & 75 & 60 & 185 & 39 & 42 & 57 & 45 & 48 \\
\hline As & 0 & 0 & 0 & 1.1 & 0 & 0 & 0 & 0 & -0 & - \\
\hline $\mathrm{Br}$ & 0 & 0 & 0 & 0.25 & 0.35 & 0 & 0 & 0 & 0 & 0 \\
\hline $\mathbf{R b}$ & 0 & 0 & 0 & 11 & 10 & 6 & 0 & 0 & 0 & 0 \\
\hline $\mathrm{Sr}$ & 0 & 0 & 528 & 1720 & 141 & 0 & 0 & 0 & 0 & 0 \\
\hline $\mathrm{Sb}$ & - & 0 & 0 & 0 & 0 & 0 & 0.2 & 0 & 0.1 & 0 \\
\hline Cs & - & 0 & 0 & 0.18 & 0.31 & 0 & 0.21 & 0.14 & 0.06 & 0 \\
\hline $\mathrm{Ba}$ & 0 & 45 & 49 & 222 & 0 & 0 & 0 & 13 & 0 & 0 \\
\hline La & 4.29 & 2.65 & 3.83 & 8.33 & 3.44 & 0.51 & 1.02 & 1.5 & 1.17 & 0.17 \\
\hline $\mathrm{Ce}$ & 12.9 & 10 & 10.3 & 16.4 & 10.1 & 2.2 & 1.9 & 3.8 & 4.6 & 0.8 \\
\hline Nd & 10 & 10.9 & 0 & 6.2 & 0 & 0 & 0 & 0 & 4.2 & 0.4 \\
\hline $\mathrm{Sm}$ & 4.01 & 3.68 & 2.88 & 1.21 & 2.54 & 0.23 & 1.38 & 0.75 & 1.69 & 0.01 \\
\hline Eu & 1.48 & 1.26 & 1.13 & 1.144 & 0.89 & 0.097 & 0.57 & 0.319 & 0.575 & 0 \\
\hline $\mathrm{Tb}$ & 0.62 & 0.68 & 0.507 & 0.133 & 0.396 & 0.07 & 0.38 & 0.145 & 0.314 & 0.035 \\
\hline $\mathrm{Yb}$ & 1.24 & 1.35 & 0.97 & 0.27 & 0.9 & 0.34 & 1.8 & 0.42 & 0.63 & 0.02 \\
\hline Lu & 0.236 & 0.179 & 0.124 & 0.042 & 0.139 & 0.04 & 0.312 & 0.043 & 0.077 & 0.004 \\
\hline Hf & 2.83 & 2.28 & 1.55 & 0.73 & 1.56 & 0.15 & 0.62 & 0.6 & 1 & 0 \\
\hline $\mathrm{Ta}$ & 1.48 & 0.46 & 0.53 & 1.5 & 0.47 & 0.49 & 0.08 & 0.35 & 0.03 & 0.23 \\
\hline Th & 0 & 0 & 0 & 0.39 & 0.18 & 0.14 & 0.44 & 0.1 & 0 & 0.05 \\
\hline
\end{tabular}




\begin{tabular}{|c|c|c|c|c|c|c|c|c|c|c|}
\hline $\begin{array}{l}\text { Sample } \\
\text { Type }\end{array}$ & $\begin{array}{l}90040 \mathrm{U} 1 \\
\text { Perid } \\
\text { rock }\end{array}$ & $\begin{array}{c}90041 \mathrm{~B} \\
\text { Gran } \\
\text { rock }\end{array}$ & $\begin{array}{c}90041 \mathrm{~B} \\
\text { Gran } \\
\mathrm{cpx}\end{array}$ & $\begin{array}{c}90041 \mathrm{C} \\
\text { Gran } \\
\text { rock }\end{array}$ & $\begin{array}{c}90041 C \\
\text { Gran } \\
\text { cpx }\end{array}$ & $\begin{array}{c}\text { 90054Aa } \\
\text { Perid } \\
\text { rock }\end{array}$ & $\begin{array}{l}\text { 90054Ab } \\
\text { Perid } \\
\text { rock }\end{array}$ & $\begin{array}{l}\text { b 90054B } \\
\text { Perid } \\
\text { rock }\end{array}$ & $\begin{array}{c}\text { 90054B } \\
\text { Perid } \\
\text { cpx }\end{array}$ & $\begin{array}{c}90054 \mathrm{C} \\
\text { Pyxite } \\
\text { rock }\end{array}$ \\
\hline $\mathrm{Sc}$ & 14.76 & 16.81 & 42.8 & 25.14 & 92.5 & 27.29 & 6.96 & 13.22 & 58.8 & 61.3 \\
\hline $\mathrm{Cr}$ & 2785 & 228.8 & 572 & 79.4 & 292 & 5951 & 1139 & 2806 & 6196 & 985 \\
\hline $\mathrm{Ni}$ & 1978 & 269 & 318 & 84. & 0 & 1798 & 2711 & 1984 & 450 & 352 \\
\hline $\mathrm{Zn}$ & 39 & 47 & 68 & 24 & 65 & 50 & 48 & 47 & 23 & 95 \\
\hline As & - & - & - & - & - & - & - & - & - & - \\
\hline $\mathrm{Br}$ & 0 & 0 & 0 & 0 & 0 & 0.44 & 0 & 0 & 0 & 42 \\
\hline $\mathbf{R b}$ & 0 & 0 & 0 & 0 & 0 & 8 & 0 & - & - & - \\
\hline $\mathrm{Sr}$ & 0 & 611 & 273 & 628 & 0 & 0 & 0 & 0 & 243 & 0 \\
\hline Sb & 0 & 0 & 0 & 0.1 & 0 & 0 & 0 & 0 & 0.2 & 0 \\
\hline Cs & 0 & 0.1 & 0 & 0 & 0.18 & 0 & 0 & 0 & 0.22 & 0 \\
\hline Ba & 17 & 56 & 82 & 41 & 57 & 18 & 0 & - & - & - \\
\hline $\mathrm{La}$ & 0.06 & 1.62 & 2.1 & 2.9 & 2.92 & 0.8 & 0.23 & 1.62 & 12.76 & 2.98 \\
\hline $\mathrm{Ce}$ & 0 & 3.6 & 5.5 & 7 & 7.3 & 3.1 & 0.48 & 4.8 & 40.1 & 10.9 \\
\hline $\mathrm{Nd}$ & 0 & 2.4 & 0 & 0 & 0 & 2.4 & 0 & 0 & 0 & 0 \\
\hline Sm & 0.17 & 0.54 & 1.27 & 0.81 & 1.97 & 0.57 & 0.1 & 0.55 & 4.93 & 2.94 \\
\hline Eu & 0.08 & 0.437 & 0.68 & 0.448 & 0.57 & 0.259 & 0.036 & 0.177 & 1.63 & 1 \\
\hline $\mathrm{Tb}$ & 0.076 & 0.111 & 0.32 & 0.133 & 0.41 & 0.161 & 0.02 & 0.072 & 0.7 & 0.46 \\
\hline $\mathrm{Yb}$ & 0.34 & 0.23 & 0.72 & 0.4 & 1.23 & 0.38 & 0.09 & 0.37 & 1.79 & 1.15 \\
\hline $\mathrm{Lu}$ & 0.055 & 0.034 & 0.088 & 0.051 & 0.165 & 0.065 & 0.009 & 0.052 & 0.277 & 0.17 \\
\hline Hf & 0.09 & 0.2 & 0.61 & 0.64 & 1.28 & 0.23 & 0.14 & 0.24 & 1.7 & 1.96 \\
\hline $\mathrm{Ta}$ & 0.18 & 0.14 & 0.19 & 0.49 & 0.47 & 0.19 & 0.3 & 0.24 & 0.27 & 0.32 \\
\hline Th & 0 & 0 & 0 & 0.57 & 0.83 & 0.12 & 0 & 0 & 0.18 & 0 \\
\hline$\overline{\text { Sample }}$ & $90054 \mathrm{E}$ & $90054 \mathrm{~K}$ & $90054 \mathrm{~K}$ & PK4G & PK4L & PK4C1 & PK4C1 & PK4G1 & PK4H1a F & $\overline{\text { PK4H1b }}$ \\
\hline Type & $\begin{array}{l}\text { Perid } \\
\text { rock }\end{array}$ & $\begin{array}{c}\text { Perid } \\
\text { rock }\end{array}$ & $\begin{array}{c}\text { Perid } \\
\mathrm{cpx}\end{array}$ & $\begin{array}{c}\text { Perid } \\
\text { rock }\end{array}$ & $\begin{array}{l}\text { Pyxite } \\
\text { rock }\end{array}$ & $\begin{array}{l}\text { Gran } \\
\text { rock }\end{array}$ & $\begin{array}{c}\text { Gran } \\
\text { cpx }\end{array}$ & $\begin{array}{l}\text { Perid } \\
\text { rock }\end{array}$ & $\begin{array}{l}\text { Perid } \\
\text { rock }\end{array}$ & $\begin{array}{c}\text { Perid } \\
\text { rock } \\
\end{array}$ \\
\hline $\mathrm{Sc}$ & 11.25 & 54.9 & 45.3 & 37.5 & 50.3 & 39.8 & 71.9 & 7.56 & 3.93 & 26.41 \\
\hline $\mathrm{Cr}$ & 2936 & 335 & 439 & 5399 & 1216 & 421 & 685 & 2187 & 1580 & 4227 \\
\hline $\mathrm{Ni}$ & 2185 & 184 & 343 & 1283 & 223 & 255 & 193 & 2216 & 2790 & 1454 \\
\hline $\mathrm{Zn}$ & 54 & 117 & 178 & 24 & 62 & 63 & 60 & 41 & 51 & 39 \\
\hline As & - & - & - & - & - & 0 & 0 & 0 & 0.33 & 0 \\
\hline $\mathrm{Br}$ & 0 & 0 & 0 & 0 & 0 & 0 & 0 & 0 & 0.29 & 0 \\
\hline $\mathbf{R b}$ & - & - & - & - & - & - & - & - & - & - \\
\hline Sr & 0 & 0 & 0 & 163 & 0 & 262 & 0 & 0 & 0 & 0 \\
\hline $\mathrm{Sb}$ & 0 & 0 & 0 & 0 & 0 & - & - & - & - & - \\
\hline Cs & 0.03 & 0.04 & 0 & 0 & 0 & 0.23 & 0 & 0 & 0 & 0.1 \\
\hline $\mathrm{Ba}$ & - & - & - & - & - & 86 & 0 & 0 & 0 & 30 \\
\hline La & 0.94 & 2.19 & 1.69 & 6.89 & 0.58 & 0.95 & 1.24 & 0.09 & 0.19 & 1.85 \\
\hline $\mathrm{Ce}$ & 2.7 & 8.3 & 7.2 & 12 & 2.5 & 3.2 & 6.8 & 0 & 0 & 4.6 \\
\hline $\mathrm{Nd}$ & 1.8 & 0 & 6 & 3.6 & 0 & - & - & - & - & - \\
\hline $\mathrm{Sm}$ & 0.33 & 3.28 & 2.53 & 0.46 & 2.08 & 1.46 & 3 & 0.03 & 0.02 & 0.43 \\
\hline Eu & 0.092 & 1.24 & 0.99 & 0.155 & 0.92 & 0.782 & 1.26 & 0.02 & 0.029 & 0.167 \\
\hline $\mathrm{Tb}$ & 0.092 & 0.62 & 0.5 & 0.086 & 0.38 & 0.326 & 0.71 & 0 & 0.026 & 0.12 \\
\hline $\mathrm{Yb}$ & 0.32 & 1.38 & 1.01 & 0.46 & 0.61 & 0.95 & 1.83 & 0.09 & 0 & 0.59 \\
\hline Lu & 0.056 & 0.187 & 0.152 & 0.07 & 0.102 & 0.119 & 0.209 & 0.012 & 0.014 & 0.082 \\
\hline Hf & 0.11 & 2.07 & 1.35 & 0.33 & 0.38 & 0.79 & 1.32 & 0 & 0 & 0.29 \\
\hline $\mathrm{Ta}$ & 0.23 & 0.23 & 0.13 & 0.49 & 0 & 0.19 & 0.05 & 0.22 & 0.13 & 0.25 \\
\hline Th & 0 & 0.1 & 0.15 & 0.56 & 0.09 & 0 & 0 & $0^{\circ}$ & 0 & 0.18 \\
\hline
\end{tabular}




\begin{tabular}{|c|c|c|c|c|c|c|c|c|c|c|}
\hline $\begin{array}{l}\text { Sample } \\
\text { Type }\end{array}$ & $\begin{array}{c}\text { PK4H1b } \\
\text { Perid } \\
\text { cpx }\end{array}$ & $\begin{array}{l}\text { PK4H1c } \\
\text { Perid } \\
\text { rock }\end{array}$ & $\begin{array}{l}\text { PK4H1c } \\
\text { Perid } \\
\text { cpx }\end{array}$ & $\begin{array}{c}\text { PK4L1 } \\
\text { Gran } \\
\text { rock }\end{array}$ & $\begin{array}{c}\text { PK4N1a } \\
\text { Perid } \\
\text { rock } \\
\end{array}$ & $\begin{array}{l}\text { PK4N1a } \\
\text { Perid } \\
\text { cpx } \\
\end{array}$ & $\begin{array}{c}\text { PK4N1f } \\
\text { Perid } \\
\text { cpx } \\
\end{array}$ & $\begin{array}{l}\text { PK4N1f } \\
\text { Perid } \\
\text { rock } \\
\end{array}$ & $\begin{array}{l}\text { PK5D } \\
\text { Perid } \\
\text { rock }\end{array}$ & $\begin{array}{l}\text { PK5J } \\
\text { Perid } \\
\text { rock }\end{array}$ \\
\hline Sc & 56.1 & 15.07 & 54.1 & 42.7 & 44.6 & 39.5 & 13.62 & 57.9 & 5.27 & 13.18 \\
\hline $\mathrm{Cr}$ & 6629 & 2565 & 4626 & 365 & 4377 & 422 & 2669 & 4799 & 1535 & 2812 \\
\hline $\mathrm{Ni}$ & 511 & 2127 & 499. & 259 & 1495 & 263 & 2219 & 526 & 2527 & 2047 \\
\hline $\mathrm{Zn}$ & 34 & 41 & 24 & 65 & 29 & 63 & 51 & 41 & 44 & 47 \\
\hline As & 0 & 0 & 0 & 0 & 0 & 1.2 & 0.25 & 0 & 0 & 0 \\
\hline $\mathrm{Br}$ & 0 & 0 & 0 & - & - & - & - & - & - & - \\
\hline $\mathbf{R b}$ & - & - & - & - & - & - & - & - & - & - \\
\hline Sr & 0 & 0 & 0 & 314 & 0 & 443 & 0 & 0 & 137 & 0 \\
\hline Sb & - & - & - & - & - & - & - & - & - & - \\
\hline Cs & 0 & 0 & 0 & 0 & 0.17 & 0.3 & 0 & 0 & 0 & 0 \\
\hline $\mathbf{B a}$ & 0 & 0 & 37 & 0 & 0 & 45 & 0 & 96 & 0 & 0 \\
\hline $\mathrm{La}$ & 4.74 & 0.84 & 4.65 & 1 & 0.53 & 0.96 & 0.55 & 0.64 & 0.18 & 0 \\
\hline $\mathrm{Ce}$ & 11.3 & 2.4 & 10.9 & 3.8 & 3.1 & 2.9 & 0 & 3.7 & 0 & 0 \\
\hline Nd & - & - & - & - & - & - & - & - & - & - \\
\hline $\mathrm{Sm}$ & 1.36 & 0.24 & 1.18 & 1.69 & 1.33 & 1.52 & 0.18 & 1.35 & 0.04 & 0.12 \\
\hline Eu & 0.51 & 0.103 & 0.447 & 0.844 & 0.489 & 0.8 & 0.072 & 0.53 & 0.01 & 0.037 \\
\hline $\mathrm{Tb}$ & 0.36 & 0 & 0.36 & 0.407 & 0.374 & 0.348 & 0.063 & 0.36 & 0 & 0.042 \\
\hline $\mathrm{Yb}$ & 1.4 & 0.31 & 1.36 & 1.19 & 1.25 & 1 & 0.29 & 1.52 & 0 & 0.26 \\
\hline $\mathrm{Lu}$ & 0.206 & 0.049 & 0.206 & 0.159 & 0.162 & 0.119 & 0.043 & 0.219 & 0.013 & 0.041 \\
\hline $\mathrm{Hf}$ & 0.91 & 0.17 & 0.58 & 1.2 & 0.78 & 0.72 & 0 & 0.82 & 0 & 0.12 \\
\hline Ta & 0.12 & 0.14 & 0.17 & 0.15 & 0.22 & 0.2 & 0.23 & 0 & 0.17 & 0.15 \\
\hline Th & 0.57 & 0 & 0.6 & 0.17 & 0 & 0 & 0 & 0 & 0 & 0 \\
\hline
\end{tabular}

\begin{tabular}{|c|c|c|c|c|c|c|}
\hline $\begin{array}{l}\text { Sample } \\
\text { Type }\end{array}$ & $\begin{array}{c}\text { MB69Ba } \\
\text { Perid } \\
\text { cpx }\end{array}$ & $\begin{array}{l}\text { MB69Bb } \\
\text { Perid } \\
\text { cpx }\end{array}$ & $\begin{array}{c}\text { MB69F } \\
\text { Perid } \\
\text { rock }\end{array}$ & $\begin{array}{c}\text { MB69F } \\
\text { Perid } \\
\text { cpx }\end{array}$ & $\begin{array}{c}\text { MB69H } \\
\text { Perid } \\
\text { rock }\end{array}$ & $\begin{array}{l}\text { Silica } \\
\text { tema }\end{array}$ \\
\hline Sc & 65.2 & 64.3 & 16.14 & 61.8 & 11.75 & 0.22 \\
\hline $\mathrm{Cr}$ & 6696 & 5656 & 3214 & 5770 & 2124 & 4 \\
\hline $\mathrm{Ni}$ & 566 & 462 & 2123 & 259 & 2177 & 0 \\
\hline $\mathrm{Zn}$ & 18 & 49 & 41 & 29 & 45 & 0 \\
\hline As & 0 & 0 & 0 & 0.34 & 0 & 0.32 \\
\hline $\mathrm{Br}$ & - & 0 & 0 & 0.34 & 0 & 0.32 \\
\hline $\mathbf{R b}$ & - & 0 & 0 & 0 & 0 & 9 \\
\hline $\mathrm{Sr}$ & 0 & 0 & 0 & 0 & 0 & 0 \\
\hline Sb & - & 0 & 0 & 0 & 0 & 0.1 \\
\hline Cs & 0 & 0 & 0 & 0 & 0 & 0.2 \\
\hline Ba & 0 & 0 & 30 & 0 & 0 & 104 \\
\hline $\mathrm{La}$ & 0.48 & 0.33 & 0.14 & 0.37 & 0.06 & 1.04 \\
\hline $\mathrm{Ce}$ & 1.1 & 0 & 0 & 0 & 0 & 1.74 \\
\hline $\mathrm{Nd}$ & - & 0 & 0 & 0 & 0 & 0 \\
\hline $\mathrm{Sm}$ & 0.88 & 0.88 & 0.19 & 0.93 & 0.18 & 0.1 \\
\hline Eu & 0.37 & 0.38 & 0.069 & 0.37 & 0 & 0.075 \\
\hline $\mathrm{Tb}$ & 0.37 & 0.4 & 0.07 & 0.29 & 0.074 & 0.027 \\
\hline $\mathbf{Y b}$ & 1.69 & 1.59 & 0.32 & 1.46 & 0.28 & 0 \\
\hline Lu & 0.257 & 0.229 & 0.052 & 0.222 & 0.049 & 0.01 \\
\hline $\mathrm{Hf}$ & 0.87 & 0.83 & 0 & 0.77 & 0.3 & 0.3 \\
\hline Ta & 0.09 & 0 & 0.18 & 0 & 0.12 & 0.68 \\
\hline Th & 0 & 0 & 0 & 0 & 0 & 0.29 \\
\hline
\end{tabular}




\section{Appendix six \\ ISOTOPIC ANALYSES}

\section{Introduction}

$\mathrm{Sr}, \mathrm{Nd}$ and $\mathrm{Pb}$ isotopic ratios were determined on a VG354 multicollector mass spectrometer in the radiogenic isotope laboratory at Royal Holloway University of London following conventional ion exchange separation techniques. Analytical details are described in Thirlwall et al. (in press). $\mathrm{Sr}$ and $\mathrm{Nd}$ isotopic data were determined using the multidynamic procedures outlined in Thirlwall (1991a and 1991b). Pb isotope data was measured statically.

$\mathrm{Sr}$ isotope data is reported relative to a value of 0.71025 for the NBS standard SRM 987. Internal precision ( 2 se) was always better than \pm 0.000015 . However, the mean value obtained for SRM987 during the period of analysis was $0.710248 \pm 20(2 \mathrm{sd}, \mathrm{n}=22)$ and is a truer reflection of data quality. Similarly, the internal precision of $\mathrm{Nd}$ isotope data was always better than \pm 0.000006 and an internal laboratory $\mathrm{Nd}$ standard, Aldrich, yielded a mean value of $0.511421 \pm 11$ ( 2 sd, $n=35$ ) during the period of analysis. This value corresponds to values of 0.512648 and 0.512860 for the international standards BCR- 1 and La Jolla.

$\mathrm{Pb}$ isotope data was corrected for mass fractionation by normalisation to the average value obtained for the NBS standard SRM981 during the period of analysis: 206/204 $16.892 \pm 12,207 / 20415.433 \pm 10$ and 208/204 $36.509 \pm 30(2 \mathrm{sd})$. Internal precision was typically better than $\pm 0.005, \pm 0.005$ and 0.008 for $206 / 204$, $207 / 204$ and 208/204 respectively. 
A6.1 MBL xenolith isotopic analyses

\begin{tabular}{|c|c|c|c|c|c|}
\hline $\begin{array}{l}\text { Sample No. } \\
\text { Type } \\
\end{array}$ & $\begin{array}{c}90029 \mathrm{G} 1 \\
\text { Granulite }\end{array}$ & $\begin{array}{c}90029 \mathrm{H} 1 \\
\text { Granulite }\end{array}$ & $\begin{array}{c}\text { 90031D } \\
\text { Granulite }\end{array}$ & $\begin{array}{c}90033 \mathrm{C} \\
\text { Pyroxenite }\end{array}$ & $\begin{array}{c}90033 X \\
\text { Granulite }\end{array}$ \\
\hline Rb ppm & 2 & 1 & 4 & 3 & 1 \\
\hline Sr ppm & 1190 & 903 & 1122 & 420 & 869 \\
\hline $87 \mathrm{Sr} / 86 \mathrm{Sr}$ & $0.703454+-20$ & $0.703250+-10$ & $0.703490+-9$ & $0.703066+-12$ & $0.703758+-11$ \\
\hline Nd ppm & 17.0 & & 21.1 & & \\
\hline Sm ppm & 3.49 & & 5.61 & & \\
\hline $144 \mathrm{Nd} / 143 \mathrm{Nd}$ & $0.512864+-5$ & & $0.512870+-5$ & & \\
\hline $\mathrm{Pb}$ ppm & 4 & & 6 & & 5 \\
\hline $206 \mathrm{~Pb} / 204 \mathrm{~Pb}$ & 19.364 & & 19.598 & & 18.005 \\
\hline $207 \mathrm{~Pb} / 204 \mathrm{~Pb}$ & 15.650 & & 16.660 & & 15.577 \\
\hline $208 \mathrm{~Pb} / 204 \mathrm{~Pb}$ & 39.008 & & 39.182 & & 37.876 \\
\hline$\Delta 180 \%$ & & 4.62 & 5.33 & & 4.04 \\
\hline
\end{tabular}

\begin{tabular}{lccccc}
\hline $\begin{array}{l}\text { Sample No. } \\
\text { Type }\end{array}$ & $\begin{array}{c}\text { 90039G } \\
\text { Granulite }\end{array}$ & $\begin{array}{c}\text { 90039Sa } \\
\text { Pyroxenite }\end{array}$ & $\begin{array}{c}\text { 90039Sb } \\
\text { Pyroxenite }\end{array}$ & $\begin{array}{c}90039 \mathrm{Y} \\
\text { Pyroxenite }\end{array}$ & $\begin{array}{c}\text { 90040H } \\
\text { Peridotite }\end{array}$ \\
\hline Rb ppm & 1 & 1 & 1 & 4 & 2 \\
Sr ppm & 849 & 67 & 529 & 80 & 41 \\
87Sr/86Sr & $0.703250+-9$ & $0.702886+-17$ & $0.702861-7$ & $0.702931+-11$ & $0.702690+-8$ \\
& & & & & \\
\hline
\end{tabular}

Nd ppm

Sm ppm

6.2

1.21

$144 \mathrm{Nd} / 143 \mathrm{Nd}$

$0.502819+-5$

\section{Pb ppm}

$206 \mathrm{~Pb} / 204 \mathrm{~Pb}$

$207 \mathrm{~Pb} / 204 \mathrm{~Pb}$

$208 \mathrm{~Pb} / 204 \mathrm{~Pb}$
3

17.653

15.539

37.378
5

18.252

15.607

38.087

$\Delta 180 \%$

4.13

3.78 


\begin{tabular}{|c|c|c|c|c|c|}
\hline $\begin{array}{l}\text { Sample No. } \\
\text { Type }\end{array}$ & $\begin{array}{c}90040 I \\
\text { Granulite } \\
\end{array}$ & $\begin{array}{c}\text { 90041B } \\
\text { Granulite } \\
\end{array}$ & $\begin{array}{c}90041 \mathrm{C} \\
\text { Granulite } \\
\end{array}$ & $\begin{array}{c}90054 \mathrm{C} \\
\text { Pyroxenite } \\
\end{array}$ & $\begin{array}{c}90054 \mathrm{~K} \\
\text { Pyroxenite } \\
\end{array}$ \\
\hline Rb ppm & 2 & 1 & 2 & 1 & 1 \\
\hline Sr ppm & 771 & 559 & 588 & 74 & 61 \\
\hline $87 \mathrm{Sr} / 86 \mathrm{Sr}$ & $0.704333+-10$ & $0.704416+-10$ & $0.703283+-10$ & $0.702688+-86$ & $0.702820+-12$ \\
\hline
\end{tabular}

Nd ppm

Sm ppm

$144 \mathrm{Nd} / 143 \mathrm{Nd}$

Pb ppm

$206 \mathrm{~Pb} / 204 \mathrm{~Pb}$

$207 \mathrm{~Pb} / 204 \mathrm{~Pb}$

208Pb/204Pb

\begin{tabular}{lcccc}
\hline $\begin{array}{l}\text { Sample No. } \\
\text { Type }\end{array}$ & $\begin{array}{c}\text { PK4L } \\
\text { Pyroxenite }\end{array}$ & $\begin{array}{c}\text { PK4C1 } \\
\text { Granulite }\end{array}$ & $\begin{array}{c}\text { PK4L1 } \\
\text { Granulite }\end{array}$ & $\begin{array}{c}\text { PK4L1 (cpx) } \\
\text { Granulite }\end{array}$ \\
\hline Rb ppm & 1 & 2 & & 1 \\
Sr ppm & 37 & 302 & 259 \\
87Sr/86Sr & $0.704576+-15$ & $0.704242+-10$ & & $0.704198+-46$ \\
\end{tabular}

Nd ppm

Sm ppm

2.08

1.69

$144 \mathrm{Nd} / 143 \mathrm{Nd} \quad 0.512771+-6$

$0.512819+-5 \quad 0.512818+-5$

$\begin{array}{lcc}\mathrm{Pb} \text { pPm } & 2 & 2 \\ 206 \mathrm{~Pb} / 204 \mathrm{~Pb} & 19.179 & 19.048 \\ 207 \mathrm{~Pb} / 204 \mathrm{~Pb} & 15.647 & 15.650 \\ 208 \mathrm{~Pb} / 204 \mathrm{~Pb} & 38.883 & 38.830\end{array}$




\section{GLOSSARY OF TERMS}

Adiabatic Interior: The region of the mantle with a Rayleigh number far above critical, where convection results in vigorous mixing of the region, disrupting geochemical anomalies. It is overlain by the Thermal Boundary Layer.

AFC: Assimilation - Fractional Crystallisation.

Antarctic Peninsula: One of several tectono-stratigraphic provinces that accreted to East Antarctica in Paleozoic times, to form West Antarctica.

Assimilation - Fractional Crystallisation: The combined process of Assimilation, and Fractional Crystallisation, resulting in the evolution of a silicate melt to a more evolved composition.

Assimilation: The incorporation of foreign material by melting into a magma, resulting in a change in composition.

Conrad discontinuity: A seismic discontinuity typically at $16-18 \mathrm{~km}$ depth in continental crust, where the seismic velocity of P-waves increases from approximately 6.0 to $6.7 \mathrm{~km} / \mathrm{s}$, and inferred to represent the top of the lower crust.

Crust: The outer carapace of the lithosphere, which includes more felsic and thick continental crust, and more mafic and thin oceanic crust.

East Antarctica: A tectono-stratigraphic province of Antarctica, consisting of a stable pre-Cambrian shield. The boundary between East and West Antarctica extends from the Transantarctic Mountains to the Pensacola Mountains and to the eastern Filchner Ice Shelf, all of which form part of East Antarctica.

ECR: Executive Committee Range.

Ellsworth Mountains: One of several tectono-stratigraphic provinces that accreted to East Antarctica in Paleozoic times, to form West Antarctica.

Executive Committee Range: A linear chain of strato-volcanoes in central Marie Byrd Land, comprising (south to north): Mounts Waesche, Sidley, Hartigan, Cumming and Hampton. 
Ford Ranges: A mountain range in the Fosdick Mountains, on the Ruppert Coast of Marie Byrd Land.

Fosdick Mountains: A mountain range on the Ruppert Coast of Marie Byrd Land, which includes the Ford Ranges.

Fractional Crystallisation: The crystallisation of mineral phases by a melt, and their subsequent removal from the melt, resulting in a more evolved melt composition.

Geotherm: The geothermal gradient (the relationship between temperature and depth in the Earth), estimated from P-T calculations of mineral equilibria.

Gondwana: A Mesozoic supercontinent which included Africa, Antarctica, Australia, India, New Zealand and South America.

Granulites: Plagioclase-bearing rocks which have equilibrated to granulite facies (high-temperature metamorphic facies) conditions. Granulite conditions are inferred to be present at lower crustal depths. Mafic granulites are typically derived from mafic igneous rocks, and consist of one or two phases of pyroxene, and/or olivine. Micas, K-feldspar and quartz are absent in mafic granulites.

Heavy Rare Earth Elements: Rare Earth Elements with higher atomic number range of the Lanthanide series (i.e. ...Tm, Yb, Lu).

HFSEs: High Field Strength Elements.

High Field Strength Elements: Trace elements with generally high charges, and small atomic radii (e.g. $\mathrm{Ti}, \mathrm{V}, \mathrm{Zr}$ )

Host Rock: Volcanic rocks that as melts entrained xenoliths, and brought them to the surface. Host melts may or may not interact with the xenoliths, resulting in secondary mineral reactions.

HREEs: Heavy Rare Earth Elements.

Kaersutitisation: A secondary reaction, common in pyroxenite xenoliths, characterised by the replacement of clinopyroxene by kaersutite, due to interaction with hydrous silicate melts.

Large Ion Lithophile Elements: Lithophile elements (elements with a strong affinity for oxygen that generally occur in silicates) with large ionic radii and low charge (e.g. Rb, $\mathrm{Sr}, \mathrm{Ba}$ ).

Light Rare Earth Elements: Rare Earth Elements at the lower atomic number range of the Lanthanide series (i.e. $\mathrm{La}, \mathrm{Ce}, \mathrm{Pr}$..).

LILEs: Large Ion Lithophile Elements.

Lithosphere: The rigid outer carapace of the earth, floating on partially molten asthenospheric mantle. The lithosphere consists of the crust, and lithospheric mantle. 
Lower crust: The lower region of the crust, consisting of granulite and eclogite facies rocks. Its lower limit is the crust-mantle boundary (the 'Moho'), and its upper limit is poorly defined, and may be taken as the Conrad discontinuity, a point mid-way between the Moho and the surface, or the upper limit of granulite facies conditions.

LREEs: Light Rare Earth Elements.

Major Elements: Elements which are naturally abundant ( $>1 \% \mathrm{wt} . \%)$ in the Earth.

Marie Byrd Land: One of several tectono-stratigraphic provinces that accreted to East Antarctica in Paleozoic times, to form West Antarctica.

MBL: Marie Byrd Land.

Mechanical Boundary Layer: The region of the mantle with a Rayleigh number far below critical, which moves rigidly with respect to the crust, preserving geochemical anomalies indefinitely. It is underlain by the Thermal Boundary Layer.

Metamorphism: The closed-system re-equilibration of rock systems in response to a change in temperature and/or pressure conditions. Metamorphism is essentially a solid state reaction, with little or no fluid or volatile phases present. Metamorphism involving a change in composition (i.e. open-system) is termed metasomatism.

Metasomatism: The in situ open-system replacement of minerals in host rocks by other minerals, facilitated by fluids (e.g. silicate melts) passing along grain boundaries. Modal (or patent) metasomatism results in the growth of secondary minerals from the metasomatising agent, whereas cryptic metasomatism is the chemical enrichment of host minerals without any new mineral growth.

Moho: Mohorovicic discontinuity.

Mohorovicic discontinuity: A seismically defined discontinuity inferred to represent the boundary between the crust and the mantle.

Mount Cumming: A stratovolcano $(2612 \mathrm{~m}$ asl) at the southern end of the Executive Committee Range. Granulite and peridotite xenoliths have been collected from Mount Cumming.

Mount Hampton: A stratovolcano at the northern end of the Executive Committee Range, consisting of two calderas; Mount Hampton (3323 m asl), and Whitney Peak (3003 m asl). Granulite, pyroxenite and peridotite xenoliths have been collected from Mount Hampton.

Mount Hartigan: A deeply eroded stratovolcano at the southern end of the Executive Committee Range, consisting of two adjacent volcanoes (northern is $2811 \mathrm{~m}$ asl, and southern volcano is $2652 \mathrm{~m}$ asl). 
Mount Murphy: An eroded stratovolcano (2703 m asl) on the Walgreen coast of Marie Byrd Land. Granulite, pyroxenite and peridotite xenoliths have been collected from various sites around Mount Murphy.

Mount Sidley: A stratovolcano (4181 $\mathrm{m} \mathrm{asl}$ ) at the southern end of the Executive Committee Range. Mount Sidley is the highest volcano in Antarctica. Granulite and pyroxenite xenoliths have been collected from Mount Sidley.

Mount Waesche: A stratovolcano at the southern end of the Executive Committee Range, consisting of two coalesced volcanoes; Mount Waesche (4181 $\mathrm{m}$ asl) and Chang Peak (2920 m asl). Rare granulite xenoliths have been collected from Mount Waesche.

Oxidation: A secondary mineral reaction, common in granulite xenoliths, characterised by the oxidation of $\mathrm{Fe} 2+$ to $\mathrm{Fe} 3+$, and the breakdown of olivine into two phases. Oxidation reactions are a result of interaction of the xenoliths with silicate melts, and is accompanied by the replacement of olivine by Fe-Ti oxides, and the growth of apatite crystals and plagioclase overgrowths.

Percolative Fractional Crystallisation: The process of fractional crystallisation by a percolating melt. PFC differs from normal crystal fractionation, as the melt maintains at least partial equilibrium with the host rock phases; e.g. equilibrium with olivine

Peridotite: Upper mantle rocks (including lherzolite, harzburgite, wehrlite and dunite) consisting of olivine, pyroxene (typically $\mathrm{Cr}$-diopsides), and spinel or garnet. Plagioclase and hydrous phases (e.g. kaersutite or phlogopite) may also be present.

Petrologic Moho: The base of the lower crust defined by petrologic means, and taken to be a preponderance of ultramafic rocks. This often differs with the seismic Moho.

PFC: Percolative Fractional Crystallisation.

Pyroxenite: Lower crustal and/or upper mantle rocks (including websterites, clinopyroxenites and orthopyroxenites) dominated by pyroxene (typically Alaugite), and spinel or garnet. Olivine, plagioclase, and hydrous phases (typically kaersutite or pargasite) may also be abundant .

Rare Earth Elements: Trace elements belonging to the Lanthanide series ( $\mathrm{La}$ to $\mathrm{Lu}$; atomic no 57-71) of the periodic table. These elements have 3 valance electrons, and have very similar chemical properties. They are therefore intimately associated in nature.

RE: Ross (Sea) Embayment.

REEs: Rare Earth Elements. 
Ross Orogeny: A widespread deformational event (c $500 \mathrm{Ma}$ ) along the paleoPacific margin of Gondwana. The Ross Orogeny has been recognised extensively in the Transantarctic Mountains, but not in northern Victoria Land, in Marie Byrd Land, or in New Zealand.

Ross Sea Embayment: An informal, but widely used designation for the area covering the Ross Sea, and the Ross Ice Shelf.

Secondary Mineral Reactions: Secondary processes that alter the composition of the primary mineral assemblage and/or result in the growth of secondary minerals.

Secondary Minerals: Mineral phases that formed as a result of secondary processes, including metasomatism, after the formation of the initial mineral assemblage.

Seismic Moho: The base of the lower crust as defined by seismic data, and taken as a change in velocity corresponding with the base of seismic layering in the crust. This often differs with the petrologic Moho.

Thermal Boundary Layer: The region of the mantle with a Rayleigh number close to critical. It is not rigid, but does not convect vigorously, allowing geochemical anomalies to accumulate over a short term. It is overlain by the Mechanical Boundary Layer, and underlain by the Adiabatic Interior, and is the region in which the geotherm inflects towards isothermal adiabatic state.

Thurston Island: One of several tectono-stratigraphic provinces that accreted to East Antarctica in Paleozoic times, to form West Antarctica.

TM: Transantarctic Mountains.

Trace elements: Elements which occur naturally in the Earth in abundances of < 0.1 wt. \% (i.e. measured in ppm).

Transantarctic Mountains: A linear mountain chains extending across the EastWest boundary of the Antarctic continent. The Transantarctic Mountains are the most conspicuous feature in Antarctica, and rise to heights in excess of $4,000 \mathrm{~m}$ asl. Upper mantle: The upper region of the mantle, consisting of peridotite rocks. The upper mantle includes the rigid lithospheric mantle, and the underlying partially molten asthenospheric mantle.

USAS Escarpment: A mountain range to the north of the Executive Committee Range in central Marie Byrd Land, which includes peridotite-bearing scoria cones. WAVE: The 'West Antarctic Volcano Exploration' programme.

West Antarctic Rift: A Cenozoic rift system inferred to exist along the West and East Antarctic boundary. The nature and dimensions of the rift are difficult to assess, however it is thought to be $750 \mathrm{~km}$ across, and $3000 \mathrm{~km}$ long, and consist of 
a series of block faulted horsts and grabens similar to the Basin and Range province of western United States.

West Antarctic Volcano Exploration programme: A joint New Zealand, United States and United Kingdom project initiated to study the late Cenozoic volcanoes and lithosphere of West Antarctica. Two field seasons were completed by the WAVE programme, in 1989/90 and 1990/91.

West Antarctica: A tectono-stratigraphic province of Antarctica, consisting of a number of allochthonous crustal blocks that accreted to east Antarctica in Paleozoic times. The crustal blocks include (from west to east): Marie Byrd Land; Thurston Island; the Ellsworth Mountains; and the Antarctic Peninsula.

Xenolith: Fragments of foreign rock entrained in, and brought to the surface by, ascending magmas. 


\section{REFERENCES}

Adams, C.J., 1981: Geochronological correlations of Precambrian and Paleozoic orogens in New Zealand, Marie Byrd Land (West Antarctica), northern Victoria Land (East Antarctica), and Tasmania. In: M.M. Cresswell; P.V. Vella (eds), Gondwana Five. A.A. Balkema, Rotterdam. Pp 191-197.

- 1986: Geochronological studies of the Swanson Formation of Marie Byrd Land, West Antarctica, and correlation with northern Victoria Land, East Antarctica and South Island, New Zealand. New Zealand journal of geology and geophysics 29: 345-358.

- 1987: Geochronology of granite terranes in the Ford Ranges, Marie Byrd Land, West Antarctica. New Zealand journal of geology and geophysics 30: 51-72.

Anderson, A.T., 1968: Oxidation of the La Bloche Lake titaniferous magnetite deposit, Quebec. Journal of geology 76: 528-547.

Aoki, K.; Shiba, I., 1973: Pyroxenes from lherzolite inclusions of Itinomegata, Japan. Lithos 6: 41-51.

Arculus, R.J.; Delano, J.W., 1980: Implications for the primitive atmosphere of the oxidation state of earths upper mantle. Nature 288: 72-74.

- 1981: Intrinsic oxygen fugacity measurements: techniques and results for spinels from upper mantle peridotites and megacryst assemblages. Geochimica et cosmochimica acta 45: 899-913.

Arculus, R.J.; Ferguson, J.; Chappell, B.W.; Smith, D.; McCulloch, M.T.; Jackson, I.; Hensel, H.D.; Taylor, S.R.; Knutson, J.; Gust, D.A., 1988: Trace element and isotopic characteristics of eclogites and other xenoliths derived from the lower continental crust of southeastern Australia and southwestern Colorado Plateau, U.S.A. In: D.C. Smith (ed.) Eclogites and eclogite-facies rocks. Elsevier, Amsterdam. Pp 335-386. 
Bailey, D.K., 1970: Volatile flux, heat-focussing and the generation of magma. In: Newall; Rust (eds), Mechanism of igneous intrusion. Geological Journal special issue. Gallery Press, Liverpool. Pp 177-186.

1972: Uplift, rifting, magmatism and continental plates. Journal of earth science (Leeds) 8: 225-239.

1982: Mantle metasomatism - continuing chemical change within the Earth. Nature 296: 525-530.

Baker, J.A., 1990: The geology of the western margin of the Tapuaenuku plutonic complex, Marlborough, New Zealand. MSc thesis lodged at Victoria University of Wellington, New Zealand. $214 \mathrm{pp}$.

Barrett, P.J., 1981: History of the Ross Sea during the deposition of the Beacon Supergroup 400-180 million years ago. Journal of the Royal Society of New Zealand 11: 447-458.

Barrett, P.J.; Adams, C.J.; McIntosh, W.C.; Swisher III, C.C.; Wilson, G.S., 1992: Geochronological evidence supporting Antarctic deglaciation three milion years ago. Nature 359: 816-818.

Barrett, P.J.; Brooker, M.R., 1989: Grain size analyses at V.U.W. Research School of Earth Sciences, Victoria Universtiy of Wellington. 22p.

Barrett, P.J.; Pyne, A.R.; Hambry, M.J.; Harwood, D.B.; Webb, P.N., 1989: Antarctic glacial history from Ross Sea drilling (abstract). International geological congress abstracts, 28-1-92.

Bedard, J.H., 1993: Oceanic crust as a reactive filter: synkinematic intrusion, hybridization and assimilation in an ophiolitic magma chamber, western Newfoundland. Geology 21: 77-80.

Behrendt, J.C.; Le Masurier, W.; Cooper, A.K., 1992: The West Antarctic Rift System - a propagating rift "captured" by a mantle plume? In: Y. Yoshida; K. Kaminuma; K. Shiraishi (eds), Recent progress in Antarctic earth science. Terra Scientific Publishing Company, Tokyo. Pp 315-322.

Behrendt, J.C.; Le Masurier, W.E.; Cooper, A.K.; Tessensohn, F.; Trehu, A.M.; Damaske, D., 1991: Geophysical studies of the West Antarctic rift system. Tectonics 10: 1257-1273.

Bence, A.E.; Albee, A.L., 1968: Empirical correction factors for the electron microprobe analysis of silicates and oxides. Journal of geology 76: 382-403.

Bentley, C.R., 1991: Configuration and structure of the subglacial crust. In: R.J. Tingey (ed.), The geology of Antarctica. Oxford University Press and Clarendon Press, Oxford, United Kingdom. Pp 335-364..

Bentley, C.R.; Crary, A.P.; Ostenso, N.A.; Thiel, E.C., 1960: Structure of West Antarctica. Science 131: 131-136. 
Bentley, C.R.; Ostenso, N.A., 1962: On the paper of F.F. Evison, C.E. Ingham, R.H. Orr and H.J. Le Fort, "Thickness of the earths crust in Antarctica and surrounding oceans." Geophysical journal 6: 292-297.

Berg, J.H., 1991: Geology, petrology and tectonic implications of crustal xenoliths in Cenozoic volcanic rocks of southern Victoria Land. In: M.R.A. Thomson; J.A. Crame; J.W. Thomson (eds), Geological evolution of Antarctica - Proceedings of the 5th International Symposium on Antarctic Earth Sciences. Cambridge Universtiy Press, Cambridge. Pp 311-315.

Berg, J.H.; Herz, D.L., 1986: Thermobarometry of two-pyroxene granulite inclusions in Cenozoic rocks of the McMurdo Sound region. Antarctic journal of the United States 21(5): 19-20.

Berg, J.H.; Wu, B., 1992: Crustal xenoliths from Cape McCormack Crater, northern Victoria Land. In: Y. Yoshida; K. Kaminuma; K. Shiraishi (eds), Recent progress in Antarctic earth science. Terra Scientific Publishing Company, Tokyo. Pp 265-271.

Bertrand, P.; Mercier, J.-C.C, 1985: The mutual solubility of coexisting ortho- and clinopyroxene: toward an absolute geothermometer for the natural system? Earth and planetary science letters 76: 109-122.

Best, M.G., 1982: Igneous and metamorphic petrology. W.H. Freeman and Company, New York. 630pp.

Bhattacharyya, C., 1971: An evolution of the chemical distinctions between igneous and metamorphic orthopyroxenes. American mineralogist 56: 499-506.

Blundell, D.J.; Raynaud, B., 1985: Modelling lower crust reflections observed on BIRPS profiles. In M. Barazangi (ed.) Deep structure of the continental crust. American Geophysical Union, Geodynamics series.

Bohlen, S.R., 1987: Pressure - temperature - time paths and a tectonic model for the evolution of granulites. Journal of geology 95: 617-632.

Bohlen, S.R.; Mezger, K., 1989: Origin of granulite terranes and the formation of the lowermost continental crust. Science 244: 326-329.

Borg, S.G., 1983: Petrology and geochemistry of the Queen Maud Batholith, central Transantarctic Mountains, with implications for the Ross Orogeny. In: R.L.Oliver; P.R. James; J.B.Jago (eds), Antarctic Earth Science. Australian Academy of Science, Canberra and Cambridge University Press, Cambridge. Pp 165-169.

Borg, S.G.; DePaolo, D.J., 1991: A tectonic model of the Antarctic Gondwana margin with implications for southeastern Australia: isotopic and geochemical evidence. Tectonophysics 196: 339-358. 
Borg, S.G.; DePaolo, D.J.; Smith, B.M., 1990: Isotopic structure and tectonics of the central Transantarctic Mountains. Journal of geophysical research 95: 66476667.

Borg, S.G.; Stump, E.; Chappell, B.W.; McCulloch, M.T.; Wyborn, D.; Armstrong, R.L.; Holloway, J.R., 1987: Granitoids of northern Victoria Land, Antarctica: implications of chemical and isotopic variations to regional crustal structure and tectonics. American journal of science 287: 127-169.

Borg, S.G.; Stump, E.; Holloway, J.R., 1986: Granitoids of northern Victoria Land, Antarctica: a reconnaissance study of field relations, petrography and geochemistry. In: E. Stump (ed.), Geological Investigations in Northern Victoria Land. Antarctic Research Series 46: 115-188. American Geophysical Union, Washington D.C.

Bradley, S.D.; McCallum, M.E., 1984: Granulite facies and related xenoliths from Colorado - Wyoming kimberlite. In: J. Kornprobst (ed.), Kimberlites II The mantle and crust-mantle relationships. Elseveir, Amsterdam. Pp 205218.

Bradshaw, J.D., 1987: Terrane boundaries and terrane displacement in northern Victoria Land, Antarctica: some problems and constraints. In: E. Leitch; E. Schreibner (eds), Terane Accretion and Orogenic Belts. American Geophysical Union. Washington D.C.

Bradshaw, J.D.; Andrews, P.B.; Adams, C.J., 1981: Carboniferous to Cretaceous on the Pacific margin of Gondwana. In: M.M. Cresswell; P.V. Vella (eds), Gondwana Five. A.A. Balkema, Rotterdam. Pp 217-221.

Bradshaw, J.D.; Andrews, P.B.; Field, B.D., 1983: Swanson Formation and related rocks of Marie Byrd Land and a comparison with Roberston Bay Groups and Bowers Supergroup, northern Victoria Land, Antarctica. In: R.L. Oliver; P.R. James; J.B. Jago (eds), Antarctic Earth Science. Canberra, Australian Academy of Science. Pp 274-279.

Brown, G.E., 1970: The crystal chemistry of the olivines. PhD thesis lodged at Virginia Polytechnic and State University, Blacksburg, Virginia. 121p.

Buddington, A.F.; Lindsley, D.H., 1964: Iron-titanium oxide minerals and synthetic equivalents. Journal of petrology 5: 310-357.

Bulau, J.R.; Waff, H.S.; Tyburczy, J.A., 1979: Mechanical and thermodynamic constraints on fluid distribution in partial melts. Journal of geophysical research 84: 6201-6108.

Cameron, K.L.; Carman, M.F.; Butler, J.C., 1970: Rhönite from Big Bend National Park, Texas. American mineralogist 55 : 864-874. 
Cameron, M.; Papike, J.J., 1980: Crystal chemistry of silicate pyroxenes. In: C.T. Prewitt (ed.), Pyroxenes. Mineralogical society of America, Reviews in mineralogy 7: 5-92.

Cande, S.C.; Mutter, J.C., 1982: A revised identification of the oldest sea floor spreading anomalies between Australia and Antarctica. Earth and planetary science letters 58(2): 151-160.

Carmichael, I.S.E., 1967: The iron-titanium oxides of salic volcanic rocks and their associated ferromagnesian silicates. Contributions to mineralogy and petrology 14: 36-64.

Cheadle, M.J., 1989: Properties of texturally equilibriated two phase aggregates. PhD thesis lodged at the University of Cambridge, England.

Cheadle, M.; McGeary, S.; Warer, M.R.; Matthews, D.H., 1987: Extensional structures on the U.K. continental shelf: a review of evidence from deep seismic profiling. In: M. Coward; J.F. Dewey; P.L. Hancock (eds) Continental Extension Tectonics, special publication of the Geological Society of London 28: 445-465.

Cooper, R.A.; Davey, F.J.; Hinz, K., 1991: Crustal extension and origin of sedimentary basinsbeneath the Ross Sea and Ross Ice Shelf, Antarctica. In: M.R.A. Thomson; J.A. Crame; J.W. Thomson (eds), Geological evolution of Antarctica - Proceedings of the 5th International Symposium on Antarctic Earth Sciences. Cambridge Universtiy Press, Cambridge. Pp 285292.

Cooper, R.A.; Landis, C.A.; Le Masurier, W.E.; Speden, I.G., 1982: Geologic history and regional patterns in New Zealand and West Antarctica - their paleotectonic and palaeographic significance. In: C. Craddock (ed.), Antarctic geoscience. University of Wisconsin Press, Madison. Pp 43-53.

Courtney, R.C.; White, R.S., 1986: Anomalous heat flow and geoid across the Cape Verde Rise: evidence of dynamic support from a thermal plume in the mantle. Geophysical journal of the Royal Astronomical Society 87: 815-868.

Cox, K.G.; Bell, J.D.; Pankhurst, R.J., 1979: The Interpretation of Igneous Rocks. George Allen \& Unwin, London. 450pp.

Craddock, C., 1972: Antarctic tectonics. In: R.J. Adie (ed.), Antarctic geology and geophysics. Universitetsforlaget, Oslo. Pp 449-455.

Dalziel, I.W.D., 1991: Pacific margins of Laurentia and East Antarctica-Australia as a conjugate rift pair: evidence and implications for an Eocambrian supercontinent. Geology 19: 598-601.

Dalziel, I.W.D.; Elliott, D.H., 1982: West Antarctica: Problem child of Gondwanaland. Tectonics 1: 3-19. 
Davey, F.J.; Cooper, A.K.,1987: Gravity studies of the Victoria Land Basin and Iselin Bank. In: A.K. Cooper; F.J. Davey (eds), The Antarctic Continental Margin: Geology and geolphysics of the Western Ross Sea. CPCEMR Earth Science Series 5B. Pp 119-137.

Dawson, J.B., 1982: Contrasting types of mantle metasomatism. Terra Cognita 2: 232-233.

, 1984: Contrasting types of upper mantle metasomatism. In: J. Kornprobst (ed.), Kimberlites II - The mantle and crust-mantle relationships. Elseveir, Amsterdam. pp 289-294.

Deer, W.A.; Howie, R.A. and Zussman, J., 1966: An introduction to the rockforming minerals. Longman Group Ltd. $528 \mathrm{pp}$.

Dewey, J.F., 1986: Diversity in the lower continental crust. In: J.B. Dawson; D.A. Corswell; J. Hall; K.H. Wedepohl (eds), The nature of the lower continental crust. Blackwell Scientific Publications, Oxford. Geological Society special publication 24: 71-78.

Dodd, R.T., 1973: Minor element abundances in olivine of the Sharps (H-3) chondrites. Contributions to mineralogy and petrology 42: 159-167.

Dodge, F.C.W.; Calk, L.C.; Kistler, R.W., 1986: Lower crustal xenoliths, Chinese Peak lava flow, central Sierra Nevada. Journal of petrology 27: 1277-1304.

Dodge, F.C.W.; Lockwood, J.P.; Calk, L.C., 1988: Fragments of the mantle and crust from beneath the Sierra Nevada batholith: xenoliths in a volcanic pipe near Big Creek, California. Geological Society of America bulletin 100: 938947.

Dohr, G.; Fuchs, K., 1967: Statistical evaluation of deep crustal reflections in Germany. Geophysics 32: 951-967.

Dostal, J.; Dupuy, C.; Leyreloup, A., 1980: Geochemistry and petrology of metaigneous granulite xenoliths in Neogene volcanic rocks of the Massif Central, France - implications for the lower crust. Earth and planetary science letters 50: 31-40.

Doumani, G.A., 1964: Volcanoes of the Executive Committee Range, Marie Byrd Land. In: R.J. Adie (ed.), Antarctic Geology. North-Holland, Amsterdam. Pp 666-675.

Doumani, G.A.; Ehlers, E.G., 1962: Petrography of rocks from mountains in Marie Byrd Land, West Antarctica. Geological Society of America bulletin 73(7): 877-822.

Drewry, D.J., 1982: Ice flow, bedrock, and geothermal studies from radio-echo sounding inland of McMurdo Sound, Anarctica. In: C. Craddock (ed.), Antarctic geoscience. University of Wisconsin Press, Madison. Pp 977-83. 
Du Toit, A.L., 1937: Our Wandering Continents. Oliver and Boyd, Edinburgh.

Duggan, M.B.; Smith, I.E.M.; Weaver, S.D., 1989: New Zealand intraplate volcanism. In: R.W. Johnson (ed.), Intraplate volcanism in eastern Australia and New Zealand. Australian Academy of Sciences, Cambridge University Press. Pp 171-172.

Eggler, D.H.; 1983: Upper mantle oxidation state: evidence from olivine orthopyroxene - ilmenite assemblages. Geophysical research letters 10: 365368.

Eggler, D.H.; Baker, D.K., 1982: Reduced volatiles in the system C-O-H: implications for mantle melting, fluid formation and diamond genesis. In: S. Akimoto; M.H. Manghnani (eds), High-pressure research in geophysics. Advances in earth and planetary sciences 12: 237-250.

Elliot, D.H., 1986: Physical geography - geological evolution. In: W.N. Bonner; W.H. Walton (eds), Key environments, Anarctica. Pergamon Press, Oxford. Pp 39-61.

Emery, J.V.; Arculus, R.J.; Henderson, C.E., 1985: A possible mineral host for the unusual $\mathrm{Sr}$ - and Ba-enrichments in some lower crustal granulites and eclogites. Eos 66: 387.

Esperanca, S.; Carlson, R.W.; Shirey, S.B., 1988: Lower crustal evolution under central Arizona: $\mathrm{Sr}, \mathrm{Nd}$ and $\mathrm{Pb}$ isotopic and geochemical evidence from mafic xenoliths of Camp Creek. Earth and planetary science letters 90: 2640.

Evison, F.F.; Ingham, C.E.; Orr, R.H. Le Fort, J.H., 1960: Thickness of the Earth's crust in Antarctica and surrounding oceans. Geophysical journal 3: 289306.

Findlay, R.H., 1987: A review of the problems important for interpretation of the Cambro-Ordovician paleogeography of Northern Victoria Land (Antatrctica), Tasmania and New Zealand. In: G.D. McKenzie (ed.), Gondwana six: Structure, tectonics and geophysics. American Geophysical Union, Washington D.C. Geophysical Monograph 40: 49-66.

Finnerty, A.A.; Boyd, F.R., 1978: Pressure-dependent solubility of calcium in forsterite coexisting with diopside and enstatite. Carnegie Institute of Washington year book 77: 713-717.

Frey, F.A.; Prinz, M. 1978: Ultramafic inclusions from San Carlos, Arizona: petrologic and geochemical data bearing on their petrogenesis. Earth and planetary science letters 38: 129-176, 
Freydier, C., 1991: Transition visqueux - plastique en regime de cisaillement: modelisation analogique et applications de terrain [diplome etude approfondie]. Univerite de Montpellier II, Montpellier, France. 50p

Futa, K.; Le Masurier, W.E., 1983: Nd and Sr isotopic studies on Cenozoic mafic lavas from West Antarctica: another source for continental alkali basalts. Contributions to mineralogy and petrology 38: 38-44.

Gamble, J.A., 1990: West Antarctica Volcano Exploration (WAVE). In: K.J. Woolfe (ed.) Antarctic Expedition 1989-90, immediate report. Antractic Research Centre, Victoria University of Wellington. Pp 23-25.

, 1990: Reports to D.S.I.R. Antarctica from participants on West Antarctic Volcano Exploration (WAVE) expedition to Mount Murphy and the northern Executive Committee Range. Antractic Research Centre immediate report, Victoria University of Wellington. 4pp.

Gamble, J.A.; Kyle, P.R., 1987: The origin of glass and amphibole in spinel wehrlite xenoliths form Foster Crater, McMurdo Volcanic Group, Antarctica. Journal of petrology 28: 755-780.

Gamble, J.A.; McGibbon, F.; Kyle, P.R.; Menzies, M.A.; Kirsch, I., 1988: Metasomatised xenoliths from Foster Crater, Antarctica: Implications for lithospheric structure and processes beneath the Transantarctic Mountain Front. Journal of petrology, s 109-138.

Gamble, J.A.; Wysoczanski, R.J.; Brooker, J., 1993: Immediate scientific report. K048: Antarctic Ross Sea Lithosphere Study (ARSLS). New Zealand Antarctic Programme 1992/93. Antractic Research Centre immediate report, Victoria University of Wellington. 4pp.

Gasparik, T., 1984: Two - pyroxene thermobarometry with new experimental data in the system $\mathrm{CaO}-\mathrm{MgO}-\mathrm{Al}_{2} \mathrm{O}_{3}-\mathrm{SiO}_{2}$. Contributions to mineralogy and petrology 87: 87-97.

Goleby, B.R.; Shaw, R.D.; Wright, C.; Kennett, B.L.N.; Lambeck, K., 1988: Geophysical evidence for "thick skinned" crustal deformation in central Australia. Nature 337: 325-337.

Graham, I.J.; Blattner, P.; McCulloch, M.T., 1990: Meta-igneous granulite xenoliths from Mount Ruapehu, New Zealand: fragments of altered oceanic crust? Contributions to mineralogy and petrology 105: 650-661.

Grapes, R.H., 1975: Petrology of the Blue Mountain Igneous Complex, Marlborogh, New Zealand. Journal of petrology 16: 371-428.

Griffin, W.L.; Carswell, D.A.; Nixon, P.H., 1979: Lower crustal granulites and eclogites from Lesotho, southern Africa. In: F.R. Boyd; H.O.A. Meyer (eds) 
The mantle sample: inclusions in kimberlites. American Geophysical Union, Washington D.C. Pp 59-86.

Griffin, W.L.; O'Reilly, S.Y., 1986: The lower crust in eastern Australia: xenolith evidence. In: J.B. Dawson; D.A. Corswell; J. Hall; K.H. Wedepohl (eds), The nature of the lower continental crust. Blackwell Scientific Publications, Oxford. Geological Society special publication 24: 363-374.

- 1987a: The composition of the lower crust and the nature of the continental Moho - xenolith evidence. In: P.H. Nixon (ed.), Mantle xenoliths. Wiley, Chichester. Pp 413-430.

, 1987b: Is the continental Moho the crust-mantle boundary? Geology 15: 241-244.

Griffin, W.L.; Sutherland, F.L.; Hollis, J.D., 1987: Geothermal profile and crustmantle transition beneath east-central Queensland: volcanology, xenolith petrology and seismic data. Journal of volcanology and geothermal research 31: 177-203.

Griffin, W.L.; Wass, S.Y.; Hollis, J.D., 1984: Ultramafic xenoliths from Bullenmerri and Gnotuk maars, Victoria, Australia: petrology of a subcontinental crustmantle transition. Journal of petrology 25: 53-87.

Grindley, G.W.; Davey, F.J., 1982: The reconstruction of New Zealand, Australia and Antarctica. In: C. Craddock (ed.), Antarctic geoscience. University of Wisconsin Press, Madison. Pp 15-29.

Grindley, G.W.; McDougall, I., 1969: Age and correlation of the Nimrod Group and other PreCambrian rock units in the central Transantarctic Mountains, Antarctica. New Zealand journal of geology and geophysics 12: 391-411.

Grindley, G.W.; Mildenhall, D.C.; Schopf, J.M., 1980: A mid-late Devonian flora from the Ruppert Coast, Marie Byrd Land, Antarctica. Journal of the Royal Society of New Zealand 10(3): 271-285.

Grindley, G.W.; Oliver, P.J., 1983: Paleomagnetism of Cretaceous volcanic rocks from Marie Byrd Land, Antarctica. In: R.L. Oliver; P.R. James; J.B. Jago (eds), Antarctic Earth Science. Canberra, Australian Academy of Science. Pp 573-578.

Groushinsky, N.P.; Sazhina, N.B., 1982: Some features of Antarctic crustal structure. In: C. Craddock (ed.), Antarctic geoscience. University of Wisconsin Press, Madison. Pp 907-911.

Grünhagen, H.; Seck, H.A., 1972: Rhönit aus einem Melaphonolith vom Puy de Saint-Sandoux (Auvergne). Tschermaks mineral. petrogr. Mitt 18: 17-38. 
Gunn, G.M.; Warren, G., 1962: Geology of Victoria Land between the Mawson and Mullock Glaciers, Antarctica. New Zealand Geological Survey bulletin 71. $172 \mathrm{pp}$.

Haggerty, S.E.,1990: Redox state of the continental lithosphere. In: M.A. Menzies (ed.): Continental Mantle. Oxford Monograph on Geology and Geophysicis No. 16, Clarendon Press, Oxford.

Hall, J., 1986: The physical properties of layered rocks in deep continental crust. In; J.B. Dawson; D.A. Corswell; J. Hall; K.H. Wedepohl (eds), The nature of the lower continental crust. Blackwell Scientific Publications, Oxford. Geological Society special publication 24: 51-56.

Halpern, M., 1968: Ages of Antarctica and Argentine rocks bearing on continental drift. Earth and planetary science letters 5: 159-167.

Hantzschell, W., 1975: Trace fossils and problimatica. In: C. Teichert (ed.), Treatise on Invertibrate Paleontology, Part W, Supplement 1. Geological Society of America / University of Kansas Press.

Harland, W.B.; Cox, A.V.; Llewellyn, P.G.; Pickton, C.A.E.; Smith, A.G.; Walters, R., 1982: A geological time scale. Cambridge University Press, Cambridge. 131 pp.

Harte, B., 1983: Mantle peridotites and processes - the kimberlite sample. In: C.J. Hawkesworth, M.J. Norry (eds), Continental basalts and mantle xenoliths. Shiva, Nantwich. pp 46-91.

, 1987: Metasomatic events recorded in mantle xenoliths: an overview. In:

P.H. Nixon (ed.), Mantle xenoliths. Wiley, Chichester. Pp 625-640.

Harte, B.; Hunter, R.H.; Kinny, P.D., 1993: Melt geometry, movement and crystallisation, in relation to mantle dykes, veins and metasomatism. Philosophical transactions of the Royal Society of London 342: 1-21.

Harwood, D.M.; Webb, P.N.; Barrett, P.J., 1992: The search for consistency between several indices of Antarctic Cenozoic glaciation (abstract). In: Cenozoic Glaciations and Deglaciations, abstracts volume. Geological Society, London.

Herron, E.M.; Tucholke, B.E., 1975: Seafloor magnetic pattern and basement structure in the southeastern Pacific. Initial report on Deep Sea Drilling Project 35: 263-278.

Herzberg, C.T., 1978: Pyroxene geothermometry and geobarometry: experimental and thermodynamic evaluation of some subsolidus phase relations invoving pyroxenes in the system $\mathrm{CaO}-\mathrm{MgO}-\mathrm{Al}_{2} \mathrm{O}_{3}-\mathrm{SiO}_{2} \cdot$ Geochimica et cosmochimica acta 42: 945-957 
Hoffman, P.F., 1991: Did the breakout of Laurentia turn Gondwanaland inside out? Science 252: 1409-1412.

Hole, M.J.; Le Masurier, W.E., 1990: Geochemical variations and tectonic affinites of Cenozoic alkali basaltic rocks from the Pacific margin of West Antarctica (abstract). Transactions of the American Geophysical Union 71: 1699.

Hurich, C.A.; Smithson, S.B.; Fountain, D.M.; Humphreys, M.C., 1985: Seismic evidence of mylonite reflectivity and deep structure in the Kettle Dome metamorphic arc complex, Washington. Geology 13: 577-580.

Irving, A.J., 1974: Geochemical and high pressure experimental studies of garnet pyroxenite and pyroxene granulite xenoliths from the Delegate basaltic pipes, Australia. Journal of petrology 15: 1-40.

- 1978: A review of experimental studies of crystal/liquid trace element partitioning.Geochimica et cosmochimica acta 42: 743-770.

- 1980: Petrology and geochemistry of composite ultramafic xenoliths in alkalic basalts and implications for magmatic processes within the mantle. American journal of science 280A: 389-426.

Irving, A.J.; Price, R.C., 1981: Geochemistry and evolution of lherzolite-bearing phonolitic lavas from Nigeria, Australia, East Germany and New Zealand. Geochimica et cosmochimica acta 45: 1309-1320..

Irvine, T.N., 1982: Terminology for layered intrusions. Journal of petrology 23: 127-162.

Jackson, E.D., 1969: Discussion on the paper 'The origin of ultramafic and ultrabasic rocks'; P.J. Wyllie. Tectonophysics 7: 517-518.

Jones, A.P.; Smith, J.V.; Dawson, J.B.; Hansen, E.C., 1983: Metamorphism, partial melting and K-metasomatism of garnet-scapolite-kyanite granulite xenoliths from Lashire, Tanzania. Journal of geology 91: 143-166.

Kalamarides, R.I.; Berg, J.H., 1991: Geochemistry and tectonic implications of lower-crustal granulites included in Cenozoic volcanic rocks of Southern Victoria Land. In: M.R.A. Thomson; J.A. Crame; J.W. Thomson (eds), Geological evolution of Antarctica - Proceedings of the 5th International Symposium on Antarctic Earth Sciences. Cambridge Universtiy Press, Cambridge. Pp 305-310.

Kalamarides, R.I.; Berg, J.H.; Hank, R.A., 1987: Lateral isotopic discontinuity in the lower crust: an example from Antarctica. Science 237: 1192-1195.

Kay, R.W.; Kay, S.M., 1986: Petrology and geochemistry of the lower continental crust: an overview. In: J.B. Dawson; D.A. Corswell; J. Hall; K.H. Wedepohl (eds), The nature of the lower continental crust. Blackwell Scientific Publications, Oxford. Geological Society special publication 24: 147-159. 
Kay, S.M.; Kay, R.W., 1983: Thermal history of the deep crust inferred from granulite xenoliths, Queensland, Australia. American journal of science 283(A): 486-513.

Kempton, P.D.; Harmon, R.S.; Hawkesworth, C.J.; Moorbath, S., 1990: Petrology and geochemistry of lower crustal granulites from the Geronimo Volcanic field, southeastern Arizona. Geochimica et cosmochimica acta 54: 34013426.

Kennett, J.P., 1982: Marine Geology. Prentice Hall Inc., New York. 813p.

Kimborough, D.L.; Richard, S.M., 1991: Geochronology of basement rocks in the Fosdick Mountain region of West Antarctica and correlation with Cretaceous extensional terranes of southern New Zealand (abstract). Sixth International Symposium on Antarctic Earth Sciences, abstracts volume. Pp 313-316.

Kovach, R.L.; Press, F., 1961: Surface wave depression and crustal structure in Antarctica and surrounding oceans. Annali di geofisica 14: 211-224.

Kretz, R., 1982: Transfer and exchange equilibria in a portion of the pyroxene quadrilateral as deduced from natural and experimental data. Geochimica et cosmochimica acta 46: 411-421.

Kushiro, I.; Yoder, H.S.Jr; Mysen, B.O., 1976: Viscosities of basalt and andesite melts at high pressures. Journal of geophysical research 81: 6351-6356.

Kyle, P.R.; McIntosh, W.C.; Panter, K. Smellie, J., 1991: Is volcanism in Marie Byrd Land related to a mantle plume? (abstract). In: Sixth International Symposium on Antarctic Earth Sciences, abstracts volume. Pp 313-316.

Kyle, P.R.; Price, R., 1975: Occurrences of rhonite in the McMurdo Volcanic Group, Antarctica and Otago Volcano, New Zealand. American mineralogist 60: 722-725.

Kyle, P.R.; Rankin, P.C., 1976: Rare earth element geochemistry of late Cenozoic alkaline lavas of the McMurdo Volcanic Group, Antarctica. Geochimica et cosmochimica acta 40: 1497-1507.

Kyle, P.R.; Wright, A.; Kirsch, I.D., 1987: Ultramafic xenoliths in late Cenozoic McMurdo Volcanic Group, Western Ross Sea Embayment, Antarctica. In: P.H. Nixon (ed.), Mantle xenoliths. Wiley, Chichester. Pp 289-293.

Laird, M.G., 1991a: The Late Proterzoic - Middle Paleozoic rocks of Antarctica. In: R.J. Tingey (ed.), The geology of Antarctica. Oxford University Press and Clarendon Press, Oxford, United Kingdom. , 1991b: Lower - mid - Paleozoic sedimentation and tectonic patterns on the palaeo-Pacific margin of Antarctica. In: M.R.A. Thomson; J.A. Crame; J.W. Thomson (eds), Geological evolution of Antarctica - Proceedings of the 5th 
International Symposium on Antarctic Earth Sciences. Cambridge Universtiy Press, Cambridge. Pp 177-185.

Lawver, B.E.; Royer, J.Y.; Sandwell, D.T.; Scotese, C.R., 1991: Evolution of the Antarctic continental margins. In: M.R.A. Thomson; J.A. Crame; J.W. Thomson (eds), Geological evolution of Antarctica - Proceedings of the 5th International Symposium on Antarctic Earth Sciences. Cambridge Universtiy Press, Cambridge. Pp 533-539.

Le Bas, M.J.; Le Maitre, R.W.; Streckeisen, A. and Zanettin, B., 1986: A chemical classification of volcanic rocks based on the total alkali - silica diagram. Journal of petrology 27: 745-790.

Le Marchand, F.; Villemant, B.; Calas, G., 1987: Trace element distribution coefficients alkaline series. Geochimica et cosmochimica acta 51: 1071-1081.

Le Masurier, W.E., 1972: Volcanic record of Cenozoic glacial history of Marie Byrd Land. In: R.J. Adie (ed.) Antarctic geology and geophysics. Universitetsforlaget, Oslo. Pp 251-260.

, 1990: Marie Byrd Land. In: W.E. Le Masurier; J.W. Thomson (eds), Volcanoes of the Antarctic Plate and Southern Oceans. American Geophysical Union, Washington D.C. Antarctic Research Series vol 48: 146-255.

Le Masurier, W.E.; Rex, D.C., 1983: Rates of uplift and the scale of ice level instabilities recorded by volcanic rocks in Marie Byrd Land, West Antarctica. In: R.L. Oliver; P.R. James; J.B. Jago (eds), Antarctic Earth Science. Canberra, Australian Academy of Science. Pp 16-20.

, 1989: Evolution of linear volcanic ranges in Marie Byrd Land, West Antarctica. Journal of geophysical research 94: 7223-7236.

- 1991: The Marie Byrd Land volcanic province and its relation to the Cainozoic West Antarctic rift system. In: R.J. Tingey (ed.), The geology of Antarctica. Oxford University Press and Clarendon Press, Oxford, United Kingdom. Pp249-284.

Le Matire, R.W., 1984: A proposal by the I.U.G.S Subcommission on the systematics of igneous rocks for a chemical classification of volcanic rocks based on the total alkali-silica (TAS) diagram. Australian journal of earth sciences 31: 243-255.

Leake, B.E., 1978: Nomenclature of amphiboles. Mineralogical magazine 42: 533563.

Lee, D-C.; Halliday, A.N.; Hunter, R.H.; Holden, P.; Upton, B.G.J., 1993: Rb-Sr and $\mathrm{Sm}-\mathrm{Nd}$ isotopic variations in dissected crustal xenoliths. Geochimica et cosmochimica acta 57: 219-230. 
Leyreloup, A.; Bodinier, J.L.; Dupoy, C.; Dostal, J., 1982: Petrology and geochemistry of granulite xenoliths from Central Hoggar (Algeria) - Implications for the lower crust. Contributions to mineralogy and petrology 79: 68-75.

Leyreloup, A.; Dupoy, C.; Andriambololona, R., 1977: Catazonal xenoliths in French Neogene volcanic rocks: constitution of the lower crust 2 . Chemical composition and consequences of the evolution of the French Massif Central pre-Cambrian crust. Contributions to mineralogy and petrology 62: 283-300.

Lindsley, D.H., 1983: Pyroxene thermometry. American mineralogist 68: 477-493.

Lindsley, D.H.; Spencer, K.J., 1982: Fe-Ti oxide geothermometry: reducing analyses of coexisting Ti-magnetite (Mt) and ilmenite (Ilm). Transactions of the American Geophysical Union 63: 471.

Lopatin, B.G.; Krylov, A.Ya.; Alaipyshev, O.A., 1974: Main tectonomagmatic stages of development of Marie Byrd Land, and Eights Coast, West Antarctica, according to radioactive data. USSR Academy of Science, Soviet Committee on Antarctic Research, 'Antarktika: Doklody Komissu' 13: 3651.

Luyendyk, B.P.; Richard, S.M.; Smith, C.H.; Kimbrough, D.L., 1992: Geological and geophysical exploration in the northern Ford Ranges, Marie Byrd Land, West Antarctica. In: Y. Yoshida; K. Kaminuma; K. Shiraishi (eds), Recent progress in Antarctic earth science. Terra Scientific Publishing Company, Tokyo. Pp 315-322.

Malpas, J., 1978: Magma generation in the upper mantle, field evidence from ophiolite suites, and application to the generation of oceanic lithosphere. Philosophical transactions of the Royal Society of London A288: 527-546.

Matthews, D.H., 1986: Seismic reflections from the lower crust around Britain. In: J.B. Dawson; D.A. Corswell; J. Hall; K.H. Wedepohl (eds), The nature of the lower continental crust. Blackwell Scientific Publications, Oxford. Geological Society special publication 24: 11-21.

Matthews, D.J.; Cheadle, M.J., 1986: Deep reflections from the Caledonides and Variscides west of Britain and comparison with the Himalayas. In: M. Bakazanei; L. Brown (eds), Reflection seismology: A global perspective. American Geophysical Union geodynamics series 13: 5-20.

Mattinson, J.M.; Kimbrough, D.L.; Bradshaw, J.Y., 1986: Western Fiordland orthogneiss: early Cretaceous arc magmatism and granulite facies metamorphism, New Zealand. Contributions to mineralogy and petrology 92: 383-392. 
McCarthy, J.; Mutter, J.C.; Morton, J.L.; Sleep, N.H.; Thompson, G.A., 1988: Relic magma chamber structures preserved within the Mesozoic North Atlantic crust? Geological Society of America bulletin 100: 1423-1436.

McCulloch, M.T.; Bradshaw, J.Y.; Taylor, S.R., 1987: Sm-Nd and Rb-Sr isotopic and geochemical systematics in Phanerozoic granulites from Fiordland, Southwest New Zealand. Contributions to mineralogy and petrology 97: 183-195.

McGeary, S.; Warner, M.R., 1985: Seismic profiling of the continental lithosphere. Nature 317: 795-797.

McGibbon, F.M., 1991: Geochemistry and petrology of ultramafic xenoliths of the Erebus Volcanic Province. In: M.R.A. Thomson; J.A. Crame; J.W. Thomson (eds), Geological evolution of Antarctica - Proceedings of the 5th International Symposium on Antarctic Earth Sciences. Cambridge Universtiy Press, Cambridge. Pp 317-321.

McKenzie, D., 1984: A possible mechanism for eperiogenic uplift. Nature 307: 616618.

McKenzie, D.; Bickle, M.J., 1988: The volume and composition of melt generated by extension of the lithosphere. Journal of petrology 29: 625-679.

McKenzie, D.; O’Nions, R.K., 1991: Partial melt distributions from inversionof rare earth concentrations. Journal of petrology 32: 1021-1091.

Meissner, R., 1973: The Moho as a transition zone. Geophysical surveys 1: 195-216.

Menzies, M.A., 1983: Mantle ultramafic xenoliths in alkaline magmas: evidence for mantle heterogeneity modified by magmatic activity. In: C.J. Hawkesworth; M.J.Norry (eds), Continental basalts and mantle xenoliths. Shiva, Nantwich. Pp 92-110.

Menzies, M.A.; Kempton, P.; Dungon, M., 1985: Interaction of continental lithosphere and asthenosphere melts below the Geronimo volcanic field, Arizona, U.S.A. Journal of petrology 26: 663-693.

Menzies, M.; Rogers, N.; Tindle, A.; Hawkesworth, C., 1987: Metasomatism and enrichment processes in lithospheric peridoties, an effect of asthenosphere - lithosphere interaction. In: M. Menzies; C. Hawkesworth (eds), Mantle metasomatism. Academic Press. pp 313-360.

Moores, E.M., 1991: Southwest U.S. - East Antarctic (SWEAT) connection: a hypothesis. Geology 19: 425-428.

Morimoto, N.; Fabries, J.; Ferguson, A.K.; Ginsburg, I.U.; Ross, M.; Seifert, F.A.; Zussman, J.; Aoki, K. and Gottardi, G., 1988: Nomenclature of pyroxenes.. American mineralogist 3: 1123-1133. 
Muller, O.; Roy, R., 1974: The major ternary structure families. Springer-Verlag, New York.

Navon, O.; Stolder, E., 1987: Geochemical consequences of melt percolation: the upper mantle as a chromatographic column. Journal of petrology 95:285317.

Nicholas, A.; Freydier, C.; Godard, M.; Vaucher, A., 1993: Magma chambers at oceanic ridges: How large? Geology 21: 53-56.

Nickel, K.G.; Brey, G.P.; Kogarko. L., 1985: Orthopyroxene - clinopyroxene in the system $\mathrm{CaO}-\mathrm{MgO}-\mathrm{Al}_{2} \mathrm{O}_{3}-\mathrm{SiO}_{2}$ (CMAS): new experimental results and implications fro two-pyroxene thermometry. Contributions to mineralogy and petrology 91: 44-53.

Nicol, E.R., 1977: Igneous petrology of the Clarence and Awatere Valleys, Marlborough. PhD thesis lodged at Victoria University of Wellington, New Zealand. 328pp.

Norrish, K.; Chappell, B.W., 1977: X-ray fluorescence spectrometry. In: J. Zussman (ed.), Physical methods in determinative mineralogy (2nd ed.). Academic Press, London. Pp 201-272.

Norrish, K.; Hutton, J.T., 1969: An accurate x-ray spectrographic method for analysis of a whole range of geologic samples. Geochimica et cosmochimica acta 33: 431-453.

O'Neill, H.C.; Wall, V.J., 1987: The olivine - orthopyroxene - spinel oxygen geobarometer, the nickle precipitation curve, and the oxygen fugacity of the Earth's upper mantle. Journal of petrology 28: 1169-1191.

O'Reilly, S.Y.; Nicholls, I.A.; Griffin, W.L., 1989: Xenoliths and megacrysts of Eastern Australia. In: R.W. Johnson (ed.), Intraplate volcanism in eastern Australia and New Zealand. Australian Academy of Sciences, Cambridge University Press. 408pp.

O'Reilly, S.Y.; Griffin, W.L., 1985: A xenolith-derived geotherm for southeastern Australia and its geophysical implications. Tectonophysics 111: 41-63.

, 1987: Eastern Australia - 4000 kilometres of mantle samples. In: P.H. Nixon (ed.), Mantle xenoliths. Wiley, Chichester. Pp 267-280.

O'Reilly, S.Y.; Griffin, W.L.; Stabel, A., 1988: Evolution of Phanerozoic eastern Australian lithosphere: isotopic evidence for magmatic and tectonic underplating. Journal of petrology, special lithosphere issue: 89-108.

Padovani, E.R.; Carter, J.L., 1977: Aspects of the deep crustal evolution beneath south central New Mexico. In: J.G. Heacock (ed.), The Earth's crust. American Geophysical Union, Washington D.C. Pp 19-55. 
Palmer, K., 1990: XRF analyses of granitoids and associated rocks, St Johns Range, South Victoria Land, Antarctica. RSES Geology Board of Studies publication No. 5, Analytical Facility contribution No. 13, Antarctic Data Series 15.

Panter, K.S.; McIntosh, W.C.; Smellie, J.L., in prep: The volcanic history of Mount Sidley, a major alkaline volcano in Marie Byrd Land, Antarctica.

Panter, K.S.; McIntosh, W.C.; Smellie, J.L., Gamble, J.A., 1991: Volcanic history of Mount Sidley, Marie Byrd Land, Antarctica (abstract). In: Sixth International Symposium on Antarctic Earth Sciences, abstracts volume. p476.

Parsons, B.; McKenzie, D., 1978: Mantle convection and the thermal structure of plates. Journal of geophysical research 83: 4485-4496.

Parsons, I. (ed.), 1987: Origin of igneous layering. D Reidel Publishing Company. 660pp.

Pearce, J.A., 1983: The role of sub-continental lithosphere in magma genesis at destructive plate margins. In: C.J. Hawkesworth; M.J.Norry (eds), Continental basalts and mantle xenoliths. Shiva, Nantwich. Pp 230-249.

Peddy, C.P., 1984: Displacement of the Moho by the Outer Isles thrust shown by seismic modelling. Nature 312: 628-630.

Phinney, R.A.; Jurdy, D.M., 1979: Seismic imaging of deep crust. Geophysics 44: 637-660.

Pitcher, W.S., 1983: Granite type and tectonic environment. In: K.J. Hsu (ed.), Mountain building processes. Academic Press, London and New York. Pp $19-40$.

Poldervaart, A., 1955: Chemistry of the Earth's crust. Geological Society of America special paper 62: 119-182.

Powell, R., 1978: The thermodynamics of pyroxene geotherms. Philosophical transactions of the Royal Society of London series A 288: 457-469.

Ramsay, J.G., 1982: Rock ductility and its influence on the development of tectonic structures in mountain belts. In: K.J. Hsu (ed.), Mountain building processes. Academic press, London and New York. Pp 111-127.

Reay, A.; Sipiera, P.P., 1987: Mantle xenoliths from the New Zealand region. In: P.H. Nixon (ed.), Mantle xenoliths. Wiley, Chichester. Pp 347-358.

Reid, M.R.; Hart, S.R.; Padovani, E.R.; Wandless, G.A., 1989: Contribution of metapelitic sediments to the composition, heat production, and seismic velocity of the lower crust of southern New Mexico. Earth and planetary science letters 95: 367-381. 
Richard, S.M., 1992: Structure and cooling history of the Fosdick Metamorphic Complex, Marie Byrd Land, West Antarctica. In: Y. Yoshida; K. Kaminuma; K. Shiraishi (eds), Recent progress in Antarctic earth science. Terra Scientific Publishing Company, Tokyo. Pp289-294.

Roberts, S.; Ruiz, J., 1989: Geochemical zonation and evolution of the lower crust in Mexico. Journal of geophysical research 94: 7961-7974.

Rogers, N.W.; Hawkesworth, C.J., 1982: Proterozoic age and cumulate origin of granulite xenoliths, Lesotho. Nature 299: 409-413.

Rosendahl, B.R.; Meyers, J.; Groschel, H.; Scott, D., 1992: Nature of the transition from continental to oceanic crust and the meaning of the reflection Moho. Geology 20: 721-724.

Roser, B.P., 1983: Comparative studies of copper and manganese mineralisation in the Torlesse, Waipapa and Haast Schist terranes, New Zealand. PhD thesis lodged at Victoria University of Wellington, New Zealand. 491pp.

Rowell, A.J.; Rees, M.N.; Cooper, R.A.; Draitt, B.R., 1988: Early Paleozoic history of the central Transantarctic Mountains: evidence from the Holyoake Range, Antarctica. New Zealand journal of geology and geophysics 31(4): 397-404.

Rudnick, R.L., 1992: Xenoliths - samples of the lower continental crust. In: D.M. Fountain; R.J. Arculus; R.W. Kay (eds), The continental lower crust. Elsevier, Amsterdam. Pp 269-316.

Rudnick, R.L.; Goldstein, S.L., 1990: The Pb isotopic composition of lower crustal xenoliths and the evolution of lower crustal $\mathrm{Pb}$. Earth and planetary science letters 98: 192-207.

Rudnick, R.L.; McDonough, W.F.; McCulloch, M.T.; Taylor, S.R., 1986: Lower crustal xenoliths from Queensland, Australia: evidence for deep crustal assimilation and fractionation of continental basalts. Geochimica et cosmochimica acta 50: 1099-1115.

Rudnick, R.L.; Presper, T., 1990: Geochemistry of intermediate- to high-pressure granulites. In: D. Vielzeuf; P. Vidal (eds), Granulites and crustal evolution. Klower, Dordrecht. Pp 523-550.

Rudnick, R.L.; Taylor, S.R., 1987: The composition and petrogenesis of the lower crust: a xenolith study. Journal of geophysical research 92: 13981-14005.

Rushmer, T., 1993: Experimental high-pressure granulites: some applications to natural mafic xenolith suites and Archean granulite terranes. Geology 21: 411-414.

Salisbury, M.H.; Keen, C.E., 1993: Listric faults imaged in oceanic crust. Geology 21: 117-120. 
Sass, J.H.; Lachenbruch, A.H., 1979: Thermal regime of the Australian continental crust. In: M.W. McElhinny (ed.), The Earth - its origin, structure and evolution. Academic Press, London. Pp 301-352.

Sato, M., 1970: An electrochemical method of oxygen fugacity control of furnace atmosphere for mineral synthesis. American mineralogist 55: 1424-1437.

, 1972: Intrinsic oxygen fugacities of iron-bearing oxide and silicate minerals under low total pressure. Geological Society of America memoirs 135: 289-307.

Schmidt, D.L. 1983: Proterozoic to Mesozoic mobile-belt geology, Pensacola Mountains, Antarctica (abstract). United States Geological Survey Polar Research Symposium abstracts volume. Geological Survey circular 911: 1213.

Segawa, J.; Matsumoto, T.; Kaminuma, K., 1986: Gravity anomaly in and around Antarctica and its tectonic implications. Journal of geodynamics 6: 309-326.

Selverstone, J., 1982: Fluid inclusions as petrogenic indicators in granulite xenoliths, Pali-Aike volcanic field, Chile. Contributions to mineralogy and petrology $79 ; 28-36$.

Selverstone, J.; Stern, C.R., 1983: Petrochemistry and recrystallisation history of granulite xenoliths from the Pali-Aike volcanic field, Chile. American mineralogist 68: 1102-111.

Sewell, R.J.; Hobden, B.J.; Weaver, S.D., 1993: Mafic and ultramafic mantle and deep crustal xenoliths from Banks Peninsula, South Island, New Zealand. New Zealand journal of geology and geophysics 36: 223-231.

Shaw, D.M.; Cramer, J.J.; Higgins, M.D.; Truscott, M.G., 1986: Composition of the Canadian PreCambrian sheild and the continental crust of the earth. In: J.B. Dawson; D.A. Corswell; J. Hall; K.H. Wedepohl (eds), The nature of the lower continental crust. Blackwell Scientific Publications, Oxford. Geological Society special publication 24: 147-159.

Simkin, T.; Smith, J.V., 1970: Minor-element distribution in olivine. Journal of Geology 78: 304-325.

Smellie, J.L.; McIntosh, W.C.; Gamble, J.A.; Panter, K.S.; Kyle, P.R.; Dunbar, N.W., 1993: Preliminary lithofacies assessment and ${ }^{40} \mathrm{Ar} /{ }^{39} \mathrm{Ar}$ ages of Cenozoic volcanic sequences in eastern Marie Byrd Land. Antarctic science 5(1) 105106.

Smellie, J.L.; Panter, K.S., 1991: Geolchemical evolution of volcanoes in the Executive Committee Range, central Marie Byrd Land, West Antarctica (abstract). In: Sixth International Symposium on Antarctic Earth Sciences, abstracts volume. p 536. 
Smith, C.H., 1992: Metapelites and migmatites at the granulite facies transition, Fosdick Metamorphic Complex, Marie Byrd Land, West Antarctica. In: Y. Yoshida; K. Kaminuma; K. Shiraishi (eds), Recent progress in Antarctic earth science. Terra Scientific Publishing Company, Tokyo. Pp 295-301.

Smith, J.V., 1975: Some chemical properties of feldspars. In: P.H. Ribbe (ed.), Feldspar Mineralogy. Mineralogical Society of America Reviews in Mineralogy, Chelsea, Michigan.

Smithson, S.B.; Johnson, R.A.; Wong, Y.K., 1981: Mean crustal velocity: a critical parameter for interpreting crustal structure and crustal granulites. Earth and planetary science letters 53: 323-332.

Spera. F.J., 1980: Aspects of magma transport. In: R.B. Hargraves (ed.), Physics of magmatic processes. Princton University Press. Pp 265-323.

St John, W., 1986: Antarctica - geology and hydrocarbon potential. In: M. Halbouty (ed.), Future petroleum provinces of the world. American Association of Petroleum Geologists memoir 40: 55-99.

Stock, J.; Molnar. P., 1982: Uncertainties in the relative positions of the Australia, Antarctica, Lord Howe and Pacific plates since the Late Cretaceous. Journal of geophisical research 87(B6): 4697-4714.

1987: Revised history of early Tertiary plate moion in the south-west Pacific. Nature 325: 495-499.

Stolz, A. J.; Davies, G.R., 1989: Metasomatised lower crustal and upper mantle xenoliths from north Queensland: chemical and isotopic evidence bearing on the composition and source of the fluid phase. Geochimica et cosmochimica acta 53: 649-660.

Storey, B.C.; Alabaster, T., 1991: Tectonomagnetic controls on Gondwana break-up models: evidence from the Proto-Pacific margin of Antarctica. Tectonics 10: $1274-1288$.

Stormer, J.C., 1973: Calcium zoning in olivine and its relationship to silica activity and pressure. Geochimica et cosmochimica acta 37: 1815-1821.

, 1983: The effects of recalculation on estimates of temperature and oxygen fugacity from analyses of multicomponent iron-titanium oxides. American Mineralogst 68: 586-594.

Stosch, H.-G.; Lugmair, G.W.; Kovalenko, V.I., 1986: Spinel peridotite xenoliths from the Tasriat Depression, Mongolia II: Geochemistry and Nd and Sr isotopic composition and their implications for the evolution of the subcontinental lithosphere. Geochimica et cosmochimica acta 50: 2601-2614.

Streckeisen, A., 1976: To each plutonic rock its proper name. Earth science reviews 12: 1-33. 
Stump, E., 1981: Observations on the Ross Orogen, Antarctica. In: M.M. Cresswell; P. Vella, (eds), Gondwana Five. A.A.Balkena, Rotterdam. Pp 205-208.

, 1982: The Ross Supergroup in the Queen Maud Mountains. In: C. Craddock (ed.), Antarctic geoscience. University of Wisconsin Press, Madison. Pp 565-569.

Stump, E.; Miller, J.M.G.; Korsch, R.J.; Edgerton, D.E., 1988: Diamictite from Nimrod Glacier area, Antarctica: possible Proterozoic glaciation on the seventh continent. Geology 16(3): 225-228.

Taylor, H.P., 1980: The effects of assimilation of country rocks by magmas on ${ }^{18} \mathrm{O} /{ }^{16} \mathrm{O}$ and ${ }^{87} \mathrm{Sr} /{ }^{86} \mathrm{Sr}$ systematics in igneous rocks. Earth and planetary science letters 47: 243-254.

Taylor, S.R.; McLennan, S.M., 1981: The composition and evolution of the continental crust: rare earth element evidence from sedimentary rocks. Philosophical transactions of the Royal Society of London 301: 381-399.

- 1985: The continental crust: its composition and evolution. Blackwell, Oxford. 312pp.

Thirlwall, M.F., 1991a: High-precision multicollector isotopic analysis of low levels of $\mathrm{Nd}$ as oxide. Chemical geology (isotope geoscience section) 94: 1322.

1991b: Long term reproducibility of multicollector $\mathrm{Sr}$ and $\mathrm{Nd}$ isotope ratio analysis. Chemical geology (isotope geoscience section) 94: 85-104.

Thirlwall, M.F.; Upton, B.G.J.; Jenkins, C., in press: Interaction between continental lithosphere and the iceland plume - $\mathrm{Sr}-\mathrm{Nd}-\mathrm{Pb}$ isotope geochemistry of Tertiary basalts, NE Greenland. Journal of petrology. 
Veevers, J.J., 1986: Break-up of Australia and Antarctica estimated as midCretaceous ( $95 \pm 5 \mathrm{Ma}$ ) from magnetic and seismic data at the continental margin. Earth and planetary science letters 77(1): 91-99.

Vetter, V.; Tessensohn, F., 1987: S- and I-type granitoids of north Victoria Land, Antarctica, and their inferred geotectonic setting. Geologische rundschau 76(1): 233-243.

Vinx, R.; Jung, D., 1977: Pargasitic - kaersutitic amphibole from a basanitic diatreme at the Rosenberg, north of Kassel (North Germany). Contributions to mineralogy and petrology 65: 135-142.

Vissers, R.L.M.; Drury, M.R.; Hoogerduijn Strating, E.H.; van der Wal, D., 1991: Shear zones in the upper mantle: a case study in an alpine lherzolite massif. Geology 19: 990-993.

Wade, F.A.; Cathey, C.A.; Oldham, J.B., 1977a: Reconnaissance geologic map of the Boyd Glacier quadrangle, Marie Byrd Land, Antarctica, 1: 250 000. USARP Map A-7. U.S. Geological Survey, Washington D.C.

1977b: Reconnaissance geologic map of the Guest Peninsula quadrangle, Marie Byrd Land, Antarctica, 1: 250 000. USARP Map A-6. U.S. Geological Survey, Washington D.C.

1978: Reconnaissance geologic map of the Gutenko Nunataks quadrangle, Marie Byrd Land, Antarctica, 1: 250 000. USARP Map A-11. U.S. Geological Survey, Washington D.C.

Wade, F.A.; Couch, D.R., 1982: The Swanson Formation, Ford Ranges, Marie Byrd Land - Evidence for and against a direct relationship with the Robertson Bay Group, Northern Victoria Land. In: C. Craddock (ed.), Antarctic geoscience. University of Wisconsin Press, Madison. Pp 609-617.

Wager, L.R.; Brown, G.M., 1968: Layered igneous rocks. Oliver and Boyd, Edinburgh. 588pp.

Warner, M.R.; McGeary, S., 1987: Seismic reflection coefficients from mantle fault zones. Royal Astronomical Society geophysical journal 89: 223-309.

Wass, S.Y., 1979: Multiple origins of clinopyroxenes in alkali basaltic rocks. Lithos 12: 115-132.

Wass, S.Y.; Rogers, N.W., 1980: Mantle metasomatism - precursor to continental alkaline volcanism. Geochimica et cosmochimica acta 44: 1811-1823.

Weaver, B.L.; Tarney, J., 1980a: Continental crust composition and nature of the lower crust: constraints from mantle Nd-Sr isotope correlation. Nature 286: 342-346. 
, 1980b: Rare earth geochemistry of Lewisian granulite - facies gneisses, northwest Scotland: implications for the petrogenesis of the Archaen lower continental crust. Earth and planetary science letters 51: 279-296.

, 1984: Empirical approach to estimating the composition of the continental crust. Nature 310: 575-577.

Weaver, S.D.; Bradshaw, J.D.; Adams, C.J., 1991: Granitoids of the Ford Ranges, Marie Byrd Land, Antarctica. In: M.R.A. Thomson; J.A. Crame; J.W. Thomson (eds), Geological evolution of Antarctica - Proceedings of the 5th International Symposium on Antarctic Earth Sciences. Cambridge Universtiy Press, Cambridge.

Weaver, S.D.; Bradshaw, J.D.; Laird, M.E., 1984: Geochemistry of Cambrian volcanics of the Bowers Supergroup and implications for the early Paleozoic tectonic evolution of northern Victoria Land, Antarctica. Earth and planetary science letters 68: 128-140.

Weissel, J.K.; Hyes, D.E.; Herron, E.M., 1977: Plate tectonic synthesis: displacements between Australia, New Zealand and Antarctica since the late Cretaceous. Marine Geology 25: 231-277.

Wells, P.R.A., 1977: Pyroxene thermometry in simple and complex systems. Contributions to mineralogy and petrology 62: 129-140.

Wheatley, M.R.; Rock, N.M.S., 1988: A Macintosh program to generate normalised multi-element spidergrams. American mineralogist 73: 919-921.

White, A.J.R.; Chappell, B.W., 1983: Granitoid types and their distribution in the Lachlan Fold Belt, southeastern Australia. Geological Society of America memoir 159: 21-34.

White, R.S., 1988: The Earth's crust and lithosphere. Journal of petrology - special lithosphere issue: 1-10.

White, R.S.; Detrick, R.S.; Mutter, J.C.; Buhl, P; Minshull, T.A.; Morris, E., 1990: New seismic images of oceanic crustal structure. Geology 18: 462-465.

Wilson, G.S., 1993: Ice induced sea level change in the late Neogene. PhD thesis lodged at Victoria University of Wellington, New Zealand. 452 pp.

Wilson, M., 1989: Igneous petrogenesis. Unwin Hyman, London. 466pp.

Wood, B.J., 1987: Thermodynamics of multicomponent systems containing several solid solutions. In: I.S.E. Carmichael; H.P. Eugster (eds), Thermodynamic modelling of geological materials: minerals, fluids and melts. Mineralogical Society of America, Washington D.C. Pp 71-95.

Wood, B.J.; Banno, S., 1973: Garnet - orthopyroxene and orthopyroxene clinopyroxene relationships in simple and complex systems. Contributions to mineralogy and petrology 42: 109-124. 
Woolfe, K.J., 1991: History of the Ross Sea sector of Antarctica as recorded by the Beacon Supergroup in southern Victoria Land and the Darwin Mountains. PhD thesis lodged at Victoria University of Wellington, New Zealand.

Worner, G.; Viereck, L.; Hertogen, J.; Niephaus, H., 1989: The Mt Melbourne Volcanic Field (Victoria Land, Antarctica) II. Geochemistry and magma genesis. Geologische jahrbuch E38: 395-433.

Wysoczanski, R.J., 1993: Mineral and whole rock analyses of lithospheric xenoliths from Marie Byrd Land, West Antarctica. RSES Geology Board of Studies publication, 13 Analytical Facility contribution No. 15, Antarctic Data Series 17.

Wysoczanski, R.J.; Gamble, J.A., 1992: Xenoliths from the Volcanic Province of West Antarctica and implications for lithospheric structure and processes. In: Y. Yoshida; K. Kaminuma; K. Shiraishi (eds), Recent progress in Antarctic earth science. Terra Scientific Publishing Company, Tokyo. Pp 273-277.

Yagi, K.; Hariya, Y.; Onuma, K.; Fukushima, N., 1975: Stability reaction of kaersutite. Journal of the facuilty of science of Hokkaido University series IV (16): 331-3423.

Yardley, B.W.D., 1989: An introduction to metamorphic petrology. Congman, England. 248pp.

Zanettin, B., 1984: Proposed new chemical classification of volcaic rocks. Episodes 7: 19-20. 